\section{Pacific Northwest} National Laboratory

Operated by Battelle for the U.S. Department of Energy

\title{
Hanford Site Environmental Report for Calendar Year 1999
}

\author{
Editors \\ T. M. Poston \\ R. W. Hanf \\ R. L. Dirkes
}

September 2000

Prepared for the U.S. Department of Energy under Contract DE-AC06-76RLO 1830 


\title{
DISCLAIMER
}

This report was prepared as an account of work sponsored by an agency of the United States Government. Reference herein to any specific commercial product, process, or service by trade name, trademark, manufacturer, or otherwise does not necessarily constitute or imply its endorsement, recommendation, or favoring by the United States Government or any agency thereof, or Battelle Memorial Institute.

\author{
PACIFIC NORTHWEST NATIONAL LABORATORY \\ operated by \\ BATTELLE \\ for the \\ UNITED STATES DEPARTMENT OF ENERGY \\ under Contract DE-ACO6-76RLO 1830
}

\author{
Printed in the United States of America \\ Available to DOE and DOE contractors from the \\ Office of Scientific and Technical Information, P.O. Box 62, Oak Ridge, TN 37831; \\ prices available from (615) 576-8401.
}

\begin{abstract}
Available to the public from the National Technical Information Service,
U.S. Department of Commerce, 5285 Port Royal Rd., Springfield, VA 22161
\end{abstract}

This report cover shows photos of world weather patterns, the shrub-steppe ecosystem as viewed from the Rattlesnake Hills on the Hanford Site, and sandstone stratification. The images are intended to represent climatology, environmental surveillance, and groundwater monitoring activities conducted on the Site. The sandstone photo helps illustrate the concept of groundwater, although groundwater on the Hanford Site is found in a. cobble/sand strata, not in layered sedimentary rock as shown.

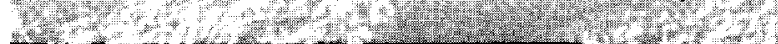

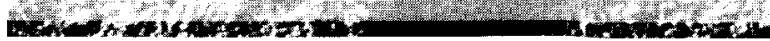

(3) The document was printed on recycled paper. 


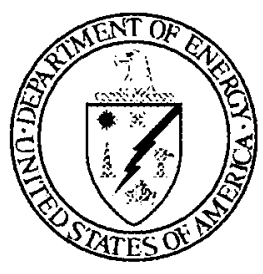

00-OSS-431

\section{Department of Energy}

Richland Operations Office

P.O. Box 550

Richland, Washington 99352

AUS 12000

\section{Addressees:}

\section{THE HANFORD SITE ENVIRONMENTAL REPORT FOR CALENDAR YEAR (CY) 1999, RICHLAND, WASHINGTON, SEPTEMBER 2000}

The Hanford Site Environmental Report is prepared and published annually by the U.S. Department of Energy (DOE) for distribution to local, state, and federal government agencies, Congress, the public, the news media, and Hanford Site employees. The purpose of the report is to provide the reader with the most recent information available on Hanford Site environmental management activities and environmental compliance issues.

This report includes information for CY 1999 (including some historical and early 2000 information) and contains sections summarizing the results of environmental monitoring efforts on and around the site, information on the Hanford Site's conformance to environmental permits, the status of the site's compliance with federal, state, and local regulations, and discusses important issues and actions.

The report was prepared for DOE by the Pacific Northwest National Laboratory (PNNL) with the support of other site contractors and describes programs conducted by PNNL, the research and development contractor; Fluor Hanford, Inc., the prime contractor for the nuclear legacy cleanup; Bechtel Hanford, Inc., the environmental restoration contractor; CH2M HILL Hanford Group, Inc., the contractor responsible for nuclear and chemical waste stored in Hanford's 177 underground storage tanks; MACTEC-ERS, a prime contractor to DOE's office in Grand Junction, Colorado, which is performing vadose zone work at Hanford; and numerous subcontractors and affiliate companies at the Hanford Site.

If you have any questions, please contact us, or your staff may contact Dana Ward, Office of Site Services, on (509) 372-1261 or by email at Dana C Ward@r.r.gov.

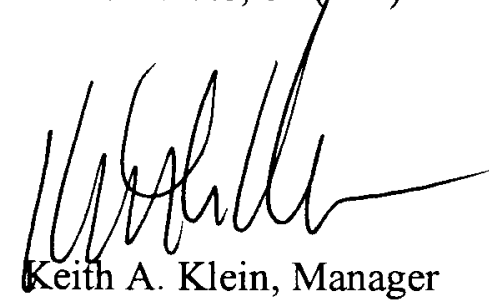

Richland Operations Office

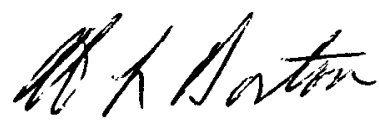

Harry L. Boston, Acting Manager Office of River Protection

Attachment:

Hanford Site Environmental Report 


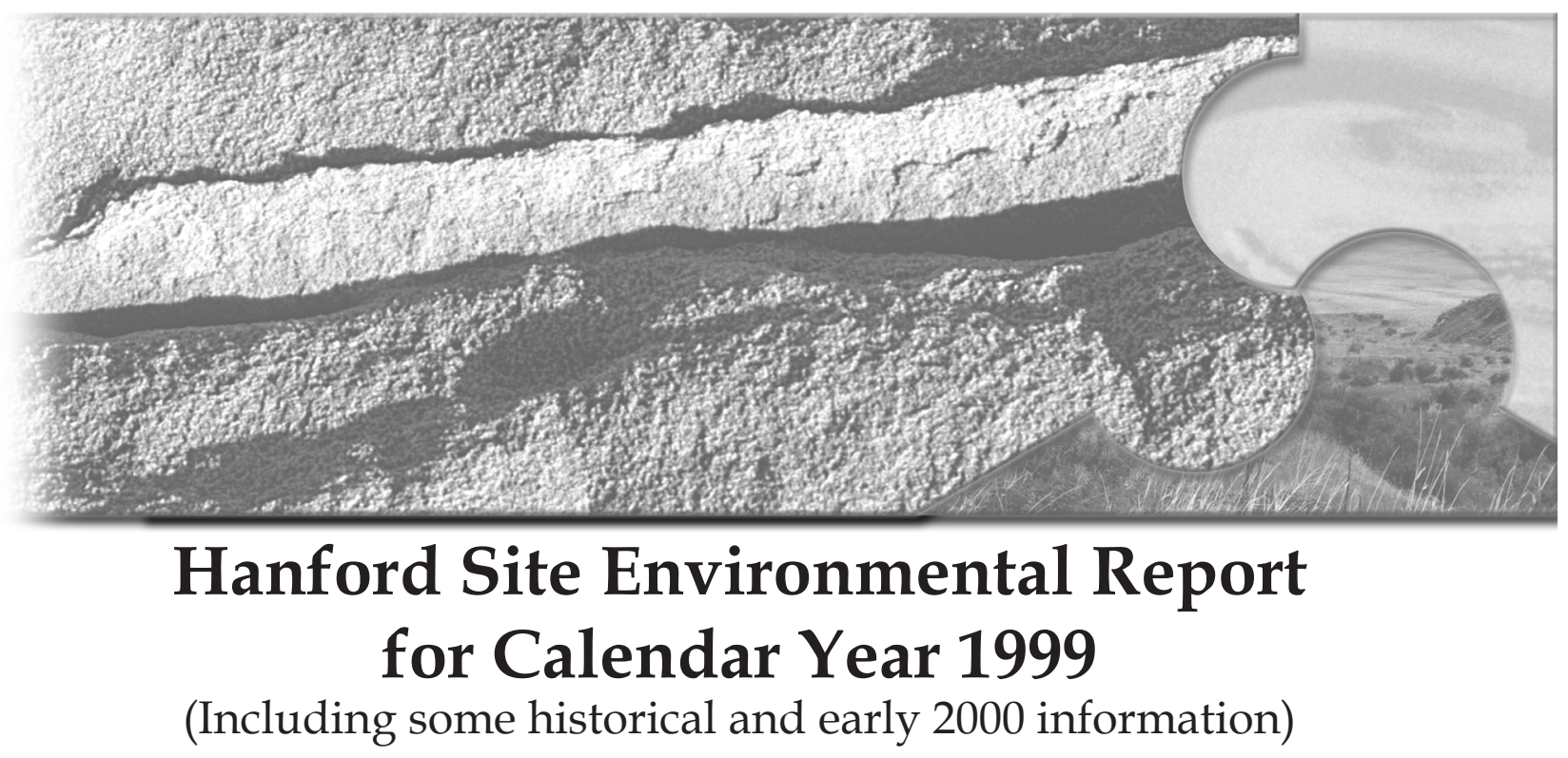

Editors

T. M. Poston

R. W. Hanf

R. L. Dirkes

September 2000

Prepared for the U.S. Department of Energy by Pacific Northwest National Laboratory under contract DE-AC06-76RLO 1830, with contributions from Fluor Hanford, Inc. and its affiliate companies, Bechtel Hanford, Inc. and its subcontractors, CH2M HILL Hanford Group, Inc., and MACTEC-ERS 


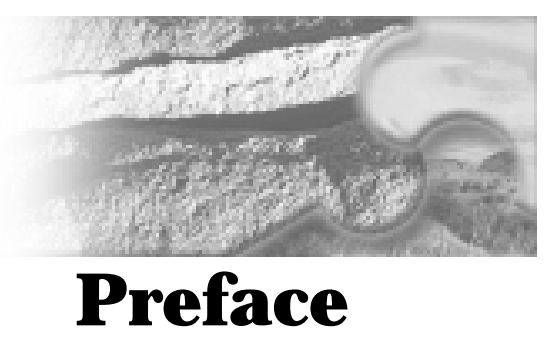

U.S.Department of Energy (D O E) 0 rder 5400.1, "G eneral Environmental Protection Program," establishesthe requirement for environmental protection programsat DOE sitesand facilities. These programs ensure that DOE operations comply with applicable federal, state, and local environmental lawsand regulations, executive orders, and Department policies.

This $\mathrm{H}$ anford Site environmental report is prepared annually pursuant to DOE Order 231.1A, "Environment, Safety, and $\mathrm{H}$ ealth Reporting," and DOE M 231.1-1, Environment, Safety and $H$ ealth Reporting $M$ anual, to summarize environmental data that characterize $\mathrm{H}$ anford Site en vironmental management performance and demonstrate compliance status. The report al so highlights significant environmental programsand efforts. M ore detailed environmental compliance, monitoring, surveillance, and study reports may be of value; therefore, to the extent practical, these additional reports have been referenced in the text.

A Ithough this report was written to meet $\mathrm{DOE}$ reporting requirements and guidelines, it was also intended to beuseful to members of the public, public officials, regulators, and $\mathrm{H}$ anford Site contractors. The "H elpful Information" section lists acronyms, abbreviations, conversion information, and nomenclature that may be useful for understanding this report.

This report is produced for the DOE Richland O perations 0 ffice, 0 ffice of Site Services, by the
Pacific N orthwest $\mathrm{N}$ ational Laboratory'sPublic Safety and Resource Protection Program. Pacific N orthwest $\mathrm{N}$ ational Laboratory isoperated by Battelle (the site research and development contractor) for $\mathrm{DOE}$. Battelle is a not-for-profit, independent, contract research institute. $M$ ajor portions of the report were written by staff from the Pacific $\mathrm{N}$ orthwest $\mathrm{N}$ ational Laboratory and selected subcontractors and alliance subcontractors of Fluor $\mathrm{H}$ anford, Inc. (the site management and integration contractor). Bechtel $\mathrm{H}$ anford, Inc. (the site environmental restoration contractor), CH 2M HILL H anford G roup, Inc. (O ffice of River Protection waste storage and retrieval contractor), and M A C T EC-ERS al so prepared or provided input to selected sections.

Copies of this report have been provided to many libraries in communities around the $\mathrm{H}$ anford Site and to several university librariesin W ashington and Oregon. Copies can also be found at DOE's $\mathrm{H}$ anford $\mathrm{R}$ eading $\mathrm{R}$ oom located in the $\mathrm{C}$ onsolidated Information Center on the campus of $W$ ashington State $U$ niversity at T ri-Cities. Copies of the report can be obtained from M r. R. W . (Bill) H anf, K6-75, Pacific N orthwest N ational Laboratory, P.O. Box 999, Richland, W ashington 99352 (bill.hanf@pnl.gov) while supplies last or can be purchased from the $N$ ational T echnical Information Service, U .S. Department of Commerce, 5285 Port Royal Road, Springfield, Virginia 22161.

This report has been issued in two hard-copy formats and an electronic format. The hard copy includes this la rge technical report and a smaller (approximately 50 pages), less-detailed summary report. The electronic versions of both hard-copy documents are available on the Internet at http:// hanford.pnl.gov/ envreport/ or http:/ / hanford.pnl.gov/ envreport/ 1999.

Inquiries regarding this report may be directed to M r. D. C. (Dana) W ard, A 2-15, DO E Richland $O$ perations 0 ffice, $O$ ffice of Site Services, P.O. Box 550 , Richland, W a shington 99352 (Dana_C_Ward@rl.gov) or to M r. T. M. (Ted) Poston, K6-75, Pacific N orthwest N ational Laboratory, P.O. Box 999, Richland, W ashing ton 99352 (ted.poston@pnl.gov). 


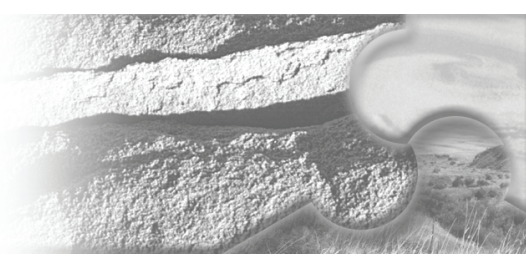

\section{Contents}

Preface.

Summary

xxvii

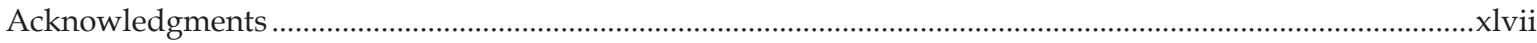

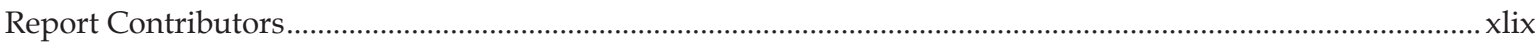

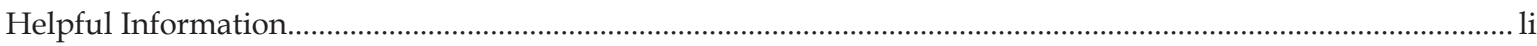

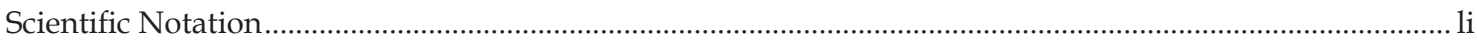

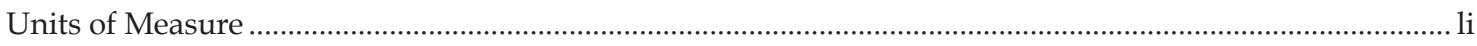

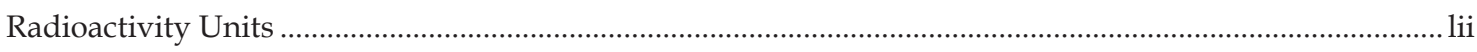

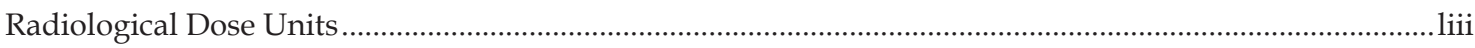

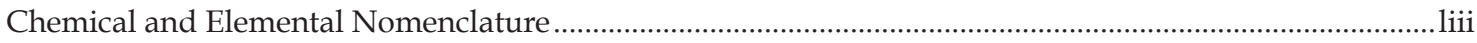

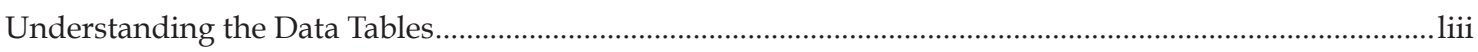

Total Propagated Analytical Uncertainty …............................................................................ liii

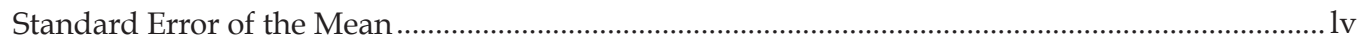

Median, Maximum, and Minimum Values ............................................................................... lv

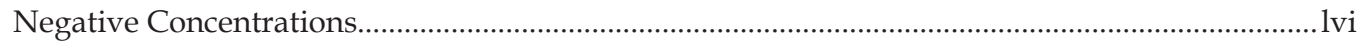

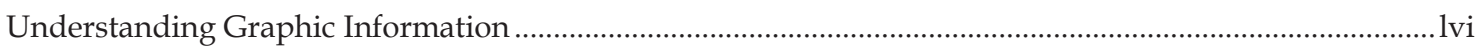

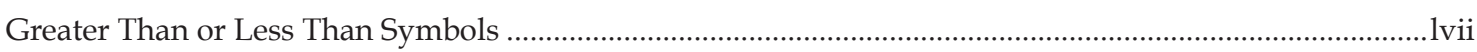

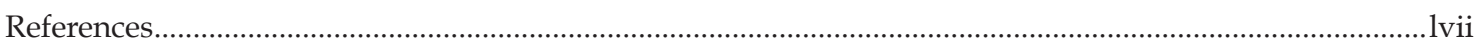

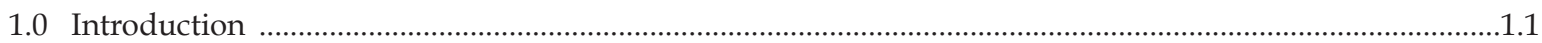

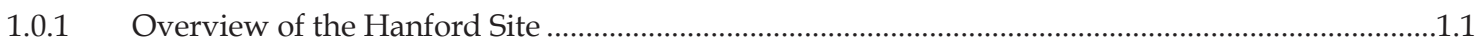

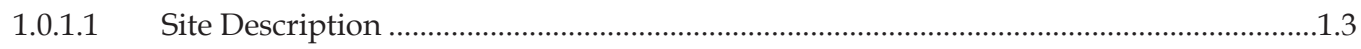

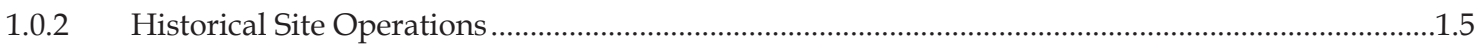

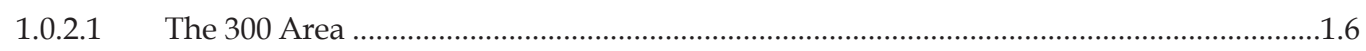

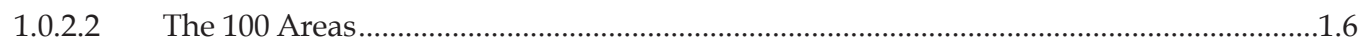

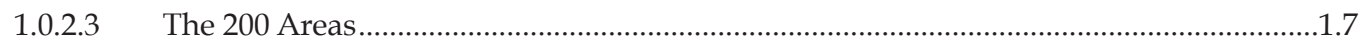

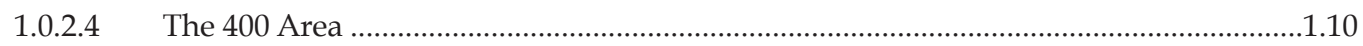

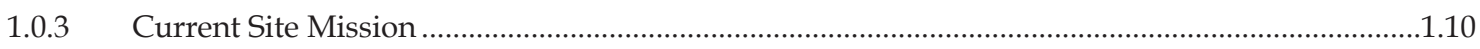

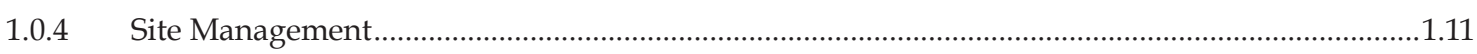

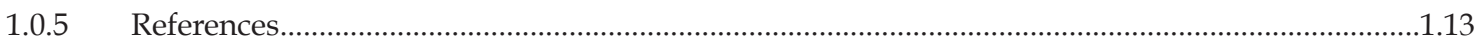

2.0 Environmental and Regulatory Compliance Summary …....................................................................2.

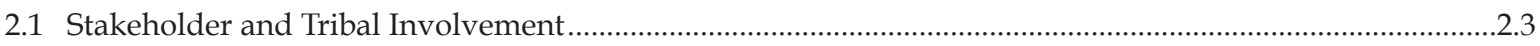

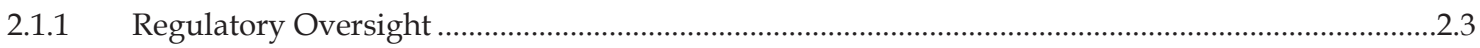

2.1.2 Hanford Federal Facility Agreement and Consent Order............................................................2.4

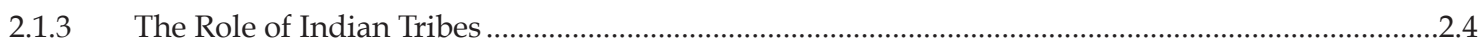

2.1.4 Hanford Natural Resource Trustee Council..................................................................................2.5 


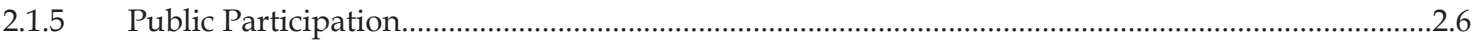

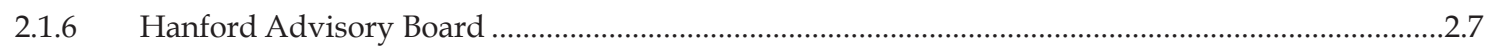

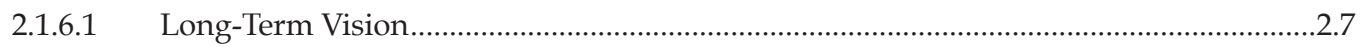

2.1.6.2 Near-Term Vision ........................................................................................................

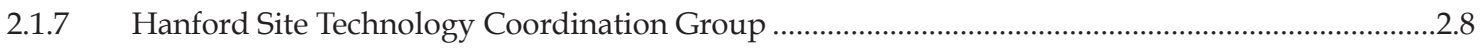

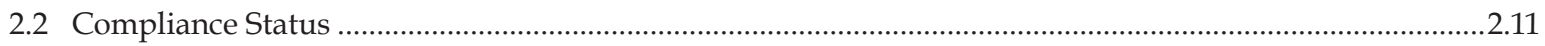

2.2.1 Hanford Federal Facility Agreement and Consent Order, 1999 Performance .................................2.11

2.2.2 Environmental Management Systems ………………………...................................................... 2.11

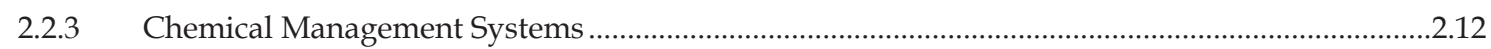

2.2.4 Comprehensive Environmental Response, Compensation, and Liability Act.................................2.12

2.2.5 Emergency Planning and Community Right-To-Know Act............................................................

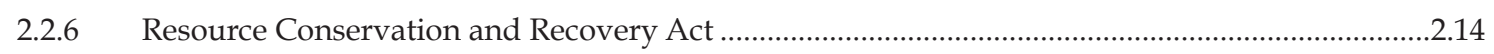

2.2.6.1 Hanford Facility RCRA Permit ...................................................................................2.14

2.2.6.2 RCRA/Dangerous Waste Permit Applications and Closure Plans ..................................2.14

2.2.6.3 RCRA Groundwater Monitoring Project Management......................................................15

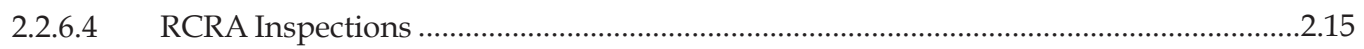

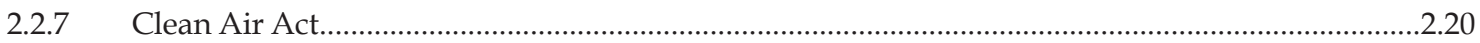

2.2.7.1 Clean Air Act Enforcement Inspections ......................................................................2.2.22

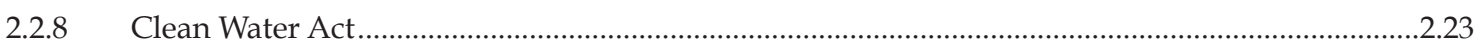

2.2.8.1 Liquid Effluent Consent Order ......................................................................................2.2.25

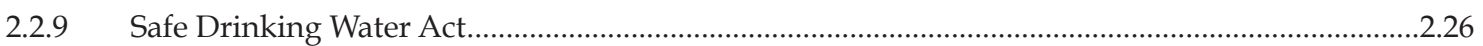

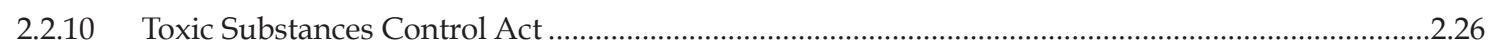

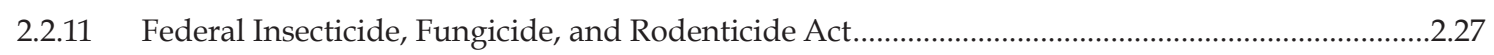

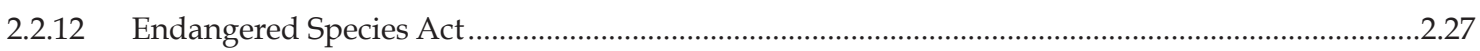

2.2.13 National Historic Preservation Act, Archaeological Resources Protection Act,

Native American Graves Protection and Repatriation Act, American Indian Religious

Freedom Act, Historic Sites Buildings and Antiquities Act, Archaeological and Historic

Preservation Act, and American Antiquities Preservation Act ....................................................2.2.28

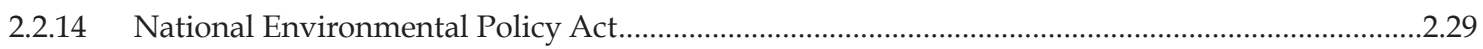

2.2.14.1 Recent Environmental Impact Statements .......................................................................2.29

2.2.14.2 Programmatic Environmental Impact Statements ...........................................................2.30

2.2.14.3 Site-Specific Environmental Impact Statements in Progress ...........................................2.30

2.2.14.4 Recent Environmental Assessments.................................................................................2.30

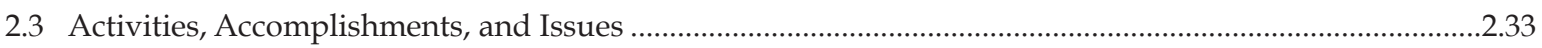

2.3.1 Hanford Federal Facility Agreement and Consent Order.............................................................2.33

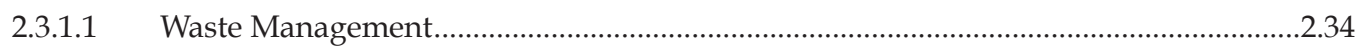

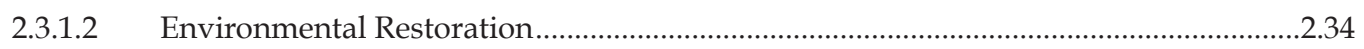

2.3.1.3 Office of River Protection..............................................................................................2.35

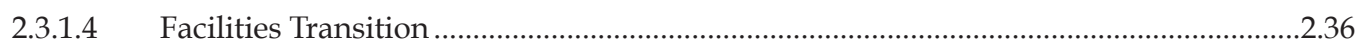

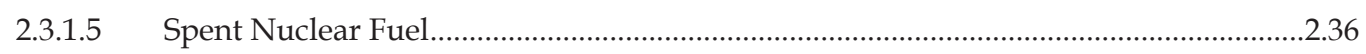

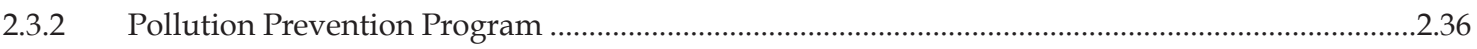

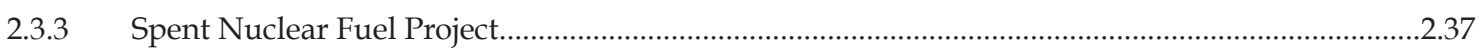




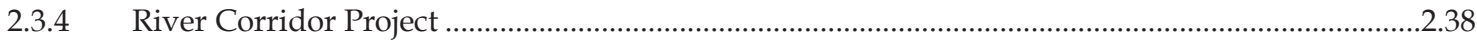

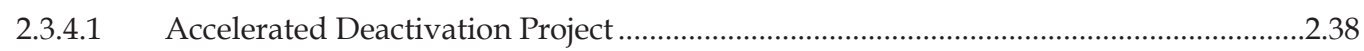

2.3.4.2 324 and 327 Facilities Deactivation Project..................................................................2.39

2.3.4.3 300 Area Treated Effluent Disposal Facility …………………………………....................39

2.3.4.4 Plutonium Finishing Plant.............................................................................................. 2.40

2.3.4.5 Plutonium-Uranium Extraction Plant ............................................................................2. 2.40

2.3.4.6 Waste Encapsulation and Storage Facility.............................................................................

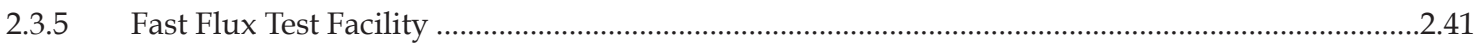

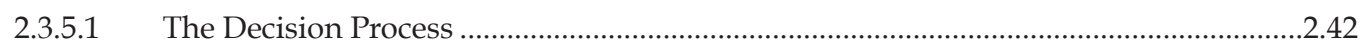

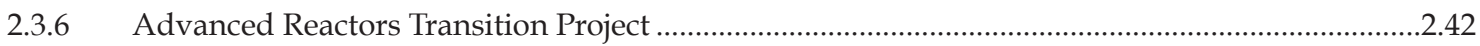

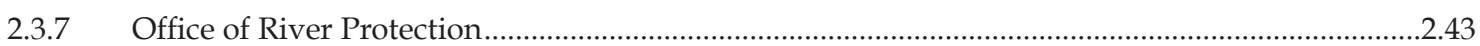

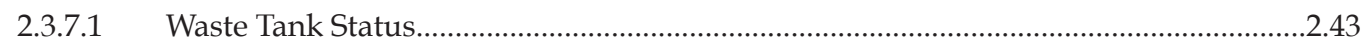

2.3.7.2 Waste Tank Safety Issues..................................................................................................2.4

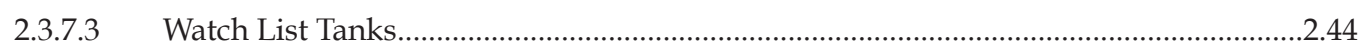

2.3.7.4 Vadose Zone Characterization Near Single-Shell Underground Waste Storage

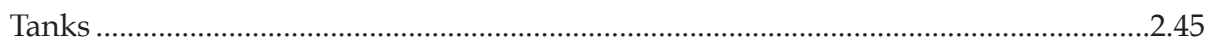

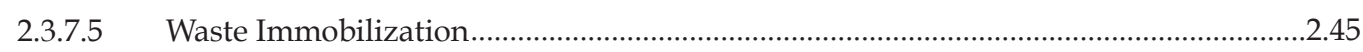

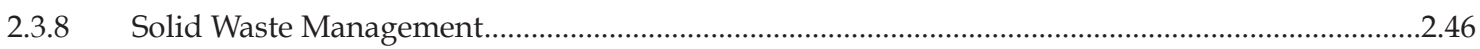

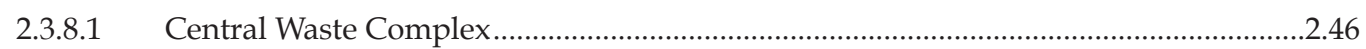

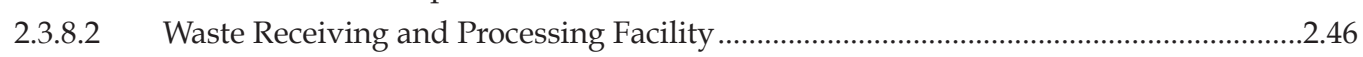

2.3.8.3 Radioactive Mixed Waste Disposal Facilities................................................................2.4.

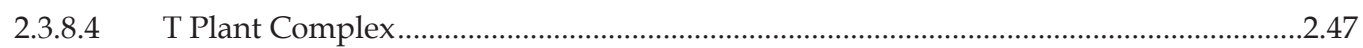

2.3.8.5 Radioactive Mixed Waste Treatment and Disposal.........................................................2.4.

2.3.8.6 Radioactive Mixed Waste Treatment Contracts...................................................................2.4.

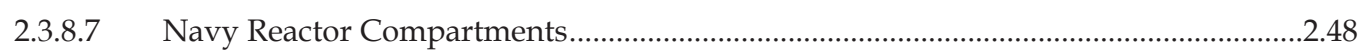

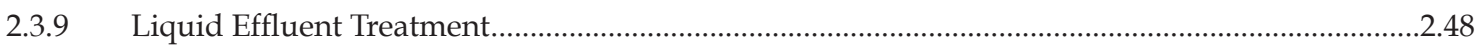

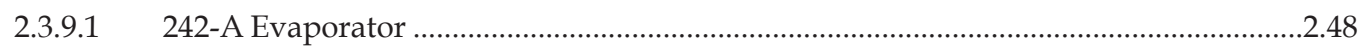

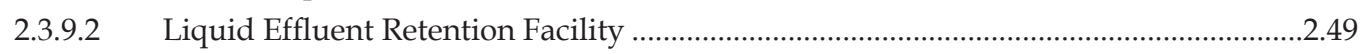

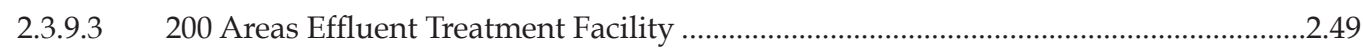

2.3.9.4 200 Areas Treated Effluent Disposal Facility .....................................................................2.50

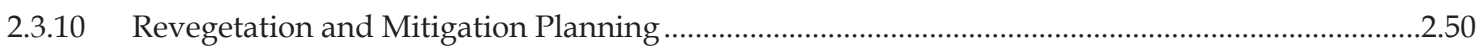

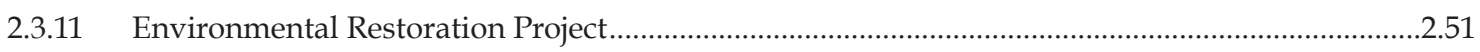

2.3.11.1 Environmental Restoration Disposal Facility ..................................................................... 2.51

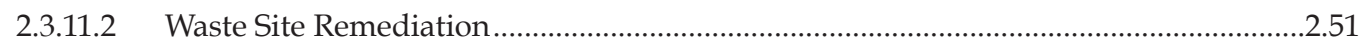

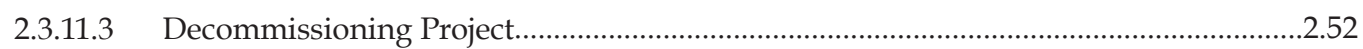

2.3.11.4 Surveillance/Maintenance and Transition Project.........................................................2.52

2.3.12 Groundwater/Vadose Zone Integration Project ................................................................................2.53

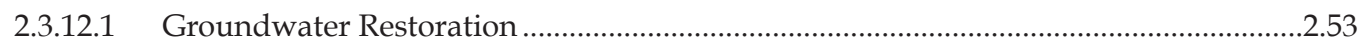

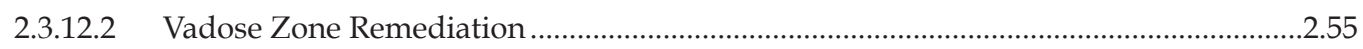

2.3.12.3 Vadose Zone Characterization in the 200 Areas ................................................................2. 2.55

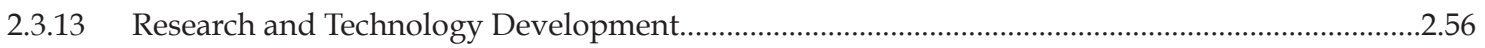

2.3.13.1 Corrosion Control .................................................................................................2.5

2.3.13.2 Technical Alternatives for Hanford Tank Waste Privatization .......................................2.57

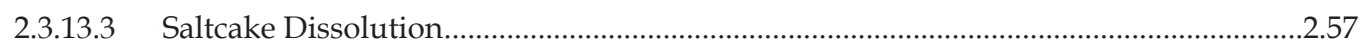




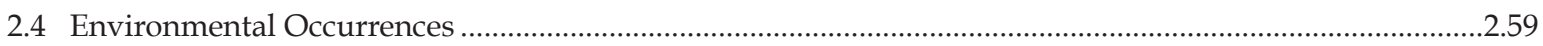

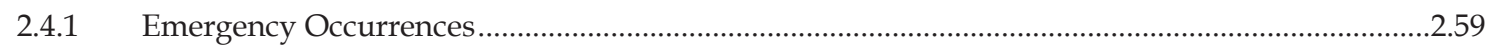

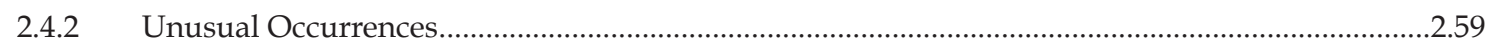

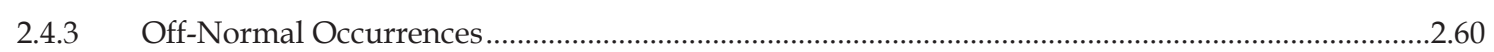

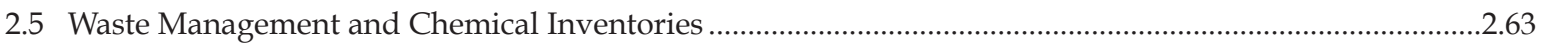

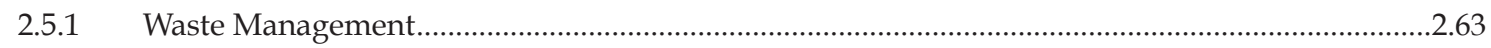

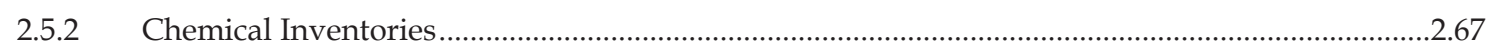

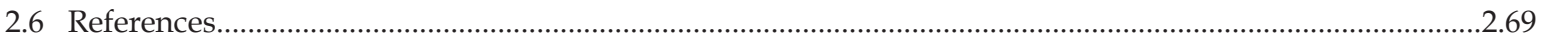

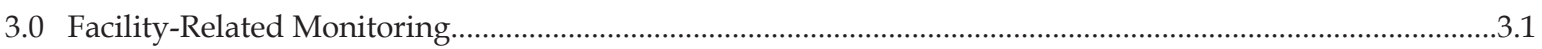

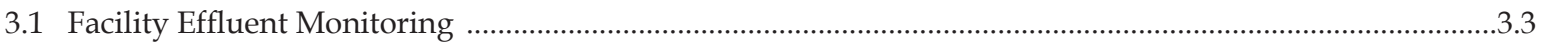

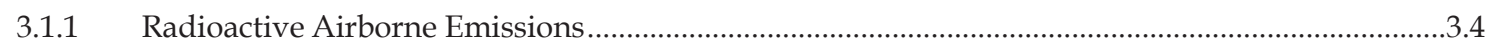

3.1.2 Nonradioactive Airborne Emissions ................................................................................................

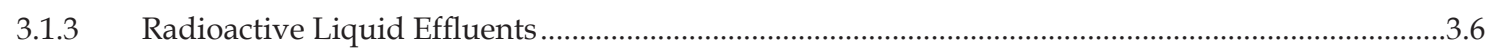

3.1.4 Nonradioactive Hazardous Materials in Liquid Effluents.............................................................

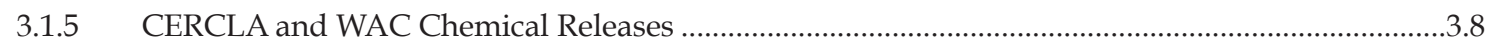

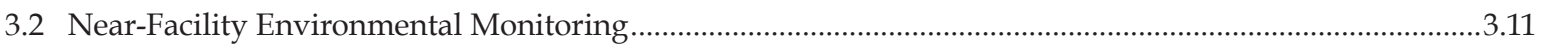

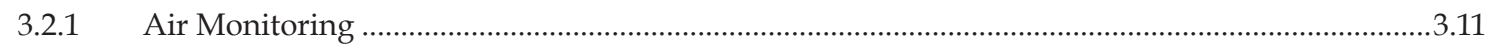

3.2.2 Surface-Water Disposal Units and 100-N Area Riverbank Springs Monitoring...........................3.18

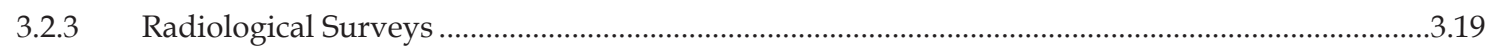

3.2.4 Soil and Vegetation Sampling from Operational Areas.................................................................3.19

3.2.4.1 Radiological Results for Soil Samples ...........................................................................21

3.2.4.2 Radiological Results for Vegetation Samples.................................................................2.22

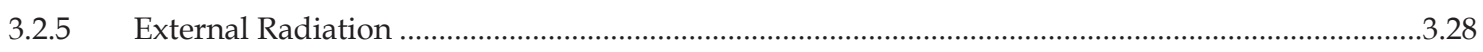

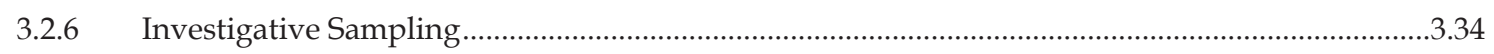

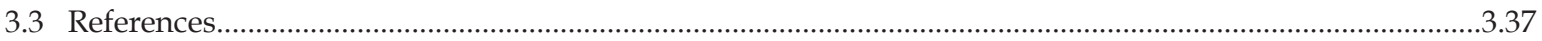

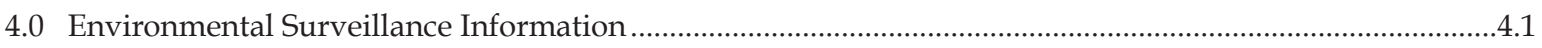

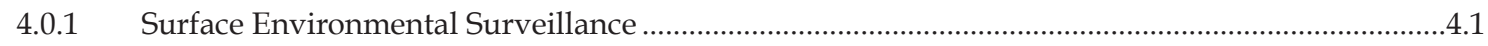

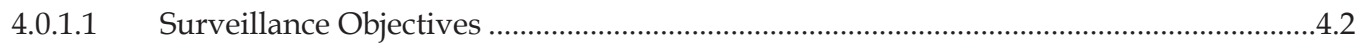

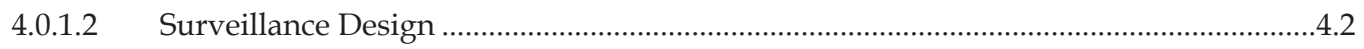

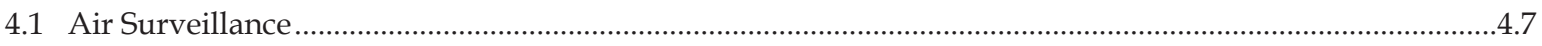

4.1.1 Collection of Air Samples and Analytes Tested for at Each Sample Location ...............................4.7

R.1.2 Radiological Results for Air Samples .....................................................................................4.11 


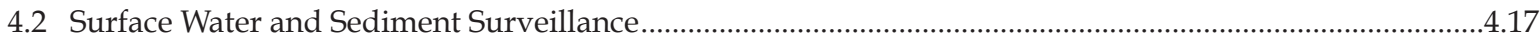

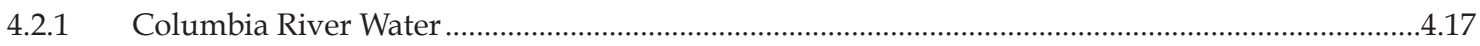

4.2.1.1 Collection of River-Water Samples and Analytes of Interest.........................................4.21

4.2.1.2 Radiological Results for River-Water Samples ............................................................24.23

4.2.1.3 Nonradiological Results for River-Water Samples.........................................................4.28

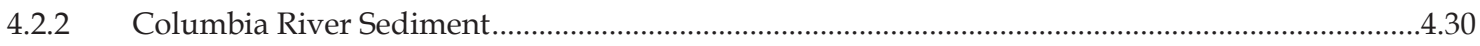

4.2.2.1 Collection of Sediment Samples and Analytes of Interest ...........................................4.30

4.2.2.2 Radiological Results for Samples from River Sediment..............................................4.31

4.2.2.3 Radiological Results for Sediment Samples from Riverbank Springs.........................4.32

4.2.2.4 Nonradiological Results for Sediment Samples from the Columbia and Snake Rivers and from Riverbank Springs...................................................................4.33

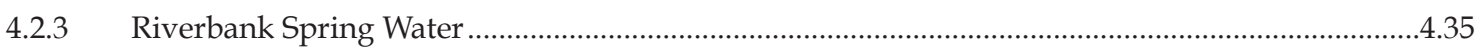

4.2.3.1 Collection of Water Samples from Riverbank Springs and Analytes of

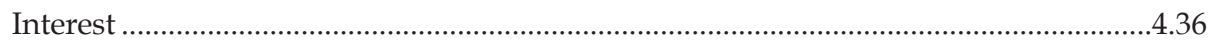

4.2.3.2 Radiological Results for Water Samples from Riverbank Springs..............................4.36

4.2.3.3 Nonradiological Results for Water Samples from Riverbank Springs .........................4.40

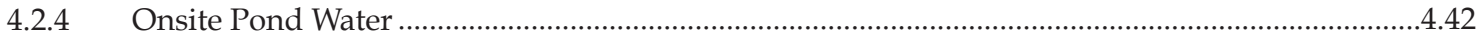

4.2.4.1 Collection of Pond Water Samples and Analytes of Interest .......................................4.42

4.2.4.2 Radiological Results for Pond Water Samples.................................................................4.42

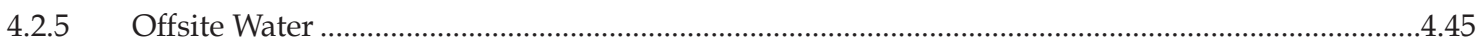

4.2.5.1 Collection, Analysis, and Results for Irrigation Canal Water ......................................4.45

4.3 Radiological Surveillance of Hanford Site Drinking Water .......................................................................4.47

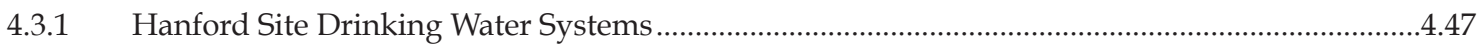

4.3.2 Hanford Site Drinking Water Supply Facilities .........................................................................4.47

4.3.3 Collection of Drinking Water Samples and Analytes of Interest ...............................................4.50

4.3.4 Radiological Results for Hanford Site Drinking Water ..............................................................4.51

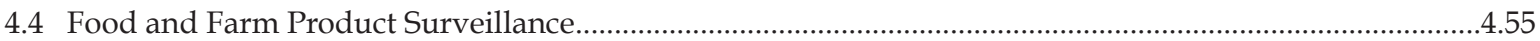

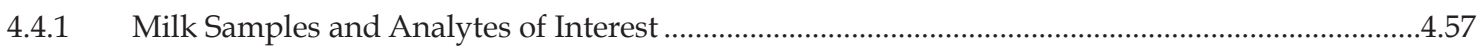

4.4.2 Vegetable Samples and Analytes of Interest ............................................................................4.59

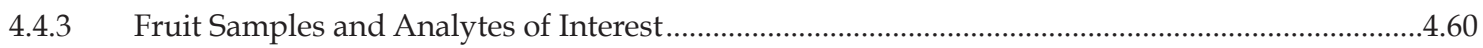

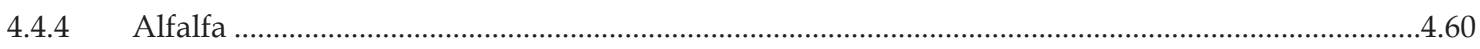

4.4.5 Wine Samples and Analytes of Interest ....................................................................................61

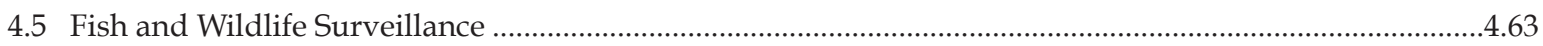

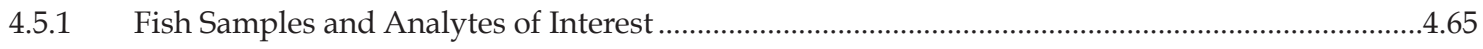

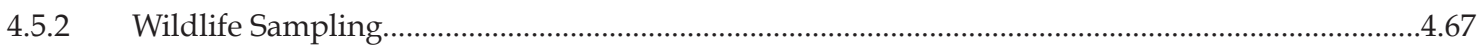

4.5.2.1 Elk Samples and Analytes of Interest....................................................................67

4.5.2.2 Goose Samples and Analytes of Interest ....................................................................69

4.5.2.3 Rabbit Samples and Analytes of Interest ...................................................................69 
4.6 Soil and Vegetation Surveillance.

4.6.1 Surveillance of Columbia River Shoreline Vegetation ..................................................................4.71

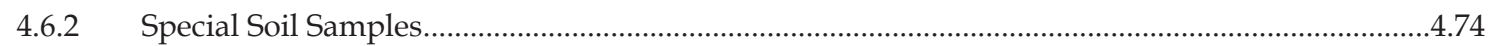

4.6.3 Vegetation Samples Submitted by the Wanapum People ............................................................4.75

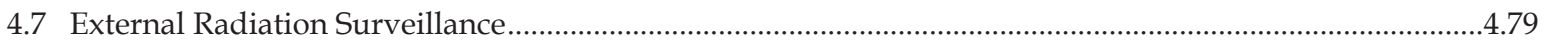

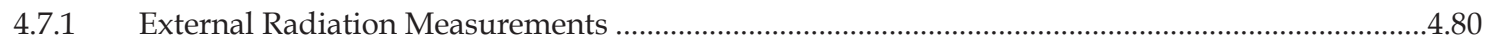

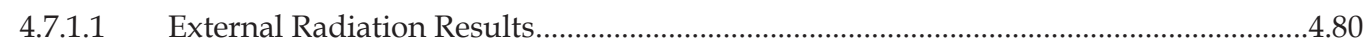

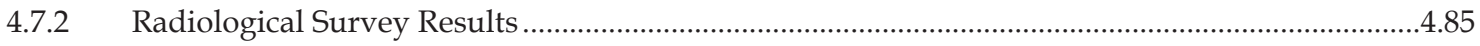

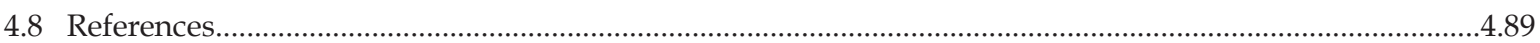

5.0 Potential Radiological Doses from 1999 Hanford Operations.......................................................................

5.0.1 Maximally Exposed Individual Dose...............................................................................................

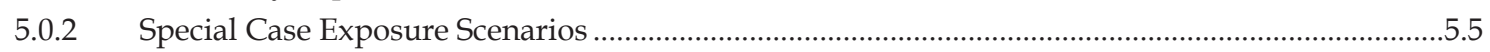

5.0.2.1 Maximum “Boundary" Dose Rate.................................................................................. 5.6

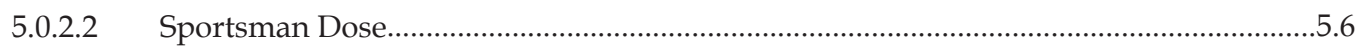

5.0.2.3 Fast Flux Test Facility Drinking Water ......................................................................5.7

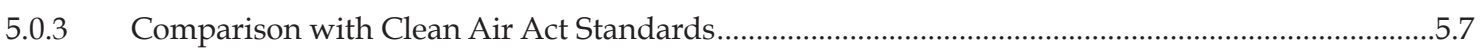

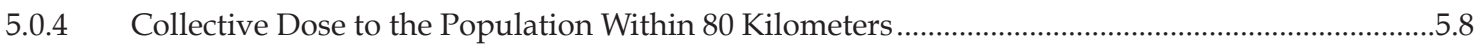

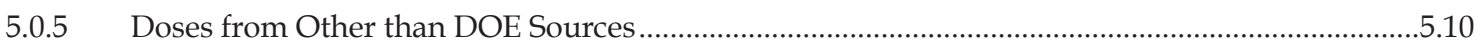

5.0.6 Hanford Public Radiological Dose in Perspective ......................................................................5.11

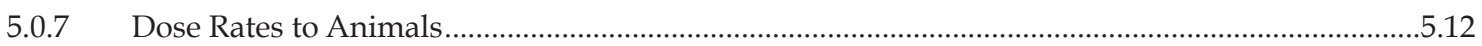

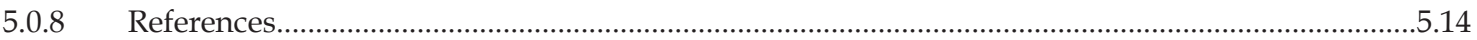

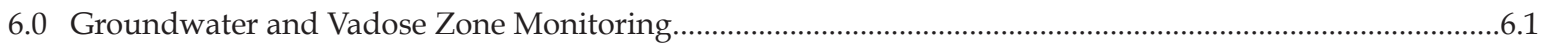

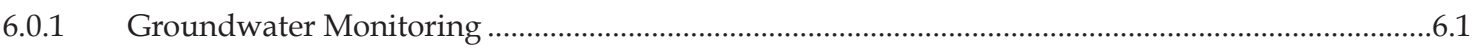

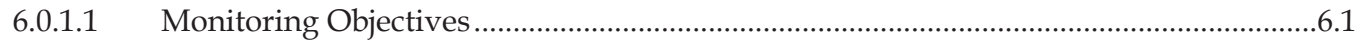

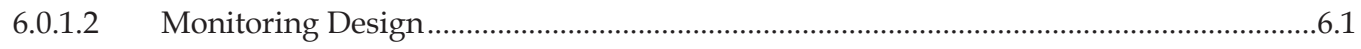

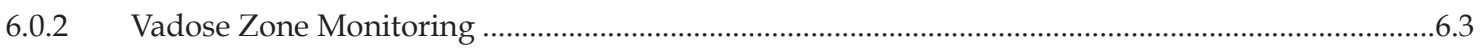

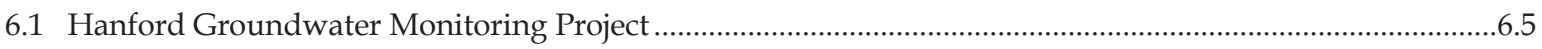

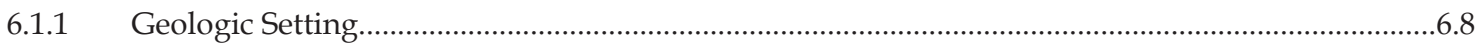

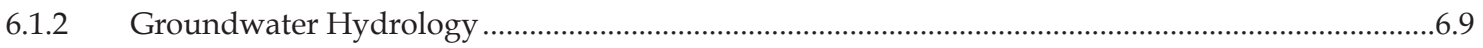

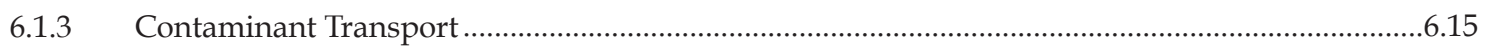

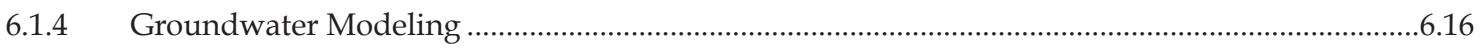

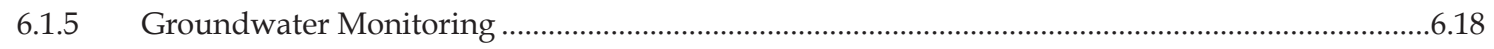

6.1.5.1 Groundwater Sampling and Analytes of Interest ...................................................6.18

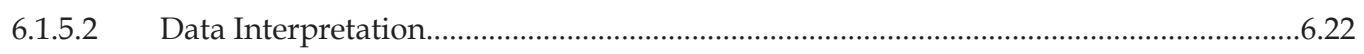

6.1.6 Groundwater Monitoring Results ...........................................................................................24

6.1.6.1 Radiological Monitoring Results for the Unconfined Aquifer ....................................6.25

6.1.6.2 Chemical Monitoring Results for the Unconfined Aquifer..........................................6.49

6.1.6.3 Radiological and Chemical Monitoring Results for the Basalt-Confined

Aquifer. 
6.1.7 RCRA Summary

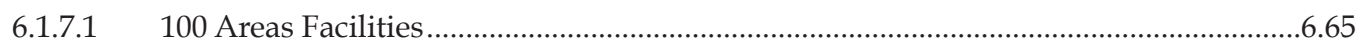

6.1.7.2 200 Areas Single-Shell Tank Farms .........................................................................6.68

6.1.7.3 200 Areas Liquid Effluent Disposal Facilities ..........................................................6.70

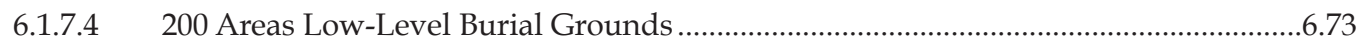

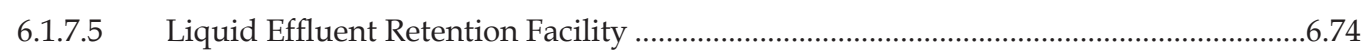

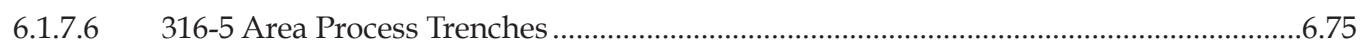

6.1.7.7 Nonradioactive Dangerous Waste Landfill …...........................................................6.75

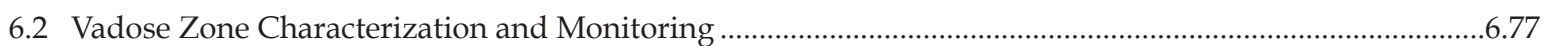

6.2.1 Vadose Zone Characterization and Monitoring at Tank Farms .................................................6.77

6.2.1.1 Borehole Characterization at the SX Tank Farm .........................................................6.77

6.2.1.2 Tank Farms Baseline Vadose Zone Characterization Project.......................................6.82

6.2.2 Vadose Zone Characterization and Monitoring at Liquid Waste Disposal Facilities....................6.95

6.2.2.1 Soil Remediation at 116-C-1 Trench, 100-B,C Area...........................................................6.96

6.2.2.2 Soil Sampling and Analysis at 1301-N and 1325-N Trenches, 100-N Area .................6.97

6.2.2.3 Bench Scale Distribution Coefficient and Leach Studies on Hexavalent Chromium in Contaminated Vadose Zone Sediment from 100-D Area .......................6.97

6.2.2.4 Carbon Tetrachloride Monitoring and Remediation in 200-West Area......................6.100

6.2.2.5 Spectral Gamma-Ray and Neutron Moisture Monitoring of 200-East

Area Inactive Liquid Waste Disposal Facilities............................................................6.106

6.2.3 Hanford Site Surface Barrier Technology ..............................................................................6.109

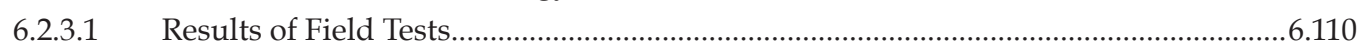

6.2.4 Measurement of Tritium in Soil Moisture and Helium-3 in Soil Gas at the Old

Hanford Townsite and KE Reactor ..............................................................................................113

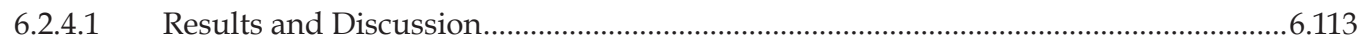

6.3 References.

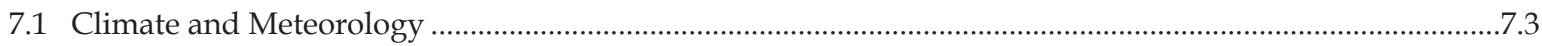

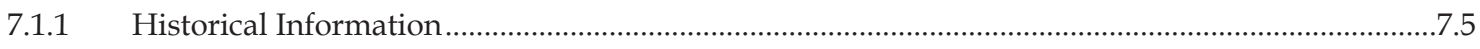

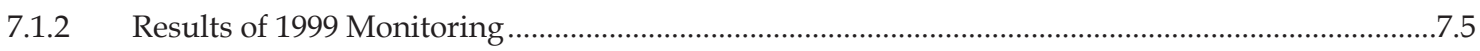

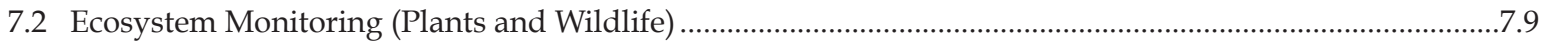

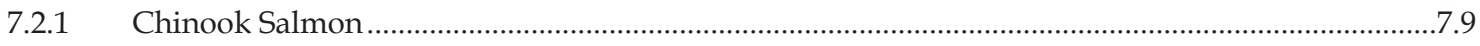

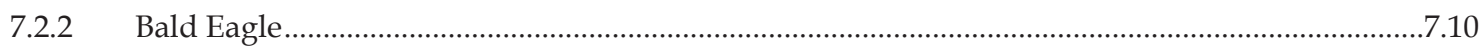

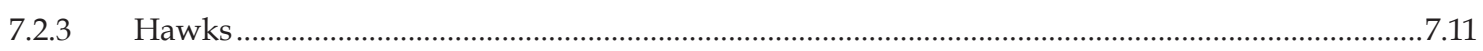

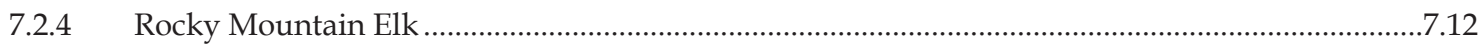

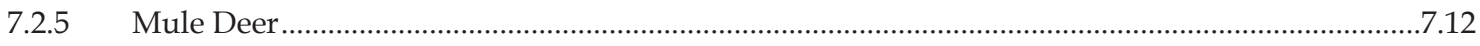

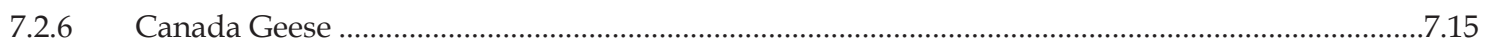

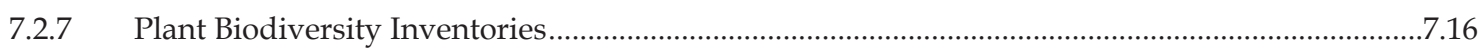


7.2.9 Other Important Biological Resources ......................................................................................19

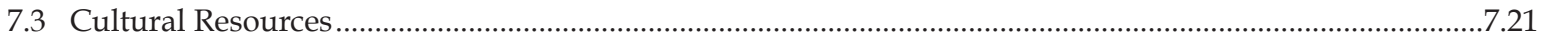

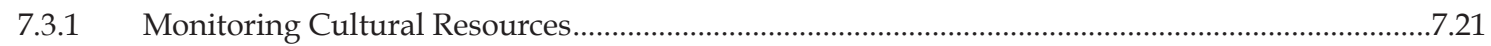

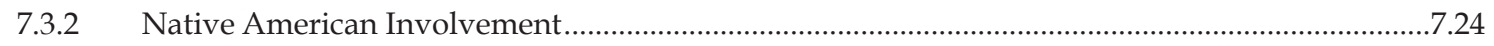

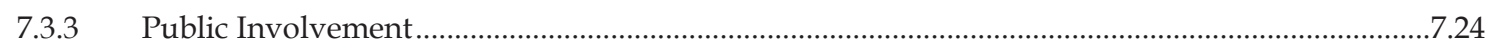

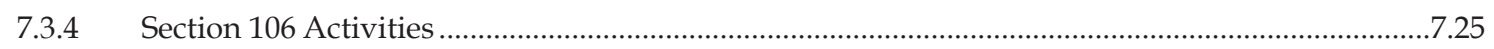

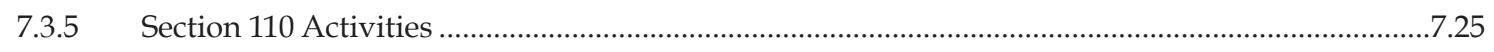

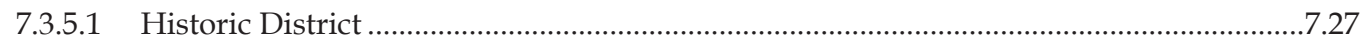

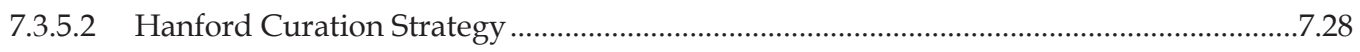

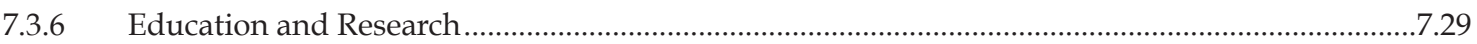

7.4 Community-Operated Environmental Surveillance Program ...............................................................31

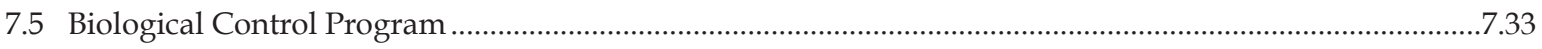

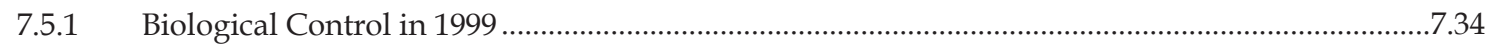

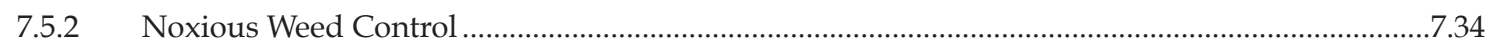

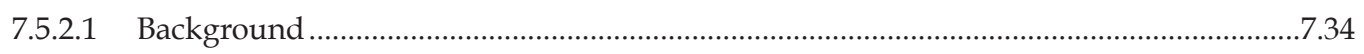

7.5.2.2 1999 Noxious Weed Control ...................................................................................................7.35

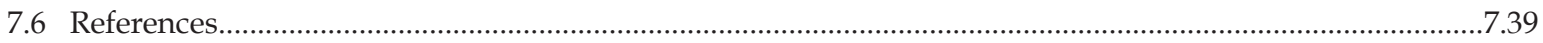

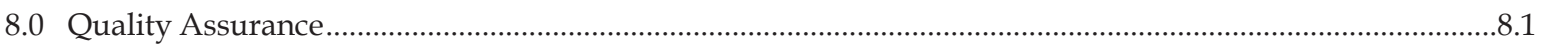

Environmental Surveillance and Groundwater Monitoring ...........................................................8.1

8.0.1.1 Project Management Quality Assurance …...................................................................8.1

8.0.1.2 Sample Collection Quality Assurance/Quality Control ................................................8.2

8.0.1.3 Analytical Results Quality Assurance/Quality Control .................................................8.2

8.0.1.4 DOE and EPA Comparison Studies...............................................................................

8.0.1.5 Pacific Northwest National Laboratory Evaluations …..................................................8.4

8.0.1.6 Laboratory Internal Quality Assurance Programs ............................................................8.5

8.0.1.7 Media Audits and Comparisons ....................................................................................8.

8.0.2 Effluent Monitoring and Near-Facility Environmental Monitoring................................................8.8

8.0.2.1 Sample Collection Quality Assurance.......................................................................... 8.9

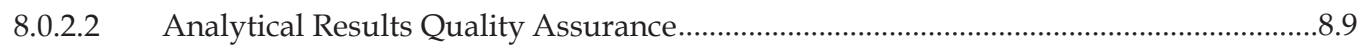

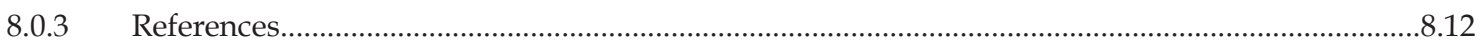

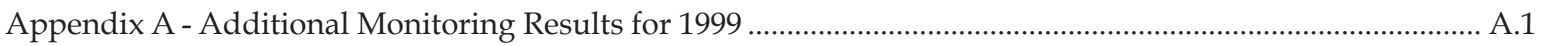

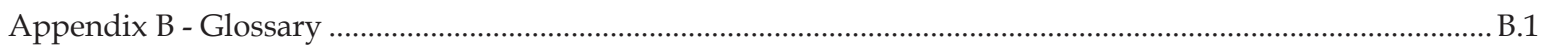

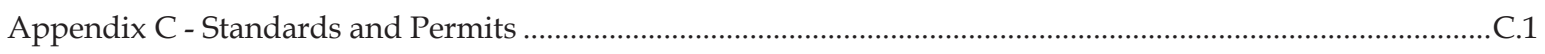

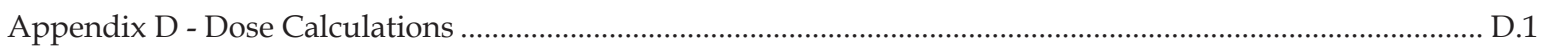

Appendix E - Radionuclides Detected by Gamma Spectroscopy …................................................................... E.1

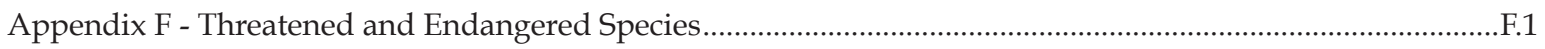




\section{Figures}

H.1 Data Plotted Using a Linear Scale.

lvi

H.2 Data Plotted Using a Logarithmic Scale ..........................................................................................

H.3 Data with Error Bars Plotted Using a Linear Scale ................................................................................ii

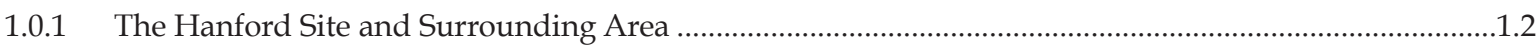

1.0.2 Waste Processing, Storage, and Disposal Facilities in the 200 Areas .......................................................

3.1.1 Liquid Releases of Selected Radionuclides from Hanford Site Facilities, 1992 Through 1999.

3.1.2 Airborne Releases of Selected Radionuclides from Hanford Site Facilities, 1992 Through 1999.

3.2.1 Average Concentrations of Selected Radionuclides in Near-Facility Air Samples Compared to Those in Distant Communities, 1994 Through 1999.

3.2.2 Average Concentrations of Selected Radionuclides in Near-Facility Soil Samples Compared to Those in Distant Communities, 1994 Through 1999.

3.2.3 Average Concentrations of Selected Radionuclides in Near-Facility Vegetation Samples Compared to Those in Distant Communities, 1994 Through 1999

3.2.4 Average Annual Dose Rate at N Springs

3.2.5 Annual Average Thermoluminescent Dosimeter Results in the 100-N Area

3.2.6 Annual Average Thermoluminescent Dosimeter Results in the 200 Areas

3.2.7 Annual Average Thermoluminescent Dosimeter Results in the 300/400 Areas and at the 300 Area Treated Effluent Disposal Facility

4.0.1 Primary Exposure Pathways

4.1.1 Air Sampling Locations, 1999.

4.1.2 Gross Alpha in Airborne Particulate Samples, 1994 Through 1999.

4.1.3 Annual Average Tritium Concentrations in Air, 1995 Through 1999 
4.1.4 Gross Beta in Airborne Particulate Samples, 1994 Through 1999

4.1.5 Annual Average Strontium-90 Concentrations in Air, 1994 Through 1999

4.1.6 Iodine-129 Concentrations in Air, 1994 Through 1999.

4.1.7 Annual Average Plutonium-239/240 Concentrations in Air, 1994 Through 1999

4.1.8 Annual Average Uranium-238 Concentrations in Air, 1994 Through 1999

4.2.1 Water and Sediment Sampling Locations, 1999.

4.2.2 Mean Monthly Columbia River Flow Rates, 1999.

4.2.3 Annual Average Gross Alpha Concentrations in Columbia River Water, 1994 Through 1999

4.2.4 Annual Average Gross Beta Concentrations in Columbia River Water, 1994 Through 1999.

4.2.5 Annual Average Tritium Concentrations in Columbia River Water, 1994 Through 1999

4.2.6 Annual Average Strontium-90 Concentrations in Columbia River Water, 1994 Through 1999.

4.2.7 Annual Average Total Uranium Concentrations in Columbia River Water, 1994 Through 1999

4.2.8 Annual Average Iodine-129 Concentrations in Columbia River Water, 1994 Through 1999. 4.26

4.2.9 Tritium Concentrations in Water Samples from Columbia River Transects, September 1999

4.2.10 U.S. Geological Survey Columbia River Water Quality Measurements, 1994 Through 1999.

4.2.11 Median, Maximum, and Minimum Concentrations of Selected Radionuclides Measured in Columbia and Snake River Sediments, 1994 Through 1999

4.2.12 Median, Maximum, and Minimum Concentrations of Selected Metals Measured in Columbia and Snake River Sediments, 1999

4.2.13 Average Acid Volatile Sulfide, Simultaneously Extracted Zinc, and Sum of Simultaneously Extracted Metals in Columbia River and Snake River Sediments for 1997, 1998, and 1999

4.2.14 Concentrations of Constituents of Interest in Columbia River Riverbank Spring Water at the Old Hanford Townsite, 1994 Through 1999 
4.2.15 Concentrations of Constituents of Interest in Water from a Columbia River Riverbank Spring

Near the 300 Area, 1994 Through 1999.

4.2.16 Median, Maximum, and Minimum Gross Beta and Tritium Concentrations in Fast Flux Test Facility Pond Water Samples, 1994 Through 1999

4.2.17 Median, Maximum, and Minimum Concentrations of Selected Radionuclides in West Lake Water Samples, 1994 Through 1999.

4.3.1 Hanford Site Primary Drinking Water Supply Facilities, 1999.

4.3.2 Tritium Concentrations in Drinking Water from Three Wells in the 400 Area, 1984 Through 1999

4.4.1 Food and Farm Product Sampling Locations, 1999

4.4.2 Median, Maximum, and Minimum Strontium-90 Concentrations in Milk, 1994 Through 1999.

4.4.3 Median, Maximum, and Minimum Iodine-129 Concentrations in Milk, 1994 Through 1999.

4.4.4 Tritium Concentrations in Milk Collected Near the Hanford Site, 1999.

4.4.5 Regression of Tritium Concentrations in Milk and Dairy Water

4.4.6 Median, Maximum, and Minimum Tritium Concentrations in Wine Samples Collected in 1994 Through 1999

4.5.1 Fish and Wildlife Sampling Locations, 1999

4.5.2 Average and Maximum Strontium-90 Concentrations in Bass Carcasses, 1983 Through 1999

4.5.3 Comparison of Average and Maximum Cesium-137 Concentrations in Elk and Deer Muscle

4.5.4 Comparison of Average and Maximum Strontium-90 Concentrations in Elk and Deer Bone

4.6.1 Columbia River Shoreline Vegetation Sampling Locations on and Near the Hanford Site, 1999.

4.6.2 Tritium in Columbia River Shoreline Vegetation 1990-1992 and 1999

4.6.3 Strontium-90 in Columbia River Shoreline Vegetation 1990-1992 and Mulberry Tree and Reed Canary Grass in 1999 
4.6.4 Strontium-90 in Mulberry Leaf Samples Collected Along the Columbia River in Early Summer and Fall, 1999

4.6.5 Soil Sampling Locations in and Near the Former 1100 Area, 1999

4.7.1 Thermoluminescent Dosimeter Locations and Station Numbers on the Hanford Site, 1999

4.7.2 Thermoluminescent Dosimeter Locations and Station Numbers for Community, Distant, and Perimeter Sites, 1999

4.7.3 Thermoluminescent Dosimeter Locations and Station Numbers Along the Columbia River, 1999.

4.7.4 Annual Average Dose Rates, 1994 Through 1999.

5.0.1 Locations Important to Dose Calculations

5.0.2 Calculated Dose to the Hypothetical, Maximally Exposed Individual, 1995 Through 1999.

5.0.3 Calculated Dose to the Population Within 80 Kilometers of the Hanford Site, 1995 Through 1999.

5.0.4 National Annual Average Radiological Doses from Various Sources

6.1.1 Active Liquid Wastewater Discharge Sites at Hanford

6.1.2 Water Supply Wells in the Unconfined Aquifer

6.1.3 Geologic Cross Section of the Hanford Site.

6.1.4 Saturated Thickness of the Unconfined Aquifer

6.1.5 Water-Table Elevations for the Unconfined Aquifer at the Hanford Site and in Adjacent Areas East and North of the Columbia River, March 1999

6.1.6 Transmissivity Distribution in the Unconfined Aquifer.

6.1.7 Change in Water-Table Elevations, June 1998 Through March 1999.

6.1.8 Unconfined Aquifer Monitoring Well Locations

6.1.9 Confined Aquifer Monitoring Well Locations 6.20

6.1.10 Locations of RCRA Groundwater Monitoring Projects 6.21 
6.1.11 Average Tritium Concentrations in the Unconfined Aquifer, 1999.

6.1.12 Tritium Concentrations in Well 199-K-30, 1982 Through 1999

6.1.13 Tritium Concentrations in Well 699-40-1, 1962 Through 1999

6.1.14 Tritium Concentrations in Well 699-24-33, 1962 Through 1999

6.1.15 Historical Tritium Concentrations on the Hanford Site 6.31

6.1.16 Average Tritium Concentrations and Groundwater Flow Near the 300 Area, 1999 6.34

6.1.17 Average Iodine-129 Concentrations in the Unconfined Aquifer, 1999 6.36

6.1.18 Average Technetium-99 and Strontium-90 Concentrations in the Unconfined Aquifer Near the 200-East Area, 1999.

6.1.19 Average Technetium-99 Concentrations and Uranium Concentrations in the Unconfined Aquifer in the 200-West Area, 1999

6.1.20 Average Uranium Concentrations in the Unconfined Aquifer in the 300 Area, 1999, and Concentration Trends for Select Wells

6.1.21 Average Strontium-90 Concentrations in the Unconfined Aquifer in the 100-B,C Area, 1999 6.44

6.1.22 Average Strontium-90 Concentrations in the Unconfined Aquifer in the 100-N Area, 1999. 6.45

6.1.23 Average Carbon-14 Concentrations in the 100-K Area, 1999. 6.47

6.1.24 Average Nitrate Concentrations in the Unconfined Aquifer, 1999 6.50

6.1.25 Average Filtered Chromium Concentrations in the 100-D and 100-H Areas, 1999 6.54

6.1.26 Average Filtered Chromium Concentrations in the 100-K Area, 1999 6.56

6.1.27 Average Carbon Tetrachloride Concentrations in the Unconfined Aquifer in the 200-West Area, 1999

6.1.28 Average Chloroform Concentrations in the Unconfined Aquifer in the 200-West Area, 1999 .6 .60

6.1.29 Average Trichloroethylene Concentrations in the Unconfined Aquifer in the 200-West Area, 1999 
6.1.30 Average Trichloroethylene Concentrations in the Vicinity of the Former Horn Rapids

Landfill and Richland North Area, 1999

6.2.1 Temperature Distribution in Borehole 41-09-39.

6.2.2 Plan View of T Tank Farm with Monitoring Boreholes

6.2.3 Example of a Radionuclide Concentration Log.

6.2.4 Vadose Zone Contamination at the A Tank Farm, 200-East Area

6.2.5 Vadose Zone Contamination at the T Tank Farm, 200-West Area

6.2.6 Vadose Zone Contamination at the T Tank Farm, 200-West Area

6.2.7 Vadose Zone Contamination at the B Tank Farm, 200-East Area.

6.2.8 Location of Wells and Deep Soil-Vapor Monitoring Probes at the Carbon Tetrachloride Vapor-Extraction Site, 200-West Area.

6.2.9 Time Series Concentrations of Carbon Tetrachloride in Soil Vapor Extracted from the 216-Z-9 Well Field and the 216-Z-1A/-12/-18 Well Fields in 1999

6.2.10 Conceptual Model of Carbon Tetrachloride and Wastewater Migration Beneath 216-Z-9 Trench, 200-West Area.

6.2.11 Cross Section of the Hanford Site Prototype Barrier Showing Interactive Water Balance Processes, Gravel Side Slope, and Basalt Riprap Slope

6.2.12 Temporal Variation in Mean Soil Water Storage at the Prototype Surface Barrier, November 1994 to September 1998

6.2.13 Cumulative Drainage at the Prototype Surface Barrier from November 1994 Through October 1998 from Four Side-Slope Plots and One Soil Plot that Drained

6.2.14 Comparison of Helium-3/Helium-4 Radios for Samples Collected at the Old Hanford Townsite.

6.2.15 Helium-3/Helium-4 Ratios at the Study Site Near KE Reactor

7.1.1 Hanford Meteorological Monitoring Network Wind Roses, 1999

7.2.1 Chinook Salmon Spawning Redds in the Hanford Reach, 1948 Through 1999. .7 .10 
7.2.3 Elk on the Hanford Site: Post-Calving and Post-Hunting Periods, 1975 Through 1999

7.2.4 Roadside Survey Results Depicting Percent of Bucks with Testicular Atrophy on the Hanford Site, 1993-1999.

7.2.5 Roadside Survey Results for Trends in Fawn Ratios Seen Per Survey on the Hanford Site, 1993-1999

7.2.6 Number of Canada Goose Nests Along the Hanford Reach, 1954 Through 1999

7.2.7 Rare Plant Locations on the Hanford Site Based on 1994, 1995, 1997, and 1998 Surveys

Conducted by The Nature Conservancy of Washington

7.2.8 Sage Sparrow and Loggerhead Shrike Occurrences in Big Sagebrush/Bunchgrass Communities on the Hanford Site, 1996-1999

7.2.9 Relative Abundance of Small Mammals in Shrub-Steppe Communities on the Hanford Site

7.3.1 Total Measured Loss at Locke Island's Erosion Transects Between November 1995 and September 1999

7.3.2 Measured Loss at Locke Island's Erosion Transects During Fiscal Year 1999

7.3.3 Cultural Resources Reviews Requested Each Calendar Year .7 .26

7.3.4 Historic Sites are Commonly Found During Surveys Conducted at the Hanford Site

7.3.5 Hanford Buildings and Structures Documented with a Washington State Historic Property Inventory Form

7.3.6 105-C Reactor, One of Several Structures Included in the Hanford Site Manhattan Project and Cold War Era Historic District.

7.4.1 Community Members See Environmental Surveillance in Action at a Community-Operated Environmental Surveillance Station in Richland. 


\section{Tables}

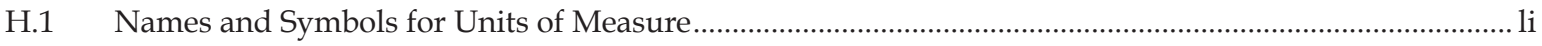

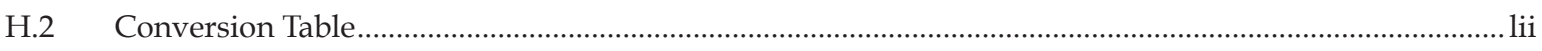

H.3 Names and Symbols for Units of Radioactivity …........................................................................... lii

H.4 Names and Symbols for Units of Radiation Dose or Exposure ….......................................................iii

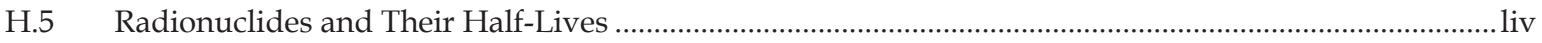

H.6 Elemental and Chemical Constituent Nomenclature .................................................................... lv

2.2.1 Emergency Planning and Community Right-To-Know Act Compliance Reporting, 1999 ..................2.14

2.2.2 RCRA Interim- and Final-Status Groundwater Monitoring Projects ..................................................2.16

2.2.3 New Well Installation Summary for Calendar Year 1999 ..................................................................2.19

2.2.4 Noncompliance for Outfall 001 at the 310 Treated Effluent Disposal Facility, 1999.............................2.24

2.5.1 Quantities of Solid Waste Generated on the Hanford Site ..................................................................2.64

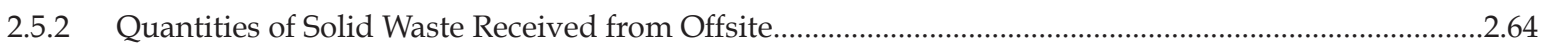

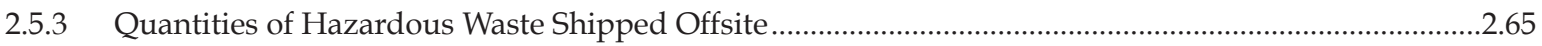

2.5.4 Radioactive Solid Waste Stored or Disposed of on the Hanford Site, 1999 .......................................2.66

2.5.5 Quantities of Liquid Waste Generated and Stored Within the Tank Farm System on the Hanford Site in Calendar Year 1999 and in Each of the Previous 5 Calendar Years ..............................2.67

2.5.6 Average Balance of Ten Hazardous Chemicals Stored in Greatest Quantity on the Hanford Site, 1999

3.1.1 Radionuclides Discharged to the Atmosphere at the Hanford Site, 1999

3.1.2 Nonradioactive Constituents Discharged to the Atmosphere at the Hanford Site, 1999

3.1.3 Radionuclides in 200 Areas' Liquid Effluents Discharged to the State-Approaved Land Disposal Site in 1999 
3.1.5 Releases to the Environment at the Hanford Site, 1999

3.2.3 Annual Average and Maximum Concentrations of Radionuclides in Near-Facility Air Samples, 1999.

3.2.4 Radionuclides Concentrations in 100-N Area Riverbank Springs, 1999.

3.2.5 Outdoor Contamination Status, 1999

3.2.7 Average Radionuclide Concentrations Detected in Surface Soil Samples Near the 1301-N Liquid Waste Disposal Facility, 1994 Through 1999.

3.2.8 Average Radionuclide Concentrations Detected in 100-N Area Surface Soil Samples, 1994

Through 1999

3.2.9 Concentration of Selected Radionuclides in 100-N Area Soil, 1999

3.2.10 Concentration of Selected Radionuclides in 200/600 Areas Soil, 1999

3.2.11 Concentration of Selected Radionuclides in 300/400 Areas Soil, 1999

3.2.12 Radionuclide Concentrations in Environmental Restoration Contractor Projects' Soil Samples, 1999

3.2.13 Average Radionuclide Concentrations Detected in Vegetation Samples Collected Near the 1301-N Liquid Waste Disposal Facility, 1994 Through 1999

3.2.14 Average Radionuclide Concentrations Detected in 100-N Area Vegetation Samples, 1994 to 1999.

3.2.15 Average Radionuclide Concentrations Detected in N Springs Vegetation Samples, 1994 to 1999

3.2.16 Concentration of Selected Radionuclides in 100-N Area Vegetation, 1999. 
3.2.19 Thermoluminescent Dosimeter Results for Waste Handling Facilities, 1998 and 1999, mrem/year Based on 24 hours/day

4.0.1 Routine Environmental Surveillance Sample Types and Measurement Locations, 1999.

4.0.2 Samples Collected for the Surface Environmental Surveillance Project and Analytical Results Obtained, 1999

4.1.1 Air Sampling Locations, Sample Composite Groups, and Analyses, 1999

4.1.2 Airborne Radionuclide Concentrations in the Hanford Environs, 1999 Compared to Previous Years.

4.2.1 Surface-Water Surveillance, 1999

4.2.2 Sediment Surveillance, 1999

4.2.3 Selected Radionuclide Concentrations in 100-N Area Riverbank Spring Water, 1994 Through 1999

4.2.4 Concentration Ranges of Selected Chemicals in Water from Columbia River Riverbank Springs, 1997 Through 1999

4.3.1 DOE-Owned Drinking Water Systems on the Hanford Site, 1999

4.3.2 Selected Radiological Constituents in Hanford Site Drinking Water, 1999 Annual Average Concentrations

4.3.3 Tritium Concentrations in 400 Area Drinking Water Wells, 1999

4.4.1 Locations, Sampling Frequencies, and Analyses Performed for Routinely Sampled Food and Farm Products, 1999

4.5.1 Locations, Species, and Contaminants Sampled for Fish and Wildlife, 1999 .4 .65

4.5.2 Strontium-90 Concentrations in Columbia River Fish Carcasses, 1999 Compared to Previous 9 Years. .4 .66

4.5.3 Cesium-137 and Strontium-90 Concentrations in Canada Geese, 1999 Compared to Previous 5 Years. .4 .69 
4.5.4 Cesium-137 and Strontium-90 Concentrations in Rabbits, 1999 Compared to Previous

9 Years

4.6.1 Concentrations of Selected Radionuclides in Surface Soil Samples Collected in and Near the Former 1100 Area in July 1999 and at Hanford Site Perimeter Locations in Previous Years....

4.6.2 Strontium-90 Concentrations in Vegetation Samples Collected on the Hanford Site by the Wanapum People, June 1999

4.7.1 Dose Rates Measured by Thermoluminescent Dosimeters at Perimeter and Offsite Locations, 1999 Compared to Previous 5 Years

4.7.2 Dose Rates Measured by Thermoluminescent Dosimeters Along the Hanford Reach of the Columbia River, 1999 Compared to Previous 5 Years

4.7.3 Dose Rates Measured by Thermoluminescent Dosimeters on the Hanford Site, 1999

Compared to Previous 5 Years

4.7.4 Average Exposure Rates Measured by Pressurized Ionization Chambers at Four Offsite Locations, 1999

4.7.5 Quarterly Average Exposure Rates Measured by Thermoluminescent Dosimeters at Four Offsite Locations, 1999

5.0.1 Dose to the Hypothetical, Maximally Exposed Individual Residing at Sagemoor from 1999 Hanford Operations

5.0.2 Dose to the Population from 1999 Hanford Operations

5.0.3 Summary of Doses to the Public in the Vicinity of the Hanford Site from Various Sources, 1999.

5.0.4 Estimated Risk from Various Activities and Exposures

5.0.5 Activities Comparable in Risk to the 0.008-mrem Dose Calculated for the 1999 Maximally Exposed Individual

6.1.1 Chemical and Radiological Groundwater Contaminants and Their Link to Site Operations. 6.15

6.1.2 Operable Units and Associated Contaminants of Concern 
6.1.4 Radionuclides and Chemicals Analyzed for in Groundwater, 1999.

6.2.1 Composition of Sediment from Borehole 41-09-39 in SX Tank Farm .....

6.2.2 Water Leachable Chemicals in Sediment from Borehole 41-09-39 in SX Tank Farm.....

6.2.3 Acid Extractable Chemicals in Sediment from Borehole 41-09-39 in SX Tank Farm.

6.2.4 Estimates of Mobility of Cesium, Technetium, and Chromium in Samples from Borehole 41-09-39 in the SX Tank Farm, Based on the Percent of the Constitiuent Leached by Water.

6.2.5 Calculated In Situ Distribution Coefficients for Samples from Borehole 41-09-39 in SX Tank Farm . 6.82

6.2.6 Average 4-Day Sediment-Water Contact Time $\mathrm{K}_{\mathrm{d}}$ and Standard Deviation for Hexavalent Chromium and Total Chromium Adsorption in Batch Adsorption Tests on Contaminated Vadose Zone Sediments from the 100-D Area 6.99

6.2.7 Average 14-Day Sediment-Water Contact Time $\mathrm{K}_{\mathrm{d}}$ and Standard Deviation for Hexavalent Chromium and Total Chromium Adsorption in Batch Adsorption Tests on Contaminated Vadose Zone Sediments from the 100-D Area 6.99

6.2.8 Carbon Tetrachloride Inventory in 200-West Area Primary Disposal Sites 6.102

6.2.9 Liquid Disposal Facilities and Associated Boreholes and Wells in the 200-East Area Monitored with Spectral Gamma-Ray and Neutron Moisture Tools, Fiscal Year 1999 6.107

7.1.1 Monthly Climatological Data from the Hanford Meteorology Station, 1999

7.2.1 Numbers of Rorippa columbiae Stems Counted Along the Hanford Reach of the Columbia River, 1994, 1998, and 1999.

8.0.1 Summary of Surface Environmental Surveillance Project Field Duplicate Results, 1999

8.0.2 Summary of Performance on EPA Water Pollution and Water Supply Studies, 1999 .....

8.0.3 Summary of Performance on DOE Quality Assessment Program Samples, 1999

8.0.4 Summary of Performance on Environmental Resource Associates Proficiency Testing Program, 1999

8.0.5 Summary of Hanford Groundwater Monitoring Project Double-Blind Spike Determinations, 1999. 
8.0.6 Summary of Surface Environmental Surveillance Project Blind Spiked Determinations,

1999.

8.0.7 Comparison of U.S. Food and Drug Administration Cosampling, 1999

8.0.8 Comparison of Thermoluminescent Dosimeter Results with Known Exposure, 1999

8.0.9 Hanford Site Laboratories Used by Contractor and Sample Type, 1999

8.0.10 Waste Sampling and Characterization Facility Performance on DOE Quality Assessment Program Samples, 1999

8.0.11 222-S Analytical Laboratory Performance on DOE Quality Assessment Program Samples, 1999.

8.0.12 222-S Analytical Laboratory Performance on Environmental Resource Associates Laboratory Water Pollution Inorganic Studies, 1999.

A.1 Radionuclide Concentrations in Columbia River Water at Priest Rapids Dam, 1999 Compared to Previous 5 Years

A.2 Radionuclide Concentrations in Columbia River Water at the Richland Pumphouse, 1999

Compared to Previous 5 Years

A.3 Radionuclide Concentrations Measured in Columbia River Water Along Transects of the Hanford Reach, 1999.

A.4 Radionuclide Concentrations Measured in Columbia River Water at Nearshore Locations in the Hanford Reach, 1999

A.5 Selected U.S. Geological Survey Columbia River Water Quality Data, 1999 A.6

A.6 Radionuclide Concentrations in Sediments from the Columbia and Snake Rivers and from Columbia River Riverbank Springs, 1999 Compared to Previous 5 Years

A.7 Median Metal Concentrations in Columbia and Snake River Sediments, 1999

A.8 Radionuclide Concentrations Measured in Riverbank Springs Water, 1999 Compared to Previous 5 Years

C.1 Washington State Water Quality Standards for the Hanford Reach of the Columbia River .....

C.2 Selected Drinking Water Standards. .C.3 
C.3 Selected Surface Freshwater Quality Criteria for Toxic Pollutants

C.4 Radiation Standards for Protection of the Public from All Routine DOE Concentrations...

C.5 Selected Derived Concentration Guides......

C.6 Environmental Permits

D.1 Food Pathway Parameters Used in Dose Calculations, 1999 .............................................................. D.4

D.2 Dietary Parameters Used in Dose Calculations, 1999 …....................................................................... D.5

D.3 Residency Parameters Used in Dose Calculations, 1999 ................................................................ D.5

D.4 Recreational Parameters Used in Dose Calculations, 1999 .............................................................. D.6

D.5 Technical Details of 100 Areas Airborne Release Dose Calculations, 1999 _......................................... D.6

D.6 Technical Details of 100-N Area Liquid Release Dose Calculations, 1999 .......................................... D.7

D.7 Technical Details of 200 Areas Airborne Release Dose Calculations, 1999 _........................................ D.8

D.8 Technical Details of 300 Area Airborne Release Dose Calculations, 1999.......................................... D.9

D.9 Technical Details of 400 Area Airborne Release Dose Calculations, 1999......................................... D.10

D.10 Annual Dose to Workers in the 400 Area from Ingestion of Drinking Water Obtained from Groundwater Wells, 1999

E.1 Radionuclides Analyzed by Gamma Spectroscopy

F.1 Federal- or Washington State-Listed Threatened and Endangered Species on the Hanford Site

F.2 Washington State Candidate Animal Species on the Hanford Site.

F.3 Washington State Plant Species of Concern on the Hanford Site 


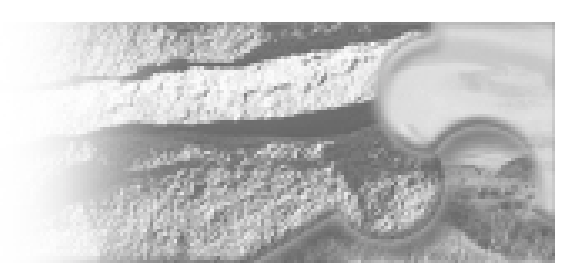

\section{Summary}

This Hanford Site environmental report is prepared annually to summarize environmental data and information, to describe environmental management performance, to demonstrate the status of compliance with environmental regulations, and to highlight major environmental programs and efforts.

The report is written to meet requirements and guidelines of the U.S. Department of Energy (DOE) and to meet the needs of the public. This summary has been written with a minimum of technical terminology.

Individual sections of the report are designed to

- describe the Hanford Site and its mission

- summarize the status of compliance with environmental regulations
- describe the environmental programs at the Hanford Site

- discuss the estimated radionuclide exposure to the public from 1999 Hanford Site activities

- present the effluent monitoring, environmental surveillance, and groundwater protection and monitoring information

- discuss the activities to ensure quality.

More detailed information can be found in the body of the report, the cited references, and the appendixes.

\section{The Hanford Site and its Mission}

The Hanford Site in southcentral Washington State is $\sim 1,517$ square kilometers (586 square miles) of semiarid shrub and grasslands located just north of the confluence of the Snake and Yakima Rivers with the Columbia River. This land, with restricted public access, provides a buffer for the smaller areas historically used for the production of nuclear materials, waste storage, and waste disposal. Approximately $6 \%$ of the land area has been disturbed, is actively used, and is divided into operational areas:

- the 100-B,C, 100-D, 100-F, 100-H, 100-K, and 100-N Areas, which lie along the south shore of the Columbia River in the northern portion of the Hanford Site (containing reactors used primarily for plutonium production; now all shut down)

- the 200-East and 200-West Areas, which lie in the center of the Hanford Site near the basalt outcrops of Gable Mountain and Gable Butte (formerly used for plutonium processing; now focused on waste management)
- the 300 Area, near the southern border of the Hanford Site (containing laboratories, support facilities, and former reactor fuel manufacturing facilities)

- the 400 Area, between the 300 and 200 Areas (home of the Fast Flux Test Facility)

- the Richland North Area, in the northern part of the city of Richland (includes leased office buildings for DOE and its contractors).

The 600 Area is the land between the operational areas. Areas off the Hanford Site used for research and technology development and administrative functions can be found in Richland, Kennewick, and Pasco, the nearest cities.

The Hanford Site was acquired by the federal government in 1943 and, until 1989, was dedicated primarily to the production of plutonium for national defense and the management of the resulting wastes. With the shutdown of the production facilities in the 1970s and 1980s, DOE ended the production of 
nuclear materials for weapons at the Hanford Site. The current mission being implemented by DOE is now:

- waste management, environmental restoration, and facilities stabilization

- research and technology development.

Current waste management at the Hanford Site focuses primarily on managing wastes with high and low levels of radioactivity (from the nuclear materials production activities) in the 200-East and 200-West Areas. Key waste management facilities include the underground waste storage tanks, Environmental Restoration Disposal Facility, Central Waste Complex, low-level burial grounds, 200 Areas Effluent Treatment Facility, Waste Receiving and Processing Facility, 242-A Evaporator, State-Approved Land Disposal Site, Liquid Effluent Retention Facility, and 200 Areas Treated Effluent Disposal Facility. In addition, irradiated nuclear fuel is stored in the 100-K Area in fuel storage basins.

Environmental restoration includes activities to decontaminate and decommission facilities and to clean up or restore inactive waste sites. The Hanford surplus facilities program conducts surveillance and maintenance of such facilities; the cleanup and disposal of more than 100 facilities have begun.

Development of research and technology capabilities is intended to improve the techniques and reduce the costs of waste management, environmental protection, and site restoration.

DOE manages operations on the Hanford Site through six prime contractors and numerous subcontractors. Each contractor is responsible for the safe, environmentally sound maintenance and management of its facilities and operations, management of its wastes, and monitoring of its operations and effluents for environmental compliance.

The principal contractors include the following:

- Fluor Hanford, Inc.

- Battelle Memorial Institute

- Bechtel Hanford, Inc.

- Hanford Environmental Health Foundation

- CH2M HILL Hanford Group, Inc.

- MACTEC-ERS.

Non-DOE operations and activities include commercial power production by Energy Northwest (formerly known as the Washington Public Power Supply System) at its WNP-2 Reactor and operation of a commercial low-level radioactive waste burial site by US Ecology, Inc. Kaiser Aluminum and Chemical Corporation leases the 313 Building to operate a formerly DOE-owned extrusion press. The National Science Foundation built the Laser Interferometer Gravitational-Wave Observatory facility near Rattlesnake Mountain. R. H. Smith Distributing operates vehicle fueling stations in the former 1100 Area and the 200 Areas. Washington State University at TriCities operates three laboratories in the 300 Area. Livingston Rebuild Center, Inc. leases the former 1171 Building in the former 1100 Area to rebuild train locomotives. Johnson Controls, Inc. operates 42 diesel and natural gas package boilers to produce steam in the 200 and 300 Areas and also has compressors that supply compressed air to the site. Immediately adjacent to the southern boundary of the Hanford Site, Siemens Power Corporation operates a commercial nuclear fuel fabrication facility and Allied Technology Group Corporation operates a low-level radioactive waste decontamination, supercompaction, and packaging disposal facility.

\section{Compliance with Environmental Regulations}

DOE Order 5400.1, "General Environmental Protection Program," describes the environmental standards and regulations applicable at DOE facilities. These standards and regulations fall into three categories: 1) DOE directives; 2) federal legislation and executive orders; and 3) state and local 
statutes, regulations, and requirements. The following summarizes the status of Hanford's compliance with applicable regulations.

A key element in Hanford's compliance program is the Hanford federal facility agreement and consent order (also known as the Tri-Party Agreement; Ecology et al. 1998). The Tri-Party Agreement is an agreement among the U.S. Environmental Protection Agency (EPA), Washington State Department of Ecology, and DOE for achieving compliance with the remedial action provisions of the Comprehensive Environmental Response, $C$ ompensation, and L iability A ct (CERCLA) and with treatment, storage, and disposal unit regulation and corrective action provisions of the Resource C onservation and Recovery A ct (RCRA). From 1989 through 1999, a total of 636 enforceable Tri-Party Agreement milestones and 253 unenforceable target dates were completed on or ahead of schedule. Forty-one milestones scheduled for 1998 were completed.

\section{Comprehensive Environmental Response, Compensation, and Liability Act}

This act established a program to ensure that responsible parties or the government cleans up sites contaminated by hazardous substances. The act primarily covers waste cleanup of inactive sites.

Preliminary assessments conducted for the Hanford Site revealed 2,200 known individual waste sites where hazardous substances may have been disposed of in a manner that requires further evaluation to determine impact to the environment.

DOE is actively pursuing the remedial investigation/feasibility study process at some operable units on the Hanford Site. The operable units currently being studied were selected as a result of Tri-Party Agreement negotiations.

In 1999, the Hanford Site was in compliance with requirements of the act. Cleanup is under way at various areas on the site. Full-scale remediation of waste sites continued in the 100 and 300 Areas in 1999.

\section{Emergency Planning and Community Right-To-Know Act}

This act requires that the public be provided with information about hazardous chemicals in the community and establishes emergency planning and notification procedures to protect the public from a release. The act calls for creation of state emergency response commissions to guide planning for chemical emergencies. State commissions have also created local emergency planning committees to ensure community participation and planning.

To provide the public with the basis for emergency planning, the act contains requirements to report periodically on hazardous chemicals stored and/or used near the community. An updated material safety data sheet listing was issued in April 1999 to the State Emergency Response Commission, local county emergency management committees, and local fire departments. The listing consisted of 33 hazardous chemicals present in quantities exceeding minimum threshold levels, including three extremely hazardous substances. No subsequent updates to the listing were required during 1999. The 1999 Hanford Site Tier Two Emergency and Hazardous Chemical Inventory was issued in February 2000. During 1999, the Hanford Site was in compliance with the reporting and notification requirements contained in this act.

\section{Resource Conservation and Recovery Act}

This act establishes regulatory standards for the generation, transportation, storage, treatment, and disposal of hazardous wastes. The Washington State Department of Ecology has been authorized by EPA to implement its dangerous waste program except for 
some provisions of the Hazardous and Solid Waste Amendments of 1984. The Washington State Department of Ecology implements the state's regulations, which are often more stringent. The act primarily covers ongoing waste management at active facilities.

The Hanford Site is considered a single facility with over 70 treatment, storage, and disposal units. The Tri-Party Agreement recognized that all of these units could not be issued permits simultaneously, and a schedule was established for submitting unitspecific permit applications and closure plans to the Washington State Department of Ecology. During 1999, five Part A revisions and one new Part A application were submitted to the Washington State Department of Ecology. Two Part B applications were also submitted, and three closure-related documents were filed.

Subtitle I of the act deals with regulation of underground storage tank systems. The Hazardous and Solid Waste Amendments of 1984 added these regulations to the act. EPA developed regulations to implement technical standards for tank performance and management, including standards governing the cleanup and closure of leaking tanks. However, these regulations do not apply to the single- and doubleshell waste tanks at Hanford, which are regulated as treatment, storage, and disposal facilities.

DOE and its contractors are working to resolve several outstanding notices of violation and warning letters of noncompliance from the Washington State Department of Ecology that were received following inspections in 1999. Each of the notices lists specific violations.

\section{Clean Air Act}

The purpose of the Clean A ir A ct is to protect public health and welfare by safeguarding air quality, bringing polluted air into compliance, and protecting clean air from degradation. In Washington State, EPA, Washington State Department of Ecology, Washington State Department of Health, and local air authorities implements the provisions of the act.
Washington State regulations require applicable controls and annual reporting of all radioactive air emissions. The Hanford Site operates under a license for such emissions. The conditions specified in the license will be incorporated into the Hanford Site air operating permit, scheduled to be issued in 2000.

Revisions to the act for radioactive air emissions were issued in December 1989. Emissions from the Hanford Site are within the state and EPA offsite emissions standard of $10 \mathrm{mrem} / \mathrm{yr}$. Nearly all Hanford Site sources currently meet the procedural requirements for flow measurement, emissions measurement, quality assurance, and sampling documentation.

The local air authority (the Benton Clean Air Authority) regulations pertain to detrimental effects, open burning, odor, opacity, and asbestos handling. The authority has also been delegated responsibility to enforce the EPA asbestos regulations under the revised act.

There were several compliance findings following inspections by the Washington State Department of Health and the Washington State Department of Ecology in 1999. All but one were resolved by the end of calendar year 1999 .

\section{Clean Water Act}

The C lean W ater A ct applies to point discharges to waters of the United States. At the Hanford Site, the regulations are applied through National Pollutant Discharge Elimination System permits that govern effluent discharges to the Columbia River. The permits specify discharge points (called outfalls), effluent limitations, and monitoring requirements. The National Pollutant Discharge Elimination System permits for the Hanford Site were revised and combined into a single permit in April 1999. The single permit covers all three active outfalls: one for the 300 Area Treated Effluent Disposal Facility and two at the 100-K Area. All other former outfalls are inactive. Several permit violations occurred at the 
300 Area Treated Effluent Disposal Facility in 1999 despite the use of best available technology.

\section{Safe D rinking Water Act}

The National Primary Drinking Water Regulations of the Safe D rinking $W$ ater $A$ ct apply to the drinking water supplies at the Hanford Site and are enforced by the Washington State Department of Health. In 1999, all Hanford Site water systems were in compliance with requirements and agreements.

\section{Toxic Substances Control Act}

The requirements of the T oxic Substances C ontrol A ct are applied to regulate Hanford Site chemicals called polychlorinated biphenyls. The site is currently in compliance with an agreement to store these wastes beyond the regulatory limit. All radioactive polychlorinated biphenyl wastes are being stored pending development of treatment and disposal technologies and capabilities.

The EPA issued one Federal Facility Notice of Significant Noncompliance in early 1999 following inspections of the Hanford Site in 1998. The findings included 16 corrective actions. DOE Richland Operations Office submitted the required responses to the notice 16 days after the notice was issued.

\section{Federal Insecticide, Fungicide, and Rodenticide Act}

EPA is responsible for ensuring that a chemical, when used according to label instructions, will not present unreasonable risks to human health or the environment. This act and specific chapters of the Revised Code of Washington apply to storage and use of pesticides. In 1999, the Hanford Site was in compliance with these requirements.

\section{Endangered Species Act}

Many rare species of native plants and animals are known to occur on the Hanford Site. Two of these (bald eagle and the peregrine falcon) are listed by the U.S. Fish and Wildlife Service as endangered or threatened. Steelhead trout and spring chinook salmon are listed by the National Marine Fisheries Service. Other species are listed by the Washington State Department of Fish and Wildlife as endangered, threatened, or sensitive. Hanford Site activities complied with the requirements of this act in 1999.

National Historic Preservation Act, Archaeological Resources Protection Act, $\mathrm{N}$ ative American Graves Protection and Repatriation Act, American Indian Religious Freedom Act, $H$ istoric Sites Buildings and Antiquities Act, Archeological and Historic Preservation Act, and American Antiquities Preservation Act

Cultural resources on the Hanford Site are subject to the provisions of these acts. In 1999, the Hanford Site was in compliance with these acts.

\section{National Environmental Policy Act}

The $\mathrm{N}$ ational Environmental Policy Act establishes environmental policy to prevent or eliminate damage to the environment and to enrich our understanding of ecological systems and natural resources. This act requires that major federal projects that may significantly impact the environment be carefully reviewed and reported to the public in environmental impact statements. Other documents such as 
environmental assessments are also prepared in accordance with requirements of the act.

Several environmental impact statements related to programs or activities on the Hanford Site are in process or in the planning stage.

\section{Environmental Occurrences}

Onsite and offsite environmental occurrences (spills, leaks) of radioactive and nonradioactive effluent materials during 1999 were reported to DOE and other federal and state agencies as required by law. All emergency, unusual, and off-normal occurrence reports, including event descriptions and corrective actions, are available for review in the DOE Hanford Reading Room located on the campus of Washington State University at Tri-Cities, Richland, Washington. There were no emergency occurrence reports and one environmentally significant unusual occurrence report filed in 1999. There were several off-normal environmental release-related occurrence reports filed during 1999.

\section{Environmental Management Services}

Major contractors have issued Integrated Environment, Health, and Safety Management Systems plans at the Hanford Site. These programs, contractually mandated by DOE, are intended to protect the worker, public, and environment by integrating environment, health, and safety into the way work is planned and performed. An international voluntary consensus standard and DOE policy form the bases of the systems.

\section{Waste Management and Chemical Inventories}

Radioactive, hazardous, and mixed waste is generated at approximately 200 facilities on the Hanford Site. These wastes are handled and prepared for safe storage on the site or shipped off the site for treatment and disposal. In addition to newly generated waste, significant quantities of waste remain from over 50 years of nuclear material production. This waste from past operations at the Hanford Site resides in waste sites or is stored in several places awaiting cleanup and ultimate safe storage or disposal. Examples are high-level radioactive waste stored in single- and double-shell tanks and transuranic waste stored in vaults and on storage pads. Most of the environmental monitoring performed at the Hanford Site is focused on protecting the public from exposure to this waste and waste handling activities. See Section 2.5, "Waste Management and Chemical Inventories," for details.

\section{Environmental Monitoring Information}

Environmental monitoring of the Hanford Site consists of effluent monitoring, environmental surveillance, and groundwater and vadose zone monitoring. Effluent monitoring is performed as appropriate by the operators at the facility or at the point of release to the environment. Additional monitoring is conducted in the environment near facilities that discharge, or have discharged, effluents. Environmental surveillance consists of sampling and analyzing environmental media on and off the site to detect and quantify potential contaminants and to assess their environmental and human health significance.

The overall objectives of the monitoring and surveillance programs are to demonstrate compliance with applicable federal, state, and local regulations; confirm adherence to DOE environmental protection policies; and support environmental management decisions. 


\section{Effluent M onitoring}

Effluent monitoring includes facility effluent monitoring (monitoring effluents at the point of release to the environment) and near-facility environmental monitoring (monitoring the environment near operating facilities).

Facility Effluent Monitoring. Liquid and gaseous effluents that may contain radioactive and/or hazardous constituents are continually monitored at the Hanford Site. The monitoring is done mainly by collecting effluent samples near points where the effluent is released into the environment. These samples are analyzed for selected constituents and the results evaluated against federal, state, and local regulatory standards and permit requirements.

Effluent stream flows are determined mostly through the use of measuring instruments, with a lesser number calculated using process information. Effluents with the potential of containing radioactivity that may reach prescribed threshold levels are monitored for gross alpha and gross beta levels and, as warranted, specific gamma-emitting radionuclides. When warranted, nonradioactive hazardous constituents are also monitored.

The radioactivity in effluents released from most Hanford facilities is at or near levels practically indistinguishable from naturally occurring radioactivity present everywhere in the world. Cumulatively, these low levels contribute very little to the radiation dose received by people living in areas surrounding the site.

\section{Near-Facility Environmental Monitoring.}

The near-facility environmental monitoring program is designed to protect the environment adjacent to Hanford facilities and to ensure compliance with federal, state, and local regulations. Specifically, this program monitored new and existing sites, processes, and facilities for potential impacts and releases; fugitive emissions and diffuse sources from contaminated areas; and surplus facilities before decontamination or decommissioning. Air, surface water, springs, surface contamination, soil, vegetation, external radiation, and investigative sampling (which can include wildlife) were sampled. Some of the parameters typically monitored are $\mathrm{pH}$, radionuclide activities, radiation exposure levels, and concentrations of selected hazardous chemicals. Samples are collected from known or expected effluent pathways. These pathways are generally downwind of potential or actual airborne releases and downgradient of liquid discharges.

Near-Facility A ir Monitoring. Radioactivity in air was sampled by a network of continuously operating samplers at 85 locations near nuclear facilities. Air samplers were primarily located within $\sim 500$ meters (1,500 feet) of sites and/or facilities having the potential for, or history of, environmental releases, with an emphasis on the prevailing downwind directions. Of the radionuclide analyses performed, strontium-90, cesium-137, plutonium-239/ 240 , and uranium were consistently detected in the $100-\mathrm{K}, 100-\mathrm{N}$, and 200 Areas. Cobalt- 60 was consistently detected in the 100-N Area. Air levels for these radionuclides were elevated near facilities and compared to levels measured off the site.

100-N Springs Monitoring. Groundwater springs along the 100-N Area shoreline are sampled annually to verify the reported radionuclide releases to the Columbia River from past N Reactor operations. By characterizing the radionuclide concentrations in the springs along the shoreline, the results can be compared to the concentrations measured at the effluent monitoring well. In 1999, the radionuclide levels detected in samples from shoreline springs were highest in springs nearest the effluent monitoring well.

$\mathrm{N}$ ear-F acility Radiological Surveys. In 1999, there were $\sim 3,628$ hectares $(8,964$ acres $)$ of posted outdoor contamination areas and 594 hectares ( 1,468 acres) of posted underground radioactive materials areas, not including active facilities, at the Hanford Site. These areas were typically associated with burial grounds, covered ditches, cribs, and tank 
farms. The posted contamination areas vary between years because of an ongoing effort to clean, stabilize, and remediate areas of known contamination. During this time, new areas of contamination were being identified. It was estimated that the external dose rate at $80 \%$ of the identified outdoor contamination areas was less than $1 \mathrm{mrem} / \mathrm{h}$ measured at 1 meter ( 3.28 feet), though direct dose rate readings from isolated radioactive specks (a diameter of less than 0.6 centimeter [0.25 inch]) could have been considerably higher. Contamination levels of this magnitude did not significantly add to dose rates for the public or Hanford Site workers in 1999.

Soil and Vegetation Sampling from 0 perational A reas. Soil and vegetation samples were collected on or adjacent to waste disposal units and from locations downwind and near or within the boundaries of the operating facilities. Samples were collected to detect potential migration and deposition of facility effluents. Special samples were also taken where physical or biological transport problems were identified. Migration can occur as the result of resuspension from radioactively contaminated surface areas, absorption of radionuclides by the roots of vegetation growing on or near underground and surface-water disposal units, or by waste site intrusion by animals. Some radionuclide concentrations in soil and vegetation samples from near facilities were elevated when compared to concentrations measured off the site. The levels show a large degree of variance; in general, samples collected on or adjacent to waste disposal facilities had significantly higher radionuclide concentrations than those collected farther away.

Near-Facility External Radiation. External radiation fields were measured near facilities and waste handling, storage, and disposal sites to measure, assess, and control the impacts of operations.

Three new thermoluminescent dosimeter monitoring sites were established in the 100-H Area during late 1999 to evaluate environmental restoration activities at the 116-H-7 Water Retention Basin and the 116-H-1 Liquid Waste Disposal Trench. The 1999 average was comparable to offsite background levels.

Five thermoluminescent dosimeter locations in the 100-D,DR Area evaluated environmental restoration activities at the 116-D-7 and 116-DR-9 water retention basins. The 1999 readings were comparable to offsite background levels.

Thermoluminescent dosimeters are placed in the $100-\mathrm{K}$ Area, surrounding the $105-\mathrm{K}$ East and 105-K West Fuel Storage Basins (K Basins) and adjacent reactor buildings. Dose rates decreased noticeably in 1999 as the result of the removal of stored radioactive waste.

At the 100-N Area, the 1999 thermoluminescent dosimeter results indicate that direct radiation levels were again highest near facilities that had contained or received liquid effluent from $\mathrm{N}$ Reactor. These facilities primarily include the $1301-\mathrm{N}$ and 1325-N Liquid Waste Disposal Facilities. The results for these two facilities were noticeably higher than those for other $100-\mathrm{N}$ Area thermoluminescent dosimeter locations, and they were $~ 5 \%$ higher than exposure levels measured at these locations in 1998.

The highest dose rates in the 200/600 Areas were measured near waste handling facilities such as tank farms. The highest dose rate was measured at tank farm A (200-East Area). The average annual dose rate in the 200 Areas measured in 1999 was $110 \mathrm{mrem} / \mathrm{yr}, \sim 6 \%$ higher than the dose rate measured in 1998.

Ten thermoluminescent dosimeter locations around the perimeter of the Tank Waste Remediation System, Phase I demonstration project indicated that the 1999 dose rates were comparable to those observed in 1998, as well as offsite levels.

One new thermoluminescent dosimeter site was established in the 200 North Area in 1999. This location is at the 212- $\mathrm{R}$ (contaminated) Railroad Car Disposition Area. Results were, as expected, noticeably elevated. 
Two thermoluminescent dosimeter locations at the Environmental Restoration Disposal Facility evaluate the disposal activities in progress. Readings in 1999 were comparable to offsite background levels.

The highest dose rates in the 300 Area were measured at the 316 process trench. The average annual dose rate measured in the 300 Area in 1999 was $110 \mathrm{mrem} / \mathrm{yr}$, equal to the average measured in 1998. The average annual dose rate at the 300 Area Treated Effluent Disposal Facility in 1999 was $82 \mathrm{mrem} / \mathrm{yr}$, a slight increase (1\%) relative to the average dose rate measured in 1998.

The average annual dose rate measured in the 400 Area in 1999 was $87 \mathrm{mrem} / \mathrm{yr}$, a decrease of 1\% compared to the average dose rate measured in 1998.

Investigative Sampling. To confirm the absence or presence of radioactive or hazardous contaminants, or to verify radiological conditions at specific project sites, investigative samples were collected from across the Hanford Site in 1999.

Generally, the predominant radionuclides discovered during these efforts were activation products in the 100 and 200 Areas, and uranium in the 300 Area. Hazardous chemicals generally have not been identified above background levels in preoperational environmental monitoring samples.

Investigative samples in 1999 included soil, vegetation, nests, mammal feces, insects, and wildlife. The samples were collected where known or suspected radioactive contamination was present or to verify radiological conditions at project sites. In 1999, samples were analyzed for radionuclides and showed some level of contamination. In addition, samples were collected and disposed of without isotopic analyses, though field instrument readings were recorded.

\section{Environmental Surveillance}

Environmental surveillance at the Hanford Site includes monitoring environmental media on and off the Hanford Site for potential chemical and radiological contaminants originating from site operations. The media monitored included air, surface water and sediment, drinking water, food and farm products, fish, wildlife, soil, vegetation, and external radiation.

A ir Surveillance. Radioactive materials in air were sampled continuously at 44 onsite locations, at the site perimeter, and in nearby and distant communities. Nine of these locations were communityoperated environmental surveillance stations that were managed and operated by local school teachers. At all locations, particulates were filtered from the air and analyzed for radionuclides. Air was sampled and analyzed for selected gaseous radionuclides at key locations. Several radionuclides released at the site are also found worldwide from two other sources: naturally occurring radionuclides and radioactive fallout from historical nuclear activities not associated with Hanford. The potential influence of emissions from site activities on local radionuclide concentrations was evaluated by comparing differences between concentrations measured at distant locations within the region and concentrations measured at the site perimeter.

For 1999, no differences were observed between the annual average gross alpha air concentrations measured at the site perimeter and those measured at distant community locations concentrations. The site perimeter annual average gross beta air concentration was slightly higher than the distant community concentrations. Quarterly composite samples were analyzed for numerous specific gamma-emitting radionuclides; however, no radionuclides of Hanford origin were detected.

Annual average tritium concentrations for 1999 at the Hanford Site perimeter were not significantly different than annual average concentrations at the distant community locations. As a result of tritium studies in selected 300 Area facilities, 300 Area annual average concentrations in air were elevated when compared to other onsite locations. However, 
this effect did not increase annual average levels at site perimeter locations.

Iodine-129 concentrations were statistically elevated at the site perimeter compared to the distant locations, indicating a measurable Hanford source; however, the average concentration at the site perimeter was only $0.000001 \%$ of the DOE derived concentration guide of $70 \mathrm{pCi} / \mathrm{m}^{3}$. The DOE derived concentration guide is the air concentration that would result in a radiation dose equal to the DOE public dose limit (100 mrem/yr).

The annual average strontium-90 concentrations at the Hanford Site perimeter were not significantly higher than the annual average levels at the distant community locations. The maximum level was $0.004 \%$ of the DOE derived concentration guide of $9 \mathrm{pCi} / \mathrm{m}^{3}$.

Plutonium-239/240 concentrations were not significantly different for air samples collected at the site perimeter compared to the distant locations. The average concentration at the perimeter locations was less than $0.002 \%$ of the DOE derived concentration guide of $0.02 \mathrm{pCi} / \mathrm{m}^{3}$.

Uranium isotopic concentrations (uranium-234, uranium-235, and uranium-238) were similar on the site, at the perimeter, and at the distant locations for 1999. The annual average uranium concentration at the site perimeter was $0.03 \%$ of the $0.1-\mathrm{pCi} / \mathrm{m}^{3} \mathrm{DOE}$ derived concentration guide.

No air samples were collected in 1999 to test for chemical contaminants.

\section{Surface-Water and Sediment Surveillance.}

The Columbia River was one of the primary environmental exposure pathways to the public during 1999 as a result of past operations at the Hanford Site. Radiological and chemical contaminants entered the river along the Hanford Reach primarily through seepage of contaminated groundwater. Water samples were collected from the river at various locations throughout the year to determine compliance with applicable standards.
Although radionuclides associated with Hanford operations continued to be identified routinely in Columbia River water during the year, concentrations remained extremely low at all locations and were well below standards. The concentrations of tritium and iodine- 129 were significantly higher (5\% significance level) at the Richland Pumphouse (downstream from the site) than at Priest Rapids Dam (upstream from the site), indicating contribution along the Hanford Reach. Transect (multiple samples collected across the river) and near-shore sampling in 1999 revealed elevated tritium levels along the Benton County shoreline near the 100-N Area, Old Hanford Townsite, 300 Area, and Richland Pumphouse. Total uranium concentrations were elevated along the Franklin County shoreline near the 300 Area and the Richland Pumphouse and likely resulted from groundwater seepage and water from irrigation return canals on the east shore of the river that contained naturally occurring uranium.

Several metals and anions were detected in transect samples collected upstream and downstream of the site. Nitrate concentrations were slightly elevated along both the Benton County and Franklin County shoreline of the 300 Area and Richland Pumphouse transects. With the exception of nitrate, sulfate, and chloride, no consistent differences were found between average quarterly metal and anion contaminant concentrations in the Vernita Bridge and Richland Pumphouse transect samples. All metal and anion concentrations in Columbia River water collected in 1999 were less than the Washington State ambient surface-water quality criteria levels for both acute and chronic toxicity. Arsenic concentrations exceeded EPA standards; however, similar concentrations were found at Vernita Bridge (background location) and Richland Pumphouse.

In 1999, samples of Columbia River surface sediment were collected from monitoring sites above McNary Dam (downstream of the site), Priest Rapids Dam (upstream of the site), and from sediment deposited along the Hanford Reach (including some riverbank springs). In addition, sediment samples 
were collected behind Ice Harbor Dam on the Snake River. Strontium-90 was the only radionuclide to exhibit consistently higher median concentrations at McNary Dam compared to the other locations. In 1999, no other radionuclides measured in sediment exhibited appreciable differences in concentration between locations. The concentrations of radionuclides in sediment collected from riverbank springs were similar and were comparable to levels observed in 1999 river sediment. Detectable amounts of most metals were found in all river sediment samples with similar levels in riverbank springs sediment. River sediment was also analyzed for simultaneously extracted metals and acid volatile sulfide (SEM/ AVS). The SEM/AVS ratios are typically a better indicator of sediment toxicity than traditional total metals concentrations. When the amount of sulfide exceeds the amount of the metals (SEM/AVS ratio is below 1), the metal concentration in the sediment porewater will be low because of the limited solubility of the metal sulfides. For 1999, the SEM/AVS molar ratios were close to one for Priest Rapids Dam and Hanford Reach sediment, with zinc as the dominant metal. The molar ratios for sediment from McNary Dam were above one, indicating a potential for some metals to be present in the sediment porewater, with zinc as the primary metal present. Ice Harbor Dam had similar concentrations of acid volatile sulfide as McNary Dam, but zinc concentrations were lower.

Water samples were collected from eight Columbia River shoreline springs in 1999. All concentrations of radiological contaminants measured in water from riverbank springs in 1999 were less than DOE derived concentration guides. However, the spring at the 100-N Area that has historically exceeded the DOE derived concentration guide for strontium-90 was not flowing during the 1999 sample collection visit. Tritium concentrations at the Old Hanford Townsite and gross alpha concentrations at the 300 Area riverbank springs exceeded the applicable Washington State ambient surface-water quality criteria. Gross beta concentrations at the Old Hanford Townsite and 300 Area riverbank springs were close to the state criteria. There are currently no ambient surface-water quality criteria levels directly applicable to uranium; however, total uranium exceeded the site-specific proposed EPA drinking water standard in the 300 Area riverbank spring. All other radionuclides were below the Washington State ambient surface-water quality criteria levels.

Nonradiological contaminants measured in riverbank springs located on the Hanford shoreline in 1999 were below Washington State ambient surface-water acute toxicity levels, except for chromium at the 100-B, 100-D, 100-K, 100-F, 100-H Area, and 300 Area riverbank springs and for copper, lead, and zinc at the 300 Area. Arsenic concentrations in water from riverbank springs were well below the applicable ambient surface water chronic toxicity levels, but concentrations in all samples exceeded the federal limit (including upriver Columbia River water samples). Nitrate concentrations at all locations were below the EPA drinking water standard.

Water was collected from two onsite ponds located near operational areas in 1999. Although the ponds were not accessible to the public and did not constitute a direct offsite environmental impact during the year, they were accessible to migratory waterfowl and other animals. As a result, a potential biological pathway existed for the removal and dispersal of onsite pond contaminants. With the exception of uranium-234 and uranium-238 in water samples from West Lake, radionuclide concentrations in the onsite pond water were below DOE derived concentration guides. The median gross alpha, gross beta, and total uranium concentrations in West Lake exceeded the applicable ambient surface-water quality criteria levels. Concentrations of most radionuclides in water collected from both ponds during 1999 were similar to those observed during past years.

Irrigation water from the Riverview canal near Pasco was sampled three times in 1999 to determine radionuclide levels. Radionuclide concentrations in offsite irrigation water were below both the $\mathrm{DOE}$ 
derived concentration guides and ambient surfacewater quality criteria levels and were similar to those observed in Columbia River water.

Drinking Water Surveillance. Surveillance of Hanford Site drinking water was conducted to verify the quality of water supplied by site drinking water systems and to comply with regulatory requirements. Radiological monitoring was performed by the Pacific Northwest National Laboratory; nonradiological monitoring was conducted by DynCorp Tri-Cities Services, Inc. Radiological results are discussed in this report; nonradiological results are reported directly to the Washington State Department of Health.

During 1999, radionuclide concentrations in Hanford Site drinking water were similar to those observed in recent years and were in compliance with Washington State Department of Health and EPA drinking water standards.

Food and Farm Product Surveillance. The Hanford Site is situated in a large agricultural area that produces a wide variety of food products and alfalfa. In 1999, milk, vegetables, fruit, and wine were collected from areas around the site and were analyzed for cobalt-60, strontium-90, iodine-129, cesium-137, and tritium.

Most farm products sampled did not contain measurable levels of cobalt- 60 or cesium-137. Iodine129 was measured in milk at levels equivalent to those seen at the downwind location. Levels of iodine-129 in milk collected at downwind locations have remained relatively stable for the past 5 years. Strontium-90 was detected in only 1 of 12 milk samples analyzed in 1999. The one positive result was close to the analytical detection limit. Tritium was also measured in milk samples and concentrations were believed to be influenced by the source of water used by the dairies. Tritium levels were low in all samples but were higher in the Sagemoor area than in the Wahluke and Sunnyside areas. Tritium levels in wine were low and the Yakima Valley wines were lower than the Columbia Basin wines. Measurable levels of most man-made radioactivity were not detected in vegetable and fruit samples collected in 1999. Strontium-90 was detected in two leafy vegetable samples at levels approaching the analytical detection limit. The sample with the highest concentration was re-analyzed and the result was below the analytical detection limit. Cesium-137 and other man-made gamma-emitting radionuclides were not detected in alfalfa in 1999. Strontium-90 was found above the detection limit in three of the four samples analyzed and levels were consistent with measurements in alfalfa over the past 5 years.

Fish and Wildlife Surveillance. Bass, whitefish, and large-scale suckers were collected from the Columbia River in 1999. Cesium-137 was not detected in any of the muscle samples analyzed. Strontium-90 was found in 7 of 16 carcass samples but levels were similar to those observed in Hanford Reach and background area fish.

Wildlife sampled and analyzed in 1999 for radioactive constituents included elk, geese, and rabbits. Radionuclide levels in Hanford-resident geese and elk were similar to levels in wildlife collected at reference background locations. Cesium-137 was not detected in any of the goose and elk samples analyzed and the highest strontium-90 levels were seen in elk collected in Idaho. Levels of cesium-137 and strontium-90 were low in most rabbit samples also but levels in one rabbit collected in the 100-N Area was high enough to suggest some onsite exposure to Hanford Site contaminants.

Soil and Vegetation Surveillance. Routine soil and vegetation samples were not collected by Pacific Northwest National Laboratory on and around the Hanford Site in 1999, but two special studies were conducted. Reed canary grass and mulberry trees were sampled along the Columbia River, and soil samples were collected in and near the former 1100 Area. Plants collected on the Hanford Site by the Wanapum People were also analyzed. Elevated tritium levels were seen in mulberry trees growing in the 100-B,C Area where a groundwater tritium plume is known to exist. The highest strontium-90 
concentrations were seen in vegetation collected in the 100-N Area with levels in vegetation from other reactor areas being slightly lower. Soil samples collected in the former 1100 Area in July 1999 were analyzed for potential radiological contaminants from prior DOE activities in the area and from airborne deposition from both DOE and private facilities on and around the site. All concentrations were similar to concentrations measured at Hanford Site perimeter locations between 1992 and 1997.

External Radiation Surveillance. Using thermoluminescent dosimeters, radiological dose rates were measured at both onsite and offsite locations during 1999. Radioactive substances contributing to the measured dose rates were of either natural or man-made origin. The dose rates did not change significantly from the dose rates measured in previous years. The 1999 annual average background dose rate measured in communities distant from the Hanford Site was $74 \pm 2 \mathrm{mrem} / \mathrm{yr}$; in 1998, the average background was $70 \pm 2$. The 1999 annual average perimeter dose rate was $90 \pm 4 \mathrm{mrem} / \mathrm{yr}$; in 1998, the average measured dose rate was $88 \pm$ $7 \mathrm{mrem} / \mathrm{yr}$. All onsite thermoluminescent dosimeters averaged $88 \pm 3 \mathrm{mrem} / \mathrm{yr}$, which compares favorably with the average of $85 \pm 9$ mrem/yr measured in 1998. Columbia River shoreline dosimeters had a 1999 average of $91 \pm 6 \mathrm{mrem} / \mathrm{yr}$; in 1998, the average was $90 \pm 6 \mathrm{mrem} / \mathrm{yr}$. The average dose rate along the 100-N Area shoreline (120 $226 \mathrm{mrem} / \mathrm{yr})$ was $\sim 50 \%$ higher than the typical shoreline dose rate $(87 \pm 3 \mathrm{mrem} / \mathrm{yr})$.

\section{G roundwater M onitoring}

Monitoring of radiological and chemical constituents in groundwater at the Hanford Site was performed to characterize physical and chemical trends in the flow system, to establish groundwater quality baselines, to assess groundwater remediation, and to identify new or existing groundwater problems. Groundwater monitoring was also performed to verify compliance with applicable environmental laws and regulations and to fulfill commitments made in official DOE documents. Samples were collected from over 600 wells to determine the distribution of radiological and chemical constituents in Hanford Site groundwater. In addition, hydrogeologic characterization and modeling of the groundwater flow system were used to assess the monitoring network and to evaluate the potential impact of groundwater contaminants. Modeling of Hanford Site groundwater was also used to assess performance of waste disposal facilities and evaluate remediation strategies.

\section{Groundwater Protection and Monitoring.}

The Hanford Groundwater Monitoring Project was responsible for groundwater surveillance and monitoring activities at the Hanford Site. This project incorporates sitewide groundwater monitoring mandated by DOE orders with near-field groundwater monitoring conducted to ensure that operations in and around specific waste-disposal facilities comply with applicable regulations. Groundwater monitoring was required by RCRA at 26 waste treatment, storage, and disposal units. Monitoring status and results for each of these units are summarized in this report.

To assess the quality of groundwater, measured sample concentrations were compared with the EPA drinking water standards and the DOE derived concentration guides. Groundwater is used for drinking at three locations on the Hanford Site. In addition, water supply wells for the city of Richland are located near the southern boundary of the Hanford Site. Radiological constituents detected at levels greater than their respective EPA drinking water standards in one or more wells included tritium, iodine-129, technetium-99, uranium, strontium-90, carbon-14, gross alpha, and gross beta. Tritium, uranium, and strontium-90 were detected at levels greater than their respective DOE derived concentration guides.

Extensive tritium plumes extend from the 200-East and 200-West Areas into the 600 Area. The plume from the 200-East Area extends east and southeast, discharging to the Columbia River between the Old Hanford Townsite and the 300 Area. This 
plume has affected tritium concentrations in the 300 Area, located in the southern part of the Hanford Site, at levels of more than one-half the EPA drinking water standard. The spread of this plume farther south than the 300 Area is restricted by the groundwater flow away from the Yakima River, recharge from agricultural irrigation, and the recharge basins associated with the north Richland well field. A much smaller tritium plume from the 200-West Area extends east to the US Ecology facility. Groundwater with tritium at levels above the EPA drinking water standard also discharges to the Columbia River near the 100-N Area. A small but high-level tritium plume in the $100-\mathrm{K}$ Area also may discharge to the river. Tritium in groundwater at levels greater than the EPA drinking water standard were also found in the 100-B,C, 100-D, and 100-F Areas and at the State-Approved Land Disposal Site north of the 200-West Area. Tritium occurred at levels equal to or greater than the $\mathrm{DOE}$ derived concentration guide in small areas in the $100-\mathrm{K}, 200$, and 600 Areas. Tritium was detected above the guide for the first time near the $618-11$ burial ground in the eastern 600 Area.

Iodine-129 was detected at levels greater than the EPA drinking water standard in the 200-East Area and in part of the 600 Area to the east and southeast. Iodine-129 contamination extends as far to the east as the Columbia River but at levels less than the EPA standard. The iodine-129 and tritium plumes share common sources. Iodine-129 at levels greater than the EPA standard also extends into the 600 Area to the northwest of the 200-East Area, into the 600 Area in the southern part of the 200-West Area, and to the northeast in the north-central part of the 200-West Area.

Technetium-99 concentrations greater than the EPA drinking water standard were found in the northwestern part of the 200-East Area and adjacent 600 Area. Technetium-99 was also detected at levels greater than the EPA standard in the 200-West Area and adjacent 600 Area to the east. Approximately 357 million liters ( 99 million gallons) of groundwater have been treated and $\sim 61.7$ grams ( 2.2 ounces) of technetium-99 have been removed from groundwater since a pump-and-treat system began operating in the 200-West Area in 1994.

Uranium was detected at levels greater than the EPA drinking water standard in groundwater in the 100-F, 100-H, 200, 300, and 600 Areas. Wells near U Plant in the 200-West Area showed concentrations greater than the DOE derived concentration guide. A pump-and-treat system has removed 101.1 kilograms (223 pounds) of uranium from groundwater in the 200-West Area since 1994. Groundwater with uranium levels greater than the EPA standard is discharging to the Columbia River in the 300 Area.

The strontium- 90 plume in the $100-\mathrm{N}$ Area contains levels greater than the EPA drinking water standard and the DOE derived concentration guide. Strontium-90 at these levels is discharging to the Columbia River. Strontium-90 entering the river could potentially reach an ecological receptor. A pump-and-treat method to reduce the amount of strontium- 90 entering the river removed $\sim 0.2$ curie from extracted groundwater in fiscal year 1999. Strontium-90 at levels greater than the DOE derived concentration guide also occurred in localized areas in the $100-\mathrm{K}$ and 200 -East Areas. Strontium-90 was detected at levels greater than the EPA drinking water standard in the 100,200, and 600 Areas.

Carbon-14 exceeded the EPA drinking water standard in two small plumes near each of the $100-\mathrm{K}$ Area reactors.

Cesium-137 occurs at levels above the EPA drinking water standard in a localized area associated with a former injection well in the 200-East Area. Plutonium also occurs in this localized area at levels greater than the $100-\mathrm{mrem} / \mathrm{yr}$ dose equivalent guideline.

Cobalt-60 was detected in the 200-East Area and adjacent 600 Area but at levels less than the EPA drinking water standard. 
Several nonradioactive chemicals regulated by EPA and Washington State were also present in Hanford Site groundwater. These were nitrate, chromium, carbon tetrachloride, chloroform, trichloroethylene, cis-1,2-dichloroethylene, cyanide, and fluoride. Of these chemicals, nitrate, chromium, and carbon tetrachloride are the most widely distributed in Hanford Site groundwater.

Nitrate concentrations exceeded the EPA drinking water standard in all areas, except the 400 Area. The nitrate plumes in the 100 Areas discharge to the Columbia River. Nitrate from sources in the northwestern part of the 200-East Area is present in the adjacent 600 Area at levels greater than the EPA drinking water standard. Nitrate levels greater than the EPA standard occur in two areas of the 200-West Area and adjoining 600 Area. A pump-and-treat system in the 200-West Area has removed 12,770 kilograms (28,153 pounds) of nitrate from groundwater. Nitrate is widely distributed in groundwater in the 100-F and adjoining 600 Area. A wide area of nitrate contamination occurs along part of the southern boundary of the Hanford Site. This contamination is affected by agricultural and industrial nitrate sources off the Hanford Site.

Chromium was detected above the EPA drinking water standard in the $100-\mathrm{D}, 100-\mathrm{H}$, and $100-\mathrm{K}$ Areas and in localized sites in the 100-B,C, 100-K, 200, and 600 Areas. Plume boundaries were defined better in the 100-D Area because new monitoring wells were installed. Since pump-and-treat systems began operating in the $100-\mathrm{D}, 100-\mathrm{H}$, and $100-\mathrm{K}$ Areas in 1997, 136 kilograms (300 pounds) of chromium has been removed from groundwater.

An extensive plume of carbon tetrachloride at levels greater than the EPA drinking water standard occurs in groundwater in the 200-West Area and adjoining 600 Area. Two pump-and-treat systems operating in the 200-West Area have treated 1,312 million liters (351 million gallons), resulting in the removal of $\sim 3,402$ kilograms ( 7,500 pounds) of carbon tetrachloride. At the pump-and-treat system near the Plutonium Finishing Plant, the portion of the carbon tetrachloride plume with the highest concentrations has increased in size because of the effects of pumping from the extraction wells.

Trichloroethylene and chloroform levels were above the EPA drinking water standard in the 200-West Area. Trichloroethylene was found at levels greater than the EPA standard in small areas in the 100-F Area and nearby 600 Area, 100-K Area, 300 Area, and near the former Horn Rapids Landfill near the southern boundary of the Hanford Site.

Cis-1,2-dichloroethylene concentrations were above the EPA drinking water standard in one well in the 300 Area. Cyanide was detected at levels above the EPA drinking water standard in the 200-East Area. Fluoride was detected above the EPA drinking water standard in the 200-West Area.

\section{Vadose Zone M onitoring}

The vadose zone is the region in the subsurface between the ground surface and the top of the water table. Radioactive and hazardous wastes in the soil column from past intentional disposal of liquid waste, unplanned leaks, solid waste burial grounds, and underground tanks at the Hanford Site are potential sources of continuing and future vadose zone and groundwater contamination. In 1999, subsurface source characterization and vadose zone monitoring, soil-vapor monitoring, sediment sampling and characterization, and vadose zone remediation were conducted to better understand and alleviate the spread of subsurface contamination.

Vadose Zone Characterization and Monitoring at T ank Farms. Several vadose zone characterization activities occurred at the single-shell tank farms in 1999. At the SX tank farm, in the 200-West Area, samples were collected and characterized from the decommissioning of one borehole drilled to characterize deep vadose zone contamination. Analytical results from the samples showed very high concentrations of cesium-137. The region 
between 18.6 and 25.3 meters ( 61 and 83 feet) had the highest concentrations of cesium-137 reaching 1.759 $x 10^{7} \mathrm{pCi} / \mathrm{g}$ at 25 meters ( $82 \mathrm{feet}$ ) depth. Levels were the highest obtained from under leaking tanks in the past 35 years. Very little cesium-137 was leached by a water extraction procedure, indicating that most cesium-137 in the sediment from the borehole is not soluble and is bound to the sediment.

The multiyear vadose zone baseline characterization project at the single-shell tank farms was completed by the end of 1999. During 1999, tank summary data reports were completed for the remaining tanks in $\mathrm{T}$ and $\mathrm{B}$ tank farms and the report for $\mathrm{T}$ tank farm was completed. Tank summary data reports were issued for a total of 133 single-shell tanks. Also, by the end of 1999, 11 of 12 tank farm reports had been issued; only the $\mathrm{B}$ tank farm report remained to be completed. During 1999, repeat logging was completed and a high-count rate logging system was deployed to measure radionuclide concentrations in borehole intervals where high gamma flux led to saturation of the spectral gamma logging system. It is anticipated that the final tank farm report will be issued by the end of March 2000. Work is underway to prepare a series of addenda for earlier tank farm reports that will present additional data from high rate and repeat logging, as well as modifications to the visualizations based on re-evaluation of existing data.

V adose Zone Characterization and Monitoring at Liquid Waste Disposal Facilities. The 116-C-1 process effluent trench, in the 100-B, CArea was remediated in 1997, and a test pit was dug to groundwater in early 1998 by Bechtel Hanford, Inc. to evaluate the remediation effort. Analyses of the soil samples showed that most remaining contamination in the vadose zone was within $\sim 5$ meters ( 16 feet) of the base of the remedial action excavation. However, the more mobile contaminants, such as strontium-90, were slighter deeper in the soil column. The most mobile contaminants, such as hexavalent chromium, were flushed through the vadose zone to groundwater. Remediation of the 116-C-1 trench met cleanup standards and the site was reclassified as closed in accordance with the Tri-Party Agreement (Ecology et al. 1998).

Important decisions affecting the cost and extent of remedial actions in the 100 Areas are currently based on the predictions of the very conservative computer model RESRAD. To date, the RESRAD code has used on the distribution coefficient $\left(K_{d}\right)$, and not leachability, to evaluate the effect to groundwater. $\left(K_{d}\right.$ is a measure of the relative concentration of contaminant sorbed on the sediment to that dissolved in solution; the smaller the $\mathrm{K}_{\mathrm{d}}$, the amore contaminant is in solution.) Experiments were done in 1999 to measure both the leach rate and $\mathrm{K}_{\mathrm{d}}$ for hexavalent chromium using sediment samples from the 100-D Area. The findings of the study suggest that there is very little soluble chromium in the vadose zone of the 100-D Area. This is contrary to the existence of high chromium concentrations in groundwater from some 100-D locations. The apparent incongruity may be an artifact of sampling (i.e., samples were collected outside areas of chromium contamination) or of an, as yet, unidentified geochemical process.

Soil vapor extraction is being used to remove carbon tetrachloride from the vadose zone in the 200-West Area. The EPA and the Washington State Department of Ecology authorized DOE to initiate this remediation in 1992 as a CERCLA expedited response action. Between March 29 and September 30, 1999, 832 kilograms (1,800 pounds) of carbon tetrachloride were removed from the vadose zone in the 200-West Area. As of September 1999, $\sim 76,500$ kilograms ( 168,700 pounds) of carbon tetrachloride had been removed from the vadose zone since extraction operations started in 1992.

The Hanford Groundwater Monitoring Project monitored 25 inactive liquid waste disposal facilities in the 200-East Area of the Hanford Site in 1999. The facilities consisted of 6 cribs and 19 specific retention facilities. Specific retention facilities were liquid waste disposal sites designed to use the moisture retention capability of the soil to retain contaminants. These facilities were chosen for 
monitoring because they are among the highest priority sites as determined by an evaluation of pastpractice, liquid waste disposal facilities (PNNL-11958, Rev. 2). These sites represent potential sources for future contamination of groundwater at the Hanford Site. Monitoring of the past practice sites consisted of spectral gamma-ray and neutron moisture logging of 28 wells and boreholes.

Only four of the boreholes logged in 1999 had previous spectral gamma logs for comparison. Two of those logs showed that changes in the subsurface distribution of man-made radioisotopes had occurred since 1992. Although the changes are not great, they do point to continued movement of contaminants in the vadose zone. None of the facilities monitored in 1999 have been used for at least 30 years and some for 40 years. Thus, the driving force for the changes is not known for certain but must be either natural recharge, residual moisture from past facility operations, or moisture from adjacent facilities. The radionuclides that were observed to have moved since 1992 are cesium-137 and cobalt-60. Given the amount of movement and the half-lives of the isotopes, it is expected that they will decay to insignificant amounts before reaching groundwater.
In 1999, the Hanford Groundwater Monitoring Project sampled and analyzed soil gas and soil moisture to 1) demonstrate the adaptability of soil gas sampling techniques to the measurement of tritium and helium-3 concentrations in Hanford Site soil, 2) determine tritium and helium-3 concentrations in soil gas at two locations on the Hanford Site, and 3) attempt to extrapolate tritium and helium-3 concentrations in the soil to tritium concentrations in groundwater at the 100-K Area.

Measurements of tritium in soil moisture do not appear to be useful for delineating tritium groundwater plumes or estimating concentrations of tritium in groundwater. The major source of moisture in the vadose zone at the two investigated sites appears to be natural precipitation and not upward migration of moisture from groundwater into the vadose zone.

Analyses of soil gas from samples collected at the Old Hanford Townsite area show that the gas is enriched in helium-3. This enrichment is due to decay of tritium in the groundwater beneath the site. The amount of enrichment appears to vary with time, most likely because of atmospheric influences. Nevertheless, helium-3 can be a useful tracer for either vadose zone or groundwater sources of tritium.

\section{Potential Radiological Doses from 1999 Hanford Operations}

In 1999, potential radiological doses to the public, resulting from exposure to Hanford Site liquid and gaseous effluents, were evaluated to determine compliance with pertinent regulations and limits. These doses were calculated using reported effluent releases and environmental surveillance data using version 1.485 of the GENII computer code and Hanford-specific parameters. The potential dose to the maximally exposed individual in 1999 from site operations was $0.008 \mathrm{mrem}(0.08 \mu \mathrm{Sv})$ compared to 0.02 mrem $(0.2 \mu \mathrm{Sv})$ calculated for 1998. The radiological dose to the population within 80 kilometers (50 miles) of the site, estimated to be 380,000 persons, from 1999 site operations was
0.25 person-rem $(0.0025$ person-Sv), which is a slight increase of the population dose calculated for 1998 (0.2 person-rem [0.002 person-Sv]). The average per-capita dose from 1999 site operations was $0.0007 \mathrm{mrem}(0.007 \mu \mathrm{Sv})$. The national average dose from background sources, according to the National Council on Radiation Protection, is $\sim 300 \mathrm{mrem} / \mathrm{yr}(3 \mathrm{mSv} / \mathrm{yr})$, and the current DOE radiological dose limit for a member of the public is $100 \mathrm{mrem} / \mathrm{yr}(1 \mathrm{mSv} / \mathrm{yr})$. Therefore, the average individual potentially received $0.0007 \%$ of the DOE limit and $0.0002 \%$ of the national average background. Special exposure scenarios not included in the dose estimate above included the hunting and 
consumption of game animals residing on the Hanford Site and exposure to radiation at a publicly accessible location with the maximum exposure rate. Doses from these scenarios would have been small compared to the DOE dose limit. Radiological dose through the air pathway was $0.03 \%$ of the EPA limit of $10 \mathrm{mrem} / \mathrm{yr}(0.1 \mathrm{mSv} / \mathrm{yr})$.

\section{Other Hanford Site Environmental Programs}

\section{Climate and M eteorology}

Meteorological measurements are taken to support Hanford Site emergency preparedness, site operations, and atmospheric dispersion calculations. Weather forecasting and maintenance and distribution of climatological data are provided.

The Hanford Meteorology Station is located on the 200 Areas plateau, where the prevailing wind direction is from the northwest during all months. The secondary wind direction is from the southwest. The average speed for 1999 was $14.2 \mathrm{~km} / \mathrm{h}$ $(11.1 \mathrm{mi} / \mathrm{h})$, which was $1.8 \mathrm{~km} / \mathrm{h}(1.1 \mathrm{mi} / \mathrm{h})$ above normal and was the windiest year on record. The peak gust for the year was $105 \mathrm{~km} / \mathrm{h}(65 \mathrm{mi} / \mathrm{h})$.

Precipitation for 1999 totaled 9.6 centimeters (3.75 inches), $60 \%$ of normal, with 1.5 centimeters (0.6 inch) of snow recorded.

Temperatures for 1999 ranged from $-7.8^{\circ}$ Celsius $\left(18^{\circ}\right.$ Fahrenheit) in January to $40.6^{\circ}$ Celsius (105 Fahrenheit) in July.

\section{Cultural Resources}

Management of archaeological, historical, and traditional cultural resources at the Hanford Site is provided in compliance with the $\mathrm{N}$ ational $\mathrm{H}$ istoric Preservation A ct, A rchaeological Resources Protection $\mathrm{A}$ ct, $\mathrm{N}$ ative $\mathrm{A}$ merican $\mathrm{G}$ raves Protection and Repatriation A ct, A merican Indian Religious F reedom A ct, $\mathrm{H}$ istoric Sites Buildings and A ntiquities A ct, A rcheological and $H$ istoric P reservation $A$ ct, and $A$ merican $A$ ntiquities Preservation A ct. During 1999, 176 proposed projects were reviewed to consider their potential effect on significant cultural resources. Other activities included the continuation of a multiyear monitoring study of cutbank erosion and the associated impact to National Register archaeological sites at Locke Island, a large channel island located in the northern extent of the Hanford Reach of the Columbia River. Mitigation of historic buildings and structures continued in 1999 as required by the programmatic agreement for the built environment and the historic district treatment plan.

Public involvement activities are important components of a cultural resources management program. To accomplish this goal, DOE developed mechanisms that allow the public access to cultural resources information and the ability to comment and make recommendations concerning the management of cultural resources on the Hanford Site. In 1999, these mechanisms were woven into a draft involvement plan that includes input provided by the public and Hanford Site staff over the past several years. Native American involvement included the completion of several field surveys, construction monitoring, and monthly cultural issues meetings.

\section{Community-Operated Environmental Surveillance Program}

This program was initiated in 1990 to increase the public's involvement in and awareness of Hanford's surveillance program. Nine citizenoperated radiological surveillance stations were operating in 1999.

\section{Biological Control Program}

The Biological Control Program was established at the Hanford Site in 1999 to control the spread of 
radiological contamination by plants and animals (including insects) and to control pests (including noxious weeds) that may affect the workplace or the environment. Program efforts focused on controlling plants and animals, locating and cleaning up both new and old areas of contamination, and post-cleanup remediation. Remediation was performed when there was a potential for recurrence of the problem, with the objective of preventing the recurrence.

All reported incidents of radiological contamination spread by plants and animals in 1999 were confined to the site and were either cleaned up or scheduled for clean up. In 1999, three contaminated house flies were collected at a transfer facility in the 200-East Area, 86 incidents of contaminated vegetation were identified, and 14 contaminated animals were detected.

The noxious weed control program on the Hanford Site was developed in response to federal,

\section{Quality Assurance}

Comprehensive quality assurance programs, which include various quality control practices and methods to verify data, are maintained to ensure data quality. The programs are implemented through quality assurance plans designed to meet requirements of the American National Standards Institute/ American Society of Mechanical Engineers and DOE Orders. Quality assurance plans are maintained for all activities, and auditors verify conformance. Quality control methods include, but are not limited to, replicate sampling and analysis, analysis of field blanks and blind reference standards, participation in interlaboratory crosscheck studies, and splitting state, and local laws requiring eradication or control of noxious weeds. A noxious weed is defined as any plant that, when established, is highly destructive, competitive, or difficult to control by cultural or chemical practices. Typically, noxious weeds are non-native species that invade and displace native species, reduce habitat for fish and wildlife, and contribute to the extinction of sensitive species. Nine plants are on the high-priority list for control at the Hanford Site. These include yellow starthistle, rush skeletonweed, babysbreath, dalmation toadflax, spotted knapweed, diffuse knapweed, Russian knapweed, saltcedar, and purple loosestrife. All these plants were monitored in 1999, but control measures focused on the more invasive species. In 1999, $\sim 4,617$ hectares (11,400 acres) of the site were treated with herbicide to control undesirable vegetation and $\sim 2$ hectares (5 acres) were re-seeded with native vegetation to prevent the growth of tumbleweeds.

samples with other laboratories. Sample collection and laboratory analyses are conducted using documented and approved procedures. When sample results are received, they are screened for anomalous values by comparing them to recent results and historical data. Analytical laboratory performance on the submitted double blind samples, the EPA Laboratory Intercomparison Studies Program, and the national DOE Quality Assessment Program indicated that laboratory performance was adequate overall, was excellent in some areas, and needed improvement in others. 


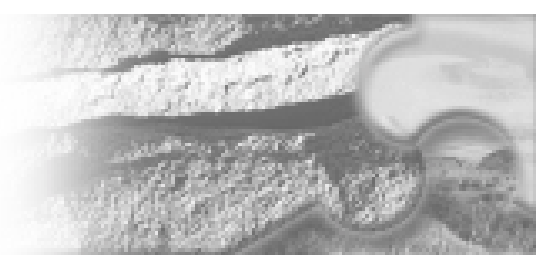

\section{Acknowledgments}

The production of this report was managed by the Pacific Northwest National Laboratory's Public Safety and Resource Protection Program under the direction of R. L. Dirkes.

Community-operated environmental surveillance stations were managed by local teachers who were responsible for collecting the samples and maintaining the stations. The managers and alternate managers for each station included the following:

Leslie Groves Park, Richland: C. A. Wagner, Manager, and D. R. Johns, Alternate Manager

Basin City Elementary School, Basin City: C. L. Stevenson, Manager, and K. McEachen, Alternate Manager

Edwin Markham Elementary School, North Franklin County: M. P. Madison, Manager, and K. A. Thomas, Alternate Manager

Kennewick: T. Droppo, Manager, and C. Zwiener-Thomas, Alternate Manager

Kiona-Benton High School, Benton City: A. J. Williamson, Manager, and K. Jones, Alternate Manager.

Mattawa: D. Weberling, Manager, and T. Lyall, Alternate Manager
Othello: J. Oord, Manager, and B. Taylor, Alternate Manager

Columbia Basin College, Pasco: L. DeWitt, Manager, and J. O'Neill, Alternate Manager

Heritage College, Toppenish: R. A. Landvoy, Manager, and D. F. Brown, Alternate Manager.

The authors appreciate the comprehensive reviews of the draft report by A. L. Bunn, M. J. Sula, and K. R. Price (Pacific Northwest National Laboratory).

The report was prepared by Pacific Northwest National Laboratory staff: L. F. Morasch, text editor, and K. R. Neiderhiser, text processor. Graphics were prepared by D. L. Liddell (Lockheed Martin Services, Inc.) and M. A. Chamness, C. A. Newbill, D. C. Lanigan, J. T. Rieger, W. D. Webber, and R. K. Zufelt (Pacific Northwest National Laboratory). J. Winslow (WinSome Design, Richland, Washington) designed the report cover and layout. Duplicating and printing arrangements were managed by S. J. Kophs, who was supported by G. A. Rowlette. This report was produced using Adobe ${ }^{\circledR}$ PageMaker and formatted for the Internet by J. C. Melland and others in Pacific Northwest National Laboratory's Electronic Communications Section. 


\section{Report Contributors}

The production of this Hanford Site environmental report requires the knowledge, skills, experience, and cooperation of many people and several organizations. The contributions and cooperation, often under demanding time constraints, of the following individuals are gratefully acknowledged. The lead authors are listed on each main section

\section{of the report.}

Bechtel Hanford, Inc.

A. L. Johnson

J. G. Woolard

CH2M HIL Hanford, Inc.

J. F. Ollero

V. J. Rohay

CH2M HIL Hanford Group, Inc.

P. A. Powell

Critique, Inc.

K. S. Ballinger

DynCorp Tri-Cities Services, Inc.

L. M. Kelly

Fluor Hanford, Inc.

S. G. Arnold

B. M. Barnes

H. C. Boynton

G. D. Cummins

L. P. Diediker

R. H. Engelmann

T. P. Frazier

D. A. Gantt

M. T. Jansky

D. B. Jensen

A. R. Johnson

J. J. Kapadia

O. S. Kramer

S. S. Lowe

W. J. McKenna

D. E. N ester

D. H. Nichols

J. K. Perry
K. A. Peterson

A. L. Prignano

F. M. Simmons

J. C. Sonnichsen

C. P. Strand

D. J. Watson

D. E. Zaloudek

International Technology Corp. D. A. M yers

MACTEC-ERS

R. C. McCain

Pacific Northwest National Laboratory

E. J. Antonio

T. M. Brouns

L. L. Cadwell

D. D. Dauble

J. L. Downs

P. E. Dresel

J. C. Evans

L. L. Fassbender

G. W. Gee

B. M. Gillespie

R. W. Hanf

M. J. Hartman

D. W. Harvey

D. J. Hoitink

D. G. Horton

G. V. Last

D. R. Newcomer

K. B. Olsen

G. W. Patton

T. M. Poston

K. R. Price 

K. Rhoads
R. J. Serne
M. A. Simmons
H. T. Tilden II
B. L. Tiller
A. L. Ward
B. A. W illiams
M. K. W right
R. K. Zufelt

Waste Management Technical Services, Inc., Northwest Operations
C. J. Perkins
B. M. Markes
S. K. McKinney
R. M. M itchell
J. M. Rodriquez
R. C. Roos

U.S. Department of Energy, Richland Operations Office

K. V. Clarke

J. H. Zeisloft 


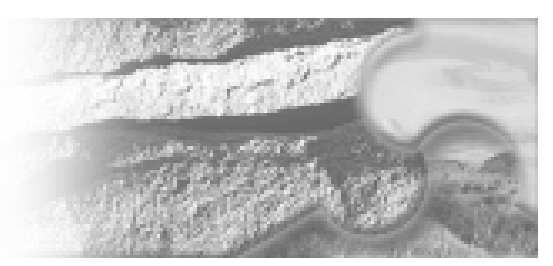

Helpful Information

The following information is provided to assist the reader in understanding this report. Definitions of technical terms can be found in Appendix B,
"Glossary." A public information summary document is available and may be obtained by following the directions given in the "Preface."

\section{Scientific Notation}

Scientific notation is used in this report to express very large or very small numbers. For example, the number 1 billion could be written as 1,000,000,000 or, by using scientific or "E" notation, written as $1 \mathrm{x}$ $10^{9}$ or $1.0 \mathrm{E}+09$. Translating from scientific notation to a more traditional number requires moving the decimal point either left or right from its current

location. If the value given is $2.0 \times 10^{3}$ (or $2.0 \mathrm{E}+03$ ), the decimal point should be moved three places to the right so that the number would then read 2,000. If the value given is $2.0 \times 10^{-5}$ (or 2.0E-05), the decimal point should be moved five places to the left so that the result would be 0.00002 .

\section{Units of Measure}

The primary units of measure used in this report and corresponding symbols (metric and nonmetric). are metric. Table H. 1 summarizes and defines the terms

\begin{tabular}{|c|c|c|c|}
\hline \multirow[b]{2}{*}{ Symbol } & \multicolumn{2}{|c|}{ Table H.1. Names and Symbols for Units of Measure } & \multirow[b]{2}{*}{$\underline{\text { Name }}$} \\
\hline & $\underline{\text { Name }}$ & Symbol & \\
\hline \multicolumn{4}{|l|}{ Temperature } \\
\hline${ }^{\circ} \mathrm{C}$ & degree Celsius & $\mathrm{cm}$ & centimeter $\left(1 \times 10^{-2} \mathrm{~m}\right)$ \\
\hline${ }^{\circ} \mathrm{F}$ & degree Fahrenheit & $\mathrm{ft}$ & foot \\
\hline \multicolumn{4}{|c|}{ Uegice I dinterintert } \\
\hline d & day & $\mathrm{km}$ & kilometer $\left(1 \times 10^{3} \mathrm{~m}\right)$ \\
\hline $\mathrm{h}$ & hour & $\mathrm{m}$ & meter \\
\hline $\min$ & minute & $\mathrm{mi}$ & mile \\
\hline s & second & $\mathrm{mm}$ & millimeter $\left(1 \times 10^{-3} \mathrm{~m}\right)$ \\
\hline $\mathrm{yr}$ & year & $\mu \mathrm{m}$ & micrometer $\left(1 \times 10^{-6} \mathrm{~m}\right)$ \\
\hline \multicolumn{4}{|l|}{ Rate } \\
\hline cfs $\left(\right.$ or $\left.\mathrm{ft}^{3} / \mathrm{s}\right)$ & cubic foot per second & ha & hectare $\left(1 \times 10^{4} \mathrm{~m}^{2}\right)$ \\
\hline gpm & gallon per minute & $\mathrm{km}^{2}$ & square kilometer \\
\hline mph & mile per hour & $\mathrm{mi}^{2}$ & square mile \\
\hline \multicolumn{4}{|r|}{ square foot } \\
\hline $\mathrm{cm}^{3}$ & cubic centimeter & Mass & \\
\hline $\mathrm{ft}^{3}$ & cubic foot & g & gram \\
\hline gal & gallon & $\mathrm{kg}$ & kilogram $\left(1 \times 10^{3} \mathrm{~g}\right)$ \\
\hline $\mathrm{L}$ & liter & $\mathrm{mg}$ & milligram $\left(1 \times 10^{-3} \mathrm{~g}\right)$ \\
\hline $\mathrm{m}^{3}$ & cubic meter & $\mu g$ & microgram $\left(1 \times 10^{-6} \mathrm{~g}\right)$ \\
\hline $\mathrm{mL}$ & milliliter $\left(1 \times 10^{-3} \mathrm{~L}\right)$ & ng & nanogram $\left(1 \times 10^{-9} \mathrm{~g}\right)$ \\
\hline $\mathrm{yd}^{3}$ & cubic yard & $\mathrm{lb}$ & pound \\
\hline & & Concentration & wergnit percent \\
\hline & & $\mathrm{ppb}$ & parts per billion \\
\hline & & ppm & parts per million \\
\hline
\end{tabular}




\begin{tabular}{|c|c|c|c|c|c|}
\hline \multirow[b]{2}{*}{ Multiply } & \multirow[b]{2}{*}{ By } & \multicolumn{2}{|c|}{ Table H.2. Conversion Table } & \multirow[b]{2}{*}{ By } & \multirow[b]{2}{*}{ To Obtain } \\
\hline & & To o btain & Multiply & & \\
\hline in. & 2.54 & $\mathrm{~cm}$ & $\mathrm{~cm}$ & 0.394 & in. \\
\hline $\mathrm{ft}$ & 0.305 & $\mathrm{~m}$ & $\mathrm{~m}$ & 3.28 & $\mathrm{ft}$ \\
\hline $\mathrm{mi}$ & 1.61 & $\mathrm{~km}$ & $\mathrm{~km}$ & 0.621 & $\mathrm{mi}$ \\
\hline $\mathrm{lb}$ & 0.454 & $\mathrm{~kg}$ & $\mathrm{~kg}$ & 2.205 & $\mathrm{lb}$ \\
\hline gal & 3.785 & $\mathrm{~L}$ & $\mathrm{~L}$ & 0.2642 & gal \\
\hline $\mathrm{ft}^{2}$ & 0.093 & $\mathrm{~m}^{2}$ & $\mathrm{~m}^{2}$ & 10.76 & $\mathrm{ft}^{2}$ \\
\hline acre & 0.405 & ha & ha & 2.47 & acres \\
\hline $\mathrm{mi}^{2}$ & 2.59 & $\mathrm{~km}^{2}$ & $\mathrm{~km}^{2}$ & 0.386 & $\mathrm{mi}^{2}$ \\
\hline $\mathrm{yd}^{3}$ & 0.7646 & $\mathrm{~m}^{3}$ & $\mathrm{~m}^{3}$ & 1.308 & $y d^{3}$ \\
\hline$n C i$ & 0.001 & $\mathrm{pCi}$ & $\mathrm{pCi}$ & 1,000 & $\mathrm{nCi}$ \\
\hline $\mathrm{pCi} / \mathrm{L}$ & $10^{-9}$ & $\mu \mathrm{Ci} / \mathrm{mL}$ & $\mu \mathrm{Ci} / \mathrm{mL}$ & $10^{9}$ & $\mathrm{pCi} / \mathrm{L}$ \\
\hline $\mathrm{pCi} / \mathrm{m}^{3}$ & $10^{-12}$ & $\mathrm{Ci} / \mathrm{m}^{3}$ & $\mathrm{Ci} / \mathrm{m}^{3}$ & $10^{12}$ & $\mathrm{pCi} / \mathrm{m}^{3}$ \\
\hline $\mathrm{pCi} / \mathrm{m}^{3}$ & $10^{-15}$ & $\mathrm{mCi} / \mathrm{cm}^{3}$ & $\mathrm{mCi} / \mathrm{cm}^{3}$ & $10^{15}$ & $\mathrm{pCi} / \mathrm{m}^{3}$ \\
\hline $\mathrm{mCi} / \mathrm{km}^{2}$ & 1.0 & $\mathrm{nCi} / \mathrm{m}^{2}$ & $\mathrm{nCi} / \mathrm{m}^{2}$ & 1.0 & $\mathrm{mCi} / \mathrm{km}^{2}$ \\
\hline $\mathrm{Bq}$ & $2.7 \times 10^{-11}$ & $\mathrm{Ci}$ & $\mathrm{Ci}$ & $3.7 \times 10^{10}$ & $\mathrm{~Bq}$ \\
\hline $\mathrm{Bq}$ & 27 & $\mathrm{pCi}$ & $\mathrm{pCi}$ & 0.03704 & $\mathrm{~Bq}$ \\
\hline Gy & 100 & $\mathrm{rad}$ & $\mathrm{rad}$ & 0.01 & Gy \\
\hline Sv & 100 & rem & rem & 0.01 & Sv \\
\hline ppb & 0.001 & ppm & ppm & 1,000 & $\mathrm{ppb}$ \\
\hline${ }^{\circ} \mathrm{F}$ & $\left({ }^{\circ} \mathrm{F}-32\right) \div 9 / 5$ & ${ }^{\circ} \mathrm{C}$ & ${ }^{\circ} \mathrm{C}$ & $\left({ }^{\circ} \mathrm{C} \times 9 / 5\right)+32$ & ${ }^{\circ} \mathrm{F}$ \\
\hline g & 0.035 & $\mathrm{oz}$ & $\mathrm{Oz}$ & 28.349 & g \\
\hline metric ton & 1.1 & ton & ton & 0.9078 & metric ton \\
\hline
\end{tabular}

\section{Radioactivity Units}

Much of this report deals with levels of radioactivity in various environmental media. Radioactivity in this report is usually discussed in units of curies (Table H.3). The curie is the basic unit used to describe the amount of radioactivity present, and activities are generally expressed in terms of fractions of curies in a given mass or volume (e.g., picocuries per liter). One curie is equivalent to 37 billion disintegrations per second or is a quantity of any radionuclide that decays at the rate of 37 billion disintegrations per second. Nuclear disintegrations produce spontaneous emissions of alpha or beta particles, gamma radiation, or combinations of these. In most instances in this report, radioactivity values are expressed with two sets of units, one of which is usually included in parentheses or footnotes. These units belong to the International System of Units (SI), and their inclusion in this report is mandated by DOE. SI units are the internationally accepted units and may eventually be the standard for reporting radioactivity and radiation dose in the United States. The basic unit for discussing radioactivity, the curie, can be converted to the equivalent SI unit, the becquerel, by multiplying the number of curies by 37 billion. The becquerel is defined as one nuclear disintegration per second.

\begin{tabular}{|ll|}
\hline \multicolumn{1}{|c|}{$\begin{array}{c}\text { Table H.3. Names and Symbols for } \\
\text { Units of Radioactivity }\end{array}$} \\
\hline Symbol & Name \\
$\mathrm{Ci}$ & curie \\
$\mathrm{cpm}$ & counts per minute \\
$\mathrm{mCi}$ & millicurie $\left(1 \times 10^{-3} \mathrm{Ci}\right)$ \\
$\mu \mathrm{Ci}$ & microcurie $\left(1 \times 10^{-6} \mathrm{Ci}\right)$ \\
$\mathrm{nCi}$ & nanocurie $\left(1 \times 10^{-9} \mathrm{Ci}\right)$ \\
$\mathrm{pCi}$ & picocurie $\left(1 \times 10^{-12} \mathrm{Ci}\right)$ \\
$\mathrm{aCi}$ & attocurie $\left(1 \times 10^{-18} \mathrm{Ci}\right)$ \\
$\mathrm{Bq}$ & becquerel $\left(3.7 \times 10^{-10} \mathrm{Ci}\right)$ \\
\hline
\end{tabular}




\section{Radiological Dose Units}

The amount of ionizing radiation energy absorbed by a living organism is expressed in terms of radiological dose. Radiological dose in this report is usually written in terms of effective dose equivalent and reported numerically in units of millirem or in the SI unit millisievert (Table H.4). Millirem (millisievert) is a term that relates ionizing radiation and biological effect or risk (to humans). A dose of 1 millirem (0.01 millisievert) has a biological effect similar to the dose received from an approximate 1-day exposure to natural background radiation. An acute (short-term) dose of 100,000 to 400,000 millirems (1,000 to 4,000 millisieverts) can cause radiation sickness in humans. An acute dose of 400,000 to 500,000 millirems (4,000 to 5,000 millisieverts), if left untreated, results in death approximately $50 \%$ of the time. Exposure to lower amounts of radiation (1,000 millirems [10 millisieverts] or less) produces no immediate observable effects, but long-term (delayed) effects are possible. The average person in the United States receives an annual dose from exposure to naturally produced radiation of approximately 300 millirems (3 millisieverts). Medical and dental $x$-rays and air travel add to this total. (See Section 5.0.6, "Hanford Public Radiological Dose in Perspective," for a more in-depth discussion of risk comparisons.) To convert the most commonly used dose term in this report, the millirem, to the SI equivalent, the millisievert, multiply millirem by

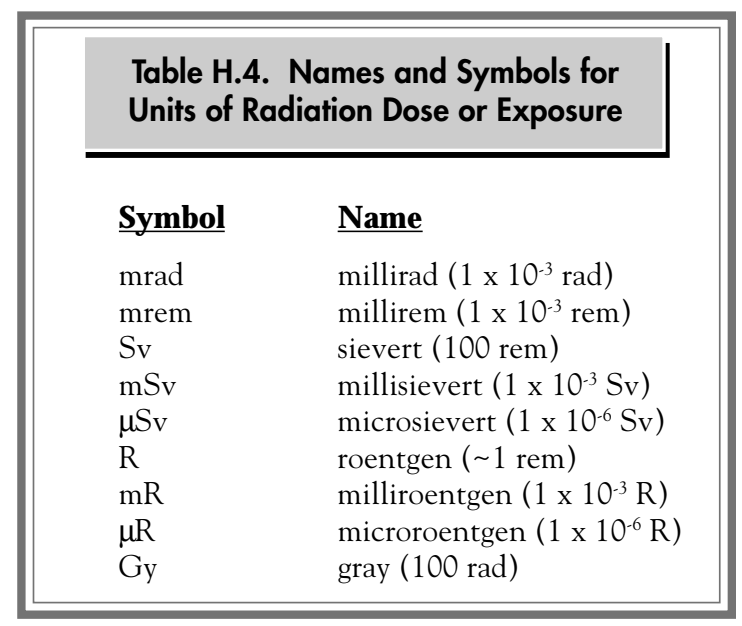

0.01. The unit "rad," for radiation absorbed dose, or the SI unit, gray, are also used in this report. The rad is a measure of the energy absorbed by any material, whereas a rem relates to both the amount of radiation energy absorbed by humans and its consequence. A roentgen is a measure of radiation exposure with no SI equivalent. Generally speaking, 1 roentgen of exposure will result in an effective dose equivalent of 1 rem (10 millisieverts).

Additional information on radiation and dose terminology can be found in Appendix B, "Glossary." A list of the radionuclides discussed in this report, their symbols, and their half-lives are included in Table H.5.

\section{Chemical and Elemental Nomenclature}

The chemical contaminants discussed in this report are listed in Table H.6 along with their chemical (or elemental) names and their corresponding symbols.

\section{Understanding the Data Tables}

\section{Total Propagated Analytical Uncertainty (2-Sigma Error)}

Some degree of uncertainty is associated with all analytical measurements. This uncertainty is the consequence of a series of minor, often unintentional or unavoidable, inaccuracies related to collecting and analyzing the samples. These inaccuracies could include errors associated with reading or recording the result, handling or processing the sample, 
Table H.5. Radionuclides and Their Half-Lives ${ }^{(a)}$

\begin{tabular}{|c|c|c|c|c|c|}
\hline Symbol & Radionuclide & Half-Life & Symbol & Radionuclide & Half-Life \\
\hline${ }^{3} \mathrm{H}$ & tritium & $12.35 \mathrm{yr}$ & ${ }^{137 m} \mathrm{Ba}$ & barium-137m & $2.552 \mathrm{~min}$ \\
\hline${ }^{7} \mathrm{Be}$ & beryllium-7 & $53.44 \mathrm{~d}$ & ${ }^{152} \mathrm{Eu}$ & europium-152 & $13.3 \mathrm{yr}$ \\
\hline${ }^{14} \mathrm{C}$ & carbon-14 & $5,730 \mathrm{yr}$ & ${ }^{154} \mathrm{Eu}$ & europium-154 & $8.8 \mathrm{yr}$ \\
\hline${ }^{40} \mathrm{~K}$ & potassium-40 & $1.3 \times 10^{8} \mathrm{yr}$ & ${ }^{155} \mathrm{Eu}$ & europium-155 & $5 \mathrm{yr}$ \\
\hline${ }^{51} \mathrm{Cr}$ & chromium-51 & $27.7 \mathrm{~d}$ & ${ }^{212} \mathrm{~Pb}$ & lead-212 & $10.6 \mathrm{~h}$ \\
\hline${ }^{54} \mathrm{Mn}$ & manganese-54 & $312.7 \mathrm{~d}$ & ${ }^{220} \mathrm{Rn}$ & radon-220 & $56 \mathrm{~s}$ \\
\hline${ }^{55} \mathrm{Fe}$ & iron-55 & $2.7 \mathrm{yr}$ & ${ }^{222} \mathrm{Rn}$ & radon-222 & $3.8 \mathrm{~d}$ \\
\hline${ }^{59} \mathrm{Fe}$ & iron-59 & $44.63 \mathrm{~d}$ & ${ }^{232} \mathrm{Th}$ & thorium-232 & $1.4 \times 10^{10} \mathrm{yr}$ \\
\hline${ }^{59} \mathrm{Ni}$ & nickel-59 & $75,000 \mathrm{yr}$ & $\mathrm{U}$ or uranium ${ }^{(\mathrm{b})}$ & uranium total & .. (c) \\
\hline${ }^{60} \mathrm{Co}$ & cobalt -60 & $5.3 \mathrm{yr}$ & ${ }^{233} \mathrm{U}$ & uranium-233 & $1.59 \times 10^{5} \mathrm{yr}$ \\
\hline${ }^{63} \mathrm{Ni}$ & nickel-63 & $100.1 \mathrm{yr}$ & ${ }^{234} \mathrm{U}$ & uranium-234 & $2.4 \times 10^{5} \mathrm{yr}$ \\
\hline${ }^{65} \mathrm{Zn}$ & zinc -65 & $243.9 \mathrm{~d}$ & ${ }^{235} \mathrm{U}$ & uranium-235 & $7 \times 10^{8} \mathrm{yr}$ \\
\hline${ }^{85} \mathrm{Kr}$ & krypton-85 & $10.7 \mathrm{yr}$ & ${ }^{237} \mathrm{~Np}$ & neptunium-237 & $2.14 \times 10^{6} \mathrm{yr}$ \\
\hline${ }^{90} \mathrm{Sr}$ & strontium-90 & $29.1 \mathrm{yr}$ & ${ }^{238} \mathrm{U}^{1}$ & uranium-238 & $4.5 \times 10^{9} \mathrm{yr}$ \\
\hline${ }^{90} \mathrm{Y}$ & yttrium-90 & $64.1 \mathrm{~h}$ & ${ }^{238} \mathrm{Pu}$ & plutonium-238 & $87.7 \mathrm{yr}$ \\
\hline${ }^{95} \mathrm{Zr}$ & zirconium-95 & $63.98 \mathrm{~d}$ & ${ }^{239} \mathrm{Pu}$ & plutonium-239 & $2.4 \times 10^{4} \mathrm{yr}$ \\
\hline${ }^{99} \mathrm{Tc}$ & technetium-99 & $2.1 \times 10^{5} \mathrm{yr}$ & ${ }^{240} \mathrm{Pu}$ & plutonium-240 & $6.5 \times 10^{3} \mathrm{yr}$ \\
\hline${ }^{103} \mathrm{Ru}$ & ruthenium-103 & $39.3 \mathrm{~d}$ & ${ }^{241} \mathrm{Pu}$ & plutonium-241 & $14.4 \mathrm{yr}$ \\
\hline${ }^{106} \mathrm{Ru}$ & ruthenium-106 & $368.2 \mathrm{~d}$ & ${ }^{242} \mathrm{Pu}$ & plutonium-242 & $3.76 \times 10^{5} \mathrm{yr}$ \\
\hline${ }^{113} \mathrm{Sn}$ & $\operatorname{tin}-113$ & $115 \mathrm{~d}$ & ${ }^{241} \mathrm{Am}$ & americium-241 & $432.2 \mathrm{yr}$ \\
\hline${ }^{125} \mathrm{Sb}$ & antimony-125 & $2.8 \mathrm{yr}$ & ${ }^{243} \mathrm{Am}$ & americium-243 & $7,380 \mathrm{yr}$ \\
\hline${ }^{129} \mathrm{I}$ & iodine- 129 & $1.6 \times 10^{7} \mathrm{yr}$ & ${ }^{243} \mathrm{Cm}$ & curium-243 & $28.5 \mathrm{yr}$ \\
\hline${ }^{131} \mathrm{I}$ & iodine- 131 & $8 \mathrm{~d}$ & ${ }^{244} \mathrm{Cm}$ & curium-244 & $18.11 \mathrm{yr}$ \\
\hline${ }^{134} \mathrm{Cs}$ & cesium-134 & $2.1 \mathrm{yr}$ & ${ }^{245} \mathrm{Cm}$ & curium-245 & $8,500 \mathrm{yr}$ \\
\hline${ }^{137} \mathrm{Cs}$ & cesium-137 & $30 \mathrm{yr}$ & & & \\
\hline
\end{tabular}

(a) From Shleien 1992.

(b) Total uranium may also be indicated by U-natural (U-nat) or U-mass.

(c) Natural uranium is a mixture dominated by ${ }^{238} \mathrm{U}$, thus the half-life is approximately $4.5 \times 10^{9}$ years.

calibrating the counting instrument, and numerical rounding. With radionuclides, inaccuracies can also result from the randomness of radioactive decay.

Many of the individual measurements in this report are accompanied by a plus/minus $( \pm)$ value, referred to as the total propagated analytical uncertainty (or 2-sigma error). For samples that are prepared or manipulated in the laboratory prior to counting (counting the rate of radioactive emissions from a sample), the total propagated analytical uncertainty includes both the counting uncertainty and the uncertainty associated with sample preparation and chemical separations. For samples that are not manipulated in the laboratory before counting, the total propagated analytical uncertainty only accounts for the uncertainty associated with counting the sample. The uncertainty associated with samples that are analyzed but not counted includes only the analytical process uncertainty.

The total propagated analytical uncertainty gives information on what the measurement (or result) might be if the same sample were analyzed again under identical conditions. The uncertainty implies that approximately $95 \%$ of the time a recount or reanalysis of the same sample would give a value somewhere between the reported value minus the uncertainty and the reported value plus the uncertainty.

If the reported concentration of a given constituent is smaller than its associated uncertainty 


\begin{tabular}{|c|c|c|c|}
\hline \multirow[b]{2}{*}{ Symbol } & \multicolumn{2}{|c|}{ Table H.6. Elemental and Chemical Constituent Nomenclature } & \multirow[b]{2}{*}{ Constituent } \\
\hline & Constituent & Symbol & \\
\hline $\mathrm{Ag}$ & silver & $\mathrm{Hg}$ & mercury \\
\hline $\mathrm{Al}$ & aluminum & $\mathrm{K}$ & potassium \\
\hline As & arsenic & $\mathrm{LiF}$ & lithium fluoride \\
\hline $\mathrm{B}$ & boron & $\mathrm{Mg}$ & magnesium \\
\hline $\mathrm{Ba}$ & barium & $\mathrm{Mn}$ & manganese \\
\hline $\mathrm{Be}$ & beryllium & Mo & molybdenum \\
\hline $\mathrm{Br}$ & bromine & $\mathrm{NH}_{3}$ & ammonia \\
\hline $\mathrm{C}$ & carbon & $\mathrm{NH}_{4}^{+}$ & ammonium \\
\hline $\mathrm{Ca}$ & calcium & $\mathrm{N}$ & nitrogen \\
\hline $\mathrm{CaF}_{2}$ & calcium fluoride & $\mathrm{Na}$ & sodium \\
\hline $\mathrm{CCl}_{4}^{2}$ & carbon tetrachloride & $\mathrm{Ni}$ & nickel \\
\hline $\mathrm{Cd}^{4}$ & cadmium & $\mathrm{NO}_{2}^{-}$ & nitrite \\
\hline $\mathrm{CHCl}_{3}$ & trichloromethane & $\mathrm{NO}_{3}^{-}$ & nitrate \\
\hline $\mathrm{Cl}^{-3}$ & chloride & $\mathrm{Pb}^{3}$ & lead \\
\hline $\mathrm{CN}^{-}$ & cyanide & $\mathrm{PO}_{4}^{-3}$ & phosphate \\
\hline $\mathrm{Cr}^{+6}$ & chromium (species) & $\mathrm{P}^{4}$ & phosphorus \\
\hline $\mathrm{Cr}$ & chromium (total) & $\mathrm{Sb}$ & antimony \\
\hline $\mathrm{CO}_{3}^{-2}$ & carbonate & Se & selenium \\
\hline Co & cobalt & $\mathrm{Si}$ & silicon \\
\hline $\mathrm{Cu}$ & copper & $\mathrm{Sr}$ & strontium \\
\hline $\mathrm{F}^{-}$ & fluoride & $\mathrm{SO}_{4}^{-2}$ & sulfate \\
\hline $\mathrm{Fe}$ & iron & $\mathrm{Ti}^{4}$ & titanium \\
\hline $\mathrm{HCO}_{3}^{-}$ & bicarbonate & $\mathrm{Tl}$ & thallium \\
\hline & & $\mathrm{V}$ & vanadium \\
\hline
\end{tabular}

(e.g., $40 \pm 200$ ), the sample may not contain that constituent. Such low-concentration values are considered to be below detection, meaning the concentration of the constituent in the sample is so low that it is undetected by the method and/or instrument. In this situation, the total propagated analytical uncertainty is assumed to be the nominal detection limit.

\section{Standard Error of the Mean}

Just as individual values are accompanied by counting uncertainties, mean values (averages) are accompanied by \pm 2 times the standard error of the calculated mean ( \pm 2 standard error of the mean). If the data fluctuate randomly, then two times the standard error of the mean is a measure of the uncertainty in the estimated mean of the data from this randomness. If trends or periodic (e.g., seasonal) fluctuations are present, then two times the standard error of the mean is primarily a measure of the variability in the trends and fluctuations about the mean of the data. As with total propagated analytical uncertainty, two times the standard error of the mean implies that approximately $95 \%$ of the time the next calculated mean will fall somewhere between the reported value minus the standard error and the reported value plus the standard error.

\section{Median, Maximum, and Minimum Values}

Median, maximum, and minimum values are reported in some sections of this report. A median value is the middle value when all the values are arranged in order of increasing or decreasing magnitude. For example, the median value in the series of numbers, 123345556 , is 4 . The maximum value would be 6 and the minimum value would be 1 . Median, maximum, and minimum values are reported when there are too few analytical results to accurately determine the mean with a \pm statistical 
uncertainty or when the data do not follow a bellshape (i.e., normal) distribution.

\section{Negative Concentrations}

There is always a small amount of natural radiation in the environment. The instruments used in the laboratory to measure radioactivity in Hanford Site environmental media are sensitive enough to measure the natural, or background, radiation along with any contaminant radiation in a sample. To obtain a true measure of the contaminant level in a sample, the natural, or background, radiation level must be subtracted from the total amount of radioactivity measured by an instrument. Because of the randomness of radioactive emissions and the very low activities of some contaminants, it is possible to obtain a background measurement that is larger than the actual contaminant measurement. When the larger background measurement is subtracted from the smaller contaminant measurement, a negative result is generated. The negative results are reported because they are essential when conducting statistical evaluations of the data.

\section{Understanding Graphic Information}

Graphs are useful when comparing numbers collected at several locations or at one location over time. Graphs make it easy to visualize differences in data where they exist. However, while graphs may make it easy to evaluate data, they also may lead the reader to incorrect conclusions if they are not interpreted correctly. Careful consideration should be given to the scale (linear or logarithmic), concentration units, and type of uncertainty used.

Some of the data graphed in this report are plotted using logarithmic, or compressed, scales. Logarithmic scales are useful when plotting two or more

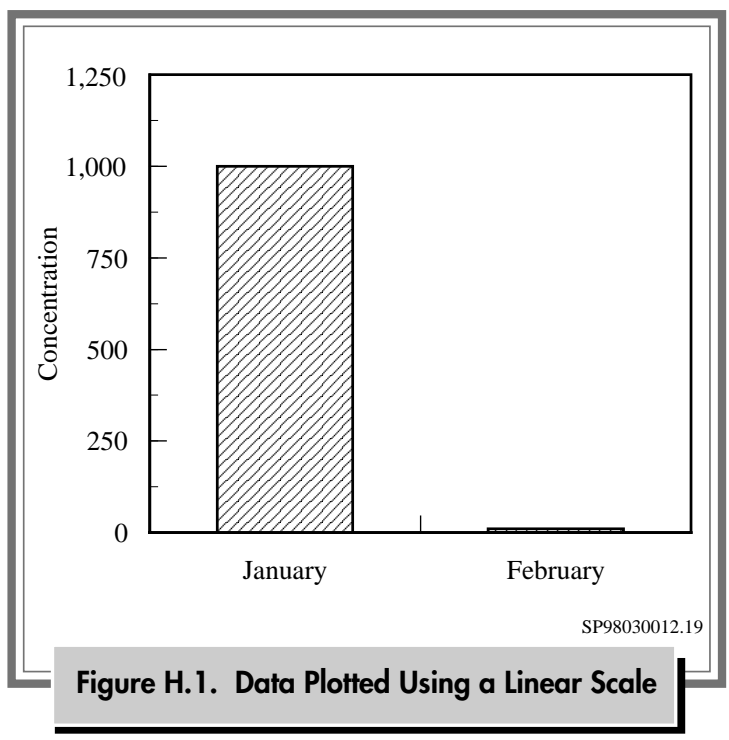

1999 Annual Environmental Report numbers that differ greatly in size. For example, a sample with a concentration of 5 grams per liter would get lost at the bottom of the graph if plotted on a linear scale with a sample having a concentration of 1,000 grams per liter (Figure H.1). A logarithmic plot of these same two numbers allows the reader to see both data points clearly (Figure H.2).

The mean (average) and median (defined earlier) values graphed in this report have vertical lines extending above and below the data point. When used with a mean value, these lines (called error bars) indicate the amount of uncertainty (total propagated

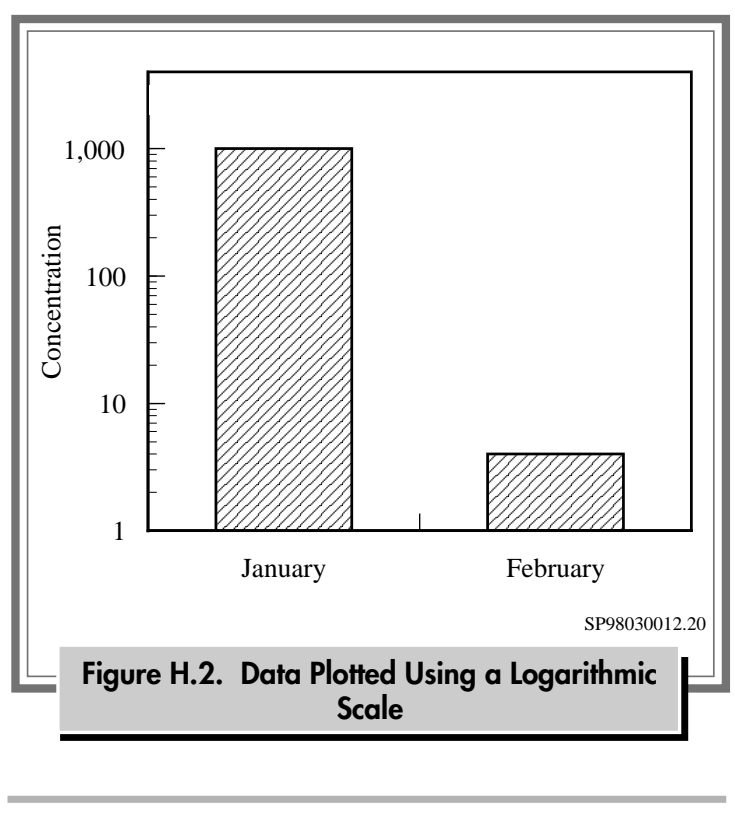


analytical uncertainty or two standard error of the mean) in the reported result. The error bars in this report represent a $95 \%$ chance that the mean is between the upper and lower ends of the error bar and a $5 \%$ chance that the true mean is either lower or higher than the error bar. ${ }^{(a)}$ For example, in Figure H.3, the first plotted mean is $2.0 \pm 1.1$, so there is a $95 \%$ chance that the true mean is between 0.9 and 3.1 , a $2.5 \%$ chance that it is less than 0.9 , and a $2.5 \%$ chance that it is greater than 3.1. Error bars are computed statistically, employing all of the information used to generate the mean value. These bars provide a quick, visual indication that one mean may be statistically similar to or different from another mean. If the error bars of two or more means overlap, as is the case with means 1 and 3 and means 2 and 3 , the means may be statistically similar. If the error bars do not overlap (means 1 and 2), the means may be statistically different. Means that appear to be very different visually (means 2 and 3) may actually be quite similar when compared statistically.

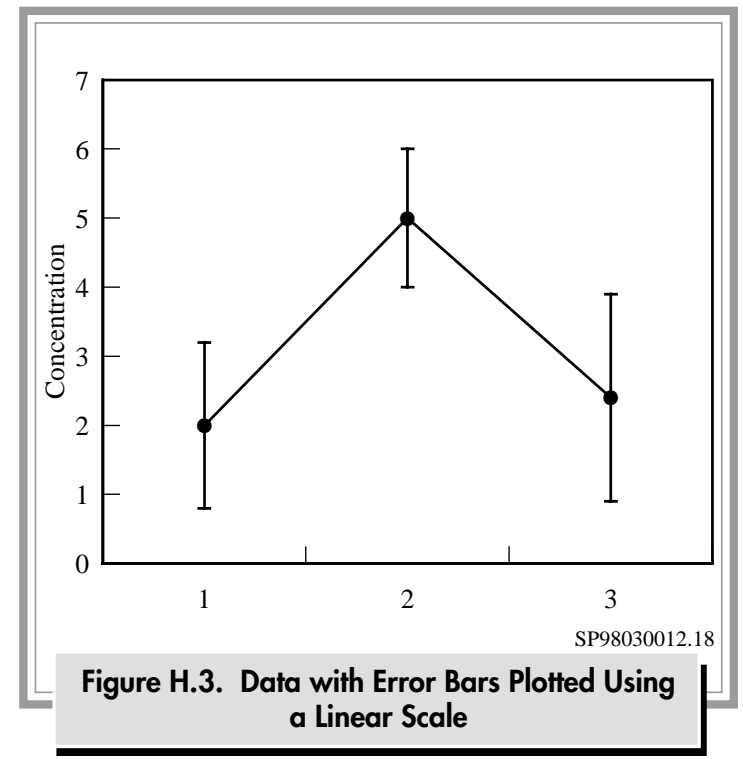

When vertical lines are used with median values, the lower end of each bar represents the minimum concentration measured; the upper end of each bar represents the maximum concentration measured.

\section{Greater Than $(>)$ or Less Than $(<)$ Symbols}

Greater than $(>)$ or less than $(<)$ symbols are used to indicate that the actual value may either be larger than the number given or smaller than the number given. For example, $>0.09$ would indicate that the actual value is greater than 0.09. An inequality symbol pointed in the opposite direction

\section{References}

American Indian Religious Freedom Act. 1978. Public Law 95-341, as amended, 42 USC 1996, et seq.

Archaeological Resources Protection Act. 1979. Public Law 96-95, as amended, 93 Stat. 721.

Clean Air Act. 1986. Public Law 88-206, as amended, 42 USC 7401 et seq.

(a) Assuming a normal statistical distribution of the data.
$(<0.09)$ would indicate that the number is less than the value presented. An inequality symbol used with an underscore $(\leq$ or $\geq$ ) indicates that the actual value is less than or equal to or greater than or equal to the number given, respectively.

Clean Water Act. 1997. Public Law 95-217, as amended, 91 Stat. 1566 and Public Law 96-148 as amended.

Comprehensive Environmental Response, Compensation, and Liability Act. 1980. Public Law 96-150, as amended, 94 Stat. 2767, 42 USC 9601 et seq.

DOE Order 231.1A. "Environment, Safety, and Health Reporting." 
DOE Order 5400.1. "General Environmental Protection Program."

DOE M 231.1-1. 1995. Environment, Safety and $\mathrm{H}$ ealth Reporting M anual. U.S. Department of Energy, Assistant Secretary for Environment, Safety and Health, Office of Nuclear Facility Safety, Washington, D.C.

Emergency Planning and Community Right-To-Know Act. 1986. Public Law 99-499, as amended, 100 Stat. 1728, 42 USC 11001 et seq.

Endangered Species Act. 1973. Public Laws 93-205 through 100-707, as amended, 87 Stat. 884, 16 USC 1531 et seq.

Federal Insecticide, Fungicide, and Rodenticide Act. 1975. Public Laws 94-51 through 94-140, as amended, 7 USC 136 et seq.

ISO 14001. 1996. Environmental M anagement Systems- Specifications with $\mathrm{G}$ uidance for $\mathrm{U}$ se. American Society for Testing and Materials, West Conshohocken, Pennsylvania.
National Environmental Policy Act. 1969. Public Laws 91-190, as amended, 42 USC 4321 et seq.

National Historic Preservation Act. 1966. Public Law 89-665, as amended, 80 Stat. 915-919.

Native American Graves Protection and Repatriation Act. 1990. Public Law 101-601, as amended, 25 USC 3001 et seq.

Resource Conservation and Recovery Act. 1976. Public Law 94-580, as amended, 90 Stat. 2795, 42 USC 6901 et seq.

Safe Drinking Water Act. 1974. Public Law 93-523, as amended, 88 Stat. 1660, 42 USC 300 f et seq.

Shleien, B. 1992. TheH ealth Physics and Radiological $\mathrm{H}$ ealth $\mathrm{H}$ andbook, Revised Edition. Scinta, Inc., Silver Spring, Maryland. 


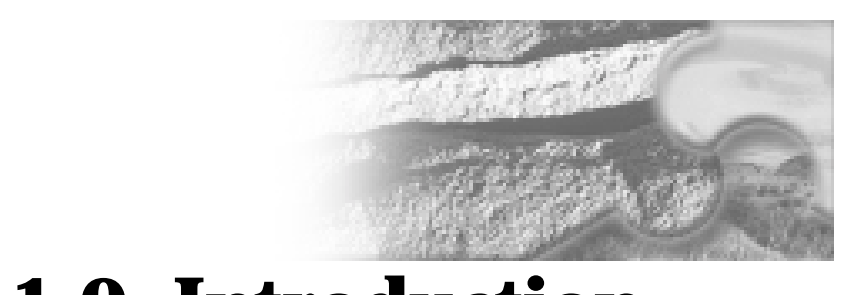

1.0 Introduction

\section{R. W. H anf and K. R. Price}

This Hanford Site environmental report is produced through the joint efforts of the principal site contractors (Pacific Northwest National Laboratory, Fluor Hanford, Inc. and its subcontractors, Bechtel Hanford, Inc. and its subcontractors, CH2M HILL Hanford Group, Inc., and MACTEC-ERS). This report, published annually since 1958, includes information and summary data that 1) characterize environmental management performance at the Hanford Site; 2) demonstrate the status of the site's compliance with applicable federal, state, and local environmental laws and regulations; and 3) highlight significant environmental monitoring and surveillance programs and projects.

Specifically, this report provides a short introduction to the Hanford Site and its history; discusses the site mission; and briefly highlights the site's various waste management, waste remediation, environmental restoration, effluent monitoring, environmental surveillance, and environmental compliance programs and projects. Included are summary data and descriptions for the Hanford Site Groundwater/Vadose Zone Integration Project, the Environmental Restoration Project, the NearFacility Environmental Monitoring Program, the Integrated Biological Control Program, the Surface Environmental Surveillance Project, the Hanford Groundwater Monitoring Project, the Hanford Cultural Resources Laboratory, wildlife studies, climate and meteorological monitoring, and information about other programs and projects. Also included are sections discussing environmental occurrences, current issues and actions, environmental cleanup and restoration activities, compliance issues, and descriptions of major operations and activities. Readers interested in more detail than that provided in this report should consult the technical documents cited in the text and listed in the reference sections. Descriptions of specific analytical and sampling methods used in the monitoring efforts are contained in the Hanford Site environmental monitoring plan (DOE/RL-91-50, Rev. 2).

\subsubsection{Overview of the Hanford Site}

The Hanford Site lies within the semiarid Pasco Basin of the Columbia Plateau in southeastern Washington State (Figure 1.0.1). The site occupies an area of $\sim 1,517$ square kilometers ( 586 square miles) (68 square kilometers [26 square miles] larger this year to include U.S. Department of Energy [DOE] owned portions of the Columbia River) located north of the city of Richland and the confluence of the Yakima and Columbia Rivers (DOE/EIS-0222). This large area has restricted public access and provides a buffer for the smaller areas on the site that historically were used for production of nuclear materials, waste storage, and waste disposal. Only $\sim 6 \%$ of the land area has been disturbed and actively used. The Columbia River flows eastward through the northern part of the Hanford Site and then turns south, forming part of the eastern site boundary. The Yakima River flows near a portion of the southern boundary and joins the Columbia River at the city of Richland. Portions of the site are managed by the U.S. Fish and Wildlife Service as part of the Arid Lands National Wildlife refuge complex.

The Hanford Site is the largest single source of employment in the Tri-Cities. However, the number of employees at Hanford is down considerably from a 


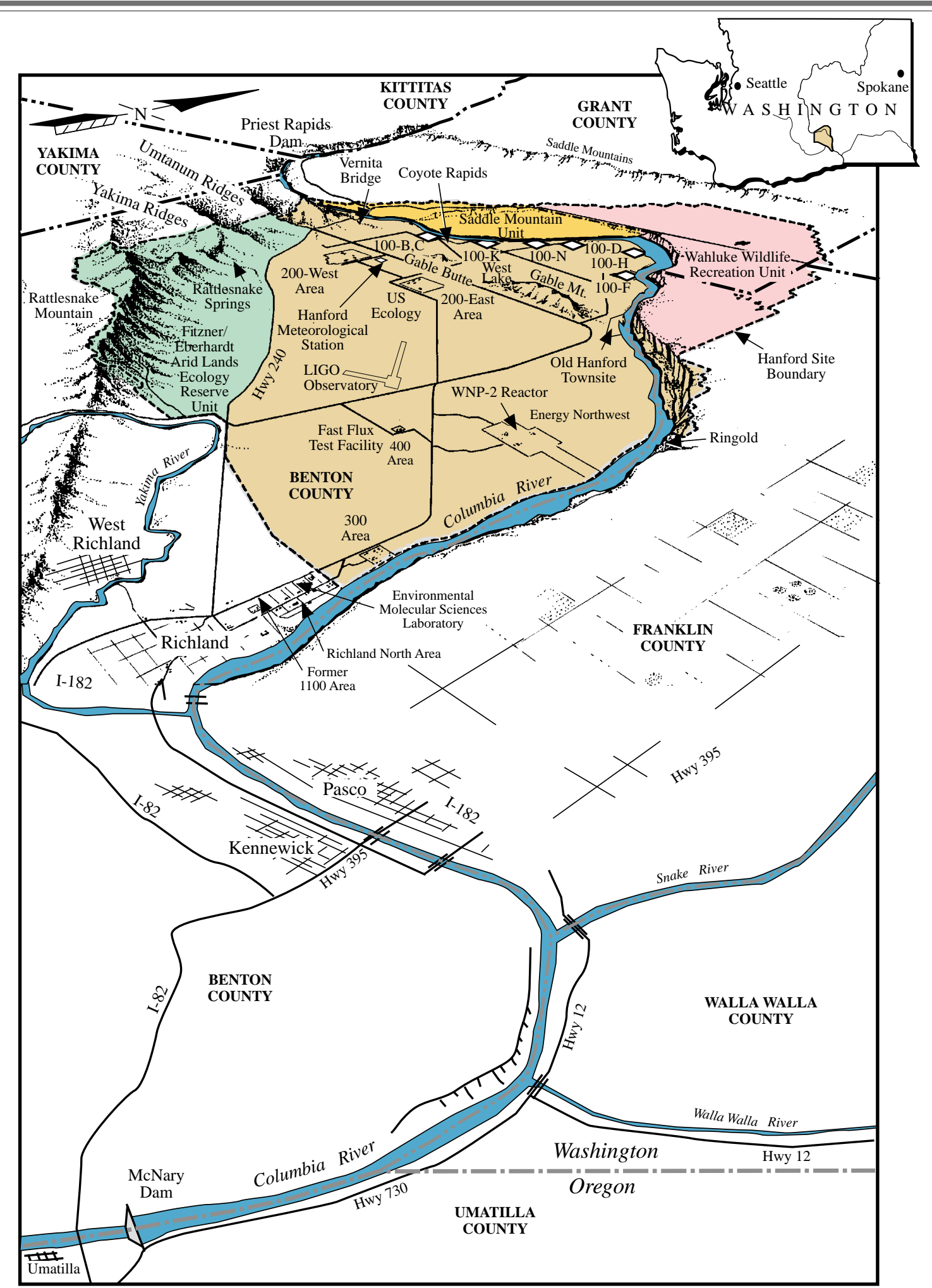

G00020011.2

Figure 1.0.1. The Hanford Site and Surrounding Area 
peak of 19,200 in fiscal year 1994. DOE employed 10,400 federal and contractor employees in fiscal year 1999. Hanford's large portion of the Tri-Cities' employment has affected other areas of employment, directly or indirectly accounting for $32 \%$ of all jobs in the Tri-Cities (DOE/RL-2000-32). The five largest non-Hanford Site employers employed 5,115 people in Benton and Franklin Counties in 1999.

Estimates for 1999 placed population totals for Benton and Franklin Counties at 138,900 and 45,100, respectively (Washington State Office of Financial Management 1999). When compared to the 1990 census data (U.S. Bureau of the Census 1994) in which Benton County had 112,560 individuals and Franklin County had 37,473 individuals, the population totals reflect continued growth. The populations in Benton and Franklin Counties increased by 1,400 and 700, respectively, in 1999.

The 1999 estimates distributed the Tri-Cities' population within each city as follows: Richland 36,880, Pasco 26,600, and Kennewick 50,950. The combined populations of Benton City, Prosser, and West Richland totaled 14,700 in 1999. The unincorporated population of Benton County was 36,370. In Franklin County, incorporated areas (cities and towns) other than Pasco have a total population of 3,470 . The unincorporated rural population of Franklin County was 15,030 (Washington State Office of Financial Management 1999).

The 1999 estimates of racial/ethnic distribution (Washington State Office of Financial Management 1999) indicate that Asians represent a lower proportion and individuals of Hispanic origin represent a higher proportion of the population in Benton and Franklin Counties than those in Washington State. At the time of the 1990 census (U.S. Bureau of Census 1994), Hispanics accounted for nearly $81 \%$ of the minority population around the Hanford Site. The site is also surrounded by a relatively large percentage ( 9\%) of Native Americans.

Benton and Franklin Counties account for 3.2\% of Washington State's population (Washington State
Office of Financial Management 1998). In 1999, the population demographics of Benton and Franklin Counties were similar to those found within Washington State. The population in Benton and Franklin Counties under the age of 35 was $53.1 \%$, compared to $49.3 \%$ for the state. In general, the population of Benton and Franklin Counties was somewhat younger than that of the state. The 0 - to 14-year-old age group accounted for $26.2 \%$ of the total bicounty population, compared to $22.3 \%$ for the state. In 1999, the 65-year-old and older age group constituted $9.6 \%$ of the population of Benton and Franklin Counties, compared to $11.4 \%$ for the state.

\subsubsection{Site Description}

The entire Hanford Site was designated a National Environmental Research Park (one of four nationally) by the former U.S. Energy Research and Development Administration, a precursor to the DOE.

The major areas on the site (see Figure 1.0.1) include the following:

- The 100 Areas, on the south shore of the Columbia River, are the sites of nine retired plutonium production reactors, including the dualpurpose N Reactor. The 100 Areas occupy $\sim 11$ square kilometers (4 square miles).

- The 200-West and 200-East Areas are located on a plateau and are $\sim 8$ and 11 kilometers (5 and 7 miles), respectively, south and west of the Columbia River. The 200 Areas cover $\sim 16$ square kilometers (6 square miles).

- The 300 Area is located just north of the city of Richland. This area covers 1.5 square kilometers ( 0.6 square mile).

- The 400 Area is $\sim 8$ kilometers (5 miles) northwest of the 300 Area.

- The 600 Area includes all of the Hanford Site not occupied by the 100,200,300, and 400 Areas. 
- The former 311-hectare (768-acre) 1100 Area is located generally between the 300 Area and the city of Richland and included site support services such as general stores and transportation maintenance. On October 1, 1998, this area was transferred to the Port of Benton as a part of the DOE's Richland Operations Office economic diversification efforts and is no longer part of the Hanford Site. However, DOE contractors continue to lease facilities in this area.

- The Richland North Area (off the site) includes DOE and contractor facilities, mostly leased office buildings, generally located in the northern part of the city of Richland.

Other facilities (office buildings) are located in the Richland Central Area (located south of Saint Street and Highway 240 and north of the Yakima River), the Richland South Area (located between the Yakima River and Kennewick), and the Kennewick/Pasco area.

Several areas of the site, totaling 665 square kilometers (257 square miles), have special designations. These include the Fitzner/Eberhardt Arid Lands Ecology Reserve (310 square kilometers [120 square miles]), the U.S. Fish and Wildlife Service Saddle Mountain National Wildlife Refuge ( 130 square kilometers [50 square miles]), and Wahluke Wildlife Recreation Area (225 square kilometers [87 square miles]). Together, these make up the Arid Lands National Wildlife Refuge Complex. The Fitzner/ Eberhardt Arid Lands Ecology Reserve was established in 1967 by the U.S. Atomic Energy Commission, a precursor to DOE, to preserve shrub-steppe habitat and vegetation. In 1971, the reserve was classified a Research Natural Area as a result of a federal interagency cooperative agreement. In June 1997, DOE transferred management of the reserve, including access management, from Pacific Northwest National Laboratory to the U.S. Fish and Wildlife Service, who will continue to operate the reserve using the in-place management policy (PNL-8506) until a new management plan can be written. This is scheduled to occur within 3 years of the June 1997 transfer date.
Since 1971, the west portion of the Wahluke Slope Area (Saddle Mountain National Wildlife Refuge) has been managed under permit by the U.S. Fish and Wildlife Service and the east and north portion (Wahluke Wildlife Recreation Area) has been managed by the Washington State Department of Fish and Wildlife. In early 1999, the Washington State Department of Fish and Wildlife withdrew from management of the Wahluke Wildlife Recreation Area. Secretary of Energy Bill Richardson announced in April 1999 the proposal to manage the entire Wahluke Slope area as a national wildlife refuge. The recreation area and the Saddle Mountain National Wildlife Refuge were renamed the Wahluke Wildlife Recreation and Saddle Mountain Units, respectively, and will be managed by the U.S. Fish and Wildlife Service. The Wahluke Slope is a prime example of a shrub-steppe habitat that is quickly disappearing in the Pacific Northwest. This land has served as a safety and security buffer zone for Hanford Site operations since 1943, resulting in an ecosystem that has been relatively untouched.

Non-DOE operations and activities on Hanford Site leased land or in leased facilities include commercial power production by Energy Northwest (Columbia Generating Station, formerly the WNP-2 reactor) (4.4 square kilometers [1.6 square miles]) and operation of a commercial low-level radioactive waste burial site by US Ecology, Inc. (0.4 square kilometer [0.2 square mile]). Kaiser Aluminum and Chemical Corporation is leasing the 313 Building in the 300 Area to use an extrusion press that was formerly DOE owned. The National Science Foundation has built the Laser Interferometer Gravitational-Wave Observatory facility near Rattlesnake Mountain for gravitational wave studies. R. H. Smith Distributing operates vehiclefueling stations in the former 1100 Area and 200 Areas. Washington State University at Tri-Cities operates three laboratories in the 300 Area. Livingston Rebuild Center, Inc. has leased the 1171 Building, in the former 1100 Area, to rebuild train locomotives. Johnson Controls, Inc. operates 42 diesel and natural gas package boilers to produce 
steam in the 200 and 300 Areas (replacing the old coal-fired steam plants) and also has compressors supplying compressed air to the site. Near the city of Richland, immediately adjacent to the southern boundary of the Hanford Site, Siemens Power Corporation operates a commercial nuclear fuel fabrication facility and Allied Technology Group
Corporation operates a low-level radioactive waste decontamination, super compaction, and packaging facility.

Much of the above information is from PNNL6415, Rev. 12, where more detailed information can be found.

\subsubsection{Historical Site Operations}

This section addresses the historic operational mission of the Hanford Site. However, with the end of the Cold War and the advent of waste treatment and disposal technologies and environmental management, this original mission has been replaced by cleanup. Section 1.0.3, "Current Site Mission" and Section 2.3, "Activities, Accomplishments, and Issues," summarize current activities at the Hanford Site.

The Hanford Site was established in 1943 to use technology developed at the University of Chicago and the Clinton Laboratory in Oak Ridge, Tennessee, to produce plutonium for some of the nuclear weapons tested and used in World War II. Hanford was the first plutonium production facility in the world. The site was selected by the U.S. Army Corps of Engineers because it was remote from major populated areas and had 1) ample electrical power from Grand Coulee Dam, 2) a functional railroad, 3) clean water from the nearby Columbia River, and 4) sand and gravel that could be used to construct large concrete structures. For security, safety, and functional reasons, the site was divided into numbered areas (see Figure 1.0.1).

Hanford Site operations have produced liquid, solid, and gaseous wastes. Most waste resulting from site operations has had at least the potential to contain radioactive materials. From an operational standpoint, radioactive waste was originally categorized (see Table 10.3 in Fitzgerald 1970) as "high level," "intermediate level," or "low level," which referred to the level of radioactivity present. Some high-level solid waste, such as large pieces of machinery and equipment, were placed onto railroad flatcars and stored in underground tunnels. Both intermediate- and low-level solid wastes, consisting of tools, machinery, paper, or wood, were placed into covered trenches at storage and disposal sites known as "burial grounds." Beginning in 1970, solid waste was segregated according to the makeup of the waste material. Solids contaminated with plutonium and other transuranic materials were packaged in special containers and stored in trenches covered with soil for possible later retrieval. High-level liquid waste was stored in large underground tanks. Intermediatelevel liquid waste streams were usually routed to underground structures of various types called "cribs." Occasionally, trenches were filled with the liquid waste and then covered with soil after the waste had soaked into the ground. Low-level liquid waste streams were usually routed to surface impoundments (ditches and ponds). Nonradioactive solid waste was usually burned in "burning grounds." This practice was discontinued in the late 1960s in response to the Clean A ir Act, and the materials were buried at sanitary landfill sites. These storage and disposal sites, with the exception of high-level waste tanks, are now designated as "active" or "inactive" waste sites, depending on whether the site currently receives waste.

All unrestricted discharges of radioactive liquid waste to the ground were discontinued in 1997 . The 616-A crib (also known as the State-Approved Land Disposal Site) receives radioactive (tritium) liquid waste from the 200 Areas Effluent Treatment Facility. This effluent is the only discharge of radioactive liquid waste to the ground at Hanford. All other 
liquids discharged to the ground are licensed by permit from the state of Washington. National Pollutant Discharge Elimination System permits issued by the U.S. Environmental Protection Agency (EPA) govern liquid discharges to the Columbia River (40 CFR 122). Permits from EPA, the Washington State Department of Health, and the Washington State Department of Ecology govern the discharge of gaseous effluents to the atmosphere. See Section 2.2, "Compliance Status," for details. The status of the high-level waste tanks is discussed in Section 2.3.7, "Office of River Protection."

\subsubsection{The 300 Area}

From the early 1940s until the advent of the cleanup mission, most research and development at the Hanford Site were carried out in the 300 Area, located just north of Richland. The 300 Area was also the location of nuclear fuel fabrication. Nuclear fuel in the form of pipe-like cylinders (fuel elements) was fabricated from metallic uranium shipped in from offsite production facilities. Metallic uranium was extruded into the proper shape and encapsulated in aluminum or zirconium cladding. Copper was an important material used in the extrusion process, and substantial amounts of copper, uranium, and other heavy metals ended up in 300 Area liquid waste streams. Initially, these streams were routed to the 300 Area waste ponds, which were located near the Columbia River shoreline. In more recent times, the low-level liquid waste was sent to process trenches or shipped to a solar evaporation facility in the $100-\mathrm{H}$ Area (183-H solar evaporation basins). This practice has been discontinued. At this time, all liquid process waste generated in the 300 Area is treated at the 300 Area Treated Effluent Disposal Facility and released to the Columbia River according to the requirements of a National Pollutant Discharge Elimination System permit. Sewage waste is released into the city of Richland sanitary water treatment system.

Former fuel fabrication buildings and facilities are now used for other purposes or are in various stages of cleanup or restoration. For example, the
313 Building that houses a very large and unique aluminum extrusion press is leased by DOE to Kaiser Aluminum and Chemical Corporation.

\subsubsection{The 100 Areas}

The fabricated fuel elements were shipped by rail from the 300 Area to the 100 Areas. The 100 Areas are located on the Columbia River shoreline, where up to nine nuclear reactors were in operation. The main component of the nuclear reactors consisted of a large stack (pile) of graphite blocks that had tubes and pipes running through it. The tubes were receptacles for the fuel elements while the pipes carried water to cool the graphite pile. Placing large numbers of slightly radioactive uranium fuel elements into the reactor piles created an intense radiation field, and a radioactive chain reaction resulted in the conversion of some uranium atoms into plutonium atoms. Other uranium atoms were split into radioactive "fission products." The intense radiation field also caused some nonradioactive atoms in the structure to become radioactive "activation products."

The first eight reactors, constructed between 1944 and 1955, used water from the Columbia River for direct cooling. Large quantities of water were pumped through the reactor piles and discharged back into the river. The discharged cooling water contained primarily activation products from impurities in the river water made radioactive by neutron activation and radioactive materials that escaped from the fuel elements or tube walls during the irradiation process. The ninth reactor, N Reactor, was completed in 1963 and was a modified design. Purified water was recirculated through the reactor core in a closed-loop cooling system. Beginning in 1966, the heat from the closed-loop system was used to produce steam that was sold to Energy Northwest to generate electricity at the adjacent Hanford Generating Plant.

When fresh fuel elements were pushed into the front face of a reactor's graphite pile, irradiated fuel 
elements were forced out the rear into a deep pool of water called a "fuel storage basin." After a brief period of storage in the basin, the irradiated fuel was shipped to the 200 Areas for processing. The fuel was shipped in casks by rail in specially constructed railcars. Most of the irradiated fuel produced by the N Reactor from the early 1970s to the early 1980s was the result of electricity production runs. This material was not weapons grade, so was never processed for recovery of plutonium.

Beginning in 1975, NReactor irradiated fuel was shipped to the K-East and K-West fuel storage basins ( $\mathrm{K}$ basins) for temporary storage, where it remains today. This fuel accounts for the majority of the total fuel inventory stored under water in the $\mathrm{K}$ basins. From the early 1980s until its shutdown in 1987, $\mathrm{N}$ Reactor operated to produce weapons-grade material. Electricity production continued during this operating period but was actually a byproduct of the weapons production program. The majority of weapons-grade material produced during these runs was processed in the 200-East Area at the PlutoniumUranium Extraction Plant prior to its shutdown. The remainder is stored in the K basins. See Section 2.3.3, "Spent Nuclear Fuel Project," for the status and details regarding the storage of spent fuel.

All of the Hanford production reactors and most of the associated facilities have been shut down and deactivated, and each 100 Area is in some stage of cleanup, decommissioning, or restoration. For example, C Reactor has been cocooned and placed into interim safe storage as a large-scale demonstration, a state that it can safely remain in for many years. Of the 24 facilities associated with the reactor, 23 have been removed. See Section 2.3, "Activities, Accomplishments, and Issues," for the status of various facilities.

\subsubsection{The 200 Areas}

The 200-East and 200-West Areas are located on a plateau approximately in the center of the site.
These areas house facilities that received and dissolved irradiated fuel and then separated out the valuable plutonium (Figure 1.0.2). These facilities were called "separations plants." Three types of separations plants were used over the years to process irradiated fuel. Each of the plutonium production processes began with the dissolution of the aluminum or zirconium cladding material in solutions containing ammonium hydroxide/ammonium nitrate/ ammonium fluoride followed by the dissolution of the irradiated fuel elements in nitric acid. All three separations plants, therefore, produced large quantities of waste nitric acid solutions that contained high levels of radioactive materials. These wastes were neutralized and stored in large underground tanks. Fumes from the dissolution of cladding and fuel and from other plant processes were discharged to the atmosphere from tall smokestacks. Filters were added to the stacks after 1950 .

Both B and T plants used a "bismuth phosphate" process to precipitate and separate plutonium from acid solutions during the early days of site operations. Leftover uranium and high-level waste products were not separated and were stored together in large, underground, single-shell tanks (i.e., tanks constructed with a single wall of steel). The leftover uranium was later salvaged, purified into uranium oxide powder at the Uranium-TriOxide Plant, and transported to uranium production facilities in other parts of the country for reuse. The salvage process used a solvent extraction technique that resulted in radioactive liquid waste that was discharged to the soil in covered trenches at the $\mathrm{BC}$ cribs area south of the 200-East Area.

After T Plant stopped functioning as a separations facility, it was converted to a decontamination operation, where pieces of equipment and machinery could be radiologically decontaminated for reuse. B Plant was later converted into a facility to separate radioactive strontium and cesium from high-level waste. The strontium and cesium were then concentrated into a solid salt material, melted, and encapsulated at the adjacent encapsulation facility. Canisters 
State-Approved

Land Disposal Site for

and Process Mixed Effluent Treatment

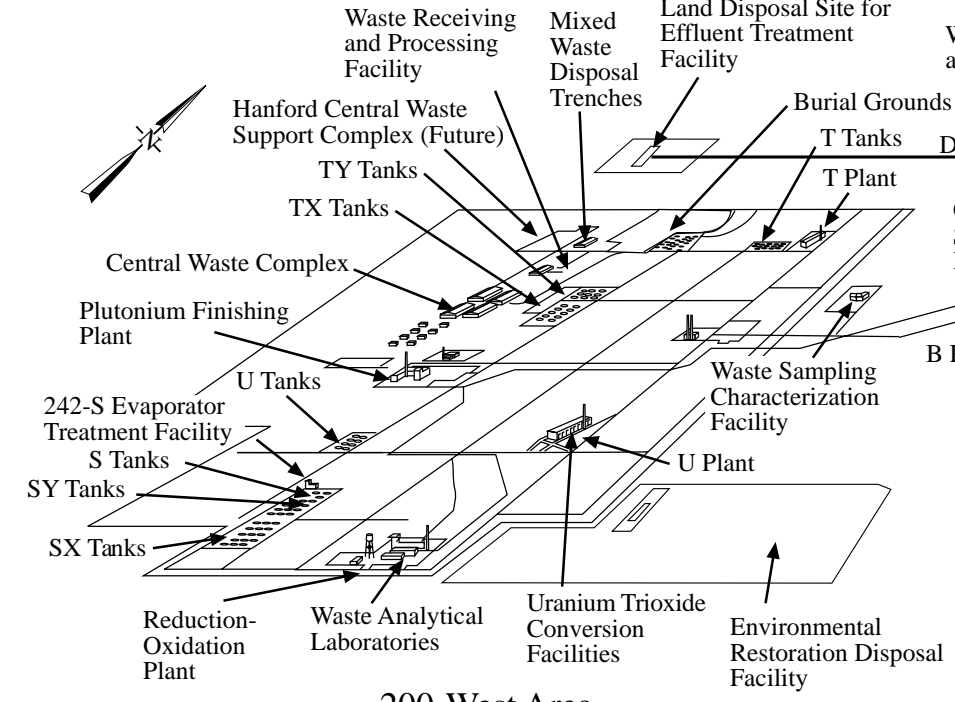

Waste Encapsulation and Storage Facility

AZ 200 Areas Effluent

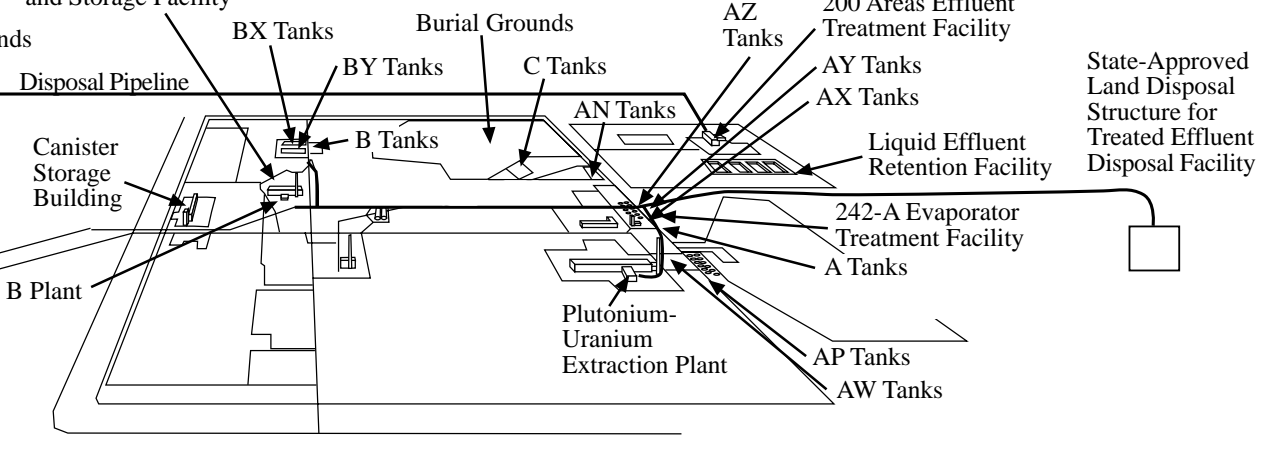

200-East Area

G99030045.102

Figure 1.0.2. Waste Processing, Storage, and Disposal Facilities in the 200 Areas 
of encapsulated strontium and cesium are currently stored in a water storage basin at the encapsulation facility.

In 1952, U Plant in the 200-West Area, built during World War II but not needed as a processing canyon, was retrofitted as the Metal Recovery Plant. Its mission was to use a new tributyl phosphate/ saturated kerosene extraction technique to recover uranium from the waste stored in Hanford's tank farms. The scarcity of high-grade uranium supplies made this mission crucial and much of the United States' supply of uranium was housed in Hanford's tanks. The separated uranium was purified into uranium oxide powder at the Uranium-TriOxide Plant.

The Reduction-Oxidation and PlutoniumUranium Extraction Plants used solvent extraction techniques to separate plutonium from leftover uranium and radioactive waste products. Most of the irradiated fuel produced at the site was processed at either of these two plants. The solvent extraction method separates chemicals based on their differing solubilities in water and organic solvents (i.e., hexone at the Reduction-Oxidation Plant and tributylphosphate at the Plutonium-Uranium Extraction Plant). High-level liquid wastes were neutralized and stored in single-shell tanks (Reduction-Oxidation Plant) or double-shell tanks (Plutonium-Uranium Extraction Plant). Occasionally, organic materials such as solvents and resins ended up in high-level liquid waste streams sent to the tanks. Various chemicals and radioactive materials precipitated and settled to the bottom of the tanks. This phenomenon was later used to advantage. The liquid waste was heated in special facilities (evaporators) to remove excess water and concentrate the waste into salt cake and sludge, which remained in the tanks. The evaporated and condensed water contained radioactive tritium and was discharged to cribs. Intermediateand low-level liquid wastes discharged to the soil from the Reduction-Oxidation and PlutoniumUranium Extraction Plants typically contained tritium and other radioactive fission products as well as nonradioactive nitrate. Intermediate-level liquid wastes discharged to cribs from the ReductionOxidation Plant sometimes contained hexone used in the reduction-oxidation process. Cooling water from the Reduction-Oxidation Plant was discharged to the 216-S-10 pond (B Pond). Cooling water from the Plutonium-Uranium Extraction Plant was discharged to the Gable Mountain and 216-B-3 ponds.

The Reduction-Oxidation and PlutoniumUranium Extraction Plants produced uranium nitrate for recycle and plutonium nitrate for weapons component production. Uranium nitrate was shipped by tank truck to the Uranium-TriOxide Plant for processing. The Uranium-TriOxide Plant used specially designed machinery to heat the uranium nitrate solution and boil off the nitric acid, which was recovered and recycled to the separations plants. The product (uranium oxide) was packaged and shipped to other facilities in the United States for recycle. Plutonium nitrate, in small quantities for safety reasons, was placed into special shipping containers (P-R cans) and hauled by truck to Z Plant (later called the Plutonium Finishing Plant) for further processing.

The purpose of Plutonium Finishing Plant operations was to convert the plutonium nitrate into plutonium metal blanks (buttons) that were shipped off the site for manufacture into nuclear components. The conversion processes used nitric acid, hydrofluoric acid, carbon tetrachloride, and other organic compounds. Varying amounts of all these materials ended up in the intermediate-level liquid wastes that were discharged to cribs. Cooling water from the Plutonium Finishing Plant was discharged via open ditch to the 216-U-10 pond (U Pond). High-level solid wastes containing plutonium scraps were segregated and packaged for storage in special earthcovered trenches.

All of the former activities in the separations plants, the Reduction-Oxidation Plant, and the Plutonium Finishing Plant have been shut down and the facilities are in various stages of decontamination 
and decommissioning or alternate use. For example, the former $T$ Plant complex now consists of two operational facilities used for waste sampling and verification, waste repackaging, equipment decontamination, and storage of a small amount of irradiated fuel from the former Shippingport, Pennsylvania reactor. See Section 2.3.4, "River Corridor Project," for additional information. Untreated low-level liquid wastes are no longer released to surface ponds, ditches, or cribs. These facilities are in various states of decommissioning, decontamination, and restoration. See Section 2.2, "Compliance Status" (especially Table 2.2.2), for details.

\subsubsection{The 400 Area}

In addition to research and development activities in the 300 Area, the Hanford Site has supported several test facilities. The largest is the Fast Flux Test Facility, located $\sim 8$ kilometers ( 5 miles) northwest of the 300 Area. This special nuclear reactor was designed to test various types of nuclear fuel. The facility operated for $\sim 13$ years and was shut down in 1993. The reactor was a unique design that used liquid metal sodium as the primary coolant. The heated liquid sodium was cooled with atmospheric air in heat exchangers. Spent fuel from the facility resides in the 400 Area, while other wastes were transported to the 200 Areas. With the exception of the spent fuel, no major amounts of radioactive waste were stored or disposed of at the Fast Flux Test Facility site. In January 1997, DOE made a decision to keep the Fast Flux Test Facility in standby while evaluating its potential for tritium and medical isotope production, as well as plutonium disposition. Tritium, a necessary ingredient in some nuclear weapons, decays relatively quickly so must be replenished. Medical isotopes are radioactive elements that are useful for the treatment of medical conditions such as cancer. Excess plutonium, no longer needed for national defense, could be disposed of by converting it to reactor fuel that could be burned in commercial reactors. Through the end of calendar year 1999, the future of the Fast Flux Test Facility was still undecided.

In spring 1999, the Nuclear Energy Research Advisory Committee (an independent advisor to the DOE) suggested to the DOE that more information was needed before a recommendation about continuing with the production of an environmental impact statement could be made. As a consequence, Pacific Northwest National Laboratory was asked by the Secretary of Energy in May to determine whether or not a compelling rationale existed for restarting the reactor. The results of the study were presented to the Nuclear Energy Research Advisory Committee in July and the committee recommended that the DOE proceed toward a record of decision on the test facility. In September, the DOE announced its decision to prepare an environmental impact statement to review the environmental effects associated with using the Fast Flux Test Facility to produce isotopes for medical use and plutonium-238 for space missions and nuclear research and development. A final impact statement is expected in October 2000. If the decision at that time is to initiate restart activities, it is expected that the reactor could be operational by January 2005. If a decision is made to shut down the facility, it is anticipated that deactivation would be complete by 2006. Details can be found in Section 2.3.5, "Fast Flux Test Facility."

\subsubsection{Current Site Mission}

For more than 40 years, Hanford Site facilities were dedicated primarily to the production of plutonium for national defense and to the management of the resulting wastes. In recent years, efforts at the site have focused on developing new waste treatment and disposal technologies and cleaning up contamination left over from historical operations.

The Hanford Site has two major missions: 1) environmental management and 2) science and 
technology. The environmental management mission includes the following:

- management of waste and the handling, storage, treatment, and disposal of radioactive, hazardous, mixed, or sanitary waste from past and current operations

- stabilizing facilities by transitioning them from an operating mode to a long-term surveillance and maintenance mode. This includes maintaining facilities in a safe and compliant status, deactivating primary systems to effectively reduce risks, providing for the safe storage of nuclear materials and reducing risks from hazardous materials and contamination. These activities are intended to allow the lowest surveillance and maintenance cost to be attained while awaiting determination of a facility's final disposition.

- maintaining the Fast Flux Test Facility reactor and its associated support facilities while alternative future missions for the reactor are explored (e.g., medical isotope production)

- maintenance and cleanup of several hundred inactive radioactive, hazardous, and mixed waste disposal sites; remediation of contaminated groundwater; and surveillance, maintenance, and decommissioning of inactive facilities.

The science and technology mission includes the following:

- research and development in energy, health, safety, environmental sciences, molecular

\subsubsection{Site Management}

The Hanford Site is managed by the DOE's Richland Operations Office and the Office of River Protection through the following contractors and subcontractors. Each contractor is responsible for safe, environmentally sound maintenance and management of its activities or facilities; for waste sciences, environmental restoration, waste management, and national security

- developing new technologies for environmental restoration and waste management, including site characterization and assessment methods; waste minimization, treatment, and remediation technology.

DOE's goal is to clean up Hanford Site waste and ensure that its facilities are always in compliance with federal, state, and local environmental laws. In addition to its environmental management mission, DOE also supports other special initiatives to accomplish its national objectives.

The highest priority of the DOE's Hanford Site offices is to achieve daily excellence in protection of the worker and the public and in stewardship of the environment, both on and off the Hanford Site. By meeting the most rigorous standards, the DOE's Richland Operations Office and Office of River Protection provide safe and healthful workplaces and protect the environment across the Hanford Site. Fundamental to the attainment of this policy are personal commitment and accountability, mutual trust, open communication, continuous improvement, worker involvement, and full participation of all interested parties. Consistent with the strategic plan for the site (DOE/RL-96-92), both DOE offices on the site will reduce accidents, radiological and toxicological exposures, and regulatory noncompliances.

management; and for monitoring any potential effluents to ensure environmental compliance.

The principal contractors and their respective responsibilities include the following:

DOE Richland Operations Office. The DOE Richland Operations Office manages legacy cleanup, 
research, and other programs at the Hanford Site. Hanford supplied plutonium for the United States nuclear weapons defense for more than four decades, and is now engaged in the world's largest environmental cleanup project. Three cleanup outcomes are being pursued: restoring the Columbia River corridor, transitioning the central plateau for waste treatment and long-term storage, and putting DOE's assets to work solving regional and global environmental problems.

- Fluor Hanford, Inc. is the prime contractor for the nuclear legacy cleanup. Fluor Hanford, Inc.'s four principal subcontractors are Numatec Hanford Corporation, Waste Management Federal Services of Hanford, Inc., DynCorp Tri-Cities Services, Inc., and Protection Technology Hanford. As part of the commitment to the economic development of the Tri-Cities region, Fluor Hanford, Inc. and its major subcontractors established affiliate companies that are separate businesses with the flexibility to pursue and perform non-Hanford work.

- Numatec Hanford Corporation - provides best-in-class engineering and project management services and technical expertise and implements relevant technologies to accelerate cleanup.

- DynCorp Tri-Cities Services, Inc. - provides essential infrastructure services for the Hanford Site, including utilities, facility maintenance, real estate and site planning, emergency response, property management, fleet and transportation operations, and crane and rigging.

- Protection Technology Hanford - provides management, operation, and integration of all safeguards and security services of the Hanford Site, except those of Pacific Northwest National Laboratory. These services include function design, testing and upgrade of safeguards and security systems, material control and accountability, physical security, personnel security, technical security, information security (classified and unclassified), vulnerability assessment, and the Hanford Patrol.

In addition, several affiliate (formerly enterprise) companies were created to provide services to Fluor Hanford, Inc. These subcontractors and their areas of responsibility include the following:

- Fluor Federal Services, Inc. - provides project management, engineering, procurement, and construction services to government clients including the Energy, Defense, and State departments, as well as clients at the Hanford Site.

- Lockheed Martin Services, Inc. - provides telecommunications and network engineering, Internet technology integration, software modernization, maintenance and support, engineering computational resources, data center management, imaging and document management, and multimedia services to other Lockheed Martin Corporation companies, government, and commercial industry.

- Waste Management Technical Services, Inc. - role includes privatization of a select group of capabilities that were developed at Hanford. These transportation, engineering, environmental, and training services capabilities are unique, state-of-the-art, or simply acknowledged as being among the best available.

- COGEMA Engineering Corporation develops and designs waste sampling characterization and retrieval equipment, specialized analytical methods, and techniques. COGEMA Engineering Corporation applies its expertise in field screening and sampling to Hanford cleanup, as well as its special welding technique development and application.

- Bechtel Hanford, Inc., the environmental restoration contractor, plans, manages, executes, 
and integrates a full range of activities for the cleanup of groundwater, contaminated soils, and inactive nuclear facilities. Bechtel Hanford, Inc.'s subcontractors are CH2M HILL Hanford, Inc. and Thermo Hanford, Inc.

- Hanford Environmental Health Foundation. Hanford Environmental Health Foundation's Health Risk Management program works with the site to identify and analyze the hazards that Hanford personnel face in the work environment. Hanford Environmental Health Foundation's occupational health services provide occupational medicine and nursing, medical surveillance, ergonomics assessment, exercise physiology, case management, psychology and counseling, fitness for duty evaluations, health education, infection control, immediate health care, industrial hygiene, and health, safety, and risk assessment.

- Pacific Northwest National Laboratory. Battelle operates the Pacific Northwest National Laboratory for DOE's national security and energy missions. The core mission is to deliver environmental science and technology in the service of the nation and humanity. Pacific Northwest National Laboratory services include molecular science research, advanced processing technology, biotechnology, global environmental change research, and energy technology development.

DOE-Office of River Protection. The Office of River Protection was established by Congress in

\subsubsection{References}

40 CFR 122. U.S. Environmental Protection Agency. "EPA Administered Permit Programs: The National Pollutant Discharge Elimination System." $C$ ode of Federal Regulations.

Clean Air Act. 1986. Public Law 88-206, as amended, 42 USC 7401 et seq.
1998, as a DOE field office, to manage DOE's largest, most complex environmental cleanup projectHanford tank waste retrieval, treatment, and disposal. Sixty percent of the nation's high-level radioactive waste is stored at Hanford in aging, deteriorating tanks. In late spring of 2000, the Office of River Protection conducted an expedited bidding process to complete the design and construction of a waste vitrification facility. The contract is scheduled to be awarded by January 2001.

- MACTEC-ERS is a prime contractor to the DOE Grand Junction Office and performs vadose zone characterization and monitoring work beneath single-shell underground waste storage tanks in the 200 Areas.

- CH2M HILL Hanford Group, Inc. is the Office of River Protection's prime contractor with responsibility for storing and retrieving for treatment 204 million liters (54 million gallons) of highly radioactive and hazardous waste stored in 177 underground tanks. The company's role includes characterizing the waste and delivering it to the future waste vitrification facility.

- BNFL, Inc. was chosen by DOE to design, license, construct, and operate a vitrification facility to separate, treat, and immobilize radioactive liquid waste and sludges stored in the underground tanks at Hanford. Their contract with DOE was terminated in June 2000 and a replacement contractor is being sought.

DOE/EIS-0222. 1999. Final $\mathrm{H}$ anford Comprehensive Land-U se Plan Environmental I mpact Statement. Online report. http://nepa.eh.doe.gov/eis/ eis0222/eis0222.html 
DOE/RL-91-50, Rev. 2. 1997. Environmental M onitoring Plan, U nited States Department of Energy Richland 0 perations 0 ffice. U.S. Department of Energy, Richland Operations Office, Richland, Washington.

DOE/RL-96-92. 1996. H anford Strategic Plan. U.S. Department of Energy, Richland Operations Office, Richland, Washington. Also available at URL: http://www.hanford.gov/hsp/index.html

DOE/RL-2000-32. 2000. H anford, Diversification, and theT ri-C itiesE conomy FY 1999. U.S. Department of Energy, Richland Operations Office, Richland, Washington.

Fitzgerald, J. J. 1970. A pplied Radiation Protection and Control. Gordon and Breach Science Publishers. New York.

PNL-8506. 1993. A rid Lands E cology Facility M anagement Plan. Pacific Northwest Laboratory, Richland, Washington.
PNNL-6415, Rev. 12. 2000. H anford Site $N$ ational Environmental Policy A ct (NEPA) C haracterization. D. A. Neitzel (ed.), and E. J. Antonio, R. A. Fowler, C. S. Glantz, S. M. Goodwin, D. W. Harvey, P. L. Hendrickson, D. J. Hoitink, D. G. Horton, T. M. Poston, A. C. Rohay, P. D. Thorne, and M. K. Wright, Pacific Northwest National Laboratory, Richland, Washington.

Washington State Office of Financial Management. 1998. Inter-C ensal and Post-C ensal Estimates of C ounty Populations by A ge and Sex: State of W ashington 1980-1998. Forecasting Division, Olympia, Washington.

Washington State Office of Financial Management. 1999. 1999 D ata B ook, State of W ashington. Forecasting Division, Olympia, Washington.

U.S. Bureau of the Census. 1994. C ounty and C ity Data Book. U.S. Government Printing Office, Library of Congress, No. 52-4576, Washington, D.C. 


\subsection{Environmental and Regulatory Compliance Summary}

This section describes how environmental compliance is achieved for the Hanford Site. Included are sections describing 1) stakeholder and tribal involvement in the environmental restoration and waste management missions at the Hanford Site, 2 ) the current status of the site's compliance with principal regulations, 3 ) issues and actions arising from these compliance efforts, 4) an annual summary of environmentally significant occurrences, and 5) waste management and chemical inventory information.

It is the policy of the U.S. Department of Energy (DOE) that all activities be carried out in compliance with all applicable federal, state, and local environmental laws and regulations, DOE Orders, Secretary of Energy Notices, DOE Headquarters and site operations office directives, policies, and guidance. This includes those specific requirements, actions, plans, and schedules identified in the Hanford Federal Facility Agreement and Consent Order (also known as the Tri-Party Agreement; Ecology et al. 1998) and other compliance or consent agreements. Both the Richland Operations Office and Office of River Protection recognize the importance of maintaining a proactive program of self-assessment and regulatory reporting to ensure that environmental compliance is achieved and maintained at the Hanford Site. 


\title{
2.1 Stakeholder and Tribal \\ Involvement
}

\author{
K. R. Price
}

Many entities have a role in DOE's missions of environmental restoration, waste management and protection of the Columbia River at the Hanford Site. Stakeholders include federal, state, and local regulatory agencies; environmental groups; regional communities and governments; and the public.
Indian tribes and Nations also have a special and unique involvement with the Hanford Site. The following sections describe the roles of the principal agencies, organizations, and public at the Hanford Site.

\subsubsection{Regulatory Oversight}

Several federal, state, and local regulatory agencies are responsible for monitoring and enforcing compliance with applicable environmental regulations at the Hanford Site. The major agencies include the U.S. Environmental Protection Agency (EPA), Washington State Department of Ecology, Washington State Department of Health, and Benton Clean Air Authority. These agencies issue permits, issue legal orders, determine compliance schedules, negotiate compliance agreements, review budgets and workscope, review environmental reports and documentation, participate in joint monitoring programs, inspect facilities and operations, and/or oversee compliance with applicable regulations. DOE, through compliance audits and directives, initiates and assesses actions for compliance with environmental requirements. These include air requirements, water requirements, soil requirements, land use, cultural resources, ecological resources, historic resources, and waste management.

EPA is the primary federal regulatory agency that develops, promulgates, and enforces environmental regulations and standards as directed in statutes passed by Congress. In some instances, EPA has delegated authority to the state or authorized the state program to operate in lieu of the federal program when the state's program meets or exceeds EPA's requirements. For instance, EPA has delegated or authorized certain enforcement authorities to the Washington State Department of Ecology for air pollution control and hazardous waste management. In other activities, the state program is assigned direct oversight of the DOE Richland Operations Office as provided by federal law. For example, the Washington State Department of Health has direct authority under the Clean A ir Act to enforce the standards and requirements under a statewide program to regulate radionuclide air emissions at applicable facilities (e.g., the Hanford Site). Where federal regulatory authority is not delegated or only partially authorized to the state, EPA Region 10 is responsible for reviewing and enforcing compliance with EPA regulations as they pertain to the Hanford Site. In addition, EPA periodically reviews the adequacy of various state environmental programs and reserves the right to directly enforce federal environmental regulations.

Although the State of Oregon does not have direct regulatory authority at the Hanford Site, DOE recognizes its interest in Hanford Site cleanup 
because of Oregon's location downstream along the Columbia River. Oregon participates in the State and Tribal Government Working Group for the Hanford Site, which reviews the site's cleanup plans.

\subsubsection{Hanford Federal Facility Agreement and Consent Order}

This order (also known as the Tri-Party Agreement; Ecology et al. 1998) is an agreement among the Washington State Department of Ecology, EPA, and DOE to achieve environmental compliance at the Hanford Site with the Comprehensive Environmental Response, Compensation, and Liability Act (CERCLA), including the Superfund A mendments and Reauthorization A ct of 1986 remedial action provisions, and with the Resource Conservation and Recovery A ct (RCRA) treatment, storage, and disposal unit regulation and corrective action provisions. The Tri-Party Agreement 1) defines RCRA and CERCLA cleanup commitments, 2) establishes responsibilities, 3 ) provides a basis for budgeting, and 4) reflects a concerted goal of achieving regulatory compliance and remediation with enforceable milestones in an aggressive manner. Also, the Tri-Party Agreement contains requirements for how to involve the public.

The Tri-Party Agreement has continued to evolve as cleanup of the Hanford Site has progressed. Significant changes to the agreement have been negotiated between the Washington State Department of Ecology, EPA, and DOE to meet the changing conditions and needs of the cleanup. The most complex changes were worked out in 1993 with further modifications each year since. All significant changes to the agreement undergo a process of public involvement that ensures communication and addresses the public's concerns prior to final approvals. Copies of the agreement are publicly available at the DOE's Hanford Reading Room located in the Consolidated Information Center on the campus of Washington State University at Tri-Cities, Richland, Washington, and at information repositories in Seattle and Spokane, Washington, and Portland, Oregon. To get on the mailing list to obtain Tri-Party Agreement information, contact the EPA or DOE directly, or call the Washington State Department of Ecology at 1-800-321-2008. Requests by mail can be sent to:

Hanford Mailing List: Informational Mailings Mail Stop B3-35

P.O. Box 1000

Richland, WA 99352

or

Hanford Update

Department of Ecology

P.O. Box 47600

Olympia, WA 98504-7600

\subsubsection{The Role of Indian Tribes}

The Hanford Site is located on land ceded to the United States government by the Yakama Nation and the Confederated Tribes of the Umatilla Indian Reservation in the Treaties of 1855 . These two tribes, as well as the $\mathrm{Nez}$ Perce Tribe, have treaty fishing rights on portions of the Columbia River. These tribes reserved the right to fish "at all usual and accustomed places" and the privilege to hunt, gather roots and berries, and pasture horses and cattle on open and unclaimed land. The Wanapum are not a federally recognized tribe; however, they have historic ties to the Hanford Site and are routinely consulted regarding cultural and religious freedom issues.

The Hanford Site environment supports a number of Native American foods and medicines and contains sacred places important to tribal cultures. 
The tribes hope to use these resources in the future and want to assure themselves that the Hanford environment is clean and healthy.

The DOE American Indian Policy (DOE Order 1230.2) states, "American Indian Tribal Governments have a special and unique legal and political relationship with the Government of the United States, defined by history, treaties, statutes, court decisions, and the U.S. Constitution." In recognition of this relationship, DOE and each tribe interact and consult directly. The three tribes belong to DOE groups such as the State and Tribal Government Working Group, the Hanford Tribal Cultural Issues Team, and the Hanford Natural Resources Trustee Council. They actively participate in many projects, including the Hanford Site Groundwater/Vadose Zone Integration Project and the Cultural Resources Program. The three tribes have made presentations to the DOE and its contractors on treaty rights, tribal sovereignty, the United States government trust responsibility, and the unique status of tribal governments.
DOE interaction with tribes in Hanford plans and activities is guided by the DOE American Indian Policy that states, among other things, "The Department shall: Consult with Tribal governments to assure that Tribal rights and concerns are considered prior to DOE taking actions, making decisions, or implementing programs that may affect Tribes." In addition to the American Indian policy, laws such as the A merican Indian Religious Freedom Act, the A rchaeological Resources Protection $\mathrm{A}$ ct, the $\mathrm{N}$ ational $\mathrm{H}$ istoric Preservation $\mathrm{Act}$, and the $\mathrm{N}$ ative A merican $G$ raves Protection and R epatriation $A$ ct require consultation with tribal governments. The combination of the Treaties of 1855 , federal policy, executive orders, laws, and regulations provide the basis for tribal participation in Hanford Site plans and activities.

DOE provides financial assistance through cooperative agreements with the Yakama Nation, the Confederated Tribes of the Umatilla Indian Reservation, and the Nez Perce Tribe to support their involvement in environmental management activities of the Hanford Site.

\subsubsection{Hanford Natural Resource Trustee Council}

The President is required by CERCLA to appoint federal officials to act on behalf of the public as trustees for natural resources when natural resources may be injured, destroyed, lost, or threatened as a result of a release of hazardous substances. The President appointed the Secretary of Energy as the primary federal natural resource trustee for all natural resources located on, over, or under land administered by DOE. Other designated federal trustees for Hanford natural resources include the U.S. Department of the Interior represented by the U.S. Fish and Wildlife Service and the Bureau of Land Management, and the U.S. Department of Commerce represented by the National Oceanic and Atmospheric Administration.

CERCLA also authorizes state governors to designate a state lead trustee to coordinate all state trustee responsibilities. CERCLA further states that chairmen (or heads of governing bodies) of Indian tribes have essentially the same trusteeship over natural resources belonging to or held in trust for the tribe as state trustees. Indian tribes and State organizations have been designated as natural resource trustees for certain natural resources at or near the Hanford Site. Indian tribes include the Yakama Nation, the Confederated Tribes of the Umatilla Indian Reservation, and the Nez Perce Tribe. State organizations include the state of Washington represented by the Washington State Department of Ecology and the Washington State Department of Fish and Wildlife, and the state of Oregon represented by the Oregon Department of Energy.

In order to address their responsibilities, the Hanford trustees have signed a Memorandum of Agreement (1996) formally establishing the Hanford Natural Resource Trustee Council. The primary 
purpose of the council is to facilitate the coordination and cooperation of the member trustees in their efforts to mitigate the impacts to natural resources that result from either hazardous substance releases within the Hanford Site or the remediation of those releases. The council also adopted by-laws to direct the process of arriving at consensus agreements.

The Natural Resource Trustee Council is performing an ongoing assessment of potential injury to Columbia River aquatic resources from exposure to hazardous substances released within the Hanford 100 Areas. The initial phase of this assessment involved preparation of an aquatic resources

\subsubsection{Public Participation}

Individual citizens of the state of Washington and neighboring states may influence Hanford Site cleanup decisions through public participation activities. The public is provided opportunities to contribute their input and influence decisions through many forums, including Hanford Advisory Board meetings, Tri-Party Agreement activities, $\mathrm{N}$ ational Environmental Policy $\mathrm{A}$ ct public meetings on various environmental impact statements and environmental assessments, Hanford Site Issues Exchange Forum, and many other outreach programs.

A framework for integrated communications and public involvement for the Hanford Site outlines the DOE commitment to plan for involving the public in decisions. The Office of Intergovernmental, Public and Institutional Affairs (DOE Richland Operations Office) is responsible for establishing the planning and scheduling of public participation activities for the Hanford Site.

The Tri-Party Agreement provides a means for Hanford to become compliant with environmental regulatory requirements. The Community Relations Plan (Ecology et al. 1997), a companion to the Tri-Party Agreement, describes how public information and involvement activities are conducted for assessment plan by the U.S. Fish and Wildlife Service, using the natural resource damage assessment regulations in 43 CFR 11 as guidance. The plan focused on several contaminant releases, including chromium releases that have migrated via groundwater flow to sections of the Columbia River used by fall Chinook salmon for spawning. As recommended in the assessment plan, the council is studying the potential for these chromium releases to injure the spawning salmon. The results of this study will aid the trustees, regulators, and DOE to develop, evaluate, and select remedial actions that minimize or eliminate any injury to the salmon.

Tri-Party Agreement decisions. DOE, Washington State Department of Ecology, and EPA developed and negotiated the plan with input from the public. The plan was approved in 1990 . The plan is updated on an as-needed basis; the most recent revision occurred in 1997.

Before each public participation event, the press is informed of the issues to be discussed, and notices are sent to elected officials, community leaders, and special interest groups. A mailing list of $\sim 3,800$ individuals who have indicated an interest in participating in Hanford Site decisions is maintained and kept current. The mailing list is also used to send topic-specific information to those people who have requested it.

To apprise the public of upcoming opportunities for public participation, the Hanford Update, a synopsis of all ongoing and upcoming Tri-Party Agreement public involvement activities, is published bimonthly. In addition, the Hanford Happenings calendar, which highlights Tri-Party Agreement scheduled meetings and comment periods, is distributed each month to the entire mailing list.

Most of Hanford's stakeholders reside in Washington, Oregon, and Idaho. To allow them better 
access to up-to-date Hanford Site information, four information repositories have been established. They are located in Richland, Seattle, and Spokane, Washington, and Portland, Oregon.

The three parties respond to questions that are received via a toll-free telephone line (800-321-2008). Members of the public can request information about any public participation activity and receive a response by contacting the Office of Intergovernmental, Public and Institutional Affairs (DOERichland Operations Office) at (509) 376-7501.

Also, there is a calendar of public involvement opportunities on the Internet: http:// www.hanford.gov/whc/cal/cal.html.

\subsubsection{Hanford Advisory Board}

The Hanford Advisory Board was chartered in January 1994 to advise DOE on major Hanford Site cleanup policy questions. The board was the first of many such advisory groups created by DOE at weapons production cleanup sites across the national DOE complex. The board consists of 31 members who represent a broad cross section of interests: environmental, economic development, tribes and other governments, and the public. Each board member has at least one alternate. Merilyn Reeves, of Amity, Oregon, is the chairperson.

The board has five standing committees: 1) Dollars and Sense, which deals with DOE budget issues; 2) Health, Safety, and Waste Management; 3) Environmental Restoration; 4) the board's internal executive committee; and 5) the Public Involvement committee. Committees study issues and develop policy recommendations for board action. In addition, special groups or ad hoc committees are formed on an as-needed basis and have a limited life span. The Tank Waste Treatment Ad Hoc group has been formed to deal with tank waste issues. This is not a standing committee.

The board held six 2-day meetings in 1999 . Members received in-depth briefings from the TriParty Agreement agencies, reviewed technical reports and proposed budgets, and sought out more information on major policy issues. From October 1998 through September 1999, the board produced 13 new pieces of consensus advice (making a total of 100), cosponsored several public meetings, produced numerous pieces of "sounding board" advice, and engaged in an ongoing dialogue with the Tri-Party Agreement agencies. The board's advice, and responses to that advice, can be found on the Internet at http://www.hanford.gov/boards/hab/advice/ adviceindex.htm.

The Hanford Advisory Board statement of principles was prepared for and presented to Carolyn Huntoon, Assistant Secretary of Energy for Environmental Management, on September 20, 1999 (Sections 2.1.6.1 and 2.1.6.2).

\subsubsection{Long-Term Vision}

The long-term vision of the Hanford Advisory Board states that the Hanford Site will become a clean, accessible, and healthy environment by

- protecting the health and safety of communities and workers

- protecting the Columbia River and the environment

- moving resolutely forward to site cleanup through use of existing technologies and resources where solutions exist, and through focused research and development of solutions where solutions do not exist

- respecting treaty rights of affected Native American Indian Tribes

- embracing the Tri-Party Agreement, which has widespread and deep public support in the Northwest, as the basic framework and blueprint for the Hanford cleanup 
- preparing the site for future productive uses and transitions from the dominance of DOE-funded activities to more privately sponsored activities

- fostering economic prosperity through scientific research and innovation in the development and testing of waste management approaches and cleanup technologies that have benefits locally and worldwide.

\subsubsection{Near-Term Needs}

The Hanford Advisory Board has developed a statement of principles regarding the near-term needs of the Hanford Site. The board agreed that DOE should

- reduce the footprint of future stewardship needs by cleanup and waste stabilization
- maintain integrity of the Tri-Party Agreement; meet milestones

- design, construct, and operate a tank waste vitrification plant

- remove spent nuclear fuel and sludge from the K basins

- decontaminate and stabilize the Plutonium Finishing Plant

- complete cleanup along the Columbia River

- protect workers; improve and enhance their morale and productivity.

\subsubsection{Hanford Site Technology Coordination Group}

The Hanford Site Technology Coordination Group was established in 1994. Its structure was modified in early 2000, so it now consists of a Management Council and five subgroups aligned with the Environmental Management Focus Areas: 1) deactivation and decommissioning, 2) mixed waste, 3) subsurface contaminants, 4) tanks, and 5) nuclear materials. DOE's Office of Environmental Management established the focus areas to develop and deliver solutions to technology needs identified at DOE sites across the nation. Subgroups of the Hanford Site Technology Coordination Group provide detailed documentation of the Hanford Site's technology needs to guide the focus areas' efforts in technology development.

The Management Council focuses on Hanford Site policy issues related to technology development and deployment. Subgroups of the Hanford Site Technology Coordination Group identify and prioritize the site's science and technology needs, identify technology demonstration opportunities, interface with the Environmental Management Focus Areas, and ensure that demonstrated technologies are deployed.

During 1999, the Management Council endorsed the description of science and technology needs developed by the subgroups for submittal to the Environmental Management Focus Areas and the Environmental Management Science Program. The Environmental Management Science Program sponsors basic research to address fundamental issues that may be critical to ongoing technology development. This research will decrease public and worker risks, provide major cost reduction opportunities, reduce the time required to achieve DOE's cleanup mission, and address problems considered intractable without new knowledge. Hanford's science and technology needs can be found on the Internet at http://www.pnl.gov/stcg/needs.stm. In addition, the subgroups endorsed numerous Accelerated Site Technology Deployment proposals and heard presentations on a variety of new technologies being demonstrated and/or deployed on the Hanford Site. 
The DOE Richland Operations Office Deputy Manager for Site Transition now chairs the Management Council. It includes six DOE Richland Operations Office Assistant Managers (Environmental Restoration and Waste Management, Facility Transition, Technology Management, Planning and Integration, Engineering and Standards, and Spent Nuclear Fuels), as well as representatives from the Office of Training Services and Asset Transition and the Fast Flux Test Facility Project Office. Representatives from the DOE Office of River Protection also participate. The Management Council includes two representatives from EPA; two from the Washington State Department of Ecology; one from the Oregon Office of Energy; three from the Hanford Advisory Board; and three from American Indian tribes (Yakama Nation, Nez Perce Tribe, and Confederated Tribes of the Umatilla Indian Reservation). The Hanford Site contractors have also designated representatives on the Management Council.

The elements of the Hanford Site Technology Coordination Group mission statement are as follows:

- involve user organizations (both DOE and the contractors), technology providers, regulators, American Indian tribes, and stakeholders; promote broad information exchange among all interested parties; maintain a helpful attitude and serve as a conscience for technology improvement at Hanford; contribute to DOEwide communications and lessons learned

- identify, prioritize using systems analysis, and seek consensus on Hanford Site and programspecific problems, science and technology needs, and requirements; recognize baseline schedule insertion points for technology; focus on the baseline, but also identify technologies to support potential baseline alternatives if they offer risk reduction benefits or high financial return on investment by improvements in environmental, safety, or health protection; devote
$20 \%$ of the effort to science needs and $80 \%$ to technology needs and deployment

- be a forum for assessing and recommending potential technologies for application at Hanford; look for technologies that provide improved end results, improved effectiveness, improved schedules, or improved costs in accomplishing the required results; look for technologies to reduce surveillance and maintenance costs while maintaining safe operations; focus on life-cycle costs and benefits, improvements in environmental, safety, or health protection, and improvements in performance, pollution prevention, and waste minimization relative to alternative remedies; make appropriate referrals for vendors (e.g., to DOE or the contractors)

- champion and facilitate demonstration and deployment of innovative, modified, or existing technologies that are new to Hanford and share information with other sites to best leverage all available resources

- create a viable market for technology with the DOE Richland Operations Office and contractors and eliminate barriers (e.g., resistance to change and acceptance of technologies developed offsite)

- promote competitive privatization and commercialization by communicating information on Hanford's science and technology needs and schedule insertion points, as well as demonstration and deployment opportunities, to commercial technology providers; help break barriers to involvement by companies new to Hanford

- provide input to decision-makers (e.g., DOE Richland Operations Office, DOE Headquarters, Congress, and heads of regulatory agencies) on Hanford's highest-priority science and technology needs to ensure critical needs are funded; provide feedback to them on the site's accomplishments. 


\title{
2.2 Compliance Status
}

\author{
K. R. Price
}

This section summarizes the activities conducted to ensure that the Hanford Site is in compliance with federal environmental protection statutes and related state and local environmental protection regulations. Also discussed is the status of compliance with these requirements. Environmental permits required under the environmental protection regulations are discussed under the applicable statute.

\subsubsection{Hanford Federal Facility Agreement and Consent Order, 1999 Performance}

The Tri-Party Agreement (Ecology et al. 1998) commits DOE to achieve compliance with the remedial action provisions of CERCLA and with the treatment, storage, and disposal unit regulations and corrective action provisions of RCRA, including the state's implementing regulations.

From 1989 through 1999, a total of 636 enforceable milestones and 253 unenforceable target dates were completed on or ahead of schedule. In 1999, there were 44 specific cleanup milestones and target dates scheduled for completion: 41 were completed on or before their required due dates and 2 were delayed because of privatization issues, and 1 was delayed because of RCRA barrier concerns. Highlights of the work accomplished in 1999 are listed in Section 2.3, "Activities, Accomplishments, and Issues."

\subsubsection{Environmental Management Systems}

At the Hanford Site, major contractors have issued Integrated Environment, Health, and Safety Management Systems plans. These programs, contractually mandated by DOE, are intended to protect the worker, public, and environment by integrating environment, health, and safety into the way work is planned and performed. The international voluntary consensus standard ISO 14001, Environmental $M$ anagement Systems- Specifications with $G$ uidance for $U$ se, and DOE P 450.4, Safety M anagement System Policy, form the basis of the systems.
In 1998, DOE Headquarters approved the Integrated Environment, Safety, and $\mathrm{H}$ ealth Program Description (https://sbms.pnl.gov/program/ pd03d010.htm) for the Pacific Northwest National Laboratory. Also in 1998, Fluor Hanford, Inc. issued an Integrated Environmental, Safety, and $\mathrm{H}$ ealth $\mathrm{M}$ anagement System Plan (HNF-MP-003); and Bechtel Hanford, Inc. issued an Integrated Environmental, Safety, and $\mathrm{H}$ ealth $\mathrm{M}$ anagement System Description (BHI-01199). Efforts continued in 1999 to implement and improve these environmental, safety, and health programs. 


\subsubsection{Chemical Management Systems}

The Hanford Site, with its numerous contractors, facilities, and processes uses a variety of approaches for chemical management. The prime contractors developed chemical management system requirements for the Hanford Site. The requirements were approved by the prime contractors on November 25, 1997, and transmitted to the DOE Richland Operations Office. These requirements are applicable within the Hanford Site to the acquisition, use, storage, transportation, and final disposition of chemicals including hazardous chemicals as defined in the Occupational Safety and Health Administration's Hazard Communication Standard (29 CFR 1910.1200, Appendixes A and B).

During the first quarter of 1998, each contractor performed a gap analysis of their chemical operations against the chemical management system requirements. The gaps identified, including procedure development and/or modifications, were translated into needs. These were then evaluated, using a graded approach that considered complexity of operations and associated hazards. The outcome of the gap analysis was identification of actions for each of the prime contractors to obtain conformance with the chemical management system requirements. The prime contractors worked toward conforming to the established requirements and achieved closure of identified gaps in calendar year 1999. Periodic reviews of chemical management programs are being conducted; further enhancements to prime contractor chemical management systems are anticipated to be implemented in 2000 and beyond.

Details on the chemical inventories stored at the Hanford Site may be found in Section 2.5.2, "Chemical Inventories."

\subsubsection{Comprehensive Environmental Response, Compensation, and Liability Act}

In 1980, CERCLA was enacted to address past releases or potential releases of hazardous substances, pollutants, and contaminants to the environment. The EPA is the federal agency responsible for oversight of DOE's implementation of CERCLA. There is significant overlap between the state RCRA corrective action program (see Section 2.2.6) and CERCLA, and many waste management units are subject to remediation under both programs. The CERCLA program is implemented via 40 CFR 300, "National Oil and Hazardous Substances Pollution Contingency Plan," which establishes procedures for characterization, evaluation, and remediation. The Tri-Party Agreement addresses CERCLA implementation at Hanford and is generally consistent with the contingency plan process.

There are several remediation activities under way at Hanford that are accomplished using the CERCLA process (e.g., remedial investigation in the 200 and 300 Areas, cleanup in the 100 and 300 Areas). Specific project activities and accomplishments are described in Section 2.3.11, "Environmental Restoration Project."

\subsubsection{Emergency Planning and Community Right-To- Know Act}

This act requires states to establish a process to develop chemical emergency preparedness programs and to distribute within communities information on hazardous chemicals present in facilities. The act has 
two subtitles: Subtitle A includes requirements for emergency planning (Sections 301-303) and emergency release notification (Section 304); Subtitle B requires periodic reporting of chemical inventories and associated hazards (Sections 311312), releases, and waste management activities (Section 313).

Sections 301-303 require states to establish a state emergency response commission and local emergency planning committees. These organizations gather information and develop emergency plans for local planning districts in the state. Facilities that produce, use, or store extremely hazardous substances in quantities above threshold planning quantities must identify themselves to the state emergency response commission and the local emergency planning committee, provide any additional information the local emergency planning committee requires for development of the local emergency response plan, and notify the committee of any changes occurring at the facility that may be relevant to emergency planning. It should be noted that the entire Hanford Site is considered a single facility for the purpose of determining threshold planning and reporting quantities. This does not include, however, activities conducted by others on Hanford Site lands covered by leases, use permits, easements, and other agreements whereby land is used by parties other than DOE.

Under Section 304, facilities must also notify the state emergency response commission and the local emergency planning committee immediately after an accidental release of an extremely hazardous substance over the reportable quantity established for that substance, and follow up the notification with a written report. Extremely hazardous substances are listed in 40 CFR 355 (Appendixes A and B) along with the applicable threshold planning quantity.

Sections 311 and 312 require facilities that store hazardous chemicals in amounts above minimum threshold levels to report information regarding those chemicals to the state emergency response commission, local emergency planning committee, and local fire department. Both sections cover chemicals that are considered physical or health hazards by the Occupational Safety and Health Act of 1970 Hazard Communication Standard (29 CFR 1910.1200). The minimum threshold level is 4,545 kilograms $(10,000$ pounds) for hazardous chemicals. If the chemical is an extremely hazardous substance, the minimum threshold level is 277 kilograms (500 pounds) or the listed threshold planning quantity, whichever is less. These thresholds apply to the total quantities of such chemicals that are stored or received in aggregate at the Hanford Site, not to individual facilities at the site. Section 311 calls for the submittal of a material safety data sheet for each hazardous chemical present above minimum threshold levels or a listing of such chemicals with associated hazard information. The listing must be updated within 3 months of any change to the list, including receipt of new chemicals above minimum threshold levels or discovery of significant new hazard information regarding existing chemicals. Section 312 requires annual submittal of more detailed quantity and storage information regarding the same list of chemicals, in the form of a Tier One or Tier Two Emergency and Hazardous Chemical Inventory report.

The Hanford Site provides appropriate hazardous chemical inventory information to the Washington State Department of Ecology Community Right-To-Know Unit; local emergency planning committees for Benton, Franklin, and Grant Counties; and to both the Richland and Hanford Site fire departments. An updated material safety data sheet was issued in April 1999, which consisted of 33 hazardous chemicals present in quantities exceeding minimum threshold levels, including three extremely hazardous substances. No subsequent updates to the list were required during 1999. The 1999 Hanford Site Tier Two Emergency and Hazardous Chemical Inventory (DOE/RL-2000-08) was issued in February 2000. 
Under Section 313, facilities must report total annual releases of certain toxic chemicals. The Pollution Prevention A ct requires additional information with the report, and Executive Order 12856 (EPA 100-K-93-001) extends the requirements to all federal facilities, regardless of the types of activities conducted. Based on evaluation of toxic chemical usage data during calendar year 1998 at the Hanford Site, chlorine was the only chemical used in quantities exceeding concentration thresholds that require reporting under Section 313. Because the associated activities resulted in minimal quantities of chlorine released to the environment or entering waste streams, the site was eligible to apply the alternate 455,000-kilogram (1,000,000-pound) threshold for manufacture, process, or other use of the chemical. The site submitted the required forms for chlorine in June 1999, certifying that the criteria for applying the alternate threshold were met. An evaluation of toxic chemical usage data for calendar year 1999 at the Hanford Site is currently being performed. An appropriate report will be issued in 2000.

Table 2.2.1 provides an overview of 1999 reporting under the Emergency Planning and Community Right-T o-K now A ct.

\subsubsection{Resource Conservation and Recovery Act}

\subsubsection{Hanford Facility RCRA Permit}

The Hanford Facility RCRA Permit (\#WA7890008967), Dangerous Waste Portion, that was issued by the Washington State Department of Ecology has been in effect since late September 1994 (DOE/RL-91-28, Rev. 4). The permit provides the foundation for all future RCRA permitting on the Hanford Site in accordance with provisions of the Tri-Party Agreement (Ecology et al. 1998).

\subsubsection{RCRA/Dangerous Waste Permit Applications and Closure Plans}

For purposes of the RCRA and the Washington State dangerous waste regulations (WAC 173-303), the Hanford Site is considered a single facility that encompasses over 70 treatment, storage, and disposal units. The Tri-Party Agreement recognized that all of the treatment, storage, and disposal units could

Table 2.2.1. Emergency Planning and Community Right-to-Know Act Compliance Reporting, 1999(a)

\section{Sections of the Act}

302-303: Planning notification

304: Extremely hazardous substances release notification

311-312: Material safety data sheet/chemical inventory

313: Toxic chemical release inventory reporting

(for calendar year 1998)

\begin{tabular}{|c|c|c|}
\hline Yes & No & Not Required \\
\hline \multicolumn{3}{|l|}{$\mathrm{X}^{(\mathrm{b})}$} \\
\hline & & $X$ \\
\hline $\mathrm{X}$ & & \\
\hline X & & \\
\hline
\end{tabular}

(a) "Yes" indicates that notifications were provided and/or reports were issued under the applicable provisions. "No" indicates that notifications or reports should have been provided but were not. "Not Required" indicates that no actions were required under the applicable provisions, either because triggering thresholds were not exceeded or no releases occurred.

(b) These notifications apply to the Hanford Site but were completed prior to 1999. 
not be issued permits simultaneously and a schedule was established for submitting unit-specific Part B dangerous waste permit applications and closure plans to the Washington State Department of Ecology. During 1999, five Part A, Form 3, revisions and one new Part A, Form 3, were certified and submitted to the Washington State Department of Ecology. In 1999, two Part B permit applications for final status were certified and submitted. In addition, three closure-related documents (DOE/RL-99-43, DOE/RL-99-46, and DOE/RL-99-11) were filed with the Washington State Department of Ecology.

\subsubsection{RCRA Groundwater Monitoring Project $M$ anagement}

Table 2.2.2 lists the facilities and units (or waste management areas) that require groundwater monitoring and notes their monitoring status. Samples were collected from 238 RCRA wells sitewide in 1999; this was six less than during 1998.

Groundwater samples were analyzed for a variety of dangerous waste constituents and site-specific constituents, including selected radionuclides. The constituent lists meet the minimum RCRA regulatory requirements and are integrated to supplement other groundwater project requirements (e.g., CERCLA) at the Hanford Site.

During 1999, eight new RCRA wells were installed (Table 2.2.3) to fulfill requirements of the Tri-Party Agreement. Milestone M-24-00K (Ecology et al. 1998) required the installation of eight new RCRA groundwater monitoring wells. The installation of these eight wells was successfully completed on February 17, 2000. Of these, six were installed as new groundwater assessment wells; three at Waste Management Area S-SX, one at Waste Management Area TX-TY located in the 200-West Area, and two at Waste Management Area B-BX-BY, located in the 200-East Area. Two groundwater monitoring wells were installed to replace wells going dry; one well was installed at the former 216-S-10 pond and ditch located in 200-West Area and the other was installed at the former 216-B-3 pond located in 200-East Area. All the wells are completed as shallow (top of the aquifer) monitoring wells. The four new 200-West Area wells have 4.6-meter (15-feet) -long well screens intended to monitor the uppermost portion of the unconfined aquifer. Four of the eight wells were drilled to the top of basalt, i.e., the base of the upper aquifer system, to characterize the vertical extent of known groundwater contaminants and define aquifer flow. Well data packages, PNNL-13199, PNNL-13200, PNNL13201, PNNL-13198, and BHI-01367, Rev. 0 contain more detail information about these new wells, including the detailed geologic and geophysical descriptions and a complete set of sample data results.

At the end of 1999, 14 RCRA waste management areas were monitored under interim status indicator parameter evaluation, 7 were monitored under interim status assessment, and 2 were monitored under final status corrective action. The Waste Management Area U entered an assessment phase during August 1999 due to elevated specific conductance above the critical mean. The former 120-D-1 ponds in the 100-D Area were clean closed during 1999 and require no additional groundwater monitoring. All the facilities being monitored under RCRA are scheduled for closure under the Site Part-B RCRA Permit except the Liquid Effluent Retention Facility and low-level burial ground, which are operating facilities that will be monitored under final status detection evaluation as soon as final status groundwater monitoring plans are approved.

\subsubsection{RCRA Inspections}

DOE and its contractors are working to resolve outstanding notices of violation and warning letters of noncompliance from the Washington State Department of Ecology that were received during 1999. Each of these notices lists specific violations. RCRA noncompliance events for 1999 are detailed below. 
Table 2.2.2. RCRA Interim- and Final-Status Groundwater Monitoring Projects

Groundwater Monitoring

TSD Units, date

initiated

1301-N LWDF

December 1987

1324-N/NA LWDF,

December 1987

1325-N LWDF,

December 1987

120-D-1 ponds,

April 1992

183-H solar evaporation

basins, June 1985

WMA S-SX

October 1991

WMA T,

February 1990

WMA TX-TY,

September -October 199

WMA U,

October 1990

216-S-10 pond and

ditch, August 1991

216-U-12 crib,

September 1991

\section{Groundwater Quality \\ Assessment}

Indicator

Parameter Evaluation $^{\text {(a) }}$

date initiated

X, clean
closed in
FY 1999

FY 1999

X, 1996

X, 1993

X, 1993

X, 1999

X, 1993
Final-Status TSD Unit

\section{Groundwater Monitoring}

Corrective

Detection Action, date

Evaluation initiated

Regulations

40 CFR 265.93(b) WAC 173-303-400

40 CFR 265.93(b) WAC 173-303-400

40 CFR 265.93(b) WAC $173-303-400$

40 CFR 265.93(b) WAC $173-303-400$

X, 1998

40 CFR 264 WAC 173-303-645(10)

40 CFR 265.93(d) WAC 173-303-400

40 CFR 265.93(d) WAC 173-303-400

40 CFR 265.93(d) WAC 173-303-400

40 CFR 265.93(b) WAC 173-303-400

40 CFR 265.93(b) WAC 173-303-400

40 CFR 265.93(d) WAC 173-303-400
Scheduled for

Part B or

Closure

1999(c)

1999(c)

$1999^{\text {(c) }}$

$1998^{(\mathrm{d})}$

$1994^{(c)}$

$>2000^{\text {(c) }}$

$>2000^{(\mathrm{c})}$

$>2000^{(c)}$

$>2000^{(c)}$

$>2000^{(\mathrm{c})}$

$>2000^{(c)}$ 
Table 2.2.2. (contd)

Interim-Status TSD Unit

Groundwater Monitoring

\section{TSD Units, date}

initiated

LLWMA 3,

October 1988

LLWMA 4,

WMA A-AX,

February 1990

WMA B-BX-BY,

February 1990

WMA C,

February 1990

PUREX cribs $^{(\mathrm{g})}$

1988

216-B-3 pond,

November 1988

216-A-29 ditch,

November 1988

216-B-63 trench,

August 1991

LERF, July 1991

LLWMA 1,

September 1988

LLWMA 2,

September 1988
October 1988
Groundwater Quality Assessment,

date initiated

\section{Parameter Evaluation (a)}

X, 1996

X

X, 1997
Final-Status TSD Unit

Groundwater Monitoring

\begin{tabular}{cc} 
Corrective \\
Detection & $\begin{array}{c}\text { Action, date } \\
\text { Evaluation }\end{array}$ \\
\hline
\end{tabular}

initiated

\section{Regulations}

40 CFR 265.93(b) WAC $173-303-400$

40 CFR 265.93(b)

WAC 173-303-400

40 CFR 265.93(b)

WAC $173-303-400$

40 CFR 265.93(d)

WAC 173-303-400

40 CFR 265.93(b)

WAC 173-303-400

40 CFR 265.93(d) WAC 173-303-400

40 CFR 265.93(b) WAC $173-303-400$

40 CFR 265.93(b)

WAC 173-303-400

40 CFR 265.93(b)

WAC 173-303-400

40 CFR 265.93(b)

WAC $173-303-400$

40 CFR 265.93(b)

WAC 173-303-400

40 CFR 265.93(b)

WAC 173-303-400
Year

Scheduled for

Part B or

Closure

$\mathrm{TBD}^{(\mathrm{e}, \mathrm{f})}$

$T B D^{(e, f)}$

$>2000^{(c)}$

$>2000^{(c)}$

$>2000^{\prime}$

$>2000^{(c)}$

$2000^{(c)}$

$2000^{(c)}$

$>2000$

$1998^{(\mathrm{e})}$

$\mathrm{TBD}^{(\mathrm{g}, \mathrm{h})}$

$\mathrm{TBD}^{(\mathrm{g}, \mathrm{h})}$ 
Table 2.2.2. (contd)

Interim-Status TSD Unit

\section{Groundwater Monitoring}

\section{TSD Units, date}

initiated
Indicator

Parameter Evaluation $^{\text {(a) }}$

\section{Groundwater Quality}

Assessment,

date initiated
Final-Status TSD Unit

\section{Groundwater Monitoring}

Detection Corrective

Evaluation initiated

Requlations

Scheduled for

Part B or

Closure

$>2000^{(c)}$

40 CFR 265.93(b)

WAC $173-303-400$

X, 1996

40 CFR 264
WAC $173-303-645(10)$

316-5 process trenches, June 1985

(a) Specific parameters ( $\mathrm{pH}$, specific conductance, total organic carbon, and total organic halides) used to determine if a facility is affecting groundwater quality. Exceeding the established limits means that additional evaluation and sampling are required (groundwater quality assessment). An X in the assessment column indicates whether an evaluation was needed or an assessment was required.

(b) Monitored according to interim-status plan as specified in closure plans.

(c) Closure/postclosure plan; TSD unit will close under final status.

(d) Closure plan approval expected in fiscal year 1999; facility groundwater monitoring not required after clean closure.

(e) Part B permit; TSD unit scheduled to operate under final-status regulations beginning in year indicated.

(f) Facility Part B permit and final-status groundwater monitoring plan contingent on completion of solid waste environmental impact statement.

(g) 216-A-10, - A-36B, and A-37-1 combined into one RCRA monitoring unit. RCRA monitoring will be performed according to interim-status groundwater quality assessment requirements.

(h) Will monitor groundwater under interim status until final-status groundwater monitoring plan is approved.

(i) Closure plan pending approval from Washington State Department of Ecology.

CERCLA = Comprehensive Environmental Response, Compensation, and Liability Act of 1980.

LERF = Liquid effluent retention facility.

LLWMA = Low-level waste management area

LWDF $\quad=$ Liquid waste disposal facility.

NRDWL $=$ Nonradioactive Dangerous Waste Landfill

PUREX = Plutonium-uranium extraction (plant)

RCRA $=$ Resource Conservation and Recovery Act of 1976

$\mathrm{TBD}=$ To be determined.

TSD = Treatment, storage, or disposal (unit)

WMA = Waste management area (single-shell tank farm).

$>\quad=$ Beyond the year 2000 . 


\begin{tabular}{|ccc|}
\hline \multicolumn{2}{|c|}{$\begin{array}{c}\text { Table 2.2.3. New Well Installation } \\
\text { Summary for Calendar Year 1999 }\end{array}$} \\
\hline Well & & O perational \\
Number & $\underline{\text { Location }}$ & $\underline{\text { A rea }}$ \\
299-W15-41 & TX-TY Tank Farm & 200 West \\
299-W22-48 & S-SX Tank Farm & 200 West \\
299-W22-49 & S-SX Tank Farm & 200 West \\
299-W22-50 & S-SX Tank Farm & 200 West \\
299-W26-13 & 216-S-10 & 200 West \\
699-43-44 & Former B Pond & 200 East \\
299-E33-344 & B-BX-BY Tank Farm & 200 East \\
299-E33-335 & B-BX-BY Tank Farm & 200 East \\
\hline
\end{tabular}

- The EPA and Washington State Department of Ecology conducted an inspection of the Hanford Site from May through July 1998. The inspection identified concerns that resulted in the issuance of a complaint by EPA citing three violations of RCRA regulations that included storage without a permit, failure to make a hazardous waste determination, and failure to immediately amend a contingency plan. Civil penalties were assessed for the sum of $\$ 367,078$.

The DOE Richland Operations Office made a formal response to the complaint and included a request for a hearing. In addition, the response identified defenses for each of the three counts and made a request for dismissal. The third count was subsequently dismissed. A settlement for the remainder of the complaint is being negotiated and will probably include performing supplemental environmental projects.

- The Washington State Attorney General, Washington State Department of Ecology, DOE Richland Operations Office, Fluor Hanford, Inc., and Lockheed Martin Hanford Corporation entered into a settlement agreement on March 15, 1999, resolving Administrative Order 98NW-009 and Notice of Penalty 98NW007 issued by the Washington State Department of Ecology on September 24, 1998 and July 23, 1998, respectively. The settlement agreement stipulated the resolution of penalty, enforcement duration, dispute resolution, reporting requirements, and leak detection provisions regarding operation of the Double-Shell Tank System.

- The Washington State Department of Ecology issued a Notice of Correction following a follow-up enforcement inspection at the 222-S Laboratory Complex conducted on February 9, 1999. One violation, three concerns, and one corrective measure were identified regarding the inspection of satellite accumulation areas in accordance with the Pollution Control Hearings Board Order of Dismissal \#97-189.

The DOE Richland Operations Office responded on June 1, 1999, and submitted the required corrective measure report. The Washington State Department of Ecology responded on June 3, 1999, and provided written acceptance and approval of the documentation submitted, closing the corrective actions.

- The Washington State Department of Ecology issued a Notice of Correction on June 3, 1999, following a compliance inspection of the Hanford Site Land Disposal Restriction program on September 29, 1998. The inspection was in support of the 1998 Hanford Site Land Disposal Restriction Report per Tri-Party Agreement Milestone M-26-01H (Ecology et al. 1998). The Notice of Correction identified 4 violations, 13 concerns, and 5 corrective measures.

The DOE Richland Operations Office and Washington State Department of Ecology signed a modified Stay of Proceedings on July 27, 1999. The DOE Richland Operations Office transmitted a response to the Land Disposal Restriction Notice of Correction on August 18, 1999, in accordance with the modified Stay of Proceedings. Efforts to resolve the identified issues continue.

- The Washington State Attorney General offered the DOE Richland Operations Office, 
Fluor Hanford, Inc., and BWHC an opportunity to enter into a settlement agreement resolving Notice of Penalty 97NM-248 issued by the Washington State Department of Ecology on September 16, 1997. This Notice of Penalty was associated with a chemical release that occurred in 1997. The proposed settlement agreement stipulated the duration of agreement, innovative settlement payment, and enforcement and dispute resolution provisions during the term of agreement. The Pollution Control Hearings Board approval was obtained on July 7, 1999, making the settlement agreement effective.

- Following an investigation by the South Carolina Department of Health and Environmental Control, violation of state and federal regulations were identified. On May 20, 1999, it was discovered that a shipping cask received at Chem-Nuclear Systems at Barnwell, South Carolina, had removable contamination levels exceeding U.S. Department of Transportation limits. In another cask shipment on November 24, 1999, a sample container rack and liquids were discovered in the cask upon arrival at Barnwell that were not listed on the shipment manifest. Both casks had been shipped from Hanford to Chem-Nuclear Systems for maintenance work.

The DOE Richland Operations Office submitted corrective documentation to the South Carolina Department of Health on July 26, 1999. The corrective action included measures to

\subsubsection{Clean Air Act}

Federal, state, and local agencies enforce the standards and requirements of the $\mathrm{Clean} \mathrm{A}$ ir $\mathrm{A}$ ct to regulate air emissions at facilities such as the Hanford Site. A summary of the major agency interfaces prevent reoccurrence. The South Carolina Department of Health and Environmental Control reviewed the corrective measures and accepted them on August 23, 1999.

- Following a September 1999 inspection, the Washington State Department of Ecology issued a notice of penalty for $\$ 9,700$ on November 17, 1999, alleging failure to properly label a gallon of tributyl phosphate waste. The waste is not considered a hazardous waste under RCRA, but it is considered a dangerous waste under Washington State regulations. The waste was generated at U Plant and disposed of at the Environmental Restoration Disposal Facility.

For the same waste, EPA issued a Notice of Violation under the Hanford Federal Facility Agreement alleging failure to prepare a Waste Control Plan prior to generating the waste, and for failing to implement a Sampling and Analysis Plan. Following the submittal of corrective action plans, EPA issued a $\$ 55,000$ civil penalty.

The DOE Richland Operations Office responded to the Notice of Violation and the Notice of Correction on November 24, 1999. The Washington State Department of Ecology responded on February 17, 2000, and concurred with the actions taken. The Washington State Department of Ecology considers the September 1999 inspection closed.

and applicable regulations for the Hanford Site is provided in the following paragraphs.

The $\mathrm{N}$ ational Emission Standards for $\mathrm{H}$ azardous A ir Pollutants: Radionuclides Federal Facility 
Compliance Agreement (FFCA 1994) was signed by EPA and DOE. The agreement provides a compliance plan and schedule that are being followed to bring the Hanford Site into compliance with Clean A ir A ct requirements under 40 CFR 61, Subpart H, for continuous measurement of emissions from applicable airborne emission sources. All 1999 scheduled milestones of the Federal Facility Compliance Agreement were met, and Hanford Site air emissions during 1999 remained well below the levels that approach the state and EPA offsite emission standard of 10 millirems per year. The requirements for flow and emissions measurements, quality assurance, and sampling documentation have been implemented at all Hanford Site sources and/or are tracked for milestone progress in accordance with a schedule approved by EPA and monitored by the Washington State Department of Health.

The Washington State Department of Health's Division of Radiation Protection regulates radioactive air emissions statewide through delegated authority from EPA and Washington State legislative authority. Washington State Department of Health implements the federal/state requirements under state regulation (WAC 246-247). Prior to commencing any work that would result in creating a new or modified source of radioactive airborne emissions, a notice of construction application must be submitted to the Washington State Department of Health, and EPA for review and approval. Ensuring adequate emission controls, emissions monitoring/sampling, and/or annual reporting of air emissions are typical requirements for radioactive air emission sources. The Hanford Site operates under state license FF-01 for such emissions. Conditions specified in the FF-01 license will be incorporated into the Hanford Site air operating permit, scheduled to be issued in late 2000. The Hanford Site air operating permit will be issued in accordance with Title $\mathrm{V}$ of the $\mathrm{Clean} \mathrm{A}$ ir A ct $\mathrm{A}$ mendments of 1990, and will be implemented through federal and state programs under 40 CFR 70 and WAC 173-401. The permit is intended to provide a compilation of applicable C lean A ir A ct requirements both for radioactive emissions and for nonradioactive emissions at the Hanford Site. The permit requires the DOE Richland Operations Office to submit periodic reports and an annual compliance certification to the lead agency.

The Washington State Department of Ecology Nuclear Waste Program regulates air toxic and criteria pollutant emissions from the Hanford Site. The Department enforces state regulatory controls for air contaminants as allowed under the Washington C lean A ir A ct (RCW 70.94). The Washington State Department of Ecology's implementing requirements (e.g., WAC 173-400, WAC 173-460) specify a review of new source emissions, permitting, applicable controls, reporting, notifications, and provisions of compliance with the general standards for applicable sources of Hanford Site emissions.

EPA regulates other potential air emission sources at the Hanford Site. Under 40 CFR 61, Subpart M, EPA regulations specifically address asbestos management requirements under the $\mathrm{Clean}$ A ir A ct. These regulations apply at the Hanford Site with regard to building demolition and/or asbestos renovation and waste disposal operations. Asbestos at Hanford is handled in accordance with EPA regulations and approved contractor procedures. In addition, Title VI of the $\mathrm{C}$ lean $\mathrm{A}$ ir A ct $\mathrm{A}$ mendments of 1990 require regulation of the service, maintenance, repair, and disposal of appliances containing Class I and Class II ozone-depleting substances (refrigerants) through implementation of the requirements in 40 CFR 82. Implementation of the ozonedepleting substance management requirements on the Hanford Site is administered at the facility/ project level, as applicable.

At the local level, EPA designated the Benton Clean Air Authority with responsibility to oversee and enforce EPA asbestos regulations under the national emission standards for hazardous air pollutants (40 CFR 61, Subpart M). In addition, the Benton Clean Air Authority regulates open burning, as an extension of the Washington State 
Department of Ecology's open burning requirements (WAC 173-425). In both areas of responsibility, the Benton Clean Air Authority enforces/adopts the federal and/or state regulations, by reference, as well as imposes additional requirements on sources such as the Hanford Site from the local agency level.

\subsubsection{Clean Air Act Enforcement Inspections}

DOE and its contractors work to resolve outstanding compliance findings from the Washington State Department of Health and Washington State Department of Ecology inspections. The noncompliance events in 1999 are listed below.

- The Washington State Department of Health issued a Notice of Correction (AIR-95-905 and AIR-99-907) in response to a compliance inspection of the 296-B-10 emission unit and sampling system conducted on June 24, 1999. The 296-B-10 emission unit provides ventilation for the Waste Encapsulation and Storage Facility located in the 200-East Area. The inspection noted that the sample holder appeared to be cross-threaded. While facility personnel were checking the system, the sample holder became disengaged and separated, drawing into question the accuracy and reliability of the sampling results. The inspection concluded that the procedure governing the inspection and the sample exchange for the stacks record sampler should be modified to ensure personnel are verifying the proper configuration. A response was sent to the Washington State Department of Health on November 8, 1999 (00-OSS-022). The issue is still open.

- The Washington State Department of Health issued a Notice of Correction (AIR 99-914) in response to a compliance inspection of the 291-Z-1 emission unit conducted on May 19, 1999. The 291-Z-1 emission unit provides ventilation for the Plutonium Finishing Plant in the 200-West Area of the Hanford Site. The inspection noted concerns with the amount of elapsed times between air filter annual in-place aerosol tests. This issue was identified in previous inspections and has been resolved. The DOE Richland Operations Office responded to the Notice of Correction. The Washington State Department of Health accepted the response and closed the inspection on October 8, 1999.

- The Washington State Department of Health issued a Notice of Correction (AIR 99-1001) in response to a compliance inspection of the 296-A-17 and 296-P-26 units conducted on April 7, 1999. The emission units were identified as currently shut down but had provided ventilation to the 241-AY and 241-AZ Tank Farms in the 200-East Area the previous year. During the inspection, concerns were noted with the documentation of record sampling system flow rates. The lack of documentation raises questions with the quality of the air sample data. The Washington State Department of Health requested that procedures adequately document the daily record sample flow rate. The Washington State Department of Health on October 1, 1999 closed this inspection.

- The Washington State Department of Health issued a Notice of Correction (AIR 99-901) in response to a compliance inspection of the 296-C-5 emission unit conducted on February 8,1999 . The 296-C-5 unit provides ventilation for the 244-CR Vault located in the 200-East Area. During the inspection, concerns were noted with the lack of an adequate review. The Washington State Department of Health requested that an adequate air emission unit review process be developed and implemented. Subsequently, another Notice of Correction was issued against this inspection. It was determined corrective actions identified in an earlier compliance inspection conducted in 1997 were not completed. The Notice of Correction identified four corrective actions to be completed. The Washington State Department of Health requested that an inspection team be established to identify deficiencies of compliance 
concerning emissions. The Washington State Department of Health on September 3, 1999 closed this inspection.

- The Washington State Department of Health issued a Notice of Correction (AIR 99-502) in response to a compliance inspection of the 296-T-18 emission unit conducted on December 17, 1998. The Notice of Correction contains two corrective actions identified during an earlier inspection conducted in 1997. The Washington State Department of Health requested that training and documentation be provided on the need for maintaining caps and plugs on all emission unit injection and sample ports. The Washington State Department of Health on May 11, 1999 closed this inspection.

- The Washington State Department of Health issued two Notices of Correction in response to a sitewide quality assurance audit the week of December 7, 1998. The audit identified two Notices of Correction (AIR 99-108) and 15 Best Management Practices. The Washington State

\subsubsection{Clean Water Act}

The C lean W ater A ct applies to point source discharges to waters of the United States. At the Hanford Site, the regulations are applied through National Pollutant Discharge Elimination System (40 CFR 122) permits that govern effluent discharges to the Columbia River.

In the past, there were two National Pollutant Discharge Elimination System permits for the site. Permit \#WA-000374-3 included four inactive outfalls $(005,006,007$, and 009 in the 100-N Area) and three active outfalls (003 and 004 in the 100-K Area and 013 in the 300 Area).

An application for a permit modification for the 300 Area Treated Effluent Disposal Facility (permit \#WA-002591-7) was submitted to EPA in November 1997. The application requested the transfer of outfalls 003 and 004 (100-K Area) from existing
Department of Health requested responses to the two Notices of Correction and one of the Best Management Practices. The Washington State Department of Health required the Pacific Northwest National Laboratory to perform external audits more frequently and to submit a schedule of the audits in response to Notice of Correction No. 1. There was no sampling procedure in place for minor radioactive airborne emission sources, and a procedure for minor emission sources was required in response to Notice of Correction No. 2. For Best Management Practice No. 1, the Project Hanford Management Contract Deficiency Tracking System did not track environmental deficiencies sufficiently, and a change to the system was requested. The DOE Richland Operations Office responded on March 25, 1999. When the procedure for a minor emission unit has been reviewed and finalized, the Washington State Department of Health will be provided a copy and the audit will be closed.

permit \#WA-000374-3 to permit \#WA-002591-7. The 100-N outfalls (005, 006, 007, 009, and N Springs) identified in permit\#WA-000374-3 were not included in the application because active discharges to these outfalls have ceased. N Springs may have some residual seepage from the ground and this is being addressed under the CERCLA program. A summary discussing why another outfall (013A in the 300 Area) should be exempt from permitting was also attached to the application.

The revised National Pollutant Discharge Elimination System permit was issued in April 1999 and it was effective as of May 5, 1999. Now there is only one National Pollutant Discharge Elimination System permit, WA-002591-7, for the Hanford Site. This permit covers all three active outfalls: one (outfall 001) for the 300 Area Treated Effluent Disposal Facility and two (outfall 003 and 004) at 
the 100-K Area. All other outfalls as mentioned above are no longer part of the National Pollutant Discharge Elimination System permit. Fluor Hanford, Inc. is the permitee for this National Pollutant Discharge Elimination System permit.

There were no noncompliances for Outfalls 003 and 004, located at 100-K Area. Table 2.2.4 lists noncompliances for Outfall 001 for the 300 Area Treated Effluent Disposal Facility.

The Hanford Site was covered by two stormwater permits in 1999. WAR-10-000F is the stormwater general permit for construction activities covering five acres or more. In accordance with the September 30, 1998, Federal Register (63 FR 52430), the stormwater general permit for industrial activity (WAR-00-000F) was terminated and replaced by the multisector general stormwater permit (WAR05-A45F). On December 28, 1998, a Notice of Intent was submitted to EPA for coverage under the
National Pollutant Discharge Elimination System multisector general stormwater permit. In compliance with this permit, the Hanford Site Stormwater Pollution Prevention Plan (HNF-4081) was completed and issued in March 1999.

The DOE Richland Operations Office has a pretreatment permit (CR-IU005) from the city of Richland to discharge wastewater from the William R. Wiley Environmental Molecular Sciences Laboratory in the Richland North Area. Also, there are numerous sanitary waste discharges to the ground, as well as 400 Area sanitary waste discharge to the Energy Northwest (formerly known as the Washington Public Power Supply System) treatment facility (see Figure 1.0.1 for Energy Northwest location). Sanitary waste from the 300 Area, the former 1100 Area, and other facilities north of, and in, Richland discharge to the city of Richland treatment facility.

\begin{tabular}{|c|c|c|c|}
\hline \multicolumn{4}{|c|}{$\begin{array}{l}\text { Table 2.2.4. Noncompliances for Outfall } 001 \text { at } \\
\text { the } 310 \text { Treated Effluent Disposal Facility, } 1999\end{array}$} \\
\hline $\begin{array}{c}\text { Date of } \\
\text { Exceedence }\end{array}$ & Parameter & $\begin{array}{c}\text { Measured } \\
\text { Concentration } \\
\end{array}$ & $\begin{array}{l}\text { Permit } \\
\text { Limit }^{(a)}\end{array}$ \\
\hline January & Copper & $4.3 \mu \mathrm{g} / \mathrm{L}$ & $3 \mu \mathrm{g} / \mathrm{L}^{(\mathrm{b})}$ \\
\hline February 11 & Copper & $5.1 \mu \mathrm{g} / \mathrm{L}$ & $5 \mu \mathrm{g} / \mathrm{L}^{(\mathrm{c})}$ \\
\hline February & Copper & $4.9 \mu \mathrm{g} / \mathrm{L}$ & $3 \mu \mathrm{g} / \mathrm{L}^{(\mathrm{b})}$ \\
\hline October 6 & Nitrite & $104.5 \mathrm{mg} / \mathrm{L}$ & $104 \mathrm{mg} / \mathrm{L}^{(\mathrm{c})}$ \\
\hline October & Nitrite & $69.5 \mathrm{mg} / \mathrm{L}$ & $60 \mathrm{mg} / \mathrm{L}^{(\mathrm{b})}$ \\
\hline November & Metals & $\mathrm{NA}^{(\mathrm{d})}$ & $\mathrm{NA}^{(\mathrm{d}, \mathrm{e})}$ \\
\hline \multicolumn{4}{|c|}{ Digestion of samples not performed as specified in method. } \\
\hline December 12 & Copper & $75 \mu \mathrm{g} / \mathrm{L}$ & $15 \mu \mathrm{g} / \mathrm{L}^{(\mathrm{c}, \mathrm{f})}$ \\
\hline December 12 & Manganese & $110 \mu \mathrm{g} / \mathrm{L}$ & $17 \mu \mathrm{g} / \mathrm{L}^{(\mathrm{c}, \mathrm{f})}$ \\
\hline December 12 & Zinc & $100 \mu \mathrm{g} / \mathrm{L}$ & $43 \mu \mathrm{g} / \mathrm{L}^{(\mathrm{c}, \mathrm{f})}$ \\
\hline $\begin{array}{l}\text { (a) } \text { Permit } \mathrm{Nc} \\
\text { (b) Average } \mathrm{m} \\
\text { (c) Maximum } \\
\text { (d) } \mathrm{NA}=\mathrm{Not} \\
\text { (e) EPA 200.8 } \\
\text { (f) } \text { Process up }\end{array}$ & $\begin{array}{l}\text { WA-002591-7. } \\
\text { nthly limit. } \\
\text { honthly limit. } \\
\text { nalyzed. } \\
\text { nethod deviation. } \\
\text { t. }\end{array}$ & & \\
\hline
\end{tabular}




\subsubsection{Liquid Effluent Consent Order}

The Washington State Department of Ecology liquid effluent consent order (DE91NM-177), which regulates Hanford Site liquid effluent discharges to the ground, contains compliance milestones for Hanford Site liquid effluent streams designated as Phase I, Phase II, and Miscellaneous Streams. Each scheduled State Waste Discharge Permit has been issued completing all Liquid Effluent Consent Order activities. Completion of the Consent Order activities was recognized by the Washington State Department of Ecology in writing on April 1, 1999.

The first Hanford Site miscellaneous streams categorical permit was issued by the Washington State Department of Ecology for hydrotest, maintenance, and construction discharges. The permit became effective May 30, 1997 and expires on May 30, 2002. A second miscellaneous streams categorical permit for cooling water and condensate discharges was issued on May 1, 1998. The third and final miscellaneous streams permit for industrial stormwater discharges was issued by the Washington State Department of Ecology on April 1, 1999. In 1999, there were eight noncompliances with four of the eight state waste discharge permits in place at the Hanford Site. Details are listed below.

- Permit No. ST 4502, 200 Areas Treated Effluent Disposal Facility - 200 Areas facility experienced one emergency overflow at Pump Station 3. The overflow resulted from a level switch malfunction that lasted $\sim 14$ hours and discharged 1,800,000 liters (480,000 gallons) of wastewater to the 216-B-3C expansion pond.

- Permit No. ST 4500, 200 Areas Effluent Treatment Facility - The onsite laboratory performing effluent and groundwater monitoring sample analysis was not accredited by the Washington State Department of Ecology for tritium. The services of an alternate laboratory were secured until such time as the onsite laboratory was accredited for tritium analysis.
- Permit No. ST 4502, 200 Areas Treated Effluent Disposal Facility - The onsite laboratory performing effluent and groundwater monitoring was not accredited for the analysis of Washington Total Petroleum HydrocarbonsGasoline. The services of an alternate laboratory were secured until such time as the onsite laboratory was accredited for Washington Total Petroleum Hydrocarbons-Gasoline analysis.

- Permit No. ST 4502, 200 Areas Treated Effluent Disposal Facility - The monthly average discharge limit for iron was exceeded for September. An investigation revealed elevated iron levels in waste streams discharged to the 200 Areas Treated Effluent Disposal Facility. The elevated levels may be attributable to the aging pipes. The investigation also revealed issues with sample homogeneity and the need for filtered samples.

- Permit No. ST 4507, 100-N Sewage Lagoon A discrepancy was discovered between analytical methods required by ST 4507 and those methods being used by the state accredited laboratory performing sample analysis. The issue was discussed with the Washington State Department of Ecology, which agreed the methods being used by the analytical laboratory were more appropriate for testing sewage lagoon effluent. A permit modification addressing the analytical method discrepancy was requested and granted by the Washington State Department of Ecology on January 5, 2000.

- Permit No. ST 4507, 100-N Sewage Lagoon It was determined that $\mathrm{pH}$ and total suspended solids exceeded effluent discharge limitations for the month of April 1999. Seasonal algae growth was attributed to the elevated $\mathrm{pH}$ and total suspended solids within the stabilization ponds. Operational changes are anticipated to improve effluent quality.

- Permit No. ST 4507, 100-N Sewage Lagoon Following a review of continuous flow 
monitoring data, questionable data led to the determination that freezing weather had caused the lagoon flow meter to malfunction. The manufacturer was consulted and a replacement flow meter less prone to malfunction in freezing conditions was installed.

- Permit No. ST 4508, Hydrotest, Maintenance, Construction Discharges - During an annual review of water line flushing data, personnel noted that five water line flushes conducted in April 1999 exceeded the instantaneous flow rate limit of 3,800 liters per minute (1,000 gallons per minute). Flushing procedures and associated $\log$ sheets were modified to more clearly identify discharge limits.

\subsubsection{Safe Drinking Water Act}

There were 12 public water systems on the Hanford Site in 1999. All public water systems are required to meet the Safe D rinking $W$ ater $A$ ct, the Safe D rinking W ater A ct A mendments of 1986, and the Safe D rinking $W$ ater $A$ ct $A$ mendments of 1996. Specific performance requirements are defined within the federal regulations (40 CFR 141, EPA-570/9-76-003, EPA 822-R-96-001) and WAC 246-290. The drinking water program has been updated to comply with the changing regulatory requirements. A complete revision of WAC246-290 was issued on April 9, 1999 and all site water programs have had the necessary changes incorporated.

The compliance monitoring program elements are updated annually with monitoring cycles beginning in January. Drinking water is monitored for radionuclides, inorganics, synthetic and volatile organics, lead and copper, asbestos, and coliform bacteria. All sampling results for 1999 met the requirements of the Washington State Department of
Health. Sample results for radiological monitoring of drinking water are discussed in Section 4.3, "Radiological Surveillance of Hanford Site Drinking Water."

During 1999, the 200-East Area pump and water treatment plant was taken out of service but remains in standby if needed. The 283-W, 200-West Area Water Treatment Plant now provides potable water to customers in both 200 Areas as the primary water supply. The 300 Area pump and water treatment system was taken out of service and potable water is now supplied from the city of Richland water system. The 300 Area pump and treatment plant remain in standby if needed. The well that supplied water to the Hanford Patrol Training Academy was taken out of service in May 1999 and will not remain in standby. The training academy is now supplied by the city of Richland who will maintain the system and sample the quality of the drinking water.

\subsubsection{Toxic Substances Control Act}

Requirements in this act that apply to the Hanford Site primarily involve regulation of polychlorinated biphenyls. Federal regulations for use, storage, and disposal of polychlorinated biphenyls are found in 40 CFR 761. The state of Washington also regulates certain classes of polychlorinated biphenyls through the dangerous waste regulations in WAC 173-303. 170 .
Electrical transformers on the site have been sampled and characterized. Fourteen transformers with polychlorinated biphenyl concentrations above 500 parts per million remain in service at the Fast Flux Test Facility. The timing of the replacement and disposal of these transformers will be based on the Record of Decision to restart reactor operations or resume transition to shutdown for the Fast 
Flux Test Facility. The transformers will be needed if the facility is restarted.

Defueled, decommissioned, naval reactor compartments shipped by the United States Navy to the Hanford Site for disposal contain small quantities of polychlorinated biphenyls, which are tightly bound in materials such as thermal insulation, cable coverings, and rubber. Because polychlorinated biphenyls are present, the reactor compartments were regulated under this act, through a compliance agreement between EPA and DOE. In November 1999, EPA and DOE agreed the polychlorinated biphenyls in the Navy reactor compartments meet the requirements for polychlorinated biphenyl bulk product waste under the revised Toxic Substances C ontrol A ct regulations, which allows for disposal of this waste in a landfill authorized to accept radionuclides. Therefore, disposal of the Navy reactor compartments is now in compliance with the current Toxic Substances Control Act regulations and the compliance agreement was terminated.

Nonradioactive polychlorinated biphenyl waste is stored and disposed of in accordance with 40 CFR
761. Radioactive polychlorinated biphenyl waste remains in storage onsite, pending the development of adequate treatment and disposal technologies and capacities. Requirements for the storage of radioactive polychlorinated biphenyl wastes were included in 1998 revision to the disposal amendments and have effectively removed the need for a compliance agreement between DOE and EPA, which previously provided a mechanism for the storage of these wastes. The Hanford Site continues to examine disposal and treatment options for radioactive polychlorinated biphenyl wastes.

The EPA issued a Federal Facility Notice of Significant Noncompliance on February 10, 1999, following Toxic Substances C ontrol A ct inspections conducted as a part of the multimedia inspection of the Hanford Site. The inspection was conducted from May 13 through May 15, 1998. The findings included 16 corrective actions. DOE Richland Operations Office responded on February 26, 1999, and submitted the required responses to the Federal Facility Notice of Significant Noncompliance.

\subsubsection{Federal Insecticide, Fungicide, and Rodenticide Act}

This act is administered by EPA. The standards administered by the Washington State Department of Agriculture to regulate the implementation of the Act in Washington State include: W ashington Pesticide C ontrol A ct (RCW 15.58), W ashington Pesticide A pplication A ct (RCW 17.21), and rules relating to general pesticide use codified in WAC 16-228. At the Hanford Site, pesticides are applied by commercial pesticide operators who are listed on one of two commercial pesticide applicator licenses and by a private commercial applicator. In 1999, the Hanford Site was in compliance with the federal and state standards.

\subsubsection{Endangered Species Act}

Many rare species of native plants and animals are known to exist on the Hanford Site. Four species that may occur onsite (the bald eagle, Aleutian Canada goose, steelhead trout, and spring chinook salmon) are listed by the U.S. Fish and Wildlife
Service as either threatened or endangered (50 CFR 17.11). Others are listed by the Washington State Department of Fish and Wildlife as endangered, threatened, or sensitive species (see Appendix F). The bald eagle is currently under 
review for a change in listing status. The site wildlife monitoring program is discussed in Section 7.2, "Ecosystem Monitoring (Plants and Wildlife)."

Bald eagles are seasonal visitors to the Hanford Site. Several nesting attempts along the Hanford Reach were documented by Pacific Northwest National Laboratory in the 1990s. In compliance with the Endangered Species A ct, the Hanford Site bald eagle management plan (DOE/RL-94-150) was finalized in 1994 . That plan established seasonal 800-meter (2,600-foot) restricted access zones around all active nest sites and five major communal roosting sites. If nesting activities at the historical nesting sites are observed in January and early February, all Hanford-related activities within the restricted access zone are constrained or limited until the pair abandons nesting or successfully rears young. In 1997 and 1998, nests were built by two pairs of eagles, but the nesting attempts were abandoned by May. One pair attempted to nest again in 1999. The pair occupied and tended the nest through August, but no eggs were laid and no young were reared. Eagle protection efforts occurred through August at this site.
Steelhead and salmon are regulated as evolutionary significant units by the National Marine Fisheries Service based on their historical geographic spawning areas. The evolutionary significant units for the upper Columbia River steelhead and the upper Columbia River spring-run chinook salmon were listed as endangered in August 1997 and March 1999, respectively. A Hanford Site steelhead management plan (DOE/RL-2000-27, Rev. 0) was prepared that will serve as the formal plan for the National Marine Fisheries Service as required under the Endangered Species Act. Like the bald eagle management plan, the steelhead management plan discusses mitigation strategies and lists activities that can be conducted without impacting steelhead trout or their habitats.

As part of the $\mathrm{N}$ ational Environmental Policy A ct review process, an ecological review was conducted on all Hanford Site projects to evaluate their potential of affecting federal- and/or state-listed species within the proposed project area (PNNL-6415, Rev. 12). The ecological reviews included efforts to quantify the potential impacts of project activities to and identify mitigation strategies to minimize or eliminate such impacts.

\subsubsection{National Historic Preservation Act, Archaeological Resources Protection Act, Native American Graves Protection and Repatriation Act, American Indian Religious Freedom Act, Historic Sites Buildings and Antiquities Act, Archeological and Historic Preservation Act, and American Antiquities Preservation Act}

Cultural resources on the Hanford Site are subject to the provisions of these seven acts. Compliance with the applicable regulations is accomplished through an active management and monitoring program that includes a review of all proposed projects to assess potential impacts on cultural resources, periodic inspections of known archaeological and historic sites to determine their condition and eligibility for listing on the National Register of Historic Places, determination of the effects of land management policies on the sites and buildings, and management of a repository for 
federally owned archaeological collections. In 1999, 176 cultural resource reviews were requested and conducted on the Hanford Site.

The A merican Indian Religious Freedom Act requires federal agencies to help protect and preserve the rights of Native Americans to practice their traditional religions. DOE cooperates with Native Americans by providing site access for organized religious activities. See Section 7.3, "Cultural Resources," for more details regarding the cultural resources program on the Hanford Site.

\subsubsection{National Environmental Policy Act}

The $\mathrm{N}$ ational Environmental Policy $\mathrm{A}$ ct requires preparation of an environmental impact statement. The environmental impact statement analyzes the effects associated with major federal actions that have the potential to affect the quality of the human environment.

The following sections address environmental impact statements related to the Hanford Site. Other $\mathrm{N}$ ational Environmental Policy $\mathrm{A}$ ct documents include an environmental assessment, which is prepared when it is uncertain if a proposed action has the potential to impact the environment significantly and, therefore, would require the preparation of an environmental impact statement. A summary and status of environmental assessments that apply to specific activities and facilities on the Hanford Site may be found in the $\mathrm{N}$ ational Environmental Policy A ct Source $\mathrm{G}$ uide for the $\mathrm{H}$ anford Site (HNF-SP-0903, Rev. 6). This report is updated annually.

Additionally, certain types of actions may fall into typical classes that have already been analyzed by DOE and have been determined not to result in a significant environmental impact. These actions are called categorical exclusions, and, if eligibility criteria are met, they are exempt from $N$ ational $E$ nvironmental Policy Act environmental assessment or environmental impact statement requirements. Typically, over 20 specific categorical exclusions are documented by the DOE Richland Operations Office annually, involving a variety of actions by multiple contractors. In addition, sitewide categorical exclusions are applied to routine, typical actions conducted daily on the Hanford Site. In 1999, there were 20 sitewide categorical exclusions.
The Council on Environmental Quality, which reports directly to the President, was established to oversee the $\mathrm{N}$ ational Environmental Policy A ct process. $\mathrm{N}$ ational Environmental Policy Act documents are prepared and approved in accordance with Council on Environmental Quality N ational Environmental Policy A ct regulations (40 CFR 1500-1508), DOE $\mathrm{N}$ ational Environmental Policy $\mathrm{A}$ ct implementation procedures (10 CFR 1021), and DOE Order 451.1A. In accordance with the Order, DOE documents prepared for CERCLA projects incorporate $\mathrm{N}$ ational Environmental Policy Act values such as analysis of cumulative, offsite, ecological, and socioeconomic impacts to the extent practicable in lieu of preparing separate $\mathrm{N}$ ational Environmental Policy Act documentation.

\subsubsection{Recent Environmental Impact Statements}

The potential environmental impact associated with ongoing, major operations at the Hanford Site have been analyzed in environmental impact statements issued in the past several years, followed by records of decision. Additional $\mathrm{N}$ ational Environmental Policy A ct reviews, as appropriate, are being conducted during the course of the actions, moving forward as described in the records of decision. Environmental impact statements issued in 1999, and/or those that had significant related documentation issued are described below.

- A final environmental impact statement for the stabilization of plutonium-bearing materials at the Plutonium Finishing Plant was 
issued in May 1996 (DOE/EIS-0244F). The proposed action is stabilization of selected plutonium-bearing materials for interim storage and immobilization of some materials for transport to a Hanford Site solid waste management facility. The record of decision was issued in July 1996 (61 FR 36352). A supplemental analysis (DOE/EIS-0244-FS/SA1) issued on March 28, 1997, provided a basis to determine whether a supplemental environmental impact statement was required prior to packaging concreted plutonium-bearing materials. It was determined that no additional $\mathrm{N}$ ational Environmental Policy A ct analysis was required. A supplement analysis (DOE/EIS-0244-FS/SA2) issued on August 2, 1999, provided a basis to determine whether a supplemental environmental impact statement was required prior to increasing the batch size for thermal stabilization of metals, oxides, and process residues. It was determined that no additional $\mathrm{N}$ ational Environmental Policy A ct analysis was required.

- A final environmental impact statement for a comprehensive land-use plan at the Hanford Site was issued in September 1999 (DOE/EIS0222-F). The purpose of this land-use plan and its policies and procedures is to facilitate decisions about the site's uses and facilities over the next 50 years. The record of decision was issued in November 1999 (64 FR 61615). The U.S. Fish and Wildlife Service adopted the environmental impact statement and issued a record of decision of their own (64 FR 66928) making a refuge acquisition decision for the Wahluke Slope.

\subsubsection{Programmatic Environmental Impact Statements}

A final environmental impact statement was issued in May 1997 (DOE/EIS-0200F) to evaluate management and national siting alternatives for the treatment, storage, and disposal of five types of radioactive and hazardous waste. The Hanford Site was considered in all alternatives. A record of decision was issued in January 1998 (63 FR 3623) on treatment and storage of transuranic waste. A subsequent record of decision on hazardous waste treatment was issued in August 1998 (63 FR 41810). A record of decision for storage of immobilized high-level waste was issued in August 1999 (64 FR 46661).

A draft environmental impact statement (DOE/ EIS-0287ID was issued by the Idaho National Engineering and Environmental Laboratory in December 1999 for the disposition of Idaho high-level waste and facilities in which Hanford was listed as an alternative.

The Office of Nuclear Energy, DOE Headquarters, is preparing a separate programmatic environmental impact statement, to evaluate expanded civilian nuclear energy research and development and isotope production missions in the United States. This environmental impact statement includes the role of the Hanford Site's Fast Flux Test Facility. It is anticipated that a draft environmental impact statement will be issued in 2000 .

\subsubsection{Site-Specific Environmental Impact Statements in Progress}

An environmental impact statement is being prepared for the Hanford Site Solid Waste (Radioactive and Hazardous) Program (DOE/EIS-0286). A draft is being prepared in cooperation with the Yakama Nation; it is expected to be issued for public comment in 2000.

\subsubsection{Recent Environmental Assessments}

An environmental assessment was prepared to determine whether an environmental impact statement would be required to widen trench 36 of the 
218-E-12 low-level burial ground (DOE/EA-1276). The environmental assessment analyzed the impact of modifying, expanding, and operating a currently unused solid waste trench to better manage bulk low-level solid waste. The analysis of the anticipated impacts led to a conclusion that no significant impacts were expected. A finding of no significant impact was issued on February 11, 1999, determining that no further review was required under the $\mathrm{N}$ ational Environmental Policy $\mathrm{A}$ ct.

An environmental assessment, $T$ reatment of $L$ owLevel $M$ ixed $W$ aste at an 0 ffsite Thermal T reatment F acility (DOE/EA-1135), was prepared in May 1999.
The purpose of the assessment was to determine whether an environmental impact statement would be required for a proposal to transport low-level mixed waste from an Hanford Site storage facility to an offsite, RCRA permitted, thermal treatment facility. The facility, to be operated by a service contractor in Richland, Washington, would treat the waste by thermal destruction and return the residual ash to the Hanford Site for disposal. The analysis of the anticipated impact led to a conclusion that no significant impact was expected. A finding of no significant impact was issued on May 6, 1999, determining that no further review was required under the $\mathrm{N}$ ational Environmental Policy $\mathrm{A}$ ct. 


\title{
2.3 Activities, Accomplishments, and Issues
}

\author{
K. R. Price
}

This section describes DOE's progress in meeting its mission at the Hanford Site. Section 2.2, "Compliance Status," described activities relating to compliance with regulations. This section describes other, major, ongoing activities. Ongoing compliance self-assessments, knowledge gained in implementing Tri-Party Agreement (Ecology et al. 1998) milestones, and communications with stakeholders continue to identify environmental compliance issues. Relevant issues are discussed openly with the regulators and with the public to ensure that environmental compliance issues are resolved.

\subsubsection{Hanford Federal Facility Agreement and Consent Order}

Highlights of accomplishments (not documents or publications), with the associated Tri-Party Agreement milestone numbers, include the following:

- submitted Gable Mountain/B Pond and Ditch Cooling Water Group Work Plan (M-13-20)

- submitted Chemical Sewer Group Work Plan (M-13-21)

- submitted U Pond/Z Ditches Cooling Water Group Work Plan (M-13-22)

- completed all remaining 100 Area Operable Unit Pre-Record of Decision Site Investigations Under Approved Work Plan Schedules (100-KR-2, 100-KR-3, 100-FR-2, 100-HR-2, 100-IU-2, and 100-IU-6) (M-15-00A)

- completed all 300 Area Operable Unit PreRecord of Decision Site Investigation Under Approved Work Plan Schedules (M-15-00B)

- submitted 300-FF-2 Focus Feasibility Study and Proposed Plan for Regulator Review $(\mathrm{M}-15-23 \mathrm{~B})$

- initiated remedial action for 100-HR-1 Operable Unit (M-16-26A)
- completed Environmental Restoration Disposal Facility Cells 3 and 4 to Accept Remediation Waste (M-16-92B)

- initiated tank pumping for T-104, T-110, SX-104, SX-106, S-102, S-106, and S-103 meeting the enforceable commitments in the decree order

- resolved the criticality safety issues (M-40-12)

- started construction upgrades in a second tank farm (M-43-13)

- completed the Waste Information Requirements Document cycle (issue to Ecology, finalize, characterize, and issue reports) (M-44)

- completed sluicing retrieval of tank 241-C-106 sludge (M-45.03)

- completed updates for reports supporting M-45

- completed double-shell tank space evaluation $(\mathrm{M}-46)$

- submitted revised Canister Storage Facility Part A Dangerous Waste Permit Application (M-90-12) 
- submitted 105-B Hazards Assessment and Characterization Report to EPA (M-93-04)

- completed cross-site transfers via the new crosssite transfer system

- completed the mitigation of 241-SY-101 Waste Tank.

Since this report was issued last year, negotiated changes to the Tri-Party Agreement established 29 new enforceable milestones. A summary of the significant changes is given in the following sections.

\subsubsection{Waste Management}

There were three change requests related to waste management approved during 1999.

Milestone M-26-01 is an annually occurring milestone that requires the submittal of a report dealing with Land Disposal Restrictions wastes at the Hanford Site. On June 3, 1999, the Washington State Department of Ecology issued a notice of correction regarding the Land Disposal Restrictions report. Issues arising from the notice of correction became the subject of dispute resolution procedures contained within the Tri-Party Agreement. To avoid producing a year 2000 Land Disposal Restrictions report that may not have been satisfactory to both parties, the due date for the year 2000 report was extended from April 30, 2000, to July 31, 2000.

RCRA interim status compliance upgrades to the 219-S Waste Handling Facility encountered delays due to resolution of polychlorinated biphenyl and completion of requirements. The final due date for completion of the upgrades was extended from April 30, 1999, to June 30, 1999.

Milestone M-32-03-T06 was originally intended to include major capital upgrades to the T Plant canyon facility tank system (building 221-T). These upgrades would ensure that decontamination operations would be in accordance with the regulatory standards for secondary containment and leak detection. Subsequent studies concluded that the best option was to move future decontamination activities from the $T$ Plant canyon to nearby buildings 2706-T and 2706-TA and to eliminate the use of the 221-T storage tanks. The scope of the milestone was modified to delete upgrades to the T Plant canyon tank system and increase the scope of work for buildings 2706-T and 2706-TA by providing a new, compliant, dangerous waste tank system.

\subsubsection{Environmental Restoration}

There were six change requests related to environmental restoration approved during 1999.

DOE's environmental restoration program began assessing the contamination at $\sim 700$ waste sites, within 23 operable units, located in the 200-East and 200-West Areas of the Hanford Site. DOE, Washington State Department of Ecology, and EPA worked together to prioritize the assessment of the operable units based on criteria such as potential threats to health and the environment. The initial prioritization is reflected in milestones that establish dates for developing assessment work plans, characterization, and evaluating cleanup alternatives. The parties agreed to review the prioritization as work progressed to determine if there were any necessary changes to the criteria or ranking process. In July 1999, DOE, Washington State Department of Ecology, and EPA met to reassess operable unit prioritization needs. As a result of this reassessment Milestone M-13-23 was reassigned from the 200-PW-2 Operable Unit to the 200-TW-1 Operable Unit and the date was extended from April 30, 2000, to August 31, 2000. Milestone M-13-24 was reassigned from the 200-PW-4 Operable Unit to the 200-TW-2 Operable Unit with no change to the due date. Two new milestones were created, M-13-25 requiring the submittal of the 200-PW-2 Operable Unit work plan by December 31,2000, and M-13-26 requiring the submittal of the 200-PW-4 Operable Unit work plan by June 30, 2001. 
Two sets of changes were approved to groundwater sampling and analysis plans for the 100-FR-3 and 100-BC-5 Operable Units. These changes continue the established trend to produce a more integrated and cost effective monitoring system. Any resulting changes in samples, analytes, and frequency of sampling are expected to result in minimal or negligible loss of relevant information.

A number of unanticipated issues occurred that affected the sequence of work and the duration of remedial activities at several $300-$ FF-1 Operable Unit waste sites. These events necessitated changes to the controlling milestone, $\mathrm{M}-16-03 \mathrm{D}$. The original milestone was deleted and two new milestones M-16-03E and M-16-03F were added to the TriParty Agreement addressing the remediation of waste sites in the 300-FF-1 Operable Unit.

The completion date for remediation and backfill of 19 liquid waste sites in the 100-BC-1 and 100-BC-2 Operable Units had to be extended by 6 months. This extension became necessary due to the discovery of chromium and additional contaminated material in the 116-C-5 waste site. Additional sampling requirements and the discovery of additional plumes affected the completion date resulting in the 6-month extension of milestone M-16-08B.

Each year the number and location of RCRA monitoring wells are mutually determined by the DOE and Washington State Department of Ecology. For calendar year 1999, it was determined that eight new wells were necessary and these were added to the Tri-Party Agreement under five new milestones.

\subsubsection{Office of River Protection}

There were four change requests related to the Office of River Protection approved during 1999.

During Tri-Party Agreement negotiations in 1993, it was recognized that the Grout Facility, while in a standby condition, could be restarted. Therefore, interim milestone M-32-08 and milestone
M-32-08-T01 were included in the Tri-Party Agreement to require the completion of an integrity assessment of the Grout tank system prior to processing double-shell tank waste. The decision has since been made that the Grout Facility will not process double-shell tank waste. Therefore, the interim milestone and target date are no longer needed and were deleted from the Tri-Party Agreement.

Because difficulties have delayed the completion of interim stabilization (i.e., removal of liquids) of the single-shell tanks, DOE and Washington State Department of Ecology agreed that the requirements to complete the stabilization should be filed as a consent decree with the United States District Court for the Eastern District of Washington (Consent Decree CT-99-5076-EFS). Consequently, DOE, Washington State Department of Ecology, and EPA agreed to, and then approved, the deletion of the interim stabilization program from the scope of the Tri-Party Agreement.

DOE requested an extension to interim milestone $\mathrm{M}-45-03 \mathrm{~A}$ that requires the sluicing retrieval of waste from tank C-106 by October 31, 1997. The extension became necessary when safety issues effected the work. Washington State Department of Ecology denied the request for extension and set conditions and a new date for completion of the work. The Pollution Control Hearings Board subsequently upheld the action by the Washington State Department of Ecology. DOE and Washington State Department of Ecology approved a new milestone date of December 31, 1999.

The 244AR Vault is a multi-cell concrete structure housing four single walled tanks. Early planning for the 244AR Vault was based on the assumption that operations to transfer waste from the vault would eventually restart. Therefore, milestones were established to conduct necessary integrity assessment work. DOE and Washington State Department of Ecology have since agreed that the vault will not be used as a waste transfer facility and should 
eventually be closed. DOE and Washington State Department of Ecology approved the deletion of the existing 244AR milestones and established new milestones covering interim stabilization of the vault pending the facility's eventual closure.

\subsubsection{Facilities Transition}

There were three change requests related to facilities transition approved during 1999.

In light of recent decisions and after extensive public involvement, DOE and Washington State Department of Ecology approved two change requests placing the Tri-Party Agreement milestones for the Fast Flux Test Facility in "abeyance" until the Secretary of Energy issues a final decision on whether or not to restart the Fast Flux Test Facility (see Section 2.3.5, "Fast Flux Text Facility," for details regarding recent decisions).

Tank 241-Z-361 is a tank within the Plutonium Finishing Plant and Operable Unit 200-PW-1 that is to be remediated under the authority of CERCLA. Although completion of the usual CERCLA work plan for this operable unit is not planned until the end of calendar year 2001, the resolution of urgent safety issues necessitated early action. DOE and EPA approved commitments to sample, analyze, and provide a recommendation to dispose of sludge from tank 241-Z-361.

Major Milestone M-89-00 required DOE to complete closure of nonpermitted mixed waste units in the 324 Building Radiochemical Engineering Cells, B Cell, D Cell, and High Level Vault. DOE and Washington State Department of Ecology were required to agree on a date for this milestone following Ecology's September 1, 1998, approval of the plan to close 324 Building REC/HLV. Based on the approved closure plan, DOE and Washington State Department of Ecology approved the final due date of October 31, 2005, for Major Milestone M-89-00.

\subsubsection{Spent Nuclear Fuel}

There were two change requests related to spent nuclear fuel approved during 1999.

The $\mathrm{K}$ basins are two aging basins within the 100-K Area of the Hanford Site where spent nuclear fuel is stored (see Section 2.3.3, "Spent Nuclear Fuel Project"). In 1998, extensive negotiations took place between DOE, Washington State Department of Ecology, and EPA to establish a schedule for the removal of spent nuclear fuel, debris, sludge, and water from the KE and KW basins. In early 1999, DOE, Washington State Department of Ecology, and EPA approved a Tri-Party Agreement change request establishing a baseline of milestones and target dates.

In February 1999, an internal review found deficiencies in the analytical modeling of possible cask drop accidents in the south loading pit of the KW Basin. These deficiencies in the analytical modeling of the facility structure challenged earlier conclusions about the basins. Assessment of the problem, resolution of the concerns, and implementation of mitigation steps resulted in extension of interim Milestone M-34-14A, "Complete K West Cask Facility modifications" from September 30, 1999, to February 29, 2000.

\subsubsection{Pollution Prevention Program}

Pollution prevention is DOE's preferred approach to environmental management. The Hanford Site Pollution Prevention Program is an organized and continuing effort to reduce the quantity and toxicity of hazardous, radioactive, mixed, and sanitary wastes.
The program fosters the conservation of resources and energy, the reduction of hazardous substance use, and the prevention or minimization of pollutant releases to all environmental media from all operations and site cleanup activities. 
The program is designed to satisfy DOE requirements, executive orders, and federal and state regulations and requirements. In accordance with sound environmental management, preventing pollution through source reduction is the first priority in this program; the second priority is environmentally safe recycling. Waste treatment to reduce quantity, toxicity, or mobility (or a combination of these) will be considered only when source reduction and recycling are not possible or practical. Disposal to the environment is the last option.

Overall responsibility for the Hanford Site Pollution Prevention Program resides with the DOE Richland Operations Office. The office defines overall program requirements that each prime contractor is responsible for meeting.
Hanford Site pollution prevention efforts in 1999 helped to reduce disposal requirements through source reduction and recycling an estimated 2.8 cubic meters ( 3.7 cubic yards) of radioactive mixed waste, 164 metric tons (362 tons) of RCRA hazardous/dangerous waste, 144 million liters (38 million gallons) of process wastewater, and 5,616 metric tons (12,380 tons) of sanitary waste. Estimated waste disposal cost savings in 1999 exceeded \$54 million for these activities. During 1999, the Hanford Site recycled 476 metric tons ( 1,050 tons) of paper products, 529 metric tons (1,170 tons) of various metals, and 11 metric tons (24 tons) of tires.

\subsubsection{Spent Nuclear Fuel Project}

The Spent Nuclear Fuel Project was established in February 1994 to provide safe, economic, and environmentally sound management of Hanford Site spent nuclear fuel in a manner that readies it for final disposition. DOE strategic planning recommends that the fuel stored in $\mathrm{K}$ basins and other spent nuclear fuel on the site and throughout the DOE complex be placed in a geologic repository for final disposition.

Through 1999, the project continued to make progress on its accelerated strategy for moving the wet-stored $\mathrm{K}$ Basin fuel away from the Columbia River and into the Canister Storage Building. The 40-year-old $\mathrm{K}$ basins are used to store 2,100 metric tons (2,300 tons) of $\mathrm{N}$ Reactor irradiated fuel and a small quantity of slightly irradiated single-pass reactor fuel. The cladding on much of the fuel was damaged, allowing the fuel to corrode and degrade during storage underwater. The reactor fuel eventually will be removed from underwater storage in the $\mathrm{K}$ basins and placed in dry interim storage in the 200-East Area. Prior to interim storage, the fuel will be cleaned to remove corrosion products and particulates, packaged into fuel storage containers called
Multi-Canister Overpacks, and vacuum processed to remove the water from the packaged fuel. The vacuum processing will be done at the cold Vacuum Drying Facility that has been completed in the 100-K Area. Following the drying process, the fuel will be transported to the Canister Storage Building that has been constructed in the 200-East Area (see Figure 1.0.2). The Multi-Canister Overpacks will be sealed, and the fuel will be maintained in storage pending a decision by the Secretary of Energy on its final disposition. If necessary, the fuel could remain in dry storage for up to 40 years. This strategy supports completion of fuel removal from the $\mathrm{K}$ basins by the Tri-Party Agreement date of July 2004. An Operational Readiness Review is scheduled to take place during the summer of 2000 to support startup of the new fuel handling systems in the 105-KW Basin, fuel conditioning processes in the Cold Vacuum Drying Facility, and storage operations in the Canister Storage Building. This review is expected to determine that the facilities are ready to start operations, so fuel removal from the KW Basin can begin by November 30, 2000. 
Fuel corrosion and fuel handling operations have led to the accumulation of $\sim 50$ cubic meters of sludge and corrosion products in fuel storage canisters and on the floors of the $\mathrm{K}$ basins. The majority of the sludge is in the KE Basin. Following the removal of the spent nuclear fuel from the $\mathrm{K}$ basins, activities will be undertaken to remove the sludge from the basins by August 2004.

Debris, empty fuel canisters, and water remaining in the $\mathrm{K}$ basins will also be removed, treated as necessary, and disposed. The debris will be disposed at the Environmental Restoration Disposal Facility on the Hanford Site to the extent possible. If the debris is such that it does not meet the waste criteria to be accepted by the Environmental Restoration Disposal Facility, then it will be transferred to an existing permitted waste management facility. The water will be treated at the Hanford Site 200 Areas Effluent Treatment Facility and will be disposed of onsite. The $\mathrm{K}$ basins then will be prepared for interim stabilization, pending final remediation.

The Spent Nuclear Fuel Project also specifies that other spent nuclear fuel stored on the Hanford Site will be relocated to the 200-East Area Interim Storage Area or to the Canister Storage Building. Other stored spent nuclear fuel can be found at

- Fast Flux Test Facility fuel in the 400 Area

- Training, Research, and Isotope Production General Atomics fuel in the 400 Area
- Shippingport, Pennsylvania, reactor fuel at T Plant in the 200-West Area

- miscellaneous special case and research reactor fuels in the 324, 325, and 327 buildings in the 300 Area.

A CERCLA Record of Decision for K Basins cleanup (99-SFD-190) was signed by DOE, Washington State Department of Ecology, and EPA. In addition, some of the major accomplishments for calendar year 1999 were

- completed construction of the 105-KW Basin fuel retrieval system and integrated water treatment system

- completed construction and installation of the process equipment in two bays of the Cold Vacuum Drying Facility

- completed installation of the sample station at the Canister Storage Building

- completed placement of 220 storage tubes at the Canister Storage Building

- awarded a contract for the production of the Multi-Canister Overpacks and began fabrication

- began onsite fabrication of fuel and scrap baskets

- prepared extensive safety analysis documentation.

\subsubsection{River Corridor Project}

The mission of the River Corridor Project is to deactivate contaminated facilities in preparation for decontamination and decommissioning. The project also provides for safe and secure storage of special nuclear material, nuclear material, and nuclear fuel until these materials can be transferred to another facility, sold, or otherwise dispositioned.

Within the River Corridor Project are multiple subprojects and facilities which are discussed in the following sections.

\subsubsection{Accelerated Deactivation Project}

The mission of the Accelerated Deactivation Project is to complete facility deactivation and closure activities while maintaining the facilities in a safe and compliant status, until turnover to the Environmental Restoration Program.

300 A rea Fuel Supply Shutdown Subproject. Facilities managed under the Accelerated 
Deactivation Project include those associated with the 300 Area Fuel Supply Shutdown subproject. The fuel supply subproject includes buildings dating back to 1943 that housed manufacturing equipment to produce fuel for Hanford Site reactors. These processing operations were discontinued in 1987 when $\mathrm{N}$ Reactor was shut down and placed in a standby mode.

During 1999, RCRA treatment, storage, and disposal unit closure activities were performed for the 300 Area Waste Acid Treatment System. As part of this effort, the Washington State Department of Ecology approved the decontamination and inspection activities associated with the treatment, storage, and disposal unit closure campaign.

\subsubsection{324 and}

\section{Facilities Deactivation Project}

Construction of the 324 and 327 buildings was completed and operations were initiated in 1966 and 1953, respectively. These buildings house hot cells that were used for radiological research and development work. Both facilities were transferred to Fluor Hanford, Inc. in 1996 for deactivation and closure.

During 1999, the Accelerated Deactivation Project accomplished the following tasks:

- performed 324 Building B Cell equipment and rack (storage rack) size reduction activities. These activities included placement of debris into containers that will be used for transport to Hanford waste management storage facilities.

- collected and containerized dispersible materials from the 324 Building B Cell floor

- completed and submitted updated safety documentation for both the 324 and 327 buildings to DOE Richland Operations Office for approval
- packaged and shipped 23 drums (containing 96 legacy transuranic and low-level waste "buckets" from the 327 Building hot cells) to safe storage in the 200-West Area, which exceeded the goal of 20 drums. Twelve additional drums (containing 51 hot cell buckets) associated with the spent nuclear fuel program, were also packaged and shipped.

- developed and submitted the 300 Area SpecialCase Waste Project Management Plan (HNF5068) to the DOE Richland Operations Office ahead of schedule, which provides an opportunity for early completion of the Tri-Party Agreement Milestones M-92-13 and M-92-14.

\subsubsection{300 Area Treated Effluent Disposal Facility}

Industrial wastewater generated throughout the Hanford Site is accepted and treated in the 300 Area Treated Effluent Disposal Facility. Laboratories, research facilities, office buildings, and former fuel fabrication facilities in the 300 Area constitute the primary sources of wastewater. The wastewater consists of once-through cooling water, steam condensate, and other industrial wastewaters. The facility began operation in December 1994.

This facility is designed for continuous receipt of wastewater, with a storage capacity of up to 5 days at the design flow rate of 1,100 liters per minute (300 gallons per minute). The treatment process includes iron coprecipitation to remove heavy metals, ion exchange to remove mercury, and ultraviolet light/hydrogen peroxide oxidation to destroy organics and cyanide. Sludge from the iron coprecipitation process is dewatered and used for backfill in the low-level waste burial grounds. The treated liquid effluent is monitored and discharged through an outfall to the Columbia River under a National Pollutant Discharge Elimination System permit No. WA 002591-7. The permit was revised in 1999 to modify discharge limits and to allow for dangerous waste treatment in accordance with state dangerous 
waste regulations. However, treatment of dangerous wastes has not been implemented and there is no current schedule for treatment to begin. Capability exists to divert the treated effluent to holding tanks before discharge, if needed, until a determination can be made for final disposal based on sampling. In 1999, $\sim 223$ million liters (59 million gallons) of wastewater were treated.

\subsubsection{Plutonium Finishing Plant}

In 1949, the Plutonium Finishing Plant began to process plutonium nitrate solutions into metallic forms for shipment to nuclear weapons production facilities. Operation of this plant continued into the late 1980s. In 1996, DOE issued a shutdown order for the plant, authorizing deactivation and transition of the plutonium processing portions of the facility in preparation for decommissioning. The mission is to stabilize, repackage, immobilize and/or properly dispose of plutonium-bearing materials in the plant; to deactivate the processing facilities; and to provide for the safe and secure storage of nuclear materials until final disposition.

Significant accomplishments achieved at the Plutonium Finishing Plant during 1999 include the following:

- processed 150 items of oxides and sludge in the muffle furnaces- 40 more than targeted

- installed three more furnaces to increase plutonium stabilization capacity

- restarted a prototype denitration calciner to stabilize plutonium solutions

- completed design for a new, long-term technology for stabilizing solutions, the magnesium hydroxide precipitation process, which is scheduled to become operational in mid-2000

- determined stabilization plans for the remaining plutonium-bearing materials including metals, polycubes, and residues left from processing.
In addition, the long-range project plan for the plant-the Integrated Project Management Plan (HNF-3617, Rev. 0)—was revamped by a multidisciplinary panel of experts from across the DOE complex to determine ways to accelerate work at the Plutonium Finishing Plant. The new plan is expected to save $\$ 1.2$ billion by accelerating stabilization and deactivation of the plant and shorten the timeline by 22 years.

On February 1, 2000, Westinghouse Safety Management Solutions, a new technical and management team, took over management of the Plutonium Finishing Plant under Fluor Hanford, Inc. The new team, which brings a depth of relevant experience in plutonium stabilization from other DOE sites, will provide new perspectives and innovation to further accelerate work at the plant.

\subsubsection{Plutonium-Uranium Extraction Plant}

The Plutonium-Uranium Extraction Plant represents one of the Hanford Site's earliest successes to identify innovative ways to greatly accelerate facility deactivation, through information sharing, technology, and by working closely with regulators. The plant was deactivated 14 months ahead of schedule, saving \$75 million. In September 1999, the plant was transferred to Bechtel Hanford, Inc., the Hanford Site environmental restoration contractor. Bechtel Hanford, Inc. will maintain the plant in a surveillance and maintenance phase until disposition is determined. Before deactivation, the plant required $\sim \$ 35$ million annually to maintain it safely in a standby condition. It now requires less than $\$ 1$ million a year to be safely maintained in the surveillance and maintenance mode.

\subsubsection{Waste Encapsulation and Storage Facility}

The mission of the Waste Encapsulation and Storage Facility project is to provide safe interim 
storage of encapsulated radioactive cesium and strontium. The facility was initially constructed as a portion of the B Plant complex and began service in 1974. In 1998, B Plant was deactivated and disconnected from the Waste Encapsulation and Storage Facility. There are currently 601 strontium fluoride capsules and 1,335 cesium chloride capsules stored at the facility. DOE applied for a Part A (Form 3) permit for dangerous waste storage and is awaiting approval from the Washington State Department of Ecology. The capsules will be stored at Waste Encapsulation and Storage Facility until 2013. Beginning in 2013, the capsules will be shipped to the vitrification plant in preparation for high-level waste vitrification. The final capsule shipment is scheduled for 2017.

\subsubsection{Fast Flux Test Facility}

The Fast Flux Test Facility, a 400-MW thermal, liquid metal cooled reactor, located in the 400 Area, was built in the late 1970s to test plant equipment and fuel for the Liquid Metal Fast Breeder Reactor Program. Although the facility is not a breeder reactor, this program demonstrated the technology of commercial breeder reactors. The Fast Flux Test Facility operated from April 1982 to April 1992, during which time it successfully tested advanced nuclear fuels, materials, and safety designs and also produced a variety of different isotopes for medical research.

The reactor has been in a hot-standby condition since December 1993. In November 1995, DOE decided to limit deactivation work at the Fast Flux Test Facility to those activities that would not prohibit a return to service while DOE studied the facility's capability to produce tritium and medical isotopes. The fuel was removed from the reactor vessel, and fuel assemblies (sealed metal tubes that hold fuel pellets) were contained in two fuel storage vessels and in aboveground, dry storage casks. Of the facility's 100 plant systems, 23 are deactivated. The facility continues to be maintained in a standby mode in accordance with state and federal requirements.

On December 22, 1998, the Secretary of Energy announced the decision to remove the Fast Flux Test Facility from consideration as a tritium supply source. However, DOE will investigate further the facility's potential role in the department's national nuclear technology infrastructure. In May 1999, after careful consideration of the recommendations from the Nuclear Energy Research Advisory Committee and other analyses, the Secretary concluded that the facility could possibly serve a valuable science and research role. As such, the Secretary asked that a program plan be developed that clearly defines the potential use of the facility and the roles and responsibilities of potential users.

In July 1999, following a review of the program plan, the Nuclear Energy Research Advisory Committee voted 19 to 2, in favor of a resolution recommending DOE proceed toward a Record of Decision on the Fast Flux Test Facility. The committee further recommended that a nonproliferation policy review, cost evaluation, and mission assessment be conducted to inform the Record of Decision. The committee also recommended that a comprehensive research and development plan be prepared under its oversight and that the plan include the Fast Flux Test Facility.

Based on the program plan and the Nuclear Energy Research Advisory Committee recommendations, the Secretary announced on August 18, 1999, that the department would initiate a $\mathrm{N}$ ational Environmental Policy Act review of the environmental impacts associated with the restart and operation of the Fast Flux Test Facility as a nuclear research and medical isotope production facility. The results from the $\mathrm{N}$ ational Environmental Policy A ct review would inform a Record of Decision for the establishment of either a restart project or a deactivation project for the Fast Flux Test Facility. 


\subsubsection{The Decision Process}

DOE is preparing a programmatic environmental impact statement that will evaluate options for managing DOE's nuclear research infrastructure to meet projected national research and development needs. These needs include a reliable supply of isotopes and irradiation services for medicine, industry, research, and space exploration. DOE's nuclear facility infrastructure is diminishing while the demand for steady-state neutron sources continues to increase. Presently, DOE does not have sufficient neutron sources to meet its projected irradiation needs for medical isotope production, plutonium-238 production for future space exploration missions, and nuclear research and development. To address this neutron source deficiency, the programmatic environmental impact statement will evaluate a range of options including the use of existing operating facilities, the restart and operation of the Fast Flux Test
Facility, and the construction of entirely new facilities. The options to be analyzed also include making no changes to DOE's existing facilities and permanently deactivating the Fast Flux Test Facility. No preferred alternative will be identified in the draft programmatic environmental impact statement.

The programmatic environmental impact statement, scheduled for completion in November 2000, will be supported by a comprehensive research and development plan developed under the oversight of the Nuclear Energy Research Advisory Committee and nonproliferation and cost analyses. In December 2000, DOE plans to issue a Secretarial Record of Decision, which will be informed by the results from the programmatic environmental impact statement, nonproliferation and cost analyses, a Fast Flux Test Facility waste minimization and management plan, and Nuclear Energy Research Advisory Committee reviews.

\subsubsection{Advanced Reactors Transition Project}

The mission of this project is to transition or convert the Plutonium Recycle Test Reactor facility and other nuclear energy legacy facilities into structures that are in a safe and stable condition. Legacy facilities are those used as part of the former nuclear production and research projects conducted at the Hanford Site. The transition process includes minimum safe surveillance and maintenance activities. Deactivation of legacy facilities also includes the disposition of nonradioactive sodium and sodiumpotassium alloy.

At the Plutonium Recycle Test Reactor/ 309 Building, located in the 300 Area, the deteriorated exterior insulation and weather coating on the containment dome were removed in 1999. The dome was then re-coated with a polyurea material. The insulating and roofing materials removed were suspected of containing asbestos; however, only a minor amount was found. In total, the task generated $\sim 180$ cubic meters $(6,350$ cubic feet $)$ of demolition debris and 1.13 cubic meter ( 40 cubic feet) of asbestos waste.

During 1999, 570 kilograms (1,250 pounds) of metallic sodium, previously drained from retired test systems into 208-liter (55-gallon) drums, was shipped offsite. Also, 450 kilograms (1,000 pounds) of sodium-potassium alloy drained from a cooling system in 1998 was shipped offsite. Sodium residue removal operations via the water vapor-nitrogen process resumed. Three small tanks, ranging in size from 115 liters ( 30 gallons) to 1,150 liters ( 300 gallons) were cleaned or in the process of being cleaned in 1999. Concentrated sodium hydroxide produced during the cleaning process is shipped to the 300 Area Treated Effluent Disposal Facility for their use. Rinse water with $\mathrm{pH}$ less than 11 is sent through the process sewer line to the 300 Area Treated Effluent Disposal Facility. 


\subsubsection{Office of River Protection}

Congress established the Office of River Protection in 1998 as a DOE Field Office reporting directly to the DOE Assistant Secretary for Environmental Management. The Office of River Protection is responsible for managing DOE's River Protection Project to store, retrieve, treat, and dispose of high-level tank waste from the Hanford Site.

\subsubsection{Waste Tank Status}

The status of the 177 waste tanks as of December 1999 was reported in HNF-EP-0182-141. This report is published monthly; the December report provided the following information:

- number of waste tanks

- 149 single-shell tanks

- 28 double-shell tanks

- number of tanks assumed to have leaked

- 67 single-shell tanks

- O double-shell tanks

- chronology of single-shell tank leaks

- 1956: first tank reported as suspected of leaking (tank 241-U-104)

- 1973: largest estimated leak reported (tank 241-T-106; 435,000 liters [115,000 gallons])

- 1988: tanks 241-AX-102, -C-201, -C-202, -C-204, and -SX-104 confirmed as having leaked

- 1992: latest tank (241-T-101) added to list of tanks assumed to have leaked, bringing total to 67 single-shell tanks

- 1994: tank 241-T-111 was declared to have leaked again

- number of ferrocyanide tanks on the watch list

- O (the ferrocyanide issue was closed in 1996)
- number of flammable gas tanks on the watch list

- 19 single-shell tanks

- 6 double-shell tanks

- number of organic tanks on the watch list

- 2 single-shell tanks (18 tanks were removed from the watch list in December 1998)

- number of high-heat tanks on the watch list

- 0 (one single-shell tank was removed from the watch list in December 1999).

So far, 120 single-shell tanks have been stabilized; the tank stabilization program is scheduled to be completed in 2004. At the end of 1999, 108 single-shell tanks had intrusion prevention devices completed, and 51 single-shell tanks were disconnected from the piping system and capped to avoid inadvertent liquid additions to the tanks.

The total estimated volume to date of radioactive waste leakage from single-shell tanks is $2,300,000$ to $3,400,000$ liters $(600,000$ to 900,000 gallons).

During 1999, waste was pumped from ten single-shell tanks to the double-shell tank system. Portions of waste in tanks 241-SX-104, SX-106, T-104, T-110, S-102, S-103, S-106, U-103, and U-109 (all in the 200-West Area) were removed, and the majority of waste in tank 241-C-106 (in 200-East Area) was removed.

\subsubsection{Waste Tank Safety Issues}

The Waste Tank Safety Program was established in 1990 as the focal point for identification and resolution of safety issues involving high-priority waste tanks. The tasks to resolve safety issues are 
planned and implemented in the following logic sequence: 1) evaluate and define the associated safety issue, 2) identify and close any associated unreviewed safety questions, 3) mitigate any hazardous conditions to ensure safe storage of the waste, 4) monitor waste storage conditions, and 5) resolve the respective safety issues. Each of these steps has supporting tasks of some combination of monitoring, mathematical analyses, laboratory studies, and in-tank sampling or testing. The path followed depends on whether the waste requires treatment or can be stored safely by implementing strict controls.

The Safety Issue Resolution Project focuses on resolution of safety issues involving flammable gas, organic, high-heat, and criticality as described below. The tanks of concern are placed on a watch list and categorized by safety issue. By 1996, all 24 ferrocyanide tanks had been removed from the watch list, and the issue was deemed resolved by DOE and the Defense Nuclear Facilities Safety Board. In 1998, 18 tanks containing organic contaminants were removed from the watch list, leaving the 2 tanks containing organic solvent on the list. During 1999, the high-heat tank was removed from the watch list. At the end of 1999, there were 27 tanks remaining on the watch list: 25 tanks containing flammable gas and 2 tanks containing organic solvents. These tanks were identified in accordance with the $D$ efenseA uthorization A ct, Section 3137, "Safety Measures for Waste Tanks at Hanford Nuclear Reservation” (1990).

\subsubsection{Watch List Tanks}

In early 1991, all Hanford Site high-level waste tanks were evaluated and organized into categories to ensure increased attention and monitoring. Other safety concerns, including the possibility of nuclear criticality in a waste tank, have been addressed.

Flammable Gas. The flammable gas safety issue involves the generation, retention, and potential release of flammable gases by tank waste. Twentyfive tanks have been identified and placed on the watch list. In prior years, work controls were instituted to prevent introduction of spark sources into these tanks, and evaluations were completed to ensure that installed equipment was intrinsically safe.

Conditions within tank 241-SY-101 changed in 1997, which led to a continuous rise in the waste level. In February 1998, the DOE Richland Operations Office declared an unreviewed safety question related to the waste surface level changes. The responsible contractor formed a project team to remediate the waste level rise and a project plan was issued (HNF-3824). During 1999, the increasing level of waste in tank 241-SY-101 was stopped through the transfer and dilution of the waste in this tank. Additional discussion on this issue can be found in Section 2.3.13.3, "Saltcake Dissolution."

Hydrogen monitors were installed on all 25 tanks on the flammable gas watch list; in addition, another 17 monitors were installed to gather more data on a variety of tanks and operations. These systems continuously monitor for hydrogen and have the capability to obtain grab samples for additional analyses.

The Tri-Party Agreement milestone for resolution of the safety issues surrounding tanks containing flammable gas is scheduled for September 2001.

High-Heat Tank. This safety issue was resolved in December 1999, based on the transfer of the majority of the waste in tank 241-C-106 to tank 241-AY-102. This safety issue concerned tank 241-C-106, a single-shell tank in the 200-East Area that required water additions and forced ventilation for evaporative cooling. The retrieval and transfer of 712,000 liters (188,000 gallons) of 241-C-106 waste was completed in 1999. In December 1999, DOE-Headquarters approved the closure of the highheat issue for tank 241-C-106, and removed it from the high-heat watch list.

Organic T anks. This safety issue involves the potential for uncontrolled exothermic reactions of 
organic complexants and organic solvents present in some of the tanks. DOE identified 20 singleshell tanks for the organic watch list between 1991 and 1994. In 1998, DOE closed the organic complexant safety issue and removed 18 tanks containing organic complexant from the watch list.

The two remaining tanks on the organic watch list contain organic solvents. DOE is expected to resolve safety issues concerning these tanks per the Tri-Party Agreement milestone scheduled for September 2001.

Criticality. DOE closed the safety question regarding the potential for criticality in the highlevel waste tanks in 1999. Additional analyses, stronger tank criticality prevention controls, and improved administrative procedures and training (WHC-SD-WM-SARR-003) provided the technical basis to resolve the safety issue and satisfy the related Tri Party Agreement milestone.

\subsubsection{Vadose Zone Characterization Near Single- Shell Underground Waste Storage Tanks}

Since 1995, the DOE Grand Junction Office has performed baseline spectral gamma borehole logging characterization of the vadose zone around the single-shell underground waste storage tanks at the Hanford Site. This characterization work is done in part to comply with RCRA requirements to identify contamination sources and to determine the nature and extent of the contamination from the single-shell tanks. The work also will assist with RCRA closure of the tanks.

The logging operations for the baseline characterization began in 1995 and were completed in early 1999. During 1999, boreholes surrounding tanks in the T and B tank farms, in the 200-West and 200-East Areas, respectively, were logged. The details of this work are discussed in Section 6.2.1.2, "Tank Farms Baseline Vadose Zone Characterization Project."
Preparation of tank summary data reports began in 1995. During 1999, the remaining 16 tank summary data reports for tanks in the $B$ and $T$ tank farms (200-East and 200-West Areas, respectively) were prepared using data acquired from boreholes logged between 1996 and 1998 (e.g., GJ-HAN-106). During 1999, a report for the A tank farm was issued. Other reports were in various stages of preparation.

During 1999, logging was repeated at selected intervals in boreholes at all 12 single-shell tank farms. A new high rate logging system was developed and used to characterize zones of high gamma flux where the older spectral gamma logging system had been ineffective. The new system provided useful data in zones with concentrations on the order of $50,000,000 \mathrm{pCi} / \mathrm{g}$. With the completion of the final tank farm report in 2000, the baseline characterization project will begin to analyze high count rate and repeated data. These data will be combined with the results of shape factor analysis and used to modify the data required for three-dimensional visualizations. Revised visualizations will be prepared and published in addenda to the original tank farm reports.

The baseline characterization work completed in 1999 identified several areas where additional work is required to broaden knowledge of contamination conditions in the tank farm vadose zone. See Section 6.2.1.2, "Tank Farms Baseline Vadose Zone Characterization Project," for additional details regarding specific tank farms and for references to detailed reports.

\subsubsection{Waste Immobilization}

Approximately 204 million liters (54 million gallons) of radioactive and hazardous wastes, accumulated from more than 40 years of plutonium production operations, are stored in 149 underground single-shell tanks and 28 underground double-shell tanks. The River Protection Program is currently upgrading facilities to deliver waste to the planned treatment facility. Treatment will separate the 
wastes into a low-radioactivity fraction and a highradioactivity and transuranic fraction. Both fractions will be vitrified in a process that will destroy or extract organic constituents, neutralize or deactivate dangerous wastes, and immobilize toxic metals. The immobilized low-radioactivity fraction will be disposed of in a facility on the Hanford Site. The immobilized high-radioactivity fraction will be stored onsite until a geologic repository is available offsite for permanent disposal. Tri-Party Agreement milestones specify December 2028 for completion of pretreatment and immobilization of the tank wastes.

At this time, work continues on the design and permitting of the vitrification plant. DOE is seeking a new contractor to complete the design and construction of the plant and is attempting to maintain the agreed upon schedule.

\subsubsection{Solid Waste Management}

Solid waste may be from work on the Hanford Site or may be from sources offsite that are authorized by DOE to ship waste to the site. Treatment, storage, and disposal of solid waste takes place at a number of locations on the Hanford Site. Information about specific locations is contained in the following sections.

\subsubsection{Central Waste Complex}

Solid waste is received at the Central Waste Complex in the 200-West Area (see Figure 1.0.2) from sources of radioactive waste at the Hanford Site and any sources offsite that are authorized by DOE to ship waste to the Hanford Site for treatment, storage, and disposal. Ongoing cleanup and research and development activities on the Hanford Site, as well as remediation activities, generate the waste received at the Central Waste Complex. Offsite waste has been primarily from DOE research facilities, other DOE sites, and Department of Defense facilities. The characteristics of the waste received vary greatly, from low-level, transuranic, mixed waste, and radioactively contaminated polychlorinated biphenyls.

The planned capacity of the Central Waste Complex to store low-level mixed waste and transuranic waste is 15,540 cubic meters $(20,330$ cubic yards). This capacity is adequate to store the projected volumes of low-level, transuranic, mixed waste, and radioactively contaminated polychlorinated biphenyls to be generated, assuming on-schedule treatment of the stored waste. Treatment of mixed waste began in December 1999. Treatment will reduce the amount of waste in storage and make room for newly generated mixed waste. The dangerous waste designation of each container of waste is determined at its point of generation based on process knowledge of the waste placed in the container or on sample analysis if sufficient process knowledge is unavailable.

\subsubsection{Waste Receiving and Processing Facility}

During 1994, construction was started on the first major solid waste processing facility associated with cleanup of the Hanford Site. Having started operation in March 1997, the Waste Receiving and Processing Facility is staffed to analyze, characterize, and prepare drums and boxes of wastes for disposal. The 4,800-square meter (52,000-square foot) facility is near the Central Waste Complex in the 200-West Area (see Figure 1.0.2). The facility is designed to process $\sim 6,800$ drums and 70 boxes of waste annually for 30 years.

Waste destined for the Waste Receiving and Processing Facility include Hanford's legacy waste as well as newly generated waste from current and future site cleanup activities. The waste consists primarily of clothing, gloves, face masks, and small 
tools suspected of being contaminated with plutonium. Waste containers might also contain other radioactive materials and hazardous components. Processed waste that qualifies as low-level waste and meets disposal requirements will be buried directly at the Hanford Site. Low-level waste not meeting burial requirements will be treated in the facility until it meets the requirements or will be prepared for future treatment at other onsite or offsite treatment, storage, and disposal facilities. Waste designated at the facility to be transuranic will be certified and packaged for shipment to the Waste Isolation Pilot Plant in Carlsbad, New Mexico for permanent storage. Materials that require further processing to meet disposal criteria will be retained at the Hanford Site, pending treatment.

\subsubsection{Radioactive Mixed Waste Disposal Facilities}

The radioactive mixed waste disposal facilities at the Hanford Site are the first in DOE's complex for the disposal of radioactive mixed wastes. These facilities are located in the 218-W-5 low-level waste burial ground in the 200-West Area and are designated as trenches 31 and 34 . Trench 34 began to operate in the disposal mode during September 1999. Prior to this, trenches 31 and 34 were operating in the storage mode. Trench 31 will continue to operate in the storage mode when needed to accommodate large items awaiting disposal into trench 34 . Currently, no waste is stored in trench 31 . The trenches are rectangular landfills, with approximate base dimensions of 76 by 30 meters ( 250 by 100 feet). The bottoms of the excavations slope slightly, giving a variable depth of 9 to 12 meters (30 to 40 feet).

These trenches comply with RCRA requirements by having double liners and leachate collection and removal systems. The bottom and sides of the facilities are covered with a layer of soil (1 meter [ 3 feet]) to protect the liner system during fill operations. There is a recessed section at the end of each excavation that houses a sump for leachate collection. Access to the bottom of each trench is provided by ramps along the perimeter walls.

\subsubsection{T Plant Complex}

The function of the T Plant complex in the 200-West Area (see Figure 1.0.2) is to provide waste treatment and storage and decontamination services for the Hanford Site. The T Plant complex currently operates under interim status. T Plant complex waste handling activities in 1999 included the following:

- performing content verification of wastes being shipped to solid waste facilities for storage or disposal

- repackaging and/or sampling waste to meet solid waste acceptance criteria or to determine acceptability of waste for treatment

- treating dangerous and mixed wastes to meet RCRA requirements for land disposal

- decontaminating equipment to allow for reuse or disposal as waste

- storing 27 metric tons (30 tons) of spent reactor fuel (from Shippingport, Pennsylvania) in a water basin.

\subsubsection{Radioactive Mixed Waste Treatment and Disposal}

During 1999, 26 cubic meters ( 34 cubic yards) of DOE mixed waste were treated and/or disposed of. The waste materials were obtained from a number of projects and included the following:

- 25 cubic meters ( 120 - 55-gallon drums) of soil originating from various single-shell and double-shell tank farms at the Hanford Site were disposed into the low-level burial grounds. It was determined that the soil did not contain hazardous constituents (i.e., a "Contained-In" 
determination), which was subsequently approved by the Washington State Department of Ecology.

- 1 cubic meter (5 - 55-gallon drums) of mixed low-level waste was disposed into the Radioactive Mixed Waste Disposal facility (Trench 218-W-34). Waste was designated with StateOnly waste codes and met the disposal requirements specified in the Hanford Site Solid Waste Acceptance Criteria.

\subsubsection{Radioactive Mixed Waste Treatment Contracts}

In November 1995, DOE awarded a contract to Allied Technology Group, Inc., Richland, Washington, for thermal treatment of Hanford's mixed waste in accordance with RCRA and the T oxic Substances Control A ct. The contract provides for treating up to 5,135 cubic meters ( 6,715 cubic yards) of mixed waste over 5 years with five 1 -year renewal options. Waste processing is scheduled to begin in fiscal year 2001 .

During 1997, a competitive procurement was conducted for the processing of mixed waste requiring nonthermal treatment in accordance with RCRA. The resulting contract provides for treatment of up to 1,860 cubic meters (2,432 cubic yards) of waste. The contract, which was also awarded to
Allied Technology Group, Inc., has a 1-year base period (fiscal year 2000) with two extension options (for fiscal years 2000-2001 and 2001-2002, respectively). During 1999, Allied Technology Group, Inc. was granted their RCRA/T oxic Substance C ontrol Act operating permit from Washington State Department of Ecology/EPA. Construction on their treatment facility began in July 1999, and treatment was initiated on December 22, 1999.

\subsubsection{Navy Reactor Compartments}

Nine disposal packages containing defueled United States Navy reactor compartments were received and placed in Trench 94 in the 200-East Area during 1999. Three reactor compartments were from submarines and six were from cruisers. This brings the total number of reactor compartments received to 86. All reactor compartments shipped to the Hanford Site for disposal have originated from decommissioned nuclear-powered submarines or cruisers.

Washington State Department of Ecology regulates the disposal of reactor compartments as dangerous waste because lead is used as shielding. The reactor compartments are also managed as mixed waste because of their radioactivity.

\subsubsection{Liquid Effluent Treatment}

Hazardous and radioactive liquid waste is no longer discharged directly to the environment at the Hanford Site. Liquid effluents are managed in treatment, storage, and disposal facilities in compliance with RCRA and state regulations.

\subsubsection{242-A Evaporator}

Available storage space to support remediation of tank waste and cleanup of the Hanford Site is limited in the double-shell tanks. The 242-A Evaporator in the 200-East Area (see Figure 1.0.2) processes double-shell tank waste into a concentrate (that is returned to the tanks) and a process condensate stream. One campaign was conducted at the 242-A evaporator in 1999. The run treated 3.83 million liters $(1,012,000$ gallons) of tank waste to produce 3.56 million liters $(940,000$ gallons) of aqueous waste that were sent to the Liquid Effluent Retention Facility (discussed in Section 2.3.9.2). One 242-A evaporator campaign is planned for 2000 , and two campaigns are planned for 2001.

Effluent treatment and disposal capabilities are available to support the continued operation of the 
242-A evaporator. The 200 Area Effluent Treatment Facility near the 200-East Area was constructed to treat the process condensate. Process condensate is temporarily stored in the Liquid Effluent Retention Facility while awaiting treatment in the 200 Areas Effluent Treatment Facility. Cooling water and nonradioactive steam condensate from the evaporator are discharged to the 200 Areas Treated Effluent Disposal Facility.

\subsubsection{Liquid Effluent Retention Facility}

This facility consists of three RCRA-compliant surface impoundments for storing and treating process condensate from the 242-A evaporator and other aqueous wastes. The facility treats waste by equalizing the flow and adjusting the $\mathrm{pH}$ of the feed to the 200 Areas Effluent Treatment Facility. The maximum capacity of the Liquid Effluent Retention Facility is 89 million liters (23.4 million gallons). The basins are constructed of two, flexible, highdensity, polyethylene membrane liners. A system is provided to detect, collect, and remove leachate from between the primary and secondary liners. Beneath the secondary liner is a soil/bentonite barrier should the primary and secondary liners fail. Each basin has a mechanically tensioned floating membrane cover constructed of very low-density polyethylene to keep out unwanted material and to minimize evaporation of the basin contents. The facility began operation in April 1994 and receives aqueous waste from both RCRA- and CERCLAregulated cleanup activities. Approximately $38.8 \mathrm{mil}$ lion liters (10.3 million gallons) of aqueous waste were stored in the basins at the end of 1999 .

\subsubsection{200 Areas Effluent Treatment Facility}

This facility provides treatment and storage for hazardous and radioactive aqueous waste. The treated effluent is stored in verification tanks, sampled and analyzed, and discharged to the 616-A crib (also called the State-Approved Land Disposal Site). The treatment process constitutes best available technology, and includes $\mathrm{pH}$ adjustment, filtration, ultraviolet light/peroxide destruction of organic compounds, reverse osmosis to remove dissolved solids, and ion exchange to remove the last traces of contaminants. The facility began operation in December 1995. Treatment capacity of the facility is 570 liters per minute ( 150 gallons per minute). Approximately 81.5 million liters (21.5 million gallons) of aqueous waste were treated in 1999.

The treated effluent is sampled to verify that the radioactive and hazardous waste constituents have been reduced to regulatory levels; then discharged via a dedicated pipeline to the State-Approved Land Disposal Site. The disposal site is located north of the 200-West Area and is an underground drain field. The percolation rates for the field have been established by site testing and evaluation of soil characteristics. Tritium in the liquid effluent cannot be practically removed, and the location of the disposal site maximizes the time for migration to the Columbia River to allow for radioactive decay. The disposal site is permitted under WAC 173-216. The discharge permit requires monitoring of the groundwater and the treated effluent to ensure that levels for certain constituents are not exceeded. Constituent level limits were not exceeded in 1999. The discharge permit for the 200 Areas Effluent Treatment Facility is scheduled to be renewed in 2000.

Secondary waste from treating aqueous waste is concentrated, dried, and packaged in 208-liter (55-gallon) drums. The secondary waste from treating regulated aqueous waste is transferred to the Central Waste Complex for subsequent treatment (if needed to meet land disposal restriction treatment standards) and disposal in the radioactive mixed waste disposal facility, Trench 34 , in the 200-West Area. The secondary waste from treating CERCLA-regulated aqueous waste is disposed of in the Environmental Restoration Disposal Facility near the 200-West Area. 


\subsubsection{200 Areas Treated Effluent Disposal Facility}

This disposal facility is a collection and disposal system for non-RCRA-permitted waste that has been treated using "best available technology/ all known and reasonable treatment." Implementation of regulatory "best available technology/all known and reasonable treatment" is the responsibility of the generating facilities. There are 14 waste generating facilities in the 200 Areas that send waste to the 200 Areas Treated Effluent Disposal Facility (see Figure 1.0.2).
This facility began operation in April 1995 and has a capacity of 12,900 liters per minute $(3,400$ gallons per minute). Approximately 534 million liters (141 million gallons) of effluent were discharged in 1999. The effluent is discharged to two 2-hectare (5-acre) disposal ponds located east of the 200-East Area. The discharge permit requires monitoring of the effluent and the groundwater to ensure that concentrations for certain constituents are not exceeded. The discharge permit for the 200 Areas Treated Effluent Disposal Facility is scheduled to be renewed in 2000.

\subsubsection{Revegetation and Mitigation Planning}

Bechtel Hanford, Inc. planted 77 hectares (190 acres) of sagebrush in several small areas on the Fitzner/Eberhardt Arid Lands Ecology Reserve to mitigate the effects from construction of Cells 3 and 4 of the Environmental Restoration Disposal Facility in 1998. Representative plots of each area were selected and sagebrush survival was estimated. Low survival was noted at two of the plots. In December 1999, an additional 250 sagebrush seedlings were planted to compensate for the low survival rates.

In 1997, bitterbrush plants were salvaged from the perimeter of the 618-4 burial ground (600 Area) and transplanted to the area surrounding the burial ground. An additional 293 container grown sagebrush seedlings were planted adjacent to the bitterbrush to make up for the loss of mature shrubs during remediation of the burial ground. Examination of the plantings showed that all the bitterbrush and $46 \%$ of the planted sagebrush died. In November 1999, the dead sagebrush plants were replaced with new sagebrush seedlings. In addition to planting 126 sagebrush seedlings, 50 bitterbrush seedlings were planted east of the 618-4 burial ground. All bitterbrush plants were protected with biodegradable plastic mesh tubes that were staked into the ground to prevent browsing by deer.

A second bat gate was installed at the DR Reactor building allowing access to both noncontaminated process water tunnels. These tunnels provide habitat for a Washington State protected bat species that has been living in the reactor building (Washington State Department of Fish and Wildlife 1996). The bat gates were constructed to allow bats into the tunnels while preventing human intrusion. An existing structure at the DR Reactor building was used to preserve an important maternity roost that bats have used for many years.

Revegetation of 100-B,Cliquid effluent disposal sites 116-C-5, 116-B-1, and 116-B-11 was completed as part of the CERCLA Remedial Action Project for the 100-B,C Area. The remediated sites, 5.27 hectares (13 acres) were replanted with Sandberg's bluegrass, needle-and-thread grass, sagebrush, snow buckwheat, Carey's Balsamroot, yarrow, and small amounts of cushion fleabane and Piper's daisy. 


\subsubsection{Environmental Restoration Project}

In 1994, DOE selected an environmental restoration contractor to oversee the restoration of the Hanford Site. The Environmental Restoration Project includes characterization and remediation of contaminated soil and groundwater, decontamination and decommissioning of facilities, surveillance and maintenance of inactive waste sites, transition of facilities into the surveillance and maintenance program, and sitewide vadose zone/ groundwater integration.

\subsubsection{Environmental Restoration Disposal Facility}

The Environmental Restoration Disposal Facility is located near the 200-West Area (see Figure 1.0.2). The facility began operations in July of 1996 and was designed to serve as the central disposal site for contaminated waste removed during cleanup operations conducted underCERCLA on the Hanford Site. In order to provide a protective barrier, the 918,000 -cubic meter (1,200,000-cubic yard) earthen facility was constructed with double liners and a leachate collection system. In 1999, the Environmental Restoration Disposal Facility was expanded to provide additional storage space for contaminated materials from ongoing remediation work. The expansion more than doubled the capacity of the original two cells. Cleanup materials relocated to the facility include soil, rubble, or other materials (excluding liquids) contaminated with hazardous, low-level radioactive or mixed (combined hazardous chemical radioactive) wastes. As of early calendar year 2000, the facility had received $1,975,000$ metric tons $(2,177,000$ tons) of contaminated soil and other waste.

\subsubsection{Waste Site Remediation}

Full-scale remediation of waste sites began in the 100 Areas in 1996. Remediation continued through
1999 at several liquid waste disposal sites in the 100-B,C and 100-D/DR Areas. In March 1999, remediation work began in the 100-HR Area.

- In the 100-B,C Area, 51,700 metric tons (57,000 tons) of soil were removed in 1999 from 13 different waste sites. Through December $1999,621,100$ metric tons (685,000 tons) of contaminated soil have been removed and shipped to the Environmental Restoration Disposal Facility. Backfill activities were completed at five waste sites.

- In the 100-DR Area, 112,200 metric tons (124,000 tons) of soil were removed from 15 waste sites. The removal of effluent pipelines at 100-DR was the first significant removal of pipe at the reactors. Through December 1999, 549,000 metric tons $(610,000$ tons) of contaminated soil was removed and shipped to the Environmental Restoration Disposal Facility.

- In the 100-HR Area, 200,000 metric tons (224,000 tons) of soil were removed from the six waste sites and around effluent pipelines. The startup of remedial actions at 100-HR completed Tri-Party Agreement milestone M-16-26A.

Remediation work at the 300-FF-1 Operable Unit began in the 300 Area in 1997. Historically, both chemical and radiological materials were disposed of at the 300-FF-1 waste sites. In 1999, remediation operations excavated nearly 214,000 metric tons (236,000 tons) of contaminated soils and debris that were shipped to the Environmental Restoration Disposal Facility. Over 388,754 metric tons (428,000 tons) have been removed to date. Remediation (excavation) of the 316-2 North Process Pond (300 Area) was completed in 1999, remediation (excavation) continued in the 316-1 South Process Pond, and in December of 1999, remediation in 300 Area Landfills 1A (300-49) and 1B (300-50) was initiated. 
A Record of Decision (EPA 1999a) was issued for the 100 Areas remaining sites in 1999. It specified a cleanup remedy, remove/treat/dispose, for contaminated soil, structures, and debris at the remaining sites. The cleanup remedy is the method applied to 100 Areas Record of Decision sites and is consistent with cleanup actions that are currently being conducted within the 100 Areas.

The Record of Decision for remaining sites includes $\sim 300$ waste sites that were not previously addressed in the 1995100 Areas Record of Decision or the 1997 amendment to the 100 Areas Record of Decision (100 Areas solid waste burial sites and waste sites at 100-N Area also not included). Issuance of the remaining sites Record of Decision leaves only one outstanding 100 Areas Record of Decision for the solid waste burial sites, which is expected in 2000.

In 1999, DOE began design of remedial actions for the remaining sites. These actions are expected to be completed in 2000. A Record of Decision (EPA $1999 b$ ) for remediation of $\sim 80$ waste sites and groundwater at the 100-N Area was also issued in 1999. The Record of Decision specified remove/treat/dispose for remediation of the waste sites and continuation of pump-and-treat operations for remediation of groundwater. Design of remedial activities began for 100-N treatment, storage, and disposal units in 1999 in anticipation of a Record of Decision for the treatment, storage, and disposal units in 2000.

\subsubsection{Decommissioning Project}

Decontamination and decommissioning continued in 1999 in the 100-DR and 100-F Areas. During the year, ancillary facilities that supported the DR and $F$ reactors were removed and disposed. The activities support the interim safe storage of the reactor buildings. Other decontamination and decommissioning work was completed during the year that reduced the skyline in both $100-\mathrm{D} / \mathrm{DR}$ Areas and 100-F Area. A four-story laboratory (108-F) located near the $105-\mathrm{F}$ reactor was decontaminated and demolished. Two, 200-foot exhaust stacks were demolished by explosive demolition at the 100-D/DR Area. The stack rubble was packaged and shipped to the 200 Area Environmental Restoration Disposal Facility for final disposal. Decontamination and decommissioning work continued at the 233-S laboratory building located in the 200-West Area. The facility poses special challenges to workers and work methods due to high levels of radiation.

\subsubsection{Surveillance/ Maintenance and Transition Project}

This project performs surveillance and maintenance of inactive facilities until final disposition. The project also provides for the transition of facilities and waste sites into the Environmental Restoration Program after deactivation is complete. The project includes the Radiation Area Remedial Action Program, which is responsible for the surveillance, maintenance, and decontamination or stabilization of 837 inactive waste sites. These include cribs, ponds, ditches, trenches, unplanned release sites, and burial grounds. These sites are maintained by performing periodic surveillances, radiation surveys, and herbicide applications and by initiating timely responses to identified problems. The overall objective of this project is to maintain these sites in a safe and stable configuration until final remediation strategies are identified and implemented. The main focus of this objective is to prevent the contaminants contained in these sites from spreading in the environment. This project also analyzed the final status/ condition of the canyon facilities (i.e., large concrete structures formerly used in Hanford Site production missions) that the project currently oversees and those that are coming to the project through facility transition activities. The canyon disposition initiative is evaluating the potential to use the canyon facilities as waste disposal units, compared to standard decontamination and decommissioning of the facilities. The canyon disposition initiative has a potential to achieve a saving of $\$ 1$ billion compared to removal of the facilities. 


\subsubsection{Groundwater/Nadose Zone Integration Project}

The Groundwater/Vadose Zone Integration Project brings together all activities that effect Hanford's subsurface, and ultimately, the Columbia River. Many of these activities are part of multiple cleanup projects that report to different managers and contractors.

A focus of the Groundwater/Vadose Zone Integration Project involves preparation of a cumulative impact assessment of Hanford Site radioactive and hazardous contaminants that have, or may, affect the uses and users of the Columbia River. The project continues to work on the design of a system assessment capability to meet the needs identified in the $C$ olumbia River $C$ omprehensive I mpact $A$ ssessment Part II report (DOE/RL-96-16). To be successful, the project must

- adopt a sitewide approach to project planning, funding, and data and information management to support cleanup decisions

- ensure that management attention is maintained on the subsurface and river resources

- be recognized for technical and scientific excellence in all products

- establish and ensure effective two-way communication with diverse project participants.

\subsubsection{Groundwater Restoration}

Chromium. Groundwater contaminated with chromium underlies portions of the 100-D, 100-H, and 100-K Areas (the 100-HR-3 and 100-KR-4 Operable Units) and is of concern because of its potential to impact the Columbia River ecosystem. Low levels of chromium are toxic to aquatic organisms, particularly those that use the riverbed sediment as habitat (DOE/RL-94-102,DOE/RL-94-113). The relevant standard for protection of freshwater aquatic life is $10 \mathrm{mg} / \mathrm{L}$ of chromium (WAC
173-201A). Chromium concentrations exceeding $600 \mathrm{mg} / \mathrm{L}$ have been measured in the pore-water sediments of the Columbia River (BHI-00778). In 1994, a groundwater extraction system was installed in the 100-D Area to test chromium removal from groundwater using ion exchange technology. Following the approval of the record of decision in 1996 (EPA 1996), full-scale pump-and-treat systems were constructed in the 100-D, 100-H, and 100-K Areas. The objective of the pump-and-treat systems is to prevent chromium contamination in the groundwater from reaching the Columbia River.

In 1999, the total amount of water treated for the $100-\mathrm{D}$ and $100-\mathrm{H}$ pump-and-treat systems was 251 million liters (66.3 million gallons), with the removal of 20.4 kilograms (45.0 pounds) of chromium. To date, more than 652 million liters (172 million gallons) of groundwater have been treated, with 73 kilograms (160.9 pounds) of chromium removed (DOE/RL 2000-14, Rev. 0). Treated groundwater is reinjected into the aquifer upgradient from the $100-\mathrm{H}$ Area extraction wells since both sites use the same treatment system.

In 1999, the 100-KR pump-and-treat system treated 310 million liters (81.9 million gallons) of groundwater. During the process, 38.2 kilograms (84.2 pounds) of chromium were removed. Total chromium removed since operations began is 79 kilograms (174.2 pounds) through treatment of 611 million liters (161.4 million gallons) of water. Treated groundwater is reinjected into the aquifer upgradient from the 100-KR-4 extraction wells.

To further evaluate chromium and other groundwater contamination that might enter the Columbia River, 178 aquifer sample tubes were installed in 1997 along and parallel to the Columbia River shoreline. The distance between the sample tubes was $\sim 610$ meters (2,000 feet), except in known chromium plumes, where this was reduced to 
305 meters (1,000 feet). Sample tubes are constructed of 0.6 centimeter ( $0.25 \mathrm{inch}$ ) inner-diameter polyethylene tubing with a screen at the bottom that is placed anywhere from 0.9 to 9 meters ( 3 to 30 feet) below ground surface. Sample tube installations begin near the 100-B,C Area and continue downstream $\sim 40$ kilometers ( 25 miles) to near the Old Hanford Townsite.

In the fall of 1999, samples were collected from 29 sample tube locations. These samples were analyzed for chromium, nitrate, sulfate, tritium, strontium-90, total uranium, gross beta, and carbon14. The results are being used to characterize near Columbia River groundwater/river water in support of remediation operations, monitoring objectives, and other environmental programs. Sample tube data provide site specific information on the distribution of chromium that enters the river at locations near sensitive ecological receptors (e.g., salmon spawning areas).

Pore water and aquifer sample tube data collected in 1995 were instrumental in finding chromium contaminated groundwater at the 100-D Area where it previously was not identified (BHI-00778). A technology called In Situ Redox Manipulation was selected to remediate this high-concentration area beginning in fiscal year 2000. This technology using a chemical barrier was tested and successfully applied during a chromium treatability test in the 100-D Area from 1997 to 1999. The barrier will be constructed to intercept and neutralize chromium contaminated groundwater moving from the aquifer to the Columbia River. The current pump-and-treat systems will also continue to operate.

Strontium-90. The 100-NR-2 (N Springs) pump-and-treat system began operations in 1995 north of the N Reactor complex and was designed to reduce the flux of strontium-90 to the Columbia River. The pump-and-treat system operates extraction wells to maintain hydraulic capture. Groundwater is pumped into a treatment system to remove the strontium-90 contamination, with treated water reinjected upgradient into the aquifer. The system was upgraded in 1996 and has continued to operate through 1999. About 114 million liters (30.1 million gallons) were processed in fiscal year 1999. During that period, 0.2 curie of strontium were removed from the groundwater. Over 422.2 million liters (111.5 million gallons) have been processed since the system began operation, removing 0.7 curie of strontium.

Carbon T etrachloride. The carbon tetrachloride plume in the 200-West Area (underlying the 200-ZP-1 Operable Unit) covers over 11 square kilometers (4.2 square miles). The 200-ZP-1 pumpand-treat system has operated since 1997. In 1999, 339.9 million liters ( 89.8 million gallons) of groundwater were treated, removing over 1,287 kilograms (2,837 pounds) of carbon tetrachloride. A total of about 954.8 million liters (252.3 million gallons) have been processed since startup removing 3,386.5 kilograms (7,466 pounds) of carbon tetrachloride. An Innovative Technology Remediation Demonstration project was initiated in 1999 to evaluate ways to accelerate and enhance the removal of carbon tetrachloride, and to identify characterization tools that could be used to define the full extent of the plume beneath the ground surface.

U ranium, Technetium-99, Carbon T etrachloride, and $\mathbf{N}$ itrates. Treatment of the groundwater plume underlying the 200-UP-1 Operable Unit in the 200-West Area continued throughout 1999. The contaminant plume contains uranium, technetium-99, carbon tetrachloride, and nitrate. A pump-and-treat system has operated since 1994 to contain the high concentration area of the uranium and technetium-99 plume. During early operations, groundwater was treated using ionexchange resin to remove the uranium and technetium-99, and granular activated carbon to remove carbon tetrachloride. Since 1997, contaminated groundwater is transported to Basins 43 at the 200 Areas Effluent Treatment Facility. Sophisticated treatment technology removes all four contaminants. 
Treated groundwater is then discharged north of the 200-West Area at the State-Approved Land Disposal Site.

The pump-and-treat system operated continually during the year, except for a period of shutdown in December 1999 because of concerns about possible computer problems at the beginning of 2000 . The single extraction well was used to pump 93.5 million liters (24.7 million gallons) of groundwater, which were treated to remove 7.8 grams (0.0172 pound) of technetium-99, 20.7 kilograms (45.6 pounds) of uranium, 2.0 kilograms (4.4 pounds) of carbon tetrachloride, and 4,859 kilograms $(10,712$ pounds) of nitrate. The pump-and-treat operation made significant progress toward reducing technetium-99 concentrations to below required cleanup concentration levels, but less progress was made with uranium (DOE/RL-99-79).

\subsubsection{Vadose Zone Remediation}

Soil vapor extraction systems designed to remove carbon tetrachloride vapor from the vadose zone beneath the 200-West Area began operating in 1992 and continued through 1999 . Soil vapor extraction has been conducted in the vicinity of three historical carbon tetrachloride disposal sites: the 216-Z 1A tile field, the 216-Z-9 trench, and the 216-Z-18 crib. Soil vapor is pumped through granular activated carbon, which absorbs carbon tetrachloride. The granular activated carbon is then shipped offsite for treatment. Since 1993, carbon tetrachloride concentrations have been monitored using infrared photoacoustic spectrometers at soil vapor extraction inlets, vent stacks, individual wells, and soil vapor probes.

The magnitude and rate of carbon tetrachloride rebound (i.e., a buildup of carbon tetrachloride vapor in the soil following cessation of extraction activities) was studied in 1997. Data indicated that carbon tetrachloride concentrations increased when a shutdown period followed continuous extraction operations. This resulted in a modification to the operating strategy at the three extraction sites. The modification was to operate only the 14.2 -cubic meters per minute (500-cubic feet per minute) flow rate system. The 28.3- and 42.5-cubic meters per minute (1,000- and 1,500-cubic feet per minute) flow rate systems were placed on standby. The 14.2-cubic meters per minute (500-cubic feet per minute ) flow rate system is now moved periodically among the well fields extracting vapor from beneath the 216-Z-1A tile field, 216-Z-9 trench, 216-Z-12 crib, and 216-Z-18 crib. The system was shutdown for 6 months in 1999 to let carbon tetrachloride concentrations at the extraction sites rebound. In 1999, the soil vapor extraction system removed 827 kilograms (1,823 pounds) of carbon tetrachloride from the vadose zone in the 200-West Area. Since operations began, soil vapor extraction has removed 76,460 kilograms (168,560 pounds) of carbon tetrachloride from the vadose zone.

\subsubsection{Vadose Zone Characterization in the 200 Areas}

In 1999, characterization data were collected at 2 of the 23 operable units located within the 200 Areas. This was the first characterization to be conducted for the process-based waste site operable units defined in the 200 Areas Remedial Investigation/Feasibility Study Implementation Plan (DOE/RL-98-28).

200-CS-1 O perable U nit. A characterization borehole (B8817) was drilled to the groundwater near the former 216-S-10 pond and ditch, 200-West Area, during late November and early December 1999. The borehole was completed as a RCRA groundwater monitoring well (299-W26-13) as part of an integration effort with the RCRA Groundwater Monitoring Program. The pond is one of four representative sites for which data will be collected as specified in the 200-CS-1 Operable Unit Remedial Investigation/Feasibility Study Work Plan andRCRA 
Treatment, Storage, and Disposal Unit Sampling Plan (DOE/RL-99-44). The borehole was drilled to obtain characterization information to support the remedial investigation and feasibility study for the operable unit. The former 216-S-10 pond and ditch routinely received large quantities of nondangerous, low-level radioactive liquid effluent from the Reduction-Oxidation facility chemical sewer and the Chemical Engineering Laboratory within the Reduction-Oxidation Plant.

A total of ten vadose zone soil samples including three quality control samples were collected and analyzed for various radionuclides, metals, inorganic compounds, volatile organic compounds, semivolatile organic compounds, polychlorinated biphenyls, and diesel. In addition, three soil physical property samples were collected (one within each of the three geological units) and analyzed for moisture content, particle size distribution, and bulk density. Geophysical surveys of the borehole B8817 included both spectral gamma logging and neutron-neutron logging. The data collected will be reported in a borehole summary report scheduled for completion in 2000.

200-CW-1 O perable U nit. A characterization borehole (B8758) was drilled in the former 216-B-3 main pond in the 200-East Area. The borehole was drilled to groundwater to support vadose zone sample collection for the 200-CW-1 Operable Unit remedial investigation/feasibility study process. Drilling continued on the borehole and it was ultimately completed as a RCRA groundwater monitoring well
(299-43-44) as part of an integration effort with the RCRA Groundwater Monitoring Program. A characterization borehole (B8757) was drilled in the former 216-A-25 Gable Mountain Pond near the 200-East Area. The borehole was drilled to 11 meters (37 feet) below the ground surface, several feet into the basalt at that location. Soil samples were collected and the borehole was backfilled. Geophysical surveys of both boreholes were conducted using spectral gamma and neutron-neutron logging tools. Physical property samples were collected from the boreholes.

A total of 29 test pits, used to collect soil samples at various depths below the surface, were constructed at four representative sites within the operable unit. Sixteen test pits were constructed at the former 216-A-25 Gable Mountain Pond; five at the former 216-B-3 main pond; five at the 216-B-3-3 ditch; and three at the former 216-B-2-2 ditch. Soil samples were collected from the pond or ditch bottom to a maximum of 8 meters ( 25 feet) below ground surface in each of the test pits. A total of 203 characterization samples were collected from the representative sites and analyzed for varying constituents including radionuclides, metals, inorganic compounds, volatile organic compounds, semivolatile organic compounds, polychlorinated biphenyls, and diesel fuel.

The data collected will be reported in a borehole and test pit summary report and a remedial investigation report for the operable unit; both reports are scheduled to be completed in 2000 .

\subsubsection{Research and Technology Development}

In 1994, the Tanks Focus Area was created by DOE's Office of Environmental Management to integrate tank waste remediation across the DOE complex. The Tanks Focus Area leverages resources from other DOE programs, industry, and university partners to deliver technical solutions to five DOE sites: Idaho National Engineering and Environmental Laboratory; Hanford Site, Oak Ridge
Reservation, Savannah River Site, and the West Valley Demonstration Project.

In support of DOE's newly formed Office of River Protection and its River Protection Project (previously known as the Tank Waste Remediation System under the auspices of DOE's Richland Operations Office), the Tanks Focus Area addressed a 
number of high priority issues in 1999. Many of these activities contribute to improved tank farm operations at the Hanford Site, while others directly support future waste retrieval, treatment, and tank closure.

\subsubsection{Corrosion Control}

Since 1993, the Tanks Focus Area has assisted the Hanford Site in developing and deploying electrochemical noise corrosion probes to guard against tank wall corrosion and reduce waste volumes requiring downstream processing. Each new probe (four are now installed) improved upon the previous version. In 1999, the latest "multi-function" corrosion probe, including a complete electronics package, was successfully tested and delivered to the tank farms for installation in double-shell tank 241-AN105. Information gathered by the probes will be integrated in a central monitoring station for realtime comparative data analysis. Replacement of current chemistry monitoring techniques with corrosion monitoring equipment is being considered.

\subsubsection{Technical}

\section{Alternatives for Hanford Tank Waste Privatization}

A team of national experts was convened to identify technical improvements and alternative processes for the Hanford Site high-level waste treatment program. Specifically, the team evaluated the technical risks and identified technical alternatives for the high-risk portions of current Hanford Site tank waste treatment. The team was also asked to recommend preferred technical alternatives and a prioritized list of new work required to implement the alternatives. The results of this evaluation were published in a report, "Technical Alternatives to Reduce Risk in the Hanford Tank Waste Remediation System Phase I Privatization Project" (DOE/EM-0493).

\subsubsection{Saltcake Dissolution}

Possible mitigation measures for the saltcake crust growth in tank 241-SY-101 was investigated by running the Environmental Simulation Program model. Results of these scenarios were presented at a workshop to investigate and evaluate various options for mitigating and remediating the crust layer in waste tanks. The final recommendation for transferring waste from tank 241-SY-101 to tank 241-SY-102 was a four-step process, with decision points following each step to assess the success of the previous step.

The transfer and dilution strategy proved successful. In December 1999 and January 2000, tank farm operations staff transferred approximately $1,200,000$ liters (317,000 gallons) of original waste from tank 241-SY-101. After the waste transfers were completed, the addition of dilution water to tank 241-SY-101 began. In-tank cameras and level detectors indicated no further evidence of the troublesome thick saltcake layer. The Office of River Protection plans to continue with transfers and water dilutions to ensure that the waste will not revert to crust growth and gas retention.

\subsubsection{Recommendations on Operating Regimes for Cross-Site Pipeline Transfers}

A new cross-site transfer line was constructed at the Hanford Site to manage the volume of tank farm waste and the future delivery of waste to a treatment facility. Previous waste transfer operations have experienced problems with pipeline blockage. In preparation for use of the new transfer line, viscosity tests were performed to determine the key chemicals that can interfere with waste transfer. The tests indicated that phosphate concentration, ionic strength, and temperature must be controlled to prevent chemical plugs during waste transfers. Further experiments are under way to determine safe transfer conditions based on these results. 


\subsubsection{Feasibility Testing for the Fluidic Sampler}

A new sampling system that uses power fluidics technology to collect and transfer tank waste samples is being designed and tested. Consistent with RCRA sampling requirements, the modified sample collection method uses an upright (as opposed to inverted) sample bottle with a septum and a needle, thereby achieving the RCRA-required zero headspace in the bottle. In 1999, Phase I feasibility tests were successfully conducted on the new sampler to 1) demonstrate that representative samples could be obtained, 2) optimize the process to minimize bottle-filling time, and 3) demonstrate recovery from a plugged condition. 


\title{
2.4 Environmental Occurrences
}

\author{
G. W. Patton
}

Onsite and offsite environmental releases of radioactive and regulated materials are reported to DOE and other federal and state agencies as required by law. The specific agencies notified depend on the type, amount, and location of the individual occurrences. In some cases, an occurrence may be under continuing observation and evaluation. All emergency, unusual, and off-normal occurrences at the Hanford Site are reported to the Hanford Site Occurrence Notification Center. This center is responsible for maintaining both a computer database and a hard-copy file of event descriptions and corrective actions. Copies of occurrence reports are made available for public review in the DOE's Hanford Reading Room located in the Consolidated Information Center on the campus of Washington State University at Tri-Cities, Richland, Washington. The following sections summarize some of the emergency and off-normal environmental occurrences not previously discussed or that were not discussed in detail. For each occurrence, the title and report number from the Hanford Site Occurrence Notification Center is given in the heading.

\subsubsection{Emergency Occurrences}

As defined in DOE Order 232.1A, emergency occurrences "are the most serious occurrences and require an increased alert status for onsite personnel and, in specified cases, for offsite authorities." There were no emergency occurrence reports filed in 1999.

\subsubsection{Unusual Occurrences}

An unusual occurrence is defined in the DOE Order as "a non-emergency occurrence that exceeds the Off-Normal Occurrence threshold criteria, is related to safety, environment, health, security, or operations, and requires immediate notification to DOE." There was one environmentally significant unusual occurrence report filed during 1999.

- Contaminated Shipping Cask (RL-PHMCSNF-1999-0013)

On May 12, 1999, a Chem-Nuclear shipping cask was transported from the 100-K Area to ChemNuclear Systems in Barnwell, South Carolina. The pre-shipment surveys indicated that external contamination levels were within U.S. Department of Transportation allowable shipment limits. Upon receipt in Barnwell on May 20,1999, the cask protective overpack was removed and smear samples were taken on the cask body and base plate. These smears indicated areas where the contamination limit of 22,000 disintegrations per minute/100 $\mathrm{cm}^{2}$ (beta/ gamma, no alpha) was exceeded. An investigation found that the contamination leached from the outer surface of the cask following immersion of the cask in the $105-K$ East Basin prior to shipping. In the future, this type of shipping cask will not be used, and the shipping procedure for this cask has been cancelled. 


\subsubsection{Off-Normal Occurrences}

Off-normal environmental occurrences are classified in the DOE Order as "abnormal or unplanned events or conditions that adversely affect, potentially affect, or are indicative of degradation in the safety, safeguards and security, environmental or health protection, performance or operation of a facility." Several of these occurrences and the results of state and federal inspections are discussed in Section 2.2.6.4, "RCRA Inspections," and Section 2.2.8, "Clean Water Act."

Three environmentally related off-normal occurrences took place in 1999, and one potential exposure of workers to beryllium was reported.

- Chlorine Gas Leak at the 283-East Water Plant (RL-PHMC-S\&W-1999-0002)

On March 25, 1999, an alarm indicating high chlorine levels activated in the chlorine injector room during activities to restart the potable water system at the 283-East Water Plant. Momentary over-pressurization of the chlorine injector system can occur during startup and the chlorine is vented to the outdoors through a vent pipe. However, the vent pipe was broken and this allowed the gas to vent into the chlorine injector room. Within 45 minutes of the alarm, chlorine gas was no longer detectable in the chlorine injector room. However, 0.6 parts per million chlorine was detected in the lower level pump room. Personnel were not injured as a result of this event; however, seven personnel who reported smelling chlorine gas were taken to the Hanford Environmental Health Foundation for evaluation. All personnel were examined and returned to work with no noted medical conditions or deficiencies from this event. The preventative maintenance plan was modified to include periodic replacement of the vent pipe because the chlorine gas could cause the pipe to become brittle.
- Potential Exposure to Beryllium Contamination (RL-PNNLBOPER-1999-0010)

In mid-March 1999, three beryllium sample holders for $\mathrm{x}$-ray and scanning electron microscopy were cut into sections using a wet-cutting technique. Potential hazards were identified during cleanup operations at the conclusion of work on April 13, 1999. Fourteen smear samples were taken in the work area, with five locations at or above the Hanford release limit. Several staff members were potentially exposed to beryllium because of this incident. Corrective actions taken included a recovery plan for laboratory cleanup and disposal of beryllium contamination, notifications to staff who were potentially exposed, discussions of possible beryllium health issues and monitoring, and modification to procedures and management controls related to work activities involving potentially hazardous materials.

- A Fire Alarm Results in a Halon ${ }^{\circledR} 1301$ Discharge to Gloveboxes in Building 234-5Z (200-West Area) (RL-PHMC-PFP-1999-0031)

On July 28, 1999, a fire alarm activated in zone 46 in building 234-5Z (200-West Area). This resulted in the release of $\sim 154$ kilograms ( 340 pounds) of Halon ${ }^{\circledR} 1301$ into the gloveboxes located in this zone. All personnel immediately evacuated the building. The Hanford Fire Department responded and determined that no fire existed in the affected area. Two operators in the area at the time of the fire alarm were sent to the Hanford Environmental Health Foundation as a precautionary measure for follow-up medical evaluation. No adverse health affects were expected as a result of this occurrence. The cause of the fire alarm was determined to be a broken fire alarm manual pull box. Halon ${ }^{\circledR} 1301$ is a fairly nontoxic chemical but is hazardous in high concentrations because it displaces oxygen. In addition, Halon $^{\circledR} 1301$ is an ozone-depleting compound, and accidental releases should be minimized. 
- Range Fire in a Soil Contamination Area in the BC Control Area (RL-BHI-IFSM-1999. 0005)

On July 16, 1999, the Hanford Patrol Operations Center was notified of a range fire between Route 4-South (milepost 5) and Army Loop Road on the Hanford Site. The fire was in the BC cribs control area, which is posted as a soil contamination area. The Hanford Fire Department was dispatched and estimated the fire at 1 to 2 hectares ( 3 to 5 acres). The fire crew entered the soil contamination area and extinguished the fire in $\sim 40$ minutes using portable equipment. The cause of the fire was determined to be a lightning strike. Upon exiting the soil contamination area, the equipment was surveyed and no contamination was detected. The ground was largely undisturbed during the firefighting efforts, and no radiological release was detected. 


\title{
2.5 Waste Management and Chemical Inventories
}

\author{
L. P. D iediker and D. B. Jensen
}

Waste produced from Hanford Site cleanup operations is classified as either radioactive, nonradioactive, mixed, or toxic. Radioactive waste is categorized as transuranic, high-level, and low-level. Mixed waste has both radioactive and hazardous nonradioactive substances. Hazardous waste

\subsubsection{Waste Management}

Radioactive and mixed waste is currently handled in several ways. High-level waste is stored in singleand double-shell tanks. Low-level waste is stored in double-shell tanks, on storage pads, or is buried. The method used to manage low-level waste depends on the source, composition, and concentration of the waste. Transuranic waste is stored in vaults or on underground and aboveground storage pads from which it can be retrieved.

An annual report lists the dangerous waste and extremely hazardous waste generated, treated, stored, and disposed of onsite and offsite (DOE/RL-2000-14, Rev. 0). Dangerous waste is treated, stored, and prepared for disposal at several Hanford Site facilities. Dangerous waste generated at the site also is shipped offsite for disposal, destruction, or recycling.

Nondangerous waste generated at the Hanford Site has historically been buried near the 200 Areas Solid Waste Landfill. Beginning in December 1995, nondangerous waste has been disposed of at the city of Richland's Landfill, a municipal landfill located at the southern edge of the Hanford Site boundary. Since 1996, medical waste has been shipped to Waste Management of Kennewick. Asbestos has been shipped to Basin Disposal, Inc. in Pasco and the contains either dangerous waste or extremely hazardous waste or both, as defined in WAC 173-303. Hanford's hazardous waste is managed in accordance with WAC 173-303. Approximately 200 Hanford Site facilities have the capacity to generate dangerous and toxic waste.

onsite Environmental Restoration Disposal Facility. Since 1996, nonregulated drummed waste has been shipped to Waste Management of Kennewick.

Nondangerous waste originates at a number of areas across the site. This waste consists of construction debris, office trash, cafeteria waste, and packaging materials. Other materials and items classified as waste are solidified filter backwash and sludge from the treatment of river water, failed and broken equipment and tools, air filters, uncontaminated used gloves and other clothing, and certain chemical precipitates such as oxalates. Ash generated at powerhouses in the 200 Areas is buried in designated sites near those powerhouses. Demolition waste from 100 Areas decommissioning projects is buried in situ or in designated sites in the 100 Areas.

Annual reports document the quantities and types of solid waste generated onsite, received, shipped offsite, and disposed of at the Hanford Site (HNF-EP$0125-12$ ). The solid waste program is regulated by the Resource $C$ onservation and Recovery A ct and T oxic Substances C ontrol Act, discussed in Section 2.2, "Compliance Status." Solid waste quantities generated onsite, received from offsite, shipped offsite, and disposed of at the Hanford Site from 1994 through 
1999 are shown in Tables 2.5.1 through 2.5.3. Table 2.5.4 provides a detailed summary of the radioactive solid waste stored or disposed of in 1999.

The quantities of liquid waste generated in 1999 and stored in underground storage tanks are included in the annual dangerous waste report (DOE/RL-2000-14, Rev. 0). Table 2.5.5 is a summary of the liquid waste generated from 1994 through 1999, which are stored in underground storage tanks.

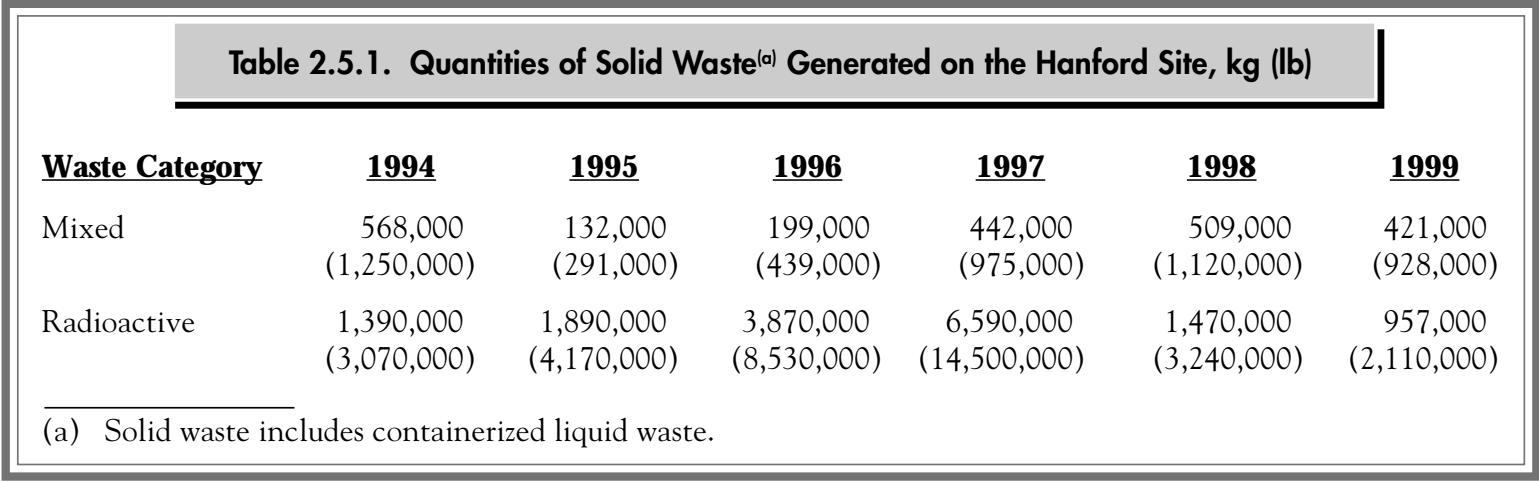

\begin{tabular}{|c|c|c|c|c|c|c|}
\hline \multirow[b]{2}{*}{ Waste C ategon } & \multicolumn{5}{|c|}{ Table 2.5.2. Quantities of Solid Waste(a) Received from Offsite, kg (lb) } & \multirow[b]{2}{*}{$\underline{1999}$} \\
\hline & 1994 & $\underline{1995}$ & $\underline{1996}$ & $\underline{1997}$ & $\underline{1998}$ & \\
\hline Mixed & $\begin{array}{c}96,000 \\
(212,000)\end{array}$ & $\begin{array}{c}52,800 \\
(116,000)\end{array}$ & $\begin{array}{c}2,070 \\
(4,560)\end{array}$ & $\begin{array}{c}3,560 \\
(7,850)\end{array}$ & $\begin{array}{c}267 \\
(589)\end{array}$ & $\begin{array}{c}1,306 \\
(2,880)\end{array}$ \\
\hline Radioactive & $\begin{array}{c}1,360,000 \\
(2,990,000)\end{array}$ & $\begin{array}{c}1,310,000 \\
(2,890,000)\end{array}$ & $\begin{array}{c}1,670,000 \\
(3,680,000)\end{array}$ & $\begin{array}{c}1,430,000 \\
(3,150,000)\end{array}$ & $\begin{array}{c}2,870,000 \\
(6,330,000)\end{array}$ & $\begin{array}{c}2,325,700 \\
(5,128,000)\end{array}$ \\
\hline $\begin{array}{l}\text { (a) Solid wast } \\
\text { submarine }\end{array}$ & $\begin{array}{l}\text { udes containe } \\
\text { or compartme }\end{array}$ & $\begin{array}{l}\text { zed liquid wast } \\
\text { s. }\end{array}$ & Solid waste & antities do no & clude United & tates Navy \\
\hline
\end{tabular}




\begin{tabular}{|c|c|c|c|c|c|c|}
\hline \multirow[b]{2}{*}{ Waste Categor } & \multicolumn{5}{|c|}{ Table 2.5.3. Quantities of Hazardous Waste (a) Shipped Offsite, kg (lb) } & \multirow[b]{2}{*}{$\underline{1999}$} \\
\hline & $\underline{1994}$ & $\underline{1995}$ & $\underline{1996}$ & $\underline{1997}$ & $\underline{1998}$ & \\
\hline \multirow[t]{2}{*}{ Containerized } & $\begin{array}{c}267,000 \\
(589,000)\end{array}$ & $\begin{array}{c}224,000 \\
(494,000)\end{array}$ & $\begin{array}{c}590,000 \\
(1,300,000)\end{array}$ & $\begin{array}{c}110,000 \\
(243,000)\end{array}$ & $\begin{array}{c}65,700 \\
(145,000)\end{array}$ & $\begin{array}{c}1,732,700^{(b)} \\
(3,820,600)\end{array}$ \\
\hline & & & & & & $\begin{array}{c}70,000^{(c)} \\
(154,000)\end{array}$ \\
\hline Bulk Solids & $\begin{array}{c}2,870,000 \\
(6,330,000)\end{array}$ & $\begin{array}{c}478,000 \\
(1,050,000)\end{array}$ & 0 & $\begin{array}{c}335,000 \\
(739,000)\end{array}$ & $\begin{array}{c}47,500 \\
(105,000)\end{array}$ & $\begin{array}{c}402,300^{(\mathrm{d})} \\
(887,000)\end{array}$ \\
\hline Bulk Liquids & $\begin{array}{c}249,000 \\
(549,000)\end{array}$ & $\begin{array}{c}130,000 \\
(287,000)\end{array}$ & $\begin{array}{c}98,800 \\
(218,000)\end{array}$ & $\begin{array}{c}5,025,000 \\
(11,100,000)\end{array}$ & $\begin{array}{c}41,800 \\
(92,200)\end{array}$ & 0 \\
\hline Total & $\begin{array}{c}3,386,000^{(e)} \\
(7,470,000)\end{array}$ & $\begin{array}{c}832,000 \\
(1,840,000)\end{array}$ & $\begin{array}{c}689,000 \\
(1,520,000)\end{array}$ & $\begin{array}{c}5,470,000 \\
(12,100,000)\end{array}$ & $\begin{array}{c}155,000 \\
(342,000)\end{array}$ & $\begin{array}{c}2,205,000 \\
(4,862,000)\end{array}$ \\
\hline $\begin{array}{l}\text { (a) Does not in } \\
\text { (b) Hazardous } \\
\text { (c) Mixed wast } \\
\text { (d) Includes } 39 \\
\text { (e) Includes 2, } \\
\text { tetrachlori }\end{array}$ & $\begin{array}{l}\text { e Toxic Substa } \\
\text { e only. } \\
\text { adioactive and } \\
5 \mathrm{~kg}(881,724 \\
000 \mathrm{~kg}(5,865, \\
\text { il extraction } \mathrm{n}\end{array}$ & $\begin{array}{l}\text { ces Control A } \\
\text { azardous). } \\
\text { ) from extract } \\
0 \text { lb) from Wa } \\
\text { r the Plutoniu }\end{array}$ & $\begin{array}{l}\text { waste. } \\
\text { n of carbon } \\
\text { luke Slope c } \\
\text { Finishing P }\end{array}$ & $\begin{array}{l}\text { trachloride } \mathrm{fr} \\
\text { Inup and } 161 \\
\text { at, 200-West }\end{array}$ & $(355,005$ & rom carbon \\
\hline
\end{tabular}




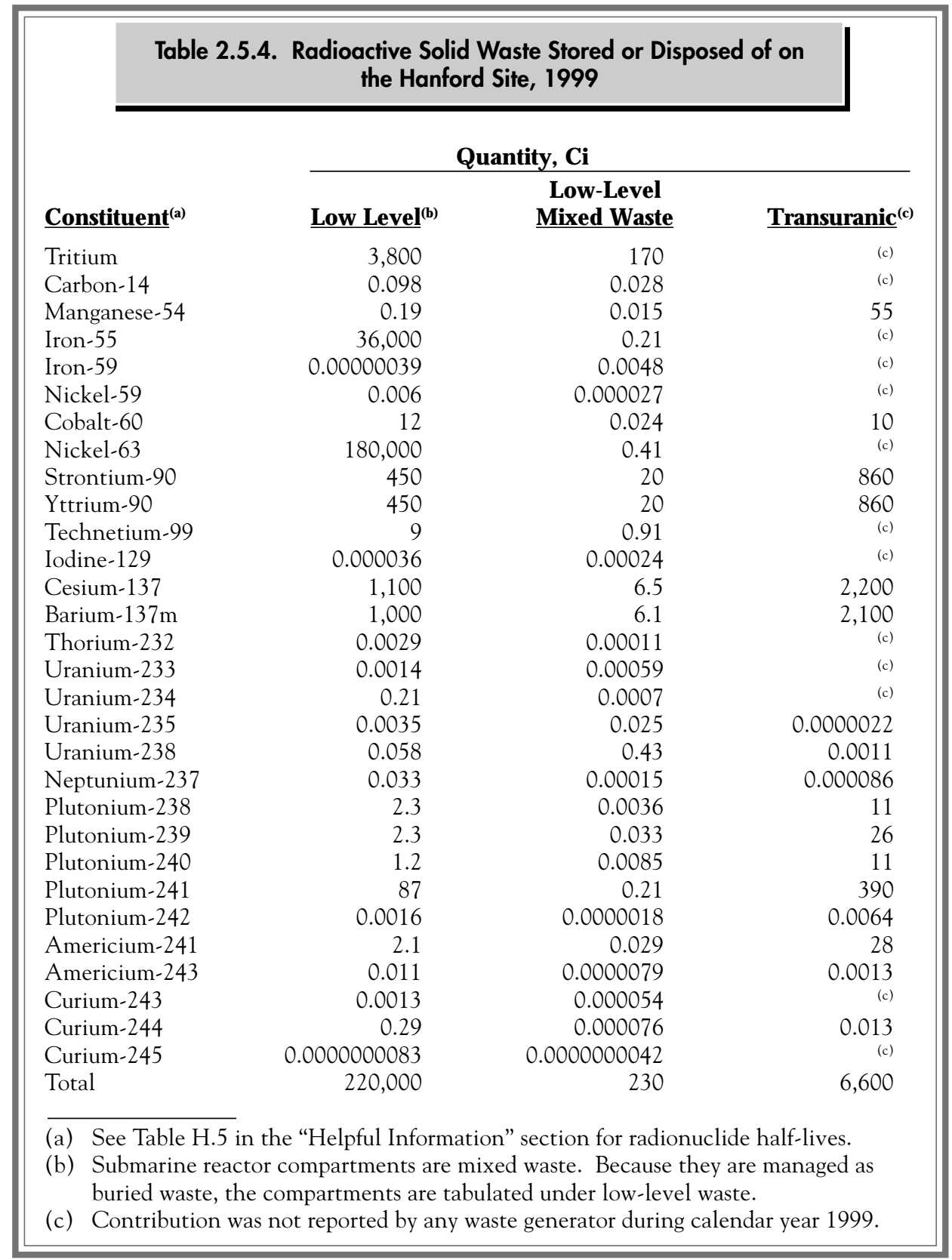


Table 2.5.5. Quantities of Liquid Waste(a) Generated and Stored Within the Tank Farm System on the Hanford Site in Calendar Year 1999 and in Each of the Previous 5 Calendar Years, L (gal)

\begin{tabular}{|c|c|c|c|c|c|c|}
\hline & ${\underline{1994^{(a)}}}$ & $\underline{1995}^{\text {(a) }}$ & $\underline{1996}^{(b)}$ & $\underline{1997}^{(b, c)}$ & $\underline{1998}^{(b, c)}$ & ${\underline{1999^{(b, c)}}}$ \\
\hline $\begin{array}{l}\text { Volume of waste added } \\
\text { to double-shell tanks }\end{array}$ & $\begin{array}{l}10,700,000 \\
(2,827,000)\end{array}$ & $\begin{array}{l}18,200,000 \\
(4,808,000)\end{array}$ & $\begin{array}{l}2,420,000 \\
(639,000)\end{array}$ & $\begin{array}{c}796,000 \\
(210,000)\end{array}$ & $\begin{array}{l}1,715,000 \\
(453,000)\end{array}$ & $\begin{array}{c}5,420,000 \\
(1,432,000)\end{array}$ \\
\hline $\begin{array}{l}\text { Total volume in double- } \\
\text { shell tanks }\end{array}$ & & & $\begin{array}{c}72,256,000 \\
(19,090,000)\end{array}$ & $\begin{array}{c}69,245,000 \\
(18,295,000)\end{array}$ & $\begin{array}{c}70,969,000 \\
(18,750,000)\end{array}$ & $\begin{array}{l}73,290,000 \\
(19,363,000)\end{array}$ \\
\hline $\begin{array}{l}\text { Volume evaporated at } \\
242 \text {-A }\end{array}$ & & & $\begin{array}{l}4,341,000 \\
(1,147,000)\end{array}$ & $\begin{array}{c}3,800,000 \\
(1,004,000)\end{array}$ & 0 & $\begin{array}{r}3,097,000 \\
(818,000)\end{array}$ \\
\hline $\begin{array}{l}\text { Volume pumped from } \\
\text { single-shell tanks }\end{array}$ & & & $\begin{array}{l}630,000 \\
(166,000)\end{array}$ & $\begin{array}{l}244,000 \\
(64,000)\end{array}$ & $\begin{array}{l}859,000 \\
(227,000)\end{array}$ & $\begin{array}{r}2,930,000 \\
(774,100)\end{array}$ \\
\hline \multicolumn{7}{|c|}{$\begin{array}{l}\text { (a) Quantity of liquid waste is defined as liquid waste sent to double-shell underground storage tanks during these years. This } \\
\text { does not include containerized waste (e.g., barreled) included in the solid waste category. } \\
\text { (b) Quantity of liquid waste is defined as shown by different categories on left-hand side of table during these years. This does } \\
\text { not include containerized waste (e.g., barreled) included in the solid waste category. }\end{array}$} \\
\hline
\end{tabular}

\subsubsection{Chemical Inventories}

Types, quantities, and locations of hazardous chemicals are tracked through compliance activities associated with the E mergency Planning and $\mathrm{C}$ ommunity Right-T o-Know Act (see Section 2.2.5). The 1999 Tier T wo Emergency and $\mathrm{H}$ azardous $\mathrm{C}$ hemical
Inventory (DOE/RL-2000-08) was issued in February 2000 in compliance with Section 312 of the Act. Table 2.5.6 summarizes the information reported, listing the ten chemicals stored in greatest quantity on the Hanford Site in 1999.

\begin{tabular}{|c|c|}
\hline \multicolumn{2}{|c|}{$\begin{array}{l}\text { Table 2.5.6. Average Balance of Ten } \\
\text { Hazardous Chemicals Stored in Greatest } \\
\text { Quantity on the Hanford Site, } 1999\end{array}$} \\
\hline Hazardous Chemical & $\begin{array}{c}\text { A verage } \\
\text { Quantity, kg (lb) }\end{array}$ \\
\hline Mineral oil & $1,700,000(3,800,000)$ \\
\hline Sodium & $1,000,000(2,300,000)$ \\
\hline Diesel fuel (Grades 1 and 2) & $500,000(1,100,000)$ \\
\hline $\begin{array}{l}\text { Crystalline silica (quartz, } \\
\text { cristobalite, tridymite) }\end{array}$ & $450,000(990,000)$ \\
\hline Bentonite & $270,000(600,000)$ \\
\hline Ethylene glycol & $250,000(550,000)$ \\
\hline Nitrogen & $89,000(200,000)$ \\
\hline Argon & $73,000(160,000)$ \\
\hline Sulfuric acid & $54,000(120,000)$ \\
\hline Propane & $38,000(84,000)$ \\
\hline
\end{tabular}




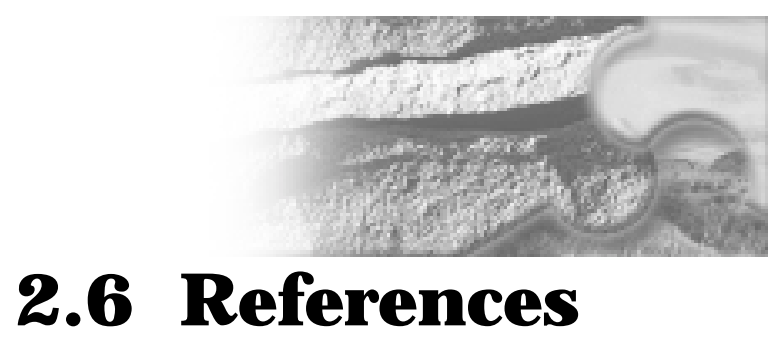

10 CFR 1021. U.S. Department of Energy. "Compliance with the National Environmental Policy Act." Code of Federal Regulations.

29 CFR 1910. U.S. Department of Labor. "Occupational Safety and Health Standards." Code of Federal Regulations.

29 CFR 1910.1200. U.S. Department of Labor. "Hazard Communication." Code of Federal Regulations.

40 CFR 61, Subpart H. U.S. Environmental Protection Agency. "National Emissions Standards for Emissions of Radionuclides Other Than Radon From Department of Energy Facilities." Code of Federal Regulations.

40 CFR 61, Subpart M. U.S. Environmental Protection Agency. "National Emission Standard for Asbestos." Code of Federal Regulations.

40 CFR 70. U.S. Environmental Protection Agency. "State Operating Permit Programs." Code of Federal Regulations.

40 CFR 82. U.S. Environmental Protection Agency. "Protection of Stratospheric Ozone." Code of Federal Regulations.

40 CFR 122. U.S. Environmental Protection Agency. "EPA Administered Permit Programs: The National Pollutant Discharge Elimination System." Code of Federal Regulations.

40 CFR 141. U.S. Environmental Protection Agency. "National Primary Drinking Water Regulations; Radionuclides; Proposed Rule." Code of Federal Regulations.

40 CFR 261. U.S. Environmental Protection Agency. "Identification and Listing of Hazardous Waste." Code of Federal Regulations.
40 CFR 264. U.S. Environmental Protection Agency. "Standards for Owners and Operators of Hazardous Waste Treatment, Storage, and Disposal Facilities." Code of Federal Regulations.

40 CFR 265. U.S. Environmental Protection Agency. "Interim Status Standards for Owners and Operators of Hazardous Waste Treatment, Storage, and Disposal Facilities." Code of Federal Regulations.

40 CFR 300. U.S. Environmental Protection Agency. "National Oil and Hazardous Substances Pollution Contingency Plan." Code of Federal Regulations.

40 CFR 355. U.S. Environmental Protection Agency. "Emergency Planning and Notification." Code of Federal Regulations.

40 CFR 761. U.S. Environmental Protection Agency. "Polychlorinated Biphenyls (PCBs) Manufacturing, Processing, Distribution in Commerce, and Use Prohibitions." Code of Federal Regulations.

40 CFR 1500-1508. Council on Environmental Quality. "Regulations for Implementing the Procedural Provisions of the National Environmental Policy Act." Code of Federal Regulations.

43 CFR 11. U.S. Department of the Interior. "Natural Resource Damage Assessments." Code of Federal Regulations.

50 CFR 17.11. U.S. Department of the Interior. "Endangered and Threatened Wildlife." Code of Federal Regulations.

61 FR 10736. U.S. Department of Energy. "Record of Decision: Management of Spent Nuclear Fuel from the K Basins at the Hanford Site, Richland, WA." Federal Register. 
61 FR 36352. U.S. Department of Energy. "Record of Decision for Plutonium Finishing Plant Stabilization Final Environmental Impact Statement, Hanford Site, Richland, Washington." Federal Register.

63 FR 3623. U.S. Department of Energy. "Record of Decision for the Department of Energy's Waste Isolation Pilot Plant Disposal Phase; Notice.” Federal Register.

63 FR 41810. U.S. Department of Energy. "Record of Decision for the Department of Energy's Waste Management Program: Treatment of NonWastewater Hazardous Waste." Federal Register.

63 FR 52430. U.S. Environmental Protection Agency. "Final Modification of the National Pollutant Discharge Elimination System (NPDES) Storm Water Multi-Sector General Permit for Industrial Activities; Termination of the EPA NPDES Storm Water Baseline Industrial General Permit; Notice." Federal Register.

64 FR 46661. U.S. Department of Energy. "Record of Decision for the Department of Energy's Waste Management Program: Storage of High-Level Radioactive Waste.” Federal Register.

64 FR 61615. U.S. Department of Energy. "Record of Decision for Hanford Comprehensive Land-Use Plan Environmental Impact Statement." Federal Register.

64 FR 66928. U.S. Department of the Interior. "Extension of the Saddle Mountain National Wildlife Refuge Acquisition Boundary." Federal Register.

American Antiquities Preservation Act. 1906. 16 USC 431-433.

American Indian Religious Freedom Act. 1978. Public Law 95-341, as amended, 42 USC 1996 et seq.

Archaeological and Historic Preservation Act. 1974. Public Law 93-291, as amended, 16 USC 469-469c-1.
Archaeological Resources Protection Act. 1979. Public Law 96-95, as amended, 93 Stat. 721.

BHI-00778. 1996. Chromium in River Substrate Pore Water and Adjacent Groundwater: 100-D/DR Area, Hanford Site, Washington. Bechtel Hanford Inc., Richland, Washington.

BHI-01199. 1999. Integrated Environmental, Safety, and Health Management System Description. Bechtel Hanford, Inc., Richland, Washington.

BHI-01367, Rev. 0. 2000. 200-CW-1 Operable Unit Borehole/Test Pit Summary Report. Prepared by CH2M HILL Hanford, Inc. for Bechtel Hanford, Inc. for the U.S. Department of Energy, Richland, Washington.

Clean Air Act. 1986. Public Law 88-206, as amended, 42 USC 7401 et seq.

Clean Air Act Amendments. 1990. Public Law 101549 , as amended.

Clean Water Act. 1997. Public Law 95-217, as amended, 91 Stat. 1566 and Public Law 96-148 as amended.

Comprehensive Environmental Response, Compensation, and Liability Act. 1980. Public Law 96150, as amended, 94 Stat. 2767, 42 USC 9601 et seq.

DE-91-NM-177. 1992. Consent Order No. DE-91NM-177 for the Permitting of Liquid Effluent Discharges Under the Washington Administrative Code (WAC) 173-216. C. O. Gregoire, Washington State Department of Ecology, Olympia, Washington, and J. D. Wagoner, U.S. Department of Energy, Richland Operations Office, Richland, Washington.

Defense Authorization Act. 1990. Public Law 101510, as amended.

DOE/EA-1135. 1999. Environmental Assessment: Offsite Thermal Treatment of Low-Level Mixed Waste. U.S. Department of Energy, Richland Operations Office, Richland, Washington. 
DOE/EA-1276. 1999. Environmental Assessment: Widening Trench 36 of the 218-E-12B Low-Level Burial Ground, Hanford Site, Richland, Washington. U.S. Department of Energy, Richland Operations Office, Richland, Washington.

DOE/EIS-0200F (5 vols). 1997. Final Waste Management Programmatic Environmental Impact Statement For Managing Treatment, Storage, and Disposal of Radioactive and Hazardous Waste. U.S. Department of Energy, Office of Environmental Management, Washington, D.C.

DOE/EIS-0222-F. 1999. Final Hanford Comprehensive Land-Use Plan Environmental Impact Statements. U.S. Department of Energy, Richland, Washington.

DOE/EIS-0244F. 1996. Final Environmental Impact Statement - Plutonium Finishing Plant Stabilization, May 1996. U.S. Department of Energy, Richland, Washington.

DOE/EIS-0244-FS/SA1. 1997. Supplement Analysis for the Immobilization of Plutonium-Bearing Materials at the Plutonium Finishing Plant, Hanford Site, Richland, Washington. U.S. Department of Energy, Richland Operations Office, Richland, Washington.

DOE/EIS-0244-FS/SA2. 1999. Increasing Batch Size for Thermal Stabilization of Plutonium Finishing Plant Metals, Oxides, and Process Residues, 200 West Area, Hanford Site, Richland, Washington. U.S. Department of Energy, Richland Operations Office, Richland, Washington.

DOE/EIS-0245/SA1. 1998. Supplement Analysis of Environmental Effects of Changes in DOE's Preferred Alternative for Management of Spent Nuclear Fuel from the K Basins at the Hanford Site, Richland, Washington. U.S. Department of Energy, Richland Operations Office, Richland, Washington.

DOE/EIS-0245F. 1996. Addendum (Final Environmental Impact Statement) Management of Spent Nuclear Fuel from the K Basins at the Hanford Site, Richland, Washington. U.S. Department of Energy, Richland Operations Office, Richland, Washington.
DOE/EM-0493. 1999. Technical Alternatives to Reduce Risk in the Hanford Tank Waste Remediation System Phase I Privatization Project. U.S. Department of Energy, Office of Environmental Management, Office of Science and Technology, Tanks Focus Area, Washington, D.C.

DOE Order 232.1A. "Occurrence Reporting and Processing of Operations Information."

DOEOrder451.1A. "National Environmental Policy Act Compliance Program."

DOE Order 1230.2. "American Indian Tribal Government Policy."

DOE P 450.4. 1996. Safety Management System Policy. U.S. Department of Energy, The Office of Environment, Safety and Health, Washington D.C.

DOE/RL-91-28, Rev. 4. 1998. Hanford Facility Waste Permit Application, General Information Portion. U.S. Department of Energy, Richland Operations Office, Richland, Washington.

DOE/RL-93-94, Rev. 1. 1994. Plan and Schedule for Disposition and Regulatory Compliance for Miscellaneous Streams. U.S. Department of Energy, Richland Operations Office, Richland, Washington.

DOE/RL-94-102. 1995. Proposed Plan for Interim Remedial Measure at the 100-HR-3 Operable Unit. Prepared by CH2M HILL Hanford, Inc. for Bechtel Hanford, Inc. for U.S. Department of Energy, Richland Operations Office, Richland, Washington.

DOE/RL-94-113. 1995. Proposed Plan for Interim Remedial Measure at the 100-KR-4 Operable Unit. Prepared by CH2M HILL Hanford, Inc. for Bechtel Hanford, Inc. for U.S. Department of Energy, Richland Operations Office, Richland, Washington.

DOE/RL-94-150. 1994. Bald Eagle Site Management Plan for the Hanford Site, South-Central Washington. R. E. Fitzner and S. G. Weiss, Pacific Northwest Laboratory and CH2M HILL Hanford, Inc. for U.S. Department of Energy, Richland Operations Office, Richland, Washington. 
DOE/RL-96-16. 1998. Screening Assessment and Requirements for a Comprehensive Assessment. Published by U.S. Department of Energy, Richland, Washington.

DOE/RL-96-40. 1996. Miscellaneous Streams Best Management Practices (BMP) Report. U.S. Department of Energy, Richland Operations Office, Richland, Washington.

DOE/RL-98-28. 1999. 200 Areas Remedial Investigation/Feasibility Study Implementation Plan Evironmental Restoration Program. U.S. Department of Energy, Richland Operations Office, Richland, Washington.

DOE/RL-99-11, Decisional Draft. 1999. 200-BP-1 Prototype Barrier Treatability Test Report. U.S. Department of Energy, Richland Operations Office, Richland, Washington.

DOE/RL-99-43. 1999. 600 Area Purgewater Storage and Treatment Facility Closure Plan. U.S. Department of Energy, Richland Operations Office, Richland, Washington.

DOE/RL-99-44. 1999. 200-CS-1 Operable Unit RI/FS Work Plan and RCRA TSD Unit Sampling Plan. U.S. Department of Energy, Richland Operations Office, Richland, Washington.

DOE/RL-99-46. 1999. 2401-W Waste Storage Building Closure Plan. U.S. Department of Energy, Richland Operations Office, Richland, Washington.

DOE/RL-99-79. 1999. Fiscal Year 1999 Annual Summary Report for the 200-UP-1, 200-ZP-1, and 100-NR-2 Pump-and-Treat Operations and Operable Units. U.S. Department of Energy, Richland Operations Office, Richland, Washington.

DOE/RL-2000-08. 2000. 1999 Tier Two Emergency and Hazardous Chemical Inventory -- Emergency Planning and Community Right-To-Know Act, Section 312. U.S. Department of Energy, Richland Operations Office, Richland, Washington.
DOE/RL-2000-14, Rev. 0. 2000. Hanford Facility Annual Dangerous Waste Report, Calendar Year 1999. U.S. Department of Energy, Richland, Washington.

DOE/RL-2000-27, Rev. 0. 2000. Threatened and Endangered Species Management Plan: Salmon and Steelhead. U.S. Department of Energy, Richland Operations Office, Richland, Washington.

Ecology - see Washington State Department of Ecology.

Emergency Planning and Community Right-ToKnow Act. 1986. Public Law 99-499, as amended, 100 Stat. 1728, 42 USC 11001 et seq.

Endangered Species Act. 1973. Public Laws 93-205 through 100-707, as amended, 87 Stat. 884, 16 USC 1531 et seq.

EPA 100-K-93-001. 1993. Pollution Prevention and Right-to-Know in the Government, Executive Order 12856. U.S. Environmental Protection Agency, Office of the Administrator, Washington, D.C.

EPA-570/9-76-003. 1976. National Interim Primary Drinking Water Regulations. U.S. Environmental Protection Agency, Office of Water Supply, Washington, D.C.

EPA 822-R-96-001. 1996. Drinking Water Regulations and Health Advisories. U.S. Environmental Protection Agency, Office of Water, Washington, D.C.

Federal Facility Compliance Agreement for Radionuclide NESHAP. 1994. J. D. Wagoner, U.S. Department of Energy, and G. A. Emison, U.S. Environmental Protection Agency, Seattle, Washington.

Federal Insecticide, Fungicide, and Rodenticide Act. 1975. Public Laws 94-51 through 94-140, as amended, 7 USC 136 et seq.

GJ-HAN-6. 1997. Hanford Tank Farms Vadose Zone, BY Tank Farm Report. Prepared by MACTECERS for U.S. Department of Energy, Grand Junction Office, Grand Junction, Colorado. 
GJ-HAN-106. 1998. Hanford Tank Farms Vadose Zone, Tank Summary Data Report for Tank A-101. Prepared by MACTEC-ERS for U.S. Department of Energy, Grand Junction Office, Grand Junction, Colorado.

Historic Sites, Buildings and Antiquities Act. 1935. Public Law 89-249, as amended, 16 USC 461-467.

HNF-3617, Rev. 0. 1999. Integrated Project Management Plan for the Plutonium Finishing Plant Stabilization and Deactivation Project. Prepared by B\&W Hanford Company for Fluor Daniel Hanford, Inc., Richland, Washington

HNF-3824. 1999. Tank 241-SY-101 Surface-LevelRise Remediation Project Plan. R. E. Raymond, Lockheed Martin Hanford Corporation for Fluor Daniel Hanford, Inc., Richland, Washington.

HNF-4081. 1999. National Pollutant Discharge Elimination System, Multi-Sector General Permit Storm Water Pollution Prevention Plan for $100 \mathrm{~K}$ Area 1908-K Outfall. Fluor Hanford, Inc., Richland, Washington.

HNF-5068. 2000. Project Management Plan for the 300 Area Special-Case Waste. R. M. Millikin, Fluor Hanford, Inc., Richland, Washington.

HNF-EP-0125-12. 2000. Summary of Radioactive Solid Waste Received in the 200 Areas During Calendar Year 1999. D. L. Hagel, Waste Management Federal Services of Hanford, Inc., Richland, Washington.

HNF-EP-0182-141. 2000. Waste Tank Summary Report for Month Ending December 31, 1999. CH2M HILL Hanford Group, Richland, Washington.

HNF-MP-003. 1997. Integrated Environment, Safety and Health Management System Plan. Fluor Daniel Hanford, Inc., Richland, Washington.

HNF-SP-0903, Rev. 6. 1999. National Environmental Policy Act Source Guide for the Hanford Site. Fluor Daniel Hanford, Inc., Richland, Washington.
ISO 14001. 1996. Environmental Management Systems-Specifications with Guidance for Use. American Society for Testing and Materials, West Conshohocken, Pennsylvania.

Memorandum of Agreement. 1996. Memorandum of Agreement Among the United States Department of Energy, United States Department of the Interior, Nez Perce Tribe, State of Oregon, Confederated Tribes of the Umatilla Indian Reservation, State of Washington (including the Departments of Ecology and fish and Wildlife), and the Confederated Tribes and Bands of the Yakama Indian Nation. U.S. Department of Energy, Richland Operations Office, Richland, Washington.

Memorandum of Understanding. 1994. "Memorandum of Understanding for the Establishment of a Federal Interagency Committee for the Management of Noxious and Exotic Weeds." G. Buntrock, S. W. Goodman, R. E. Slater, and T. O'Toole, U.S. Department of Agriculture, U.S. Department of Defense, U.S. Department of Transportation, and U.S. Department of Energy, Washington, D.C.

National Environmental Policy Act. 1969. Public Laws 91-190, as amended, 42 USC 4321 et seq.

National Historic Preservation Act. 1966. Public Law 89-665, as amended, 80 Stat. 915-919.

Native American Graves Protection and Repatriation Act. 1990. Public Law 101-601, as amended, 25 USC 3001 et seq.

PNNL-6415, Rev. 12. 1999. Hanford Site National Environmental Policy Act (NEPA) Characterization. D. A. Neitzel (ed.), and C. J. Fosmire, R. A. Fowler, S. M. Goodwin, D. W. Harvey, P. L. Hendrickson, D. J. Hoitink, T. M. Poston, A. C. Rohay, P. D. Thorne, and M. K. Wright, Pacific Northwest National Laboratory, Richland, Washington.

PNNL-11958, Rev. 2. 1999. Proposal for Fiscal Year 1999 Vadose Zone Monitoring and Guidance for Subsequent Years for Liquid Waste Disposal Facilities. D. G. Horton, S. P. Reidel, and G. V. Last, Pacific Northwest National Laboratory, Richland, Washington. 
PNNL-13198. 2000. Borehole Data Package for the 216-S-10 Pond and Ditch, Well 299-W26-13. D. G. Horton, B. A. Williams, and C. S. Cearlock, Pacific Northwest National Laboratory, Richland, Washington.

PNNL-13199. 2000. Borehole Data Package for Wells 299-E33-334 and 299-E33-335 at Single-Shell Tank Waste Management Area B-BX-BY. D. G. Horton, Pacific Northwest National Laboratory, Richland, Washington.

PNNL-13200. 2000. Borehole Data Package for Wells 299-W22-48, 299-W22-49, and 299-W22-50 at SingleShell Tank Waste Management Area S-SX. D. G. Horton and V. G. Johnson, Pacific Northwest National Laboratory, Richland, Washington.

PNNL-13201. 2000. Borehole Data Package for Well 299-W15-41 at Single-Shell Tank Waste Management Are TX-TY. D. G. Horton and F. N. Hodges, Pacific Northwest National Laboratory, Richland, Washington.

Pollution Prevention Act. 1990. Public Law 101. 508, as amended, 104 Stat. 1388-321, 41 USC 13101 et seq.

Record of Decision. 1996. Declaration of the Record of Decision, USDOE Hanford 100 Areas, 100-HR-3 and 100-KR-4 Operable Units, Hanford Site, Benton County, Washington, April 1996. State of Washington Department of Ecology, U.S. Environmental Protection Agency, and U.S. Department of Energy, Richland Operations Office, Richland, Washington.

Resource Conservation and Recovery Act. 1976. Public Law 94-580, as amended, 90 Stat. 2795, 42 USC 6901 et seq.

Revised Code of Washington (RCW) 15.58. Washington Pesticide Control Act.

Revised Code of Washington (RCW) 17.21. Washington Pesticide Application Act.

Revised Code of Washington (RCW) 70.94. Washington Clean Air Act.
Safe Drinking Water Act. 1974. Public Law 93-523, as amended, 88 Stat. 1660, 42 USC 300 fet seq.

Safe Drinking Water Act Amendments of 1986. 1986. Public Law 99-339, as amended, Stat. 666, 42 USC $300 f$ et seq.

Safe Drinking Water Act Amendments of 1996. 1996. Public Law 104-182, as amended, Stat. 1613, 42 USC $300 f$ et seq.

Superfund Amendments and Reauthorization Act. 1986. Public Law 99-499, as amended, 100 Stat. 161342 USC 11001 et seq.

Toxic Substances Control Act. 1976. Public Law 94-469, as amended, 90 Stat. 2003, 15 USC 2601 et seq.

U.S. Environmental Protection Agency (EPA). 1996. Records of Decision for the 100-HR-3 and 100-KR-4 Operable Units. U.S. Environmental Protection Agency, Washington, D.C.

U.S. Environmental Protection Agency (EPA). 1999a. Interim Remedial Action Record of Decision for the 100-BC-1, 100-BC-2, 100-DR-1, 100-DR-2, 100FR-1, 100-FR-2, 100-HR-1, 100-HR-2, 100-KR-1, 100-KR-2, 100-IU-2, 100-IU-6, and 200-CW-3 Operable Units, Hanford Site, Benton County, Washington. U.S. Environmental Protection Agency, Region 10, Seattle, Washington.

U.S. Environmental Protection Agency (EPA). 1999b. Interim Remedial Action Record of Decision for the 100-NR-1 and 100-NR-2 Operable Unit, Hanford Site, Benton County, Washington. U.S. Environmental Protection Agency, Region 10, Seattle, Washington.

WAC 16-228. "Pesticide Regulations." Washington Administrative Code, Olympia, Washington.

WAC 173-201A. "Water Quality Standards for Surface Waters of the State of Washington." Washington Administratiave Code, Olympia, Washington. 
WAC 173-216. "State Waste Discharge Program." Washington Administrative Code, Olympia, Washington.

WAC 173-218. "Underground Injection Control Program." Washington Administrative Code, Olympia, Washington.

WAC 173-303. "Dangerous Waste Regulations." Washington Administrative Code, Olympia, Washington.

WAC 173-303-170. "Requirements for Generators of Dangerous Waste." Washington Administrative Code, Olympia, Washington.

WAC 173-360. "Underground Storage Tank Regulations." Washington Administrative Code, Olympia, Washington.

WAC 173-400. "General Regulations for Air Pollution Sources." Washington Administrative Code, Olympia, Washington.

WAC 173-401. "Operating Permit Regulation." Washington Administrative Code, Olympia, Washington.

WAC 173-425. "Open Burning." Washington Administrative Code, Olympia, Washington.

WAC 173-460. "Controls for New Sources of Toxic Air Pollutants." Washington Administrative Code, Olympia, Washington.
WAC 246-247. "Radiation Protection-Air Emissions." Washington Administrative Code, Olympia, Washington.

WAC 246-290. "Group A Public Water Supplies." Washington Administrative Code, Olympia, Washington.

Washington State Department of Ecology, U.S. Department of Energy, and U.S. Environmental Protection Agency. 1997. Community Relations Plan for the Hanford Federal Facility Agreement and Consent Order. Olympia, Richland, and Seattle, Washington.

Washington State Department of Ecology, U.S. Environmental Protection Agency, and U.S. Department of Energy. 1998. Hanford Federal Facility Agreement and Consent Order. Document No. 89-10, Rev. 5 (The Tri-Party Agreement), Olympia, Washington.

Washington State Department of Fish and Wildlife. 1996. Priority Habitats and Species List. Olympia, Washington. Available URL: http://www.wa.gov/ wdfw/hab/phspage.htm

WHC-SD-WM-SARR-003. 1994. High-Level Waste Tank Subcriticality Safety Assessment. D. J. Braun and S. A. Szendre, Westinghouse Hanford Company, Richland, Washington. 


\subsection{Facility-Related Monitoring}

The following sections provide information about facility-related environmental monitoring programs at the Hanford Site, including effluent monitoring (Section 3.1) and near-facility environmental monitoring (Section 3.2).

The monitoring of effluents and contaminants at Hanford Site facilities is necessary to determine the effects these materials may have on the public, workers at the site, and the environment. Effluent monitoring is conducted by the various site contractors at their facilities pursuant to requirements in DOE Order 5400.1. At the Hanford Site, effluent monitoring includes 1) collecting samples for analyses, 2) measuring liquid and airborne effluents to characterize and quantify contaminants released to the environment, 3 ) providing source terms for assessing potential impact to the public, 4) providing a means to control effluents at or near the point of discharge, and 5) determining compliance with applicable standards and permit requirements.

Near-facility environmental monitoring consists of routine monitoring of environmental media near facilities that have the potential to discharge or have discharged, stored, or disposed of radioactive or hazardous contaminants. Monitoring locations are generally associated with major, nuclear-related installations, waste storage and disposal units, and remediation efforts.

Additional program sampling and effluent information is contained in $\mathrm{H}$ anford Site $\mathrm{N}$ ear-Facility Environmental $M$ onitoring $D$ ata Report for $C$ alendar Year 1999 (PNNL-13230, APP. 2) and in Environmental Releases for C alendar Year 1999 (HNF-EP0527-9). 


\title{
3.1 Facility Effluent Monitoring
}

\author{
L. P. D iediker and D. B. Jensen
}

Liquid and airborne effluents that may contain radioactive or hazardous constituents are continually monitored when released to the environment at the Hanford Site. Facility operators perform the monitoring mainly through analyzing samples collected near points of release into the environment. Effluent monitoring data are evaluated to determine the degree of regulatory compliance for each facility or the entire site, as appropriate. The evaluations are also useful in assessing the effectiveness of effluent treatment and control systems and management practices. Major facilities have their own individual effluent monitoring plans, which are part of the comprehensive Hanford Site environmental monitoring plan (DOE/RL-91-50, Rev. 2).

Measuring devices quantify most facility effluent flows, but some flows are calculated using process information. Effluent sampling methods include continuous sampling or periodic measurements for most radioactive air emission units and proportional or grab sampling for most liquid effluent streams. Liquid and airborne effluents with a potential to contain radioactive materials at prescribed threshold levels are measured for gross alpha and beta activity and, as warranted, specific radionuclides. Nonradioactive constituents are also either monitored or sampled, as applicable.

Small quantities of tritium, cobalt- 60 , strontium90, antimony-125, iodine-129, cesium-137, plutonium-238, plutonium-239/240, plutonium-241, and americium-241 were released to the environment through state and federally permitted release points. However, most radionuclides in effluents at the site are approaching levels indistinguishable from background or naturally occurring concentrations. The site mission of environmental cleanup is largely responsible for the improved trend in radioactive emissions. This decreasing trend results in smaller offsite radiation doses to the maximally exposed individual attributable to site activities. Figures 3.1.1 and 3.1.2 depict quantities of several dose-contributing radionuclides released from the site over recent years. In 1999, releases of radioactive and nonradioactive constituents in effluents were less than applicable standards.

Effluent release data are documented in several reports in addition to this one, and all are available to the public. For instance, the U.S. Department of Energy (DOE) annually submits to the U.S. Environmental Protection Agency (EPA) and the Washington State Department of Health a report of radioactive airborne emissions from the site (DOE/ RL-2000-37), in compliance with 40 CFR 61, "National Emission Standards for Hazardous Air Pollutants," and WAC 246-247, "Radiation Protection-Air Emissions." Data quantifying the radioactive liquid and airborne effluents are reported to DOE annually in the environmental releases report (HNF-EP-0527-9). Monitoring results for liquid streams regulated by the National Pollutant Discharge Elimination System permit are reported to EPA. Monitoring results from liquid effluent streams regulated by WAC 173-216 are reported to the Washington State Department of Ecology. Nonradioactive air emissions are reported annually to the Washington State Department of Ecology. 

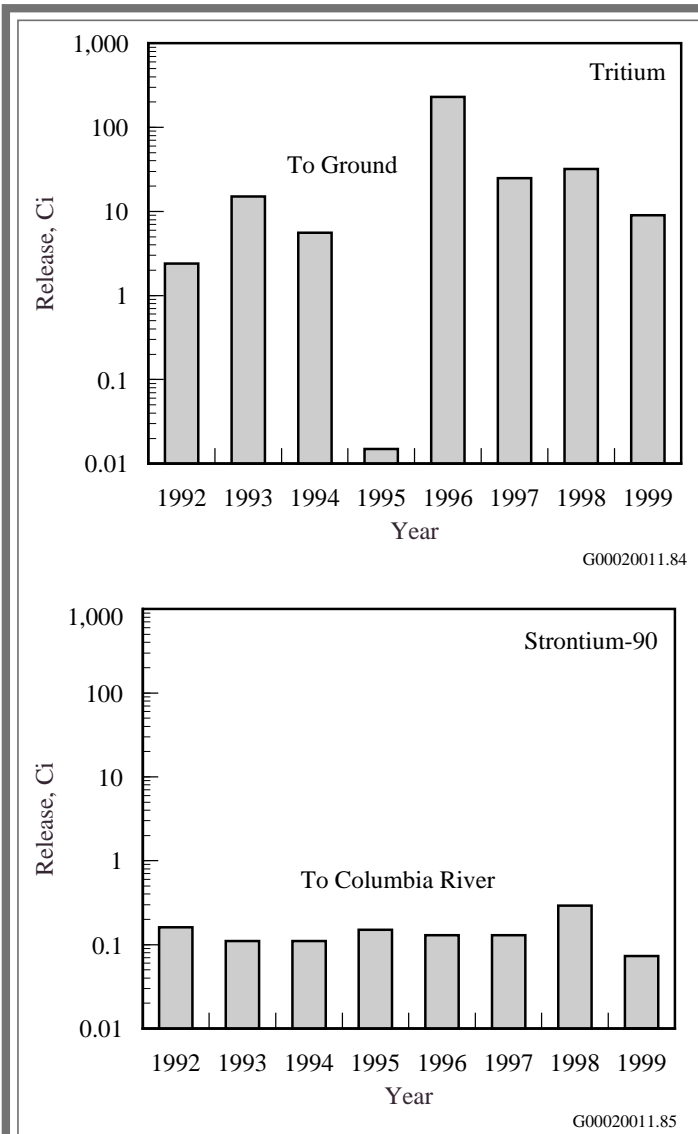

Figure 3.1.1. Liquid Releases of Selected Radionuclides from Hanford Site Facilities, 1992 Through 1999

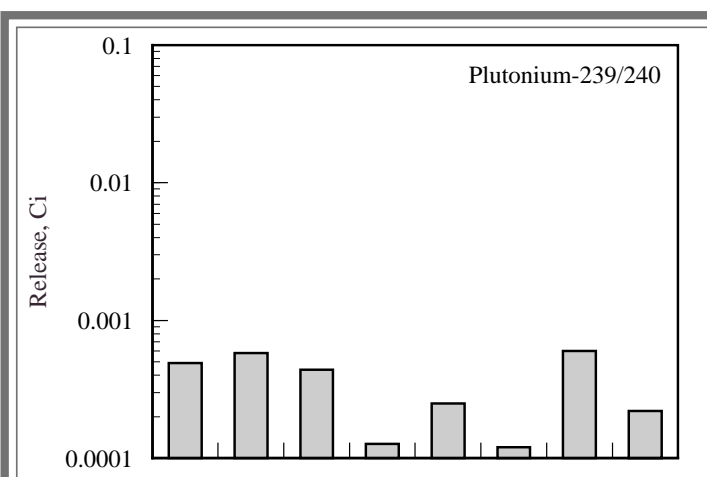

$\begin{array}{llllllll}1992 & 1993 & 1994 & 1995 & 1996 & 1997 & 1998 & 1999\end{array}$ Year

G00020011.86

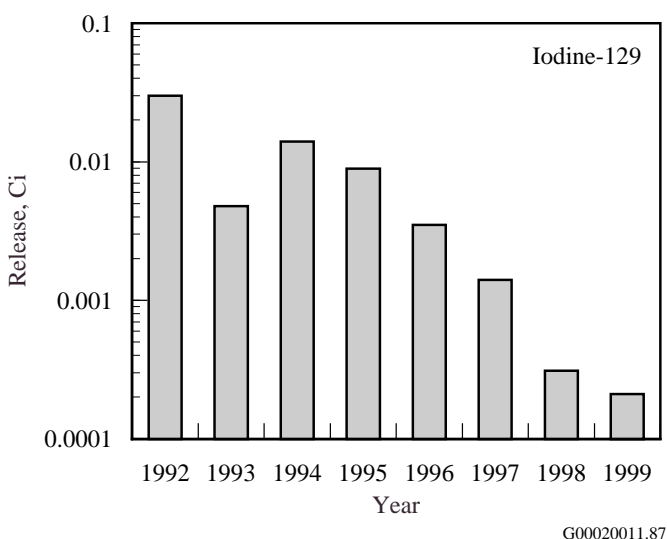

Figure 3.1.2. Airborne Releases of Selected Radionuclides from Hanford Site Facilities, 1992 Through 1999

\subsubsection{Radioactive Airborne Emissions}

Radioactive airborne emissions from site activities contain at least one of these forms of radionuclides: particles, noble gases, or volatile compounds. Emissions having the potential to exceed $1 \%$ of the $10-\mathrm{mrem} / \mathrm{yr}$ standard for offsite doses are monitored continuously.

The continuous monitoring of radioactive emissions involves analyzing samples collected at points of discharge to the environment, usually from a stack or vent. Samples are analyzed for gross alpha and beta activity, as well as selected radionuclides. The selection of the specific radionuclides sampled, analyzed, and reported is based on 1) an evaluation of maximum potential unmitigated emissions expected from known radionuclide inventories in a facility or activity area, 2) the sampling criteria given in contractor environmental compliance manuals, and 3) the potential each radionuclide has to contribute to the offsite public dose. Continuous air monitoring systems with alarms are also used at selected discharge points, when a potential exists for radioactive emissions to exceed normal operating ranges by levels requiring immediate personnel alert.

Radioactive emission discharge points are located in the 100, 200, 300, and 400 Areas. The sources for these emissions are summarized below.

- Five radioactive emission points were active in the 100 Areas during 1999. In these areas, 
emissions originate from the deactivation of $\mathrm{N}$ Reactor, the two water-filled storage basins (K-East and K-West Fuel Storage Basins) that contain irradiated fuel, the 1706-KE laboratory facility, and from sample preparation at the radiological counting facility.

- During 1999, 49 radioactive emission points were active in the 200 Areas. The 200 Areas contain inactive facilities for nuclear fuel chemical separations, reprocessing, and steam generation. The active facilities are for waste handling and disposal. Primary sources of radionuclide emissions are the Plutonium-Uranium Extraction Plant, Plutonium Finishing Plant, T Plant, 222-S Laboratory, underground tanks for storage of high-level radioactive waste, and waste evaporators.

- During 1999, 23 radioactive emission discharge points were active in the 300 Area. The 300 Area primarily contains laboratories and research facilities. Primary sources of airborne radionuclide emissions are the 324 Waste Technology Engineering Laboratory, 325 Applied
Chemistry Laboratory, 327 Post-Irradiation Laboratory, and 340 Vault and Tanks. Radioactive emissions arise from research and development work and waste handling operations.

- The 400 Area had five radioactive emission discharge points active during 1999. The Fast Flux Test Facility, the Maintenance and Storage Facility, and the Fuels and Materials Examination Facility are located in this area. Operations at the Fast Flux Test Facility and Maintenance and Storage Facility released small quantities of radioactive material to the environment, even though the reactor did not operate in 1999.

- The 600 Area had two radioactive emission points active during 1999. The Waste Sampling and Characterization Facility, at which low-level radiological and chemical analyses on various types of samples are performed, is located in this area.

A summary of the Hanford Site's 1999 radioactive airborne emissions is provided in Table 3.1.1. Several constituents not detected or not measured are included in the table for historical comparisons.

\subsubsection{Nonradioactive Airborne Emissions}

Nonradioactive air pollutants emitted from power generating and chemical processing facilities are monitored when activities at a facility are known to generate potential pollutants of concern.

In past years, gaseous ammonia has been emitted from the Plutonium-Uranium Extraction Plant, 242-A evaporator, 200 Areas Effluent Treatment Facility, tank farm 241-AP, and tank farm 241-AW all located in the 200-East Area. Ammonia emissions are estimates calculated when activities at these facilities are capable of generating them. The 200 Area tank farms discharged ammonia to the atmosphere during 1999 (Table 3.1.2).

Onsite, fossil fuel powered steam and electrical generators emitted particulate matter, sulfur oxides, nitrogen oxides, volatile organic compounds, carbon monoxide, and lead. The total annual releases of these constituents are reported in accordance with the air quality standards established in WAC 173 400. Steam and electrical generator emissions are calculated from the quantities of fossil fuel consumed, using approved emission factors (AP-42 or applicable notice of construction).

Should activities lead to chemical emissions in excess of quantities reportable under the $C$ omprehensive $\mathrm{E}$ nvironmental Response, $\mathrm{C}$ ompensation, and Liability A ct (CERCLA), the release totals are reported immediately to EPA. If the emissions remain stable at predicted levels, they may be reported annually with the EPA's permission. Table 3.1.2 summarizes the 1999 emissions of nonradioactive constituents (it should be noted that the 100,400, and 600 Areas have no nonradioactive emission sources of regulatory concern). 
Table 3.1.1. Radionuclides Discharged to the Atmosphere at the Hanford Site, 1999

\begin{tabular}{|c|c|c|c|c|c|c|}
\hline \multirow[b]{2}{*}{ Radionuclide } & \multirow[b]{2}{*}{$\underline{\text { Half-Life }}$} & \multicolumn{5}{|c|}{ Release, $\mathbf{C i}^{(a)}$} \\
\hline & & 100 A reas & $\underline{\text { 200-East A rea }}$ & 200-West A rea & 300 A rea & $\underline{400 \text { A rea }}$ \\
\hline Tritium (as HT) ${ }^{(b)}$ & $12.3 \mathrm{yr}$ & $\mathrm{NM}^{(\mathrm{a})}$ & NM & NM & $4.0 \mathrm{E}+01$ & NM \\
\hline Tritium (as HTO) $)^{(\mathrm{b})}$ & $12.3 \mathrm{yr}$ & NM & NM & NM & $1.5 \mathrm{E}+02$ & $1.4 \mathrm{E}+00$ \\
\hline Cobalt -60 & $5.3 \mathrm{yr}$ & $3.9 \mathrm{E}-08$ & $1.6 \mathrm{E}-09$ & $\mathrm{ND}^{(\mathrm{a})}$ & ND & NM \\
\hline Strontium-90 & $29.1 \mathrm{yr}$ & $1.9 \mathrm{E}-05$ & $9.6 \mathrm{E}-05^{(\mathrm{c})}$ & $2.9 \mathrm{E}-04^{(\mathrm{c})}$ & $1.0 \mathrm{E}-05^{(\mathrm{c})}$ & NM \\
\hline Ruthenium-106 & $368 \mathrm{~d}$ & ND & ND & NM & ND & NM \\
\hline Antimony-125 & $2.77 \mathrm{yr}$ & 5.0E-08 & ND & ND & $1.1 \mathrm{E}-07$ & NM \\
\hline Iodine-129 & $1.6 \times 10^{7} \mathrm{yr}$ & NM & $1.9 \mathrm{E}-04$ & NM & NM & NM \\
\hline Cesium-134 & $2.1 \mathrm{yr}$ & ND & ND & ND & ND & NM \\
\hline Cesium-137 & $30 \mathrm{yr}$ & $4.5 \mathrm{E}-05$ & 3.9E-05 & $2.5 \mathrm{E}-09$ & $4.2 \mathrm{E}-07$ & $1.9 \mathrm{E}-06^{(\mathrm{d})}$ \\
\hline Europium-154 & $8.8 \mathrm{yr}$ & $4.8 \mathrm{E}-08$ & ND & ND & ND & NM \\
\hline Plutonium-238 & $87.7 \mathrm{yr}$ & $5.8 \mathrm{E}-07$ & $1.9 \mathrm{E}-08$ & $4.9 \mathrm{E}-06$ & ND & NM \\
\hline Plutonium-239/240 & $2.4 \times 10^{4} \mathrm{yr}$ & 4.2E-06 & $6.9 \mathrm{E}-07^{(\mathrm{e})}$ & $2.1 \mathrm{E}-04^{(\mathrm{e})}$ & $1.1 \mathrm{E}-06^{(\mathrm{e})}$ & $3.0 \mathrm{E}-07^{(\mathrm{e})}$ \\
\hline Plutonium-241 & $14.4 \mathrm{yr}$ & $5.1 \mathrm{E}-05$ & $1.2 \mathrm{E}-06$ & $1.2 \mathrm{E}-04$ & $7.9 \mathrm{E}-08$ & NM \\
\hline Americium-241 & $432 \mathrm{yr}$ & $2.4 \mathrm{E}-06$ & $5.6 \mathrm{E}-07$ & $4.5 \mathrm{E}-05$ & $1.4 \mathrm{E}-07$ & NM \\
\hline
\end{tabular}

(a) $1 \mathrm{Ci}=3.7 \mathrm{E}+10$ becquerel; $\mathrm{NM}=$ not measured; $\mathrm{ND}=$ not detected (i.e., either the radionuclide was not detected in any sample during the year or the average of all the measurements for that given radionuclide or type of radioactivity made during the year was below background levels).

(b) $\mathrm{HT}=$ Elemental tritium; $\mathrm{HTO}=$ tritiated water vapor.

(c) This value includes gross beta release data. Gross beta and unspecified beta results assumed to be strontium-90 for dose calculations.

(d) This value includes gross beta release data. Gross beta results assumed to be cesium-137 for dose calculations from Fast Flux Test Facility emissions

(e) This value includes gross alpha release data. Gross alpha and unspecified alpha results assumed to be plutonium-239/240 for dose calculations.

\subsubsection{Radioactive Liquid Effluents}

Liquid effluents are discharged from facilities in all areas of the Hanford Site. Effluents that normally or potentially contain radionuclides include cooling water, steam condensates, process condensates, and wastewater from laboratories and chemical sewers. These wastewater streams are sampled and analyzed for gross alpha and beta activity, as well as selected radionuclides.

In 1999, facilities in the 200 Areas discharged radioactive liquid effluents to the 616-A crib (also known as the State-Approved Land Disposal Site). A summary of these radioactive liquid effluents is provided in Table 3.1.3. Table 3.1.4 summarizes data on radionuclides in liquid effluents released from the 100 Areas to the Columbia River. These measurements are used to determine potential radiation doses to the public. Several constituents not detected are included in the tables for historical comparisons. 
Table 3.1.2. Nonradioactive Constituents Discharged to the Atmosphere at the Hanford Site, 1999(a)

\section{Constituent}

Particulate matter

Nitrogen oxides

Sulfur oxides

Carbon monoxide

Lead

Volatile organic compounds ${ }^{(b)}$

Ammonia ${ }^{(c)}$

Other toxic air pollutants ${ }^{(e)}$

\begin{tabular}{rrlrl} 
& \multicolumn{4}{c}{ Release, $\mathbf{~ k g ~ ( l b ) ~}$} \\
\cline { 2 - 5 } & \multicolumn{2}{c}{ 200 A reas } & \multicolumn{2}{c}{ 300 A rea } \\
& 886 & $(1,954)$ & 596 & $(1,314)$ \\
24,000 & $(52,920)$ & 3,680 & $(8,114)$ \\
3,370 & $(7,431)$ & 40 & $(88)$ \\
& 17,700 & $(39,029)$ & 12,700 & $(28,004)$ \\
& 53 & $(117)$ & 0 & \\
& 6,920 & $(15,259)$ & 809 & $(1,784)$ \\
& 9,810 & $(21,631)$ & $\mathrm{NE}$ & \\
& 2,970 & $(6,549)$ & $\mathrm{NE}$ &
\end{tabular}

(a) The estimate of volatile organic compounds does not include emissions from certain laboratory operations.

(b) Produced from burning fossil fuel for steam and electrical generators, calculated estimates from the 200-East and 200-West Area tank farms, and operation of the 242-A Evaporator and the 200 Areas Effluent Treatment Facility.

(c) Ammonia releases are calculated from the 200-East and 200-West Area tank farms and operation of the 242-A Evaporator and the 200 Areas Effluent Treatment Facility.

(d) $\mathrm{NE}=$ No emissions.

(e) Releases are a composite of calculated estimates of toxic air pollutants, excluding ammonia, from the 200-East and 200-West Area tank farms, and operation of the 242-A Evaporator and the 200 Areas Effluent Treatment Facility.

Table 3.1.3. Radionuclides in 200 Areas' Liquid Effluents Discharged to the StateApproved Land Disposal Site in 1999

\begin{tabular}{|ccc|}
\hline Radionuclide & Half-Life & Release, Ci \\
\cline { 2 - 3 } Tritium & $12.3 \mathrm{yr}$ & 9 \\
\hline
\end{tabular}

Table 3.1.4. Radionuclides in 100 Areas' $^{\prime}$ Liquid Effluents Discharged to the Columbia River, 1999

Radionuclide

$\begin{array}{cc}\text { Half-Life } & \text { Release, Ci } \\ 29.1 \mathrm{yr} & 0.073^{\text {(a) }} \\ 2.4 \times 10^{4} \mathrm{yr} & 0.000015 \\ 432 \mathrm{yr} & 0.000016\end{array}$

Strontium-90

Plutonium-239/240

Americium-241 (b)

$432 \mathrm{yr}$

(a) Includes releases from $\mathrm{N}$ Springs $(0.072 \mathrm{Ci})$ and the 1908-K Outfall (0.00054 Ci).

(b) Releases from the 1908-K Outfall. 


\subsubsection{Nonradioactive Hazardous Materials in Liquid Effluents}

Nonradioactive hazardous materials in liquid effluents are monitored in the 100, 200, 300, and 400 Areas. These effluents are discharged to the State-Approved Land Disposal Site and the Columbia River. Effluents entering the environment at designated discharge points are sampled and analyzed to determine compliance with the National Pollutant Discharge Elimination System permits and the state waste discharge permits for the site (40 CFR 122 and WAC 173-216). Should chemicals in liquid effluents exceed quantities reportable under CERCLA, the release totals are reported immediately to the EPA. If emissions remain stable at predicted levels, they may be reported annually with the EPA's permission. A synopsis of the National Pollutant Discharge Elimination System and state waste discharge permit violations in 1999 is given in Section 2.2.8, "Clean Water Act."

Liquid waste containing both radioactive and hazardous constituents is stored at the 200 Areas in underground waste storage tanks or monitored interim storage facilities.

\subsubsection{CERCLA and WAC Chemical Releases}

Reportable releases include spills or discharges of hazardous substances or dangerous wastes to the environment, other than releases permitted under state or federal law. These releases almost entirely consist of accidental spills. Releases of hazardous substances exceeding specified quantities that are continuous and stable in quantity and rate must be reported as required by Section 103(f)(2) of CERCLA.

Spills or nonpermitted discharges of dangerous wastes or hazardous substances to the environment are required to be reported (WAC 173-303-145).
This requirement applies to spills or discharges onto the ground, into the groundwater, into surface water, or into the air such that human health or the environment is threatened, regardless of the quantity of dangerous waste or hazardous substance.

There were seven releases reported under CERCLA reportable quantities or WAC 173-303145 requirements by Hanford Site contractors in 1999. Table 3.1.5 contains a synopsis of these reportable releases. 


\begin{tabular}{|c|c|c|}
\hline \multirow[b]{2}{*}{ Material } & \multicolumn{2}{|c|}{ Table 3.1.5. Releases to the Environment at the Hanford Site, 1999} \\
\hline & Quantity & Location \\
\hline Radioactive air & $8.5 \mathrm{E}-12 \mu \mathrm{Ci} / \mathrm{ml}$ of plutonium & $\begin{array}{l}\text { 291-Z-1 stack ( } 200-\text { West Area), fixed contamination } \\
\text { release during high wind, conservative estimate made }\end{array}$ \\
\hline Chlorine gas & Detectable & $\begin{array}{l}283 \text { Water Filter Plant (200-East Area), high alarm } \\
\text { annunciated during changeout of chlorine gas cylinder, } \\
\text { vented to atmosphere }\end{array}$ \\
\hline Radioactive water & 7.7 to $11.5 \mathrm{~kg}$ & $\begin{array}{l}\text { SX Tank Farm Complex (200-West Area), contaminated } \\
\text { water accidentally released from contaminated, bagged, } \\
\text { equipment }\end{array}$ \\
\hline Radioactive air & $\begin{array}{l}\text { Undetermined amount of } \\
\text { strontium-90 } \\
\text { Gross alpha } 2.02 \mathrm{E}-12 \mu \mathrm{Ci} / \mathrm{ml} \\
\text { Gross beta } 3.77 \mathrm{E}-10 \mu \mathrm{Ci} / \mathrm{ml}\end{array}$ & $\begin{array}{l}\text { 241-U Tank Farm Complex (200-West Area), job specific } \\
\text { air sampler indicated release of strontium-90 }\end{array}$ \\
\hline Radioactive air & $\begin{array}{l}\text { Undetermined amount of } \\
\text { strontium-90 } \\
\text { Gross alpha } 5.6 \mathrm{E}-13 \mu \mathrm{Ci} / \mathrm{ml} \\
\text { Gross beta } 2.53 \mathrm{E}-10 \mu \mathrm{Ci} / \mathrm{ml}\end{array}$ & $\begin{array}{l}\text { AY-AZ Tank Farm Complex ( } 200 \text {-East Area), job specific } \\
\text { air sampler indicated release of strontium- } 90\end{array}$ \\
\hline Radioactive air & Undetermined & $\begin{array}{l}\text { 241-U Tank Farm Complex (200-West Area), air leak } \\
\text { discovered in plastic bag around piping }\end{array}$ \\
\hline Radioactive air & Undetermined & $\begin{array}{l}\text { B Plant (200-East Area), radioactive air release during } \\
\text { stack filter changeout }\end{array}$ \\
\hline
\end{tabular}




\title{
3.2 Near-Facility Environmental Monitoring
}

\author{
C. J. Perkins, B. M. M arkes, S. M. M cKinney, R. M. M itchell, and R. C. Roos
}

Near-facility (near-field) environmental monitoring is defined as routine monitoring near facilities that have potential to discharge, or have discharged, stored, or disposed of radioactive or hazardous contaminants. Monitoring locations are associated with nuclear facilities such as the Plutonium Finishing Plant and the $\mathrm{K}$ Basins; inactive nuclear facilities such as N Reactor and Plutonium-Uranium Extraction Plant; and waste storage or disposal facilities such as burial grounds, cribs, ditches, ponds, tank farms, and trenches.

Much of the monitoring program consists of collecting and analyzing environmental samples and methodically surveying areas near facilities releasing effluents and waste streams. The program is also designed to evaluate acquired analytical data, determine the effectiveness of facility effluent monitoring and controls, measure the adequacy of containment at waste disposal units, and detect and monitor unusual conditions. The program implements applicable portions of DOE Orders 435.1, 5400.1, 5400.5, and 5484.1; 10 CFR 835 and 40 CFR 61; and WAC 246-247.

Near Hanford Site facilities, several types of environmental media are sampled, and various radiological and nonradiological measurements are taken to monitor the effectiveness of effluent treatment and control practices, diffuse source emissions, and contamination control in waste management and restoration activities. These include air, surface and spring water, surface contamination, soil and vegetation, external radiation, and investigative samples (which can include wildlife). Samples are collected from known or expected effluent pathways. These pathways are generally downwind of potential or actual airborne releases and downgradient of liquid discharges.

Active and inactive waste disposal sites and the terrain surrounding them are surveyed to detect and characterize radioactive surface contamination. Routine survey locations include cribs, trenches, retention basin perimeters, pond perimeters, ditch banks, solid waste disposal sites (e.g., burial grounds), unplanned release sites, tank farm perimeters, stabilized waste disposal sites, roads, and firebreaks in and around the site operational areas.

Sampling and analysis information and analytical results for 1999 are summarized in the following sections. Additional data may be found in $\mathrm{H}$ anford Site $\mathrm{N}$ ear- $\mathrm{F}$ acility Environmental $\mathrm{M}$ onitoring $\mathrm{D}$ ata Report for Calendar Year 1999 (PNNL-13230, APP. 2). Near-facility monitoring in 1999 is summarized in Table 3.2.1, which shows the type, quantity, and general location of samples collected.

\subsubsection{Air Monitoring}

Monitoring for radioactivity in air near Hanford Site facilities used a network of continuously operating samplers at 85 locations (Table 3.2.2) (sampling locations illustrated in PNNL-13230, APP. 2). Air

samplers were located primarily at or within $\sim 500$ meters $(1,500$ feet $)$ of sites and/or facilities having the potential for, or history of, environmental releases, with an emphasis on the prevailing 


\section{Table 3.2.1. Near-Facility Routine Environmental Monitoring Samples and Locations, 1999}

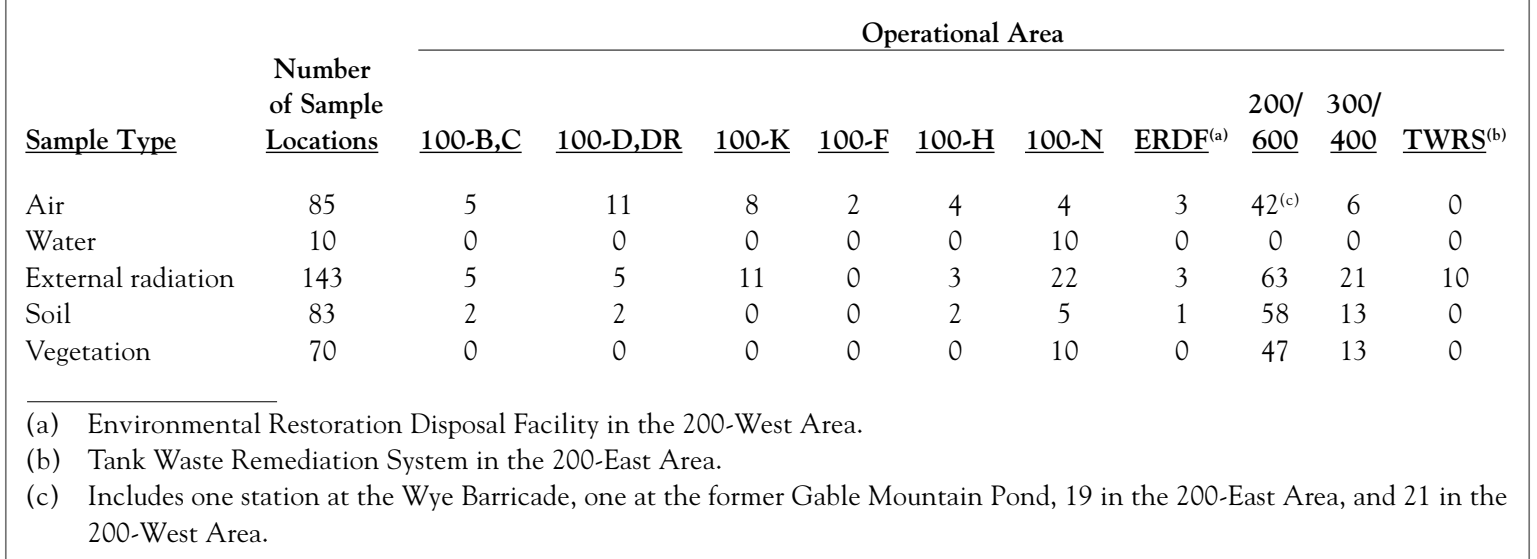

downwind direction. To avoid duplication of sampling, air data for the 300 and 400 Areas, some onsite remediation projects, and some offsite distant locations were obtained from existing Pacific Northwest National Laboratory air sampling stations.

Samples were collected according to a schedule established before the 1999 monitoring year. Airborne particles were sampled at each of these stations by drawing air through a glass-fiber filter. The filters were collected biweekly, field surveyed for gross radioactivity, held for at least 7 days, and then analyzed for gross alpha and beta activity. The 7-day holding period was necessary to allow for the decay of naturally occurring radionuclides that would otherwise obscure detection of longer-lived radionuclides associated with emissions from nuclear facilities. The gross radioactivity measurements were used to indicate changes in trends in the near-facility environment.

For most specific radionuclide analyses, the amount of radioactive material collected on a single filter during a 2-week period was too small to be measured accurately. The accuracy of the sample analysis was increased by compositing the samples into biannual samples for each location.

Figure 3.2.1 shows the average concentrations of selected radionuclides in the 100 and 200/600 Areas compared to the DOE derived concentration guides and air samples measured in distant communities. The DOE derived concentration guides (DOE Order 5400.5) are reference values that are used as indexes of performance. The data indicate a large degree of variability. Air samples collected from areas located at or directly adjacent to Hanford Site facilities had higher concentrations than did those samples collected farther away. In general, analytical results for most radionuclides were at or near Hanford Site background levels and much less than the DOE derived concentration guides. In all areas, the data also show that concentrations of certain radionuclides were higher within different operational areas. Table 3.2.3 shows the annual average and maximum concentration of radionuclides in near-facility air samples during 1999.

The 1999 analytical results for the 100-B,C, $100-\mathrm{D}$, and $100-\mathrm{H}$ Areas remedial action projects generally indicated that for most radionuclides, concentrations were greater than levels measured off the site. The levels of strontium-90 at the 100-B,C site were noticeably higher than the offsite levels and were the highest measured on site in 1999. At the 100-B,C project, ambient air monitoring locations included one upwind Pacific Northwest National Laboratory sampler at the Yakima Barricade and five 


\begin{tabular}{|c|c|c|c|c|}
\hline \multicolumn{4}{|c|}{ Table 3.2.2. Near-Facility Air Sampling Locations and Analyses, 1999} & \\
\hline \multirow{2}{*}{\multicolumn{2}{|c|}{$\begin{array}{l}\text { Number of } \\
\underline{\text { Samplers }}\end{array}$}} & \multirow[b]{2}{*}{$\underline{\text { EDP Code }}^{(\mathrm{a})}$} & Analyses & \\
\hline & & & $\underline{\text { Biweekly }}$ & Composite \\
\hline $\begin{array}{l}\text { 100-B,C remedial action } \\
\text { project }\end{array}$ & 5 & $\begin{array}{l}\text { N464, N465, N466, N496, } \\
\text { N497 }\end{array}$ & $\begin{array}{l}\text { Gross alpha, } \\
\text { gross beta }\end{array}$ & $\begin{array}{l}\text { GEA, }{ }^{(b)} \mathrm{Sr}-90, \mathrm{Pu} \text {-iso, }{ }^{(\mathrm{c})} \\
\mathrm{U}^{- \text {iso }^{(\mathrm{d})}}\end{array}$ \\
\hline $\begin{array}{l}100-\mathrm{D} \text { remedial action } \\
\text { project }\end{array}$ & 9 & $\begin{array}{l}\text { N467, N468, N469, N470, } \\
\text { N511, N512, N513, N514, } \\
\text { N515 }\end{array}$ & $\begin{array}{l}\text { Gross alpha, } \\
\text { gross beta }\end{array}$ & $\begin{array}{l}\text { GEA, Sr-90, Pu-iso, } \\
\text { U-iso }\end{array}$ \\
\hline $\begin{array}{l}100-\mathrm{DR} \text { interim safe storage } \\
\text { project }\end{array}$ & 2 & N492, N493 & $\begin{array}{l}\text { Gross alpha, } \\
\text { gross beta }\end{array}$ & $\begin{array}{l}\text { GEA, Sr-90, Pu-iso, } \\
\text { U-iso }\end{array}$ \\
\hline $\begin{array}{l}100-\mathrm{F} \text { interim safe storage } \\
\text { project }\end{array}$ & 2 & N494, N495 & $\begin{array}{l}\text { Gross alpha, } \\
\text { gross beta }\end{array}$ & $\begin{array}{l}\text { GEA, Sr-90, Pu-iso, } \\
\text { U-iso }\end{array}$ \\
\hline $\begin{array}{l}100-\mathrm{H} \text { remedial action } \\
\text { project }\end{array}$ & 4 & N507, N508, N509, N510 & $\begin{array}{l}\text { Gross alpha } \\
\text { gross beta }\end{array}$ & $\begin{array}{l}\text { GEA, Sr-90, Pu-iso, } \\
\text { U-iso }\end{array}$ \\
\hline $100-\mathrm{K}$ spent nuclear fuels & 8 & $\begin{array}{l}\text { N401, N402, N403, N404, } \\
\text { N476, N477, N478, N479 }\end{array}$ & $\begin{array}{l}\text { Gross alpha, } \\
\text { gross beta }\end{array}$ & $\begin{array}{l}\text { GEA, } \mathrm{Sr}-90, \mathrm{Pu} \text {-iso, } \\
\text { U-iso, } \mathrm{Pu}-241, \mathrm{Am}-241\end{array}$ \\
\hline $\begin{array}{l}100-\mathrm{N} \text { surveillance and } \\
\text { maintenance/transition }\end{array}$ & 4 & N102, N103, N105, N106 & $\begin{array}{l}\text { Gross alpha, } \\
\text { gross beta }\end{array}$ & $\begin{array}{l}\text { GEA, Sr-90, Pu-iso, } \\
\text { U-iso }\end{array}$ \\
\hline 200-East Area & 17 & $\begin{array}{l}\text { N019, N158, N498, N499, } \\
\text { N957, N967, N968, N969, } \\
\text { N970, N972, N973, N976, } \\
\text { N977, N978, N984, N985, } \\
\text { N999 }\end{array}$ & $\begin{array}{l}\text { Gross alpha, } \\
\text { gross beta }\end{array}$ & $\begin{array}{l}\text { GEA, Sr-90, Pu-iso, } \\
\text { U-iso }\end{array}$ \\
\hline $\begin{array}{l}\text { Canister Storage Building, } \\
\text { 200-East Area }\end{array}$ & 2 & N480, N481 & $\begin{array}{l}\text { Gross alpha, } \\
\text { gross beta }\end{array}$ & $\begin{array}{l}\text { GEA, Sr-90, Pu-iso, } \\
\text { U-iso, Pu-241, Am-241 }\end{array}$ \\
\hline 200-West Area & 21 & $\begin{array}{l}\text { N155, N161, N165, N168, } \\
\text { N200, N304, N433, N441, } \\
\text { N442, N449, N456, N457, } \\
\text { N956, N963, N964, N965, } \\
\text { N966, N974, N975, N987, } \\
\text { N994 }\end{array}$ & $\begin{array}{l}\text { Gross alpha, } \\
\text { gross beta }\end{array}$ & $\begin{array}{l}\text { GEA, Sr-90, Pu-iso, } \\
\text { U-iso }\end{array}$ \\
\hline $\begin{array}{l}\text { 300-FF- } 1 \text { remedial action } \\
\text { project ( } 300 \text { Area) }\end{array}$ & 6 & $\begin{array}{l}\text { N130, N485, N486, N487, } \\
\text { N488, N489 }\end{array}$ & $\begin{array}{l}\text { Gross alpha, } \\
\text { gross beta }\end{array}$ & GEA, U-iso \\
\hline 600 Area & 1 & N981 & $\begin{array}{l}\text { Gross alpha, } \\
\text { gross beta }\end{array}$ & $\begin{array}{l}\text { GEA, Sr-90, Pu-iso, } \\
\text { U-iso }\end{array}$ \\
\hline $\begin{array}{l}\text { Former Gable Mountain } \\
\text { Pond }\end{array}$ & 1 & N516 & $\begin{array}{l}\text { Gross alpha, } \\
\text { gross beta }\end{array}$ & $\begin{array}{l}\text { GEA, Sr-90, Pu-iso, } \\
\text { U-iso }\end{array}$ \\
\hline $\begin{array}{l}\text { Environmental Restoration } \\
\text { Disposal Facility }\end{array}$ & 3 & N482, N483, N484 & $\begin{array}{l}\text { Gross alpha, } \\
\text { gross beta }\end{array}$ & $\begin{array}{l}\text { GEA, Sr-90, Pu-iso, } \\
\text { U-iso }\end{array}$ \\
\hline \multicolumn{5}{|c|}{$\begin{array}{l}\text { (a) EDP Code = Sampler location code. See PNNL-13230, APP. } 2 . \\
\text { (b) GEA = Gamma energy analysis. } \\
\text { (c) Isotopic plutonium-238 and }-239 / 240 . \\
\text { (d) Isotopic uranium-234, }-235 \text {, and }-238 .\end{array}$} \\
\hline
\end{tabular}



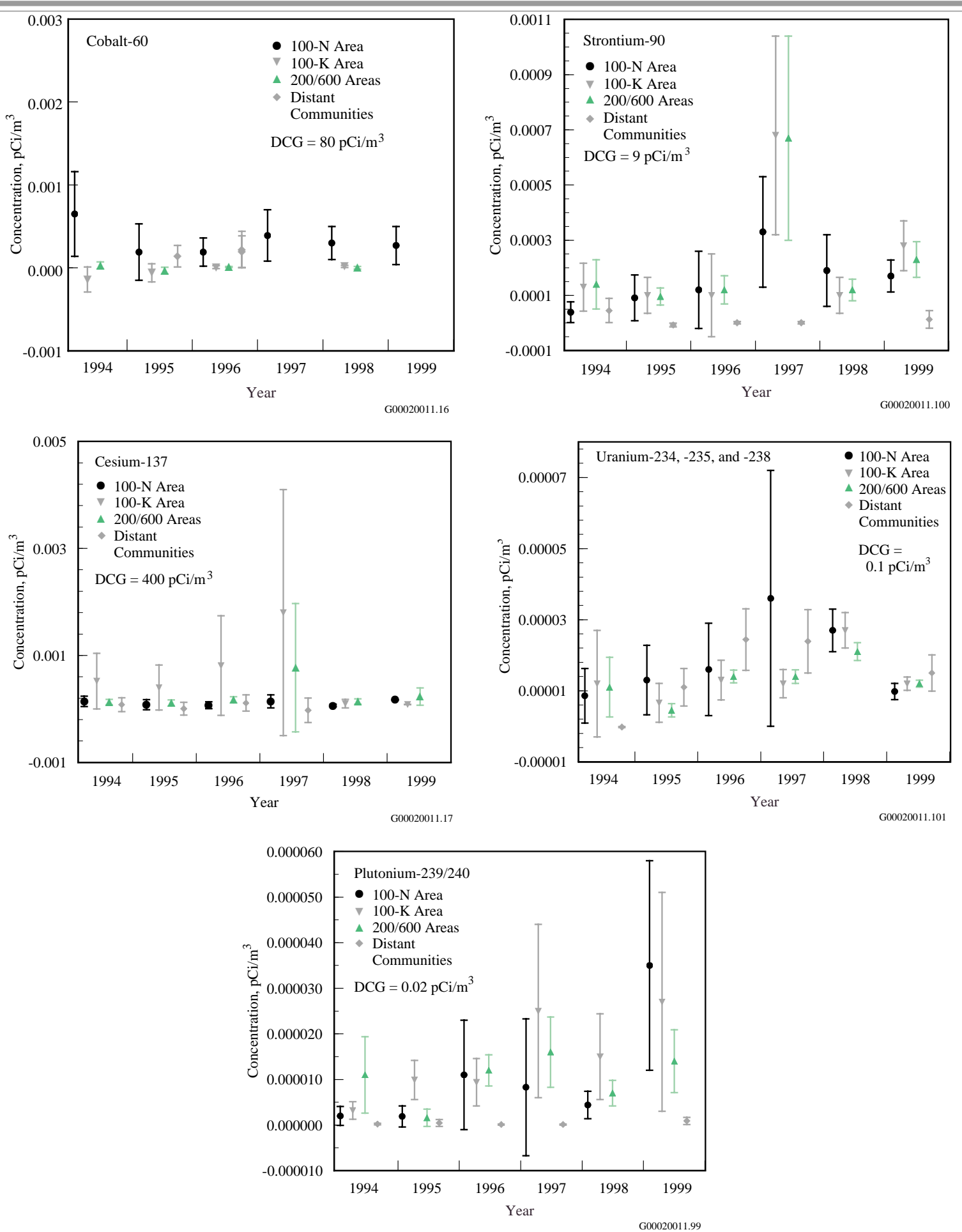

Figure 3.2.1. Average Concentration ( \pm 2 standard error of the mean) of Selected Radionuclides in Near-Facility Air Samples Compared to Those in Distant Communities, 1994 Through 1999. As a result of figure scale, some uncertainties (error bars) are concealed by point symbol. Cobalt-60 was not detected in the 100-K or 200/600 Areas in 1999. DCG = Derived concentration guide (DOE Order 5400.5). 


\begin{tabular}{|c|c|c|c|c|c|c|c|}
\hline \multicolumn{8}{|c|}{$\begin{array}{l}\text { Table 3.2.3. Annual Average and Maximum Concentrations }\left(\mathrm{aCi} / \mathrm{m}^{3}\right) \text { of Radionuclides in } \\
\text { Near-Facility Air Samples, } 1999\end{array}$} \\
\hline \multicolumn{4}{|c|}{ Cobalt-60 } & \multicolumn{4}{|c|}{ Uranium-234 } \\
\hline Site & A verage $^{(a)}$ & Maximum $^{(\mathbf{b})}$ & $\underline{E D P}$ Code $^{(\mathrm{c})}$ & Site & Average $^{(\mathrm{a})}$ & Maximum $^{(\mathbf{b})}$ & EDP Code ${ }^{(\mathrm{c})}$ \\
\hline$\overline{100-B, C}$ & $8.8 \pm 25.2$ & $\overline{36 \pm 360}$ & $\mathrm{~N} 465$ & $\overline{100-B, C}$ & $36 \pm 21$ & $56 \pm 35.3$ & $\mathrm{~N} 464$ \\
\hline 100-D & $32.2 \pm 31.6$ & $110 \pm 94.6$ & N470 & 100-D & $23 \pm 6.1$ & $41 \pm 21.7$ & N511 \\
\hline $100-\mathrm{F} / \mathrm{DR}$ & $11 \pm 39$ & $150 \pm 210$ & $\mathrm{~N} 493$ & $100-\mathrm{F} / \mathrm{DR}$ & $31 \pm 9.8$ & $38 \pm 19$ & $\mathrm{~N} 493$ \\
\hline $100-\mathrm{H}$ & $19.7 \pm 19.4$ & $66 \pm 73.3$ & N509 & $100-\mathrm{H}$ & $21 \pm 8.9$ & $36 \pm 15.5$ & N507 \\
\hline $100-\mathrm{K}$ & $6.7 \pm 20.8$ & $110 \pm 100.1$ & N478 & $100-K$ & $17 \pm 4$ & $31 \pm 13.3$ & $\mathrm{~N} 403$ \\
\hline $100-\mathrm{N}$ & $270 \pm 230$ & $300 \pm 189$ & N105 & $100-\mathrm{N}$ & $16 \pm 4.8$ & $20 \pm 8.2$ & N105 \\
\hline 200-East & $-5.5 \pm 15.1$ & $75 \pm 90$ & N976 & 200-East & $17 \pm 2.7$ & $38 \pm 15.2$ & N158 \\
\hline 200-West & $170 \pm 134.3$ & $170 \pm 134.3$ & N168 & 200-West & $17 \pm 2.3$ & $40 \pm 16.4$ & N155 \\
\hline $300-F F-1^{(d)}$ & $-6.5 \pm 13.3$ & $37 \pm 67$ & N485 & $300-\mathrm{FF}-1^{(\mathrm{d})}$ & $96 \pm 62$ & $370 \pm 118.4$ & $\mathrm{~N} 487$ \\
\hline $\mathrm{ERDF}^{(\mathrm{e})}$ & $32.4 \pm 26.9$ & $83 \pm 78.9$ & $\mathrm{~N} 483$ & $\mathrm{ERDF}^{(\mathrm{e})}$ & $22 \pm 11$ & $35 \pm 14.4$ & $\mathrm{~N} 484$ \\
\hline Former Gable & & & & Former Gable & & & \\
\hline Mtn Pond & $200 \pm 440$ & $200 \pm 440$ & N516 & Mtn Pond & $85 \pm 48$ & $85 \pm 48$ & N516 \\
\hline $\begin{array}{l}\text { Distant } \\
\text { community }^{(f)}\end{array}$ & $-52 \pm 134$ & $234 \pm 690$ & & $\begin{array}{l}\text { Distant } \\
\text { community }^{(f)}\end{array}$ & $23 \pm 7$ & $41 \pm 15$ & \\
\hline $\mathrm{DCG}^{(\mathrm{g})}$ & & $80,000,000$ & & $\mathrm{DCG}^{(\mathrm{g})}$ & & 90,000 & \\
\hline \multicolumn{4}{|c|}{$\underline{\text { Strontium-90 }}$} & \multicolumn{4}{|c|}{$\underline{\text { Uranium-235 }}$} \\
\hline Site & Average $^{(a)}$ & Maximum $^{(\mathbf{b})}$ & EDP Code ${ }^{(c)}$ & $\underline{\text { Site }}$ & Average $^{(\mathrm{a})}$ & $\underline{\text { Maximum }}^{(\mathrm{b})}$ & EDP Code \\
\hline $100-B, C$ & $910 \pm 1,400$ & $\overline{2,100 \pm 903}$ & $\mathrm{~N} 465$ & $100-B, C$ & $26 \pm 17$ & $33 \pm 25.4$ & N464 \\
\hline $100-\mathrm{D}$ & $250 \pm 130$ & $520 \pm 156$ & N514 & $100-\mathrm{D}$ & $8 \pm 3.5$ & $11 \pm 6.9$ & $\mathrm{~N} 467$ \\
\hline $100-F / D R$ & $310 \pm 130$ & $410 \pm 205$ & $\mathrm{~N} 494$ & $100-\mathrm{F} / \mathrm{DR}$ & $16 \pm 8$ & $34 \pm 19$ & $\mathrm{~N} 492$ \\
\hline $100-\mathrm{H}$ & $230 \pm 210$ & $310 \pm 124$ & N509 & $100-\mathrm{H}$ & $12 \pm 16$ & $12 \pm 8$ & N507 \\
\hline $100-\mathrm{K}$ & $280 \pm 90$ & $410 \pm 123$ & N479 & $100-\mathrm{K}$ & $8.4 \pm 2.9$ & $13 \pm 8.2$ & N477 \\
\hline $100-\mathrm{N}$ & $170 \pm 58$ & $250 \pm 100$ & N102 & $100-\mathrm{N}$ & $5.3 \pm 7.6$ & $5.8 \pm 4.2$ & N106 \\
\hline 200-East & $230 \pm 65$ & $1,000 \pm 250$ & N969 & 200-East & $10 \pm 4.2$ & $40 \pm 19.6$ & N499 \\
\hline 200-West & $270 \pm 57$ & $620 \pm 248$ & N165 & 200-West & $9.6 \pm 2.4$ & $27 \pm 11.9$ & N956 \\
\hline $300-F F-1^{(d)}$ & $140 \pm 140$ & $140 \pm 98$ & N130 & $300-\mathrm{FF}-1^{\text {(d) }}$ & $37 \pm 33$ & $150 \pm 52.5$ & $\mathrm{~N} 487$ \\
\hline $\mathrm{ERDF}^{(e)}$ & $220 \pm 310$ & $240 \pm 96$ & $\mathrm{~N} 483$ & $\mathrm{ERDF}^{(\mathrm{e})}$ & $8.7 \pm 5.1$ & $14 \pm 7.4$ & $\mathrm{~N} 484$ \\
\hline Former Gable & & & & Former Gable & & & \\
\hline Mtn Pond & $170 \pm 559$ & $170 \pm 559.3$ & N516 & Mtn Pond & $31 \pm 31$ & $31 \pm 31$ & N516 \\
\hline $\begin{array}{l}\text { Distant } \\
\text { community }^{(f)} \\
\text { DCG }^{(g)}\end{array}$ & $13 \pm 32$ & $\begin{array}{c}79 \pm 37 \\
9,000,000\end{array}$ & & $\begin{array}{l}\text { Distant } \\
\text { community }^{(f)} \\
\text { DCG }^{(g)}\end{array}$ & $0.6 \pm 1.7$ & $\begin{array}{c}6.2 \pm 6.3 \\
100,000\end{array}$ & \\
\hline \multicolumn{4}{|c|}{ Cesium-137 } & \multicolumn{4}{|c|}{ Uranium-238 } \\
\hline Site & A verage $^{(a)}$ & Maximum $^{(\mathbf{b})}$ & EDP Code ${ }^{(c)}$ & Site & Average $^{(\mathrm{a})}$ & Maximum $^{(\mathbf{b})}$ & EDP Code ${ }^{(c)}$ \\
\hline $100-B, C$ & $68 \pm 192.5$ & $420 \pm 462$ & N464 & $100-B, C$ & $35 \pm 35$ & $96 \pm 48$ & N464 \\
\hline 100-D & $170 \pm 150$ & $210 \pm 77.7$ & N470 & $100-\mathrm{D}$ & $19 \pm 5.7$ & $36 \pm 19.8$ & N511 \\
\hline $100-\mathrm{F} / \mathrm{DR}$ & $54.5 \pm 46.4$ & $230 \pm 140.3$ & N495 & $100-\mathrm{F} / \mathrm{DR}$ & $20 \pm 6.6$ & $26 \pm 13.8$ & N492 \\
\hline $100-\mathrm{H}$ & $170 \pm 92$ & $170 \pm 92$ & N509 & $100-\mathrm{H}$ & $14 \pm 4.4$ & $18 \pm 9.5$ & N507 \\
\hline $100-\mathrm{K}$ & $84 \pm 61$ & $84 \pm 61$ & $\mathrm{~N} 402$ & $100-K$ & $12 \pm 2.3$ & $18 \pm 8.8$ & $\mathrm{~N} 403$ \\
\hline $100-\mathrm{N}$ & $170 \pm 85$ & $170 \pm 85$ & N105 & $100-\mathrm{N}$ & $10 \pm 3.4$ & $13 \pm 6.9$ & N106 \\
\hline 200-East & $230 \pm 160$ & $320 \pm 128$ & N158 & 200-East & $14 \pm 1.5$ & $25 \pm 11$ & $\mathrm{~N} 480$ \\
\hline 200-West & $290 \pm 120$ & $600 \pm 156$ & N155 & 200-West & $13 \pm 2.1$ & $32 \pm 14.1$ & N155 \\
\hline $300-F F-1^{(d)}$ & $160 \pm 110$ & $160 \pm 110.4$ & $\mathrm{~N} 489$ & $300-F F-1^{(\mathrm{d})}$ & $53 \pm 24$ & $140 \pm 49$ & N487 \\
\hline $\mathrm{ERDF}^{(\mathrm{e})}$ & $19.4 \pm 19.3$ & $52 \pm 61.9$ & $\mathrm{~N} 484$ & $\mathrm{ERDF}^{(\mathrm{e})}$ & $19 \pm 8.6$ & $26 \pm 11.7$ & N483 \\
\hline Former Gable & & & & Former Gable & & & \\
\hline Mtn Pond & $-130 \pm 360$ & $-130 \pm 360.1$ & N516 & Mtn Pond & $68 \pm 46$ & $68 \pm 46$ & N516 \\
\hline $\begin{array}{l}\text { Distant } \\
\text { community } \\
\text { DCG }^{(f)}\end{array}$ & $13 \pm 218$ & $\begin{array}{c}390 \pm 580 \\
400,000,000\end{array}$ & & $\begin{array}{l}\text { Distant } \\
\text { community }^{(f)} \\
\text { DCG }^{(g)}\end{array}$ & $22 \pm 5$ & $\begin{array}{l}33 \pm 15 \\
100,000\end{array}$ & \\
\hline
\end{tabular}




\section{Table 3.2.3. (contd)}

\begin{tabular}{|c|c|c|c|c|c|c|c|}
\hline \multicolumn{4}{|c|}{ Plutonium-238 } & \multicolumn{4}{|c|}{ Plutonium-241 } \\
\hline Site & Average $^{(a)}$ & $\underline{\text { Maximum }}^{(\mathbf{b})}$ & $\underline{E D P ~ C o d e}^{(c)}$ & Site & A verage $^{(a)}$ & $\underline{\text { Maximum }}^{(\mathbf{b})}$ & $\underline{E D P ~ C o d e}^{(c)}$ \\
\hline$\overline{100}-\mathrm{B}, \mathrm{C}$ & $39 \pm 23$ & $39 \pm 23$ & N496 & $100-K$ & $1,300 \pm 325$ & $1,300 \pm 325$ & N403 \\
\hline $100-D$ & $5.6 \pm 4.9$ & $19 \pm 16.9$ & N512 & 200-East & $5 \pm 890.3$ & $810 \pm 202.5$ & N480 \\
\hline $100-\mathrm{F} / \mathrm{DR}$ & $-0.2 \pm 4.7$ & $14 \pm 23.9$ & N492 & Distant & & & \\
\hline $100-\mathrm{H}$ & $-1.4 \pm 8.9$ & $20 \pm 19$ & N510 & community $^{(\mathrm{f})}$ & & Not reported & \\
\hline $100-K$ & $0.2 \pm 2.9$ & $10 \pm 20$ & N478 & $\mathrm{DCG}^{(\mathrm{g})}$ & & $1,000,000$ & \\
\hline $100-\mathrm{N}$ & $2.5 \pm 5.1$ & $10 \pm 11$ & N105 & & & & \\
\hline 200-East & $19 \pm 28$ & $23 \pm 16.6$ & N969 & \multirow{2}{*}{\multicolumn{4}{|c|}{ Americium-241 }} \\
\hline 200-West & $2.1 \pm 2$ & $18 \pm 14$ & N964 & & & & \\
\hline $300-F F-1^{(d)}$ & $2.3 \pm 0.5$ & $2.5 \pm 7.7$ & N130 & Site & Average $^{(a)}$ & Maximum $^{(\mathrm{b})}$ & $\underline{E D P ~ C o d e}^{(c)}$ \\
\hline \multirow{2}{*}{$\begin{array}{l}\text { ERDF }^{(\mathrm{e})} \\
\text { Former Gable }\end{array}$} & $4.9 \pm 3.4$ & $11 \pm 11$ & N484 & $100-\mathrm{K}$ & $29 \pm 6.8$ & $43 \pm 22.8$ & N403 \\
\hline & & & & 200-East & $25 \pm 37$ & $29 \pm 14.5$ & N481 \\
\hline $\begin{array}{l}\text { Mtn Pond } \\
\text { Distant } \\
\text { community }^{(f)} \\
\text { DCG }^{(\mathrm{g})}\end{array}$ & $\begin{array}{l}-55 \pm 66 \\
-0.3 \pm 0.2\end{array}$ & $\begin{array}{c}-55 \pm 66 \\
0.2 \pm 1.2 \\
30,000\end{array}$ & N516 & $\begin{array}{l}\text { Distant } \\
\text { community }^{(f)} \\
\text { DCG }^{(\mathrm{g})}\end{array}$ & & $\begin{array}{c}\text { Not reported } \\
20,000\end{array}$ & \\
\hline & Plutoniu & $-239 / 240$ & & & & & \\
\hline Site & A verage $^{(\mathrm{a})}$ & Maximum $^{(\mathbf{b})}$ & EDP Code ${ }^{(\mathrm{c})}$ & & & & \\
\hline $100-B, C$ & $16 \pm 9.1$ & $16 \pm 9.1$ & N466 & & & & \\
\hline $100-\mathrm{D}$ & $14 \pm 8.6$ & $38 \pm 16$ & N470 & & & & \\
\hline $100-\mathrm{F} / \mathrm{DR}$ & $30 \pm 39$ & $61 \pm 27.5$ & N492 & & & & \\
\hline $100-\mathrm{H}$ & $8.2 \pm 7.8$ & $12 \pm 7.2$ & N507 & & & & \\
\hline $100-K$ & $27 \pm 24$ & $100 \pm 35$ & N403 & & & & \\
\hline $100-\mathrm{N}$ & $35 \pm 23$ & $82 \pm 29.5$ & N103 & & & & \\
\hline 200-East & $14 \pm 6.9$ & $64 \pm 23.7$ & N158 & & & & \\
\hline 200-West & $23 \pm 8.3$ & $100 \pm 35$ & N161 & & & & \\
\hline $300-F F-1^{(d)}$ & $12 \pm 17$ & $12 \pm 6.8$ & N130 & & & & \\
\hline $\mathrm{ERDF}^{(\mathrm{e})}$ & $6.2 \pm 2.2$ & $9.6 \pm 6$ & N482 & & & & \\
\hline Former Gable & & & & & & & \\
\hline Mtn Pond & $4.2 \pm 19$ & $4.2 \pm 19$ & N516 & & & & \\
\hline $\begin{array}{l}\text { Distant } \\
\text { community }^{(f)} \\
\text { DCG }^{(g)}\end{array}$ & $0.9 \pm 0.8$ & $\begin{array}{c}3.2 \pm 2.9 \\
20,000\end{array}$ & & & & & \\
\hline $\begin{array}{l}\text { (a) } \pm 2 \text { stand } \\
\text { the overa }\end{array}$ & $\begin{array}{l}\text { error of the me } \\
\text { nalytical error. }\end{array}$ & , except for data $\mathrm{p}$ & points that repres & gle value above de & ection limits. $\mathrm{F}$ & r these, the unce & tainty value is \\
\hline (b) \pm overall & alytical error. & & & & & & \\
\hline (c) Sampler 1 & tion code. Se & NNL-13230, APP & P. 2. & & & & \\
\hline (d) 300 Area & & & & & & & \\
\hline (e) $\quad \mathrm{ERDF}=\mathrm{I}$ & ironmental Re & oration Disposal Fa & Facility. & & & & \\
\hline (f) See Secti & 4.1, "Air Surve & lance." & & & & & \\
\hline (g) DOE Der & d Concentratic & Guide. & & & & & \\
\hline
\end{tabular}

project-specific downwind samplers. Remedial action activities for fiscal year 1999 were completed at the 100-B,C site and ambient air monitoring ended in May. At the 100-D Area, ambient air monitoring locations included nine samplers. Eight samplers, four of which were added in August 1999 to accommodate expanded activities, were dedicated to the remedial action project. One other sampler, dedicated to the 100-D stack demolition project, was in service from the end of July through the end of September 1999. At the 100-H Area, ambient air monitoring locations included four project-specific samplers, one upwind and three downwind. Consistently detectable radionuclides at the $100-\mathrm{H}$ project were strontium-90 and uranium-234, and -238 . Plutonium-239/240 was occasionally detectable. 
Two samplers for each of the 100-F and DR interim safe storage projects were in operation in 1999. The quarterly analytical results from both projects indicated that the strontium-90 concentrations were slightly greater than levels measured off the site. Consistently detectable radionuclides were uranium-234, -235 , and -238. Plutonium-239/240 was occasionally detectable.

The airborne contaminant levels in the $100-\mathrm{K}$ Area were greater than levels measured off the site. Facility emissions in the 100-K Area decreased substantially in 1996, and subsequent radionuclide concentrations in the ambient air samples have been near detection limits. Consistently detectable radionuclides were uranium-234, -238, and americium241. Occasionally detectable radionuclides included strontium-90, uranium-235, and plutonium-239/240.

Analytical results from ambient air samples taken from the 100-N Area were greater than levels measured off the site. Consistently detectable radionuclides were strontium-90, uranium-234, -238 , and plutonium-239/240. Occasionally detectable radionuclides were cobalt-60 and uranium-235.

Radionuclide levels measured in the 200-East Area were greater than those measured off the site. Consistently detectable radionuclides were strontium90 and uranium-234 and -238. Occasionally detectable radionuclides were cesium-137, uranium-235, and plutonium-239/240.

Radionuclides levels measured in the 200-West Area were also greater than those measured off the site. Consistently detectable radionuclides were strontium-90, uranium-234, -235, and -238 , and plutonium-239/240. Cesium-137 was occasionally detectable.

Ambient air monitoring at the $300-F F-1$ operable unit remedial action project included one nearfacility monitoring upwind location at the nearby
300 Area Treated Effluent Disposal Facility; two Pacific Northwest National Laboratory upwind monitors in the 300 Area (stations \#14 "300 Trench" and \#15 “300 NE;" see Section 4.1, "Air Surveillance”); and five downwind, project-specific air monitors. The analytical results indicated that radionuclide concentrations in air samples collected at this site were much less than the DOE derived concentration guides but greater than levels measured off the site. The only consistently detectable radionuclides were uranium-234, -235 , and -238 .

The air sampling network at the Environmental Restoration Disposal Facility (200-West Area) used two existing Hanford Site monitors for upwind monitoring and three additional air monitors that provided downwind coverage. The 1999 analytical results indicated that the activities were only slightly greater than levels measured off the site. The only consistently detectable radionuclides were uranium234, -235, and -238, and plutonium-239/240. Strontium-90 was occasionally detectable.

Air monitoring was conducted intermittently at one location from August through December 1999 at the former Gable Mountain Pond (200-CW-1) remedial investigation project. The 1999 analytical results from the composite sample detected only uranium234 and -238 and these were at levels only slightly higher than offsite levels.

The remedial action, interim safe storage, and surveillance and maintenance/transition projects discussed above are described in more detail in Section 2.3.11, "Environmental Restoration Project." A complete listing of the 1999 near-facility ambient air monitoring results can be found in PNNL-13230, APP. 2. Results for selected Pacific Northwest National Laboratory air samples are also reported in PNNL-13230, APP. 2, as well as in Section 4.1, "Air Surveillance." 


\subsubsection{Surface-Water Disposal Units and 100-N Area Riverbank Springs Monitoring}

The two surface-water disposal units in the 200-East Area that historically received radiologically contaminated effluents, the 200-East Area powerhouse ditch and the 216-B-3C expansion pond, were virtually unused in 1999 . There was a single-batch discharge to the powerhouse ditch in February 1999, and a liquid grab sample was collected. This sample was screened for gross alpha and gross beta radioactivity and no unusual levels were observed. No further radionuclide specific analyses were performed. No aquatic vegetation or sediment samples were collected at these locations in 1999.

Water samples were also taken at riverbank springs in the 100-N Area. In the past, radioactive effluent streams sent to the 1301-N and 1325-N Liquid Waste Disposal Facilities in the 100-N Area contributed to the release of radionuclides to the Columbia River through their migration with the groundwater. Radionuclides from these facilities enter the Columbia River along the riverbank region sometimes called $\mathrm{N}$ Springs. Groundwater springs and/or shoreline seepage wells at the N Springs are sampled annually to verify that the reported radionuclide releases to the Columbia River are conservative (i.e., not underreported). The amount of radionuclides entering the Columbia River at these springs (i.e., release) is calculated based on analyses of monthly samples collected from monitoring well 199-N-46 located near the shoreline. Analytical results and discussion of these releases may be found in Section 3.1, "Facility Effluent Monitoring" and in HNF-EP-0527-9, "Environmental Releases for Calendar Year 1999."

In October 1999, ten samples were collected. At the time of sample collection, 3 of the 13 shoreline wells were dry, and no samples were collected at these locations. The shoreline seepage well samples were collected using a bailer, carefully lowered into each well water column to avoid sediment suspension, and a 4-liter (1-gallon) sample was obtained. Analyses of these samples included tritium, strontium-90, and gamma-emitting radionuclides.

In 1999, the levels of strontium-90 detected in samples from riverbank springs were highest in N Springs well Y303, which is nearest well 199-N-46. Strontium-90 concentrations exceeded the DOE derived concentration guide value $(1,000 \mathrm{pCi} / \mathrm{L})$ only at well Y303. The highest tritium level was measured $\sim 122$ meters (400 feet) downstream at well Y307. Tritium concentrations at all sampling locations were well below the $2,000,000 \mathrm{pCi} / \mathrm{L}$ derived concentration guide. All gamma-emitting radionuclide concentrations were below analytical detection limits in 1999. The data from 1999 riverbank springs sampling are summarized in Table 3.2.4.

\begin{tabular}{|c|c|c|c|c|c|}
\hline \multirow{3}{*}{\multicolumn{2}{|c|}{ Radionuclide }} & $\begin{array}{l}\text { 3.2.4. Radionu } \\
\text { 100-N Area Ri }\end{array}$ & $\begin{array}{l}\text { de Concentra } \\
\text { rbank Spring }\end{array}$ & $\begin{array}{l}\text { ons (pCi/L) ir } \\
1999\end{array}$ & \multirow[b]{3}{*}{$\underline{D C G}^{(c)}$} \\
\hline & & \multirow{2}{*}{$\begin{array}{c}\text { Facility Effluent } \\
\text { Monitoring Well } \\
\underline{199-\mathrm{N}-46}\end{array}$} & \multicolumn{2}{|c|}{ Shoreline Springs } & \\
\hline & & & $\underline{\text { Maximum }}^{(\mathrm{a})}$ & Average $^{(\mathbf{b})}$ & \\
\hline \multirow{2}{*}{\multicolumn{2}{|c|}{$\begin{array}{l}\text { Tritium } \\
\text { Strontium-90 }\end{array}$}} & $130 \pm 79$ & $270 \pm 110$ & $120 \pm 49$ & $2,000,000$ \\
\hline & & $3,200 \pm 480$ & $1,300 \pm 190$ & $130 \pm 230$ & 1,000 \\
\hline \multicolumn{6}{|c|}{ (a) \pm overall analytical error. } \\
\hline \multicolumn{6}{|c|}{ (b) \pm 2 standard error of the mean. } \\
\hline \multicolumn{6}{|c|}{ (c) $\mathrm{DCG}=\mathrm{DOE}$ derived concentration guide (DOE Order 5400.5). } \\
\hline
\end{tabular}




\subsubsection{Radiological Surveys}

Radiological surveys are used to monitor and detect contamination on the Hanford Site. The main types of contaminated areas are underground radioactive materials areas, contamination areas, soil contamination areas, and high contamination areas.

Underground radioactive material areas are areas that have contamination contained below the soil surface. These areas are typically "stabilized" cribs, burial grounds, covered ponds, trenches, and ditches. Barriers over the contamination sources are used to inhibit radionuclide transport to the surface environs. These areas are surveyed at least annually to document the current radiological status.

Contamination/soil contamination areas may or may not be associated with an underground radioactive material structure. A breach in the barrier of an underground radioactive materials area may result in the growth of contaminated vegetation. Insects or animals may burrow into an underground radioactive materials area and bring contamination to the surface. Vent pipes or risers from an underground structure may be a source of speck contamination (particles with a diameter less than 0.6 centimeter [0.25 inch]). Areas of contamination not related to subsurface structures can include sites contaminated with fallout from effluent stacks and sites that are the result of unplanned releases (e.g., contaminated tumbleweeds, animal feces). All radiologically controlled areas may be susceptible to contamination migration and are surveyed at least annually to document the current radiological status (locations of radiologically controlled areas are illustrated in PNNL-13230, APP. 2).
In 1999, the Hanford Site had 3,651 hectares $(9,022$ acres) of posted outdoor contamination areas (all types) and 625 hectares (1,544 acres) of posted underground radioactive materials areas not including active facilities. Table 3.2.5 lists the contamination areas and underground radioactive materials areas in 1999. Vehicles equipped with radiation detection devices and a global positioning system were again used in 1999 to measure more accurately the extent of the contamination. Area measurements are entered into the Hanford Geographical Information System, a computer database maintained by Bechtel Hanford, Inc.

The number and size of contaminated areas vary from year to year because of efforts to cleanup, stabilize, and remediate areas of known contamination. New areas of contamination also are being identified, though no areas of significance were added in 1999. Table 3.2.6 indicates the changes resulting from stabilization activities during 1999. Approximately 4.3 hectares (10.6 acres) were reclassified from contamination/soil contamination areas to underground radioactive materials areas. Newly identified areas are generally the result of either contaminant migration or an increased effort to investigate outdoor areas for radiological contamination.

It was estimated that the external dose rate at $80 \%$ of the identified outdoor contamination acreage was less than $1 \mathrm{mrem} / \mathrm{h}$, though direct dose rate readings from isolated radioactive specks could have been considerably higher.

\subsubsection{Soil and Vegetation Sampling from Operational Areas}

Soil and vegetation samples were collected on or adjacent to waste disposal units and from locations downwind and near or within the boundaries of operating facilities and remedial action activity sites. Samples were collected to evaluate long-term trends in environmental accumulation of radioactivity and 


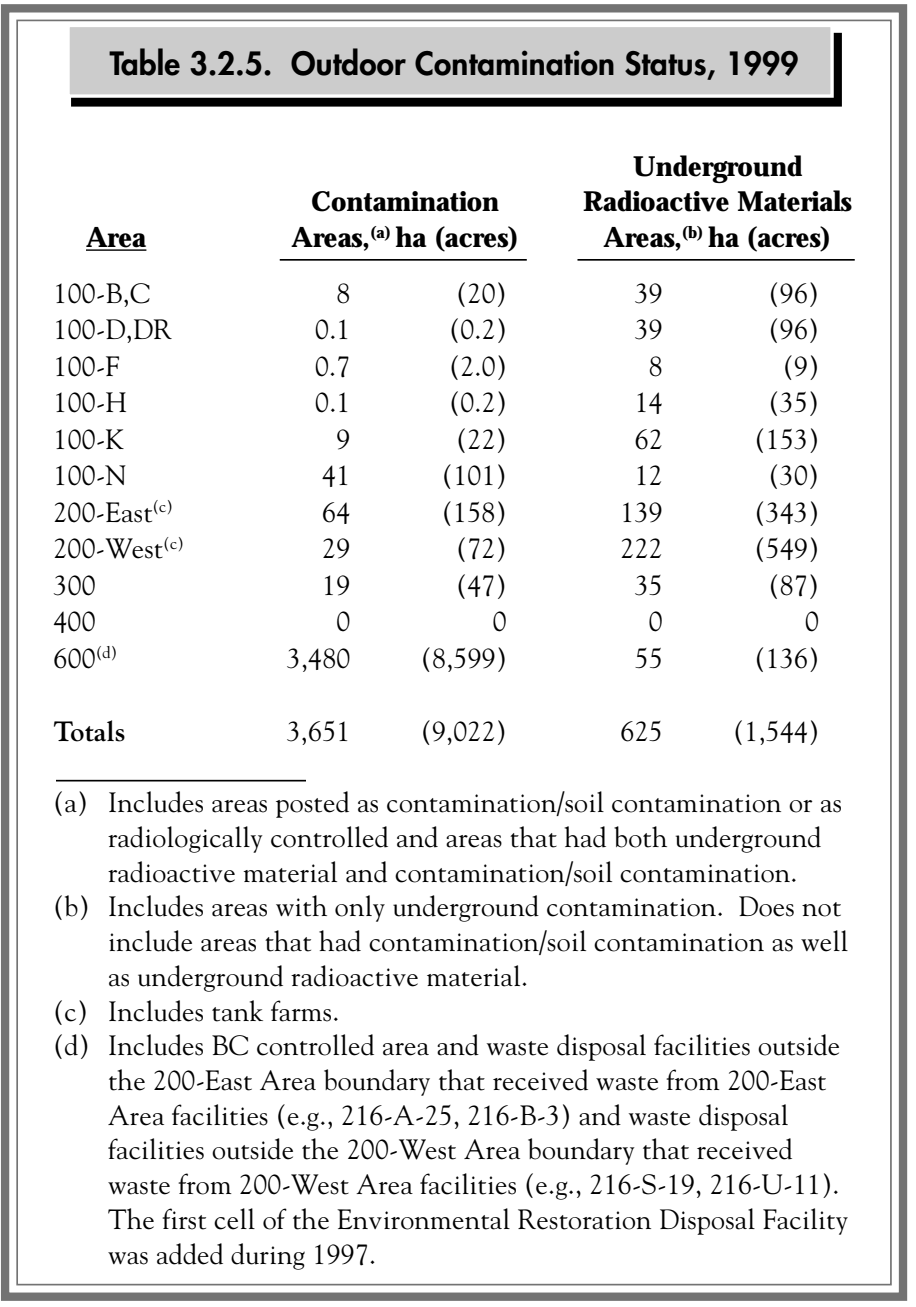

\begin{tabular}{|c|c|c|c|c|}
\hline & \multicolumn{4}{|c|}{$\begin{array}{l}\text { Table 3.2.6. Zone Status Change of Posted } \\
\text { Contamination Areas, 1999(a) }\end{array}$} \\
\hline \multicolumn{2}{|c|}{ A reas } & Zone Changes $^{(\mathbf{b})}$ & \multicolumn{2}{|c|}{ Area, ha (acres) } \\
\hline 100 & & CA to URM & 2.8 & $(6.9)$ \\
\hline $200-1$ & East & CA to URM & 1.5 & $(3.7)$ \\
\hline $200-$ & West & CA to URM & 0 & 0 \\
\hline 300 & & CA to URM & 0 & 0 \\
\hline 400 & & CA to URM & 0 & 0 \\
\hline 600 & & CA to URM & 0 & 0 \\
\hline (b) & \multicolumn{4}{|c|}{$\begin{array}{l}\text { Changes from stabilization activities, newly discovered } \\
\text { sites, or resurvey using a global positioning system. } \\
\text { CA = Contamination/soil contamination area. } \\
\text { URM = Underground radioactive materials area. }\end{array}$} \\
\hline
\end{tabular}


to detect potential migration and deposition of facility effluents. Special samples also were collected where potential physical or biological pathway problems were identified. Contaminant movement can occur as the result of resuspension from radioactively contaminated surface areas, absorption of radionuclides by the roots of vegetation growing on or near underground and surface-water disposal units, or waste site intrusion by animals. The sampling methods and locations used are discussed in detail in WMTS-OEM-001, Rev. 0. Radiological analyses of soil and vegetation samples included strontium-90, isotopic uranium, isotopic plutonium, and gammaemitting radionuclides.

The number and location of soil and vegetation samples collected in 1999 are shown in Table 3.2.1. A comprehensive presentation of the analytical data results can be found in PNNL-13230, APP. 2. Only those radionuclide concentrations above analytical detection limits are discussed in this section.

Each soil sample represents a composite of five plugs of soil 2.5 centimeters ( 1 inch) deep and 10 centimeters (4 inches) in diameter collected from each site. Each vegetation sample consists of new-growth leaf cuttings taken from the available species of interest at each sample location. Often, the vegetation sample consisted of a composite of several like members of the sampling site plant community to avoid decimation of any individual plant through overharvesting.

Early in the summer of each year, soil and vegetation samples are collected on the Hanford Site and submitted for radioanalyses. The analyses include those for radionuclides expected to be found in the areas sampled (i.e., gamma-emitting radionuclides, strontium isotopes, uranium isotopes, and/or plutonium isotopes). The results are then compared to levels found at various offsite sample locations in Yakima and in Benton and Franklin Counties (PNNL10574, PNNL-11795). Comparison of the levels can be used to determine the difference between contributions from site operations and remedial action sites and contributions from natural causes and worldwide fallout.

Soil sampling results also are compared to the "accessible soil" limits included in HNF-PRO-454, Rev. 1 developed specifically for use at the Hanford Site (see PNNL-13230, APP. 2 for complete listing). These radioactive limits were established to ensure that effective dose equivalents to the public do not exceed the established limits for any reasonable scenario, such as direct exposure, inadvertent ingestion, inhalation, and ingestion of food crops, including animal products. The conservatism inherent in pathway modeling ensures that the required degrees of protection are in place (HNF-PRO-454, Rev. 1). These limits apply specifically to the Hanford Site with respect to onsite disposal operations, stabilization and cleanup, and decontamination and decommissioning operations.

In general, radionuclide concentrations in soil and vegetation samples collected from, or adjacent to, waste disposal facilities were higher than the concentrations in samples collected farther away and were significantly higher than concentrations measured offsite. The data also show, as expected, that concentrations of certain radionuclides were higher within different operational areas when compared to concentrations measured in distant communities. Generally, the predominant radionuclides were activation and fission products in the 100-N Area, fission products in the 200 Areas, and uranium in the 300/400 Areas.

\subsubsection{Radiological Results for Soil Samples}

Of the radionuclide analyses performed, cobalt-60, strontium-90, cesium-137, plutonium-239/240, and uranium were consistently detectable. The concentrations of these radionuclides in soil samples were elevated near and within facility boundaries when compared to concentrations measured off the site. 
Figure 3.2.2 shows average soil values for 1999 and the preceding 5 years. The levels show a large degree of variability.

Generally, the surface soil samples collected near the 1301-N Liquid Waste Disposal Facility exhibited relatively higher radionuclide concentrations than those collected at the other soil sampling locations in the 100-N Area. Average radionuclide concentrations detected in the surface soil samples near the facility from 1994 through 1999 are presented in Table 3.2.7. Generally, results were at or near historical levels measured on the Hanford Site. However, concentrations of strontium- 90 and uranium-238 were somewhat elevated compared to 1998 results. Additionally, contamination levels for these radionuclides were greater than those previously measured off the Hanford Site and in the 200 and 300/400 Areas.

Average radionuclide concentrations detected in all of the surface soil samples collected in the 100-N Area from 1994 through 1999 are presented in Table 3.2.8. The average values for $100-\mathrm{N}$ Area soils were down in 1999 for cobalt-60, cesium-137, uranium-235, and plutonium-239/240, the averages for strontium-90, uranium-234 and -238 were slightly elevated over the 1998 sample results. The 1999 maximum, average, offsite average concentrations, and accessible soil limits are compared in Table 3.2.9. Offsite averages for isotopic uranium, strontium-90, and cesium-137 are from PNNL-11795 and offsite values for plutonium-239/240 are contained in PNL10574. Complete listings of radionuclide concentrations and sample location maps are provided in PNNL-13230, APP. 2.

Soil samples from 58 of 111 sample locations in the 200/600 Areas were collected in 1999. A follow-up sample location (D146) was again included this year from the southern end of the Environmental Restoration Disposal Facility (200-West Area) and is now sampled on an annual basis. The 1999 maximum, average, offsite average, and accessible soil limits are compared in Table 3.2.10. Complete listings of radionuclide concentrations and sample location maps are provided in PNNL-13230, APP. 2.
Analytical results from soil samples taken from the 200/600 Areas demonstrated somewhat higher average values for all of the radionuclides measured in 1999, with the exception of plutonium-239/240, which was slightly lower.

Soil samples from 13 sample locations in the 300/400 Areas were collected in 1999; 12 from the 300 Area and 1 from the 400 Area. The 1999 maximum, average, offsite average concentrations, and accessible soil limits are compared in Table 3.2.11. Complete listings of radionuclide concentrations and sample location maps are provided in PNNL13230, APP. 2. For the samples collected in 1999, average values were slightly higher for cesium-137, strontium-90, uranium-235, and plutonium-239/240 than in 1998. Uranium was expected to be somewhat higher in these samples because it was used during past fuel fabrication operations in the 300 Area.

In 1999, two soil samples each were collected at the remedial action locations in the 100-B,C, 100-D, and $100-\mathrm{H}$ Areas and a single sample was collected from the Environmental Restoration Disposal Facility (200-West Area) to determine the effectiveness of contamination controls. The samples collected from these locations generally represented baseline samples to be used for comparison with future samples. Table 3.2.12 provides a summary of the analytical data for selected radionuclides. All of the 1999 data are provided in PNNL-13230, APP. 2.

\subsubsection{Radiological Results for Vegetation Samples}

Of the radionuclide analyses performed, cobalt60, strontium-90, cesium-137, plutonium-239/240, and uranium were consistently detectable. Concentrations of these radionuclides in vegetation were elevated near and within facility boundaries compared to the concentrations measured off the site. Figure 3.2.3 shows average vegetation values for 1999 and the preceding 5 years. The results show a high degree of variability. 


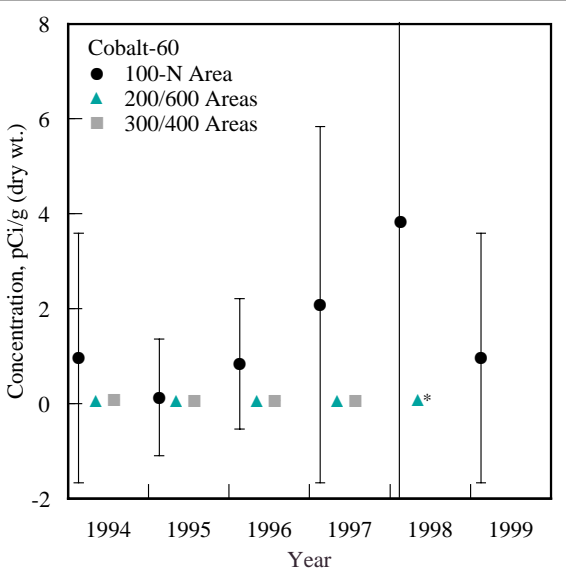

*Single value above detection limits

G00020011.11

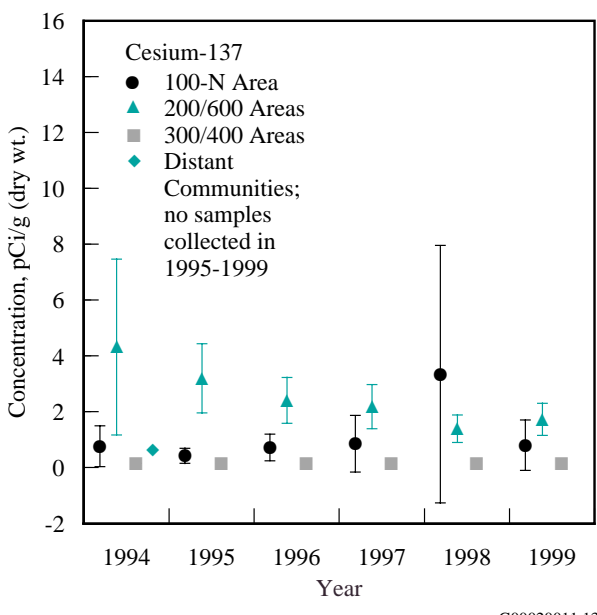

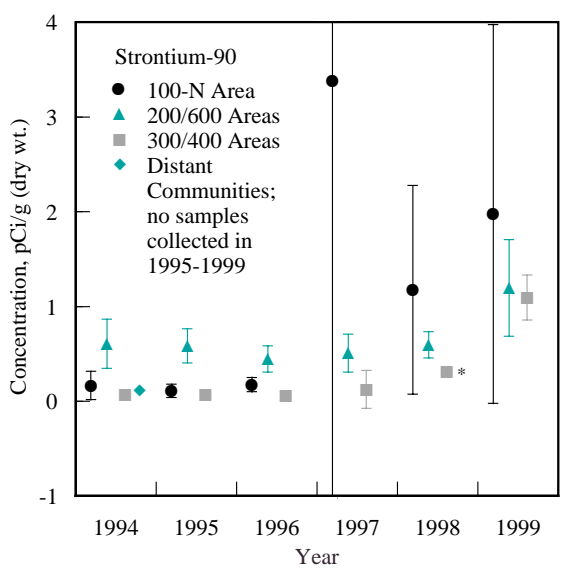

*Single value above detection limits
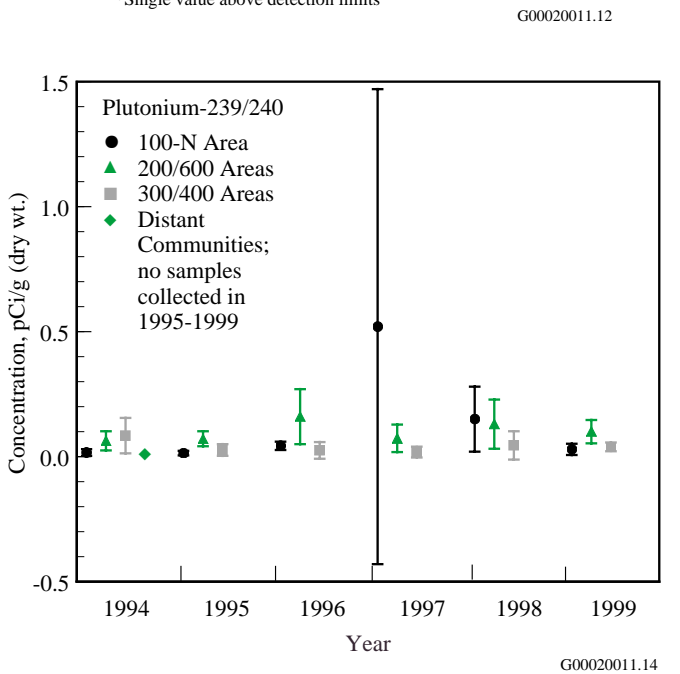

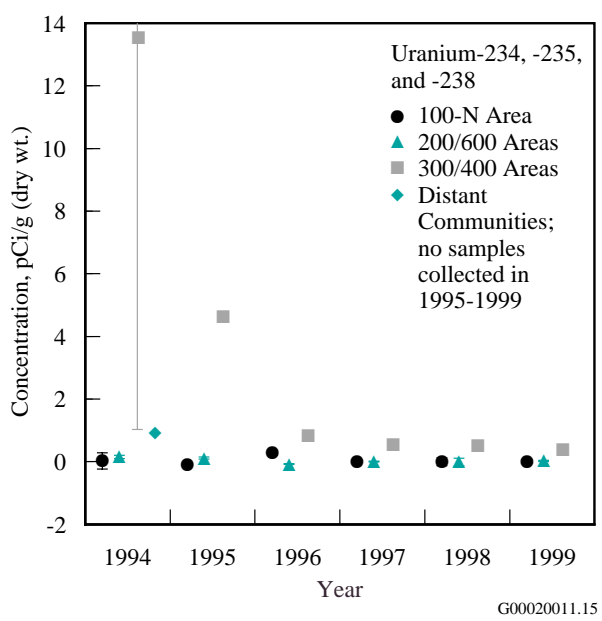

Figure 3.2.2. Average Concentration ( \pm 2 standard error of the mean) of Selected Radionulcides in NearFacility Soil Samples Compared to Those in Distant Communities, 1994 Through 1999. As a result of figure scale, some uncertainties (error bars) are concealed by point symbol. Cobalt- 60 was not detected in the $200 / 600$ or $300 / 400$ Areas in 1999. 


\begin{tabular}{|c|c|c|c|c|c|c|c|}
\hline \multirow[b]{2}{*}{ Year } & \multicolumn{6}{|c|}{$\begin{array}{l}\text { Table 3.2.7. Average Radionuclide Concentrations (pCi/g dry wt.)(a) Detected in Surface } \\
\text { Soil Samples Near the 1301-N Liquid Waste Disposal Facility, } 1994 \text { Through } 1999\end{array}$} & \multirow[b]{2}{*}{${ }^{239 / 240} \mathrm{Pu}$} \\
\hline & ${ }^{60} \mathrm{Co}$ & ${ }^{90} \mathrm{Sr}$ & ${ }^{137} \mathrm{Cs}$ & ${ }^{234} \mathbf{U}$ & ${ }^{235} \mathrm{U}$ & ${ }^{238} \mathrm{U}$ & \\
\hline 1994 & $3.7 \pm 4.8$ & $0.33 \pm 0.34$ & $1.5 \pm 1.5$ & $0.080 \pm 0.016$ & $0.005 \pm 0.002$ & $0.080 \pm 0.014$ & $0.028 \pm 0.030$ \\
\hline 1995 & $2.1 \pm 2.2$ & $0.15 \pm 0.17$ & $0.77 \pm 0.53$ & $0.078 \pm 0.015$ & $0.003 \pm 0.001$ & $0.081 \pm 0.012$ & $0.010 \pm 0.013$ \\
\hline 1996 & $2.5 \pm 1.5$ & $0.23 \pm 0.11$ & $0.98 \pm 0.57$ & $0.568 \pm 0.142$ & $0.025 \pm 0.023$ & $0.563 \pm 0.222$ & $0.048 \pm 0.026$ \\
\hline 1997 & $4.3 \pm 5.2$ & $5.8 \pm 10.8$ & $1.5 \pm 1.5$ & $0.22 \pm 0.07$ & $0.020 \pm 0.004$ & $0.218 \pm 0.057$ & $0.98 \pm 1.79$ \\
\hline 1998 & $8.5 \pm 14.4$ & $1.6 \pm 1.2$ & $5.2 \pm 7.4$ & $0.223 \pm 0.112$ & $0.039 \pm 0.007$ & $0.160 \pm 0.041$ & $0.19 \pm 0.19$ \\
\hline 1999 & $2.6 \pm 3.5$ & $2.9 \pm 3.4$ & $1.3 \pm 1.3$ & $0.210 \pm 0.061$ & $0.014 \pm 0.004$ & $0.190 \pm 0.053$ & $0.03 \pm 0.04$ \\
\hline
\end{tabular}

\begin{tabular}{|c|c|c|c|c|c|c|c|}
\hline \multirow[b]{2}{*}{ Year } & \multicolumn{6}{|c|}{$\begin{array}{l}\text { Table 3.2.8. Average Radionuclide Concentrations (pCi/g dry wt.. }{ }^{(a)} \text { Detected in } \\
\text { 100-N Area Surface Soil Samples, } 1994 \text { Through } 1999\end{array}$} & \multirow[b]{2}{*}{${ }^{239 / 240} \mathrm{Pu}$} \\
\hline & ${ }^{60} \mathrm{Co}$ & ${ }^{90} \mathrm{Sr}$ & ${ }^{137} \mathrm{Cs}$ & ${ }^{234} \mathbf{U}$ & ${ }^{235} \mathrm{U}$ & ${ }^{238} \mathrm{U}$ & \\
\hline 1994 & $1.6 \pm 2.1$ & $0.19 \pm 0.15$ & $0.81 \pm 0.65$ & $0.078 \pm 0.014$ & $0.004 \pm 0.001$ & $0.079 \pm 0.012$ & $0.016 \pm 0.013$ \\
\hline 1995 & $0.94 \pm 0.98$ & $0.13 \pm 0.07$ & $0.51 \pm 0.24$ & $0.091 \pm 0.012$ & $0.004 \pm 0.001$ & $0.097 \pm 0.014$ & $0.014 \pm 0.009$ \\
\hline 1996 & $1.5 \pm 1.1$ & $0.20 \pm 0.08$ & $0.077 \pm 0.042$ & $0.567 \pm 0.082$ & $0.038 \pm 0.021$ & $0.566 \pm 0.125$ & $0.043 \pm 0.016$ \\
\hline 1997 & $2.5 \pm 3.0$ & $3.9 \pm 7.2$ & $0.89 \pm 0.90$ & $0.21 \pm 0.04$ & $0.020 \pm 0.002$ & $0.207 \pm 0.036$ & $0.91 \pm 1.79$ \\
\hline 1998 & $4.9 \pm 8.4$ & $1.2 \pm 1.2$ & $3.1 \pm 4.4$ & $0.214 \pm 0.063$ & $0.033 \pm 0.008$ & $0.166 \pm 0.026$ & $0.15 \pm 0.14$ \\
\hline 1999 & $1.6 \pm 2.1$ & $2.0 \pm 2.0$ & $0.84 \pm 0.80$ & $0.220 \pm 0.037$ & $0.016 \pm 0.004$ & $0.200 \pm 0.033$ & $0.029 \pm 0.023$ \\
\hline
\end{tabular}

Table 3.2.9. Concentration of Selected Radionuclides (pCi/g dry wt.) in 100-N Area Soil, 1999

\begin{tabular}{|c|c|c|c|c|c|c|c|}
\hline & ${ }^{60} \mathrm{Co}$ & ${ }^{90} \mathrm{Sr}$ & ${ }^{137} \mathrm{Cs}$ & ${ }^{234} \mathrm{U}$ & $235 \mathrm{U}$ & ${ }^{238} \mathrm{U}$ & ${ }^{239 / 240} \mathrm{Pu}$ \\
\hline Maximum $^{\text {(a) }}$ & $6.1 \pm 0.5$ & $6.1 \pm 0.9$ & $2.4 \pm 0.3$ & $0.25 \pm 0.09$ & $0.021 \pm 0.015$ & $0.23 \pm 0.08$ & $0.068 \pm 0.029$ \\
\hline Average $^{(\mathrm{b})}$ & $1.6 \pm 2.1$ & $2.0 \pm 2.0$ & $0.84 \pm 0.81$ & $0.22 \pm 0.03$ & $0.016 \pm 0.003$ & $0.20 \pm 0.03$ & $0.029 \pm 0.023$ \\
\hline Offsite average $^{(b, c)}$ & $\mathrm{NR}^{(\mathrm{d})}$ & $0.062 \pm 0.052$ & $0.30 \pm 0.30$ & $0.24 \pm 0.09$ & $0.11 \pm 0.04$ & $0.25 \pm 0.10$ & $0.011 \pm 0.001$ \\
\hline \multicolumn{8}{|l|}{$\begin{array}{l}\text { Accessible soil concen- } \\
\text { tration limits }\end{array}$} \\
\hline $\begin{array}{l}\text { (a) } \pm \text { counting error. } \\
\text { (b) } \pm 2 \text { standard error of th } \\
\text { (c) PNNL-10574 and PN } \\
\text { (d) NR = Not reported. } \\
\text { (e) Hanford soils that are }\end{array}$ & $\begin{array}{l}\text { ne mean. } \\
\text { NL-11795. } \\
\text { not behind }\end{array}$ & ecurity fences. & & & & & \\
\hline
\end{tabular}


Table 3.2.10. Concentration of Selected Radionuclides (pCi/g dry wt.) in 200/600 Areas Soil, 1999

\begin{tabular}{|c|c|c|c|c|c|c|c|}
\hline & ${ }^{60} \mathrm{Co}$ & ${ }^{90} \mathrm{Sr}$ & ${ }^{137} \mathrm{Cs}$ & ${ }^{234} \mathrm{U}$ & ${ }^{235} \mathrm{U}$ & ${ }^{238} \mathrm{U}$ & ${ }^{239 / 240} \mathrm{Pu}$ \\
\hline Maximum $^{(a)}$ & $\mathrm{ND}^{(\mathrm{b})}$ & $5.9 \pm 1.2$ & $9.6 \pm 1.3$ & $0.49 \pm 0.17$ & $0.048 \pm 0.034$ & $0.50 \pm 0.20$ & $0.6 \pm 0.2$ \\
\hline Average $e^{(c)}$ & -. & $1.1 \pm 0.5$ & $1.4 \pm 0.5$ & $0.23 \pm 0.02$ & $0.026 \pm 0.003$ & $0.22 \pm 0.02$ & $0.10 \pm 0.05$ \\
\hline Offsite average $\mathrm{e}^{(\mathrm{c}, \mathrm{d})}$ & $\mathrm{NR}^{(\mathrm{e})}$ & $0.062 \pm 0.052$ & $0.30 \pm 0.30$ & $0.24 \pm 0.09$ & $0.11 \pm 0.04$ & $0.25 \pm 0.10$ & $0.011 \pm 0.001$ \\
\hline $\begin{array}{l}\text { Accessible soil concen- } \\
\text { tration limits } \\
(\text { HNF-PRO-454, Rev. 1) })^{(f)}\end{array}$ & 7.1 & 2,800 & 30 & 630 & 170 & 370 & 190 \\
\hline $\begin{array}{l}\text { (a) } \pm \text { counting error. } \\
\text { (b) ND = Not detected. } \\
\text { (c) } \pm 2 \text { standard error of th } \\
\text { (d) PNNL-10574 and PNN } \\
\text { (e) NR = Not reported. } \\
\text { (f) Hanford soils that are }\end{array}$ & $\begin{array}{l}\text { mean. } \\
\text { L-11795. } \\
\text { ot behind }\end{array}$ & ecurity fences. & & & & & \\
\hline
\end{tabular}

Table 3.2.11. Concentration of Selected Radionuclides (pCi/g dry wt.) in 300/400 Areas Soil, 1999

\begin{tabular}{|c|c|c|c|c|c|c|c|}
\hline & ${ }^{60} \mathrm{Co}$ & ${ }^{90} \mathrm{Sr}$ & ${ }^{137} \mathrm{Cs}$ & ${ }^{234} \mathrm{U}$ & ${ }^{235} \mathbf{U}$ & ${ }^{238} \mathrm{U}$ & ${ }^{239 / 240} \mathrm{Pu}$ \\
\hline Maximum $^{(a)}$ & $\mathrm{ND}^{(\mathrm{b})}$ & $1.5 \pm 0.4$ & $0.18 \pm 0.03$ & $3.9 \pm 1.2$ & $0.53 \pm 0.017$ & $3.9 \pm 1.3$ & $0.097 \pm 0.04$ \\
\hline Average $^{(c)}$ & ND & $0.87 \pm 0.19$ & $0.093 \pm 0.026$ & $0.75 \pm 0.54$ & $0.10 \pm 0.07$ & $0.71 \pm 0.53$ & $0.040 \pm 0.020$ \\
\hline Offsite average $\mathrm{e}^{(\mathrm{c}, \mathrm{d})}$ & $\mathrm{NR}^{(\mathrm{e})}$ & $0.062 \pm 0.052$ & $0.30 \pm 0.30$ & $0.24 \pm 0.09$ & $0.11 \pm 0.04$ & $0.25 \pm 0.10$ & $0.011 \pm 0.001$ \\
\hline $\begin{array}{l}\text { Accessible soil concen- } \\
\text { tration limits } \\
\left(\text { HNF-PRO-454, Rev. 1) }{ }^{(f)}\right.\end{array}$ & 7.1 & 2,800 & 30 & 630 & 170 & 370 & 190 \\
\hline $\begin{array}{l}\text { (a) } \pm \text { counting error. } \\
\text { (b) ND = Not detected. } \\
\text { (c) } \pm 2 \text { standard error of th } \\
\text { (d) PNNL-10574 and PNI } \\
\text { (e) NR = Not reported. } \\
\text { (f) Hanford soils that are }\end{array}$ & $\begin{array}{l}\text { mean. } \\
\text { L-11795 }\end{array}$ & ecurity fences. & & & & & \\
\hline
\end{tabular}

Average radionuclide concentrations detected in the vegetation samples near the retired 1301-N Liquid Waste Disposal Facility from 1994 through 1999 are presented in Table 3.2.13. In 1999, these samples had higher concentrations of cobalt60 and plutonium-239/240 and significantly higher concentrations of strontium-90 and cesium-137 at sites Y702 and Y705 (see PNNL-13230, APP. 2) when compared to 1998 levels.
Average radionuclide concentrations detected in all of the vegetation samples collected in the 100-N Area from 1994 through 1999 are presented in Table 3.2.14.

Vegetation samples collected along the 100-N Area shoreline (N Springs) contain radionuclides that were not completely retained in the soil columns beneath the retired $1301-\mathrm{N}$ and $1325-\mathrm{N}$ Liquid Waste Disposal Facilities. Values for all of the 
Table 3.2.12. Radionuclide Concentrations ( $\mathrm{pCi} / \mathrm{g}$ dry wt.) in Environmental Restoration Contractor Projects' Soil Samples, 1999

\begin{tabular}{|c|c|c|c|c|c|c|c|c|}
\hline Site & $\begin{array}{c}\text { Sample } \\
\text { Location }^{(a)}\end{array}$ & ${ }^{60} \mathrm{Co}$ & ${ }^{90} \mathrm{Sr}$ & ${ }^{137} \mathrm{Cs}$ & ${ }^{234} \mathrm{U}$ & ${ }^{235} \mathrm{U}$ & ${ }^{238} \mathrm{U}$ & ${ }^{239 / 240} \mathrm{Pu}$ \\
\hline $\mathrm{ERDF}^{(\mathrm{b})}$ & D-146 & $\mathrm{ND}^{(\mathrm{c})}$ & $0.32 \pm 0.11$ & ND & $0.19 \pm 0.07$ & $0.012 \pm 0.009$ & $0.17 \pm 0.06$ & ND \\
\hline $100-D$ & D-147 & ND & ND & $0.30 \pm 0.05$ & $0.28 \pm 0.10$ & $0.036 \pm 0.023$ & $0.26 \pm 0.10$ & $0.018 \pm 0.013$ \\
\hline $100-\mathrm{D}$ & D-148 & ND & ND & $0.30 \pm 0.05$ & $0.25 \pm 0.09$ & $0.028 \pm 0.017$ & $0.18 \pm 0.07$ & ND \\
\hline $100-B, C$ & D-149 & ND & ND & $0.37 \pm 0.06$ & $0.16 \pm 0.06$ & $0.020 \pm 0.016$ & $0.19 \pm 0.07$ & ND \\
\hline $100-\mathrm{H}$ & D-151 & ND & ND & $0.79 \pm 0.10$ & $0.23 \pm 0.08$ & $0.029 \pm 0.020$ & $0.19 \pm 0.07$ & $0.047 \pm 0.024$ \\
\hline $100-\mathrm{H}$ & D-152 & $0.032 \pm 0.010$ & ND & $0.51 \pm 0.07$ & $0.19 \pm 0.07$ & $0.013 \pm 0.011$ & $0.15 \pm 0.06$ & $0.021 \pm 0.015$ \\
\hline $100-B, C$ & D-153 & ND & ND & $0.38 \pm 0.05$ & $0.21 \pm 0.04$ & $0.045 \pm 0.015$ & $0.15 \pm 0.03$ & ND \\
\hline \multicolumn{2}{|c|}{ Offsite Average ${ }^{(\mathrm{d}, \mathrm{e})}$} & $\mathrm{NR}^{(f)}$ & $0.062 \pm 0.052$ & $0.30 \pm 0.30$ & $0.24 \pm 0.09$ & $0.11 \pm 0.04$ & $0.25 \pm 0.10$ & $0.011 \pm 0.001$ \\
\hline \multicolumn{9}{|c|}{ Accessible Soil } \\
\hline
\end{tabular}

(a) See PNNL-13230, APP. 2.

(b) ERDF = Environmental Restoration Disposal Facility.

(c) $\mathrm{ND}=$ Not detected.

(d) \pm 2 standard error of the mean.

(e) PNNL-10574 and PNNL-11795.

(f) $\quad \mathrm{NR}=$ Not reported.

(g) Hanford soils that are not behind security fences.

radionuclides analyzed were reduced in 1999, with the exception of cesium-137. Average radionuclide concentrations detected in the vegetation samples collected along N Springs in 1999 and during the previous 5 years are presented in Table 3.2.15.

The 1999 analytical results for vegetation samples collected at the 100-N Area are compared to offsite averages in Table 3.2.16. A complete list of radionuclide concentrations and sample location maps are provided in PNNL-13230, APP. 2. Analytical results from vegetation samples collected from the 100-N Area in 1999 were elevated compared to those observed in 1998, except for the results of cobalt-60. Generally, 1999 radionuclide levels in 100-N Area vegetation were greater than those previously measured off the site; levels for cobalt-60, strontium-90, and cesium-137 were higher compared to the concentrations measured in the 200 and 300/400 Areas.

In 1999, 47 vegetation samples were collected from the 200/600 Areas. The 1999 maximum, average, and offsite average are compared in Table 3.2.17. A complete list of radionuclide concentrations and sample location maps is provided in PNNL-13230, APP. 2.

Analytical results from vegetation samples taken in 1999 from the 200/600 Areas were generally comparable to those observed in previous years. Radionuclide levels for strontium-90, cesium-137, and plutonium-239/240 were greater than those previously measured off the Hanford Site and were higher for cesium-137 and plutonium-239/240 compared to the 100 and 300/400 Areas.

This was the eighth year of sampling from locations established to more directly monitor facilities and active/inactive waste sites in the 300 and 400 Areas. The 1999 maximum, average, offsite average, and accessible soil limits for 300/400 Areas samples are listed in Table 3.2.18. Complete listings of radionuclide concentrations and sample location maps are provided in PNNL-13230, APP. 2. 

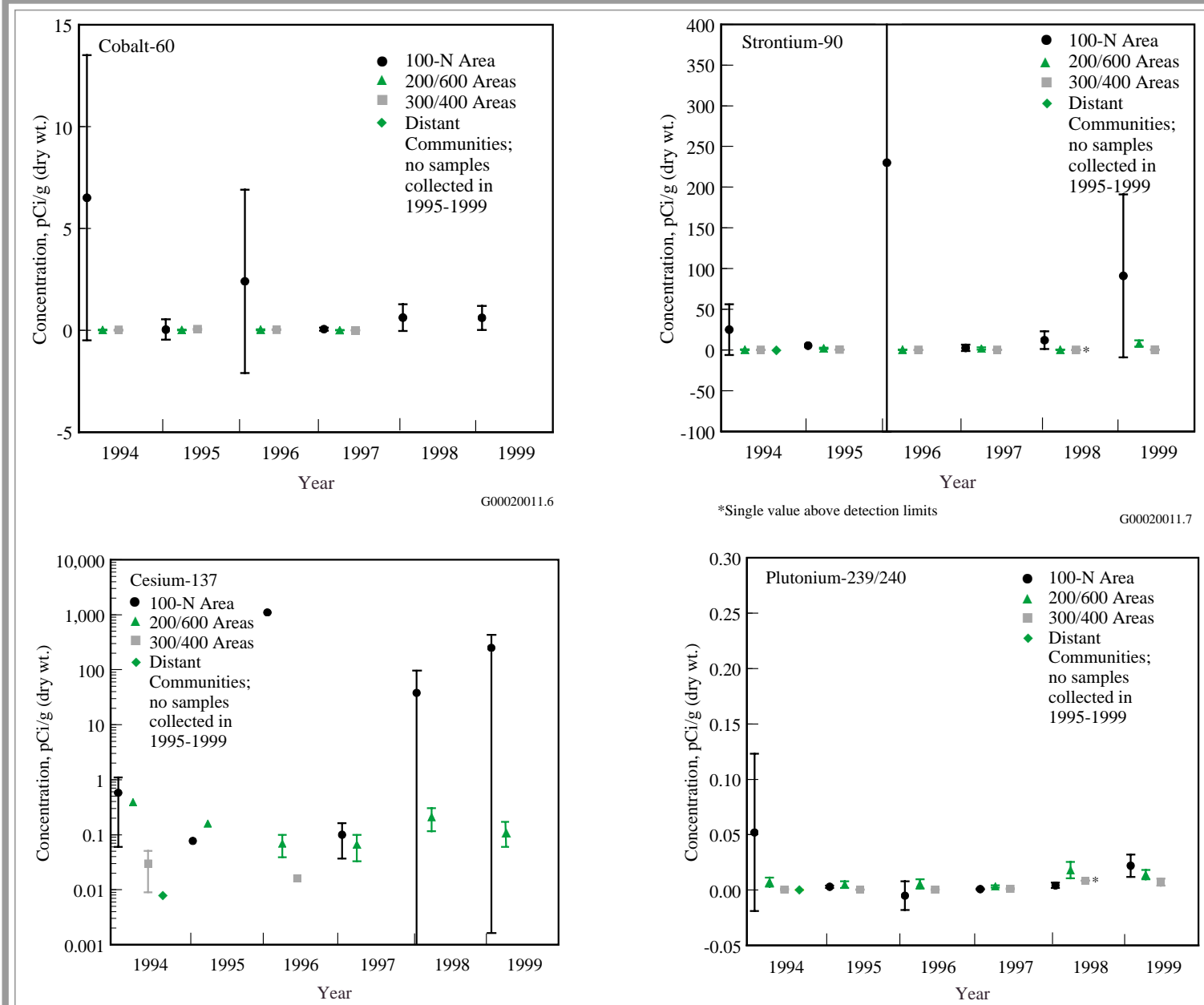

*Single value above detection limits

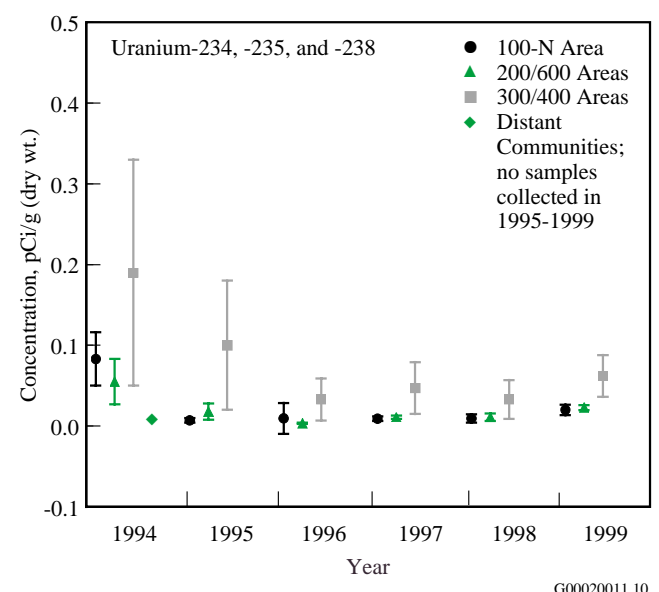

Figure 3.2.3. Average Concentration ( \pm 2 standard error of the mean) of Selected Radionulcides in Near-Facility Vegetation Samples Compared to Those in Distant Communities, 1994 Through 1999. As a result of figure scale, some uncertainties (error bars) are concealed by point symbol. The 1997 cesium-137 data point for the 300/400 Areas is less than zero and cannot be plotted on a log scale. Cobalt-60 was not detected in the $200 / 600$ or $300 / 400$ Areas in 1999. Cesium-137 was not detected in the 300/400 Areas in 1999 . 


\begin{tabular}{|c|c|c|c|c|}
\hline \multirow[b]{2}{*}{ Year } & \multicolumn{4}{|c|}{$\begin{array}{c}\text { Table 3.2.13. Average Radionuclide Concentrations (pCi/g dry wt.)(a) } \\
\text { Detected in Vegetation Samples Collected Near the } 1301-\mathrm{N} \text { Liquid } \\
\text { Waste Disposal Facility, } 1994 \text { Through } 1999\end{array}$} \\
\hline & ${ }^{60} \mathrm{Co}$ & ${ }^{90} \mathrm{Sr}$ & ${ }^{137} \mathrm{Cs}$ & ${ }^{239 / 240} \mathrm{Pu}$ \\
\hline 1994 & $24.8 \pm 31.6$ & $4.8 \pm 6.9$ & $1.8 \pm 1.8$ & $0.20 \pm 0.27$ \\
\hline 1995 & $0.054 \pm 0.10$ & $0.064 \pm 0.019$ & $0.12 \pm 0.14$ & $0.008 \pm 0.003$ \\
\hline 1996 & $6.1 \pm 11.9$ & $575 \pm 1,150$ & $2,750 \pm 5,500$ & $-0.013 \pm 0.38^{(b)}$ \\
\hline 1997 & $0.42^{(c)}$ & $0.49^{(c)}$ & $0.14 \pm 0.06$ & $N D^{(d)}$ \\
\hline 1998 & $0.54 \pm 0.93$ & $13.6 \pm 26.4$ & $50.1 \pm 99.8$ & $0.0071^{(c)}$ \\
\hline 1999 & $0.99 \pm 0.97$ & $205 \pm 201$ & $505 \pm 410$ & $0.009 \pm 0.010$ \\
\hline \multicolumn{5}{|c|}{$\begin{array}{l}\text { (a) } \pm 2 \text { standard error of the mean. } \\
\text { (b) Negative value indicates results at or below background levels of radioactivity. } \\
\text { (c) Single value above detection limit. } \\
\text { (d) ND = Not detected. }\end{array}$} \\
\hline
\end{tabular}

\begin{tabular}{|c|c|c|c|c|}
\hline \multirow[b]{2}{*}{ Year } & \multicolumn{4}{|c|}{$\begin{array}{l}\text { Table 3.2.14. Average Radionuclide Concentrations (pCi/g dry wt.)(a) } \\
\text { Detected in 100-N Area Vegetation Samples, } 1994 \text { to } 1999\end{array}$} \\
\hline & ${ }^{60} \mathrm{Co}$ & ${ }^{90} \mathrm{Sr}$ & ${ }^{137} \mathrm{Cs}$ & ${ }^{239 / 240} \mathrm{Pu}$ \\
\hline 1994 & $6.5 \pm 8.5$ & $25 \pm 33$ & $0.58 \pm 0.52$ & $0.053 \pm 0.071$ \\
\hline 1995 & $0.03 \pm 0.05$ & $5.4 \pm 4.8$ & $0.081 \pm 0.044$ & $0.0033 \pm 0.0016$ \\
\hline 1996 & $2.4 \pm 4.5$ & $230 \pm 430$ & $1,100 \pm 2,000$ & $-0.0051 \pm 0.013^{(b)}$ \\
\hline 1997 & $0.42 \pm 0.05$ & $3.6 \pm 5.3$ & $0.16 \pm 0.008$ & $\mathrm{ND}^{(\mathrm{c})}$ \\
\hline 1998 & $0.62 \pm 0.73$ & $11.7 \pm 11.1$ & $37.6 \pm 74.9$ & $0.0042 \pm 0.0029$ \\
\hline 1999 & $0.61 \pm 0.59$ & $91 \pm 100$ & $250 \pm 250$ & $0.022 \pm 0.010$ \\
\hline \multicolumn{5}{|c|}{$\begin{array}{l}\text { (a) } \pm 2 \text { standard error of the mean. } \\
\text { (b) Negative value indicates results at or below background levels of radioactivity. } \\
\text { (c) ND = Not detected. }\end{array}$} \\
\hline
\end{tabular}

Generally, the levels of most radionuclides measured in the 300 Area were greater than those measured off the site, and uranium levels were higher than measured in the 100 and 200 Areas. The higher uranium levels were expected because uranium was

\subsubsection{External Radiation}

External radiation fields were monitored near facilities and waste handling, storage, and disposal sites to measure and assess the impacts of operations. Thermoluminescent dosimeters are used at numerous released during past fuel fabrication operations in the 300 Area. The levels recorded for most other radionuclides in the 400 Area were higher than those measured off the site in previous years. fixed locations to gather dose rate information over longer periods of time. Thermoluminescent dosimeter results can be used individually or averaged to determine dose rates in a given area for a particular 


\begin{tabular}{|c|c|c|c|c|}
\hline \multirow[b]{2}{*}{ Year } & \multicolumn{4}{|c|}{$\begin{array}{l}\text { Table 3.2.15. Average Radionuclide Concentrations (pCi/g dry wt.) }{ }^{(a)} \\
\text { Detected in N Springs Vegetation Samples, } 1994 \text { to } 1999\end{array}$} \\
\hline & ${ }^{60} \mathrm{Co}$ & ${ }^{90} \mathrm{Sr}$ & ${ }^{137} \mathrm{Cs}$ & ${ }^{239 / 240} \mathrm{Pu}$ \\
\hline 1994 & $0.14 \pm 0.10$ & $60 \pm 81$ & $0.15 \pm 0.14$ & $0.002 \pm 0.001$ \\
\hline 1995 & $0.014 \pm 0.045$ & $13.4 \pm 10.2$ & $0.094 \pm 0.059$ & $0.0028 \pm 0.0008$ \\
\hline 1996 & $0.01 \pm 0.01$ & $2.4 \pm 4.2$ & $0.038 \pm 0.010$ & $-0.0015 \pm 0.002^{(b)}$ \\
\hline 1997 & $\mathrm{ND}^{(\mathrm{c})}$ & $6.2 \pm 9.9$ & $0.18 \pm 0.17$ & ND \\
\hline 1998 & $0.068^{(\mathrm{d})}$ & $21.0 \pm 19.0$ & ND & $0.0028^{(\mathrm{d})}$ \\
\hline 1999 & ND & $0.98 \pm 0.80$ & $0.28 \pm 0.49$ & ND \\
\hline \multicolumn{5}{|c|}{$\begin{array}{l}\text { (a) } \pm 2 \text { standard error of the mean. } \\
\text { (b) Negative value indicates results at or below background levels of radioactivity. } \\
\text { (c) ND = Not detected. } \\
\text { (d) Single value above detection limit. }\end{array}$} \\
\hline
\end{tabular}

Table 3.2.16. Concentration of Selected Radionuclides (pCi/g dry wt.) in 100-N Area Vegetation, 1999

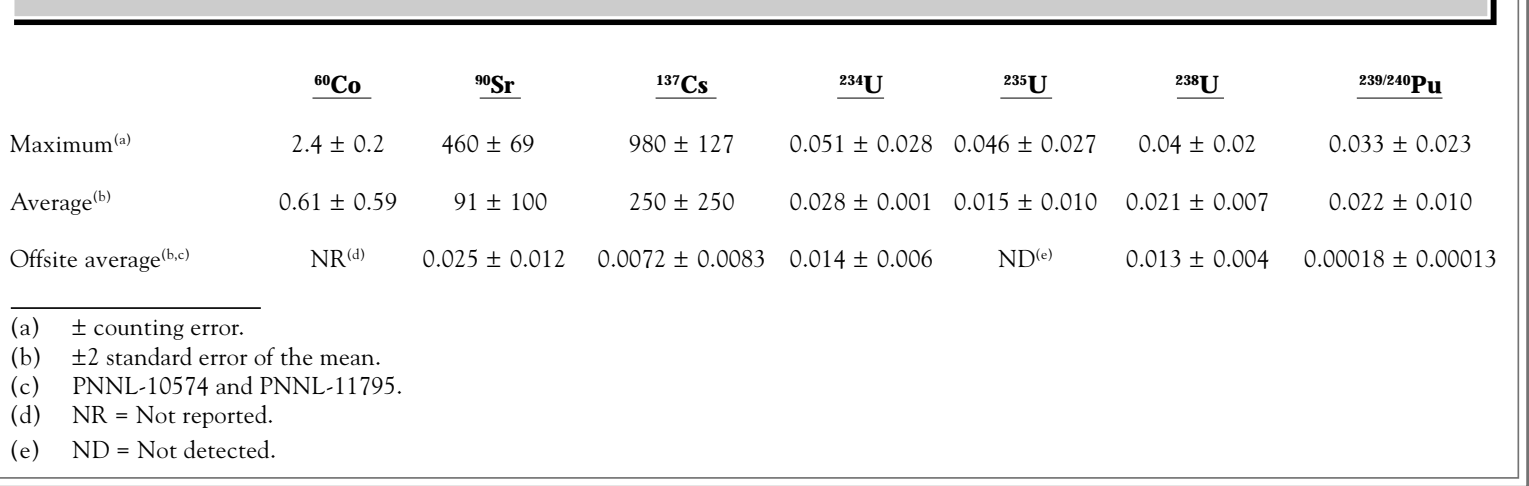

sampling period. A summary of the 1999 thermoluminescent dosimeter results can be found in Table 3.2.19. Individual thermoluminescent dosimeter results and locations are provided in PNNL-13230, APP. 2. Specific information regarding external radiation sampling methods and locations can be found in WMTS-OEM-001, Rev. 0.

The environmental thermoluminescent dosimeters measure dose rates from all types of external radiation sources. These sources include cosmic radiation, naturally occurring radioactivity in air and soil, and fallout from nuclear weapons testing, as well as any contribution from Hanford Site activities. These outside radiation sources cause an estimated
$20 \%$ deviation in results from the thermoluminescent dosimeter analyses. The results are reported in units of millirems per year.

Near-facility monitoring uses the Harshaw thermoluminescent dosimeter system, which includes the Harshaw 8807 dosimeter and the Harshaw 8800 reader. The packaging, which uses an O-ring seal, protects the dosimeter from light, heat, moisture, and dirt. The thermoluminescent dosimeters were placed 1 meter ( 3.3 feet) above the ground near facilities, active and inactive surface-water disposal sites, and remedial action projects. The dosimeters were exchanged and analyzed each calendar quarter. The Radiological Calibrations Facility in the 
Table 3.2.17. Concentration of Selected Radionuclides (pCi/g dry wt.) in 200/600 Areas Vegetation, 1999

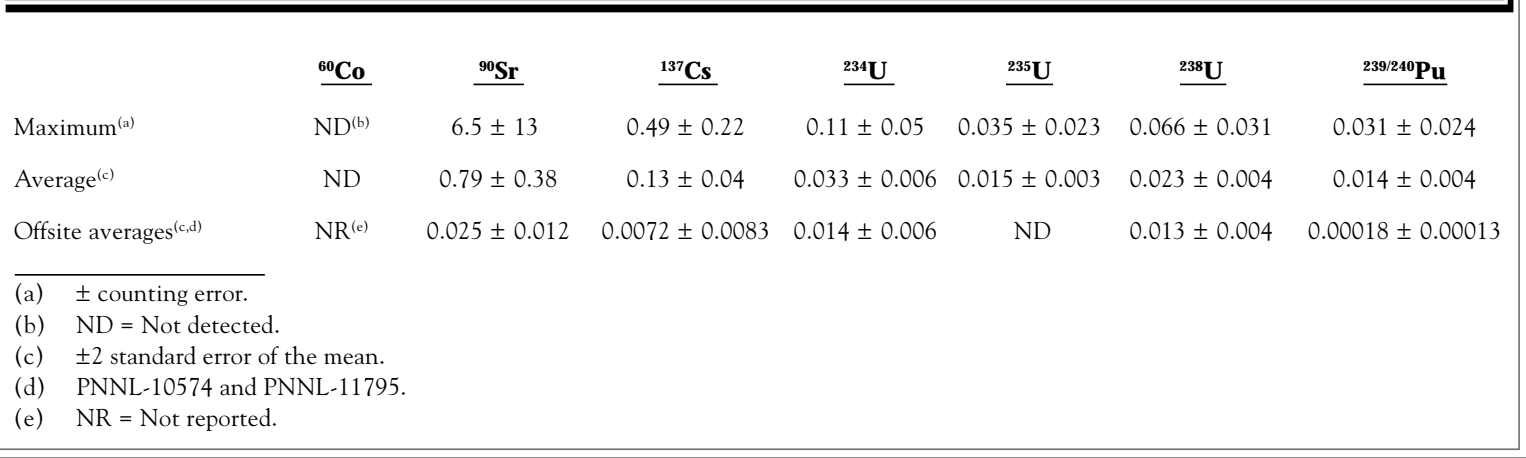

Table 3.2.18. Concentration of Selected Radionuclides (pCi/g dry wt.) in 300/400 Areas Vegetation, 1999

\begin{tabular}{|c|c|c|c|c|c|c|c|}
\hline & ${ }^{60} \mathrm{Co}$ & ${ }^{90} \mathrm{Sr}$ & ${ }^{137} \mathrm{Cs}$ & ${ }^{234} \mathrm{U}$ & ${ }^{235} \mathrm{U}$ & ${ }^{238} \mathrm{U}$ & ${ }^{239 / 240} \mathrm{Pu}$ \\
\hline Maximum $^{(\mathrm{a})}$ & $\mathrm{ND}^{(\mathrm{b})}$ & $0.64 \pm 0.16$ & ND & $0.42 \pm 0.13$ & $0.033 \pm 0.015$ & $0.39 \pm 0.12$ & $0.011 \pm 0.009$ \\
\hline Average $^{(c)}$ & ND & $0.45 \pm 0.07$ & ND & $0.094 \pm 0.053$ & $0.017 \pm 0.004$ & $0.89 \pm 0.059$ & $0.0071 \pm 0.0032$ \\
\hline Offsite averages ${ }^{(c, d)}$ & $\mathrm{NR}^{(\mathrm{e})}$ & $0.025 \pm 0.012$ & $0.0072 \pm 0.0083$ & $0.014 \pm 0.006$ & ND & $0.013 \pm 0.004$ & $0.00018 \pm 0.00013$ \\
\hline $\begin{array}{l}\text { (a) } \pm \text { counting error. } \\
\text { (b) ND = Not detected. } \\
\text { (c) } \pm 2 \text { standard error of } \\
\text { (d) PNNL } 10574 \text { and Pl } \\
\text { (e) NR = Not reported. }\end{array}$ & $\begin{array}{l}\text { Ne mean. } \\
\text { NL-11795. }\end{array}$ & & & & & & \\
\hline
\end{tabular}

\begin{tabular}{|c|c|c|c|c|c|c|}
\hline \multirow[b]{3}{*}{ Area } & \multicolumn{5}{|c|}{$\begin{array}{l}\text { Table 3.2.19. Thermoluminescent Dosimeter Results for Waste Handling Facilities, } \\
1998 \text { and } 1999 \text {, mrem/year Based on } 24 \text { hours/day }\end{array}$} & \multirow[b]{3}{*}{$\%$ Change $^{(a)}$} \\
\hline & \multirow{2}{*}{$\begin{array}{c}\text { No. of } \\
\text { Locations, } 1999\end{array}$} & \multicolumn{2}{|c|}{1998} & \multicolumn{2}{|c|}{1999} & \\
\hline & & Maximum & Mean & Maximum & Mean & \\
\hline $100-\mathrm{H}$ & 3 & NA & NA & 99 & 95 & NA \\
\hline $100-B$ & 5 & 110 & 97 & 100 & 90 & -7 \\
\hline $100-\mathrm{D}$ & 5 & 125 & 96 & 97 & 91 & -5 \\
\hline $100-\mathrm{K}$ & 11 & 720 & 180 & 370 & 125 & -30 \\
\hline $100-\mathrm{N}$ & 14 & 7,000 & 1,600 & 6,500 & 1,400 & -13 \\
\hline $200 / 600$ & 66 & 320 & 100 & 2,000 & 140 & 40 \\
\hline TWRS $^{(b)}$ & 10 & 88 & 86 & 90 & 88 & 2 \\
\hline $\mathrm{ERDF}^{(\mathrm{c})}$ & 3 & 100 & 95 & 94 & 91 & -4 \\
\hline 300 & 8 & 210 & 110 & 220 & 110 & 0 \\
\hline $300 \mathrm{TEDF}^{\mathrm{d}}$ & 6 & 89 & 83 & 90 & 85 & 2 \\
\hline & 7 & 87 & 84 & 90 & 87 & 1 \\
\hline $\mathrm{CVD}^{(\mathrm{e})}$ & 4 & NA & NA & 120 & 85 & NA \\
\hline \multicolumn{7}{|c|}{$\begin{array}{l}\text { (a) Numbers indicate a decrease (-) or increase from the } 1998 \text { mean. } \\
\text { (b) TWRS = Tank Waste Remediation System Phase I demonstration project. } \\
\text { (c) ERDF = Environmental Restoration Disposal Facility. } \\
\text { (d) TEDF = 300 Area Treated Effluent Disposal Facility. } \\
\text { (e) CVD = Cold Vacuum Drying Facility. }\end{array}$} \\
\hline
\end{tabular}


318 Building (300 Area) calibrates the response of the chips; results are reported in terms of external dose.

To evaluate environmental restoration activities at the former 116-B-11 and 116-C-1 Liquid Waste Disposal Facilities, four thermoluminescent dosimeter monitoring sites were established during the fourth quarter of 1997. An additional dosimeter location, collocated with a Washington State Department of Health dosimeter, was established during the fourth quarter of 1999. Dose rates measured at these locations were $7 \%$ lower compared to the data from 1998. The 1999 average dose rate was $90 \mathrm{mrem} / \mathrm{yr}$, comparable to the offsite ambient background average of $92 \mathrm{mrem} / \mathrm{yr}$.

This was the fourth year that thermoluminescent dosimeters were placed in the 100-D,DR Area to evaluate cleanup activities at the former 116-D-7 and 116-DR-9 Liquid Waste Disposal Facilities. Dose rates measured at these locations were 5\% lower than the results of 1998, with an average dose of $91 \mathrm{mrem} / \mathrm{yr}$, comparable to the offsite ambient background average of $92 \mathrm{mrem} / \mathrm{yr}$.

To evaluate environmental restoration activities in the 100-H Area, three new thermoluminescent dosimeter monitoring sites were established for the last three quarters of 1999. Because only three quarters of data were collected at these sites, the thermoluminescent dosimeter results were extrapolated to one year, resulting in an average of $96 \mathrm{mrem} / \mathrm{yr}$, comparable to the offsite ambient background average of $92 \mathrm{mrem} / \mathrm{yr}$.

The cleanup activities at the $\mathrm{K}$ Basins and adjacent retired reactor buildings in the $100-\mathrm{K}$ Area continue to be monitored. Dose rates in this area decreased $30 \%$, with an average of $125 \mathrm{mrem} / \mathrm{yr}$, because of the removal of radioactive waste stored in proximity to the three thermoluminescent dosimeter locations.

During the fourth quarter of 1999 , four new thermoluminescent dosimeter monitoring sites were established around the Cold Vacuum Drying Facility to perform preoperational monitoring. Because only one quarter of data was collected at these sites, the thermoluminescent dosimeter results were extrapolated to one year, resulting in an average of $85 \mathrm{mrem} / \mathrm{yr}$, which is comparable to offsite ambient background levels.

The 1999 results for the $100-\mathrm{N}$ Area indicate that direct radiation levels are highest near facilities that had contained or received liquid effluent from N Reactor. These facilities primarily include the retired 1301-N and 1325-N Liquid Waste Disposal Facilities. The results for these two facilities were noticeably higher than those for other 100-N Area thermoluminescent dosimeter locations, and were $\sim 5 \%$ higher than dose levels measured at these locations in 1998. Overall, the average dose rate measured in the 100-N Area in 1999 was $~ 13 \%$ lower than that measured in 1998.

Dose rates were measured at the $\mathrm{N}$ Springs shoreline to determine potential external radiation doses to the public as well as to onsite workers. Because of the "skyshine" effect (i.e., radiation reflected by the atmosphere back to the earth's surface) from the retired 1301-N facility, dose rates at the $\mathrm{N}$ Springs shoreline were elevated (greater than $100 \mathrm{mrem} / \mathrm{yr}$ ), which is the DOE annual external dose limit to members of the public. However, neither a member of the public nor a Hanford worker would conceivably spend an entire year at the N Springs; therefore, the values shown in Figure 3.2.4 are for comparison only.

Annual average thermoluminescent dosimeter results at 100-N Area from 1987 through 1999 are presented in Figure 3.2.5.

The highest dose rates in the 200 Areas were measured near waste handling facilities. The location within the 200 Areas exhibiting the highest dose rate was at tank farm A in the 200-East Area. The average annual dose rate measured in 1999 (110 mrem/yr) was 6\% higher than the average 1998 


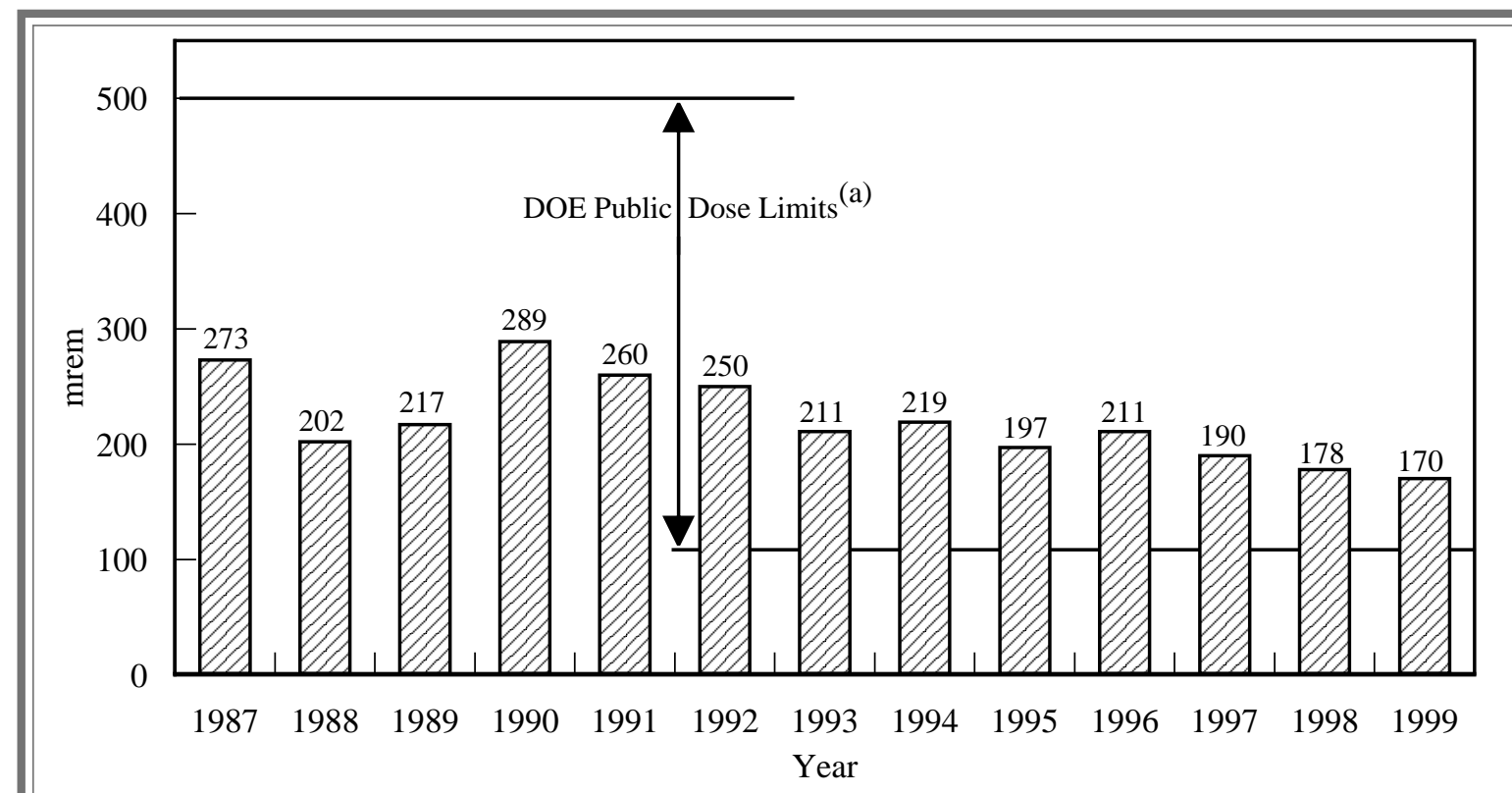

G00020011.200

Figure 3.2.4. Average Annual Dose Rate at N Springs. (a) DOE limits were reduced from $500 \mathrm{mrem} / \mathrm{yr}$ in 1992. The lower value was selected in recognition of the International Commission of Radiation Protection recommendation to limit the long-term average effective dose equivalence to $100 \mathrm{mrem}(1 \mathrm{mSv}) / \mathrm{yr}$ or less (DOE Order 5400.5).

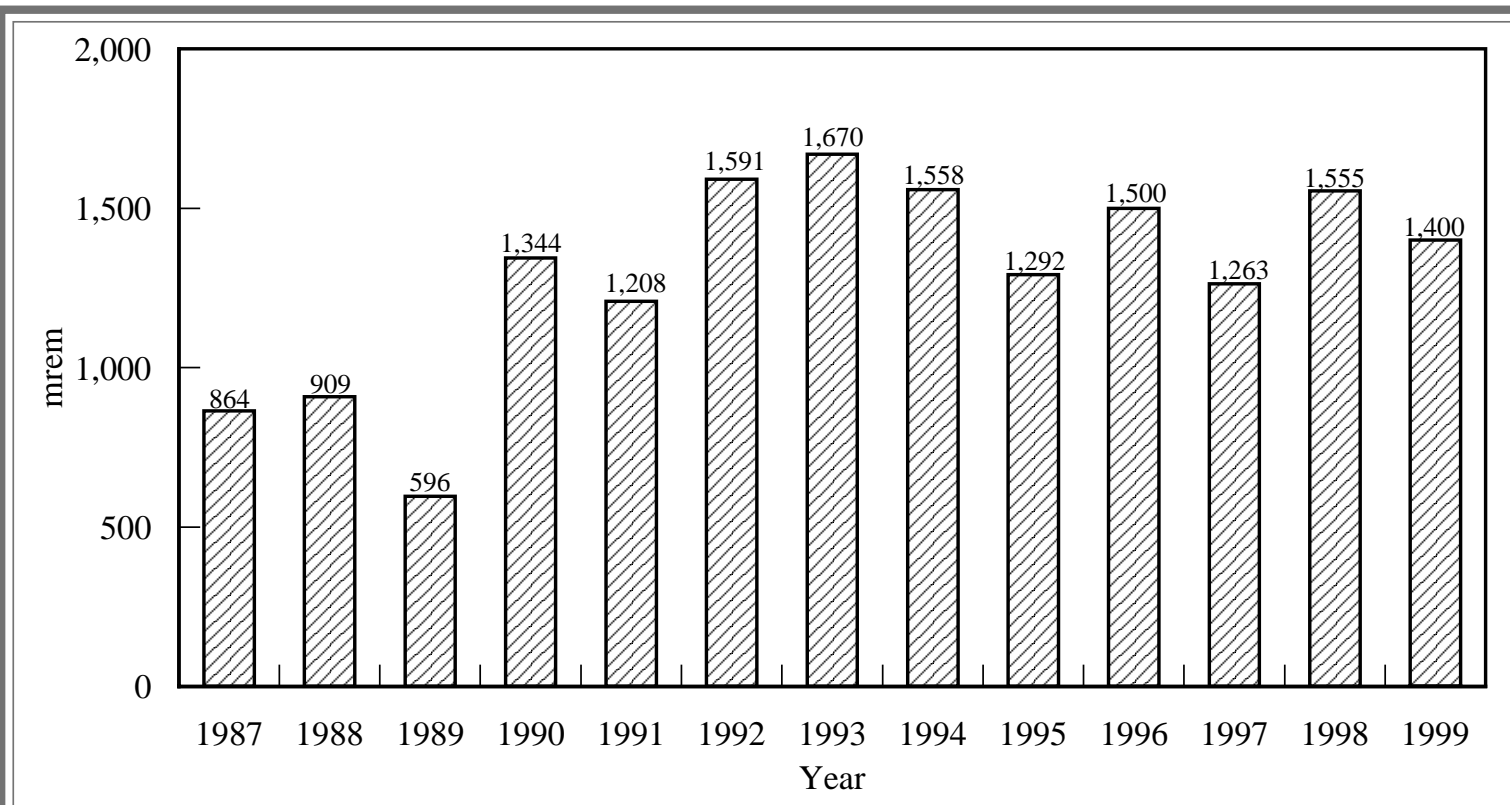

G00020011.201

Figure 3.2.5. Annual Average Thermoluminescent Dosimeter Results in the 100-N Area 
measurement. The annual average thermoluminescent dosimeter results from 1987 through 1999 are presented in Figure 3.2.6.

Ten thermoluminescent dosimeter locations were established around the perimeter of the Tank Waste Remediation System Phase I demonstration project during the fourth quarter of 1997 to collect preoperational monitoring data. Dose rates measured at these locations in 1999 were comparable to the results of 1998, with an average of $88 \mathrm{mrem} / \mathrm{yr}$. This is comparable to offsite ambient background levels.

This is the third year that thermoluminescent dosimeters have been placed at the Environmental Restoration Disposal Facility to evaluate dose rates during ongoing activities. Dose rates measured in 1999 were slightly lower than the 1998 results, with an average of $91 \mathrm{mrem} / \mathrm{yr}$, which is comparable to offsite ambient background levels.

The highest dose rates in the 300 Area in 1999 were measured near the $316-3$ process trench. The average dose rate measured in the 300 Area in 1999 was $110 \mathrm{mrem} / \mathrm{yr}$, which is equal to the average dose rate measured in 1998. The average dose rate at the 300 Area Treated Effluent Disposal Facility in 1999 was $85 \mathrm{mrem} / \mathrm{yr}$, which is a $\%$ increase compared to the average dose rate measured in 1998 . The average dose rate measured in the 400 Area in 1999 was $87 \mathrm{mrem} / \mathrm{yr}$, which is a $1 \%$ decrease to the average dose of $86 \mathrm{mrem} / \mathrm{yr}$ measured in 1998. The annual average thermoluminescent dosimeter results from 1991 through 1998 are presented in Figure 3.2.7.

One new thermoluminescent dosimeter monitoring site was established in the 200 North Area, at the (contaminated) 212-R Railroad Car Disposition Area during the second half of 1999 to monitor expected high radiation levels in the immediate vicinity. Because only two quarters of data were collected at this site, the thermoluminescent dosimeter results were extrapolated to one year, resulting in $1,900 \mathrm{mrem} / \mathrm{yr}$. This value exceeds the DOE annual external dose (greater than $100 \mathrm{mrem} / \mathrm{yr}$ ) limit to the members of the public. However, no member of the public, or Hanford worker, would conceivably spend an entire year at this location.

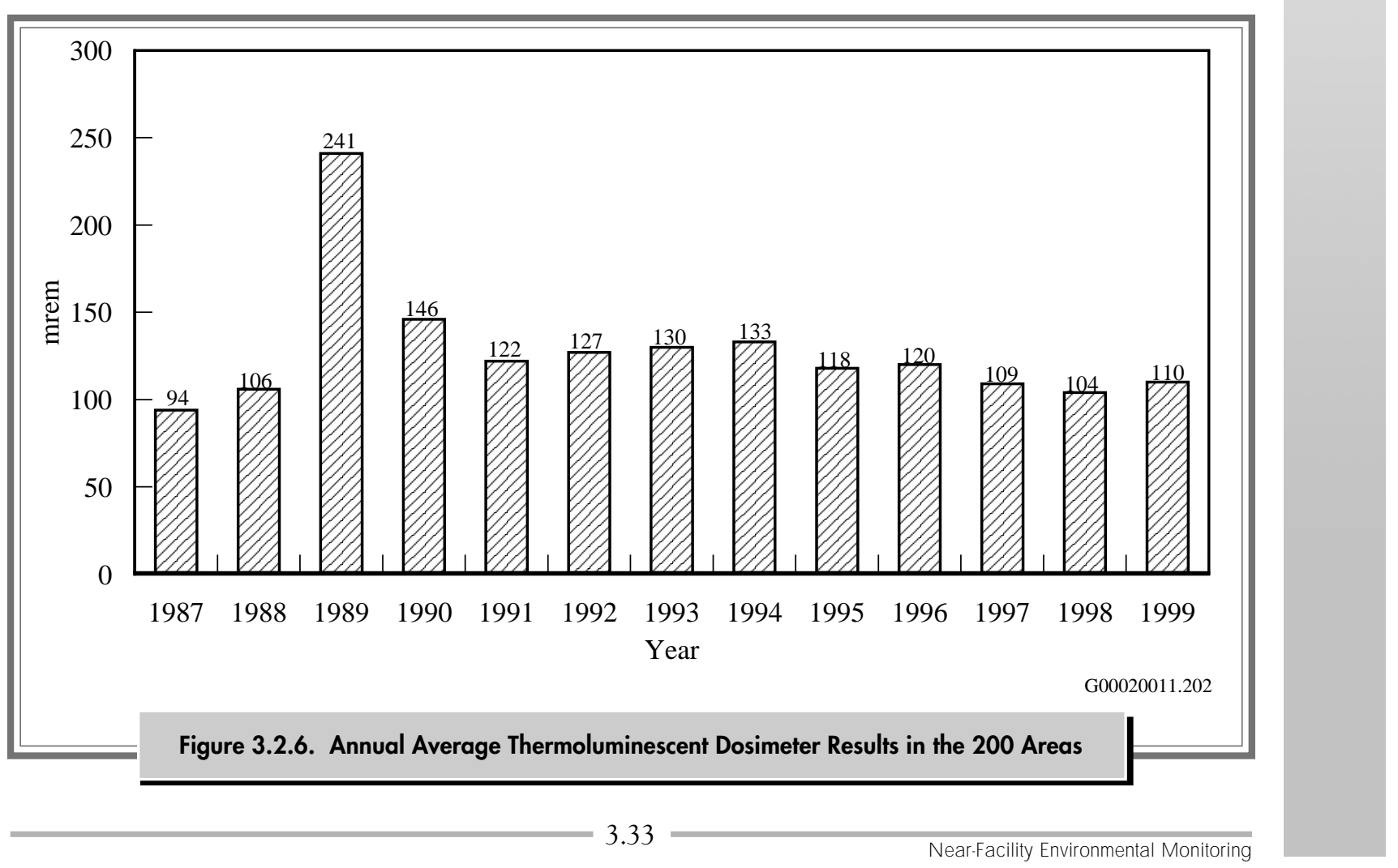




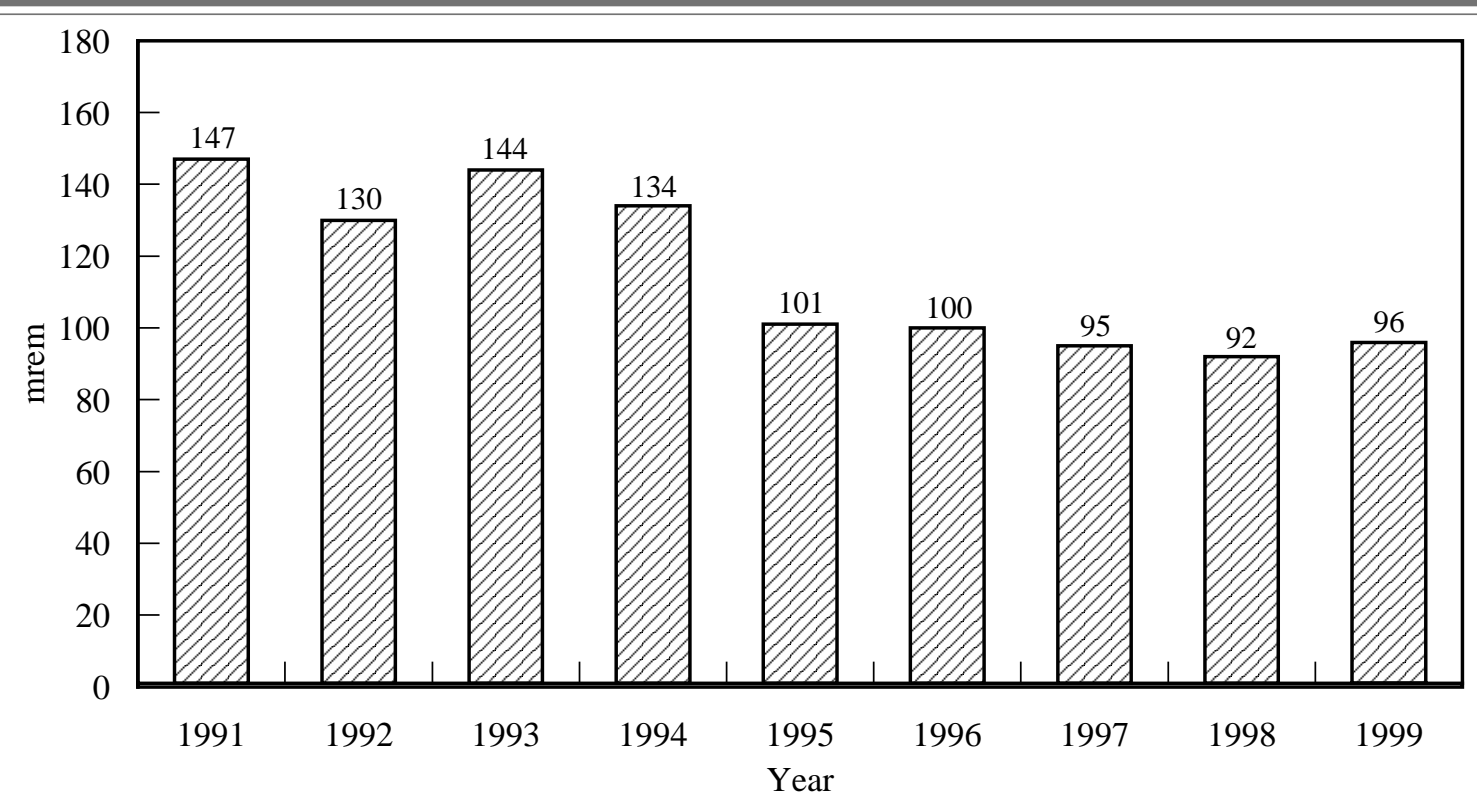

G00020011.203

Figure 3.2.7. Annual Average Thermoluminescent Dosimeter Results in the $300 / 400$ Areas and at the 300 Area Treated Effluent Disposal Facility

\subsubsection{Investigative Sampling}

Investigative sampling was conducted in the operations areas to confirm the absence or presence of radioactive and/or hazardous contaminants where known or suspected radioactive contamination was present or to verify radiological conditions at specific project sites. Investigative sampling took place near facilities such as storage and disposal sites for at least one of the following reasons:

- to follow up radiological surface surveys that had indicated radioactive contamination was present

- to conduct preoperational surveys to characterize the radiological/chemical conditions at a site before facility construction, operation, or ultimate remediation

- to determine if biotic intrusion (e.g., animal burrows or deep-rooted vegetation) has created a potential for contaminants to spread

- to determine the integrity of waste containment systems.
Generally, the predominant radionuclides discovered during these efforts were activation and fission products in the 100 and 200 Areas and uranium in the 300 Area. Hazardous chemicals generally have not been identified above background levels in preoperational environmental monitoring samples.

Investigative samples collected in 1999 included vegetation (tumbleweeds), nests (bird, wasp, ant), mammal feces (rabbit), mammals (mice, bat), and insects (fruit flies).

Methods for collecting investigative samples are described in WMTS-OEM-001, Rev. 0. Field monitoring was conducted to detect radioactivity in samples before they were submitted for analysis. Field monitoring results are expressed as disintegrations per minute when a Geiger-Müeller detector is used or as millirad per hour when an ion chamber is used. To 
obtain the field instrument readings, measured background radioactivity was subtracted from the GeigerMüeller readings (in counts per minute) and converted to disintegrations per minute per $100 \mathrm{~cm}^{2}$. Laboratory sample analysis results are expressed in picocuries per gram, except for extremely small samples. Small samples are expressed in picocuries per sample. Maximum activities, rather than averages, are presented in this section.

In 1999, 17 investigative samples were analyzed for radionuclides at the 222-S Laboratory in the 200-West Area. Of the samples analyzed, 16 showed measurable levels of activity. Analytical results are provided in PNNL-13230, APP. 2. Another 149 contaminated investigative environmental samples were reported and disposed of without isotopic analyses (though field instrument readings were recorded) during cleanup operations. These results are also provided in PNNL-13230, APP. 2. Only radionuclide activities above analytical detection limits are provided in this section.

In 1999, there were 42 instances of radiological contamination in investigative soil samples. Of the 42, 29 were identified only as speck contamination. One investigative sample was collected for radioisotopic analysis, and 43 contaminated soils or specks were found during cleanup operations and disposed of in low-level burial grounds without analysis. External radioactivity levels ranged from $8,400 \mathrm{dpm} /$ $100 \mathrm{~cm}^{2}$ to more than $1,000,000 \mathrm{dpm} / 100 \mathrm{~cm}^{2}$. The contaminated areas were radiologically posted or cleaned up.

In 1999, there were 85 instances of radiological contamination in investigative vegetation samples. Of the 85,82 were identified as tumbleweed, 1 as bunchgrass, and 2 as vegetation. Three tumbleweed samples were analyzed for radionuclide activities. There were 14 tumbleweed samples with field readings above $1,000,000 \mathrm{dpm} / 100 \mathrm{~cm}^{2}$. Of these, 7 were suspected to have originated from the 218-E-12B burial ground in the 200-East Area, and the other 7 from process facilities or transfer line corridors.
The number of contaminated vegetation incidents in 1998 (51) was the highest number of annual incidents in recent years. In 1999, an even higher number of incidents occurred (85). These high numbers can be attributed largely to situations in which herbicide applications were not made at optimum times, and in some cases, not made at all. Application techniques have improved, and administrative procedures have been implemented to improve vegetation management. Nevertheless, contaminated weeds that grew in recent years continued to be identified by radiological surveys.

The number of investigative soil contamination incidents, range of radiation dose levels, and radionuclide concentrations in 1999 were generally within historical values (WHC-MR-0418). Areas of special soil sampling that were outside radiological control areas and had levels greater than radiological control limits were cleaned up or posted as surface contamination areas. Investigative vegetation samples not sent to the laboratory for analysis were disposed of in low-level burial grounds.

Investigative wildlife samples were collected directly from or near facilities to monitor and track the effectiveness of measures designed to deter animal intrusion. Wildlife is collected either as part of an integrated pest management program designed to limit the exposure to, and potential contamination of, animals with radioactive material, or as a result of finding radiologically contaminated wildlife-related material (e.g., feces, nests) during a radiation survey.

Radiological surveys were performed after the collection of wildlife to determine whether an animal was radioactively contaminated. If a live animal was found to be free of contamination, it was taken to an area of suitable habitat, still in a controlled area, and released. If an animal was contaminated, a decision was made based on the level of contamination, location, and frequency of occurrence either to collect the animal as a sample or to dispose of the animal in a low-level burial ground. 
In 1999, nine wildlife and wildlife-related samples were submitted for analysis. This compares to 34 samples collected in 1998, 22 in 1997, 37 in 1996, 22 in 1995, and 16 in 1994. The number of samples submitted for analysis depended on opportunity (i.e., resulting from the pest control activities) and analytical budget, rather than prescheduled sampling at established sampling points. In 1998, 15 fruit flies were gathered as a result of a newly identified pathway of contamination. Only two contaminated fruit flies were identified in 1999. These two are suspected to be dried carcasses remaining in an unoccupied facility from the fall of 1998.

Seven of the nine wildlife-related samples showed detectable levels of radiological contamination. The exceptions were a house fly, which was associated with relatively low field readings of $7,500 \mathrm{dpm} /$ $100 \mathrm{~cm}^{2}$, and some coyote feces that did not show field readings.

The maximum radionuclide concentrations in 1999 were in mouse feces collected near the 241-A lift station, near A tank farm in the 200-East Area. Contaminants included strontium-90 (394,000 pCi/g), cesium-137 (75,400 pCi/g), and total uranium $(1,150,000 \mathrm{pCi} / \mathrm{g})$. The numbers of animals found to be contaminated with radioactivity, their radioactivity levels, and the range of radionuclide activities were within historical levels (WHC-MR-0418).

There were 14 cases of contaminated wildlife or related samples found during cleanup operations that were not submitted to a laboratory for analysis. These samples included dogs (field readings indicated that the contamination was attributable to radon, and the animals were released to the Benton County Humane Society), mice, mouse feces, and mouse traps. The field instrument readings for these samples ranged from $\sim 100$ to more than $10,000,000 \mathrm{dpm} / 100 \mathrm{~cm}^{2}$.

Special characterization projects conducted or completed in 1999 to verify the radiological, and in some cases, potential hazardous chemical status of site operations included the projects listed below.

- A preoperational environmental survey of the Project W-314 pipeline to be constructed in the 200-East Area was completed. This effort was in support of the Tank Waste Remediation System's plan to provide needed upgrades for waste transfer control and instrumentation for existing tank farm facilities. A final report (HNF-4401, Rev. 0) was prepared and issued.

- A preoperational environmental survey is planned in support of the Spent Nuclear Fuels Project Facilities. Environmental samples are being collected in the proximity of the Canister Storage Building and the Interim Storage Area in the 200-East Area and near the Cold Vacuum Drying Facility in the $100-\mathrm{K}$ Area. A Sampling and Analysis Plan (HNF-SD-SNFAP-003) was prepared and issued. 


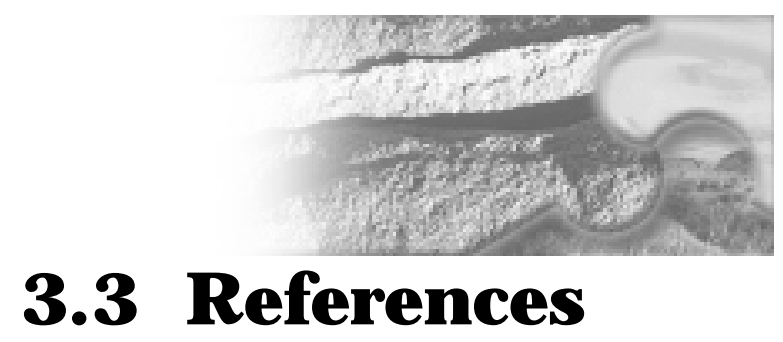

10 CFR 835. U.S. Department of Energy. "Occupational Radiation Protection." Code of Federal Regulations.

40 CFR 61. U.S. Environmental Protection Agency. "National Emission Standards for Hazardous Air Pollutants." Code of Federal Regulations.

40 CFR 122. U.S. Environmental Protection Agency. "EPA Administered Permit Programs: The National Pollutant Discharge Elimination System." Code of Federal Regulations.

AP-42. 1995. Compilation of Air Pollutant Emission Factors, Volume I: Stationary Point and Area Sources. Office of Air Quality Planning and Standards, Office of Air and Radiation, U.S. Environmental Protection Agency, Research Triangle Park, North Carolina, Fifth Edition.

Comprehensive Environmental Response, Compensation, and Liability Act. 1980. Public Law 96-150, as amended, 94 Stat. 2767, 42 USC 9601 et seq.

DOE Order 435.1. "Radioactive Waste Management."

DOE Order 5400.1. "General Environmental Protection Program."

DOE Order 5400.5. "Radiation Protection of the Public and the Environment."

DOE Order 5484.1. "Environmental Protection, Safety, and Health Protection Information Reporting Requirements."

DOE/RL-91-50, Rev. 2. 1997. Environmental Monitoring Plan, United States Department of Energy Richland Operations Office. U.S. Department of Energy, Richland Operations Office, Richland, Washington.
DOE/RL-2000-37. 2000. Radionuclide Air Emissions Report for the Hanford Site, Calendar Year 1999. D. J. Rokkan and K. Rhoads, Waste Management Federal Services of Hanford, Inc. for U.S. Department of Energy, Richland Operations Office, Richland, Washington.

HNF-4401, Rev. 0. 1999. Preoperational Environmental Survey of the Project W-314 Pipeline. R. M. Mitchell, Waste Management Federal Services, Inc., Northwest Operations for Fluor Daniel Hanford, Inc., Richland, Washington.

HNF-EP-0527-9. 2000. Environmental Releases for Calendar Year 1999. D. J. Rokkan, Waste Management Federal Services of Hanford, Inc., Richland, Washington.

HNF-PRO-454, Rev. 1. 1999. Project Hanford Procedures: Inactive Waste Sites. Fluor Daniel Hanford, Inc., Richland, Washington.

HNF-SD-SNF-AP-003. 1999. Sampling and Analysis Plan for the Preoperational Environmental Survey of the Spent Nuclear Fuels Project Facilities. R. M. Mitchell, B. M. Markes, and C. J. Perkins, Waste Management Federal Services, Inc., Northwest Operations for Fluor Daniel Hanford, Inc., Richland, Washington.

PNL-10574. 1995. Hanford Site Environmental Report for Calendar Year 1994. R. L. Dirkes and R. W. Hanf, Pacific Northwest Laboratory, Richland, Washington.

PNNL-11795. 1998. Hanford Site Environmental Report for Calendar Year 1997. R. L. Dirkes and R. W. Hanf (eds.), Pacific Northwest National Laboratory, Richland, Washington. 
PNNL-13230, APP. 2. 2000. Hanford Site NearFacility Environmental Monitoring Data Report for Calendar Year 1999. C. J. Perkins, R. M. Mitchell, B. M. Markes, S. M. McKinney, and R. C. Roos, Waste Management Technical Services for Pacific Northwest National Laboratory, Richland, Washington.

WAC 173-216. "State Waste Discharge Program." Washington Administrative Code, Olympia, Washington.

WAC 173-303-145. "Spills and Discharges Into the Environment." Washington Administrative Code, Olympia, Washington.

WAC 173-400. "General Regulations for Air Pollution Sources." Washington Administrative Code, Olympia, Washington.
WAC 246-247. "Radiation Protection-Air Emissions." Washington Administrative Code, Olympia, Washington.

WHC-MR-0418. 1994. Historical Records of Radioactive Contamination in Biota at the 200 Areas of the Hanford Site. A. R. Johnson, B. M. Markes, J. W. Schmidt, A. N. Shah, S. G. Weiss, and K. J. Wilson, Westinghouse Hanford Company, Richland, Washington.

WMTS-OEM-001, Rev. 0. 2000. Operational Environmental Monitoring. S. M. McKinney, Waste Management Technical Services, Richland, Washington. 


\subsection{Environmental Surveillance Information}

Environmental surveillance of the Hanford Site and the surrounding region is conducted to demonstrate compliance with environmental regulations, confirm adherence to U.S. Department of Energy (DOE) environmental protection policies, support DOE environmental management decisions, and provide information to the public.

Sections 4.1 through 4.7 describe results of the Hanford Site surface environmental surveillance and drinking water surveillance projects for 1999 and include, where applicable, information on both radiological and nonradiological constituents. The objectives, criteria, design, and description of these projects are summarized below and provided in detail in the Hanford Site environmental monitoring plan (DOE/RL-91-50, Rev. 2). Radiological doses associated with the surveillance results are discussed in Section 5.0, "Potential Radiological Doses from 1999 Hanford Operations." The quality assurance and quality control programs developed to ensure the value of surveillance data are described in Section 8.0, "Quality Assurance."

Many samples are collected and analyzed for the Hanford Site environmental surveillance project, and the resultant data are compiled in a large database. It is not practical nor desirable to list individual results in this report; therefore, only summary information is included, emphasizing those radionuclides or chemicals of Hanford Site origin that are important to environmental or human health and safety concerns. Supplemental data for some sections can be found in Appendix A. More detailed results for specific surface environmental surveillance sampling locations are contained in $\mathrm{H}$ anford SiteE nvironmental Surveillance Data Report for Calendar Year 1999 (PNNL-13230, APP. 1). The intent of these sections (Sections 4.1 through 4.7) is to provide current surveillance data, to compare 1999 data to past data and existing and accepted standards, and to present a general overview of Hanford Site surveillance activities.

In addition to Hanford Site environmental surveillance, environmental monitoring is conducted at or near facilities on the site. These near-facility monitoring efforts are discussed in Section 3.0, "Facility-Related Monitoring."

\subsubsection{Surface Environmental Surveillance}

The Surface Environmental Surveillance Project is a multimedia environmental monitoring effort to measure the concentrations of radionuclides and chemicals in environmental media and assess the potential effects of these materials on the environment and the public. Samples of air, surface water, sediments, soil and natural vegetation, agricultural products, fish, and wildlife are collected. Analyses include the measurement of radionuclides at very low environmental levels and nonradiological chemicals, including metals and anions. In addition, ambient external radiation is measured.
The project focuses on routine releases from DOE facilities on the Hanford Site; however, the project is also responsive to unplanned releases and releases from non-DOE operations on and near the site. Surveillance results are provided annually through this report series. In addition, unusual results or trends are reported to DOE and the appropriate facility managers when they occur. Whereas effluent and near-facility environmental monitoring are conducted by the facility operating contractor or designated subcontractor, environmental surveillance is conducted under an independent program that 
reports directly to the DOE Richland Operations Office, Office of Site Services.

\subsubsection{Surveillance Objectives}

The general requirements and objectives for environmental surveillance are contained in DOE Orders 5400.1, "General Environmental Protection Program," and 5400.5, "Radiation Protection of the Public and the Environment." The broad objectives (DOE Order 5400.1) are to demonstrate compliance with legal and regulatory requirements, to confirm adherence to DOE environmental protection policies, and to support environmental management decisions.

These requirements are embodied in the surveillance objectives stated in the DOE Orders and DOE/ EH-0173T, "Environmental Regulatory Guide for Radiological Effluent Monitoring and Environmental Surveillance," and include the following:

- determine compliance with applicable environmental quality standards and public exposure limits and applicable laws and regulations; the requirements of DOE Orders; and the environmental commitments made in environmental impact statements, environmental assessments, safety analysis reports, or other official DOE documents. Additional objectives that derive from the DOE Orders and this primary objective include

- conduct preoperational assessments

- assess radiological doses to the public and aquatic biota from site operations

- assess doses from other local sources

- report alarm levels and potential doses exceeding reporting limits (DOE Order 5400.5, Chapter II, Section 7)

- maintain an environmental monitoring plan

- determine background levels and site contributions of contaminants in the environment
- determine long-term accumulation of siterelated contaminants in the environment and predict trends; characterize and define trends in the physical, chemical, and biological conditions of environmental media

- determine effectiveness of treatment and controls in reducing effluents and emissions

- determine validity and effectiveness of models to predict the concentrations of pollutants in the environment

- detect and quantify unplanned releases

- identify and quantify new environmental quality problems.

DOE/EH-0173T stipulates that subsidiary objectives for surveillance should be considered. Subsidiary objectives applicable to the site include the following:

- obtain data and maintain the capability to assess the consequence of accidents

- provide public assurance; address issues of concern to the public, stakeholders, regulators, and business community

- enhance public understanding of site environmental issues, primarily through public involvement and by providing public information

- provide environmental data and assessments to assist the DOE in environmental management of the site.

\subsubsection{Surveillance Design}

The DOE Orders require that the content of surveillance programs be determined on a site-specific basis by the DOE site offices. The surveillance programs must reflect facility characteristics; applicable regulations; hazard potential; quantities and concentrations of materials released; extent and use of affected air, land, and water; and specific local public interest and concern. Environmental surveillance at the Hanford Site is designed to meet the listed objectives while considering the environmental characteristics of the site and potential and actual releases 
from site operations. Surveillance activities focus on the impact to the environment and compliance with public health and environmental standards or protection guides rather than on providing detailed radiological and chemical characterization. Experience gained from environmental surveillance and studies conducted at the Hanford Site for more than 50 years provides valuable technical background for planning the surveillance design.

The Hanford Site environmental surveillance project historically focused on radionuclides in various media and nonradiological water quality parameters. In recent years, surveillance for nonradiological constituents, including hazardous chemicals, has been expanded. A detailed chemical pathway and exposure analysis for the Hanford Site was completed in 1995 (PNL-10714). The analysis helped guide the selection of chemical surveillance media, sampling locations, and chemical constituents.

Each year, a radiological pathway analysis and exposure assessment is performed. The 1999 pathway analysis was based on 1999 source-term data and on the comprehensive pathway and dose assessment methods included in the Generation II (GENII) computer code (PNL-6584) used to estimate radiation doses to the public from Hanford Site operations. The CRITRII computer code (PNL-8150) and the Biota Dose Assessment Committee (BDAC) computer program were used to calculate doses to animals, and manual calculations were used to compute the doses not addressed in the computer codes. The results of the pathway analysis and exposure assessment serve as a basis for future years' surveillance program design.

Exposure is defined as the interaction of an organism with a physical or chemical agent of interest. Thus, exposure can be quantified as the amount of chemical or physical agent available for absorption at the organism's exchange boundaries (i.e., skin contact, lungs, gut). An exposure pathway is identified based on 1) examination of the types, location, and sources (contaminated soil, raw effluent) of contaminants; 2) principal release mechanisms; 3) probable environmental fate and transport (including persistence, partitioning, and intermediate transfer) of contaminants of interest; and, most important, 4) location and activities of the potentially exposed populations. Mechanisms that influence the fate and transport of a chemical through the environment and influence the amount of exposure a person might receive at various receptor locations are listed below.

Once a radionuclide or chemical is released into the environment, it may be

- transported (e.g., migrate downstream in solution or on suspended sediment, travel through the atmosphere, or be carried off the site by contaminated wildlife)

- physically or chemically transformed (e.g., deposition, precipitation, volatilization, photolysis, oxidation, reduction, hydrolysis or radionuclide decay)

- biologically transformed (e.g., biodegradation)

- accumulated in the receiving media (e.g., sorbed strongly in the soil column, stored in organism tissues).

The primary pathways for movement of radioactive materials and chemicals from the site to the public are the atmosphere and surface water. Figure 4.0.1 illustrates these potential routes and exposure pathways to humans.

The significance of each pathway was determined from measurements and calculations that estimated the amount of radioactive material or chemical transported along each pathway and by comparing the concentrations or potential doses to environmental and public health protection standards or guides. Pathways were also evaluated based on prior studies and observations of radionuclide and chemical movement through the environment and food chains. Calculations based on effluent data showed the expected concentrations off the Hanford Site to be low for all Hanford-produced radionuclides and chemicals and to be frequently below the level that could 


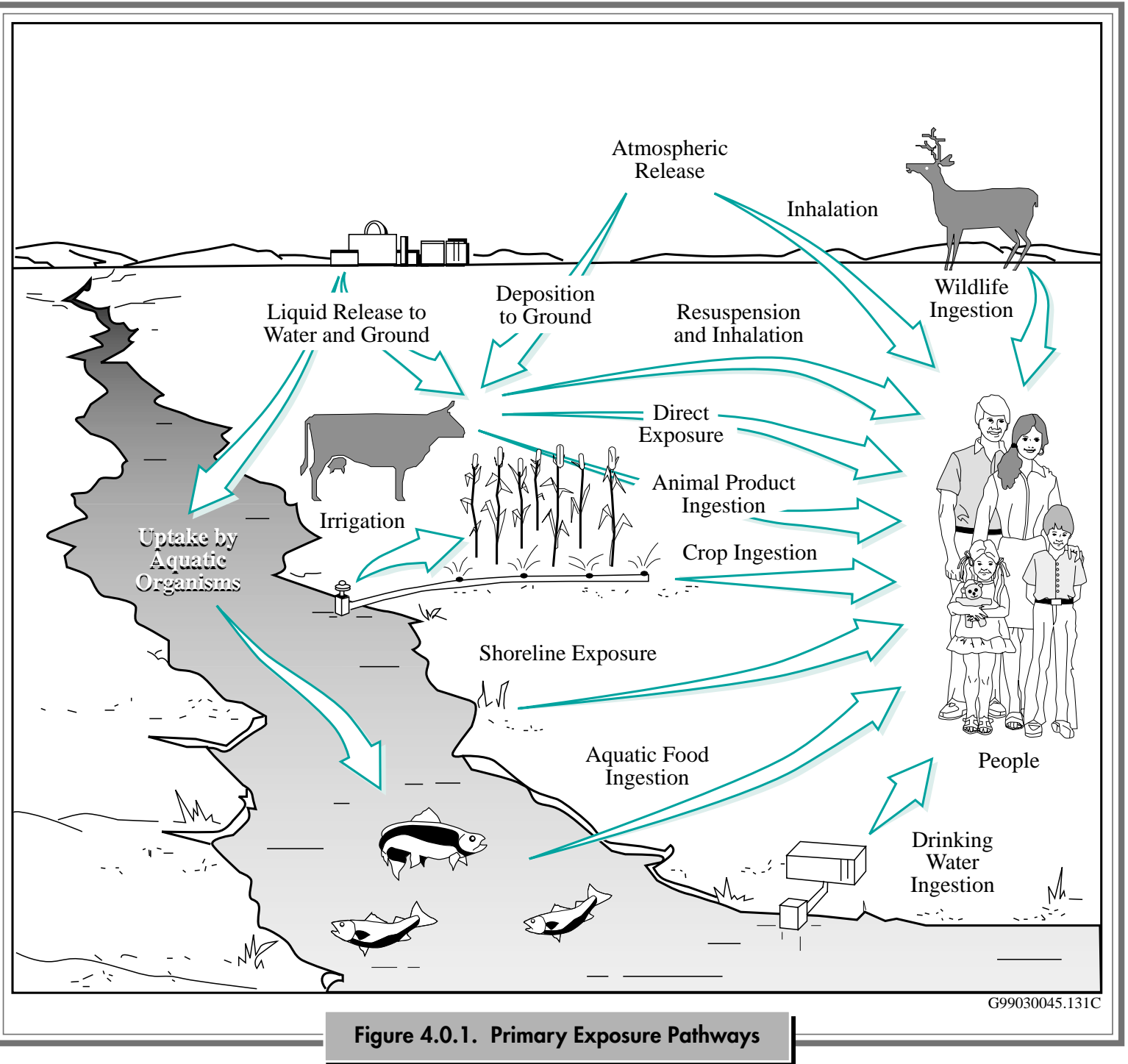

be detected by monitoring technology. To ensure that radiological and chemical analyses of samples were sufficiently sensitive, minimum detectable concentrations of key radionuclides and chemicals were established at levels well below applicable health standards.

Environmental and food chain pathways were monitored near facilities releasing effluents and at potential offsite receptor locations. The surveillance design at Hanford used a stratified sampling approach to monitor these pathways. Samples were collected, and radionuclide and chemical concentrations were measured in three general surveillance zones that extended from onsite operational areas to the offsite environs.

The first surveillance zone extended from near the operational areas to the site perimeter. The environmental concentrations of releases from facilities and fugitive sources (those released from other than monitored sources such as contaminated soils) generally would be the highest and, therefore, most easily detected in this zone. The second surveillance zone consisted of a series of perimeter sampling stations positioned near or just inside the site boundary, along State Highway 240, which runs through 
the site from Richland to the Vernita Bridge, and along the Columbia River (see Figure 1.0.1). Exposures at these locations were typically the maximum that any member of the public could receive. The third surveillance zone consisted of nearby and distant community locations within an 80-kilometer (50-mile) radius of the site. Surveillance was conducted in communities to obtain measurements at locations where a large number of people potentially could be exposed to Hanford Site releases and to document that contaminant levels were well below standards established to protect public health. Table 4.0.1 summarizes the sample types and measurement locations in all three zones for 1999. A summary of the number and types of samples collected during 1999, and the number of analytical results obtained from those samples is provided in Table 4.0.2.

Background concentrations were measured at distant locations and compared with concentrations measured on the site and at perimeter and community locations. Background locations were essentially unaffected by Hanford Site operations (i.e., these locations could be used to measure ambient environmental levels of chemicals and radionuclides). Comparing concentrations at these background locations to concentrations measured on or near the site indicated the impact, if any, of Hanford Site operations.

To the extent possible, radiological dose assessments should be based on direct measurements of dose rates and radionuclide activities in environmental media. However, the amounts of most radioactive materials released from Hanford Site operations in recent years generally have been too small to be measured directly once dispersed in the offsite environment. For the measurable radionuclides, often it was not possible to distinguish levels resulting from worldwide fallout and natural sources from those associated with Hanford Site releases. Therefore,

\begin{tabular}{|c|c|c|c|c|c|c|c|c|}
\hline \multirow[b]{4}{*}{ Type } & \multicolumn{7}{|c|}{$\begin{array}{c}\text { Table 4.0.1. Routine Environmental Surveillance Sample Types and } \\
\text { Measurement Locations, } 1999\end{array}$} & \\
\hline & \multirow[b]{3}{*}{$\begin{array}{l}\text { Total } \\
\text { Number }\end{array}$} & \multicolumn{7}{|c|}{ Sample Locations } \\
\hline & & \multirow[b]{2}{*}{ Onsite $^{(a)}$} & \multirow[b]{2}{*}{$\begin{array}{c}\text { Site } \\
\text { Perimeter }^{(b)}\end{array}$} & \multirow[b]{2}{*}{$\underline{\text { Nearby }}{ }^{(c)}$} & \multirow[b]{2}{*}{ Distant $^{(c)}$} & \multicolumn{3}{|c|}{ Columbia River } \\
\hline & & & & & & $\underline{\text { Upstream }}^{(\mathrm{c})}$ & $\begin{array}{l}\text { Hanford } \\
\text { Reach }^{(b)}\end{array}$ & Downstream $^{(c)}$ \\
\hline Air & 44 & 23 & 11 & $8^{(d)}$ & $2^{(\mathrm{e})}$ & & & \\
\hline Spring water & 8 & & & & & & 8 & \\
\hline Spring sediment & 4 & & & & & & 4 & \\
\hline Columbia River & 7 & & & & & 2 & 4 & 1 \\
\hline Irrigation water & 1 & & 1 & & & & & \\
\hline Drinking water & 5 & 5 & & & & & & \\
\hline River sediment & 6 & & & & & 1 & 3 & 2 \\
\hline Ponds & 2 & 2 & & & & & & \\
\hline Foodstuffs & 9 & & & 7 & 2 & & & \\
\hline Wildlife & 8 & 4 & & & & 2 & 2 & \\
\hline External dose & 74 & 28 & 36 & $8^{(\mathrm{d})}$ & $2^{(\mathrm{e})}$ & & & \\
\hline $\begin{array}{l}\text { External shoreline } \\
\text { radiation }\end{array}$ & 13 & & 13 & & & & & \\
\hline Exposure rate & 4 & & & $3^{(\mathrm{d})}$ & $1^{(\mathrm{d})}$ & & & \\
\hline $\begin{array}{l}\text { (a) Surveillance } \\
\text { (b) Surveillance } \\
\text { (c) Surveillance } \\
\text { (d) Community-c } \\
\text { (e) Includes one }\end{array}$ & $\begin{array}{l}\text { zone } 1 . \\
\text { zone } 2 . \\
\text { zone } 3 \text {. } \\
\text { comated en } \\
\text { community }\end{array}$ & $\begin{array}{l}\text { ronmental } \\
\text { pperated ens }\end{array}$ & $\begin{array}{l}\text { urveillance sta } \\
\text { ironmental sur }\end{array}$ & $\begin{array}{l}\text { ions. } \\
\text { veillance }\end{array}$ & & & & \\
\hline
\end{tabular}




\begin{tabular}{|c|c|c|}
\hline \multicolumn{3}{|c|}{$\begin{array}{c}\text { Table 4.0.2. Samples Collected for the } \\
\text { Surface Environmental Surveillance } \\
\text { Project and Analytical Results } \\
\text { Obtained, } 1999\end{array}$} \\
\hline Media & $\begin{array}{l}\text { Number of } \\
\text { Samples } \\
\text { Collected }\end{array}$ & $\begin{array}{c}\text { Number of } \\
\text { Analytical } \\
\text { Results } \\
\text { Obtained }\end{array}$ \\
\hline Air & 1,507 & 3,849 \\
\hline Biota & 294 & 2,141 \\
\hline Soil and sediment & 106 & 1,304 \\
\hline Surface water & 432 & 3,594 \\
\hline External radiation & 233 & 233 \\
\hline Totals & 2,572 & 11,121 \\
\hline
\end{tabular}

offsite doses in 1999 were estimated using the following methods:

- Doses from monitored air emissions and liquid effluents released to the Columbia River were estimated by applying environmental transport and dose calculation models to measured effluent monitoring data and selected environmental measurements.

- Doses from fugitive air emissions (e.g., from unmonitored, resuspended, contaminated soils) were estimated from measured airborne concentrations at site perimeter locations.

- Doses from fugitive liquid releases (e.g., unmonitored groundwater seeping into the Columbia River) were estimated by evaluating differences in measured concentrations in Columbia River water upstream and downstream from the Hanford Site.

The surveillance design is reviewed annually based on the above considerations as well as an awareness of planned waste management and environmental restoration activities. The final sampling design and schedule are documented annually in the environmental surveillance master sampling schedule (PNNL-12103). 


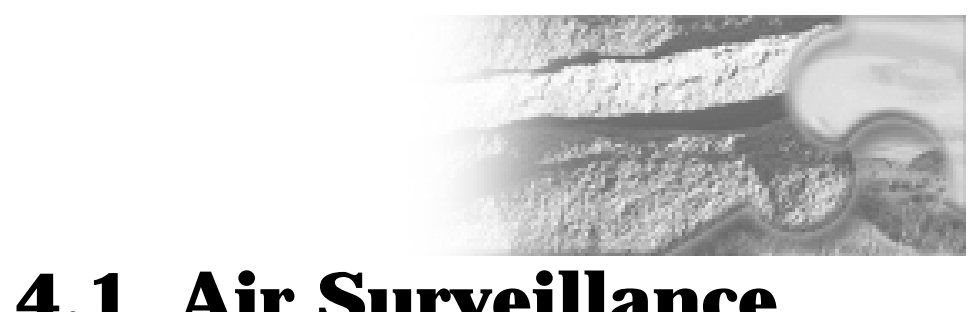

4.1 Air Surveillance

B. M. G illespie

Atmospheric releases of radioactive material from the Hanford Site to the surrounding region are a potential source of human exposure. Radioactive constituents in air are monitored at a number of locations on and around the site. The influence of Hanford emissions on the local environment was evaluated by comparing air concentrations measured at distant locations within the region to concentrations measured onsite and at the site perimeter. This section discusses sample collection techniques and analytes tested for at each location and summarizes the analytical results of the air surveillance program. A complete listing of all analytical results summarized in this section is reported separately (PNNL13230, APP. 1). A detailed description of all radiological sampling and analytical techniques is provided in the environmental monitoring plan (DOE/RL-91-50, Rev. 2).

\subsubsection{Collection of Air Samples and Analytes Tested for at Each Sample Location}

Airborne radionuclide samples were collected at 44 continuously operating samplers: 23 on the Hanford Site, 11 near the site perimeter, 8 in nearby communities, and 2 in distant communities (Figure 4.1.1 and Table 4.1.1). Nine of the stations were community-operated environmental surveillance stations (discussed in Section 7.4, "CommunityOperated Environmental Surveillance Program") that were managed and operated by local school teachers. Air samplers on the Hanford Site were located primarily around major operational areas to maximize the ability to detect radiological contaminants resulting from site operations. Perimeter samplers were located around the site, with emphasis on the prevailing downwind directions to the south and east of the site (discussed in Section 7.1, "Climate and Meteorology"). Continuous samplers located in Benton City, Kennewick, Mattawa, Othello, Pasco, and Richland provided data for the nearest population centers. Samplers in the distant communities of Toppenish and Yakima provided background data for communities essentially unaffected by Hanford Site operations.
Samples were collected according to a schedule established before the monitoring year (PNNL12103). The air sampling locations and the analytes tested for at each location are given in Table 4.1.1. Airborne particles were sampled at each of these locations by continuously drawing air through a high efficiency glass-fiber filter. The samples were transported to an analytical laboratory and stored for at least 72 hours. The storage period was necessary to allow for the decay of short-lived, naturally occurring radionuclides (e.g., radon gas decay products) that would otherwise obscure detection of longer-lived radionuclides potentially present from Hanford Site emissions. The filters were then analyzed for gross beta radioactivity, and most filters were also analyzed for gross alpha radioactivity.

For most radionuclides, the amount of radioactive material collected on the filter during the 2 -week period was too small to be readily measured. The sensitivity and accuracy of sample results were increased by combining biweekly samples for nearby locations (or, in some cases, a single location) into quarterly composite samples. The quarterly composite 


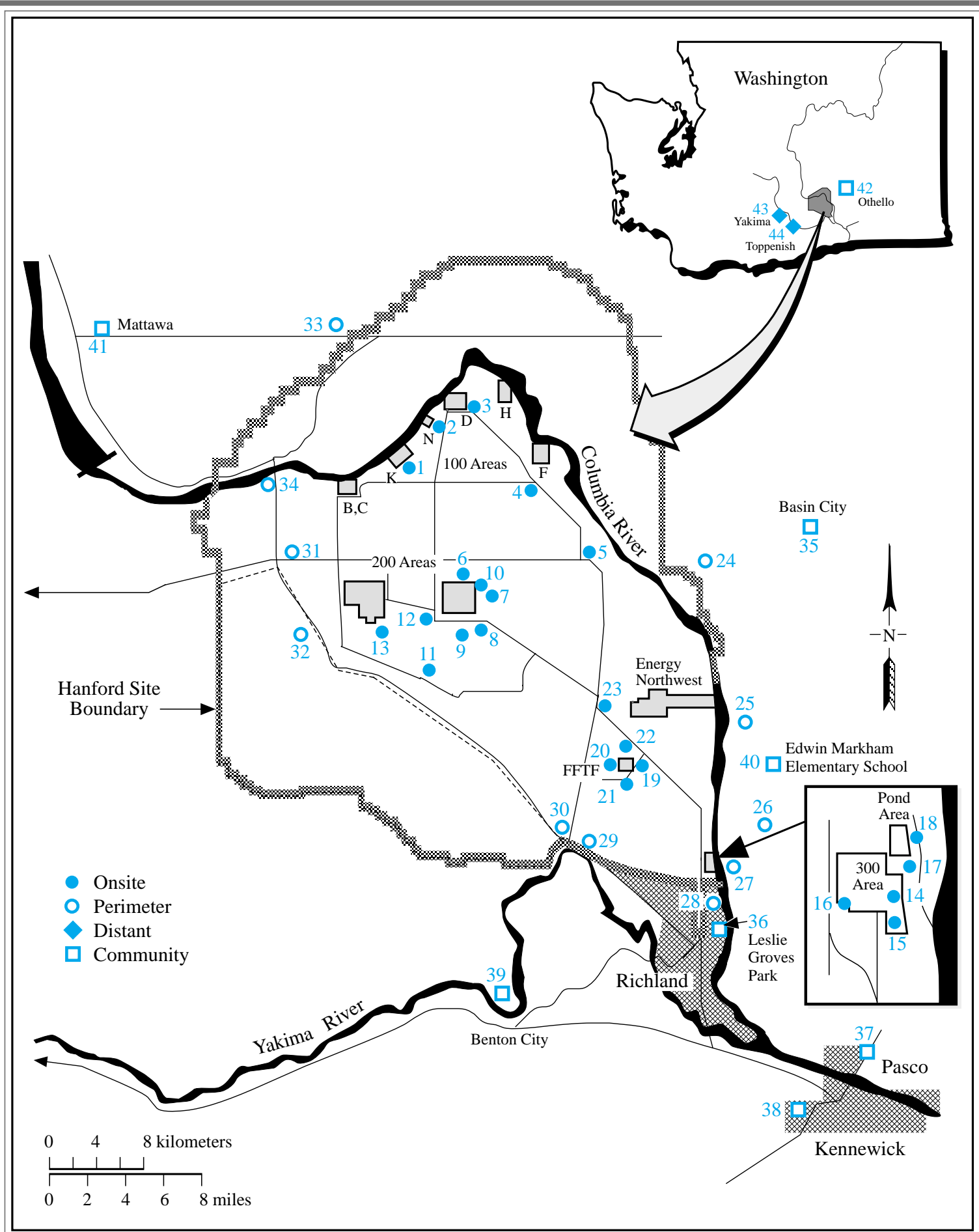

G00020011.1

Figure 4.1.1. Air Sampling Locations, 1999 (see Table 4.1.1 for location names) 
Table 4.1.1. Air Sampling Locations, Sample Composite Groups, and Analyses, 1999

Map(a)

Location

Onsite

3

4

6

7

8

9

10

11

12

13

14

15

16

17

18

19

20

21

22

23

Perimeter

24

25

26

27

28

29

30

31

32

33

34
Sampling Location

$100 \mathrm{~K}$ Area

100 N-1325 Crib

100 D Area

100 F Met Tower

Hanford Townsite

$\mathrm{N}$ of $200 \mathrm{E}$

E of $200 \mathrm{E}$

200 ESE

$S$ of $200 \mathrm{E}$

B Pond

Army Loop Camp

200 Tel. Exchange

200 W SE

300 Water Intake

300 South Gate

300 South West

300 Trench

$300 \mathrm{NE}$

$400 \mathrm{E}$

$400 \mathrm{~W}$

$400 \mathrm{~S}$

$400 \mathrm{~N}$

Wye Barricade

Ringold Met Tower

W End of Fir Road

Dogwood Met Tower

Byers Landing

Battelle Complex

Horn Rapids Substation

Prosser Barricade

Yakima Barricade

Rattlesnake Springs

Wahluke Slope

$S$ End Vernita Bridge
Analytes $^{(b)}$

Composite Group

100 Areas

Alpha, Beta, ${ }^{3} \mathrm{H}$

Alpha, Beta

Alpha, Beta

Alpha, Beta

Beta

Alpha, Beta

Alpha, Beta, ${ }^{3} \mathrm{H},{ }^{129} \mathrm{I}$

Alpha, Beta

Alpha, Beta

Alpha, Beta

Alpha, Beta, ${ }^{3} \mathrm{H}$

Alpha, Beta

Alpha, Beta, ${ }^{3} \mathrm{H}$

Alpha, Beta, ${ }^{3} \mathrm{H}$

Alpha, Beta, ${ }^{3} \mathrm{H}$

Alpha, Beta, ${ }^{3} \mathrm{H}$

Alpha, Beta, ${ }^{3} \mathrm{H}$

Alpha, Beta, ${ }^{3} \mathrm{H}$

Alpha, Beta

Alpha, Beta

Alpha, Beta

Alpha, Beta

Alpha, Beta, ${ }^{3} \mathrm{H},{ }^{129} \mathrm{I}$

Alpha, Beta

Alpha, Beta, ${ }^{3} \mathrm{H}$

Alpha, Beta, ${ }^{3} \mathrm{H},{ }^{129} \mathrm{I}$

Beta

Alpha, Beta

${ }^{3} \mathrm{H}$

Alpha, Beta

Alpha, Beta

Alpha, Beta, ${ }^{3} \mathrm{H}$

Alpha, Beta
Analytes $^{(c)}$

Gamma, Sr, Pu

Gamma, Sr, Pu

Gamma

Gamma, Sr, Pu, U

Gamma, Sr, Pu, U

Gamma, Sr, Pu, U

Gamma, Sr, Pu, U

Gamma, Sr, Pu, U

Gamma, Sr, Pu, U

Gamma, Sr, Pu

Gamma, Sr, Pu, U

Gamma, Sr, Pu

Gamma, Sr, Pu, U

Gamma, Sr, Pu, U

Gamma, Sr, Pu, U

Gamma

Gamma, Sr, Pu, U

Gamma, Sr, Pu

Gamma, Sr, Pu 


\section{Table 4.1.1. (contd)}

Map(a)

Location

Sampling Location

Analytes $^{(\mathbf{b})}$

Composite Group

Analytes $^{(c)}$

Nearby Communities

$\begin{array}{lllll}35 & \text { Basin City School }^{(\mathrm{d})} & \text { Alpha, Beta, }{ }^{3} \mathrm{H} & \text { Basin City School } & \text { Gamma, Sr, Pu, U } \\ 36 & \text { Leslie Groves-Rchlnd }^{(\mathrm{d})} & \text { Alpha, Beta, }{ }^{3} \mathrm{H} & \text { Leslie Groves-Rchlnd } & \text { Gamma, Sr, Pu, U } \\ 37 & \text { Pasco }^{(\mathrm{d})} & \text { Beta } & \text { Tri-Cities } & \text { Gamma, Sr, Pu } \\ 38 & \text { Kennewick }^{(\mathrm{d})} & \text { Alpha, Beta } & & \\ 39 & \text { Benton City }^{(\mathrm{d})} & \text { Beta } & \text { Benton City } & \text { Gamma } \\ 40 & \text { Edwin Markham }^{\text {School }}{ }^{(\mathrm{d})} & \text { Alpha, Beta, }{ }^{3} \mathrm{H} & \text { Edwin Markham } & \text { Gamma, Sr, Pu, U } \\ & \text { Mattawa }^{(\mathrm{d})} & \text { School } & \text { Gattawa } & \text { Gamma } \\ 41 & \text { Othello }^{(\mathrm{d})} & \text { Beta } & \text { Othello } & \text { Gamma }\end{array}$

\section{Distant Communities}

\begin{tabular}{|c|c|c|c|c|}
\hline 43 & Yakima & Alpha, Beta, ${ }^{3} \mathrm{H},{ }^{129} \mathrm{I}$ & Yakima & Gamma, Sr, Pu, U \\
\hline 44 & Toppenish $^{(\mathrm{d})}$ & Alpha, Beta, ${ }^{3} \mathrm{H}$ & Toppenish & Gamma, Sr, Pu, U \\
\hline
\end{tabular}

(a) See Figure 4.1.1.

(b) Alpha (gross) and beta (gross) samples are collected and analyzed every 2 weeks, ${ }^{3} \mathrm{H}$ samples are collected and analyzed every 4 weeks, and ${ }^{129} \mathrm{I}$ samples are collected every 4 weeks, combined into a quarterly composite sample and analyzed for each location.

(c) Gamma scans, strontium-90, isotopic plutonium $\left({ }^{238} \mathrm{Pu},{ }^{239 / 240} \mathrm{Pu}\right)$, and isotopic uranium $\left.{ }^{234} \mathrm{U},{ }^{235} \mathrm{U},{ }^{238} \mathrm{U}\right)$ analyses are performed on quarterly composite samples.

(d) A community-operated environmental surveillance station.

samples were analyzed for specific gammaemitting radionuclides (Appendix E), strontium-90, and plutonium isotopes, with selected composites also analyzed for uranium isotopes.

Samples were collected for iodine-129 at four locations by drawing air through a cartridge containing chemically treated, special, low-background petroleum-charcoal positioned downstream of a particle filter. Samples were collected monthly and combined to form quarterly composite samples for each location.

Atmospheric water vapor was collected for tritium analysis at 20 locations by continuously passing air through cartridges containing silica gel, which were exchanged every 4 weeks. The collection efficiency of the silica gel adsorbent is discussed in Patton et al. (1997). The collected water was distilled from the silica gel and analyzed for its tritium content.

Some air samples were collected at nine community-operated environmental surveillance stations (see Section 7.4, "Community-Operated Environmental Surveillance Program"). These samples were collected by local teachers as part of an ongoing DOE-sponsored program to promote public awareness of Hanford Site environmental monitoring programs. The samples were submitted to the analytical laboratory and treated the same as all other submitted samples. 


\subsubsection{Radiological Results for Air Samples}

Radiological air sampling results for onsite, site perimeter, nearby communities, and distant communities for gross alpha, gross beta, and specific radionuclides are summarized in Table 4.1.2.

A detectable value is defined in this section as a value reported above the minimum detectable activity or above the 2-sigma total propagated analytical uncertainty. A gamma-emitting radionuclide is detectable if the radionuclide library of the software determines an isotope activity above the minimum detectable activity of a sample. The nominal detection limit is defined as the average 2-sigma total propagated analytical uncertainty of the population of reported values.

The average gross alpha radioactivity concentrations at the site perimeter appeared to be slightly elevated compared to the levels measured at distant stations (see Table 4.1.2); however, the difference was not statistically significant (log transformed, two-tailed t-test, 5\% significance level), indicating that the observed levels were predominantly a result of natural sources and worldwide radioactive fallout. The gross alpha average concentration values were similar to values reported for 1994 through 1999 (see Figure 4.1.2). The highest onsite gross alpha concentration was at the Wye Barricade sampling location (23 on Figure 4.1.1).

Tritium concentrations measured in 1999 (excluding 300 Area samples) were similar to values reported for 1995 through 1998 (see Table 4.1.2 and Figure 4.1.3) and did not show the highly elevated concentrations and widely variable results reported for 1991 through 1994 (Section 4.1 in PNL-11139). For $1999, \sim 77 \%$ of the samples analyzed for tritium had results reported above the detection limit (the method is capable of detecting concentrations of no less than $3 \mathrm{pCi} / \mathrm{m}^{3}$ ). Sample results above the detection limit were consistently determined for the 300 Area samples. Tritium releases in the 300 Area are associated with research and development activities (see Table 3.1.1). These research and development activities are expected to continue for the next year; therefore, higher tritium concentrations are expected for the 300 Area samples in 2000 as well. Figure 4.1.3 shows the slightly elevated 300 Area average tritium concentration with respect to other onsite average tritium concentrations, as well as perimeter and distant locations.

The annual average tritium concentration measured at the site perimeter $\left(2.3 \pm 0.8 \mathrm{pCi} / \mathrm{m}^{3}\right)$ appeared to be slightly higher than the annual average value at the distant locations $\left(1.9 \pm 0.76 \mathrm{pCi} / \mathrm{m}^{3}\right)$; however, the difference was not statistically significant (log transformed, two-tailed t-test, 5\% significance level). The annual average tritium concentrations measured at the site perimeter in 1999 was less than $0.003 \%$ of the $100,000-\mathrm{pCi} / \mathrm{m}^{3}$ DOE derived concentration guide (DOE Order 5400.5).

Gross beta concentrations in air for 1999 (Figure 4.1.4) peaked during the winter, repeating a pattern of natural annual radioactivity fluctuations (Eisenbud 1987). The average gross beta concentration was slightly higher at the site perimeter than the annual average concentration value at the distant location. The values were slightly lower than values reported for 1994 through 1999 (see Table 4.1.2).

For samples analyzed for strontium-90 in 1999 (Figure 4.1.5), 21 of the 92 samples were above the detection limit (see Table 4.1.2). The perimeter average appears to be elevated with respect to the distant concentrations; however, the difference was not statistically significant (log transformed, twotailed t-test, 5\% significance level). The highest level $\left(210 \pm 190 \mathrm{aCi} / \mathrm{m}^{3}\right)$ was determined for the Leslie Groves, Richland composite sample (location 36 on Figure 4.1 .1 ), which is $0.003 \%$ of the $9,000,000-\mathrm{aCi} / \mathrm{m}^{3}$ derived concentration guide.

Iodine-129 analyses were performed on samples collected downwind of the Plutonium-Uranium 


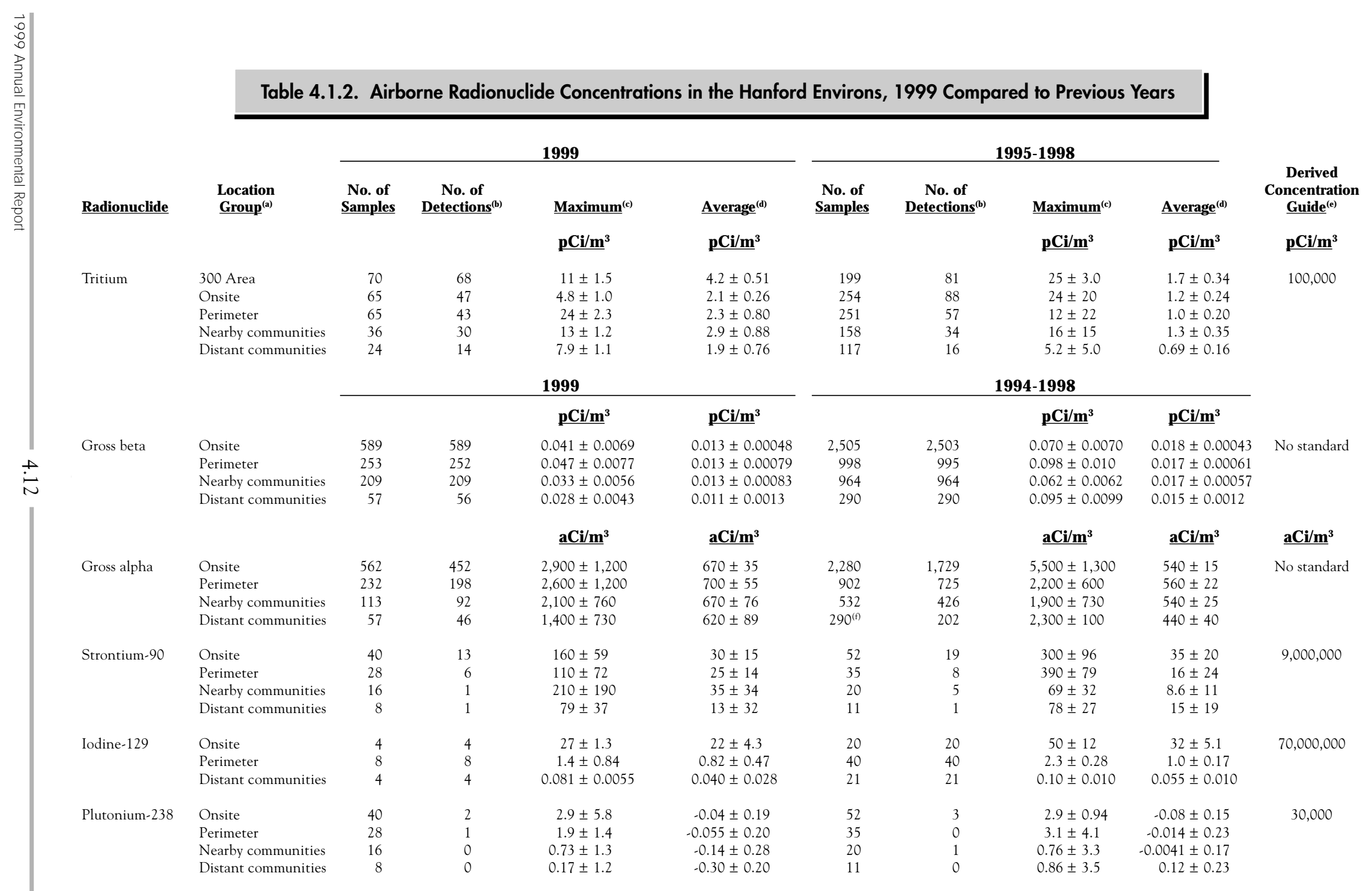


Table 4.1.2. (contd)

1999

1994-1998

\begin{tabular}{|c|c|c|c|c|c|c|c|c|c|c|}
\hline Radionuclide & $\begin{array}{l}\text { Location } \\
\text { Group }^{(\text {a) }}\end{array}$ & $\begin{array}{l}\text { No. of } \\
\text { Samples }\end{array}$ & $\begin{array}{c}\text { No. of } \\
\text { Detections }^{(b)}\end{array}$ & Maximum $^{(c)}$ & Average $^{(d)}$ & $\begin{array}{l}\text { No. of } \\
\text { Samples }\end{array}$ & $\begin{array}{c}\text { No. of } \\
\text { Detections }^{(b)}\end{array}$ & Maximum $^{(c)}$ & Average $^{(d)}$ & $\begin{array}{l}\text { Denved } \\
\text { Concentration } \\
\text { Guide' }\end{array}$ \\
\hline & & & & $\underline{\mathrm{aCi} / \mathrm{m}^{3}}$ & $\underline{\mathrm{aCi} / \mathrm{m}^{3}}$ & & & $\underline{\mathrm{aCi} / \mathrm{m}^{3}}$ & $\underline{\mathrm{aC} i / \mathrm{m}^{3}}$ & $\underline{\mathrm{aCi} / \mathrm{m}^{3}}$ \\
\hline \multirow{4}{*}{$\begin{array}{l}\text { Plutonium- } \\
239 / 240\end{array}$} & Onsite & 40 & 12 & $10 \pm 4.5$ & $1.0 \pm 0.59$ & 52 & 23 & $12 \pm 2.5$ & $1.2 \pm 0.60$ & 20,000 \\
\hline & Perimeter & 28 & 4 & $4.1 \pm 3.3$ & $0.63 \pm 0.34$ & 35 & 10 & $1.5 \pm 0.8$ & $0.34 \pm 0.13$ & \\
\hline & Nearby communities & 16 & 2 & $1.3 \pm 1.6$ & $0.46 \pm 0.29$ & 20 & 5 & $1.3 \pm 3.1$ & $0.17 \pm 0.21$ & \\
\hline & Distant communities & 8 & 1 & $3.2 \pm 2.9$ & $0.94 \pm 0.81$ & 11 & 2 & $1.2 \pm 1.2$ & $0.18 \pm 0.26$ & \\
\hline \multirow[t]{4}{*}{ Uranium-234 } & Onsite & 32 & 28 & $85 \pm 21$ & $27 \pm 7.6$ & 44 & 43 & $140 \pm 210$ & $25 \pm 6.7$ & 90,000 \\
\hline & Perimeter & 16 & 16 & $66 \pm 21$ & $34 \pm 8.4$ & 20 & 20 & $45 \pm 8.9$ & $27 \pm 4.7$ & \\
\hline & Nearby communities & 12 & 12 & $54 \pm 17$ & $33 \pm 6.9$ & 15 & 15 & $33 \pm 15$ & $24 \pm 3.0$ & \\
\hline & Distant communities & 8 & 7 & $41 \pm 15$ & $23 \pm 6.9$ & 11 & 11 & $27 \pm 8.9$ & $17 \pm 2.9$ & \\
\hline \multirow[t]{4}{*}{ Uranium-235 } & Onsite & 32 & 2 & $3.7 \pm 2.7$ & $0.63 \pm 0.46$ & 44 & 12 & $51 \pm 130$ & $2.0 \pm 2.3$ & 100,000 \\
\hline & Perimeter & 16 & 0 & $6.0 \pm 6.0$ & $0.86 \pm 1.0$ & 20 & 10 & $3.4 \pm 2.1$ & $1.3 \pm 0.45$ & \\
\hline & Nearby communities & 12 & 1 & $6.2 \pm 5.6$ & $0.85 \pm 1.3$ & 15 & 6 & $4.3 \pm 4.8$ & $1.2 \pm 0.47$ & \\
\hline & Distant communities & 8 & 0 & $6.2 \pm 6.3$ & $0.57 \pm 1.7$ & 11 & 0 & $3.3 \pm 4.0$ & $0.73 \pm 0.68$ & \\
\hline \multirow[t]{4}{*}{ Uranium-238 } & Onsite & 32 & 30 & $92 \pm 27$ & $25 \pm 7.2$ & 44 & 43 & $58 \pm 14$ & $19 \pm 3.8$ & 100,000 \\
\hline & Perimeter & 16 & 16 & $59 \pm 20$ & $29 \pm 7.7$ & 20 & 20 & $43 \pm 8.6$ & $26 \pm 4.5$ & \\
\hline & Nearby communities & 12 & 11 & $56 \pm 18$ & $28 \pm 8.3$ & 15 & 15 & $35 \pm 14$ & $24 \pm 3.7$ & \\
\hline & Distant communities & 8 & 8 & $33 \pm 15$ & $22 \pm 0.54$ & 11 & 10 & $23 \pm 8.1$ & $16 \pm 3.0$ & \\
\hline \multirow[t]{4}{*}{ Cobalt- 60} & Onsite & 50 & 0 & $430 \pm 690$ & $64 \pm 53$ & 204 & 20 & $880 \pm 490$ & $66 \pm 38$ & $80,000,000$ \\
\hline & Perimeter & 32 & 0 & $760 \pm 630$ & $120 \pm 110$ & 144 & 9 & $1,000 \pm 530$ & $23 \pm 52$ & \\
\hline & Nearby communities & 29 & 0 & $1,000 \pm 960$ & $87 \pm 110$ & 93 & 4 & $800 \pm 560$ & $1.2 \pm 65$ & \\
\hline & Distant communities & 9 & 0 & $230 \pm 690$ & $-52 \pm 130$ & 45 & 3 & $680 \pm 440$ & $170 \pm 76$ & \\
\hline \multirow[t]{4}{*}{ Cesium-137 } & Onsite & 50 & 0 & $530 \pm 730$ & $52 \pm 52$ & 204 & 14 & $710 \pm 530$ & $15 \pm 40$ & $400,000,000$ \\
\hline & Perimeter & 32 & 0 & $240 \pm 630$ & $-62 \pm 83$ & 144 & 5 & $660 \pm 620$ & $2.7 \pm 43$ & \\
\hline & Nearby communities & 29 & 0 & $240 \pm 600$ & $-76 \pm 93$ & 93 & 4 & $860 \pm 580$ & $48 \pm 50$ & \\
\hline & Distant communities & 9 & 0 & $390 \pm 580$ & $13 \pm 220$ & 45 & 1 & $390 \pm 290$ & $30 \pm 66$ & \\
\hline
\end{tabular}

Location groups are identified in Table 4.1.1.

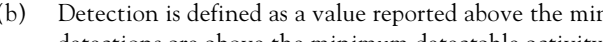

detections are above the minimum detectable activity.

(d) Average of all samples \pm 2 times the standard error of the mean.

(e) DOE derived concentration guide (DOE Order 5400.5; see Appendix C, Table C.5)

(f) Two results from the distant communities were excluded as anomalous values through the use of a Q-test $\left(26,300 \pm 3,400 \mathrm{aCi} / \mathrm{m}^{3}\right.$ at Sunnyside and 8,000 $\pm 1,000 \mathrm{aCi} / \mathrm{m}^{3}$ at Yakima [Skoog and West 1980$]$ ) 


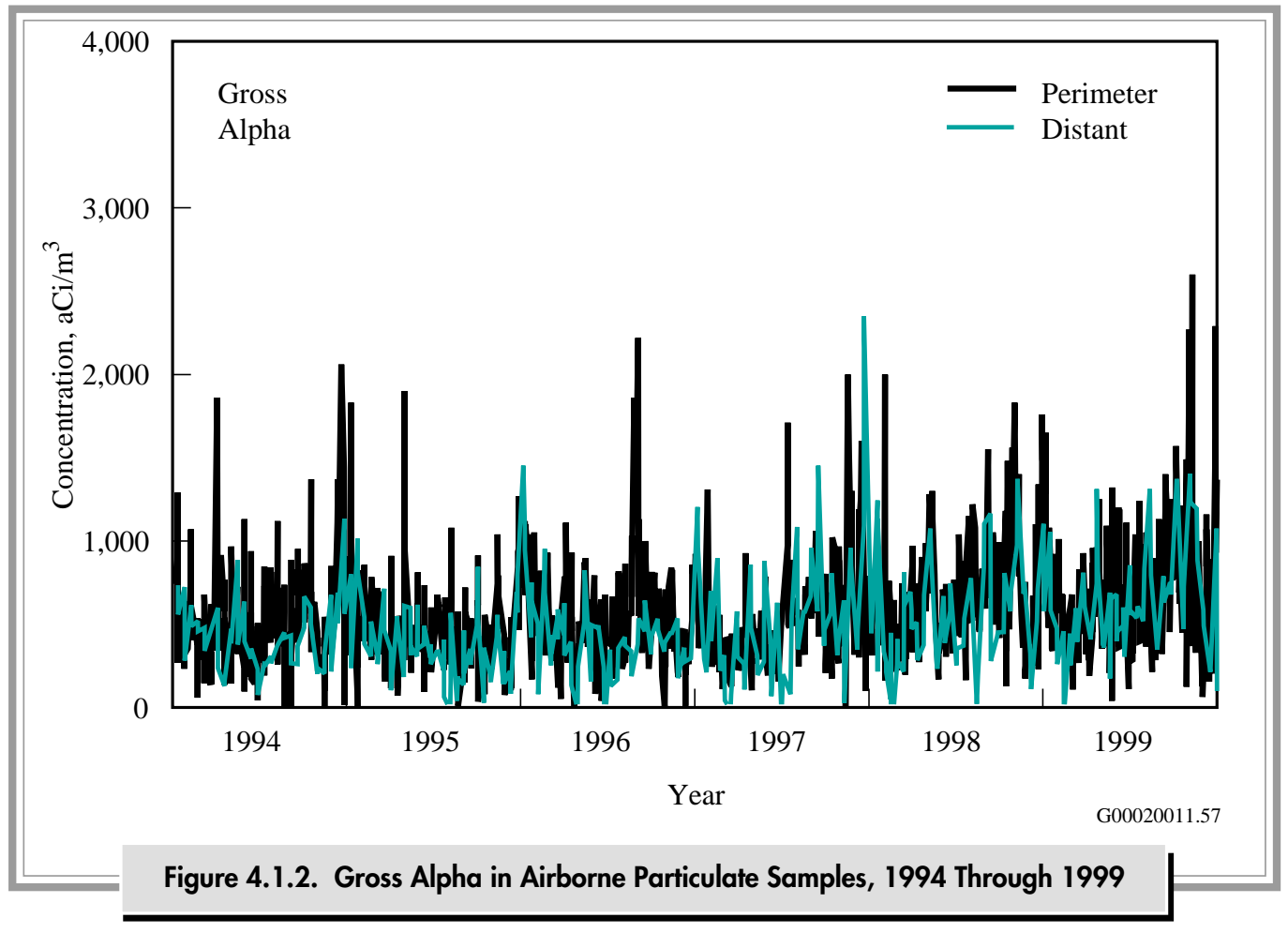

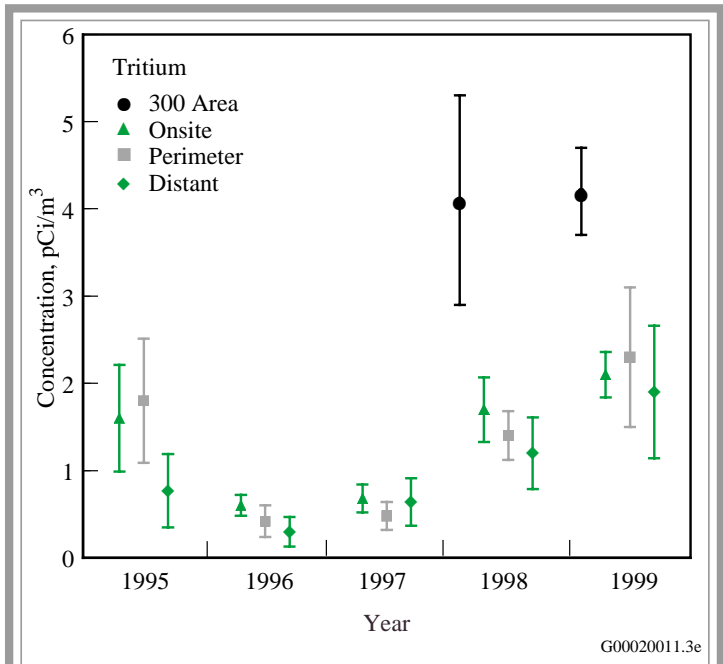

Figure 4.1.3. Annual Average Tritium Concentrations \pm 2 standard error of the mean) in Air, 1995 Through 1999
Extraction Plant, at two downwind perimeter locations, and at a distant location (Yakima) in 1999 (see Figure 4.1.1). Onsite concentrations in 1999 were elevated compared to those measured at the site perimeter, and perimeter levels were higher than those measured at Yakima, the distant location (Figure 4.1.6 and see Table 4.1.2). Iodine- 129 concentration differences between these locations were statistically significant (log transformed, two-tailed t-test, $5 \%$ significance level) and indicated a Hanford source. Onsite and perimeter air concentrations have remained at their respective levels from 1994 through 1999 (see Figure 4.1.6). Onsite air concentrations of iodine-129 were influenced by minor emissions (0.00019 curie; see Table 3.1.1) from the Plutonium-Uranium Extraction Plant and possible releases from waste storage tanks and cribs. The annual average iodine-129 concentration at the downwind perimeter in $1999\left(0.82 \pm 0.47 \mathrm{aCi} / \mathrm{m}^{3}\right)$ was less than $0.000001 \%$ of the $70,000,000-\mathrm{aCi} / \mathrm{m}^{3}$ derived concentration guide.

Plutonium-238 was detected in two onsite samples and one perimeter sample for 1999 (nominal 


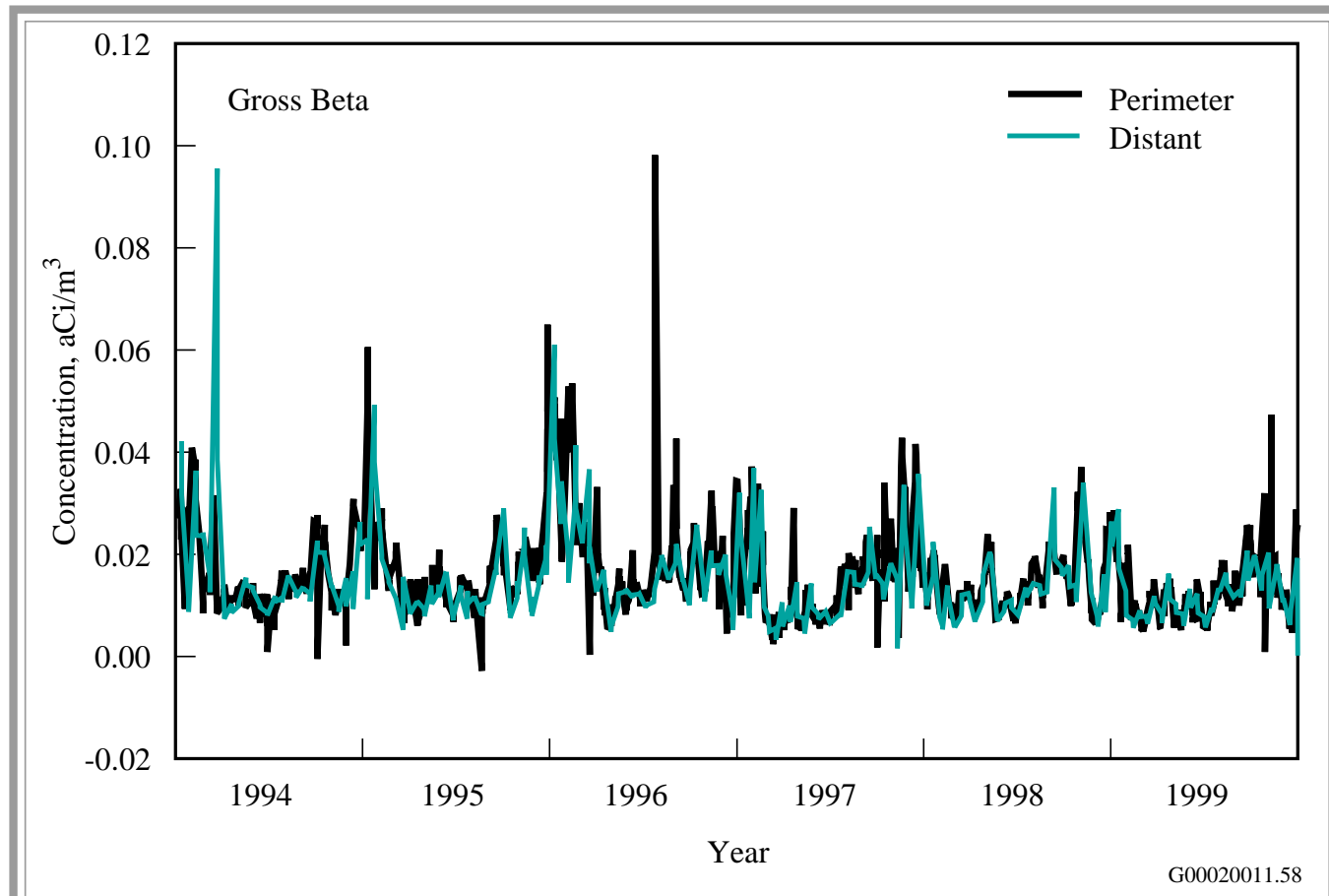

Figure 4.1.4. Gross Beta in Airborne Particulate Samples, 1994 Through 1999

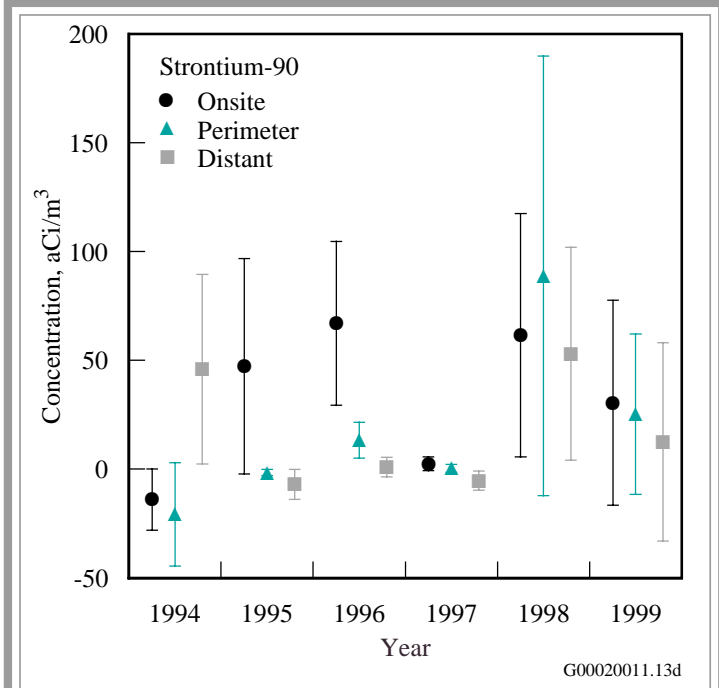

Figure 4.1.5. Annual Average Strontium-90 Concentrations \pm 2 standard error of the mean) in Air, 1994 Through 1999

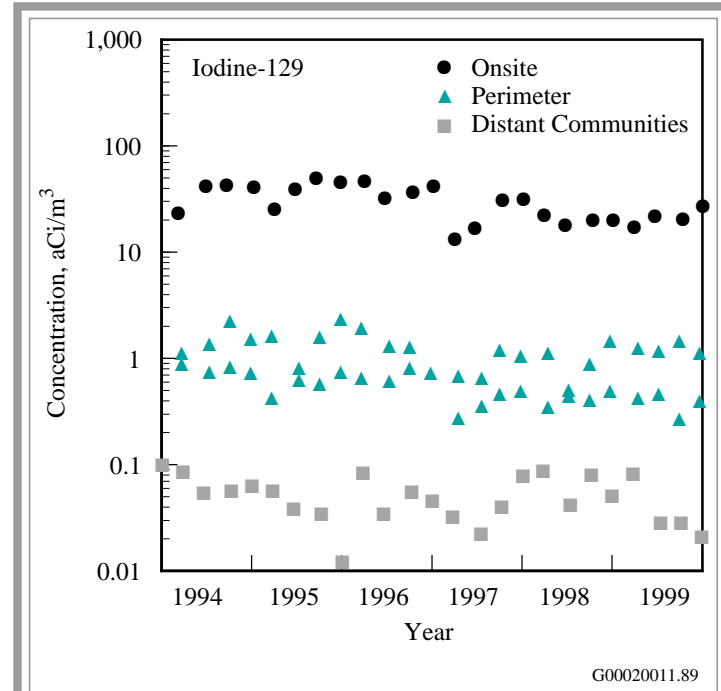

Figure 4.1.6. lodine-129 Concentrations in Air, 1994 Through 1999 
detection limit of $\left.0.98 \mathrm{aCi} / \mathrm{m}^{3}\right)$. The annual average air concentration of plutonium-238 for all samples was less than zero (i.e., not detected). The highest concentration $\left(2.9 \pm 5.8 \mathrm{aCi} / \mathrm{m}^{3}\right)$ was determined for the B Pond sample (location 10 on Figure 4.1.1 and Table 4.1.1), which is $0.01 \%$ of the $30,000-\mathrm{aCi} / \mathrm{m}^{3}$ derived concentration guide.

The average plutonium-239/240 concentrations detected in onsite and offsite air samples are given in Table 4.1.2 and Figure 4.1.7. The annual average air concentration of plutonium-239/240 at the site perimeter was $0.63 \pm 0.34 \mathrm{aCi} / \mathrm{m}^{3}$, which is less than $0.003 \%$ of the $20,000-\mathrm{aCi} / \mathrm{m}^{3}$ derived concentration guide. The annual average air concentration appeared to be slightly lower for the site perimeter locations $(0.63 \pm 0.34 \mathrm{aCi} / \mathrm{m} 3)$ than the distant locations $(0.94 \pm 0.81 \mathrm{aCi} / \mathrm{m} 3)$; however, the difference was not statistically significant (log transformed, two-tailed t-test, 5\% significance level). The maximum Hanford Site plutonium-239/240 air concentration $\left(10.0 \pm 4.5 \mathrm{aCi} / \mathrm{m}^{3}\right)$ was observed for the Wye Barricade composite sample (location 23 on Figure 4.1.1). This represents less than $0.05 \%$ of the $20,000-\mathrm{aCi} / \mathrm{m}^{3}$ derived concentration guide.

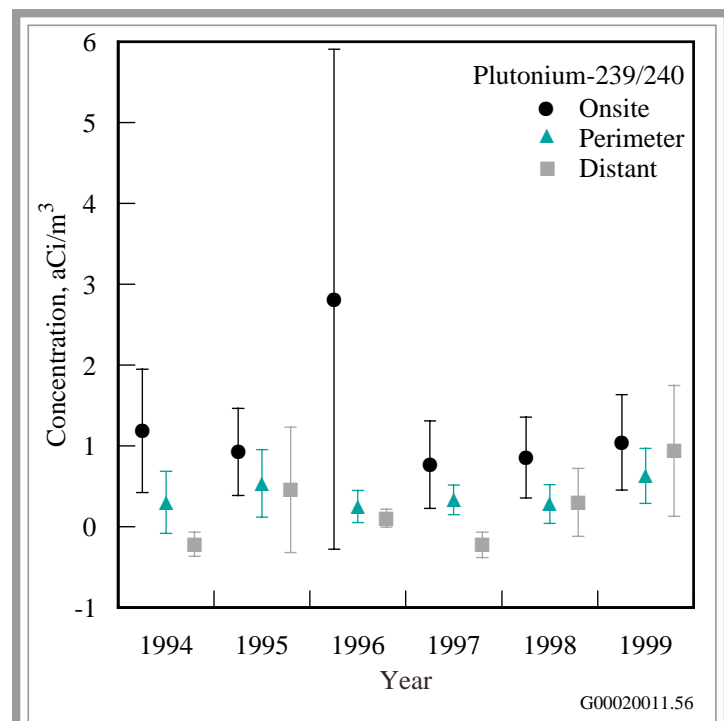

Figure 4.1.7. Annual Average Plutonium-239/ 240 Concentrations $( \pm 2$ standard error of the mean) in Air, 1994 Through 1999
Average isotopic uranium concentrations (uranium-234, -235, and -238) in airborne particulate matter in 1999 were similar on the site, at the site perimeter, and at distant communities (see Table 4.1.2). The average isotopic uranium concentrations were also similar to the past 2 years' average concentrations (Figure 4.1.8). The 1999 annual average uranium-238 concentration for the site perimeter was $29 \pm 7.7 \mathrm{aCi} / \mathrm{m}^{3}$, which is $0.03 \%$ of the $100,000-\mathrm{aCi} / \mathrm{m}^{3}$ derived concentration guide.

Samples were analyzed quarterly, and at some locations annually, by gamma spectroscopy. Naturally occurring beryllium- 7 and potassium- 40 were routinely identified. The potential Hanford-origin gamma-emitting radionuclides of cobalt- 60 and cesium-137 associated with airborne particulate matter were monitored by gamma spectroscopy. Of the 120 samples analyzed by gamma spectroscopy, none of the samples had activities above the minimum detectable level for the sample for that isotope. The cobalt-60 and cesium-137 results for 1999 samples are included in Table 4.1.2. Even the maximum estimated individual measurements for these radionuclides $\left(1,000 \pm 960\right.$ and $530 \pm 730 \mathrm{aCi} / \mathrm{m}^{3}$, respectively) were less than $0.002 \%$ of their derived concentration guides.

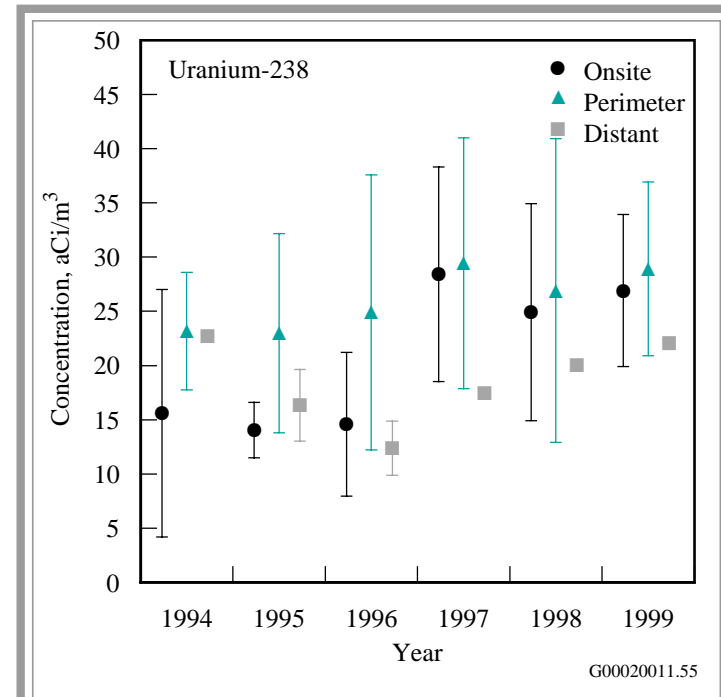

Figure 4.1.8. Annual Average Uranium-238 Concentrations $( \pm 2$ standard error of the mean) in Air, 1994 Through 1999 


\title{
4.2 Surface Water and Sediment Surveillance
}

\author{
G. W. Patton
}

Samples of surface water and sediment on and near the Hanford Site are collected and analyzed to determine the potential impact to the public and to the aquatic environment from Hanford-originated radiological and chemical contaminants. Surfacewater bodies included in routine surveillance are the Columbia River and associated riverbank springs, onsite ponds, and an offsite irrigation canal. Sediment surveillance is conducted for the Columbia
River and riverbank springs. Tables 4.2.1 and 4.2.2 summarize the sampling locations, types, frequencies, and analyses included in surface water and sediment surveillance activities during 1999. Sampling locations are identified in Figure 4.2.1. This section describes the surveillance effort and summarizes the results for these aquatic environments. Detailed analytical results are reported in PNNL13230, APP. 1.

\subsubsection{Columbia River Water}

The Columbia River is the second largest river in the continental United States in terms of total flow and is the dominant surface-water body on the Hanford Site. The original selection of the Hanford Site for plutonium production and processing was, in part, on the abundant water supply offered by the river. The river flows through the northern edge of the site and forms part of the site's eastern boundary. The river is used as a source of drinking water for onsite facilities and communities located downstream from the Hanford Site. Water from the river downstream of the site is also used for crop irrigation. In addition, the Hanford Reach of the Columbia River is used for a variety of recreational activities, including hunting, fishing, boating, waterskiing, and swimming.

Originating in the mountains of eastern British Columbia, the Columbia River drains an area of $\sim 670,000$ square kilometers (260,000 square miles) en route to the Pacific Ocean. The flow of the river is regulated by three dams in Canada and eleven dams in the United States, seven upstream and four downstream of the site. Priest Rapids Dam is the nearest upstream dam and McNary Dam is the nearest downstream dam from the site. The Hanford Reach of the Columbia River extends from Priest Rapids Dam to the head of Lake Wallula (created by McNary Dam) near Richland, Washington. The Hanford Reach is the last stretch of the Columbia River in the United States above Bonneville Dam that remains unimpounded.

River flow through the Hanford Reach fluctuates significantly and is controlled primarily by operations at Priest Rapids Dam. Annual average flows of the Columbia River below Priest Rapids Dam are nearly 3,400 $\mathrm{m}^{3}\left(120,000 \mathrm{ft}^{3}\right)$ per second (WA-94-1). In 1999, the Columbia River had higher than normal flows; the average daily flow rate below Priest Rapids Dam was 4,110 $\mathrm{m}^{3}\left(145,000 \mathrm{ft}^{3}\right)$ per second. The peak monthly average flow rate occurred during June $\left(5410 \mathrm{~m}^{3}\left[191,000 \mathrm{ft}^{3}\right]\right.$ per second) (Figure 4.2.2). The lowest monthly average flow rate occurred during October (2,670 $\mathrm{m}^{3}\left[94,400 \mathrm{ft}^{3}\right]$ per second). Daily flow rates varied from 1,480 to $6,370 \mathrm{~m}^{3}$ (52,400 to $225,000 \mathrm{ft}^{3}$ ) per second during 1999. As a result of fluctuations in discharges, the depth of the river 


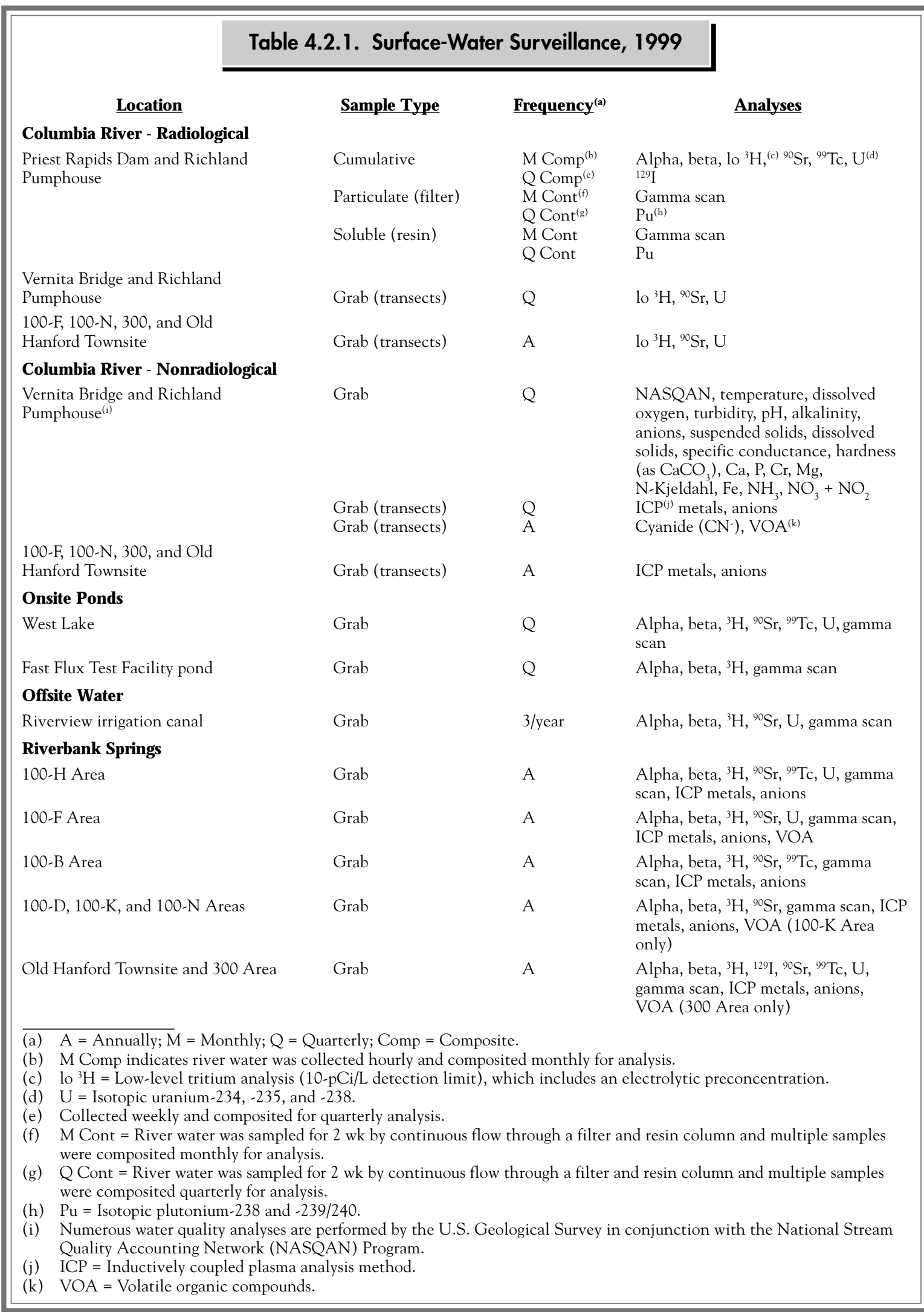




\section{Table 4.2.2. Sediment Surveillance, 1999}

\section{Location $^{(\text {a) }}$}

\section{River}

Priest Rapids Dam:

4 equally spaced (approximate)

stations on a transect from the

Grant County shore to the

Yakima County shore

2 locations near the dam

White Bluffs Slough

100-F Slough

Hanford Slough

Richland

McNary Dam:

4 equally spaced (approximate)

stations on a transect from the

Oregon shore to the Washington

shore

2 locations near the dam

Ice Harbor Dam

3 equally spaced (approximate)

stations on a transect from the

Walla Walla County shore to

the Franklin County shore

\section{Springs ${ }^{(g)}$}

100-B Area

100-K Area

100-N Area

100-F Area

Old Hanford Townsite Springs

300 Area
Frequency

$\mathrm{A}^{(f)}$

A

A

A

A

A

A

A

A

A

A

A

A

\section{Analyses}

All river sediment analyses included gamma scan, ${ }^{90} \mathrm{Sr}, \mathrm{U}^{(\mathrm{b})}, \mathrm{Pu}^{(\mathrm{c})}, \mathrm{ICP}^{(\mathrm{d})}$ metals, SEM/AVS ${ }^{(e)}$
All springs sediment analyses included gamma scan, ${ }^{90} \mathrm{Sr}, \mathrm{U}, \mathrm{ICP}$ metals
(a) See Figure 4.2.1.
(b) $\mathrm{U}=\mathrm{Uranium}-235$ and -238 analyzed by low-energy photon analysis.
(c) $\mathrm{Pu}=$ Isotopic plutonium-238 and $-239 / 240$.
(d) ICP = Inductively coupled plasma analysis method.
(e) SEM/AVS = Simultaneously extracted metals and acid volatile sulfide.
(f) $\mathrm{A}=$ Annually.
(g) Sediment is collected when available. 


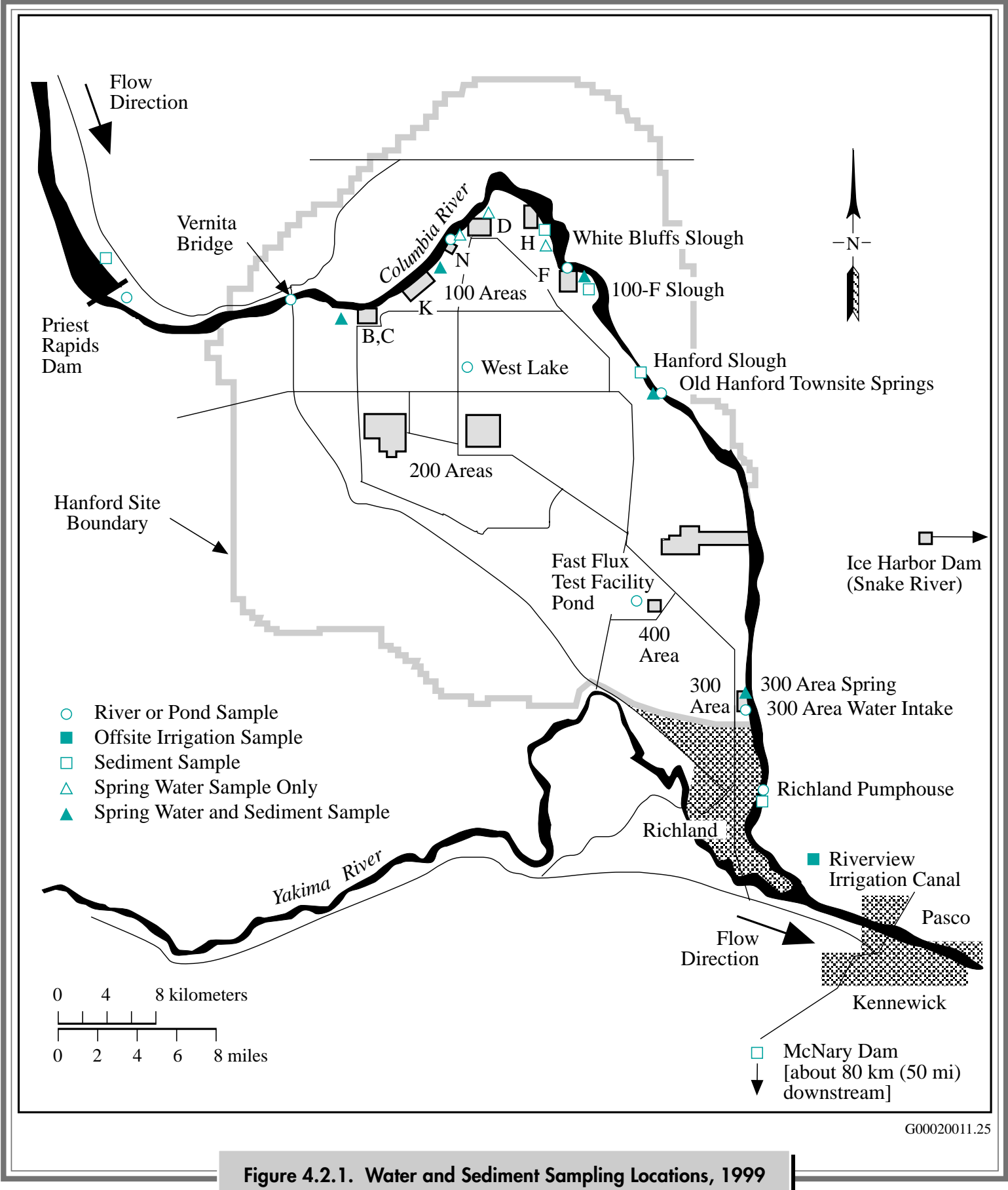




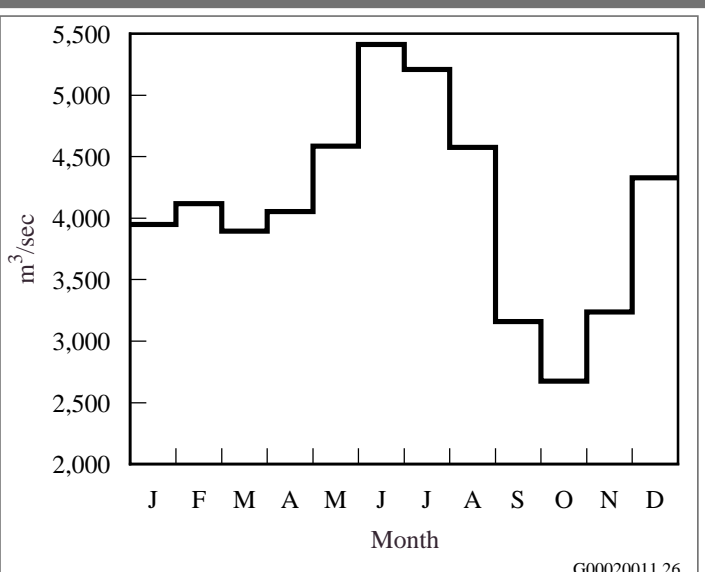

Figure 4.2.2. Mean Monthly Columbia River Flow Rates, 1999 varies significantly over time. River stage (surface level) may change along the Hanford Reach by up to 3 meters (10 feet) within a few hours (Section 3.3.7 in PNL-10698). Seasonal changes of approximately the same magnitude are also observed. River-stage fluctuations measured at the 300 Area are approximately half the magnitude of those measured near the 100 Areas because of the effect of the pool behind McNary Dam (PNL-8580) and the relative distance of each area from Priest Rapids Dam. The width of the river varies from approximately 300 to 1,000 meters (980 to 3,300 feet) through the Hanford Site.

Pollutants, both radiological and nonradiological, are known to enter the Columbia River along the Hanford Reach. In addition to permitted direct discharges of liquid effluents from Hanford facilities, contaminants in groundwater from past operational discharges to the ground are known to seep into the river (DOE/RL-92-12, PNL-5289, PNL7500, WHC-SD-EN-TI-006). Effluents from each direct discharge point are monitored routinely and reported by the responsible operating contractor; these were summarized in Section 3.1, "Facility Effluent Monitoring." Direct discharges are identified and regulated for nonradiological constituents under the National Pollutant Discharge Elimination
System in compliance with the Clean W ater Act. The National Pollutant Discharge Elimination System-permitted discharges at the Hanford Site are summarized in Section 2.2.8, "Clean Water Act."

Washington State has classified the stretch of the Columbia River from Grand Coulee Dam to the Washington-Oregon border, which includes the Hanford Reach, as Class A, Excellent (WAC 173-201A). Water quality criteria and water use guidelines have been established in conjunction with this designation and are provided in Appendix C (Table C.1).

\subsubsection{Collection of River- Water Samples and Analytes of Interest}

Samples of Columbia River water were collected throughout 1999 at the locations shown in Figure 4.2.1. Samples were collected from fixedlocation monitoring stations at Priest Rapids Dam and the Richland Pumphouse and from Columbia River transects and near-shore locations near the Vernita Bridge, 100-F Area, 100-N Area, Old Hanford Townsite, 300 Area, and Richland Pumphouse. Samples were collected upstream from Hanford Site facilities at Priest Rapids Dam and Vernita Bridge to provide background data from locations unaffected by site operations. Samples were collected from all other locations to identify any increase in contaminant concentrations attributable to Hanford operations. The Richland Pumphouse is the first downstream point of Columbia River water withdrawal for a municipal drinking water supply.

The fixed-location monitoring stations at Priest Rapids Dam and the Richland Pumphouse consisted of both an automated sampler and a continuous flow system. Using the automated sampler, unfiltered samples of Columbia River water (cumulative samples) were obtained hourly and collected weekly. Weekly samples were composited monthly for radiological analyses (see Table 4.2.1). Using the 
continuous flow system, particulate and soluble fractions of selected Columbia River water constituents were collected by passing water through a filter and then through a resin column. Filter and resin samples were exchanged approximately every 14 days and were combined into quarterly composite samples for radiological analyses. The river sampling locations and the methods used for sample collection are discussed in detail in DOE/RL-91-50, Rev. 2.

Radionuclides of interest were selected for analysis based on

- their presence in effluents discharged from site facilities or in near-shore groundwater underlying the Hanford Site

- their importance in determining water quality, verifying effluent control and monitoring systems, and determining compliance with applicable standards.

Analytes of interest in water samples collected from Priest Rapids Dam and the Richland Pumphouse included gross alpha, gross beta, selected gamma emitters, tritium, strontium-90, technetium-99, iodine-129, uranium-234, -235,-238, plutonium-238, and plutonium-239/240. Gross alpha and beta measurements are indicators of the general radiological quality of the river and provide a timely indication of change. Gamma scans provide the ability to detect numerous specific radionuclides (see Appendix E). Sensitive radiochemical analyses were used to determine the concentrations of tritium, strontium-90, technetium-99, iodine-129, uranium-234,-235,-238, plutonium-238, and plutonium-239/240 in river water during the year. Analytical detection levels for all radionuclides were less than $10 \%$ of their respective water quality criteria levels (see Appendix C, Table C.2).

Transect sampling was initiated as a result of findings of a special study conducted during 1987 and 1988 (PNL-8531). That study concluded that, under certain flow conditions, contaminants entering the river from the Hanford Site are not completely mixed when sampled at routine monitoring stations located downriver. Incomplete mixing results in a slightly conservative (high) bias in the data generated using the routine, single-point, sampling system at the Richland Pumphouse. For 1999, the transect sampling strategy was modified, with some of the midriver sampling points shifted to near-shore locations in the vicinity of the transect. For example, at the 100-N Area instead of collecting ten evenly-spaced cross-river transect samples, only six cross-river samples were collected and the other four samples were obtained at near-shore locations. This sampling pattern allows the cross-river concentration profile to be determined and provides information over a larger portion of the Hanford shoreline where the highest contaminant concentrations would be expected. The Vernita Bridge and the Richland Pumphouse transects and near-shore locations were sampled quarterly during 1999. Annual transect and near-shore sampling was conducted at the $100-\mathrm{F}$ Area, 100-N Area, Old Hanford Townsite, and 300 Area locations in the late summer during low flow.

Columbia River transect water samples collected in 1999 were analyzed for both radiological and chemical contaminants (see Table 4.2.1). Metals and anions (listed in DOE/RL-93-94, Rev. 1) were selected for analysis following reviews of existing surface-water and groundwater data, various remedial investigation/feasibility study work plans, and preliminary Hanford Site risk assessments (DOE/ RL-92-67, PNL-8073, PNL-8654, PNL-10400, PNL10535). All radiological and chemical analyses of transect samples were performed on unfiltered water, except for metals analyses which were performed on both filtered and unfiltered samples.

In addition to Columbia River monitoring conducted by Pacific Northwest National Laboratory in 1999, nonradiological water quality monitoring was also performed by the U.S. Geological Survey in conjunction with the National Stream Quality Accounting Network program. U.S. Geological Survey samples were collected along Columbia River transects quarterly at the Vernita Bridge and the 
Richland Pumphouse (Appendix A, Table A.5). Sample analyses were performed at the U.S. Geological Survey laboratory in Denver, Colorado for numerous physical and chemical constituents.

\subsubsection{Radiological Results for River-Water Samples}

Fixed Location Sampling. Results of the radiological analyses of Columbia River water samples collected at Priest Rapids Dam and Richland Pumphouse during 1999 are reported in PNNL13230, APP. 1 and summarized in Appendix A (Tables A.1 and A.2). These tables also list the maximum and mean concentrations of selected radionuclides observed in Columbia River water in 1999 and during the previous 5 years. All radiological contaminant concentrations measured in Columbia River water in 1999 were less than DOE derived concentration guides (DOE Order 5400.5) and Washington State ambient surface-water quality criteria (WAC 173-201A and 40 CFR 141) levels (see Appendix C, Tables C.5, C.3, and C.2, respectively). Significant results are discussed and illustrated below, and comparisons to previous years are provided.

Radionuclide concentrations monitored in Columbia River water were extremely low throughout the year. The radionuclides consistently detected in river water during 1999 included tritium, strontium-90, iodine-129, uranium-234, -238 , and plutonium-239/240. The concentrations of all other measured radionuclides were below detection limits in more than $75 \%$ of samples collected. Tritium, strontium-90, iodine-129, and plutonium-239/240 exist in worldwide fallout, as well as in effluents from Hanford facilities. Tritium and uranium occur naturally in the environment, in addition to being present in Hanford Site effluents.

Figures 4.2.3 and 4.2.4 illustrate the average annual gross alpha and gross beta concentrations, respectively, at Priest Rapids Dam and Richland

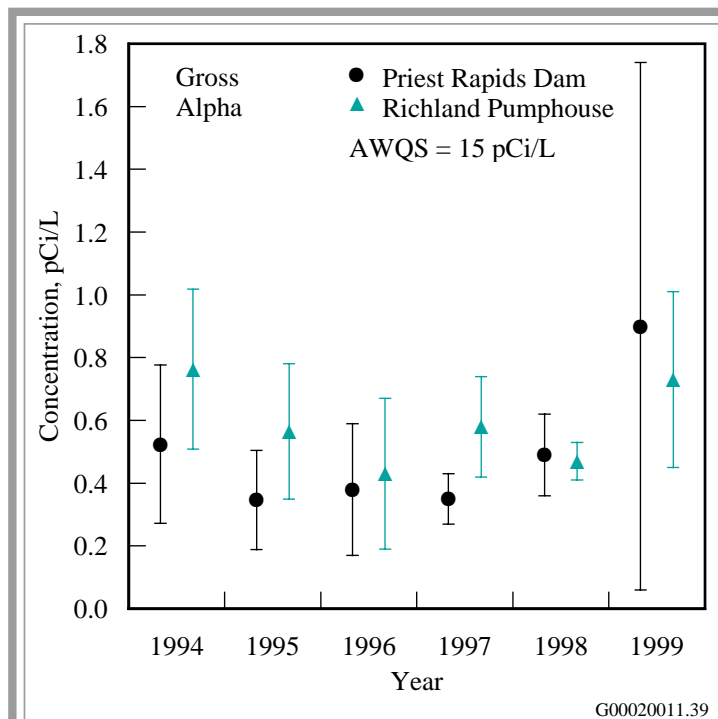

Figure 4.2.3. Annual Average Gross Alpha Concentrations \pm 2 standard error of the mean) in Columbia River Water, 1994 Through 1999 (AWQS = ambient water quality standard)

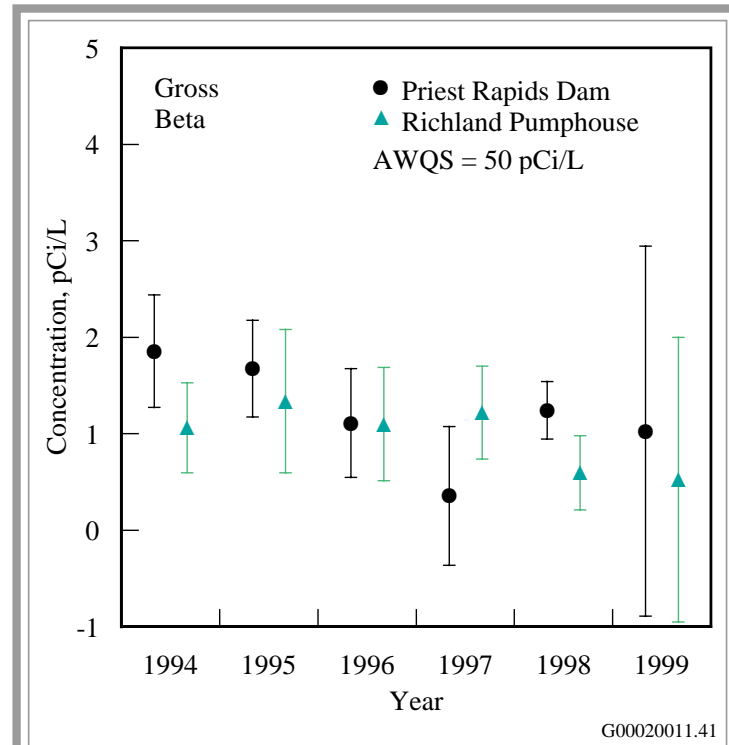

Figure 4.2.4. Annual Average Gross Beta Concentrations \pm 2 standard error of the mean) in Columbia River Water, 1994 Through 1999 (AWQS = ambient water quality standard) 
Pumphouse during the past 6 years. The 1999 average gross alpha and gross beta concentrations were similar to those observed during recent years. Monthly measurements at the Richland Pumphouse in 1999 were not statistically different (unless otherwise noted in this section, the statistical tests for difference are paired sample comparison and two-tailed t-test, 5\% significance level) from those measured at Priest Rapids Dam. The average alpha and beta concentrations in Columbia River water at the Richland Pumphouse in 1999 were less than the ambient surface-water quality criteria levels of 15 and $50 \mathrm{pCi} / \mathrm{L}$, respectively.

Figure 4.2.5 compares the annual average tritium concentrations at Priest Rapids Dam and Richland Pumphouse from 1994 through 1999. Statistical analysis indicated that monthly tritium concentrations in river water samples at the Richland Pumphouse were higher than samples at Priest Rapids Dam. However, 1999 average tritium concentrations in Columbia River water collected at the Richland Pumphouse were only $0.4 \%$ of the ambient surfacewater quality criteria level of $20,000 \mathrm{pCi} / \mathrm{L}$. Onsite

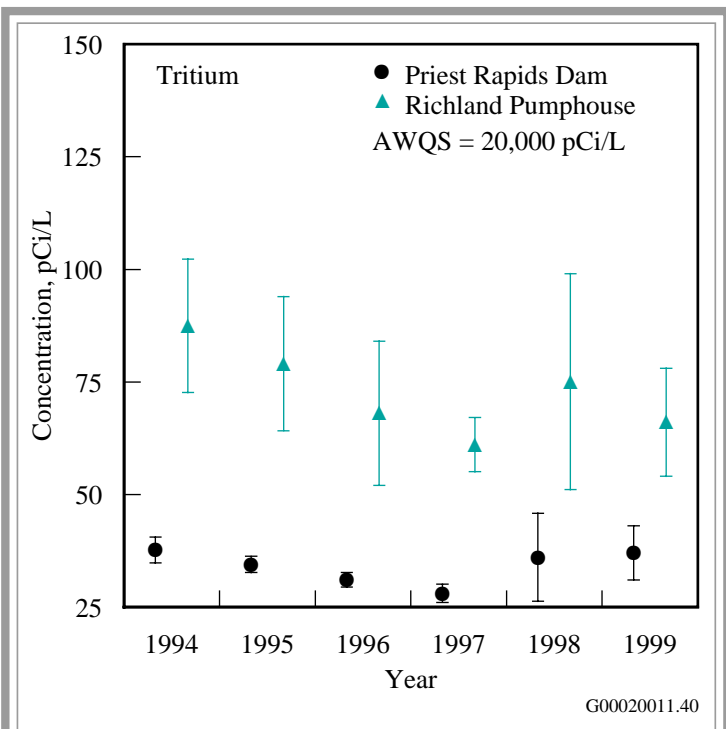

Figure 4.2.5. Annual Average Tritium Concentrations ( \pm 2 standard error of the mean) in Columbia River Water, 1994 Through 1999 (AWQS = ambient water quality standard) sources of tritium entering the river include groundwater seepage and direct discharge from outfalls located in the 100 Areas (see Section 3.1, "Facility Effluent Monitoring," and Section 6.1, "Hanford Groundwater Monitoring Project"). Tritium concentrations measured at the Richland Pumphouse, while representative of river water used by the city of Richland for drinking water, tend to overestimate the average tritium concentrations across the river at this location (PNL-8531). This bias is attributable to the contaminated 200 Areas' groundwater plume entering the river along the portion of shoreline extending from the Old Hanford Townsite to below the 300 Area, which is relatively close to the Richland Pumphouse sample intake. This plume is not completely mixed within the river at the Richland Pumphouse. Sampling along cross-river transects at the pumphouse during 1999 confirmed the existence of a concentration gradient in the river under certain flow conditions and is discussed subsequently in this section. The extent to which samples taken from the Richland Pumphouse overestimate the average tritium concentrations in the Columbia River at this location is highly variable and appears to be related to the flow rate of the river just before and during sample collection.

The annual average strontium-90 concentrations in Columbia River water collected from Priest Rapids Dam and Richland Pumphouse from 1994 through 1999 are presented in Figure 4.2.6. Levels observed in 1999 were similar to those reported previously. Groundwater plumes containing strontium-90 enter the Columbia River throughout the 100 Areas (see Section 6.1.6.1, "Radiological Monitoring Results for the Unconfined Aquifer"). The highest strontium-90 levels that have been found in onsite groundwater are the result of past discharges to the 100-N Area liquid waste disposal facilities. Despite the Hanford Site source, the differences between monthly strontium-90 concentrations at Priest Rapids Dam and Richland Pumphouse in 1999 were not statistically different. Average 


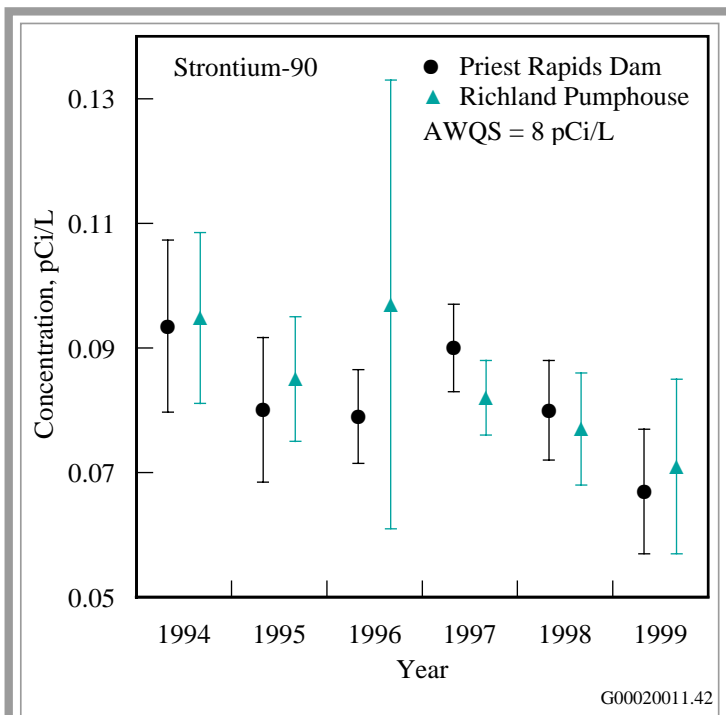

Figure 4.2.6. Annual Average Strontium-90 Concentrations $( \pm 2$ standard error of the mean) in Columbia River Water, 1994 Through 1999 (AWQS = ambient water quality standard)

strontium-90 concentrations in Columbia River water at the Richland Pumphouse were less than $1 \%$ of the 8-pCi/L ambient surface-water quality criteria level.

Annual average total uranium concentrations (i.e., the sum of uranium-234, -235, -238) at Priest Rapids Dam and Richland Pumphouse for 1994 through 1999 are shown in Figure 4.2.7. The large error associated with 1994 results was attributed to an unusually low concentration found in the December sample at each location. Total uranium concentrations observed in 1999 were similar to those observed during recent years. Monthly total uranium concentrations measured at the Richland Pumphouse in 1999 were not statistically higher than those measured at Priest Rapids Dam. Although there is no direct discharge of uranium to the river, uranium is present in the groundwater beneath the 300 Area as a result of past Hanford operations (see Section 6.1, "Hanford Groundwater Monitoring Project") and has been detected at elevated levels in riverbank springs in this area (see Section 4.2.3, "Riverbank Spring Water"). Naturally occurring uranium is also known to enter the

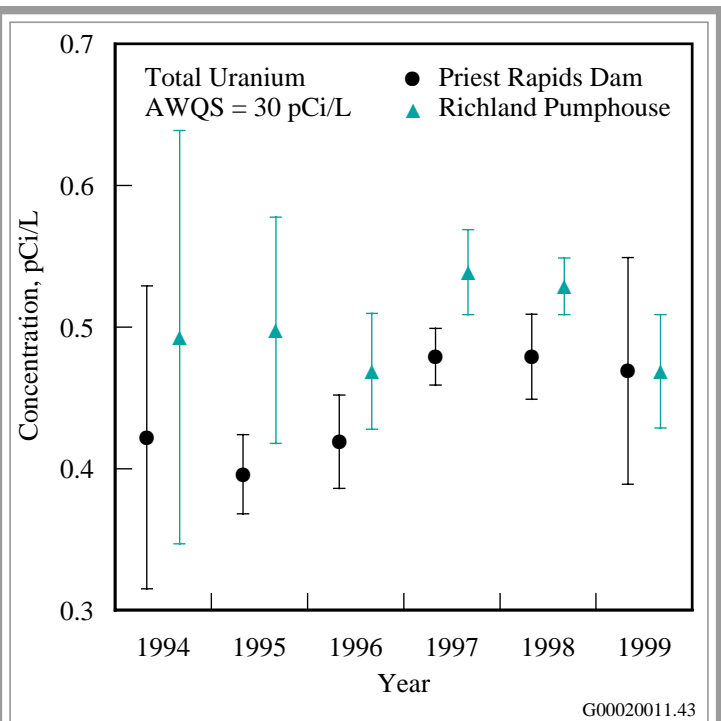

Figure 4.2.7. Annual Average Total Uranium Concentrations $( \pm 2$ standard error of the mean) in Columbia River Water, 1994 Through 1999 (AWQS = ambient water quality standard)

river across from the Hanford Site via irrigation return water and groundwater seepage associated with extensive irrigation north and east of the Columbia River (PNL-7500). There are no ambient surfacewater quality criteria levels directly applicable to uranium. However, total uranium levels in the river during 1999 were well below the proposed U.S. Environmental Protection Agency (EPA) drinking water standard of $20 \mu \mathrm{g} / \mathrm{L}(13.4 \mathrm{pCi} / \mathrm{L}$, Appendix C, Table C.2).

The annual average iodine-129 concentrations at Priest Rapids Dam and Richland Pumphouse for 1994 through 1999 are presented in Figure 4.2.8. Only one quarterly iodine-129 result was available for the Richland Pumphouse during 1995 because of construction activities at the structure. The average iodine-129 concentration in Columbia River water at the Richland Pumphouse was extremely low during 1999 (0.008\% of the ambient surface-water quality criteria level of $1 \mathrm{pCi} / \mathrm{L}[1,000,000 \mathrm{aCi} / \mathrm{L}])$ and similar to levels observed during recent years. The onsite source of iodine-129 to the Columbia River is the discharge of contaminated groundwater along 


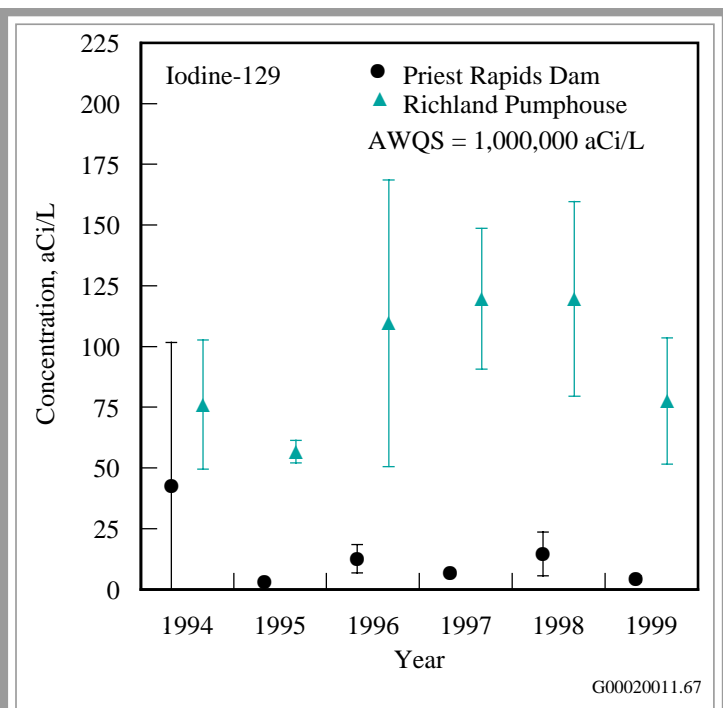

Figure 4.2.8. Annual Average lodine-129 Concentrations $( \pm 2$ standard error of the mean) in Columbia River Water, 1994 Through 1999 (AWQS = ambient water quality standard)

the portion of shoreline downstream of the Old Hanford Townsite (seeSection 6.1, "Hanford Groundwater Monitoring Project"). The iodine-129 plume originated in the 200 Areas from past waste disposal practices. Quarterly iodine-129 concentrations in Columbia River water at the Richland Pumphouse were statistically higher than those at Priest Rapids Dam.

Plutonium-239/240 concentrations were at or near the detection limits for filter (particulate) and resin (dissolved) components for all samples. Average plutonium-239/240 concentrations on filter samples at Priest Rapids Dam and Richland Pumphouse were $23 \pm 4.2$ and $26 \pm 24 \mathrm{aCi} / \mathrm{L}$, respectively. With the exception of one sample at the Richland Pumphouse, plutonium was only detected for the particulate fraction of the continuous water sample (i.e., detected on the filters but not detected on the resin column). No ambient surface-water quality criteria levels exist for plutonium-239/240. However, if the DOE derived concentration guides (see Appendix C, Table C.5), which are based on a 100-mrem dose standard, are converted to the 4-mrem dose equivalent used to develop the drinking water standards and ambient surface-water quality criteria levels, $1,200,000 \mathrm{aCi} / \mathrm{L}$ would be the relevant guideline for plutonium-239/240. There was no statistical difference in plutonium-239/240 concentrations for filter samples at Priest Rapids Dam and Richland Pumphouse. Statistical tests for dissolved plutonium concentrations at Priest Rapids Dam and the Richland Pumphouse were not performed because the majority of the samples were below the detection limit.

\section{River T ransect and N ear-Shore Sampling.}

Radiological results from samples collected along Columbia River transects and at near-shore locations near the Vernita Bridge, 100-F Area, 100-N Area, Old Hanford Townsite, 300 Area, and Richland Pumphouse during 1999 are presented in Appendix A (Tables A.3 and A.4) and PNNL13230, APP. 1. Sampling locations were documented using a global positioning system. Constituents that were consistently detected at concentrations greater than two times their associated total propagated analytical uncertainty included tritium, strontium-90, uranium-234, and uranium-238. All measured concentrations of these radionuclides were less than applicable ambient surface-water quality criteria levels.

Tritium concentrations measured along Columbia River transects during September 1999 are depicted in Figure 4.2.9. The results are displayed such that the observer's view is upstream. Vernita Bridge is the most upstream transect. Stations 1 and 10 are located along the Benton County and Franklin/Grant Counties shorelines, respectively. The 100-N Area, Old Hanford Townsite, 300 Area, and Richland Pumphouse transects have higher tritium concentrations at the Hanford shore compared to the mid-river and opposite shore results. The presence of a tritium concentration gradient in the Columbia River at the Richland Pumphouse supports previous conclusions made in HW-73672 and PNL-8531 that contaminants in the 200 Areas' groundwater plume entering the river at, and 


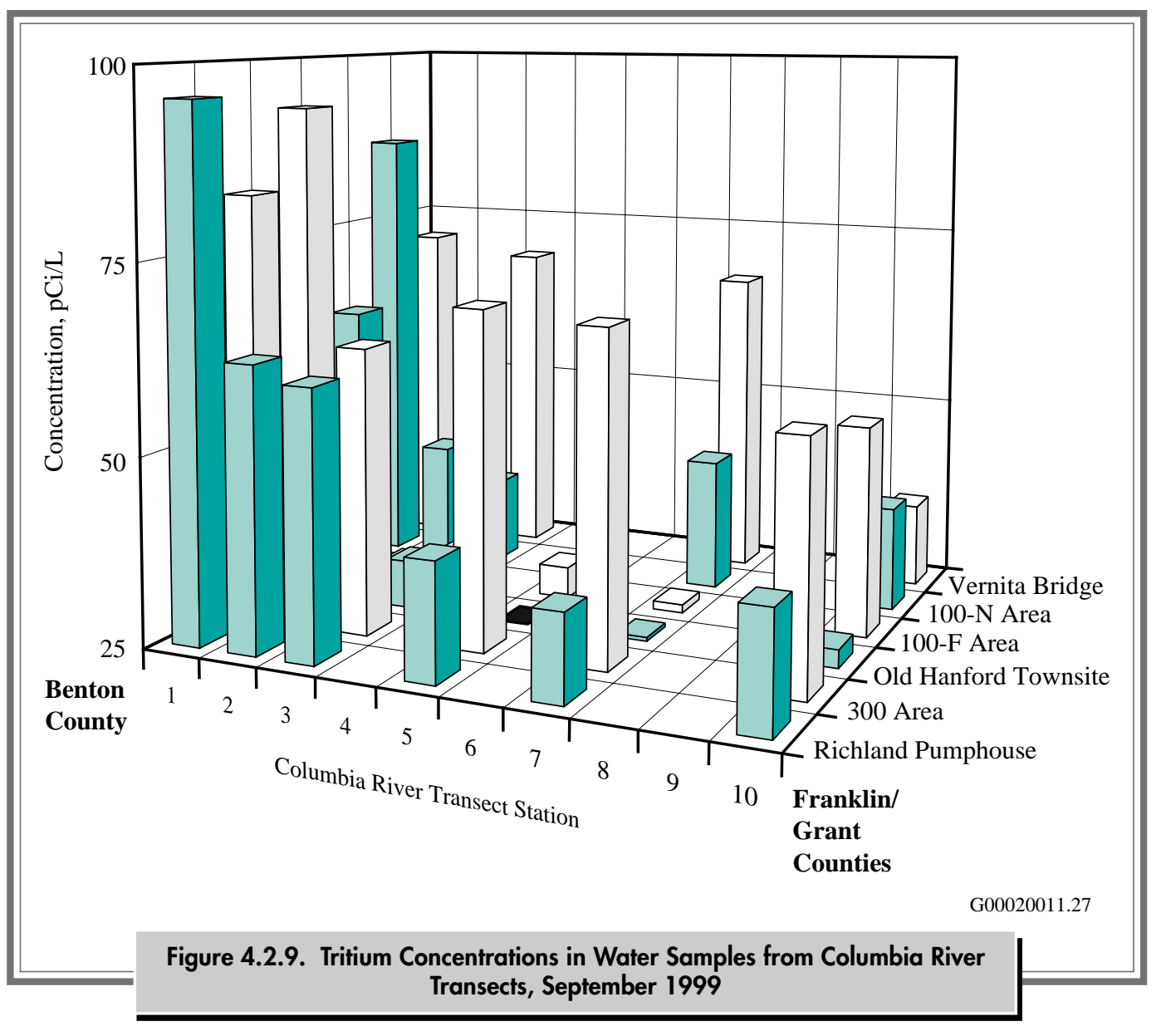

upstream of, the 300 Area are not completely mixed at the Richland Pumphouse. The gradient is most pronounced during periods of relatively low river flow. As noted since transect sampling was initiated in 1987, the mean tritium concentration measured along the Richland Pumphouse transect was less than that measured in monthly composited samples from the pumphouse, illustrating the conservative bias (i.e., overestimate) of the fixed-location monitoring station. The highest tritium concentration observed in 1999 near-shore water samples was 1,100 $\pm 95 \mathrm{pCi} / \mathrm{L}$ (see Table A.4), which was detected along the shoreline of the 300 Area. This is a location where groundwater containing tritium levels of over 2,000 $\mathrm{pCi} / \mathrm{L}$ is known to discharge to the river (see Section 6.1.6.1, "Radiological Monitoring Results for the Unconfined Aquifer"). Slightly elevated levels of tritium were also evident near the
Hanford Site shoreline at the 100-N Area, Old Hanford Townsite, and the Richland Pumphouse. The 1999 results for the Old Hanford Townsite ranged from $28 \pm 6.0$ to $51 \pm 7.2 \mathrm{pCi} / \mathrm{L}$, which were considerably below the 1998 result of $4,100 \pm$ $350 \mathrm{pCi} / \mathrm{L}$. It is not clear why the 1999 results are lower; however, mulberry tree samples and rooting zone samples collected in June also contained less tritium than expected from their proximity to the groundwater tritium plume (see Section 4.6.1, "Surveillance of Columbia River Shoreline Vegetation").

Strontium-90 concentrations in 1999 in both transect and near-shore samples were similar to background concentrations for all locations, except for the 100-N Area. The 100-N Area had elevated strontium-90 concentrations along all near-shore locations and the transect samples were elevated for 
only Hanford shoreline sample. The mean strontium-90 concentration found during transect sampling at the Richland Pumphouse was similar to that measured in monthly composite samples from the pumphouse; indicating that strontium-90 levels in water collected from the fixed-location monitoring station are representative of the average strontium-90 concentrations in the river at this location.

Total uranium concentrations in 1999 were elevated along the Franklin County shoreline of the 300 Area and Richland Pumphouse transects. The highest total uranium concentration was measured near the Franklin County shoreline of the 300 Area transect and likely resulted from groundwater seepage and water from irrigation return canals on the east side of the river that contained naturally occurring uranium (PNL-7500). The mean concentration of total uranium across the Richland Pumphouse transect was similar to that measured in monthly composited samples from the pumphouse.

\subsubsection{N onradiological Results for River-Water Samples}

The U.S. Geological Survey and the Pacific Northwest National Laboratory compiled nonradiological water quality data during 1999. A number of the parameters measured have no regulatory limits; however, they are useful as indicators of water quality and contaminants of Hanford origin. Potential sources of pollutants not associated with Hanford include irrigation return water and groundwater seepage associated with extensive irrigation north and east of the Columbia River (PNL-7500).

U.S. Geological Survey. Figure 4.2.10 shows U.S. Geological Survey results for the Vernita Bridge and Richland Pumphouse for 1994 through 1999 (1999 results are preliminary) for several water quality parameters with respect to their applicable standards. The complete list of preliminary results obtained through the U.S. Geological Survey National Stream Quality Accounting Network program is documented in PNNL-13230, APP. 1 and is summarized in Appen$\operatorname{dix}$ A (Table A.5). Final results are published annually by the U.S. Geological Survey (e.g., Wiggins et al.1996). The 1999U.S. Geological Survey results were comparable to those reported during the previous 5 years. Applicable standards for a Class Adesignated surface-water body were met. During 1999, there was no indication of any deterioration of water quality resulting from site operations along the Hanford Reach of the Columbia River (see Appendix C, Table C.1).

\section{River Transect and N ear-Shore Samples.}

Results of nonradiological sampling conducted by Pacific Northwest National Laboratory along transect and near-shore locations of the Columbia River in 1999 at Vernita Bridge, 100-F Area, 100-N Area, Old Hanford Townsite, 300 Area, and Richland Pumphouse are provided in PNNL-13230, APP. 1. The concentrations of metals and anions observed in river water in 1999 were similar to those observed in the past. Several metals and anions were detected in Columbia River transect samples both upstream and downstream of the Hanford Site. Arsenic, antimony, cadmium, chromium, lead, nickel, thallium, and zinc were detected in the majority of samples, with similar levels at most locations. Beryllium, selenium, and silver were only occasionally detected. Nitrate concentrations were slightly elevated compared to midriver samples for the Benton County shoreline near the Richland Pumphouse. Nitrate, sulfate, and chloride concentrations were slightly elevated, compared to mid-river samples, along the Franklin County shoreline at the Richland Pumphouse transects and likely resulted from groundwater seepage associated with extensive irrigation north and east of the Columbia River. Nitrate contamination of some Franklin County groundwater has been documented by the U.S. Geological Survey (1995) and is associated with high fertilizer and water usage. Numerous wells in western Franklin County exceed the EPA maximum contaminant level for nitrate (40 CFR 141; USGS Circular 1144). Nitrate, sulfate, and chloride results were slightly higher for average quarterly concentrations at the Richland Pumphouse transect compared 


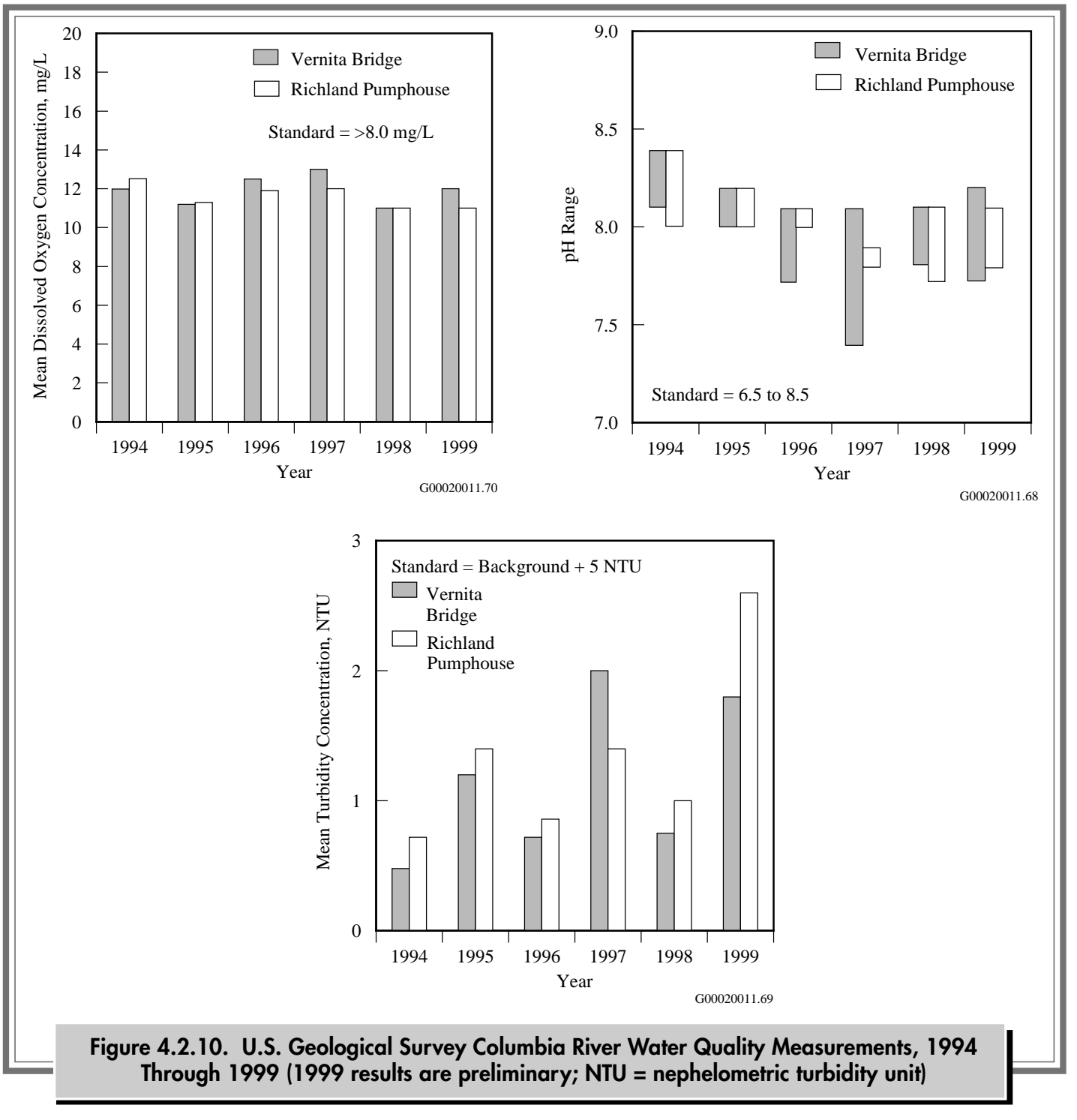

to the Vernita Bridge transect. Nitrate, chloride, and sulfate concentrations were slightly elevated, compared to mid-river, for both shorelines at the 300 Area. Nitrate, chloride, and sulfate concentrations were slightly elevated, compared to mid-river, along the Grant County shoreline near the 100-N Area. There were no apparent concentration gradients for anions measured at Vernita Bridge, the 100-F Area, and Old Hanford Townsite transect samples.

Washington State ambient surface-water quality criteria for cadmium, copper, lead, nickel, silver, and zinc are total-hardness dependent (WAC 173201A; see Appendix C, Table C.3). Criteria for Columbia River water were calculated using a total hardness of $47 \mathrm{mg} / \mathrm{L}$ as calcium carbonate, the limiting value based on U.S. Geological Survey monitoring of Columbia River water near Vernita Bridge and the Richland Pumphouse over the past 7 years. The total hardness reported by the U.S. Geological Survey at those locations from 1992 through 1999 ranged from 47 to $77 \mathrm{mg} / \mathrm{L}$ as calcium carbonate. All metal and anion concentrations in river water were less than the ambient surface-water quality criteria 
levels for both acute and chronic toxicity levels (see Appendix C, Table C.3). Arsenic concentrations exceeded EPA standards; however, similar concentrations were found at Vernita Bridge and Richland Pumphouse (see Appendix C, Table C.3).

\subsubsection{Columbia River Sediment}

As a result of past operations at the Hanford Site, radioactive and nonradioactive materials were discharged to the Columbia River. On release to the river, the materials were dispersed rapidly, sorbed onto detritus and inorganic particles, incorporated into aquatic biota, deposited on the riverbed as sediment, or flushed out to sea. Fluctuations in the river flow rate, as a result of the operation of hydroelectric dams, annual spring freshets, and occasional floods, have resulted in the resuspension, relocation, and subsequent redeposition of the contaminated sediments (DOE/RL-91-50, Rev. 2). Sediments in the Columbia River contain low concentrations of radionuclides and metals of Hanford Site origin as well as radionuclides from nuclear weapons testing fallout (Beasley et al. 1981, BNWL-2305, PNL-8148, PNL10535). Potential public exposures are well below the level at which routine surveillance of Columbia River sediment is required (PNL-3127, Wells 1994). However, periodic sampling is necessary to confirm the low levels and to ensure that no significant changes have occurred for this pathway. The accumulation of radioactive materials in sediment can lead to human exposure by ingestion of aquatic species, sediment resuspension into drinking water supplies, or as an external radiation source irradiating people who are fishing, wading, sunbathing, or participating in other recreational activities associated with the river or shoreline (DOE/EH-0173T).

Since the shutdown of the last single-pass reactor in the early 1970s, the contaminant burden in the surface sediments has been decreasing as a result of radioactive decay and the subsequent deposition of uncontaminated material. However, discharges of some pollutants from the Hanford Site to the Columbia River still occur via permit-regulated liquid effluent discharges (see Section 3.1, "Facility Effluent
Monitoring") and via contaminated groundwater seepage (see Section 4.2.3, "Riverbank Spring Water").

A special study was conducted in 1994 to investigate the difference in sediment grain-size composition and total organic carbon content at routine monitoring sites (PNL-10535). Physical and chemical sediment characteristics were found to be highly variable among monitoring sites along the Columbia River. Samples containing the highest percentage of silts, clays, and total organic carbon were collected above McNary Dam and from White Bluffs Slough. All other samples primarily consisted of sand. Higher contaminant burdens were generally associated with sediment containing higher total organic carbon and finer grain-size distributions.

\subsubsection{Collection of Sediment Samples and Analytes of Interest}

During 1999, samples of Columbia River surface sediment were collected at depths of 0 to 15 centimeters ( 0 to 6 inches) from six river locations that are permanently submerged and six riverbank springs that are periodically inundated (see Figure 4.2.1 and Table 4.2.2). Sediment sampling locations were documented using a global positioning system. In addition, sediment samples were collected behind Ice Harbor Dam on the Snake River. Samples were collected upstream of Hanford Site facilities above Priest Rapids Dam (the nearest upstream impoundment) to provide background data from an area unaffected by site operations. Samples were collected downstream of the Hanford Site above McNary Dam (the nearest downstream impoundment) to identify any increase in contaminant concentrations. Note 
that any increases in contaminant concentrations found in sediment above McNary Dam relative to that found above Priest Rapids Dam do not necessarily reflect a Hanford Site source. The confluences of the Columbia River with the Yakima, Snake, and Walla Walla Rivers lie between the Hanford Site and McNary Dam. Several towns, irrigation water returns, and factories in these drainages may also contribute to the contaminant load found in McNary Dam sediment; thus, sediment samples were taken at Ice Harbor Dam to assess Snake River inputs. Sediment samples were also collected along the Hanford Reach of the Columbia River from areas close to contaminant discharges (e.g., riverbank springs), from slackwater areas where finegrained material is known to deposit (e.g., the White Bluffs, 100-F Area, Hanford Sloughs), and from the publicly accessible Richland shoreline.

Monitoring sites located at McNary and Priest Rapids Dams consisted of four stations spaced equidistant (approximately) on a transect line crossing the Columbia River, with two additional samples collected near the dams. Three stations were sampled at Ice Harbor Dam. All other monitoring sites consisted of a single sampling location. Samples of permanently inundated river sediment, herein referred to as river sediment, were collected using a grab sampler with a 235-square-centimeter (36.4-square-inch) opening. Samples of periodically inundated river sediment, herein referred to as riverbank springs sediment, were collected using a large plastic spoon, immediately following the collection of riverbank springs water samples. Sampling methods are discussed in detail in DOE/RL-91-50, Rev. 2. All sediment samples were analyzed for gamma emitters (see Appendix E), strontium-90, uranium-235, uranium-238, and metals (DOE/RL91-50, Rev. 2). River sediment samples were also analyzed for plutonium-238, plutonium-239/240, metals, and simultaneously extracted metals/acid volatile sulfide. Sample analyses of Columbia River sediments were selected based on findings of previous Columbia River sediment investigations, reviews of past and present effluents discharged from site facilities, and reviews of contaminant concentrations observed in near-shore groundwater monitoring wells.

\subsubsection{Radiological Results for Samples from River Sediment}

Results of the radiological analyses on river sediment samples collected during 1999 are reported in PNNL-13230, APP. 1 and summarized in Appendix A (Table A.6). Radionuclides consistently detected in river sediment adjacent and downstream of the Hanford Site during 1999 included potassium-40, cobalt-60, strontium-90, cesium-137, europium-155, uranium-238, plutonium-238, and plutonium-239/240. The concentrations of all other measured radionuclides were below detection limits for most samples. Strontium-90 and plutonium239/240 exist in worldwide fallout, as well as in effluents from Hanford Site facilities. Uranium occurs naturally in the environment in addition to being present in Hanford Site effluents. Comparisons of contaminant levels between sediment sampling locations are made below. Because of variations in the bioavailability of contaminants in various sediments, no federal or state freshwater sediment criteria are available to assess the sediment quality of the Columbia River (EPA 822-R-96-001).

Radionuclide concentrations reported in river sediment in 1999 were similar to those reported for previous years (see Appendix A, Table A.6). Median, maximum, and minimum concentrations of selected radionuclides measured in Columbia and Snake River sediments from 1994 through 1999 are presented in Figure 4.2.11. Sampling areas include stations at Priest Rapids, McNary, and Ice Harbor Dams as well as the Hanford Reach stations (White Bluffs, 100-F Area and Hanford Sloughs, and the Richland Pumphouse). Strontium-90 was the only radionuclide to exhibit consistently higher median concentrations at McNary Dam from 1994 through 

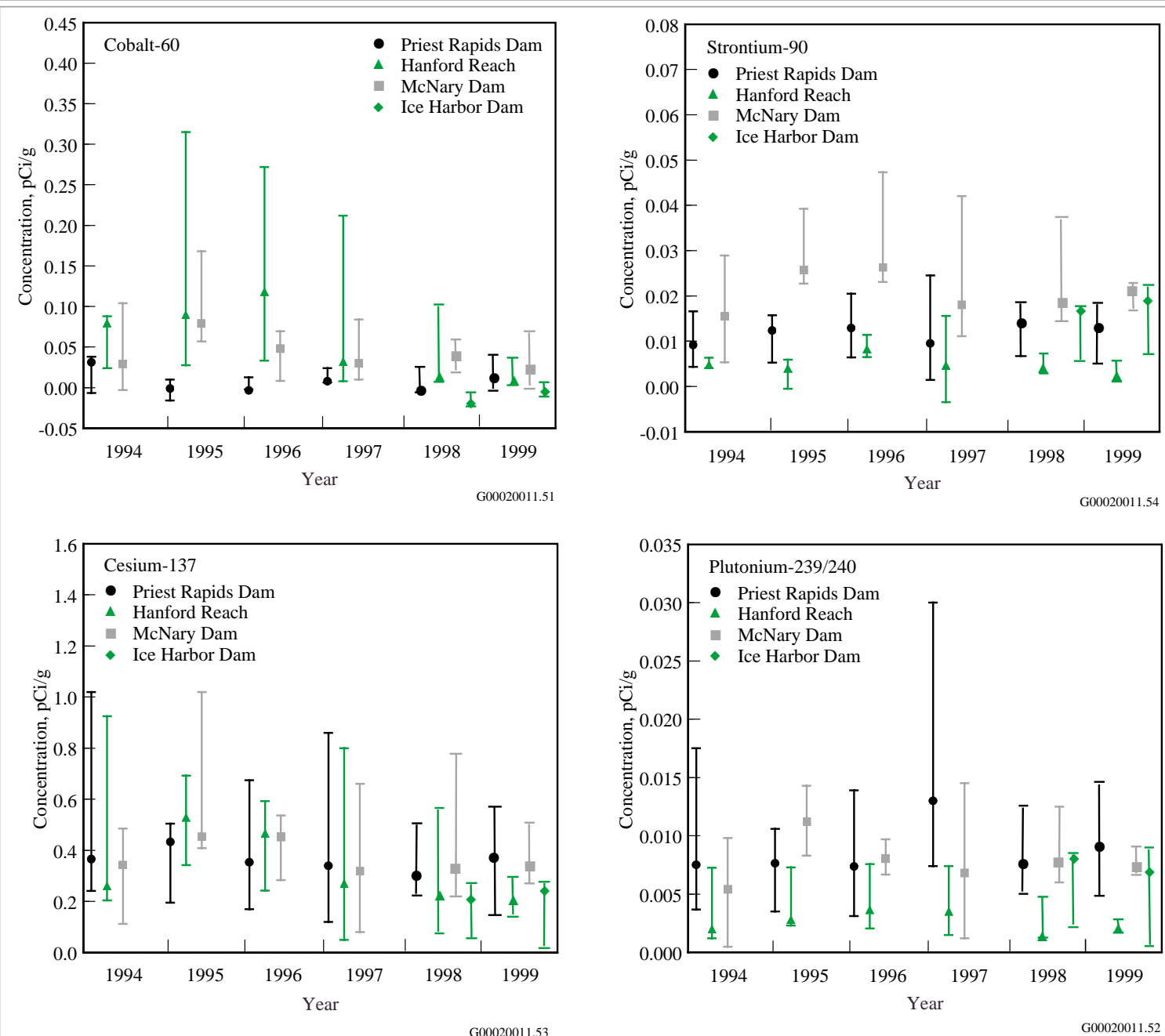

Figure 4.2.11. Median, Maximum, and Minimum Concentrations of Selected Radionuclides Measured in Columbia and Snake River Sediments, 1994 Through 1999

1999. No other radionuclides measured in 1999 exhibited appreciable differences in concentrations between locations.

\subsubsection{Radiological Results for Sediment Samples from Riverbank Springs}

Sampling of sediment from riverbank springs was begun in 1993 at the Old Hanford Townsite and 300 Area. Sampling of the riverbank springs in the 100-B, 100-F, and 100-K Areas was initiated in 1995.
Sediment at all other riverbank spring sampling locations consisted of predominantly large cobble and were unsuitable for sample collection.

Radiological results for sediment collected from riverbank springs in 1999 are presented in PNNL13230, APP. 1 and are summarized in Appendix A (Table A.6). Results were similar to those observed for previous years. In 1999, sediment samples were collected at riverbank springs in the 100-B Area, 100-F Area, Old Hanford Townsite, and 300 Area. There were no sediments available for sampling at the $100-\mathrm{K}$ and 100-N Area locations. In 1999, 
radionuclide concentrations in riverbank spring sediment were similar to those observed in river sediment.

\subsubsection{Nonradiological Results for Sediment Samples from the Columbia and Snake $R$ ivers and from Riverbank Springs}

Metal concentrations (total metals, reported on a dry weight basis) observed in Columbia and Snake River sediment in 1999 are reported in PNNL13230, APP. 1 and are summarized in Appendix A (Table A.7). Detectable amounts of most metals were found in all river sediment samples (Figure 4.2.12). Metal concentrations in riverbank spring sediment samples in 1999 were similar to 1999 Columbia River sediment samples.

From 1997 to 1999, Columbia River sediments were also analyzed for simultaneously extracted metals/acid volatile sulfide (SEM/AVS). This analysis involves a cold acid extraction of the sediments followed by analysis for sulfide and metals. The SEM/AVS ratios are typically a better indicator

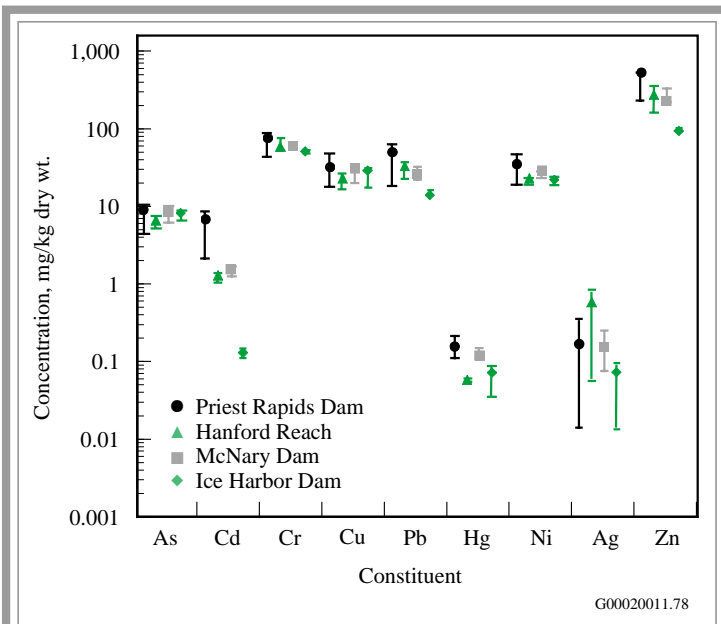

Figure 4.2.12. Median, Maximum, and Minimum Concentrations of Selected Metals Measured in Columbia and Snake River Sediments, 1999 of potential sediment toxicity than total metal concentrations (DeWitt et al. 1996, Hansen et al. 1996). Acid volatile sulfide is an important binding phase for divalent metals (i.e., metals with a valance state of $2+$, such as $\mathrm{Pb}^{2+}$ ) in sediment. Metal sulfide precipitates are typically very insoluble, and this limits the amount of dissolved metal available in the sediment porewater. For an individual metal, when the amount of acid volatile sulfide exceeds the amount of the metal (i.e., the SEM/AVS molar ratio is below 1), the metal concentration in the sediment porewater will be low because of the limited solubility of the metal sulfide. For a suite of divalent metals, the sum of the simultaneously extracted metals must be considered, with the assumption that the metal with the lowest solubility will be the first to combine with the acid volatile sulfide.

For 1997 samples, the acid volatile sulfide results were similar for sediments from the Priest Rapids Dam reservoir and the Hanford Reach, with concentrations ranging from 1.2 to $21 \mu \mathrm{mol} / \mathrm{g}$. Sediment from the McNary Dam reservoir had lower concentrations of acid volatile sulfide, with levels ranging from 0.075 to $2.6 \mu \mathrm{mol} / \mathrm{g}$. When comparing the pool of available metals to the available sulfide (i.e., SEM/AVS molar ratio), sediment from both the Priest Rapid Dam and Hanford Reach should have sufficient sulfide to limit the interstitial porewater concentrations of the divalent metals tested (Figure 4.2.13a), with zinc dominating the metal concentrations. However, for the McNary Dam sediment there was more divalent metal (primarily zinc) available than the sulfide.

The SEM/AVS results for the 1998 samples were similar to 1997 (Figure 4.2.13b), with the exception of the average acid volatile sulfide concentration for Priest Rapid Dam sediment that decreased by a factor of two. For 1998, the acid volatile sulfide values were similar for sediments from the Priest Rapid Dam reservoir and the Hanford Reach, with concentrations ranging from 0.32 to $15 \mu \mathrm{mol} / \mathrm{g}$. Sediments from the McNary Dam reservoir and the Ice Harbor 


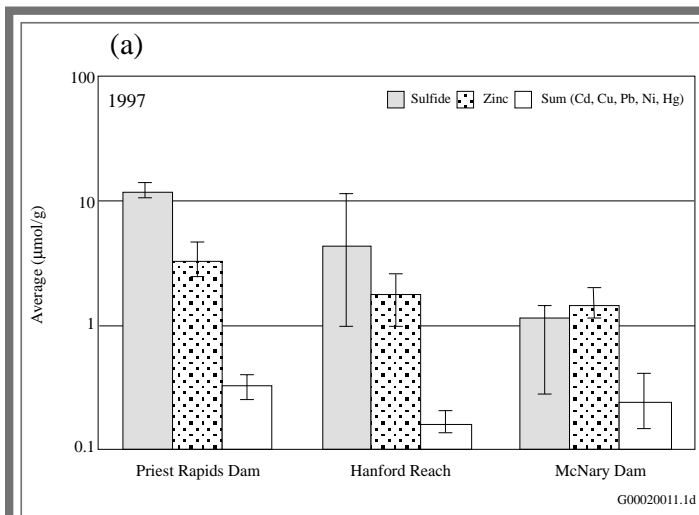

(b)

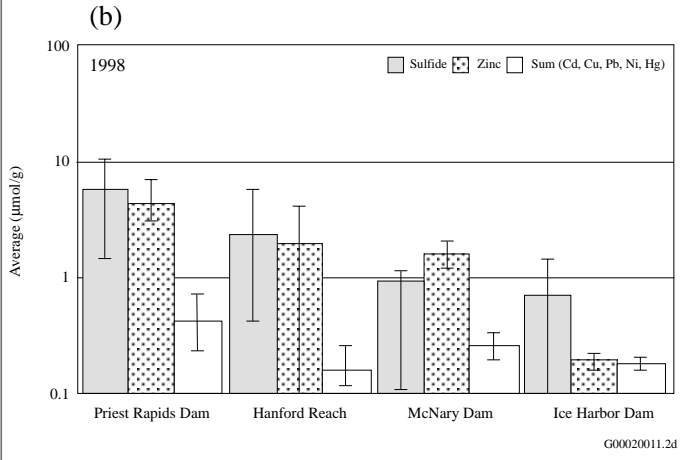

(c)

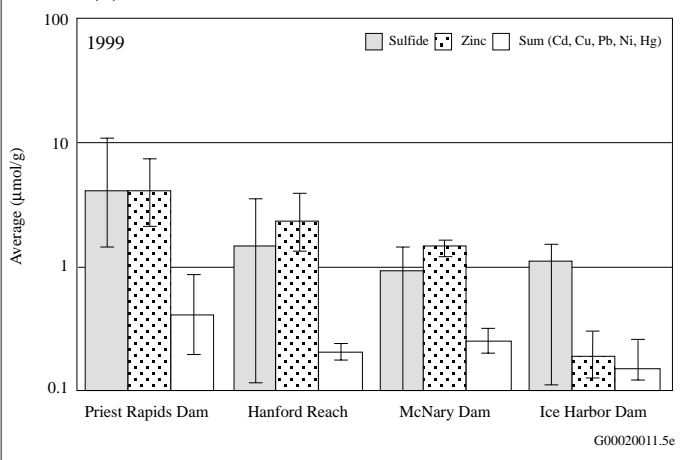

Figure 4.2.13. Average Acid Volatile Sulfide, Simultaneously Extracted Zinc, and Sum of Simultaneously Extracted Metals in Columbia River and Snake River (Ice Harbor Dam) Sediments for 1997 (a), 1998 (b), and 1999 (c) ( \pm 1 standard deviation)

Dam reservoir (Snake River) had lower concentrations of acid volatile sulfide, with values ranging from 0.033 to $2.4 \mu \mathrm{mol} / \mathrm{g}$. For 1998, the SEM/AVS molar ratios were close to one for Priest Rapids Dam and Hanford Reach sediments, with zinc as the dominant metal. For 1998, the SEM/AVS molar ratios for sediment from McNary Dam were above one, indicating a potential for some metals to be present in the sediment porewater, with zinc as the primary metal present. Ice Harbor Dam sediment had similar concentrations of acid volatile sulfide as McNary Dam; however, the zinc concentrations for Ice Harbor Dam sediment were an order of magnitude below the Columbia River sediments.

The SEM/AVS results for the 1999 samples were similar to 1998 (Figure 4.2.13c). For 1999, the acid volatile sulfide values were similar for sediment from the Priest Rapid Dam reservoir and the Hanford Reach, with concentrations ranging from 0.33 to $14 \mu \mathrm{mol} / \mathrm{g}$. Sediment from the McNary Dam reservoir and the Ice Harbor Dam reservoir (Snake River) had lower concentrations of acid volatile sulfide, with values ranging from 0.081 to $3.2 \mu \mathrm{mol} / \mathrm{g}$. For 1999, the SEM/AVS molar ratios were close to one for Priest Rapids Dam and above one for Hanford Reach sediments, with zinc as the dominant metal. For 1999, the SEM/AVS molar ratios for sediment from McNary Dam were above one, indicating a potential for some metals to be present in the sediment porewater, with zinc as the primary metal present. Ice Harbor Dam sediment had similar concentrations of acid volatile sulfide as McNary Dam; however, the average zinc concentrations for Ice Harbor Dam sediments were five times below the Columbia River sediments.

These results reveal an apparent difference in the acid volatile sulfide concentrations in sediment from Priest Rapids Dam reservoir and the Hanford Reach, which have higher concentrations than McNary Dam and Ice Harbor Dam sediment. An apportionment of acid volatile sulfide by divalent metals according to solubility values revealed that sufficient acid volatile sulfide should exist in all locations to limit the porewater concentrations of cadmium, copper, lead, and mercury. For Priest Rapids Dam, Hanford Reach, and Ice Harbor Dam sediments, zinc values were of similar magnitude as the acid volatile sulfide concentrations. For McNary 
Dam sediment, the zinc concentrations were higher than the available acid volatile sulfide pool, indicating the potential for nickel and zinc (the two most soluble of the metals tested) to be bioavailable in the sediment porewater.

\subsubsection{Riverbank Spring Water}

The Columbia River is the primary discharge area for the unconfined aquifer underlying the Hanford Site (see Section 6.1.2, "Groundwater Hydrology). Groundwater provides a means for transporting Hanford-associated contaminants, which have leached into groundwater from past waste disposal practices, to the Columbia River (DOE/ RL-92-12, PNL-5289, PNL-7500, WHC-SD-EN-TI006). Contaminated groundwater enters the Columbia River via surface and subsurface discharge. Discharge zones located above the water level of the river are identified in this report as riverbank springs. Routine monitoring of riverbank springs offers the opportunity to characterize the quality of groundwater being discharged to the river and to assess the potential human and ecological risk associated with the spring water.

The seepage of groundwater into the Columbia River has occurred for many years. Riverbank springs were documented along the Hanford Reach long before Hanford Site operations began during World War II (Jenkins 1922). In the early 1980s, researchers walked the 66-kilometer (41-mile) stretch of Benton County shoreline of the Hanford Reach and identified 115 springs (PNL-5289). They reported that the predominant areas of groundwater discharge at that time were in the vicinity of the 100-N Area, Old Hanford Townsite, and 300 Area. The predominance of the 100-N Area may no longer be valid because of declining water-table elevations in response to the decrease in liquid waste discharges to the ground from Hanford Site operations. In recent years, it has become increasingly difficult to locate riverbank springs in the $100-\mathrm{N}$ Area.
The presence of riverbank springs also varies with river stage. Groundwater levels in the 100 and 300 Areas are heavily influenced by river stage fluctuations (see Section 6.1, "Hanford Groundwater Monitoring Project"). Water levels in the Columbia River fluctuate greatly on annual and even daily cycles and are controlled by the operation of Priest Rapids Dam upstream of the site. Water flows into the aquifer (as bank storage) as the river stage rises and flows in the opposite direction as the river stage falls. Following an extended period of low river discharge, groundwater discharge zones located above the water level of the river may cease to exist once the level of the groundwater comes into equilibrium with the level of the river. Thus, springs are most readily identified immediately following a decline in river stage. Bank storage of river water also affects the contaminant concentration of the springs. Spring water discharge immediately following a river stage decline generally consists of river water or a river/ groundwater mix. The percentage of groundwater in the spring water discharge is believed to increase over time following a drop in river stage.

Because of the effect of bank storage on groundwater discharge and contaminant concentration, it is difficult to estimate the volume of contaminated groundwater discharged to the Columbia River within the Hanford Reach. The estimated total groundwater discharge from the upstream end of the 100 Areas to south of the 300 Area is $~ 66,500 \mathrm{~m}^{3}$ $\left(2,350,000 \mathrm{ft}^{3}\right)$ per day. ${ }^{(a)}$ This represents only $0.02 \%$ of the long-term average flow rate of the Columbia River, which illustrates the tremendous dilution potential afforded by the river. It should be noted

(a) Stuart Luttrell. January 1995. Personal communication with author, G. W. Patton, Pacific Northwest National Laboratory, Richland, Washington. 
that not all of the groundwater discharged to the river contains contaminants originating from Hanford Site operations. Studies of riverbank springs conducted in 1983 (PNL-5289) and in 1988 (PNL-7500) and a near-shore study (PNNL-11933) noted that discharges from the springs had a localized effect on river contaminant concentrations. Both studies reported that the volume of groundwater entering the river at these locations was very small relative to the flow of the river and that the impact of groundwater discharges to the river was minimal.

\subsubsection{Collection of Water Samples from Riverbank Springs and Analytes of Interest}

Routine monitoring of selected riverbank springs was initiated in 1988 at the $100-\mathrm{N}$ Area, Old Hanford Townsite, and 300 Area. Monitoring was expanded in 1993 to include riverbank springs in the 100-B, 100-D, 100-H, and 100-K Areas. A riverbank spring located at 100-F Area was added in 1994. The locations of all riverbank springs sampled in 1999 are identified in Figure 4.2.1. Sample collection methods are described in DOE/RL-91-50, Rev. 2. Analytes of interest for samples from riverbank springs were selected based on findings of previous investigations, reviews of contaminant concentrations observed in nearby groundwater monitoring wells, and results of preliminary risk assessments. Sampling is conducted annually when river flows are low, typically in late summer/fall.

Samples of water from riverbank springs were collected in October and November 1999. All samples collected during 1999 were analyzed for gammaemitting radionuclides, gross alpha, gross beta, and tritium. Samples from selected springs were analyzed for strontium-90, technetium-99, iodine-129, and uranium-234, -235, and -238. All samples were analyzed for metals and anions, with volatile organic compounds analyzed at selected locations. All analyses were conducted on unfiltered samples, except for metals which were analyzed for both filtered and unfiltered samples.

Hanford-origin contaminants continued to be detected in water from riverbank springs entering the Columbia River along the Hanford Site during 1999. The locations and extent of contaminated discharges were consistent with recent groundwater surveys. Tritium, strontium-90, technetium-99, iodine-129, uranium-234, -235 , and -238 , metals (antimony, arsenic, cadmium, chromium, copper, lead, mercury, nickel, selenium, thallium, zinc, and occasionally silver), and anions (chloride, fluoride, nitrate, and sulfate) were detected in springs water. Volatile organic compounds were near or below the detection limits for all samples. The contaminant concentrations in water from riverbank springs are typically lower than those found in near-shore groundwater wells because of bank storage effects.

Results of radiological and chemical analyses conducted on samples from riverbank springs in 1999 are documented in PNNL-13230, APP. 1. Radiological results obtained in 1999 are summarized in Appendix A (Table A.8) and compared to those reported in 1994 through 1998. In the following discussion, radiological and nonradiological results are addressed separately. Contaminant concentration trends are illustrated for selected locations.

\subsubsection{Radiological Results for Water Samples from Riverbank Springs}

All radiological contaminant concentrations measured in riverbank springs in 1999 were less than the DOE derived concentration guides (DOE Order 5400.5; see Appendix C, Table C.5). However, the spring at the $100-\mathrm{N}$ Area that has historically exceeded the DOE derived concentration guide for strontium-90 was not flowing during 1998 and 1999 sample collection; thus, an alternative spring was sampled in the 100-N Area. Tritium concentrations in water from riverbank springs at the Old Hanford Townsite exceeded the ambient surface-water 
quality criteria levels (WAC 173-201A and 40 CFR $141)$ and the 100-B (38-3) riverbank spring water was at the criteria level. Tritium concentrations in riverbank spring water at the $100-\mathrm{N}$ and 300 Areas were greater than $50 \%$ of the ambient surface water criteria level (WAC 173-201A and 40 CFR 141). Strontium-90 concentration in riverbank spring water was above the ambient surface water criteria level at the 100-H Area (spring 153-1) and was greater than $50 \%$ of the criteria level at the 100-B Area (spring 39-2). There are no ambient surface-water quality criteria levels directly applicable to uranium. However, total uranium concentrations exceeded the site-specific proposed EPA drinking water standard (EPA 822-R-96-001) in the 300 Area (see Appendix C, Table C.2). The gross alpha concentration exceeded the ambient surface-water quality criteria level in riverbank spring water at the 300 Area, which is consistent with the elevated uranium levels. All other radionuclide concentrations in 300 Area springs water were less than ambient surface-water quality criteria levels. Gross beta concentrations in riverbank spring water at the Old Hanford Townsite and the 300 Area were near the surface-water quality criteria level.

Tritium concentrations varied widely with location. The highest tritium concentration detected in riverbank springs water was at the Old Hanford Townsite $(110,000 \pm 4,100 \mathrm{pCi} / \mathrm{L})$, followed by the 100 -B Area $(20,000 \pm 870 \mathrm{pCi} / \mathrm{L})$, $100-\mathrm{N}$ Area $(14,000 \pm 670 \mathrm{pCi} / \mathrm{L})$, and 300 Area $(11,000 \pm 570 \mathrm{pCi} / \mathrm{L})$. The ambient surface-water quality criteria level for tritium is $20,000 \mathrm{pCi} / \mathrm{L}$. Tritium concentrations in all riverbank springs water samples were elevated compared to the 1999 average Columbia River level at Priest Rapids Dam $(37 \pm 5.0 \mathrm{pCi} / \mathrm{L})$.

Samples from riverbank springs in the $100-\mathrm{H}$ Area and Old Hanford Townsite were analyzed for technetium-99. The highest technetium-99 concentration was found in water from the Old Hanford Townsite spring $(120 \pm 8.0 \mathrm{pCi} / \mathrm{L})$, in agreement with the observed beta concentrations.
Samples from riverbank springs at the Old Hanford Townsite and 300 Area were analyzed for iodine-129. The highest concentration was measured in a water sample from the Old Hanford Townsite spring $(0.41 \pm 0.024 \mathrm{pCi} / \mathrm{L})$. This value was elevated compared to the 1999 average measured at Priest Rapids Dam $(0.0000047 \pm 0.0000013$ pCi/L) but was below the $1-\mathrm{pCi} / \mathrm{L}$ surface-water quality criteria level (see Appendix C, Table C.2).

Uranium was sampled in riverbank spring water in the 100-H Area, 100-F Area, Old Hanford Townsite, and 300 Area in 1999. The highest level was found in 300 Area spring water $(210 \pm 38 \mathrm{pCi} / \mathrm{L})$, which was collected from a spring located downgradient from the retired 300 Area process trenches. The 300 Area spring had elevated gross alpha concentration, which paralleled that of uranium.

Samples from riverbank springs were analyzed for strontium-90 in the 100-B, 100-D, 100-F, 100-H, $100-\mathrm{K}, 100-\mathrm{N}$ Areas, and 300 Area. The highest strontium-90 concentration detected in riverbank spring water was at the $100-\mathrm{H}$ Area $(14 \pm 3.1 \mathrm{pCi} / \mathrm{L})$ and this value exceeded the ambient surface water quality criteria of $8 \mathrm{pCi} / \mathrm{L}$. The strontium- 90 concentration in riverbank spring water from the $100-B$ Area was $57 \%$ of the ambient surface water quality criteria.

Historically, riverbank seepage in the $100-\mathrm{N}$ Area has been monitored for contaminants by sampling from well 199-N-8T, which is located close to the river; well 199-N-46 (caisson), which is slightly inland from well 199-N-8T (PNNL-11795, Figure 3.2.4); or riverbank springs. Since 1993, 100-N Area seepage samples for the Surface Environmental Surveillance Project have been collected only from riverbank springs. The Near-Facility Environmental Monitoring program (see Section 3.2.2, "SurfaceWater Disposal Units and 100-N Area Riverbank Springs Monitoring") also collects water samples along the $100-\mathrm{N}$ shoreline at monitoring well $199-\mathrm{N}$ 46 and at shoreline seepage wells. The Near-Facility Environmental Monitoring program reported 1999 
strontium- 90 concentrations exceeded the $1,000 \mathrm{pCi} / \mathrm{L}$ derived concentration guide for a shoreline seepage well near monitoring well 199-N-46 (see Table 3.2.4). For 1993 to 1996, 1998, and 1999 there were no visible riverbank springs directly adjacent to wells $199-\mathrm{N}-8 \mathrm{~T}$ or $199-\mathrm{N}-46$ during the sampling period. The 100-N Area riverbank springs samples were, therefore, collected from the nearest visible downstream riverbank spring.

In 1999, samples were collected from the same downstream riverbank spring sampled in previous years (i.e., downriver from well 199-N-8T). Contaminant activities measured in the water from the two riverbank springs locations sampled in previous years were distinctly different (Table 4.2.3). Historically, the concentrations of strontium-90 and gross beta were considerably higher in the riverbank spring directly adjacent to well $199-\mathrm{N}-8 \mathrm{~T}$ than for the downstream spring. Tritium levels in water from riverbank springs are typically elevated at both locations, and the 1999 tritium result was similar to those found in previous years (see Table 3.2.5). Tritium was the only contaminant detected at the $100-\mathrm{N}$ Area riverbank spring in 1999. The tritium concentration was $70 \%$ of the ambient surface-water quality criteria level (see Appendix C, Table C.2). The tritium results for the samples from 100-N Area riverbank springs are of the same magnitude as those reported in Section 3.2, "Near-Facility Environmental Monitoring," Table 3.2.7.

Concentrations of selected radionuclides in riverbank spring water near the Old Hanford Townsite (spring 28-2) from 1994 through 1999 are provided in Figure 4.2.14. Gross beta and technetium-99 concentrations show an increasing trend since 1994. The 1999 tritium and iodine-129 concentrations were similar to those in recent years. Annual fluctuations in these values may reflect the influence of bank storage during the sampling period. The maximum tritium and technetium-99 levels detected in water from Old Hanford Townsite riverbank springs in 1999 were $550 \%$ and $413 \%$ of their respective ambient surface-water quality criteria levels (see Appendix C, Table C.2). The maximum iodine-129

\begin{tabular}{|c|c|c|c|}
\hline \multicolumn{4}{|c|}{$\begin{array}{c}\text { Table 4.2.3. Selected Radionuclide Concentrations } \\
\text { in 100-N Area Riverbank Spring Water, } \\
1994 \text { Through } 1999\end{array}$} \\
\hline \multirow[b]{2}{*}{ Year } & \multicolumn{3}{|c|}{ Concentration, $\mathrm{pCi} / \mathrm{L}^{(\mathrm{a})}$} \\
\hline & Tritium & Gross B eta & Strontium-90 \\
\hline $1994^{(\mathrm{b})}$ & $31,000 \pm 2,400$ & $8.8 \pm 2.3$ & $0.13 \pm 0.11$ \\
\hline $1995^{\text {(b) }}$ & $12,000 \pm 970$ & $1.5 \pm 1.5$ & $0.079 \pm 0.10$ \\
\hline $1996^{(\mathrm{b})}$ & $17,000 \pm 1,300$ & $4.5 \pm 1.8$ & $0.053 \pm 0.048$ \\
\hline $1997^{\text {(b) }}$ & $19,000 \pm 1,500$ & $3.5 \pm 1.6$ & $0.59 \pm 0.13$ \\
\hline $1997^{\text {(c) }}$ & $14,000 \pm 1,100$ & $16,000 \pm 1,400$ & $9,900 \pm 1,800$ \\
\hline $1998^{(b)}$ & $24,000 \pm 1,900$ & $2.3 \pm 2.1$ & (d) \\
\hline $1999^{\text {(b) }}$ & $14,000 \pm 670$ & $2.9 \pm 1.7$ & $0.026 \pm 0.034$ \\
\hline \multicolumn{4}{|c|}{$\begin{array}{l}\text { (a) Concentrations are } \pm 2 \text { total propagated analytical } \\
\text { uncertainty. } \\
\text { (b) Sample collected from riverbank spring downstream of } \\
\text { well 199-N-8T. } \\
\text { (c) Samples collected from spring below well 199-N-8T } \\
\text { (100-N Area spring 8-13, see PNNL-11795, Figure 3.2.4). } \\
\text { (d) Sample was lost during processing at the analytical } \\
\text { laboratory. }\end{array}$} \\
\hline
\end{tabular}



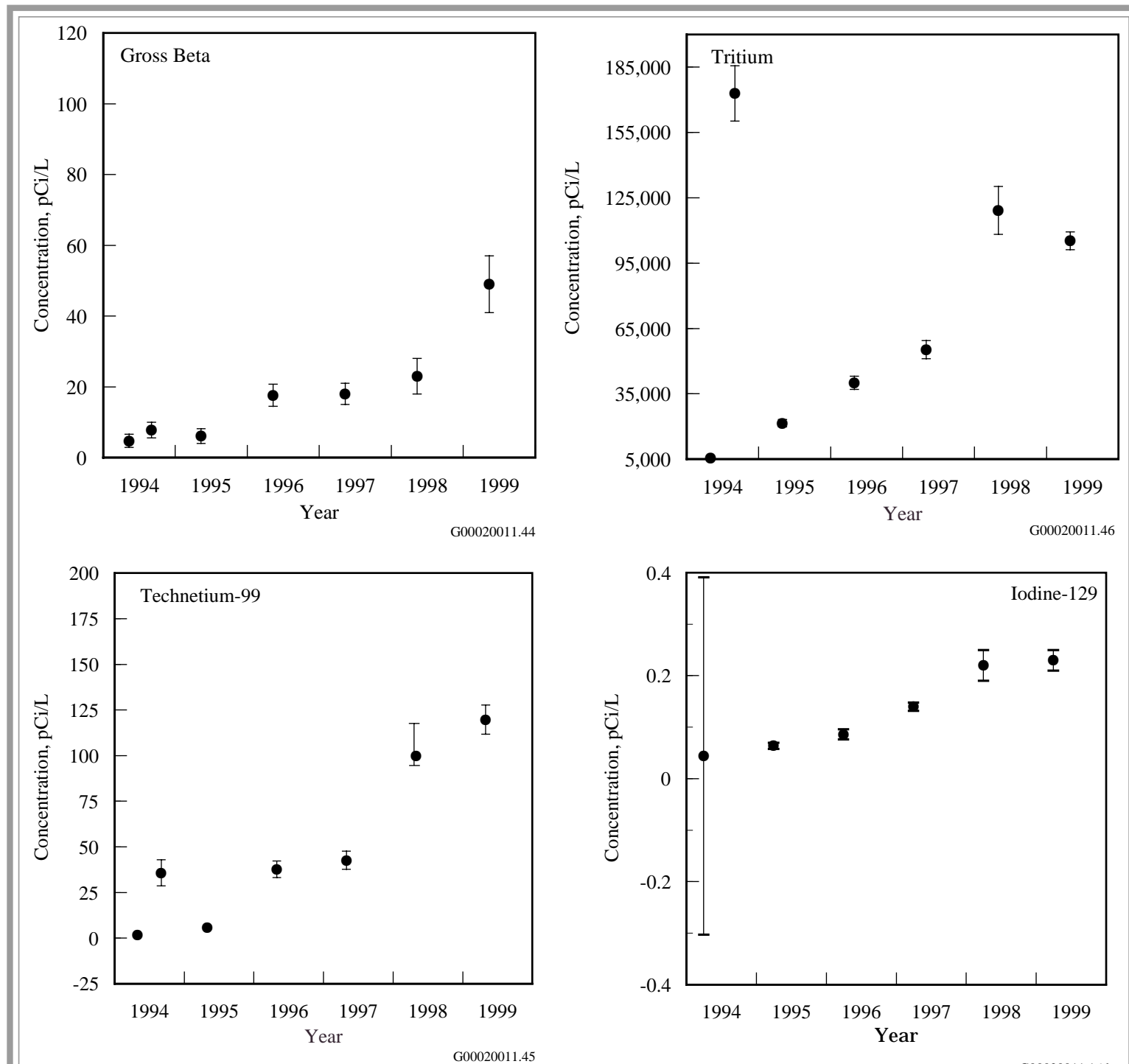

Figure 4.2.14. Concentrations (results \pm 2 total propagated analytical uncertainty) of Constituents of Interest in Columbia River Riverbank Spring Water at the Old Hanford Townsite, 1994 Through 1999. As

a result of figure scale, some uncertainties (error bars) are concealed by the point symbol.

concentration measured in water from the Old Hanford Townsite riverbank springs for 1999 was $41 \%$ of the ambient surface-water quality criteria level (see Appendix C, Table C.2).

Figure 4.2.15 depicts the concentrations of selected radionuclides in the 300 Area riverbank springs from 1994 through 1999. Results in 1999 were similar to those observed previously, except for gross beta which was elevated. The elevated tritium levels measured in the 300 Area riverbank springs are indicators of the contaminated groundwater plume from the 200 Areas (Section 5.9 in PNL-10698). In addition, iodine-129 is also contained in the 200 Areas' contaminated groundwater plume. The maximum tritium and iodine-129 concentrations in water from 300 Area riverbank springs in 1999 were $57 \%$ and $0.06 \%$ of their respective ambient surfacewater quality criteria levels (see Appendix C, Table C.2). The highest total uranium levels in riverbank 

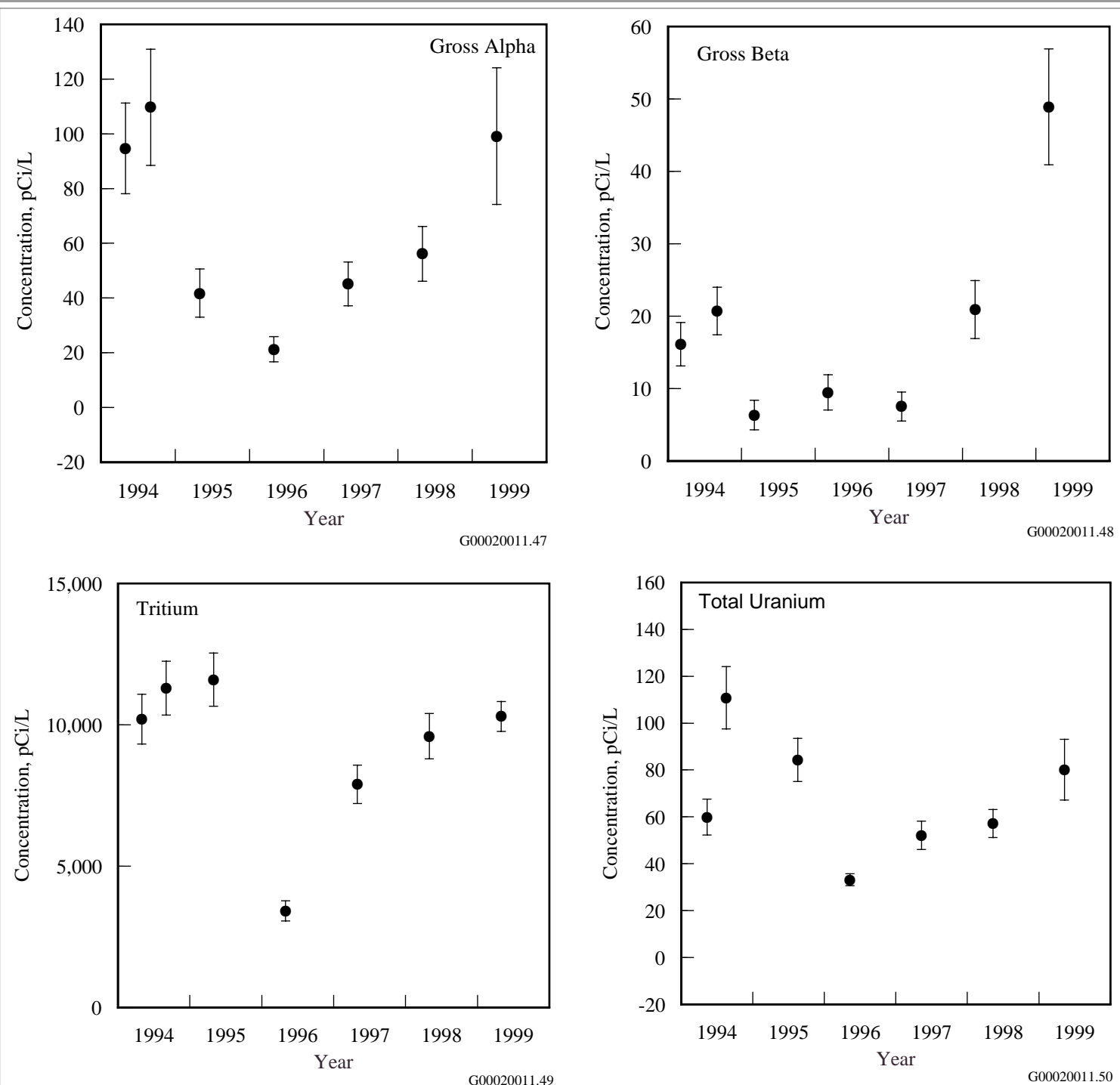

Figure 4.2.15. Concentrations (results \pm 2 total propagated analytical uncertainty) of Constituents of Interest in Water from a Columbia River Riverbank Spring Near the 300 Area (Spring 42-2), 1994 Through 1999

spring water from 1994 through 1999 were found in the 300 Area riverbank springs. The 1999 maximum total uranium value was more than 15 times higher than the proposed site-specific EPA drinking water standard (13.4 pCi/L [EPA 822-R-96-001]; see Appendix C, Table C.2). Elevated uranium concentrations exist in the unconfined aquifer beneath the 300 Area in the vicinity of uranium fuel fabrication facilities and inactive waste sites. The gross alpha and gross beta concentrations in the 300 Area riverbank springs water from 1994 through 1999 parallel uranium and are likely associated with its presence.

\subsubsection{Nonradiological Results for Water Samples from Riverbank Springs}

Concentration ranges of selected chemicals measured in riverbank springs water in 1994 through 1999 are presented in Table 4.2.4. For most 
Table 4.2.4. Concentration Ranges for Selected Chemicals in Water from Columbia River Riverbank Springs, 1997 Through 1999

\begin{tabular}{|c|c|c|c|c|c|c|c|c|}
\hline \multirow{2}{*}{$\begin{array}{c}\text { Water Quality } \\
\text { Criteria Level, } \\
\mu \mathbf{g}^{(\mathbf{a}, \mathbf{b})}\end{array}$} & \multicolumn{8}{|c|}{ Concentration, $\mu$ g/L } \\
\hline & 100-B Area & 100-K Area & 100-N Area & 100-D Area & 100-H Area & 100-F Area & $\begin{array}{l}\text { Old Hanford } \\
\text { Townsite }\end{array}$ & 300 Area \\
\hline & 4 & 3 & 4 & 4 & 4 & 3 & 5 & 4 \\
\hline .. & $0.064-0.24$ & $0.17-0.42$ & $0.15-0.27$ & $0.12-0.36$ & $0.20-0.31$ & $0.099-0.17$ & $0.098-0.42$ & $0.14-0.28$ \\
\hline 190 & $0.91-1.3$ & $1.2-1.5$ & $0.83-3.2$ & $0.67-1.4$ & $0.90-2.1$ & $2.0-2.8$ & $3.2-4.9$ & $1.1-8.2$ \\
\hline $0.64^{(\mathrm{c})}$ & $0.010-0.033$ & $0.010-0.067$ & $0.014-0.072$ & $0.02-0.088$ & $0.03-0.087$ & $0.032-0.10$ & $0.01-0.1$ & $0.010-1.6$ \\
\hline 11 & $13-20$ & $1.7-66$ & $4.1-8.9$ & $24-330$ & $17-120$ & $9.3-22$ & $2.0-5.3$ & $2.7-24$ \\
\hline $6.3^{(c)}$ & $0.36-4.9$ & $0.33-1.1$ & $0.32-0.79$ & $0.51-1.5$ & $0.53-2.9$ & $0.88-1.5$ & $0.46-1.2$ & $0.74-32$ \\
\hline $1.2^{\text {(c) }}$ & $0.33-0.9$ & $0.056-2.5$ & $0.11-0.76$ & $0.044-0.77$ & $0.20-5.8$ & $0.53-1.9$ & $0.18-1.6$ & $0.25-37$ \\
\hline $85^{(c)}$ & $0.62-2.0$ & $0.83-1.6$ & $0.78-1.6$ & $0.74-1.7$ & $0.87-2.1$ & $1.2-2.9$ & $0.71-2.1$ & $0.73-32$ \\
\hline 5 & $1.2-2.9$ & $0.55-2.2$ & $0.55-1.1$ & $0.67-2.3$ & $0.55-0.96$ & $0.55-3.0$ & $1.6-2.4$ & $1.8-3.9$ \\
\hline $1.2^{\text {(c) }}$ acute & $0.0080-0.015$ & $0.0080-0.013$ & $0.008-0.013$ & $0.008-0.016$ & $0.0080-0.013$ & $0.0080-0.029$ & $0.008-0.068$ & $0.0080-0.14$ \\
\hline .. & $0.0040-0.014$ & $0.012-0.047$ & $0.011-0.054$ & $0.025-0.098$ & $0.0081-0.055$ & $0.011-0.025$ & $0.012-0.035$ & $0.014-0.41$ \\
\hline $57^{(\mathrm{c})}$ & $0.70-5.4$ & $1.3-4.7$ & $1.2-4.4$ & $1.3-10$ & $1.3-32$ & $4.1-12$ & $0.66-110$ & $4.0-230$ \\
\hline & $1.8-4.0$ & $0.32-6.6$ & $3.1-4.8^{(\mathrm{d})}$ & $0.84-9.4$ & $1.2-10$ & $8.8-12$ & $1.8-8.1$ & $4.0-6.5$ \\
\hline
\end{tabular}

No. of Samples

3

1

3

2

4

3

Mercury

$0.012 \quad 0.00066-0.0013 \quad 0.00086$

0.00051

No. of Samples

$4 \quad 3$

4

4

$0.00065-0.0015$

2

$0.00096-0.035$

Conductivity $(\mu \mathrm{S} / \mathrm{cm})$

$253-363$

$164-378$

$228-359$

$149-271$

$190-516$

$341-505$

$285-408$

$334-455$

(a) WAC 173-201A-040

(b) Levels that result in chronic toxicity, unless otherwise noted.

(c) Ambient surface-water quality criteria level is hardness-dependent; listed value assumes a hardness of $48 \mathrm{mg} \mathrm{CaCO} / \mathrm{L}$.

(d) $n=3$. 
locations, the 1999 nonradiological sample results were similar to those reported previously (PNNL12088). Nitrate concentrations were highest in the 100-F Area. Chromium concentrations are typically highest in the 100-D, 100-H, and 100-K Areas' riverbank springs. Hanford groundwater monitoring results for 1999 indicated similar nonradiological contaminants in shoreline areas (see Section 6.1, "Hanford Groundwater Monitoring Project").

The ambient surface-water quality criteria for cadmium, copper, lead, nickel, silver, and zinc are total-hardness dependent (WAC 173-201A; see Appendix C, Table C.3). For comparison purposes, spring water criteria were calculated using the same 48-mg calcium carbonate per liter hardness given in Appendix C, Table C.3. Most metal concentrations measured in water from riverbank springs collected from the Hanford Site shoreline in 1999 were below

\subsubsection{Onsite Pond Water}

Two onsite ponds (see Figure 4.2.1), located near operational areas, were sampled periodically during 1999. The ponds are inaccessible to the public and, therefore, did not constitute a direct offsite environmental impact during 1999. However, they were accessible to migratory waterfowl, creating a potential biological pathway for the dispersion of contaminants (PNL-10174). The Fast Flux Test Facility pond is a disposal site for process water (primarily cooling tower water). West Lake, the only naturally occurring pond on the site, is located north of the 200-East Area (ARH-CD-775). West Lake has not received direct effluent discharges from Hanford Site facilities but is influenced by changing watertable elevation as a result of previous discharge of water to the ground in the 200 Areas.

\subsubsection{Collection of Pond Water Samples and Analytes of Interest}

In 1999, grab samples were collected quarterly from the Fast Flux Test Facility Pond and from West ambient surface-water acute toxicity levels (WAC 173-201A). However, concentrations of chromium in 100-B, 100-K, 100-D, 100-H, 100-F, and 300 Areas spring water, and copper, lead, and zinc concentrations in 300 Area spring water were above ambient surface water acute toxicity levels (see Appendix C, Table C.3). Arsenic concentrations in riverbank spring water were well below ambient surface water chronic toxicity levels, but all samples (including upriver Columbia River water samples) exceeded the federal limit (40 CFR 141, see Appendix C, Table C.3). Riverbank spring water was above the ambient surface water chronic toxicity levels for cadmium and mercury at the 300 Area and lead at the 100-H Area and the Old Hanford Townsite. Nitrate concentrations at all spring water locations were below the drinking water standard (see Appendix C, Table C.2).

Lake. Unfiltered aliquots of all samples were analyzed for gross alpha and gross beta concentrations, gamma-emitting radionuclides, and tritium. West Lake samples were also analyzed for strontium-90 (April 6, 1999 only), technetium-99, and uranium-234, -235 , and -238 . Constituents were chosen for analysis based on their known presence in local groundwater or in effluents discharged to the pond and their potential to contribute to the overall radiation dose to the public.

\subsubsection{Radiological Results for Pond Water Samples}

Analytical results from pond water samples collected during 1999 are reported in PNNL-13230, APP. 1. With the exceptions of uranium-234 and uranium-238 in the April and July samples from West Lake, radionuclide concentrations in onsite pond water were less than the DOE derived concentration guides (DOE Order 5400.5; see Appendix C, Table C.5). The median gross alpha, gross beta, and total uranium concentrations exceeded their 
ambient surface-water quality criteria in West Lake. The median concentrations of all other radionuclides were below ambient surface-water quality criteria levels (WAC 173-201A, 40 CFR 141; see Appendix C, Table C.2).

Figure 4.2.16 shows the annual gross beta and tritium concentrations in Fast Flux Test Facility Pond water from 1994 through 1999. Median levels of both constituents have remained stable in recent years. However, the tritium concentration in the July 1995 sample was $16,400 \mathrm{pCi} / \mathrm{L}$, which was much higher than that observed previously. The use of well 499-S0-7 during this time is most likely responsible for the high levels of tritium observed in July 1995. Tritium levels in well 499-S0-7 are typically greater than $20,000 \mathrm{pCi} / \mathrm{L}$, reflective of those observed in a portion of the local unconfined aquifer. Median gross beta and tritium concentrations in Fast Flux Test Facility Pond water during 1999 were 26\% and $21 \%$ of their respective ambient surface-water quality criteria. The concentrations of all other measured contaminants in this pond water were below detection limits, except for naturally occurring potassium- 40 .

The annual concentrations of selected radionuclides from 1994 through 1999 in West Lake water are shown in Figure 4.2.17. Median radionuclide concentrations in West Lake during 1999 were similar to those observed in the past. The gross alpha and gross beta levels in West Lake water are believed to result from high levels of naturally occurring uranium in the surrounding soil (BNWL-1979, PNL-7662). Annual median total uranium concentrations have remained stable over the last 6 years, but the range is large. The highest concentrations measured in 1999 were in the summer, when the water level in the pond was low. It is thought that the relatively large concentration of suspended sediment in the samples is causing the elevated results. Similar total uranium levels were reported in PNNL-7662 for West Lake samples that contained high concentrations of suspended sediment. Declines in groundwater levels beneath the 200 Areas have been recorded since the decommissioning of the 216-U-10 pond in 1984 and
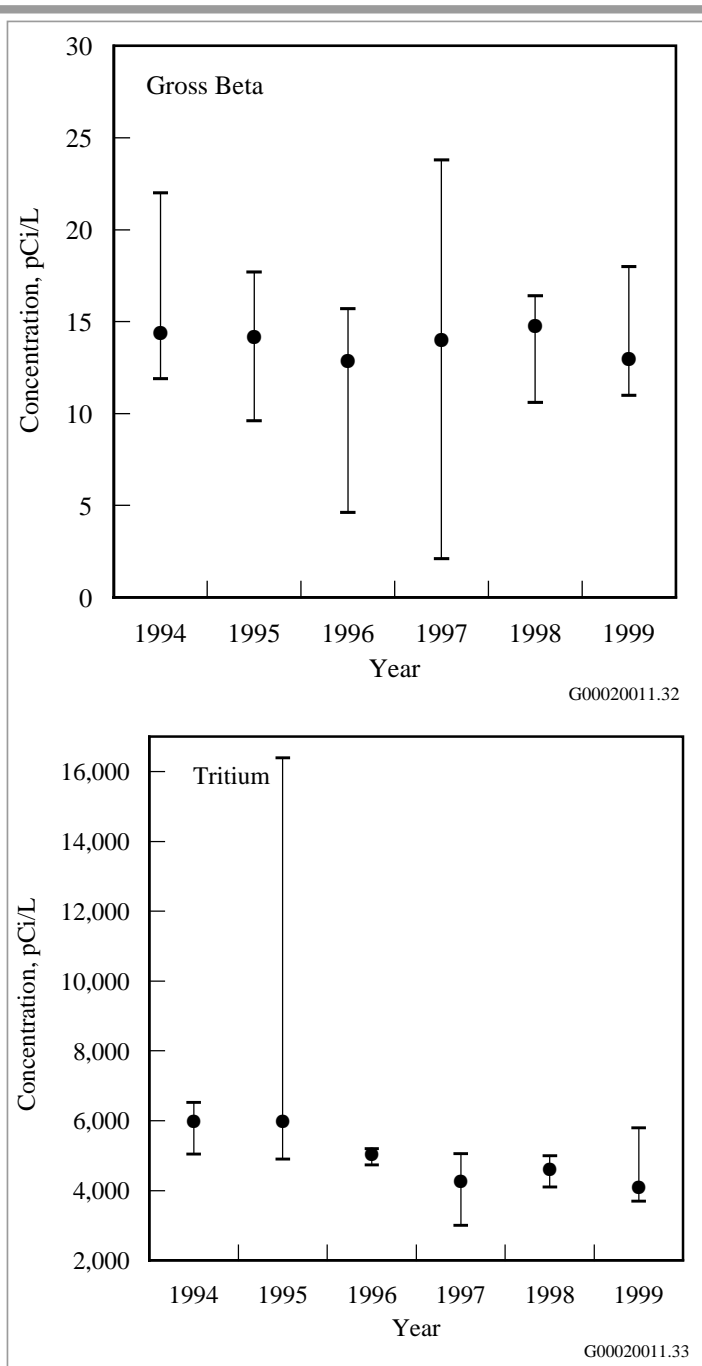

Figure 4.2.16. Median, Maximum, and Minimum Gross Beta and Tritium Concentrations in Fast Flux Test Facility Pond Water Samples, 1994 Through 1999

the shutdown of production facilities (see Section 6.1, "Hanford Groundwater Monitoring Project"). As a result, the water level in West Lake has dropped. Median concentrations of tritium, strontium-90, and technetium-99 in West Lake in 1999 were $0.33 \%, 22 \%$, and $16 \%$, respectively, of the ambient surface-water quality criteria levels and reflected local groundwater concentrations. The concentrations of all other measured radionuclides were below their detection limits, except for naturally occurring potassium-40. 

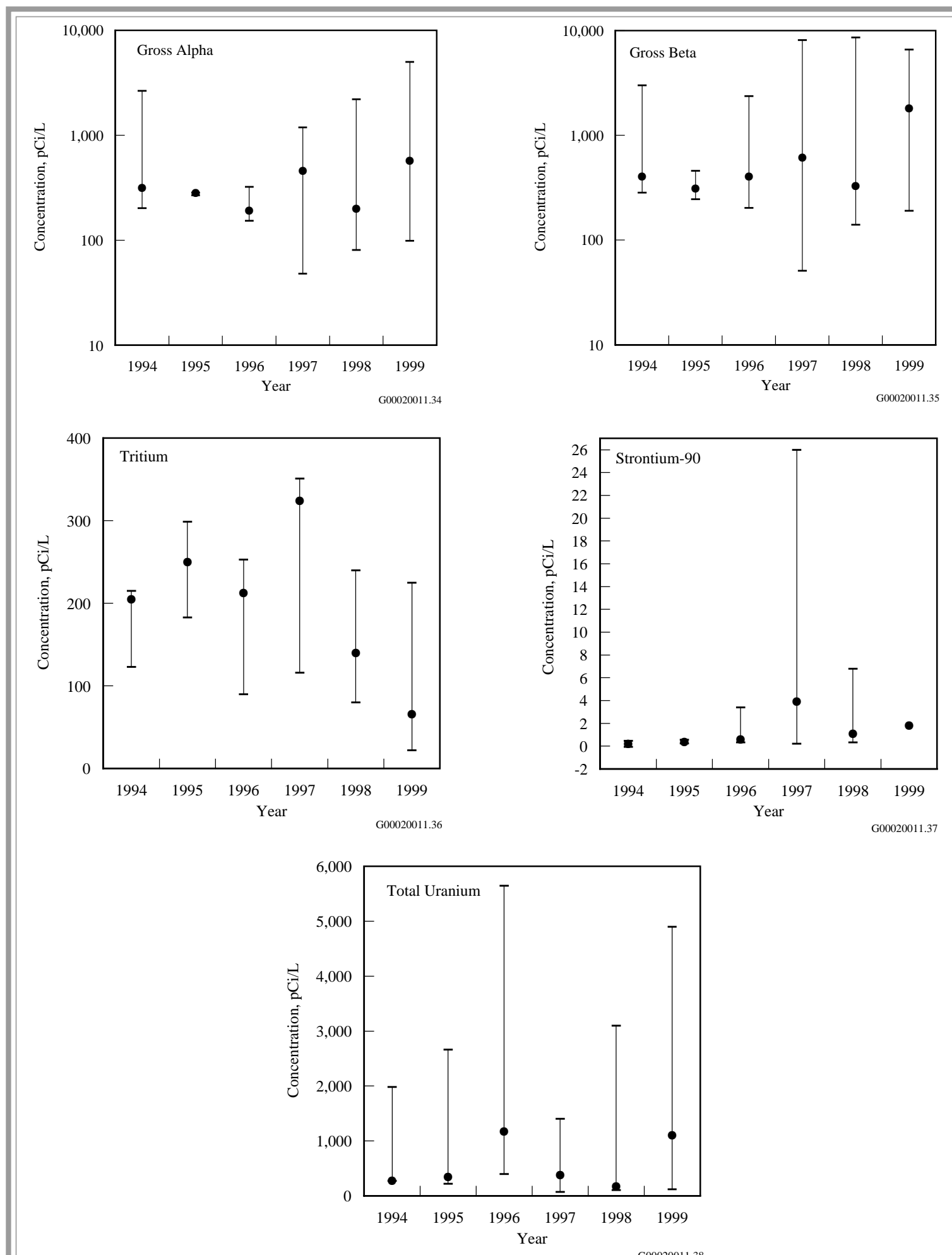

Figure 4.2.17. Median, Maximum, and Minimum Concentrations of Selected Radionuclides in West Lake Water Samples, 1994 Through 1999 


\subsubsection{Offsite Water}

During 1999, water samples were collected from an irrigation canal across the Columbia River and downstream from the Hanford Site that receives water pumped from the Columbia River near Pasco, Washington. As a result of public concern about the potential for Hanford-associated contaminants in offsite water, sampling was conducted to document the levels of radionuclides in water used by the public. Consumption of vegetation irrigated with Columbia River water downstream of the site has been identified as one of the primary pathways contributing to the potential dose to the hypothetical maximally exposed individual and any other member of the public (see Section 5.0, "Potential Radiological Doses from 1999 Hanford Operations").

\subsubsection{Collection, Analysis, and Results for Irrigation Canal Water}

Water in the Riverview irrigation canal was sampled three times in 1999 during the irrigation season. Unfiltered samples of the canal water were analyzed for gross alpha, gross beta, gamma emitters, tritium, strontium-90, and uranium-234, -235 , and -238. Results are presented in PNNL-13230, APP. 1. In 1999, radionuclide concentrations measured in this canal's water were at the same levels detected in the Columbia River. All radionuclide concentrations were below the DOE derived concentration guides and ambient surface-water quality criteria levels (DOEOrder 5400.5, WAC 173-201A, 40 CFR 141). The strontium-90 levels in the irrigation water during 1999 ranged from $0.051 \pm 0.032$ to 0.066 $\pm 0.029 \mathrm{pCi} / \mathrm{L}$ and were similar to those reported for the Columbia River at Priest Rapids Dam and the Richland Pumphouse (see Section 4.2.1, "Columbia River Water"). 


\title{
4.3 Radiological Surveillance of Hanford Site Drinking Water
}

\author{
R. W. H anf and L. M . K elly
}

The quality of drinking water at the Hanford Site is monitored by routinely collecting and analyzing drinking water samples and comparing the resulting analytical data with established drinking water standards and guidelines (WAC 246-290, 40 CFR 141, EPA-570/9-76-003, EPA 822-R-96-001, DOE Order 5400.5; see Appendix C, Tables C.2 and C.5). In 1999, radiological surveillance of drinking water supplied to Hanford Site facilities by DOE-owned pump and treatment facilities was conducted by Pacific Northwest National Laboratory for DynCorp Tri-Cities Services, Inc. Routine chemical and microbiological monitoring of these drinking water systems was conducted by DynCorp Tri-Cities Services, Inc.
The national primary drinking water regulations of the Safe D rinking W ater A ct apply to the drinking water supplies at the Hanford Site. In Washington State, these regulations are enforced by the Washington State Department of Health. Washington Administrative Code (WAC 246-290) requires that all drinking water analytical results be reported routinely to the Washington State Department of Health. In recent years, radiological results for the Hanford Site have been reported to the state through this annual environmental report and through an annual supplemental data compilation (PNNL-13230, APP. 1). Nonradiological data have been reported to the state by DynCorp Tri-Cities Services, Inc. but have not been published.

\subsubsection{Hanford Site Drinking Water Systems}

Drinking water was supplied to DOE facilities on the site by 12 DOE-owned, contractor-operated, water treatment and distribution systems (Table 4.3.1), and one system owned and operated by the city of Richland. Nine of these systems (including Richland's system) used water pumped from the Columbia River. Three systems used groundwater from beneath the site. In 1999, most of the systems were operated by DynCorp Tri-Cities Services, Inc.; however, Fluor Hanford operated two systems in the 400 and 100-K Areas, and Bechtel Hanford, Inc. operated one system in the 100-N Area that was supplied with water from a pumping station operated by DynCorp Tri-Cities Services, Inc. The city of Richland provided drinking water to the 300,700 , and Richland North Areas.

\subsubsection{Hanford Site Drinking Water Supply Facilities}

In 1999, radionuclide concentrations in onsite drinking water were monitored at the six DOEowned water supply facilities shown in Figure 4.3.1. The 100-B Area pumphouse continued to serve as the primary Columbia River pumping station for many areas on the site (100-N Area, 200-East and
200-West Areas, 251 Building, and 100 Areas Fire Station), with the 100-D Area pumphouse available as an emergency backup. Water for the 100-K Area was supplied by the 181-KE pumphouse. Water for the 200-East Area, which formerly came from the 283-E water treatment plant located in the 200-East 


\begin{tabular}{|c|c|c|}
\hline Table 4. & DOE-Owned Drinking Water & ems on the Hanford Site, 1999 \\
\hline Location/N umber & Source of Supply & Notes \\
\hline $100-\mathrm{D} / 001761$ & $\begin{array}{l}\text { Columbia River via } 181-\mathrm{B} \text { or } \\
\text { D raw water export }\end{array}$ & $\begin{array}{l}\text { Filtered and chlorinated at } 183-\mathrm{D} \text { Headhouse. } \\
\text { Operated by DynCorp Tri-Cities Services, Inc. }\end{array}$ \\
\hline $100-B / 04480 U$ & $\begin{array}{l}\text { Columbia River via } 181-B \text { or } \\
\text { D raw water export }\end{array}$ & $\begin{array}{l}\text { Filtered and chlorinated at } 182-\text { B Reservoir } \\
\text { Pumphouse. Operated by DynCorp Tri-Cities } \\
\text { Services, Inc. }\end{array}$ \\
\hline $100-K / 00177 \mathrm{~J}$ & $\begin{array}{l}\text { Columbia River via } \\
\text { 181-K Pumphouse }\end{array}$ & $\begin{array}{l}\text { Filtered and chlorinated at } 183-\text { KE Water Treat- } \\
\text { ment Plant. Operated by Fluor Hanford. }\end{array}$ \\
\hline $100-N / 418532$ & $\begin{array}{l}\text { Columbia River via } 181-B \text { or } \\
\text { D raw water export }\end{array}$ & $\begin{array}{l}\text { Filtered and chlorinated at } 183-\mathrm{N} \text { Water Treat- } \\
\text { ment Plant. Operated by Bechtel Hanford, Inc. }\end{array}$ \\
\hline $200-E / 41866 \mathrm{~V}$ & $\begin{array}{l}\text { Normally from the Columbia } \\
\text { River via the 283-W Water } \\
\text { Treatment Plant. In emergencies, } \\
\text { supplied via 181-B or D raw } \\
\text { water export and 283-E Water } \\
\text { Treatment Plant. }\end{array}$ & $\begin{array}{l}\text { Filtered and chlorinated at } 283-\text { W Water Treat- } \\
\text { ment Plant. The clearwells at } 283-E \text { serve as } \\
\text { reservoirs that supply the } 200 \text {-East Area distri- } \\
\text { bution system. Under normal conditions, the } \\
\text { clearwells are supplied from the } 283-\text { W Water } \\
\text { Treatment Plant. The } 283-\mathrm{E} \text { Water Treatment } \\
\text { Plant is maintained in standby mode for } \\
\text { emergencies. Operated by DynCorp Tri-Cities } \\
\text { Services, Inc. }\end{array}$ \\
\hline 200-W/001004 & $\begin{array}{l}\text { Columbia River via } 181-\mathrm{B} \text { or } \\
\text { D raw water export }\end{array}$ & $\begin{array}{l}\text { Filtered and chlorinated at } 283-\mathrm{W} \text { Water Treat- } \\
\text { ment Plant. Operated by DynCorp Tri-Cities } \\
\text { Services, Inc. }\end{array}$ \\
\hline $\begin{array}{l}251 \text { Building/001782 } \\
\text { (electrical switching) }\end{array}$ & $\begin{array}{l}\text { Columbia River via } 181-B \text { or } \\
\text { D raw water export }\end{array}$ & $\begin{array}{l}\text { Filtered and chlorinated at } 251 \text { Building. } \\
\text { Operated by DynCorp Tri-Cities Services, Inc. }\end{array}$ \\
\hline $\begin{array}{l}609 \text { Building/001806 } \\
\text { (100 Areas Fire Station) }\end{array}$ & $\begin{array}{l}\text { Columbia River via } 181-B \text { or } \\
\text { D raw water export }\end{array}$ & $\begin{array}{l}\text { Filtered and chlorinated at } 609 \text { Building. } \\
\text { Operated by DynCorp Tri-Cities Services, Inc. }\end{array}$ \\
\hline Yakima Barricade/001848 & Well 699-49-100C & $\begin{array}{l}\text { No treatment provided. Operated by DynCorp } \\
\text { Tri-Cities Services, Inc. }\end{array}$ \\
\hline $\begin{array}{l}\text { Patrol Training } \\
\text { Academy/00183Q }\end{array}$ & Well 699-S28-E0 & $\begin{array}{l}\text { Chlorination only. Operated by DynCorp } \\
\text { Tri-Cities Services, Inc. }\end{array}$ \\
\hline 400 Area/419470 & $\begin{array}{l}\text { Wells 499-S1-8J, 499-S0-8, } \\
\text { and 499-S0-7 }\end{array}$ & $\begin{array}{l}\text { Supplied from well 499-S1-8J (P-16); } \\
\text { well 499-S0-8 (P-14) is the emergency supply, } \\
\text { well 499-S0-7 (P-15) is the dire emergency } \\
\text { supply. Chlorination only. Operated by Fluor } \\
\text { Hanford. }\end{array}$ \\
\hline 300 Area/418408 & $\begin{array}{l}\text { Treated Columbia River water } \\
\text { via city of Richland }\end{array}$ & $\begin{array}{l}300 \text { Area distribution system. Operated by } \\
\text { DynCorp Tri-Cities Services, Inc. }\end{array}$ \\
\hline
\end{tabular}




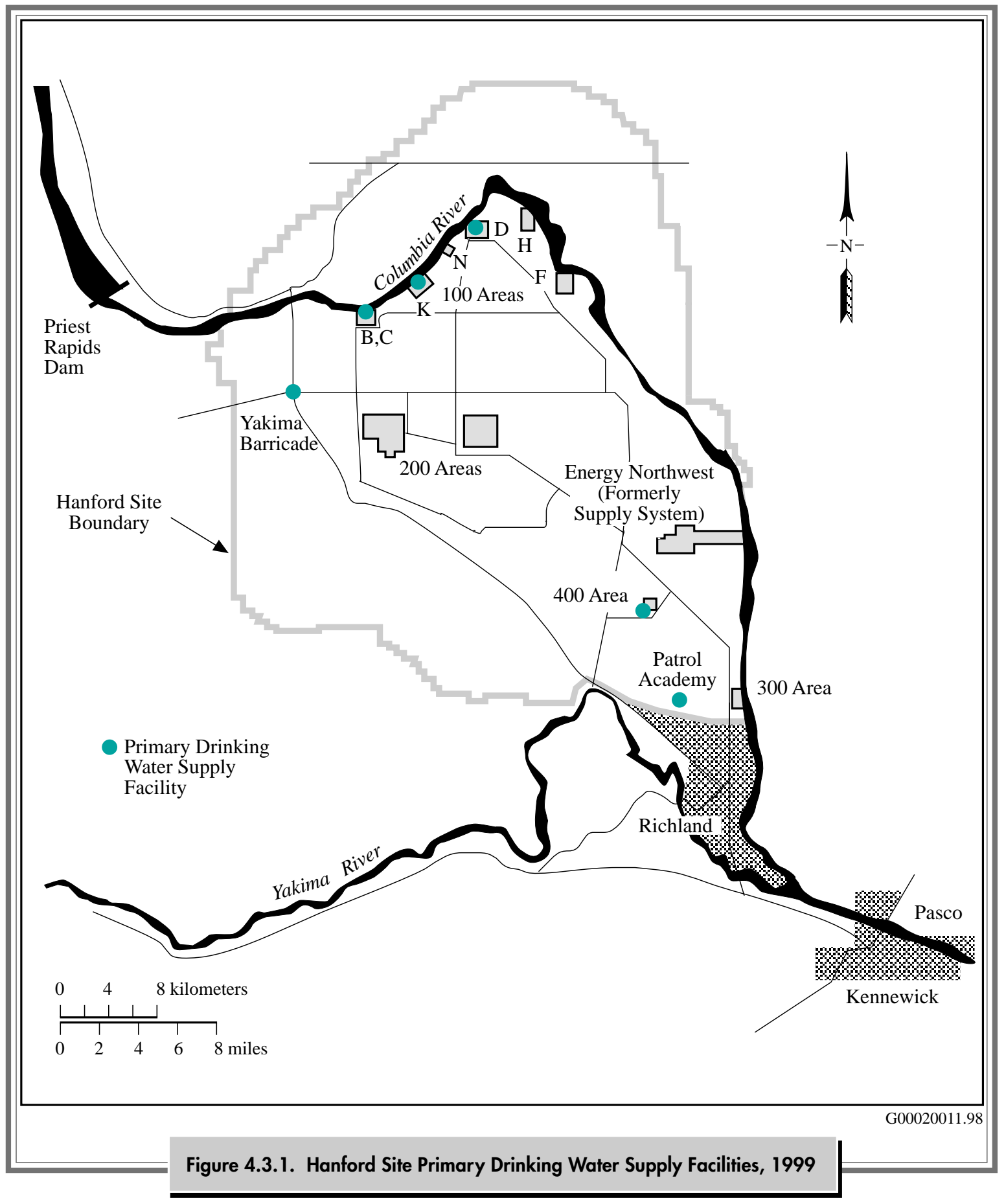


Area, was supplied by the $283-\mathrm{W}$ water treatment plant (located in the 200-West Area). The 283-E treatment plant was designated as an emergency supply facility in 1999 and was maintained in a standby mode. The Patrol Training Academy and 400 Area (Fast Flux Test Facility) obtained water from groundwater wells. However, only one sample was collected at the academy during 1999 because the academy's groundwater-supplied drinking water system was permanently shut down during the first quarter of the calendar year. The water system at the Yakima Barricade continued to operate in 1999 but was not used as a source of drinking water and was, therefore, not monitored for radiological contaminants. Water from this system was monitored for selected nonradiological contaminants by DynCorp Tri-Cities Services, Inc. The DOE-owned river water pump at 300 Area was removed from the drinking water system in late 1998 when the city of Richland began supplying drinking water to the area.
The 400 Area continued to use well 499-S1-8J (P-16) for drinking water, with well 499-S0-8 (P-14) serving as the emergency supply. Well 499. S1-8J is 122 meters (401 feet) deep and was installed in April 1985. Well 499-S0-8 is 90 meters (294 feet) deep and was installed in March 1972. Well 499. S0-8 supplied drinking water for a total of 35.6 hours in 1999 ( 1.5 hours in February, 5.2 hours in March, 12.1 hours in April, 15.7 hours in May, 1.1 hours in August) when well 499-S1-8J was offline. Well 499-S0-7 (P-15), 122 meters (399 feet) deep, was installed in March 1972 and continued to function as the dire emergency supply but was not used as a source of drinking water in 1999. In addition to supplying drinking water, these three wells were also important for maintaining fire suppression capabilities within the 400 Area.

\subsubsection{Collection of Drinking Water Samples and Analytes of Interest}

Drinking water samples for radiological analyses were collected according to a schedule established at the beginning of the calendar year (PNNL-12103). Samples at all of the locations were collected and analyzed quarterly. Samples from three locations were grab samples of untreated water. The 400 Area and Patrol Academy samples were grab samples of treated water. The Hanford Groundwater Monitoring Project also collected samples of raw well water from the 400 Area drinking water wells. These samples were analyzed monthly. Drinking water samples obtained from the 400 Area in April were cosampled with the Washington State Department of Health. The analytical results from the state's samples help to verify the quality of the drinking water data reported herein and in PNNL-13230, APP. 1.

In the 300 Area, water from the city of Richland's system was not monitored for radiological contaminants through the site drinking water surveillance project; however, personnel from Pacific Northwest National Laboratory's Surface Environmental Surveillance Project routinely collected water samples from the Columbia River at the Richland Pumphouse, which is the city of Richland's drinking water intake. The analytical results (radiological) for these raw river water samples can be found in Appendix A (Table A.2). Sampling of 300 Area drinking water for nonradiological analyses was routinely conducted by DynCorp Tri-Cities Services, Inc. to monitor the DOE-owned, contractor operated water distribution system within the area. However, as stated earlier, nonradiological data are reported directly to the state and are not discussed in this report.

All 1999 drinking water samples collected for radiological analysis were analyzed for gross alpha, gross beta, tritium, and strontium-90. 


\subsubsection{Radiological Results for Hanford Site Drinking Water}

Results for radiological monitoring of Hanford Site drinking water during 1999 are summarized in Table 4.3.2. The maximum amount of beta-gamma radiation from man-made radionuclides allowed in drinking water by Washington State and the EPA is an annual average concentration that will not produce an annual dose equivalent to the whole body or any internal organ greater than $4 \mathrm{mrem} / \mathrm{yr}$. If both tritium and strontium- 90 are present, the sum of their annual dose equivalent to bone marrow must not exceed 4 mrem. Compliance with this standard may be assumed if the annual average concentrations for gross alpha, gross beta, tritium, and strontium-90 are less than 50,15, 20,000, and $8 \mathrm{pCi} / \mathrm{L}$, respectively (40 CFR 141 and WAC 246-290). All DOE-owned drinking water systems on the Hanford Site were in compliance with Washington State and EPA annual average radiological drinking water standards in 1999, and results were similar to those observed in recent years (see Section 4.3 in PNNL-11795 and PNNL-12088).

The Hanford Groundwater Monitoring Project collected and analyzed raw water samples monthly from all three 400 Area drinking water wells. Results from these samples show that tritium levels continued to be lowest in well 499-S0-8J and consistently highest in well 499-S0-7. Tritium levels were also elevated (greater than $33,000 \mathrm{pCi} / \mathrm{L}$ ) in well 499-S0-8 from April through August (Table 4.3.3, Figure 4.3.2).

\begin{tabular}{|c|c|c|c|c|c|}
\hline \multirow[b]{2}{*}{ System } & \multicolumn{5}{|c|}{$\begin{array}{l}\text { 3.2. Selected Radiological Constituents in Hanford Site Drinking Water, } \\
1999 \text { Annual Average Concentrations }(\mathrm{pCi} / \mathrm{L})^{(\mathrm{a})}\end{array}$} \\
\hline & $\begin{array}{c}\text { No. of } \\
\text { Samples }^{(b)}\end{array}$ & Gross Alpha & Gross B eta & Tritium & Strontium-90 \\
\hline 100-B Area & $3^{(\mathrm{c}, \mathrm{d})}$ & $0.49 \pm 0.67$ & $0.04 \pm 1.14$ & $122 \pm 81$ & $0.08 \pm 0.01$ \\
\hline 100-D Area & $3^{(\mathrm{c}, \mathrm{d})}$ & $0.40 \pm 0.13$ & $0.61 \pm 0.87$ & $132 \pm 134$ & $0.07 \pm 0.01$ \\
\hline 100-K Area & $4^{(c)}$ & $0.34 \pm 0.32$ & $1.01 \pm 0.80$ & $70 \pm 48$ & $0.05 \pm 0.02$ \\
\hline 400 Area $(\text { FFTF })^{(e)}$ & 4 & $0.62 \pm 0.90$ & $6.64 \pm 0.74$ & $4,275 \pm 253$ & $-0.01 \pm 0.01$ \\
\hline Patrol Academy & $1^{(f)}$ & $3.18 \pm 1.3$ & $4.74 \pm 2.3$ & $-11.3 \pm 140$ & $-0.04 \pm 0.06$ \\
\hline Standards & & $15^{(\mathrm{g}, \mathrm{h})}$ & $50^{(\mathrm{h}, \mathrm{i})}$ & $20,000^{(\mathrm{h}, \mathrm{j})}$ & $8^{(\mathrm{g}, \mathrm{h})}$ \\
\hline \multicolumn{6}{|c|}{$\begin{array}{l}\text { (a) Average value } \pm 2 \text { standard error of the calculated mean. } \\
\text { (b) Grab samples collected and analyzed quarterly. } \\
\text { (c) Untreated raw water. } \\
\text { (d) No sample collected in first quarter of calendar year. } \\
\text { (e) FFTF = Fast Flux Test Facility; samples collected at the tap. } \\
\text { (f) Result } \pm \text { total analytical error. } \\
\text { (g) WAC } 246-290 \text {. } \\
\text { (h) } 40 \text { CFR } 141 . \\
\text { (i) Equivalent to } 4 \text { mrem/yr standard. } \\
\text { (j) Concentration assumed to yield an annual dose of } 4 \mathrm{mrem} / \mathrm{yr} \text {. }\end{array}$} \\
\hline
\end{tabular}




\begin{tabular}{|c|c|c|c|}
\hline Sampling Date & $\begin{array}{l}\text { Primary Drinking Water } \\
\text { Well 499-S1-8] (P-16) }\end{array}$ & $\begin{array}{c}\text { Emergency Drinking Water } \\
\text { Well 499-S0-8 (P-14) }\end{array}$ & $\begin{array}{c}\text { Dire Emergency Drinking Water } \\
\text { Well 499-S0-7 (P-15) }\end{array}$ \\
\hline January 12, 1999 & $4,210 \pm 485$ & $4,790 \pm 527$ & $16,700 \pm 1,390$ \\
\hline February 11, 1999 & $4,380 \pm 493$ & $4,640 \pm 513$ & $20,200 \pm 1,640$ \\
\hline April 1, 1999 & $4,260 \pm 495$ & $4,540 \pm 514$ & $18,000 \pm 1,490$ \\
\hline April 13, 1999 & $4,150 \pm 470$ & $18,900 \pm 1,160$ & $18,000 \pm 1,120$ \\
\hline May 7, 1999 & $3,990 \pm 458$ & $24,300 \pm 1,390$ & $15,100 \pm 990$ \\
\hline June 4, 1999 & $4,250 \pm 460$ & $30,900 \pm 1,650$ & $17,000 \pm 1,050$ \\
\hline July 16, 1999 & $4,370 \pm 460$ & $33,500 \pm 1,800$ & $16,600 \pm 1,000$ \\
\hline August 18, 1999 & $4,150 \pm 460$ & $33,800 \pm 1,800$ & $17,500 \pm 1,100$ \\
\hline September 10, 1999 & $4,050 \pm 450$ & $3,970 \pm 450$ & $16,800 \pm 1,000$ \\
\hline October 25, 1999 & $3,760 \pm 430$ & $4,050 \pm 450$ & $16,300 \pm 1,000$ \\
\hline November 19, 1999 & $3,820 \pm 450$ & $3,960 \pm 460$ & $16,500 \pm 1,100$ \\
\hline December 21, 1999 & $3,960 \pm 450$ & $4,020 \pm 460$ & $20,600 \pm 1,200$ \\
\hline
\end{tabular}



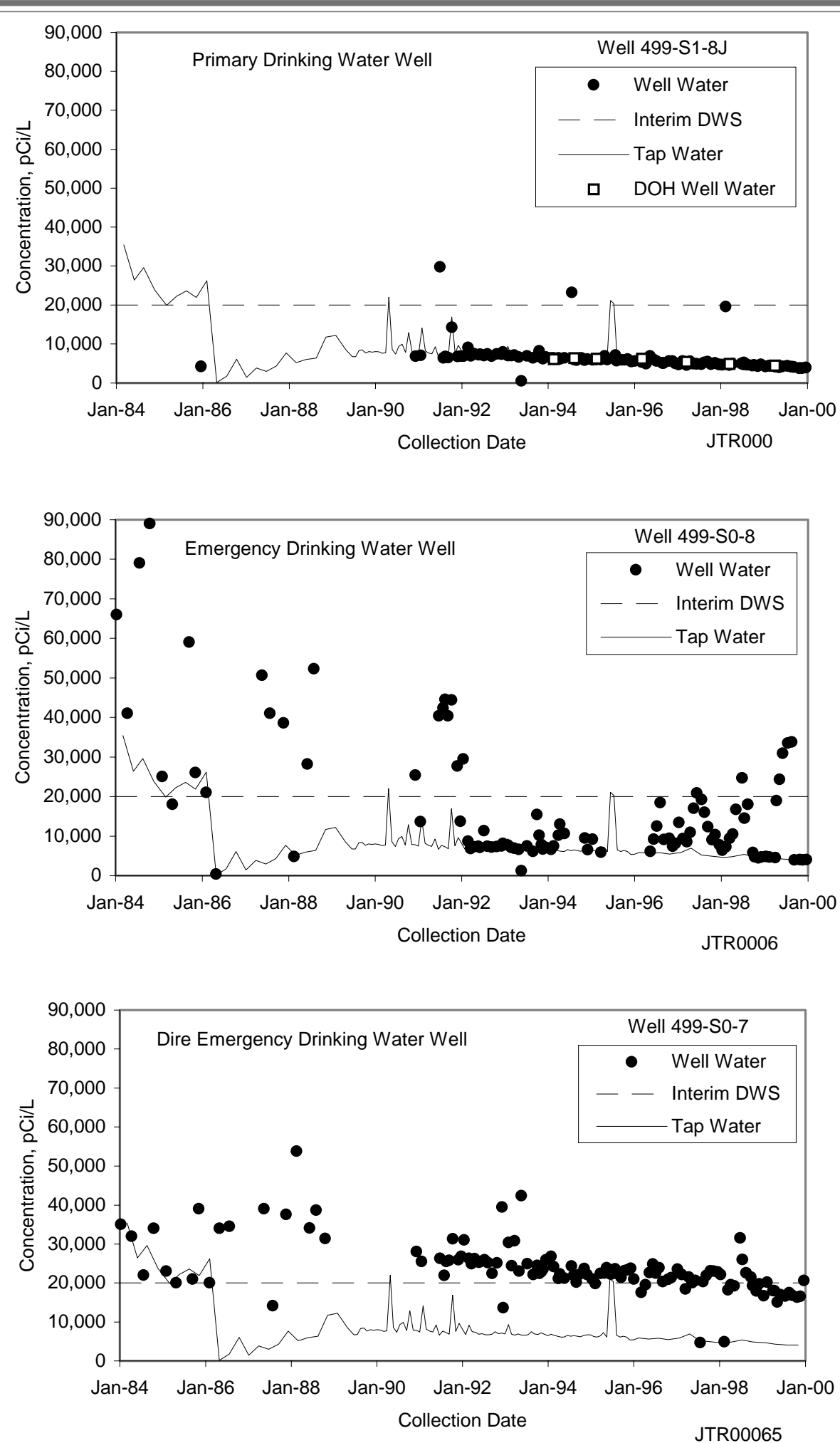

Figure 4.3.2. Tritium Concentrations in Drinking Water from Three Wells in the 400 Area, 1984 Through 1999 (DOH = Washington State Department of Health, DWS = drinking water standard) 


\title{
4.4 Food and Farm Product Surveillance
}

\author{
B. L. Tiller
}

Foodstuffs, including milk, vegetables, fruits, and wine, were collected in 1999 at several locations surrounding the Hanford Site (Figure 4.4.1). Samples were collected primarily from locations in the prevailing downwind directions (south and east of the site) where airborne effluents or fugitive dust from the Hanford Site could be deposited. Samples were also collected in generally upwind directions and at locations somewhat distant from the site to provide information on background radioactivity.

The food and farm product sampling addresses the potential influence of Hanford Site releases in two ways:

- by comparing results from several downwind locations to those from generally upwind or distant locations

- by comparing results from locations irrigated with Columbia River water withdrawn downstream from the Hanford Site to results from locations irrigated with water from other sources.

In 1996, the food and farm product sampling schedule was modified by establishing a 2- or 3-year rotation for certain farm products. Additionally, analyses for specific radionuclides that historically have not been detected in a food or farm product were discontinued. These changes were adopted because of the emphasis on cleanup of the site. Specific details of the 1999 food and farm product sampling, including sampling locations and radionuclides analyzed, are reported in DOE/RL-91-50, Rev. 2 and PNNL-12103, and are summarized in Table 4.4.1.
Gamma scans (cobalt-60, cesium-137, and other radionuclides; see Appendix E) and strontium-90 analyses were performed routinely for nearly all products. Additionally, milk was analyzed for iodine-129 and tritium; wine was analyzed for tritium. Results for fruits and vegetables are reported in picocuries per gram wet weight. Results for tritium are reported in picocuries per liter of liquid distilled from milk and wine. Most tritium is found as water, and very little tritium is organically bound to other constituents present in food products.

Tritium and iodine-129 from site facilities are released to the atmosphere and to the Columbia River via riverbank springs. Strontium-90 from Hanford is released to the Columbia River through riverbank springs. Cesium-137 is present in atmospheric fallout from weapons testing and is found in Hanford Site radiological waste.

For many radionuclides, concentrations are below levels that can be detected by the analytical laboratory. When this occurs for an entire group of samples, a nominal detection limit is estimated by using two times the total propagated analytical uncertainty (2 sigma). This value from a group of samples is used as an estimate of the lower level of detection for that analyte and particular food product. The total propagated analytical uncertainty includes all sources of analytical error associated with the analysis (e.g., counting errors and errors associated with weight and volumetric measurements). Theoretically, re-analysis of the sample should yield a result that falls within the range of the uncertainty $95 \%$ of the time. Results and uncertainties not given in this report may be found in PNNL-13230, APP. 1. 


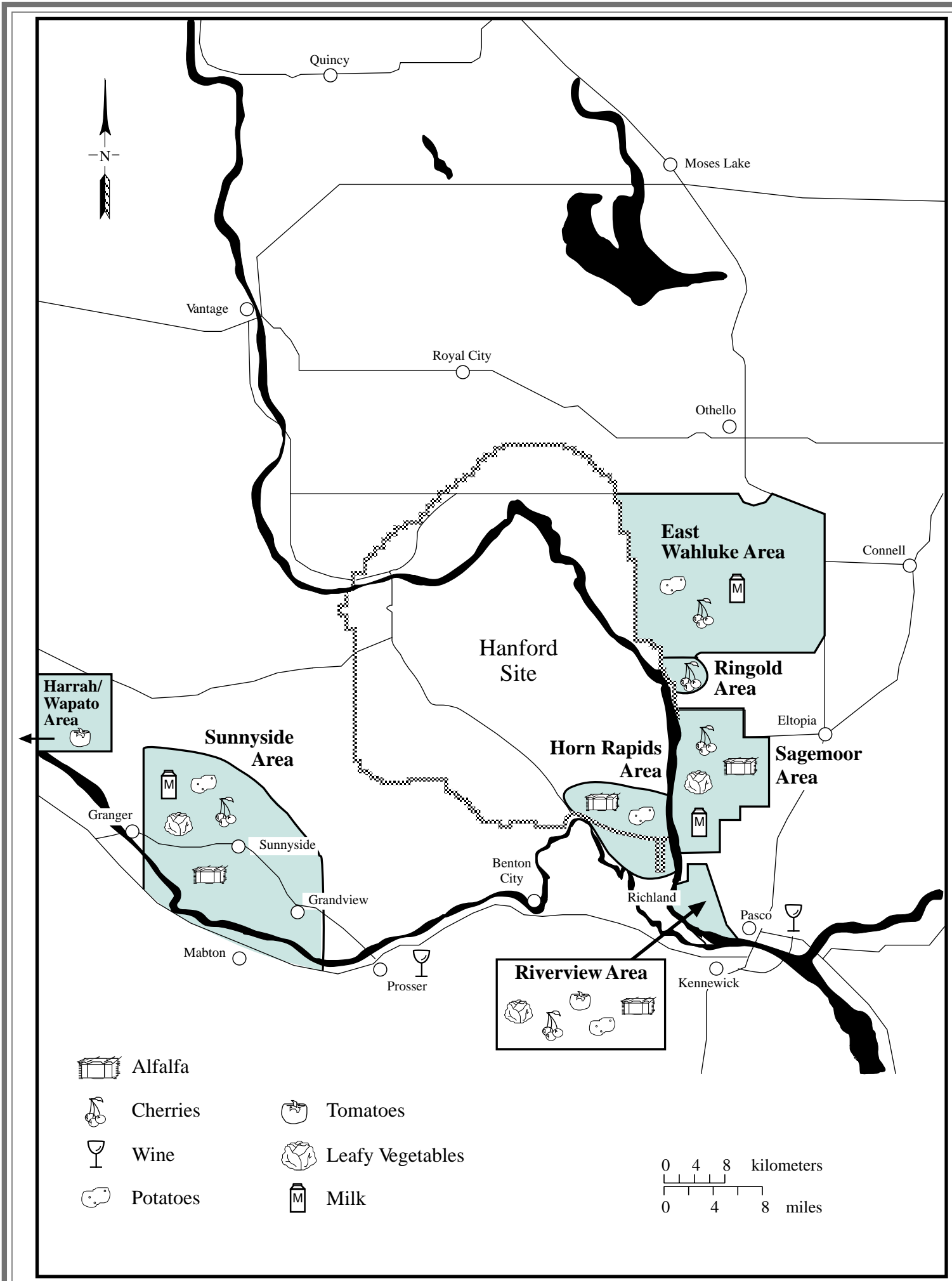

G00020011.3

Figure 4.4.1. Food and Farm Product Sampling Locations, 1999 
Table 4.4.1. Locations, Sampling Frequencies, and Analyses Performed for Routinely Sampled Food and Farm Products, 1999(a)

\section{Number of Locations}

\section{Product \\ Upwind Downwind}

Milk

Dairy water

Vegetables

Fruit

Wine

$\begin{array}{ll}1 & 2 \\ 1 & 2 \\ 1 & 2 \\ 2 & 2 \\ 2 & 2\end{array}$

Sampling Frequency
(b)
Q or SA
Q
A
A
A

\section{Number of Locations Analyzed}

$\begin{array}{cccc}{ }^{3} \underline{\mathbf{H}} & \text { Gamma } & { }^{\mathbf{9 0}} \underline{\mathbf{r}} & { }^{\mathbf{1 2 9}} \underline{\mathbf{I}} \\ 5 & 5 & 5 & 5 \\ 5 & 5 & 0 & 0 \\ 0 & 4 & 4 & 0 \\ 0 & 4 & 4 & 0 \\ 4 & 4 & 0 & 0\end{array}$

(a) Products may include multiple varieties for each category.

(b) $\mathrm{Q}=$ quarterly, $\mathrm{SA}=$ semiannually, $\mathrm{A}$ = annually.

\subsubsection{Milk Samples and Analytes of Interest}

Composite samples of raw, whole milk were collected in 1999 from three dairy farms in the East Wahluke Area and two Sagemoor Area dairy farms. These sampling areas are located near the site perimeter in the prevailing downwind direction (see Figure 4.4.1). Milk samples were also collected from a Sunnyside Area dairy to indicate background radionuclide activities at a generally upwind location.

Samples of milk were analyzed for tritium, strontium-90, iodine-129, and gamma emitters such as cesium-137 because these radionuclides have the potential to move through the air-pasture-cow milk or water-pasture-cow milk food chains to humans. Fallout radionuclides in feed and/or drinking water may be a significant source of radioactivity in milk products; however, measured levels of radionuclides in milk are usually near levels considered to be background. Gamma scans and strontium-90 analyses were conducted quarterly, and iodine-129 analyses were conducted on two semiannual composite samples. Tritium analyses were discontinued in 1995 because tritium activities had dropped below the detection level of standard liquid scintillation counting methods. In 1998, an electrolytic enrichment technique (DOE/RL-91-50, Rev. 2) for measuring tritium in milk samples was instituted. The electrolytic enrichment technique has a detection limit of $\sim 10 \mathrm{pCi} / \mathrm{L}$ of water distilled from milk as compared to $\sim 180 \mathrm{pCi} / \mathrm{L}$ for the analytical technique used prior to 1996. Milk samples were not analyzed for tritium in 1996 and 1997.

Strontium-90 was detected in only 1 of 12 (8\%) milk samples analyzed in 1999 . The one positive result $(0.51 \mathrm{pCi} / \mathrm{L})$ was collected near Sunnyside, Washington, and is close to the analytical detection limit $(0.35 \mathrm{pCi} / \mathrm{L})$. Results near or below detection are consistent with results observed during the past decade. Median, maximum, and minimum concentrations for samples collected from 1994 through 1999 are shown in Figure 4.4.2. While there is no strontium-90 standard for milk, the drinking water standard (based on a 2-liter per day consumption) is $8 \mathrm{pCi} / \mathrm{L}$ (40 CFR 141). The maximum milk consumption rate for estimating dose is $\sim 0.75$ liter per day (see Appendix D, Table D.2).

Iodine-129 was quantified for analyses by highresolution mass spectrometry in six milk samples. In recent years, the levels of iodine-129 in milk collected from generally downwind dairies in the Sagemoor and East Wahluke Areas have persisted at 


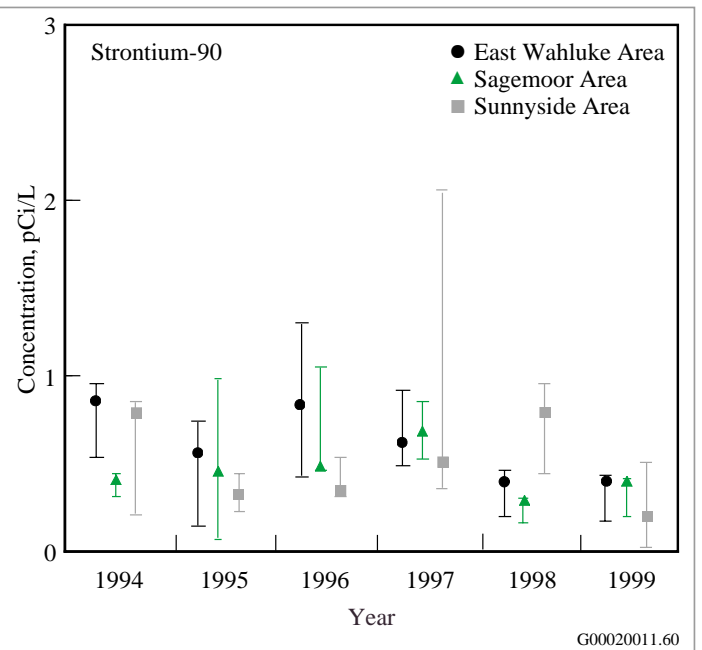

Figure 4.4.2. Median, Maximum, and Minimum Strontium-90 Concentrations in Milk, 1994 Through 1999

levels two to four times greater than levels measured upwind in Sunnyside (Figure 4.4.3). Iodine-129 concentrations have declined with the end of nuclear production on the site and contribute less than $1 \%$ of the dose to the maximally exposed individual through the consumption of dairy products (see Section 5.0, "Potential Radiological Doses from 1999 Hanford Operations"). While there is no iodine-129 standard for milk, the drinking water standard is $1 \mathrm{pCi} / \mathrm{L}$ (EPA570/9-76-003). No other man-made gamma emitters (including cesium-137) were detectable in 1999 milk samples (PNNL-13230, APP. 1).

Tritium was analyzed by an electrolytic enrichment method in quarterly composite milk samples from the Wahluke, Sagemoor, and Sunnyside Areas (see Figure 4.4.1) in 1999. The results indicate Sagemoor dairies have higher tritium concentrations as compared to both Sunnyside and the Wahluke Areas (Figure 4.4.4). As seen in previous years, the tritium concentration in the first quarter sample was lower than the concentrations in the summer and fall sampling periods. In previous years, Sagemoor Area results were consistently higher than results for both the Wahluke and Sunnyside Areas.

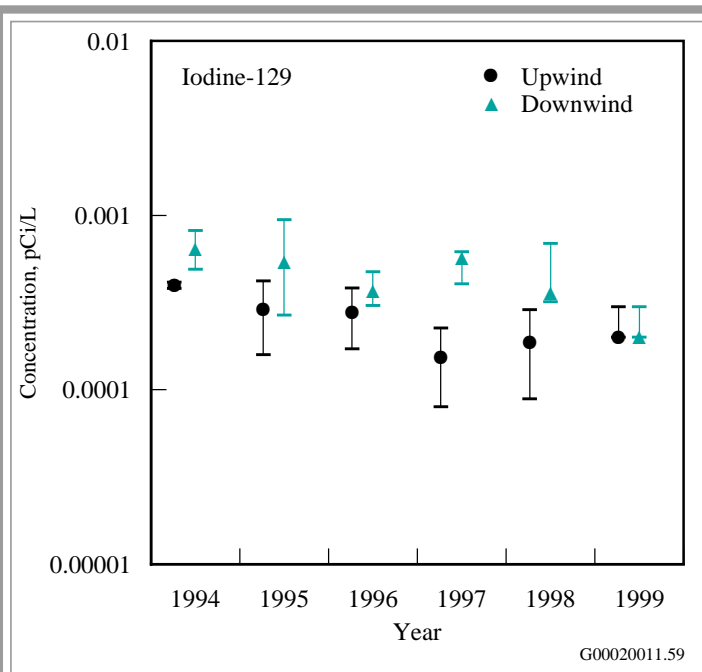

Figure 4.4.3. Median, Maximum, and Minimum lodine-129 Concentrations in Milk, 1994 Through 1999

A plausible explanation for this difference may be the drinking water provided to cows at the participating dairies. The dairies in all three areas use well water. The Franklin County aquifers used by the dairies in the Sagemoor and Wahluke Areas have historically been recharged by Columbia River water brought into the areas by the Columbia Basin Irrigation Project. Water for the Columbia Basin Irrigation Project is obtained from the Columbia River upstream of the Grand Coulee Dam. Background tritium levels in Columbia River water in the 1960s ranged from 800 to $5,540 \mathrm{pCi} / \mathrm{L}$. These concentrations were influenced by fallout from world-wide aboveground nuclear weapons testing (Wyerman et al. 1970). Irrigation water from the Columbia River containing these comparatively high tritium levels entered the groundwater aquifers in Franklin County as a result of overapplication and leaking canals. This water remains in the aquifers that provide water for the dairies in Franklin County, particularly those located in low elevation areas. Over the past 30 years, tritium levels have slowly decreased as a result of radiological decay and possible dilution caused by subsequent recharge with less-contaminated irrigation water. Based on a 12.3-year half-life, if we assume an aquifer having 


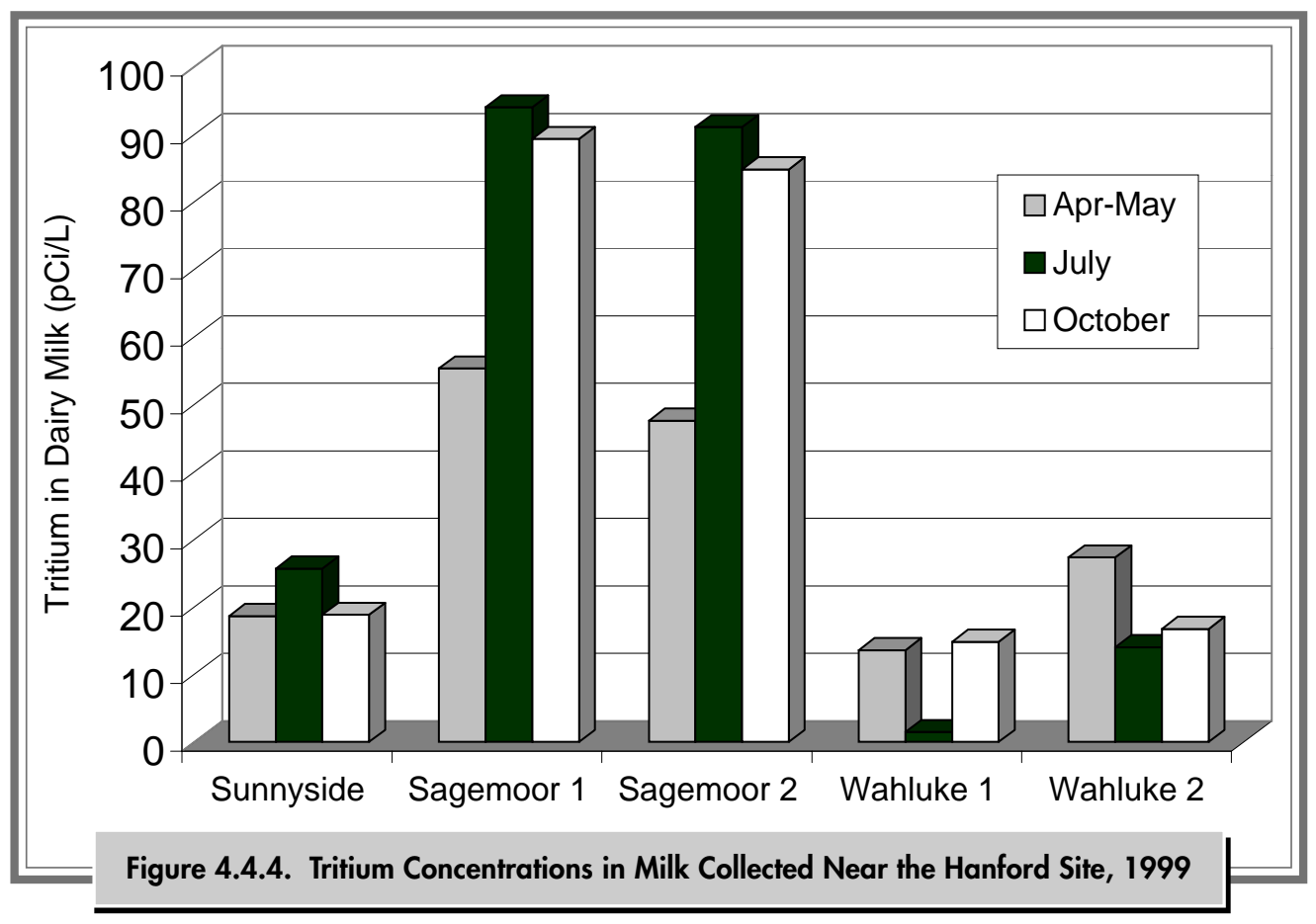

a concentration of $1,000 \mathrm{pCi} / \mathrm{L}$ in 1963 (assumes some dilution with natural groundwater), the estimated level after three half-lives in 1999 would be $115 \mathrm{pCi} / \mathrm{L}$.

To help address this question, well water samples were collected in conjunction with the milk samples in 1999. Figure 4.4.5 illustrates a regression analysis of tritium concentrations in dairy water and the corresponding concentrations found in the dairy milk. The ability to predict a tritium concentration in the dairy milk from a known tritium concentration in the dairy water is almost 1 to $1\left(\mathrm{r}^{2}=0.83\right)$.
One well water result from a sample collected in the Wahluke Area in May 1999 was not consistent with this water/milk correlation and may have been the result of analytical error. Information is being gathered on past irrigation practices in the Columbia Basin and the lower Yakima Valley. While the relationships between tritium in milk and groundwater used by the dairies are interesting, the actual levels of tritium in milk make a minor contribution to the dose of those who consume milk (see Section 5.0, "Potential Radiological Doses from 1999 Hanford Operations").

\subsubsection{Vegetable Samples and Analytes of Interest}

Samples of leafy vegetables (i.e., swiss chard and spinach) and vegetables (i.e., tomatoes, asparagus, cucumbers, and potatoes) were obtained during the summer from gardens and farms located within selected sampling areas (see Figure 4.4.1). Leafy vegetables were sampled to monitor for the potential deposition of airborne contaminants. The Riverview Area was sampled because of its exposure to potentially contaminated irrigation water withdrawn from the Columbia River downstream of the Hanford Site. All vegetable samples were analyzed for gamma-emitting radionuclides and strontium-90.

Measurements of gamma emitters in vegetable and leafy vegetable samples were all less than their respective detection limit $(0.02 \mathrm{pCi} / \mathrm{g})$ and were 


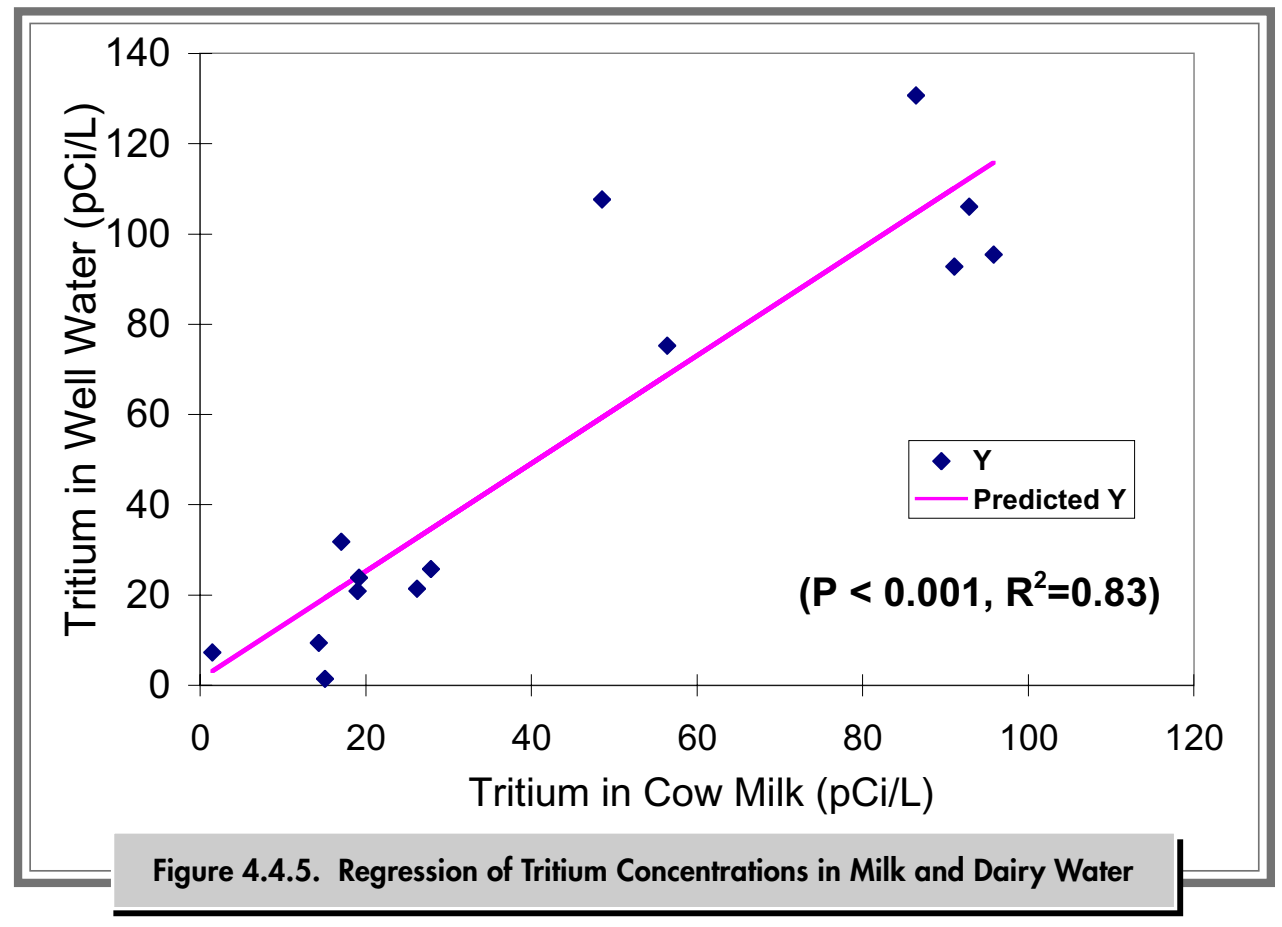

consistent with results seen in recent years (PNNL13230, APP. 1). Strontium-90 was detected in two leafy vegetable samples. The Riverview Area sample $(0.152 \pm 0.04 \mathrm{pCi} / \mathrm{g}$ wet wt. $)$ had approximately seven times the level of the Sagemoor Area sample (0.02 \pm
$0.006 \mathrm{pCi} / \mathrm{g}$ wet wt.). However, a duplicate Riverview Area sample was submitted for re-analyses and the result was below the analytical detection limit (0.05 pCi/g wet wt.). The Sunnyside Area sample fell below the analytical detection limit $(0.035 \mathrm{pCi} / \mathrm{g})$.

\subsubsection{Fruit Samples and Analytes of Interest}

Cherries were collected during harvest from the areas shown in Figure 4.4.1. All cherry samples were analyzed for gamma-emitting radionuclides and strontium-90. Measurable levels of cesium-137, strontium-90, and other man-made gamma-emitting radionuclides were not detected in cherries in 1999.

\subsubsection{Alfalfa}

Alfalfa samples were collected during harvest from the areas shown in Figure 4.4.1. All samples were analyzed for gamma-emitting radionuclides and strontium-90. Measurable levels of cesium-137 and other man-made gamma-emitting radionuclides were not detected in alfalfa in 1999. The nominal
These results are consistent with measurements in grapes, apples, and melons over recent years (PNL10575, PNNL-11140, PNNL-11473, PNNL-11796, PNNL-12088). The nominal level of detection for cesium-137 was $0.01 \mathrm{pCi} / \mathrm{g}$ wet weight.

level of detection for cesium-137 in alfalfa was $0.02 \mathrm{pCi} / \mathrm{g}$ dry wt. Strontium-90 was found above the analytical detection limit ( $0.07 \mathrm{pCi} / \mathrm{g}$ dry wt.) in three of the four samples submitted for analysis in 1999. The highest concentration $(0.92 \mathrm{pCi} / \mathrm{g}$ dry wt.) was seen in a sample from the Horn Rapids 
Area; however, a duplicate analyses of the same batch of alfalfa yielded a concentration of $0.1 \mathrm{pCi} / \mathrm{g}$ dry wt. These results were consistent with measurements in alfalfa over the past 5 years (PNL10575, PNNL-11140, PNNL-11473, PNNL-11796, PNNL-12088).

\subsubsection{Wine Samples and Analytes of Interest}

Locally produced red and white wines (1999 vintage grapes) were analyzed for gamma-emitting radionuclides and tritium. The wines were made from grapes grown at individual vineyards downwind of the site and at an upwind location in the lower Yakima Valley. Two samples each of red and white wines were obtained from each location and analyzed. An electrolytic enrichment method was used for tritium analysis in water distilled from the wine.

Tritium levels in 1999 wine samples were consistent with past results. Tritium concentrations were higher in Columbia Basin wines when compared to Yakima Valley wines (Figure 4.4.6). Red wine from the Columbia Basin contained nearly twice $(79.4 \pm 2.4 \mathrm{pCi} / \mathrm{L})$ the tritium concentration found in white wine $(38.8 \pm 1.2 \mathrm{pCi} / \mathrm{L})$ from the same region. Gamma spectroscopy did not indicate the presence of cesium-137 or any other man-made radionuclide in any of the 1999 wine samples. The observed differences between wines and/or regions are likely related to the water sources as discussed with tritium in milk (see Section 4.4.1, "Milk Samples and Analytes of Interest").

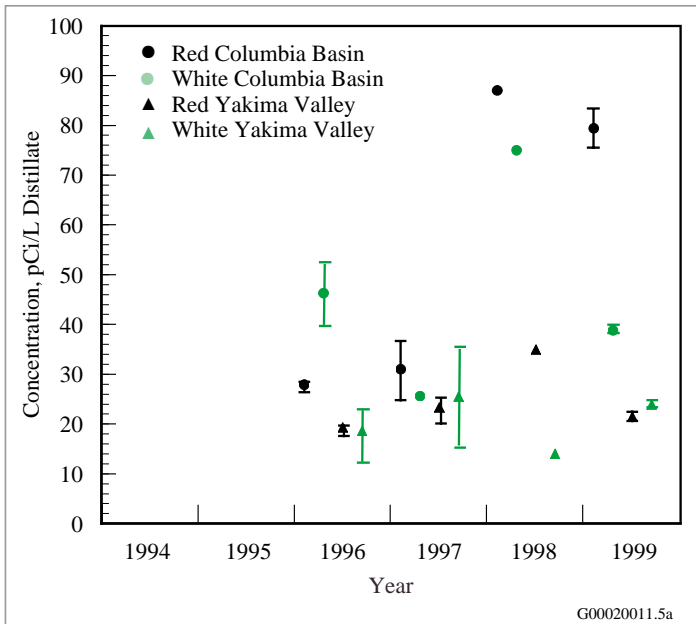

Figure 4.4.6. Median, Maximum, and Minimum Tritium Concentrations in Wine Samples Collected in 1994 Through 1999 (1998 results from Washington State Department of Health) 


\title{
4.5 Fish and Wildlife Surveillance
}

\author{
B. L. Tiller
}

Contaminants in fish and wildlife that inhabit the Columbia River and Hanford Site are monitored for several reasons. Wildlife have access to areas of the site containing radioactive or chemical contamination, and fish can be exposed to contamination entering the river along the shoreline. Fish and some wildlife species exposed to Hanford contaminants might be harvested for food and may potentially contribute to offsite public exposure. In addition, detection of contaminants in wildlife may indicate that wildlife are entering contaminated areas (e.g., burrowing in waste burial grounds) or that materials are moving out of contaminated areas (e.g., through blowing dust or food-chain transport). Consequently, fish and wildlife samples are collected at selected locations annually (Figure 4.5.1). More detailed rationale for the selection of specific species sampled in 1999 can be found in DOE/RL-91-50, Rev. 2.

Routine background sampling is conducted approximately every 5 years at locations believed to be unaffected by Hanford releases. Additional background data also may be collected during special studies.

As a result of changing operations on the Hanford Site, the frequency of fish and wildlife sampling was modified significantly in 1995. Species that had been collected annually were placed on a rotating schedule so that surveillance of all key species would be accomplished over a 3 -year period. Factors supporting these changes included the elimination of many onsite radiological sources and a decrease in environmental concentrations of radionuclides of interest. Additionally, several radionuclides that were monitored in the past had not been detected in recent wildlife samples because they were no longer present in the environment in sufficient amounts to accumulate in wildlife or they did not accumulate in fish or wildlife tissues of interest.

For each species of fish or wildlife, radionuclides are selected for analysis based on the potential for the contaminant to be found at the sampling site and to accumulate in the organism (Table 4.5.1). At the Hanford Site, strontium-90 and cesium-137 have been historically the most frequently measured radionuclides in fish and wildlife.

Strontium-90 is chemically similar to calcium; consequently, it accumulates in hard tissues rich in calcium such as bone, antlers, and eggshells. Strontium-90 has a biological half-life in hard tissue of 14 to 600 days. Hard-tissue concentrations may profile an organism's lifetime exposure to strontium90. However, strontium-90 generally does not contribute much to human dose because it does not accumulate in edible portions of fish and wildlife. Spring water in the 100-N Area is the primary source of strontium-90 from Hanford to the Columbia River; however, the current contribution relative to historical fallout from atmospheric weapons testing is small (less than 2\%) (PNL-8817).

Cesium-137 is particularly important because it is chemically similar to potassium and is found in the muscle tissue of fish and wildlife. Having a relatively short biological half-life (less than 200 days in muscle; less than 20 days in the gastrointestinal tract), cesium-137 is an indicator of more recent exposure to radioactive materials and is also a major constituent of historical fallout.

Fish and wildlife samples were analyzed by gamma spectrometry to detect a number of gamma emitters (see Appendix E). However, gamma spectrometry results for most radionuclides are not discussed here because levels were too low to measure or measured 


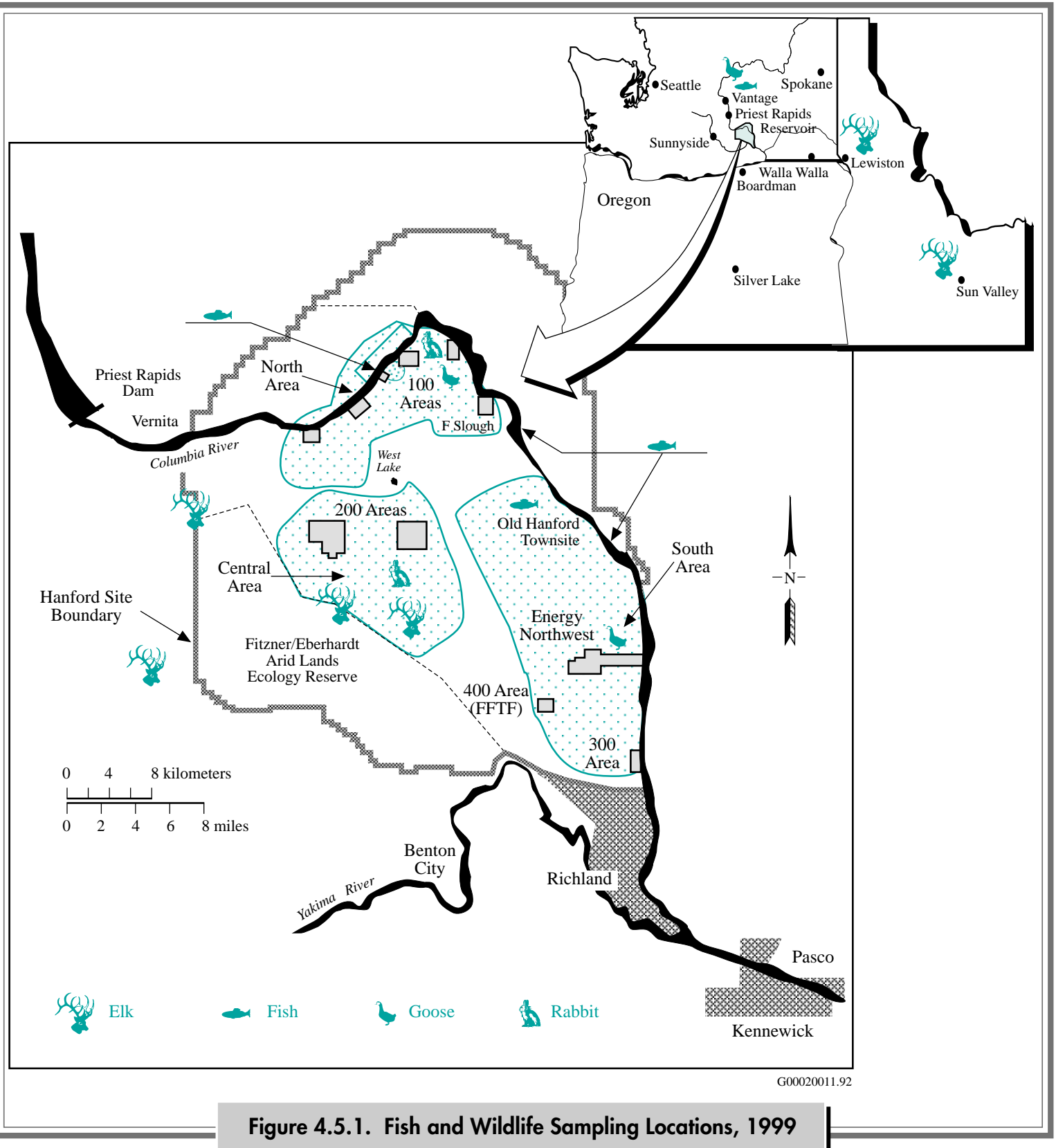

concentrations were considered artifacts of lowbackground counts. Low-background counts occur at random intervals during sample counting and can produce occasional spurious false-positive results.

For many radionuclides, concentrations are below levels that can be detected by the analytical laboratory. When this occurs for an entire group of samples, two times the total propagated analytical uncertainty is used as an estimate of the nominal detection level for that analyte and particular medium. Results and propagated uncertainties for all results may be found in PNNL-13230, APP. 1.

Wet-weight analytical detection levels for cesium-137 in muscle and strontium-90 in bone/ carcass tissues were $0.04 \mathrm{pCi} / \mathrm{g}$ and $0.01 \mathrm{pCi} / \mathrm{g}$, respectively. 


\begin{tabular}{|c|c|c|c|c|c|}
\hline & \multicolumn{5}{|c|}{$\begin{array}{l}\text { Table 4.5.1. Locations, Species, and Contaminants Sampled for Fish and } \\
\text { Wildlife, } 1999\end{array}$} \\
\hline & \multirow[b]{2}{*}{ Biota } & \multirow{2}{*}{$\begin{array}{l}\text { No. of Offsite } \\
\text { Locations }\end{array}$} & \multirow{2}{*}{$\begin{array}{l}\text { No. of Onsite } \\
\text { Locations }\end{array}$} & \multicolumn{2}{|c|}{ No. of A nalyses } \\
\hline & & & & Gamma & Strontium-90 \\
\hline \multicolumn{2}{|c|}{$\begin{array}{l}\text { Fish (suckers, } \\
\text { whitefish, bass) }\end{array}$} & $2^{(a)}$ & $3^{(\mathrm{b})}$ & 10 & 10 \\
\hline \multicolumn{2}{|c|}{ Canada goose } & $1^{(\mathrm{c})}$ & $2^{(\mathrm{d})}$ & 11 & 11 \\
\hline \multicolumn{2}{|l|}{ Elk } & $2^{(\mathrm{e})}$ & $3^{(\mathrm{f})}$ & 28 & 25 \\
\hline \multicolumn{2}{|c|}{ Rabbits } & 0 & 3 & 8 & 8 \\
\hline \multicolumn{6}{|c|}{$\begin{array}{l}\text { (a) Background samples collected from the Columbia River in the Priest Rapids and } \\
\text { Wanapum reservoirs. } \\
\text { (b) Samples collected from 100-N to 100-D and } 300 \text { Areas. } \\
\text { (c) Sample collected at Vantage, Washington. } \\
\text { (d) Samples collected from 100-D to 100-H Area. } \\
\text { (e) Samples collected in central Idaho. } \\
\text { (f) Samples collected along Highways } 240 \text { and 24, adjacent private land, and near BC cribs } \\
\text { (see Figure 4.5.1). }\end{array}$} \\
\hline
\end{tabular}

\subsubsection{Fish Samples and Analytes of Interest}

In 1999, Pacific Northwest National Laboratory staff collected a total of 16 fish samples (bass, whitefish, and large-scale suckers) from the Columbia River. Six of the 16 samples were collected 64 to 80 kilometers ( 40 to 50 miles) upstream of the Hanford Site. Fillets and the eviscerated remains (carcass) of fish were analyzed for radiological contaminants. All analytical data for 1999 samples are given in PNNL-13230, APP. 1.

Fillet (muscle) samples were analyzed with gamma spectrometry for cesium-137 and other gammaemitting radionuclides (PNNL-13230, APP. 1). Cesium-137 was not detected in any of the 10 fish fillet samples collected along the Hanford Reach in 1999 nor in the 6 samples collected upstream the Hanford Site. These results are consistent with previous fish sample results obtained in 1998. Nearly $80 \%$ (41 of 55 ) of fish samples collected between 1990 and 1999 had concentrations of cesium-137 that were below analytical detection limits.
Strontium-90 was found in 7 of 16 fish carcass samples collected and analyzed in 1999 (Table 4.5.2). Mean levels of strontium-90 in carcass tissues collected from the Hanford Reach in 1999 were not significantly different from those observed in Hanford Reach samples collected over the preceding 9 years or from the background area near Vantage, Washington.

Overall, radionuclide concentrations in Hanford Reach fishes were similar to levels observed in background carp and suckers and have generally declined in the past two decades. Figure 4.5.2 demonstrates trends in strontium- 90 concentrations in bass carcasses from 1983 to 1999. The associated hypothetical dose from the consumption of Hanford Reach fish is found in Section 5.0, "Potential Radiological Doses from 1999 Hanford Operations.” 


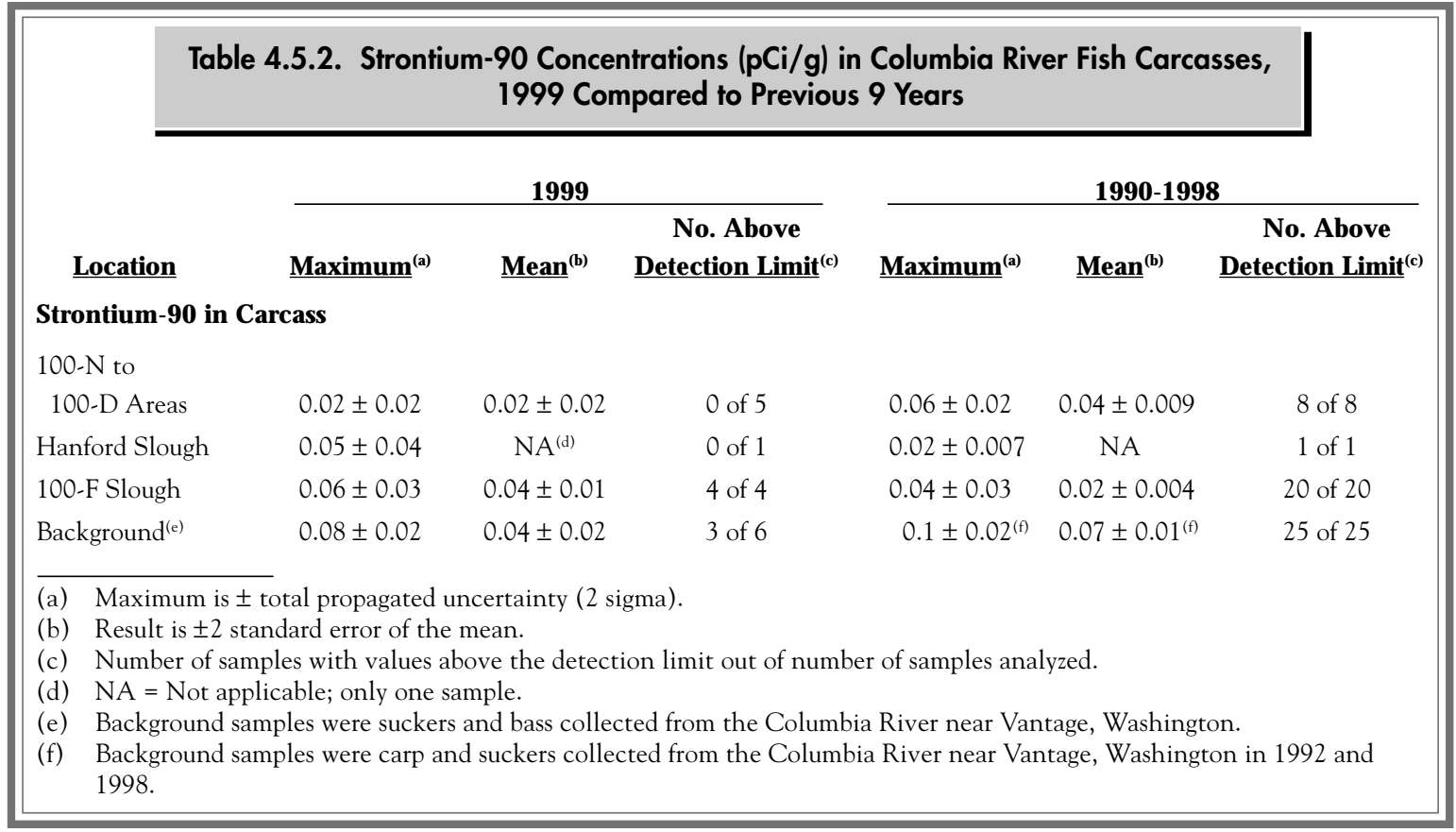

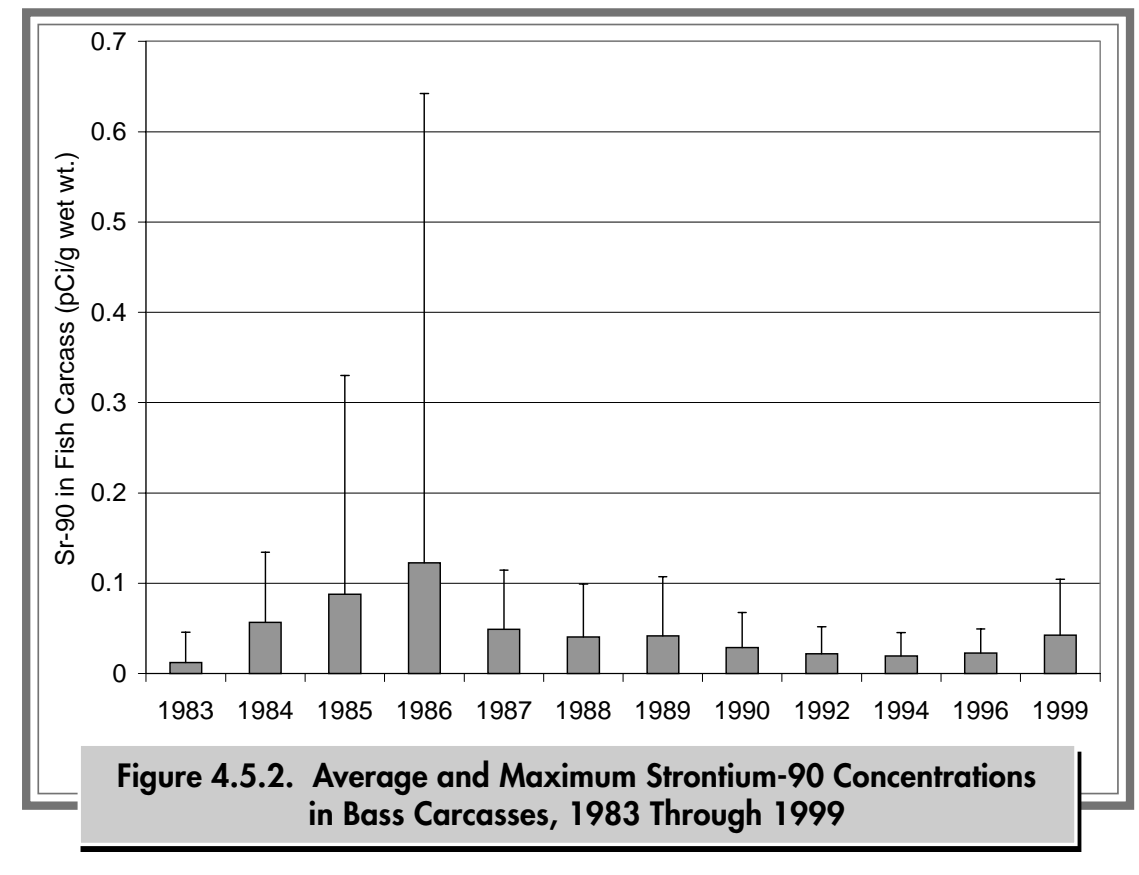




\subsubsection{Wildlife Sampling}

Wildlife sampled and analyzed for radioactive constituents in 1999 included elk, geese, and rabbits. Radiological constituents analyzed for in 1999 wildlife samples included gamma emitters and strontium-90.

\subsubsection{Elk Samples and Analytes of Interest}

Radionuclide levels in elk collected onsite were compared to levels in elk collected at two locations in Idaho. Additionally, onsite levels in elk were compared to levels in deer sampled from 1995 through 1998. These comparisons with samples from distant locations are useful in evaluating the impact of Hanford operations and cleanup activities to largebodied herbivores. The elk collected in central Idaho inhabited mountain regions that received more rainfall than Hanford.

Until recently, elk have not inhabited areas on the Hanford Site where the potential for uptake of radionuclide contaminants exists (see Section 7.2, "Ecosystem Monitoring [Plants and Wildlife]"). There are very few data available about contaminant concentrations in elk residing on or near the Hanford Site. As such, nontraditional tissues (heart, liver, kidney, intestines) were also collected and analyzed for a baseline of gamma-emitting radionuclides, and uranium, plutonium, and strontium radioisotopes.

Radiological Results for Elk Samples. Fourteen samples of elk muscle and bone were donated by local sportsman that hunted the Rattlesnake Hills in 1999. Three muscle and bone samples were donated by sportsmen from a 1999 Idaho elk hunt near Sun Valley, Idaho. Three elk muscle samples were donated by the Nez Perce Tribe near Lewiston, Idaho. In addition, samples of muscle, bone, liver, heart, kidney, intestine, and feces were collected from a roadkill elk near the Hanford Site and from five other elk that were collected on the central plateau near the
200 Areas. Cesium-137 was not detected in any of the 24 elk muscle samples collected from on or near the Hanford Site (Figure 4.5.3). Three muscle samples collected from central Idaho were the only ones above analytical detection limits. These results are consistent with historic deer results and with the trends observed in a Hanford wildlife summary report (PNL-10174). Cesium-137 concentrations in muscle samples from the three elk donated by the Nez Perce Tribe were all below analytical detection as were those elk samples collected from on or near the Hanford Site. PNL-10174 summarized wildlife radionuclide data collected from 1983 through 1992 and indicated a decline in cesium-137 levels in all wildlife examined. In addition, the levels of cesium137 found in over 60 Hanford Site deer muscle samples collected during the 1990 s were less than the background levels measured in deer samples collected from 1991 through 1995 from Stevens County, Washington, and in 1996, from Vail, Colorado (PNNL-12088).

The risk associated with radionuclide contamination found in elk or deer muscle during the 1990s can be quantified by the expected dose resulting from consumption of meat. A 50-year effective dose equivalent resulting from the consumption of 41 kilograms ( 90 pounds) of meat per year collected from a Hanford Site deer, containing the highest cesium137 levels found in the 1990s, was determined to be 0.041 millirem. An individual would need to ingest $\sim 100,000$ kilograms $(220,000$ pounds) of deer meat to approach the 100-millirem maximum annual dose allowed by DOE Order 5400.5 and the National Council on Radiation Protection and Measurements (1993). To put this dose estimate in perspective, natural background doses in the United States average $\sim 300$ millirems per year.

Strontium-90 was detected in bone from all 27 elk samples analyzed in 1999 (see Figure 4.5.4) and compliment the regional cesium-137 differences 

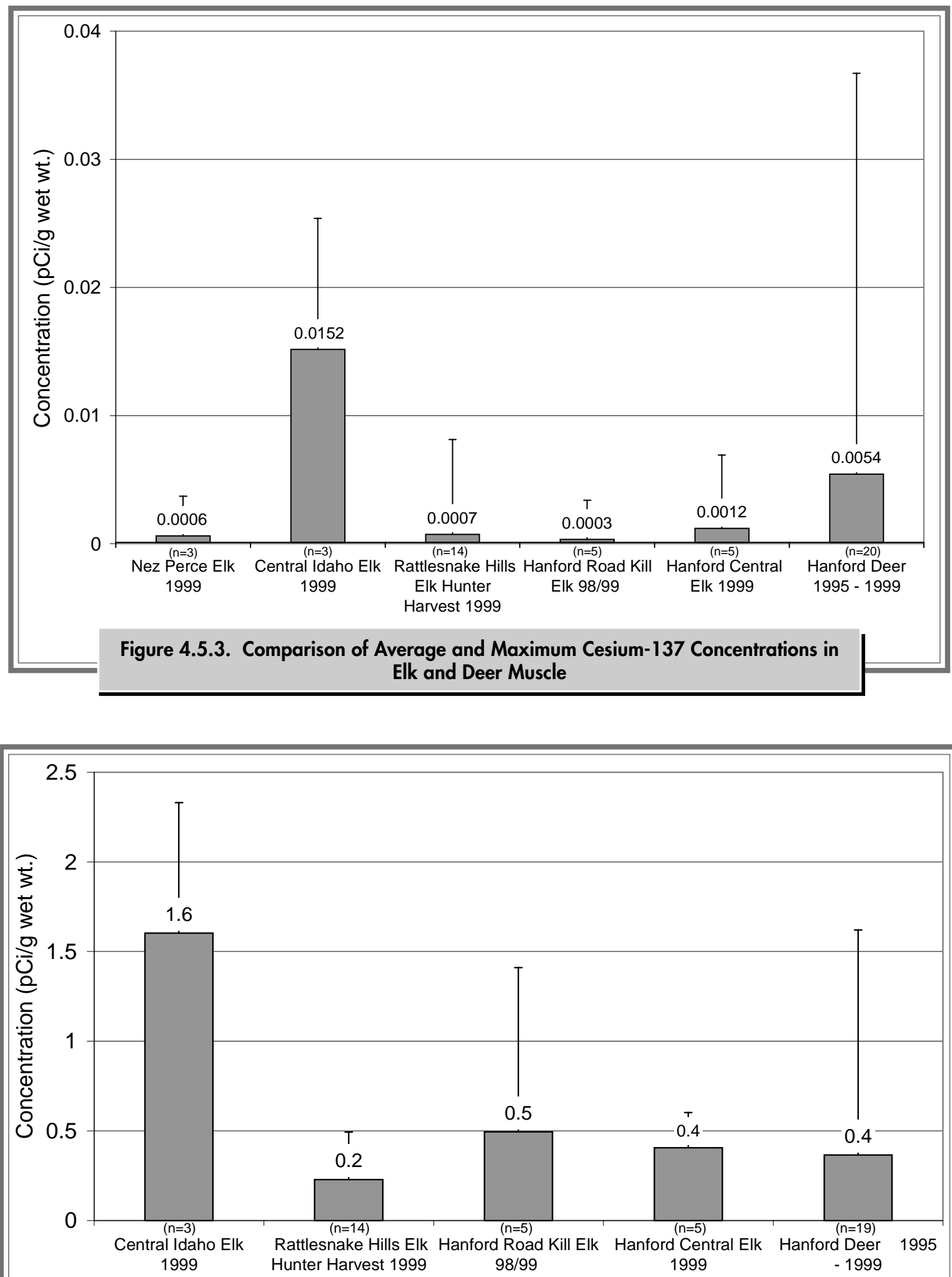

Figure 4.5.4. Comparison of Average and Maximum Strontium-90 Concentrations in Elk and Deer Bone 
found in the elk muscle samples. Again, central Idaho samples were nearly three times higher than any other samples submitted.

\subsubsection{Goose Samples and Analytes of Interest}

Eight goose samples were collected from the Hanford Reach and three were collected from the background location near Vantage, Washington in the early fall of 1999 (see Figure 4.5.1). Radionuclide levels found in these samples were compared to levels in samples collected onsite in 1994, 1995, and 1997.

Cesium-137 was detected in only one of eight goose muscle samples collected from the Hanford Site and one of three from the background site in 1999 (Table 4.5.3). The number of results reported at or below the analytical detection limit in 1999 was similar to those reported for 22 goose samples collected from the Hanford Reach between 1994 and
1997. The 1999 levels were consistent with levels reported for other waterfowl collected on the Hanford Site (PNL-10174).

Strontium-90 concentrations found in goose bone were similar between areas on the Hanford Site in 1999 and the background samples. Using $1 \mathrm{rad}$ per day as a benchmark for biological effects, a concentration of more than $600 \mathrm{pCi} / \mathrm{g}$ in bone tissue would be required to cause adverse effects, such as bone tumors.

\subsubsection{Rabbit Samples and Analytes of Interest}

Rabbits are good indicators of regional radioactive contamination because they have relatively small home ranges, occupy burrows, and can enter fenced-restricted areas. However, due to the cyclicpatterns of the populations over time, sampling rabbits can be very difficult when numbers are low. In

\begin{tabular}{|c|c|c|c|c|c|c|c|}
\hline \multirow{3}{*}{\multicolumn{2}{|c|}{ Location }} & .5.3. Cesium- & $\begin{array}{l}137 \text { and Stro } \\
1999 \text { Com }\end{array}$ & $\begin{array}{l}\text { ntium-90 Concent } \\
\text { ipared to Previou }\end{array}$ & $\begin{array}{l}\text { ations }(\mathrm{pCi} / \mathrm{s} \\
5 \text { Years }\end{array}$ & in Canada G & eese, \\
\hline & & \multicolumn{3}{|c|}{1999} & \multicolumn{3}{|c|}{ 1994-1997 } \\
\hline & & $\underline{\text { Maximum }}^{\text {(a) }}$ & Mean $^{(b)}$ & $\begin{array}{c}\text { No. A bove } \\
\text { Detection Limit( }\end{array}$ & $\underline{\text { Maximum }}^{(a)}$ & Mean $^{(b)}$ & $\begin{array}{c}\text { No. A bove } \\
\text { Detection Limit }^{(c)}\end{array}$ \\
\hline \multicolumn{8}{|c|}{ Cesium-137 in Muscle } \\
\hline \multicolumn{7}{|c|}{$100-\mathrm{N}$ to } & 1 of 11 \\
\hline & Hanford Townsite & $0.05 \pm 0.02$ & $0.024 \pm 0.03$ & 1 of 3 & $0.03 \pm 0.01$ & $0.006 \pm 0.005$ & 1 of 11 \\
\hline & kground $^{(d)}$ & $0.07 \pm 0.02$ & $0.03 \pm 0.04$ & 1 of 3 & $N S^{(e)}$ & NS & NS \\
\hline \multicolumn{8}{|c|}{ Strontium-90 in Bone } \\
\hline \multicolumn{7}{|c|}{$100-\mathrm{N}$ to } & 11 of 11 \\
\hline & Hanford Townsite & $0.4 \pm 0.04$ & $0.07 \pm 0.04$ & 3 of 3 & $0.4 \pm 0.1$ & $0.1 \pm 0.08$ & 11 of 11 \\
\hline & kground $^{(d)}$ & $0.4 \pm 0.05$ & $0.8 \pm 0.2$ & 2 of 3 & NS & NS & NS \\
\hline $\begin{array}{l}\text { (a) } \\
\text { (b) } \\
\text { (c) } \\
\text { (d) } \\
\text { (e) }\end{array}$ & \multicolumn{7}{|c|}{$\begin{array}{l}\text { Maximum is } \pm \text { total propagated analytical uncertainty ( } 2 \text { sigma). } \\
\text { Result is } \pm 2 \text { standard error of the mean. } \\
\text { Number of samples with values above the detection limit out of number of samples analyzed. } \\
\text { Background samples collected from Yakima Valley near Sunnyside, Washington. }\end{array}$} \\
\hline
\end{tabular}


1999, the black-tailed jackrabbit was identified by Washington State Department of Fish and Wildlife as a species of concern. On the Hanford Site, the number of black-tailed jackrabbits has remained relatively stable throughout the 1990 s and is likely related to the habitat provided by an overstory of sagebrush there.

In 1999, muscle and bone samples of jackrabbits and cottontails were collected from near the 200-East, 200-West, and 100-N Areas. Background samples of rabbits were collected in 1990 .

Muscle. Cesium-137 concentrations in eight rabbits collected on the Hanford Site in 1999 were all below analytical detection limit except one, which was just slightly above the detection limit (Table 4.5.4). These results are similar to those seen from background locations sampled in 1990 and do not indicate elevated exposures from Hanfordderived sources.
Bone. Strontium-90 concentrations in bone tissue of eight rabbits on the site were all above the analytical detection limit. Results from animals collected near the 200 Areas do not suggest a significant exposure attributable to Hanford Site operations. Only one cottontail rabbit was collected from 100-N Area in 1999, limiting the ability to statistically compare the results (144 $\pm 32 \mathrm{pCi} / \mathrm{g}$ wet wt.), however, this single value was over 20 times higher than concentrations from all other samples submitted in 1999 and suggests onsite exposure to low levels of strontium-90 around the 100-N Area. Future small mammal sampling efforts at the same sampling locations may shed some insight to strontium-90 sources in or near the 100-N Area that are available for biological uptake.

Table 4.5.4. Cesium-137 and Strontium-90 Concentrations (pCi/g) in Rabbits, 1999 Compared to Previous 9 Years

\begin{tabular}{|c|c|c|c|c|c|c|}
\hline \multicolumn{6}{|c|}{$\begin{array}{l}\text { Table 4.5.4. Cesium-137 and Strontium-90 Concentrations (pCi/g) in Rabbits, } 1999 \\
\text { Compared to Previous } 9 \text { Years }\end{array}$} & 999 \\
\hline \multirow[b]{2}{*}{ Location } & \multicolumn{3}{|c|}{1999} & \multicolumn{3}{|c|}{ 1990-1998 } \\
\hline & $\underline{\text { Maximum }}^{(\mathrm{a})}$ & Mean $^{(b)}$ & $\begin{array}{l}\text { No. A bove } \\
\text { Detection Limit(c) }\end{array}$ & $\underline{\text { Maximum }}^{(\mathrm{a})}$ & Mean $^{(b)}$ & $\begin{array}{l}\text { No. A bove } \\
\text { Detection Limit }\end{array}$ \\
\hline \multicolumn{7}{|c|}{ Cesium-137 in Muscle } \\
\hline 200 Areas & $0.05 \pm 0.02$ & $0.01 \pm 0.04$ & 1 of 7 & $0.25 \pm 0.05$ & $0.02 \pm 0.02$ & 11 of 22 \\
\hline 100-N Area & $0.03 \pm 0.04$ & - & 0 of 1 & $0.14 \pm 0.1$ & $0.005 \pm 0.03$ & 1 of 10 \\
\hline Background $d^{(\mathrm{d})}$ & $N S^{(e)}$ & NS & NS & $0.03 \pm 0.03$ & $0.005 \pm 0.005$ & 1 of 20 \\
\hline \multicolumn{7}{|c|}{ Strontium-90 in Bone } \\
\hline 200 Areas & $4.8 \pm 1.1$ & $1.6 \pm 2.0$ & 7 of 7 & $48.5 \pm 9.0$ & $8.5 \pm 10.1$ & 22 of 22 \\
\hline 100-N Area & $144.0 \pm 32.0$ & - & 1 of 1 & $81.3 \pm 14.0$ & $14.6 \pm 16.0$ & 10 of 10 \\
\hline Background $d^{(d)}$ & $N S^{(e)}$ & NS & NS & $0.9 \pm 0.09$ & $0.35 \pm 0.09$ & 20 of 20 \\
\hline \multicolumn{7}{|c|}{$\begin{array}{l}\text { (a) Maximum is } \pm 2 \text { total propagated analytical uncertainty ( } 2 \text { sigma). } \\
\text { (b) Mean is } \pm 2 \text { standard error of the mean. } \\
\text { (c) Number of samples with values above the analytical detection limit out of number of samples analyzed. } \\
\text { (d) Background samples collected near Boardman, Oregon, in } 1990 . \\
\text { (e) NS = No sample. }\end{array}$} \\
\hline
\end{tabular}




\title{
4.6 Soil and Vegetation Surveillance
}

\author{
T. M. Poston, R. W. Hanf, and B. L. Tiller
}

Soil surveillance provides information on longterm contamination trends and baseline environmental radionuclide activities at undisturbed locations (DOE/RL-91-50, Rev. 2). Surveillance of perennial vegetation provides information on atmospheric deposition of radioactive materials in uncultivated areas and at onsite locations adjacent to potential sources of man-made radioactivity. Accordingly, radionuclide concentration in soil and perennial vegetation provide a baseline against which unplanned releases can be compared.

Soil and perennial vegetation samples have been collected on and around the Hanford Site for greater than 50 years. Consequently, a large database exists that thoroughly documents onsite and offsite concentrations of man-made radionuclides in soil and natural vegetation at specific locations. Because the current site mission includes environmental restoration and cleanup, and because routine plutonium production operations at the site have ceased, the need for annual soil and perennial vegetation surveillance has diminished. There are several additional reasons for the reduced need for soil and perennial vegetation sampling. Man-made radionuclides with short half-lives have decayed to stable isotopes and are no longer present. Moreover, radionuclide releases from the Hanford Site in recent years have been small, and, therefore, baseline radionuclide activities have not changed appreciably for a number of years. Because only radionuclides with relatively long halflives presently are found in soil and vegetation, sitewide environmental surveillance sampling of soil and vegetation can be less frequent. Routine radiological surveillance of soil and vegetation was last conducted in 1998 (Section 4.6 in PNNL-12088). In 1999, two special studies were conducted. One study involved the analysis of samples from mulberry trees and reed canary grass collected from the Hanford Site along the Columbia River shoreline. Another study involved the analysis of soil samples collected in and near the former 1100 Area. Five different species of plants collected from the Hanford Site by the Wanapum People also were analyzed for radiological contaminants.

Other soil and vegetation sampling was conducted near active facility release points and waste sites. Results are discussed in Section 3.2, "NearFacility Environmental Monitoring."

\subsubsection{Surveillance of Columbia River Shoreline Vegetation}

Samples of mulberry trees and reed canary grass were collected along the Columbia River shoreline in early summer 1999 and analyzed for gamma emitters, tritium, strontium-90, technetium-99, and uranium isotopes. These radionuclides are present in groundwater and are known to enter the Columbia River in shoreline springs. Samples consisted of stems, leaves and, when available, mulberries. Samples were collected in the vicinity of shoreline springs at locations where elevated concentrations of radionuclides were seen in samples collected in 1990 to 1992 (PNL-8797). Background samples were collected upstream of the Hanford Site near the Vernita Bridge and immediately downstream of the site near the Port of Benton's dock in north Richland (Figure 4.6.1). Shallow groundwater was collected with drive point sampling tubes installed in the rooting zones of some mulberry trees. A drive point 


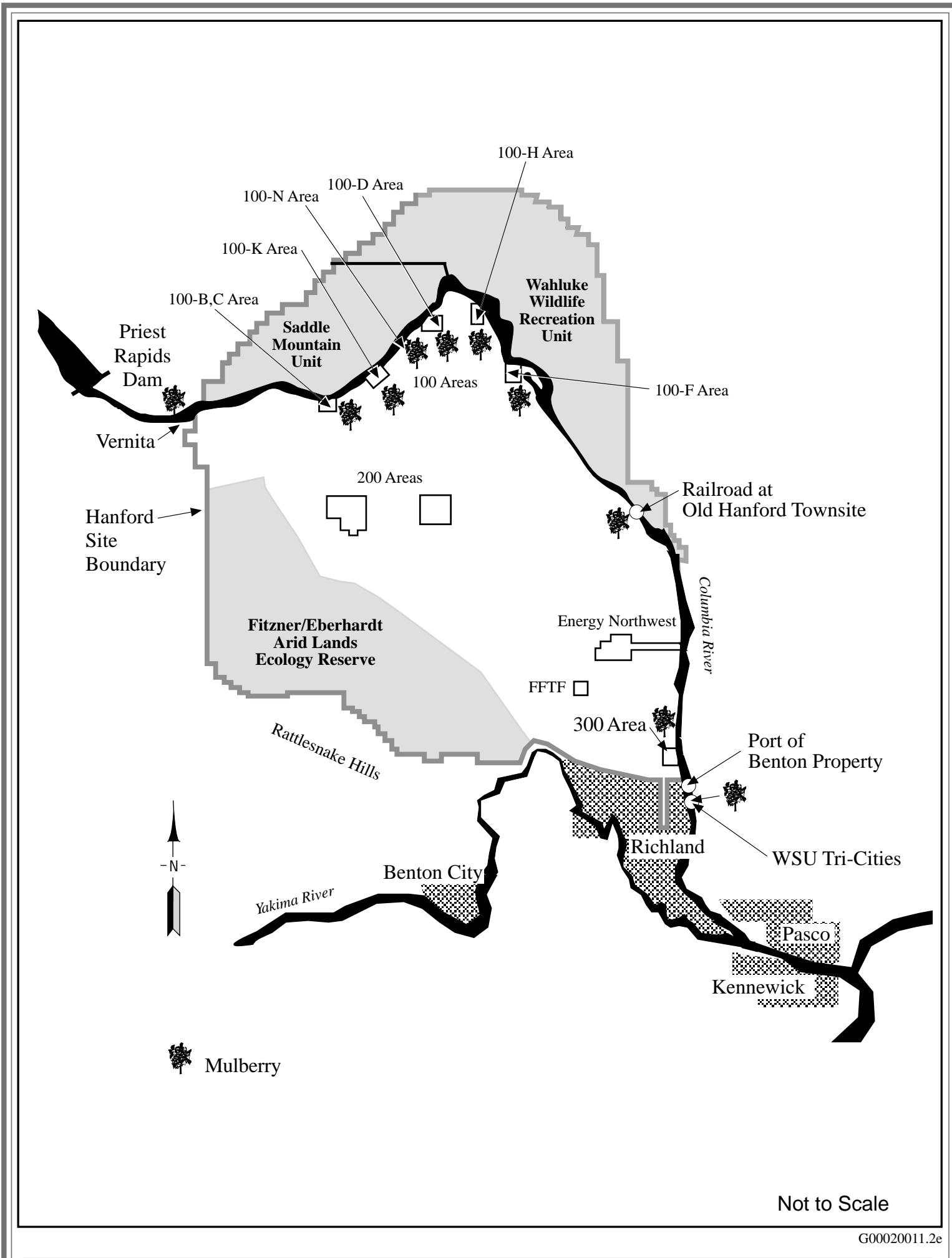

Figure 4.6.1. Columbia River Shoreline Vegetation Sampling Locations on and Near the Hanford Site, 1999 
sampling tube is a plastic tube with a metal cone on one end that is driven into the ground to obtain water. Slots are cut into the tube near the cone and covered with a fine mesh screen to exclude soil particles. Some mulberry trees were also re-sampled in the fall to determine if radionuclide concentrations had increased over the summer growing season. Observed concentrations of radionuclides were compared to concentrations observed in shoreline vegetation samples collected in 1990 to 1992.

Tritium was measured in water that was distilled from the vegetation samples and submitted to the analytical laboratory for analysis. Concentrations of tritium in the 1999 samples were similar to concentrations observed in the 1990 to 1992 samples (Figure 4.6.2). A concentration of $20,000 \mathrm{pCi} / \mathrm{L}$ of plant distillate was observed at the 100-B,C Area. This value exceeded concentrations observed in past sampling, but is not considered unusual because of the known presence of groundwater tritium plumes in the area. The tritium concentration in the mulberry tree sampled at the Old Hanford Townsite was close to background. This sample was expected to be elevated based on past sampling results and known levels of tritium in groundwater at the Old Hanford Townsite.

The pattern of strontium-90 concentrations in shoreline vegetation mirrored observations made in 1990 to 1992 (Figure 4.6.3). The highest values were observed at $\mathrm{N}$ Reactor and slightly lower values were observed near the other reactor areas. At areas upstream and downstream of the reactor areas, concentrations of strontium-90 were at background levels of around $0.1 \mathrm{pCi} / \mathrm{g}$. Strontium-90 accumulates through the growing season and is deposited in bark and tree leaves. Concentrations of strontium90 collected in October at Vernita, the 100-B,C Area, and the $100-\mathrm{H}$ Area were 1.9 to 3.8 times higher than the concentrations observed in early summer (Figure 4.6.4). Early summer and fall comparative samples collected at the 300 Area and near the Washington State University Tri-City Campus did not show the summer increase, however.

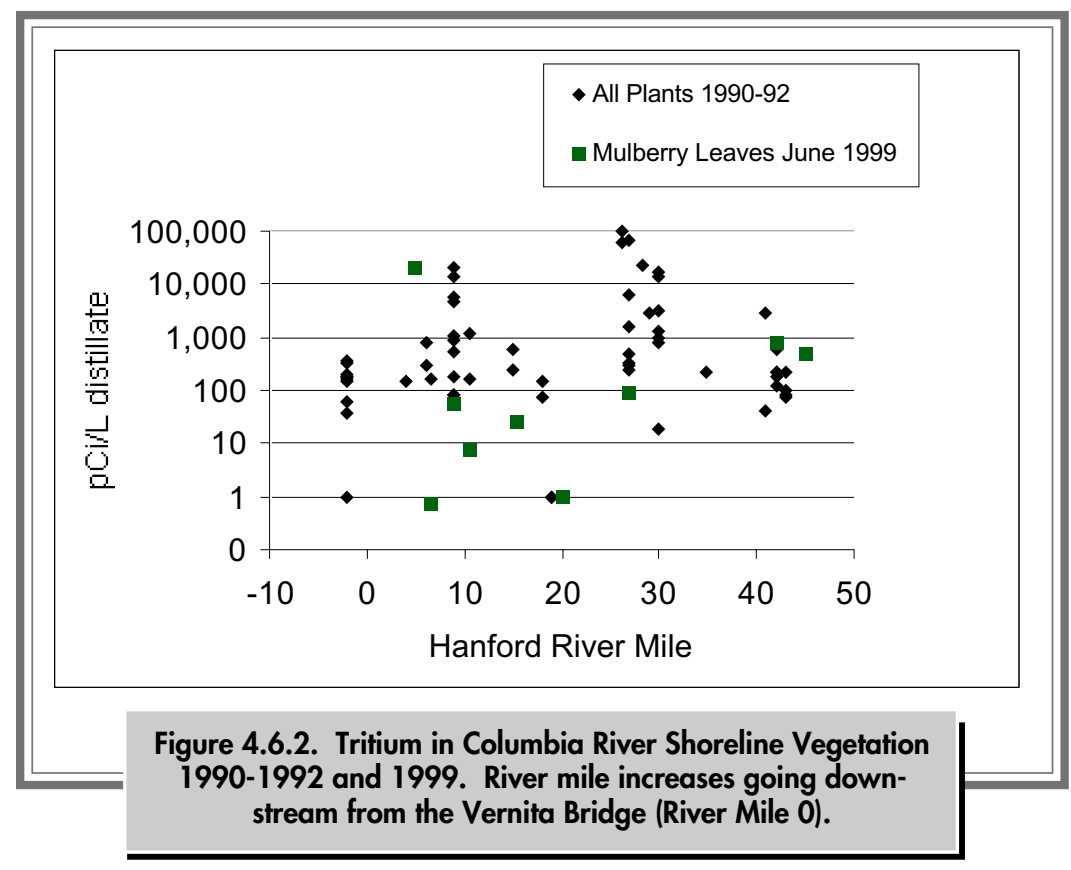



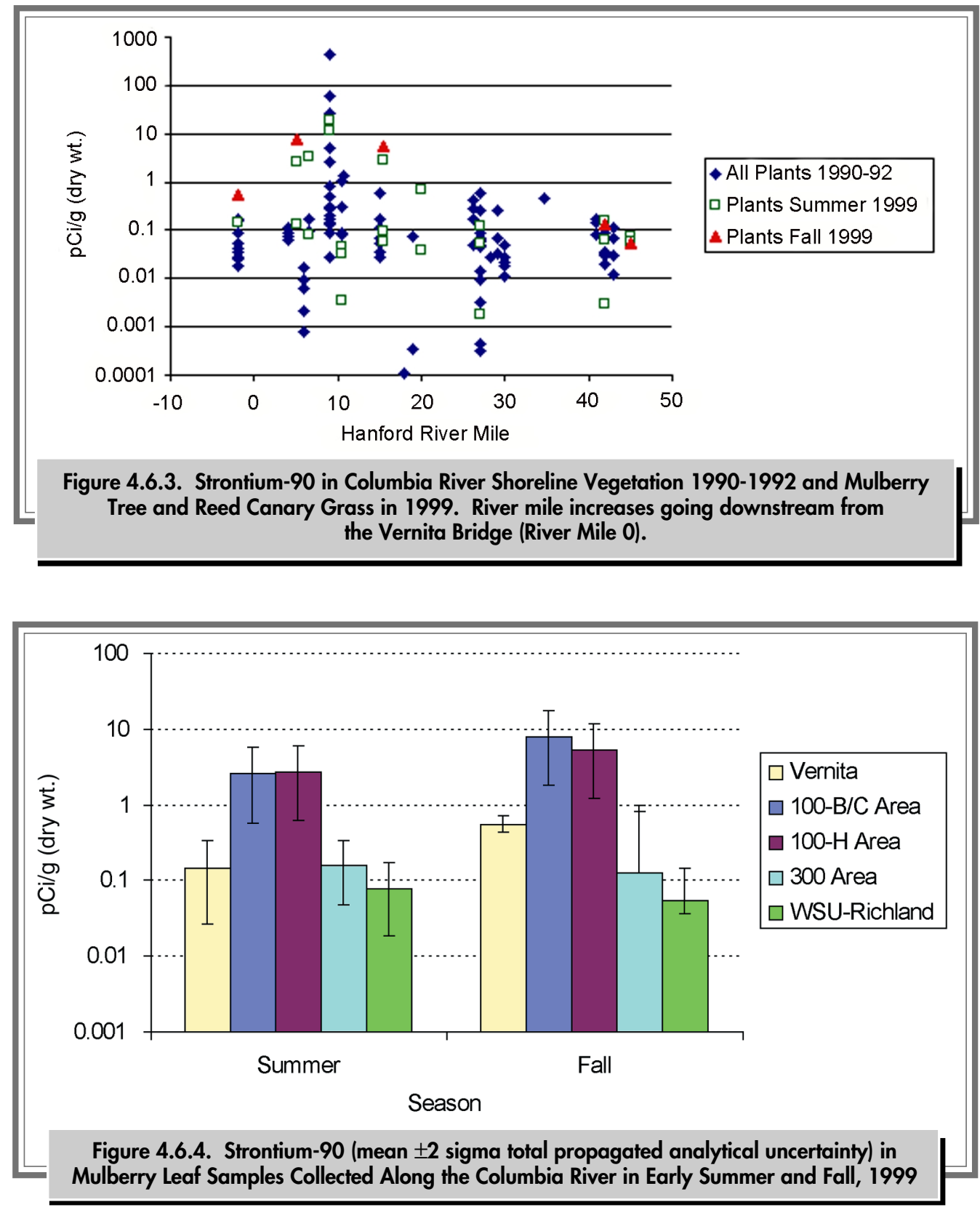

Concentrations of uranium isotopes and technetium-99 were generally below detection and when detected, were not different then values observed in 1990 to 1992. Sample results are listed in PNNL-13230, APP. 1.

\subsubsection{Special Soil Samples}

In July 1999, surface soil samples were collected in and around the former 1100 Area in north Richland and analyzed for radiological contamination. The
1100 Area was a 311-hectare (768-acre) parcel of land located between the 300 Area and the city of Richland (see Figure 1.0.1) that was transferred from 
the DOE to the Port of Benton in 1998. Under DOE ownership, this area was generally used for nonresearch and nonnuclear activities. However, nuclear materials were occasionally stored there, potentially radiologically contaminated equipment was serviced there, and some cleanup of contaminated railroad equipment occurred there. Prior to transferring the property to the Port, the DOE Richland Operations Office inspected facilities within the area for radiological contamination. After transferring the property, DOE decided surface soil within the area should also be monitored. Potential sources of contaminants, in addition to those mentioned above, included airborne materials from DOE facilities on the site, airborne materials from private nuclear facilities on and around the site, and materials that could have been carried into the area by railroad operations or other means.

A total of 16 samples from 12 locations (Figure 4.6.5) were collected and submitted to analytical laboratories for analysis. Four of the samples were collected by the Pacific Northwest National Laboratory, four were collected by the Washington State Department of Health, and four were collected jointly and each was split between the two agencies. Ten of the sampling locations were thought to have the greatest potential to have received contamination over the years. Two relatively undisturbed sites near the former 1100 Area were selected as background locations. Global positioning system readings were taken at each sampling location. Quanterra, Inc. in Richland analyzed the Pacific Northwest National Laboratory samples and the Washington State Public Health Laboratory in Seattle analyzed the Washington State Department of Health samples.

Samples were analyzed for strontium-90, uranium isotopes (uranium-234, -235, and -238), plutonium isotopes (plutonium-238 and -239/240), and gamma emitters (beryllium-7, potassium-40, cobalt60 , ruthenium-106, antimony-125, cesium-134 and -137, europium-154 and -155). A summary of analytical results for both the Pacific Northwest National Laboratory and the state are provided in Table 4.6.1. Also included for comparative purposes are Pacific Northwest National Laboratory data for Hanford Site perimeter locations collected from 1992 through 1997. In all cases, radionuclide concentrations in 1100 Area soil samples collected in 1999 were similar to concentrations measured in the background samples collected near the 1100 Area and were near or below values measured at Hanford Site perimeter locations between 1992 and 1997. Detailed analytical results are reported in PNNL-13230, APP. 1.

\subsubsection{Vegetation Samples Submitted by the Wanapum People}

Five different species of plants were collected from the Hanford Site by members of the Wanapum People in June 1999. Samples were submitted for analysis by the Surface Environmental Surveillance Project and analyzed for radioactive materials. Neither uranium isotopes, plutonium-238, nor cesium137 contaminants were detected. Plutonium-239/ 240 was marginally detected in two of the five plants at a concentration of $0.00002 \pm 0.0003 \mathrm{pCi} / \mathrm{g}$ dry weight. Strontium-90 was measured in all five samples. Concentrations ranged from $0.014 \pm 0.006$ to $0.040 \pm 0.014 \mathrm{pCi} / \mathrm{g}$ dry weight (Table 4.6.2). These strontium-90 concentrations are comparable to past monitoring results for strontium-90 in both terrestrial upland vegetation and shoreline vegetation associated with undeveloped areas of the site. 


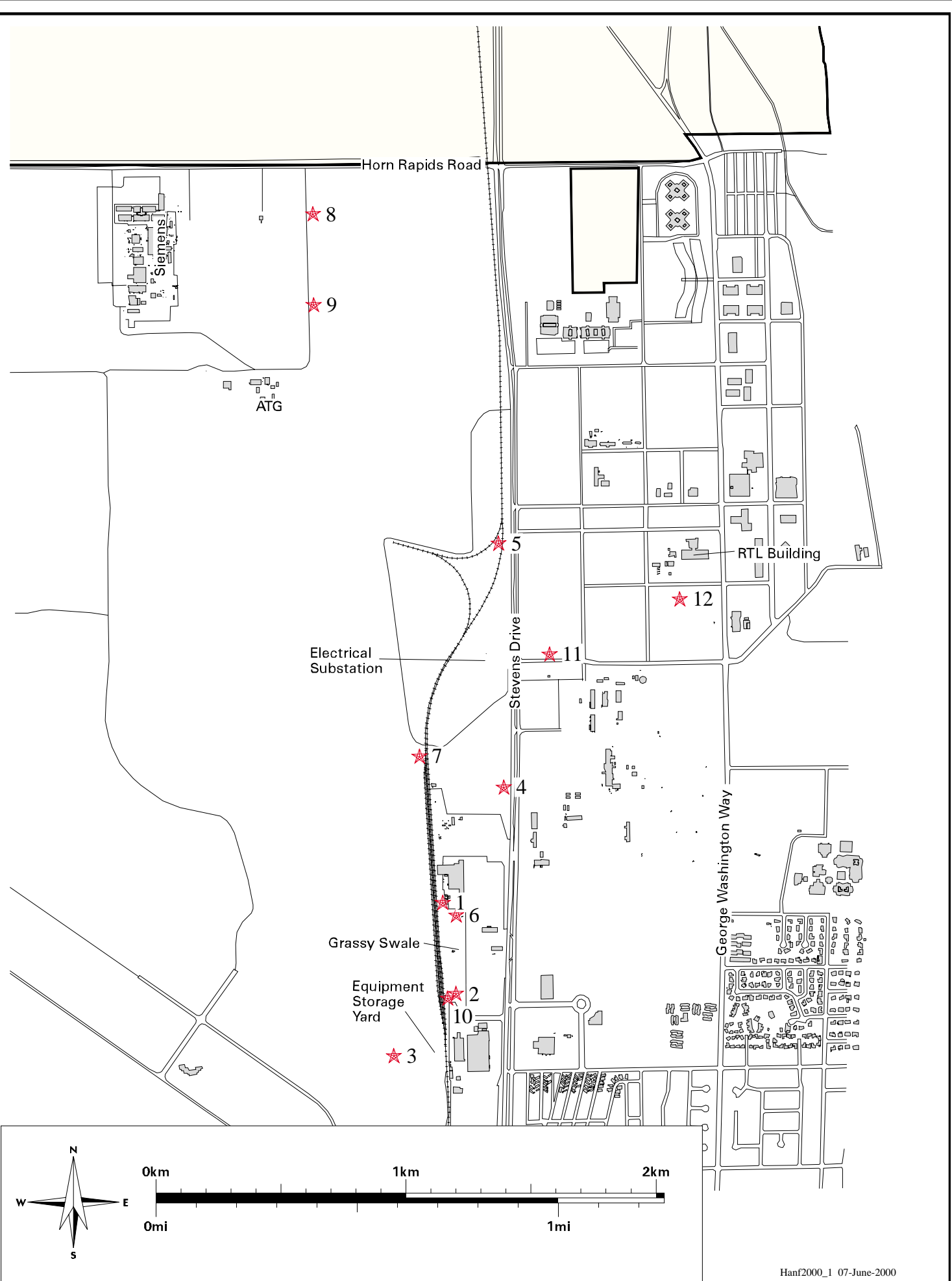

Figure 4.6.5. Soil Sampling Locations in and Near the Former 1100 Area, 1999 


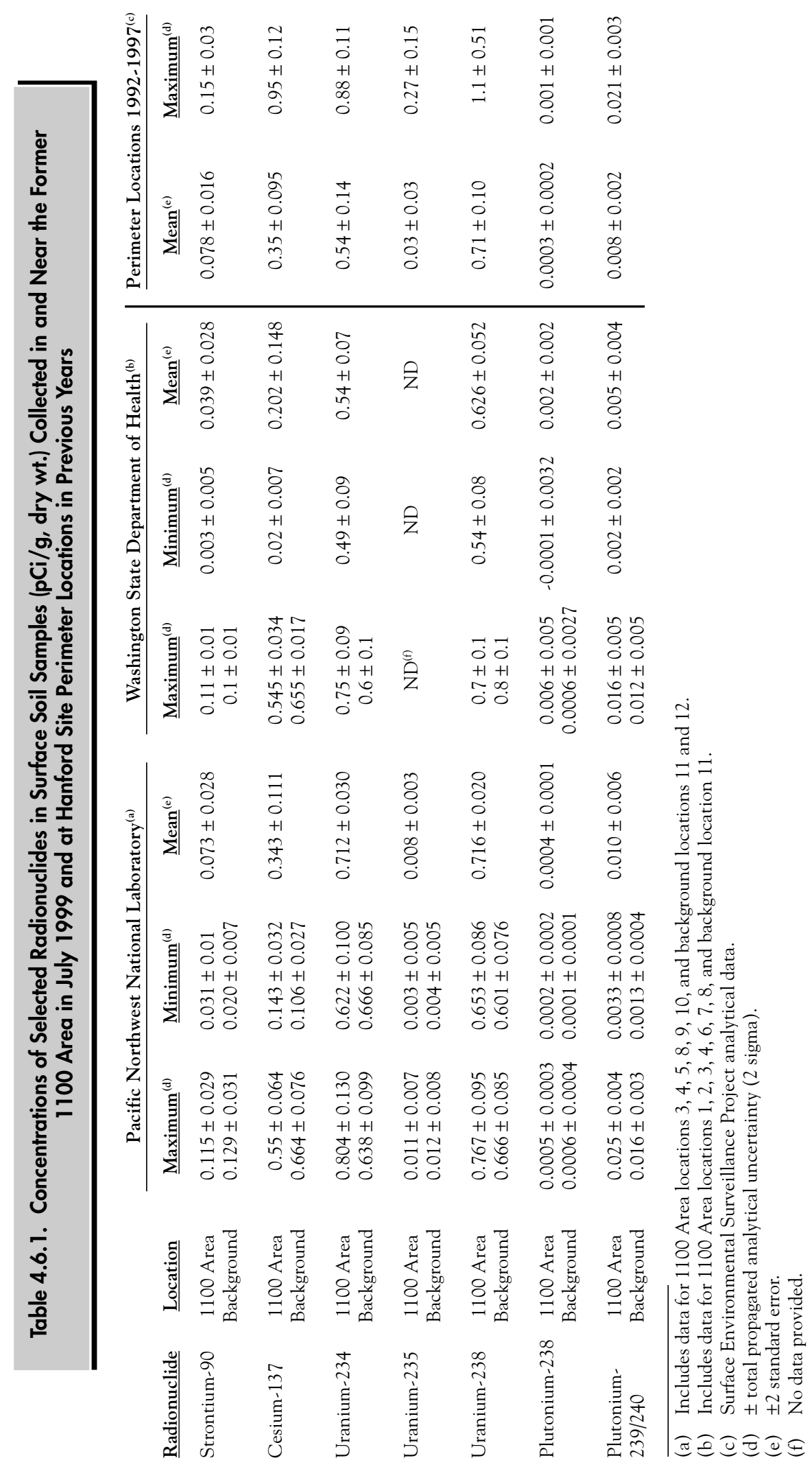


Table 4.6.2. Strontium-90 Concentrations (pCi/g, dry wt.) in Vegetation Samples Collected on the Hanford Site by the Wanapum People, June 1999

\begin{tabular}{lll}
\multicolumn{1}{c}{ Plant Name } & \multicolumn{1}{c}{ Species } & Concentration $^{(\text {a) }}$ \\
Yarrow & Achillea sp. & $0.040 \pm 0.014$ \\
Globemellow & Sphaeralcea sp. & $0.023 \pm 0.008$ \\
Tumble mustard & Sisymbrium sp. & $0.014 \pm 0.006$ \\
Willow & Salix sp. & $0.014 \pm 0.005$ \\
Balsamroot & Balsamorhiza sp. & $0.020 \pm 0.007$ \\
\hline (a) \pm total propagated analytical uncertainty (2 sigma).
\end{tabular}




\title{
4.7 External Radiation Surveillance
}

\author{
E. J. Antonio
}

External radiation is defined as radiation originating from a source external to the body. External radiation fields consist of a natural component and an anthropogenic, or man-made, component. The natural component can be divided into 1) cosmic radiation; 2) primordial radionuclides, primarily potassium-40, thorium-232, and uranium-238; and 3 ) an airborne component, primarily radon and its progeny. The man-made component consists of radionuclides generated for or from nuclear medicine, power, research, waste management, and consumer products containing nuclear materials. Environmental radiation fields may be influenced by the presence of radionuclides deposited as fallout from atmospheric testing of nuclear weapons or those produced and released to the environment during the production or use of nuclear fuel. During any year, external radiation levels can vary from $15 \%$ to $25 \%$ at any location because of changes in soil moisture and snow cover (National Council on Radiation Protection and Measurements 1987).

The interaction of radiation with matter results in energy being deposited in that matter. This is why your hand feels warm when exposed to a light source (e.g., sunlight, flame). Ionizing radiation energy deposited in a mass of material is called radiation absorbed dose. A special unit of measurement, called the rad, was introduced for this concept in the early 1950s. The International System of Units introduced the gray and is defined as follows: 1 gray is equivalent to $100 \mathrm{rad}$ (American Society for Testing and Materials 1993). For a point of reference, a radiological dose of 100,000 mrem beta/gamma to an 8-ounce cup of water will deposit enough energy in the water to increase the temperature of the water by about $1^{\circ}$ Fahrenheit.
One device for measuring radiation absorbed dose is the thermoluminescent dosimeter that absorbs and stores energy of ionizing radiation within the dosimeter's crystal lattice. By heating the material under controlled laboratory conditions, the stored energy is released in the form of light, which is measured and related to the amount of ionizing radiation energy stored in the material. Thermoluminescence, or light output exhibited by dosimeters, is proportional to the energy absorbed, which by convention is related to the amount of radiation exposure $(\mathrm{X})$, which is measured in units of roentgen (R). The exposure is multiplied by a factor of 0.98 to convert to a dose (D) in rad to soft tissue (Shleien 1992). This conversion factor relating $R$ to $r a d$ is, however, assumed to be unity (1) throughout this report for consistency with past reports. This dose is further modified by a quality factor, $Q=1$, for beta and gamma radiation and the product of all other modifying factors $(\mathrm{N}) . \mathrm{N}$ is assumed to be unity to obtain dose equivalence $(\mathrm{H})$ measured in rem. The sievert is the equivalent of the rem.

$$
\begin{aligned}
& D(\mathrm{rad})=X(R) * 1.0 \\
& H(\mathrm{rem})=D * N * Q
\end{aligned}
$$

In 1999, environmental external radiation exposure rates were measured at locations on and off the Hanford Site using thermoluminescent dosimeters and pressurized ionization chambers. External radiation and surface contamination surveys at specified locations were performed with portable radiation survey instruments. 


\subsubsection{External Radiation Measurements}

In 1995, the Harshaw 8800-series system replaced the former Hanford Standard environmental dosimeter system. The Harshaw environmental dosimeter consists of two TLD-700 chips and two TLD-200 chips and also provides both shallow and deep dose measurement capabilities. Thermoluminescent dosimeters are positioned $\sim 1$ meter ( 3 feet) above the ground at 28 onsite locations (Figure 4.7.1). Figure 4.7.2 shows the locations around the site perimeter, in nearby communities, and distant locations. Figure 4.7.3 gives the locations along the Columbia River shoreline. All thermoluminescent dosimeters are collected and read quarterly. The two TLD-700 chips at each location are used to determine the average total environmental dose at that location. The average dose rate is computed by dividing the average total environmental dose by the length of time the dosimeter was in the field. Quarterly dose equivalent rates (millirem per day) at each location were converted to annual dose equivalent rates (millirem per year) by averaging the quarterly dose rates and multiplying by 365 days per year. The two TLD200 chips are included only to determine doses in the event of a radiological emergency.

To determine the maximum dose rate for each distance classification, the annual dose rates, calculated above, for each location were compared and the highest value was reported. The uncertainties associated with the maximum dose rates were calculated as two standard deviations of the quarterly dose rates then corrected to an annual rate.

All community and most of the onsite and perimeter thermoluminescent dosimeter locations are collocated with air monitoring stations. The onsite and perimeter locations were selected based on determinations of the highest potentials for public exposures (i.e., access areas, downwind population centers) from past and current Hanford Site operations. The two background stations in Yakima and Toppenish were chosen because they are generally upwind and distant from the site.
The shoreline of the Columbia River in the Hanford Reach is monitored by a series of 24 thermoluminescent dosimeters located in the area from upstream of the B Reactor shoreline to downstream of Bateman Island at the mouth of the Yakima River. Ground contamination surveys are also conducted quarterly at 13 shoreline locations. These measurements are made to estimate radiation exposure levels attributed to sources on the Hanford Site, to estimate background levels along the shoreline, and to help assess exposures to onsite personnel and offsite populations. Ground contamination surveys are conducted using Geiger-Müeller meters (Geiger counters) and Bicron ${ }^{\circledR}$ Microrem meters. Results are reported in counts per minute and microrem per hour, respectively. Geiger counter measurements are made within 2.54 centimeters ( 1 inch) of the ground and cover a 1 -square meter (10-square feet) area. The Bicron ${ }^{\circledR}$ measurements are taken 1 meter ( 3 feet) above the ground surface and at least 10 meters (33 feet) away from devices or structures, which may contribute to the ambient radiation levels.

Pressurized ionization chambers are situated at four community-operated monitoring stations (see Section 7.4, "Community-Operated Environmental Surveillance Program"). These instruments provide a means of measuring ambient exposure rates near and downwind of the site and at locations distant and upwind of the site. Real-time exposure rate data are displayed at each station to provide information to the public and to serve as an educational tool for the teachers who manage the stations.

\subsubsection{External Radiation Results}

Thermoluminescent dosimeter readings have been converted to annual dose equivalent rates by the process described above. Table 4.7.1 shows the maximum and mean dose rates for perimeter and offsite locations measured in 1999 and the previous 5 years. External dose rates reported in Tables 4.7.1 


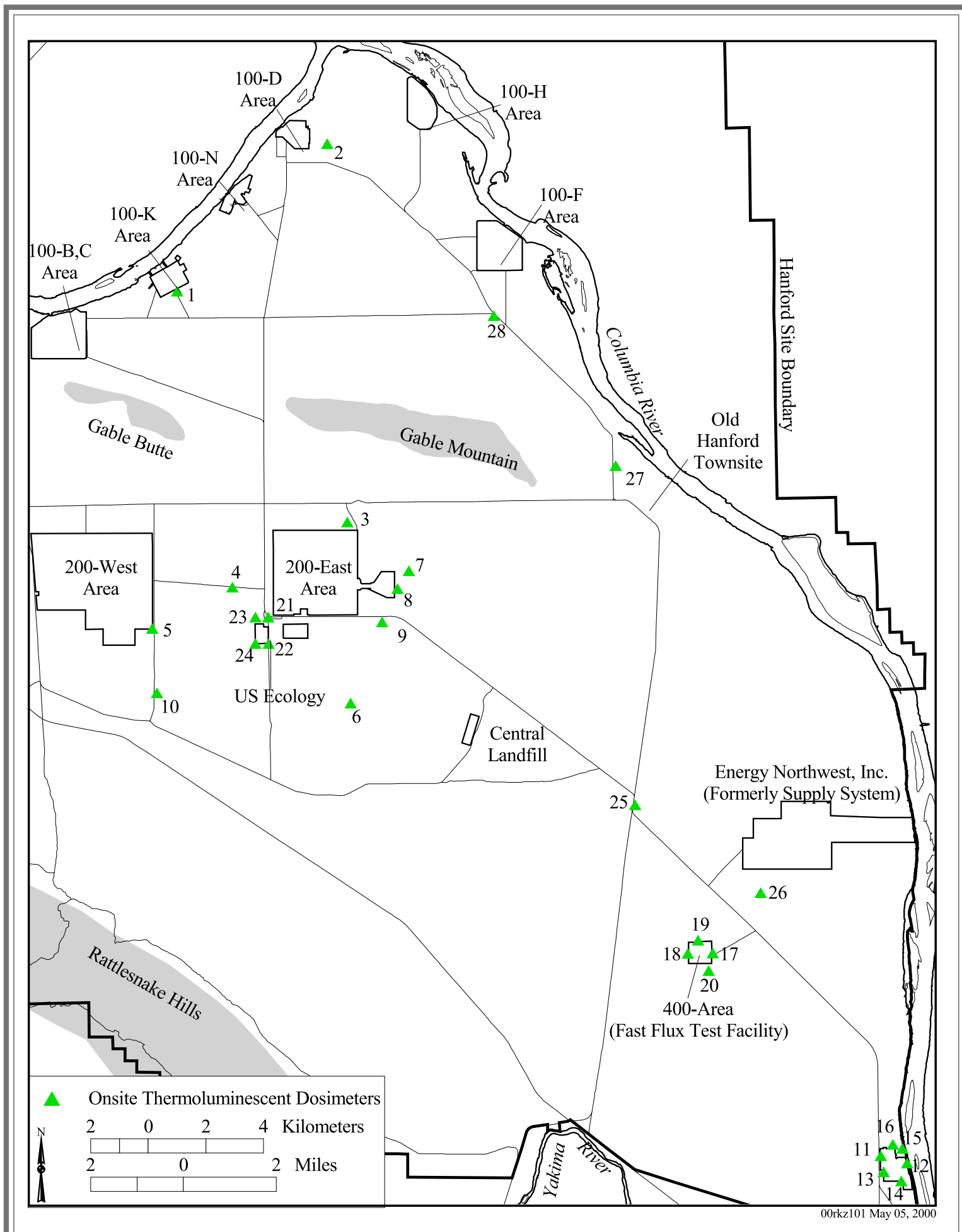

Figure 4.7.1. Thermoluminescent Dosimeter Locations and Station Numbers on the Hanford Site, 1999 


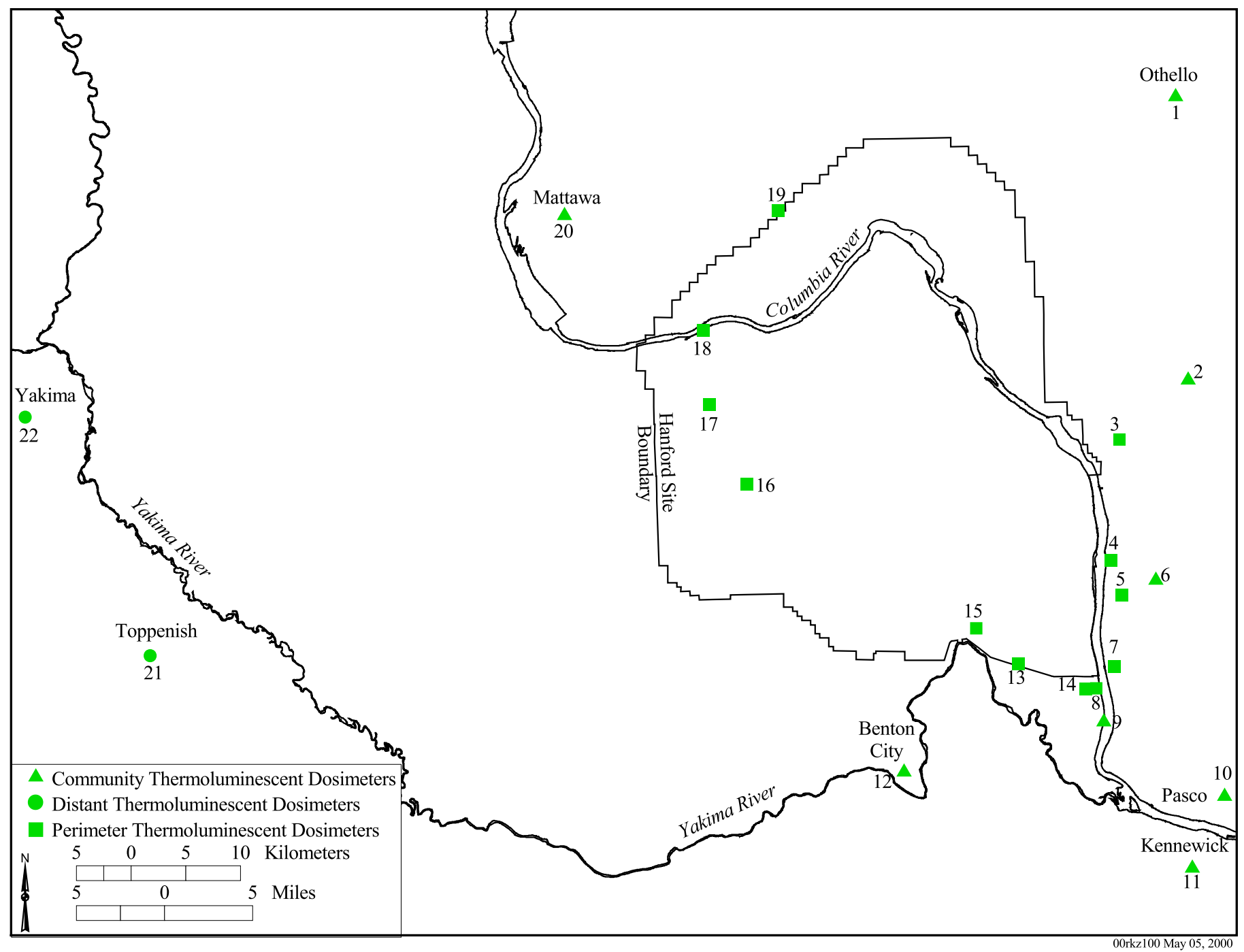

Figure 4.7.2. Thermoluminescent Dosimeter Locations and Station Numbers for Community, Distant, and Perimeter Sites, 1999 


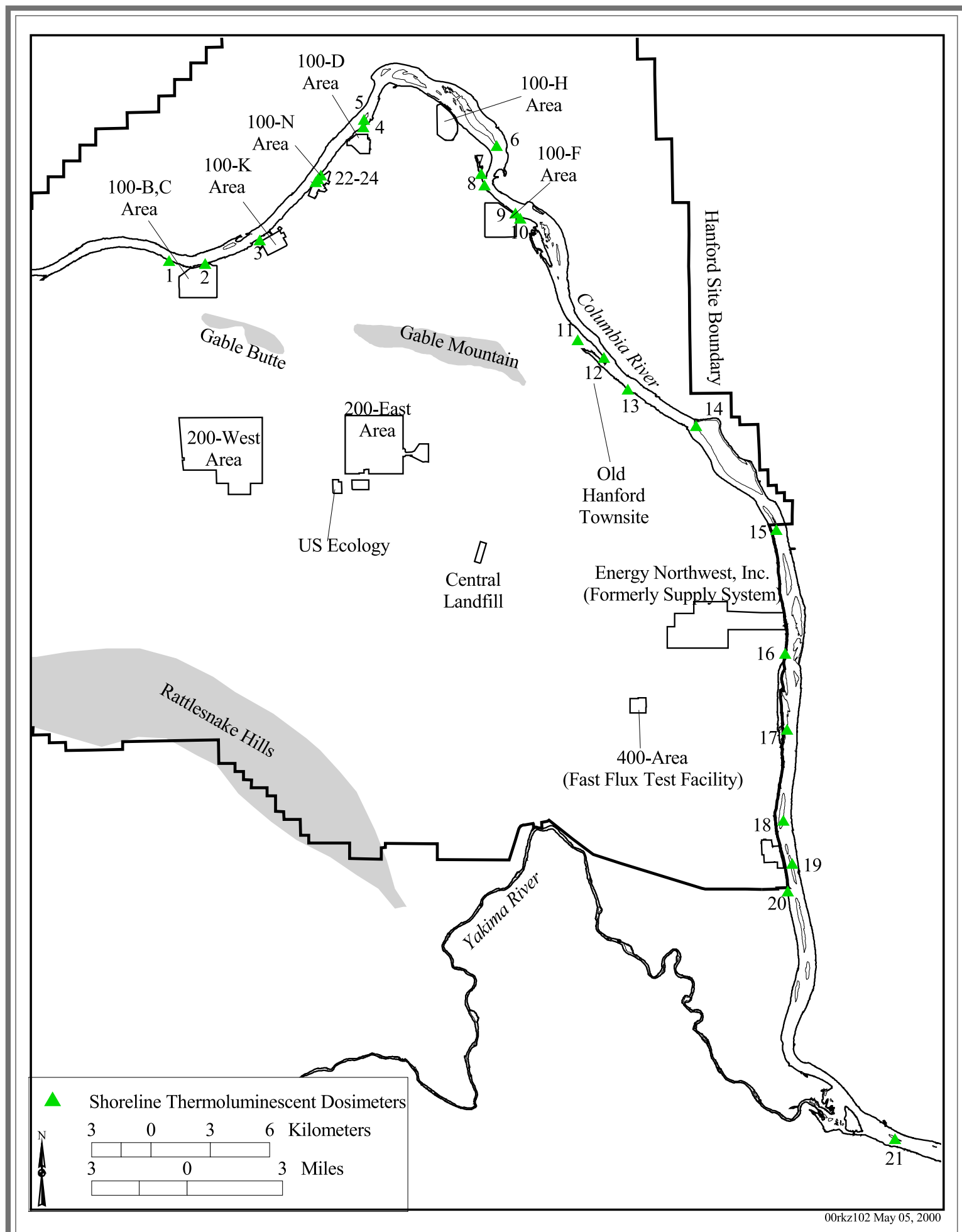

Figure 4.7.3. Thermoluminescent Dosimeter Locations and Station Numbers Along the Columbia River, 1999 


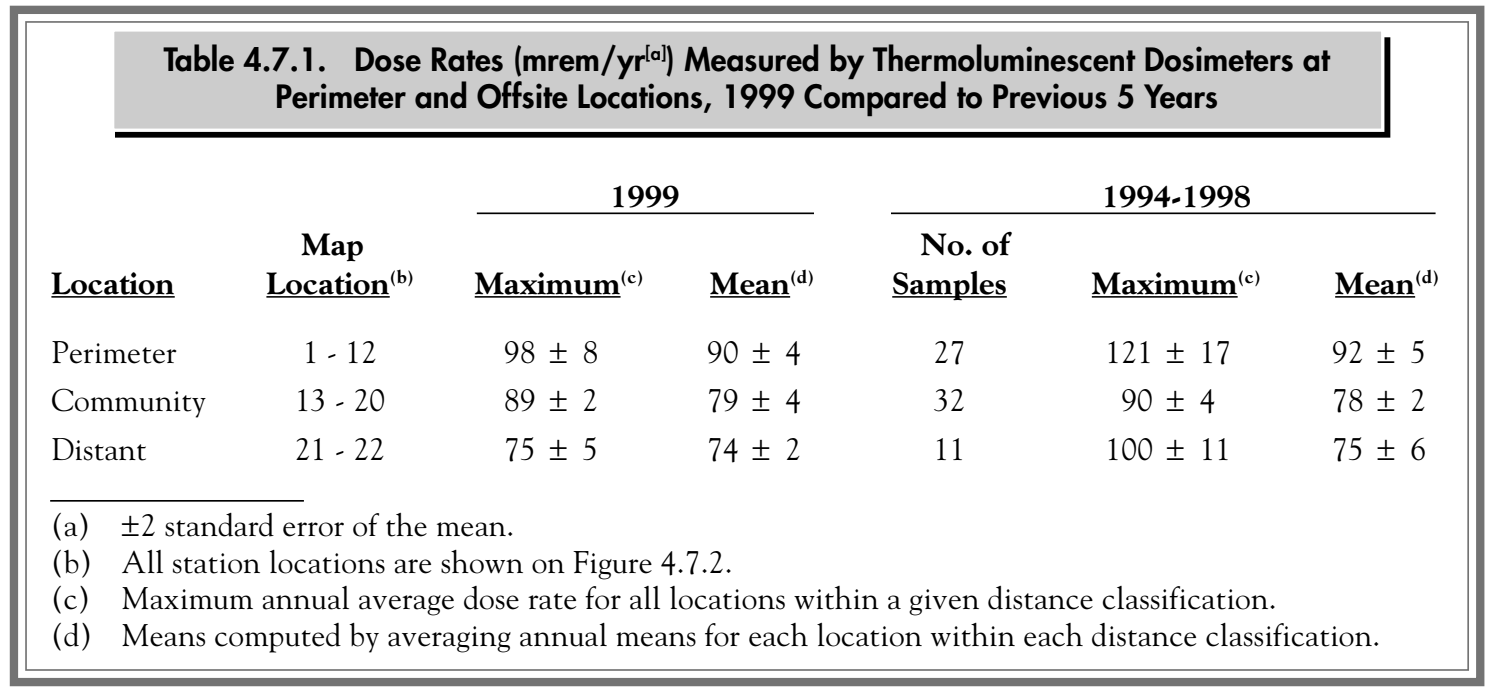

through 4.7.3 include the maximum annual dose rate ( \pm 2 standard deviations) for all locations within a given surveillance zone and the mean dose rate ( \pm 2 standard error of the mean) for each distance class. Locations were classified (or grouped) based on their proximity to the site.

The annual dose rates measured in 1999 are given in Table 4.7.1. The mean perimeter dose rate was $90 \pm 4 \mathrm{mrem} / \mathrm{yr}$; in 1999, the maximum was $98 \pm$ $8 \mathrm{mrem} / \mathrm{yr}$ and the 5 -year perimeter mean dose rate was $92 \pm 5 \mathrm{mrem} / \mathrm{yr}$. The mean background dose rate (measured at distant communities) in 1999, was $74 \pm$ $2 \mathrm{mrem} / \mathrm{yr}$, compared to the previous year's mean of $71 \pm 1 \mathrm{mrem} / \mathrm{yr}$ and the current 5 -year average of 75 $\pm 6 \mathrm{mrem} / \mathrm{yr}$. The variation in dose rates may be partially attributed to changes in natural background radiation that can occur as a result of changes in annual cosmic radiation (up to 10\%) and terrestrial radiation ( $15 \%$ to $25 \%$ ) (National Council on Radiation Protection and Measurements 1987). Other factors possibly affecting the annual dose rates reported here have been described in PNL-7124 and include variations in the sensitivity of individual thermoluminescent dosimeter zero-dose readings, fading, random errors in the readout equipment, and changes in station locations, to name a few. Figure 4.7.4 displays a comparison of dose rates between onsite, perimeter, and distant thermoluminescent dosimeter locations from 1994 through 1999.

Table 4.7.2 provides the measured dose rates for thermoluminescent dosimeters positioned along the Columbia River shoreline. Dose rates were highest along the shoreline near the 100-N Area and were $\sim 1.4$ times the typical shoreline dose rates. The higher dose rates measured along the 100-N Area shoreline have been attributed to past waste management practices in that area (PNL-3127). The 1999 maximum annual shoreline dose rate was $143 \pm$ $5 \mathrm{mrem} / \mathrm{yr}$, which is not significantly different from the maximum of $152 \pm 2 \mathrm{mrem} / \mathrm{yr}$ measured in 1998, but is significantly different than the 5-year maximum of $246 \pm 20 \mathrm{mrem} / \mathrm{yr}$. The 5 -year maximum was measured in 1994 along the $100-\mathrm{N}$ shoreline. The general public does not have legal access to the 100-N Area shoreline but does have access to the adjacent Columbia River. The dose implications associated with this access are discussed in Section 5.0, "Potential Radiological Doses from 1999 Hanford Operations."

Table 4.7.3 summarizes the results of 1999 onsite measurements, which are grouped by operational area. The average dose rates in all operational areas were higher than average dose rates measured at distant locations. The highest average dose rate on 


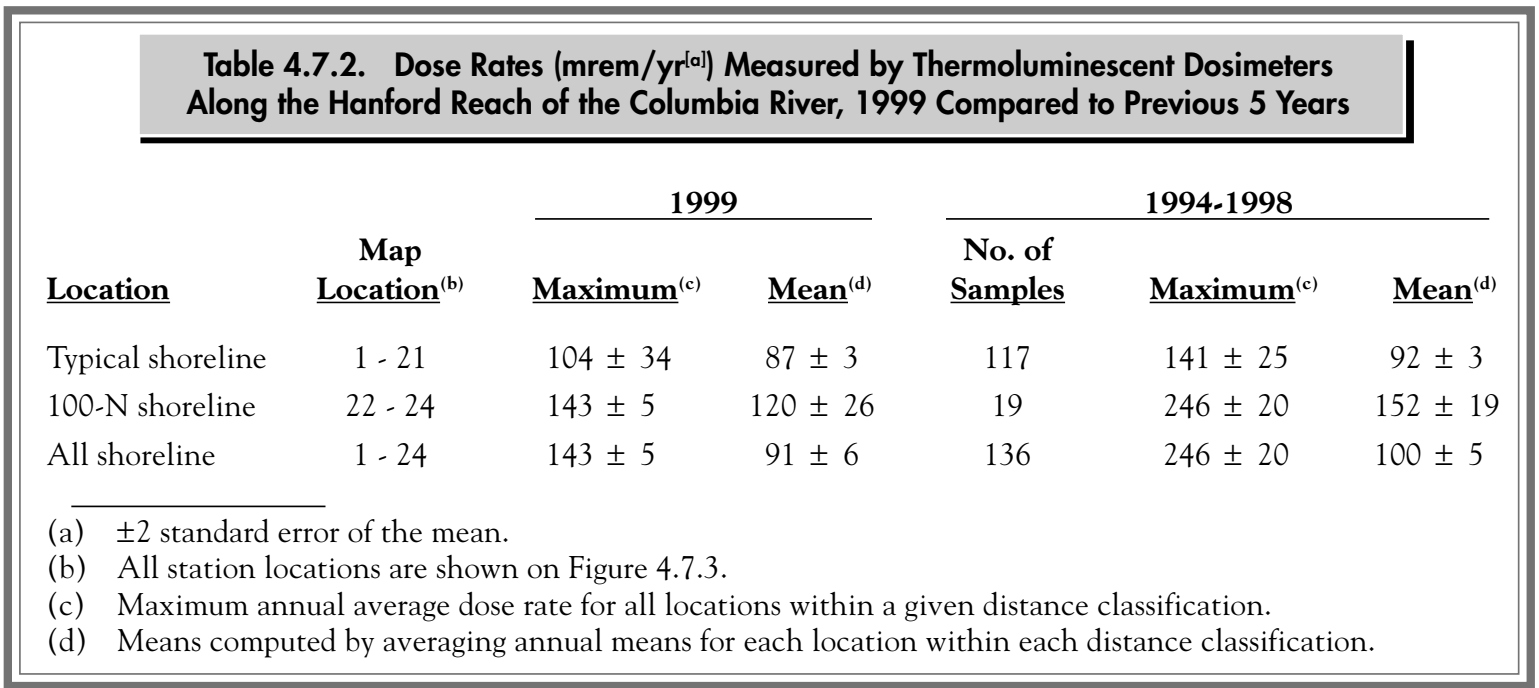

\begin{tabular}{|c|c|c|c|c|c|c|}
\hline \multirow[b]{3}{*}{ Location } & \multicolumn{5}{|c|}{$\begin{array}{l}\text { Dose Rates (mrem/yr }{ }^{[a]} \text { ) Measured by Thermoluminescent Dosimeters } \\
\text { on the Hanford Site, } 1999 \text { Compared to Previous } 5 \text { Years }\end{array}$} & \\
\hline & \multirow[b]{2}{*}{$\begin{array}{l}\text { Map } \\
\text { Location }^{(b)}\end{array}$} & \multicolumn{2}{|c|}{1999} & \multicolumn{3}{|c|}{ 1994-1998 } \\
\hline & & $\underline{\text { Maximum }}^{(\mathrm{c})}$ & $\underline{\text { Mean }}^{(\mathrm{d})}$ & $\begin{array}{c}\text { No. of } \\
\text { Samples }\end{array}$ & $\underline{\text { Maximum }}^{(\mathrm{c})}$ & $\underline{\text { Mean }}^{(\mathrm{d})}$ \\
\hline 100 Areas & $1-2$ & $88 \pm 2$ & $82 \pm 10$ & 10 & $108 \pm 11$ & $84 \pm 8$ \\
\hline 200 Areas & $3-11$ & $98 \pm 3$ & $90 \pm 4$ & 36 & $121 \pm 10$ & $92 \pm 4$ \\
\hline 300 Area & $12-17$ & $89 \pm 4$ & $85 \pm 2$ & 30 & $110 \pm 17$ & $86 \pm 4$ \\
\hline 400 Area & $18-21$ & $89 \pm 4$ & $85 \pm 3$ & 20 & $111 \pm 18$ & $87 \pm 4$ \\
\hline 600 Area & $22-28$ & $128 \pm 11$ & $93 \pm 12$ & 28 & $165 \pm 16$ & $99 \pm 8$ \\
\hline Combined onsite & $1-28$ & $128 \pm 11$ & $88 \pm 3$ & 124 & $165 \pm 16$ & $91 \pm 3$ \\
\hline $\begin{array}{l}\text { (a) } \pm 2 \text { standard } \\
\text { (b) All station } 1 \\
\text { (c) Maximum a } \\
\text { (d) Means comp }\end{array}$ & $\begin{array}{l}\text { ror of the mea } \\
\text { ations are sho } \\
\text { lual average } d \\
\text { ted by averagir }\end{array}$ & $\begin{array}{l}\text { on Figure } 4.7 .1 \\
\text { rate for all loca } \\
\text { annual means } \mathrm{f}\end{array}$ & $\begin{array}{l}\text { ns within } \\
\text { each locati }\end{array}$ & $\begin{array}{l}\text { en distanc } \\
\text { jithin each }\end{array}$ & $\begin{array}{l}\text { Issification. } \\
\text { ance classificati }\end{array}$ & \\
\hline
\end{tabular}

the site $(128 \pm 11 \mathrm{mrem} / \mathrm{yr})$ was seen in the 600 Area and was due to waste disposal activities at US Ecology, Inc., a non-DOE facility. The 5-year maximum onsite dose rate $(165 \pm 16 \mathrm{mrem} / \mathrm{yr})$ was also measured in the 600 Area, also at the US Ecology facility.

\subsubsection{Radiological Survey Results}

In 1999, Geiger counters and Bicron ${ }^{\circledR}$ Microrem meters were used to perform radiological surveys at selected Columbia River shoreline locations. These surveys provide a coarse screening for elevated radiation fields. The surveys showed that radiation levels at the selected locations were comparable to levels 


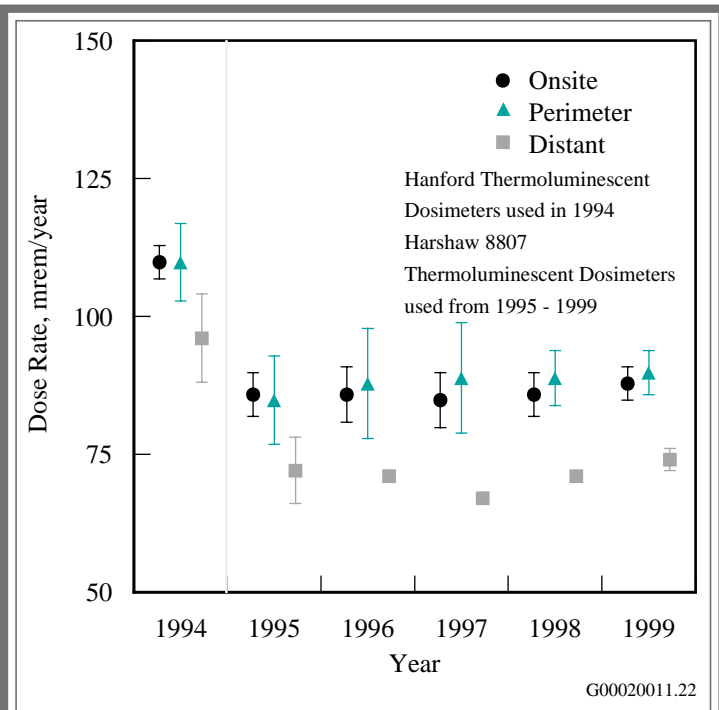

Figure 4.7.4. Annual Average Dose Rates ( \pm 2 standard error of the mean), 1994 Through 1999

observed at the same locations in previous years. The highest dose rate measured with the Bicron ${ }^{\circledR}$ Microrem meter $(20 \mu \mathrm{rem} / \mathrm{h})$ was measured in winter along the 100-N Area shoreline; the lowest dose rate measured was $4 \mu \mathrm{rem} / \mathrm{h}$ and was recorded at other locations in the spring and autumn. The highest reported count rate measured with the Geiger counter in ground level surveys was $100 \mathrm{cpm}$. The lowest ground level count rate (less than $50 \mathrm{cpm}$ ) was recorded at the same location and on the same day that the lowest Bicron ${ }^{\circledR}$ reading was recorded.

Survey data are not included in the 1998 surveillance data (PNNL-13230, APP. 1) but are maintained in the Surface Environmental Surveillance Project files at Pacific Northwest National Laboratory and can be obtained on written request.

Gamma radiation levels in air were continuously monitored in 1999 at four community-operated air monitoring stations (Section 7.4, "CommunityOperated Environmental Surveillance Program"). These stations were located in Leslie Groves Park in Richland, at Edwin Markham Elementary School in north Franklin County, at Basin City Elementary School in Basin City, and at Heritage College in
Toppenish (see Figure 4.1.1) Measurements were collected to determine ambient gamma radiation levels near and downwind of the site and upwind and distant from the site, to display real-time exposure rate information to the public living near the station, and to be an educational aid for the teachers who manage the stations.

Measurements at the Basin City and Edwin Markham Schools were obtained using Reuter-Stokes Model S 1001-EM19 pressurized ionization chambers connected to Reuter-Stokes RSS-112 Radiation Monitoring Systems. Data were collected every 5 seconds; an average reading was calculated and recorded on an electronic data card every 30 seconds. Data cards were exchanged monthly. Readings at the Leslie Groves Park and Heritage College stations were collected every 10 seconds with a Reuter-Stokes Model RSS-121 pressurized ionization chamber, and an average reading was recorded every hour by a flat panel computer system located at the station. Data were obtained monthly from the computer via modem. Data were not collected at every station every month because of problems with the instrument batteries and electrical power. The data collected at each station each month are summarized in Table 4.7.4.

The measurements recorded at Basin City, Edwin Markham, and Leslie Groves Park during the year were similar and at background levels. The readings at Heritage College were also within normal levels, but were, on average, slightly lower than those measured near the Hanford Site.

Generally, monthly exposure rates ranged from a maximum of $33.5 \mu \mathrm{R} / \mathrm{h}$ at Edwin Markham in April to a minimum of $4.8 \mu \mathrm{R} / \mathrm{h}$ at Leslie Groves Park in December (see Table 4.7.4). Median readings at the stations near Hanford were consistently between 8.0 and $8.8 \mu \mathrm{R} / \mathrm{h}$, and readings at the distant station (Heritage College) ranged between 7.8 and $8.1 \mu \mathrm{R} / \mathrm{h}$. These dose rates were consistent with those measured by thermoluminescent dosimeters at these locations (Table 4.7.5). 


\begin{tabular}{|c|c|c|c|c|}
\hline \multicolumn{5}{|c|}{$\begin{array}{l}\text { Table 4.7.5. Quarterly Average Exposure Rates }\left(\mu \mathrm{R} / \mathrm{h}^{[\mathrm{a}]}\right) \text { Measured by Thermoluminescent } \\
\text { Dosimeters at Four Offsite Locations, }{ }^{(b)} 1999\end{array}$} \\
\hline & Leslie Groves Park & Basin City & Edwin Markham & Toppenish \\
\hline \multicolumn{5}{|c|}{ Quarter Ending } \\
\hline March & $8.21 \pm 0.17$ & $8.29 \pm 0.04$ & $8.79 \pm 0.21$ & $8.21 \pm 0.46$ \\
\hline June & $8.17 \pm 0.13$ & $9.13 \pm 0.08$ & $N S^{(c)}$ & $8.92 \pm 0.29$ \\
\hline September & $7.92 \pm 0.21$ & $8.88 \pm 0.08$ & $8.63 \pm 0.04$ & $8.08 \pm 0.21$ \\
\hline December & $8.29 \pm 0.21$ & $9.08 \pm 0.04$ & $8.42 \pm 0.17$ & $8.08 \pm 0.13$ \\
\hline \multicolumn{5}{|c|}{$\begin{array}{l}\text { (a) } \pm 2 \text { standard deviation of the exposure rate. } \\
\text { (b) Sampling locations shown on Figure } 4.1 .1 \text {. } \\
\text { (c) NS = No sample; thermoluminescent dosim }\end{array}$} \\
\hline
\end{tabular}




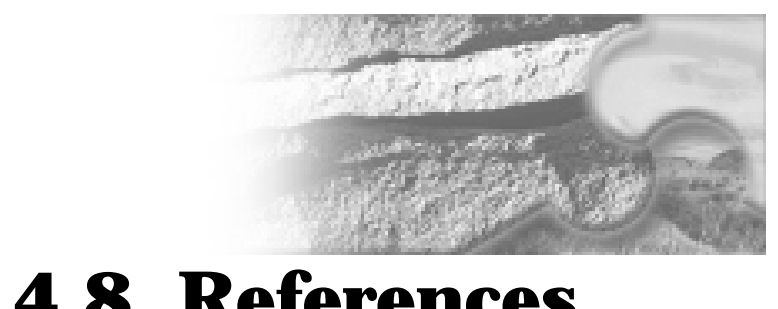

40CFR 141. U.S. Environmental Protection Agency. "National Primary Drinking Water Regulations; Radionuclides; Proposed Rule." Code of Federal Regulations.

American Society for Testing and Materials. 1993. "E 380-93 Standard Practice for Use of the International System of Units (SI) (the Modernized Metric System)." In Annual Book of ASTM Standards. Philadelphia, Pennsylvania.

ARH-CD-775. 1976. Geohydrologic Study of the West Lake Basin. R. E. Gephart, P. A. Eddy, R. C. Arnett, and G. A. Robinson, Atlantic Richfield Hanford Company, Richland, Washington.

Beasley, T. M., L. A. Ball, and J. E. Andrews III. 1981. "Hanford-Derived Plutonium in Columbia River Sediments." Science 214(20):913-915.

BNWL-1979. 1976. Environmental Surveillance at Hanford for CY-1975. D. R. Speer, J. J. Fix, and P. J. Blumer, Pacific Northwest Laboratory, Richland, Washington.

BNWL-2305. 1977. Association of Hanford Origin Radionuclides with Columbia River Sediment. D. E. Robertson and J. J. Fix, Pacific Northwest Laboratory, Richland, Washington.

Clean Water Act. 1997. Public Law 95-217, as amended, 91 Stat. 1566 and Public Law 96-148 as amended.

DeWitt, T. H., R. C. Swartz, D. J. Hansen, D. McGovern, and W. J. Berry. 1996. "Bioavailability and Chronic Toxicity of Cadmium in Sediment to the Estuarine Amphipod Leptocheirus plumulosus." Environmental Toxicology and Chemistry 15(12): 2095-2101.

DOE/EH-0173T. 1991. Environmental Regulatory Guide for Radiological Effluent Monitoring and Environmental Surveillance. U.S. Department of Energy, Washington, D.C.
DOE Order 5400.1. "General Environmental Protection Program."

DOE Order 5400.5. "Radiation Protection of the Public and the Environment."

DOE/RL-91-50, Rev. 2. 1997. Environmental Monitoring Plan, United States Department of Energy Richland Operations Office. U.S. Department of Energy, Richland Operations Office, Richland, Washington.

DOE/RL-92-12. 1992. Sampling and Analysis of 100 Area Springs. U.S. Department of Energy, Richland Operations Office, Richland, Washington.

DOE/RL-92-67. 1992. Final Remedial Investigation/ Feasibility Study - Environmental Assessment Report for the 1100-EM-1 Operable Unit, Hanford. U.S. Department of Energy, Richland Operations Office, Richland, Washington.

DOE/RL-93-94, Rev. 1. 1994. Plan and Schedule for Disposition and Regulatory Compliance for Miscellaneous Streams. U.S. Department of Energy, Richland Operations Office, Richland, Washington.

Eisenbud, M. 1987. Environmental Radioactivity from Natural, Industrial, and Military Sources. Third Edition, Chapter 5, Academic Press, Inc., New York.

EPA-570/9-76-003. 1976. National Interim Primary Drinking Water Regulations. U.S. Environmental Protection Agency, Office of Water Supply, Washington, D.C.

EPA 822-R-96-001. 1996. Drinking Water Regulations and Health Advisories. U.S. Environmental Protection Agency, Office of Water, Washington, D.C. 
Hansen, D. J., W. J. Berry, J. D. Mahony, W. S. Boothman, D. M. Di Toro, D. L. Robson, G. T. Ankley, D. Ma, Q. Yan, and C. E. Pesch. 1996. "Predicting the Toxicity of Metal-Contaminated Field Sediments Using Interstitial Concentration of Metals and Acid-Volatile Sulfide Normalizations." Environmental Toxicology and Chemistry 15(12):2080-2094.

HW-73672. 1962. Dispersion of 300 Area Liquid Effluent in the Columbia River. G. E. Backman, Hanford Atomic Products Operation, General Electric Company, Richland, Washington.

Jenkins, O. P. 1922. Underground Water Supply of the Region About White Bluffs and Hanford. State of Washington Department of Conservation and Development, Olympia, Washington.

National Council on Radiation Protection and Measurements. 1987. Ionizing Radiation Exposure of the Population of the United States. NCRP Report No. 93, Bethesda, Maryland.

National Council on Radiation Protection and Measurements. 1993. Limitation of Exposure to Ionizing Radiation. Report No. 116, Bethesda, Maryland.

Patton, G. W., A. T. Cooper, and M. R. Tinker. 1997. "Ambient Air Sampling for Tritium Determination of Breakthrough Volumes and Collection Efficiencies for Silica Gel Absorbent." Health Physics 72:397-407.

PNL-3127. 1980. Radiological Survey of Exposed Shorelines and Islands of the Columbia River Between Vernita and the Snake River Confluence. M. J. Sula, Pacific Northwest Laboratory, Richland, Washington.

PNL-5289. 1984. Investigation of Ground-Water Seepage from the Hanford Shoreline of the Columbia River. W. D. McCormack and J.M.V. Carlile, Pacific Northwest Laboratory, Richland, Washington.

PNL-6584 (3 vols). 1988. GENII - The Hanford Environmental Radiation Dosimetry Software System. B. A. Napier, R. A. Peloquin, D. L. Strenge, and J. V. Ramsdell, Pacific Northwest Laboratory, Richland, Washington.
PNL-7124. 1989. The Determination of the Penetrating Radiation Dose at Hanford. L. A. Rathbun, Pacific Northwest Laboratory, Richland, Washington.

PNL-7500. 1990. 1988 Hanford Riverbank Springs Characterization Report. R. L. Dirkes Pacific Northwest Laboratory, Richland, Washington.

PNL-7662. 1991. An Evaluation of the Chemical, Radiological, and Ecological Conditions of West Lake on the Hanford Site. T. M. Poston, K. R. Price, and D. R. Newcomer, Pacific Northwest Laboratory, Richland, Washington.

PNL-8073. 1992. Hanford Site Ground-Water Monitoring for 1990. J. C. Evans, R. W. Bryce, and D. J. Bates, Pacific Northwest Laboratory, Richland, Washington.

PNL-8148. 1992. Hanford Site Environmental Report for Calendar Year 1991. R. K. Woodruff, R. W. Hanf, and R. E. Lundgren (eds.), Pacific Northwest Laboratory, Richland, Washington.

PNL-8150. 1992. Methods for Estimating Doses to Organisms from Radioactive Materials Released into the Aquatic Environment. D. A. Baker and J. K. Soldat, Pacific Northwest Laboratory, Richland, Washington.

PNL-8531. 1993. Columbia River Monitoring: Distribution of Tritium in Columbia River Water at the Richland Pumphouse. R. L. Dirkes, Pacific Northwest Laboratory, Richland, Washington.

PNL-8580. 1993. Water Level Measurements for Modeling Hydraulic Properties in the 300-FF-5 and 100 Aggregate Area Operable Units. M. D. Campbell, W. J. McMahon, and K. R. Simpson, Pacific Northwest Laboratory, Richland, Washington.

PNL-8654. 1993. Columbia River Monitoring: Summary of Chemical Monitoring Along Cross Sections at Vernita Bridge and Richland. R. L. Dirkes, G. W. Patton, and B. L. Tiller, Pacific Northwest Laboratory, Richland, Washington. 
PNL-8797. 1993. Radiological Survey of Shoreline Vegetation from the Hanford Reach of the Columbia River, 1990-1992. E. J. Antonio, T. M. Poston, and W. H. Rickard, Jr., Pacific Northwest National Laboratory, Richland, Washington.

PNL-8817. 1993. Contribution of Hanford Liquid Effluents to Strontium-90 Levels in Offsite Soils. R. E. Jaquish, Pacific Northwest Laboratory, Richland, Washington.

PNL-10174. 1994. A Qualitative Evaluation of Radionuclide Concentrations in Hanford Site Wildlife, 1983 through 1992. T. M. Poston and A. T. Cooper, Pacific Northwest Laboratory, Richland, Washington.

PNL-10400. 1995. Identification of Contaminants of Concern, Columbia River Comprehensive Impact Assessment-Draft. B. A. Napier, N. C. Batishko, D. A. Heise-Craff, M. F. Jarvis, and S. F. Snyder, Pacific Northwest Laboratory, Richland, Washington.

PNL-10535. 1995. Environmental Monitoring of Columbia River Sediments: Grain-Size Distribution and Containment Association. M. L. Blanton, W. W. Gardiner, and R. L. Dirkes, Pacific Northwest Laboratory, Richland, Washington.

PNL-10575. 1995. Hanford Site Environmental Data for Calendar Year 1994 - Surface and Columbia River. L. E. Bisping, Pacific Northwest Laboratory, Richland, Washington.

PNL-10698. 1995. Hanford Site Ground-Water Monitoring for 1994. P. E. Dresel, P. D. Thorne, S. P. Luttrell, B. M. Gillespie, W. D. Webber, J. K. Merz, J. T. Rieger, M. A. Chamness, S. K. Wurstner, and B. E. Optiz, Pacific Northwest Laboratory, Richland, Washington.

PNL-10714. 1995. Nonradiological Chemical Pathway Analysis and Identification of Chemicals of Concern for Environmental Monitoring at the Hanford Site. M. L. Blanton, A. T. Cooper, and K. J. Castleton, Pacific Northwest Laboratory, Richland, Washington.
PNNL-11139. 1996. Hanford Site Environmental Report for Calendar Year 1995. R. L. Dirkes and R. W. Hanf (eds.), Pacific Northwest National Laboratory, Richland, Washington.

PNNL-11140. 1995. 1995 Surface Environmental Surveillance Data. L. E. Bisping, Pacific Northwest National Laboratory, Richland, Washington.

PNNL-11473. 1997. Hanford Site Environmental Data for Calendar Year 1996. L. E. Bisping, Pacific Northwest National Laboratory, Richland, Washington.

PNNL-11795. 1998. Hanford Site Environmental Report for Calendar Year 1997. R. L. Dirkes and R. W. Hanf (eds.), Pacific Northwest National Laboratory, Richland, Washington.

PNNL-11796. 1998. Hanford Site Environmental Data for Calendar Year 1997. L. E. Bisping, Pacific Northwest National Laboratory, Richland, Washington.

PNNL-11933. 1998. Survey of Radiological Contaminants in the Near Shore Environment at the Hanford Site 100-N Reactor Area. S. P. Van Verst, C. L. Albin, G. W. Patton, M. L. Blanton, T. M. Poston, A. T. Cooper, and E. J. Antonio, Pacific Northwest National Laboratory, Richland, Washington.

PNNL-12088. 1999. Hanford Site Environmental Report for Calendar Year 1998. R. L. Dirkes, R. W. Hanf, and T. M. Poston (eds.), Pacific Northwest National Laboratory, Richland, Washington.

PNNL-12103. 1999. Hanford Site Environmental Surveillance Master Sampling Schedule. L. E. Bisping, Pacific Northwest National Laboratory, Richland, Washington.

PNNL-13230, APP. 1. 2000. Hanford Site Environmental Surveillance Data Report for Calendar Year 1999. L. E. Bisping, Pacific Northwest National Laboratory, Richland, Washington.

Safe Drinking Water Act. 1974. Public Law 93-523, as amended, 88 Stat. 1660, 42 USC $300 f$ et seq. 
Shleien, B. 1992. The Health Physics and Radiological Health Handbook, Revised Edition. Scinta, Inc., Silver Spring, Maryland.

Skoog, D. A., and D. M. West. 1980. Analytical Chemistry. Third Edition, Saunders Golden Sunburst Series, Philadelphia, Pennsylvania.

U.S. Geological Survey. 1995. Nitrate Concentrations in Ground Water of the Central Columbia Plateau. Open File Report 95-445, U.S. Geological Survey, Tacoma, Washington.

U.S. Geological Survey Circular 1144. "Water Quality in the Central Columbia Plateau, Washington and Idaho, 1992-95.” A. K. Williamson, M. D. Munn, S. J. Ryker, R. J. Wagner, J. C. Ebbert, and A. M. Vanderpool, U.S. Geological Survey, Tacoma, Washington.

WA-94-1. 1995. Water Resources Data, Washington Water Year 1994. W. D. Wiggins, G. P. Ruppert, R. R. Smith, L. L. Reed, L. E. Hubard, and M. L. Courts, U.S. Geological Survey, Tacoma, Washington.

WAC 173-201A. "Water Quality Standards for Surface Waters of the State of Washington." Washington Administrative Code, Olympia, Washington.
WAC 246-290. "Group A Public Water Supplies." Washington Administrative Code, Olympia, Washington.

Wells, D. 1994. Radioactivity in Columbia River Sediments and Their Health Effects. Washington State Department of Health, Olympia, Washington.

WHC-SD-EN-TI-006. 1992. Hydrologic and Geologic Data Available for the Region North of Gable Mountain, Hanford Site, Washington. R. E. Peterson, Westinghouse Hanford Company, Richland, Washington.

Wiggins, W. D., G. P. Ruppert, R. R. Smith, L. L. Reed, L. E. Hubard, and M. L. Courts. 1996. Water Resources Data, Washington Water Year 1995. U.S. Geological Survey, Tacoma, Washington.

Wyerman, T. A., R. K. Farnswirth, and G. L. Stewart. 1970. "Tritium in Streams in the United States, 1961-1968." Radiological Health Data and Reports, pp. 421-429. 


\title{
5.0 Potential Radiological Doses from 1999 Hanford Operations
}

\author{
E. J. A ntonio and K. Rhoads
}

During 1999, radionuclides reached the environment in gaseous and liquid effluents from Hanford Site operations. Gaseous effluents were released from operating stacks and ventilation exhausts. Other potential sources include fugitive emissions from contaminated soil areas and other facilities. Liquid effluents were released from operating wastewater treatment facilities and from contaminated groundwater seeping into the Columbia River.

Potential radiological doses to the public from these releases were evaluated in detail to determine compliance with pertinent regulations and limits. Dose calculation methodology is discussed in Appendix D. The radiological impact of 1999 Hanford operations was assessed in terms of the following:

- dose to a hypothetical, maximally exposed individual at an offsite location

- maximum dose rate from external radiation at a publicly accessible location on or within the site boundary

- dose to an avid sportsman who consumes wildlife that may have acquired contamination from radionuclides on the site

- total dose to the population residing within 80 kilometers (50 miles) of the Hanford operating areas

- absorbed dose rate ( $\mathrm{rad} / \mathrm{d})$ received by animals caused by radionuclide releases to the Columbia River.

It is generally accepted that radiological dose assessments should be based on direct measurements of radiation dose rates and radionuclide concentrations in the surrounding environment. However, the amounts of most radioactive materials released during 1999 from Hanford sources were generally too small to be measured directly once they were dispersed in the offsite environment. For many of the measurable radionuclides, it was difficult to identify the contributions from Hanford sources in the presence of contributions from worldwide fallout and from naturally occurring uranium and its decay products. Therefore, in nearly all instances, offsite doses were estimated using the Generation II (GENII) computer code Version 1.485 (PNL-6584) and Hanford Site-specific parameters listed in Appendix D and in PNNL-12088, APP. 1 to calculate levels of radioactive materials in the environment from effluent releases reported by the operating contractors.

As in the past, radiological doses from the water pathway were calculated based on the differences in radionuclide concentrations between upstream and downstream sampling points. During 1999, only tritium and iodine-129 were found in the Columbia River downstream of Hanford at greater levels than predicted based on direct discharges from the 100 Areas. All other radionuclide concentrations were lower than those predicted from known releases. Riverbank spring water, containing these radionuclides, is known to enter the river along the portion of shoreline extending from the Old Hanford Townsite downstream to the 300 Area (see Section 4.2, "Surface Water and Sediment Surveillance" and Section 6.1, "Hanford Groundwater Monitoring Project"). No direct discharges of radioactive materials from the 300 Area to the Columbia River were reported in 1999. 
The national average radiological dose ${ }^{(a)}$ from natural sources is $\sim 300 \mathrm{mrem} / \mathrm{yr}$ ( $3 \mathrm{mSv} / \mathrm{yr}$ ) (National Council on Radiation Protection and Measurements 1987). The estimated dose to the maximally exposed, offsite individual from Hanford Site operations in 1999 was $0.008 \mathrm{mrem}\left(8 \times 10^{-5} \mathrm{mSv}\right)$ compared to 0.02 mrem $\left(2 \times 10^{-4} \mathrm{mSv}\right)$ reported for 1998. This 0.008 mrem was comprised of 0.006 mrem from the air pathway and $0.002 \mathrm{mrem}$ from the water pathway, based on GENII calculations. The dose $(0.25$ personrem $[0.0025$ person-Sv]) to the local population of 380,000 (PNL-7803) from 1999 operations was slightly higher than the 0.2 person-rem reported in 1998 (Section 5.0 in PNNL-12088). The 1999 average dose to the population was $\sim 0.0007 \mathrm{mrem}$ $\left(7 \times 10^{-6} \mathrm{mSv}\right)$ per person, slightly higher than in 1998. The current U.S. Department of Energy (DOE) radiological dose limit (DOE Order 5400.5) for an individual member of the public is $100 \mathrm{mrem} / \mathrm{yr}$ $(1 \mathrm{mSv} / \mathrm{yr})$ from all pathways. This includes the U.S. Environmental Protection Agency's (EPA's) limit of $10 \mathrm{mrem} / \mathrm{yr}(0.1 \mathrm{mSv} / \mathrm{yr})$ from airborne radionuclide emissions (40 CFR 61). Thus, 1999 Hanford emissions potentially contributed to the maximally exposed individual a dose equivalent to only $0.008 \%$ of the DOE limit, $0.06 \%$ of the EPA limit air pathway only, or $0.002 \%$ of the average dose received from natural radioactivity in the environment. For the average member of the local population, these contributions were $\sim 0.0005 \%$, $0.005 \%$, and $0.0002 \%$, respectively.

The uncertainty associated with the radiological dose calculations on which this report is based has not been quantified. However, when Hanfordspecific data were not available for parameter values (e.g., vegetation uptake and consumption factors), conservative values were selected from the literature for use in environmental transport models. Thus, radiological doses calculated using environmental models should be viewed as hypothetical maximum estimates of doses resulting from Hanford operations.

\subsubsection{Maximally Exposed Individual Dose}

The maximally exposed individual is a hypothetical person who lives at a location and has a lifestyle such that it is unlikely that other members of the public would receive a higher radiological dose. This individual's diet, dwelling place, and other factors were chosen to maximize the combined doses from all reasonable environmental pathways of exposure to radionuclides in Hanford Site effluents. In reality, such a combination of maximized parameters is highly unlikely to apply to any single individual.

The hypothetical location of the maximally exposed individual can vary from year to year, depending on the relative contributions of the several sources of radioactive effluents released to the air and to the Columbia River from Hanford facilities. Historically, two separate locations have been used to assess the dose to the maximally exposed individual: 1) the Ringold area, 26 kilometers (16 miles) east of separations facilities in the 200 Areas and 2) the Riverview area across the river from Richland (Figure 5.0.1). The Ringold area is closer than Riverview to Hanford facilities that historically were major contributors of airborne effluents. At Riverview, the maximally exposed individual has the highest exposure to radionuclides in the Columbia River.

Since 1993, a third location across the Columbia River from the 300 Area has been considered. Because of the shift in site operations from strategic materials production to the current mission of developing waste treatment and disposal technologies and cleaning up contamination, the significance of the air emissions from the production facilities in the

(a) Unless stated otherwise, the term "dose" in this section is the "total effective dose equivalent" (see Appendix B, "Glossary"). 


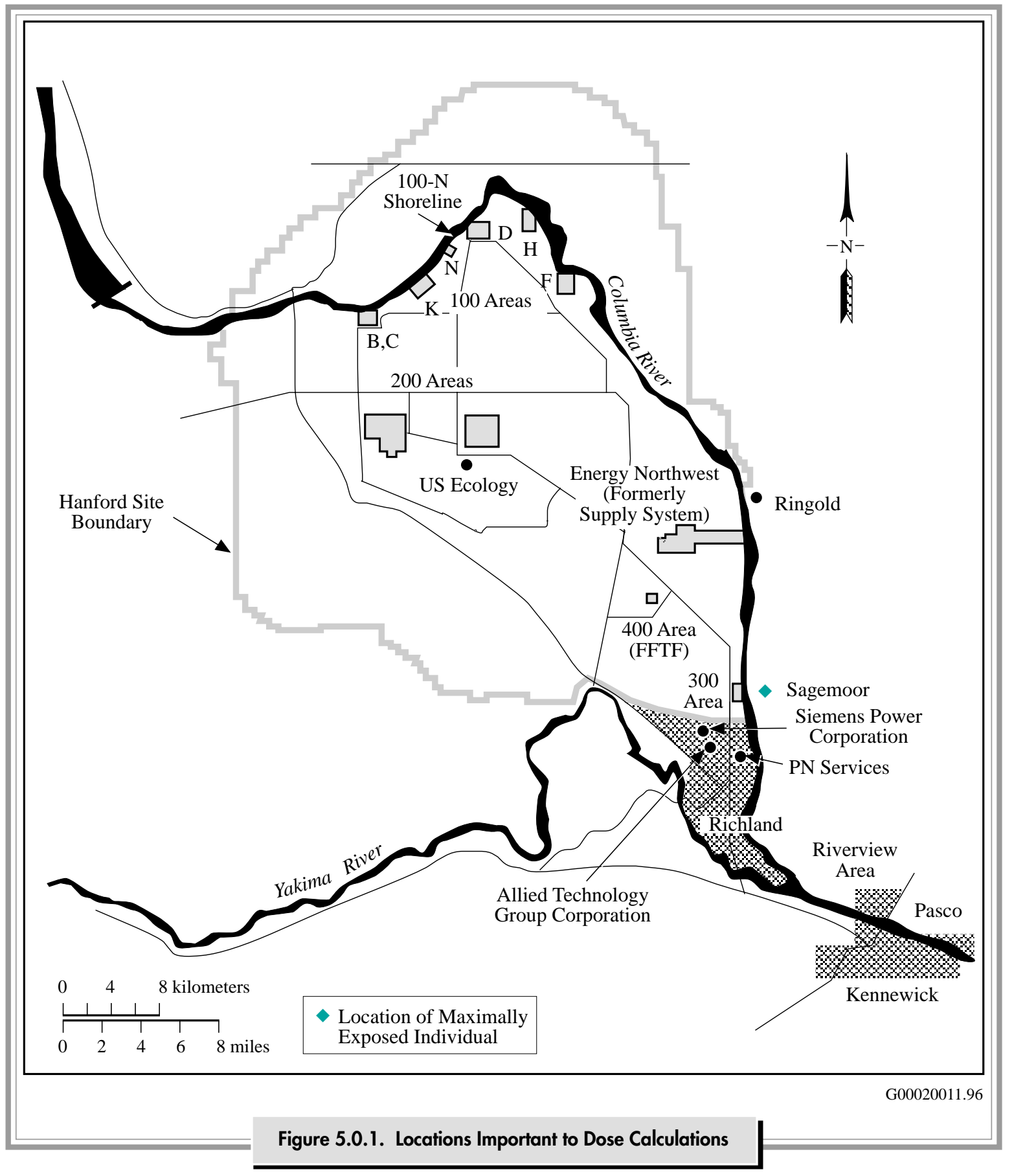

200 Areas has decreased relative to those from the 300 Area. Therefore, a receptor directly across the river from the 300 Area, at Sagemoor, would be maximally exposed to airborne radionuclides from those facilities. The applicable exposure pathways for each of these locations are described below.
The Ringold area is situated to maximize air pathway exposures from emissions in the 200 Areas, including direct exposure to the plume, inhalation, external exposure to radionuclides that deposit on the ground, and ingestion of locally grown food products. In addition, it is assumed that individuals 
at Ringold irrigate their crops with water taken from the Columbia River downstream of where groundwater enters the river from the 100 and 200-East Areas (discussed in Section 6.1, "Hanford Groundwater Monitoring Project"). This results in additional exposures from ingestion of irrigated food products and external irradiation from radionuclides deposited on the ground by irrigation. Recreational use of the Columbia River is also considered for this individual, resulting in direct exposure from water and radionuclides deposited on the shoreline and internal dose from ingestion of locally caught fish.

The Riverview area receptor is assumed to be exposed via the same pathways as the individual at Ringold, except that irrigation water from the Columbia River may contain radionuclides that enter the river at the 300 Area, in addition to those from upstream release points. This individual is also assumed to obtain domestic water from the river via a local water treatment system. Exposure of this individual from the air pathway is typically lower than exposure at Ringold because of the greater distance from the major, onsite, air emission sources.

The individual at Sagemoor, assumed to be located 1.5 kilometer (1 mile) directly across the Columbia River from the 300 Area, receives the maximum exposure to airborne effluents from the 300 Area, including the same pathways as the individual at Ringold. Domestic water at this location comes from a well rather than from the river, and wells in this region are not contaminated by radionuclides of Hanford origin (EPS-87-367A). Although the farms located across from the 300 Area obtain irrigation water from upstream of the Hanford Site, the conservative assumption was made that the diet of the maximally exposed individual residing 1.5 kilometer (1 mile) east of the 300 Area consisted totally of foods purchased from the Riverview area, which could contain radionuclides present in both liquid and gaseous effluents. The added contribution of radionuclides in the Riverview irrigation water maximizes the calculated dose from the air and water pathways combined.

The 1999 hypothetical, maximally exposed individual at Sagemoor was calculated to have received a slightly higher dose $(0.008 \mathrm{mrem} / \mathrm{yr})$ than the maximally exposed individual located at either Ringold ( $0.005 \mathrm{mrem} / \mathrm{yr}$ ) or Riverview ( $0.007 \mathrm{mrem} / \mathrm{yr})$. Radiological doses to the maximally exposed individual were calculated using the effluent data in Tables 3.1.1 and 3.1.4. Quantities of radionuclides assumed to be present in the Columbia River from riverbank springs were also calculated for input to the GENII code. The estimated releases to the river from these sources were derived from the difference between the upstream and downstream activities. These radionuclides were assumed to enter the river through groundwater seeps between the Old Hanford Townsite and the 300 Area.

The calculated doses for the hypothetical, maximally exposed individual (at Sagemoor) in 1999 are summarized in Table 5.0.1. These values include the doses received from exposure to liquid and airborne effluents during 1999, as well as the future, or committed dose from radionuclides that were inhaled or ingested during 1999. As releases from facilities and the doses from these sources decrease, the contribution of diffuse sources such as wind-blown contaminated soil becomes relatively more significant. An upper estimate of the dose from diffuse sources is discussed in Section 5.0.3, "Comparison with Clean Air Act Standards." The estimated dose from diffuse sources was similar to the dose reported in Table 5.0.1 for measured emissions. Site-specific parameters for food pathways, diet, and recreational activity used for the dose calculations are contained in Appendix D (Tables D.1, D.2, and D.4, respectively).

The total radiological dose to the hypothetical, maximally exposed, offsite individual in 1999 was 


\begin{tabular}{|c|c|c|c|c|c|c|}
\hline \multirow[b]{3}{*}{ Effluent } & \multicolumn{5}{|c|}{$\begin{array}{c}\text { Table 5.0.1. Dose to the Hypothetical, Maximally Exposed Individual Residing a } \\
\text { Sagemoor from } 1999 \text { Hanford Operations }\end{array}$} & \\
\hline & \multirow[b]{2}{*}{ Pathway } & \multicolumn{5}{|c|}{ Dose Contributions from 0 perating A reas, mrem } \\
\hline & & $\begin{array}{l}100 \\
\text { A reas }\end{array}$ & $\begin{array}{l}200 \\
\text { Areas }\end{array}$ & $\begin{array}{l}300 \\
\text { Area }\end{array}$ & $\begin{array}{l}400 \\
\text { Area }\end{array}$ & $\begin{array}{l}\text { Pathway } \\
\text { Total }\end{array}$ \\
\hline \multirow[t]{2}{*}{ Air } & $\begin{array}{l}\text { External } \\
\text { Inhalation } \\
\text { Foods }\end{array}$ & $\begin{array}{l}5.3 \times 10^{-9} \\
2.4 \times 10^{-6} \\
6.0 \times 10^{-8}\end{array}$ & $\begin{array}{l}5.2 \times 10^{-8} \\
2.8 \times 10^{-4} \\
2.3 \times 10^{-5}\end{array}$ & $\begin{array}{l}1.9 \times 10^{-8} \\
2.8 \times 10^{-3} \\
2.7 \times 10^{-3}\end{array}$ & $\begin{array}{l}6.2 \times 10^{-9} \\
5.3 \times 10^{-6} \\
9.7 \times 10^{-6}\end{array}$ & $\begin{array}{l}8.3 \times 10^{-8} \\
3.1 \times 10^{-3} \\
2.7 \times 10^{-3}\end{array}$ \\
\hline & Subtotal air & $2.5 \times 10^{-6}$ & $3.0 \times 10^{-4}$ & $5.5 \times 10^{-3}$ & $1.5 \times 10^{-5}$ & $5.8 \times 10^{-3}$ \\
\hline Water & $\begin{array}{l}\text { Recreation } \\
\text { Foods } \\
\text { Fish } \\
\text { Drinking water } \\
\text { Subtotal water }\end{array}$ & $\begin{array}{l}3.4 \times 10^{-7} \\
1.7 \times 10^{-4} \\
1.4 \times 10^{-4} \\
0.0 \\
3.1 \times 10^{-4}\end{array}$ & $\begin{array}{l}3.7 \times 10^{-6} \\
1.7 \times 10^{-3} \\
1.1 \times 10^{-4} \\
0.0 \\
1.8 \times 10^{-3}\end{array}$ & $\begin{array}{l}0.0^{(a)} \\
0.0 \\
0.0 \\
0.0 \\
0.0\end{array}$ & $\begin{array}{l}0.0 \\
0.0 \\
0.0 \\
0.0 \\
0.0\end{array}$ & $\begin{array}{l}4.0 \times 10^{-6} \\
1.9 \times 10^{-3} \\
2.5 \times 10^{-4} \\
0.0 \\
2.1 \times 10^{-3}\end{array}$ \\
\hline \multicolumn{2}{|c|}{ Combined total } & $3.1 \times 10^{-4}$ & $2.1 \times 10^{-3}$ & $5.5 \times 10^{-3}$ & $1.5 \times 10^{-5}$ & $7.9 \times 10^{-3}$ \\
\hline
\end{tabular}

calculated to be $0.008 \mathrm{mrem}\left(8 \times 10^{-5} \mathrm{mSv}\right) \mathrm{com}$ pared to $0.02 \mathrm{mrem}\left(2 \times 10^{-4} \mathrm{mSv}\right)$ calculated for 1998. The primary pathways contributing to this dose (and the percentage of all pathways) were the following:

- consumption of foods grown downwind of the 300 Area (99\%), principally tritium emissions to air from the 300 and 400 Areas

- consumption of food irrigated with Columbia River water or fish from the Columbia River (80\%), principally tritium.

The DOE radiological dose limit for any member of the public from all routine DOE operations is
$100 \mathrm{mrem} / \mathrm{yr}(1 \mathrm{mSv} / \mathrm{yr})$ (DOE Order 5400.5). The dose calculated for the maximally exposed individual for 1999 was $0.008 \%$ of the DOE limit. Thus, the Hanford Site was in compliance with applicable federal and state regulations.

The doses from Hanford operations for the maximally exposed individual for 1994 through 1999 are illustrated in Figure 5.0.2. During each year, the doses were estimated using methods and computer codes previously described. In 1992, the maximally exposed individual was located at Riverview. For 1993 through 1999, the hypothetical, maximally exposed individual was located across the Columbia River from the 300 Area at Sagemoor.

\subsubsection{Special Case Exposure Scenarios}

The parameters used to calculate dose to the maximally exposed individual were selected to describe a scenario that would yield a high exposure scenario, that scenario is unlikely to occur. The parameters used yield a dose that is an upper end (or bounding) estimate of the dose to the hypothetical maximally exposed individual. However, such a scenario does not necessarily result in the highest conceivable radiological dose. Other low-probability exposure scenarios exist that could result in somewhat higher doses. Three scenarios that could potentially lead to larger doses include 1) an individual who would spend time at the site boundary location with the maximum external radiological dose rate, 


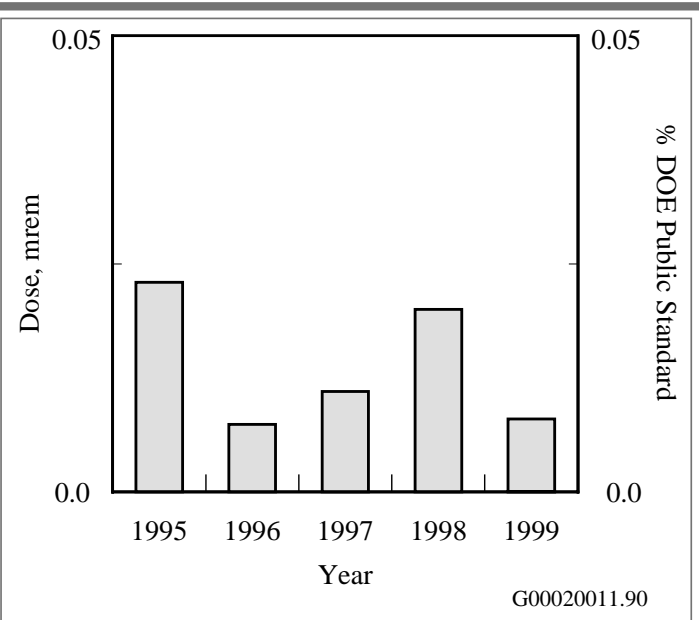

Figure 5.0.2. Calculated Dose to the Hypothetical, Maximally Exposed Individual, 1995 Through 1999

2) a sportsman who might consume contaminated wildlife that migrated from the site, and 3) a consumer of drinking water at the Fast Flux Test Facility in the 400 Area.

\subsubsection{Maximum "Boundary" D ose Rate}

The boundary radiological dose rate is the external radiological dose rate measured at publicly accessible locations on or near the site. The boundary dose rate was determined from radiation exposure measurements using thermoluminescent dosimeters at locations of expected elevated dose rates on the site and at representative locations off the site. These boundary dose rates should not be used to calculate annual doses to the general public because no one can actually reside at any of these boundary locations. However, these rates can be used to determine the dose to a specific individual who might spend some time at that location.

External radiological dose rates measured in the vicinity of the 100-N, 200, 300, and 400 Areas are described in Section 4.7, "External Radiation Surveillance." Results for the 200 Areas were not used because these locations are not accessible to the public. Radiation measurements made at the 100-N Area shoreline (see Figure 5.0.1) were consistently above the background level and represent the highest measured boundary dose rates. The Columbia River provides public access to an area within $\sim 100$ meters (330 feet) of the N Reactor and supporting facilities.

The dose rate at the location with the highest exposure rate along the $100-\mathrm{N}$ Area shoreline during 1999 was $0.02 \mathrm{mrem} / \mathrm{h}\left(2 \times 10^{-4} \mathrm{mSv} / \mathrm{h}\right)$, or approximately twice the average background dose rate of $0.01 \mathrm{mrem} / \mathrm{h}\left(1 \times 10^{-4} \mathrm{mSv} / \mathrm{h}\right)$ normally observed at other shoreline locations. Therefore, for every hour someone spent at the 100-N Area shoreline during 1999, the external radiological dose received from Hanford operations would be approximately $0.01 \mathrm{mrem}\left(1 \times 10^{-4} \mathrm{mSv}\right)$ above the natural background dose. If an individual spent 1 hour at this location, a dose would be received that is higher than the annual dose calculated for the hypothetical, maximally exposed individual at Sagemoor. The public can approach the shoreline by boat but they are legally restricted from stepping onto the shoreline. Therefore, an individual is unlikely to remain on or near the shoreline for an extended period of time.

\subsubsection{Sportsman Dose}

Wildlife have access to areas of the Hanford Site that contain radioactive materials, and some do become contaminated. Sometimes wildlife migrate off the site. Sampling is conducted on the site to estimate the maximum contamination levels that might possibly exist in animals hunted off the site. Because this scenario has a relatively low probability of occurrence, these radiological doses are not included in the maximally exposed individual calculation.

Radionuclide concentrations in most consumable portions of wildlife obtained within the Hanford Site boundary were below contractual detection limits (see Section 4.5, "Fish and Wildlife Surveillance") for gamma-emitting radionuclides, except 
for primordial potassium-40. Cesium-137 was the only radionuclide, possibly of Hanford origin, observed in edible tissue of wildlife in 1999. One rabbit had measurable cesium-137 (0.051 pCi/g) and one goose had measurable cesium-137 (0.047 pCi/g). Although bone is not normally consumed, several wildlife samples collected contained measurable amounts of strontium-90 and one elk sample had measurable uranium in the bone tissue. Because bone is not consumed, a dose estimate to a sportsman is not viewed as necessary.

The method to determine doses from consumption of wildlife was to multiply the maximum concentration measured in tissue by a dose conversion factor for ingestion of that flesh, which is addressed in more detail in PNL-7539. Listed below are estimates of the radiological doses that could have resulted if wildlife containing cesium-137 were hunted and consumed.

- The radiological dose from eating 1 kilogram (2.2 pounds) of jackrabbit that contains the maximum cesium-137 concentration $(0.051 \mathrm{pCi} / \mathrm{g})$ measured in any rabbit samples collected from within the Hanford Site boundary in 1999 is estimated to be $3 \times 10^{-3} \mathrm{mrem}$ (3 x 10-5 $\mathrm{mSv})$.

- The radiological dose from eating 1 kilogram (2.2 pounds) of Western Canada Goose flesh that contains the maximum cesium-137 activity $(0.047 \mathrm{pCi} / \mathrm{g})$ measured in Canada Goose samples collected from within the Hanford Site boundary in 1999 is estimated to be $2 \mathrm{x}$ $10^{-3} \mathrm{mrem}\left(2 \times 10^{-5} \mathrm{mSv}\right)$.

Doses to sportsmen from consuming onsite game animals harvested for surveillance purposes in
1999 are very low and are comparable to the maximally exposed individual dose. For example, if a sportsman could consume 3 kilograms (6.6 pounds) of rabbit flesh or 4 kilograms (8.8 pounds) of Western Canada Goose flesh, with the highest concentration of cesium-137 detected in 1999 samples, then he, or she, could obtain a radiological dose comparable to the dose the hypothetical maximally exposed individual receives from all pathways. Cesium-137 was not detected in any fish or elk sample collected in 1999.

\subsubsection{Fast Flux Test Facility Drinking Water}

During 1999, groundwater was used as drinking water by workers at the Fast Flux Test Facility in the 400 Area. Therefore, this water was sampled and analyzed throughout the year in accordance with applicable drinking water regulations (40 CFR 61). All annual average radionuclide concentrations measured during 1999 were well below applicable drinking water standards, but tritium was detected at levels greater than typical background values (see Section 4.3, "Radiological Surveillance of Hanford Site Drinking Water," and Appendix D). Based on the measured groundwater well concentrations, the potential dose to Fast Flux Test Facility workers (an estimate derived by assuming a consumption of 1 liter per day [0.26 gallon per day] for 240 working days) would be $\sim 0.02 \mathrm{mrem}(0.0002 \mathrm{mSv})$. Although the hypothetical Fast Flux Test Facility worker would receive a slightly higher dose than the 1999 offsite maximally exposed individual, the dose is well below the drinking water dose limit of $4 \mathrm{mrem}$ for public drinking water supplies.

\subsubsection{Comparison with Clean Air Act Standards}

Limits for radiation dose to the public from airborne radionuclide emissions at DOE facilities are provided in 40 CFR 61, Subpart H. The regulation specifies that no member of the public shall receive a dose of greater than $10 \mathrm{mrem} / \mathrm{yr}(0.1 \mathrm{mSv} / \mathrm{yr})$ from exposure to airborne radionuclide effluents, other than radon, released at DOE facilities (EPA520/ 1-89-005). The regulation also requires that each 
DOE facility submit an annual report that supplies information about atmospheric emissions for the preceding year and their potential offsite impacts. The following summarizes information that is provided in more detail in the 1999 air emissions report (DOE/ RL-2000-37).

The 1999 air emissions from monitored Hanford Site facilities resulted in a potential dose to a maximally exposed individual at Sagemoor of $0.029 \mathrm{mrem}$ $\left(2.9 \times 10^{-4} \mathrm{mSv}\right)$, which represents less than $0.3 \%$ of the standard. The $\mathrm{C}$ lean $\mathrm{A}$ ir $\mathrm{A}$ ct requires the use of CAP-88 (EPA-402-B-92-001) or otherEPA-approved models to demonstrate compliance with the standard, and the assumptions embodied in these codes differ slightly from standard assumptions used at Hanford for reporting to DOE via this report. Nevertheless, the result of calculations performed with CAP88-PC for air emissions from Hanford Site facilities agrees well with doses calculated for this report using the GENII code (for air pathways).

The December 15, 1989, revisions to the Clean $A$ ir A ct (40 CFR 61, Subpart H) require DOE facilities to estimate the dose to a member of the public for radionuclides released from all potential sources of airborne radionuclides. DOE and EPA have interpreted the regulation to include diffuse and unmonitored sources as well as monitored point sources. EPA has not specified or approved methods to estimate emissions from diffuse sources, and standardization is difficult because of the wide variety of such sources at DOE sites. Estimates of potential diffuse source emissions at Hanford were developed using environmental surveillance measurements of airborne radionuclides at the site perimeter.

During 1999, the estimated dose from diffuse sources to the maximally exposed individual at Sagemoor was $0.04 \mathrm{mrem}\left(4 \times 10^{-4} \mathrm{mSv}\right)$, which was greater than the estimated dose at that location from stack emissions (0.029 mrem, or $2.9 \times 10^{-4} \mathrm{mSv}$ ). Doses at other locations around the Hanford perimeter ranged from 0.02 to $0.05 \mathrm{mrem}\left(2 \times 10^{-5}\right.$ to $5 \times 10^{-4} \mathrm{mSv}$ ). Based on these results, the combined dose from stack emissions and diffuse and unmonitored sources during 1999 was well below the EPA standard.

\subsubsection{Collective Dose to the Population Within 80 Kilometers (50 Miles)}

Exposure pathways for the general public from releases of radionuclides to the atmosphere include inhalation, air submersion, and consumption of contaminated food. Pathways of exposure for radionuclides present in the Columbia River include consumption of drinking water, fish, and irrigated foods and external exposure during aquatic recreation. The regional collective dose from 1999 Hanford Site operations was estimated by calculating the radiological dose to the population residing within an 80-kilometer (50-mile) radius of the onsite operating areas. Results of the dose calculations are shown in Table 5.0.2. Food pathway, dietary, residency, and recreational activity assumptions for these calculations are given in Appendix D (Tables D.1 through D.4).
The collective dose calculated for the population was 0.25 person-rem ( 0.0025 person-Sv) in 1999 , and increased slightly from the 1998 population dose. The 80-kilometer (50-mile) collective doses attributed to Hanford operations from 1995 through 1999 are compared in Figure 5.0.3. Primary pathways contributing to the 1999 population dose were the following:

- consumption of foodstuffs (52\%) contaminated with radionuclides released in gaseous effluents, principally tritium

- consumption of drinking water (22\%) contaminated with radionuclides released to the Columbia River at Hanford, primarily tritium 


\begin{tabular}{|c|c|c|c|c|c|c|}
\hline \multirow[b]{3}{*}{ Effluent } & \multicolumn{5}{|c|}{ Table 5.0.2. Dose to the Population from 1999 Hanford Operations } & \\
\hline & & \multicolumn{4}{|c|}{ Dose Contributions from 0 perating A reas, person-rem } & \\
\hline & Pathway & $\begin{array}{c}100 \\
\text { A reas }\end{array}$ & $\begin{array}{c}200 \\
\text { Areas }\end{array}$ & $\begin{array}{r}300 \\
\text { A rea } \\
\end{array}$ & $\begin{array}{c}400 \\
\text { A rea }\end{array}$ & $\begin{array}{c}\text { Pathway } \\
\text { T otal }\end{array}$ \\
\hline Air & $\begin{array}{l}\text { External } \\
\text { Inhalation } \\
\text { Foods }\end{array}$ & $\begin{array}{l}9.0 \times 10^{-7} \\
5.8 \times 10^{-4} \\
1.6 \times 10^{-5}\end{array}$ & $\begin{array}{l}4.1 \times 10^{-6} \\
3.3 \times 10^{-2} \\
2.4 \times 10^{-3}\end{array}$ & $\begin{array}{l}1.1 \times 10^{-7} \\
2.4 \times 10^{-2} \\
1.3 \times 10^{-1}\end{array}$ & $\begin{array}{l}2.0 \times 10^{-7} \\
1.1 \times 10^{-4} \\
1.8 \times 10^{-6}\end{array}$ & $\begin{array}{l}5.3 \times 10^{-6} \\
5.8 \times 10^{-2} \\
1.3 \times 10^{-1}\end{array}$ \\
\hline & Subtotal air & $6.0 \times 10^{-4}$ & $3.5 \times 10^{-2}$ & $1.5 \times 10^{-1}$ & $1.1 \times 10^{-4}$ & $1.9 \times 10^{-1}$ \\
\hline Water & $\begin{array}{l}\text { Recreation } \\
\text { Foods } \\
\text { Fish } \\
\text { Drinking water }\end{array}$ & $\begin{array}{l}2.6 \times 10^{-6} \\
1.8 \times 10^{-4} \\
5.2 \times 10^{-5} \\
4.4 \times 10^{-4}\end{array}$ & $\begin{array}{l}4.6 \times 10^{-5} \\
1.9 \times 10^{-3} \\
4.1 \times 10^{-5} \\
5.6 \times 10^{-2}\end{array}$ & $\begin{array}{l}0.0 \\
0.0 \\
0.0 \\
0.0\end{array}$ & $\begin{array}{l}0.0 \\
0.0 \\
0.0 \\
0.0\end{array}$ & $\begin{array}{l}4.9 \times 10^{-5} \\
2.1 \times 10^{-3} \\
9.3 \times 10^{-5} \\
5.6 \times 10^{-2}\end{array}$ \\
\hline & Subtotal water & $6.7 \times 10^{-4}$ & $5.8 \times 10^{-2}$ & 0.0 & 0.0 & $5.9 \times 10^{-2}$ \\
\hline Combined total & & $1.3 \times 10^{-3}$ & $9.3 \times 10^{-2}$ & $1.5 \times 10^{-1}$ & $1.1 \times 10^{-4}$ & $2.5 \times 10^{-1}$ \\
\hline
\end{tabular}

- inhalation of radionuclides (23\%) that were released to the air, principally tritium emitted from the 300 Area stacks.

The average per capita dose from 1999 Hanford Site operations based on a population of 380,000 within 80 kilometers $(50$ miles) was 0.0007 mrem $\left(7 \times 10^{-6} \mathrm{mSv}\right)$. To place this dose from Hanford Site activities into perspective, the estimate may be compared with doses from other routinely encountered sources of radiation such as natural terrestrial and cosmic background radiation, medical treatment and $\mathrm{x}$-rays, natural radionuclides in the body, and inhalation of naturally occurring radon. The national average radiological dose from these other sources is illustrated in Figure 5.0.4. The estimated average per capita dose to members of the public from Hanford Site sources is $\sim 0.0002 \%$ of the annual per capita dose $(300 \mathrm{mrem})$ from natural background sources.

The doses from Hanford effluents to the maximally exposed individual and to the population within 80 kilometers (50 miles) are compared to appropriate standards and natural background radiation in
Table 5.0.3. This table shows that the calculated radiological doses from Hanford Site operations in 1999 are a small percentage of the standards and of natural background. The radiological dose from diffuse sources is approximately equal to dose from the air pathway for measured effluents.

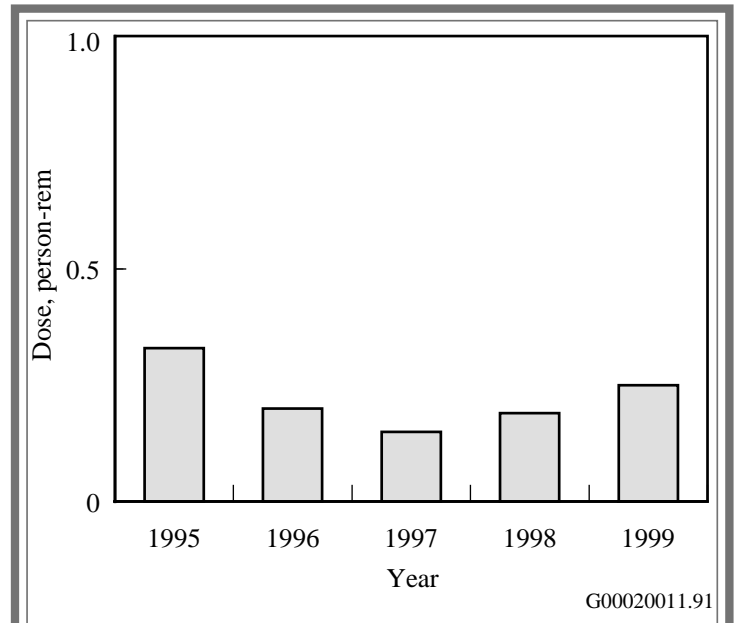

Figure 5.0.3. Calculated Dose to the Population Within 80 Kilometers (50 Miles) of the Hanford Site, 1995 Through 1999 


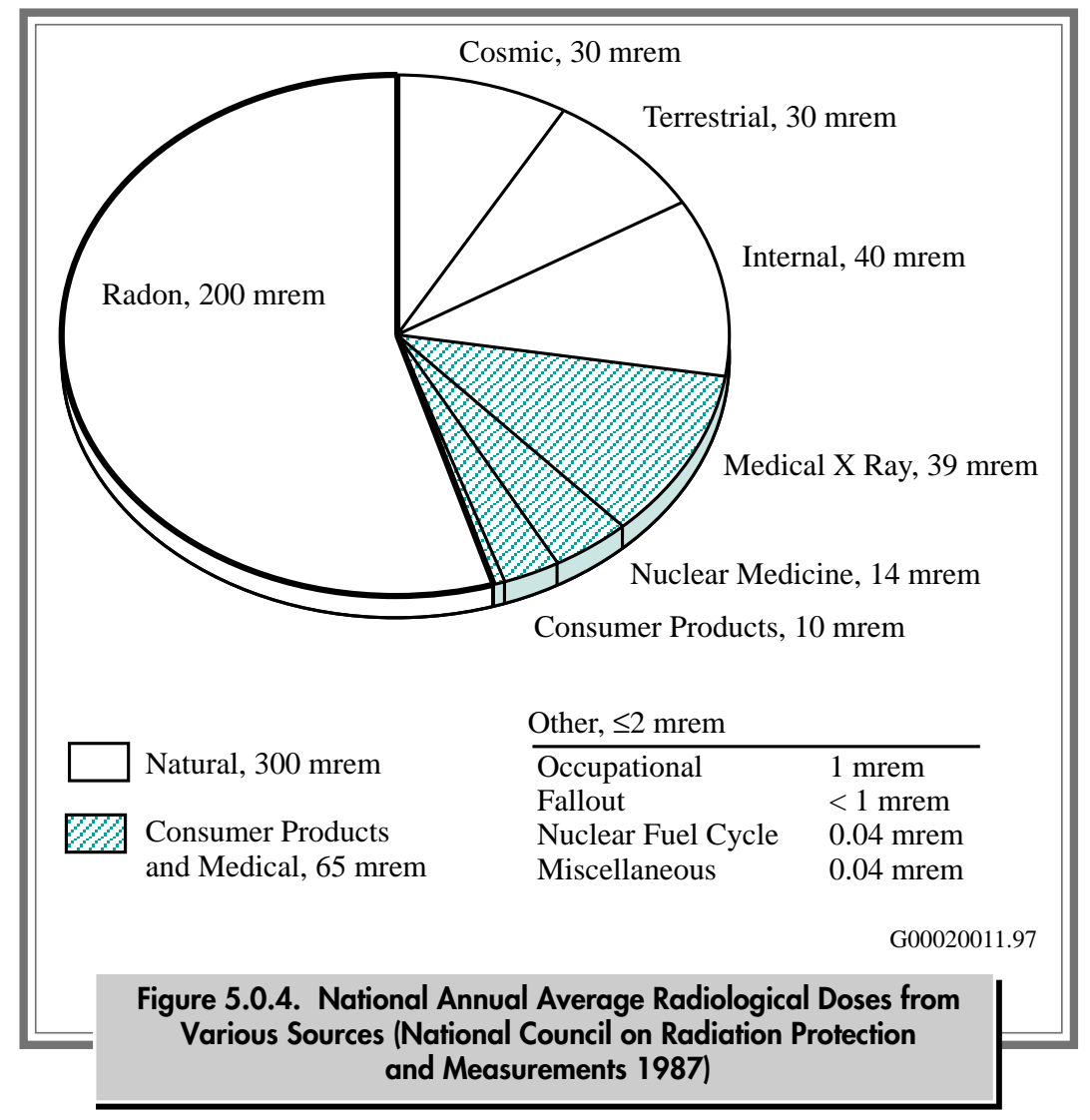

\subsubsection{Doses from Other than DOE Sources}

Various non-DOE industrial sources of public radiation exposure exist at or near the Hanford Site. These include the low-activity, commercial, radioactive waste burial ground at Hanford operated by US Ecology; the nuclear power generating station at Hanford operated by Energy Northwest (formerly known as the Washington Public Power Supply System); the nuclear fuel production plant operated by Siemens Power Corporation; the commercial, low-level, radioactive waste compacting facility operated by Allied Technology Group Corporation; and a commercial decontamination facility operated by PN Services (see Figure 5.0.1). DOE maintains an awareness of other man-made sources of radiation, which, if combined with the DOE sources, might have the potential to cause a dose exceeding $10 \mathrm{mrem}$ $(0.1 \mathrm{mSv})$ to any member of the public. With information gathered from these companies (via personal communication), it was conservatively estimated that the total 1999 individual dose from their combined activities is on the order of $0.05 \mathrm{mrem}$ $\left(5 \times 10^{-4} \mathrm{mSv}\right)$. Therefore, the combined dose from Hanford area non-DOE and DOE sources to a member of the public for 1999 was well below any regulatory dose limit. 
Table 5.0.3. Summary of Doses to the Public in the Vicinity of the Hanford Site from Various Sources, 1999

\section{Source}

All Hanford effluents DOE limit

Percent of DOE limit ${ }^{(\mathrm{b})}$

Background radiation

Hanford dose percent of background

Doses from gaseous effluents

EPA air standard ${ }^{(c)}$

Percent of EPA standard
Maximum Individual

$$
\begin{gathered}
0.008 \mathrm{mrem}^{(\mathrm{a})} \\
100 \mathrm{mrem} \\
0.008 \\
300 \mathrm{mrem} \\
<0.01 \\
0.015 \mathrm{mrem} \\
10 \mathrm{mrem} \\
0.15
\end{gathered}
$$

\section{Population}

0.25 person-rem $^{(\text {a) }}$

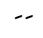

110,000 person-rem $2 \times 10^{-4}$

-

-

(a) To convert the dose values to $\mathrm{mSv}$ or person-Sv, divide by 100 .

(b) DOE Order 5400.5.

(c) 40 CFR 61.

\subsubsection{Hanford Public Radiological Dose in Perspective}

This section provides information to put the potential health risks of radionuclide emissions from the Hanford Site into perspective. Several scientific studies (National Research Council 1980, 1990; United Nations Science Committee on the Effects of Atomic Radiation 1988) have been performed to estimate the possible risk of detrimental health effects from exposure to low levels of radiation. These studies have provided vital information to government and scientific organizations that recommend radiological dose limits and standards for public and occupational safety.

Although no increase in the incidence of health effects from low doses of radiation has actually been confirmed by the scientific community, some scientists accept the hypothesis that low-level doses might increase the probability of cancer or other health effects. Regulatory agencies conservatively (cautiously) assume that the probability of these types of health effects at low doses (down to zero dose) is the same per unit dose as the same health effects observed at much higher doses (e.g., in atomic bomb victims, radium dial painters). This is also known as the linear no threshold hypothesis. Under these assumptions, even natural background radiation, which is hundreds of times greater than radiation from current Hanford releases, increases each person's probability or chance of developing a detrimental health effect.

Not all scientists agree on how to translate the available data on health effects into the numerical probability (risk) of detrimental effects from lowlevel radiological doses. Some scientific studies have indicated that low radiological doses may cause beneficial effects (Sagan 1987). Because cancer and hereditary diseases in the general population may be caused by many sources (e.g., genetic defects, sunlight, chemicals, background radiation), some scientists doubt that the risk from low-level radiation exposure can ever be conclusively proved. In developing C lean A ir A ct regulations, EPA uses a probability value of approximately 4 per 10 million $\left(4 \times 10^{-7}\right)$ for the risk of developing a fatal cancer after receiving a dose of $1 \mathrm{mrem}(0.01 \mathrm{mSv})$ (EPA 520/1-89-005). Additional data (National Research Council 1990) support the reduction of even this small risk value, possibly to zero, for certain types of radiation when the dose is spread over an extended time. 
Government agencies are trying to determine what level of risk is safe for members of the public exposed to pollutants from industrial operations (e.g., DOE facilities, nuclear power plants, chemical plants, hazardous waste sites). All of these industries are considered beneficial to people in some way such as providing electricity, national defense, waste disposal, and consumer products. These government agencies have a complex task in establishing environmental regulations that control levels of risk to the public without unnecessarily reducing needed benefits from industry.
One perspective on risks from industry is to compare them to risks involved in other typical activities. For instance, two risks that an individual receives from flying on an airliner are the risks of added radiological dose (from a stronger cosmic radiation field that exists at higher altitudes) and the possibility of being in an aircraft accident. Table 5.0.4 compares the estimated risks from various radiological doses to the risks of some activities encountered in everyday life. Table 5.0.5 lists some activities considered approximately equal in risk to that from the dose received by the maximally exposed individual from monitored Hanford effluents in 1999.

\subsubsection{Dose Rates to Animals}

Conservative (upper) estimates have been made of the radiological dose to native aquatic organisms in accordance with the DOE Order 5400.5 interim requirement for management and control of liquid discharges. Possible radiological dose rates during 1999 were calculated for several exposure modes, including exposure to radionuclides in water entering the Columbia River from springs near the

Table 5.0.4. Estimated Risk from Various Activities and Exposures ${ }^{(a)}$

Activity or Exposure Per Year

Smoking 1 pack of cigarettes per day (lung/heart/other diseases)

Home accidents

Taking contraceptive pills (side effects)

Drinking 1 can of beer or $0.12 \mathrm{~L}(4 \mathrm{oz})$ of wine per day (liver cancer/cirrhosis)

Firearms, sporting (accidents)

Flying as an airline passenger (cross-country roundtrip--accidents)

Eating approximately $54 \mathrm{~g}$ ( $4 \mathrm{tbsp}$ ) of peanut butter per day (liver cancer)

Pleasure boating (accidents)

Drinking chlorinated tap water (trace chloroform--cancer)

Riding or driving in a passenger vehicle (483 km [300 mi])

Eating $41 \mathrm{~kg}(90 \mathrm{lb})$ of charcoal-broiled steaks (gastrointestinal tract cancer)

Natural background radiation dose ( $300 \mathrm{mrem}, 3 \mathrm{mSv}$ )

Flying as an airline passenger (cross-country roundtrip--radiation)

Dose of $1 \mathrm{mrem}(0.01 \mathrm{mSv})$ for $70 \mathrm{yr}$

Dose to the maximally exposed individual living near Hanford

in 1999 (0.008 mrem, $\left.8 \times 10^{-5} \mathrm{mSv}\right)$
Risk of Fatality

$3,600 \times 10^{-6}$

$100 \times 10^{-6(b)}$

$20 \times 10^{-6}$

$10 \times 10^{-6}$

$10 \times 10^{-6(b)}$

$8 \times 10^{-6(b)}$

$8 \times 10^{-6}$

$6 \times 10^{-6(b)}$

$3 \times 10^{-6}$

$2 \times 10^{-6(b)}$

$1 \times 10^{-6}$

0 to $120 \times 10^{-6}$

0 to $5 \times 10^{-6}$

0 to $0.4 \times 10^{-6}$

0 to $0.0032 \times 10^{-6}$

(a) These values are generally accepted approximations with varying levels of uncertainty; there can be significant variation as a result of differences in individual lifestyle and biological factors (Atallah 1980; Dinman 1980; Ames et al. 1987; Wilson and Crouch 1987; Travis and Hester 1990).

(b) Real actuarial values. Other values are predicted from statistical models. For radiation dose, the values are reported in a possible range from the least conservative $(0)$ to the currently accepted most conservative value. 


\section{Table 5.0.5. Activities Comparable in Risk to the $0.008-\mathrm{mrem}\left(8 \times 10^{-5} \mathrm{mSv}\right)$ Dose}

Calculated for the 1999 Maximally Exposed Individual

Driving or riding in a car $0.77 \mathrm{~km}$ (approximately $0.5 \mathrm{mi}$ )

Smoking less than $1 / 100$ of a cigarette

Flying $2 \mathrm{~km}(1.25 \mathrm{mi})$ on a commercial airliner

Eating approximately 1.75 tsp of peanut butter

Eating one $0.13-\mathrm{kg}$ (4.6-oz) charcoal-broiled steak

Drinking approximately $0.78 \mathrm{~L}(26 \mathrm{oz})$ of chlorinated tap water

Being exposed to natural background radiation for approximately $14 \mathrm{~min}$ in a typical

terrestrial location

Drinking approximately $0.05 \mathrm{~L}(<1.4 \mathrm{oz})$ of beer or $0.016 \mathrm{~L}(0.5 \mathrm{oz})$ of wine

100-N Area and internally deposited radionuclides measured in animals collected from the river and on the site.

The aquatic animal receiving the highest potential dose from N Springs water was a hypothetical crawdad. The water flow of the N Springs is very low; no aquatic animal was observed to live directly in this spring water (PNNL-11933). Exposure to the radionuclides from the springs cannot occur until the spring water has been noticeably diluted in the Columbia River. The assumption was made that a few aquatic animals might be exposed to the maximum radionuclide concentrations measured in the spring water (see Table 4.2.4) after a 10-to-1 dilution by the river. Radiological doses were calculated for several different types of aquatic and riparian animals, using these extremely conservative assumptions and the CRITRII computer code (PNL-8150). If a crawdad population spent $100 \%$ of its time in the one-tenthdiluted spring water and consumed only plants growing there, it is possible that an individual could receive a dose rate of $3.3 \mathrm{E}-10 \mathrm{rad}$ per day. This hypothetical dose rate is $0.00000003 \%$ of the limit of $1 \mathrm{rad}$ per day for native aquatic animal organisms established by DOE Order 5400.5 . The intent of the DOE Order 5400.5 native aquatic animal organism dose limit is to protect the population of a species, not necessarily individual organisms. It is not possible for a population of crawdads to live in this spring for an entire year.
Doses also were estimated using the CRITRII code for aquatic and riparian organisms based on measured radionuclide activities in river water. The highest potential dose rate from all the radionuclides reaching the Columbia River from Hanford Site sources during 1999 was $9 \times 10^{-9}$ rad per day for hypothetical fish, mollusks, and crawdads. The highest radiological dose to riparian organisms, ducks, raccoons, or muskrats, for example, based on the same measured radioactivity in water, was calculated to be $3 \times 10^{-8}$ rad per day to the hypothetical duck consuming contaminated fish. The radiological dose rate to individual animals collected on the site or from the Columbia River was calculated using the maximum levels of radionuclides measured in muscle tissue. These doses ranged from $1 \times 10^{-6} \mathrm{rad}$ per day for a deer to $1 \times 10^{-3}$ rad per day for a pheasant. Neither the doses calculated based on Columbia River water activities nor the doses based on actual biota activities approach the dose limit set forth in DOE Order 5400.5.

DOE has developed a screening method to estimate radiological doses to aquatic and terrestrial biota, using surveillance data. This method assesses compliance with proposed rule 10 CFR 834, Subpart F. The Biota Dose Calculator is a program that uses an Excel spreadsheet to initially compare radionuclide concentrations measured by routine surveillance programs and to a set of conservatively set biota concentrations guides, then uses a sum of fractions to 
determine compliance. If a site does not initially comply, site-specific parameters (e.g., concentration ratios) may be substituted for the conservative ones in the program. If a site still does not comply, a sitespecific biota data calculation must be done.

Radiological doses to plants and animals were in compliance with proposed limits based on sediment and riverbank spring water data. Maximum concentrations of radionuclides in onsite pond water were entered into the Biota Data Calculator. The results indicated that onsite pond water exceeded the proposed dose limits. Following further investigation, it was apparent that high uranium concentrations in West Lake, a naturally occurring, spring-fed pond located north of the 200-East Area, were the reason the proposed dose limits were exceeded.

The next step in the screening was to enter the mean concentrations and rerun the program to

\subsubsection{References}

10 CFR 834, Subpart F. U.S. Department of Energy. "Radiation Protection of the Public and Environment." C ode of $F$ ederal Regulations.

40 CFR 61. U.S. Environmental Protection Agency. "National Emission Standards for Hazardous Air Pollutants." C ode of Federal Regulations.

40 CFR 61, Subpart H. U.S. Environmental Protection Agency. "National Emissions Standards for Emissions of Radionuclides Other Than Radon From Department of Energy Facilities." Code of Federal Regulations.

Ames, B. N., R. Magaw, and L. S. Gold. 1987.

"Ranking Possible Carcinogenic Hazards." Science 236:271-280.

Atallah, S. 1980. "Assessing and Managing Industrial Risk.” C hemical Engineering 9/8/80:94-103.

Clean Air Act. 1986. Public Law 88-206, as amended, 42 USC 7401 et seq. calculate dose. Using the mean concentrations, West Lake exceeded the proposed dose limits. The 'limiting organism' was an aquatic animal.

In 1991, Poston et al. reported that no records could be found documenting the presence of fish in West Lake. Additionally, the water in the lake is very salty and alkaline ( $\mathrm{pH}=9.5$ to 10.0$)$ and conductivity measurements indicate a high level of dissolved solids (23,000 to $25,000 \mu \mathrm{mhos} / \mathrm{cm}$, at $25^{\circ}$ Celsius). Recently, shorebirds have been found nesting at the lake. These birds were found to be feeding on a large population of an aquatic insect (Ephydridae) living in the lake. Samples of the birds and the insects (both larvae and adults) were collected in spring 2000 and the analytical results from these samples will be used in calendar year 2000 to further refine the dose calculations for this site.

Dinman, B. D. 1980. "The Reality and Acceptance of Risk." J ournal of the A merican M edical A ssociation (JA M A ) (11):1226-1228.

DOE Order 5400.5. "Radiation Protection of the Public and the Environment."

DOE/RL-99-41. 1999. Radionuclide A ir Emissions Report for the $\mathrm{H}$ anford Site, C alendar Year 1998. B. P. Gleckler and K. Rhoads, Waste Management Federal Services of Hanford, Inc. for U.S. Department of Energy, Richland Operations Office, Richland, Washington.

DOE/RL-2000-37. 2000. Radionuclide A ir E missions Report for the H anford Site. Calendar Year 1999. U.S. Department of Energy, Richland, Washington.

EPA-402-B-92-001. 1992. U ser's G uide for CA P88-PC, V ersion 1.0. B. S. Parks, U.S. Environmental Protection Agency, Office of Radiation Programs, Las Vegas, Nevada. 
EPA 520/1-89-005. 1989. Risk A ssessment M ethodology: Draft Environmental Impact Statement for Proposed N ESH A PS for Radionuclides, V ol. 1, Background Information D ocument. U.S. Environmental Protection Agency, Washington, D.C.

EPS-87-367A. 1988. Environmental Radiation Program, 26th A nnual Report, J anuary T hrough D ecember 1987. Washington State Department of Health, Olympia, Washington.

National Council on Radiation Protection and Measurements. 1987. Ionizing Radiation Exposure of the Population of theU nited States. NCRP Report No. 93, Bethesda, Maryland.

National Research Council. 1980. The Effects on Populations of Exposureto L ow L evels of I onizing R adiation: 1980. Committee on the Biological Effects of Ionizing Radiations, National Academy Press, Washington, D.C.

National Research Council. 1990. H ealth Effects of Exposure to Low Levels of I onizing Radiation. Committee on the Biological Effects of Ionizing Radiations, National Academy Press, Washington, D.C.

PNL-6584 (3 vols). 1988. GEN II - The H anford Environmental Radiation D osimetry Software System. B. A. Napier, R. A. Peloquin, D. L. Strenge, and J. V. Ramsdell, Pacific Northwest Laboratory, Richland, Washington.

PNL-7539. 1990. M ethodology U sed to C ompute $M$ aximum Potential $D$ oses from Ingestion of Edible Plants and Wildlife Found on the $\mathrm{H}$ anford Site. J. K. Soldat, K. R. Price, and W. H. Rickard, Pacific Northwest Laboratory, Richland, Washington.

PNL-7803. 1991. H anford A rea 1990 Population and 50-Year Projections. D. M. Beck, B. A. Napier,
M. J. Scott, A. G. Thurman, M. D. Davis, D. B. Pittenger, S. F. Shindle, and N. C. Batishko, Pacific Northwest Laboratory, Richland, Washington.

PNL-8150. 1992. M ethods for E stimating D oses to 0 rganisms from Radioactive $M$ aterials Released into the A quatic Environment. D. A. Baker and J. K. Soldat, Pacific Northwest Laboratory, Richland, Washington.

PNNL-11933. 1998. Survey of Radiological C ontaminantsin the N ear-ShoreE nvironment at the H anfordSite 100-N Reactor A rea. S. P. Van Verst, C. L. Albin, G. W. Patton, M. L. Blanton, T. M. Poston, A. T. Cooper, and E. J. Antonio, Pacific Northwest National Laboratory, Richland, Washington.

PNNL-12088. 1999. H anford Site 1998 Environmental Report. R. L. Dirkes, R. W. Hanf, and T. M. Poston (eds.), Pacific Northwest National Laboratory, Richland, Washington.

PNNL-12088, APP. 1. 1999. H anford Site Environmental Surveillance $D$ ata Report for $C$ alendar Year 1998. L. E. Bisping, Pacific Northwest National Laboratory, Richland, Washington.

Sagan, L. A. 1987. H ealth Physics Society 0 fficial Journal: Special Issue on Radiation H ormesis 52(5).

Travis, C. C., and S. T. Hester. 1990. "Background Exposure to Chemicals: What Is the Risk?" Risk A nalysis 10(4).

United Nations Science Committee on the Effects of Atomic Radiation. 1988. Sources, Effects and Risks of Ionizing Radiation. Report E.88.1X.7, United Nations, New York.

Wilson, R., and E.S.C. Crouch. 1987. "Risk Assessment and Comparisons: An Introduction." Science 236 (4799):267-270. 


\subsection{Groundwater and Vadose Zone Monitoring}

\subsubsection{Groundwater Monitoring}

\begin{abstract}
The Hanford Groundwater Monitoring Project includes sitewide groundwater monitoring mandated by U.S. Department of Energy (DOE) Orders and near-field groundwater monitoring conducted to ensure that operations in and around specific waste disposal facilities are in compliance with applicable regulations.
\end{abstract}

Collection and analysis of groundwater samples to determine the distribution of radiological and chemical constituents were major parts of the groundwater monitoring effort. In addition, hydrogeologic characterization and modeling of the groundwater flow system were used to assess the monitoring network and to evaluate potential effects of Hanford Site groundwater contamination. Other work included data management, interpretation, and reporting. The purpose of this section is to provide an overall summary of groundwater monitoring during 1999. Additional details concerning the Hanford Groundwater Monitoring Project are available in PNNL-13116, "Hanford Site Groundwater Monitoring for Fiscal Year 1999."

\subsubsection{Monitoring Objectives}

Groundwater monitoring was conducted to accomplish the following tasks:

- assess the impact of radiological and hazardous chemicals on groundwater as a result of Hanford Site operations

- provide an integrated assessment of groundwater quality on the Hanford Site

- evaluate potential offsite effects from the groundwater pathway
- verify compliance with applicable environmental laws and regulations

- evaluate effectiveness of groundwater remediation

- identify and characterize new or existing groundwater quality problems.

Sitewide groundwater monitoring is designed to meet the project objectives stated in DOE Order 5400.1 and described above. The impact of Hanford Site operations on groundwater have been monitored for more than 50 years under this project and its predecessors. Near-field monitoring of groundwater around specific waste facilities was performed to meet the requirements of the Resource $C$ onservation and Recovery A ct (RCRA) (40 CFR 265) and Washington Administrative Codes (WACs 173-303 and 173-304) as well as applicable DOE Orders (e.g., 5400.1, 5400.5). Groundwater monitoring was also performed in conjunction with cleanup investigations under the Comprehensive Environmental Response, Compensation, and Liability Act (CERCLA) (40 CFR 300).

\subsubsection{Monitoring Design}

Groundwater monitoring was designed to satisfy regulatory requirements using various criteria. Specific chemicals and radionuclides analyzed at each monitoring well and their sampling frequencies were selected based on past waste disposal (PNL-6456, WHC-EP-0527-2) and on previous analytical results. Also considered was information on the location of potential contaminant sources and hydrogeology, including groundwater flow directions. Selections involved determining those chemicals and radionu- 
clides important in assessing health risk and for understanding contaminant distribution and movement.

Groundwater surveillance was conducted using established quality assurance plans (see Section 8.0, "Quality Assurance") and written procedures (ES-SSPM-001). Computerized data management systems are used to schedule sampling; generate sample labels and chain-of-custody forms; track sample status; and load, store, and report data. The Hanford Environmental Information System is the central, consolidated database for storing and managing the results of groundwater monitoring.

Groundwater samples were collected from both the unconfined and upper confined aquifers. The unconfined aquifer was monitored extensively because it contains contaminants from Hanford Site operations (PNNL-13116) and provides a potential pathway for contaminants to reach points of human exposure (e.g., water supply wells, Columbia River). The upper confined aquifer was monitored, though less extensively and less frequently than the unconfined aquifer, because it also provides a potential pathway for contaminants to migrate off the site. Also, some sampling was conducted at the request of the Washington State Department of Health.

Areas that might be a source of contamination were monitored to characterize and define trends in the condition of the groundwater and to identify and quantify existing, emerging, or potential problems in groundwater quality. These areas included active waste disposal facilities or facilities that had generated or received waste in the past. Most of these facilities are located within the 100, 200, and 300 Areas. However, some sources such as the Solid Waste Landfill are located outside the operational areas.

Wells located within known contaminant plumes were monitored to characterize and define trends in the concentrations of the associated radiological or chemical constituents. These wells were also monitored to quantify existing groundwater quality problems and to provide a baseline of environmen- tal conditions against which future changes can be assessed. Even though releases of liquid waste to ground disposal facilities have for the most part ceased, these wells continue to be monitored as cleanup of the Hanford Site continues. This will provide a continuing assessment of the effect of remediation efforts on groundwater.

Water supplies on and near the Hanford Site potentially provide the most direct route for human exposure to contaminants in groundwater. In 1999, three of the site's 12 DOE-owned, contractor operated drinking water systems provided groundwater for human consumption on the site. One system supplied water at the Fast Flux Test Facility, and one was located at the Hanford Patrol Training Academy (see Section 4.3, "Radiological Surveillance of Hanford Site Drinking Water"). Water supply wells used by the city of Richland are located near the site's southern boundary. Monitoring wells near these water systems were routinely sampled to ensure that any potential water quality problems would be identified long before regulatory limits were reached.

To assess the effect of Hanford Site operations on groundwater quality, background conditions, or the quality of groundwater on the site unaffected by operations, must be known. Data on the concentration of contaminants of concern in groundwater that existed before site operations began are not available. Therefore, concentrations of naturally occurring chemical and radiological constituents in groundwater sampled from wells located in areas unaffected by site operations, including upgradient locations, provide the best estimate of pre-Hanford groundwater quality. Summaries of background conditions are tabulated in PNL-6886 and PNL-7120.

Groundwater samples are collected at various frequencies, depending on the historical trends of constituent data, regulatory or compliance requirements, and characterization needs. Sampling frequencies range from monthly to every 3 years.

Summary results for 1999 are discussed in Section 6.1, "Hanford Groundwater Monitoring Project." 


\subsubsection{Vadose Zone Monitoring}

The vadose zone is defined as the area between the ground surface and the water table. This subsurface zone is also referred to as the unsaturated zone, zone of suspended water, or zone of aeration. The vadose zone functions as a transport pathway or storage area for water and other materials located between the soil surface and the groundwater aquifers. Historically, the vadose zone at industrialized and waste disposal areas at the Hanford Site has been contaminated with large amounts of radioactive and nonradioactive materials through the intentional and unintentional discharge of liquid waste to the soil column, the burial of contaminated solid waste, and the deposition of airborne contaminants to the ground. Depending on the makeup of the soil, the geology of the area, the nature of the waste, the amount of water or other fluids available to mobilize the contaminant, and other factors, contaminants can move downward and laterally through the soil column, can be chemically bound to soil particles (and immobilized), or can be contained by geologic formations.

Because of concerns about the effect of some vadose zone contaminants on the groundwater beneath the Hanford Site, and the potential for contaminated groundwater to reach the Columbia River, characterization efforts are under way to learn more about the nature and extent of vadose zone contamination. At the Hanford Site, the primary method for monitoring radiological contamination in the vadose zone consists of borehole logging (monitoring radiation levels in narrow shafts bored or drilled into the soil column). Borehole logging is conducted in existing boreholes located in and around the 200 Areas single-shell tank farms and beneath former waste disposal facilities also in or near the 200 Areas. Additionally, soil-vapor extraction and monitoring are conducted as part of an expedited response action in the 200-West Area to remove carbon tetrachloride from the vadose zone.

Results for the 1999 vadose zone monitoring program are discussed in Section 6.2, "Vadose Zone Characterization and Monitoring." Section 6.2 has been divided into vadose zone characterization in the 200 Areas tank farms, vadose zone monitoring beneath former 200 Areas waste disposal facilities, surface barrier technology, and soil gas and soil moisture measurements. 


\title{
6.1 Hanford Groundwater Monitoring Project
}

\author{
D. R. N ewcomer and M. J. H artman
}

The strategy for managing and protecting groundwater resources at the Hanford Site focuses on protection of the Columbia River, human health, the environment, treatment of groundwater contamination, and limitation of contaminant migration from the 200 Areas (see Groundwater/Vadose Zone Integration Project reports DOE/RL-98-48, Draft C and DOE/RL-98-56). To implement this strategy, the Hanford Groundwater Monitoring Project continues to monitor the quality of groundwater. The project is designed to detect and characterize new contaminant plumes and to document the distribution and movement of existing groundwater contamination. Monitoring provides the historical baseline to evaluate current and future risk from exposure to groundwater contamination and to decide on remedial options. Hydrogeologic studies are an integral part of the project because the geology and hydrology of the Hanford Site control the movement of contaminants in groundwater.

The effort to protect groundwater quality at the Hanford Site is implemented through programs to minimize and eliminate waste discharged to the soil column and through remediation work on the site. The Hanford Federal Facility Agreement and Consent Order (also known as the Tri-Party Agreement; Ecology et al. 1998) provides a framework for remediation of the Hanford Site, including groundwater, over a 40-year period. A summary of accomplishments in waste minimization and site remediation is presented in Section 2.3, "Activities, Accomplishments, and Issues."

DOE prepared a Plan and Schedule to D iscontinue $\mathrm{D}$ isposal of Liquids Into the Soil Column at the $\mathrm{H}$ anford Site (DOE 1987), which includes an alternative for treatment and disposal of contaminated effluents discharged to the soil. Of the 33 major waste streams identified in DOE (1987), the Phase I (high-priority) streams have either been eliminated or are being treated and diverted to the 200 Areas Treated Effluent Disposal Facility. In 1999, the State-Approved Land Disposal Site was the only place on the Hanford Site where liquid effluent containing radionuclide contamination discharged to the soil column. The locations of active permitted facilities through which wastewater was discharged to the ground in 1999 are shown in Figures 1.0.2 and 6.1.1 and are discussed in detail in Section 2.3, "Activities, Accomplishments, and Issues." In 1999, 15\% of the total volume of wastewater at the Hanford Site was discharged to the State-Approved Land Disposal Site and $\sim 85 \%$ was discharged to the 200 Areas Treated Effluent Disposal Facility. All other facilities (e.g., cribs, trenches) where wastewater was historically discharged to the soil column are out of service. The only operational injection wells are associated with pump-and-treat remediation systems. Treated wastewater is reinjected back into the unconfined aquifer at these wells.

Groundwater is used for drinking water and other purposes at $12 \mathrm{DOE}$ facilities on the Hanford Site. Pacific Northwest National Laboratory monitors DOE drinking water supplies for radiological constituents at the point of use or at the source. Results of the radiological monitoring are summarized in Section 4.3, "Radiological Surveillance of Hanford Site Drinking Water." The locations of wells completed in the unconfined aquifer that provide water for drinking, fire suppression, and cooling are shown in Figure 6.1.2. 


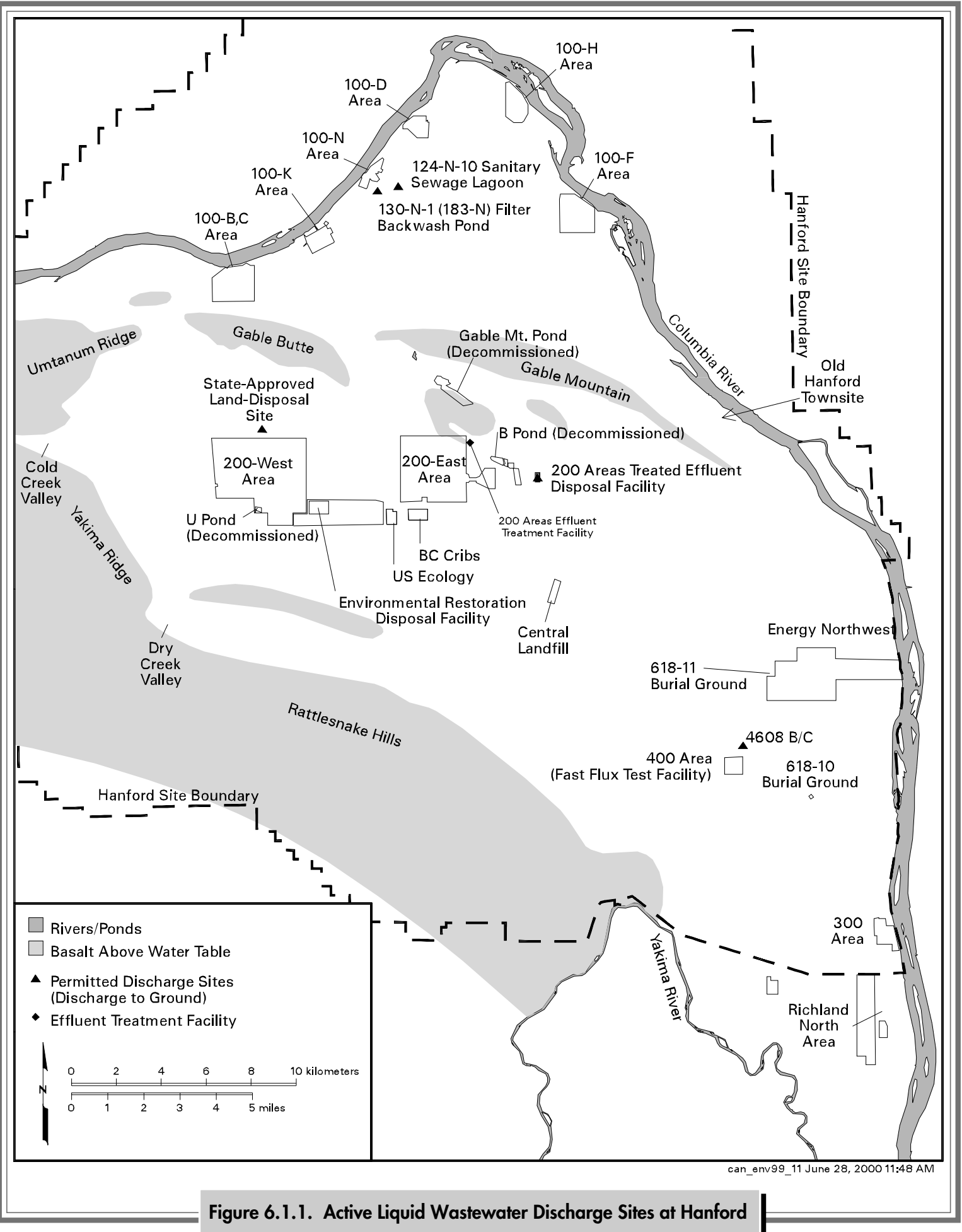




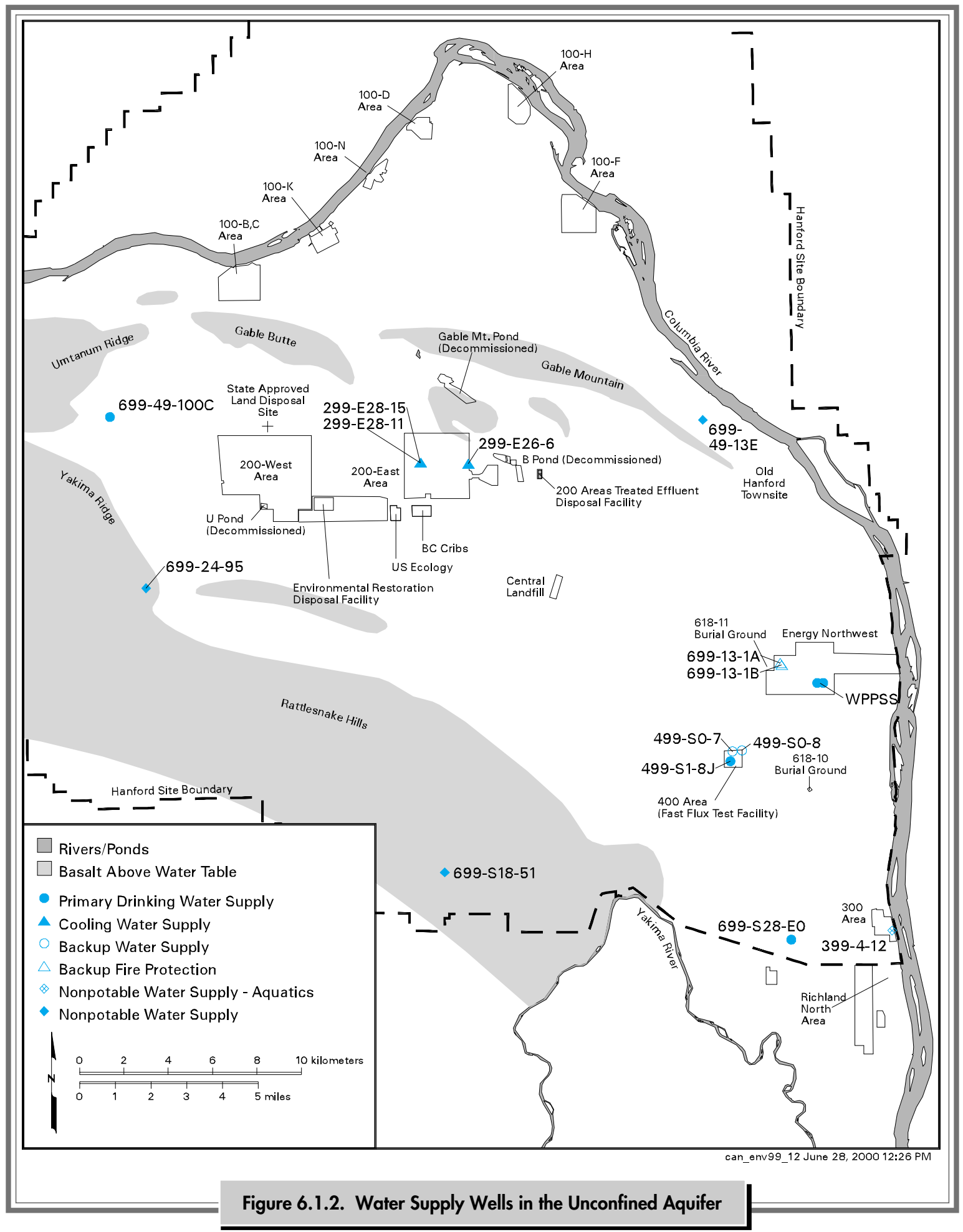




\subsubsection{Geologic Setting}

The Hanford Site lies within the Pasco Basin, one of several structural basins within the Columbia Plateau. Principal geologic units beneath the Hanford Site include, in ascending order, the Columbia River Basalt Group, the Ringold Formation, and the Hanford formation (informal name) (Figure 6.1.3).

The Columbia River basalts were formed from lava that periodically erupted from volcanic fissures. The regional river system eroded the basalt and deposited sediment across the basalt surfaces between eruptions. Zones between the basalt flows and the sediment deposited as interbeds between basalt eruptions are frequently zones that are used as water sources in areas around the Hanford Site.

During the period when basalt was deposited, tectonic pressure was slowly deforming the basalt flows into the generally east-west ridges that border the Pasco Basin today. After the last major basalt eruption, sand and gravel of the Ringold Formation were deposited in the central portion of the Pasco Basin by the ancestral Columbia River as it meandered back and forth across the relatively flat basalt surface. Following uplift of the basalts and overlying sediment, the Columbia River began to erode, rather than deposit, sediment in the Pasco Basin. The uppermost mud layer was eroded from much of the Pasco Basin, and a caliche layer, part of the PlioPleistocene unit, developed in places on the eroded surface of the Ringold Formation. The caliche forms a low-permeability layer that affects migration of water through the vadose zone.

More recently, Hanford formation sediment was deposited by catastrophic ice age floods. Fine sand and silt were deposited in slackwater areas at the margins of the basin. However, primarily sand and

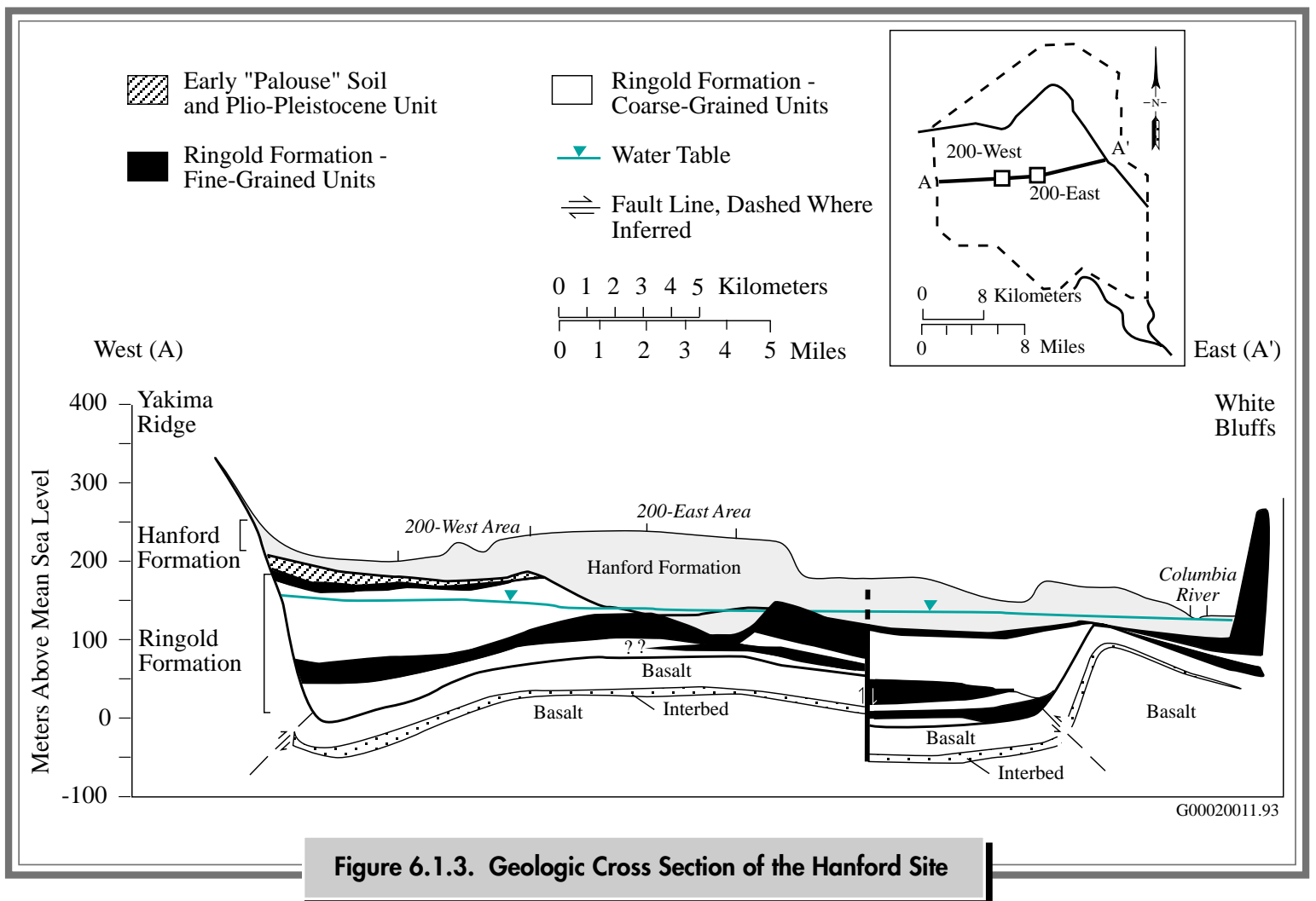


gravel were deposited on the Hanford Site. In places, the sediment is covered by up to a few meters of recent stream or windblown deposits.
More detailed information on the geology of the Pasco Basin can be found in BHI-00184, DOE/ RW-0164 (Vol. 1), PNNL-13080, WHC-MR-0391, WHC-SD-EN-TI-014, and WHC-SD-EN-TI-019.

\subsubsection{Groundwater Hydrology}

Both confined and unconfined aquifers are present beneath the Hanford Site. An aquifer is a water-saturated geologic interval or unit that has a high permeability, meaning it can transmit significant quantities of water. A confined aquifer is bounded above and below by low-permeability materials that restrict the vertical movement of water. The confining layers may be dense rock, such as the central parts of basalt flows, silt, clay, or well-cemented sediment (i.e., caliche). Extensive, confined aquifers at the site are found primarily within interflows and interbeds of the Columbia River basalts. These are referred to as basaltconfined aquifers. Locally confined aquifers are also found below the clays and silts of the Ringold Formation.

An unconfined aquifer, or water-table aquifer, is overlain by unsaturated sediment. The upper surface of the saturated zone in an unconfined aquifer, which is called the water table, rises and falls in response to changes in the volume of water stored in the aquifer. In general, the unconfined aquifer at the Hanford Site is located in the Hanford and Ringold formations. In some areas, the water table is below the bottom of the Hanford formation and the unconfined aquifer is entirely within the Ringold Formation. Sand and gravel of the Hanford formation are unconsolidated and are generally much more permeable than the compacted and silty gravel of the Ringold Formation. Clay and silt units and zones of natural cementation form low-permeability zones within the Ringold Formation.

The unconfined aquifer forms the uppermost groundwater zone and has been directly effected by wastewater disposal at the Hanford Site. The unconfined aquifer discharges primarily into the Columbia
River and is the most thoroughly monitored aquifer beneath the site. The Rattlesnake Ridge interbed is the uppermost, basalt-confined aquifer within the Pasco Basin and the Hanford Site. This aquifer and other confined aquifers are generally isolated from the unconfined aquifer by dense rock that forms the interior of the basalt flows. However, interflow between the unconfined aquifer and the basaltconfined aquifer system is known to occur at faults that bring a water bearing interbed in contact with other sediments or where the overlying basalt has been eroded to reveal an interbed (Newcomb et al. 1972, RHO-RE-ST-12 P, WHC-MR-0391). Additional information on the basalt-confined aquifer system can be found in PNL-10158 and PNL-10817.

The thickness of saturated sediment above the basalt bedrock is greater than 200 meters (656 feet) in some areas of the Hanford Site and thins out along the flanks of the uplifted basalt ridges (Figures 6.1.3 and 6.1.4). Depth from the ground surface to the water table ranges from less than 0.3 meter ( 1 foot) near the Columbia River to greater than 106 meters (348 feet) in the center of the site. The unconfined aquifer is bounded below by either the basalt surface or, in places, by relatively impervious clays and silts within the Ringold Formation. The water table defines the upper boundary of the unconfined aquifer. Laterally, the unconfined aquifer is bounded by basalt ridges and by the Yakima and Columbia Rivers. The basalt ridges have a low permeability and act as a barrier to the lateral flow of groundwater where they rise above the water table (RHO-BWIST-5, p. II-116).

The water-table elevation contours shown in Figure 6.1.5 indicate the direction of groundwater flow and the magnitude of the hydraulic gradient in 


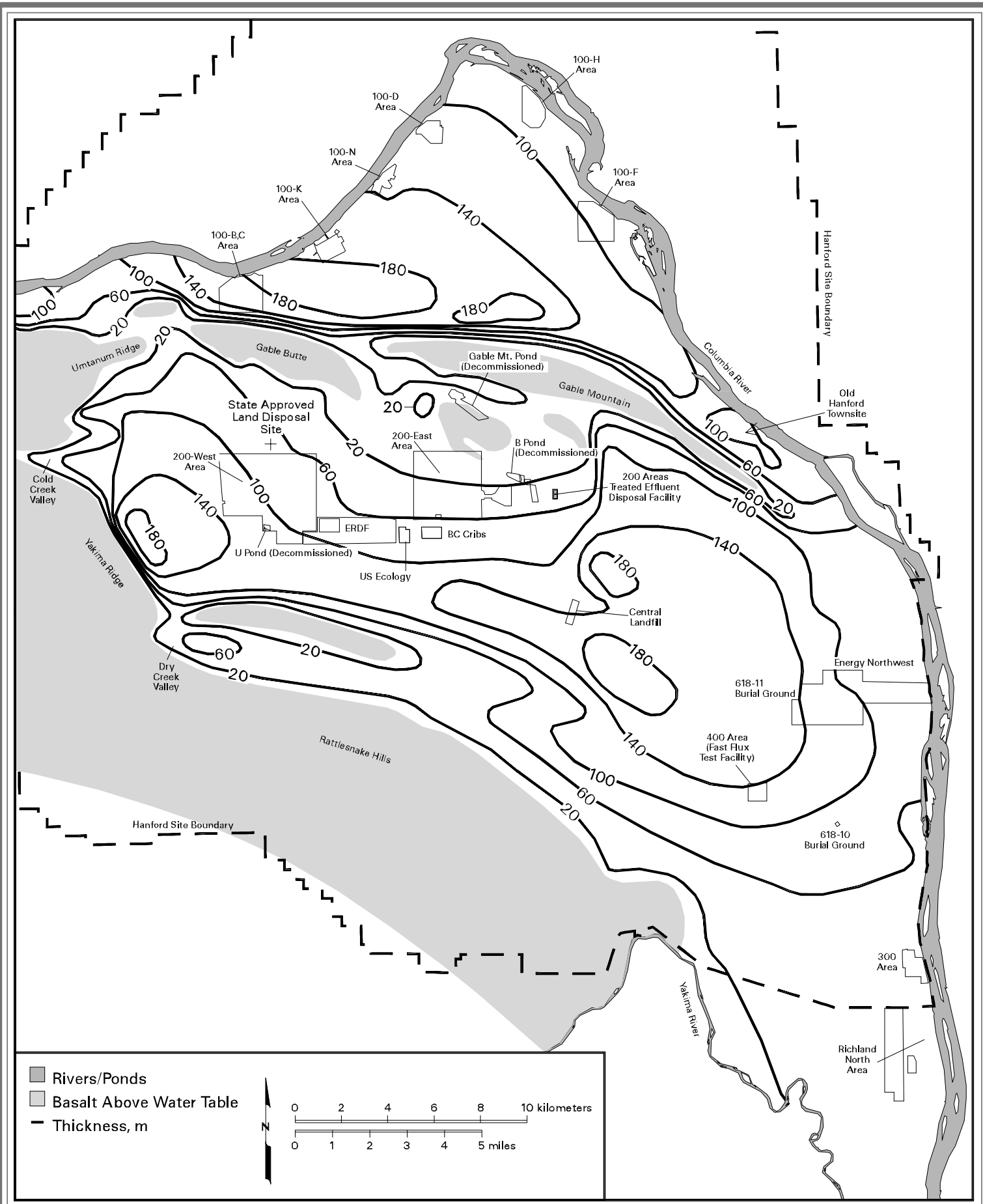

can env99 13 June 28,2000 12:26 PM

Figure 6.1.4. Saturated Thickness of the Unconfined Aquifer 


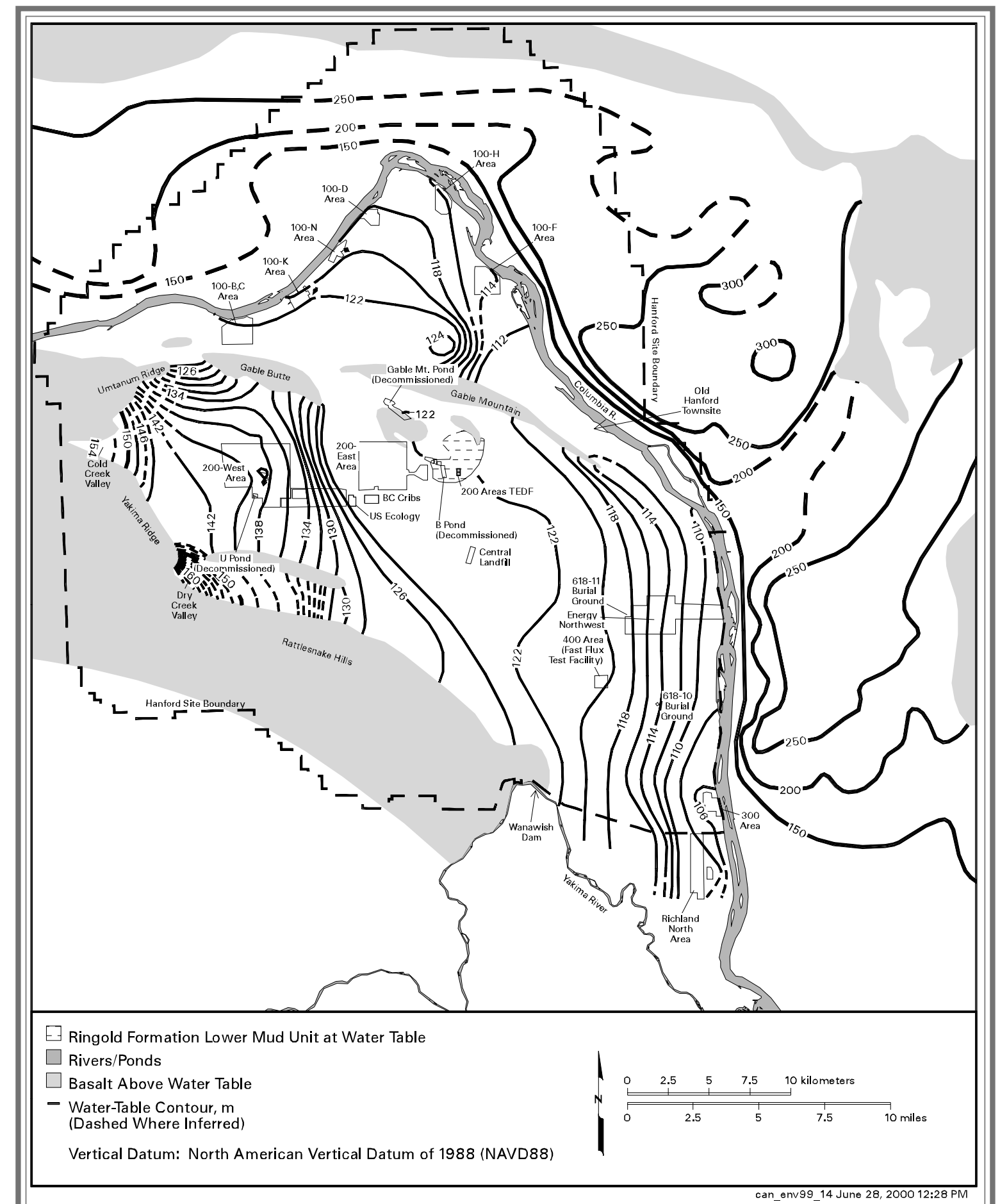

Figure 6.1.5. Water-Table Elevations for the Unconfined Aquifer at the Hanford Site and in Adjacent Areas East and North of the Columbia River, March 1999 
the unconfined aquifer. Groundwater flow is generally perpendicular to the water-table contours from areas of higher elevation, or head, to areas of lower head. Areas where the contours are closer together are high-gradient areas, where the "driving force" for groundwater flow is greater. However, because sediment with low permeabilities inhibits groundwater flow, producing steeper gradients, a high gradient does not necessarily mean high groundwater velocity. Lower transmissivity and steeper gradients are often associated with areas where the water table is below the bottom of the Hanford formation and the aquifer is entirely within the less permeable Ringold sediment. Figure 6.1.6 shows the generalized distribution of transmissivity as determined from aquifer pumping tests and groundwater flow model calibration. Additional information on aquifer hydraulic properties at Hanford is presented in DOE/RW-0164 (Vol. 2) and PNL-8337.

Recharge of water within the unconfined aquifer (RHO-ST-42) comes from several sources. Natural recharge occurs from infiltration of precipitation along the mountain fronts, runoff from intermittent streams such as Cold and Dry Creeks on the western margin of the site, and limited infiltration of precipitation on the site. The Yakima River, where it flows along the southern boundary of the site, also recharges the unconfined aquifer. The Columbia River is the primary discharge area for the unconfined aquifer. However, the Columbia River also recharges the unconfined aquifer for short periods during highriver stage, when river water is transferred into the aquifer along the riverbank. Recharge from infiltration of precipitation is highly variable on the Hanford Site both spatially and temporally. The rate of natural recharge depends primarily on soil texture, vegetation, and climate (Gee et al. 1992, PNL-10285). Natural recharge rates range from near zero, where fine-grained soils and deep-rooted vegetation are present, to greater than 10 centimeters per year (4 inches per year) in areas where soils are coarse textured and bare of vegetation.
Large-scale, artificial recharge to the unconfined aquifer occurred as a result of past liquid waste disposal in the operating areas and offsite agricultural irrigation to the west and south. Discharge of wastewater caused the water table to rise over most of the Hanford Site. Since the peak discharge in 1984, discharge of wastewater to the ground has been significantly reduced and, in response, the water table subsequently declined over most of the site. The water table continues to decline, as illustrated by Figure 6.1.7. The water table declined up to 0.5 meter ( 1.6 feet) over most of the site between 1998 and 1999. A decline of 0.5 to 1.5 meters (1.6 to 4.9 feet) in the water table along the Columbia River from west of the 100-B,C Area to the Old Hanford Townsite was due to variations in river discharge during different times of the year. Beginning in 1999, annual water-level measurements were taken in March instead of June because the March water table is considered to represent the annual average water table (PNNL-13021). River discharge is typically lower in March than in June.

The decline in the water table has altered the flow pattern of the unconfined aquifer, which is generally from the recharge areas in the west to the discharge areas (primarily the Columbia River) in the east and north. Water levels in the unconfined aquifer have continually changed as a result of variations in the volume and location of wastewater discharge. Consequently, the movement of groundwater and its associated constituents has also changed with time.

Two major groundwater mounds formed in the vicinity of the 200-East and 200-West Areas in response to wastewater discharges. The first of these mounds was created by disposal at the 216-U-10 pond (U Pond) in the 200-West Area. After U Pond was decommissioned in 1984, the mound slowly dissipated. The water table continues to decline in this area (see Figure 6.1.7). The second major mound was created by discharge to the decommissioned, or former, 216-B-3 pond (B Pond), east of the 200-East Area. The water-table elevation near B Pond 


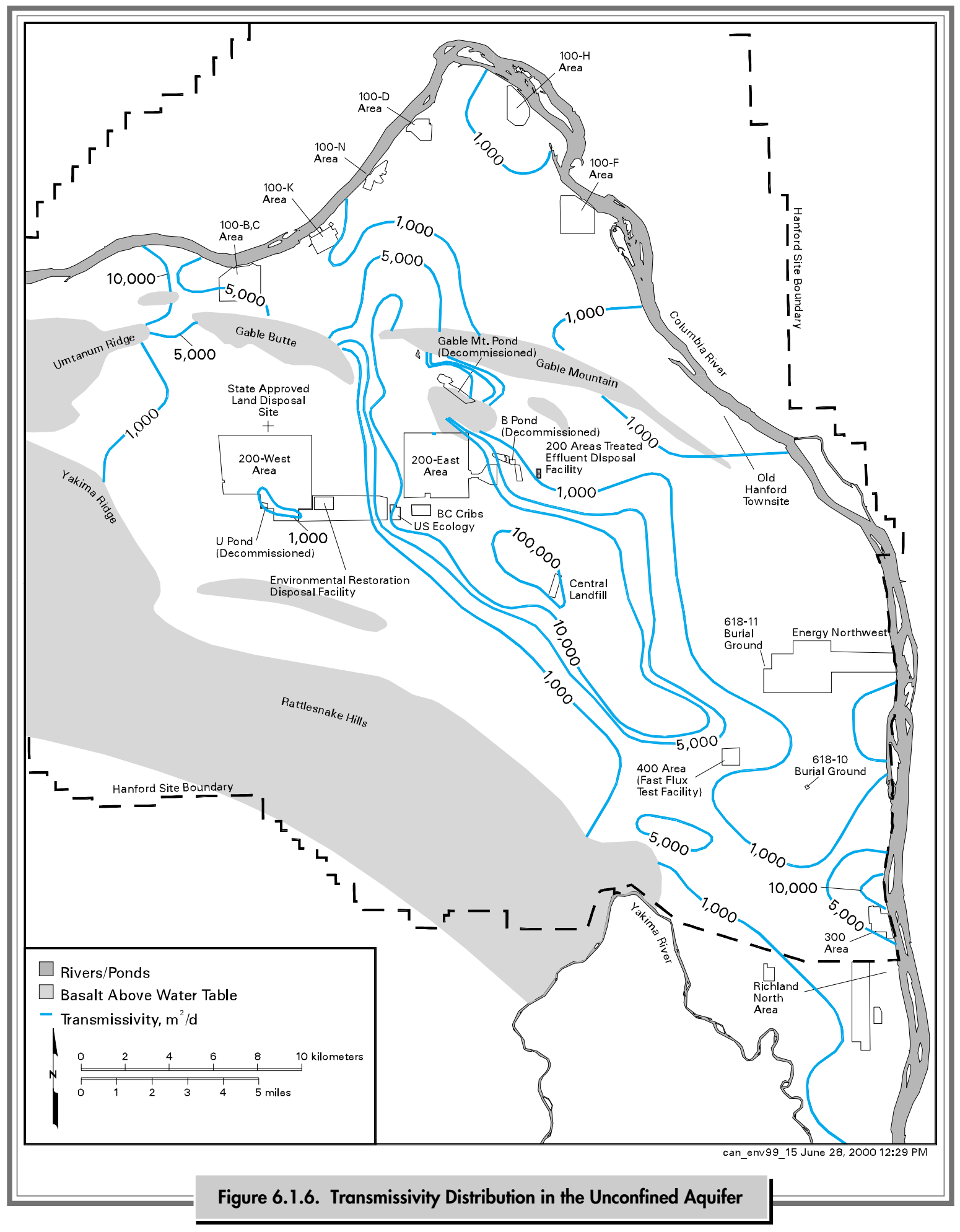




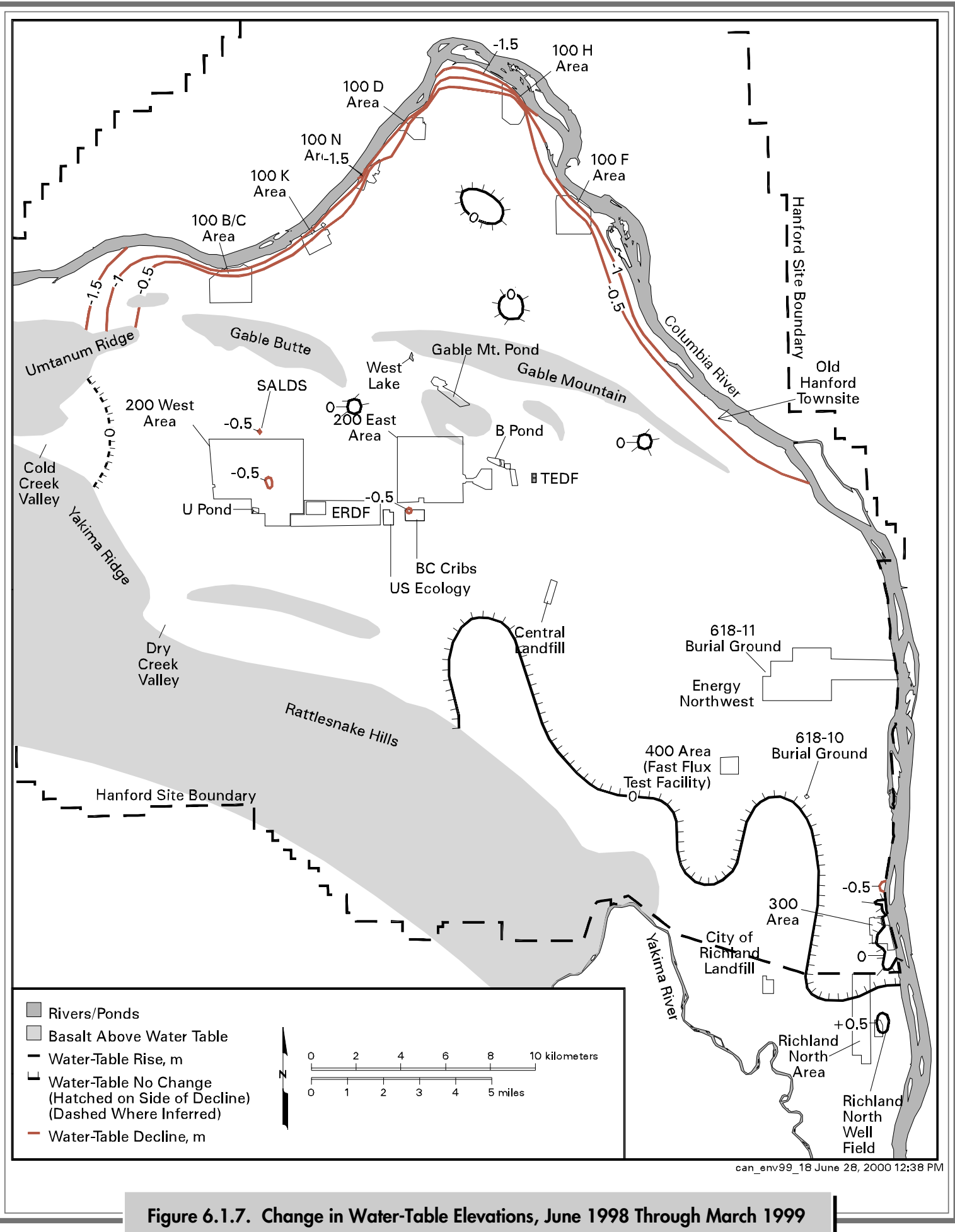


increased to a maximum before 1990 and decreased because of reduced discharge. After discharge to B Pond ceased in August 1997, the decline in the water-table elevation accelerated. In 1999, the rate of decline in the water-table elevation slowed.
Groundwater mounding related to wastewater discharges has also occurred in the 100 and 300 Areas. However, groundwater mounding in these areas is not as great as in the 200 Areas primarily because of lower discharge volumes.

\subsubsection{Contaminant Transport}

The history of contaminant releases and the physical and chemical principles of mass transport control the distribution of radionuclides and chemicals in groundwater. Processes that control the movement of these contaminants at the Hanford Site are discussed below.

Most of the groundwater contamination at the Hanford Site resulted from discharge of wastewater from reactor operations, reactor fuel fabrication, and processing of spent reactor fuel. Table 6.1.1 lists the principal contaminants found in each operational area and the type of operation that generated them. In the 100 Areas, discharges included reactor cooling water, fuel storage basin water, filter backwash, and smaller amounts of waste from a variety of other processes. In the 200 Areas, large quantities of wastewater from fuel reprocessing were discharged to the ground. Other contamination sources in the 200 Areas included plutonium purification waste and decontamination waste. The plutonium purification process resulted in the discharge of large amounts of liquid organic chemicals in addition to aqueous solutions. This organic liquid, once in contact with groundwater, slowly dissolves and produces contaminant plumes. The presence of nonaqueous liquid has a major impact on the site's groundwater remediation strategy because the organic liquid in the subsurface represents a continuing source of contamination that is very difficult to clean up. Groundwater contamination in the 300 Area resulted mainly from discharge of waste from fuel fabrication.

Liquid effluents discharged to the ground at Hanford Site facilities percolated downward through the unsaturated zone toward the water table. Radionuclide and chemical constituents move through the soil column and, in some cases, enter the groundwater. In some locations, sufficient water was discharged to saturate the soil column to the surface. Not all contaminants move at the same rate as the water in the subsurface. Chemical processes such as adsorption onto soil particles, chemical precipitation, and ion exchange slow the movement of some constituents such as strontium-90, cesium-137, and plutonium-239/240. However, these processes may be affected by the chemical characteristics of the

\begin{tabular}{|c|c|c|}
\hline \multirow[b]{2}{*}{ Areas } & \multicolumn{2}{|c|}{$\begin{array}{l}\text { Table 6.1.1. Chemical and Radiological Groundwater Contaminants } \\
\text { and Their Link to Site Operations }\end{array}$} \\
\hline & Facilities Type & Contaminants Generated \\
\hline 100 & Reactor operations & Tritium, ${ }^{60} \mathrm{Co},{ }^{90} \mathrm{Sr}, \mathrm{Cr}^{6}, \mathrm{SO}_{4}^{-2}$ \\
\hline 200 & Irradiated fuel processing & Tritium, ${ }^{90} \mathrm{Sr},{ }^{99} \mathrm{Tc},{ }^{129} \mathrm{I},{ }^{137} \mathrm{Cs}, \mathrm{Pu}, \mathrm{U}, \mathrm{CN} ; \mathrm{Cr}^{6}, \mathrm{~F}^{-}, \mathrm{NO}_{3}^{-}$ \\
\hline 200 & Plutonium purification & $\mathrm{Pu}$, carbon tetrachloride, chloroform, $\mathrm{NO}_{3}^{-}$ \\
\hline 300 & Fuel fabrication & ${ }^{99} \mathrm{Tc}, \mathrm{U}, \mathrm{Cr}^{6}$, trichloroethylene \\
\hline
\end{tabular}


waste such as high ionic strength, acidity, or presence of chemical complexants. Other radionuclides, such as technetium-99, iodine- 129 , and tritium, and chemicals, such as nitrate, are not as readily retained by the soil and move vertically through the soil column at a rate nearly equal to the infiltrating water. When the contaminants reach the water table, their concentrations are reduced by dilution with groundwater. As these dissolved constituents move with the groundwater, many radionuclides and chemicals adhere to sediment particle surfaces (adsorption) or diffuse into the particles (absorption). Radionuclide concentrations are also reduced by radioactive decay.
Outside the source areas (i.e., liquid disposal sites), there is typically little or no downward gradient (driving force or head), so contamination tends to remain in the upper part of the aquifer. In the source areas, where large volumes of wastewater were discharged, a large vertical hydraulic gradient developed that moved contaminants downward in the aquifer. Layers of low-permeability silt and clay within the unconfined aquifer also limit the vertical movement of contaminants. Flow in the unconfined aquifer is generally toward the Columbia River, which acts as a drainage area for the groundwater flow system at Hanford. Contamination that reaches the river is further diluted by river water.

\subsubsection{Groundwater Modeling}

Numerical modeling of groundwater flow and contaminant transport is performed to simulate future groundwater flow conditions and predict the migration of contaminants through the groundwater pathway. Modeling of Hanford Site groundwater is also used to assess performance of waste disposal facilities and evaluate remediation strategies. In 1999, efforts were made to consolidate sitewide groundwater models into one model. The purpose of the consolidation was to eliminate redundancies and promote consistency in groundwater modeling analyses for the Hanford Site. The scope of the model consolidation process was to define needs and requirements of a sitewide model, evaluate current sitewide models and codes, and specify recommendations for a consolidated sitewide model. The recommendations for the consolidated sitewide model were subjected to an external peer review.

DOE selected a computer model developed by Pacific Northwest National Laboratory's groundwater project for the sitewide groundwater model. The model has broad capabilities to meet the anticipated needs of the site. Capabilities of the model include a high level of resolution, a large areal extent to address the potential movement of contaminant plumes off the Hanford Site, and the effects of natural recharge. The DOE selected the Coupled Fluid, Energy, and Solute Transport (CFEST-96) code as an interim code for implementing the consolidated sitewide groundwater model (Gupta 1997). The CFEST-96 code was developed by CFEST Co., Irvine, California. The model includes up to nine layers above the top of basalt to represent the major hydrogeologic units within the unconfined aquifer system.

In 1999, the sitewide model was applied to an environmental impact statement for solid waste. The Pacific Northwest National Laboratory used the sitewide groundwater model to predict the impact of water quality on human health and the environment. The purpose of this analysis was to calculate contaminant concentrations in groundwater from source areas defined in each of the environmental impact alternatives. The calculations were compared with drinking water standards and provided a basis to estimate the potential risk to human health and ecology. The potential sources of groundwater contamination were solid and radioactive waste contained in low-level burial grounds in the 200-East and 200-West Areas.

Groundwater models were used to assess the performance of groundwater pump-and-treat 
systems in operable units in the $100-\mathrm{K}, 100-\mathrm{N}$, 100-D, 100-H, and 200-West Areas. The operable units and their associated contaminants of concern are presented in Table 6.1.2. In these pump-andtreat systems, contaminated water is removed by means of extraction wells, treated, and either disposed of to the State-Approved Land Disposal Site or returned upgradient to the aquifer through injection wells. The models were used to predict system performance and progress toward remediation goals. The modeling was used to evaluate different extraction and injection well configurations, predict effects of pumping, assess the extent of hydraulic influence and the capture zone, and evaluate groundwater travel times. Modeling was conducted using the Micro-FEM ${ }^{\odot}$ finite-element code developed by C. J. Hemker, Amsterdam, The Netherlands.

Computer modeling was used to evaluate hydraulic capture and optimize the pumping rates of the pump-and-treat systems in the operable units in the 100-K, 100-N, 100-D, and 100-H Areas. The modeling results showed that the extraction wells were reducing the net groundwater flow to the Columbia River through the targeted plume area by $~ 70 \%$ in the 100-KR-4 Operable Unit, $29 \%$ in the 100-NR-2 Operable Unit, over $90 \%$ in the 100-D Area part of the 100-HR-3 Operable Unit, and $82 \%$ in the 100-H Area part of the 100-HR-3 Operable Unit (DOE/RL-99-02; DOE/RL-99-13).

For the 200-UP-1 Operable Unit in the 200-West Area, modeling was performed to evaluate effectiveness in containing the targeted area of the technetium-99 and uranium plumes and track progress of remediation. The modeling showed that the area of high technetium-99 and uranium concentrations was captured and contained using one extraction well (299-W19-39). The extraction well removed at least one pore volume of water from the targeted plume area by the end of September 1999 (DOE/RL99-02; DOE/RL-99-79). One pore volume is the total volume of pores considered collectively within soils of the targeted plume.

For the 200-ZP-1 Operable Unit in the 200-West Area, modeling was performed to evaluate the remedial action of the pump-and-treat system. The modeling results indicated that the pump-andtreat extraction wells contained the high carbon tetrachloride concentration area of the plume and provided a hydraulic barrier to plume movement (DOE/RL-99-79). The modeling predictions showed that pumping had removed one pore volume of water from the aquifer (upper 15 meters [ 49 feet]) near the northernmost extraction wells.

\begin{tabular}{|lcl|}
\hline \multicolumn{2}{|c|}{$\begin{array}{c}\text { Table 6.1.2. } \\
\text { Operable Units and Associated Contaminants } \\
\text { of Concern }\end{array}$} \\
\hline A rea & Operable Unit & Contaminants of Concern \\
$100-\mathrm{K}$ & $100-\mathrm{KR}-4$ & Hexavalent chromium \\
$100-\mathrm{N}$ & $100-\mathrm{NR}-2$ & Strontium-90 \\
$100-\mathrm{H}$ and 100-D & $100-\mathrm{HR}-3$ & Hexavalent chromium \\
$200-$ West & $200-\mathrm{UP}-1$ & Technetium-99 and uranium \\
$200-$ West & $200-\mathrm{ZP}-1$ & Carbon tetrachloride \\
\hline
\end{tabular}




\subsubsection{Groundwater Monitoring}

Groundwater monitoring at the Hanford Site is an integral part of the $\mathrm{H}$ anford Site $\mathrm{G}$ round-W ater Protection M anagement Plan (DOE/RL-89-12, Rev. 2). That plan integrates monitoring at active waste disposal facilities to comply with requirements of the RCRA and Washington State regulations, as well as requirements for operational monitoring around reactor and chemical processing facilities and environmental surveillance monitoring. Pacific Northwest National Laboratory manages these monitoring efforts to assess the distribution and movement of existing groundwater contamination, to identify and characterize potential and emerging groundwater contamination problems, and to integrate the various groundwater projects to minimize redundancy.

The Integrated M onitoring Plan for the $\mathrm{H}$ anford G roundwater M onitoring Project (PNNL-11989, Rev. 1) describes how the DOE will implement the groundwater monitoring requirements outlined in DOE (1987) and DOE/RL-89-12, Rev. 2. The purpose of the integrated monitoring plan is to 1) describe the monitoring well networks, constituents, sampling frequencies, and criteria used to design the monitoring program; 2) identify federal and state groundwater monitoring requirements and regulations; and 3) provide a list of wells, constituents, and sampling frequencies for groundwater monitoring conducted on the Hanford Site. Federal and state regulations include RCRA, CERCLA, and Washington Administrative Codes.

Information on contaminant distribution and transport are integrated into a sitewide evaluation of groundwater quality, which is documented in an annual groundwater monitoring report (e.g., PNNL-13116). Groundwater monitoring is also carried out during CERCLA cleanup investigations. These investigations, managed by Bechtel Hanford, Inc., are documented in annual summary reports (e.g., DOE/RL-99-79).

\subsubsection{Groundwater Sampling and Analytes of Interest}

Groundwater samples were collected from 645 wells for all monitoring programs during 1999. The locations of sampled wells are shown in Figures 6.1.8 and 6.1.9; well names are indicated only for those 400 and 600 Area wells specifically discussed in the text. Because of the density of unconfined aquifer wells in the operational areas, well names in these areas are shown on detailed maps in the following sections. Figure 6.1.10 shows the locations of facilities where groundwater monitoring was conducted to comply with RCRA (Appendix A in PNNL-13116). Wells at the Hanford Site generally follow a naming system that indicates the approximate location of the well. The prefix of the well name indicates the area of the site, as shown in Table 6.1.3. The names for 600 Area wells follow a local coordinate system in which the numbers indicate the distance relative to an arbitrary datum location in the south-central part of the site.

The monitoring frequency for the wells was selected by Pacific Northwest National Laboratory based on regulatory requirements, variability of historical data, proximity to waste sources, and characteristics of the groundwater flow system at the sample location. Of the 645 wells sampled, 288 were sampled once, 164 twice, 55 three times, 88 four times, and 50 wells were sampled more than four times during the year. Beginning in 1998, the sampling frequency was changed to every 3 years for several wells that showed concentrations with steady historical trends. Wells showing larger variability are sampled more frequently (annually or more often). Wells that monitor source areas are sampled more frequently than wells that do not monitor source areas. Contaminants with greater mobility 


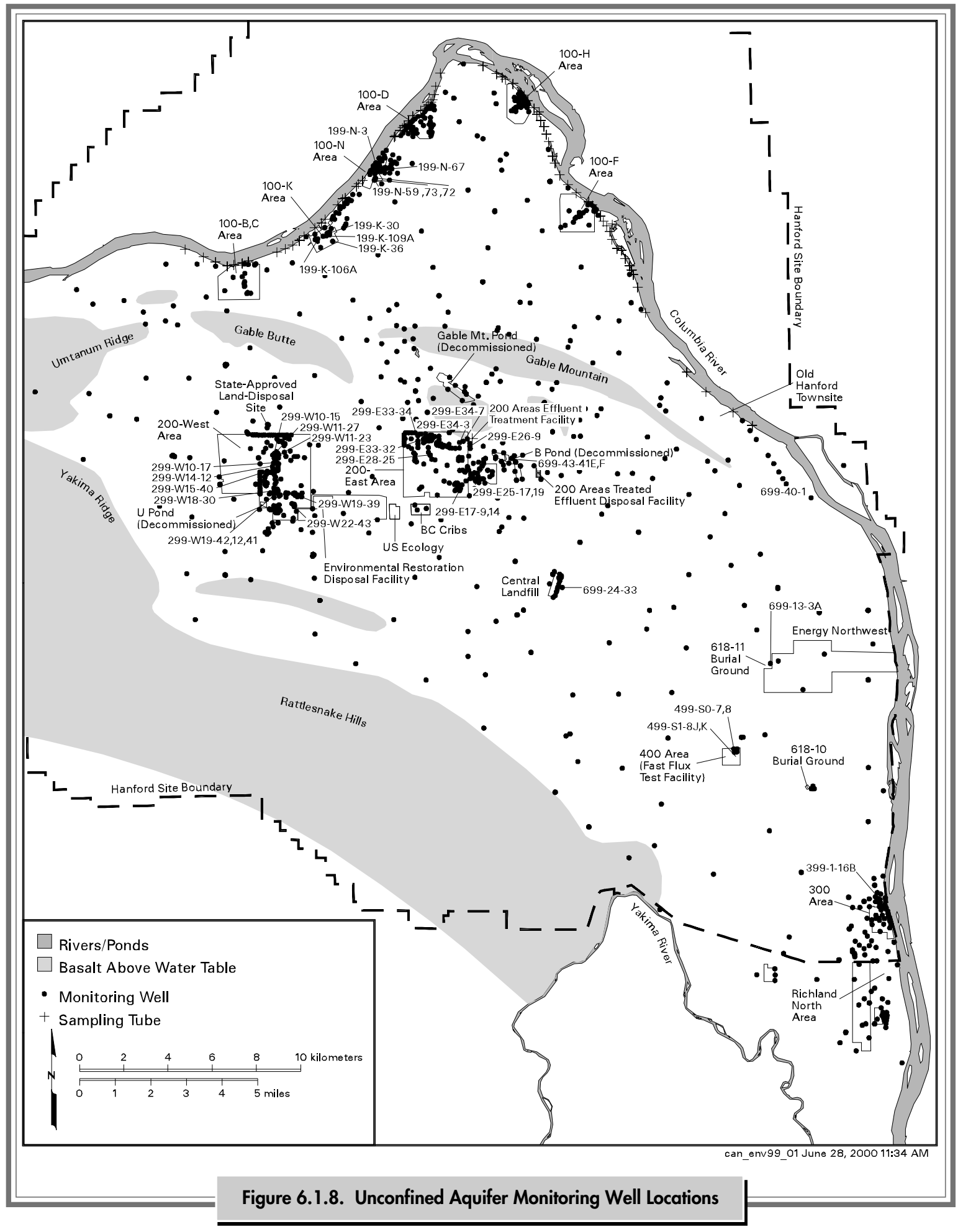




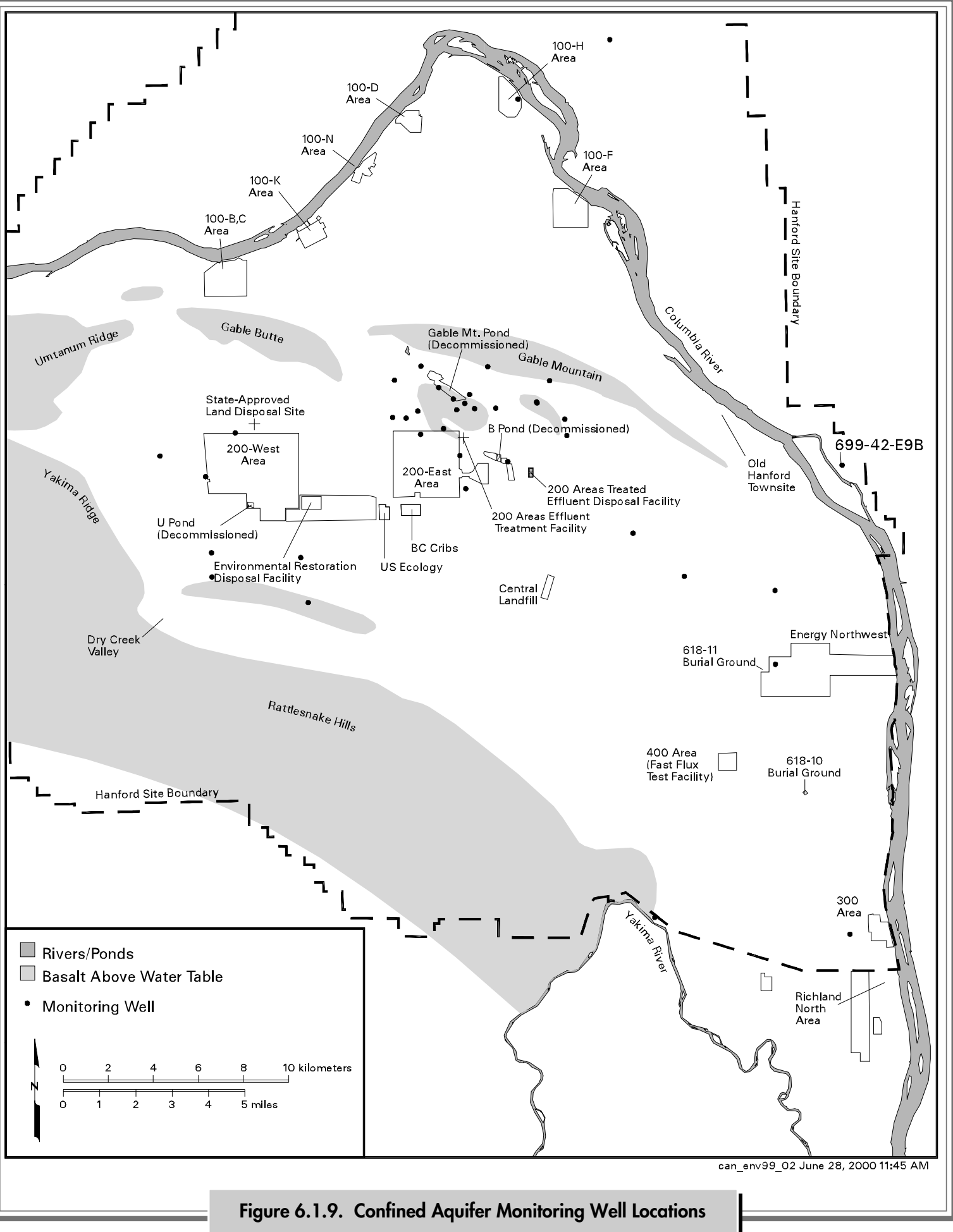




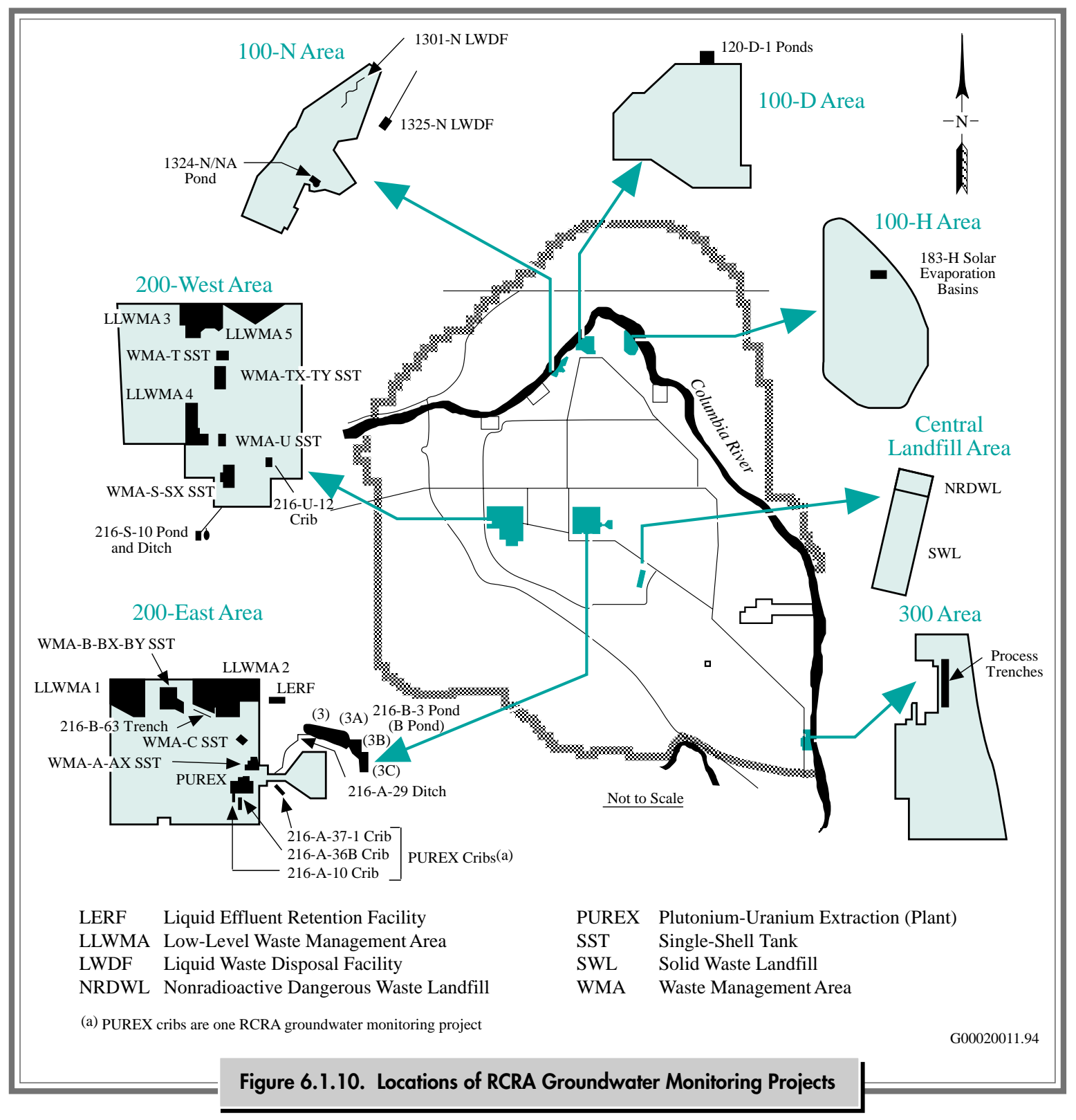

(e.g., tritium) in groundwater may be sampled more frequently than contaminants that are not very mobile (e.g., strontium-90).

Each monitoring program has access to groundwater data collected by other programs through a common database, the Hanford Environmental Information System. This database contains more than 1.6 million groundwater monitoring result records. After the data are verified and/or validated, they are made available to federal and state regulators for retrieval.

Most groundwater monitoring wells on the site are 10 to 20 centimeters ( 4 to 8 inches) in diameter. Monitoring wells for the unconfined aquifer are constructed with well screens or perforated casing generally in the upper 3 to 6 meters (10 to 20 feet) of 


\begin{tabular}{|c|c|}
\hline \multicolumn{2}{|c|}{$\begin{array}{l}\text { Table 6.1.3. Hanford Site Well } \\
\text { Naming System }\end{array}$} \\
\hline \multicolumn{2}{|l|}{ Example } \\
\hline 199- & 100 A reas \\
\hline $199-B 3-47$ & 100-B,C Area \\
\hline 199-D5-12 & 100-D Area \\
\hline $199-F 8-3$ & 100-F Area \\
\hline 199-H4-3 & 100-H Area \\
\hline 199-K-30 & 100-K Area \\
\hline $199-\mathrm{N}-67$ & 100-N Area \\
\hline 299- & 200 A reas \\
\hline 299-W19-3 & 200-West Area \\
\hline 299-E28-4 & 200-East Area \\
\hline 399- & 300 A rea \\
\hline $399-1-17 \mathrm{~A}$ & 300 Area \\
\hline 499- & 400 A rea \\
\hline 499-S1-8J & 400 Area \\
\hline 699- & 600 A rea \\
\hline $\begin{array}{l}699-50-53 A \\
699-42-E 9 A \\
699-S 19-11 \\
699-S 19-E 13\end{array}$ & $\begin{array}{l}600 \text { Area north and west of datum } \\
600 \text { Area north and east of datum } \\
600 \text { Area south and west of datum } \\
600 \text { Area south and east of datum }\end{array}$ \\
\hline $\begin{array}{l}\text { Note: Letters } \\
\text { multiple wells } \\
\text { intervals withi }\end{array}$ & $\begin{array}{l}\text { of well names distinguish either } \\
\text { d close together or multiple } \\
\text { agle well bore. }\end{array}$ \\
\hline
\end{tabular}

the unconfined aquifer, with the open interval extending across the water table. This construction allows sample collection at the top of the aquifer, where maximum concentrations of radionuclides and maximum concentrations of chemicals tend to be found. Wells monitoring the shallowest of the basalt-confined aquifers have screens, perforated casing, or an open hole within the monitored aquifer. Wells drilled before 1985 were generally constructed with carbon steel casing. Since 1985, RCRA monitoring wells and CERCLA characterization wells have been constructed with stainless steel casing and screens. Most monitoring wells on the site are sampled using either submersible or Hydrostar ${ }^{\mathrm{TM}}$ pumps (a registered trademark of Instrumentation Northwest, Inc., Redmond, Washington), though some wells are sampled with bailers or airlift systems.

Samples were collected for all programs following documented sampling procedures (PNL-6894, Rev. 1; ES-SSPM-001) based on U.S. Environmental Protection Agency (EPA) guidelines (OSWER 9950-1). Analytical techniques used are listed in DOE/RL-91-50, Rev. 2; PNNL-13080; and CERCLA work plans. The samples were analyzed for the radionuclides and chemicals listed in Table 6.1.4.

Most groundwater samples collected on the site in 1999 were analyzed for tritium. Selected samples were analyzed for other radionuclides. Sample results for radionuclides are generally presented in picocuries per liter; however, the results for total uranium, which is usually measured by laser fluorescence, are given in micrograms per liter.

Nitrate analyses were performed on many samples collected during 1999 because of the extensive areas with elevated nitrate concentrations that originate from onsite and offsite sources. However, nitrate concentrations were below the EPA 45-mg/L drinking water standard (40 CFR 141) for most of the affected area. Selected monitoring wells were used for additional chemical surveillance.

\subsubsection{Data Interpretation}

Each analysis of a groundwater sample provides information on the composition of groundwater at one time at one location in the aquifer. Uncertainty in the analyses results from a number of sources. Some of the sources of uncertainty are discussed below. Several techniques used to interpret the sample results are also discussed.

Groundwater sampling techniques are designed to collect a sample that is representative of the constituent concentration in the aquifer when the sample is taken. However, there are limitations in collecting representative samples or even defining 


\begin{tabular}{|c|c|}
\hline \multicolumn{2}{|c|}{$\begin{array}{l}\text { Table 6.1.4. Radionuclides and Chemicals Analyzed for in } \\
\text { Groundwater, } 1999\end{array}$} \\
\hline $\begin{array}{l}\text { Radiological } \\
\text { Parameters }\end{array}$ & Chemical and Biological Parameters \\
\hline Tritium & $\mathrm{pH}$ (field) \\
\hline Beryllium-7 & Conductance (field and laboratory) \\
\hline Carbon-14 & Total dissolved solids \\
\hline Potassium-40 & Alkalinity \\
\hline Cobalt -58 & Total carbon \\
\hline Iron-59 & Total organic carbon \\
\hline Cobalt -60 & Total organic halogens \\
\hline Strontium-90 & $\mathrm{Be}, \mathrm{Na}, \mathrm{Mg}, \mathrm{Al}, \mathrm{K}, \mathrm{Co}, \mathrm{Si}, \mathrm{As}, \mathrm{Se}$ \\
\hline Technetium-99 & $\mathrm{Ca}, \mathrm{V}, \mathrm{Cr}, \mathrm{Mn}, \mathrm{Fe}, \mathrm{Ni}, \mathrm{Pb}, \mathrm{Li}, \mathrm{Hg}$ \\
\hline Ruthenium-106 & $\mathrm{Cu}, \mathrm{Zn}, \mathrm{Sr}, \mathrm{Ag}, \mathrm{Cd}, \mathrm{Sb}, \mathrm{Ba}, \mathrm{Sn}, \mathrm{Tl}, \mathrm{Ti}$ \\
\hline Antimony-125 & $\mathrm{F}^{-}, \mathrm{Cl}, \mathrm{NO}_{3}^{-}, \mathrm{PO}_{4}^{-3}, \mathrm{SO}_{4}^{-2}, \mathrm{NO}_{2}^{-}, \mathrm{Br}^{-}$ \\
\hline Iodine-129 & $\mathrm{CN}^{-}$ \\
\hline Cesium-134 & $\mathrm{NH}_{4}^{+}$ \\
\hline Cesium-137 & Hexavalent chromium \\
\hline Neptunium-237 & Volatile organic compounds \\
\hline Americium-241 & Semivolatile organic compounds \\
\hline Gross alpha & Polychlorinated biphenyls \\
\hline Gross beta & Pesticides \\
\hline Europium isotopes & Chemical oxygen demand \\
\hline Plutonium isotopes & Coliform bacteria \\
\hline Radium isotopes & Dissolved oxygen (field) \\
\hline Uranium isotopes & Total petroleum hydrocarbons \\
\hline Uranium (total) & Oil and grease \\
\hline & Diesel oil \\
\hline & Gasoline \\
\hline
\end{tabular}

precisely the volume of the aquifer represented by the sample. Proper well construction and maintenance, well purging, sample preservation, and, in some instances, filtering are used to help ensure consistent and representative samples. Careful sample labeling protocols, chain-of-custody documentation, and bottle preparation avoid many gross errors in sample results. Duplicate samples and field blanks are used to assess the sampling procedure.

Uncertainties are inherent in laboratory analysis of samples. Gross errors can be introduced in the laboratory or during sampling. Gross errors include transcription errors, calculation errors, mislabeling results, field equipment problems, or other errors that result from not following established procedures. Often, these gross errors can be recognized because unreasonably high or unreasonably low values result. Data review protocols are used to investigate and correct gross errors.

Random errors are unavoidably introduced in the analytical procedures. Usually, there are insufficient replicate analyses to assess the overall random error at each sample location. Instruments for analysis of radioactive constituents count the number of radioactive decay products at a detector, and background counts are subtracted. The nature of 
radioactive decay and the instrument design result in a random counting error that is reported with the analytical result. Generally, a sample result less than the counting error indicates the constituent was not detected. The background subtraction may result in the reporting of results that are less than zero. Although below-zero results are physically impossible, the negative values are of use for some statistical analyses (see "Helpful Information" section for more details).

Systematic errors may result from problems with instrument calibration, standard or sample preparation, chemical interferences in analytical techniques, as well as sampling methodology and sample handling. Sample and laboratory protocols have been designed to minimize systematic errors. The analytical laboratories participate in interlaboratory comparisons, in which many laboratories analyze blind samples prepared by the EPA (see Section 8.0, "Quality Assurance").

In 1999, double-blind samples for specific constituents were analyzed (Section 8.0, "Quality Assurance," discusses double-blind results). Several wells were also cosampled with the Washington State Department of Health for comparison, and the results are available from that agency.

The chemical composition of groundwater may fluctuate from differences in the contaminant source, recharge, or groundwater flow field. The range of this concentration fluctuation can be estimated by taking many samples, but there is a limit to the number that can be practicably taken. Comparison of results through time helps interpret this variability.

Overall sample uncertainty may be factored into data evaluation by considering the concentration trend in a given well over time. This often helps identify gross errors, and overall, long-term trends can be distinguished from short-term variability. The interpretation of concentration trends depends on an understanding of chemical properties as well as site hydrogeology. The trend analysis, in turn, aids in refining the conceptual model of the chemical transport.

Plume maps presented in this section illustrate site groundwater chemistry. Although analytical data are available only at specific points where wells were sampled, contours are drawn to join the approximate locations of equal chemical concentration or radionuclide activity levels. The contour maps are simplified representations of plume geometry because of map scale, the lack of detailed information, and the fact that plume depth and thickness cannot be fully represented on a two-dimensional map. Plume maps are a powerful tool because knowledge of concentrations in surrounding wells, groundwater flow, site geology, and other available information are factored into their preparation.

\subsubsection{Groundwater Monitoring Results}

The following sections summarize the distribution of radioactive and chemical contaminants detected in Hanford Site groundwater during 1999. These discussions are followed by a summary of groundwater monitoring results for RCRA sites. More detailed information on groundwater monitoring, including listings of analysis results for each monitoring well in electronic format, is available in PNNL-13116. However, because PNNL-13116 (the annual groundwater report) covers the fiscal year, it does not include results from the last 3 months of 1999. This report includes results for the last 3 months of 1999.

One way to assess the impact of radionuclides and chemicals in groundwater is to compare them to EPA's drinking water standards and DOE's derived concentration guides (40 CFR 141 and DOE Order 5400.5; see Appendix C, Tables C.2 and C.5). The drinking water standards were established to protect public drinking water supplies. The derived 
concentration guides were established to protect the public from radionuclides resulting from DOE operations. Specific drinking water standards have been defined for only a few radiological constituents. Drinking water standards have been calculated for other radionuclides, using an annual dose of $4 \mathrm{mrem} / \mathrm{yr}$. Calculations of these standards consider their halflife, the energy and nature of the radioactive decay, and the physiological factors such as its buildup in particular organs. Drinking water standards are more restrictive than derived concentration guides because the standards are based on an annual dose of $4 \mathrm{mrem} / \mathrm{yr}$ to the affected organ. The guides are based on an effective dose equivalent of $100 \mathrm{mrem} / \mathrm{yr}$ (see Appendix C, Tables C.2 and C.5). In addition, the standards use older factors for calculating the concentrations that would produce a 4-mrem/yr dose than are used in calculating the guides. Thus, the values used below for standards are not always in agreement with the guides, which are available only for radionuclides. Primary and secondary drinking water standards are given for some chemical constituents; secondary standards are based on aesthetic rather than health considerations.

The total area of contaminant plumes with concentrations exceeding drinking water standards was estimated to be $\sim 254$ square kilometers (98 square miles) in 1999. This area, which is an increase of $\sim 4 \%$ compared to 1998 , occupies just under $20 \%$ of the total area of the Hanford Site. Most of the contaminant plume area lies southeast of the 200-East Area extending to the Columbia River (Figure 6.1.11). The most widespread contaminants within these plumes were tritium, iodine-129, technetium-99, uranium, strontium-90, carbon tetrachloride, nitrate, and trichloroethylene. Contaminant plumes with concentrations exceeding derived concentration guides occur in isolated areas. The only contaminants at levels above the derived concentration guide in 1999 were tritium, uranium, and strontium-90.

\subsubsection{Radiological Monitoring Results for the Unconfined Aquifer}

Hanford Site groundwater was analyzed for the radionuclides listed in Table 6.1.4. The distribution of tritium, iodine-129, technetium-99, uranium, strontium-90, carbon-14, cesium-137, cobalt-60, and plutonium are discussed in the following sections. Tritium and iodine-129 are the most widespread radiological contaminants associated with past site operations. Technetium-99 and uranium plumes are extensive in the 200 Areas and adjacent 600 Area. Strontium-90 plumes exhibit very high concentrations in the 100 Areas but are of relatively smaller extent. A carbon-14 plume is present in the $100-\mathrm{K}$ Area. Cesium-137, cobalt-60, and plutonium contamination occurs in isolated areas in the 200 Areas. Gross alpha and gross beta are used as indicators of radionuclide distribution and are not discussed in detail because the specific radionuclides contributing to these measurements are discussed individually. Several other radionuclides, including ruthenium106 , antimony-125, and americium-241, are associated with wastes from Hanford Site operations. Because of their very low activities in groundwater, they are not discussed in this section. Half-lives of the radionuclides are presented in Table H.5 in the "Helpful Information" section.

Tritium. Tritium, which is present in irradiated nuclear fuel, was released in process condensates associated with decladding and dissolution of the fuel. Tritium was also manufactured as part of the Hanford mission by irradiating targets containing lithium in several reactors from 1949 to 1952 (DOE/ EIS-0119F, WHC-SD-EN-RPT-004). In the late 1960s, tritium production took place in N Reactor (WHC-MR-0388).

Tritium was present in many historical waste streams at the Hanford Site and is highly mobile, 


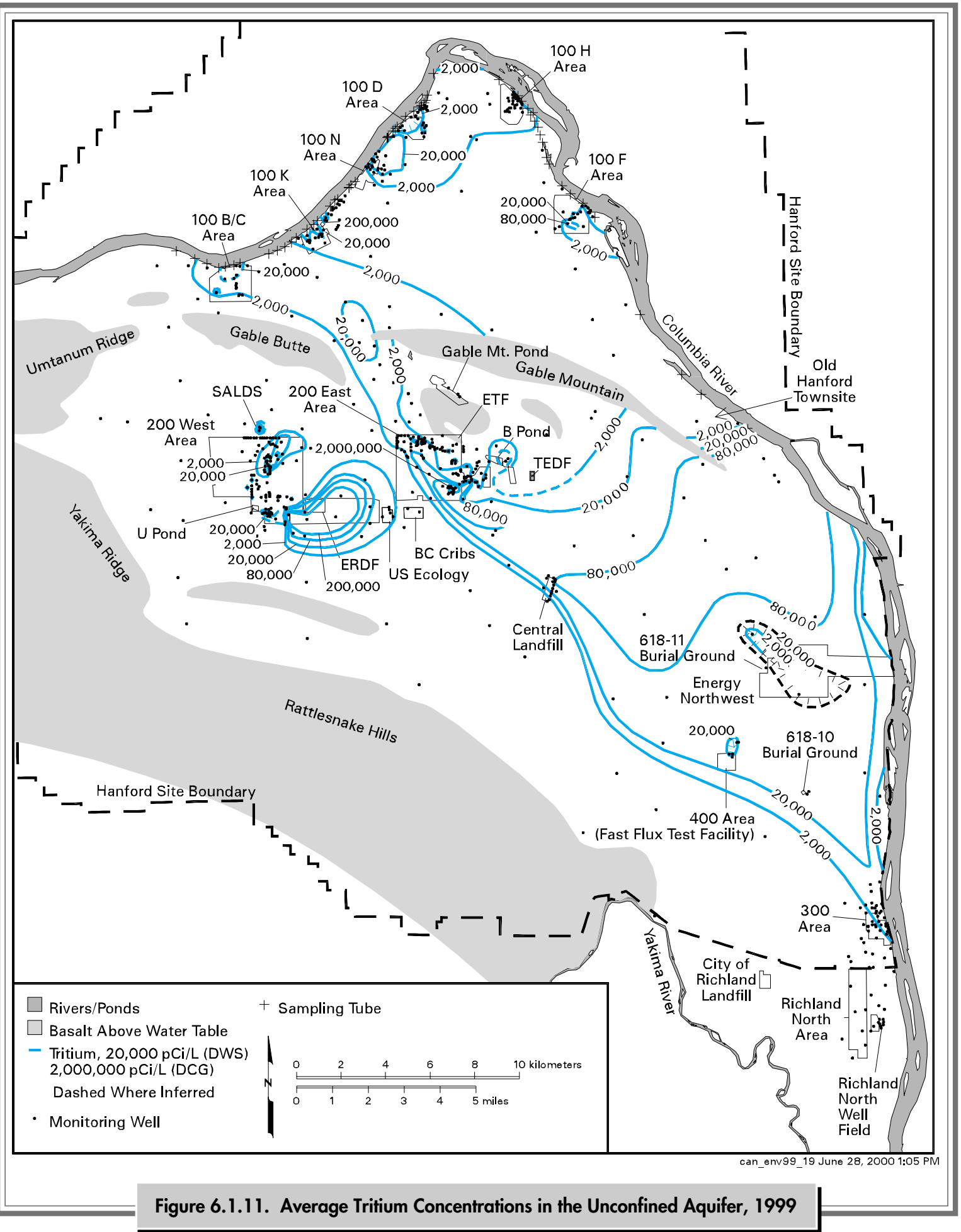


essentially moving at the same velocity as the groundwater. Consequently, the extent of groundwater contamination from site operations is generally reflected by tritium distribution. For this reason, tritium is the most frequently monitored radionuclide at the Hanford Site. Figure 6.1.11 shows the 1999 distribution of tritium in the unconfined aquifer. Tritium is one of the most widespread contaminants in groundwater across the Hanford Site and exceeded the 20,000-pCi/L drinking water standard in the 100, 200, 400, and 600 Areas. Tritium levels exceeded the 2,000,000-pCi/L derived concentration guide in the $100-\mathrm{K}$ and 200 Areas. Tritium levels are expected to decrease because of dispersion and radioactive decay (half-life is 12.35 years). In the 600 Area, tritium was detected above the derived concentration guide for the first time in a well near the 618-11 burial ground in early 2000 .

In 1999, the only tritium bearing liquid effluent discharged to the soil column on the Hanford Site occurred at the State-Approved Land Disposal Site, which began operating in 1995 and is located just north of the 200-West Area. The total radioactivity received by this facility in 1999 was $\sim 9$ curies, which was attributed solely to tritium.

Tritium in the 100 A reas. Tritium concentrations greater than the drinking water standard were detected in the 100-B,C, 100-D, 100-F, 100-K, and 100-N Areas. Tritium was detected above the derived concentration guide in the $100-\mathrm{K}$ Area. The largest tritium plume in the 100 Areas with concentrations above the drinking water standard occurs along the Columbia River from the 100-N Area to the 100-D Area.

Tritium concentrations continued to exceed the drinking water standard in several wells in the northern and southwestern parts of the 100-B,C Area in 1999. Most of these are associated with past liquid disposal practices at 100-B,C retention basins and trenches near the Columbia River. The maximum tritium concentration decreased slightly to $86,900 \mathrm{pCi} / \mathrm{L}$ in the southwestern part of the 100-B,C Area.
In the 100-D Area, tritium concentrations decreased in the southwestern corner of the area, but were still greater than the drinking water standard in 1999. The maximum tritium reported during 1999 was $20,400 \mathrm{pCi} / \mathrm{L}$ in the southwestern corner of the area and is associated with the tritium plume that extends southwest to the 100-N Area.

One well in the 100-F Area contained tritium at concentrations greater than the drinking water standard. A maximum of $36,900 \mathrm{pCi} / \mathrm{L}$ occurred near the 118-F-1 burial ground in 1999. This was a slight decrease from the 1998 maximum. This burial ground received only solid waste, and the source of the tritium contamination is not known.

Well 199-K-30, located near the KE Reactor in the $100-\mathrm{K}$ Area, continued to contain the highest tritium within the 100 Areas, with a maximum concentration of $2,230,000 \mathrm{pCi} / \mathrm{L}$. This is the only tritium concentration in the 100 Areas that exceeded the derived concentration guide in 1999. The tritium trend for well $199-\mathrm{K}-30$ is shown in Figure 6.1.12. The probable source is past disposal to a French drain east of the reactor building (DOE/ EIS-0119F). The downward migration of tritium is promoted by increased infiltration of water from the surface, which is discussed in PNNL-13116. Tritium levels greater than the drinking water standard, but much less than the derived concentration guide, occur in a small area near a pump-and-treat extraction well adjacent to the Columbia River.

A widespread tritium plume at levels exceeding the drinking water standard extends northeast from the northern part of the $100-\mathrm{N}$ Area to the 600 and 100-D Areas. This plume is associated with past liquid disposal to the 1301-N and 1325-N Liquid Waste Disposal Facilities. The highest concentrations, which have decreased in recent years, continued to decrease in 1999. The maximum tritium level reported in the $100-\mathrm{N}$ Area in 1999 was $51,600 \mathrm{pCi} / \mathrm{L}$ between the $1301-\mathrm{N}$ facility and the Columbia River. 


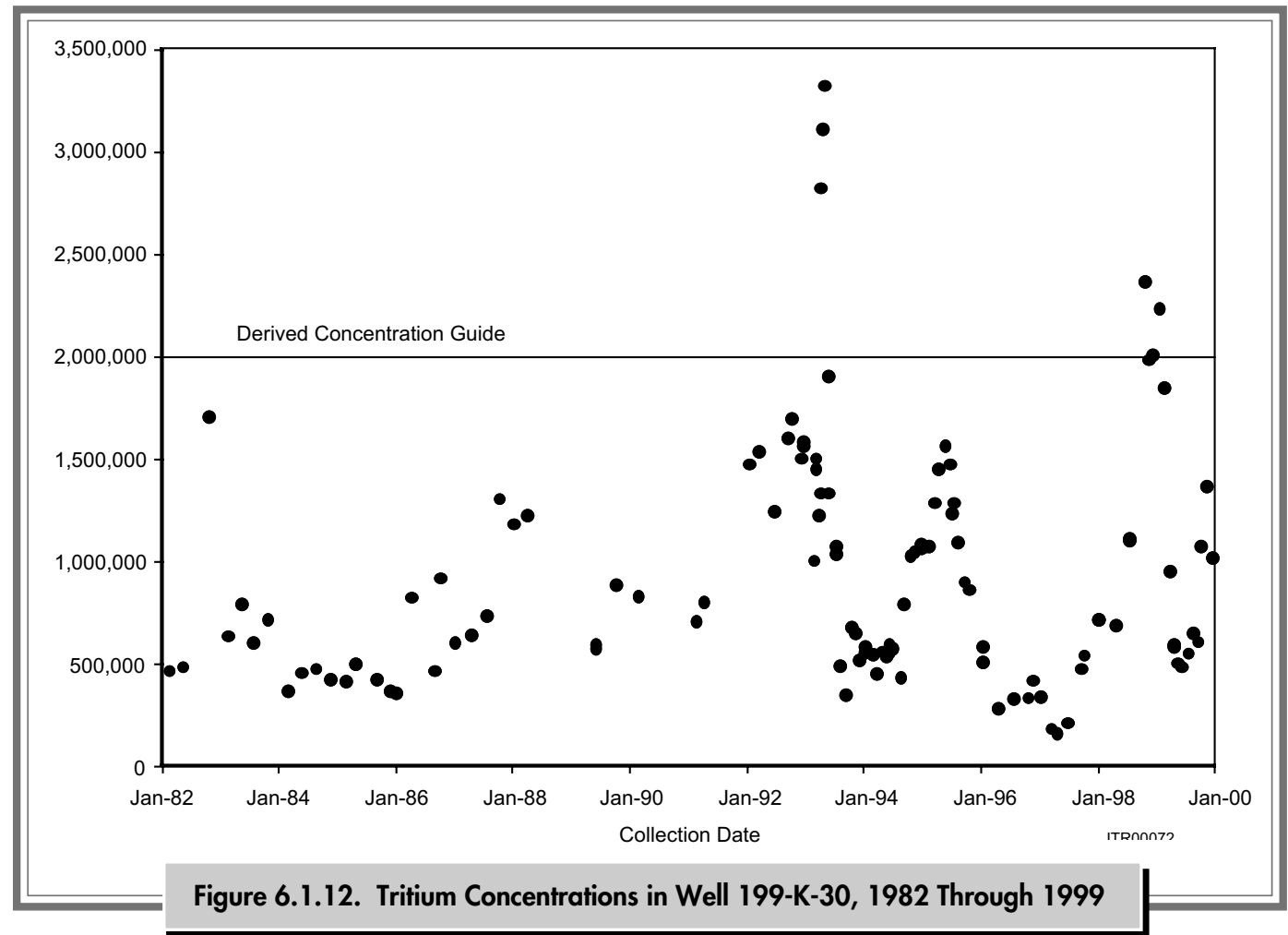

Tritium in the 200-East and 600 A reas. The highest tritium concentrations in the 200-East Area continued to be measured in wells near cribs that received effluent from the Plutonium-Uranium Extraction Plant. However, tritium levels are generally decreasing slowly in this area because of dispersion and radioactive decay. Levels greater than the derived concentration guide were detected in only one well (299-E17-9) in 1999 in the 200-East Area. The maximum tritium level detected in this well, which monitors the $216-\mathrm{A}-36 \mathrm{~B}$ crib in the southeastern part of the 200-East Area, was 2,450,000 pCi/L. This was the highest tritium level detected in any well on the Hanford Site in 1999.

In the plume that extends from the southeastern portion of the 200-East Area, tritium concentrations above $200,000 \mathrm{pCi} / \mathrm{L}$ occurred in a small area downgradient of the Plutonium-Uranium Extraction Plant and did not extend beyond the 200-East Area boundary. The plume area at levels above
200,000 pCi/L has extended at least as far southeast as the Central Landfill in the recent past (PNL-8073).

A widespread tritium plume extends from the southeastern portion of the 200-East Area to the Columbia River (see Figure 6.1.11). Movement of the plume was consistent with patterns noted in recent monitoring reports (Section 5.10.3.2 in PNNL-12086, Section 2.9.2 in PNNL-13116). Separate tritium pulses associated with the two episodes of Plutonium-Uranium Extraction Plant operations can be distinguished in the plume. A trend plot (Figure 6.1.13) of the tritium concentrations in well 699-40-1 east of the 200-East Area near the shore of the Columbia River clearly shows the arrival of a pulse in the mid-1970s. High tritium concentrations near the Columbia River result from discharges to the ground during the operation of the Plutonium-Uranium Extraction Plant from 1956 to 1972. Following an 11-year shutdown, plant operation began in 1983 and ceased in December 1988. 


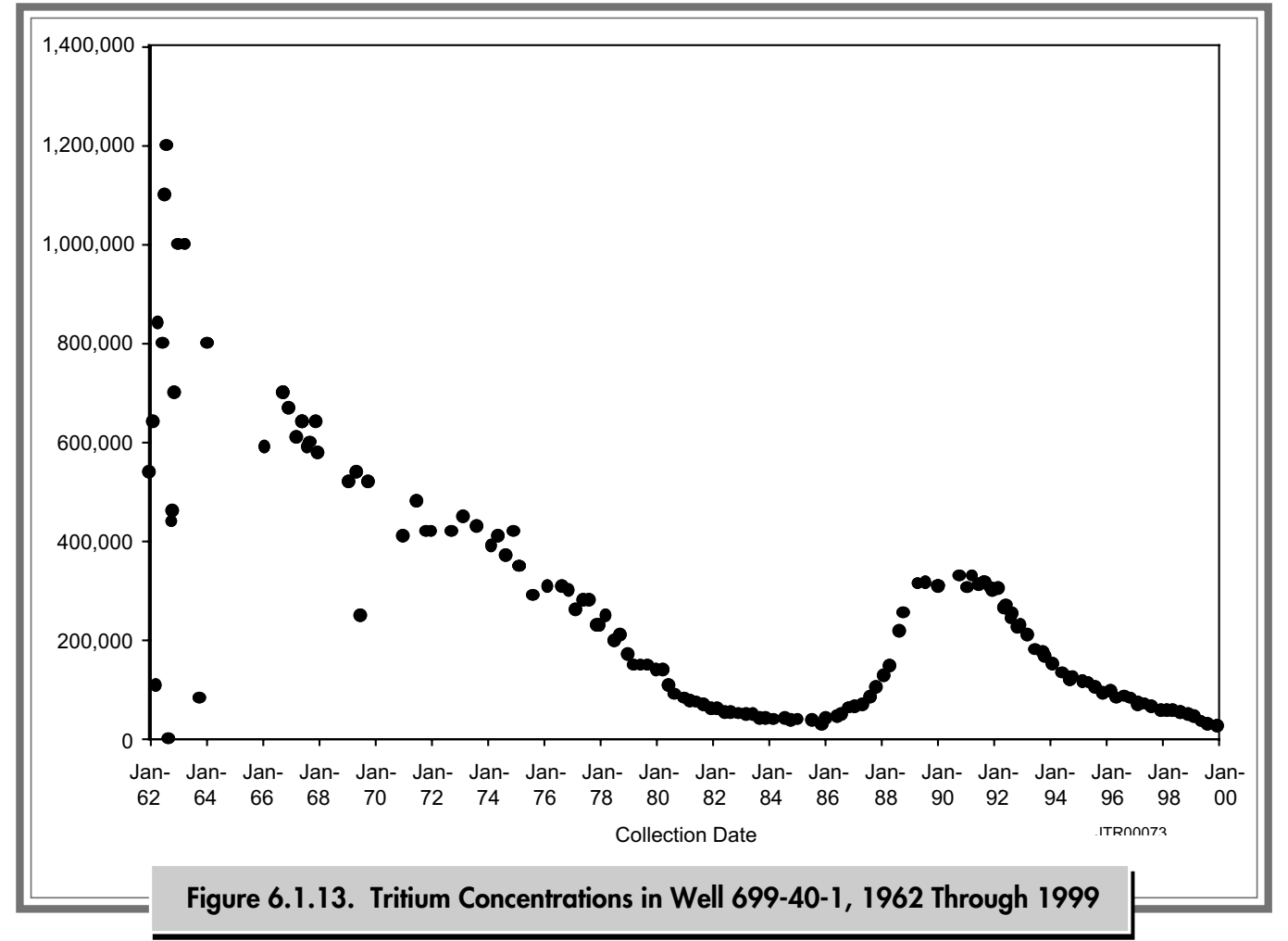

This resulted in elevated tritium levels measured in several wells downgradient from the 200-East Area. Movement of the leading edge of this later pulse is evident near the Central Landfill (Figure 6.1.14), which shows arrival in early 1987 . Tritium concentrations from the earlier pulse were at least three times the maximum concentrations in the later pulse. The effects of the 1983 to 1988 operational period have not been detected near the Columbia River.

The tritium plume, which has been monitored since the 1960s, provides information on the extent of groundwater contamination over time. Figure 6.1.15 shows the distribution of tritium in selected years from 1964 through 2000. This figure was created from maps in BNWL-90, BNWL-1970, PNL-5041, PNL-6825 (Section 5.0), PNNL-11141, and PNNL-13116. The contours in the original references were recalculated and interpreted to provide uniform contour intervals. Figure 6.1.15 shows that tritium at levels greater than the drinking water standard reached the Columbia River near the Old Hanford Townsite in approximately the mid-1970s. By the late 1980s, tritium at these levels was discharging to the Columbia River several kilometers south of the Old Hanford Townsite. The tritium plume continued to expand in the southeastern part of the Hanford Site. By 1995, tritium at concentrations exceeding $20,000 \mathrm{pCi} / \mathrm{L}$ was entering the Columbia River along greater portions of the shoreline extending between the Old Hanford Townsite and the 300 Area. Tritium levels did not change significantly between 1995 and 2000 .

The configuration of the western portion of the tritium plume shown in Figure 6.1.11 closely matches previous predictions of the direction of contaminant movement from the 200-East Area (PNL-6328). Movement is forced to the south by flow that originates at the groundwater mound beneath the former B Pond. Flow to the southeast also appears to be controlled by a zone of highly permeable sediment, stretching from the 200-East 


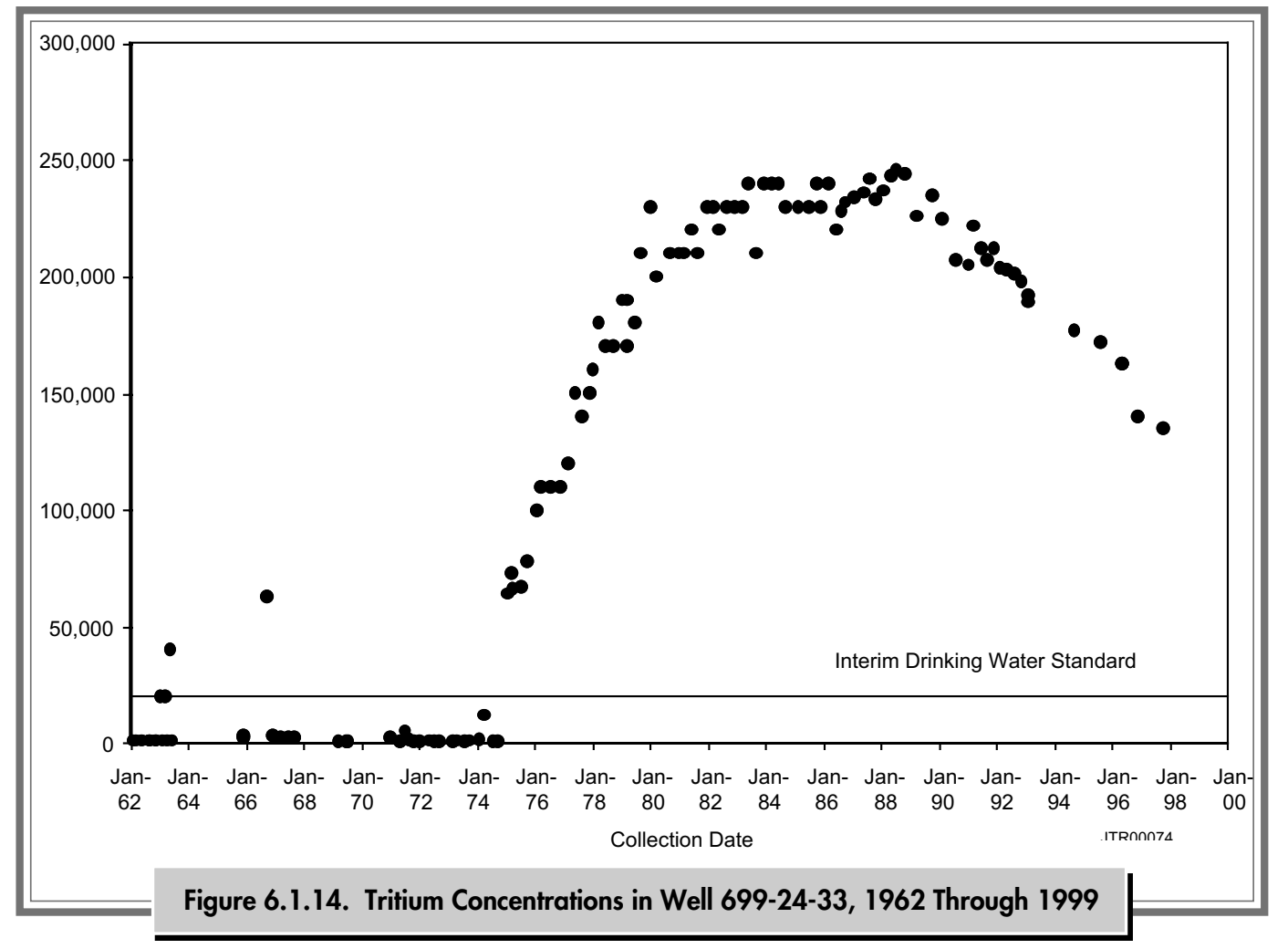

Area toward the 400 Area (PNL-7144). The shape of the tritium plume indicates that tritium discharges to the Columbia River between the Old Hanford Townsite and the 300 Area.

In January 1999, a high tritium concentration of $1,860,000 \mathrm{pCi} / \mathrm{L}$ was measured in one well (699-13-3A) near the 618-11 burial ground. This burial ground is located west of the Energy Northwest reactor complex in the eastern 600 Area (see Figure 6.1.8). The high concentration was confirmed by re-analysis. A sample collected in January 2000 measured 8,100,000 pCi/L, which is the highest tritium concentration detected at the Hanford Site in recent years. The burial ground was active from 1962 to 1967 and received a variety of low and high level waste from the 300 Area. A special investigation is being conducted in year 2000 to define the source of the high tritium levels. The Phase I sampling results are reported in PNNL-13228 and are available on the Groundwater Monitoring Project website at http://www.hanford.pnl.gov/groundwater.
The distribution of tritium near the former $B$ Pond shows an area of concentration above the drinking water standard in a limited area. B Pond produced a radial flow pattern of groundwater that mostly had low contaminant levels. The mound under the former pond has been dissipating since wastewater flow was diverted to the 200 Areas Treated Effluent Disposal Facility in August 1997.

Tritium is also found at levels above the drinking water standard in the northwestern part of the 200-East Area (see Figure 6.1.11). This plume appears to extend to the northwest through the gap between Gable Mountain and Gable Butte. The tritium distribution to the northwest and southeast of the 200-East Area indicates a divide in groundwater flow direction across the 200-East Area. A pulse of tritium levels above the drinking water standard also occurred between Gable Mountain and Gable Butte.

Tritium in the 200-WestA rea. Tritium from sources near the Reduction-Oxidation Plant forms 

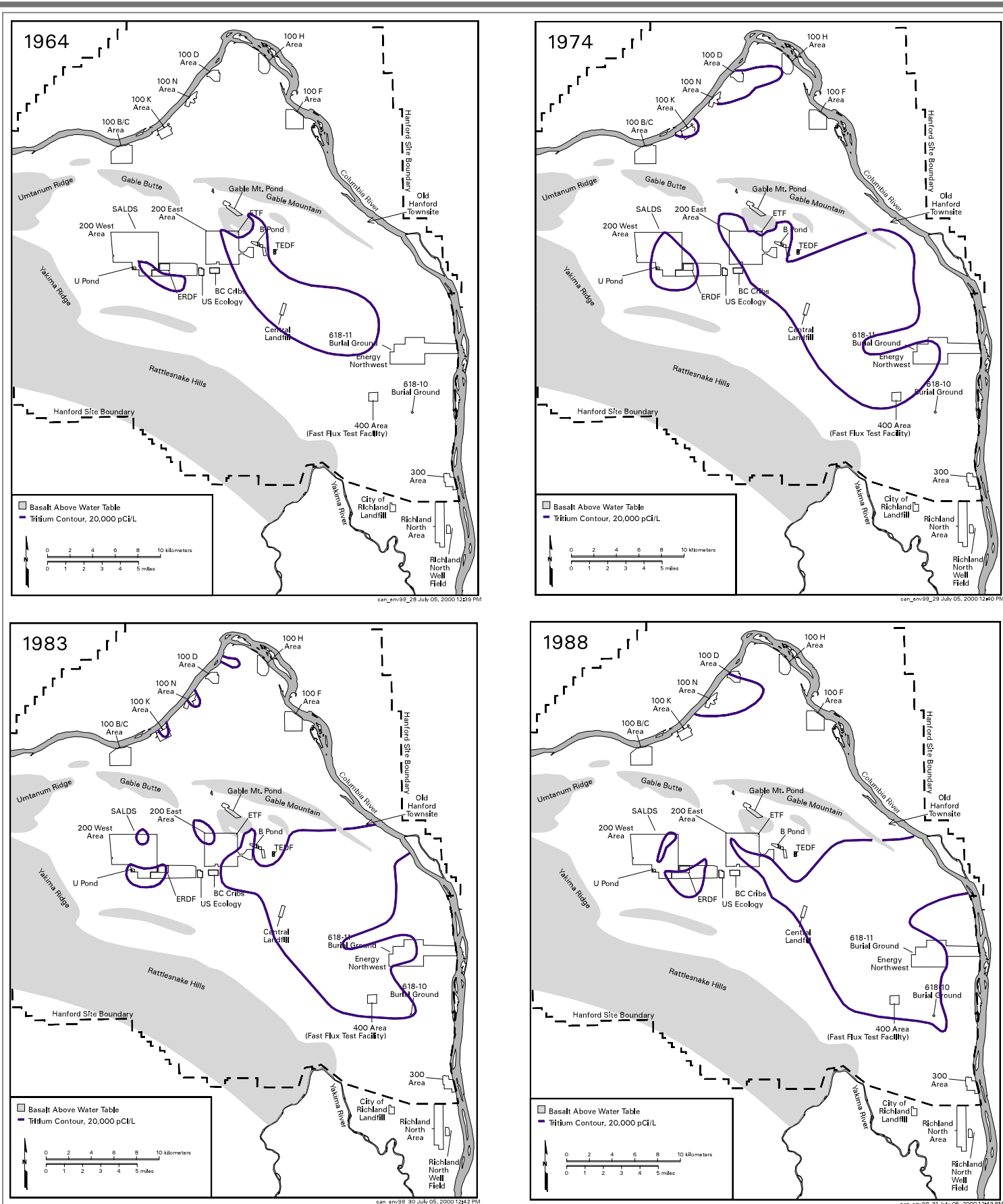

Figure 6.1.15. Historical Tritium Concentrations on the Hanford Site 


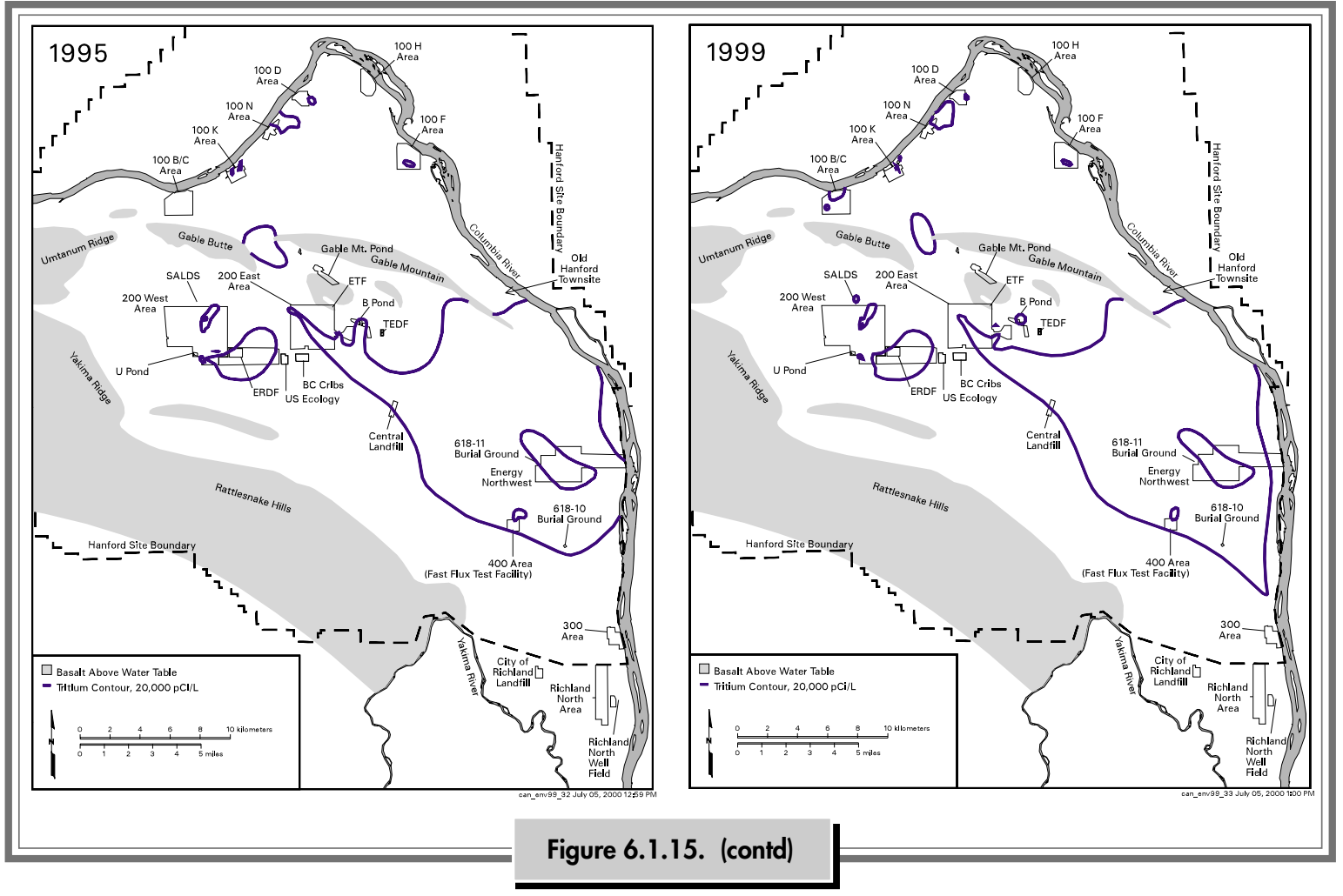

the most extensive plume associated with the 200-West Area. The Reduction-Oxidation Plant is located in the southeastern part of the 200-West Area and operated from 1951 through 1967. This plume extends into the 600 Area east of the 200-West Area to US Ecology's facility (see Figure 6.1.11). The eastern part of the plume curves to the north, but the tritium concentrations in the northern part of the plume are declining. However, concentrations continue to increase slowly in the eastern part of the plume near the US Ecology facility. Tritium concentrations exceeded the drinking water standard in much of the plume, including a small area near the former 216-S-25 crib and S-SX tank farm upgradient of the Reduction-Oxidation Plant. The maximum concentration in this plume in 1999 was $408,000 \mathrm{pCi} / \mathrm{L}$ in the 600 Area east of the Reduction-Oxidation Plant. The movement of plumes in the 200-West Area is slow because the Ringold Formation sediment that underlies the area has low permeability and restricts flow. Movement of the plumes in the 200-West Area is also slow because of declining hydraulic gradients since the closure of U Pond in 1984. This pond was located near the southern boundary of the 200-West Area.

A smaller tritium plume covers much of the northern part of the 200-West Area and extends to the northeast (see Figure 6.1.11). This plume is associated with former T Plant waste sites, including TY tank farm, the 242-T evaporator, and inactive disposal cribs. The highest tritium concentration, detected just east of the TX and TY tank farms near the 216-T-26 crib, was equal to the derived concentration guide of $2,000,000 \mathrm{pCi} / \mathrm{L}$. The area where the drinking water standard was exceeded extends northeast past the northern boundary of the 200-West Area.

Tritium concentrations were generally lower in 1999 than in 1998 at wells monitoring the StateApproved Land Disposal Site just north of the 200-West Area. The maximum concentration decreased from 2,100,000 pCi/L in 1998 to 
$610,000 \mathrm{pCi} / \mathrm{L}$ in 1999, which exceeded the drinking water standard. The lower concentrations in 1999 reflect the reduced concentration levels in effluent discharged to this facility over the past $\sim 2$ years (PNNL-13058). By the end of December 1999, $\sim 304$ curies of tritium and over 270 million liters (71.3 million gallons) of treated effluent containing tritium had been discharged to this facility since operations began in 1995 .

Tritium in the 300 A rea. The eastern portion of the tritium plume that emanates from the 200-East Area continues to move to the eastsoutheast and discharge into the Columbia River (see Figure 6.1.11). The southern edge of the tritium plume extends into the 300 Area, as shown in Figure 6.1.16. Figure 6.1.16 shows that tritium concentrations decrease from greater than $10,000 \mathrm{pCi} / \mathrm{L}$ in the northeastern part of the 300 Area to less than $100 \mathrm{pCi} / \mathrm{L}$ in the southwestern part of the 300 Area. This distribution is nearly the same as the 1998 distribution. Although tritium in the 300 Area is below the drinking water standard, a concern has been the potential migration of tritium to a municipal water supply to the south. The municipal water supply consists of the city of Richland's well field and recharge ponds (see Figure 6.1.16). The highest tritium level detected south of the 300 Area was $516 \mathrm{pCi} / \mathrm{L}$ near the well field. Monitoring data indicate that the Hanford Site tritium plume has not reached the municipal water supply.

The tritium plume is not expected to impact the well field because of the influence of groundwater flow from the Yakima River, recharge from agricultural irrigation, and recharge from infiltration ponds at the well field (see Figure 6.1.16). The Yakima River is at a higher elevation than the water table and recharges the groundwater in this area. Groundwater flows from west to east (see Figure 6.1.16), minimizing the southward movement of the contaminant plume. Recharge from agricultural irrigation occurs south of the Hanford Site boundary and contributes to eastward flow. The recharge ponds are supplied with Columbia River water, which infiltrates to the groundwater. The amount of recharge water exceeded the amount pumped at the well field by a factor of $\sim 2: 1$ in 1999, resulting in groundwater flow away from the well field. Recharge creates a mound that further ensures that tritium-contaminated groundwater will not reach the well field.

Tritium in the $\mathbf{4 0 0}$ A rea. The tritium plume that originated in the 200-East Area extends under the 400 Area. The maximum concentration detected in this area during 1999 was $33,800 \mathrm{pCi} / \mathrm{L}$ in well 499-S0-8, a backup water supply well. The average concentration in this well was $\sim 15,200 \mathrm{pCi} / \mathrm{L}$ during 1999. Tritium levels appear to fluctuate annually, but the maximum levels have increased. Samples from another backup water supply well (499-S0-7) showed a maximum tritium concentration of $20,600 \mathrm{pCi} / \mathrm{L}$. Tritium levels in the primary water supply well for the 400 Area (499-S1-8J) did not exceed the annual average drinking water standard of 20,000 pCi/L in 1999 and never exceeded $4,500 \mathrm{pCi} / \mathrm{L}$ in any one month. The water supply wells are located in the northern part of the 400 Area. Additional information on the 400 Area water supply is provided in Section 4.3, "Radiological Surveillance of Hanford Site Drinking Water."

Tritium levels below the drinking water standard north of the 400 Area are most likely due to discharge at the 400 Area process ponds (see Figure 6.1.11). A maximum tritium concentration of $20,400 \mathrm{pCi} / \mathrm{L}$ in a well near the process ponds is attributed to the 200-East Area tritium plume and not wastewater discharge to the ponds. The source of the wastewater is potable water from local water supply wells.

Iodine-129. Iodine-129 has a relatively low drinking water standard $(1 \mathrm{pCi} / \mathrm{L})$, has the potential for accumulation in the environment as a result of long-term releases from nuclear fuel reprocessing facilities (Soldat 1976), and has a long half-life (16,000,000 years). The relatively low fission yield for production of iodine- 129 combined with its long half-life limits its specific activity in Hanford Site 


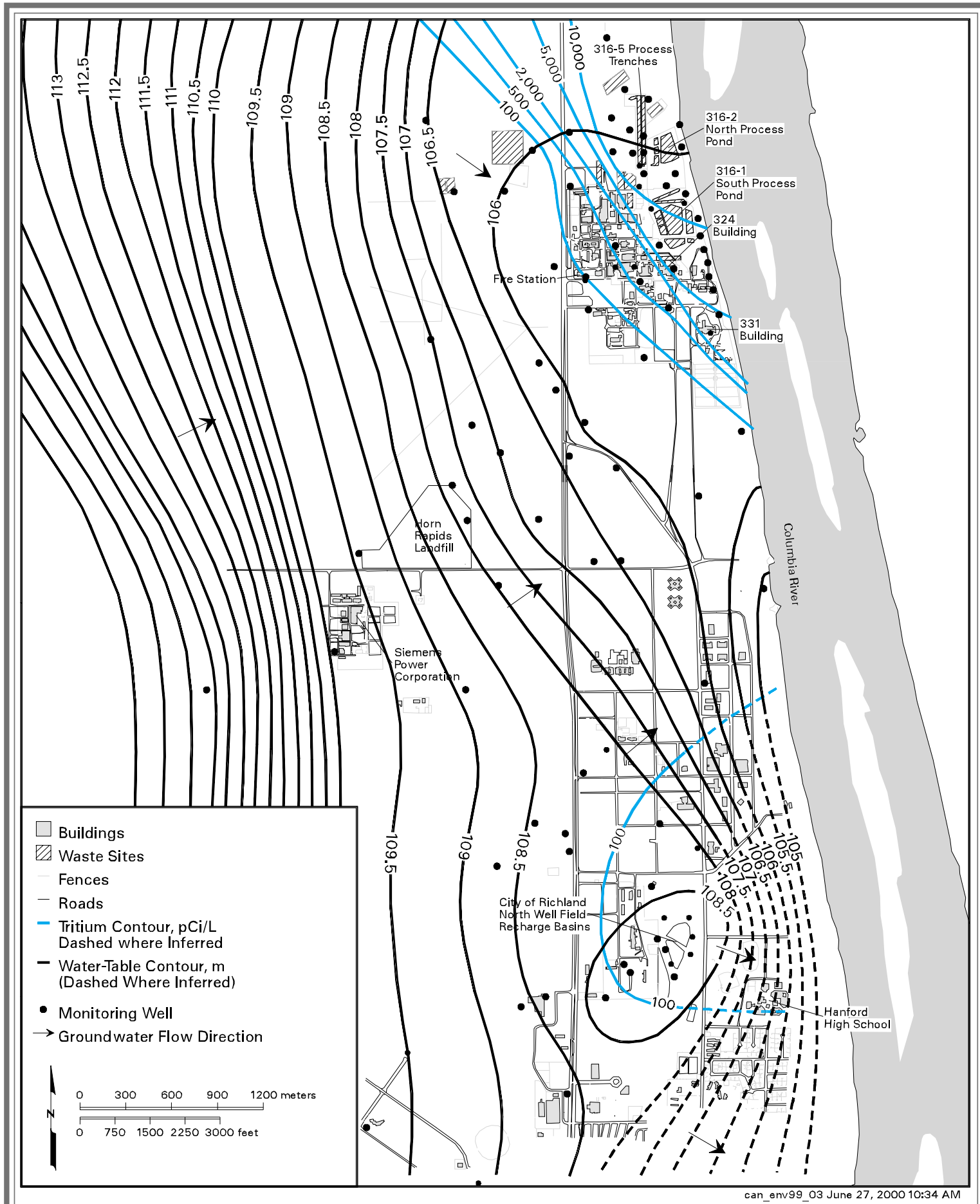

Figure 6.1.16. Average Tritium Concentrations and Groundwater Flow Near the 300 Area, 1999 
wastes. Iodine-129 may be released as a vapor during fuel dissolution and during other elevated temperature processes and, thus, may be associated with process condensate wastes. At the site, the main contributor of iodine-129 to groundwater has been liquid discharges to cribs in the 200 Areas. Iodine129 has essentially the same high mobility in groundwater as tritium. The iodine- 129 plume at levels exceeding the drinking water standard is extensive in the 200 and 600 Areas. No groundwater samples showed iodine-129 concentrations above the $500-\mathrm{pCi} / \mathrm{L}$ derived concentration guide in 1999.

lodine-129 in the 200-East A rea. The highest iodine-129 concentrations in the 200-East Area are in the northwest near the BY cribs and in the southeast near the Plutonium-Uranium Extraction Plant (Figure 6.1.17). The maximum level of iodine-129 detected in 1999 in the 200-East Area was $12.1 \mathrm{pCi} / \mathrm{L}$ south of the Plutonium-Uranium Extraction Plant near the 216-A-36B crib. Iodine129 concentrations are declining slowly or are stable. The iodine-129 plume extends from the PlutoniumUranium Extraction Plant area southeast into the 600 Area and appears coincident with the tritium plumes (see Figure 6.1.11). The plume appears smaller than the tritium plume because of the lower initial concentration of iodine-129. The iodine-129 contamination can be detected as far to the east as the Columbia River but at levels below the drinking water standard. Data indicate that iodine-129 at levels above the drinking water standard is approaching the Columbia River (see Figure 6.1.17). The plume likely had the same sources as the tritium plume. Iodine-129 is also present in groundwater at levels above the drinking water standard in the northwestern 200-East Area; however, a definite source for this plume has not been determined. This plume extends northwest into the gap between Gable Mountain and Gable Butte.

lodine-129 in the 200-WestA rea. The distribution of iodine-129 in Hanford Site groundwater is shown in Figure 6.1.17. The highest level observed in 1999 was $59.2 \mathrm{pCi} / \mathrm{L}$ near the T, TX, and TY tank farms in the northern part of the 200-West Area. This level occurs in a plume that originates near the tank farms and nearby disposal facilities and extends northeast toward T Plant. The iodine129 plume is generally coincident with the technetium-99 and tritium plumes in this area. A much larger iodine-129 plume occurs in the southeastern part of the 200-West Area, which originates near the Reduction-Oxidation Plant, and extends east into the 600 Area. This plume is essentially coincident with the tritium plume, though there appears to be a contribution from cribs to the north near U Plant. In 1999, the maximum concentration detected in this plume was $37.7 \mathrm{pCi} / \mathrm{L}$ in the 600 Area east of the Reduction-Oxidation Plant. Iodine-129 levels in this plume did not change significantly between 1998 and 1999 .

Technetium-99. Technetium-99, which has a half-life of 210,000 years, is produced as a highyield fission byproduct and is present in waste streams associated with fuel reprocessing. Reactor operations may also result in the release of some technetium-99 associated with fuel element breaches. Technetium- 99 is typically associated with uranium through the fuel processing cycle, but uranium is less mobile in groundwater. Under the chemical conditions that exist in Hanford Site groundwater, technetium-99 is normally present in solution as anions that sorb poorly to sediments. Therefore, technetium-99 is very mobile in site groundwater. The derived concentration guide is $100,000 \mathrm{pCi} / \mathrm{L}$ and the interim drinking water standard is $900 \mathrm{pCi} / \mathrm{L}$ for technetium- 99 .

Technetium-99 was found at concentrations greater than the $900-\mathrm{pCi} / \mathrm{L}$ interim drinking water standard in the 100-H, 200-East, and 200-West Areas, with the highest measured in the 200-West Area.

Technetium-99 in the 100-H Area. Technetium-99 concentration exceeded the interim drinking water standard in one well near the $183-\mathrm{H}$ solar evaporation basins in the $100-\mathrm{H}$ Area. The 


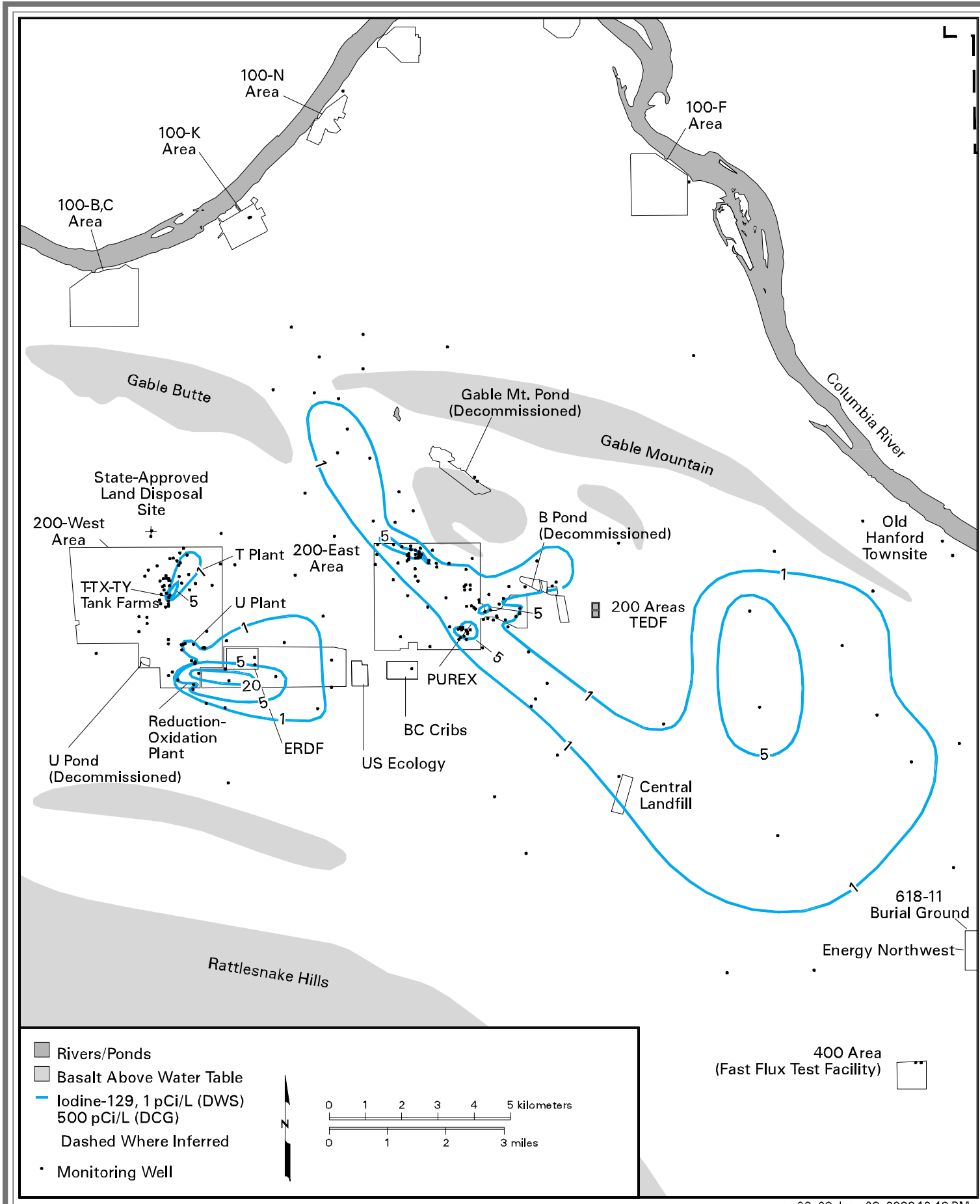

can env99 20 June $28,200012: 40$ PM

Figure 6.1.17. Average lodine-129 Concentrations in the Unconfined Aquifer, 1999 
technetium-99 concentration, which is influenced by fluctuations in Columbia River stage at this well, was $1,070 \mathrm{pCi} / \mathrm{L}$ in November 1999 . Usually concentrations are highest when river stage is low.

\section{Technetium-99 in the 200-East A rea.}

Groundwater in the northwestern part of the 200-East Area and a part of the 600 Area north of the 200-East Area contains technetium-99 at concentrations above the interim drinking water standard (Figure 6.1.18). The source of these two technetium plumes was apparently the BY cribs (Section 2.9.1 in PNNL-13116). However, some of this contamination is believed to originate from tank farms B, BX, and BY (PNNL-11826). Technetium-99 concentrations continued to increase in several wells monitoring tank farms B, BX, and BY in 1999. The maximum concentration in the 200-East Area occurred at the BY cribs at a level of $9,410 \mathrm{pCi} / \mathrm{L}$. The maximum technetium-99 concentration in the plume north of the 200-East Area in 1999 was $2,820 \mathrm{pCi} / \mathrm{L}$. This plume appears to be moving through the gap between Gable Mountain and Gable Butte. Technetium-99 levels are increasing in some of the wells in this plume.

Technetium-99 in the 200-West A rea. The largest technetium-99 plume in the 200-West Area originates from cribs that received effluent from U Plant and extends into the 600 Area to the east (Figure 6.1.19). The technetium plume is approximately in the same location as the uranium plume because technetium-99 and uranium, which are typically associated with the same fuel reprocessing cycle, were disposed to the same 216-U-1, 216-U-2, and 216-U-17 cribs. The highest technetium-99 concentrations in this plume in 1999 were measured in several wells in vicinity of the 216-U-17 crib, where remediation by a pump-and-treat method is occurring (see below). The high concentration portion of the plume, which has decreased in size, appears to be moving downgradient toward the extraction center (well 299-W19-39). The maximum level was detected in monitoring well 299-W19-29 at a level of $28,900 \mathrm{pCi} / \mathrm{L}$. This well is located approximately midway between the 216-U-1, 216-U-2, and the 216-U-17 cribs.

The purpose of the 200-UP-1 pump-and-treat system near the $216-\mathrm{U}-17 \mathrm{crib}$ is to contain and reduce the highest concentrations in the technetium99 and uranium plumes (Record of Decision 1997). As of September 1999, 61.7 grams (2.2 ounces) of technetium-99 have been removed from $\sim 357$ million liters (99 million gallons) of extracted groundwater since pump-and-treat operations began in 1994 (DOE/RL-99-79). This mass of technetium99 is equivalent to $\sim 1.1$ curie of radioactivity. Contaminated groundwater is currently pumped from one extraction well (299-W19-39) and transported via pipeline to the 200 Areas Effluent Treatment Facility, where it is treated using a number of processes. The treated groundwater is disposed of to the State-Approved Land Disposal Site north of the 200-West Area.

Several wells that monitor tank farms T, TX, and TY consistently showed technetium-99 concentrations above the interim drinking water standard in 1999 (see Figure 6.1.19). The highest was $6,200 \mathrm{pCi} / \mathrm{L}$ east of the TX and TY tank farms, where technetium-99 levels have been increasing in recent years. These increases may be related to changes in the direction of groundwater flow being influenced by the 200-ZP-1 pump-and-treat operation immediately south of the tank farms. In the northeastern corner of $\mathrm{T}$ tank farm, technetium-99 levels were above the interim drinking water standard in two wells. The maximum in this area was $7,110 \mathrm{pCi} / \mathrm{L}$ in 1999. This was a decrease from the maximum of $13,000 \mathrm{pCi} / \mathrm{L}$ in 1998 . The sources of the technetium-99 contamination were tank farms $\mathrm{T}$, TX, and TY (PNNL-11809).

Technetium-99 contamination in small areas in the southern part of the 200-West Area originates near tank farms S and SX and the 216-S-13 crib. Multiple sources of technetium-99 contribute to 


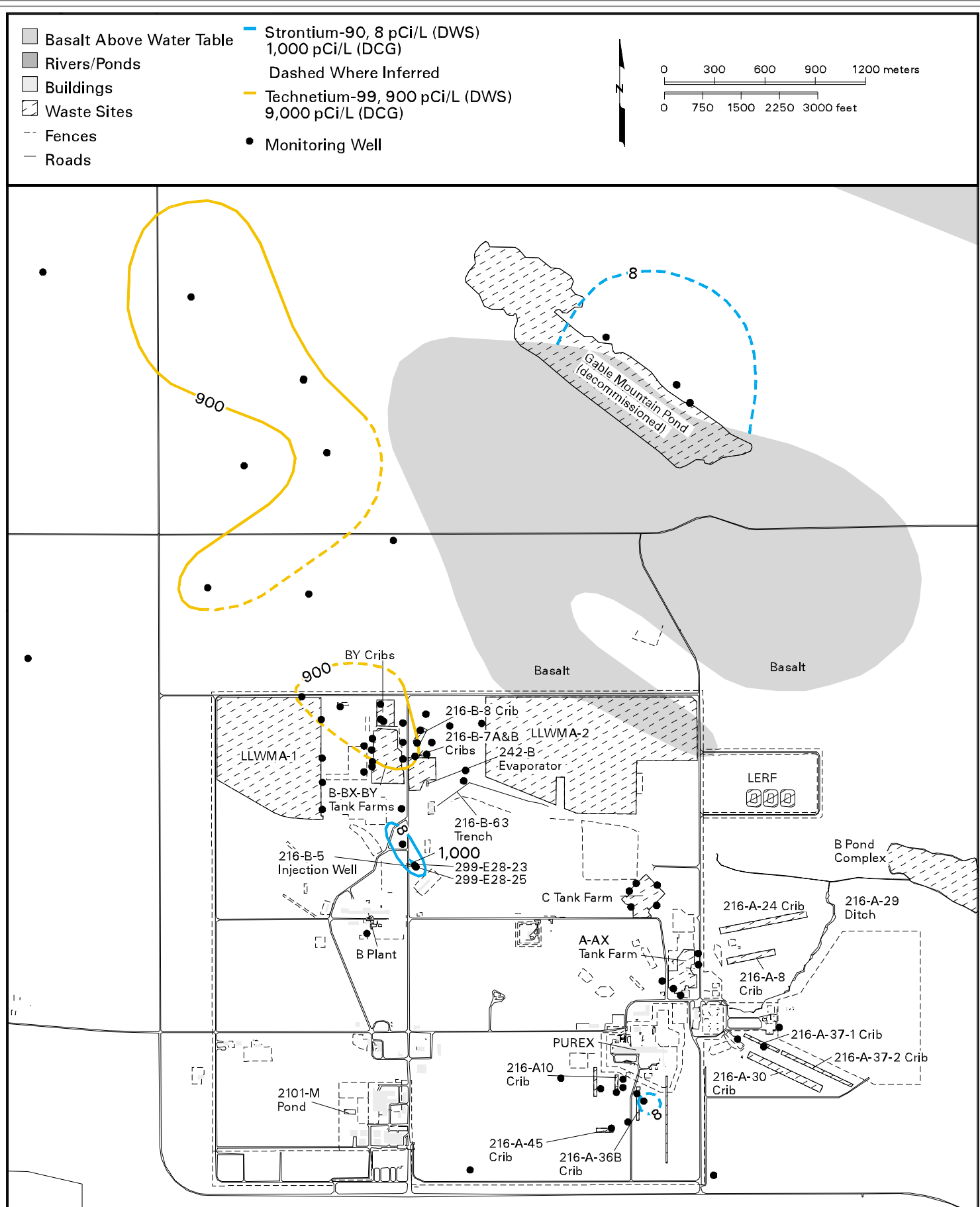

can env99 04 June 23,2000 3:37 PM

Figure 6.1.18. Average Technetium-99 and Strontium-90 Concentrations in the Unconfined Aquifer Near the 200-East Area, 1999 


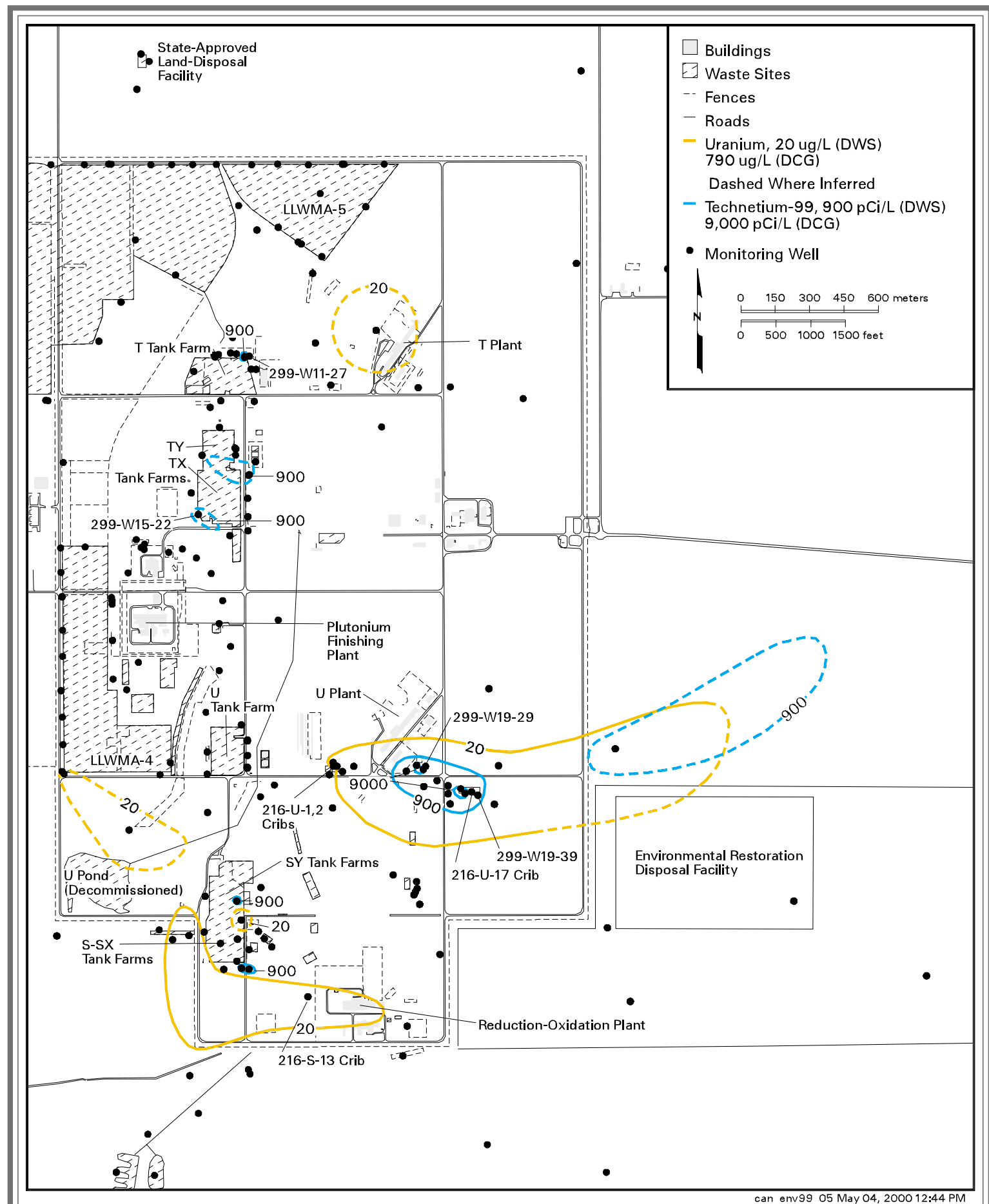

can_env99_05 May 04, 2000 12:44 PM

Figure 6.1.19. Average Technetium-99 Concentrations and Uranium Concentrations in the Unconfined Aquifer in the 200-West Area, 1999 
groundwater contamination in this area (PNNL11810). The maximum level detected was $48,600 \mathrm{pCi} / \mathrm{L}$ in a new well in the southwestern corner of tank farm SX. This was the highest technetium-99 concentration detected on the Hanford Site in 1999.

U ranium. There were numerous possible sources of uranium released to the groundwater at the Hanford Site, including fuel fabrication, fuel reprocessing, and uranium recovery operations. Uranium may exist in several states, including elemental uranium or uranium oxide as well as tetravalent and hexavalent cations. Only the hexavalent form has significant mobility in groundwater, largely by forming dissolved carbonate species. Uranium mobility is thus dependent on oxidation state, $\mathrm{pH}$, and the presence of carbonate. Uranium is observed to migrate in site groundwater but is retarded relative to more mobile species such as technetium-99 and tritium. The EPA's proposed drinking water standard for uranium is $20 \mu \mathrm{g} / \mathrm{L}$, which is based on chemical toxicity. The derived concentration guide that represents an annual effective dose equivalent of $100 \mathrm{mrem} / \mathrm{yr}$ is $790 \mu \mathrm{g} / \mathrm{L}$ for uranium.

Uranium has been detected at concentrations greater than the proposed drinking water standard in portions of the 100, 200, 300, and 600 Areas. The highest levels detected at the Hanford Site in 1999 were in the 200-West Area near U Plant, where uranium levels exceeded the derived concentration guide.

Uranium in the 100 A reas. One well near F Reactor continues to show elevated uranium levels. However, the concentration fell below the $20-\mu \mathrm{g} / \mathrm{L}$ proposed drinking water standard to $19.5 \mu \mathrm{g} / \mathrm{L}$ in 1999 .

Uranium was detected at levels higher than the proposed drinking water standard in three wells in the 100-H Area. Uranium concentrations in the 100-H Area usually fluctuate in response to changes in groundwater levels. The maximum detected in 1999 was $157 \mu \mathrm{g} / \mathrm{L}$ downgradient of the $183-\mathrm{H}$ solar evaporation basins. Past leakage from the basins is the source of the 100-H Area uranium contamination. These basins were remediated in 1996. Remediation consisted of demolition and removal of the basins and removal of the underlying contaminated soil.

U ranium in the 200-EastA rea. In the 200-East Area, uranium contamination at levels greater than the proposed drinking water standard is limited to isolated areas associated with B Plant. The uranium distribution in 1999 indicates the highest concentrations were in the vicinity of the B, BX, and BY tank farms; BY cribs; and 216-B-5 injection well that has been inactive since 1947 . The highest concentration detected was $350 \mu \mathrm{g} / \mathrm{L}$ east of the BY tank farm (southeast of the BY cribs). The source of the uranium contamination in this area is unclear. Near inactive injection well 216-B-5, one well annually shows an increasing uranium concentration greater than the proposed drinking water standard; however, this well was not sampled in 1999. The sampling schedule for this well was changed from the early to the latter part of the fiscal year and, thus, the well was not sampled during calendar year 1999. One well near B Plant showed a uranium concentration of $17.8 \mu \mathrm{g} / \mathrm{L}$ in 1999 . Wells adjacent to the inactive 216-B-62 crib showed a maximum concentration of $27.2 \mu \mathrm{g} / \mathrm{L}$ in 1999.

U ranium in the 200-West A rea. The highest uranium concentrations in Hanford Site groundwater occurred near U Plant, at wells downgradient from the inactive $216-\mathrm{U}-1$ and $216-\mathrm{U}-2$ cribs and adjacent to the 216-U-17 crib (see Figure 6.1.19). The uranium plume, which extends into the 600 Area to the east, is approximately in the same location as the technetium-99 plume discussed above. Uranium and technetium-99 were typically associated with the same fuel reprocessing cycle and were disposed to the same cribs. However, uranium is less mobile than technetium-99 because of its stronger sorption to the sediment. A greater proportion of the uranium contamination remains at or near the source area. The high concentrations exceeded the 
derived concentration guide for uranium. The maximum detected in this area in 1999 was $2,800 \mu \mathrm{g} / \mathrm{L}$ adjacent to the $216-\mathrm{U}-17 \mathrm{crib}$, the same as in 1998 .

As of September 1999, the 200-UP-1 pumpand-treat system removed a total of 101.1 kilograms (223 pounds) of uranium from approximately 357 million liters (99 million gallons) of extracted groundwater since operations began in 1994 (DOE) RL-99-79). The uranium plume at concentrations greater than the $480-\mathrm{mg} / \mathrm{L}$ cleanup level is contained and has slightly decreased in size since 1995. Uranium concentrations have increased in wells near the pump-and-treat injection well. These increases are attributed to rebound since injection well operations ceased in 1997.

Other areas with uranium contamination at levels above the proposed drinking water standard are also shown in Figure 6.1.19, including areas west and northwest of the Reduction-Oxidation Plant. Uranium concentrations in those areas are considerably lower than the concentrations detected near U Plant. The maximum uranium in these areas was $74.3 \mu \mathrm{g} / \mathrm{L}$ immediately east of tank farms S and SX (northwest of the Reduction-Oxidation Plant). In the northern part of the 200-West Area, a localized area of uranium contamination, where a single sample showed a concentration above the proposed drinking water standard at a level of $49.7 \mu \mathrm{g} / \mathrm{L}$, was found near T Plant.

U ranium in the $\mathbf{3 0 0}$ A rea. A plume of uranium contamination exists near uranium fuel fabrication facilities and inactive sites known to have received uranium waste. The plume extends downgradient from inactive liquid waste disposal facilities to the Columbia River (Figure 6.1.20). The major source of the contamination is the inactive $316-5$ process trenches, as indicated by the distribution of the uranium concentrations downgradient from these trenches. The maximum concentration detected in 1999 was $322 \mu \mathrm{g} / \mathrm{L}$ near the Columbia River. Because wastewater is no longer discharged to the $316-5$ process trenches, elevated concentrations at the south end of the process trenches indicate that the soil column contributes uranium contamination to the groundwater. Uranium levels in the 300 Area fluctuate annually but have shown an overall decline.

A localized area of elevated levels of uranium between the 324 Building and the Columbia River showed a maximum concentration of $163 \mu \mathrm{g} / \mathrm{L}$ in 1999 (see Figure 6.1.20).

U ranium in the 600 A rea. A well southeast of the 400 Area (adjacent to Route 4S) had a maximum uranium concentration of $101 \mu \mathrm{g} / \mathrm{L}$ in 1999 . Uranium levels have not changed significantly in this well in recent years. The contamination at this well is attributed to the nearby inactive $316-4$ crib. The retired 618-10 burial ground is also located near this well.

Strontium-90. Strontium-90 was produced as a high-yield fission product and was present in waste streams associated with fuel reprocessing. Reactor operations also resulted in the release of some strontium-90 associated with fuel element breaches. Strontium-90 mobility in Hanford Site groundwater is reduced by adsorption onto sediment particles. However, strontium-90 is moderately mobile in groundwater because its adsorption is much weaker than for other radionuclides such as cesium-137 and plutonium. Because of sorption, a large proportion of the strontium-90 in the subsurface is not present in solution. The half-life of strontium-90 is 29.1 years.

In 1999, strontium-90 concentrations at greater than the $8-\mathrm{pCi} / \mathrm{L}$ interim drinking water standard were found in one or more wells in each of the 100, 200, and 600 Areas. Levels of strontium-90 were greater than the $1,000-\mathrm{pCi} / \mathrm{L}$ derived concentration guide in the 100 and 200 Areas. The 100-N Area had the widest distribution with the highest concentrations detected at the Hanford Site during 1999. 


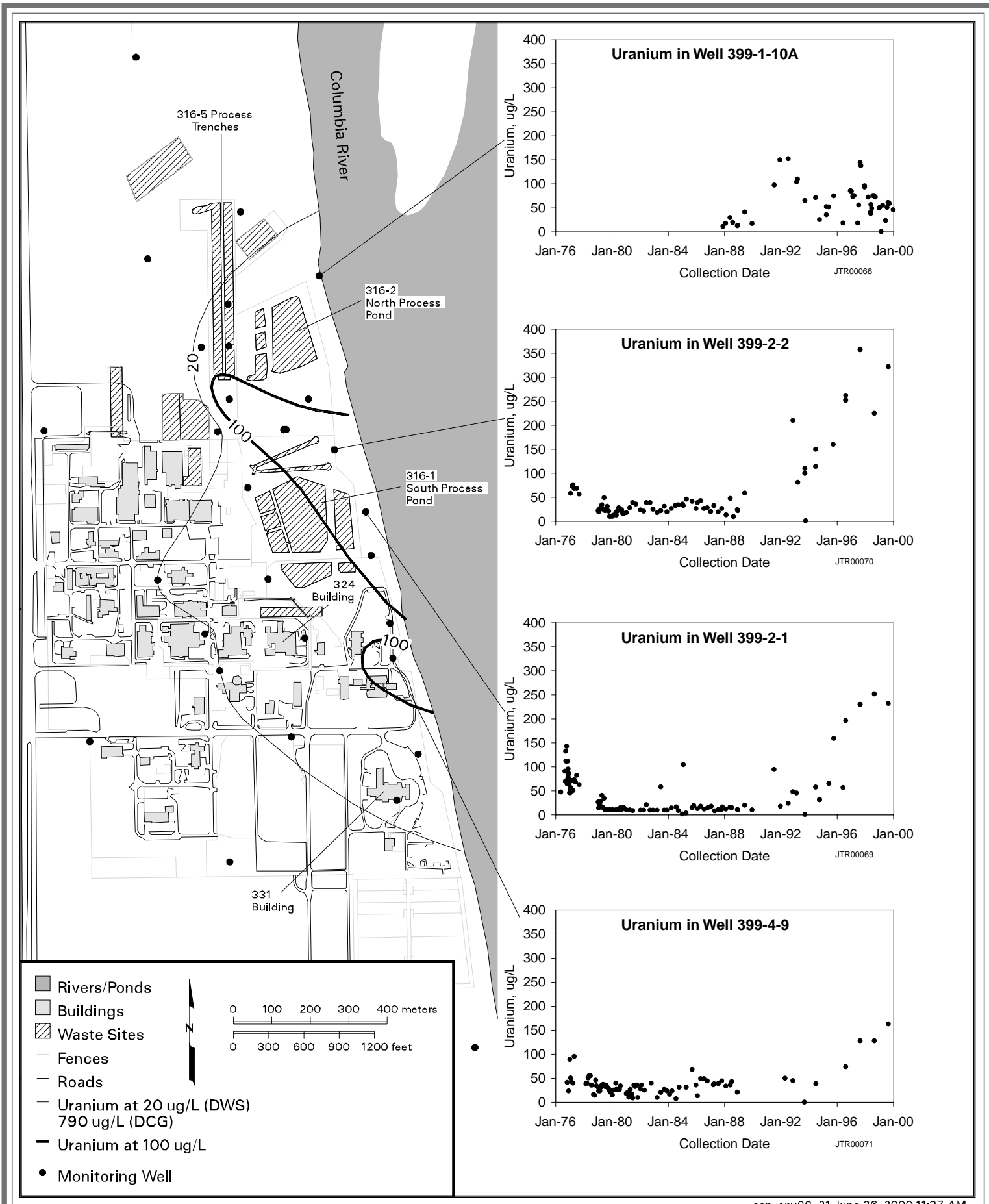

can env99 21 June 26, 2000 11:37 AM

Figure 6.1.20. Average Uranium Concentrations in the Unconfined Aquifer in the 300 Area, 1999, and Concentration Trends for Select Wells 
Strontium-90 in the 100 A reas. Strontium90 concentrations greater than the interim drinking water standard extend from the B Reactor complex to the Columbia River in the northeastern part of the 100-B,C Area (Figure 6.1.21). The highest concentrations continued to be found in wells near the inactive 116-B-1 and 116-C-1 trenches and trends indicate concentration levels are not decreasing or increasing. The maximum concentration detected in 1999 was $70 \mathrm{pCi} / \mathrm{L}$ near the inactive 116-C-1 trench. The sources for the strontium-90 appear to be liquid waste disposal sites near B Reactor and liquid overflow trenches near the Columbia River (DOE/EIS-0119F).

Strontium-90 is not widely distributed in the 100-D Area. Strontium-90 levels are consistently greater than the interim drinking water standard in one well near the inactive D Reactor fuel storage basin. The maximum level was $30.6 \mathrm{pCi} / \mathrm{L}$ in 1999 . Strontium-90 was detected at levels just above the interim drinking water standard near the former 116-D-7 retention basin in the northern part of the 100-D Area. Strontium-90 levels in the 100-D Area have not changed significantly in recent years.

Strontium-90 exceeded the interim drinking water standard near the 116-F-14 retention basins and $116-\mathrm{F}-2$ and $116-\mathrm{F}-9$ trenches in the eastern part of the 100-F Area. The maximum concentration detected in 1999 was $329 \mathrm{pCi} / \mathrm{L}$. Strontium-90 levels fluctuate in the 100-F Area.

In the $100-\mathrm{H}$ Area, strontium-90 contamination levels greater than the interim drinking water standard were present in an area adjacent to the Columbia River near the $107-\mathrm{H}$ retention basin. The maximum detected in the 100-H Area in 1999 was $55.3 \mathrm{pCi} / \mathrm{L}$ between the retention basin and the Columbia River. Strontium-90 levels in the $100-\mathrm{H}$ Area have not shown consistent trends between wells. The source of the contamination is past disposal of reactor coolant containing strontium-90 to retention basins and trenches in the $100-\mathrm{H}$ Area. Contaminated soil was excavated from the upper portion of the vadose zone at these facilities and disposed of to the Environmental Restoration Disposal Facility during 1999.

Strontium-90 at levels greater than the interim drinking water standard continues to show up in isolated areas in the 100-K Area. These areas include fuel storage basin drain fields/injection wells associated with the KE and KW Reactors and between the 116-K-2 liquid waste disposal trench and the Columbia River. The maximum concentration detected in 1999 was $6,970 \mathrm{pCi} / \mathrm{L}$ at well $199-\mathrm{K}-109 \mathrm{~A}$, the only well in the $100-\mathrm{K}$ Area where levels were above the derived concentration guide. Concentrations show a variable trend in this well. The original source of the strontium-90 in this well was identified as past-practice disposal to the 116-KE-3 drain field/injection well near KE Reactor (PNNL-12023). Maximum strontium-90 concentrations near the KW Reactor and the disposal trench were $39.1 \mathrm{pCi} / \mathrm{L}$ and $47.6 \mathrm{pCi} / \mathrm{L}$, respectively.

The distribution of strontium-90 in the 100-N Area is shown in Figure 6.1.22. Strontium-90 was detected at concentrations greater than the derived concentration guide in several wells located between the 1301-N Liquid Waste Disposal Facility, a source of the strontium-90, and the Columbia River. The 1325-N Liquid Waste Disposal Facility is also a source of strontium-90 in groundwater. The maximum level detected in 1999 was $22,000 \mathrm{pCi} / \mathrm{L}$ near the head end of the 1301-N facility (well 199. $\mathrm{N}$-67). Strong, positive correlations between high groundwater-level elevations and high strontium90 concentrations in wells indicate that strontium90 is remobilized during periods of high water levels.

In the 100-N Area, strontium-90 discharges to the Columbia River through springs along the shoreline. Section 4.2, "Surface Water and Sediment Surveillance" and Section 3.2, "Near-Facility Environmental Monitoring," give the results of spring water sampling. Because of high concentrations in wells near the river, it was expected that strontium90 exceeded the interim drinking water standard at 


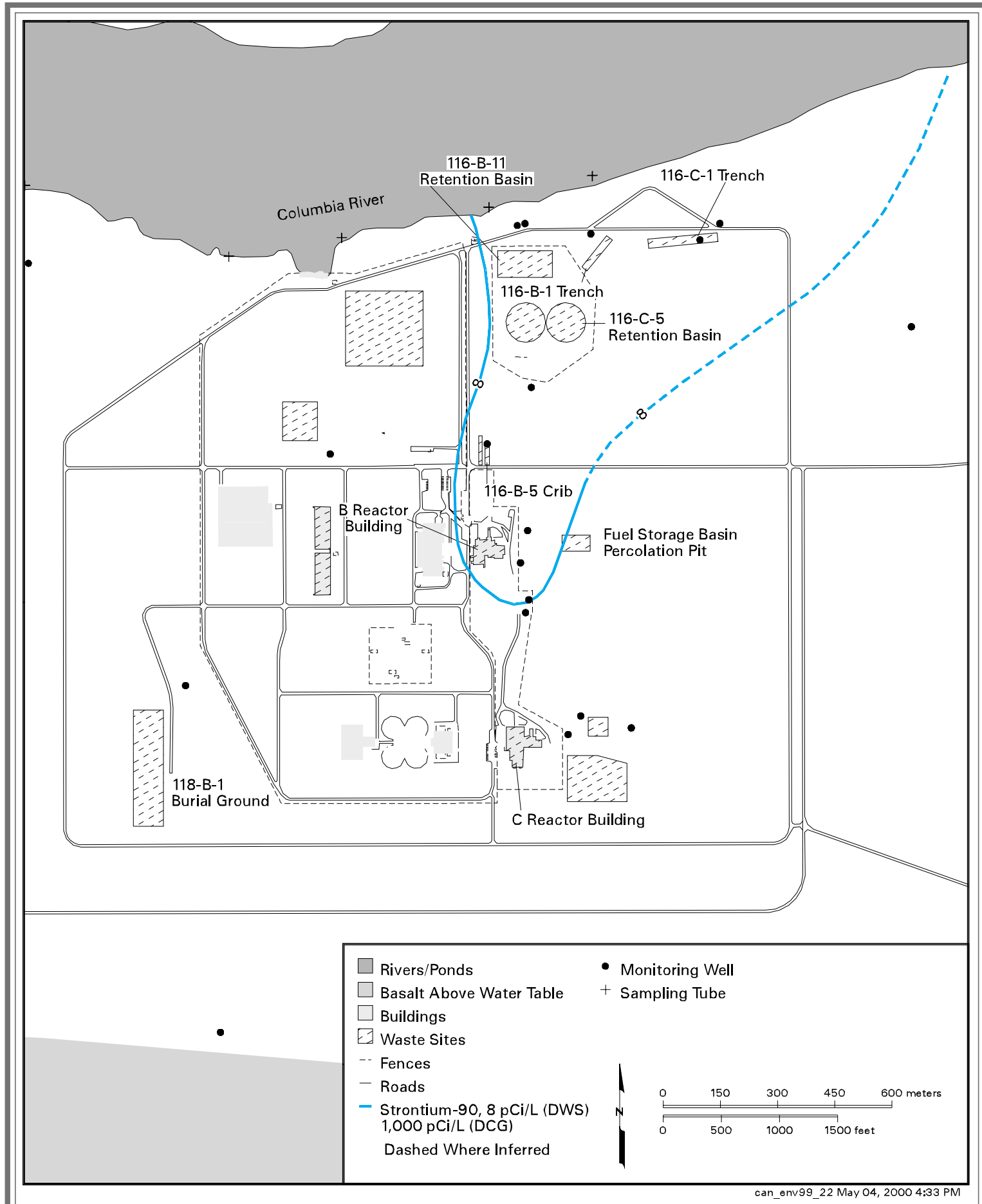

Figure 6.1.21. Average Strontium-90 Concentrations in the Unconfined Aquifer in the 100-B,C Area, 1999 


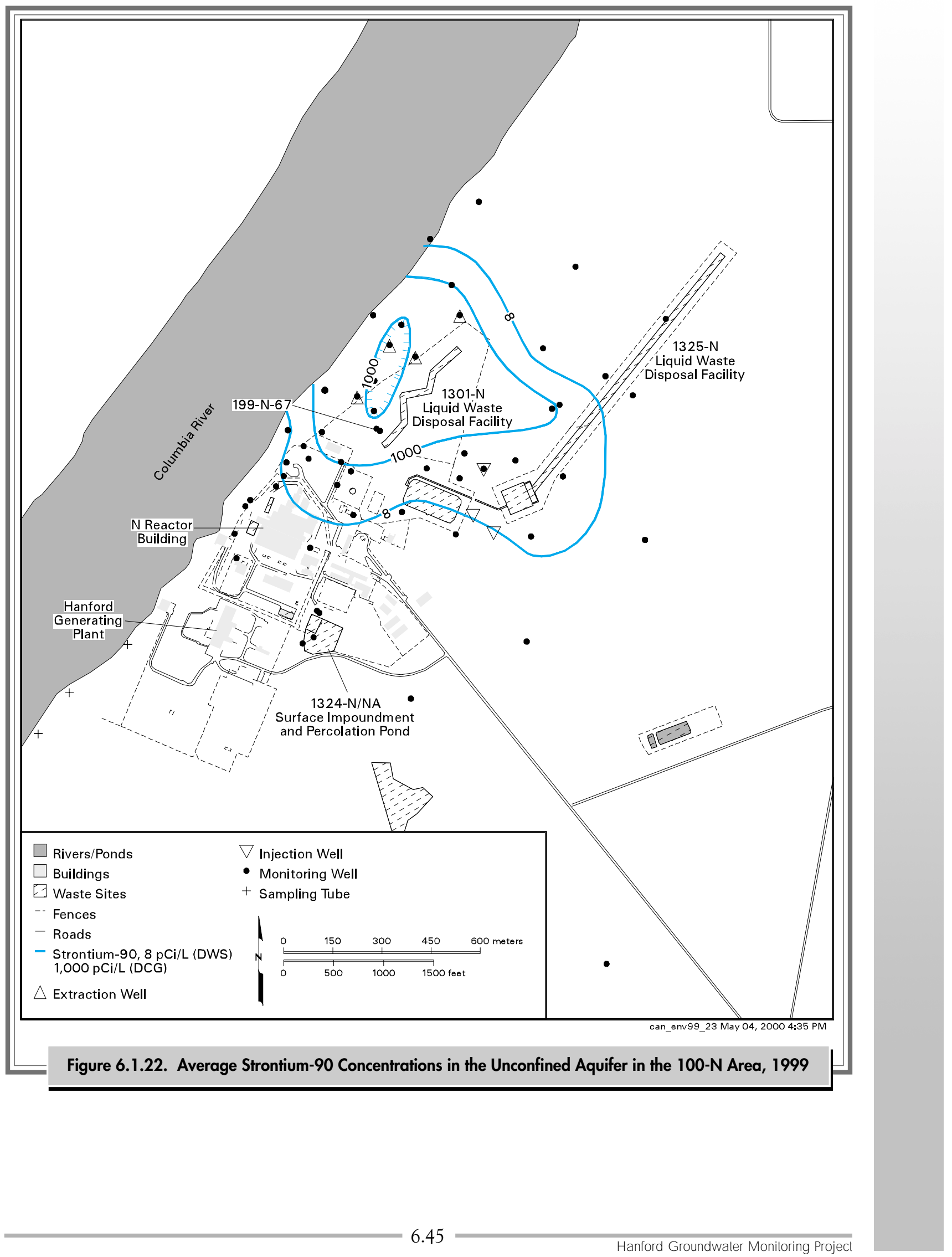


the interface between the groundwater and the river (DOE/RL-96-102). The highest strontium-90 concentration in a near-river well in 1999 was $13,100 \mathrm{pCi} / \mathrm{L}$. Groundwater contaminated with strontium-90 entering the river could potentially reach an aquatic and riparian ecological receptor through direct uptake. Ecological risks associated with groundwater discharge to the Columbia River have been quantified in PNNL-11933.

A pump-and-treat method began in 1995 to remove strontium-90 from groundwater in the $100-\mathrm{N}$ Area. The objective is to reduce the amount of strontium-90 from entering the Columbia River. Pumping from the extraction wells create a hydraulic sink between the 1301-N facility and the river. This reduces or reverses the hydraulic gradient in the groundwater toward the river and results in less groundwater and strontium-90 discharging to the river. The pump-and-treat system, which uses ionadsorption technology, removed $\sim 0.2$ curie of strontium-90 from extracted groundwater during fiscal year 1999 (DOE/RL-99-79). This is compared to an estimated total of 76 to 88 curies in the aquifer (in groundwater and adsorbed on the saturated sediments) (DOE/RL-95-110).

Strontium-90 in the 200A reas. Strontium-90 distribution in the 200-East Area is shown in Figure 6.1.18. Strontium-90 concentrations in the 200-East Area were above the derived concentration guide in one well near the inactive 216-B-5 injection well. The maximum concentration was $1,900 \mathrm{pCi} / \mathrm{L}$ in well 299-E28-25. Well 299-E28-23 had a maximum concentration of $10,800 \mathrm{pCi} / \mathrm{L}$ in December 1998. This well is scheduled to be sampled again in fiscal year 2000. Strontium-90 levels have shown a steady increase in this well since 1990. The injection well received an estimated 27.9 curies of strontium-90 during 1945 and 1946 (PNL-6456). In the 200-East Area, strontium-90 was detected above the interim drinking water standard in one well near the Plutonium-Uranium Extraction Plant cribs. Strontium-90 levels have been stable in this well.
Strontium-90 was not detected at levels above the interim drinking water standard in the 200-West Area in 1999.

Strontium-90 in the 600 Area. In the 600 Area, the highest strontium-90 concentrations were detected in wells in the former Gable Mountain Pond area (see Figure 6.1.18). In three of the wells, levels fell below the derived concentration guide in 1999 after increasing to peak levels above the guide in 1997 and 1998. The maximum strontium-90 concentration in this area in 1999 was $948 \mathrm{pCi} / \mathrm{L}$. Strontium- 90 contamination in this area resulted from the discharge of radioactive liquid waste to the former Gable Mountain Pond during its early use.

Carbon-14. Carbon-14 concentrations occur in the $100-\mathrm{K}$ Area and exceed the $2,000-\mathrm{pCi} / \mathrm{L}$ interim drinking water standard in two small plumes near the KE and KW Reactors (Figure 6.1.23). The sources of the carbon-14 were the 116-KE-1 and 116-KW-1 cribs, respectively. Carbon-14 was included with tritium in the condensate wastewater disposed to the cribs. However, the distribution of carbon-14 in groundwater is not the same as for tritium because carbon-14 interacts with carbonate minerals and thus disperses more slowly than does tritium (PNNL-12023). The maximum concentration in 1999 was $35,600 \mathrm{pCi} / \mathrm{L}$ near the $116-\mathrm{KW}-1$ crib. Carbon-14 levels have remained stable in most of the 100-K Area wells. The derived concentration guide for carbon-14 is 70,000 pCi/L. Carbon-14 has a long half-life of 5,730 years, which suggests that some of the carbon- 14 will reach the Columbia River before it decays.

Cesium-137. Cesium-137, which has a halflife of 30 years, is produced as a high-yield fission product and is present in waste streams associated with fuel processing. Former reactor operations also may have resulted in the release of some cesium-137 associated with fuel element breaches. Normally, cesium-137 is strongly sorbed on soil and, thus, is not very mobile in Hanford Site groundwater. The 


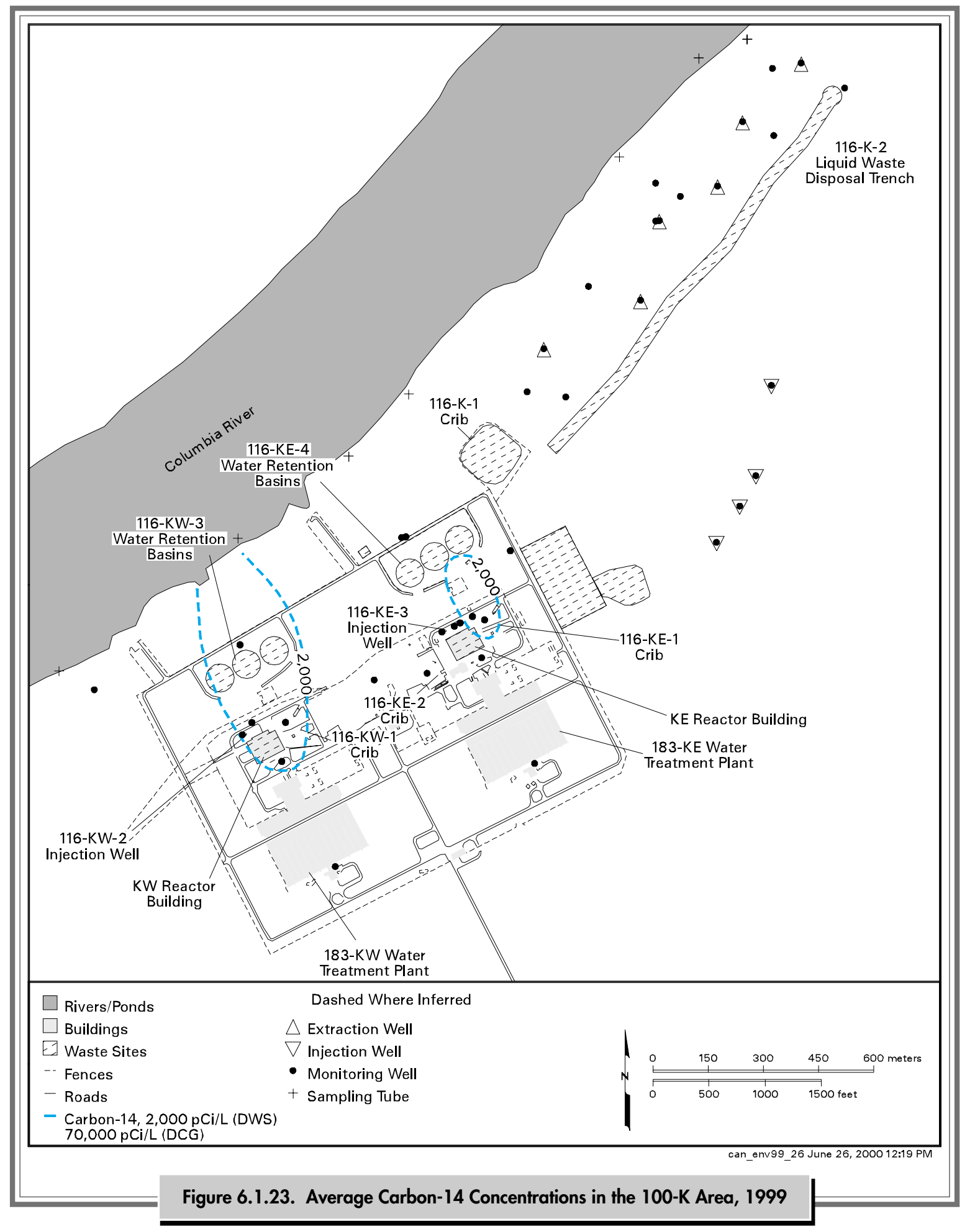


interim drinking water standard for cesium-137 is $200 \mathrm{pCi} / \mathrm{L}$; the derived concentration guide is $3,000 \mathrm{pCi} / \mathrm{L}$.

Cesium-137 was detected in three wells located near the inactive 216-B-5 injection well in the 200-East Area. The injection well received waste containing cesium-137 from 1945 to 1947. Annual measurements of cesium-137 in one of these wells consistently show levels greater than the interim drinking water standard. Because the sampling schedule was changed from December to May of the fiscal year, a sample was not collected from this well during calendar year 1999. The fiscal year 1999 sample was collected in December 1998, and the fiscal year 2000 sample was collected in May 2000. Cesium-137 appears to be restricted to the immediate vicinity of the former injection well.

Cobalt-60. Cobalt-60 in groundwater is typically associated with waste generated by reactor effluent. Cobalt-60 is normally present as a divalent transition metal cation and, as such, tends to be immobile in groundwater. However, complexing agents may mobilize it. All cobalt-60 levels in groundwater samples analyzed in 1999 were below the $100-\mathrm{pCi} / \mathrm{L}$ interim drinking water standard. The derived concentration guide for cobalt-60 is $5,000 \mathrm{pCi} / \mathrm{L}$.

Cobalt -60 concentrations were detected in the northwestern part of the 200-East Area and the adjacent 600 Area north of the 200-East Area. These are the same areas where the technetium-99 contamination associated with the BY cribs is found. Apparently, cobalt in this plume is mobilized by reaction with cyanide or ferrocyanide in the waste stream, forming a dissolved cobalt species. The maximum concentration measured in 1999 was $62.7 \mathrm{pCi} / \mathrm{L}$ at the $\mathrm{BY}$ cribs. Because of its relatively short half-life (5.3 years), much of the cobalt-60 in groundwater in this area has decayed to lower concentrations.
Plutonium. Plutonium was released to the soil column in several locations in both the 200-West and 200-East Areas. Plutonium is generally considered to sorb strongly to sediment, which limits its mobility in the aquifer. The derived concentration guide for both plutonium-239 and plutonium-240 is $30 \mathrm{pCi} / \mathrm{L}$. Radiological analysis is incapable of distinguishing between plutonium-239 and plutonium240; therefore, the results are expressed as a concentration of plutonium-239/240. There is no explicit drinking water standard for plutonium-239/ 240; however, the gross alpha drinking water standard of $15 \mathrm{pCi} / \mathrm{L}$ would be applicable at a minimum. Alternatively, if the derived concentration guide that is based on a 100 -millirem dose standard is converted to the 4-millirem dose equivalent used for the drinking water standard, $1.2 \mathrm{pCi} / \mathrm{L}$ would be the relevant guideline. The half-lives of plutonium-239 and plutonium-240 are 24,000 and 6,500 years, respectively.

The only well where plutonium isotopes have been detected in groundwater above the $30-\mathrm{pCi} / \mathrm{L}$ derived concentration guide was near the inactive 216-B-5 injection well in the 200-East Area. Because the sampling schedule was changed from December to May of the fiscal year, a sample was not collected from this well during calendar year 1999. The fiscal year 1999 sample was collected in December 1998, and the fiscal year 2000 sample was collected in May 2000. Two other wells near the inactive injection well showed levels above the 1.2-pCi/L relevant drinking water guideline. The maximum concentration in 1999 was $3.9 \mathrm{pCi} / \mathrm{L}$. Plutonium levels have not changed significantly in these three wells. Because plutonium is strongly adsorbed to sediment and may have been injected into the aquifer as suspended particles, it is likely that the values measured result in part from solid rather than dissolved material. The injection well received an estimated 244 curies of plutonium-239/ 240 during its operation from 1945 to 1947 (PNL-6456). 


\subsubsection{Chemical Monitoring Results for the Unconfined Aquifer}

In recent years, chemical analyses performed by various monitoring programs at the Hanford Site have identified several hazardous chemicals in groundwater at concentrations greater than their respective drinking water standards. Nitrate, chromium, and carbon tetrachloride are the most widely distributed of these hazardous chemicals and have the highest concentrations in groundwater at the Hanford Site. Hazardous chemicals that are less widely distributed and have lower concentrations in groundwater include chloroform, trichloroethylene, tetrachloroethylene, cis-1,2-dichloroethylene, cyanide, and fluoride.

A number of parameters such as $\mathrm{pH}$, specific conductance, total carbon, total organic carbon, and total organic halides are used as indicators of contamination. These are mainly discussed in Section 6.1.7, "RCRA Summary." Other chemical parameters listed in Table 6.1.4 are indicators of the natural chemical composition of groundwater and are usually not considered contaminants from operations at the Hanford Site. These include alkalinity, aluminum, calcium, iron, magnesium, manganese, potassium, silica, and sodium. Chloride and sulfate occur naturally in groundwater and can also be introduced as contaminants from site operations. There is no primary drinking water standard for chloride or sulfate. The secondary standard for each is $250 \mathrm{mg} / \mathrm{L}$ and is based on aesthetic rather than health considerations; therefore, they will not be discussed in detail. The analytical technique used to determine the concentration of metals in groundwater provides results for a number of constituents. These trace metal constituents, rarely observed at greater than background concentrations, include antimony, barium, beryllium, boron, cadmium, copper, nickel, silver, vanadium, and zinc.

The following presents a summary of the chemical constituents in groundwater at concentrations greater than existing or proposed drinking water standards (40 CFR 141 and EPA 822-R-96-001; see Appendix C).

Nitrate. Many groundwater samples collected in 1999 were analyzed for nitrate. Nitrate was measured at concentrations greater than the drinking water standard ( $45 \mathrm{mg} / \mathrm{L}$ as nitrate ion) in wells in all operational areas. Nitrate is associated primarily with process condensate liquid wastes, though other liquids discharged to the ground also contained nitrate. Nitrate contamination in the unconfined aquifer reflects the extensive use of nitric acid in decontamination and chemical reprocessing operations. However, additional sources of nitrate, primarily associated with agriculture, occur off the site to the south, west, and southwest. The distribution of nitrate on the Hanford Site is shown in Figure 6.1.24; this distribution is similar to previous evaluations. Although nitrate contamination can be detected over large areas of the site, the areas impacted by levels greater than the drinking water standard are small. Nitrate at levels above the drinking water standard occurs in the 100,200, and 600 Areas.

N itrate in the 100 A reas. Nitrate concentrations have generally been rising in many 100 Area wells. However, there is no current explanation for the rises. A plume containing slightly elevated levels of nitrate occurs in the northeastern part of the 100-B,C Area. In 1999, the maximum nitrate concentration in this area was $50 \mathrm{mg} / \mathrm{L}$, which exceeded the drinking water standard.

Nitrate is found at levels greater than the drinking water standard in much of the 100-D Area. The highest nitrate level found in the 100-D Area in 1999 was $100 \mathrm{mg} / \mathrm{L}$ in the southwestern part of the area and near the 120-D-1 ponds. Nitrate concentrations are not changing significantly in the 100-D Area except near the 120-D-1 ponds, where levels show increasing trends.

Nitrate continues to be widely distributed in 100-F Area groundwater. The central and southern 


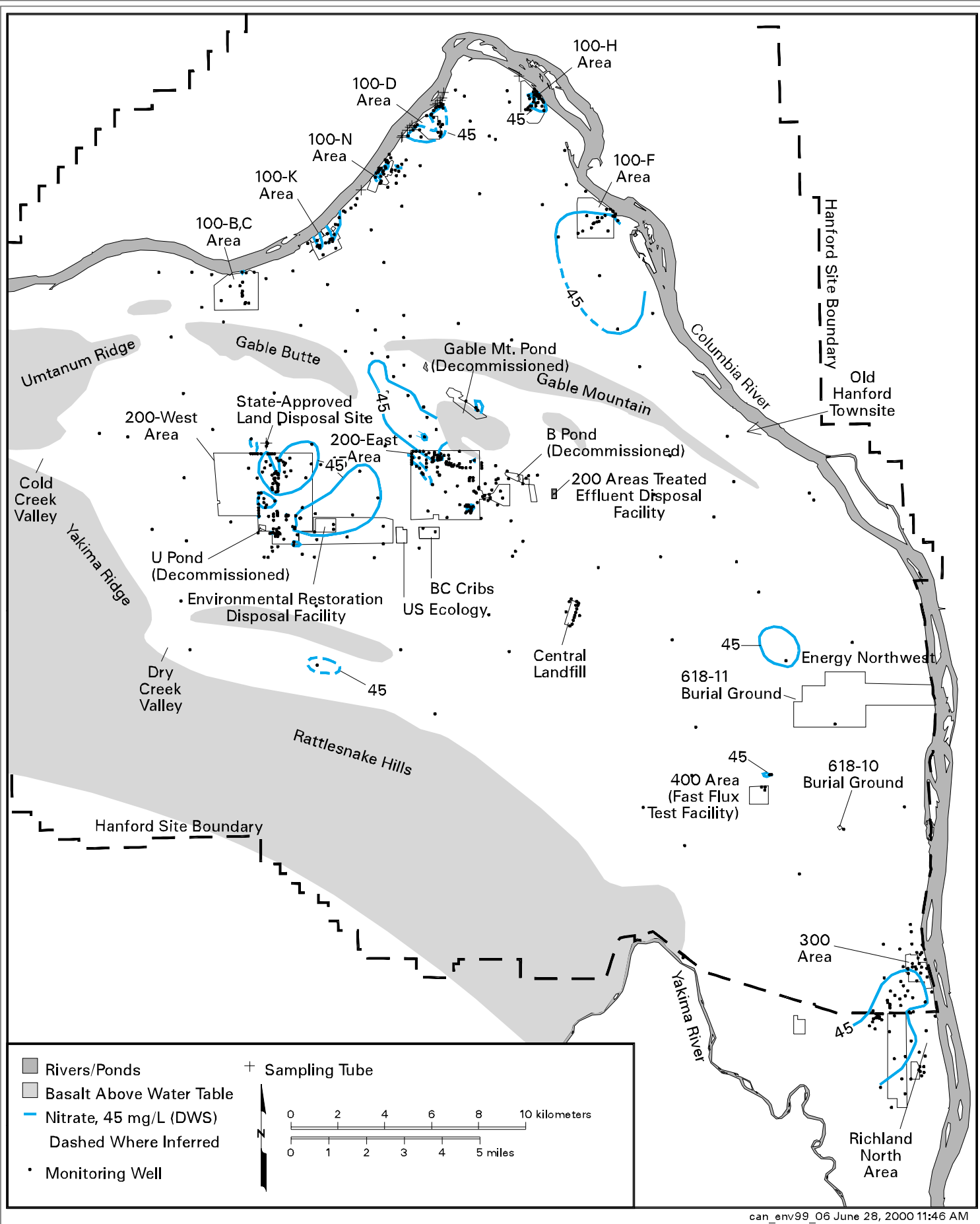

Figure 6.1.24. Average Nitrate Concentrations in the Unconfined Aquifer, 1999 
portions of the 100-F Area contain nitrate at levels greater than the drinking water standard. Trends show increasing nitrate levels in these areas. This plume extends to the south and southeast into the 600 Area from upgradient sources near F Reactor. In the southern part of the 100-F Area, groundwater flow was to the southeast. The maximum nitrate detected in the 100-F Area in 1999 was $144 \mathrm{mg} / \mathrm{L}$ in the southwestern part of the 100-F Area.

A nitrate plume with concentrations above the drinking water standard lies in the eastern portion of the 100-H Area adjacent to the Columbia River. The highest concentrations are restricted to a small area downgradient of the former $183-\mathrm{H}$ solar evaporation basins. The concentrations fluctuate in this small area and have been some of the highest on the site. The maximum nitrate detected in 1999 was $387 \mathrm{mg} / \mathrm{L}$ near the basins.

Nitrate at levels greater than the drinking water standard in the 100-K Area are found downgradient of both the KE and KW Reactors and appear to reach the Columbia River. The maximum concentration detected in 1999 was $155 \mathrm{mg} / \mathrm{L}$ in a well adjacent to the KE Reactor.

Although detected over most of the 100-N Area, nitrate contamination above the drinking water standard occurs at isolated locations in the $100-\mathrm{N}$ Area. The maximum was $150 \mathrm{mg} / \mathrm{L}$ in a well located between the 1301-N Liquid Waste Disposal Facility and the Columbia River.

Nitrate in the 200-East A rea. The nitrate plume in the 200-East Area covers a nearly identical area to that of the tritium plume. However, the area with nitrate exceeding the drinking water standard is smaller than the area with tritium exceeding its drinking water standard. Nitrate exceeds the drinking water standard in the northern part of the 200-East Area and adjacent 600 Area to the northwest and near the Plutonium-Uranium Extraction Plant in the southeastern part of the 200-East Area. In the northern part of the 200-East Area, the plume has two parts, a western plume that extends from
B Plant to the northwest and an eastern portion that extends from the BY cribs to the northwest. The two portions of the plume join northwest of the 200-East Area. A 1999 nitrate plume map of the 200-East and adjacent 600 Areas is presented in Figure 2.9-5 of PNNL-13116.

In 1999, the highest 200-East Area concentrations were reported in several wells near the 216-B-8 crib. The maximum concentration was $536 \mathrm{mg} / \mathrm{L}$ in a well adjacent to the inactive 216-B-8 crib. Nitrate levels continue to increase near the 216-B-8 and BY cribs. High nitrate concentrations in the 600 Area north of the 200-East Area are apparently related to past disposal practices at the BY cribs.

High nitrate concentrations continued to be found near liquid waste disposal facilities that received effluent from Plutonium-Uranium Extraction Plant operations. Nitrate concentrations in wells near the inactive 216-A-10 and 216-A-36B cribs have tended to decrease in the past few years but remained greater than the drinking water standard, although these cribs were removed from service in 1987. The maximum nitrate concentration detected in this vicinity was $133 \mathrm{mg} / \mathrm{L}$ adjacent to the 216 -A$36 \mathrm{~B}$ crib.

Nitrate is also elevated in a few wells near the former Gable Mountain Pond north of the 200-East Area. In 1999, the highest measured concentration in this area was $402 \mathrm{mg} / \mathrm{L}$.

Nitrate in the 200-West A rea. Nitrate concentrations greater than the drinking water standard were widespread in groundwater beneath the 200-West Area and adjacent parts of the 600 Area. The major nitrate plumes were found in wells east of U Plant and wells in the north-central part of the 200-West Area. The widespread distribution of nitrate reflects the multiple sources in the 200-West Area. Nitrate plume maps of the 200-West and adjacent 600 Areas are presented in Figures 2.8-10 and 2.8-31 of PNNL-13116. 
Some of the highest nitrate concentrations across the site continued to be found in wells southeast of U Plant, where the maximum detected in 1998 was $1,673 \mathrm{mg} / \mathrm{L}$ in a well adjacent to the inactive 216-U-17 crib. Nitrate concentrations were not monitored in wells near this crib in 1999 because nitrate is not used to indicate performance of this pump-and-treat system. The presence of nitrate in wells near this crib was detected before February 1988 when the crib went into operation. The source of nitrate is believed to be waste disposed in the 216-U-1 and 216-U-2 cribs southwest of U Plant. These cribs received more than 1,000,000 kilograms (2,200,000 pounds) of chemicals containing nitrate during their operation from 1951 to 1967 (PNL6456). As of September 1999, the pump-and-treat system near the 216-U-17 crib has removed 12,770 kilograms (28,153 pounds) of nitrate from $\sim 357$ million liters (99 million gallons) of extracted groundwater (DOE/RL-99-79). Nitrate has been removed from extracted groundwater since March 1997. However, nitrate is not the primary target of the pumpand-treat system.

Nitrate concentrations (maximum of $63 \mathrm{mg} / \mathrm{L}$ ) continued to be elevated above the drinking water standard near other inactive cribs to the south that are associated with the U Plant and ReductionOxidation Plant. These elevated levels represent nitrate plumes that coalesce with the plume from the U Plant area. A small, isolated plume of elevated nitrate occurs west of the Reduction-Oxidation Plant near the inactive 216-S-25 crib and S and SX tank farms, where the maximum concentration was $562 \mathrm{mg} / \mathrm{L}$. Nitrate concentrations in this small plume have increased or remained stable.

A large area, encompassing the northern half of the 200-West Area, contains nitrate in groundwater at concentrations much greater than the drinking water standard. Wells showing the highest concentrations are located near several inactive liquid waste disposal facilities that received waste from early T Plant operations. A large amount of nitrate was disposed to these cribs (e.g., $~ 2,300,000$ kilograms
[5,100,000 pounds] of nitrate to the $216-\mathrm{T}-7 \mathrm{crib}$ ). Maximum concentrations in these wells in 1999 ranged up to $1,049 \mathrm{mg} / \mathrm{L}$ west of $\mathrm{T}$ Plant near the inactive T, TX, and TY tank farms. Nitrate concentrations have increased or remained stable near these tank farms. High, stable concentrations of nitrate $(251 \mathrm{mg} / \mathrm{L})$ were also found in 1999 at the northeastern boundary of the 200-West Area.

A smaller area of elevated nitrate concentrations above the drinking water standard is located in vicinity of the Plutonium Finishing Plant, which is in the central part of the 200-West Area. The highest reported concentration was $440 \mathrm{mg} / \mathrm{L}$ near the Plutonium Finishing Plant in 1999. Nitrate concentrations have been stable in this area.

Nitrate in Other A reas. Nitrate contamination occurs near the city of Richland in the former 1100 Area, Richland North Area, and adjacent parts of the 600 Area along the southern boundary of the Hanford Site. This contamination is apparently affected by nitrate sources off the site. These sources may include agriculture, food processing, and nuclear fuel manufacturing at offsite commercial facilities. The part of this plume with nitrate concentrations greater than the drinking water standard extends from off the site, south of the former Horn Rapids Landfill, to the 300 Area to the northeast. The area of the nitrate plume at levels greater than the drinking water standard continued to expand in the southern part of the Hanford Site in 1999. The maximum nitrate concentration in 1999 was $168 \mathrm{mg} / \mathrm{L}$ on the northeastern edge of the Horn Rapids Landfill. Large increases in nitrate levels occurred off the Hanford Site $~ 1,200$ meters (4,000 feet) northwest of the city of Richland's north well field and recharge ponds in 1999. Nitrate concentrations changed from $48 \mathrm{mg} / \mathrm{L}$ in 1998 to $124 \mathrm{mg} / \mathrm{L}$ in 1999 at one well showing the largest increase. The most likely source of the increased levels is agricultural practices to the west. A 1999 plume map showing detail of the nitrate distribution is presented in Figure 2.12-10 in PNNL-13116. 
Although most nitrate observed on the site is the result of Hanford Site operations, elevated nitrate concentrations in the western part of the site appear to be the result of increasing agricultural activity in offsite areas (e.g., Cold Creek Valley). There is no known source of nitrate in these areas associated with site operations, and groundwater flow is from the west toward the Hanford Site facilities to the east. Nitrate levels have fluctuated considerably in wells upgradient of the 200 Areas over the past 30 years. In Cold Creek Valley, nitrate levels have been near or greater than the drinking water standard in one well since 1985. A maximum nitrate concentration of $54 \mathrm{mg} / \mathrm{L}$, the same as in 1998, was found in a well located just north of the Rattlesnake Hills.

Nitrate was detected at levels exceeding the drinking water standard in a well downgradient of the 400 Area process ponds. These levels, which have remained steady, were attributed to a former sanitary sewage lagoon west of the process ponds. The maximum concentration observed was $92 \mathrm{mg} / \mathrm{L}$ in 1999 .

Chromium. Use of chromium on the Hanford Site has been extensive. In the 100 Areas, sodium dichromate was added to cooling water as a corrosion inhibitor, and some residual chromium remains from that use. Chromium was used for decontamination in the 100,200, and 300 Areas and also was used for oxidation state control in the Reduction-Oxidation Plant process. In the hexavalent form, chromium is present in an anionic state. Thus, hexavalent chromium is freely mobile in the groundwater. The drinking water standard for chromium is $100 \mu \mathrm{g} / \mathrm{L}$.

Both filtered and unfiltered samples were collected from several of the wells onsite for analyses of chromium and other metals. Unfiltered samples may contain metals present as particulate matter, whereas filtered samples are representative of the more mobile, dissolved metals. Filtered samples also may contain some colloidal particles that are fine enough to pass through the filter. Drinking water standards are based on unfiltered concentrations. However, differences in well construction and pumping practices between monitoring wells and water supply wells make it difficult to predict potential drinking water concentrations from monitoring well data when the metals are present as particulate matter. In general, filtered samples provide the best indication of groundwater contamination levels for chromium because unfiltered samples are subject to greater variability introduced by the sampling process. Chromium concentrations in filtered samples, which are considered representative of dissolved hexavalent chromium, will be used to describe the level of contamination in the discussion below.

Chromium in the 100 Areas. Chromium has been detected above the drinking water standard in the 100-B,C, 100-D, 100-H, 100-K, and 100-N Areas. Groundwater pump-and-treat systems continued to operate in 1999 to reduce the amount of hexavalent chromium entering the Columbia River at the 100-D, 100-H, and 100-K Areas. The purpose of the pump-and-treat systems is to prevent discharge of hexavalent chromium into the Columbia River at concentrations exceeding $11 \mu \mathrm{g} / \mathrm{L}$, which is the EPA's standard for protection of freshwater aquatic life.

Chromium exceeded the drinking water standard from filtered samples in the 100-B,C Area in 1999. The maximum concentration was $111 \mu \mathrm{g} / \mathrm{L}$ downgradient of former water treatment facilities, where sodium dichromate may have leaked from storage tanks and transfer facilities. Chromium concentrations have shown a general rise in the last few years, but with annual variability.

The chromium distribution in the 100-D Area is shown in Figure 6.1.25. Chromium contamination at levels greater than the drinking water standard is defined by two plumes. The plume boundaries and concentrations in the southwestern portion of the 100-D Area were defined with better confidence in 1999 than in 1998 because twelve new monitoring 


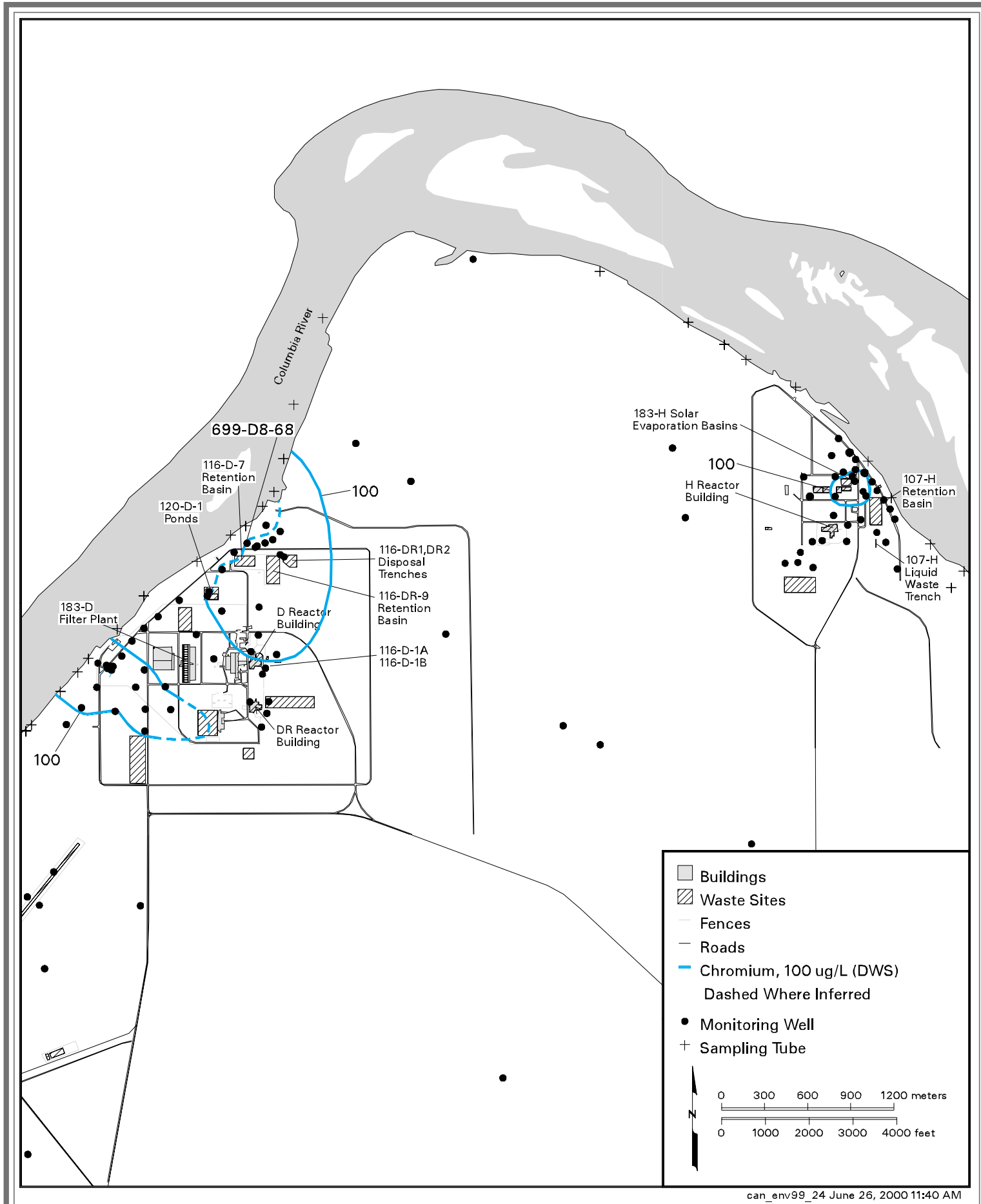

Figure 6.1.25. Average Filtered Chromium Concentrations in the 100-D and 100-H Areas, 1999 
wells drilled in 1999 were available for sampling. In 1999, the maximum chromium concentration from filtered samples was $2,210 \mu \mathrm{g} / \mathrm{L}$ in the southwestern portion of the 100-D Area. The source of this plume is suspected to be sodium dichromate used in the 190-DR building or disposed of in nearby waste sites. The source of the chromium plume in the northern part of the 100-D Area is sodium dichromate released to the ground at former facilities near D Reactor. Leakage from inactive retention basins and liquid waste disposal trenches north of D Reactor may also have contributed to the chromium plume. The maximum chromium concentration in the northern plume was $898 \mu \mathrm{g} / \mathrm{L}$.

In situ redox manipulation technology is currently being demonstrated in the southwestern 100-D Area to address hexavalent chromium contamination in groundwater. This technology immobilizes hexavalent chromium by reducing the soluble chromate ion to highly insoluble chromium hydroxide or iron chromium hydroxide. In 1999, results of a treatability study indicated that hexavalent chromium concentrations continue to be less than the detection limit $(7 \mu \mathrm{g} / \mathrm{L})$ within the treatment zone and have declined in downgradient wells.

Many samples from 100-H Area wells contained chromium at levels greater than the drinking water standard (see Figure 6.1.25). In 1999, the maximum chromium concentration from filtered samples collected from the shallow parts of the unconfined aquifer was $204 \mu \mathrm{g} / \mathrm{L}$ in a well near the former $183-\mathrm{H}$ solar evaporation basins. Chromium levels have fluctuated in response to changing water-table conditions. Potential sources include past disposal of sodium dichromate near $\mathrm{H}$ Reactor, disposal to the inactive 107-H liquid waste disposal trench, and chromium in acid wastes stored in the former $183-\mathrm{H}$ basins (Peterson and Connelly 1992). Upgradient sources include waste sites in the 100-D Area. Chromium was also found at levels above the drinking water standard in one well monitoring the deeper part of the unconfined aquifer. Filtered samples from this well, located near the former $183-\mathrm{H}$ basins, contained $182 \mu \mathrm{g} / \mathrm{L}$ of chromium in 1999 . Chromium levels in this well have been decreasing in recent years.

A groundwater remediation pump-and-treat system to decrease the amount of hexavalent chromium entering the Columbia River from the aquifer continued to operate in the 100-D and 100-H Areas in 1999. Groundwater extracted from the 100-D Area wells downgradient of the inactive retention basins is piped to the $100-\mathrm{H}$ Area for treatment. Groundwater extracted from the 100-D and 100-H Area wells is treated using ion-exchange technology and then reinjected into the aquifer in the southwestern part of the 100-H Area. Performance of the interim action to pump and treat has shown that hydraulic containment, resulting from the operation of the extraction wells, reduced the amount of chromium entering the river from the aquifer in both the 100-D and 100-H Areas. By the end of September 1999, 66 kilograms (146 pounds) of chromium were removed from groundwater extracted from these areas since pump-and-treat operations began in July 1997. Chromium concentrations have decreased in some extraction wells and monitoring wells, but the rate of decline is not consistent throughout the targeted plume area.

Chromium in the 100-K Area occurs in groundwater near or at levels greater than the drinking water standard in three areas (Figure 6.1.26). Two localized areas of chromium contamination occur near the KW Reactor and the water treatment basins southeast of the KE Reactor. The maximum concentration in 1999 was $606 \mu \mathrm{g} / \mathrm{L}$ near the KW Reactor. Trends show that chromium concentrations are increasing near the KW Reactor. Chromium concentrations reached a maximum of $161 \mu \mathrm{g} / \mathrm{L}$ in well $199-\mathrm{K}-36$ adjacent to the $183-\mathrm{KE}$ water treatment basins and inactive sodium dichromate storage tanks. This concentration is a decrease from $249 \mu \mathrm{g} / \mathrm{L}$ in 1998. A much wider area of chromium contamination is found in vicinity of the former 116-K-2 liquid waste disposal trench to the northeast. The maximum concentration in this area 


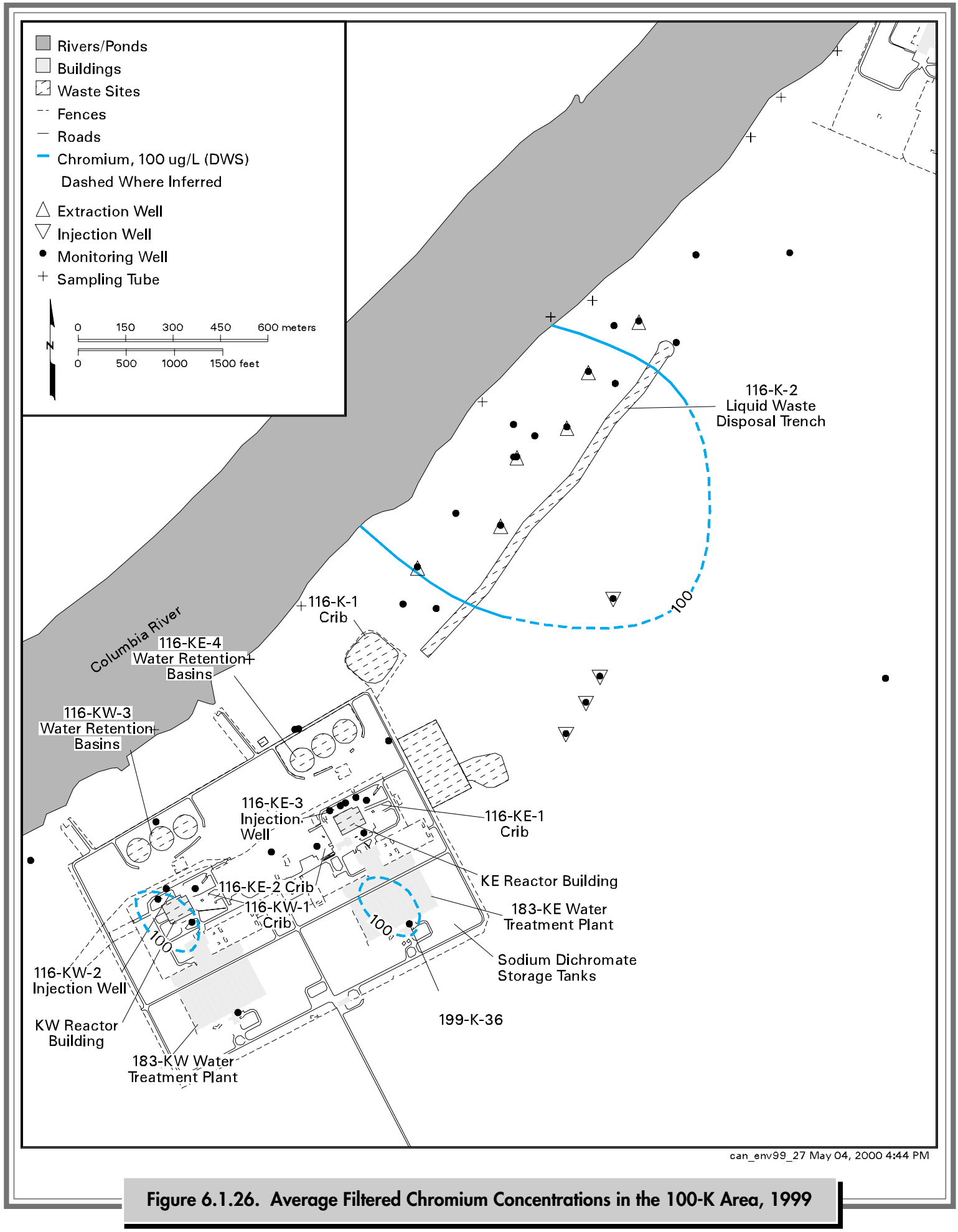


was $194 \mu \mathrm{g} / \mathrm{L}$ in 1999. A pump-and-treat system for treating chromium in groundwater between the trench and the Columbia River, which began operating in October 1997, continued to operate in 1999. Groundwater extracted from a network of wells is treated using ion-exchange technology and then returned to the aquifer upgradient of the $116-\mathrm{K}-2$ trench. By the end of September 1999, 70 kilograms (154 pounds) of chromium had been removed from extracted groundwater. Hexavalent chromium concentrations have shown a slight downward trend in several of the extraction wells, but have not fallen below the target concentration of $22 \mu \mathrm{g} / \mathrm{L}$.

In the 100-N Area, chromium contamination is not widespread in groundwater. However, filtered samples in one well that monitors a locally confined unit within the Ringold Formation have consistently shown concentrations at steady levels greater than the drinking water standard northwest of the 1301-N Liquid Waste Disposal Facility. The maximum chromium concentration in 1999 was $176 \mu \mathrm{g} / \mathrm{L}$.

The source for the contamination at this location is unknown. Chromium was disposed to the 1301-N Liquid Waste Disposal Facility until the early 1970s (DOE/RL-96-39).

Chromium in the 200 A reas. Chromium at concentrations greater than the drinking water standard in the 200-East Area was found in two wells on the southern boundary of A and AX tank farms. The maximum concentration detected in the sample was $1,420 \mu \mathrm{g} / \mathrm{L}$. Concentrations in this well have been variable, and the source of the chromium is unknown.

Chromium contamination has been found at several locations in the 200-West Area. Areas where concentrations exceeded the drinking water standard in 1999 include the T, TX, and TY tank farms and $216-S-10$ pond. Filtered samples from a well monitoring the TX and TY tank farms showed a maximum concentration of $433 \mu \mathrm{g} / \mathrm{L}$, the highest filtered chromium concentration in the 200-West
Area. The highest concentration found in the vicinity of the T tank farm was $192 \mu \mathrm{g} / \mathrm{L}$. Chromium concentrations have generally been increasing at these locations. The highest concentration near the former 216-S-10 pond was $213 \mu \mathrm{g} / \mathrm{L}$. Chromium concentrations near this former pond have generally been decreasing after rising to a peak concentration of $576 \mu \mathrm{g} / \mathrm{L}$ in 1997.

Chromium in Other Areas. Filtered chromium concentrations above the drinking water standard have been known to occur downgradient of the 200-West Area (located southwest of the 200-East Area). However, the sampling frequency of wells in this area was changed from annual to every 3 years in 1998 because historical trends showed that chromium concentrations were steady in these wells. The maximum concentration in this area in 1997 was $226 \mu \mathrm{g} / \mathrm{L}$. The extent of chromium contamination in this area is poorly defined, and the source has not been determined.

Carbon T etrachloride. Carbon tetrachloride contamination occurs above the $5-\mu \mathrm{g} / \mathrm{L}$ drinking water standard in much of the 200-West Area and represents one of the most significant contaminant plumes at the Hanford Site (Figure 6.1.27). The plume, which covers an area that is more than 11 square kilometers (4 square miles), extends past the 200-West Area boundary into the 600 Area. However, the overall carbon tetrachloride distribution has changed little since the plume was first identified in 1987.

The bulk of the contamination is believed to be from waste disposal operations associated with the Plutonium Finishing Plant in the west-central part of the 200-West Area. Major sources identified in this area include the 216-Z-9 trench, the 216-Z-1A drain/tile field, and the 216-Z-18 crib. Carbon tetrachloride was used as the carrier solvent for tributyl phosphate in the final purification of plutonium. Carbon tetrachloride was also used in the same facility as a nonflammable thinning agent while machining plutonium. A minor source of carbon 


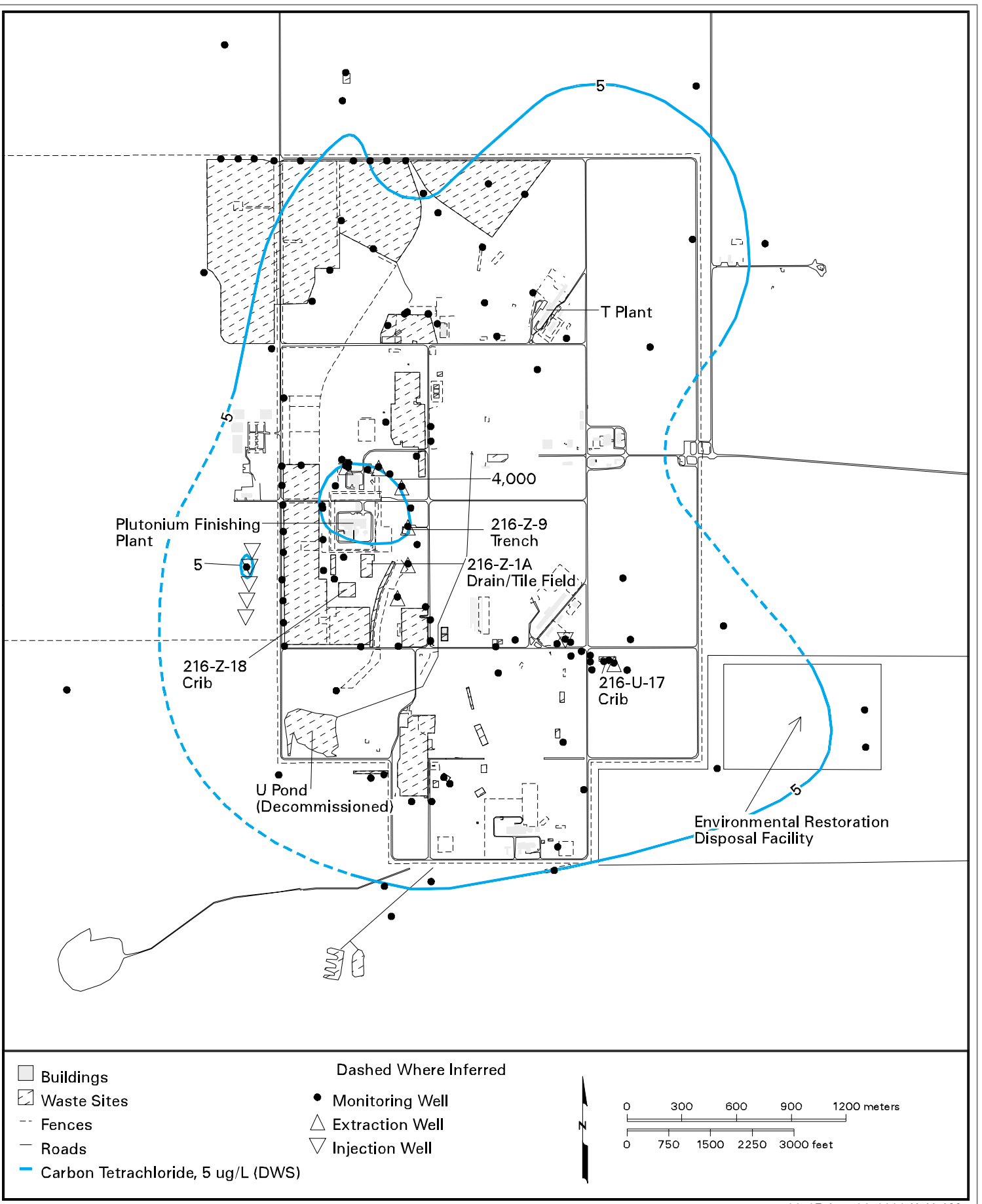

can_env99_07 June 26, 2000 11:43 AM

Figure 6.1.27. Average Carbon Tetrachloride Concentrations in the Unconfined Aquifer in the 200-West Area, 1999 
tetrachloride is a former waste disposal crib near T Plant. Carbon tetrachloride is immiscible in water but exhibits a relatively high solubility $\left(805,000 \mu \mathrm{g} / \mathrm{L}\right.$ at $20^{\circ} \mathrm{Celsius}$ [68 $68^{\circ}$ Fahrenheit]). Carbon tetrachloride has been found to have a relatively high degree of mobility in groundwater. Mobilization above the water table can also occur through vapor transport.

Wells in vicinity of the Plutonium Finishing Plant showed the highest concentrations in the plume, with levels exceeding the drinking water standard by more than two orders of magnitude. The maximum concentration was $7,900 \mu \mathrm{g} / \mathrm{L}$ near one pump-and-treat extraction well just northeast of the plant. Pump-and-treat operations, which began in 1994, have influenced the distribution of carbon tetrachloride. The area within the $4,000-\mu \mathrm{g} / \mathrm{L}$ contour has increased in size because of the effects of pumping from the extraction wells downgradient of this area. The plume center continues to move in a northerly and easterly direction toward the extraction wells, as evidenced by increased concentrations in several extraction and monitoring wells (BHI01311, Rev. 0). The extraction wells are located north and east of the Plutonium Finishing Plant. Carbon tetrachloride concentrations in vicinity of the injection wells southwest of the plant continue to decline as a result of injection of the treated water. As of September 1999, 955 million liters (252 million gallons) of extracted groundwater have been treated, resulting in the removal of 3,386 kilograms ( 7,465 pounds) of carbon tetrachloride (DOE/ RL-99-79).

Near the 216-U-17 crib in the southeastern part of the 200-West Area, the pump-and-treat system removed 15.8 kilograms (34.8 pounds) of carbon tetrachloride from $\sim 357$ million liters (99 million gallons) of extracted groundwater. This amount has been removed as of September 1999 (DOE/RL-99-79).

The extent of carbon tetrachloride contamination in deeper parts of the aquifer is uncertain because of the limited concentration data from depths below the water table. The limited amount of data indicates that the concentrations are highest at the top of the aquifer and decline with depth at most locations within the plume. A detailed summary of available data indicates that carbon tetrachloride concentrations range up to $3,789 \mu \mathrm{g} / \mathrm{L}$ in the middle part of the unconfined aquifer (BHI-01311, Rev. 0). In the lower part of the unconfined aquifer, carbon tetrachloride concentrations range up to 2,651 $\mu \mathrm{g} / \mathrm{L}$. These data represent samples collected between 1991 and 1999 .

Changes in groundwater flow since decommissioning $\mathrm{U}$ Pond may influence the plume configuration and the concentrations at particular locations. Another potential influence is the continued spreading of carbon tetrachloride above the water table, in either the liquid or the vapor phase. Free-phase, liquid, carbon tetrachloride above and possibly below the water table provides a continuing source of contamination. Therefore, lateral expansion of the carbon tetrachloride plume is expected to continue.

Chloroform. A chloroform plume appears to be associated with, but not exactly coincident with, the carbon tetrachloride plume in the 200-West Area (Figure 6.1.28). The highest chloroform concentrations were measured in vicinity of the Plutonium Finishing Plant, where the maximum level was $140 \mu \mathrm{g} / \mathrm{L}$. This is a slight increase from 1998 chloroform levels. The drinking water standard for chloroform is $100 \mu \mathrm{g} / \mathrm{L}$ (total trihalomethanes), which is 20 times higher than that for carbon tetrachloride. The origin of chloroform is suspected to be a degradation product of carbon tetrachloride or an anaerobic degradation product associated with septic drain fields.

T richloroethylene. A commonly used organic solvent, trichloroethylene has a drinking water standard of $5 \mu \mathrm{g} / \mathrm{L}$. In 1999, trichloroethylene was detected at levels greater than the drinking water standard in some wells in the $100,200,300$, and 


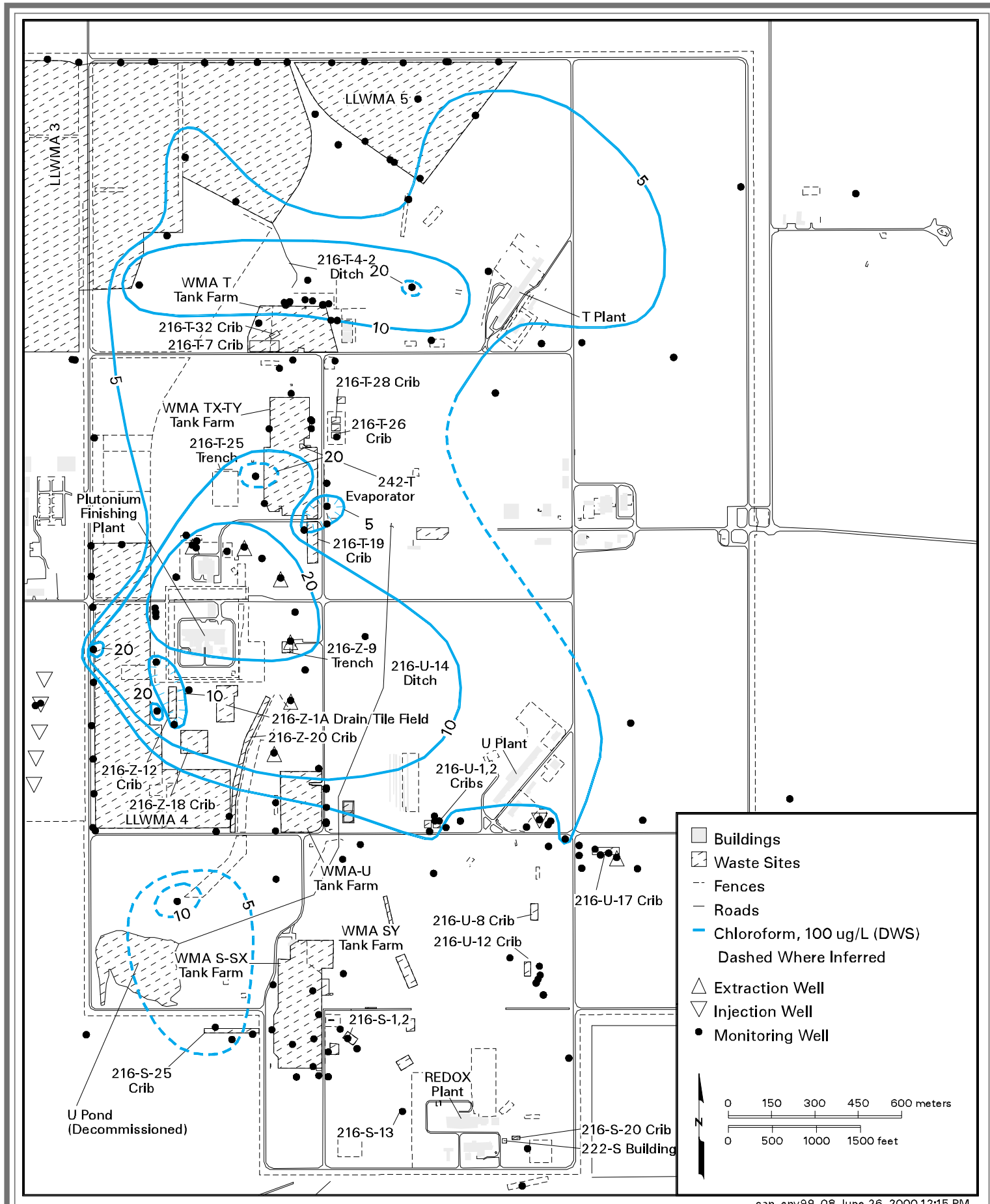

Figure 6.1.28. Average Chloroform Concentrations in the Unconfined Aquifer in the 200-West Area, 1998 
600 Areas. The most widespread area of contamination occurred in the 200-West Area.

Trichloroethylenein the100A reas. Trichloroethylene was detected at levels greater than the drinking water standard in the southwestern corner of the 100-F Area and in the adjacent 600 Area. Trichloroethylene concentrations in this area show declining trends. The maximum concentration detected in this area was $18 \mu \mathrm{g} / \mathrm{L}$ in the adjacent 600 Area. No specific sources of this contamination have been identified.

In the 100-K Area, two wells sampled contained trichloroethylene at levels above the drinking water standard, representing a localized area of contamination near the KW Reactor complex. This area of contamination resulted from the past disposal/ spillage of organic solvents. The maximum concentration was $23 \mu \mathrm{g} / \mathrm{L}$ in monitoring well 199-K-106A. Trichloroethylene concentrations appear to be decreasing with time.

Trichloroethylenein the 200 A reas. Trichloroethylene was detected at levels greater than the drinking water standard in several parts of the 200-West Area (Figure 6.1.29). The most significant area extends from the Plutonium Finishing Plant northeast to the northern boundary of the 200-West Area. The source of the contamination is presumably past disposal in these plant areas. The highest concentration was $33 \mu \mathrm{g} / \mathrm{L}$ northeast of the Plutonium Finishing Plant. A smaller, isolated area of contamination occurs downgradient of the U Plant cribs, where the maximum concentration was $15 \mu \mathrm{g} / \mathrm{L}$. Trichloroethylene concentrations in the 200-West Area did not change significantly between 1998 and 1999.

Trichloroethylene in the 300 A rea. Trichloroethylene was detected at one well in 1999 in the 300 Area at concentrations above the drinking water standard. The maximum concentration was $6 \mu \mathrm{g} / \mathrm{L}$ at well 399-1-16B. This well monitors the base of the unconfined aquifer downgradient of the former 316-5 process trenches. Trichloroethylene concentrations in the 300 Area have been declining.

Trichloroethylene in the 600 A rea. Trichloroethylene was found at levels above the drinking water standard in two wells in vicinity of the former Horn Rapids Landfill in the southern part of the site (Richland North Area). This contamination, which is degrading naturally, forms an elongated plume that extends from an area just south of the landfill to near the southwestern corner of the 300 Area and has an origin off the Hanford Site (Figure 6.1.30). Since 1990, trichloroethylene concentrations have decreased from levels exceeding $100 \mu \mathrm{g} / \mathrm{L}$. The maximum concentration detected in this plume in 1999 was $6 \mu \mathrm{g} / \mathrm{L}$ on the northeastern side of the landfill.

cis-1,2-Dichloroethylene. Concentrations of cis-1,2-dichloroethylene, a biodegradation product of trichloroethylene, remain elevated in well 399-1-16B, located near the former process trenches and ponds in the 300 Area. This well is completed in the deeper part of the unconfined aquifer and is the only well on the site where this constituent is found at levels above the $70-\mu \mathrm{g} / \mathrm{L}$ drinking water standard. In 1999 , a maximum of $180 \mu \mathrm{g} / \mathrm{L}$, the same as in 1998, was detected in this well.

Cyanide. Waste fractionation activities performed in the late 1950s used large quantities of sodium and nickel ferrocyanide to recover cesium137. Large volumes of aqueous supernatant waste containing excess ferrocyanide were disposed to the ground in both the northern and southern portions of the 200-East Area. Smaller quantities were also disposed to former cribs in the 200-West Area. Procedures used to analyze for cyanide do not distinguish between ferrocyanide and free cyanide. Cyanide results reported here are, thus, normally assumed to be residual ferrocyanide associated with the discharges from the waste fractionation activities performed more than 30 years ago. A chemical speciation study performed in 1988 indicated that 


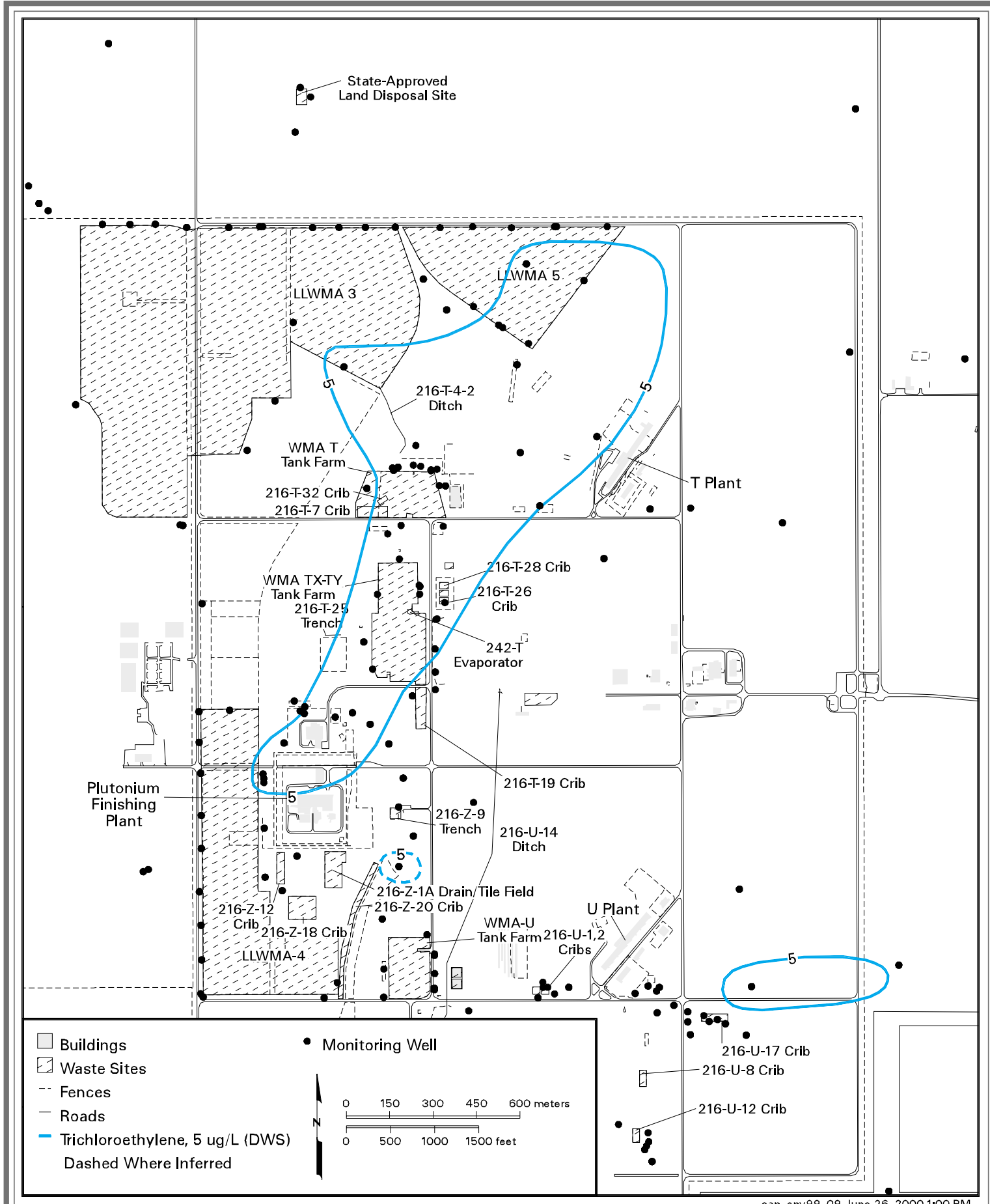

Figure 6.1.29. Average Trichloroethylene Concentrations in the Unconfined Aquifer in the 200-West Area, 1999 


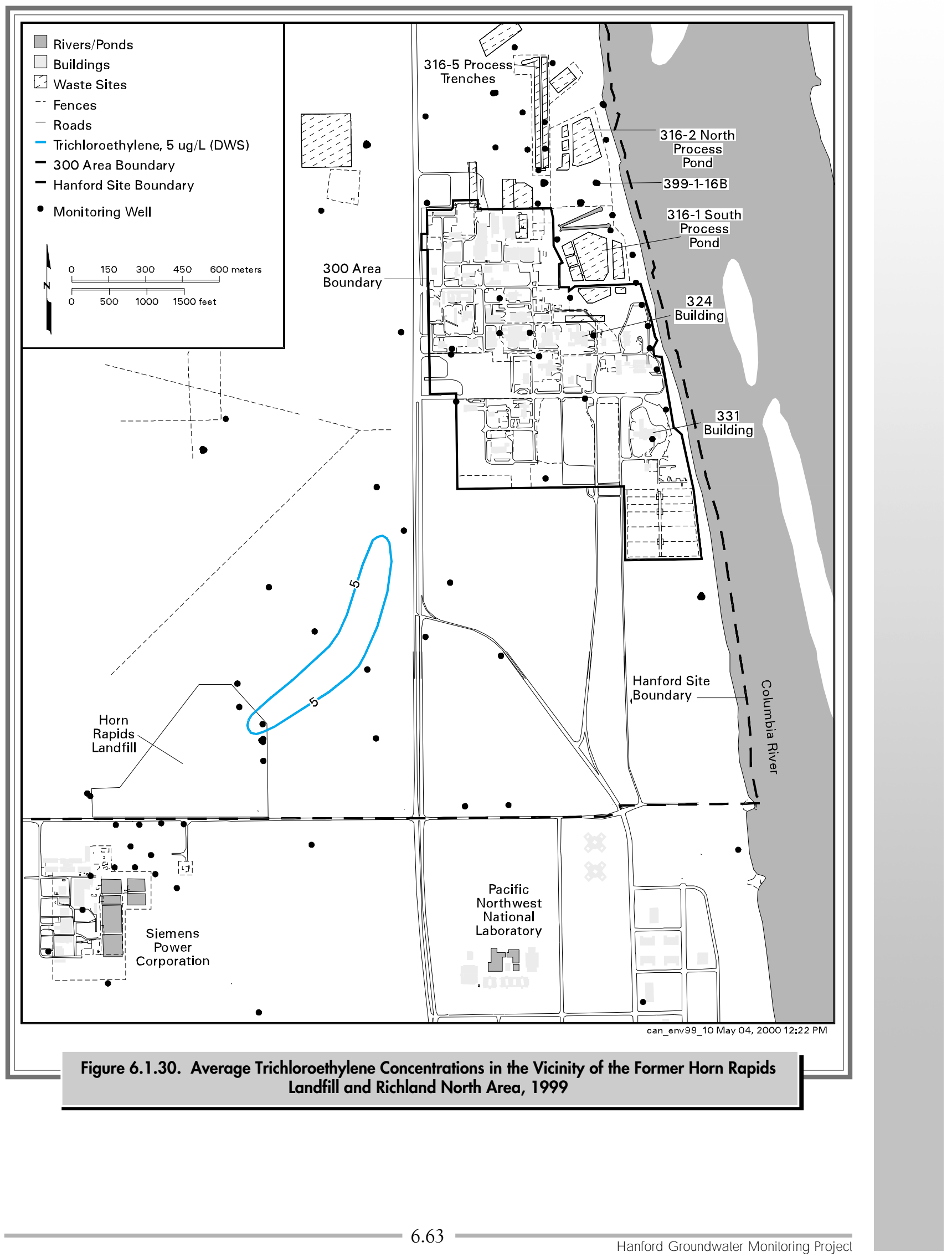


approximately one-third of the cyanide in groundwater is present as free cyanide and the rest may be present as ferrocyanide (Section 4.1 in PNL-6886 and Section 3.2.2 in PNL-7120). The drinking water standard for cyanide is $200 \mu \mathrm{g} / \mathrm{L}$.

The highest cyanide levels were detected in samples collected from wells in the northwestern part of the 200-East Area and in the 600 Area north of the 200-East Area. Samples collected from two wells near the inactive BY cribs showed concentrations above the drinking water standard in 1999. Cyanide levels are increasing near the BY cribs. The maximum concentration of $289 \mu \mathrm{g} / \mathrm{L}$ correlates with cobalt-60 levels. Wells containing cyanide often contain several radionuclides, including cobalt- 60 . Although cobalt-60 is normally immobile in the subsurface, it appears to be chemically complexed by cyanide or ferrocyanide. The complexed chemical species is more soluble and more mobile in groundwater.

Fluoride. At this time, fluoride has a primary drinking water standard of $4 \mathrm{mg} / \mathrm{L}$ and a secondary standard of $2 \mathrm{mg} / \mathrm{L}$. Secondary standards are based primarily on aesthetic rather than health considerations. Fluoride was detected above the primary drinking water standard near $\mathrm{T}$ tank farm in the 200-West Area in 1999. Fluoride levels near T tank farm increased slightly between 1998 and 1999. The maximum fluoride concentration was $5.3 \mathrm{mg} / \mathrm{L}$. A few wells near the $T$ tank farm showed concentrations above the secondary standard. Aluminum fluoride nitrate used in past 200-West Area processes is the probable source of the fluoride contamination.

\subsubsection{Radiological and Chemical M onitoring Results for the Basalt-Confined Aquifer}

Aquifers confined below the uppermost basalt layers show much less impact from Hanford Site contamination than the unconfined aquifer system within the overlying sediment. The minor contamination found in the basalt-confined aquifers may be attributed to several factors. These factors include areas where the confining layers of basalt have been eroded away, areas where disposal of large amounts of water resulted in downward gradients, and areas where wells penetrating to the confined aquifers provided pathways for contaminant migration. These factors produced intercommunication between the aquifers, meaning they permitted the flow of groundwater from the unconfined aquifer to the underlying confined aquifer, thereby increasing the potential to spread contamination.

Intercommunication between the unconfined and basalt-confined aquifers in vicinity of the northern part of the 200-East Area has been identified previously in RHO-BWI-ST-5 and RHO-REST-12 P. The hydrochemical and hydrogeologic conditions within the upper basalt-confined aquifer system and the potential for offsite migration of contaminants through confined aquifer pathways were evaluated in PNL-10817.

Several confined aquifer wells north and east of the 200-East Area that show evidence of intercommunication with the overlying unconfined aquifer were identified in PNL-10817. Intercommunication between the unconfined and confined aquifers in this area has been attributed to erosion of the upper Saddle Mountains Basalt and downward vertical gradients that result from groundwater mounding associated with waste disposal. Groundwater chemical data from most confined aquifer wells in other areas of the Hanford Site do not exhibit evidence of contamination. Exceptions are wells that were previously open to both the unconfined and confined aquifers, thus providing conduits for the downward transport of contamination.

Approximately 10 years of groundwater sample data for the basalt-confined aquifer indicate that very few areas of concern were warranted for annual sampling. Consequently, the number of wells sampled annually has progressively been reduced since 1995 . 
The schedule for most of the basalt-confined aquifer wells has been reduced to a triennial sampling frequency. Well 699-42-E9B was the only basaltconfined aquifer well sampled in 1999. Sample results from this well, located east of the Columbia River, showed essentially no contamination. The

\subsubsection{RCRA Summary}

More than 60 treatment, storage, and disposal units are recognized under the RCRA permit for the Hanford Site. Of these, 26 required groundwater monitoring during 1999. Locations of these groundwater monitoring sites were given in Figure 6.1.10. This section provides a summary of groundwater monitoring activities and results for these sites. Additional information, including RCRA groundwater monitoring and complete listings of radioactive and chemical constituents measured in monitoring wells from October 1998 through September 1999, is available in PNNL13116. Any significant changes that occurred from October through December 1999 are noted below.

RCRA groundwater monitoring is conducted under one of three phases: 1) indicator parameter/ detection, 2) groundwater quality assessment/ compliance, or 3) corrective action. Initially, a detection program is developed to monitor the impact of facility operations on groundwater. During the indicator parameter/detection phase, groundwater parameters established for the particular site are measured in wells upgradient and downgradient from the site. Statistical tests are applied to the monitoring results to calculate "critical mean" values for each monitoring parameter. These values represent the background water quality for the site. Subsequent monitoring data are compared to the critical mean values to determine if there has been a statistically significant change in the concentrations of key indicator parameters or dangerous waste constituents in the groundwater. The statistical methods used to calculate critical means and compare with monitoring data are distribution of contaminants in the basalt-confined aquifer is shown in previous annual reports (e.g., Figure 6.1.35 in PNNL-12088). The locations of wells used for monitoring confined aquifer groundwater chemistry were given in Figure 6.1.9.

described in Appendix B in PNNL-12086. If a statistically significant change from the "critical mean" is observed, then a groundwater quality assessment/compliance phase of monitoring and investigation is initiated. During this phase, groundwater monitoring is designed to determine if groundwater protection standards have been exceeded. If the source of the contaminants is determined to be the treatment, storage, and disposal unit and concentrations exceed maximum contaminant levels defined in the monitoring plan or permit, then the Washington State Department of Ecology may require corrective action to reduce the contaminant hazards to the public and environment. Groundwater monitoring during the corrective action phase is designed to assess the effectiveness of the corrective action. Table 2.2.2 in Section 2.2, "Compliance Status," lists the phase pertaining to each of the RCRA groundwater monitoring projects at the end of 1999.

\subsubsection{100 Areas Facilities}

120-D-1 Ponds. These ponds were constructed in 1977 for disposal of nonradioactive effluent derived from operating facilities in the 100-D,DR Area. This disposal facility is located in the former 188-D ash disposal basin and includes settling and percolation ponds separated by a dike. Effluent to the ponds originated from two sources: the 183-D filter plant and the 189-D building engineering testing laboratories. Some past discharges contained hydrochloric acid, sodium hydroxide, and sulfuric acid. Before 1986, the effluent may have had a pH greater than 12.5 or less than 2.0 and, thus, may 
have been dangerous waste. There was also a potential for up to 2.3 kilograms ( 5 pounds) of mercury to have been discharged to the ponds. Between 1986 and 1994, the effluent discharged to the ponds included chlorine and flocculating (clumping) agents such as aluminum sulfate. Effluent discharge to the ponds ceased in 1994. Contaminated soils were removed from the ponds in 1996.

The 120-D-1 ponds well network was sampled once in 1999. After that, the Washington State Department of Ecology implemented modification E of the Hanford Site RCRA Permit (Ecology 1994) and the site was clean closed. This means that all dangerous waste or dangerous waste constituents or residues associated with the operation of the ponds have been removed. The closure plan (DOE/RL-9271, Rev. 2) is a demonstration of clean closure, and there are no requirements for a landfill cover, postclosure care, or further groundwater monitoring. Statistical evaluations of indicator parameter data indicated that the ponds had no adverse impact on groundwater quality. Mercury is the only listed waste that may have been discharged to these ponds and was never detected in any of the downgradient monitoring wells. Chromium and nitrate from upgradient sources exceeded maximum contaminant levels.

183-H Solar Evaporation B asins. This facility consisted of four separate concrete basins surrounded by an earthen berm. The basins have been demolished and contaminated soil removed from the site. Between 1973 and 1985, the basins were used to store liquid waste, primarily from nuclear fuel fabrication activities conducted in the 300 Area. Solar evaporation reduced the volume of liquid waste. The waste was predominantly acid etch solution that had been neutralized with sodium hydroxide before being discharged into the basins. The solution included chromic, hydrofluoric, nitric, and sulfuric acids and also contained various metallic and radioactive constituents. Groundwater in the vicinity of these basins is characterized by elevated levels of chromium, nitrate, technetium-99, and uranium. All of these constituents were present in waste discharged to the basins when they were in use.

This site continued to be monitored under a final status corrective-action program during 1999 (WAC 173-303-645). The site was incorporated into the Hanford Site RCRA Permit (Ecology 1994) in 1998. Groundwater remediation is integrated with the 100-HR-3 operable unit, where remediation for chromium is under way. While the pump-andtreat system is operating, RCRA monitoring consists of annual sampling of four wells for chromium, fluoride, nitrate, technetium-99, and uranium (PNNL11573). The wells were sampled in November 1999. Contaminant concentrations fluctuate in response to changes in river stage, and continued to exceed concentration limits in one or more wells.

\section{1-N and 1325-N Liquid Waste Disposal}

Facilities. These facilities contaminated groundwater with radionuclides, most notably strontium-90 and tritium, as discussed in Section 6.1.6.1, "Radiological Monitoring Results for the Unconfined Aquifer." A pump-and-treat system is active as a CERCLA interim action to reduce the amount of strontium-90 flowing into the Columbia River at the 100-N Area. RCRA monitoring focuses on the hazardous (nonradioactive) constituents discharged to the facilities.

The 1301-N facility was the primary liquid waste disposal site for N Reactor from 1963 until 1985. Discharges were primarily radioactive fission and activation products. Minor amounts of dangerous waste and other constituents may also have been discharged, including ammonium hydroxide, cadmium, diethylthiourea, lead, morpholine, phosphoric acid, and sodium dichromate. The facility consists of a concrete basin with an unlined, zigzagging extension trench, covered with concrete panels.

The $1325-\mathrm{N}$ facility was constructed in 1983 and also received effluent from N Reactor. In 1985, discharge to 1301-N ceased, and all effluent was sent to $1325-\mathrm{N}$. All discharge to $1325-\mathrm{N}$ ceased in late 
1991. The facility consists of a concrete basin with an unlined extension trench, covered with concrete panels.

During 1999, upgradient and downgradient wells at the 1301-N and $1325-\mathrm{N}$ facilities were sampled twice. The critical mean values for indicator parameters $(\mathrm{pH}$, specific conductance, total organic carbon, and total organic halides) were revised in December 1999 to evaluate the data from September 1999 and from fiscal year 2000. The new values are based on recent data (1997 through 1999) from the upgradient wells. At the $1301-\mathrm{N}$ facility, total organic carbon in downgradient well 199-N-3 exceeded the critical mean value in January, March, and September 1999. The Washington State Department of Ecology was notified in February 1999. Because no organic constituents of concern have been identified in $1301-\mathrm{N}$ waste or sediment, the contamination is assumed to come from another source, and the site remains in indicator evaluation status.

The revised critical mean value for specific conductance at the $1325-\mathrm{N}$ facility was lower than the previous value, and two of the downgradient wells exceeded the revised mean in September 1999. DOE notified the Washington State Department of Ecology and submitted an assessment report that concluded the exceedance did not indicate contamination from the facility (see Section 2.4 of PNNL13116). Of the dangerous waste constituents or byproduct discharged to these facilities, only nitrate exceeded the maximum contaminant level, and the sources are unclear (see Section 2.4.3 of PNNL13116). The $1301-\mathrm{N}$ and $1325-\mathrm{N}$ facilities have contaminated the groundwater with tritium and strontium-90, but radionuclides are not monitored as part of the RCRA program at these facilities.

The closure plan for these facilities was revised and incorporated into a modification of the Hanford Site RCRA Permit (Ecology 1994) in 1999. Remedial actions will be integrated with the 100-NR-1 and 100-NR-2 operable units. The closure plan
(DOE/RL-96-39) states that RCRA monitoring during and after closure activities will continue, according to the existing interim status monitoring plan (WHC-SD-EN-AP-038, Rev. 2).

1324-N and 1324-N A Ponds. The 1324-N pond was a treatment facility that was in service from May 1986 to November 1988. This facility is a double-lined pond that was used for neutralizing high- and low-pH waste from a demineralization plant. The 1324-NA pond is unlined and was used for treating waste from August 1977 to May 1986 and for disposing of treated waste from May 1986 to August 1990. The effluent to both facilities contained sulfuric acid and sodium hydroxide, and the $\mathrm{pH}$ was occasionally high or low enough to classify the effluent as a dangerous waste.

Specific conductance in wells 199-N-59, 199-N-72, and 199-N-73 downgradient of the 1324-N/NA site continued to exceed the critical mean value in 1999. A previous groundwater quality assessment indicated that the high specific conductance is caused by the nonhazardous constituents sulfate and sodium (WHC-SD-EN-EV003, Rev. 1). Because an assessment has been completed already and nonhazardous constituents caused the high conductance, no further action was needed.

Concentrations of total organic carbon in downgradient well 199-N-59 continued to exceed the critical mean value in March 1999. The Washington State Department of Ecology agreed that the contamination is from another source, so assessment monitoring is not required. Total organic carbon data from September 1999 did not exceed the revised critical mean value.

The closure plan for this facility was revised and incorporated into a modification of the Hanford Site RCRA Permit (Ecology 1994) in 1999. Remedial action will be integrated with the 100-NR-1 and 100-NR-2 operable units. The closure plan (DOE/ RL-96-39) states that RCRA monitoring during and 
after closure activities will continue, according to the existing interim status monitoring plan (WHC-SD-EN-AP-038, Rev. 2).

\subsubsection{200 Areas Single- Shell Tank Farms}

Single-shell tanks are located in the A, AX, B, BX, BY, C, S, SX, T, TX, TY, and U tank farms, which have been designated as parts of RCRA Waste Management Areas A-AX, B-BX-BY, C, S-SX, T, TX-TY, and U, respectively. Waste Management Areas A-AX, B-BX-BY, and C are located in the 200-East Area; Waste Management Areas S-SX, T, TX-TY, and U are in the 200-West Area. Each waste management area includes tanks and associated ancillary systems (e.g., pipelines). The single-shell tanks store a mixture of dangerous chemical and radioactive wastes generated by reprocessing fuel irradiated in Hanford Site reactors. The single-shell tanks received mixtures of organic and inorganic liquids that contain radionuclides, solvents, and metals that were originally discharged to the tanks as alkaline slurries. Subsequent waste management operations combined waste streams from different processes. In many tanks, wastes have been concentrated by removing water through evaporation.

\section{Waste M anagementA reaA-AX. This RCRA}

site continued to be monitored under an interim status indicator evaluation program in 1999. Wells were sampled twice for indicator and site-specific parameters. Indicator parameter data from upgradient wells were statistically evaluated, and values from downgradient wells were compared to those established from the upgradient wells. The indicator parameters (specific conductance, total organic carbon, $\mathrm{pH}$, and total organic halides) did not exceed critical mean values during 1999.

Because of uncertainty in flow directions, the well network for this site may not be adequate for RCRA monitoring. The aquifer is less than 5 meters (16 feet) thick in RCRA network wells and the water table is declining. Three of the RCRA compliant wells at Waste Management Area A-AX may become unusable in 6 years.

\section{Waste M anagement A rea B-BX-BY . RCRA} assessment monitoring continued at this waste management area in 1999. Exceedances of the critical mean value for specific conductance in February 1996 at well 299-E33-32 initiated assessment monitoring. An assessment monitoring plan (WHC-SDENV-AP-002, Rev. 0) was issued in September 1996, followed by an assessment investigation. Results indicated that tank waste from this waste management area had reached the groundwater (PNNL-11826). The assessment program is continuing to investigate the rate of movement and extent of groundwater contamination at this site (see Section 2.9.1 in PNNL-13116). Wells are monitored at least quarterly, and in some cases, monthly. In 1999, iodine-129, nitrate, technetium99, and uranium exceeded maximum contaminant levels or drinking water standards in RCRA compliant wells, with corresponding exceedances of gross beta and gross alpha standards. Monitoring data from 1999 were used to define three distinct areas of contamination near the waste management area.

Originally, the RCRA groundwater monitoring network was designed for groundwater flow toward the northwest, based on regional plume maps. This method was used to determine flow direction because the water table is almost flat in the immediate area of the farms. As part of the ongoing studies, a series of steps are being taken to refine water-level measurements to allow a better determination of the approximate flow direction based on the local gradient.

Waste M anagement A rea C. This RCRA site continued to be monitored under an interim status indicator evaluation program in 1999. Monthly sampling began in fiscal year 1999 to assess the potential impact of waste removal and sluicing of tank contents. In addition, the required detection sampling was conducted twice for indicator and 
site-specific parameters. Indicator parameter data from upgradient wells were statistically evaluated. Values from downgradient wells were compared to values established from the upgradient wells. The indicator parameters (specific conductance, total organic carbon, $\mathrm{pH}$, and total organic halides) did not exceed critical mean values during 1999.

Currently, the well network for this site appears to comply only marginally with the required placement of groundwater monitoring wells because of changes and uncertainty in the direction of flow.

Waste M anagement A rea S-SX. This RCRA site continued to be monitored under an interim status assessment program during 1999. DOE initiated the assessment program in response to a directive from the Washington State Department of Ecology in 1996. The directive cited anomalous trends in technetium-99 and high specific conductance as primary reasons for the assessment. An assessment plan was submitted in August 1996 (WHC-SD-EN-AP-191). A report on the results of the assessment (PNNL-11810) concluded that this waste management area contributed to groundwater contamination. Accordingly, investigation of the rate and extent of the contamination is required. In 1999, contaminant concentrations fluctuated because of changing flow directions.

Three new wells were installed in 1999 and six more are planned in 2000 to improve spatial coverage and to replace wells going dry.

Waste M anagement A rea T. This RCRA site continued to be monitored under an interim status assessment program during 1999. Waste Management Areas T and TX-TY began assessment monitoring in November 1992 because of high specific conductance in downgradient wells (WHC-SD-ENAP-132, Rev. 0). Assessment findings (PNNL11809) indicated that contaminants in well 299-W10-15 are a result of sources outside the waste management area. There is strong evidence, however, that contaminants observed in well 299-W1127, which include chromium, cobalt-60, nitrate, technetium-99, and tritium, are a result of sources within the waste management area, so assessment work has continued. The plume detected in well 299-W11-27 has reached well 299-W11-23, located to the east of 299-W11-27, apparently as a result of changed groundwater flow direction at Waste Management Area T.

The current network of wells is inadequate for assessment monitoring. Four new wells are planned to be installed in 2000 to improve the monitoring coverage.

Waste Management Area TX-TY. This RCRA unit continued to be monitored under an interim status assessment program during 1999. Waste Management Area TX-TY began assessment monitoring in November 1991 because of high specific conductance in wells 299-W10-17 and 299W14-12 (WHC-SD-EN-AP-132, Rev. 0). The exceedance in well 299-W14-12 was accompanied by elevated cobalt-60, iodine-129, technetium-99, and tritium. Assessment results (PNNL-11809) indicated that contaminants in well 299-W10-17 are a result of sources outside the waste management area. Assessment results for well 299-W14-12 indicate that the contamination is consistent with a source within the waste management area, though upgradient sources are also possible. Because there was no direct evidence for upgradient sources, assessment continues at the site. Well 299-W15-40 was drilled near the 216-T-25 trench in 1999 to evaluate its potential role in providing the observed contamination. Results indicate that the trench is not the source of contamination. In 1999, contaminant concentrations increased in many wells, apparently as a result of changing flow directions.

The well network is inadequate for assessment monitoring. The average distance between monitoring wells along the southeastern margin of the waste management area is $\sim 70$ meters (230 feet), and a plume could pass through undetected. In addition, because well 299-W14-12 is expected to go dry, there are no wells located at intermediate or farther distances to track plume movement, and there are no 
upgradient wells for the northern portion of the waste management area (TY tank farm). Five new wells are planned to be installed in 2000.

Waste Management A rea U. Monitoring for this waste management area was elevated from indicator evaluation to assessment in 1999. Critical mean values of the indicator parameters $(\mathrm{pH}$, specific conductance, total organic carbon, and total organic halides) were revised in December 1999 based on recent upgradient data. The revised values were applied to data from August 1999. Recent specific conductance values in the upgradient wells have been lower and have had less variability than in the past, so the revised critical mean value is lower. Consequently, downgradient well 299-W19-41 exceeded the revised critical mean in August 1999. DOE submitted an assessment plan to the Washington State Department of Ecology in March 2000 (PNNL-13185).

Two downgradient wells (299-W18-30 and 299W19-42) continued to exceed the critical mean value of total organic halides during the first quarter of 1999. The exceedance is caused by an upgradient source of carbon tetrachloride, and a letter of notification and assessment report were submitted to the Washington State Department of Ecology in August 1998. Field specific conductance in two new downgradient wells (299-W19-41 and 299-W19-42) exceeded the critical mean value in February 1999. However, those values were erroneous. Anomalous, high field measurements were attributed to a bad batch of calibration solution and the problem was corrected. The critical range for $\mathrm{pH}$ was exceeded in one downgradient well (299-W19-12) during February 1999. This well was a pre-RCRA well that has had higher $\mathrm{pH}$ historically.

\subsubsection{200 Areas Liquid Effluent $D$ isposal Facilities}

216-A-10, 216-A-36B , and 216-A-37-1 Cribs.

These inactive cribs in the 200-East Area received liquid waste from the Plutonium-Uranium Extraction Plant and contributed to the widespread plumes of tritium, iodine-129, and nitrate described in Sections 6.1.6.1 and 6.1.6.2. The waste stream at the 216-A-10 crib was characteristically acidic and contained concentrated salts, hydrocarbon compounds, organic complexants, plutonium, uranium, and other radionuclides. The $216-\mathrm{A}-36 \mathrm{~B}$ crib received ammonia scrubber distillate from nuclear fuel decladding operations, in which zirconium cladding was removed from irradiated fuel by boiling in a solution of ammonium fluoride and ammonium nitrate. Other waste stream constituents included tritium, cobalt- 60 , strontium- 90 , ruthenium106, iodine-129, cesium-137, and uranium. The 216-A-37-1 crib received process condensate from the 242-A evaporator. The process condensate contained radionuclides, spent halogenated and nonhalogenated solvents, and ammonia. The radionuclides included cobalt-60, strontium-90, ruthenium-106, cesium-137, uranium, and plutonium.

The 216-A-10, 216-A-36B, and 216-A-37-1 cribs were monitored under a RCRA assessment program in 1999. The sites are monitored together under an assessment plan (PNNL-11523) because they have similar hydrogeology and waste constituents and appear to have contaminated groundwater. Combining these cribs into one RCRA groundwater monitoring area saves sampling and analysis costs because the number of near-field wells is reduced. Many of the far-field wells that formerly were sampled annually are now sampled every 3 years. These wells mainly track the extent and flow rate of the extensive iodine-129, nitrate, and tritium plumes that change very little in a 3 -year period.

During 1999, iodine-129, gross beta, nitrate, and tritium continued to exceed interim drinking water standards or maximum contaminant levels in large areas downgradient of the Plutonium-Uranium Extraction Plant cribs. Strontium-90, a beta emitter, and gross beta exceed the interim drinking water 
standards only in well 299-E17-14, which is near the 216-A-36B crib. Elevated manganese is found in wells 299-E25-19 and 299-E25-17 (both near the 216-A-37-1 crib). However, manganese exceeded the $50-\mathrm{mg} / \mathrm{L}$ maximum contaminant level only in well 299-E25-19.

216-A-29 Ditch. This is an inactive earthen ditch 2 kilometers (1.2 mile) long in the 200-East Area that conveyed Plutonium-Uranium Extraction Plant chemical waste to the $216-\mathrm{B}-3$ pond from 1955 to 1986 . The ditch received effluents that contained dangerous chemical and radioactive contaminants. Of primary concern for RCRA regulations were discharges of sodium hydroxide and sulfuric acid, which occurred daily as a result of ionexchange regeneration at the Plutonium-Uranium Extraction Plant.

This RCRA unit continued to be monitored under an interim status indicator evaluation program in 1999 and did not have an adverse impact on groundwater. Indicator parameter data from upgradient wells were statistically evaluated, and values from downgradient wells were compared to values established from the upgradient wells. All replicate averages for contamination indicator parameters were below critical mean values or limits of quantitation during 1999.

The groundwater monitoring plan for the 216A-29 ditch was revised in fiscal year 1999 (PNNL13047). The current network is adequate for detection monitoring.

216-B-3 Pond (B Pond). This former pond in the 200-East Area consisted of a main pond and three expansion ponds (216-B-3A, 216-B-3B, and 216-B-3C). The main pond began operating in 1945 and the expansions were built in the 1980s. In 1994, the main pond ceased operating, and the waste streams were rerouted to the 216-B-3C expansion pond and the 200 Areas Treated Effluent Disposal Facility. The main pond was filled with clean soil, and the expansion ponds were clean-closed (i.e., deemed free of dangerous waste and no longer regulated under RCRA). In August 1997, waste streams received by the expansion pond were diverted to the 200 Areas Treated Effluent Disposal Facility, thus ending operation of the B Pond system. In the past, B Pond received liquid waste from B Plant and the Plutonium-Uranium Extraction Plant, consisting of chemical sewer waste, cooling water, and steam condensate. These waste streams contained aluminum nitrate, nitric acid, potassium hydroxide, sulfuric acid, tritium, and other acids. In its later years, B Pond received nondangerous, nonradioactive effluent primarily from the Plutonium-Uranium Extraction Plant and B Plant.

In 1999, groundwater monitoring at B Pond continued under an interim status indicator evaluation program. The RCRA site was monitored under an assessment program from 1990 until January 1998 because of elevated total organic halides in two downgradient wells (699-43-41E and 699-4341F). Assessment results (PNNL-11604) concluded that no hazardous waste constituents affected groundwater quality beneath B Pond despite erratic, low levels of total organic halides. The site was returned to an indicator evaluation program. Groundwater beneath the site apparently was affected by tritium and nitrate from past discharges to B Pond. However, all replicate averages for contamination indicator parameters were below critical mean values or limits of quantitation during 1999.

One new well was drilled in 1999 to improve the monitoring network. The network is designed to intercept potential contamination entrained in groundwater at some distance from the facility and contamination potentially entering groundwater from the vadose zone near the facility. With the addition of the new well, the network is adequate to detect potential contamination from the facility.

216-B-63 T rench. This 200-East Area trench received liquid effluent from the B Plant chemical sewer from March 1970 to February 1992. The liquid effluent consisted of a mixture of steam condensate and raw water. Past releases to the trench 
also included sulfuric acid and sodium hydroxide solutions. Radioactive soil was dredged from the trench in August 1970, but no records exist of radioactive waste disposal to the trench.

In 1999, RCRA monitoring continued to indicate that no dangerous nonradioactive constituents from the site have entered groundwater. The well network was sampled twice for the indicator parameters $\mathrm{pH}$, specific conductance, total organic carbon, and total organic halides. All replicate averages for contamination indicator parameters were below critical mean values or limits of quantitation during 1999.

216-U-12 Crib. This crib in the 200-West Area received wastewater containing dangerous chemical waste and radionuclides from April 1960 until February 1988. It continued to be monitored under an interim status assessment program in 1999. Assessment monitoring began in 1993 because of high specific conductance in two downgradient wells (WHC-SD-LEF-EV-001, Rev. 0). The crib will not receive additional effluent and is scheduled, according to provisions of the Hanford Site RCRA Permit (Ecology 1994), to be closed under RCRA final status regulations in 2005.

In 1999, network monitoring wells were sampled quarterly for constituents of interest. Based on the results of the assessment investigation (PNNL11574), the site remains in interim status assessment monitoring because of continued elevated levels of nitrate and technetium-99. However, the objective of the assessment monitoring, rather than delineating the existing plumes, is to 1 ) determine whether the flux of constituents into the groundwater is increasing, staying the same, or decreasing; 2) monitor the known constituents until a near-term interim corrective action is defined; and 3) monitor until a final status plan is implemented. Nitrate, which had a source at this crib, remained elevated above the $45-\mathrm{mg} / \mathrm{L}$ standard in all downgradient wells in 1999. Nitrate and technetium-99 concentrations are decreasing in most of the wells.
Currently the $216-\mathrm{U}-12$ crib is monitored by only one upgradient well and two downgradient wells. Declining water levels have rendered other downgradient wells dry in the past year. The groundwater monitoring network is not adequate for RCRA interim status monitoring. The upgradient well, 299-W22-43, is now projected to go dry before the end of 2000. Two additional wells, one upgradient and one downgradient, are proposed for installation in 2000.

216-S-10 Pond and Ditch. The facility consisted of an open, unlined ditch and an open, unlined percolation pond in the 200-West Area. The pond and ditch received radioactive and dangerous chemical waste from the Reduction-Oxidation Plant from 1951 until 1985, when the pond and the lower part of the ditch were decommissioned and backfilled. The upper part of the ditch continued to receive nondangerous, unregulated wastewater from 1985 through 1991.

During 1999, this facility continued to be monitored semiannually under a RCRA interim status indicator evaluation program. Statistical evaluation of indicator parameter data from downgradient wells indicates that the site is not affecting groundwater quality.

Chromium remained elevated above the $100-\mathrm{mg} / \mathrm{L}$ standard in the upgradient well. The concentration peaked at $576 \mu \mathrm{g} / \mathrm{L}$ in 1997 and declined to $213 \mu \mathrm{g} / \mathrm{L}$ in 1999 . Because the upgradient well is located adjacent to the 216-S-10 pond, it is unclear if the elevated chromium is from an upgradient source or from past discharges to the pond. To assess the chromium source further, a proposal is being drafted to reclassify this well as a downgradient well and replace it with a new upgradient well.

Currently the 216-S-10 pond and ditch are monitored by only one upgradient well and two shallow downgradient wells because other wells have gone dry. The groundwater monitoring network is not adequate for RCRA interim status monitoring. 
One new downgradient well is being installed downgradient of the pond and will provide groundwater data for the continued evaluation of the elevated chromium. Two additional wells, one upgradient and one downgradient, are proposed for installation in 2000.

\subsubsection{200 Areas Low-Level Burial Grounds}

The low-level burial grounds are divided into five low-level waste management areas in the 200 Areas (see Figure 6.1.10). However, Low-Level Waste Management Area 5 has not been monitored for groundwater since 1996 because the burial ground never received waste. The remaining lowlevel waste management areas are in the indicator parameter phase of RCRA groundwater monitoring.

Low-Level Waste M anagement A rea 1. This waste management area in the 200-East Area consists of the 218-E-10 burial ground. Disposal activities began in 1960 and continue today. Materials placed in this facility are primarily failed equipment and mixed industrial waste from the PlutoniumUranium Extraction Plant, B Plant, and N Reactor.

Groundwater monitoring under interim status requirements continued at this RCRA site in 1999. Downgradient monitoring well 299-E33-34 continued to exceed the critical mean for specific conductance in samples from June 1999. This exceedance appears to be related to the nitrate plume and is not related to Low-Level Waste Management Area 1. A letter of notification was submitted to the Washington State Department of Ecology on March 18, 1999. Because no waste has been placed in the northern portion of this site and there is a nitrate plume from an upgradient source, no further action is necessary.

Low-Level Waste M anagementA rea2. This waste management area in the 200-East Area includes all of the 218-E-12B burial ground, which has been in use since 1968. The waste consists primarily of miscellaneous dry waste and submarine reactor compartments. Parts of two trenches contain transuranic waste.

This RCRA site continued in interim status indicator evaluation in 1999. Upgradient well 299. E34-7 exceeded the critical mean value for specific conductance, which was based on historical upgradient data. Specific conductance has been increasing in this well since 1997. The major contributors to the increase are sulfate and calcium. The source of these constituents is not known. However, there is only 0.6 meter ( 2 feet) of water remaining in this well, which is completed at the top of basalt, and the increase may be related to the basalt chemistry. An additional exceedance occurred in the quadruplicate average for total organic halides at well 299. E34-3 in January 1999. However, two of the four reported results are probably erroneous and have been flagged in the database. The quadruplicate average from April 1999 was well below the critical mean value.

Low-Level Waste M anagement A rea 3. The 218-W-3A, 218-W-3AE, and 218-W-5 burial grounds in the 200-West Area make up this area. Burial ground 218-W-3A began accepting waste in 1970 and received primarily ion-exchange resins and failed equipment (e.g., tanks, pumps, ovens, agitators, heaters, hoods, vehicles, accessories). Burial ground 218-W-3AE began operating in 1981 and contains low-level and mixed waste, including rags, paper, rubber gloves, tools, and industrial waste. Burial ground 218-W-5 first received waste in 1986, and contains low-level and low-level-mixed waste, including lead bricks and shielding.

This RCRA site continued to be monitored under interim status indicator evaluation requirements in 1999. Indicator parameter data from upgradient wells were statistically evaluated, and values from downgradient wells were compared to values established from the upgradient wells. Critical mean values for the contamination indicator parameters were not exceeded in any of the wells monitoring this waste management area. 
Several of the groundwater monitoring wells are approaching the point where representative sampling will no longer be possible because of the declining water table. Additional wells are planned in 2000.

Low-Level Waste Management A rea 4. This area in the 200-West Area consists of the 218-W-4B and $218-\mathrm{W}-4 \mathrm{C}$ burial grounds. Burial ground 218-W-4B first received waste in 1968 and contains mixed and retrievable transuranic waste in trenches and caissons. One caisson is believed to contain mixed waste. Waste was first deposited in burial ground 218-W-4C in 1978 and was classified as transuranic, mixed, or low-level and included contaminated soil, decommissioned equipment, and remote-handled transuranic waste.

Background concentrations for the general contamination indicator parameters were re-established in 1999 because the influence of a nearby pump-andtreat system is causing a reversal in the groundwater flow direction. The critical mean value for total organic halides was exceeded in one downgradient well in January and July 1999. This well used to be an upgradient well, and the exceedance is believed to be caused by carbon tetrachloride from an upgradient source.

Indicator parameters will not be evaluated statistically until groundwater flow stabilizes. Meanwhile, wells are sampled semiannually to determine when flow stabilizes and to maintain continuity in the database. This monitoring network is marginally adequate to detect releases from Low-Level Waste Management Area 4. Additional monitoring wells may be necessary in the future, as the water level continues to decline and to provide greater downgradient coverage. There are tentative plans to change the designation of this waste management area so that it will no longer be a RCRA facility. If this change occurs, additional monitoring wells will not be installed, and groundwater monitoring will defer to surveillance monitoring.

\subsubsection{Liquid Effluent Retention Facility}

This facility consists of three lined basins located east of the 200-East Area and serves as temporary storage for condensate from the 242-A evaporator. Constituents detected in the effluent stream from the 242-A evaporator were acetone, aluminum, ammonium, 1-butanol, 2-butanone, tritium, strontium-90, ruthenium-106, and cesium-137.

This facility is subject to final status monitoring and is included in the Hanford Site RCRA Permit (Ecology 1994). Until the final status plan is approved by the regulators, groundwater is monitored under the existing interim status plan (WHCSD-EN-AP-024, Rev. 1). In 1999, groundwater monitoring indicated that no dangerous, nonradioactive constituents from the site have entered the groundwater.

Specific conductance in two downgradient wells exceeded the critical mean value in January 1999. DOE notified the Washington State Department of Ecology and submitted a groundwater quality assessment plan and report in March 1999. The plan concluded that the Liquid Effluent Retention Facility was not the source of the high specific conductance and detection monitoring should continue.

In June 1999, downgradient well 299-E26-9 was removed from the monitoring network because it went dry. In September 1999, the Washington State Department of Ecology directed DOE to continue the current monitoring using three wells (one upgradient and two downgradient) for 18 months. During this period, an alternative method of monitoring should be identified.

\subsubsection{316-5 Area Process Trenches}

These two unlined trenches in the 300 Area were used for the disposal of liquid wastes generated 
in the 300 Area, beginning in 1975, and received uranium and other radioactive and chemical constituents. From 1985 through 1991, the trenches received nondangerous effluent, and all discharges ceased in 1991.

This site continued to be monitored with a final status corrective-action network in 1999. The objective of groundwater monitoring during the corrective-action period is to monitor the trend of the constituents of concern to confirm that they are naturally attenuating, as expected by the CERCLA record of decision for the 300-FF-5 Operable Unit (Record of Decision 1996). A proposed groundwater monitoring plan for corrective action calls for samples from the same wells as in the compliance period, but with fewer independent samples from each well during each sampling period (i.e., four to one). Also, each well showing an exceedance of one of the constituents of concern will be sampled quarterly to better follow the trends of contaminant concentration. The other wells in the network will continue to be sampled semiannually. The proposed plan is being reviewed by the regulator. Until the proposed plan is implemented, the final status compliance monitoring program (WHC-SD-EN-AP-185, Rev. 1) remains in effect. This plan calls for four independent groundwater samples from each network well (eight) during each semiannual sampling period.

In 1999, uranium, trichloroethylene, and cis1,2-dichloroethylene continued to exceed concentration limits specified in the permit. Uranium, gross alpha, and tetrachloroethylene exceeded maximum contaminant levels in one or more wells monitoring near the water table. Cis-1,2dichloroethylene and trichloroethylene exceeded standards in one downgradient well that monitors the base of the unconfined aquifer. Concentrations of uranium and various volatile organic compounds rose sharply in 1995 after the large quantities of relatively clean waste cooling water ceased to be discharged to the $316-5$ process trenches. However, since that time, concentrations of those constituents have begun a slight downward trend as was expected.

\subsubsection{Nonradioactive Dangerous Waste Landfill}

The Nonradioactive Dangerous Waste Landfill (Central Landfill) in the 600 Area southeast of the 200-East Area received waste from 1975 through 1985 that included asbestos, miscellaneous laboratory waste, solvents, paints, sewage, acids, batteries, and mercury.

This site continued to be monitored under an interim status indicator evaluation program in 1999. Statistical evaluations indicated the site has not adversely affected groundwater quality. The groundwater monitoring plan for the landfill was rewritten during 1999 (PNNL-12227) to update the operating procedures and bring the plan up to date with the current monitoring well network and constituents monitored. 


\subsection{Vadose Zone Characterization and Monitoring}

The vadose zone is the region in the subsurface between the ground surface and the top of the water table. Radioactive and hazardous wastes in the soil column from past intentional liquid waste disposals, unplanned leaks, solid waste burial grounds, and underground tanks at the Hanford Site are potential sources of continuing and future vadose zone and groundwater contamination. Subsurface source characterization and vadose zone monitoring, soil-vapor monitoring, sediment sampling and characterization, and vadose zone remediation were conducted in 1999 to better understand and alleviate the spread of subsurface contamination. This section summarizes major findings from these efforts, focused primarily on vadose zone soil contamination associated with reactor operations, past single-shell tank leaks, and liquid disposal to ground as a result of spent fuel processing.

\subsubsection{Vadose Zone Characterization and Monitoring at Tank Farms}

Several vadose zone characterization activities occurred at the single-shell tank farms in 1999. At tank farm SX, in the 200-West Area, samples were collected and characterized from the decommissioning of one borehole drilled to characterize deep vadose zone contamination and from a second, new borehole adjacent to tank SX-115. Tank SX-115 was selected because it is the source of the largest measured leak in the SX tank farm. Also, in the SX tank farm, preliminary temperature and neutron capture borehole logging was accomplished. During 1999, baseline spectral gamma-ray logging at two single-shell tank farms (tank farms $\mathrm{T}$ and $\mathrm{B}$ in the 200-West and 200-East Areas, respectively) was completed and relogging of the highest count rate zones at the SX tank farm was initiated.

\subsubsection{Borehole Characterization at the SX Tank Farm}

\section{R. J. Serne, D. G. Horton, D. A. Myers}

Decommissioning of Borehole 41-09-39. Borehole 41-09-39 is located adjacent to single-shell tank SX-109 in the SX tank farm in the Hanford
Site's 200-West Area. This borehole was originally constructed in 1996 to a depth of 40 meters (131 feet). The primary purpose of the borehole was to determine the presence of cesium-137 at depths of 24 to 40 meters ( 79 to 131 feet) below ground surface. The borehole was deepened in 1997 and temporarily used as a monitoring well for collecting groundwater samples.

In 1999, the borehole was decommissioned (taken apart and backfilled) to eliminate it as a potential pathway for contaminants to reach the groundwater. As part of the decommissioning effort, sidewall samples were collected from the previously unsampled portion of the hole and submitted for chemical and radiological analysis of contaminants to supplement the data collected in previous years.

Two or three sediment samples were obtained from each of 15 selected depths. One of the samples obtained at 19.8 to 20.1 meters (64.9 to 65.9 feet) was 10 times more radioactive than the other two samples from that depth, so the higher activity sample was kept separate. All samples from each depth interval, except those from 19.8 to 20.1 meters (64.9 to 65.9 feet), were mixed together to form one composite sample for each depth. 
Analytical results showed very high concentrations of cesium-137. Levels were the highest obtained from under leaking tanks in the past 35 years. Table 6.2.1 lists the descriptive lithology of the borehole and the results of measurements made directly on the sediment. There appeared to be some correlation between the particle size of the sediment and the cesium- 137 content between depths of 18.6 and 33.2 meters (61 and 109 feet). Generally, finer grained sediment has more surface area for greater cesium-137 sorption. The region between depths of 18.6 and 25.3 meters (61 and 83 feet) had the highest concentration of cesium-137. A smaller region with high cesium-137 concentration existed between depths of 31.1 and 33.2 meters (102 and 109 feet).

Several of the samples obtained from borehole 41-09-39 contained insufficient pore water to obtain enough for chemical analyses. Therefore, a water extract, using 1 part water to 1 part dry sediment (by weight), was done on those samples to obtain sufficient leachate for analysis. The water extract gives an indication of which contaminants are readily leached and, therefore, fairly mobile. Table 6.2.2 lists the analytical results of water extracts from the sediment.

The data in Table 6.2.2 show large amounts of water leachable chromium (presumably hexavalent chromium), nitrate, sodium, and technetium-99 in the sediment. Some selenium and cesium-137 were also leached from some samples in concentrations greater than background concentrations. (See DOE/ RL-92-24, Rev. 3 and DOE/RL-96-12, Rev. 0 for background values.) The $\mathrm{pH}$ of the water extract was elevated slightly above natural $\mathrm{pH}$ values of 8.0 to 8.5 for samples from 18.6 to 25.3 meters (61 to 83 feet) below ground surface. The original tank fluids had $\mathrm{pH}$ values above 14 and free hydroxide concentrations perhaps as large as 1 molar or higher. The water

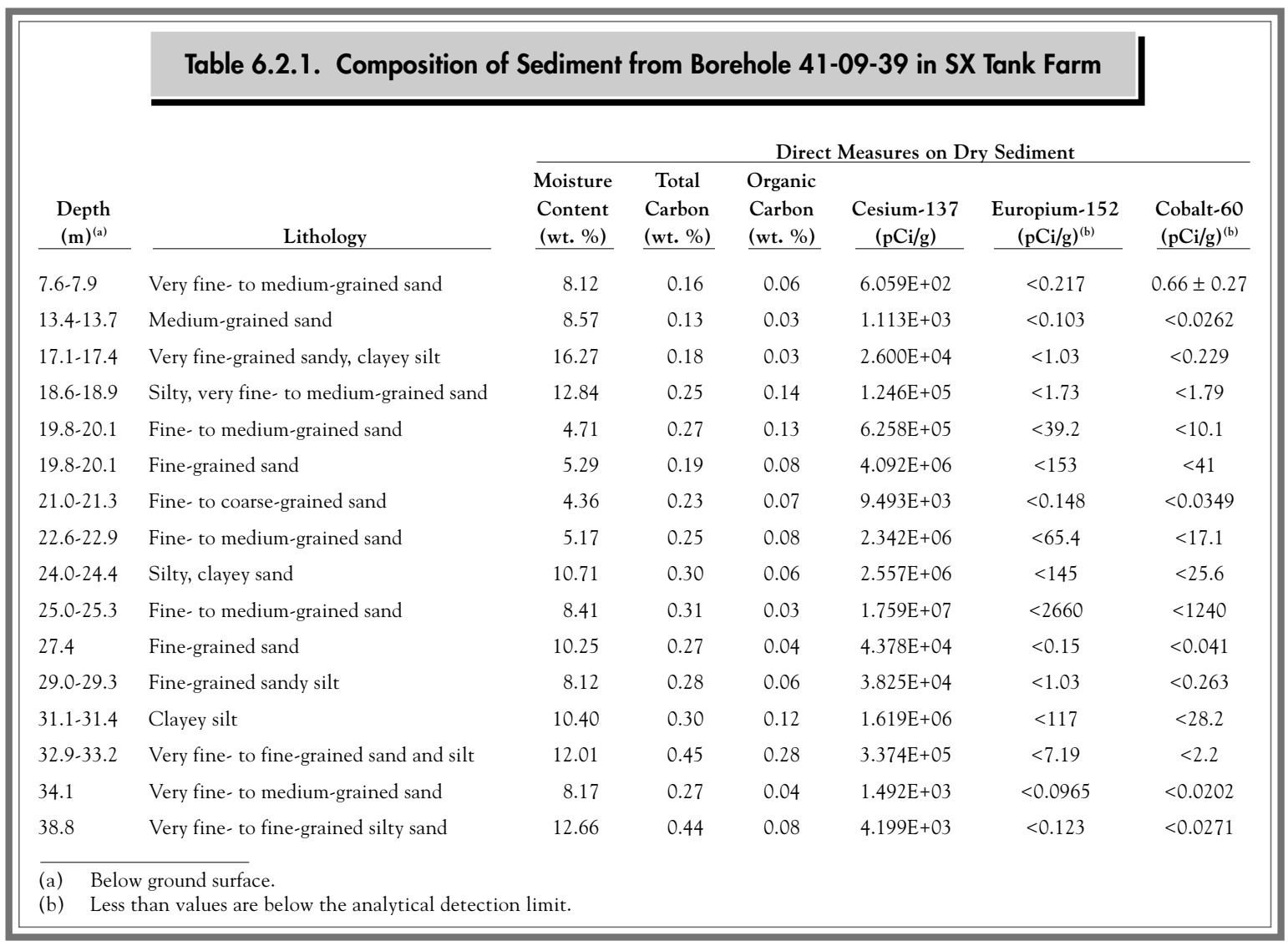




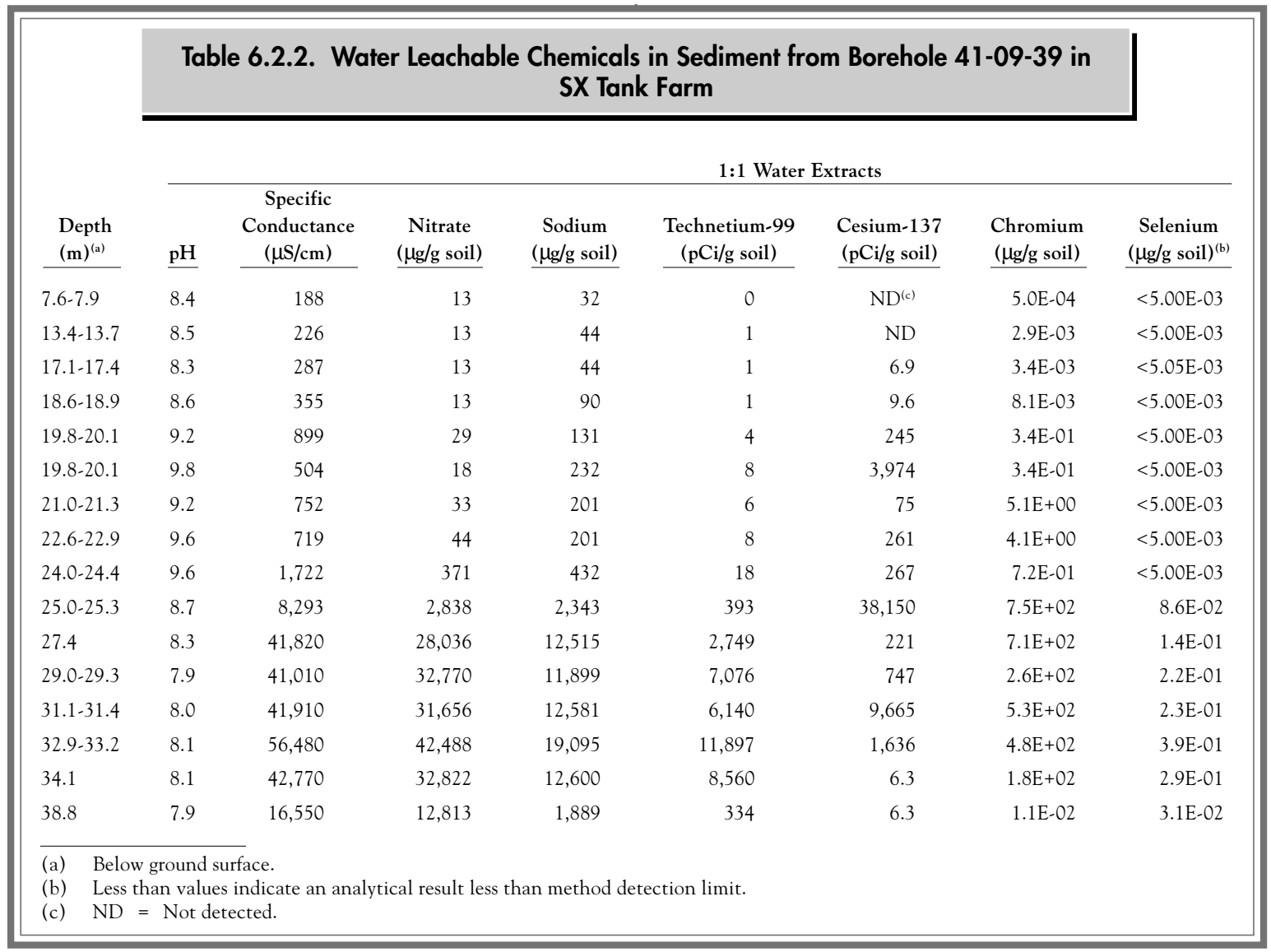

extract $\mathrm{pH}$ values showed that the sediments had substantially buffered the $\mathrm{pH}$ of leaked fluids.

Analytical results of a strong acid ( 8 molar nitric acid) leach of the sediment samples are shown in Table 6.2.3. These results approximate the total amount of contaminant in the sediment that would be environmentally available per EPA suggestions in SW-846. The data show that greater than background levels of chromium, molybdenum, selenium, and technetium-99 are leached from the sediment. Concentrations of americium-241, neptunium-237, plutonium-239/240, and strontium-90 were not present in the sediment at levels above $1 \mathrm{pCi} / \mathrm{g}$ and are not included in the table. Concentrations of aluminum and iron (also not shown in Table 6.2.3) appear to be slightly elevated in samples where cesium-137, chromium, nitrate, and sodium are definitely present.
Table 6.2.4 shows the percent of cesium-137 that was leached from the sediment by the water extraction procedure compared to the total cesium137 present in the sediment (from Table 6.2.1). The table also shows the percentages of chromium and technetium-99 that were leached by water compared to the amounts leached by the strong acid extract. The latter is an approximation of the total technetium-99 and chromium in the sediment.

Very little cesium-137 was leached by the water extraction procedure, indicating that most cesium137 in the sediment from borehole 41-09-39 is not soluble and is bound to the sediment. Conversely, significant percentages of the chromium and technetium-99 were leached by the water extraction. These data can be used to estimate in situ distribution coefficients $\left(K_{d}\right)$ for each chemical in each sediment sample. $K_{d}$ is a measure of the relative concentration 


\begin{tabular}{|c|c|c|c|c|c|c|}
\hline \multirow[b]{3}{*}{$\begin{array}{r}\text { Depth } \\
(\mathrm{m})^{(\mathrm{a})}\end{array}$} & \multicolumn{5}{|c|}{$\begin{array}{l}\text { Table 6.2.3. Acid Extractable Chemicals in Sediment from Borehole 41-09-39 in } \\
\text { SX Tank Farm }\end{array}$} & \\
\hline & \multicolumn{6}{|c|}{ Acid Extract } \\
\hline & $\begin{array}{c}\text { Technetium-99 } \\
(\mathrm{pCi} / \mathrm{g}) \\
\mathrm{ICP}_{\mathrm{MS}} \mathrm{MS}^{(\mathrm{b})} \\
\end{array}$ & $\begin{array}{c}\text { Technetium-99 } \\
\text { (pCi/g) Radiolog- } \\
\text { ical Analysis } \\
\end{array}$ & $\begin{array}{c}\text { Uranium-238 } \\
\qquad(\mathrm{pCi} / \mathrm{g}) \\
\mathrm{ICP} / \mathrm{MS}^{(\mathrm{b})} \\
\end{array}$ & $\begin{array}{l}\text { Chromium } \\
(\mu \mathrm{g} / \mathrm{g})\end{array}$ & $\begin{array}{l}\text { Molybdenum } \\
(\mu \mathrm{g} / \mathrm{g})\end{array}$ & $\begin{array}{l}\text { Selenium } \\
(\mu \mathrm{g} / \mathrm{g})\end{array}$ \\
\hline $7.6-7.9$ & $<19.95$ & -47 & 0.14 & 6.5 & $7.89 \mathrm{E}-02$ & $9.73 \mathrm{E}-02$ \\
\hline $13.4-13.7$ & $<5.94$ & -5 & 0.23 & 6.0 & 4.01E-01 & $1.23 \mathrm{E}-01$ \\
\hline $17.1-17.4$ & 28 & 292 & 0.20 & 24.1 & $6.01 \mathrm{E}-01$ & $9.39 \mathrm{E}-02$ \\
\hline $18.6-18.9$ & 11 & -18 & 0.21 & 130.3 & $2.00 \mathrm{E}-01$ & $6.85 \mathrm{E}-02$ \\
\hline $19.8-20.1$ & 26 & -12 & 0.13 & 80.3 & $1.03 \mathrm{E}+00$ & $1.21 \mathrm{E}-01$ \\
\hline $19.8-20.1$ & $13 \pm 4$ & $0 \pm 22$ & 0.13 & 69.5 & 3.99E-01 & 7.91E-02 \\
\hline $21.0-21.3$ & $<25.3$ & 96 & 0.15 & 42.3 & $9.72 \mathrm{E}-01$ & $1.09 \mathrm{E}-01$ \\
\hline $22.6-22.9$ & $<35.3$ & 12 & 0.15 & 122.0 & $1.50 \mathrm{E}+00$ & $7.83 \mathrm{E}-02$ \\
\hline $24.0-24.4$ & 2,400 & 3,006 & 0.15 & 597.4 & $1.08 \mathrm{E}+01$ & $8.29 \mathrm{E}-02$ \\
\hline $25.0-25.3$ & $1,088 \pm 336$ & $1,160 \pm 280$ & 0.21 & $1,458.6$ & $1.28 \mathrm{E}+01$ & $1.66 \mathrm{E}-01$ \\
\hline 27.4 & 3,241 & 3,586 & 0.15 & $1,277.8$ & $5.23 \mathrm{E}+00$ & $1.14 \mathrm{E}-01$ \\
\hline $29.0-29.3$ & 7,618 & 7,468 & 0.16 & 710.7 & $1.71 \mathrm{E}+00$ & $1.61 \mathrm{E}-01$ \\
\hline $31.1-31.4$ & 12,979 & 13,036 & 0.21 & $1,169.6$ & $4.39 \mathrm{E}+00$ & $1.56 \mathrm{E}-01$ \\
\hline $32.9-33.2$ & 13,766 & 13,877 & 0.19 & 783.9 & $2.29 \mathrm{E}+00$ & $2.59 \mathrm{E}-01$ \\
\hline 34.1 & 9,840 & 9,906 & 0.12 & 298.5 & 4.39E-01 & $2.16 \mathrm{E}-01$ \\
\hline 38.8 & 405 & 405 & 0.16 & 15.8 & $2.26 \mathrm{E}+00$ & $5.10 \mathrm{E}-02$ \\
\hline \multicolumn{7}{|c|}{ (a) Below ground surface. } \\
\hline
\end{tabular}

of contaminant sorbed on the sediment to that dissolved in solution; the smaller the $\mathrm{K}_{\mathrm{d}}$, the more contaminant is in solution. The calculated $\mathrm{K}_{\mathrm{d}}$ s are shown in Table 6.2.5.

The apparent large in situ $K_{d}$ values for technetium-99, and perhaps chromium, in selected samples merit additional, more detailed investigations to determine whether the sediment contains adsorbed or co-precipitated technetium-99 and chromium. The chromium $K_{d}$ values for some of the samples that did not contain elevated total chromium concentrations represent native trivalent chromium in the sediment. The $\mathrm{K}_{\mathrm{d}}$ values for the samples from 7.6, 13.4, 17.1, and 38.8 meters $(24.9,44.3,56.1$, and 127.3 feet), in Table 6.2.5 may represent immobile native trivalent chromium. Large in situ $\mathrm{K}_{\mathrm{d}}$ values for chromium in samples from other depths are unexplained at this time. Also, the reason for the large variation in cesium-137 $\mathrm{K}_{\mathrm{d}}$ values is unknown and will require further work.

\section{New Borehole at Single-Shell Tank}

SX-115. A new characterization borehole (299. W23-19) was completed at tank farm SX adjacent to tank SX-115 in 1999. This tank was selected for investigation because it is the source of the largest measured leak in the SX tank farm. The tank had a measured loss of 189,000 liters (49,890 gallons) during a sodium nitrate retrieval effort in the mid1960s; this volume contained a significant amount of technetium-99. Groundwater monitoring wells to the southeast of the tank were some of the first to show increased technetium-99 concentrations at this site. The new borehole was located near the tank adjacent to a zone of high, subsurface gamma flux reported in BNWL-CC-701. Near-continuous samples were collected through the Hanford formation by driving a split-spoon sampler ahead of a 


\begin{tabular}{|c|c|c|c|}
\hline \multirow[b]{2}{*}{$\begin{array}{l}\text { Depth } \\
(\mathrm{m})^{(\mathrm{a})}\end{array}$} & \multicolumn{3}{|c|}{$\begin{array}{l}\text { Table 6.2.4. Estimates of Mobility of Cesium, Technetium, and Chromium in Samples } \\
\text { from Borehole 41-09-39 in the SX Tank Farm, Based on the Percent of the } \\
\text { Constituent Leached by Water }\end{array}$} \\
\hline & $\begin{array}{l}\text { \% Cesium-137 Leached } \\
\text { by Water Versus Total } \\
\text { Cesium in the Sediment }\end{array}$ & $\begin{array}{l}\text { \% Technetium-99 Leached } \\
\text { by Water Versus Total } \\
\text { Acid Extractable Technetium } \\
\text { (b) }\end{array}$ & $\begin{array}{l}\% \text { Chromium Leached } \\
\text { by Water Versus Total } \\
\text { Acid Extractable Chromium }\end{array}$ \\
\hline $7.6-7.9$ & NA & $>81$ & 0.01 \\
\hline $13.4-13.7$ & NA & $>16$ & 0.05 \\
\hline $17.1-17.4$ & 0.03 & 1.8 & 0.01 \\
\hline $18.6-18.9$ & 0.01 & 6.5 & 0.01 \\
\hline $19.8-20.1$ & 0.04 & 15.8 & 0.43 \\
\hline $19.8-20.1$ & 0.10 & 60.1 & 0.50 \\
\hline $21.0-21.3$ & 0.79 & $>22$ & 11.97 \\
\hline $22.6-22.9$ & 0.01 & $>22$ & 3.35 \\
\hline $24.0-24.4$ & 0.01 & 0.8 & 0.12 \\
\hline $25.0-25.3$ & 0.22 & 36.1 & 51.09 \\
\hline 27.4 & 0.50 & 84.8 & 55.71 \\
\hline $29.0-29.3$ & 1.95 & 92.9 & 36.63 \\
\hline $31.1-31.4$ & 0.60 & 47.3 & 45.14 \\
\hline $32.9-33.2$ & 0.48 & 86.4 & 61.34 \\
\hline 34.1 & 0.42 & 87.0 & 58.73 \\
\hline 38.8 & 0.15 & 82.4 & 0.07 \\
\hline
\end{tabular}

casing string. The borehole was drilled into the groundwater (at 69 meters [226 feet]) to allow sampling for the RCRA monitoring program. Analysis of the groundwater samples revealed technetium-99 concentrations up to $48,000 \mathrm{pCi} / \mathrm{L}$, the highest levels found to date on the Hanford Site. Because of this finding, the well is to be completed as a RCRA assessment well rather than decommissioned as originally planned.

\section{Geophysical Logging at Boreholes 41-09-39} and 299-W23-19. Geophysical logging was conducted in both the 41-09-39 and 299-W23-19 boreholes. Logging consisted of spectral gamma-ray, moisture, temperature, and neutron capture gamma spectroscopy logs. A neutron moisture probe was used to assess the distribution of water throughout the vadose zone in both boreholes. Water in the vadose zone provides the mobilizing force to transport contaminants to the groundwater. Temperature logs were obtained in single-cased portions of both boreholes, and borehole wall temperatures (no casing) were logged in 41-09-39 as the borehole was decommissioned. Temperatures were taken using a side-looking infrared instrument so that the temperatures represent the casing or borehole wall conditions and not the air inside the borehole. The results of the temperature log of borehole 41-09-39 are presented in Figure 6.2.1. The temperature distribution corresponds to an increase in gamma activity as seen on the gross gamma-ray log and to the distribution of radionuclides as determined by laboratory measurements. For comparison, subsurface temperatures measured at similar depths in uncontaminated boreholes at the Hanford Site are near 17 to $19^{\circ}$ Celsius (62 to $66^{\circ}$ Fahrenheit). 


\begin{tabular}{|c|c|c|c|}
\hline \multicolumn{4}{|c|}{$\begin{array}{l}\text { Table 6.2.5. Calculated In Situ Distribution Coefficients }\left(K_{\mathrm{d}}\right)^{(a)} \text { for } \\
\text { Samples from Borehole 41-09-39 in SX Tank Farm }\end{array}$} \\
\hline $\begin{array}{r}\text { Depth } \\
(\mathrm{m})^{(\mathrm{b})}\end{array}$ & $\begin{array}{l}\text { Cesium } \\
\text { In Situ K } \\
(\mathrm{mL} / \mathrm{g})\end{array}$ & $\begin{array}{c}\text { Technetium } \\
\text { In Situ K } \\
(\mathrm{mL} / \mathrm{g})\end{array}$ & $\begin{array}{c}\text { Chromium } \\
\text { In Situ K } \\
(\mathrm{mL} / \mathrm{g})\end{array}$ \\
\hline $7.6-7.9$ & $\mathrm{ND}^{(\mathrm{c})}$ & $<130^{(\mathrm{d})}$ & 13,059 \\
\hline $13.4-13.7$ & $\mathrm{ND}^{(c)}$ & 5.17 & 2,090 \\
\hline $17.1-17.4$ & 3,772 & 54.97 & 7,047 \\
\hline $18.6-18.9$ & 13,017 & 14.44 & 15,994 \\
\hline $19.8-20.1$ & 2,554 & 5.33 & 234 \\
\hline $19.8-20.1$ & 1,030 & 0.66 & 201 \\
\hline $21.0-21.3$ & 127 & 3.58 & 7.4 \\
\hline $22.6-22.9$ & 8,989 & 3.58 & 28.8 \\
\hline $24.0-24.4$ & 9,589 & 131.22 & 832 \\
\hline $25.0-25.3$ & 461 & 1.77 & 1.0 \\
\hline 27.4 & 199 & 0.18 & 0.8 \\
\hline $29.0-29.3$ & 51 & 0.08 & 1.7 \\
\hline $31.1-31.4$ & 168 & 1.11 & 1.2 \\
\hline $32.9-33.2$ & 206 & 0.16 & 0.6 \\
\hline & 237 & 0.15 & 0.7 \\
\hline & 53,262 & 0.21 & 1,377 \\
\hline \multicolumn{4}{|c|}{$\begin{array}{l}\text { (a) A measure of the relative concentration of contaminant sorbed on the } \\
\text { sediment to that dissolved in solution. The smaller the } \mathrm{K}_{\mathrm{d}} \text {, the more } \\
\text { contaminant is in solution. } \\
\text { (b) Below ground surface. } \\
\text { (c) ND = Not detected. } \\
\text { (d) Less than value indicates a water leach result that is less than method } \\
\text { detection limit. }\end{array}$} \\
\hline
\end{tabular}

Neutron capture spectroscopy logs were run in both boreholes. These logs were generated by exciting elements within the sediments with neutrons from a radioactive source and measuring gamma-ray energies emitted following excitation. The resulting spectra were then analyzed to determine a distribution of specific elements. However, the instrument used for this work was calibrated for chlorine only and provided only a relative abundance of other elements.

Both the temperature $\log$ and the neutron gamma-capture log represent new analytical tools for Hanford and the initial results illustrate their potential usefulness.

\subsubsection{Tank Farms Baseline Vadose Zone Characterization Project}

\section{R. G. McCain}

In 1994, the Tank Farms Vadose Zone Baseline Characterization Project was initiated by the Department of Energy Grand Junction Office at the request of the DOE Richland Operations Office. The purpose, as documented in technical plan P-GJPO1786 , was to perform a baseline characterization of gamma-emitting radionuclides in the vadose zone under the single-shell tank farms. 


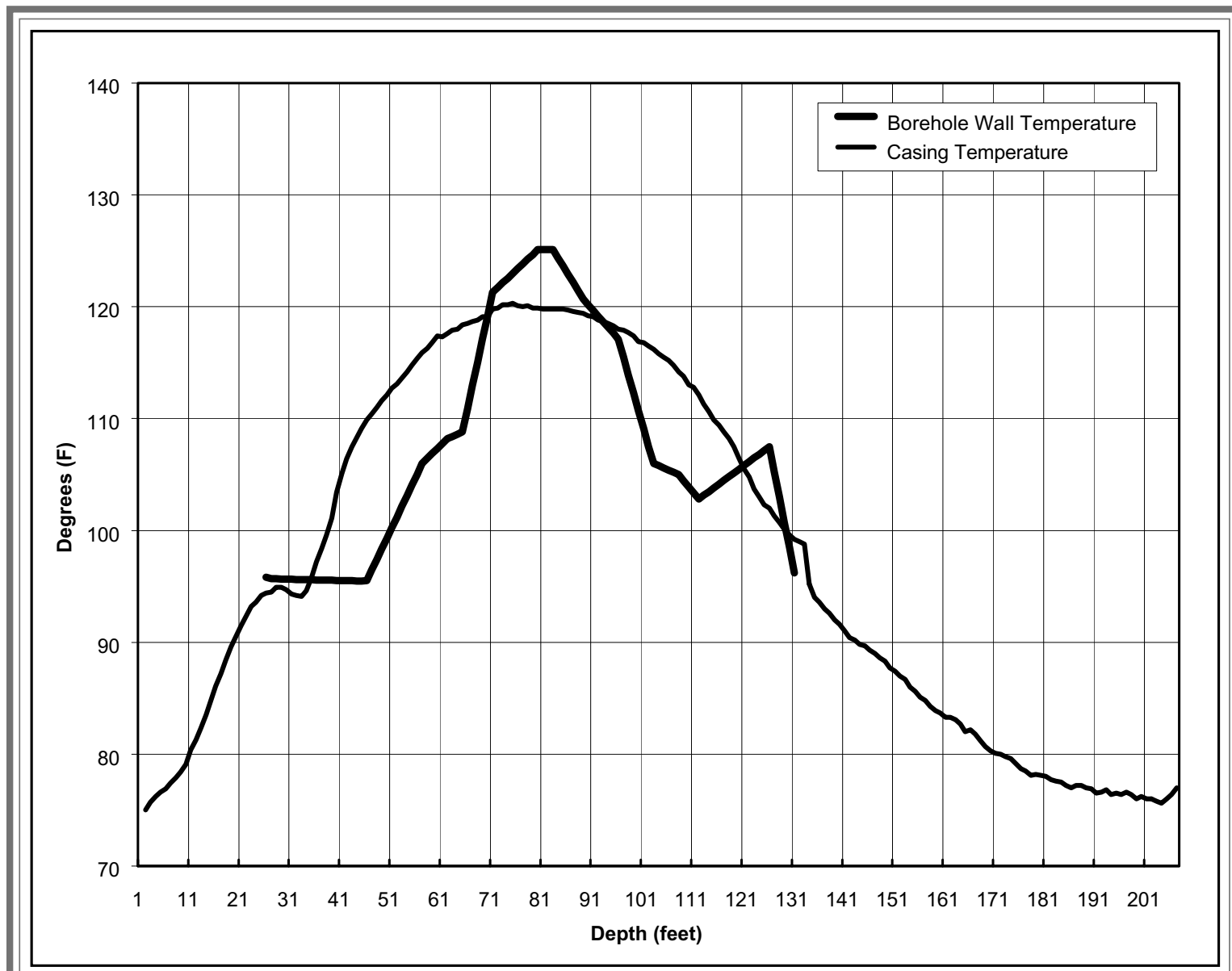

wdw99004

Figure 6.2.1. Temperature Distribution in Borehole 41-09-39

By the end of 1999, the baseline characterization program was essentially complete. During 1999, tank summary data reports were completed for the remaining tanks in tank farms $\mathrm{T}$ and $\mathrm{B}$ and the tank farm report for tank farm $\mathrm{T}$ (GJO-99-101-TAR, GJO-HAN-27) was completed. Tank summary data reports had been issued for a total of 133 single-shell tanks; the 16 smaller 208,000 liter (55,000-gallon) tanks were not addressed because of lack of available boreholes from which spectral gamma data could be collected. Also by the end of 1999, 11 of 12 tank farm reports had been issued; only the B tank farm report remains to be completed. During 1999, repeat logging of selected boreholes was completed and a high count rate logging system was deployed to measure radionuclide concentrations in borehole intervals where high gamma flux led to saturation of the spectral gamma logging system. It is anticipated that the final tank farm report will be issued by the end of March 2000. Work is underway to prepare a series of addenda for earlier tank farm reports that will present additional data from high rate and repeat logging, as well as modifications to the visualizations based on re-evaluation of existing data, including shape factor analysis where appropriate. The addenda will also include estimates of contaminant inventories in the vadose zone. Project reports and data are posted on the DOE's Grand Junction Office web page at: http:/ /www.doegjpo.com/programs/hanf/HTFVZ.html 
The baseline project has provided valuable information regarding the nature and extent of vadose zone contamination associated with gammaemitting radionuclides in the vicinity of the singleshell tanks. Specific contaminant plumes have been delineated and it is possible to identify locations for more detailed investigative and sampling efforts. Borehole logging in existing boreholes represents an effective means to identify subsurface contamination plumes. Spectral gamma logging also allows specific gamma-emitting radionuclides to be identified and quantified. However, gamma logging in boreholes is unable to detect radionuclides such as tritium, strontium-90, or technetium-99, which do not emit significant gamma rays. Drilling and sampling are required to detect and quantify these contaminants.

The baseline data also provide the basis for selection of borehole intervals for future monitoring. Routine monitoring of gross gamma levels in dry wells surrounding the single-shell tank farms has been performed since the 1940s. Numerous additional dry wells were installed around individual tanks in the 1970s to monitor for leaks. Gross gamma logs are available in electronic format from 1974 through 1994, when routine monitoring was discontinued.

Individual dry wells can be monitored over time and compared to the baseline to detect and quantify short-term or long-term changes. Long-term monitoring data over a 5- to 10-year period can be used to estimate contaminant migration rates and to provide supporting data necessary to verify predictive models. Short-term monitoring is useful for identifying recent changes associated with tank farms operations and/or tank leaks.

A plan view of a typical single-shell tank farm is shown in Figure 6.2.2. Each single-shell tank farm consists of between 4 and 18 underground waste storage tanks. There are 149 single-shell tanks organized into 12 tank farms. Individual tank capacities are 208,000 liters (55,000 gallons), 2,017,405 liters (533,000 gallons), 2,869,030 liters (758,000 gallons), or $3,785,000$ liters $(1,000,000$ gallons $)$. The 208,000 liter (55,000-gallon) tanks are 6.1 meters (20 feet) in diameter and all other tanks are 22.9 meters ( 75 feet) in diameter. The larger tanks are surrounded by monitoring boreholes or dry wells that provide access to the subsurface for geophysical logging probes.

The baseline characterization project involves logging the boreholes surrounding the single-shell tanks with a high resolution spectral gamma logging system and analyzing the resulting spectra to produce logs of both natural and man-made gammaemitting radionuclides showing concentration (in terms of specific activity) as a function of depth. Figure 6.2.3 presents an example of a typical log plot for man-made and natural radionculide concentrations, as well as total gamma activity and the latest available historical gross gamma log.

Data from individual logs surrounding a tank are incorporated into a tank summary data report. The tank summary data report also includes a discussion of geologic conditions, as well as tank construction and operational history. When appropriate, the tank summary data report may also include a limited analysis of historical gross gamma logs or other available data. Each tank summary data report provides an assessment of the implications of the spectral gamma logging data, including recommendations regarding future data needs and/or any corrective action that may be required.

After the tank summary data reports are completed for a tank farm, the information from each report is incorporated into a tank farm report. The tank farm report provides an integrated summary of available information for the tank farm. The log data from individual boreholes are incorporated into a geostatistical model that is used to estimate the spatial distribution of contaminants. Commercially available three-dimensional visualization software is used to provide views of contaminant plumes within the vadose zone. The tank farm report provides a discussion of the nature and extent of subsurface 


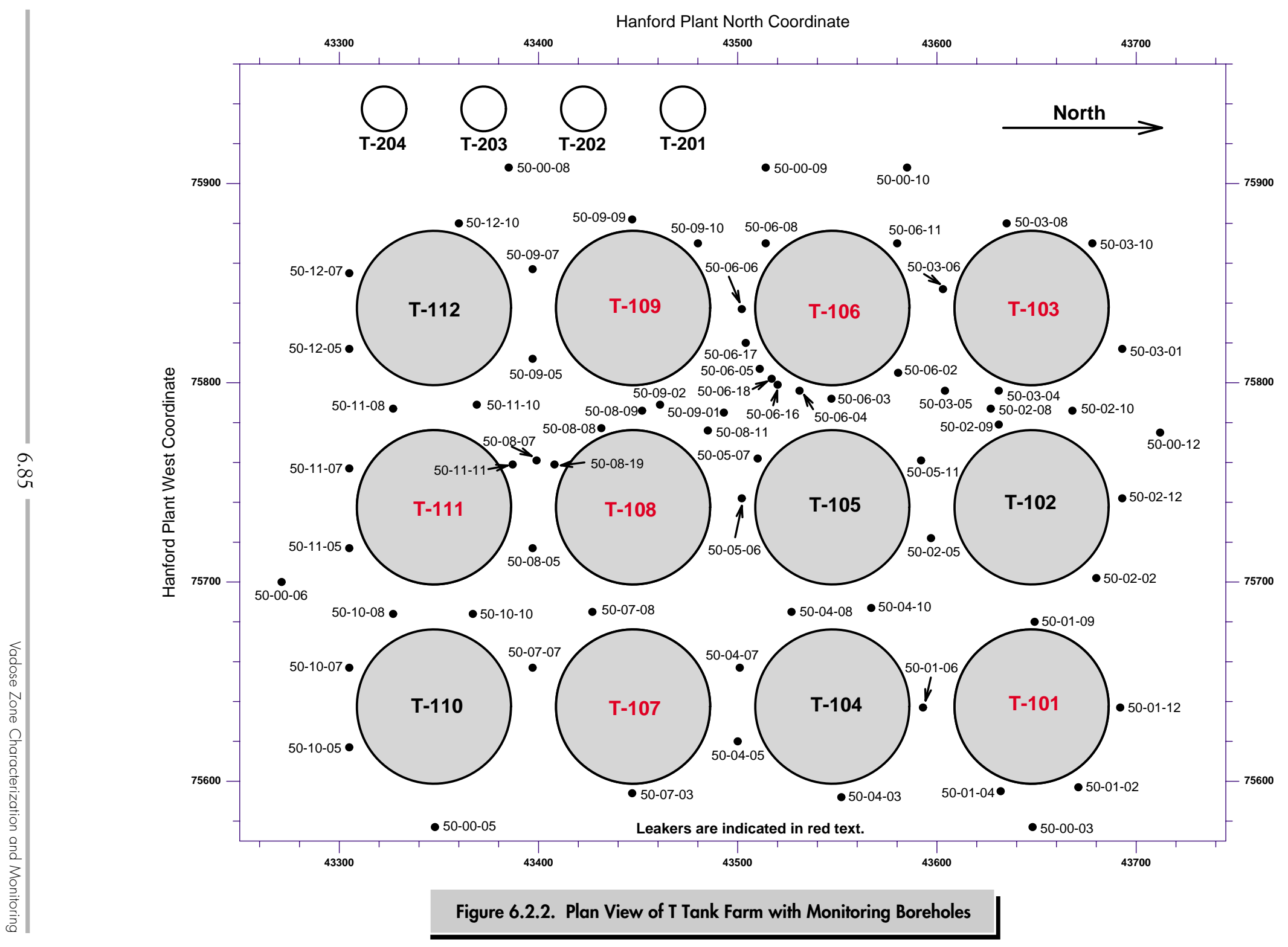




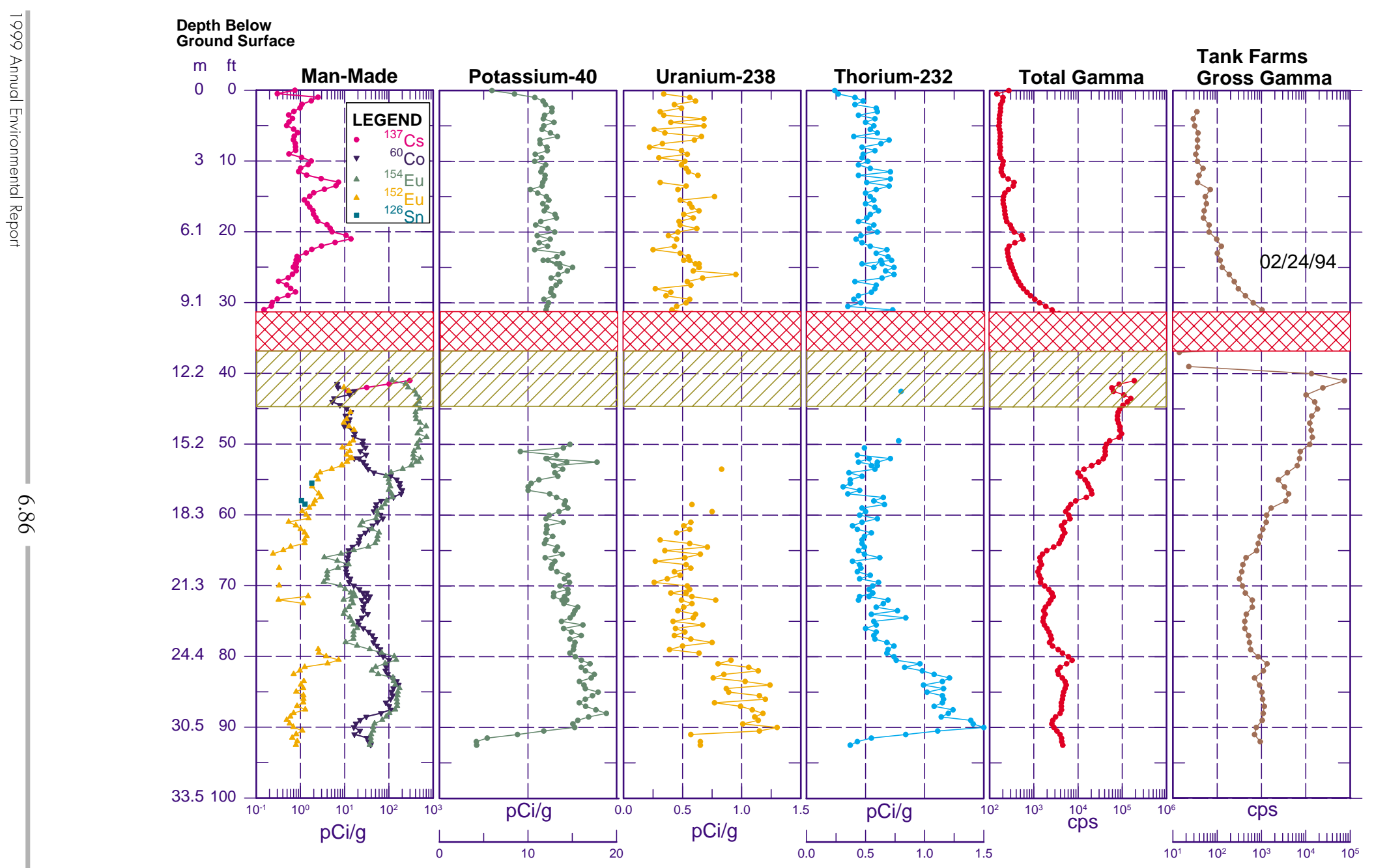

$\$$ - indicates zone of very high dead time or detector saturation (no usable spectral data)

$Z / A$ - indicates zone of 60 to 85 percent dead time (marginal spectral data)

Figure 6.2.3. Example of a Radionuclide Concentration Log 
contamination and provides recommendations for future data collection activities and corrective actions, as appropriate.

Data Collection and Analysis. Two borehole logging trucks were specially fabricated for the baseline logging project. Downhole spectra are collected using a high-purity germanium semiconductor detector with $35 \%$ relative efficiency. This combination of detector and logging truck is referred to as the spectral gamma logging system.

The spectral gamma logging system is able to quantify radionuclide concentrations from background levels up to several thousand picocuries per gram. Frequently, however, zones of more intense radiation are encountered in which the detector becomes saturated and ineffective. In order to provide data in these intervals, an additional detector was developed and deployed in 1999. The high rate logging system utilizes a 6-millimeter diameter high purity germanium detector. It operates with the same logging trucks and electronics system as the spectral gamma logging system. Two tungsten shields that can be used individually or in combination are available to extend the range of the high rate detector.

Data acquisition is performed in accordance with logging procedures provided in MAC-VZCP. 1.7.10-1 (Rev. 2), and governed by quality assurance requirements specified in the project management plan MAC-VZCP-1.7.2 (Rev. 1).

The spectral gamma logging system was initially calibrated using the borehole calibration standards constructed at the DOE's Grand Junction Office specifically for borehole nuclear logging. Continuing calibration is performed at regular intervals using the Hanford calibration models. Results of the most recent continuing calibrations are reported in the sixth and seventh recalibration reports (GJO-99. 100-TAR, GJO-HAN-26; GJO-2000-142-TAR, GJO-HAN-30). The calibration of the high rate logging system is described in GJO-99-118-TAR, GJO-HAN-29.
Spectral gamma log data analysis is performed in accordance with procedures documented in MACVZCP-1.7.9 (Rev. 1). Verification measurements are made before and after each logging run. The verification spectra are evaluated to ensure consistent system performance and to provide energy and resolution calibration for spectral analysis. Data files containing specific activity, uncertainty, and minimum detectable activity as a function of depth are generated for each radionuclide. A file is also generated for total gamma activity as a function of depth. These files are imported into a commercially available graphics package and log plots are created.

If significant concentrations of cesium-137 or cobalt-60 are encountered, shape factor analysis may be performed. The concept of shape factor analysis is that the relationship between background radiation and the full energy peak in a gamma energy spectrum is influenced by the spatial distribution of the gamma ray source with respect to the detector. Various ratios, or shape factors are computed and plotted to help identify the likely distribution of the source of the gamma activity. For example, the contamination may be localized on the inside or outside of the casing. In addition, large gamma signals associated with a strictly localized source, such as a nearby pipeline, may be detected. These situations are not representative of vadose zone contamination, and must be recognized if an accurate baseline is to be produced.

High rate log data analysis is performed using the same general approach and software as that used for spectral gamma analysis. However, only the cesium137 peak is used for energy calibration. A correction for 6-inch-diameter, 0.28-inch-thick casing is built into the calibration of the high rate detector, and there is no provision for a water correction. If the shields are used, the calculated concentration is increased by a factor based on relative attenuation. Adjustments for other casing configurations are also made on the basis of attenuation relative to a 0.28-inch-thick casing. The method of shape factor analysis cannot be applied to the high rate spectra. 


\section{Activities During 1999}

\section{Baseline Logging, Tank Summary Data} Reports, and Tank Farm Reports. In early 1999, spectral gamma baseline logging for boreholes associated with single-shell tanks was completed. During 1999, the remaining 16 tank summary data reports and 2 tank farm reports were completed. In addition, the high rate logging system was developed and deployed. The tank summary data reports included tanks B-102 (GJ-HAN-113), B-104 through B-112 (GJ-HAN-125 through GJ-HAN-133), and T-101 through T-106 (GJ-HAN-115 through GJ-HAN120). The report for tank farm A (GJO-98-64-TAR, GJO-HAN-23) was issued early in 1999, and the report for tank farm $\mathrm{T}$ was completed and issued in September 1999 (GJO-99-101-TAR, GJO-HAN-27). Work was also in progress on the $\mathrm{B}$ tank farm report, which is scheduled to be issued in March 2000 as GJO-99-113-TAR, GJO-HAN-28. The B tank farm report is the last of the 12 tank farm reports to be issued. During 2000, the Tank Farms Vadose Zone Characterization Project is scheduled to complete shape factor analysis for those tank farms where it was not initially applied, process and analyze repeat logging and high rate logging data, and to prepare addenda to the tank farm reports that summarize the additional data and present revised visualizations. The revised three-dimensional visualizations also will be used to estimate the total volume of contaminated material and total activity in curies represented by the contaminant plumes shown in the visualizations. The estimates will be prepared to present contaminated volume and total activity as a function of contaminant threshold level.

\section{Vadose Zone Characterization of Tank}

Farm A. The tank summary data reports for tank farm A in the 200-East Area were completed in 1998. The A tank farm report (GJO-98-64-TAR, GJOHAN-23) was issued in March 1999. Figure 6.2.4 shows a three-dimensional visualization of subsurface contamination in the A tank farm.
Cesium-137 and cobalt-60 were the major gamma-emitting contaminants detected in the $\mathrm{A}$ tank farm vadose zone. Cesium-137 contamination was detected at the ground surface throughout the tank farm. This contamination, which migrated or was carried downward through the backfill sediments to depths between 3 and 6.1 meters ( 10 and 20 feet), is related to spills and leaks associated with tank farm operations. The highest surface cesium-137 concentrations of more than $100 \mathrm{pCi} / \mathrm{g}$ were measured in an area north of tanks A-105 and A-106. Below depths of about 6.1 meters (20 feet), concentrations generally decreased to less than $0.1 \mathrm{pCi} / \mathrm{g}$, which is the minimum detection limit of the logging systems.

The highest cesium-137 concentrations (greater than $1,000 \mathrm{pCi} / \mathrm{g}$ ) measured in tank farm A occurred along the southeast side of tank A-101 and are associated with a leak from the 241-A-01B sluice pit located above the dome of tank A-101.

The most continuous cobalt- 60 contamination occurred along the southeastern quarter of tank A-101; this plume of contamination is more than 7.6 meters ( 25 feet) thick and is associated with leakage from the 241-A-01B sluice pit. Cesium-137 and europium-154 were also detected within this plume.

Cesium-137 was detected in boreholes surrounding tanks A-103 and A-105, both of which are assumed to be leaking. The contamination detected in the boreholes around these two tanks is relatively minimal, suggesting the leakage from these tanks may have migrated more vertically than laterally and that the contamination did not reach the monitoring boreholes. Gross gamma anomalies were detected in the lateral boreholes under both tanks.

Tank A-104 is also assumed to have leaked, and elevated gamma-ray activity was detected in the leak detection lateral boreholes beneath this tank. Minimal cesium-137 contamination was detected in the boreholes surrounding this tank, also suggesting the leakage did not reach the lateral extent necessary to be detected in the tank monitoring boreholes. 


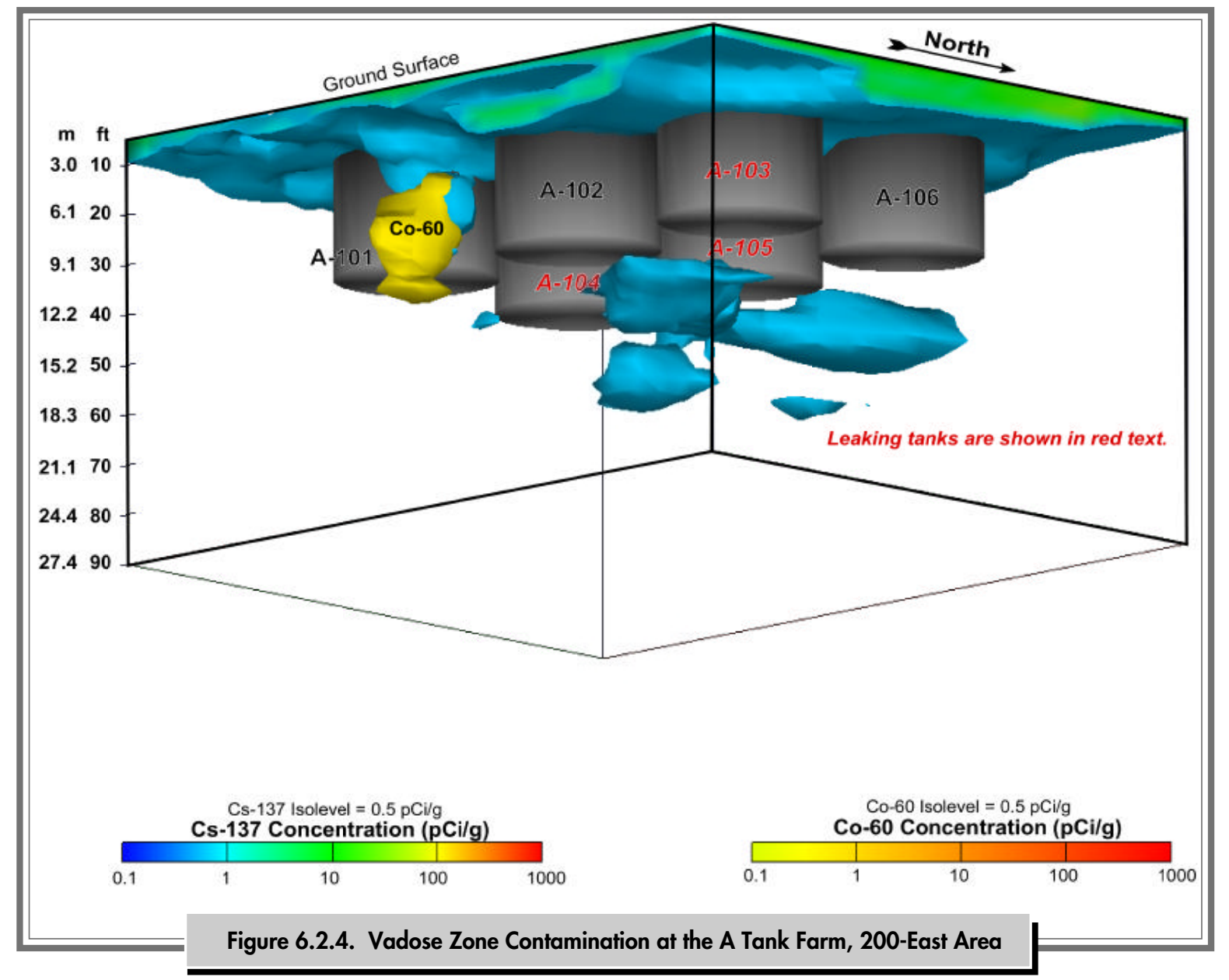

Cesium-137 was detected continuing to the bottoms of several of the 38.1-meter (125-feet) boreholes. Because the boreholes were not deep enough to intercept the bottoms of contamination intervals, the vertical extent of cesium-137 into the deeper regions of the vadose zone could not be determined.

Correlation of man-made contaminant distribution with naturally occurring potassium-40, uranium238, and thorium-232 concentration data suggests that much of the contamination occurs within the Hanford formation upper gravel sequence, which may have encouraged vertical contaminant migration.

Vadose Zone Characterization of Tank Farm T. Two tanks in tank farm $\mathrm{T}$ (located in the
200-West Area), T-107 and T-110, were characterized in 1995, and the tank summary data reports were issued in August 1995 as GJ-HAN-2 and GJ-HAN-1, respectively. However, most of the boreholes associated with the T tank farm were logged in 1998. Tank summary data reports for T-108, T-109, $\mathrm{T}-111$, and T-112 were issued in 1998 as GJ-HAN121, GJ-HAN-122, GJ-HAN-123, and GJ-HAN124, respectively. Tank summary data reports for T-101 to T-106 were issued in 1999 as GJ-HAN-115 through GJ-HAN-120. The report from tank farm $T$ was issued as GJO-99-101-TAR, GJOHAN-27 in September 1999. Figures 6.2.5 and 6.2.6 show three-dimensional visualizations of subsurface contamination in the $\mathrm{T}$ tank farm. 

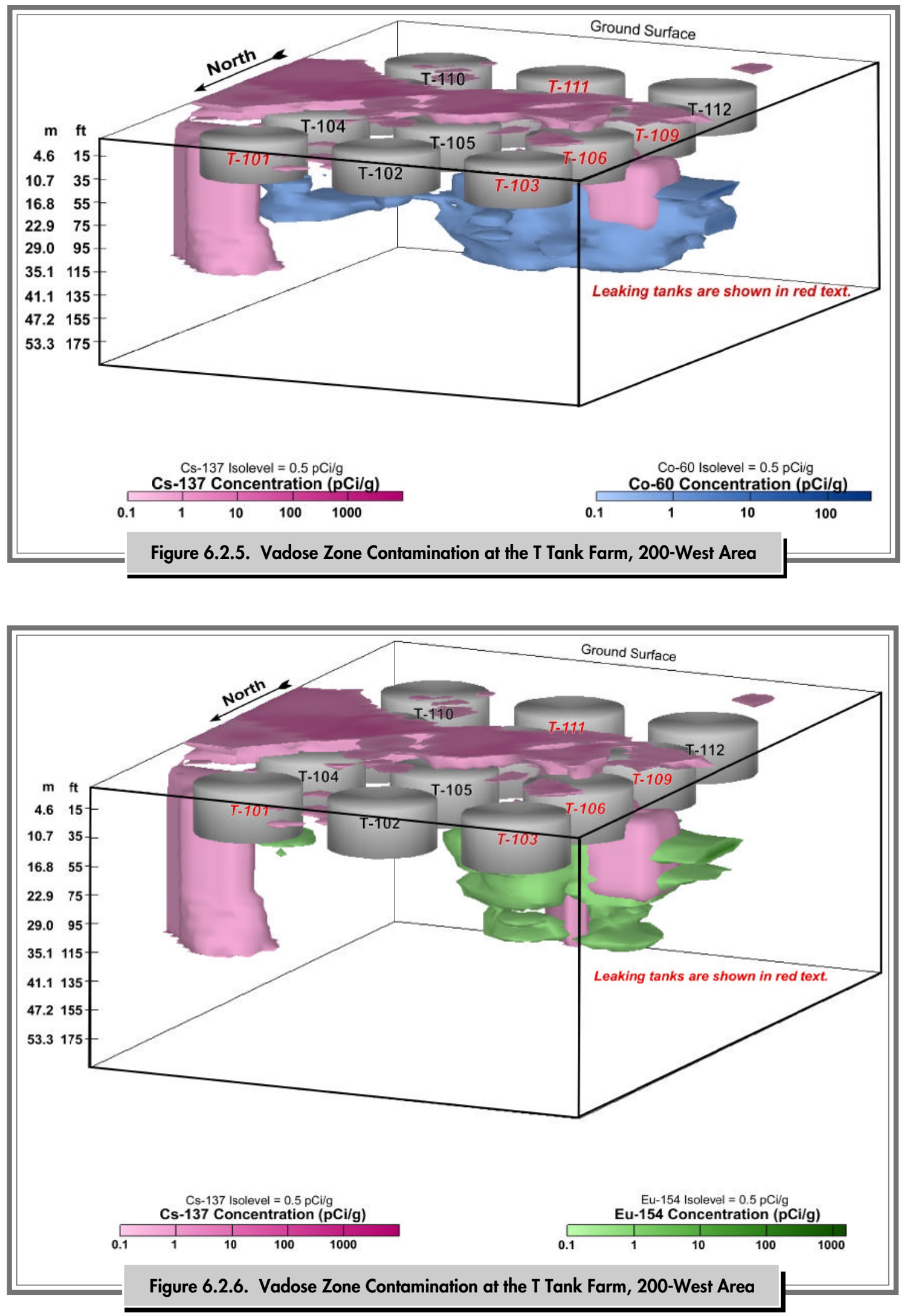
Cesium-137, cobalt-60, europium-154, and, to a lesser degree, europium-152 were the major gammaemitting contaminants detected in the vadose zone at tank farm T. Limited and relatively isolated occurrences of niobium-94, antimony-125, tin-126, uranium-235, and uranium-238 were also detected around several boreholes.

Most of the monitoring boreholes in the T tank farm were modified in the late 1970s, apparently in an effort to control infiltration of surface runoff through the monitoring boreholes. The 15-centimeter (6-inch) casing was perforated near the bottom and top of the borehole and a 10-centimeter (4-inch) casing was installed and grouted into place. The presence of the double casing and grout reduces the gamma flux inside the borehole by at least $40 \%$ and effectively precludes the application of shape factor analysis. Spectra count times were increased from 100 to 200 seconds to compensate for the lower gamma flux, and the casing correction allows for the additional thickness of steel, but it is impossible to determine a reliable correction factor to account for the presence of variable amounts of annular grout. Therefore, most $\log$ data results from tank farm $\mathrm{T}$ are labeled as apparent concentration.

Near-surface and shallow subsurface cesium-137 contamination was detected primarily in the central and eastern portions of tank farm $T$. This contamination most likely resulted from surface spills or leaks from piping systems related to routine tank farm operations. The highest cesium-137 concentrations were detected within the near-surface backfill material in the east-central portion of the tank farm between tanks T-104 and T-107. The thickest distributions ( 8.2 meters or 27 feet) of cesium-137 contamination were also detected in this region, suggesting a larger spill or several spills or leaks may have occurred in this area.

A vertically continuous, elongated cesium-137 plume was detected around one borehole near the southeast side of tank T-101, which is assumed to have leaked. The plume extends to a depth of more than 30 meters (100 feet) and appears to be the result of a large volume leak that probably resulted from overfilling the tank. The overfilling may have resulted in leakage through penetrations installed along the southeast quadrant of the tank for spare inlet lines. A large cobalt-60 and europium-154 plume identified near the south side of tank T-101 may also have originated from the same leak source. The visualization shows that the cobalt- 60 component of the plume trends in a southwesterly direction, passing under the southern portion of tank T-101 and portions of tanks T-104 and T-105.

A cesium-137 and cobalt-60 plume was identified in one borehole near the south side of tank T-102. Although tank T-102 is classified as sound, the data indicate that the plume probably originated from a leak from the spare inlet ports in a manner similar to leaks originating from adjacent tanks within the cascade series. The cesium-137 component of the plume appears to have spread laterally from the suspected leak source to the south and west along the base of the tank farm excavation.

A distinct plume of cobalt-60, europium-154, and europium-152 contamination was intercepted by boreholes located near the southeast and south sides of tank T-103. The contamination is believed to have originated from a leak at the spare fill line on the southeast side of the tank. Some of the contamination within the plume has migrated laterally to the south and has apparently intermingled with contamination resulting from a large leak from tank T-106.

The extensive plume of cesium-137, cobalt-60, europium-154, and europium-152 contamination identified around and below the base of the tank $\mathrm{T}-106$ originated from the large leak that occurred in 1973. The leak source is located on the southeast side of the tank, and the resulting plume extends laterally as much as 30 meters (100 feet). Man-made radionuclide contamination was detected at the bottom of several of the deepest boreholes monitoring tank 
farm $\mathrm{T}$, indicating that contamination associated with this leak has penetrated to a depth of at least 37 meters (120 feet).

\section{Vadose Zone Characterization of Tank}

Farm B. The B tank farm is located in the 200-East Area. Tank summary data reports for tanks B-101 and B-103 were issued in July 1998 as GJ-HAN-112 and GJ-HAN-114, respectively. The tank summary data reports for B-102 and B-104 through B-112 were issued in 1999 as GJ-HAN-113 and GJ-HAN-125 through GJ-HAN-133. The report from tank farm B is scheduled to be issued in March 2000 as GJO-99. 113-TAR, GJO-HAN-28. Figure 6.2.7 shows a three-dimensional visualization of subsurface contamination in a portion of tank farm B.

Cesium-137 was the major gamma-emitting contaminant detected in the B tank farm vadose zone. Cobalt-60, europium-154, and, to a lesser degree, europium-152 were also detected in the vadose zone sediments and were often associated with occurrences of cesium-137. In addition, the presence of the beta-emitting radionuclide strontium-90 is suspected around several boreholes.

Near-surface cesium-137 contamination was detected primarily in the southern portion of the B tank farm. This contamination most likely resulted from surface spills that migrated into the shallow backfill material. The maximum nearsurface cesium-137 contamination was detected in the southeast portion of the tank farm between tanks B-101 and B-104.

Shallow subsurface cesium-137 contamination was generally detected throughout the area of the B tank farm. This contamination may also be the result of surface spills or possibly leaks from piping systems that migrated into the backfill material. In

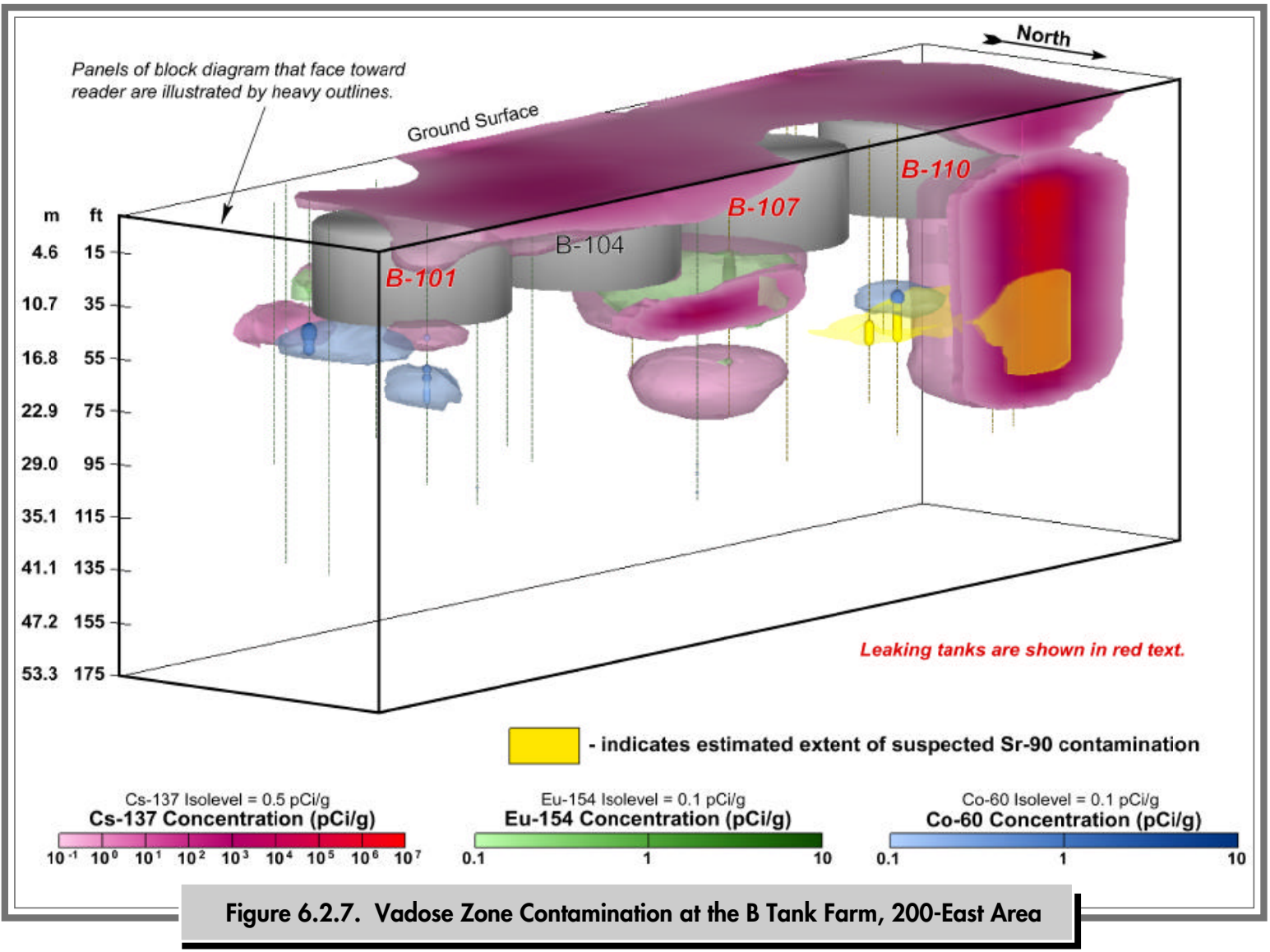


a few cases, some of the shallow cesium-137 contamination may have remobilized and migrated deeper into the backfill material. The thickest distributions of cesium-137 are 3 to 6 meters ( 10 to 20 feet) thick and were detected in the southeast, northeast, and southwest portions of the tank farm, suggesting a larger spill or several spills or leaks may have occurred in these areas.

A small plume of cesium-137 and europium-154 was identified around one borehole near the south side of tank B-101, a tank that is assumed to have leaked. Regions of cesium-137 and cobalt-60 contamination were also detected deeper in the vadose zone around boreholes located near the northeast and south sides of the tank. This contamination is believed to have originated from a leak in the wall of tank B-101 near the maximum operating level of the tank.

An interval of deep, low intensity cobalt-60 contamination was identified around one borehole near the west side of tank B-102. The contamination appears to have migrated from a distant leak source such as tank B-105 to the west, or tank B-103 to the north, both of which are designated as leaking tanks.

Regions of highly concentrated cesium-137 contamination were detected around individual boreholes located near both the north and south sides of tank B-105. Available data suggest the contamination detected in these boreholes probably originated from tank B-105, but from separate leak events.

A large plume of cesium-137, cobalt-60, and europium-154 contamination detected around one borehole located near the northeast side of tank B-107 is probably directly attributable to a leak from tank B-107. A deeper plume of cesium-137 contamination detected around this borehole probably also originated from a leak from tank B-107 and migrated to this region through the Hanford formation sediment.

A discrete zone of cesium-137 and europium154 contamination was detected around one borehole located near a cluster of inlet pipes connected to the southwest side of tank B-110. Available data suggest this contamination may consist of residual waste contained within the inlet piping.

An extensive region of highly concentrated cesium-137 contamination was detected around one borehole located near the north side of tank B- 110 . This contamination likely originated from a leak from the B-110 to B-111 cascade line or from tank B-110 itself. The location and magnitude of the cesium-137 contamination within this region of the vadose zone indicate that this borehole is very close to the leak source. The plume appears to be comprised primarily of cesium-137, but probably also contains strontium-90 and lesser amounts of cobalt60 and europium-154. Suspected strontium-90 contamination has been identified at the same depth intervals around boreholes located $\sim 12$ meters (40 feet) southeast and 24 meters ( 80 feet) northeast of the leak source, suggesting the presence of a relatively extensive contaminant plume.

Shape Factor Analysis. Experience with logging in the tank farm drywells has shown that contamination localized to the borehole can be a significant factor in overall log response. This may occur either as a result of contaminant dragdown during drilling, internal or external contamination of the casing, or possible contaminant migration along the borehole. Because this contamination is not representative of subsurface plumes, it must be identified and removed from the data set to present a representative visualization of subsurface contamination. The technique of shape factor analysis was developed in response to Expert Panel recommendations after the report for tank farm SX was issued. This approach takes into account the shape of the overall spectra and the ratio between peak counts and the low energy background counts to provide insights as to the probable distribution of the contamination with respect to the borehole axis. Shape factor analysis is described in GJO-96-13-TAR, GJOHAN-7 and GJO-97-25-TAR, GJO-HAN-15. 
Shape factor analysis was applied to boreholes in the $\mathrm{A}, \mathrm{B}, \mathrm{BX}, \mathrm{C}, \mathrm{S}$, and TY tank farms, and the results have been incorporated in the tank summary data reports for those tank farms. Intervals of contamination attributable to borehole effects or remote contamination were identified and eliminated from the interpreted data set used to prepare the visualizations. Shape factor analysis is generally not applicable to boreholes in tank farm $\mathrm{T}$ because almost all boreholes are double-cased. However, the tank summary data reports and tank farm reports for tank farms AX, BY, SX, TX, and U were prepared without benefit of shape factor analysis. During 1998 and 1999, shape factor analysis was performed on baseline log data from boreholes in these farms and the results will be used to help revise the interpreted data set to be used in preparation of the three-dimensional visualizations. These results will be discussed in tank farm report addenda to be prepared in 2000.

Repeat Logging. As a quality assurance measure, selected intervals in boreholes in all 12 tank farms were relogged by the spectral gamma logging system in 1999. Intervals selected for repeat logging were selected to resolve ambiguities or possible depth errors with the original baseline date, or to investigate intervals of potential contaminant migration. Repeat logging operations were completed in 1999. The data will be processed and analyzed in 2000 and discussed in the respective tank farm report addenda.

High Rate Logging. In 1999, a high rate logging system was developed and deployed to investigate borehole intervals where radiation levels exceeded the range of the spectral gamma logging system. High rate log data will be processed and analyzed in 2000 and discussed in the respective tank farm report addenda.

Evaluation of historical gross gamma data from intervals of high gamma flux suggests that count rates may be anomalously low in some intervals. This may be due in part to detector paralysis, a phenomenon in which the detector system fails to respond properly at high gamma flux. Although the spectral gamma logging system is nonparalyzable, and can be corrected for dead time effects, it becomes ineffective in zones of very high gamma flux, and individual peaks cannot be identified because of detector "saturation." In previous work, cesium-137 values in the range of 8,000 to $10,000 \mathrm{pCi} / \mathrm{g}$ were assumed in intervals of detector saturation. The high rate logging system was specifically designed to operate in zones of high gamma flux, and tungsten shields are provided to further extend the measurement range. Preliminary evaluation of high rate logging data indicate cesium-137 concentrations as high as $50,000,000$ to $100,000,000 \mathrm{pCi} / \mathrm{g}$. Inclusion of the high rate data in the interpreted data set used to create the three-dimensional visualizations is expected to have a relatively minor impact on the spatial distribution of the contaminant plumes, but it will have a substantial impact on the estimated total curie activity within the plume volume.

Both the spectral gamma logging system and the high rate logging system are essentially nonparalyzable. In nonparalyzable systems, the deposition of photon energy in the detector is followed by a dead period of fixed duration. During this time, the system is unresponsive to any additional photons that may enter the detector. Any photons that interact with the detector during this time are simply ignored. As the gamma-ray flux increases, more and more photons may be uncounted, but the length of the dead period is not affected. Thus, as the gamma flux increases, the count rate rises, but it is nonlinear in relation to flux. Linearity can be imposed by applying a dead time correction, which is a function of the proportion of the accumulated dead periods relative to the total count time. The percent dead time is reported by the logging system.

The high rate logging system was specifically designed to operate in regions of high gamma flux intense enough to "saturate" the spectral gamma logging system. Saturation refers to the circumstance in which the spectral peaks are tiny or even absent. This situation is an extreme manifestation of "pileup" (Knoll 1989). Pileup events yield output pulses with 
variable amplitudes because the amplitude of each output pulse depends on the total energy of multiple photons that impact the detector within a very short time period, so that they cannot be counted individually. These pulses add counts to the background continuum, and the individual photons are "lost," in the sense that they do not contribute to a peak. Consequently, the peak intensities are no longer proportional to the source concentrations. The high rate logging system achieves a higher radiation measurement capability in part by utilizing a smaller and less efficient detector, such that a smaller fraction of incident photons interact with the detector. In addition, it is provided with two tungsten shields, which can be used individually or in combination to extend the range of the system. With both shields in place, the maximum detection capability is extended by approximately two orders of magnitude. In previous work, concentration values in the range of 8,000 to $10,000 \mathrm{pCi} / \mathrm{g}$ were assumed for saturated intervals. Preliminary evaluation of high rate $\log$ data indicates maximum cesium- 137 concentrations on the order of $50,000,000$ to $100,000,000 \mathrm{pCi} / \mathrm{g}$ ( 50 to $100 \mu \mathrm{Ci} / \mathrm{g}$ ). Inclusion of the high rate data in the interpreted data set used to create the threedimensional visualizations is expected to have a relatively minor impact on the spatial distribution of the contaminant plumes, but it will have a substantial impact on the estimated total curie activity within the plume volume.

Future Work. With the completion of the tank farm addenda, the baseline characterization project will be completed. The data and reports generated by this project provide a "snapshot" showing the nature and extent of contamination resulting from gammaemitting radionuclides (primarily cesium-137, cobalt-60, uranium-235/238, and europium-154/152) within the vadose zone in the immediate vicinity of the single-shell tanks. Individual reports contain conclusions regarding the nature of subsurface contamination and provide specific recommendations regarding additional investigative and monitoring activities. This information, in conjunction with evaluation of historical gross gamma data from 1974 to 1994 , can be used to assess the stability of contaminant plumes resulting from gamma-emitting radionuclides; evaluate contaminant transport mechanisms and verify contaminant transport models; suggest probable migration pathways for nongammaemitting contaminants of concern, such as strontium-90 or technetium-99; and provide a basis for planning future investigation and monitoring activities.

\subsubsection{Vadose Zone Characterization and Monitoring at Liquid Waste Disposal Facilities}

\section{G. Horton}

Vadose zone characterization and monitoring activities were conducted at past-practice liquid waste disposal facilities in the 100 and 200 Areas of the Hanford Site in 1999. Considerable vadose zone contamination is associated with those past-practice activities in those areas. Current decontamination and remediation activities focus on sites in the 100 Area because they are located near the Columbia River. Most of the current vadose zone monitoring occurs in the 200 Areas because that is where most effluent was discharged to the soil column.
Vadose zone characterization activities that occurred in the 100 Areas in 1999 included soil sampling and analysis to support remediation of the 116-C-1 process effluent trench, in the 100-B,C Area, and the 1301-N and 1325-N cribs and trenches in the 100-N Area. Also accomplished were sampling and analysis to select a waste site for initial deployment of technology for in situ reduction of hexavalent chromium and laboratory studies to measure the distribution coefficient and leachability of chromium in sediment to support future remedial action goals and plans. 
The 200 Areas are the locations of the most significant vadose zone contamination at the Hanford Site. Vadose zone activities that occurred in the 200 Areas in 1999 included spectral gamma-ray logging at specific retention facilities in the 200-East Area, which are some of the most significant remaining potential sources of groundwater contamination. Also, remediation and monitoring of carbon tetrachloride in the 200-West Area continued during 1999. An additional 832 kilograms (1,660 pounds) of carbon tetrachloride were removed from the 200-West Area vadose zone in fiscal year 1999.

\subsubsection{Soil Remediation at 116-C-1 Trench, 100-B,C Area}

The 116-C-1 process effluent trench was remediated in 1997, and a test pit was dug to groundwater in early 1998 by Bechtel Hanford, Inc. to evaluate the remediation effort. Analysis of data from the pit became available in 1999 (CVP-98-00006, Rev. 0).

The 116-C-1 trench is located in the northeast corner of the 100-B,C Area of the Hanford Site. The trench was used to dispose of 700 million liters (185 million gallons) of contaminated cooling water from the 100-B,C Area retention basins after ruptured fuel elements were detected in the reactors. The 116-C-1 trench continued to receive contaminated cooling water until reactor operations ceased in 1968. An additional 40 billion liters ( 10.5 billion gallons) of high-temperature reactor cooling water was discharged to the trench during a 150-day infiltration test in 1967. (Infiltration tests are used to measure the capacity of the soil column to transmit water.) That water contained 700 parts per billion chromium as the major contaminant. The water from the infiltration test likely redistributed contaminants beneath the site.

The vadose zone beneath the 116-C-1 site consists of predominantly sand and gravel with various amounts of silt and cobble-size material. The groundwater is $\sim 12.8$ meters ( 42 feet) below the surface.
The test pit was 38 by 38 meters ( 125 by 125 feet) square and was centered at an area of elevated radioactivity near the trench inlet pipe. Material was removed from the pit in 1.5-meter (5-foot) depth increments using a backhoe. Soil samples were taken from each quadrant of the test pit and composited for each of the eight lifts.

Analyses of the soil samples showed that most remaining contamination in the vadose zone was within $\sim 5$ meters ( 16 feet) of the base of the remedial action excavation. The more mobile contaminants, such as strontium-90, however, were slightly deeper in the soil column. The most mobile contaminants, such as hexavalent chromium, were flushed through the vadose zone to groundwater by the infiltration test done on the trench after disposal of contaminated cooling water.

As part of the remedial action, the RESRAD computer code (ANL 1997) was used to model the impact of residual contaminants of concern in the vadose zone, groundwater, and Columbia River. A rural residential exposure scenario was used because, at the time the work was done, the future land use of the 100-B,C Area was not yet defined (CVP-9800006, Rev. 0). The model predicted a maximum dose rate from direct exposure to the soil of $8.2 \mathrm{mrem} / \mathrm{yr}$ in 1999 , decreasing to $0.066 \mathrm{mrem} / \mathrm{yr}$ in 1,000 years. The total excess cancer risk from direct exposure was calculated to be $7.7 \times 10^{-5}$, in 1999 , and decreasing to $1.8 \times 10^{-7}$ in 1,000 years.

All concentrations of the nonradionuclide contaminants of concern (total chromium, hexavalent chromium, lead, and mercury) were below remedial action goals, or cleanup levels, for direct exposure to the soil. The excess cancer risk from hexavalent chromium in the overburden and the excavated zone was well below the individual and cumulative risk limits.

The estimated radionuclide dose via the groundwater and/or the Columbia River was well below the 4-mrem/yr dose rate limit. Also, the remaining concentrations of total chromium, hexavalent 
chromium, lead, and mercury in the soil were either less than 100 times the maximum contamination level, less than background concentration, or modeled with RESRAD to be less than remedial action goals.

Remediation of the 116-C-1 trench met cleanup standards and the site was reclassified as closed in accordance with the Tri-Party Agreement (Ecology et al. 1998). A more complete description of the project and the results can be found in CVP-9800006, Rev. 0.

\subsubsection{Soil Sampling and Analysis at 1301-N and 1325-N Trenches, 100-N Area}

Bechtel Hanford, Inc. collected and analyzed four subsurface soil samples from test pits excavated in each of the 1301-N and 1325-N trenches in 1998. Both trenches are located in the 100-N Area. They also collected and analyzed four samples of surface soil from each of the $1301-\mathrm{N}$ trench and the $1325-\mathrm{N}$ crib. The purpose of the sampling was to facilitate the disposal of contaminated soil excavated from the site.

The 1301-N and 1325-N cribs and trenches received radioactive liquid waste containing activation and fission products as well as small quantities of corrosive liquids and laboratory chemicals generated by various $\mathrm{N}$ Reactor operations. Overflow from the cribs was discharged to the trenches. As the liquid waste percolated through the vadose zone soil beneath the trenches, radioactive and hazardous materials were sorbed onto the soil. Different contaminants would have migrated to different depths based on adsorption characteristics of individual constituents.

Four samples of soil were obtained from the surface of the $1301-\mathrm{N}$ trench and four from the surface of the $1325-\mathrm{N}$ crib. The data from analysis of the samples showed that, within a factor of 10 , concentrations of radionuclides were fairly constant within the $1325-\mathrm{N}$ crib and along the length of the 1301-N trench.
A hydraulic excavator was used to dig one test pit in each trench. Three discrete grab samples of soil were collected at selected depths in each pit. One composite soil sample was created at each trench by combining and homogenizing a portion of each grab sample. The samples from the 1301-N trench were collected from depths of 0 to 0.3 meter ( 0 to 1 foot), 0.3 to 0.6 meter ( 1 to 2 feet), and 0.6 to 1.5 meters (2 to 5 feet). Samples from the $1325-\mathrm{N}$ trench were obtained from depths of 0.61 to 1 meter ( 2 to 3.2 feet), 1 to 1.4 meters (3.2 to 4.6 feet), and 1.4 to 1.8 meters ( 4.6 to 6 feet). A 0.61 -meter (2-foot) layer of backfill was removed before collecting the shallowest sample.

Field instruments were used to map the soil in each excavation bucket to locate the highest alpha and beta-gamma concentrations. Samples were collected from the areas of highest concentration.

The analytical data show that the concentrations of most radionuclides drop off rapidly with depth by a factor of 10 to 100 within the first 0.6 meter ( 2 feet) of the surface at the $1301-\mathrm{N}$ trench or from the base of the gravel backfill at the $1325-\mathrm{N}$ trench. However, the concentrations of most isotopes below 0.6 meter ( 2 feet) remain substantial. A full description of this work can be found in BHI01271, Rev. 0.

\subsubsection{Bench Scale Distribution Coefficient and Leach Studies on Hexavalent Chromium in Contaminated Vadose Zone Sediment from 100-D Area}

\section{R. J. Serne and D. G. Horton}

Important decisions affecting the cost and extent of remedial actions in the 100 Areas are currently based on the predictions of the very conservative computer model RESRAD. To date, the RESRAD code has used only the distribution coefficient $\left(\mathrm{K}_{\mathrm{d}}\right)$, and not leachability, to evaluate impact to 
groundwater. The $K_{d}$ is a measure of the relative concentration of contaminant sorbed on the sediment to that dissolved in solution; the smaller the $\mathrm{K}_{\mathrm{d}}$, the more contaminant is in solution (groundwater). The modeling results indicate a potential impact to groundwater from contaminated vadose sediment at the 100-D Area, assuming a hexavalent chromium $\mathrm{K}_{\mathrm{d}}$ value of zero (i.e., $100 \%$ in solution).

Use of the distribution coefficient by the model assumes that hexavalent chromium is adsorbed on mineral surfaces in the sediment. Alternatively, hexavalent chromium, in 100-D Area contaminated sediment, may be present as an insoluble precipitate. Leach tests are appropriate to evaluate this alternative. The rate of hexavalent chromium movement through the vadose zone to groundwater will depend on which alternative releases hexavalent chromium to pore water.

Experiments were done in 1999 to measure both the leach rate and $K_{d}$ of hexavalent chromium using sediment samples from the 100-D Area. The RESRAD computer model can evaluate hexavalent chromium impact on groundwater using leachability parameters, which represent combined dissolution and desorption effects. Implementing the results of the 1999 experiments will provide a more accurate picture of actual potential impact to groundwater and support future remedial action cleanup goals and planning.

Samples and Methods. The 116-D-7 retention basin, in the 100-D Area, was selected as the field area to obtain samples for $\mathrm{K}_{\mathrm{d}}$ and leach tests. Both contaminated and uncontaminated samples were obtained. The primary objectives of the tests were to estimate $\mathrm{K}_{\mathrm{d}}$ and leach rates for hexavalent chromium specific to the Hanford formation sediment in the 100 Areas.

Batch adsorption tests used 50 grams ( 1.75 ounces) of oven dry Hanford formation sediment and 200 milliliters (0.05 gallon) of Hanford Site groundwater spiked with hexavalent chromium. Three different spike levels, 0.1, 1.0, and 10 milligrams per liter of hexavalent chromium (as sodium dichromate) were used. Tests were run in triplicate for contact times of 4 and 14 days.

In addition, one leach test was performed using contaminated Hanford formation sediment from the 100-D Area. The test was done by allowing uncontaminated Hanford Site groundwater to flow through a measured amount of sediment at a constant rate for 43 days.

Hexavalent chromium was measured by colorimetry in solutions from the batch tests and by both colorimetry and inductive coupled plasma/mass spectrometry in column leach tests.

Results and Conclusion. The results of the $K_{d}$ batch adsorption tests are shown in Tables 6.2.6 and 6.2.7. The conclusion from the tests is that there was no significant hexavalent chromium adsorption onto the Hanford formation sediment. Most $\mathrm{K}_{\mathrm{d}} \mathrm{s}$ measured were zero or near zero (standard deviation larger than $K_{d}$ ). The very low $K_{d}$ measured from the smallest hexavalent chromium concentrations may well be an artifact of 1) using batch tests with very low sorbing constituents and 2) using concentrations very near the analytical detection limit.

The results of the column leach test show that typical Hanford Site groundwater does not readily leach chromium bound to the Hanford formation sediment. After 43 days, less than 1\% of the chromium present in the sediment was removed by leaching with $\sim 12$ pore volumes of uncontaminated groundwater. The 12 pore volumes represent the total amount of water that would flush through the vadose zone from 15 centimeters (59 inches) of rainfall and 0.76 meter (2.5 feet) of irrigation per year.

Measurements of the hexavalent chromium in the sediment before and after leaching showed no measurable loss of hexavalent chromium from the sediment. This corroborates the leachate solution analyses that found less than $1 \%$ of the hexavalent chromium was removed from the sediment. 
Table 6.2.6. Average 4-Day Sediment-Water Contact Time $K_{d}{ }_{d}^{(a)}$ and Standard

Deviation for Hexavalent Chromium (Cr[VI]) and Total Chromium Adsorption

in Batch Adsorption Tests on Contaminated Vadose Zone Sediments

from the 100-D Area

$\mathrm{Cr}(\mathrm{VI})$

Concentration (mg/L)

0.1

1.0

10.0

\begin{tabular}{c}
$\begin{array}{c}\text { Standard } \\
\text { Deviation } \\
(\mathrm{mL} / \mathrm{g})\end{array}$ \\
\hline 0.1 \\
0.0 \\
0.05
\end{tabular}

\begin{tabular}{c}
$\begin{array}{c}\mathrm{K}_{\mathrm{d}} \text { for Total } \mathrm{Cr} \\
(\mathbf{m L} / \mathrm{g})\end{array}$ \\
\hline 0.0 \\
0.2 \\
0.3
\end{tabular}

0.3
Standard

Deviation $(\mathrm{mL} / \mathrm{g})$

0.3

0.3

0.3

(a) A measure of the relative concentration of contaminant sorbed on the sediment to that dissolved in solution. The smaller the $\mathrm{K}_{\mathrm{d}}$, the more contaminant is in solution.

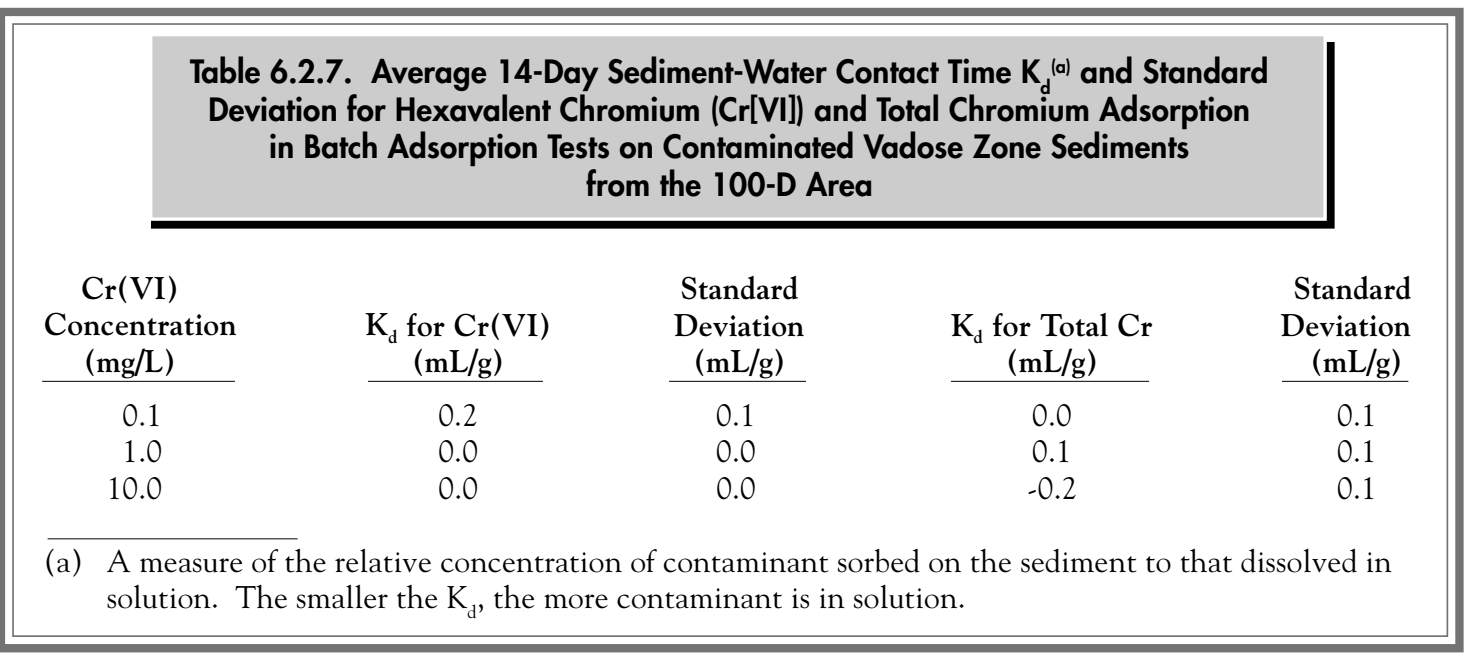

The findings of this study suggest that there is very little soluble chromium in the vadose zone sediment of the 100-D Area. This is contrary to the existence of high chromium concentrations in groundwater from some 100-D locations. The apparent incongruity may be an artifact of sampling (i.e., samples were collected outside areas of chromium contamination) or of an, as yet, unidentified geochemical process.

The leach test results from mixing contaminated sediment with uncontaminated groundwater suggest that a hexavalent chromium-bearing precipitate, that is very insoluble in Hanford Site groundwater, may be present in the sediment. Alternatively, the chromium in the sediment may be trivalent chromium that slowly oxidizes when leached with water. If hexavalent chromium in solution is controlled by slow oxidation of trivalent chromium, then more kinetic testing is needed to extrapolate from the short-term laboratory leach data to the longer time spans of natural dissolution of chromium in Hanford formation sediment. 


\subsubsection{Carbon Tetrachloride Monitoring and Remediation in 200-West Area}

\author{
V. J. Rohay, D. G. Horton
}

Soil-vapor extraction is being used to remove carbon tetrachloride from the vadose zone in the 200-West Area. The EPA and the Washington State Department of Ecology authorized DOE to initiate this remediation in 1992 as a CERCLA expedited response action. The primary focus in the following discussion is on 1999 activities associated with the carbon tetrachloride removal.

\section{Monitoring at the Soil-Vapor Extraction}

System. Soil-vapor extraction to remove carbon tetrachloride from the vadose zone operated from March 29 to June 30, 1999, at the 216-Z-9 well field (Figure 6.2.8). Initial on-line wells were selected close to the 216-Z-9 trench. As extraction continued, wells farther away from the crib were brought on-line. Each selection of on-line wells included wells open near the groundwater and wells open near a less-permeable zone above the groundwater table, where the highest carbon tetrachloride concentrations have consistently been detected. Initial carbon tetrachloride concentrations measured at the soilvapor extraction inlet were $\sim 90 \mathrm{ppmv}$ (Figure 6.2.9). After 3 months of extraction, concentrations had decreased to $\sim 30$ ppmv. The daily mass-removal rate increased significantly twice during the 3 months of extraction as a result of adjustments in the mix of on-line wells and the flow rate (see Figure 6.2.9).

Soil-vapor extraction resumed June 30, 1999, at the $216-Z-1 \mathrm{~A} /-12 /-18$ well field (see Figure 6.2.8). Extraction wells open near the less permeable zone were selected within the 216-Z-1A tile field to optimize mass removal of contaminant. Initial carbon tetrachloride concentrations measured at the soilvapor extraction inlet were $\sim 40$ ppmv. After 3 months of extraction, concentrations had decreased to $\sim 25$ ppmv. The daily mass-removal rate increased significantly twice during the 3 months of extraction as a result of adjustments in the mix of on-line wells and the flow rate (see Figure 6.2.9).

Between March 29 and September 30, 1999, 832 kilograms (1,800 pounds) of carbon tetrachloride were removed from the vadose zone in the 200-West Area. Of this total, 447 kilograms (985 pounds) were removed from the 216-Z-9 well field during 93 days of operation and 385 kilograms (850 pounds) were removed from the $216-Z-1 \mathrm{~A} /-12$ / -18 well field during 92 days of operation.

As of September 1999, 76,500 kilograms $(168,700$ pounds) of carbon tetrachloride had been removed from the vadose zone since extraction operations started in 1992 (Table 6.2.8). Since initiation, the extraction systems are estimated to have removed $7 \%$ of the residual mass at the $216-\mathrm{Z}-1 \mathrm{~A} /$ $-12 /-18$ well field and $22 \%$ of the mass at the 216 Z-9 well field. This estimate assumes that all of the mass that has not been lost to the atmosphere (21\% of the original inventory), dissolved in groundwater ( $2 \%$ of the original inventory), or biodegraded ( $1 \%$ of the original inventory) is still available in the vadose zone as residual mass (BHI-00720, Rev. 3; WHC-SD-EN-TI-101).

\section{Monitoring at Off-Line Wells and Probes.} During October 1998 through March 1999, soilvapor concentrations of carbon tetrachloride were monitored near the groundwater and near the ground surface to assess whether nonoperation of the soilvapor extraction system was allowing carbon tetrachloride to migrate out of the vadose zone. The maximum concentration detected near the ground surface (between 2 and 10 meters [6.5 and 33 feet] below ground surface) was 8 ppmv. Near the groundwater, at depths ranging from 58 to 64 meters (190 to 210 feet) below ground surface, the maximum concentration was 29 ppmv.

Soil-vapor concentrations were also monitored near the less permeable zone located above the groundwater table to provide an indication of vapor concentrations that could be expected during restart of the soil-vapor extraction system. The maximum 


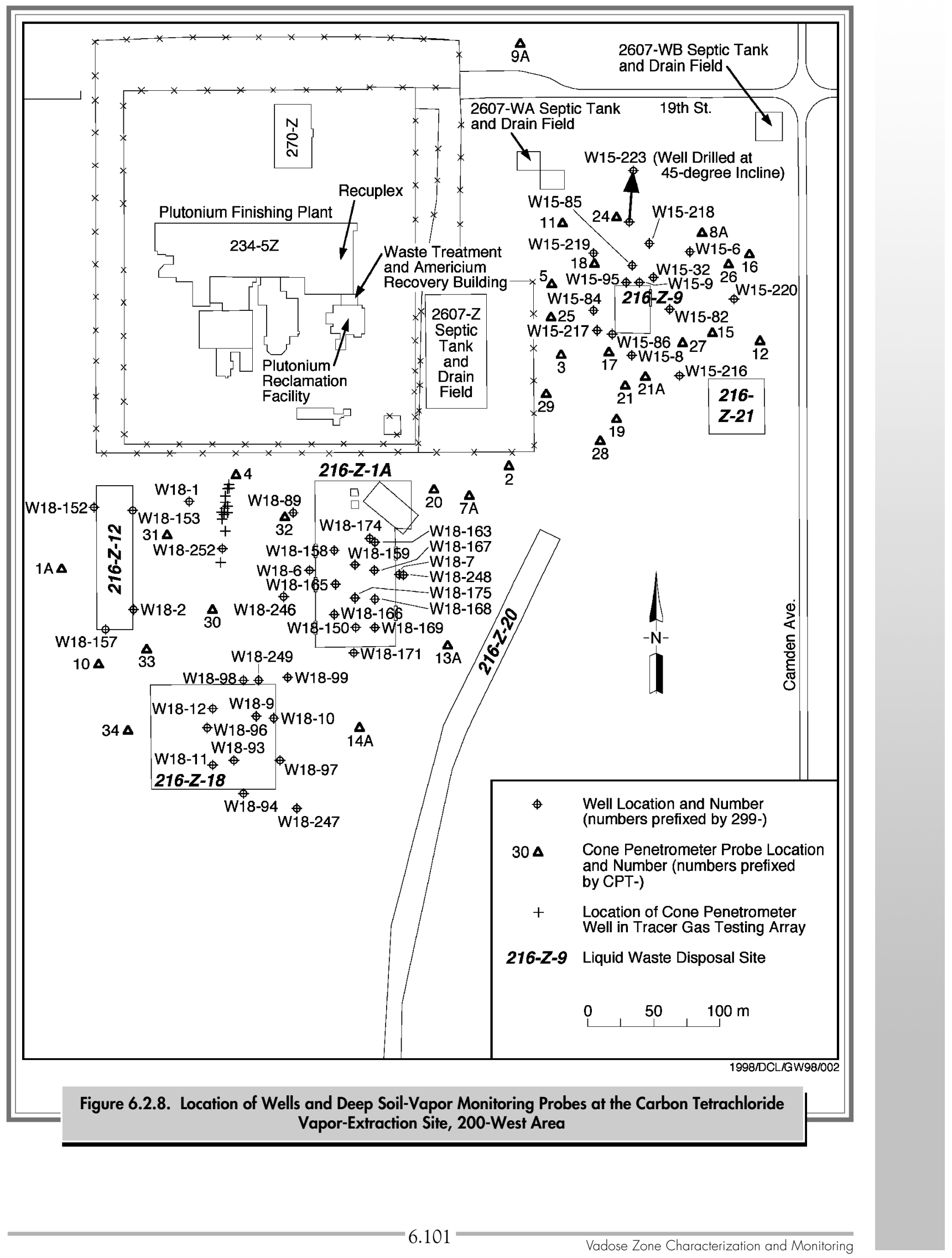




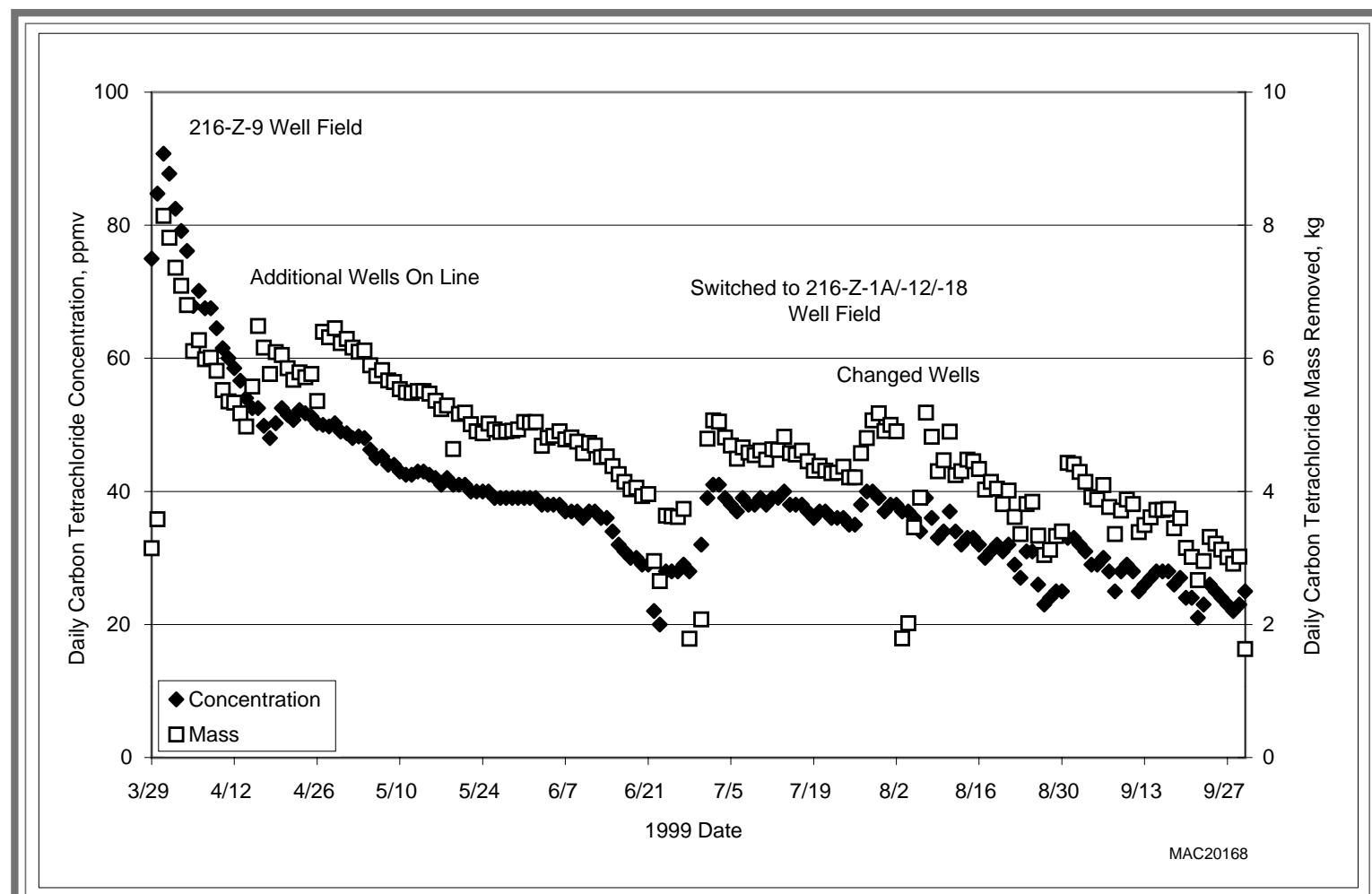

Figure 6.2.9. Time Series Concentrations of Carbon Tetrachloride in Soil Vapor Extracted from the 216-Z-9 Well Field and the 216-Z-1A/-12/-18 Well Fields (200-West Area) in 1999

Table 6.2.8. Carbon Tetrachloride Inventory in 200-West Area Primary Disposal Sites

\begin{tabular}{|c|c|c|c|}
\hline Well Field & $\begin{array}{l}\text { Estimated Mass } \\
\text { Discharged } 1955 \\
\text { to } 1973^{\text {(a) }}(\mathrm{kg}) \\
\end{array}$ & $\begin{array}{c}\text { Estimated Mass } \\
\text { Lost to Atmosphere } \\
1955 \text { to } 1990^{\text {(b) }}(\mathrm{kg}) \\
\end{array}$ & $\begin{array}{l}\text { Mass Removed From Vadose Zone } \\
\text { Sediments Using Soil-Vapor } \\
\text { Extraction } 1991 \text { to } 1999^{(\mathrm{c})}(\mathrm{kg}) \\
\end{array}$ \\
\hline $216-Z-1 A$ & 270,000 & 56,700 & $23,508^{(\mathrm{d})}$ \\
\hline $216-Z-9$ & 130,000 to 480,000 & 27,300 to 100,800 & 52,954 \\
\hline $216-Z-18$ & 170,000 & 35,700 & \\
\hline Total & 570,000 to 920,000 & 119,700 to 196,800 & 76,462 \\
\hline $\begin{array}{l}\text { (a) Based } \\
\text { (b) Based } \\
\text { (c) Based } \\
\text { (d) Includ }\end{array}$ & $\begin{array}{l}\text { RL-91-32, Draft B. } \\
\text {-SD-EN-TI-101. } \\
\text { 0720, Rev. } 3 . \\
\text { moved from 216-Z-18 }\end{array}$ & $\mathrm{d}$ as a combined valu & e well fields overlap. \\
\hline
\end{tabular}


concentration detected near this zone (between 25 and 41 meters [ 82 and 134 feet] below ground surface) was 561 ppmv. These results, after 6 to 9 months of nonoperation of the soil-vapor extraction system, were similar to those obtained during the 8-month rebound study conducted in fiscal year 1997 (BHI-01105) and during the 6 months of nonoperation during the winter of fiscal year 1998 (BHI00720, Rev. 3).

During April through June 1999, soil-vapor monitoring was continued at the $216-\mathrm{Z}-1 \mathrm{~A} /-12 /-18$ well field, while the soil-vapor extraction system was operated at the 216-Z-9 site. Concentrations detected during these additional 3 months of rebound (a buildup of carbon tetrachloride vapor following cessation of extraction activities) were similar to those observed during the previous 6 months. Near the less permeable zone, maximum concentrations ranged from 0 to $492 \mathrm{ppmv}$. These results were obtained after 9 months of rebound and are similar to those obtained during the 8-month rebound study conducted in fiscal year 1997 (BHI-01105).

During July through September 1999, soil-vapor monitoring was resumed at the 216-Z-9 site while the soil-vapor extraction system was operated at the 216-Z-1A/-12/-18 site. The highest concentration detected near the ground surface was $4 \mathrm{ppmv}$ and the highest concentration detected near the groundwater was $24 \mathrm{ppmv}$. The maximum concentration detected was $267 \mathrm{ppmv}$ at the less permeable zone. These results were obtained after only 3 months of rebound.

Because carbon tetrachloride concentrations did not increase significantly at the near-surface probes monitored in 1999, temporarily suspending operation of the soil-vapor extraction system for 6 to 9 months appears to have caused minimal detectable vertical transport of carbon tetrachloride through the soil to the atmosphere. Because carbon tetrachloride concentrations did not increase significantly near the water table during this time, temporarily suspending operation of the soil-vapor extraction system appears to have had no immediate negative impact on groundwater quality.

Carbon Tetrachloride Migration. Three major pathways through the vadose zone to groundwater are possible:

- sinking and lateral spreading of a heavier-thanair vapor phase down to the top of the aquifer

- transport of an organic liquid phase, or dense, nonaqueous-phase liquid, down through the vadose zone over time, which eventually reaches the water column, dissolves, and settles through the saturated zone to an unknown depth

- transport of carbon tetrachloride dissolved in the aqueous phase either through disposal of aqueous waste or by contact between infiltrating recharge and carbon tetrachloride soil vapor and/or residual, dense, nonaqueous-phase liquid (WHC-SD-EN-TI-248).

A schematic representation, or conceptual model, of the subsurface behavior of carbon tetrachloride beneath the 216-Z-9 trench is shown in Figure 6.2.10. A numerical model was developed (BHI-00459) to simulate the primary transport processes shown in Figure 6.2.10, using local stratigraphy, documented discharge volumes to the well field, and soil properties. Results of initial simulations suggested that over two-thirds of the discharged carbon tetrachloride would be retained in the soil column and that a dense, nonaqueous-phase liquid would continue to drain slowly through the vadose zone and be transported into the underlying aquifer for years into the future. The initial modeling results indicated that the dense, nonaqueous-phase liquid dissolved in the groundwater and the depth of penetration was dependent on the groundwater flow rate.

Additional modeling is needed to assess the influence of porosity and groundwater velocity. Nevertheless, the modeling results support the conceptualization of the liquid-phase transport illustrated in Figure 6.2.10. The vapor-phase results were 


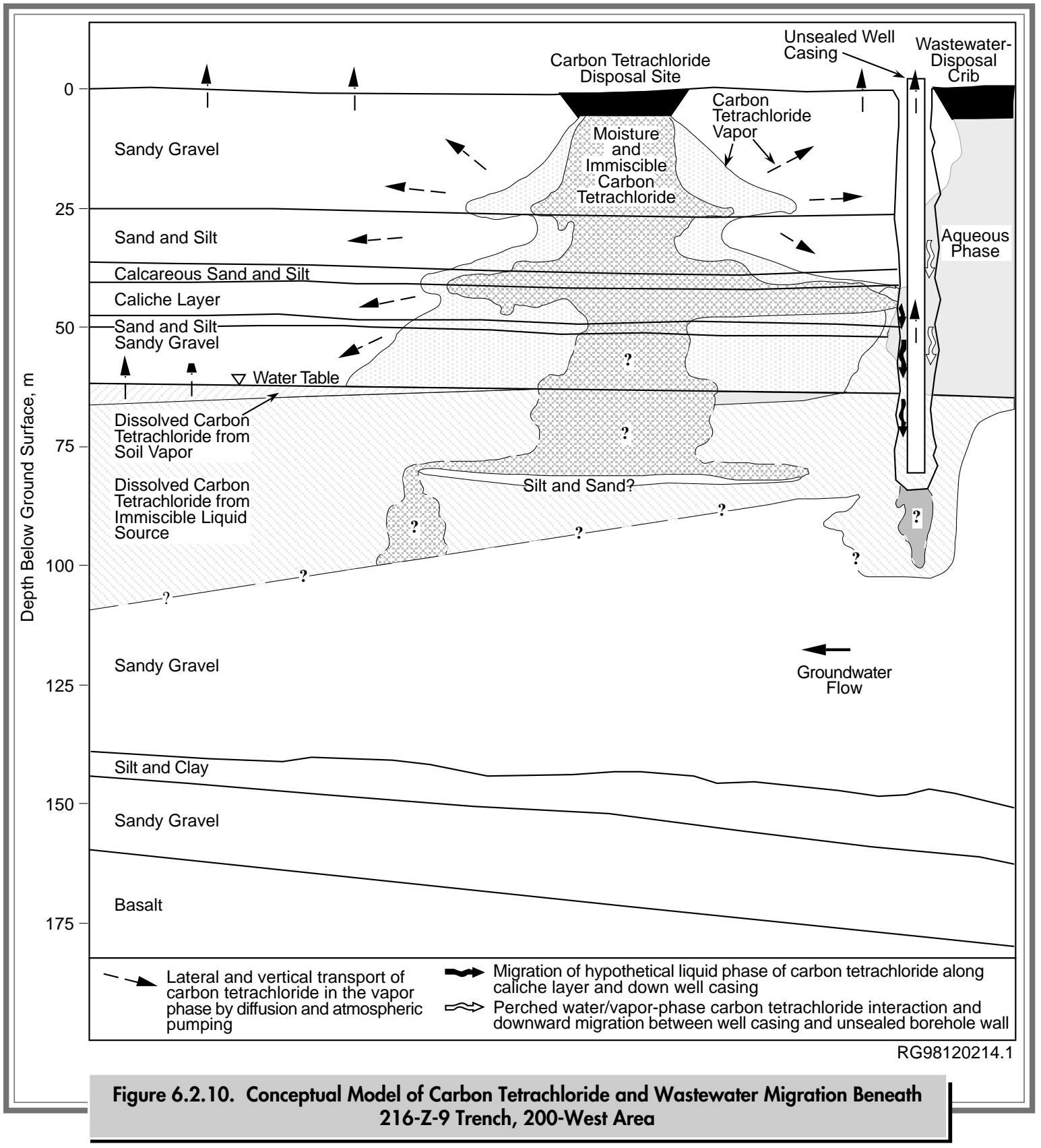

less definitive but suggested that vapor-phase transport is secondary to dense, nonaqueous-phase liquid as a groundwater contamination pathway in the vicinity of the disposal site.

Field measurements of carbon tetrachloride vapor concentrations are not completely consistent with the numerical modeling results. If a major fraction of the carbon tetrachloride originally discharged to the 216-Z-9 trench is still present in the soil column as a nonaqueous phase, a relatively high soil-vapor concentration would be expected. For example, vapor-extraction concentrations more than $12,000 \mathrm{ppmv}$ of carbon tetrachloride would indicate that the soil near the extraction well is saturated with nonaqueous-phase liquid. During 
initial extraction operations at the 216-Z-9 well field, soil-vapor carbon tetrachloride concentrations extracted from wells open above the less permeable zone were more than $12,000 \mathrm{ppmv}$, suggesting the presence of a nonaqueous phase. Soil vapor extracted from wells open below the less permeable zone were an order of magnitude lower and do not suggest the presence of a nonaqueous-phase liquid. However, the depths and locations of the extraction wells below the less permeable zone may not have been optimal to detect the presence of a nonuniformly distributed contaminant, and the presence of a nonaqueous-phase liquid cannot be ruled out.

During the soil-vapor monitoring of rebound concentrations conducted in 1997 through 1999, the carbon tetrachloride vapor concentrations monitored deep within the vadose zone at the 216-Z-9 trench did not exceed 60 ppmv. These low vapor concentrations do not indicate the presence of a nonaqueous-phase liquid remaining in the vadose zone below the less permeable zone; however, these measurements were not taken directly under the 216-Z-9 trench or at depth-discrete, narrow zones above the water table. Although carbon tetrachloride volatilizing from a residual nonaqueous-phase liquid source may have been diluted by the time the vapor reached the sampling locations, the data suggest that soil-vapor extraction may have removed much of the remaining deep, vadose zone, nonaqueous-phase, liquid source in the area of the 216-Z-9 trench and that the continuing groundwater source may now be within the aquifer (BHI-01105).

The apparent discrepancy between the numerical modeling results and the field measurements may be a result of

- nonuniform discharge, migration, and distribution of the nonaqueous-phase carbon tetrachloride

- nonoptimal locations for monitoring

- nonequilibrium partitioning of carbon tetrachloride within the vadose zone
- discharge of organic mixtures containing carbon tetrachloride rather than the pure phase

- vadose zone geologic heterogeneities and nonhorizontal geologic layers.

Vertical and areal distribution of dissolved carbon tetrachloride in groundwater is consistent with a dense, nonaqueous-phase, liquid transport mechanism. If the numerical model predictions are correct, for example, slowly dissolving carbon tetrachloride distributed with depth in the aquifer should continue to emanate from the point of origin over time, with the highest concentrations at the source, and should result in dissolved carbon tetrachloride distributed with depth in the aquifer (BHI-00459). If vapor-phase transport was a primary pathway, the top of the aquifer should have the highest concentrations and concentrations should decline rapidly with depth over a 1- to 2-meter (3.3- to 6.5-foot) interval.

The carbon tetrachloride plume map and vertical profiles (Section 2.8.1.2, PNNL-13116) suggest there is a continuing source of groundwater contamination that produces somewhat uniform carbon tetrachloride concentrations with depth in the aquifer. A dense, nonaqueous-phase liquid that drained from the vadose zone into the aquifer and is slowly dissolving could produce such a pattern. One alternative explanation for the depth-distribution pattern is that a secondary source of water passing near or through an area containing a dense, nonaqueous-phase liquid and soil-vapor carbon tetrachloride could absorb this slightly soluble chlorinated hydrocarbon and carry it into the aquifer under saturated flow conditions. This would theoretically drive the contaminated water deep into the aquifer.

The continuing presence, 35 years after termination of disposal operations, of relatively high, dissolved, carbon tetrachloride concentrations in groundwater in the immediate vicinity of the 216-Z-9 trench suggests that a dense, nonaqueousphase liquid is slowly dissolving within the aquifer. Although this liquid phase may be slowly draining from the vadose zone to groundwater, the soil-vapor 
concentrations monitored deep within the vadose zone during fiscal year 1997 through 1999 suggest that soil-vapor extraction remediation may have removed much of the vadose zone source and that the continuing groundwater source resides within the aquifer. Carbon tetrachloride concentrations in the soil vapor and underlying groundwater do not appear to be in equilibrium, and the expected direction of carbon tetrachloride migration is from the groundwater to the vadose zone (BHI-01105).

Carbon tetrachloride rebound concentrations indicate that, in many areas, much of the readily accessible mass has been removed during soil-vapor extraction operations and that the supply of additional carbon tetrachloride is limited by desorption and/or diffusion from contaminant-rich regions in the subsurface (e.g., lower-permeability zones such as the lower Hanford formation silt, Plio-Pleistocene Unit). Under these conditions, the removal rate of the additional carbon tetrachloride using soil-vapor extraction is controlled by the desorption and diffusion rates of the contaminant.

\subsubsection{Spectral Gamma-Ray and Neutron Moisture Monitoring of 200-East Area Inactive Liquid Waste Disposal Facilities}

\section{G. Horton}

The Hanford Groundwater Monitoring Project monitored 25 inactive liquid waste disposal facilities in the 200-East Area of the Hanford Site in 1999 (PNNL-12222; PNNL-13077). The monitored facilities consisted of 6 cribs and 19 specific retention facilities. Specific retention facilities were liquid waste disposal sites designed to use the moisture retention capability of the soil to retain contaminants. These facilities were chosen for monitoring because they are among the highest priority sites as determined by an evaluation of pastpractice, liquid waste disposal facilities (PNNL-11958,
Rev. 2). Ideally, liquid disposed to specific retention facilities was to be limited to $6 \%$ to $10 \%$ of the soil volume between the facility and the groundwater so that the liquid would be retained in the soil and not reach the groundwater (WHC-MR-0227). No such limits were imposed at normal cribs and trenches. The relatively small volumes of liquid discharged to specific retention facilities was probably insufficient to flush contaminants through the vadose zone to groundwater. Thus, these sites represent potential sources for future contamination of groundwater at the Hanford Site. Monitoring of the past practice sites consisted of spectral gamma-ray and neutron moisture logging of 28 wells and boreholes.

The facilities monitored in 1999 can be placed into three groups based on geographic location and the type of effluent received. The three groups are

- Plutonium-Uranium Extraction facilities

- BC controlled area facilities

- BX trenches.

Table 6.2.9 lists the facilities that were monitored in each group. Descriptions of the facilities, their associated waste streams and operating histories can be found in DOE/RL-92-04, Rev. 0 and DOE/ RL-92-05, Rev. 0.

High-resolution gamma spectroscopy instrumentation and a neutron moisture tool were used to log the boreholes. Details concerning the logging methods, data analysis, and data interpretation can be found in PNNL-13080 and PNNL-13077.

Four of the wells logged in 1999 were previously logged with the high-resolution spectral gamma logging instrument. Time-lapse comparison of spectral $\log$ data was done for those boreholes. Also, historical gross gamma logs were compared with the gross gamma logs collected by the spectral instrument in 1999. Interpretations of contaminant redistribution were based on changes among the data sets.

All depths referred to in the following discussion of results are relative to ground surface. 
Table 6.2.9. Liquid Disposal Facilities and Associated Boreholes and Wells in the 200-East Area Monitored with Spectral Gamma-Ray and Neutron Moisture Tools, Fiscal Year 1999

\begin{tabular}{lll} 
Facility & $\begin{array}{c}\text { Well or } \\
\text { Borehole }\end{array} \quad$ Facility & $\begin{array}{c}\text { Well or } \\
\text { Borehole }\end{array}$ \\
\cline { 2 - 3 } & & Pan
\end{tabular}

216-A-2 crib

216-A-4 crib

216-B-14 crib

216-B-15 crib

216-B-16 crib

216-B-17 crib

216-B-18 crib

216-B-19 crib

216-B-23 trench

216-B-25 trench

216-B-35 trench

216-B-37 trench

216-B-38 trench
PUREX Facilities ${ }^{(a)}$

$\begin{array}{ll}\text { 299-E24-53 } & \text { 216-A-7 crib } \\ \text { 299-E24-54 } & \text { 216-A-18 trench }\end{array}$

BC Controlled Area Facilities

299-E13-1
$299-E 13-2$
$299-E 13-2$
$299-E 13-21$
$299-E 13-4$
$299-E 13-5$
$299-E 13-6$
$299-E 13-55$
$299-E 13-56$

216-B-26 trench

216-B-27 trench

216-B-30 trench

216-B-31 trench

216-B-32 trench

216-B-33 trench

216-B-52 trench

216-B-53A trench

299-E25-54

299-E25-10

299-E13-12

299-E13-57

299-E13-52

299-E13-58

299-E13-59

299-E13-60

299-E13-54

299-E13-61

BX Trenches

$299-E 33-286$
$299-E 33-287$
$299-E 33-288$
$299-E 33-289$
$299-E 33-290$

299-E33-286

216-B-41 trench

299-E33-8

299-E33-10

(a) PUREX = Plutonium-Uranium Extraction.

\section{Plutonium-Uranium Extraction Facilities.}

The isotopes cesium-137, cobalt-60, europium-154, uranium-235, and uranium-238 were identified on the spectral gamma logs from boreholes monitoring the Plutonium-Uranium Extraction specific retention facilities. One gross gamma log obtained in 1976 was digitized for comparison with the $1999 \log$ (borehole 299-E24-53 at the 216-A-2 crib). The presence of several man-made, gamma-emitting radionuclides made the comparison very difficult, but the two logs showed the same general character suggesting no vertical movement of radionuclides. Lateral movement could not be ruled out by the comparison. Qualitative, visual (not digitized) comparisons of the other 1999 gross gamma logs with historical gross gamma logs, from the monitored PlutoniumUranium Extraction facilities, suggested that no vertical movement of radionuclides had occurred since the previous logging events. Most differences between historical logs and the 1999 logs could be explained by decay of relatively short-lived radionuclides.

BC Controlled Area Cribs and Trenches. The isotopes antimony-125, cesium-137, cobalt-60, and europium-154 were identified on the spectral gamma logs from boreholes monitoring the $\mathrm{BC}$ controlled area cribs and trenches. Three of the wells in this area had been previously logged in 1992 with a spectral gamma tool. In two of the three wells with 
both 1992 and 1999 logs, zones were identified where the cesium-137 concentration had increased since 1992. The cesium-137 concentration increased by 20\% between 20 and 27 meters ( 66 and 88 feet) in well 299-E13-1, at the 216-B-14 crib, and by 32\% at $\sim 25$ meters (82 feet) in well 299-E13-5, at the 216-B-18 crib. The movement of cesium-137 in well 299-E13-5 is interpreted to be lateral because there was no change in cesium-137 concentration above and below the zone of increase. The increase in cesium-137 concentration in well 299-E13-1 could have resulted from vertical movement but more information is needed to make a definite interpretation.

Historical gross gamma logs from two wells, 299-E13-2 and 299-E13-4 were digitized to allow comparison with 1999 gross gamma logs. Differences between the 1976 and 1999 logs can be explained by natural decay of relatively short-lived radionuclides; the comparison, however, is qualitative. Similarly, most of the differences between the 1999 logs and other historical logs reflect the decay of relatively deeper, short-lived isotopes and the much slower decay of the shallower and longer-lived isotopes.

BX Specific Retention Trenches. The isotopes antimony-125, cesium-137, and cobalt- 60 were identified on the spectral gamma logs from boreholes at the $\mathrm{BX}$ specific retention trenches. The antimony-125 and cobalt- 60 were identified only at or near detection limits.

A 1984 gross gamma log from borehole 299-E33289 was digitized and compared to the 1999 gross gamma results. The different instrument efficiencies allow only qualitative comparison but the depth profile of the contaminants match very well. It is believed that no vertical migration of contaminants has occurred in the borehole since 1984 .

Borehole 299-E33-290 at the 216-B-38 trench was previously logged with a spectral gamma tool in 1992. Cesium-137 was the only man-made radioisotope noted in both the 1992 and 1999 logs. Comparison of the 1992 and 1999 gross gamma logs indicated that a change in the distribution of cesium-137 was highly unlikely. Most of the qualitative differences between the 1999 logs and the historical logs from the BX trenches reflect the decay of short-lived isotopes, primarily ruthenium-106.

Summary. Only four of the boreholes logged in 1999 had previous spectral gamma logs for comparison. Two of those logs showed that changes in the subsurface distribution of man-made radioisotopes had occurred since 1992. Although the changes are not great, they do point to continued movement of contaminants in the vadose zone. The logs obtained in 1999 create a larger baseline for comparison with future logs.

None of the facilities monitored in 1999 have been used for at least 30 years and some for 40 years. Thus, the driving force for the changes is not known for certain but must be either natural recharge, residual moisture from past facility operations, or moisture from adjacent facilities. There are several facilities, including cribs and tank farms near the $\mathrm{BX}$ trenches, that may contribute moisture to the subsurface under the trenches. There are no nearby liquid waste disposal facilities near the cribs and trenches in the $\mathrm{BC}$ controlled area, so the driving force there must be residual moisture from past operations or natural recharge.

The radionuclides that were observed to have moved since 1992 are cesium-137 and cobalt-60. Given the amount of movement and the half-lives of the isotopes, it is expected that they will decay to insignificant amounts before reaching groundwater. Although not seen to have moved in 1999, the same is expected for all of the other detected isotopes except those of uranium.

Unfortunately, gamma-ray logging cannot detect many of the contaminants of interest such as technetium-99, nitrate, and iodine-129, all of which can be highly mobile in the vadose zone and, for the radionuclides, have long half-lives. The time series of gross gamma logs (ARH-ST-156) for many of the specific retention facilities show large decreases in gamma intensity between the late 1950s 
and 1976. The maximum intensity is generally between a depth of 10 and 20 meters ( 66 feet). The rapid decay is probably due to ruthenium-106 (halflife 1.02 year), and the ruthenium-106 probably reached a maximum depth of 10 to 20 meters ( 33 to 66 feet) with the original slug of water disposed in the short time (generally $\sim 1$ month) the facilities operated. Depending on the chemical characteristics of the waste stream, the mobility of iodine-129 and technetium-99, as gauged by experimentally determined $K_{d}$ s, is either near that of or greater than that of ruthenium-106. Thus, the minimum depth that iodine-129, nitrate, and technetium-99 probably reached during facility operation is indicated by the depth of rapid ruthenium-106 decay. Subsequent movement of the long-lived and mobile nongamma emitting constituents cannot be measured with the available geophysical logging tools.

\subsubsection{Hanford Site Surface Barrier Technology}

\section{G. W. Gee, A. L. Ward}

A field-scale prototype surface barrier was constructed in 1994 over an existing waste site as part of a CERCLA treatability test. The barrier was designed to be used at waste sites in arid climates and to have a 1,000-year performance. The barrier was monitored for 4 years to ascertain its stability and long-term performance. The 4 years of data were compiled and analyzed in 1999. A summary of those data is presented here; a more complete discussion is found in DOE/RL-99-11, Rev. 0.

Natural construction materials (e.g., fine soil, sand, gravel, cobble, basalt riprap, asphalt) were selected because of the demand for the barrier to perform for at least 1,000 years without maintenance. The current barrier consists of a 2 -meter (6.5-foot) thick, fine-soil layer overlying other layers of coarser materials that include sands, gravels, and basalt rock (riprap) and a low permeability asphalt layer. The barrier is designed to limit recharge to less than 0.5 millimeter ( $0.02 \mathrm{inch}$ ) per year. Figure 6.2.11 shows the construction details of the barrier.

Each layer serves a distinct purpose. The fine soil layer (silt) acts as a medium to store moisture until the processes of evaporation and transpiration recycle excess water back to the atmosphere. The fine soil layer also provides the medium to establish plants that are necessary for transpiration to take place. The coarser materials placed directly below the fine soil layer create a capillary break that inhibits downward movement of water through the barrier. The placement of fine soil directly over coarser materials also encourages plants and animals to limit their biological activities to the upper portion of the barrier, thereby reducing biointrusion into the lower layers. The coarser materials also help to deter inadvertent human intruders from digging deeper into the barrier profile.

Low-permeability layers are placed below the capillary break to 1) divert any percolating water that crosses the capillary break away from the waste zone and 2) limit the upward movement of noxious gases from the waste zone. The coarse materials located above the low-permeability layers also serve as a drainage medium to channel any percolating water to the edges of the barrier.

In addition to testing the performance of a capillary barrier, the prototype is being used to test two different side-slope designs:

- a relatively flat apron (10:1, horizontal:vertical) of clean fill gravel

- a relatively steep (2:1) embankment of fractured basalt riprap (PNL-8391; Ward and Gee 1997).

A shrub and grass cover was established on the soil surfaces of the prototype in November 1994. Shrubs were planted at a density of two plants per square meter with four sagebrush (Artemsia tridentata) plants to every one rabbitbrush (Chrysothamnus nauseosus) plant. 


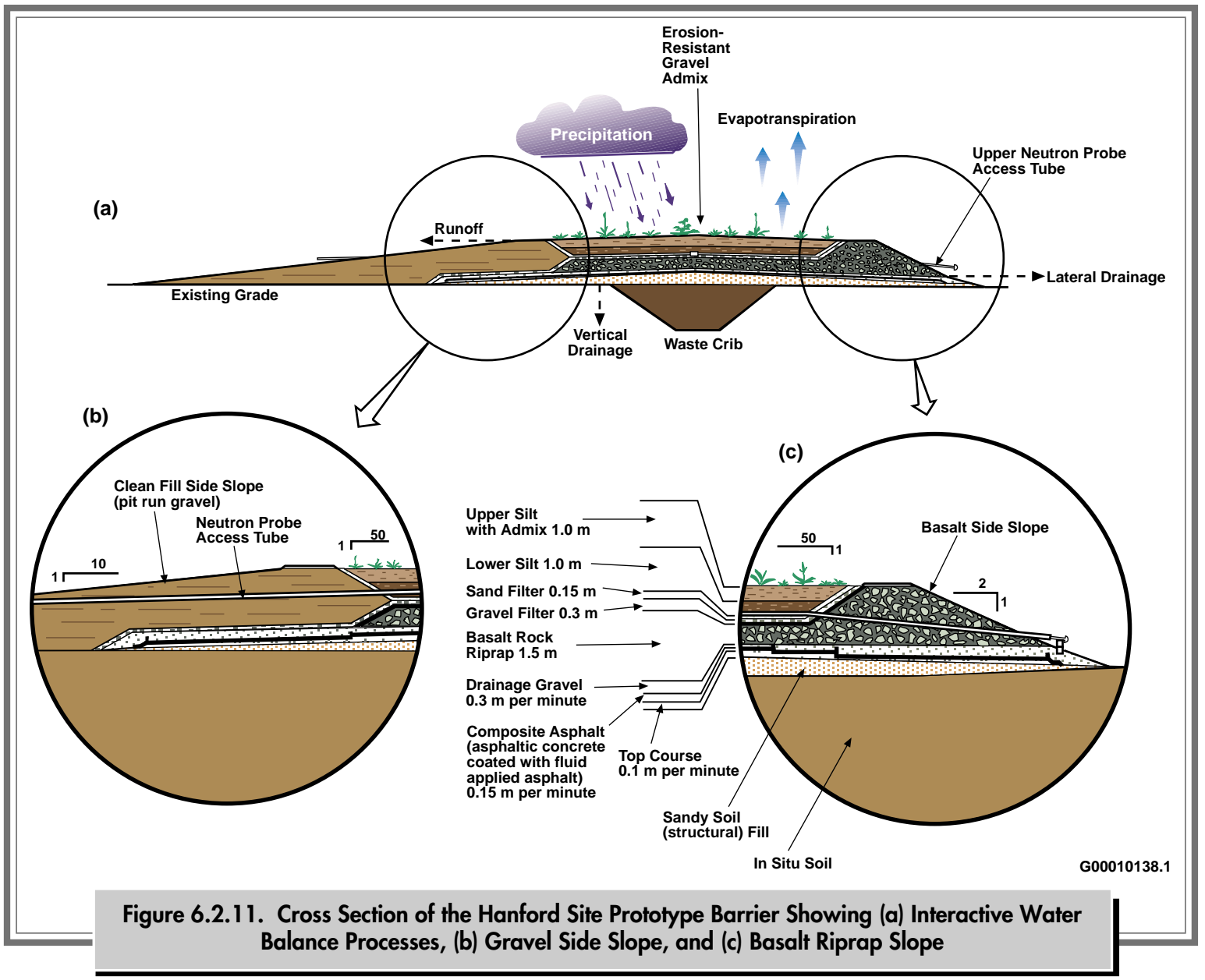

\subsubsection{Results of Field Tests}

From November 1994 through October 1997, soil plots on the northern half of the prototype barrier were irrigated such that the total water applied, including natural precipitation, was 480 millimeters per year (18.9 inches per year) or 3 times the longterm annual average. This treatment included application of sufficient irrigation water on 1 day, during the last week of March for 3 years (1995 through 1997), to mimic a 1,000 -year storm (70 millimeters [2.75 inches] of water).

Survival rates of the transplanted shrubs have been remarkably high; $97 \%$ for sagebrush and $57 \%$ for rabbitbrush (PNNL-11367). Grass cover, consisting of 12 varieties of annuals and perennials, including cheatgrass, several bluegrasses, and bunch grasses, dominated the surfaces, particularly those that were irrigated. Approximately $75 \%$ of the surface was covered by vegetation; a cover value typical of shrubsteppe plant communities. In all respects, the vegetated cover appeared to be healthy and normal. There was nearly twice as much grass cover on the irrigated surfaces than on the nonirrigated surfaces (PNNL-11367).

Figure 6.2.12 compares temporal changes in mean soil water storage on the irrigated and nonirrigated portions of the prototype barrier through September 1998. All irrigation and natural precipitation plus all available stored soil water were removed via evapotranspiration during the first year of surface barrier operation. By late summer of each year, water was removed via evapotranspiration 


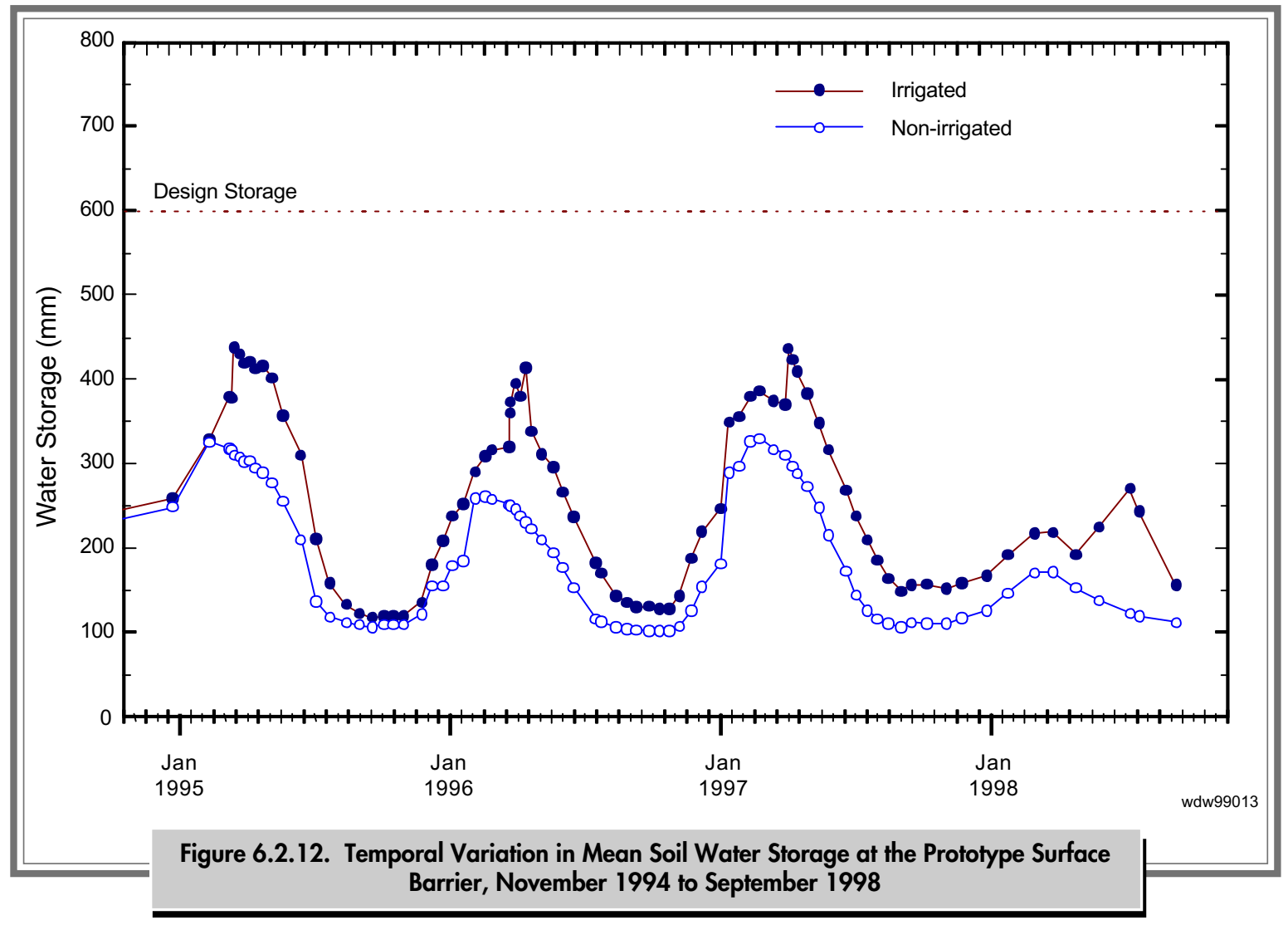

from the entire soil profile so that the soil water content of both irrigated and nonirrigated plots reached a relatively uniform lower limit of 5 to 8 volume percent throughout the soil profile. Correspondingly, water storage was reduced to levels of 100 to 150 millimeters (3.9 to 5.9 inches) (i.e., lower limit of plant-available water), for both the irrigated and nonirrigated soil surfaces. This is approximately one-fifth the amount of water required for drainage. Based on these observations and considering the irrigation treatment to represent the extreme in wet climate, the soil cover would not be expected to drain, even under the wettest Hanford Site climate conditions.

Figure 6.2.12 also shows that all of the water was removed from the soil profile following each simulated 1,000-year storm. Because no drainage occurred, the change in storage is attributed to water loss by evapotranspiration, thus demonstrating the continued positive benefits of having vegetation on the barrier surface. Evapotranspiration for the irrigated plots was nearly double that for the nonirrigated (ambient) plots, suggesting that vegetation is capable of adjusting to water applications. It is apparent that the capacity of vegetation for water consumption has not been exceeded even at three times the long-term annual average precipitation rates. This further supports the hypothesis that the combination of vegetation and soil storage capacity is more than sufficient to remove all applied water under the imposed test conditions.

Drainage did not occur from the soil covered part of the prototype barrier until the third year and then only in a minute amount (less than 0.2 millimeter [0.008 inch] for one of the soil plots subjected to irrigation. The drainage was attributed to lateral flow from water diverted off an adjacent roadway. These observations agree with the results of extensive lysimeter testing of capillary barrier designs (PNL-7209; PNL-8911) and suggest that the water 
storage capacity of the soil is well in excess of three times the long-term annual average (480 millimeter [19 inches] precipitation. (Lysimeters measure moisture content and movement through the soil.) In contrast, both side-slope configurations drained, though the amount of drainage was significantly less than predicted, based on the lysimeter testing that has been done with coarse materials (PNL-8911).

Figure 6.2.13 compares cumulative drainage from the gravel and riprap slopes through October 1998. On the nonirrigated treatments, the total amount of drainage from the gravel side-slope was greater than that from the basalt riprap side slopes. A similar trend was observed on the irrigated slopes up until November 1995. Whereas irrigation of the soil surfaces started in February 1995, irrigation of the side slopes did not start until November 1995. A closer look at these results show a seasonal influence on drainage. Whereas drainage from the gravel side slope was continuous, there was essentially no drainage from the riprap in the summer. In the winter, both sideslope configurations drained at similar rates.

The rapid establishment of vegetation on the soil surface was thought to be responsible for at least three positive benefits to surface barrier performance. First, the vegetation was dominant in the water removal process from the soil surfaces. Second, the surface was stabilized against water erosion and runoff. Runoff from the 1,000-year storm in 1995 was 1.8 millimeter $(0.07$ inch) [ 2\% of the 70 millimeters (2.75 inches)]. There was no runoff in 1996. The improvement was attributed to plant growth. Finally, there has been a positive benefit in controlling wind erosion. There has been no measurable loss of soil from the surface of the prototype barrier by wind erosion since the establishment of plants in November 1994.

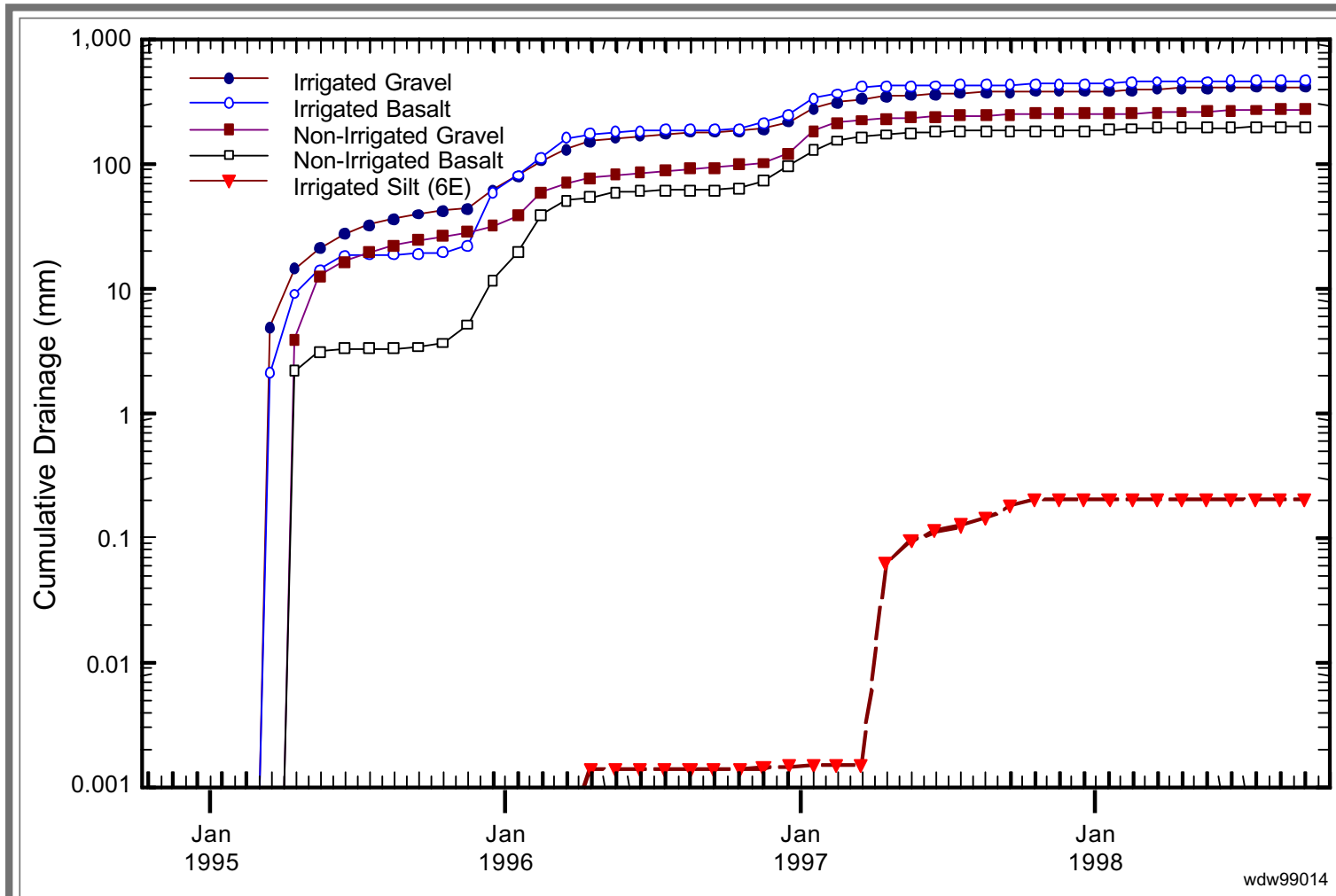

Figure 6.2.13. Cumulative Drainage at the Prototype Surface Barrier from November 1994 Through October 1998 from Four Side-Slope Plots and One Soil Plot that Drained 
Four years of testing provided important but limited information for long-term barrier performance estimates. Because only a finite amount of time exists to test a barrier that is intended to function for a minimum of 1,000 years, the testing program was designed to stress the prototype so that barrier performance could be determined within a reasonable time frame.

\subsubsection{Measurement of Tritium in Soil Moisture and Helium-3 in Soil Gas at the Old Hanford Townsite and KE Reactor}

K. B. Olsen, G. W. Patton, E. P. Dresel, J. C. Evans

The Hanford Groundwater Monitoring Project sampled and analyzed soil gas and soil moisture in 1999 to

- demonstrate the adaptability of soil gas sampling techniques to the measurement of tritium and helium-3 concentrations in Hanford Site soil

- determine tritium and helium-3 concentrations in soil gas at two locations on the Hanford Site

- attempt to extrapolate tritium and helium-3 concentrations in the soil to tritium concentrations in groundwater at the $100-\mathrm{K}$ Area.

Tritium/helium-3 age dating of shallow aquifer groundwater was successfully applied in the late 1980s by Poreda et al. (1988). The technique is based on the presence of the radioactive isotope tritium and its decay to the stable, inert isotope, helium-3. (Helium-4 is the common, stable isotope of helium found in the atmosphere.) At the Hanford Site, tritium was released to the soil column as effluent from past operations. In some areas of the Hanford Site, the effluent migrated through the vadose zone to mix with groundwater. In other areas, the effluent was retained in the vadose zone. Subsequently, moisture laden with tritium evaporated from the flow path and the water table and began to diffuse upward through the vadose zone toward the surface.

At the same time, helium-3 began to build up in both the groundwater and the vadose zone at the rate of tritium decay (the half-life of tritium is 12.3 years) and diffuse upward to the surface. Throughout this process, helium-3 was expected to act as a conservative (nonreactive) tracer moving through the vadose zone. Tritium, as tritiated water, would be a reactive tracer freely exchanging with hydroxyl groups on the surface of sediment, which would retard its movement through the vadose zone. Based on the above principles and conceptual model, soil gas and soil moisture samples were collected and analyzed to obtain a better understanding of their vadose zone properties and attempt to map vadose zone and groundwater tritium distribution.

Two areas of the Hanford Site were chosen to investigate: south of the Old Hanford Townsite and east of the KE Reactor. The Old Hanford Townsite was chosen because it is an area with a known tritium plume at groundwater depths similar to those in the 100 Areas and the site had easy access. Eight samples were collected during July and September 1999 at the Old Hanford Townsite. The KE Reactor was chosen as a study area because there is a known tritium plume; however, there is some uncertainty as to its distribution. Sixteen samples were collected in September 1999 at the KE Reactor. It was hoped that the helium-3/helium-4 isotope ratio would help better define the existing groundwater contamination. Details describing the sampling points and the experimental methods are given in PNNL-13116.

\subsubsection{Results and Discussion}

Analysis of the soil moisture samples found no detectable tritium (minimum detection limit less than $240 \mathrm{pCi} / \mathrm{L}$ ) in the soil moisture from either the 
Old Hanford Townsite or KE Reactor sampling points. This suggests that tritiated moisture from groundwater is not migrating upward to the sampling points. This is in spite of the fact that tritium in groundwater from a well adjacent to the soil moisture sampling points, occurs at a concentration of $117,000 \mathrm{pCi} / \mathrm{L}$ at a depth to groundwater of 21 meters (69 feet). These data indicate that the soil moisture can be attributed to recharge of natural precipitation into the vadose zone at the Old Hanford Townsite, which agrees with work done by Fayer et al. (1997). The lack of tritium in soil moisture at the KE Reactor also suggests that there are no vadose zone sources of tritium in the immediate study area.

Results of the helium analyses of the soil gas samples from the Old Hanford Townsite showed significant enrichment of helium-3 concentrations compared to ambient air, and an inverse relationship between helium-3 concentration and distance from the source (groundwater). Helium-3/-4 ratios at the
Old Hanford Townsite location ranged from 1.012 at 1.5 meters ( 5 feet) below ground surface to 2.157 at 9.7 meters (32 feet) below ground surface (Figure 6.2.14). For comparison, the helium-3/-4 ratio of normal atmosphere is very close to 0 .

Helium-3/-4 ratios show a significant variability with time. Figure 6.2.14 shows the helium-3/-4 ratios from samples taken at the beginning and at the end of the 24 hour July sampling event. In all but one sample, the ratios at the end of the event were greater than at the beginning of the event. The variability with time was even more pronounced by comparing the July and September sampling events. The greatest difference is shown by the helium-3/-4 ratios from the 5.9 meters (19 feet) samples from the SG-1 cluster. Comparing the two results shows a $62 \%$ increase in enrichment of helium-3 in the September sample.
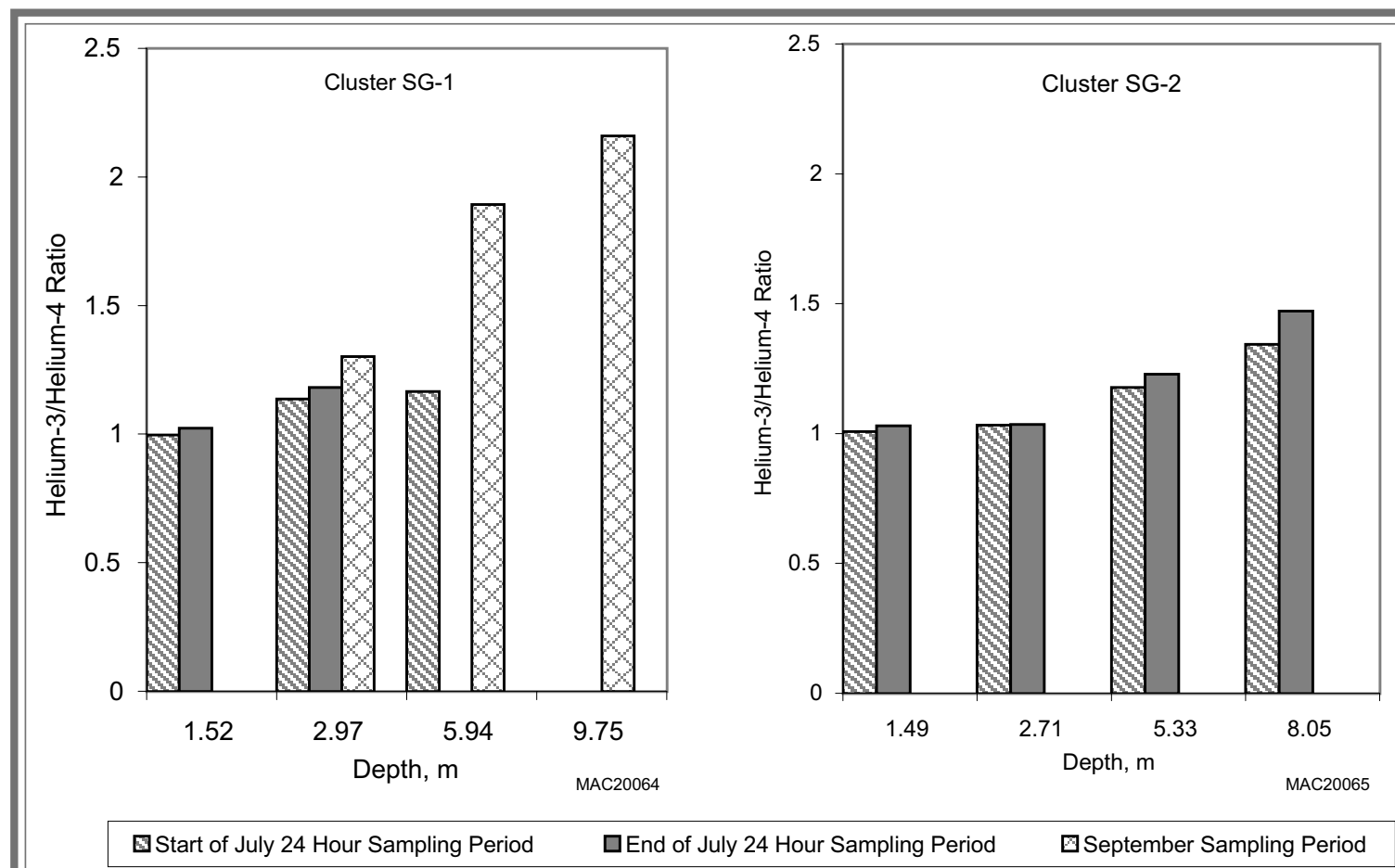

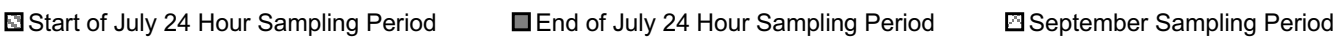

Figure 6.2.14. Comparison of Helium-3/Helium-4 Ratios for Samples Collected at the Old Hanford Townsite. Sample cluster SG-1 is 12 meters (39 feet) from Well 699-42-1A and sample cluster SG-2 is 48 meters (157 feet) from well 699-42-1A. 
The temporal variations might be attributable to dilution of the helium-3 in the vadose zone with low helium-3/-4 atmospheric air during times of high atmospheric pressure. Thus, the helium-3/-4 ratios from the soil samples probably reflect atmospheric conditions as well as soil vapor.

Helium-3/-4 ratios in the soil gas samples collected near the KE Reactor ranged from 0.972 to 1.131 (Figure 6.2.15). The greatest helium-3 enrichment is in the southeastern part of the study area suggesting that there may be a tritium source around that location. Because there was no tritium found in the soil moisture in the immediate area of sample site SG-16 (see Figure 6.2.15), helium-3 must be coming from a source farther than 3 meters (10 feet) from SG-16. This source may be located in the vadose zone or groundwater. The source could possibly be the solid waste burial ground or one or more of several cribs east of the KE Reactor. Alternatively, the source could be from the groundwater plume in the area. However, a groundwater monitoring well, 199-K-111 located adjacent to several soil gas monitoring points at the southeastern end of the study area has no measurable tritium (minimum detection level below $240 \mathrm{pCi} / \mathrm{L}$ ). This suggests that a tritium groundwater plume, if it exists, could be located farther to the south of the study area. Further investigation is necessary to define and identify the source of helium-3 around the southeastern corner of the study area. The helium-3 results from all the sampling points near the KE Reactor suggest no tritium plume is located within the study area.
Conclusions. Measurements of tritium in soil moisture do not appear to be useful for delineating tritium groundwater plumes or estimating concentrations of tritium in groundwater. The major source of moisture in the vadose zone at the two investigated sites appears to be natural precipitation and not upward migration of moisture from groundwater into the vadose zone. However, analysis of vadose zone moisture samples for tritium may be helpful in identifying vadose zone sources of tritium near the sampling sites.

Analyses of soil gas from samples collected at the Old Hanford Townsite area show that the gas is enriched in helium-3. This enrichment is due to decay of tritium in the groundwater beneath the site. The amount of enrichment appears to vary with time, most likely because of atmospheric influences. Nevertheless, helium-3 can be a useful tracer for either vadose zone or groundwater sources of tritium.

Helium-3 results from samples from the KE Reactor area do not suggest the presence of tritiated groundwater beneath the study area. Based on the relative enrichment factors for helium-3, there may be a groundwater or vadose zone source of tritium southeast of the study area. Potential sources include a groundwater tritium plume, the solid waste burial ground, the 116-KE-1 gas condensate crib east of the KE Reactor, or KE fuel storage basins. 


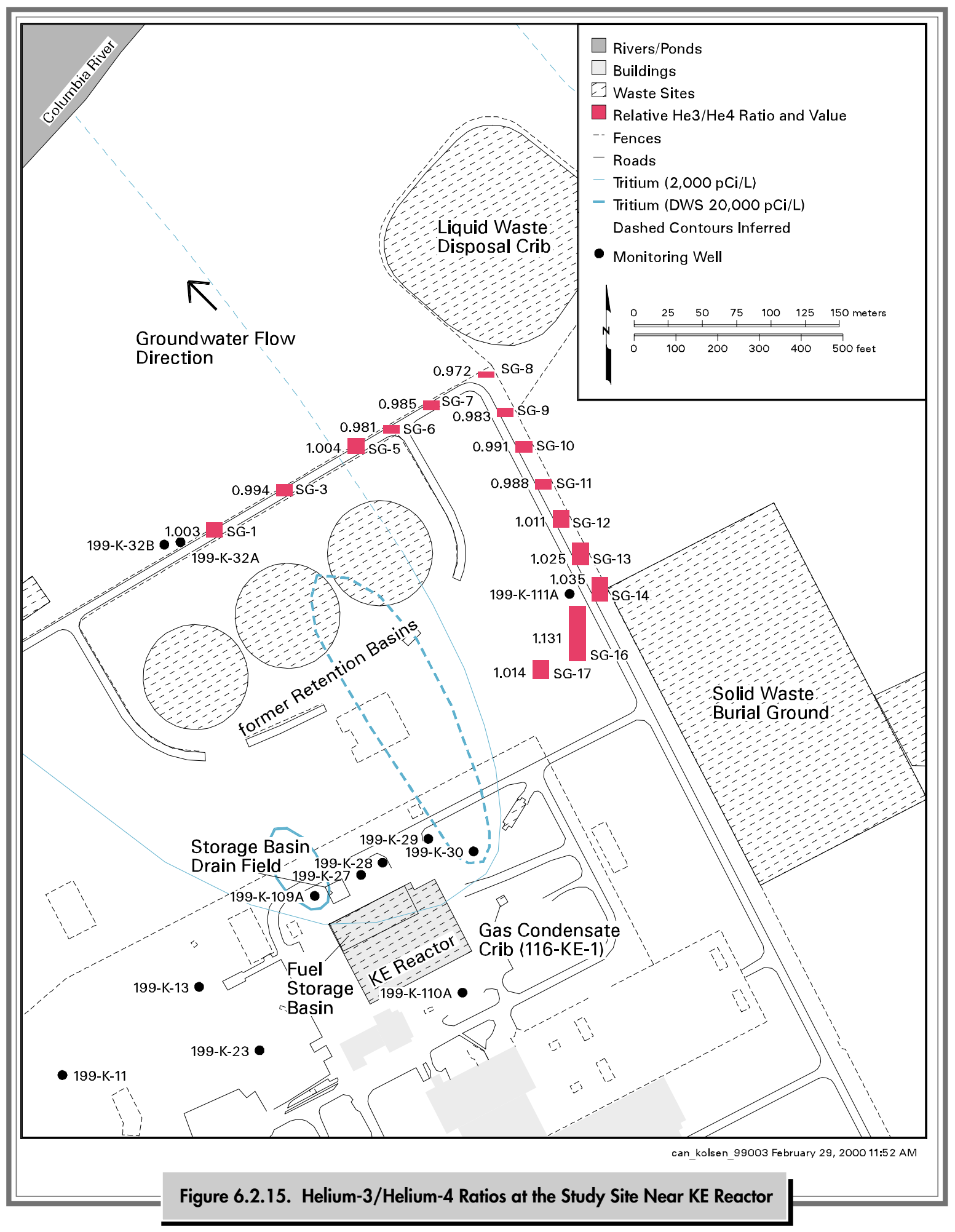




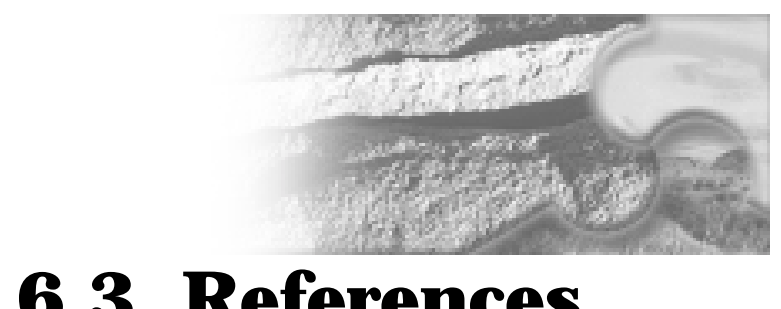

40CFR 141. U.S. Environmental Protection Agency. "National Primary Drinking Water Regulations; Radionuclides; Proposed Rule." Code of Federal Regulations.

40 CFR 265. U.S. Environmental Protection Agency. "Interim Status Standards for Owners and Operators of Hazardous Waste Treatment, Storage, and Disposal Facilities." Code of Federal Regulations.

40 CFR 300. U.S. Environmental Protection Agency. "National Oil and Hazardous Substances Pollution Contingency Plan." Code of Federal Regulations.

ANL - Argonne National Laboratory. 1997. RESRAD for Windows, Version 5.781. Argonne National Laboratory, Environmental Assessment Division, Argonne, Illinois.

ARH-ST-156. 1977. Evaluation of Scintillation Probe Profiles from 200 Area Crib Monitoring Wells. K. R. Fecht, G. V. Last, and K. R. Price, Atlantic Richfield Hanford Company, Richland, Washington.

BHI-00184. 1995. Miocene- to Pliocene-Aged Suprabasalt Sediments of the Hanford Site, SouthCentral Washington. K. A. Lindsey, Bechtel Hanford, Inc., Richland, Washington.

BHI-00459. 1996. Numerical Analysis of Carbon Tetrachloride Movement in the Saturated and Unsaturated Zones in the 200 West Area, Hanford Site. M. G. Piepho, Bechtel Hanford, Inc., Richland, Washington.

BHI-00720, Rev. 3. 1999. Performance Evaluation Report for Soil Vapor Extraction Operations at the Carbon Tetrachloride Site, February 1992 - September 1998. V. J. Rohay, Bechtel Hanford, Inc., Richland, Washington.

BHI-01105. 1997. Rebound Study Report for the Carbon Tetrachloride Soil Vapor Extraction Site, Fiscal Year 1997. V. J. Rohay, Bechtel Hanford, Inc., Richland, Washington.
BHI-01271, Rev. 0. 1998. Data Summary Report for 116-N-1 and 116-N-3 Facility Soil Sampling to Support Remedial Design. J. D. Ludowise, Bechtel Hanford, Inc., Richland, Washington.

BHI-01311, Rev. 0. 1999. Hydrogeologic Conceptual Model for the Carbon Tetrachloride and Uranium/ Technetium Plumes in the 200 West Area: 1994 Through 1999 Update. L. C. Swanson, V. J. Rohay, and J. M. Faurote, Bechtel Hanford, Inc., Richland, Washington.

BNWL-90. 1965. Evaluation of Radiological Conditions in the Vicinity of Hanford for 1964. R. H. Wilson (ed.), Pacific Northwest Laboratory, Richland, Washington.

BNWL-1970. 1976. Environmental Monitoring Report on Radiological Status of the Ground Water Beneath the Hanford Site, January-December 1974. J. R. Raymond, D. A. Myers, J. J. Fix, V. L. McGhan, and P. M. Schrotke, Pacific Northwest Laboratory, Richland, Washington.

BNWL-CC-701. 1966. Characterization of Subsurface Contamination in the SX TankFarm. J.R. Raymond and E. G. Shdo, Battelle Northwest Laboratories, Richland, Washington.

Comprehensive Environmental Response, Compensation, and Liability Act. 1980. Public Law 96-150, as amended, 94 Stat. 2767, 42 USC 9601 et seq.

CVP-98-00006, Rev. 0. 1999. Cleanup Verification Package for the 116-C-1 Process Effluent Trench. Bechtel Hanford, Inc., Richland, Washington.

DOE - U.S. Department of Energy. 1987. Plan and Schedule to Discontinue Disposal of Liquids Into the Soil Column at the Hanford Site. Richland, Washington. 
DOE/EIS-0119F. 1992. Decommissioning of Eight Surplus Production Reactors at the Hanford Site, Richland, Washington, Final Environmental ImpactStatement. U.S. Department of Energy, Washington, D.C.

DOE Order 5400.1. "General Environmental Protection Program."

DOE Order 5400.5. "Radiation Protection of the Public and the Environment."

DOE/RL-89-12, Rev. 2. 1995. Hanford Site GroundWater Protection Management Plan. D. B. Barnett, J. S. Schmid, S. S. Lowe, W. L. Allen, N. A. Ballantyne, C. H. Dohrer, M. J. Hartman, F. N. Hodges, D. G. Horton, V. G. Johnson, K. J. Lueck, D. J. Ortiz, A. J. Knepp, B. H. Ford, S. P. Hope, D. K. Tyler, R. D. Hildebrand, D. E. Olson, R. E. Peterson, G. L. Kasza, D. A. Myers, S. P. Luttrell, P. D. Thorne, and K. R. Moser. U.S. Department of Energy, Richland Operations Office, Richland, Washington.

DOE/RL-91-32, Draft B. 1991. Expedited Response Action Proposal (EE/CA E EA) for 200 West Area Carbon Tetrachloride Plume, Appendix B. V. J. Rohay and V. G. Johnson for U.S. Department of Energy, Richland Field Office, Richland, Washington.

DOE/RL-91-50, Rev. 2. 1997. Environmental Monitoring Plan, United States Department of Energy Richland Operations Office. U.S. Department of Energy, Richland Operations Office, Richland, Washington.

DOE/RL-92-04, Rev. 0. 1993. PUREX Source Aggregate Area Management Study Report. U.S. Department of Energy, Richland Operations Office, Richland, Washington.

DOE/RL-92-05, Rev. 0. 1993. B-Plant Source Aggregate Area Management Study Report. U.S. Department of Energy, Richland Operations Office, Richland, Washington.

DOE/RL-92-24, Rev. 3. 1995. Hanford Site Background: Part 1, Soil Background for Nonradionuclide Analytes. U.S. Department of Energy, Richland Operations Office, Richland, Washington.
DOE/RL-92-71, Rev. 2. 1998. 100-D Ponds Closure Plan. U.S. Department of Energy, Richland Operations Office, Richland, Washington.

DOE/RL-95-110. 1996. N-Springs Expedited Response Action Performance Evaluation Report. U.S. Department of Energy, Richland Operations Office, Richland, Washington.

DOE/RL-96-12, Rev. 0. 1996. Hanford Site Background: Part 2, Soil Background for Radionuclides. U.S. Department of Energy, Richland Operations Office, Richland, Washington.

DOE/RL-96-39. 1998. 100-NR-1 Treatment, Storage, and Disposal Units Corrective Measure Study/ Closure Plan. U.S. Department of Energy, Richland Operations Office, Richland, Washington.

DOE/RL-96-102. 1998. Proposed Plan for Interim Remedial Actions at the 100-NR-1 Source Sites Operable Unit and the 100-NR-2 Groundwater Operable Unit. U.S. Department of Energy, Richland Operations Office, Richland, Washington.

DOE/RL-98-48, DraftC. 1998. Groundwater/Vadose Zone Integration Project Specification. Prepared by Bechtel Hanford, Inc. for the U.S. Department of Energy, Richland Operations Office, Richland, Washington.

DOE/RL-98-56. 1999. Groundwater/Vadose Zone Integration Project, Project Management Plan. U.S. Department of Energy, Richland Operations Office, Richland, Washington.

DOE/RL-99-02. 1999. Fiscal Year 1998 Annual Summary Report for the 200-UP-1, 200-ZP-1, and 100-NR-2 Pump-and-Treat Operations and Operable Units. U.S. Department of Energy, Richland Operations Office, Richland, Washington.

DOE/RL-99-11, Rev. 0. 1999. Prototype Barrier Treatability Test Report. U.S. Department of Energy, Richland Operations Office, Richland, Washington. 
DOE/RL-99-13. 1999. Annual Summary Report, February to December 1998, for the 100-HR-3 and 100-KR-4 Pump-and-Treat Operations and Operable Units. U.S. Department of Energy, Richland Operations Office, Richland, Washington.

DOE/RL-99-79. 2000. Fiscal Year 1999 Annual Summary Report for the 200-UP-1, 200-ZP-1, and 100-NR-2 Pump-and-Treat Operations and Operable Units. U.S. Department of Energy, Richland Operations Office, Richland, Washington.

DOE/RW-0164 (2 vols). 1988. Consultation Draft, Site Characterization Plan, Reference Repository Location, Hanford Site, Washington. U.S. Department of Energy, Richland Operations Office, Richland, Washington.

Ecology - See Washington State Department of Ecology.

EPA 822-R-96-001. 1996. Drinking Water Regulations and Health Advisories. U.S. Environmental Protection Agency, Office of Water, Washington, D.C.

ES-SSPM-001. 1998. Sampling Services Procedures Manual. Waste Management Federal Services, Inc., Northwest Operations, Richland, Washington.

Fayer, M. J., G. W. Gee, M. L. Rockhold, M. D. Freshley, and T. B. Walters. 1997. "Estimating Recharge Rates for a Groundwater Model Using a GIS.” J. Environ. Qual. 25:510-518.

Gee, G. W., M. J. Fayer, M. L. Rockhold, and M. D. Campbell. 1992. "Variations in Recharge at the Hanford Site." Northwest Science 66(4):237.

GJ-HAN-1. 1995. Vadose Zone Characterization Project at the Hanford Tank Farms, Tank Summary Data Reportfor TankT-110. Prepared by Rust Geotech for the Grand Junction Projects Office, Grand Junction, Colorado.
GJ-HAN-2. 1995. Vadose Zone Characterization Project at the Hanford Tank Farms, Tank Summary Data Reportfor Tank T-107. Prepared by Rust Geotech for the Grand Junction Projects Office, Grand Junction, Colorado.

GJ-HAN-112. 1998. Hanford Tank Farms Vadose Zone, Tank Summary Data Report for Tank B-101. Prepared by MACTEC-ERS for U.S. Department of Energy, Grand Junction Office, Grand Junction, Colorado.

GJ-HAN-113. 1998. Hanford Tank Farms Vadose Zone, Tank Summary Data Report for Tank B-102. Prepared by MACTEC-ERS for U.S. Department of Energy, Grand Junction Office, Grand Junction, Colorado.

GJ-HAN-114. 1998. Hanford Tank Farms Vadose Zone, Tank Summary Data Report for Tank B-103. Prepared by MACTEC-ERS for U.S. Department of Energy, Grand Junction Office, Grand Junction, Colorado.

GJ-HAN-115. 1999. Hanford Tank Farms Vadose Zone, Tank Summary Data Report for Tank T-101. Prepared by MACTEC-ERS for U.S. Department of Energy, Grand Junction Office, Grand Junction, Colorado.

GJ-HAN-116. 1999. Hanford Tank Farms Vadose Zone, Tank Summary Data Report for Tank T-102. Prepared by MACTEC-ERS for U.S. Department of Energy, Grand Junction Office, Grand Junction, Colorado.

GJ-HAN-117. 1999. Hanford Tank Farms Vadose Zone, Tank Summary Data Report for Tank T-103. Prepared by MACTEC-ERS for U.S. Department of Energy, Grand Junction Office, Grand Junction, Colorado.

GJ-HAN-118. 1999. Hanford Tank Farms Vadose Zone, Tank Summary Data Report for Tank T-104. Prepared by MACTEC-ERS for U.S. Department of Energy, Grand Junction Office, Grand Junction, Colorado. 
GJ-HAN-119. 1999. Hanford Tank Farms Vadose Zone, Tank Summary Data Report for Tank T-105. Prepared by MACTEC-ERS for U.S. Department of Energy, Grand Junction Office, Grand Junction, Colorado.

GJ-HAN-120. 1999. Hanford Tank Farms Vadose Zone, Tank Summary Data Report for Tank T-106. Prepared by MACTEC-ERS for U.S. Department of Energy, Grand Junction Office, Grand Junction, Colorado.

GJ-HAN-121. 1998. Hanford Tank Farms Vadose Zone, Tank Summary Data Report for Tank T-108. Prepared by MACTEC-ERS for U.S. Department of Energy, Grand Junction Office, Grand Junction, Colorado.

GJ-HAN-122. 1998. Hanford Tank Farms Vadose Zone, Tank Summary Data Report for Tank T-109. Prepared by MACTEC-ERS for U.S. Department of Energy, Grand Junction Office, Grand Junction, Colorado.

GJ-HAN-123. 1998. Hanford Tank Farms Vadose Zone, Tank Summary Data Report for Tank T-111. Prepared by MACTEC-ERS for U.S. Department of Energy, Grand Junction Office, Grand Junction, Colorado.

GJ-HAN-124. 1998. Hanford Tank Farms Vadose Zone, Tank Summary Data Report for Tank T-112. Prepared by MACTEC-ERS for U.S. Department of Energy, Grand Junction Office, Grand Junction, Colorado.

GJ-HAN-125. 1999. Hanford Tank Farms Vadose Zone, Tank Summary Data Report for Tank B-104. Prepared by MACTEC-ERS for U.S. Department of Energy, Grand Junction Office, Grand Junction, Colorado.

GJ-HAN-126. 1999. Hanford Tank Farms Vadose Zone, Tank Summary Data Report for Tank B-105. Prepared by MACTEC-ERS for U.S. Department of Energy, Grand Junction Office, Grand Junction, Colorado.
GJ-HAN-127. 1999. Hanford Tank Farms Vadose Zone, Tank Summary Data Report for Tank B-106. Prepared by MACTEC-ERS for U.S. Department of Energy, Grand Junction Office, Grand Junction, Colorado.

GJ-HAN-128. 1999. Hanford Tank Farms Vadose Zone, Tank Summary Data Report for Tank B-107. Prepared by MACTEC-ERS for U.S. Department of Energy, Grand Junction Office, Grand Junction, Colorado.

GJ-HAN-129. 1999. Hanford Tank Farms Vadose Zone, Tank Summary Data Report for Tank B-108. Prepared by MACTEC-ERS for U.S. Department of Energy, Grand Junction Office, Grand Junction, Colorado.

GJ-HAN-130. 1999. Hanford Tank Farms Vadose Zone, Tank Summary Data Report for Tank B-109. Prepared by MACTEC-ERS for U.S. Department of Energy, Grand Junction Office, Grand Junction, Colorado.

GJ-HAN-131. 1999. Hanford Tank Farms Vadose Zone, Tank Summary Data Report for Tank B-110. Prepared by MACTEC-ERS for U.S. Department of Energy, Grand Junction Office, Grand Junction, Colorado.

GJ-HAN-132. 1999. Hanford Tank Farms Vadose Zone, Tank Summary Data Report for Tank B-111. Prepared by MACTEC-ERS for U.S. Department of Energy, Grand Junction Office, Grand Junction, Colorado.

GJ-HAN-133. 1999. Hanford Tank Farms Vadose Zone, Tank Summary Data Report for Tank B-112. Prepared by MACTEC-ERS for U.S. Department of Energy, Grand Junction Office, Grand Junction, Colorado.

GJO-96-13-TAR, GJO-HAN-7. 1997. Spectrum Shape-Analysis Technique Applied to the Hanford Tank Farms Spectral Gamma Logs. R. D. Wilson, MACTECERS for U.S. Department of Energy, Grand Junction Office, Grand Junction, Colorado. 
GJO-97-25-TAR, GJO-HAN-15. 1998. Enhancements, Validations, and Applications of Spectrum ShapeAnalysis Techniques Applied to Hanford Tank Farms Spectral Gamma Logs. R. D. Wilson, MACTEC-ERS for U.S. Department of Energy, Grand Junction Office, Grand Junction, Colorado.

GJO-98-64-TAR, GJO-HAN-23. 1999. Hanford Tank Farms Vadose Zone, A Tank Farm Report. MACTEC-ERS for U.S. Department of Energy, Grand Junction Office, Grand Junction, Colorado.

GJO-99-100-TAR, GJO-HAN-26. 1998. Hanford Tank Farms Vadose Zone, Sixth Recalibration of Spectral Gamma-Ray Logging Systems Used for Baseline Characterization Measurements in the Hanford Tank Farms. Prepared by MACTEC-ERS for U.S. Department of Energy, Grand Junction Office, Grand Junction, Colorado.

GJO-99-101-TAR, GJO-HAN-27. 1999. Hanford Tank Farms Vadose Zone, T Tank Farm Report. Prepared by MACTEC-ERS for U.S. Department of Energy, Grand Junction Office, Grand Junction, Colorado.

GJO-99-113-TAR, GJO-HAN-28. 1999. Hanford Tank Farms Vadose Zone, B Tank Farm Report. Prepared by MACTEC-ERS for U.S. Department of Energy, Grand Junction Office, Grand Junction, Colorado.

GJO-99-118-TAR, GJO-HAN-29. 1998. Hanford Tank Farms Vadose Zone, Base Calibration of a High Rate Logging System for Characterization of Intense Radiation Zones in the Hanford Tank Farms. Prepared by MACTEC-ERS for U.S. Department of Energy, Grand Junction Office, Grand Junction, Colorado.

GJO-2000-142-TAR, GJO-HAN-30. 2000. Hanford Tank Farms Vadose Zone, Seventh Recalibration of Spectral Gamma-Ray Logging Systems Used for Baseline Characterization Measurements in the Hanford Tank Farms. Prepared by MACTEC-ERS for U.S. Department of Energy, Grand Junction Office, Grand Junction, Colorado.
Gupta, S. K. 1997. Draft User's Manual, CFEST-96 Flow and Solute Transport, Constant/Variable Density, Computationally Efficient, and Low Disk PC/Unix Version. Environmental System Technologies, Irvine, California.

Knoll, G. F. 1989. Radiation Detection and Measurements, 2nd Ed. John Wiley and Sons, New York.

MAC-VZCP-1.7.2, Rev. 1. 1997. Hanford Tank Farms Vadose Zone, Project Management Plan. Prepared by MACTEC-ERS for U.S. Department of Energy, Grand Junction Office, Grand Junction, Colorado.

MAC-VZCP-1.7.9, Rev. 1. 1997. Hanford Tank Farms Vadose Zone, Data Analysis Manual. Prepared by MACTEC-ERS for U.S. Department of Energy, Grand Junction Office, Grand Junction, Colorado.

MAC-VZCP-1.7.10-1, Rev. 2. 1997. Hanford Tank Farms Vadose Zone, High-Resolution Passive Spectral Gamma-Ray Logging Procedures. Prepared by MACTEC-ERS for U.S. Department of Energy, Grand Junction Office, Grand Junction, Colorado.

Newcomb, R. C., J. R. Strand, and F. J. Frank. 1972. Geology and Ground-Water Characteristics of the Hanford Reservation of the U.S. Atomic Energy Commission, Washington. Geological Survey Professional Paper 717, U.S. Geological Survey, Washington, D.C.

OSWER 9950-1. 1986. Ground-Water Monitoring TechnicalEnforcement Guidance Document. U.S. Environmental Protection Agency, Washington, D.C.

Peterson, R. E., and M. P. Connelly. 1992. "Characterization of a Chromium Plume in Groundwater Along the Columbia River Shoreline, Hanford Site, Washington." Presented at 1992 Fall Meeting, American Geophysical Union, San Francisco, California, December 7-11, 1992. EOS Transactions, American Geophysical Union 73:43; also WHC-SA-1674-VA, Westinghouse Hanford Company, Richland, Washington. 
P-GJPO-1786. 1995. Vadose Zone Characterization Project at the Hanford Tank Farms, Spectral GammaRay Borehole Geophysical Logging Characterization and Baseline Monitoring Plan for the Hanford SingleShell Tanks. Prepared by Rust Geotech for U.S. Department of Energy, Grand Junction Projects Office, Grand Junction, Colorado.

PNL-5041. 1984. Ground-Water Surveillance at the Hanford Site for CY 1993. L. S. Prater, J. T. Rieger, C. S. Cline, E. J. Jensen, T. L. Liikala, K. R. Oster, and P. A. Eddy, Pacific Northwest Laboratory, Richland, Washington.

PNL-6328. 1988. Estimation of Ground-Water Travel Time at the Hanford Site: Description, Past Work, and Future Needs. M. D. Freshley and M. J. Graham, Pacific Northwest Laboratory, Richland, Washington.

PNL-6456. 1988. Hazard Ranking System Evaluation of CERCLA Inactive Waste Sites at Hanford. R. D. Stenner, K. H. Cramer, K. A. Higley, S. J. Jette, D. A. Lamar, T. J. McLaughlin, D. R. Sherwood, and N. C. Van Houten, Pacific Northwest Laboratory, Richland, Washington.

PNL-6825. 1989. Hanford Site Environmental Report for Calendar Year 1988. R. E. Jaquish and R. W. Bryce, Pacific Northwest Laboratory, Richland, Washington.

PNL-6886. 1989. Hanford Site Ground-Water Monitoring for January Through June 1988. J. C. Evans, R. W. Bryce, and D. R. Sherwood, Pacific Northwest Laboratory, Richland, Washington.

PNL-6894, Rev. 1. 1993. Procedures for GroundWater Investigations. Pacific Northwest Laboratory, Richland, Washington.

PNL-7120. 1989. Hanford Site Ground-Water Monitoring for July Through December 1988. J. C. Evans, R. W. Bryce, D. R. Sherwood, M. L. Kemner, and D. R. Newcomer, Pacific Northwest Laboratory, Richland, Washington.
PNL-7144. 1990. An Initial Inverse Calibration of the Ground-Water Flow Model for the Hanford Unconfined Aquifer. E. A. Jacobson and M. D. Freshley, Pacific Northwest Laboratory, Richland, Washington.

PNL-7209. 1990. Field Lysimeter Test Facility: Second Year (FY 1989) Test Results. M. D. Campbell, G. W. Gee, M. J. Kanyid, and M. L. Rockhold, Pacific Northwest Laboratory, Richland, Washington.

PNL-8073. 1992. Hanford Site Ground-Water Monitoring for 1990. J. C. Evans, R. W. Bryce, and D. J. Bates, Pacific Northwest Laboratory, Richland, Washington.

PNL-8337. 1992. Summary and Evaluation of Available Hydraulic Property Data for the Hanford Site Unconfined Aquifer System. P. D. Thorne and D. R. Newcomer, Pacific Northwest Laboratory, Richland, Washington.

PNL-8391. 1993. Testing and Monitoring Plan for the Permanent Isolation Surface Barrier Prototype. G. W. Gee, L. L. Cadwell, H. D. Freeman, M. W. Ligotke, S. O. Link, R. A. Romine, and W. H. Walters, Jr., Pacific Northwest Laboratory, Richland, Washington.

PNL-8911. 1993. Field Lysimeter Test Facility Status Report IV: FY 1993. G. W. Gee, D. G. Felmy, J. C. Ritter, M. D. Campbell, J. L. Downs, M. J. Fayer, R. R. Kirkham, and S. O. Link, Pacific Northwest Laboratory, Richland, Washington.

PNL-10158. 1994. Summary and Evaluation of Hydraulic Property Data Available for the Hanford Site Upper Basalt Confined Aquifer System. F. A. Spane, Jr. and V. R. Vermeul, Pacific Northwest Laboratory, Richland, Washington.

PNL-10285. 1995. Estimated Recharge Rates at the Hanford Site. M. J. Fayer and T. B. Walters, Pacific Northwest Laboratory, Richland, Washington. 
PNL-10817. 1995. Hydrochemistry and Hydrogeologic Conditions Within the Hanford Site Upper Basalt Confined Aquifer System. F. A. Spane, Jr. and W. D. Webber, Pacific Northwest Laboratory, Richland, Washington.

PNNL-11141. 1996. Hanford Site Ground-Water Monitoring for 1995. P. E. Dresel, J. T. Rieger, W. D. Webber, P. D. Thorne, B. M. Gillespie, S. P. Luttrell, S. K. Wurstner, and T. L. Liikala, Pacific Northwest National Laboratory, Richland, Washington.

PNNL-11367. 1996. Hanford Protective Barrier Status Report. FY 1996. G. W. Gee, A. L. Ward, B. G. Gilmore, S. O.Link, G. W. Dennis, and T.K. O'Neil, Pacific Northwest National Laboratory, Richland, Washington.

PNNL-11523. 1997. Combination RCRA Groundwater Monitoring Plan for the 216-A-10, 216-A-36B, and 216-A-37-1 PUREX Cribs. J. W. Lindberg, Pacific Northwest National Laboratory, Richland, Washington.

PNNL-11573. 1997. Groundwater Monitoring Plan for the 183-H Solar Evaporation Basins. M.J.Hartman, Pacific Northwest National Laboratory, Richland, Washington.

PNNL-11574. 1997. Results of RCRA Groundwater Quality Assessment Program at the 216-U-12 Crib. B. A. Williams and C. J. Chou, Pacific Northwest National Laboratory, Richland, Washington.

PNNL-11604. 1997. Results of RCRA Groundwater Quality Assessment at the 216-B-3 Pond Facility. D. B. Barnett and S. S. Teel, Pacific Northwest National Laboratory, Richland, Washington.

PNNL-11809. 1998. Results of Phase I Groundwater Quality Assessment for Single-Shell Tank Waste Management Areas T and TX-TY at the Hanford Site. F. N. Hodges, Pacific Northwest National Laboratory, Richland, Washington.
PNNL-11810. 1998. Results of Phase I Groundwater Quality Assessment for Single-Shell Tank Waste Management Areas S-SX at the Hanford Site. V. G. Johnson and C. J. Chou, Pacific Northwest National Laboratory, Richland, Washington.

PNNL-11826. 1998. Results of Phase I Groundwater Quality Assessment for Single-Shell Tank Waste Management Areas B-BX-BY at the Hanford Site. S. M. Narbutovskih, Pacific Northwest National Laboratory, Richland, Washington.

PNNL-11933. 1998. Survey of Radiological Contaminants in the Near-Shore Environment at the Hanford Site 100-N Reactor Area. S. P. Van Verst, C. L. Albin, G. W. Patton, M. L. Blanton, T. M. Poston, A. T. Cooper, and E. J. Antonio, Pacific Northwest National Laboratory, Richland, Washington.

PNNL-11958, Rev. 2. 1999. Monitoring Guidance for Vadose Zone Monitoring of Liquid Waste Disposal Facilities for the Hanford Groundwater Project. D. G. Horton, S. P. Reidel, and G. V. Last, Pacific Northwest National Laboratory, Richland, Washington.

PNNL-11989, Rev. 1. 1998. Integrated Monitoring Plan for the Hanford Groundwater Monitoring Project. M. J. Hartman, P. E. Dresel, J. P. McDonald, R. B. Mercer, D. R. Newcomer, and E. C. Thornton, Pacific Northwest National Laboratory, Richland, Washington.

PNNL-12023. 1998. Groundwater Monitoring for the 100-K Area Fuel-Storage Basins: July 1996 through April 1998. V.G. Johnson, C. J. Chou, M. J. Hartman, and W. D. Webber, Pacific Northwest National Laboratory, Richland, Washington.

PNNL-12222. 1999. Monitoring Plan for Fiscal Year 1999 Borehole Logging at 200 East Area Specific Retention Facilities. D. G. Horton, Pacific Northwest National Laboratory, Richland, Washington.

PNNL-12227. 1999. Groundwater Monitoring Plan for the Nonradioactive Dangerous Waste Landfill. J. W. Lindberg and M. J. Hartoman, Pacific Northwest National Laboratory, Richland, Washington. 
PNNL-12086. 1999. Hanford Site Groundwater Monitoring for Fiscal Year 1998. M. J. Hartman (ed.). Pacific Northwest National Laboratory, Richland, Washington.

PNNL-12088. 1999. Hanford Site 1998 Environmental Report. R. L. Dirkes, R. W. Hanf, and T. M. Poston (eds.), Pacific Northwest National Laboratory, Richland, Washington.

PNNL-13021. 1999. Water-Level Monitoring Plan for the Hanford Groundwater Monitoring Project. J. P. McDonald, M. A. Chamness, and D. R. Newcomer, Pacific Northwest National Laboratory, Richland, Washington.

PNNL-13047. 1999. Groundwater Monitoring Plan for the 216-A-29 Ditch. M. D. Sweeney, Pacific Northwest National Laboratory, Richland, Washington.

PNNL-13058. 1999. Results of Tritium Tracking and Groundwater Monitoring at the Hanford Site 200 Area State-Approved Land Disposal Site--FY 1999. D. B. Barnett, Pacific Northwest National Laboratory, Richland, Washington.

PNNL-13077. 1999. Results of 1999 Spectral GammaRay and Neutron Moisture Monitoring of Boreholes at Specific Retention Facilities in the 200 East Area, Hanford Site. D. G. Horton and R. R. Randall, Pacific Northwest National Laboratory, Richland, Washington.

PNNL-13080. 2000. Hanford Site Groundwater: Settings, Sources, and Methods. M. J. Hartman (ed.), Pacific Northwest National Laboratory, Richland, Washington.

PNNL-13116. 2000. Hanford Site Groundwater Monitoring for Fiscal Year 1999. M. J. Hartman, L. F. Morasch, and W. D. Webber (eds.), Pacific Northwest National Laboratory, Richland, Washington.

PNNL-13185. 2000. Groundwater Quality Assessment Plan for Single-Shell Tank Waste Management Area $U$ at the Hanford Site. F. N. Hodges and C. J. Chou, Pacific Northwest National Laboratory, Richland, Washington.
PNNL-13228. 2000. Evaluation of Elevated Tritium Levels in Groundwater Downgradient from the 618-11 Burial Ground Phase I Investigations. P. E. Dresel, B. A. Williams, J. C. Evans, R. M. Smith, C. J. Thompson, and L. C. Hulstrom, Pacific Northwest National Laboratory, Richland, Washington.

Poreda, R. J., T.E. Cerling, and D. K. Salomon. 1988. "Tritium and Helium Isotopes as Hydrologic Tracers in a Shallow Unconfined Aquifer." Journal of Hydrology 103:1-9.

Record of Decision. 1996. Record of Decision for the 300-FFf-1 and 300-FF-5 Operable Units. State of Washington Department of Ecology, U.S. Environmental Protection Agency, and U.S. Department of Energy, Richland Operations Office, Richland, Washington.

Record of Decision. 1997. Declaration of the Record of Decision, U.S. DOE Hanford 200 Area, Hanford Site, Benton County, Washington (200-UP-1). State of Washington Department of Ecology, U.S. Environmental Protection Agency, and U.S. Department of Energy, Richland Operations Office, Richland, Washington.

Resource Conservation and Recovery Act. 1976. Public Law 94-580, as amended, 90 Stat. 2795, 42 USC 6901 et seq.

RHO-BWI-ST-5. 1979. Hydrologic Studies Within the Columbia Plateau, Washington: An Integration of Current Knowledge. R. E. Gephart, R. C. Arnett, R. G. Baca, L. S. Leonhart, F. A. Spane, Jr., D. A. Palumbo, and S. R. Strait, Rockwell Hanford Operations, Richland, Washington.

RHO-RE-ST-12 P. 1984. An Assessment of Aquifer Intercommunication in the B Pond - Gable Mountain Pond Area of the Hanford Site. M. J. Graham, G. V. Last, and K. R. Fecht, Rockwell Hanford Operations, Richland, Washington. 
RHO-ST-42. 1981. Hydrology of the Separations Area. M. J. Graham, M. D. Hall, S. R. Strait, and W. R. Brown, Rockwell Hanford Operations, Richland, Washington.

Soldat, J. K. 1976. "Radiation Doses from Iodine129 in the Environment." Health Physics 30:61-70.

SW-846. 1986. Test Methods for Evaluating Solid Wastes: Physical/Chemical Methods, 3rd ed. Office of Solid Waste and Emergency Response, U.S. Environmental Protection Agency, Washington, D.C.

Ward, A. L., and G. W. Gee. 1997., "Performance Evaluation of a Field-Scale Surface Barrier." J.Environ. Qual. 26:694-705.

WAC 173-303. "Dangerous Waste Regulations." Washington Administrative Code, Olympia, Washington.

WAC 173-303-645. "Releases from Regulated Units." Washington Administrative Code, Olympia, Washington.

WAC 173-304. "Minimal Functional Standards for Solid Waste Handling." Washington Administrative Code, Olympia, Washington.

Washington State Department of Ecology. 1994. Dangerous Waste Portion of the Resource Conservation and Recovery Act Permit for the Treatment, Storage, and Disposal of Dangerous Waste, as amended. Permit Number WA7890008967, effective September 28, 1994, Olympia, Washington.

Washington State Department of Ecology, U.S. Environmental Protection Agency, and U.S. Department of Energy. 1998. Hanford Federal Facility Agreement and Consent Order. Document No. 89-10, Rev. 5 (The Tri-Party Agreement), Olympia, Washington.

WHC-EP-0527-2. 1993. Environmental Releases for Calendar Year 1992. L. P. Diediker and D. J. Rokkan, Westinghouse Hanford Company, Richland, Washington.
WHC-MR-0227. 1991. Tank Wastes Discharged Directly to the Soil at the Hanford Site. J. L. Waite, Westinghouse Hanford Company, Richland, Washington.

WHC-MR-0388. 1992. Past Practices Technical Characterization Study - 300 Area - Hanford Site. M. S. Gerber, Westinghouse Hanford Company, Richland, Washington.

WHC-MR-0391. 1992. Field Trip Guide to the Hanford Site. S. P. Reidel, K. A. Lindsey, and K. R. Fecht, Westinghouse Hanford Company, Richland, Washington.

WHC-SD-EN-AP-024, Rev. 1. 1991. Interim Status Groundwater Monitoring Plan for the 200 East Area Liquid Effluent Retention Facility. J. S. Schmid, Westinghouse Hanford Company, Richland, Washington.

WHC-SD-EN-AP-038, Rev. 2. 1996. Groundwater Monitoring Plan for the 1301-N, 1325-N, and 1324-N/ NA Sites. M. J. Hartman, Westinghouse Hanford Company, Richland, Washington.

WHC-SD-EN-AP-132, Rev. 0. 1993. Interim-Status Groundwater Quality Assessment Plan for the Single Shell Tank Waste Management Areas T and TX-TY. J. A. Caggiano and C.J.Chou, Westinghouse Hanford Company, Richland, Washington.

WHC-SD-EN-AP-185, Rev. 0. 1995. Groundwater Monitoring Plan for the 300 Area Process Trenches. J. W. Lindberg, C. J. Chou, and V. G. Johnson, Westinghouse Hanford Company, Richland, Washington.

WHC-SD-EN-AP-191. 1996. Assessment Groundwater Monitoring Plan for Single-Shell Tank Waste Management Area S-SX. J. A. Caggiano, Westinghouse Hanford Company, Richland, Washington.

WHC-SD-EN-EV-003, Rev. 1. 1992. Results of Groundwater Quality Assessment Monitoring at the 1301-N and 1324-N/NA Facilities. M. J. Hartman, Westinghouse Hanford Company, Richland, Washington. 
WHC-SD-EN-RPT-004. 1993. Summary of 100-B/C Reactor Operations and Resultant Wastes, Hanford Site. M. S. Gerber, Westinghouse Hanford Company, Richland, Washington.

WHC-SD-EN-TI-014. 1992. Hydrogeologic Model for the 200 West Groundwater Aggregate Area. M. P. Connelly, B. H. Ford, and J. V. Borghese, Westinghouse Hanford Company, Richland, Washington.

WHC-SD-EN-TI-019. 1992. Hydrogeologic Model for the 200 East Groundwater Aggregate Area. M. P. Connelly, B. H. Ford, J. W. Lindberg, S. J. Trent, and C. D. Delaney, Westinghouse Hanford Company, Richland, Washington.

WHC-SD-EN-TI-101. 1993. Carbon Tetrachloride Evaporative Losses and Residual Inventory Beneath 200 West Area at the Hanford Site. Westinghouse Hanford Company, Richland, Washington.
WHC-SD-EN-TI-248. 1994. 1994Conceptual Model of the Carbon Tetrachloride Contamination in the 200 West Area at the Hanford Site. V. J. Rohay, K. J. Swett, and G. V. Last, Westinghouse Hanford Company, Richland, Washington.

WHC-SD-ENV-AP-002, Rev. 0. 1996. Assessment Groundwater Monitoring Plan for SST Waste Management Area B-BX-BY. J. A. Caggiano, Westinghouse Hanford Company, Richland, Washington.

WHC-SD-LEF-EV-001, Rev. 0. 1996. Effluent Variability Study REsults for the 200 Area Effluent Disposal Facility (W-049H). C. J. Chou and V. G. Johnson, Westinghouse Hanford Company, Richland, Washington. 


\subsection{Other Hanford Site Environmental Programs}

A t the $\mathrm{H}$ anford Site, a variety of environmental activities are performed to comply with laws and regulations, to enhance environmental quality, and to monitor the impact of environmental pollutants from site operations.

This section summarizes activities conducted in 1999 to monitor the climatology and meteorology, to assess the status of the ecosystem, to monitor and manage cultural resources, to actively involve the public in environmental surveillance activities, to control the incidents of radioactive contamination spread by plants or animals, and to control noxious weeds on the $\mathrm{H}$ anford Site. 


\title{
7.1 Climate and Meteorology
}

\author{
D. J. H oitink
}

Meteorological measurements are taken to support Hanford Site emergency preparedness and response, operations, and atmospheric dispersion calculations for dose assessments (Appendix D, Tables D.5 and D.7 through D.9). Support is provided through weather forecasting and maintenance and distribution of climatological data. Forecasting is provided to help manage weather-dependent operations. Climatological data are provided to help plan weather-dependent activities and are used as a resource to assess the environmental effects of site operations.

Local data to support the Hanford Meteorology Station operations are provided via the Hanford Meteorological Monitoring Network. This network consists of 30 remote monitoring stations that transmit data to the Hanford Meteorology Station via radio telemetry every 15 minutes. There are twentyseven 9-meter (30-foot) towers and three 61-meter (200-foot) towers. Meteorological parameters collected at these stations include wind speed, wind direction, temperature, precipitation, atmospheric pressure, and relative humidity; however, not all parameters are collected at all stations. Figure 7.1.1 shows the wind roses (diagrams showing direction and frequencies of wind) measured at a height of 9 meters (30 feet) for the network.

The Cascade Range, beyond Yakima to the west, greatly influences the climate of the Hanford Site area by means of its rain shadow effect. The regional temperatures, precipitation, and winds are greatly affected by the presence of mountain barriers. The Rocky Mountains and ranges in southern British Columbia are effective in protecting the inland basin from the more severe cold polar air masses moving southward across Canada and winter storms associated with them.
The Hanford Meteorology Station is located on the 200 Areas plateau, where the prevailing wind direction is from the northwest during all months of the year. The secondary wind direction is from the southwest. Summaries of wind direction indicate that winds from the northwest quadrant occur most often during winter and summer. During spring and fall, the frequency of southwesterly winds increases, with a corresponding decrease in the northwesterly flow. Monthly average wind speeds are lowest during winter months, averaging 10 to 11 kilometers per hour (6 to 7 miles per hour), and highest during summer, averaging 13 to 15 kilometers per hour ( 8 to 9 miles per hour). Wind speeds that are well above average are usually associated with southwesterly winds. However, summertime drainage winds are generally northwesterly and frequently reach 50 kilometers per hour ( 30 miles per hour). These winds are most prevalent over the northern portion of the site.

Atmospheric dispersion is a function of wind speed, wind duration and direction, atmospheric stability, and mixing depth. Dispersion conditions are generally good if winds are moderate to strong, the atmosphere is of neutral or unstable stratification, and there is a deep mixing layer. Good dispersion conditions associated with neutral and unstable stratification exist approximately $57 \%$ of the time during summer. Less favorable conditions may occur when wind speed is light and the mixing layer is shallow. These conditions are most common during winter, when moderately to extremely stable stratification exists $\sim 66 \%$ of the time. Occasionally, there are extended periods of poor dispersion conditions, primarily during winter, that are associated with stagnant air in stationary high-pressure systems. 


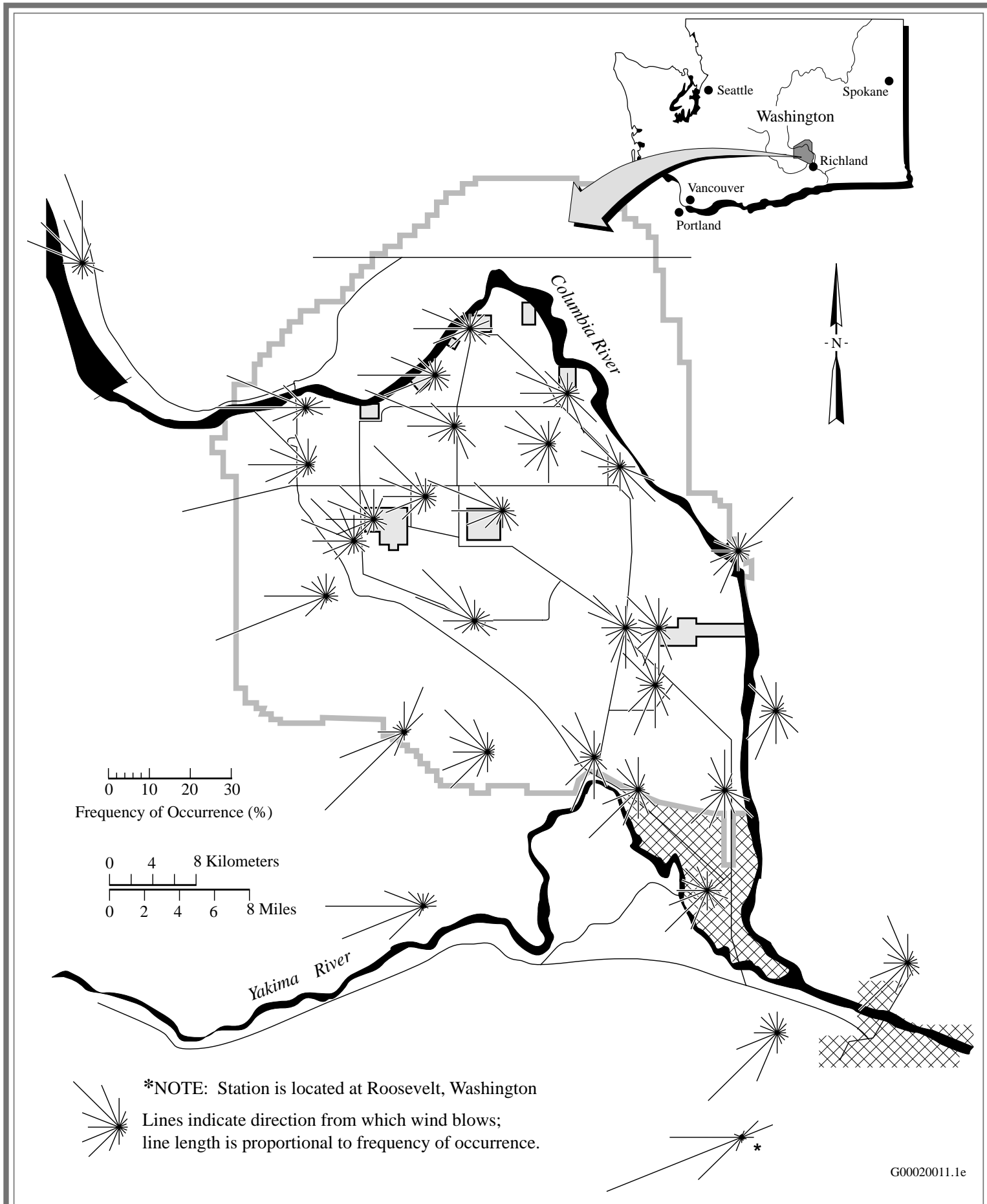

Figure 7.1.1. Hanford Meteorological Monitoring Network Wind Roses (measured at a height of 9 meters [30 feet]), 1999. Individual lines indicate direction from which wind blows. 


\subsubsection{Historical Information}

Daily and monthly averages and extremes of temperature, dew point temperature, and relative humidity for 1945 through 1999 are reported in PNNL-13117. From 1945 through 1999, the record maximum temperature was $45^{\circ}$ Celsius $\left(113^{\circ} \mathrm{Fahr}\right.$ enheit) recorded in August 1961, and the record minimum temperature was $-30.6^{\circ}$ Celsius $\left(-23^{\circ}\right.$ Fahrenheit) in February 1950. Normal monthly average temperatures ranged from a low of $-0.4^{\circ}$ Celsius $\left(31.3^{\circ}\right.$ Fahrenheit) in January to a high of $24.6^{\circ}$ Celsius $\left(76.2^{\circ}\right.$ Fahrenheit) in July. During winter, the highest monthly average temperature at the Hanford Meteorology Station was $6.9^{\circ}$ Celsius (44.5 $5^{\circ}$ Fahrenheit) in February 1991, and the record lowest was $-11.1^{\circ} \mathrm{Celsius}\left(12.1^{\circ} \mathrm{Fahrenheit}\right.$ ) in January 1950. During summer, the record maximum monthly average temperature was $27.9^{\circ}$ Celsius
(82.2 ${ }^{\circ}$ Fahrenheit) in July 1985, and the record minimum was $17.2^{\circ}$ Celsius (63.0 $0^{\circ}$ Fahrenheit) in June 1953. The average annual relative humidity at the Hanford Meteorology Station is 54\%. Humidity is highest during winter, averaging $~ 76 \%$, and lowest during summer, averaging $\sim 36 \%$. Average annual precipitation at the Hanford Meteorology Station is 15.9 centimeters (6.26 inches). The wettest year on record, 1995, received 31 centimeters (12.3 inches) of precipitation; the driest, 1976, received 8 centimeters (2.99 inches). Most precipitation occurs during late autumn and winter, with more than half of the annual amount occurring from November through February. The snowiest winter on record, 19921993, received 142.5 centimeters (56.1 inches) of snow.

\subsubsection{Results of 1999 Monitoring}

1999 was slightly warmer than normal and precipitation was much below normal.

The average temperature for 1999 was $12.4^{\circ}$ Celsius (54.4 $4^{\circ}$ Fahrenheit), which was $0.6^{\circ}$ Celsius $\left(1.1^{\circ}\right.$ Fahrenheit $)$ above normal $\left(11.8^{\circ}\right.$ Celsius [53.3 Fahrenheit]). Six months during 1999 were warmer than normal, and six months were cooler than normal. January had the greatest positive departure, $3.9^{\circ}$ Celsius (7.0 Fahrenheit); and May, at $1.9^{\circ}$ Celsius ( $3.4^{\circ}$ Fahrenheit) below normal, had the greatest negative departure. The maximum temperature of $17.8^{\circ}$ Celsius (64 Fahrenheit) on August 31, 1999 was the coldest maximum temperature ever recorded during the month of August; and the maximum temperature of $24.4^{\circ}$ Celsius $\left(74^{\circ}\right.$ Fahrenheit) on November 13, 1999 was the warmest maximum temperature ever recorded during the month of November.

Precipitation for 1999 totaled 9.6 centimeters (3.75 inches), $60 \%$ of normal (15.9 centimeters [6.26 inches]) and was the fourth driest year on record. In addition, only 1.5 centimeters ( 0.6 inch) of snow were recorded (compared to an annual normal snowfall of 35.1 centimeters [13.8 inches]). The month of September received no precipitation whatsoever.

1999 was the windiest year on record, with an average wind speed of 14.2 kilometers per hour (8.8 miles per hour), which was 1.8 kilometers per hour (1.1 miles per hour) above normal. The peak gust for the year was 105 kilometers per hour (65 miles per hour) on February 6. February 1999 tied April 1972 as the windiest month on record, averaging 17.9 kilometers per hour (11.1 miles per hour). 1999 established a new record for days with wind gusts greater than 40 kilometers per hour (25 miles per hour) with 192; the previous record was 190 such days in 1953. Figure 7.1.1 shows the 1999 wind roses (diagrams showing direction and frequencies of wind) measured at a height of 9 meters (30 feet) for the 30 meteorological monitoring stations on and around the Hanford Site. There was 
one dust storm recorded at the Hanford Meteorology Station during 1999. It occurred on February 2. There have been an average of five dust storms per year at the Hanford Meteorology Station during the entire period of record (1945-1999).
Table 7.1.1 provides monthly and annual climatological data from the Hanford Meteorology Station for 1999. 
Table 7.1.1. Monthly Climatological Data from the Hanford Meteorology Station, 1999

Hanford Meteorology Station, 40 kilometers (25 miles) northwest of Richland, Washington,

latitude $46^{\circ} 34 ' \mathrm{~N}$, longitude $119^{\circ} 35^{\prime} \mathrm{W}$, elevation 223 meters ( 733 feet)

\begin{tabular}{|c|c|c|c|c|c|c|c|c|c|c|c|c|c|c|c|c|c|c|c|}
\hline \multirow[b]{3}{*}{$\begin{array}{l}\text { F } \\
\text { 든 }\end{array}$} & \multicolumn{8}{|c|}{ Temperatures, ${ }^{\circ} \mathrm{C}$} & \multicolumn{4}{|c|}{ Precipitation $(\mathrm{cm})$} & \multirow{2}{*}{\multicolumn{2}{|c|}{$\begin{array}{c}\text { Relative } \\
\text { Humidity } \\
\text { (\%) }\end{array}$}} & \multicolumn{5}{|c|}{ 15-m Wind ${ }^{(a)}$} \\
\hline & \multicolumn{4}{|c|}{ Averages } & \multicolumn{4}{|c|}{ Extremes } & \multirow[b]{2}{*}{$\begin{array}{l}\overline{8} \\
8 \\
\end{array}$} & \multirow[b]{2}{*}{ 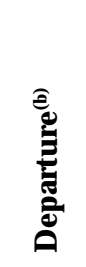 } & \multicolumn{2}{|c|}{ Snowfall } & & & \multirow[b]{2}{*}{ 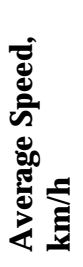 } & \multirow[b]{2}{*}{$\begin{array}{l}\frac{\bar{g}}{0} \\
\frac{0}{2} \\
\frac{0}{0} \\
\frac{0}{0} \\
0\end{array}$} & \multicolumn{3}{|c|}{ Peak Gusts } \\
\hline & 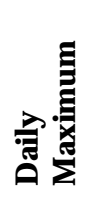 & 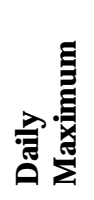 & 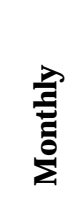 & $\begin{array}{l}\frac{\mathrm{g}}{\mathrm{d}} \\
\frac{2}{2} \\
\frac{t}{\mathrm{~d}} \\
\frac{0}{0}\end{array}$ & $\begin{array}{l}\text { ty } \\
\frac{c}{5} \\
\text { 음 }\end{array}$ & 壳 & せ্ & 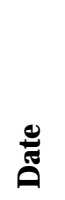 & & & $\begin{array}{l}\overline{\mathbb{B}} \\
0 \\
-\end{array}$ & 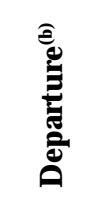 & 产 & 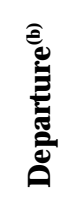 & & & 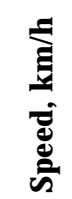 & 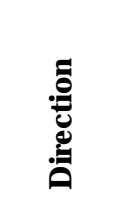 & 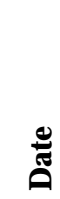 \\
\hline $\mathrm{J}$ & 8.1 & -1.1 & 3.5 & +3.9 & 16.7 & 14 & -7.8 & 3 & 2.3 & +0.2 & $\mathrm{~T}^{(\mathrm{c})}$ & -9.9 & 74.0 & -2.4 & 12.4 & +1.9 & 88 & $\mathrm{~S}$ & 29 \\
\hline $\mathrm{F}$ & 10.4 & 0.4 & 5.4 & +2.1 & 16.7 & 24 & -6.7 & 11 & 1.8 & +0.2 & $\mathrm{~T}$ & -5.1 & 61.5 & -8.8 & 17.9 & +6.3 & 105 & SSW & 6 \\
\hline $\mathrm{M}$ & 14.1 & 1.8 & 7.9 & +0.4 & 23.9 & 20 & -3.9 & 2 & 0.2 & -1.0 & 0 & -0.8 & 52.8 & -3.1 & 15.0 & +1.6 & 84 & SW & 29 \\
\hline A & 18.6 & 2.4 & 10.5 & -1.0 & 27.8 & 24 & -3.9 & 10 & $\mathrm{~T}$ & -1.0 & 0 & $-\mathrm{T}$ & 43.7 & -3.5 & 14.2 & -0.3 & 64 & NW & 2 \\
\hline $\mathrm{M}$ & 22.1 & 6.6 & 14.4 & -1.9 & 36.1 & 24 & -1.1 & 8 & 0.9 & -0.4 & 0 & 0 & 41.0 & -1.7 & 16.7 & +2.1 & 72 & WNW & 25 \\
\hline $\mathrm{J}$ & 27.4 & 11.9 & 19.7 & -1.3 & 38.9 & 15 & 3.3 & 6 & 0.8 & -0.2 & 0 & 0 & 39.8 & +1.0 & 15.6 & +0.8 & 68 & W & 8 \\
\hline $\mathrm{J}$ & 31.6 & 14.8 & 23.2 & -1.3 & 40.6 & 28 & 7.2 & 3 & 0.2 & -0.3 & 0 & 0 & 34.2 & +0.7 & 15.1 & +1.0 & 71 & NW & 24 \\
\hline A & 32.6 & 16.5 & 24.6 & +0.6 & 38.3 & 2 & 6.1 & 31 & 1.4 & +0.8 & 0 & 0 & 40.9 & +5.1 & 13.2 & +0.5 & 71 & NW & 29 \\
\hline S & 27.4 & 9.2 & 18.3 & -0.4 & 32.8 & $22^{(\mathrm{d})}$ & 2.2 & 28 & 0 & -0.8 & 0 & 0 & 36.3 & -6.7 & 12.4 & +0.5 & 69 & WSW & 25 \\
\hline $\mathrm{O}$ & 18.2 & 3.9 & 11.0 & -0.6 & 27.2 & 13 & -2.8 & 27 & 1.2 & +0.2 & 0 & -0.2 & 49.4 & -5.8 & 12.4 & +1.9 & 74 & W & 31 \\
\hline $\mathrm{N}$ & 12.6 & 2.7 & 7.7 & +3.1 & 24.4 & 13 & -3.3 & 3 & 0.7 & -1.7 & 0 & -4.6 & 72.2 & -1.2 & 12.1 & +1.8 & 66 & SW & 8 \\
\hline $\mathrm{D}$ & 6.9 & -0.6 & 3.2 & +3.5 & 16.7 & 16 & -6.7 & 8 & 0.2 & -2.4 & 1.5 & -13.0 & 75.4 & -4.9 & 12.1 & +2.6 & 100 & WSW & 18 \\
\hline$Y^{(\mathrm{e})}$ & 19.2 & 5.7 & 12.4 & +0.6 & 40.6 & $\begin{array}{c}\text { Jul } \\
28\end{array}$ & -7.8 & $\begin{array}{r}\mathrm{Jan} \\
3\end{array}$ & 9.6 & -6.4 & 1.5 & -33.6 & 51.8 & -2.5 & 14.2 & +1.8 & 105 & SSW & $\begin{array}{r}\text { Feb } \\
6\end{array}$ \\
\hline
\end{tabular}

NOTE: See Table H.2, Conversion Table in "Helpful Information" for unit conversion information.

(a) Measured on a tower 15 meters (50 feet) above the ground.

(b) Departure columns indicate positive or negative departure of meteorological parameters from 30-year (1961-1990) climatological normals.

(c) Trace.

(d) Latest of several occurrences.

(e) Yearly averages, extremes, and totals. 


\title{
7.2 Ecosystem Monitoring (Plants and Wildlife)
}

\author{
L. L. C adwell, D. D. Dauble, J. L. Downs, M. A. Simmons, and B. L. T iller
}

The Hanford Site is a relatively large, undisturbed area of shrub-steppe that contains a rich, natural diversity of plant and animal species adapted to the region's semiarid environment. Terrestrial vegetation on the site consists of ten major plant communities: 1) sagebrush/bluebunch wheatgrass, 2) sagebrush/cheatgrass or sagebrush/Sandberg's bluegrass, 3) sagebrush-bitterbrush/cheatgrass, 4) grease wood/cheatgrass-saltgrass, 5) winterfat/Sandberg's bluegrass, 6) thyme buckwheat/Sandberg's bluegrass, 7) cheatgrass-tumble mustard, 8) willow or riparian, 9) spiny hopsage, and 10) sand dunes (PNNL-6415, Rev. 12). Over 600 species of plants have been identified on the site and recent work by The Nature Conservancy of Washington has further delineated thirty distinct plant community types (Nature Conservancy 1999) from within those ten major communities.

There are two types of natural aquatic habitats on the Hanford Site. One is the Columbia River and associated wetlands, and the second is upland aquatic sites. The upland sites include small spring streams and seeps located mainly on the Fitzner/Eberhardt Arid Lands Ecology Reserve on Rattlesnake Mountain (e.g., Rattlesnake Springs, Dry Creek, Snively Springs) and West Lake. West Lake is a small, natural pond near the 200 Areas; the level of the pond has been affected by operational aqueous discharges to the soil column in the 200 Areas.

\subsubsection{Chinook Salmon}

Chinook salmon are an important resource in the Pacific Northwest; they are caught commercially and for recreation. Salmon are also of cultural
More than 1,000 species of insects (Soll and Soper 1996), 3 species of reptiles and amphibians (PNNL-6415, Rev. 12), 44 species of fish (Gray and Dauble 1977; PNNL-6415, Rev. 12), 214 species of birds (Soll and Soper 1996), and 39 species of mammals (PNNL-6415, Rev. 12) have been found on the Hanford Site. Deer and elk are the major large mammals, coyotes are plentiful, and the Great Basin pocket mouse is the most abundant mammal. Waterfowl are numerous on the Columbia River, and the bald eagle is a regular winter visitor along the river. Salmon and steelhead are the fish species of most interest to sport fishermen and are commonly consumed by local Native American tribes.

Although no Hanford Site plant species have been identified from the federal list of threatened and endangered species (50 CFR 17.12), biodiversity inventory work conducted in collaboration with The Nature Conservancy of Washington identified more than 100 populations of 31 different rare plant taxa (Hall 1998). The U.S. Fish and Wildlife Service lists the bald eagle as threatened (50 CFR 17.11). The bald eagle is a common winter resident and has initiated nesting on the site but has never successfully produced offspring. Several species of mammals, birds, molluscs, reptiles, and invertebrates occurring on the site are candidates for formal listing under the Endangered Species A ct. Appendix F lists special-status species that could occur on the site.

importance to Native American tribes. Today, the most important natural spawning area in the mainstem Columbia River for the fall chinook salmon is 
found in the free-flowing Hanford Reach. In the early years of the Hanford Site, there were few spawning nests (redds) in the Hanford Reach (Figure 7.2.1). Between 1943 and 1971, a number of dams were constructed on the Columbia River, their reservoirs

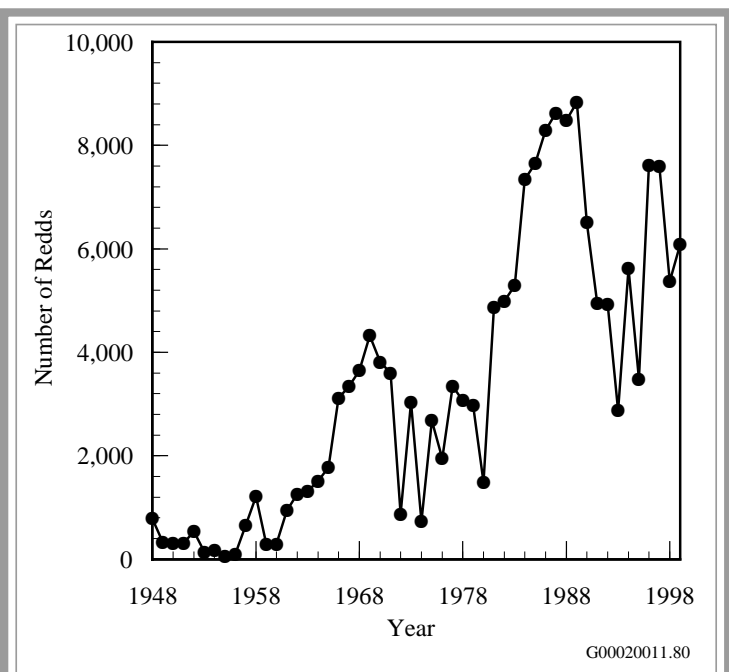

Figure 7.2.1. Chinook Salmon Spawning Redds in the Hanford Reach, 1948 Through 1999

\subsubsection{Bald Eagle}

The bald eagle is listed as a federally threatened species (50 CFR 17.11) and also a Washington State threatened species (Washington State Department of Wildlife 1994); however, the bald eagle is currently under review for removal from federal listing. Protection for bald eagles on the Hanford Site is guided by the management plan contained in DOE/RL-94-150 and coordinated with representatives of the U.S. Fish and Wildlife Service.

Historically, bald eagles have wintered along the Hanford Reach of the Columbia River. The wintering eagles originate from various places, including interior Alaska, British Columbia, Northwest Territories, Saskatchewan, and possibly Manitoba. However, when monitoring began in the early 1960s, numbers were low (Figure 7.2.2). Following passage eliminating most mainstem spawning areas, resulting in increased numbers of salmon spawning in the Hanford Reach. Fisheries management strategies aimed at maintaining spawning populations in the mainstem Columbia River also have contributed to the increases.

The number of fall chinook salmon redds counted in the Hanford Reach by aerial surveys increased during the 1960s, 1970s, and 1980s until reaching a high in 1989 of nearly 9,000 (see Figure 7.2.1). In the early 1990s, redd counts declined to approximately one-third of the 1989 peak, but they appear to have rebounded in recent years. In 1999, 6,068 redds were observed, an increase of 700 from 1998 and $\sim 80 \%$ of the 1996 and 1997 totals. It should be noted that aerial surveys do not yield absolute redd counts because visibility varies, depending on water depth and other factors, and because the number of redds in high-density locations cannot be counted accurately. However, redd survey data generally agree with adult numbers obtained by counting migrating adult fish at fish ladders on the Columbia River.

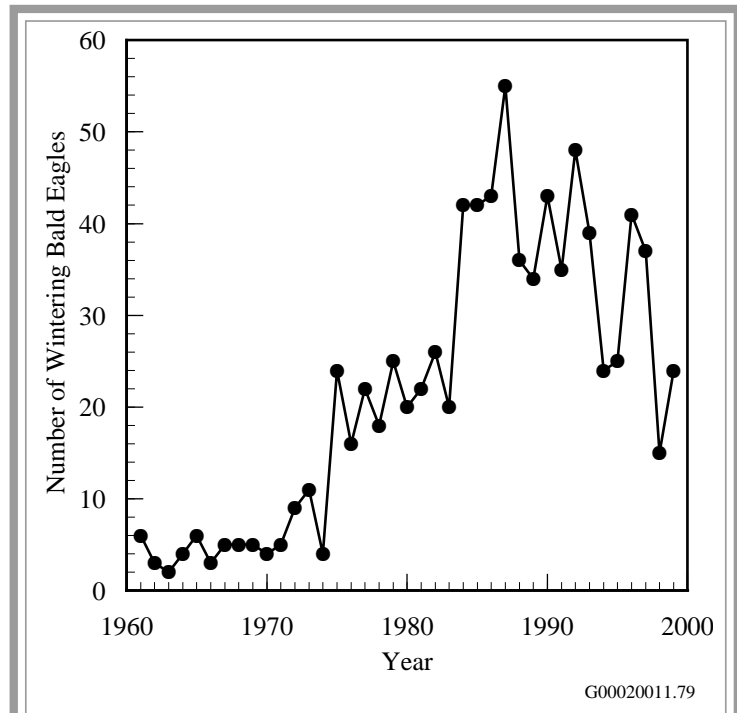

Figure 7.2.2. Bald Eagles Observed Along the Hanford Reach, 1960 Through 1999 
of the Endangered Species A ct, the number of wintering bald eagles generally has increased. Primary reasons for this increase are 1) reduced persecution in Alaska, 2) protection of bald eagles at nesting locations, and 3) nationwide elimination of dichlorodiphenyltrichloroethane (DDT) as an agricultural pesticide in 1972.

The number of nesting eagles was estimated at $\sim 25,000$ in the lower 48 states when the bird was adopted as our national symbol in 1782 . From fewer than 450 nesting pairs in the early 1960s, there are now more than 4,000 nesting pairs in the lower 48 states. When eagles were federally listed as endangered, recovery goals included at least 800 nesting pairs collectively in California, Idaho, Montana, Oregon, Utah, and Washington (i.e., the Pacific states). In 1997, the wildlife experts estimated more than 1,200 nesting pairs in the Pacific states region. Only two pairs of nesting eagles are known to occur in southeastern Washington.

A maximum count of 24 eagles (14 adults and 10 juveniles) were observed along the Hanford Reach in 1999. Only four full surveys were successfully completed due to adverse weather and equipment

\subsubsection{Hawks}

The undeveloped land of the semiarid areas of the Hanford Site provides nest sites and food for three species of migratory buteo hawks: Swainson's, red-tailed, and ferruginous. Under natural conditions, these hawks nest in trees, on cliffs, or on the ground. Power-line towers and poles also can serve as nest sites. These structures are used extensively by nesting hawks on the site because of the relative scarcity of trees and cliffs. The ferruginous hawk is a Washington State threatened species (Washington State Department of Wildlife 1994) as well as a U.S. Fish and Wildlife Service candidate species for listing as threatened or endangered (50 CFR 17.11). Approximately one quarter of the state's ferruginous hawk nesting territories are located on the site. delays. However, all four surveys were conducted during December and January when maximum counts typically occur. This maximum count is similar to those seen in the late 1970s and early 1980s and indicates that the low count in 1998 likely reflected changes in food availability near the birds nesting territories and hence winter migration patterns.

Changes in the number of eagles on the Hanford Site generally have corresponded to changes in the number of returning fall chinook salmon, a major fall and winter food source for eagles (compare Figures 7.2.1 and 7.2.2 to see similarity in the patterns of salmon redd counts and bald eagle counts). In 1999, one eagle pair defended an historic nest site through mid-August. This extended nesting attempt by an eagle pair, one of which was just reaching adulthood, suggests the birds were born and raised near this area. A more serious nesting attempt may be made by these birds in 2000 if disturbances, such as recreational fishing activities, do not cause them to abandon the nest site. The pair arrived in November 1999, and a nest site protection buffer of 0.8 kilometer $(0.5$ mile) was initiated for all Hanford activities.

Since 1995, the number of ferruginous hawks nesting on the Hanford Site has ranged from 7 to 12 . There were eight active nests in 1999 and seven were successful. The site continues to provide hawk nesting habitats that are administratively protected from public intrusion. An evaluation of selected aspects of ferruginous hawk ecology on the site and adjacent lands was completed in 1996 (Leary 1996). That work suggested that ferruginous hawks nest on the site because of suitable, disturbance-free habitat, and the proximity of agricultural fields available for foraging.

Ten ferruginous hawks nesting in southcentral Washington State were captured in 1999 and tagged with satellite telemetry transmitters. Seven of the 
ten birds (four females and three males) occupied nest sites located on the Hanford Site. The transmitters send signals to satellites that relay location information back to ground stations. From there, biologists retrieve the information daily via computer, within 2 to 6 hours of signal reception, to track the hawks movements. The 2-year study lead by Washington State Department of Fish and Wildlife, in cooperation with Pacific Northwest National Laboratory, was initiated to learn more about the bird's migration

\subsubsection{Rocky Mountain Elk}

Rocky Mountain elk did not inhabit the Hanford Site when it was established in 1943. Elk were first observed on the Fitzner/Eberhardt Arid Lands Ecology Reserve in the winter of 1972. A few animals stayed and reproduced. Since that time, the herd has grown and now occupies portions of the Hanford Site, the United States Army's Yakima Training Center, and private land along Rattlesnake Ridge. Herd size was estimated from census data at 838 animals prior to the 1999 hunting season (Figure 7.2.3). The 1999 harvest was 101 animals. The larger number of elk harvested in 1999 ( 11\% of the population) may be related to a new hunting strategy that established three separate hunting seasons prior to the opening of deer season. In addition, a dry fall may have resulted in more elk using irrigated private lands adjacent to the Hanford Site during the hunting season. The increased harvest, as well as plans for moving some of the elk off the site in 2000 , should help to alleviate damage to both the natural plant community on the Hanford Site and crops on adjacent private lands in future years.

\subsubsection{Mule Deer}

Epidemiological data and microscopic examinations of mule deer ( 0 docoileus hemionus) residing on the Hanford Site in the early 1990s revealed that nearly one quarter of the male deer (bucks) had undergone some level of testicular atrophy (degeneration of the testicles after maturity). A special study patterns and help recover their declining populations nationwide.

The four radio-equipped female hawks that nested on the Hanford Site left and traveled to southwestern Montana. As of August 1999, the male birds captured on or near the Hanford Site were widely dispersed. One male settled near Edmonton, Alberta; another near Provo, Utah; and another in southwest Montana.

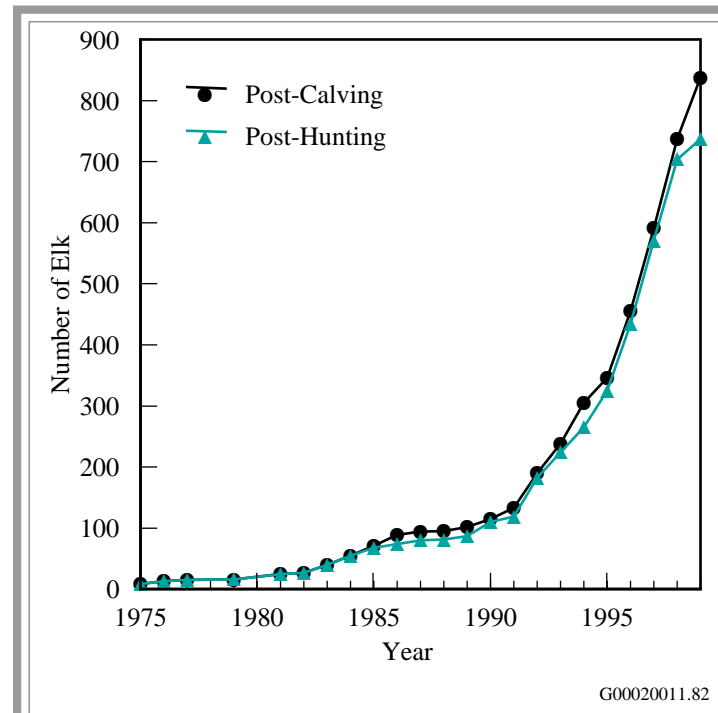

Figure 7.2.3. Elk on the Hanford Site: PostCalving (August through September) and Post-Hunting (December through January) Periods, 1975 Through 1999 was initiated in 1992 to better describe the occurrences on a spatial scale and to examine possible influences of contaminates from the Hanford Site. The results of this study (Tiller et al. 1997, PNNL11518) provide a comprehensive discussion of possible causes of testicular atrophy and the likelihood of 
their influence on the atypical condition in this deer herd. No single factor was identified as the primary cause; however, analyses of affected animal movement patterns revealed no spatial correlations with Hanford Site contamination plumes. In addition, contaminate levels found within the study animals were well below levels that have been shown to cause testicular atrophy in experimental cases. Elevated liver enzyme activations caused from man-made contaminates were also not detected in normal or affected animals.

Dating back to as early as 1916, testicular atrophy has been documented in other deer populations throughout the United States, including Arizona, California, Texas, Colorado, and Ohio. Tiller et al. (1997) described a positive relationship between the frequency of this anomaly and the age class distribution within the population. The 1-year-old bucks essentially were normal, intermediate lesions were detected in one 3-year-old buck, and severely degenerative/atrophic testes occurred in the 5- to 12-year-old bucks. Hunting is not allowed on Hanford Site property and, therefore, provides deer with a unique opportunity for high survival rates in the older (5+ years) age classes, magnifying the frequency of this condition in the Hanford Site deer and making it difficult to compare with other mule deer populations.

PNNL-11518 also describes the reproductive status of the Hanford Site mule deer herd. Examination of several females captured in early spring (January-March) indicated all animals were pregnant. This suggests that although a portion of the males were infertile, enough fertile males were present to maintain reproductive capacity of the herd.

Systematic roadside observations have been conducted during the post-hunting (December-January) periods since 1993. The surveys were conducted primarily to monitor trends in age and sex ratios of mule deer and to examine trends in the relative abundance of deer on the Hanford Site. The precharted route was $\sim 40$ kilometers ( 25 miles) long and was traveled by vehicle at an average speed of 16 kilometers per hour (10 miles per hour). The number of deer observed along the route were recorded. Deer observations were classified as bucks, does, fawns, or unknown. Bucks were further classified as affected or normal during the post-hunting surveys based on antler morphometry (velvetcovered antlers indicate atrophic testes).

Figure 7.2.4 illustrates the observed frequency of bucks (number of affected males per 100 males) that exhibited signs of testicular atrophy (velvet-covered antlers) during the post-hunting roadside surveys. In 1993, Tiller et al. (1997) and PNNL-11518 estimated $15 \%$ of the males observed during deer capture events and radio-tracking efforts exhibited velvetcovered antlers and atrophic (shrunken) testicles. In 1994, systematic survey results suggested $22 \%$ of all bucks exhibited velvet-covered antlers, a direct indicator of testicular dysfunction. The percentage of males considered affected declined during the years 1995 through 1997; however, results in 1998 and 1999 indicated the frequency of the anomaly was back up to near the levels reported in 1993.

This change is likely attributed to an increase in the proportion of older age class males (greater than 5 years of age) alive in the resident deer herd. This is in part due to the fact that ten affected males were removed from the population in the fall of 1995 for histological and chemical analyses. Continued monitoring will help determine if this is indeed the only responsible mechanism for the observed change.

Monitoring the total number of deer observed per survey per year may provide a useful index for changes in the total deer population over time. In addition, fawn recruitment (number of fawns surviving the first year after birth) is helpful to support the observed population trends. PNNL-11518 estimated that 330 deer reside along the riverine regions of the Hanford Site (Benton County side only). This estimate was conducted in 1995.

Figure 7.2.5 illustrates trends in fawn ratios seen per survey from 1993 through 1999. The numbers of 

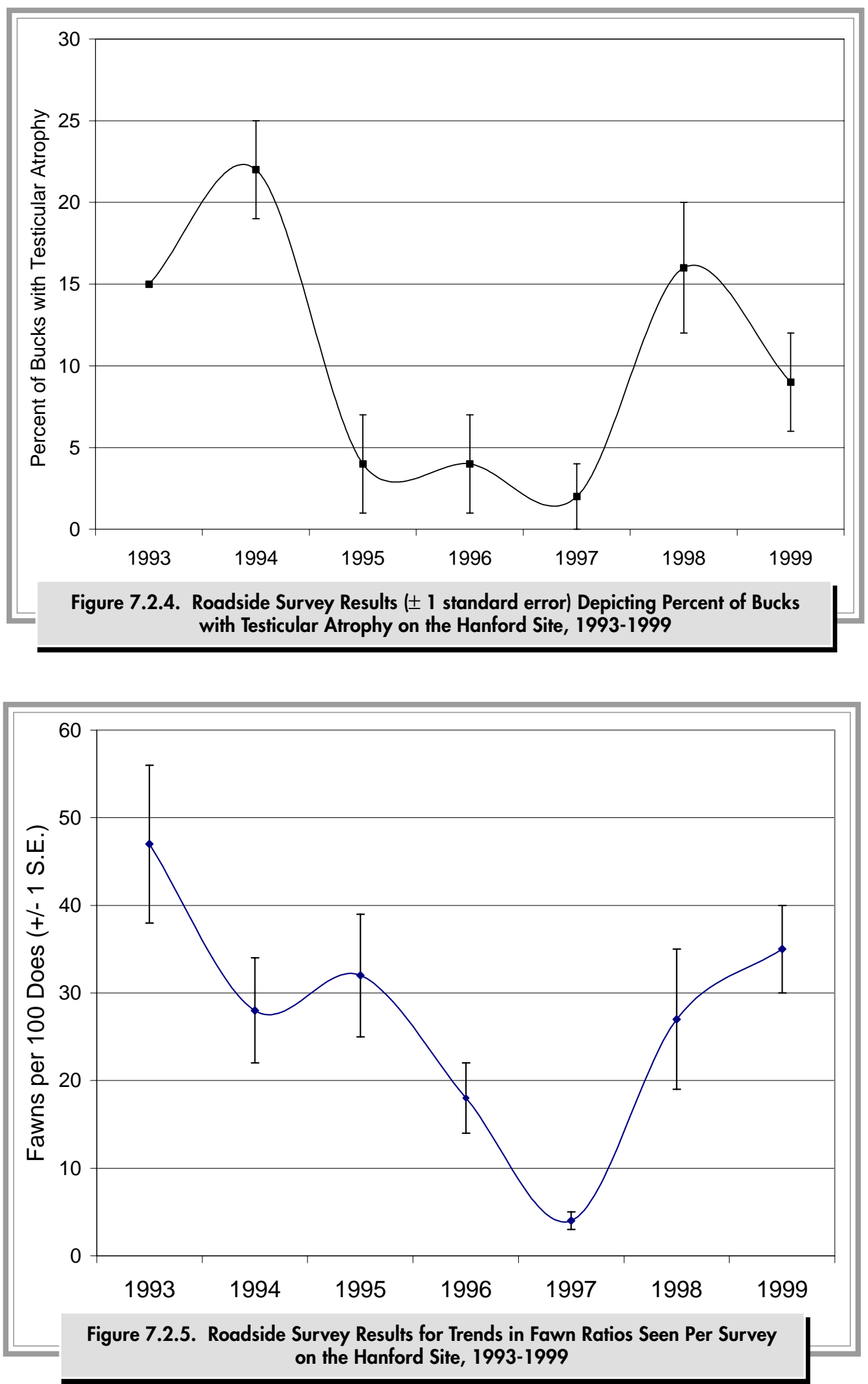
fawns (standardized to 100 does) declined from 1993 hitting a low of 4 fawns per 100 does in 1997 but has rebounded to 35 fawns per 100 does in 1999 .

Roadside surveys are a simple and inexpensive index to monitor for changes in the frequency of testicular atrophy and sex and age composition of the deer along the Hanford riverine corridor. The number of fertile males in this deer herd is such that reproductive capacity has not been impaired. The frequency of affected males along the riverine areas of the Hanford Site was dramatically reduced subsequent to the special investigation and now appears to have increased to near the frequency originally observed in 1993 and 1994 (15 to 20\% of all males).

Observed trends in the fawn recruitment rates suggest patterns of cycling. Pregnancy rates determined in 1993 (PNNL-11518) were at or near 100\% of all deer sampled. The pregnancy rate was sampled in the early stages of gestation and, therefore, does

\subsubsection{Canada Geese}

Nesting Canada geese are valuable recreational and aesthetic resources along the Snake and Columbia Rivers in eastern Washington. Goose nesting surveys began in the 1950s to monitor changes in response to reactor operations (Figure 7.2.6). The gradual decline in the late 1960s and early 1970s is attributed to persistent coyote predation, mostly on the Columbia River islands upstream from the Old Hanford Townsite. Since the 1970s, the majority of nesting geese have shifted from the upstream islands to the downstream islands near Richland, which in recent years have been relatively free from coyote predation. Since 1995, nesting surveys have been conducted every two years.

In 1999, nest positions were identified using a Global Positioning System and eggs were marked with the respective nest number, using a permanent, nontoxic marker. All nests were monitored until the fate of each nest (i.e., eggs hatched, destroyed by predators, flooded, abandoned) was documented. In not reflect subsequent birth rates or survival rates of the fawns. The loss of over $70 \%$ of the in-utero fawns (35 fawns per 100 does surviving past year 1) may be the result of increased neonatal mortality (i.e., fetal resorbtion or abortion) or increased post-natal mortalities (increased predation, old-aged adults) or a combination of all of these factors. Results from the post-hunting surveys in 1999 indicate the number of fawns per 100 does rebounded to the levels seen in the early 1990s and are similar to other deer populations in shrub-steppe ecosystems.

It is unknown whether the observed cycles are the result of natural processes or man-induced change. Continued roadside surveys to monitor the frequency of testicular atrophy and age and sex classes will document the demographical trends of mule deer on the Hanford Site. This data will be necessary to determine the persistence of testicular atrophy in the Hanford mule deer population.

1999, there were 241 nests surveyed, with 193 (80\%) that successfully hatched at least one egg. The fate

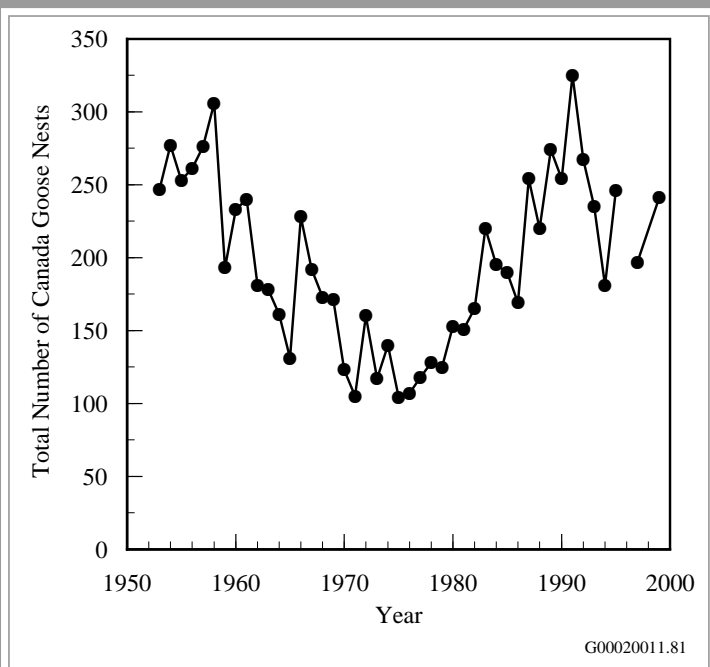

Figure 7.2.6. Number of Canada Goose Nests Along the Hanford Reach, 1954 Through 1999 (no surveys conducted in 1996 and 1998) 
of the remaining nests was affected equally by predation, flooding, abandonment, or other unidentified disturbances. By marking the eggs, the reuse of several nest sites during the year by other nesting geese was documented. Had the eggs not been marked (as in all previous years), it is likely that only a single nesting event would have been recorded at each of these nest sites. Canada goose populations have been successful on the Hanford Reach because the islands are restricted from human uses during the nesting period and because shoreline habitats provide adequate food and cover for successful brood rearing (Eberhardt et al. 1989).

\subsubsection{Plant Biodiversity Inventories}

The Hanford Site contains biologically diverse shrub-steppe plant communities that have been protected from disturbance, except for fire, over the past 55 years. This protection from disturbance has allowed plant species to thrive at Hanford that have been displaced by agriculture and development in other parts of the Columbia Basin. Surveys and mapping efforts conducted by The Nature Conservancy of Washington and the Pacific Northwest National Laboratory Ecosystem Monitoring Project document the occurrence and extent of rare plant populations and plant community types on the Hanford Site (Nature Conservancy). Populations of rare plants include taxa listed by Washington State as endangered, threatened, or sensitive and the locations of species that are listed as review group 1 (i.e., taxa in need of additional field work before status can be determined) (Washington Natural Heritage Program 1997). The data provide information that is critical to site planning processes and land-use policy development.

Figure 7.2.7 shows the known locations of more than 100 rare plant populations of 31 different taxa. Five of these 31 taxa (including the two new species, Eriogonum codium and Lesquerella tuplashensis [Umtanum buckwheat and White Bluffs bladderpod]) have been designated as species of concern in the Columbia River Basin Ecoregion by the U.S. Fish and Wildlife Service. In addition to the rare plant populations, several areas on the Hanford Site are designated as special habitat types with regard to potential occurrence of plant species of concern. These include areas that could support populations of rare annual forbs found in adjacent habitat.
During 1999, a small population of N icotiana attenuata (Torr.) (coyote tobacco) was discovered on the Fitzner/Eberhardt Arid Lands Ecology Reserve. This state-sensitive species had not been documented in Benton County for more than 100 years, and, although historically documented in Franklin County, has not been located in recent years. Surveys in 1999 also indicated significant increases in the numbers of E rigeron piperianus (Piper's daisy) a species of concern occurring in the 200 Areas. Populations of another species of concern in the Columbia River Basin Ecoregion, Rorippa columbiae (persistent sepal yellowcress), still appear to be in decline as a result of the high river flow levels over the past 4 years. Rorippa columbiae is a rhizomatous perennial found in moist soils along the Columbia River within the Hanford Site. This species is often inundated by river flows, but little is known concerning long-term survival under continuous inundation. Surveys in 1999 showed low numbers of stems at the 100-F cobble beach on the Hanford Reach (Table 7.2.1) and no stems have been observed in flower for the past 2 years.

Maps showing the extent and distribution of vegetation cover types found on the Hanford Site have been updated to include recent work delineating the plant communities in central Hanford (Salstrom and Easterly 1997, Nature Conservancy 1999). These were merged with existing map data for the Fitzner/Eberhardt Arid Lands Ecology Reserve, the Wahluke Wildlife Recreation Unit, and the Saddle Mountain Unit. Data included in this representation of vegetation on the site have been developed over several years by staff of the Ecosystem 


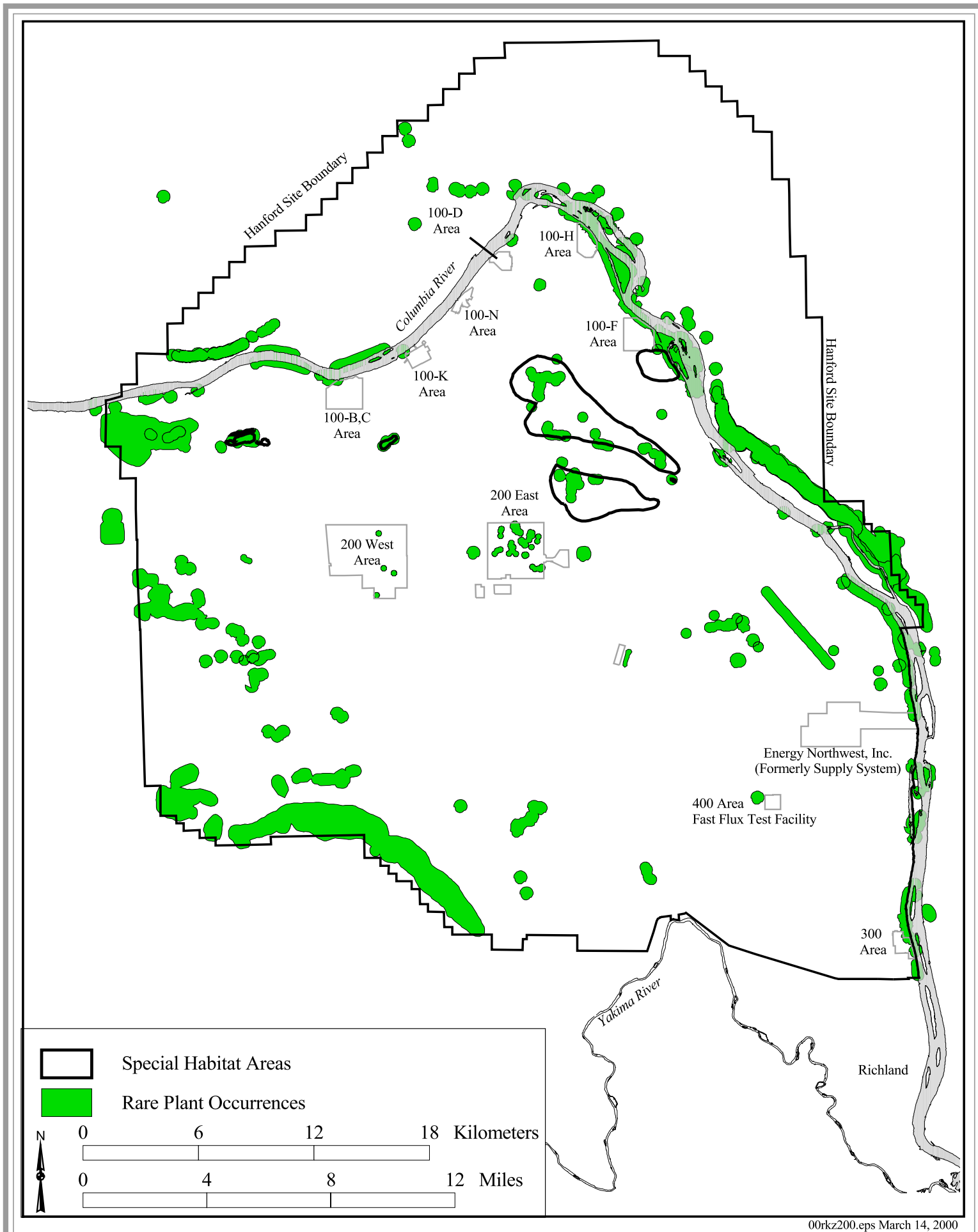

Figure 7.2.7. Rare Plant Locations on the Hanford Site Based on 1994, 1995, 1997, and 1998 Surveys Conducted by The Nature Conservancy of Washington 


\begin{tabular}{|lccc|}
\hline $\begin{array}{c}\text { Table 7.2.1. Numbers of Rorippa columbiae Stems Counted Along the } \\
\text { Hanford Reach of the Columbia River, 1994, 1998, and 1999 }\end{array}$ \\
\hline Survey Location & $\underline{\mathbf{1 9 9 4} \text { Counts }}$ & $\underline{\mathbf{1 9 9 8} \text { Counts }}$ & $\mathbf{1 9 9 9}$ Counts \\
100-F beach & $>15,000$ & 70 & 94 \\
Locke Island & $>10,000$ & 117 & Not surveyed \\
Island $18^{(\text {b) }}$ & $>10,000$ & 0 & Not surveyed \\
\hline (a) High water levels prevented access to populations. & \\
(b) Located in the Columbia River at the 300 Area. & \\
\hline
\end{tabular}

Monitoring Program and contractors for The Nature Conservancy of Washington. These maps are documented in the draft of the Hanford Site Biological

\subsubsection{Sagebrush Die-Off}

Big sagebrush (A rtemisia tridentata subspecies wyomingensis) is the most common shrub component of shrub-steppe vegetation on the Hanford Site. Sagebrush stands represent an important resource for sagebrush-obligate wildlife species such as black-tailed jackrabbits, sage sparrows, sage thrashers, and loggerhead shrikes. Since 1993, site biologists have documented areas of sagebrush die-off in stands near the 100-D Area, the cause of which is not known. Shrub die-offs are not uncommon in the intermountain west and such episodes have been reported from British Columbia, Idaho, Nevada, Utah, and Wyoming (Dobrowolski and Ewing 1990). Die-off of shrubs has been attributed to severe rootlet mortality, root rot, soil salinity and anaerobiosis, and vascular shoot wilt induced by fungal pathogens (Nelson et al. 1989, Weber et al. 1989).

The extent of the die-off on the Hanford Site was mapped and survey data were collected in 1996 and 1997 to establish a baseline for monitoring future expansion of the die-off (PNNL-11700). The resulting report indicated that a total area of 1,776 hectares (4,388 acres) showed evidence of sagebrush decline, with a central portion of 280 hectares (692 acres) where shrub death was estimated to be $\sim 80 \%$ or
Resource Management Plan and can be viewed on the Ecosystem Monitoring Project web page (www.pnl.gov/ ecology/ecosystem/). greater. Observations of shrub vigor (percent canopy defoliation) show continuing declines in shrub health in the die-off areas and along the boundary of the dieoff areas.

Surveys from 1997, 1998, and 1999 of shrubs within the die-off areas indicate that sagebrush plants are continuing to decline. Shrubs along transects were classified by amount of live canopy in the following manner: dead, less than 50\% live canopy, 50 to $90 \%$ live canopy, and more than 90\% live canopy. These measurements indicated that although few shrubs actually died along each measured transect, $10 \%$ to $35 \%$ of shrubs measured declined by at least one category.

During 1999, four of the original six monitoring transects (three in the die-off area and one in a control area) were surveyed to evaluate possible re-establishment of sagebrush seedlings. No seedlings from the 1999 growing season were found on the transects in the die-off area or on the control transect. The absence of seedlings in any one year does not necessarily indicate decline or a change in community dynamics. Germination and seedling establishment are dependent on climatic conditions, particularly precipitation, during the early winter 
and spring growing season. However, no young sagebrush (shrubs less than 30 centimeters [12 inches] tall) were found within 50 meters (164 feet) of transects in the die-off area. In the area surrounding a control transect outside the die-off, shrubs in different age classes were observed. Although not abundant, young shrubs were found within 50 meters (164 feet) of the existing transect. These observations may indicate a need to further investigate the community dynamics and recruitment of sagebrush seedlings in both the die-off areas and sagebrush stands growing in similar soils.

\subsubsection{Other Important Biological Resources}

A number of biological resources have been measured in several distinct community types on site. The resources include vegetation, cryptogamic crusts (mosses and lichens), reptiles, invertebrates, birds, and mammals. Figure 7.2.8 depicts trends in abundance of two bird species within big sagebrush/ bunchgrass communities on the Hanford Site. The sage sparrow and loggerhead shrike are known as sagebrush-dependant species, especially during nesting and brood rearing. Populations of these two species have declined substantially over the past decade within their historical ranges. Results collected from the baseline monitoring on the Hanford
Site from 1996 through 1999 suggest consistency in absolute and relative numbers for shrikes and sage sparrows within the big sagebrush/bunchgrass communities there.

Figure 7.2.9 depicts the composition and abundance of small mammals within active and inactive (unstable and stable) sand dunes, and big sagebrush/ bunchgrass communities (pre- and post-fire) on the Hanford Site. Active sand dunes contained a small mammal species known as the western harvest mouse, which was not found in the inactive dunes. All four communities contained large populations of deer

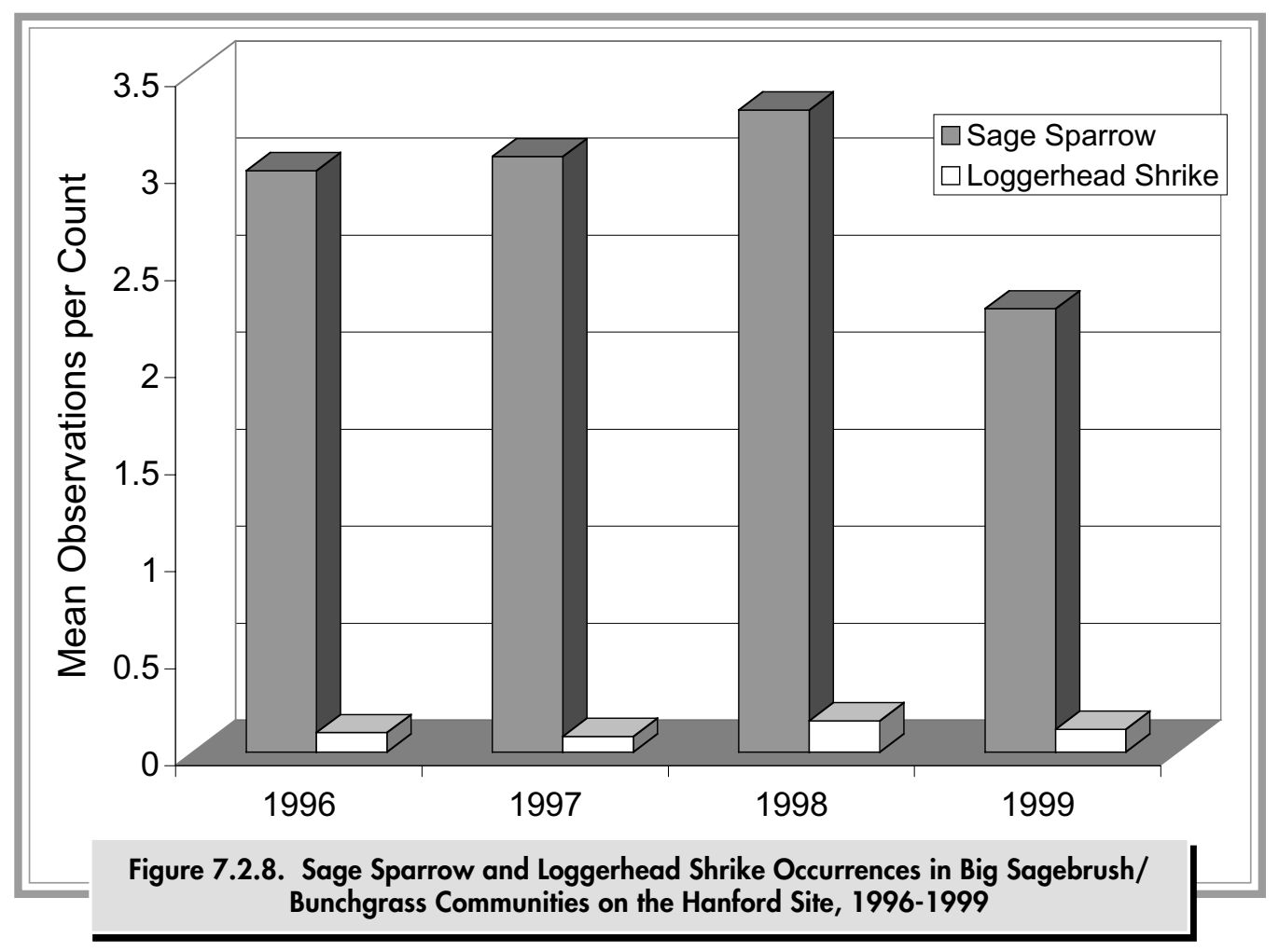




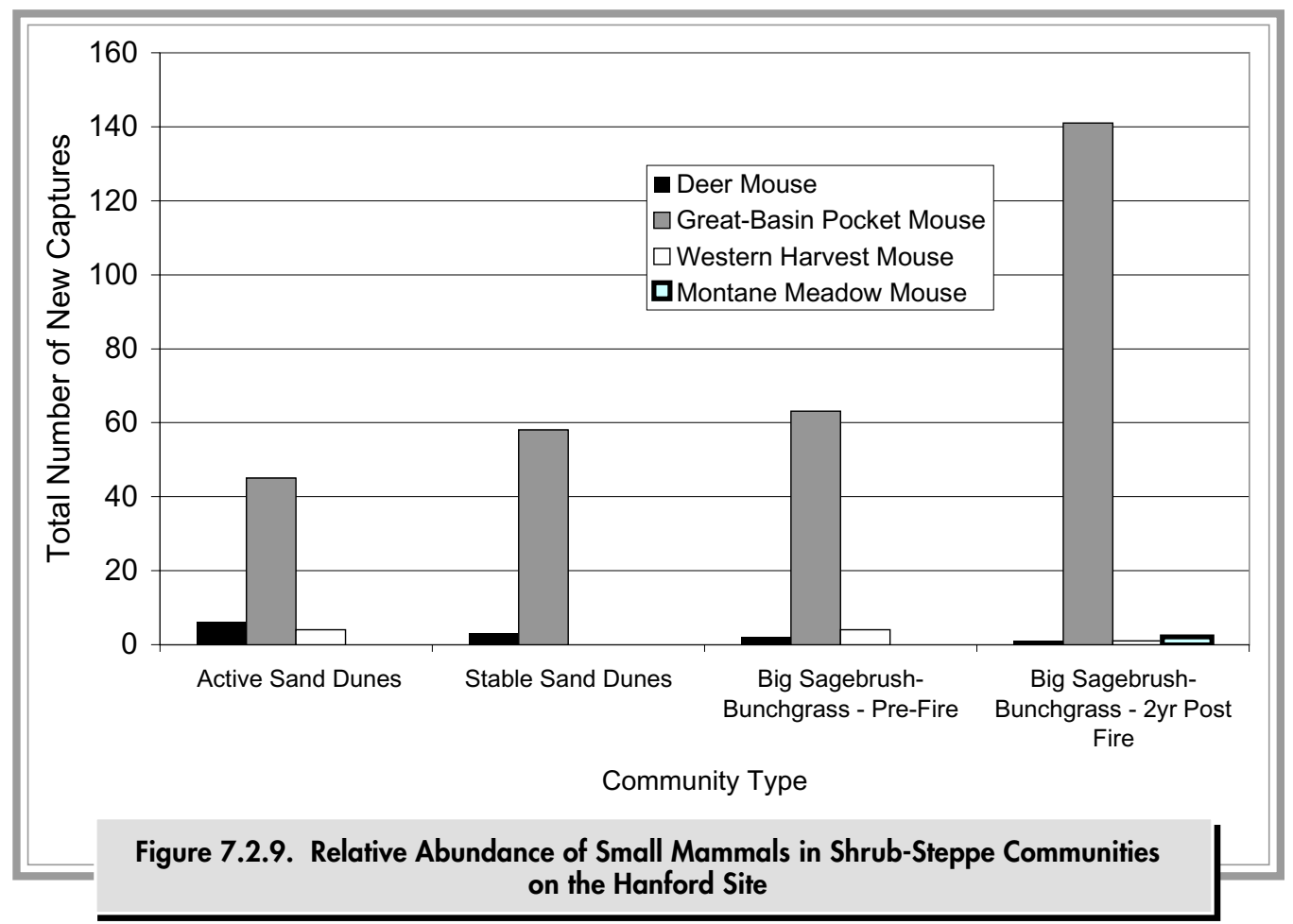

mice and Great-Basin pocket mice as well as other species unique to their communities.

For the first time in over two decades, several confirmed sightings of sage grouse were made on the Fitzner/Eberhardt Arid Lands Ecology Reserve in 1999. This is significant because the Washington State western sage grouse ( $C$ enttocercusurophaqsianus phaios) population has been in decline for many years and the species was recently listed by the Washington State Department of Fish and Wildlife as threatened. Should a sizable population of sage grouse become established on the reserve, the potential for these birds to escape total eradication in Washington State would be increased. 


\title{
7.3 Cultural Resources
}

\author{
M. K. W right and D. W. H arvey
}

The U.S. Department of Energy (DOE), Richland Operations Office, established a cultural resources program in 1987 that is managed by the Hanford Cultural Resources Laboratory as part of Pacific Northwest National Laboratory (PNL-6942). Pacific Northwest National Laboratory, Bechtel Hanford, Inc., and CH2M HILL Hanford, Inc. provided support to DOE for the cultural resources program on the Hanford Site throughout 1999. The U.S. Department of Fish and Wildlife Service and DOE Richland Operations Office, have managed cultural resources on the Fitzner/Eberhardt Arid
Land Ecology Reserve and North Slope areas of the Hanford Site since October 1999. Thus, management of archaeological, historical, and traditional cultural resources at the Hanford Site was provided in compliance with the A merican A ntiquities Preservation $\mathrm{A}$ ct, $\mathrm{H}$ istoric Sites Buildings and $\mathrm{A}$ ntiquities $\mathrm{A}$ ct, $\mathrm{N}$ ational $\mathrm{H}$ istoric Preservation $\mathrm{Act}$, as amended, A rcheological and $\mathrm{H}$ istoric Preservation $\mathrm{A}$ ct, A rchaeological Resources Protection $A$ ct, $N$ ative $A$ merican $G$ raves Protection and Repatriation A ct, and A merican Indian Religious F reedom A ct.

\subsubsection{Monitoring Cultural Resources}

The DOE Richland Operations Office provides the stewardship of all onsite archaeological resources, traditional-use areas, cultural landscapes, Native American cemeteries and places with human remains, paleontological deposits, and historic period properties as manager of the Hanford Site. The DOE Richland Operations Office, therefore, has the responsibility for determining whether its management and protection policies are effective and when they are inadequate. The Hanford Cultural Resources Laboratory has maintained a monitoring program since 1987 to determine the impact of DOE Richland Operations Office policies and to safeguard cultural resources from adverse effects associated with natural processes or unauthorized excavation and collection that violate the A rchaeological R esources P rotection $\mathrm{A}$ ct or the $\mathrm{N}$ ative $\mathrm{A}$ merican $G$ raves Protection and Repatriation $A$ ct.

Monitoring conducted during 1999 focused on four site or place categories: Locke Island's erosion transects, archaeological sites with natural and visitor impacts, buildings, and places with Native American burials.

The first monitoring category, monitoring erosion impacts at Locke Island, has been ongoing since 1994. Locke Island, located in the Hanford Reach of the Columbia River, contains some of the best preserved evidence of prehistoric village sites extant in the Columbia Basin and is included within the Locke Island National Register Archaeological District. The island has sustained loss due to erosion along its eastern shoreline that has affected archaeological materials. Recent studies have shown that this is due to movement of a large landslide on the opposite side of the Columbia River.

In the 1960s and 1970s, intensive irrigation development began to occur east of Locke Island, above the White Bluffs, which form the eastern boundary of the Columbia River channel in this area. As a result, the White Bluffs began to show geological failures as excess irrigation water seeped 
out along the bluffs. One of the largest such failures, known as the "Locke Island Landslide," is located just east of Locke Island. By the early 1980s, this landslide had moved westward into the river channel toward the island and was diverting the current at the island's eastern perimeter. Erosion of the bank in the center of the island accelerated, threatening the cultural resources. By the early 1990s, the erosion had exposed cultural features and artifacts along the bank, leading to the beginning of intermittent monitoring of the cutbank. In 1994, DOE initiated more scheduled, systematic monitoring of island erosion to better understand the physical processes involved as well as mitigate ongoing loss of the archaeological record (PNNL-11970).

Erosion monitoring continued at the Locke Island's erosion transects during 1999. The greatest loss recorded at any one monitoring transect was a total of 2.1 meters (6.9 feet), as measured perpendicularly from the Columbia River (Figure 7.3.1). This amount of erosion was less than the 19.6 meters (64.3 feet) of horizontal cut bank lost to the river at a single transect during 1997 (PNNL-11970). The overall reduction in erosion observed from 1997 to 1999 was likely attributable to several factors including a slow and steady snowmelt following the 19981999 winter season, less dramatic river fluctuations during periods of high water, and a wider channel on the east side of Locke Island (Figure 7.3.2).

Monitoring associated with the second category, archaeological sites with natural and visitor impacts, was initiated in 1998 and expanded in 1999. Four archaeological sites were monitored to gather empirical data about

- the natural characteristics of each site (i.e., landform, stratigraphy)

- the processes adversely impacting the site (such as riverbank erosion, eolian, or human visitation)

- the trends in change at the site (e.g., likelihood of increasing erosion or eventual stability).

Monitoring stations established at each archaeological site in this category facilitated the collection of standardized data that were unique to each site. In 1999, effects observed and measured at these sites were due to recreational use, visitor impact, and/or natural weathering processes. The data collected at these archaeological sites will be used to detect changes that may impact the site, predict outcomes, and proactively manage other similar archaeological sites across the Hanford Site.

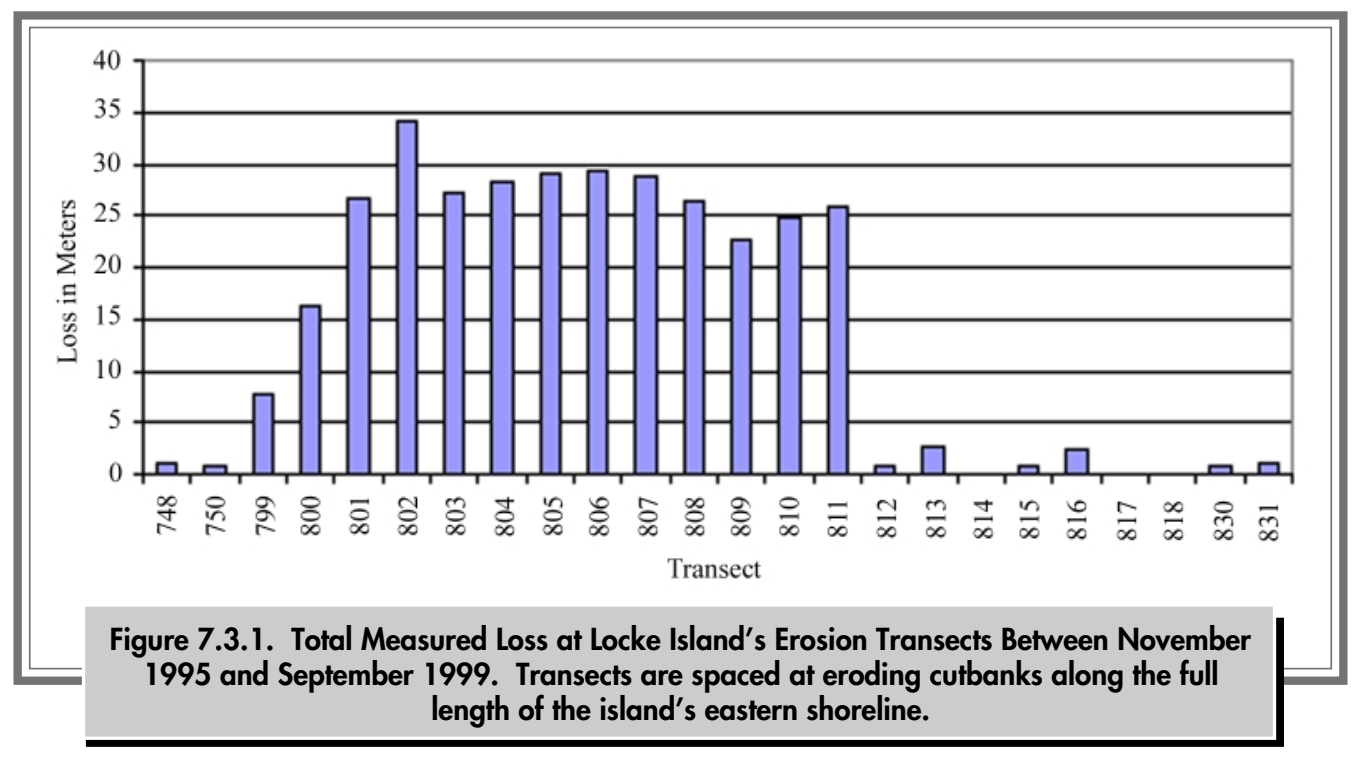




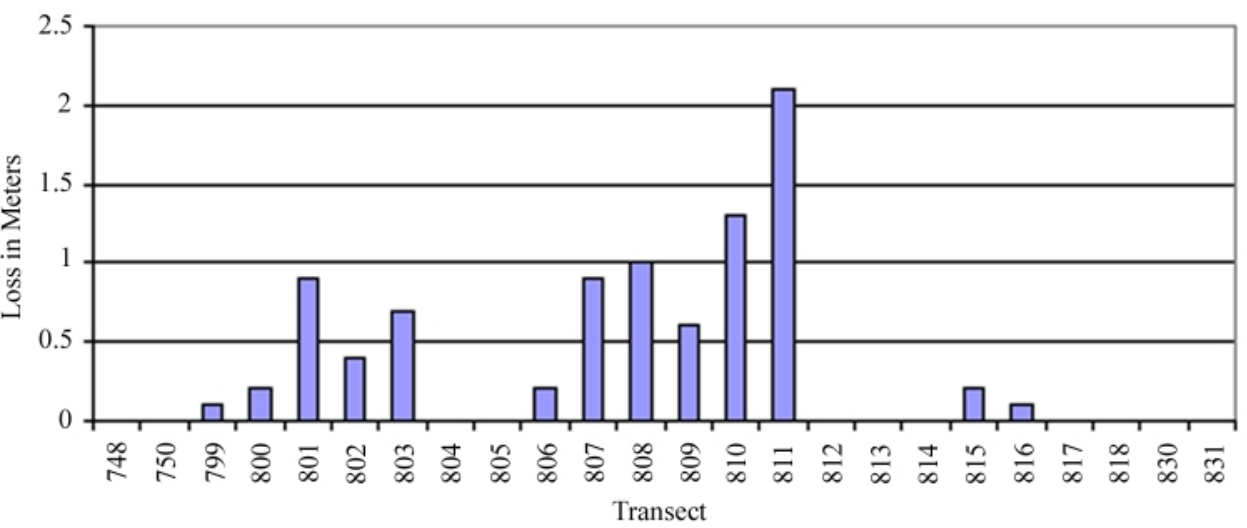

Figure 7.3.2. Measured Loss at Locke Island's Erosion Transects During Fiscal Year 1999. Transects are spaced at eroding cutbanks along the full length of the island's eastern shoreline.

The third category, monitoring of buildings, focused on the Bruggeman's Warehouse, the only cobblestone structure remaining on the Hanford Site. The building's structural integrity was photographed and locations of potential failure were identified. Future monitoring inspections will continue to gather data about any crack widening and structural leaning that may occur.

The final category, places with cemeteries or known human remains, are sacred to the Wanapum People, Yakama Nation, Confederated Tribes of the Umatilla Indian Reservation, and the Nez Perce Tribe. These places were monitored to document baseline conditions, determine whether wind or water erosion had caused exposures of human remains, and ensure that violations of the $\mathrm{N}$ ative $A$ merican $\mathrm{G}$ raves Protection and Repatriation A ct and/or A rchaeological Resources P rotection A ct were not present or ongoing at these important places. During 1999, all but two such places were monitored due to access restrictions imposed by Hanford Site requirements to protect and reduce harassment of nesting birds. Overall, places with human remains were found to be stable in 1999 with no evidence of recent A rchaeological Resources Protection A ct violations such as collector digging or surface collection at cemeteries or places with human remains. However, the impact from natural processes such as wind and water erosion and recreational uses was documented. Wind and water erosion were responsible for exposure of faunal remains at one place with human remains during 1999.

A total of 26 archaeological sites, a building, and cemetery or burial locations were monitored during 1999. Of the incidents recorded at these monitored places $(n=71), 69 \%$ were related to natural causes such as animal trailing and digging, wind-caused deflation or aggradation, and water erosion. Twentyone percent of the incidents were determined to be human-related causes such as vehicle traffic where sites were exposed in roads, or recreational activities such as fishing or duck hunting. Ten percent of the incidents were found to be associated with recent collector digging within archaeological site boundaries and/or surface collection of artifacts. Such collector digging and artifact collection is in violation of the A rchaeological Resources Protection A ct. 


\subsubsection{Native American Involvement}

Members of the Confederated Tribes of the Umatilla Indian Reservation, Yakama Indian Nation, Nez Perce Tribe, and Wanapum People were actively involved in the cultural resources program during 1999. Each tribe was involved in deciding DOE's cultural resource program work scope, budget, and schedule. Monthly cultural resource issues meetings provided a venue for the exchange of information between DOE, tribal staff members, and site contractors about projects and work on the Hanford Site. These meetings included discussions of sitewide projects dealing with a wide range of topics: the groundwater/vadose zone, sagebrush mitigation, survey of Hanford's large dune fields, elk relocation and trapping efforts, the Office of River Protection's Project W-519, and Hanford's native plants. Tribal staff and site contractors worked together during the completion of several field surveys to identify and record cultural features, sites, and landscapes in advance of

\subsubsection{Public Involvement}

Public involvement is an important component of a cultural resources management program. To accomplish this, DOE developed mechanisms that allow the public access to cultural resources information and the ability to comment and make recommendations concerning the management of cultural resources on the Hanford Site. In 1999, these mechanisms were woven into a draft involvement plan that includes input provided by the public and Hanford Site staff over the past several years.

The cultural resources staff of the Pacific Northwest National Laboratory, Bechtel Hanford, Inc., and CH2M HILL Hanford, Inc. assisted DOE in organizing and conducting workshops to seek public comment on a variety of cultural resource initiatives and projects undertaken by DOE. Comments were sought on an update on the draft Hanford Cultural Resources Management Plan and a review of the draft Public Involvement Plan. The purpose of the Public Involvement Plan was to determine the process that the new construction and monitor numerous projects requiring excavation during the year. The Confederated Tribe of the Umatilla Indian Reservation taught a law enforcement training workshop on the A rchaeological Resources Protection A ct at Hanford's Hazardous Materials Management Emergency Resources. The purpose of the workshop was to train participants in reporting and documenting violations of the A rchaeological Resources Protection A ct.

One Wanapum Band member, hired by Pacific Northwest National Laboratory in 1998, continued working as an archaeological technician assisting with cultural resource surveys, site form preparation, records management, and equipment use. In addition, a Wanapum Traditional Cultural Properties Report was completed with Wanapum elders under contract to Pacific Northwest National Laboratory.

Hanford Cultural Resources Program will follow to interact with interested groups. Major interest groups involved in assisting DOE with cultural resource initiatives included the B Reactor Museum Association, White Bluffs - Hanford Pioneer Association the Washington State Railroad Historical Society, and local historical societies and museums.

At the public workshops, there were discussions pertaining to a White Bluffs Memorial on the Hanford Site. The memorial is planned to commemorate the veterans of the Second World War from the Priest Rapids valley and the former Euro-American and Native American residents who were resettled following government acquisition of the Hanford Site in 1943. There was also a presentation on studies conducted for Bruggeman Warehouse and the White Bluffs Bank, two pre-Manhattan Project era structures still standing on the site. The feasibility studies were conducted to assess the buildings' structural condition and the work required to stabilize and 
restore them. Recommendations concerning the feasibility of converting the Bruggeman Warehouse into a visitor's center were sent to DOE.

Additional discussions at the workshop focused on the ongoing curation of Manhattan Project and Cold War era artifacts into the Hanford collection and an update on the independent peer review of the draft $\mathrm{H}$ istory of the Plutonium Production Facilities at the $\mathrm{H}$ anford Site H istoric D istrict, 1943-1990. Comments were sought on the Tower Removal Project, located near the 200 Areas, including the addition of the Atmospheric Dispersion Test Facility, located near the 200-East Area, to the Historic District Treatment Plan. Finally, there was a discussion of local historic preservation issues by Dr. Allyson Brooks, State Historic Preservation Officer.

These workshop discussions indicated strong support for the use of B Reactor as a publicly accessible museum. A millennium grant proposal to fund renovation of $B$ Reactor was discussed as were the preservation of $B$ Reactor artifacts and a proposal for a boat dock at 100-B to serve the B Reactor museum.

\subsubsection{Section 106 Activities}

Changes in the Section 106 of the $\mathrm{N}$ ational $\mathrm{H}$ istoric Preservation $\mathrm{A}$ ct and the Code of Federal Regulations resulted in several modifications to the DOE cultural resource review process in 1999. Pursuant to Section 106 of the $\mathrm{N}$ ational $\mathrm{H}$ istoric Preservation $A$ ct, cultural resources reviews must be conducted before each proposed ground disturbance or building alteration/demolition project can take place. Although cultural resources reviews have always been required to identify properties within the proposed project area that may be eligible for, or listed in, the National Register of Historic Places and evaluate the project's potential to effect any such property, the recently modified cultural resource review process includes two review options. The first option allows DOE to determine that proposed projects have no potential to effect historic properties after which all parties are notified and the review process is considered complete. A second option is used if a project has potential to effect a historic property. The latter involves notification of the State Historic Preservation Officer, tribes, and other interested parties of the proposed project and a 30-day response period.

During 1999, 176 cultural resources reviews were requested (Figure 7.3.3). A majority of the reviews involved project areas that had been previously surveyed or were located in previously disturbed ground. Of the projects reviewed, 10 were also monitored during the construction phase, 4 required archaeological surveys, and 18 involved building modification or demolition. The surveys covered a total of 37.2 hectares (99 acres) and resulted in the discovery of one isolated find and three archaeological sites (Figure 7.3.4).

A survey done for the Sagebrush Mitigation Planting project covered 155 hectares (385 acres) on the Fitzner/Eberhardt Arid Lands Ecology Reserve and recorded five archaeological sites and three isolated finds. The sites recorded were mostly prehistoric lithic concentrations. This survey was the largest conducted for Section 106 activities during 1999.

\subsubsection{Section 110 Activities}

Section 110 of the $\mathrm{N}$ ational $\mathrm{H}$ istoric Preservation

A ct requires that federal agencies undertake a program to identify, evaluate, and nominate historic properties and consider the use and reuse of historic buildings or structures. Agencies are further required to maintain and manage historic properties in a way that considers preservation of their value and ensures that preservation-related activities are completed in 


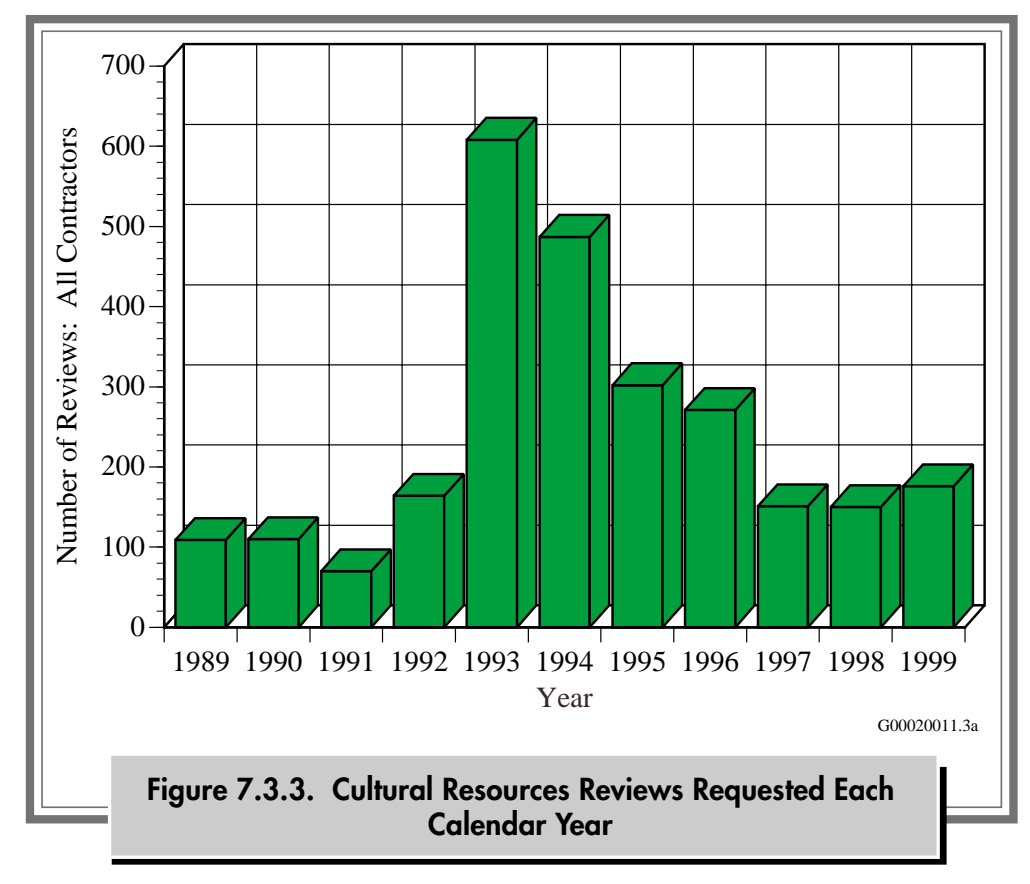

consultation with other agencies, the tribes, and the general public. Staff of DOE, Bechtel Hanford, Inc., and Pacific Northwest National Laboratory applied for a "Save America's Treasures" millennium grant to fund renovation of the historic B Reactor as a publicly accessible museum and the historic Bruggeman Warehouse as an interpretive center. While the nomination was not approved, DOE's proposal rated very high and they were urged to re-submit the nomination next year.

During 1999, DOE was in the process of evaluating the feasibility of retaining various historic structures on the Hanford Site, including the Bruggeman Warehouse and White Bluffs Bank, two preManhattan Project era buildings. An assessment of the structural condition of both buildings was completed. The studies detailed existing conditions, interim actions, conservation needs, and immediate stabilization requirements. Both studies developed cost estimates for stabilization. A follow-up study was conducted of the White Bluffs Bank that outlined emergency stabilization options and costs. The Bruggeman Warehouse study made recommendations concerning the feasibility of converting the former fruit warehouse into a visitor's center.
In 1999, management activities conducted to fulfill Section 110 requirements included continual implementation of the programmatic agreement for the built environment (DOE/RL-96-77) and application of the Hanford Site curation strategy to identify, evaluate, and preserve Manhattan Project and Cold War era artifacts (DOE/RL-97-71). Since Section 110 activities began on the Hanford Site, 525 buildings/structures have been documented on

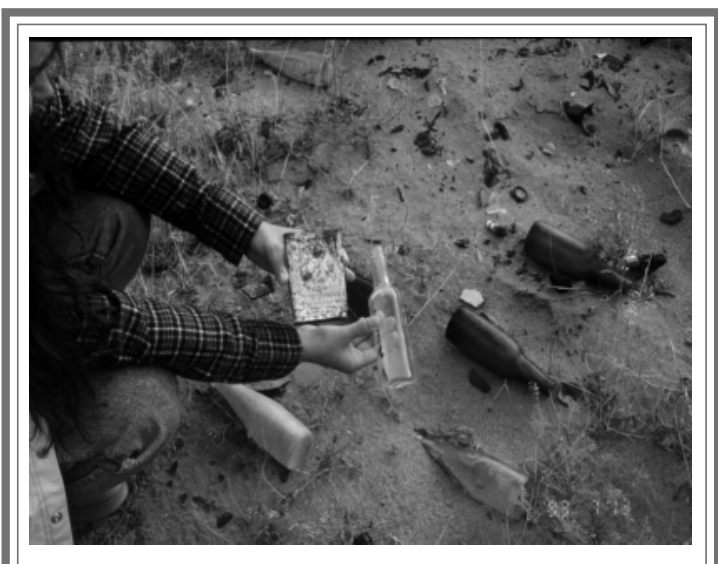

Figure 7.3.4. Historic Sites are Commonly Found During Surveys Conducted at the Hanford Site 
historic property inventory forms and are on file at the Hanford Cultural Resources Laboratory (Figure 7.3.5).

The Dunes Archaeological Block Survey was an intensive survey performed intermittently from March to July, 1999. Approximately 1,405 hectares $(3,473$ acres $)$ were surveyed along the river from the 300 Area to the northern end of the large active dune area south of the Hanford Townsite. Forty-four newly recorded archaeological sites and 36 newly recorded isolated finds were documented during the survey. Twenty-four previously recorded sites were re-recorded and amended. Of all the sites recorded, six of the previously recorded sites were already listed as part of the Wooded Island Archaeological District on the National Register of Historic Places. This survey represented a cooperative approach to investigate previously unsurveyed lands on the site. The Nez Perce Tribe, DOE, Pacific Northwest National Laboratory and one volunteer from the general public participated in the survey.

\subsubsection{Historic District}

During 1999, implementation of the building mitigation project continued to carry out the programmatic agreement (DOE/RL-96-77) and the sitewide treatment plan (DOE/RL-97-56, Rev. 1). The treatment plan is stipulated in the programmatic agreement and directs a mitigation document be provided that chronicles the history of the Hanford Site during the Manhattan Project and Cold War periods.

The Hanford Site Manhattan Project and Cold War Era Historic District was established in 1996, and 185 buildings, structures, and complexes were recommended for mitigation. Subsequent public meetings and staff evaluations identified additional properties in the 600, 700, and former 1100 Areas, including the Hanford Site railroad, as contributing properties within the historic district and recommended mitigation, bringing the total to 190 (Figure 7.3.6). Of the buildings, structures, and complexes

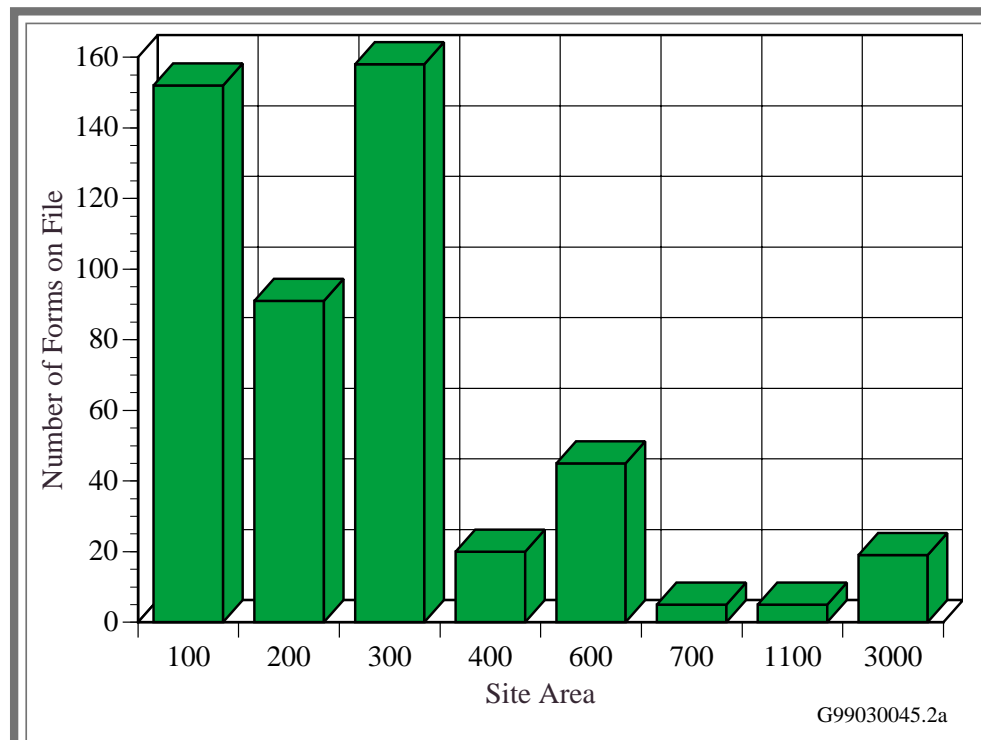

Figure 7.3.5. Hanford Buildings and Structures Documented with a Washington State Historic Property Inventory Form 


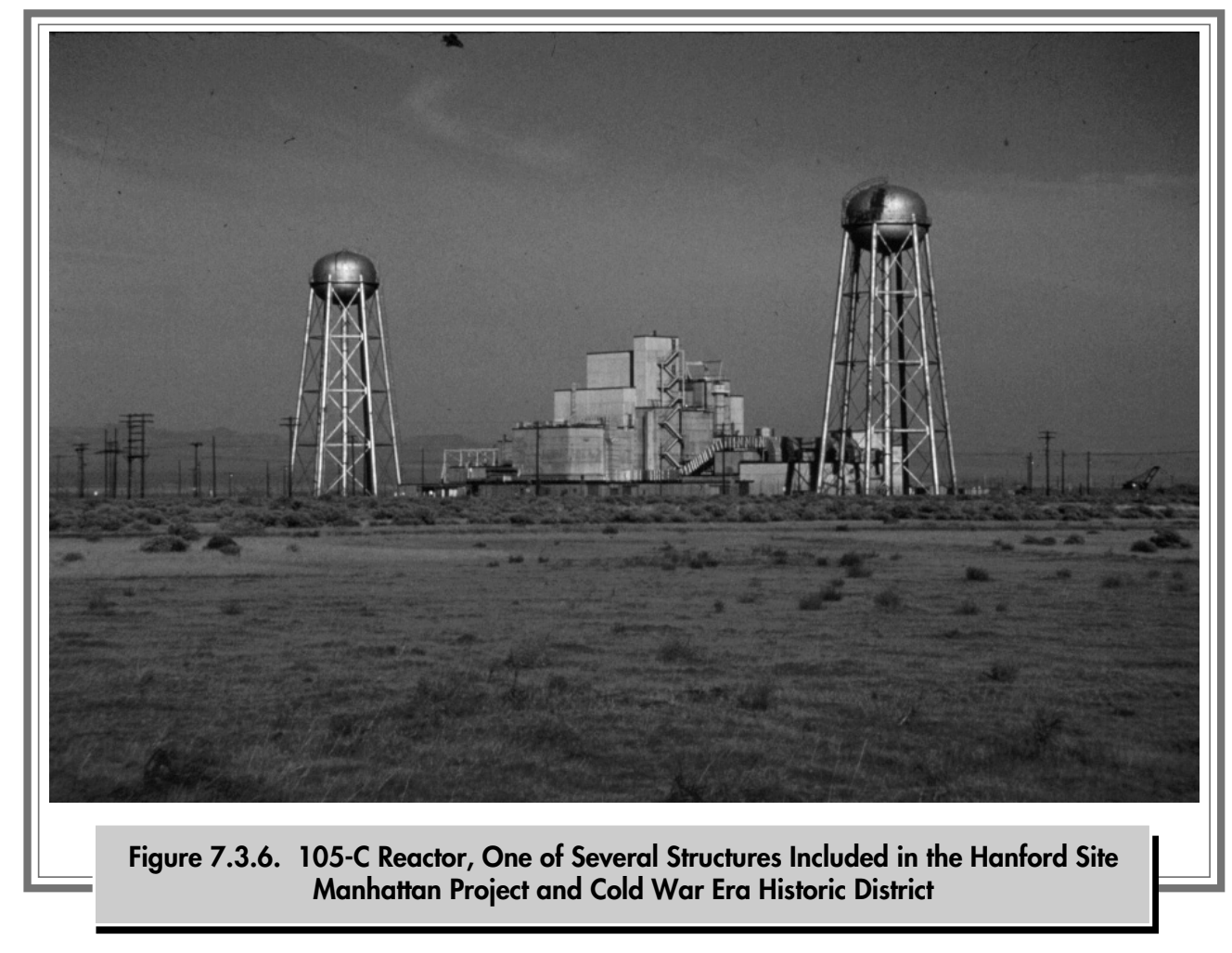

recommended for mitigation, 173 have been documented according to mitigation standards identified in the sitewide treatment plan (DOE/RL-97-56, Rev. 1). Six historic properties, including B Reactor, have been documented at the Historic American Engineering Record level, 38 have been documented with Expanded Historic Property Inventory Forms, while standard Historic Property Inventory Forms have been prepared for the remaining 124 buildings and structures.

Approximately 900 buildings and structures have been identified as either contributing properties with no individual documentation requirement (not selected for mitigation) or as noncontributing/ exempt buildings and structures. These buildings will be documented in a database maintained by DOE. According to the programmatic agreement (DOE/ RL-96-77), certain property types such as mobile trailers, modular buildings, storage tanks, towers, wells, and structures with minimal or no visible surface manifestations are exempt from the identification and evaluation requirement.

\subsubsection{Hanford Curation Strategy}

The application of the curation strategy for artifacts and records associated with the Hanford Site Manhattan Project and Cold War Era Historic District continued in 1999. The strategy is stipulated in the programmatic agreement (DOE/RL-96-77), which directs DOE to assess the contents of Hanford's historic buildings and structures prior to the commencement of deactivation, decontamination, or decommissioning activities. The purposes of these assessments are to identify and preserve any artifacts (e.g., control panels, signs, scale models, machinery) that may have interpretive or educational value as exhibits within national, state, or local museums. The assessments are accomplished by conducting walkthroughs of the contributing properties within the historic district by teams made up of cultural resources specialists, historians, archivists/curators, and facility experts. Eleven assessments/walkthroughs were conducted in 1999, at two facilities in the 
300 Area, KE Reactor, and eight structures in the 200 Areas including T Plant, U Plant, ReductionOxidation Plant, and Plutonium-Uranium Extraction Plant. Industrial artifacts associated with the Manhattan Project and Cold War are curated with the Columbia River Exhibition of History, Science and Technology museum.

DOE's archaeological collections and associated records continued to be housed in Pacific Northwest
National Laboratory's repository during 1999. A draft management plan that deals specifically with archaeological collections, developed in 1998, was used during 1999 to guide access to, and uses of, the collections and to provide guidelines for acquisition and deaccessioning processes. A pest management and monitoring effort for archaeological collections conducted during 1999 resulted in no indications of pest infestations.

\subsubsection{Education and Research}

Educational activities associated with the cultural resources program in 1999 included lectures on a variety of topics including preservation and protection legislation to groups, ranging from public school classrooms to civic groups, colleges, and professional societies. Several symposia were organized throughout the Pacific Northwest region to present DOE's cultural resources management techniques to professional groups and societies. Washington's Archaeology Month provided educational opportunities in the form of lectures and social gatherings for residents of the Tri-Cities' area through the efforts of staff and professionals from Washington State University, DOE, and Pacific Northwest National Laboratory.
Pacific Northwest National Laboratory participated in the Associated Western Universities, Inc., Northwest program by hosting three student interns involved in field and laboratory work with Hanford Cultural Resources Laboratory staff.

Research activities continued as part of compliance work. Research in the field of archaeology and history focused on archaeological site preservation and protection and documentation of the built environment of the Manhattan Project and Cold War periods. 


\title{
7.4 Community-Operated Environmental Surveillance Program
}

\author{
R. W. H anf
}

Since 1991, citizens living near the Hanford Site have actively participated in site environmental surveillance activities through the CommunityOperated Environmental Surveillance Program. During 1999, nine radiological air sampling stations were operated by local teachers at selected locations around the site perimeter. These stations were located in Basin City, Richland, Pasco, Kennewick, north Franklin County, Othello, Mattawa, Toppenish, and Benton City, Washington (see Figure 4.1.1). Each station consisted of equipment to collect air samples and to monitor ambient radiation levels. Four of the

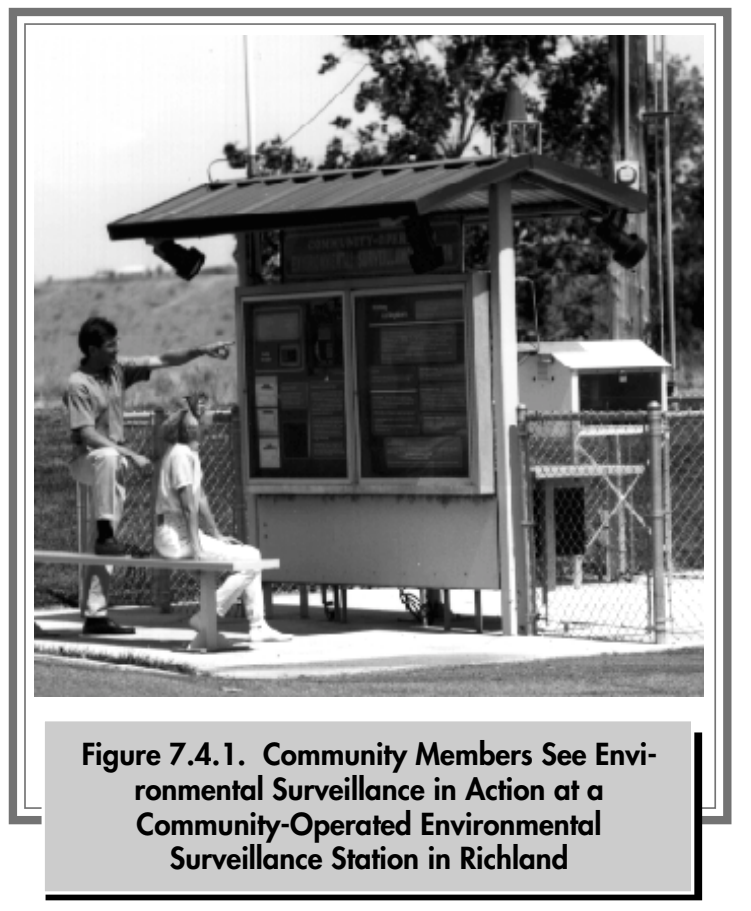

nine stations also included large, lighted, informational displays that provided real-time meteorological and radiological information as well as general information on station equipment, sample types, and analyses (Figure 7.4.1). The station managers' names and telephone numbers were provided on the four displays for anyone desiring additional information about the purpose of the station, station equipment, or analytical results.

Two teachers from schools located near the stations were selected to operate each station. The teachers were responsible for collecting a variety of air samples, preparing the samples and collection records for submission to the analytical laboratory, monitoring the performance of station equipment, performing minor station maintenance, and participating in scheduled training. They also served as spokespersons for the Community-Operated Environmental Surveillance Program and are points of contact for local citizens. Pacific Northwest National Laboratory staff worked closely with the teachers to provide training, maintain station equipment and displays, and coordinate sampling and analytical efforts with other Hanford Site environmental surveillance. Analytical results for samples collected at these stations in 1999 are discussed in Section 4.1, "Air Surveillance." Results of gamma radiation measurements obtained at selected stations are discussed briefly in Section 4.7, "External Radiation Surveillance." 


\title{
7.5 Biological Control Program
}

\author{
A. R. Johnson and R. C. Roos
}

The Biological Control Program was established in 1999 in response to a DOE inquiry (DOE-RL 98-EAP-58) into increasing incidents of radioactive contamination spread by biological vectors. A biological vector is a plant or animal species (including arthropods) that is involved in the transport of radioactive contamination. A common Hanford example is the tumbleweed, whose taproot may transport radionuclides from below the ground surface into aboveground plant tissue, making it available for dispersal across the site by wind or other means.

Biological control (or often simply "control") is any activity to prevent, limit, clean up, or remediate the impact to the environment, or human health and safety, from contaminated or undesirable plants or animals. The radiological component includes activities to control the spread of radioactive contamination. The nonradiological component includes activities to control pests (e.g., noxious weeds) that may affect the workplace and to ensure compliance with federal, state, and local laws. The Biological Control Program is responsibile for integration of 1) expanded radiological surveillance, 2) control of plants and animals, 3) cleanup of legacy and new contamination, and 4) restoration of sites effected by radioactive contamination spread by plants and animals.

Biological control of industrial weeds, noxious weeds, and pests have similar methods of prevention and response. Because the methods may overlap, nonradiological control of biota also was integrated into the new Biological Control Program. Industrial weeds, i.e., weeds on industrial sites such as
Hanford, are not only a nuisance but also cause fire hazards and reduce the efficiency of men and machines working in the area. Occasionally, the objective of an industrial weed control program is to totally eliminate vegetation in the effected area. On the Hanford Site, the control of industrial weeds occurs at tank farms, pumping installations, industrial sites, transmission lines and stations, buildings, storage and work areas, and along fence lines. Noxious weeds are discussed further in Section 7.5.2, "Noxious Weed Control." Animal control prevents, limits, or removes undesirable animals through the application of chemical, cultural, or mechanical methods.

Biological control may include preventive measures or measures in response to existing contamination spread. Important activities to prevent the spread of contamination include surveys of the ground, vegetation, and flying insects; preventive controls, such as herbicide spraying; and the placement of engineered biological barriers. If plants or animals have spread radioactive contamination, typical response measures may include posting the area with radiation signs and stabilizing the contamination to keep it from spreading farther, followed by cleanup and removal of the contamination to an approved disposal location.

In some cases, remediation following the contamination cleanup and removal is necessary. Remediation is a common activity on the Hanford Site, but has specific meanings and limitations when applied to biological control. Remediation may include soil removal and replacement, revegetation 
of soil surface, or placement of engineered barriers to stop biological intrusion (biological barriers). Such remediation is typically performed where there is a potential for surface contamination or infestation problems to recur, with the objective of preventing recurrence.

\subsubsection{Biological Control in 1999}

There were no incidents of offsite contamination by plants or animals in 1999, and all reported cases of new contamination on the site were cleaned up or scheduled for cleanup. In all areas of biological control, access to contaminated sites by professional control and cleanup crews improved in 1999. Facilities were able to request cleanup support without waiting to obtain contracts or set up work orders. Professionals were able to identify and treat problem areas without waiting for facility management to request or approve assistance.

During 1999, flying insects were routinely monitored on the Hanford Site and three contaminated houseflies were captured at a transfer facility in the 200-East Area. The source of the contamination was identified and sealed within two days. The contamination was then cleaned up and surveillance of the cleaned sites, as well as of flying insects, was conducted weekly until it was evident there were no additional problems.

In 1999, 86 incidents of contaminated vegetation were identified. This is an increase of $\sim 80 \%$ compared to 1998. However, the increase is likely due to aggressive work by surveillance/cleanup teams to discover the contamination, rather than the creation of newly contaminated sites. During 1999, 11,400 acres were treated with herbicide to control undesirable vegetation compared to 4,000 acres in 1998. Herbicide effectiveness in 1999 was $\sim 85 \%$ compared to $\sim 65 \%$ in 1998 . Approximately 100 acres including $\sim 2$ miles of posted roadways were cleaned of windblown tumbleweeds and the roads opened. On the Hanford Site, 5 acres were reseeded with native vegetation to prevent the growth of tumbleweeds.

In 1999, there were 5,500 animal control responses and 14 contaminated animals detected, a decrease of $\sim 65 \%$ compared to 1998 . The control of rodents around the perimeter of the Hanford Site used $\sim 750$ traps/bait stations compared to $\sim 400$ in 1998. There were decreased areas for animals to hide/ live because of increased effectiveness of vegetation control.

\subsubsection{Noxious Weed Control}

Noxious weed control on the Hanford Site was developed in response to federal, state, and local laws requiring eradication or control of noxious weeds. Developed in an effort to satisfy agreements made in the federal interagency memorandum of understanding (1994), the noxious weed control program has been designated as a model for other DOE sites.

The four counties surrounding the Hanford Site (Adams, Benton, Franklin, and Grant Counties) have noxious weed control programs to protect their important agricultural industries, native ecology, and other interests. The Hanford Site is viewed with great interest and concern as a potential source for invasion of noxious weeds into these counties (Nature Conservancy 1999).

\subsubsection{Background}

According to the Revised Code of Washington, a noxious weed is any plant which when established is highly destructive, competitive, or difficult to control by cultural or chemical practices (RCW 17.10.010). Typically, noxious weeds are nonnative 
(alien) species that invade and displace native species, reduce habitat for fish and wildlife, and contribute to the extinction of sensitive species. These are often plants that form unnoticeable components of their native communities, but have become aggressive invaders in new environments and can overcome native species. Noxious weed control is essential to preserve native ecosystems and wildlife habitat in some areas of the Hanford Site.

Priorities for control of noxious weeds on the Hanford Site are based primarily on 1) the potential for a weed species to spread and cause ecological damage, 2) the potential for a weed species to spread into radiological control areas and serve as a biological vector of contamination (take up stabilized underground radioactive elements and bring them to the surface), 3) the potential for a weed species to cause financial harm to neighboring landowners, and 4) cooperation and coordination with the control activities of neighboring counties and weed managers.

Planning and field control for the noxious weed program at Hanford is closely coordinated with the Washington State Department of Agriculture and Adams, Benton, Franklin, and Grant Counties. Weed control plans and progress of ongoing field activities are reviewed in quarterly meetings. Other agencies and groups attending the quarterly meetings and assisting in the technical review of the program include Washington State University Agricultural Extension Service, U.S. Fish and Wildlife Service, Washington Department of Fish and Wildlife, U.S. Bureau of Reclamation, and South Columbia Irrigation District.

\subsubsection{1999 Noxious Weed Control}

Nine plant species are on a high-priority list for control at the Hanford Site. These species are listed below, with a summary of the 1999 control activities.
Yellow starthistle (C entaurea solstitialis) is the most rapidly expanding weed infestation in the western United States. Hanford is at a critical point in the infestation cycle. Over 1,200 hectares (3,000 acres) of the site have been heavily infested, and a large seed bank has been established in the soil. Many additional acres have scattered starthistle infestation. In the absence of control, starthistle will take over additional acres in the next few years, multiplying the size of the current infestation. Pioneer populations have begun in areas widely separated from the main infestation. Pioneer populations are infestations of noxious weeds that have established in areas away from the main infestation, and not previously infested by the species. These populations usually expand rapidly in size and serve as seed sources for even wider distribution.

Efforts to control yellow starthistle were concentrated in two major areas in 1999: 1) monitoring and spot treatment (as necessary) of pioneer populations and 2) aerial application of herbicides near the Old Hanford Townsite. Known locations of small infestations were treated with herbicides in 1998, and control from these applications remained effective through the 1999 season. Sites of previous infestation were monitored and plants that escaped treatment, or germinated near treatment sites, were destroyed by hand pulling or chemical treatment. Approximately 880 hectares (2,200 acres) were treated aerially in 1999. Control from this application was effective. Control also remained effective over the $\sim 320$ hectares ( 800 acres) that were aerially treated in 1998. Between the two applications, the major infestation of yellow starthistle was controlled in 1999. Considerable effort was made to treat plants growing near trees and along the Columbia River where aerial applications were not made.

Over a very large area, 100\% eradication of weeds is not possible to achieve over the short term. Nevertheless, control of yellow starthistle was highly effective in 1999. Preliminary observations 
indicate that controls will remain effective through the 2000 growing season. These effective controls will allow resources to be concentrated in fiscal year 2000 on areas where individual weeds are widely scattered, making aerial application impractical.

Biological control organisms have been released in the major population of yellow starthistle over the past 3 years. As chemical controls reduce the number and size of populations, it is hoped that biocontrols will assist in reducing seed production in scattered plants and isolated populations.

Rush skeletonweed (C hondrilla juncea) is widely scattered across the Hanford Site. It is the dominant or codominant species in four populations of one or more acres on the site. Additional plants or small plant patches are scattered across the site. Each of the four large populations of skeletonweed was treated with herbicide in 1999. Additionally, approximately two-thirds of the area known to harbor scattered skeletonweed plants was surveyed, and the plants were treated with herbicide as they were located.

Rush skeletonweed has a deep, extensive root system and minimal leaf area. These characteristics make it very difficult to control. Although initial chemical control of individual plants has appeared very effective, sprouts from deep roots that were not killed by the herbicide occasionally appear at the surface within 2 to 3 years following treatment. Treated skeletonweed populations are monitored for several years to identify and re-treat sprouts before the plants fully recover from previous control efforts.

Biological controls for rush skeletonweed have been introduced at Hanford. Effectiveness of controls varies widely from population to population and from year to year. In 1999, as in most other years, some populations were highly affected by the biocontrols and flowering was eliminated. Other populations were less affected and some were not significantly impacted by the biocontrol agents. On the Hanford Site, biocontrol agents available for rush skeletonweed rarely, if ever, prove lethal to the plants. Nevertheless, under good conditions, individual populations can be prevented from flowering and setting seed under conditions favorable to the biological controls.

Babysbreath ( $G$ ypsophila paniculata) is also found on the Hanford Site. Babysbreath is difficult to control and efforts continued in 1999. Treatment used at Hanford has effectively killed the aerial portions of the plants, even though a high percentage of the roots remain viable. By killing the aerial portion of the plants, flowering is prevented, eliminating seed set in treated plants.

Although many roots remain viable after treatment, destroying the leaves and stems curtails photosynthesis, preventing plants from storing energy reserves for winter and spring sprouting. Plants not killed by the treatments have been weakened. With consistent, follow-up treatment, it is expected that the plants will ultimately be weakened to the point of death. The babysbreath invasion is relatively small, and control by attrition is a practical alternative.

Dalmation toadflax (Linaria genistifolia ssp. Dalmatica) has been found in four populations on the Hanford Site. Three populations were treated in 1998 and monitored in 1999. No evidence of resprouting was found. A larger population was identified near the 100-B,C Area and treated in 1999. Monitoring will continue at all sites. Any resprouting or new plants will be treated immediately.

Spotted knapweed (C entaurea maculosa) has been identified in five populations on the Hanford Site. All were monitored in 1999, and control took place at three populations where live plants were identified. Spotted knapweed is a prolific seed producer and seeds remain viable in the soil for 10 years or more. All populations will be monitored in subsequent years to check for resprouting and follow-up control. 
Diffuse knapweed (C entaurea diffusa) has become established in several locations on the Hanford Site and is rapidly invading and expanding in many areas. Invasion of this weed threatens much of the site. Major populations of diffuse knapweed were sprayed aerially with herbicide to reduce overall seed production. Diffuse knapweed is present as widely scattered individuals over several hundred hectares (acres) at Hanford. Considerable effort was made to locate and spot treat individual plants in the 100 Areas to prevent spread of the population. A special effort was made to treat roadways to prevent seed production. Vehicle traffic is a major vector for dispersal of diffuse knapweed. Isolated populations can serve as seed sources to infest large areas and were spot sprayed. By controlling these pioneer populations, relatively large areas can be kept free of knapweed. Diffuse knapweed is a prolific seed producer and seeds remain viable in the soil for 10 years or more. All populations will be monitored in subsequent years to check for resprouting and to coordinate additional control measures.

Russian knapweed (A croptilon repens) was treated in a series of large test applications. Evaluation of herbicide effectiveness will take place in late spring of 2000. Subsequent applications will be adjusted based on findings from the 1999 test applications.

Saltcedar (T amarix spp.) are found on the Hanford Site, south and west of the Columbia River. Several industrial plants remain from ornamental plantings around homes in the early part of this century. These plants are being controlled to prevent seed dispersal to sensitive habitats where uncontrolled populations may establish. A few populations are the result of natural seed dispersal; all plants were treated in 1999.

Saltcedar has an extensive root system that is very difficult to eliminate. Most plants on the Hanford Site have been treated for 4 years; however, some continue to sprout new growth. Monitoring and annual treatment will continue until saltcedar is eradicated.

Actively reproducing populations of saltcedar have also established on DOE-owned land north and east of the Columbia River. These lands are leased and managed by the U.S. Fish and Wildlife Service. An active program is in place by this agency, and the associated counties, to control saltcedar on these lands.

Purple loosestrife (Lythrum salicaria) were monitored in portions of Hanford's riparian areas in 1999. Two populations were identified and treated. Several immature plants were identified within the populations. Nonflowering immature plants are difficult to see, and therefore, often escape herbicide application. Follow-up monitoring and treatment will occur in the future. Populations of purple loosestrife at Hanford remain too small and diffuse for effective use of biological control organisms. 


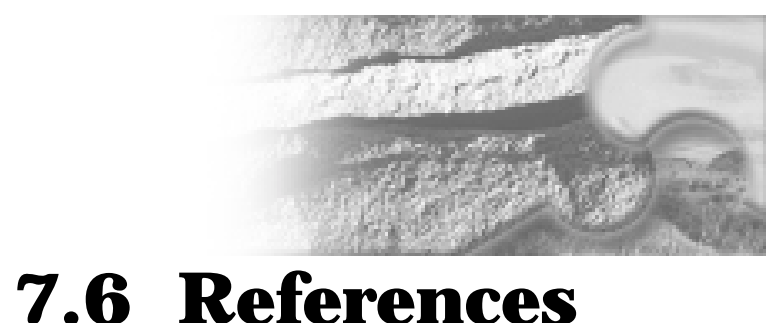

50 CFR 17. U.S. Fish and Wildlife Service, Department of the Interior. "Endangered and Threatened Wildlife and Plants." Code of Federal Regulations.

50 CFR 17.11. U.S. Department of the Interior. "Endangered and Threatened Wildlife." Code of Federal Regulations.

50 CFR 17.12. U.S. Department of the Interior. "Endangered and Threatened Plants." Code of Federal Regulations.

American Antiquities Preservation Act. 1906. 16 USC 431-433.

American Indian Religious Freedom Act. 1978. Public Law 95-341, as amended, 42 USC 1996 et seq.

Archaeological and Historic Preservation Act. 1974. Public Law 93-291, as amended, 16 USC 469-469c-1.

Archaeological Resources Protection Act. 1979. Public Law 96-95, as amended, 93 Stat. 721.

Dobrowolski, J. P., and K. Ewing. 1990. "Vegetation Dynamics and Environmental Attributes of a Great Basin Valley Exhibiting Widespread Shrub Dieback." In Symposium on Cheatgrass Invasion, Shrub Die-Off, and Other Aspects of Shrub Biology and Management, Las Vegas, Nevada. U.S. Department of Agriculture, Intermountain Research Station, Provo, Utah, pp. 103-114.

DOE/RL-94-150. 1994. Bald Eagle Site Management Plan for the Hanford Site, South-Central Washington. R. E. Fitzner and S. G. Weiss, Pacific Northwest Laboratory and CH2M Hill for U.S. Department of Energy, Richland Operations Office, Richland, Washington.
DOE/RL-96-77. 1996. Programmatic Agreement Among the U.S. Department of Energy, Richland Operations Office, the Advisory Council on Historic Preservation, and the Washington State Historic Preservation Office for the Maintenance, Deactivation, Alteration, and Demolition of the Built Environment on the Hanford Site, Washington. U.S. Department of Energy, Richland Operations Office, Richland, Washington.

DOE/RL-97-56, Rev. 1. 1998. Hanford Site Manhattan Project and Cold War Era Historic District Treatment Plan. T. E. Marceau, Bechtel Hanford, Inc. for U.S. Department of Energy, Richland Operations Office, Richland, Washington

DOE/RL-97-71. 1997. Hanford Curation Strategy: Manhattan Project and Cold War Era Artifacts and Records. U.S. Department of Energy, Richland Operations Office, Richland, Washington.

Eberhardt, L. E., G. G. Brooks, R. G. Anthony, and W. H. Rickard. 1989. "Activity Budgets of Canada Geese During Brood Rearing." The Auk 106:218-224.

Endangered Species Act. 1973. Public Laws 93-205 through 100-707, as amended, 87 Stat. 884, 16 USC 1531 et seq.

Gray, R. H., and D. D. Dauble. 1977. "Checklist and Relative Abundance of Fish Species from the Hanford Reach of the Columbia River." Northwest Science 51:208-215.

Hall, J. A. (ed.). 1998. Biodiversity Inventory and Analysis of the Hanford Site: 1997 Annual Report. The Nature Conservancy of Washington, Seattle, Washington.

Historic Sites, Buildings and Antiquities Act. 1935. Public Law 89-249, as amended, 16 USC 461-467. 
Leary, A. W. 1996. Home Ranges, Core Use Areas, and Dietary Habits of Ferruginous Hawks in Southcentral Washington. Master Thesis in Raptor Biology, Boise State University, Boise, Idaho.

Memorandum of Understanding. 1994. "Memorandum of Understanding for the Establishment of a Federal Interagency Committee for the Management of Noxious and Exotic Weeds." G. Buntrock, S. W. Goodman, R. E. Slater, and T. O'Toole, U.S. Department of Agriculture, U.S. Department of Defense, U.S. Department of Transportation, and U.S. Department of Energy, Washington, D.C.

National Historic Preservation Act. 1966. Public Law 89-665, as amended, 16 USC 470 et seq.

Native American Graves Protection and Repatriation Act. 1990. Public Law 101-601, as amended, 25 USC 3001 et seq.

Nature Conservancy. 1999. Biodiversity Inventory and Analysis of the Hanford Site. Final Report 19941999. The Nature Conservancy of Washington, Seattle, Washington.

Nelson, D. L., D. J. Weber, and S. C. Garvin. 1989. "The Possible Role of Plant Disease in the Recent Wildland Shrub Dieoff in Utah." In Symposium on Cheatgrass Invasion, Shrub Die-Off, and Other Aspects of Shrub Biology and Management, Las Vegas, Nevada. U.S. Department of Agriculture, Intermountain Research Station, Provo, Utah, pp. 84-90.

PNL-6942. 1989. Hanford Cultural Resources Management Plan. J. C. Chatters (ed.), Pacific Northwest Laboratory, Richland, Washington.

PNNL-6415, Rev. 12. 1999. Hanford Site National Environmental Policy Act (NEPA) Characterization. D. A. Neitzel (ed.), and C. J. Fosmire, R. A. Fowler, S. M. Goodwin, D. W. Harvey, P. L. Hendrickson, D. J. Hoitink, T. M. Poston, A. C. Rohay, P. D. Thorne, and M. K. Wright, Pacific Northwest National Laboratory, Richland, Washington.
PNNL-11518. 1997. Investigation of Anatomical Anomalies in the Hanford Site Mule Deer. B. L. Tiller, G. E. Dagle, L. L. Cadwell, T. M. Poston, and A. Oganesian, Pacific Northwest National Laboratory, Richland, Washington.

PNNL-11700. 1997. Characterization of a Sagebrush (Artemisia tridentata subsp. Wyomingensis) Die-Off on the Hanford Site. A. Cardenas, J. Lewinsohn, C. Auger, J. L. Downs, L. L. Cadwell, and R. Burrows, Pacific Northwest National Laboratory, Richland, Washington.

PNNL-11970. 1998. Monitoring Bank Erosion at the Locke Island Archaeological National Register District: Summary of 1996/1997 Field Activities. P. R. Nickens (ed.), B. N. Bjornstad, N. A. Cadoret, and M. K. Wright, Pacific Northwest National Laboratory, Richland, Washington.

PNNL-13117. 2000. Hanford Site Climatological Data Summary 1999 With Historical Data. D. J. Hoitink, K. W. Burk, and J. V. Ramsdell, Pacific Northwest National Laboratory, Richland, Washington.

Salstrom, D., and R. Easterly. 1997. Central Hanford 1997 Plant Community Inventory. Report to The Nature Conservancy of Washington, Seattle, Washington.

Soll, J. A., and C. Soper (eds.). 1996. Biodiversity Inventory and Analysis of the Hanford Site: 1995 Annual Report. The Nature Conservancy of Washington, Seattle, Washington.

Tiller, B. L., G. E. Dagle, and L. L. Cadwell. 1997. "Testicular Atrophy in a Mule Deer Population." J. Wildl. Manage. 33(3):420-429.

Washington Natural Heritage Program. 1997. Rare Plant Species County List. Washington State Department of Natural Resources, Olympia, Washington (Available URL: http://www.wa.govdnr/htdocs/fr/ nhp/plantco.html) 
Washington State Department of Wildlife. 1994. Species of Special Concern in Washington. Olympia, Washington.
Weber, D. J., D. L. Nelson, W. M. Hess, and R. B. Bhat. 1989. "Salinity and Moisture Stress in Relation to Dieoff of Wildland Shrubs." In Symposium on Cheatgrass Invasion, Shrub Die-Off, and Other Aspects of Shrub Biology and Management, Las Vegas, Nevada. U.S. Department of Agriculture, Intermountain Research Station, Provo, Utah. 


\title{
8.0 Quality Assurance
}

\author{
B. M. G illespie, L. P. Diediker, and D. B. Jensen
}

Quality assurance and quality control practices encompass all aspects of Hanford Site environmental monitoring and surveillance programs. Samples are collected and analyzed according to documented standard analytical procedures. Analytical data quality is verified by a continuing program of internal laboratory quality control, participation in interlaboratory crosschecks, replicate sampling and analysis, submittal of blind standard samples and blanks, and splitting samples with other laboratories.
Quality assurance/quality control for the Hanford Site environmental monitoring program also includes procedures and protocols to

- document instrument calibrations

- conduct program-specific activities in the field

- maintain groundwater wells to ensure representative samples are collected

- use dedicated well sampling pumps to avoid cross-contamination.

This section discusses specific measures taken to ensure quality in project management, sample collection, and analytical results.

\subsubsection{Environmental Surveillance and Groundwater Monitoring}

Comprehensive quality assurance programs, including various quality control practices, are maintained to ensure the quality of data collected through the Surface Environmental Surveillance Project and the Hanford Groundwater Monitoring Project. Quality assurance plans are maintained for all program activities and define the appropriate controls and documentation required by the U.S. Environmental Protection Agency (EPA) and/or the U.S. Department of Energy (DOE) for the project-specific requirements.

\subsubsection{Project Management Quality Assurance}

Site environmental surveillance, groundwater monitoring, and related programs such as processing of thermoluminescent dosimeters and performing dose calculations are subject to an overall quality assurance program. This program implements the requirements of DOE Order 5700.6C.

The site surveillance and groundwater monitoring projects have quality assurance plans that describe the specific quality assurance elements that apply to each project. These plans are approved by a quality assurance organization that conducts surveillances and audits to verify compliance with the plans. Work performed through contracts such as sample analysis must meet the same quality assurance requirements. Potential equipment and service suppliers are audited before service contracts or material purchases that could have a significant impact on quality within the project are approved and awarded. 


\subsubsection{Sample Collection Quality Assurance/Q uality Control}

Surface Environmental Surveillance Project samples are collected by staff trained to conduct sampling according to approved and documented procedures (PNL-MA-580, Rev. 2). Continuity of all sampling location identities is maintained through careful documentation. Field duplicates are collected for specific media and a summary of the results is provided in Table 8.0.1. The percentage of acceptable field duplicate results for 1999 was $89 \%$.

Samples for the Hanford Groundwater Monitoring Project are collected by trained staff according to approved and documented procedures (ES-SSPM001). Chain-of-custody procedures are followed (SW-846) that provide for the use of evidence tape in sealing sample bottles to maintain the integrity of the samples during shipping. Full trip blanks and field duplicates are obtained during field operations. Summaries of the 1999 groundwater field quality control sample results are provided in Appendix B of PNNL13116 or at the web address http://hanford.pnl.gov/ groundwater/gwrep $99 / \mathrm{html} / \mathrm{start} 1$.htm. The percentages of acceptable field blank and duplicate results in fiscal year 1999 were very high, 92\% for blanks and $98 \%$ for field duplicates.

\subsubsection{Analytical Results Quality Assurance/Quality Control}

Routine chemical analyses of water samples were performed primarily by the Quanterra Laboratory, St. Louis, Missouri, for environmental and groundwater surveillance. Some routine analyses of hazardous and nonhazardous chemicals for the C omprehensiveE nvironmental R esponse, $\mathrm{C}$ ompensation, and Liability A ct (CERCLA) groundwater program were also performed by Recra Environmental, Inc., Lionsville, Pennsylvania. Each laboratory participates in the EPA Water Pollution and Water Supply Performance Evaluation Studies. Each laboratory maintains an internal quality control program that meets

Table 8.0.1. Summary of Surface Environmental Surveillance Project Field Duplicate Results, 1999

\begin{tabular}{|c|c|c|c|}
\hline Medium & Radionuclides & $\begin{array}{c}\begin{array}{c}\text { N umber of } \\
\text { Results Reported }\end{array} \\
\end{array}$ & $\begin{array}{l}\text { N umber Within } \\
\text { Control Limits }\end{array}$ \\
\hline Air filters & $\begin{array}{l}\text { Gross alpha } \\
\text { Gross beta } \\
{ }^{3} \mathrm{H} \\
{ }^{7} \mathrm{Be},{ }^{40} \mathrm{~K},{ }^{60} \mathrm{Co},{ }^{106 \mathrm{Ru}},{ }^{125} \mathrm{Sb},{ }^{134} \mathrm{Cs},{ }^{137} \mathrm{Cs},{ }^{154} \mathrm{Eu},{ }^{155} \mathrm{Eu}\end{array}$ & $\begin{array}{l}26 \\
25 \\
12 \\
36\end{array}$ & $\begin{array}{c}17 \\
25 \\
6 \\
36\end{array}$ \\
\hline Water & $\begin{array}{l}\text { Gross alpha } \\
\text { Gross beta } \\
{ }^{3} \mathrm{H} \\
{ }^{7} \mathrm{Be},{ }^{40} \mathrm{~K},{ }^{60} \mathrm{Co},{ }^{106} \mathrm{Ru},{ }^{125} \mathrm{Sb},{ }^{134} \mathrm{Cs},{ }^{137} \mathrm{Cs},{ }^{154} \mathrm{Eu},{ }^{155} \mathrm{Eu} \\
{ }^{234} \mathrm{U},{ }^{235} \mathrm{U},{ }^{238} \mathrm{U}\end{array}$ & $\begin{array}{l}1 \\
1 \\
4 \\
9 \\
3 \\
9\end{array}$ & $\begin{array}{l}1 \\
0 \\
3 \\
8 \\
2 \\
9\end{array}$ \\
\hline Milk & $\begin{array}{l}{ }^{7} \mathrm{Be},{ }^{60} \mathrm{Co},{ }^{106} \mathrm{Ru},{ }^{125} \mathrm{Sb},{ }^{134} \mathrm{Cs},{ }^{137} \mathrm{Cs},{ }^{154} \mathrm{Eu},{ }^{155} \mathrm{Eu} \\
{ }^{90} \mathrm{Sr}\end{array}$ & $\begin{array}{c}36 \\
4\end{array}$ & $\begin{array}{c}36 \\
4\end{array}$ \\
\hline
\end{tabular}

(a) Control limit of $\pm 30 \%$ for sample and duplicate results above the detection limit or minimum detectable concentration. 
the requirements in SW-846, which is audited and reviewed internally and by Pacific Northwest National Laboratory. Pacific Northwest National Laboratory submits additional quality control double-blind spiked samples for analysis.

Routine radiochemical analyses on samples for the Surface Environmental Surveillance Project and the Hanford Groundwater Monitoring Project were performed primarily by Quanterra's Richland, Washington laboratory. Data from Thermo NUtech, Richmond, California, were also used in the fiscal year 1999 groundwater evaluations. Each laboratory participates in DOE's Quality Assessment Program at the Environmental Measurements Laboratory in New York, and the Proficiency Testing Program at Environmental Resource Associates in Arvada, Colorado. The Environmental Resource Associates program replaced the EPA's Laboratory Intercomparison Studies Program which terminated in December 1998. Environmental Resource Associates prepares and distributes proficiency standard samples according to EPA requirements. Environmental Resource Associates is also accredited by the National Voluntary Laboratory Accreditation Program (NVLAP Lab Code 200386-0) to offer this program. An additional quality control blind spiked sample program is conducted for each project. Each laboratory also maintains an internal quality control program, which is audited and reviewed internally and by Pacific Northwest National Laboratory. Additional information on these quality control efforts is provided in the following sections.

\subsubsection{DOE and EPA Comparison Studies}

Standard water samples are distributed blind to participating laboratories as part of the EPA performance evaluation program. These samples contain specific organic and inorganic analytes that have concentrations unknown to the analyzing laboratories. After analysis, the results are submitted to Environmental Resource Associates, the EPA performance evaluation program sponsor, for comparison with known values and results from other participating laboratories. Summaries of the results for 1999 are provided in Table 8.0.2 for the primary laboratory, Quanterra, St. Louis, Missouri. The percentage of acceptable results is high for the laboratory, indicating acceptable performance.

\begin{tabular}{|l|l|l|}
\hline Table 8.0.2. Summary of Performance on EPA Water Pollution and Water Supply \\
Studies, 1999
\end{tabular}


The DOEQuality Assessment Program and Environmental Resource Associates' Proficiency Testing Program provide standard samples of environmental media (e.g., water, air filters, soil, vegetation) that contain specific amounts of one or more radionuclides that were unknown by the participating laboratory. After analysis, the results are forwarded to DOE or Environmental Resource Associates for comparison with known values and results from other laboratories. Both DOE and Environmental Resource Associates have established criteria for evaluating the accuracy of results (NERL-Ci-0045, EML-604, EML-605). Summaries of the 1999 results are provided in Tables 8.0.3 and 8.0.4.

\subsubsection{Pacific Northwest National Laboratory Evaluations}

In addition to DOE and EPA interlaboratory quality control programs, Pacific Northwest National Laboratory maintains a quality control program to evaluate analytical contractor precision and accuracy and to conduct special intercomparisons. This program includes the use of blind spiked samples. Blind spiked quality control samples and blanks were prepared and submitted to check the accuracy and precision of analyses at Quanterra. In 1999, blind

\begin{tabular}{|c|c|c|c|}
\hline \multirow[b]{2}{*}{ Medium } & \multicolumn{2}{|c|}{$\begin{array}{l}\text { Summary of Performance on DOE Quality Assessment Program } \\
\text { Samples, } 1999\end{array}$} & gram \\
\hline & Radionuclides & $\begin{array}{l}\text { Number of Results } \\
\text { Reported for Each } \\
\text { Analyte }\end{array}$ & $\begin{array}{c}\text { Number Within } \\
\text { Acceptable Control } \\
\text { Limits }^{(a)}\end{array}$ \\
\hline \multicolumn{4}{|c|}{ Quanterra Environmental Services, Richland, Washington } \\
\hline \multirow[t]{2}{*}{ Air filter particulate } & $\begin{array}{l}\text { Gross alpha, gross beta, }{ }^{57} \mathrm{Co},{ }^{60} \mathrm{Co} \text {, } \\
{ }^{90} \mathrm{Sr},{ }^{137} \mathrm{Cs},{ }^{234} \mathrm{U},{ }^{238} \mathrm{Pu},{ }^{238} \mathrm{U},{ }^{239} \mathrm{Pu}, \\
{ }^{241} \mathrm{Am} \text {, total uranium }\end{array}$ & 2 & 2 \\
\hline & ${ }^{54} \mathrm{Mn},{ }^{106} \mathrm{Ru},{ }^{125} \mathrm{Sb}$ & 1 & 1 \\
\hline \multirow[t]{3}{*}{ Soil } & $\begin{array}{l}{ }^{40} \mathrm{~K},{ }^{90} \mathrm{Sr},{ }^{137} \mathrm{Cs},{ }^{212} \mathrm{~Pb},{ }^{214} \mathrm{Bi},{ }^{214} \mathrm{~Pb} \\
{ }^{228} \mathrm{Ac},{ }^{234} \mathrm{U},{ }^{238} \mathrm{U},{ }^{239} \mathrm{Pu},{ }^{241} \mathrm{Am}, \\
\text { total uranium }\end{array}$ & 2 & 2 \\
\hline & ${ }^{234} \mathrm{Th}$ & 2 & 1 \\
\hline & ${ }^{238} \mathrm{Pu}$ & 1 & 1 \\
\hline Vegetation & ${ }^{40} \mathrm{~K},{ }^{60} \mathrm{Co},{ }^{90} \mathrm{Sr},{ }^{137} \mathrm{Cs},{ }^{239} \mathrm{Pu},{ }^{241} \mathrm{Am}$ & 2 & 2 \\
\hline \multirow[t]{2}{*}{ Water } & $\begin{array}{l}\text { Gross alpha, gross beta, }{ }^{3} \mathrm{H},{ }^{60} \mathrm{Co} \\
{ }^{63} \mathrm{Ni} \text {, }{ }^{90} \mathrm{Sr},{ }^{137} \mathrm{Cs},{ }^{234} \mathrm{U},{ }^{238} \mathrm{Pu},{ }^{239} \mathrm{Pu} \\
{ }^{241} \mathrm{Am} \text {, total uranium }\end{array}$ & 2 & 2 \\
\hline & ${ }^{238} \mathrm{U}$ & 2 & 1 \\
\hline
\end{tabular}


Table 8.0.4. Summary of Performance on Environmental Resource Associates Proficiency Testing Program, 1999

Medium

Radionuclides

\section{N umber of Results Reported for Each} Analyte

\section{N umber Within Control Limits for Each Analyte ${ }^{(a)}$}

Quanterra Environmental Services, Richland, Washington

Water

Gross alpha, ${ }^{226} \mathrm{Ra},{ }^{228} \mathrm{Ra}$
Total uranium
Gross beta
${ }^{90} \mathrm{Sr}$
${ }^{134} \mathrm{Cs},{ }^{137} \mathrm{Cs}$
${ }^{60} \mathrm{Co}$
${ }^{89} \mathrm{Sr}$
${ }^{3} \mathrm{H},{ }^{65} \mathrm{Zn},{ }^{133} \mathrm{Ba}$
${ }^{131} \mathrm{I}$

$\begin{array}{ll}5 & 5 \\ 5 & 4 \\ 5 & 2 \\ 4 & 4 \\ 4 & 3 \\ 4 & 2 \\ 3 & 2 \\ 2 & 2 \\ 1 & 1\end{array}$

(a) Control limits are from NERL-Ci-0045.

spiked samples were submitted for groundwater (Table 8.0.5) and for air filters, vegetation, soil, and surface water (Table 8.0.6). For all water samples, $89 \%$ of nonradiochemistry blind spiked determinations were within control limits (see discussion of results in Appendix B of PNNL-13116). For all media, 91\% of Quanterra's radiochemistry blind spiked determinations were within control limits, which indicates acceptable results.

Pacific Northwest National Laboratory also participates in a Quality Assurance Task Force, a program conducted by the Washington State Department of Health. Public and private organizations from Idaho, Oregon, and Washington participate in analyzing the intercomparison samples. Samples from a Hanford Site well were collected for the 1999 intercomparison sample exchange. The data have not yet been compiled. Results will appear in the annual 2000 Hanford Site Environmental Report.

\subsubsection{Laboratory Internal Quality Assurance Programs}

The analyzing laboratories are required to maintain an internal quality assurance and control program. Periodically, the laboratories are audited internally for compliance to the quality assurance and control programs. At Quanterra St. Louis, the quality control programs meet the quality assurance and control criteria in SW-846. The laboratories are also required to maintain a system for reviewing and analyzing the results of the quality control samples to detect problems that may arise from contamination, inadequate calibrations, calculation errors, or improper procedure performance. Method detection levels are determined at least annually for each analytical method.

The internal quality control program at Quanterra Richland involves routine calibrations of 


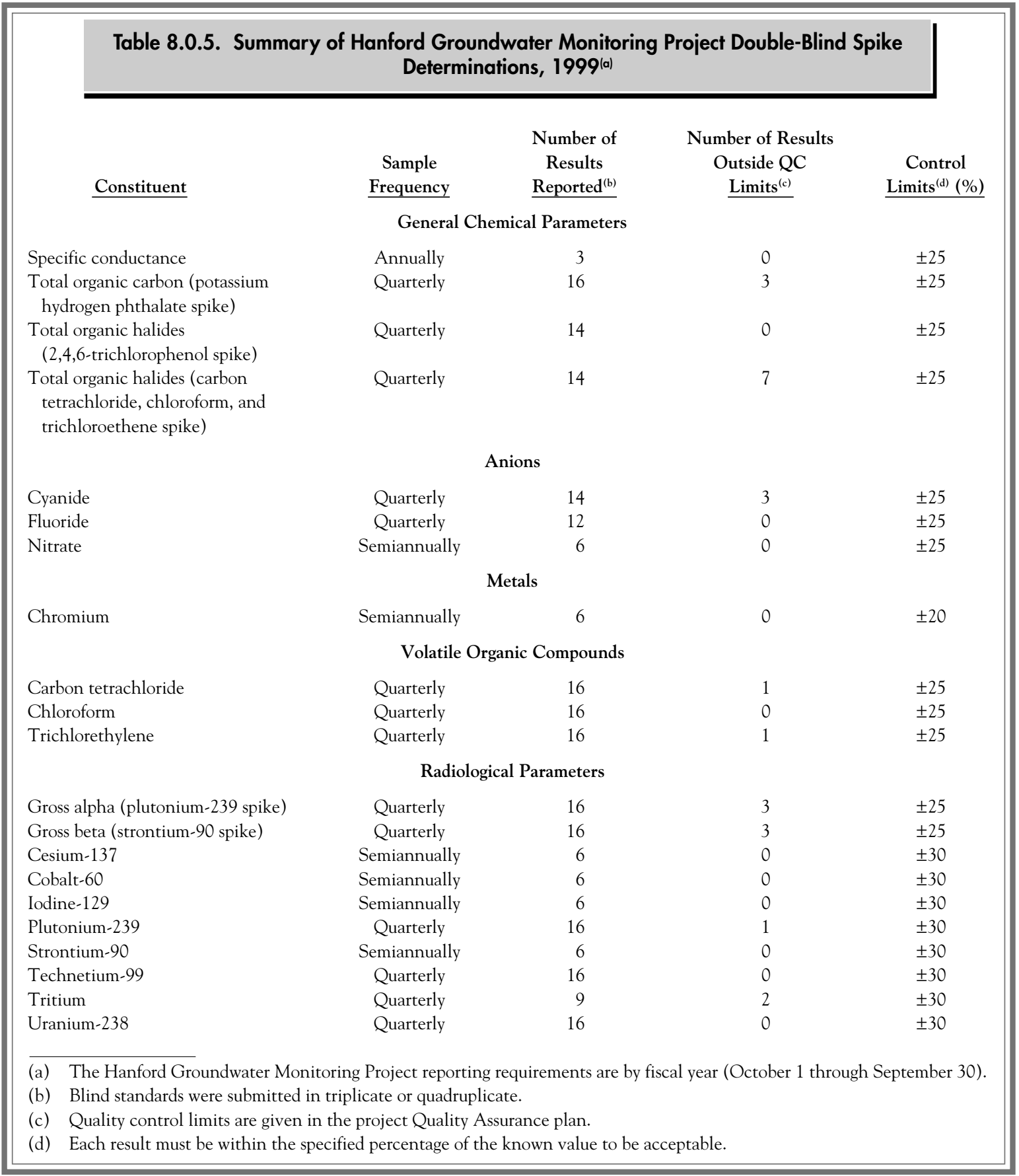

counting instruments, yield determinations of radiochemical procedures, frequent radiation check sources and background counts, replicate and spiked sample analyses, matrix and reagent blanks, and maintenance of control charts to indicate analytical deficiencies. Available calibration standards traceable to the National Institute of Standards and Technology are used for radiochemical calibrations. Calculation of minimum detectable concentrations involves the use of factors such as the average counting efficiencies and background for detection instruments, length of time for background and sample counts, 


\section{Table 8.0.6. Summary of Surface Environmental Surveillance Project Blind Spiked Determinations, 1999}

\begin{tabular}{lc} 
Medium & \multicolumn{1}{c}{ Radionuclides } \\
Air filters & ${ }^{60} \mathrm{Co},{ }^{90} \mathrm{Sr},{ }^{106} \mathrm{Ru},{ }^{125} \mathrm{Sb},{ }^{134} \mathrm{Cs},{ }^{137} \mathrm{Cs}$, \\
Soil & ${ }^{238} \mathrm{Pu},{ }^{239} \mathrm{Pu}$ \\
Water & ${ }^{40} \mathrm{~K},{ }^{90} \mathrm{Sr},{ }^{137} \mathrm{Cs},{ }^{234} \mathrm{U},{ }^{238} \mathrm{U},{ }^{238} \mathrm{Pu},{ }^{239} \mathrm{Pu}$ \\
Vegetation & ${ }^{3} \mathrm{H},{ }^{60} \mathrm{Co},{ }^{90} \mathrm{Sr},{ }^{134} \mathrm{Cs},{ }^{137} \mathrm{Cs},{ }^{238} \mathrm{Pu},{ }^{239} \mathrm{Pu}$ \\
& ${ }^{40} \mathrm{~K},{ }^{60} \mathrm{Co},{ }^{90} \mathrm{Sr},{ }^{137} \mathrm{Cs},{ }^{238} \mathrm{Pu},{ }^{239} \mathrm{Pu}$
\end{tabular}

\section{N umber of Results Reported}

(a) Control limit of $\pm 30 \%$.

sample volumes, radiochemical yields, and a predesignated uncertainty multiplier (EPA 520/ 1-80-012).

Periodically, inspections of services are performed that document conformance with contractual requirements of the analytical facility and provide the framework for identifying and resolving potential performance problems. Responses to assessment and inspection findings are documented by written communication, and corrective actions are verified by follow-up audits and inspections. Assessments of Quanterra St. Louis and Quanterra Richland were conducted in 1999 by the Hanford Site's Integrated Contractor Assessment Team, consisting of representatives from Bechtel Hanford, Inc., Pacific Northwest National Laboratory, and Waste Management Federal Services of Hanford, Inc. The purpose of the assessment of services was to evaluate the continued capability of the laboratories to analyze and process samples for the Hanford Site as specified in the statement of work between the DOE contractors and the laboratories.

Internal laboratory quality control program data are reported with the analytical results. Scientists at Pacific Northwest National Laboratory summarized the results quarterly. The results of the quality control sample summary reports indicated an acceptably functioning internal quality control program.

\subsubsection{Media Audits and Comparisons}

Additional audits and comparisons are conducted on several specific types of samples. The Washington State Department of Health routinely cosampled various environmental media and measured external radiation levels at multiple locations during 1999. Media that were cosampled and analyzed for radionuclides included groundwater from 32 wells, water from 12 locations along and across the Columbia River, water from 4 riverbank springs, groundwater from 5 drive point locations near the Columbia River's edge, water from 1 onsite drinking water location, sediment from 10 Columbia River sites, surface soil samples from 8 locations, samples from 3 air monitoring stations, thermoluminescent dosimeters from 16 sites, a Canadian goose and an elk. Also cosampled and analyzed for radionuclides were upwind and downwind samples of leafy vegetables, fruit, potatoes, and wine. Results will be published in the Washington State Department of Health 1999 annual report.

The U.S. Food and Drug Administration also cosampled and analyzed cucumbers, cherries, leafy vegetables (swiss chard and spinach), and potatoes for radionuclides from upwind and downwind sampling locations. The data are presented in Table 8.0.7. 


\begin{tabular}{|c|c|c|c|c|c|c|}
\hline \multirow[b]{2}{*}{ Medium } & \multicolumn{5}{|c|}{ able 8.0.7. Comparison of U.S. Food and Drug Administration Cosampling, 1999} & \multirow[b]{2}{*}{$\begin{array}{l}\text { lodine-13] } \\
\text { pCi/g/(c) }\end{array}$} \\
\hline & Area $^{(\mathrm{a})}$ & Organization $^{(\mathbf{b})}$ & $\begin{array}{c}\text { Strontium-90, } \\
\mathrm{pCi} / \mathrm{g}^{(\mathrm{c})}\end{array}$ & $\begin{array}{c}\text { Cesium-137, } \\
\text { pCi } / \mathbf{g}^{(\mathrm{c})}\end{array}$ & $\begin{array}{l}\text { Ruthenium-106, } \\
\qquad \mathrm{pCi} / \mathrm{g}^{(\mathrm{c})}\end{array}$ & \\
\hline \multirow[t]{2}{*}{ Leafy vegetables } & Riverview & $\begin{array}{l}\mathrm{FDA}^{(\mathrm{d})} \\
\text { FDA } \\
\mathrm{PNNL}^{(\mathrm{f})}\end{array}$ & $\begin{array}{c}0.0043 \pm 0.0013^{(\mathrm{e})} \\
0.0044 \pm 0.0012^{(\mathrm{e})} \\
<0.032\end{array}$ & $\begin{array}{l}<0.045 \\
<0.045 \\
<0.062\end{array}$ & $\begin{array}{l}<0.045 \\
<0.045 \\
<0.022\end{array}$ & \\
\hline & Sunnyside & $\begin{array}{l}\text { FDA } \\
\text { FDA } \\
\text { PNNL }\end{array}$ & $\begin{array}{l}<0.002 \\
<0.002 \\
<0.035\end{array}$ & $\begin{array}{l}<0.045 \\
<0.045 \\
<0.044\end{array}$ & $\begin{array}{l}<0.045 \\
<0.045 \\
<0.37\end{array}$ & \\
\hline \multirow[t]{2}{*}{ Potatoes } & Sunnyside & $\begin{array}{l}\text { FDA } \\
\text { FDA } \\
\text { PNNL }\end{array}$ & $\begin{array}{l}<0.002 \\
<0.002 \\
<0.0026\end{array}$ & $\begin{array}{l}<0.045 \\
<0.045 \\
<0.0063\end{array}$ & $\begin{array}{l}<0.045 \\
<0.045 \\
<0.052\end{array}$ & \\
\hline & Horn Rapids & $\begin{array}{l}\text { FDA } \\
\text { FDA } \\
\text { PNNL }\end{array}$ & $\begin{array}{l}<0.002 \\
<0.002 \\
<0.0028\end{array}$ & $\begin{array}{l}<0.045 \\
<0.045 \\
<0.0061\end{array}$ & $\begin{array}{l}<0.045 \\
<0.045 \\
<0.052\end{array}$ & \\
\hline Cherries & Sagemoor & $\begin{array}{l}\text { FDA } \\
\text { FDA } \\
\text { PNNL }\end{array}$ & $\begin{array}{l}<0.002 \\
<0.002 \\
<0.00351\end{array}$ & $\begin{array}{l}<0.045 \\
<0.045 \\
<0.0045\end{array}$ & $\begin{array}{l}<0.045 \\
<0.045 \\
<0.0677\end{array}$ & \\
\hline Cucumber & Eltopia & $\begin{array}{l}\text { FDA } \\
\text { FDA } \\
\text { PNNL }\end{array}$ & $\begin{array}{l}<0.002 \\
<0.002 \\
\mathrm{NA}^{(\mathrm{g})}\end{array}$ & $\begin{array}{l}<0.045 \\
<0.045 \\
<0.0025\end{array}$ & $\begin{array}{l}<0.045 \\
<0.045 \\
<0.022\end{array}$ & $\begin{array}{c}<0.1 \\
<0.1 \\
<0.0026\end{array}$ \\
\hline $\begin{array}{l}\text { (a) Locations ar } \\
\text { (b) Two samples } \\
\text { (c) Less than (< } \\
\text { (d) FDA = U.S. } \\
\text { (e) } \pm 2 \text { sigma tot } \\
\text { (f) } \text { PNNL = Pa } \\
\text { (g) NA = Not a }\end{array}$ & $\begin{array}{l}\text { identified in } F \\
\text { of each medium } \\
\text { values are the } \\
\text { food and Drug } \\
\text { l propagated an } \\
\text { fic Northwest I } \\
\text { alyzed. }\end{array}$ & $\begin{array}{l}\text { igure } 4.4 .1 \text {. } \\
2 \text { sigma total propa } \\
\text { Administration. } \\
\text { nalytical uncertaint } \\
\text { National Laborator }\end{array}$ & $\begin{array}{l}\text { FDA, one for PNNL } \\
\text { gated analytical unce }\end{array}$ & rtainties. & & \\
\hline
\end{tabular}

Quality control for environmental thermoluminescent dosimeters includes the audit exposure of three environmental thermoluminescent dosimeters per quarter to known values of radiation (between 18 and $28 \mathrm{mR}$ ). A summary of 1999 results is shown in Table 8.0.8. On average, the thermoluminescent dosimeter measurements were biased 3\% higher than the known values.

\subsubsection{Effluent Monitoring and Near-Facility Environmental Monitoring}

The Effluent Monitoring and Near-Facility Environmental Monitoring Programs are subject to the quality assurance requirements specified in the Hanford Analytical Services Quality Assurance Requirements Document (DOE/RL-96-68). These quality assurance programs comply with DOE Order 5700.6C, using standards from the American
Society of Mechanical Engineers (ASME NQA-11997 Edition) as their basis. The programs also adhere to the guidelines and objectives in EPA/005/80 and EPA QA/R-5.

The monitoring programs each have a quality assurance project plan describing applicable quality 
Table 8.0.8. Comparison of Thermoluminescent Dosimeter Results with Known Exposure, 1999

\begin{tabular}{|c|c|c|c|c|}
\hline Quarter & Exposure Date & 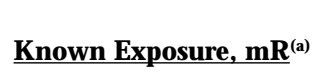 & Determined Exposure, $\mathbf{m R}^{(\mathrm{b})}$ & $\begin{array}{c}\begin{array}{c}\% \text { of Known } \\
\text { Exposure }\end{array} \\
\end{array}$ \\
\hline \multirow[t]{3}{*}{1 st } & February 10, 1999 & $18 \pm 0.67$ & $17.85 \pm 0.35$ & 99 \\
\hline & February 10, 1999 & $21 \pm 0.78$ & $19.86 \pm 0.39$ & 95 \\
\hline & February 10, 1999 & $27 \pm 1.00$ & $29.60 \pm 0.12$ & 110 \\
\hline \multirow[t]{3}{*}{ 2nd } & May 14, 1999 & $19 \pm 0.70$ & $20.38 \pm 0.20$ & 107 \\
\hline & May 14, 1999 & $23 \pm 0.85$ & $24.78 \pm 0.48$ & 108 \\
\hline & May 14, 1999 & $28 \pm 1.04$ & $30.78 \pm 1.83$ & 110 \\
\hline \multirow[t]{3}{*}{$3 \mathrm{rd}$} & August 13, 1999 & $19 \pm 0.70$ & $19.79 \pm 0.02$ & 104 \\
\hline & August 13, 1999 & $24 \pm 0.89$ & $24.59 \pm 0.08$ & 102 \\
\hline & August 13, 1999 & $27 \pm 1.00$ & $27.39 \pm 1.40$ & 101 \\
\hline \multirow[t]{3}{*}{4 th } & November 15, 1999 & $18 \pm 0.67$ & $17.80 \pm 0.70$ & 99 \\
\hline & November 15, 1999 & $22 \pm 0.81$ & $22.27 \pm 0.65$ & 101 \\
\hline & November 15, 1999 & $26 \pm 0.96$ & $26.21 \pm 0.24$ & 101 \\
\hline
\end{tabular}

assurance elements. These plans are approved by contractor quality assurance groups, who conduct surveillances and audits to verify compliance with the plans. Work such as sample analysis performed through contracts must meet the requirements of these plans. Suppliers are audited before the contract selection is made for equipment and services that may significantly impact the quality of a project.

\subsubsection{Sample Collection Quality Assurance}

Samples for the Effluent Monitoring and NearFacility Environmental Monitoring Programs are collected by staff trained for the task in accordance with approved procedures. Established sampling locations are accurately identified and documented to ensure continuity of data for those sites and are described in DOE/RL-91-50, Rev. 2.

\subsubsection{Analytical Results Quality Assurance}

Samples for the Effluent Monitoring and NearFacility Environmental Monitoring Programs are analyzed by four different analytical laboratories. The use of these laboratories is dependent on the Hanford contractor collecting the samples and contract(s) established between the contractor and the analytical laboratory(s). Table 8.0 .9 provides a summary of the Hanford Site's analytical laboratories used for effluent monitoring and near-facility monitoring samples.

The quality of the analytical data is ensured by several means. Counting room instruments, for instance, are kept within calibration limits through daily checks, the results of which are stored in computer databases. Radiochemical standards used in analyses are regularly measured and the results are 


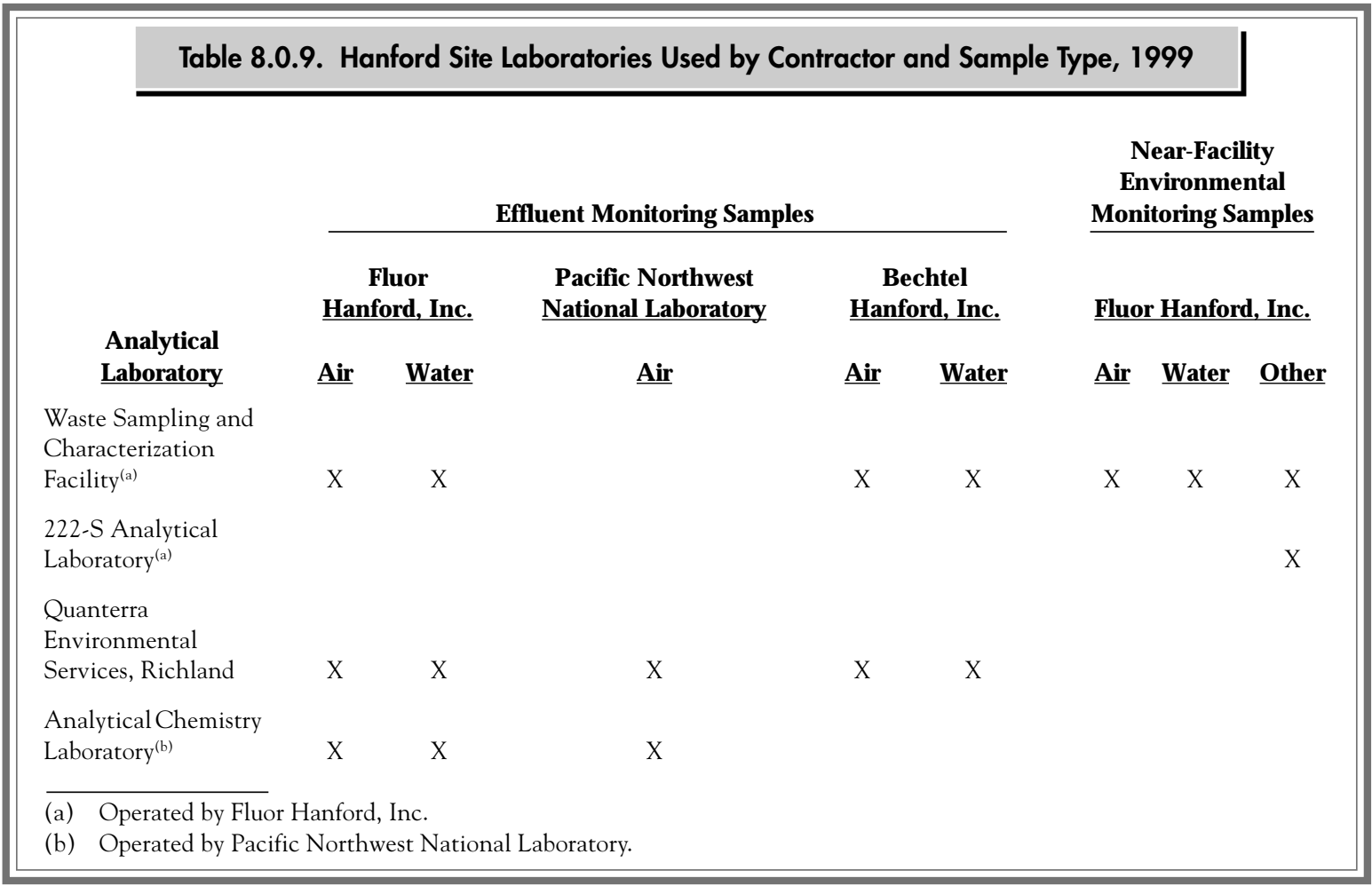

reported and tracked. Formal, written laboratory procedures are used in analyzing samples. Analytical procedural control is ensured through administrative procedures. Chemical technologists at the laboratory qualify to perform analyses through formal classroom and on-the-job training.

The participation of the Hanford Site analytical laboratories in EPA and DOE laboratory performance programs also serves to ensure the quality of the data produced. Laboratory performance program results for calendar year 1999 for the Waste Sampling and Characterization Facility were evaluated in two different studies. In the EPA Water Pollution Study \#WP-55, 50 different parameters, analytes, and compounds were submitted to the Waste Sampling Characterization Facility for analysis. Analysis results were unacceptable for only 2 analytes (4,4'DDD [4,4'-dichlorodiphenyldichloroethane] and methoxychlor [dimethoxy-DDT]), for a total of 96\% acceptable analysis results. In the DOE Mixed Analyte Performance Evaluation Program study MAPEP-99-S6, 49 analytes and/or compounds were submitted to the Waste Sampling Characterization Facility for analysis. Analysis results were unacceptable for only one analyte (strontium-90), for a total of $98 \%$ acceptable analysis results. Other performance results are presented in Tables 8.0.10 through 8.0.12. 
Table 8.0.10. Waste Sampling and Characterization Facility(a) Performance on DOE Quality Assessment Program Samples, 1999

\begin{tabular}{|c|c|c|c|}
\hline Medium & Radionuclide & $\begin{array}{l}\text { Number } \\
\text { of Results } \\
\text { Reported }\end{array}$ & $\begin{array}{c}\text { Number } \\
\text { Within Control } \\
\text { Limits }\end{array}$ \\
\hline Air filters & $\begin{array}{l}{ }^{54} \mathrm{Mn},{ }^{57} \mathrm{Co},{ }^{60} \mathrm{Co},{ }^{90} \mathrm{Sr},{ }^{125} \mathrm{Sb},{ }^{137} \mathrm{Cs}, \\
{ }^{234} \mathrm{U},{ }^{238} \mathrm{Pu},{ }^{238} \mathrm{U},{ }^{239} \mathrm{Pu},{ }^{241} \mathrm{Am} \text {, gross } \\
\text { alpha, gross beta }\end{array}$ & 23 & 21 \\
\hline Soil & $\begin{array}{l}{ }^{40} \mathrm{~K},{ }^{90} \mathrm{Sr},{ }^{137} \mathrm{Cs},{ }^{234} \mathrm{U},{ }^{238} \mathrm{U},{ }^{239} \mathrm{Pu}, \\
{ }^{241} \mathrm{Am}\end{array}$ & 12 & 10 \\
\hline Vegetation & $\begin{array}{l}{ }^{40} \mathrm{~K},{ }^{60} \mathrm{Co},{ }^{90} \mathrm{Sr},{ }^{137} \mathrm{Cs},{ }^{239} \mathrm{Pu},{ }^{241} \mathrm{Am}, \\
{ }^{244} \mathrm{Cm}\end{array}$ & 13 & 11 \\
\hline Water & $\begin{array}{l}{ }^{3} \mathrm{H},{ }^{60} \mathrm{Co},{ }^{90} \mathrm{Sr},{ }^{137} \mathrm{Cs},{ }^{234} \mathrm{U},{ }^{238} \mathrm{Pu},{ }^{238} \mathrm{U} \\
{ }^{239} \mathrm{Pu},{ }^{241} \mathrm{Am} \text {, gross alpha, gross beta }\end{array}$ & 22 & 19 \\
\hline
\end{tabular}

Table 8.0.11. 222-S Analytical Laboratory (a) Performance on DOE Quality Assessment Program Samples, 1999

\begin{tabular}{|c|c|c|c|}
\hline Medium & Radionuclide & $\begin{array}{l}\text { Number } \\
\text { of Results } \\
\text { Reported }\end{array}$ & $\begin{array}{c}\text { Number } \\
\text { W ithin Control } \\
\text { Limits }\end{array}$ \\
\hline Air filters & $\begin{array}{l}{ }^{54} \mathrm{Mn},{ }^{57} \mathrm{Co},{ }^{60} \mathrm{Co},{ }^{90} \mathrm{Sr},{ }^{125} \mathrm{Sb},{ }^{137} \mathrm{Cs}, \\
{ }^{238} \mathrm{Pu},{ }^{239} \mathrm{Pu},{ }^{241} \mathrm{Am}\end{array}$ & 15 & 15 \\
\hline Soil & ${ }^{90} \mathrm{Sr},{ }^{137} \mathrm{Cs},{ }^{239} \mathrm{Pu}$, total uranium & 5 & 4 \\
\hline Vegetation & ${ }^{60} \mathrm{Co},{ }^{90} \mathrm{Sr},{ }^{137} \mathrm{Cs},{ }^{239} \mathrm{Pu},{ }^{241} \mathrm{Am},{ }^{244} \mathrm{Cm}$ & 10 & 9 \\
\hline Water & $\begin{array}{l}{ }^{3} \mathrm{H},{ }^{60} \mathrm{Co},{ }^{90} \mathrm{Sr},{ }^{137} \mathrm{Cs},{ }^{238} \mathrm{Pu},{ }^{239} \mathrm{Pu},{ }^{241} \mathrm{Am} \text {, } \\
\text { total uranium }\end{array}$ & 15 & 11 \\
\hline
\end{tabular}

(a) Onsite "high-level" radiological laboratory operated by Fluor Hanford, Inc. (Note: These samples are "low-level" environmental activity samples.)

Table 8.0.12. 222-S Analytical Laboratory (a) Performance on Environmental Resource Associates Laboratory Water Pollution Inorganic Studies, 1999

\begin{tabular}{|c|c|c|}
\hline Laboratory & $\begin{array}{l}\text { Water Pollution Study } \\
\text { A pril } 1999 \\
\% \text { A cceptable }\end{array}$ & $\begin{array}{l}\text { Water Pollution Study } \\
\text { N ovember } 1999 \\
\% \text { A cceptable }\end{array}$ \\
\hline 222-S Analytical Laboratory & $91^{\text {(b) }}$ & $97^{(\mathrm{c})}$ \\
\hline \multicolumn{3}{|c|}{$\begin{array}{l}\text { Onsite "high-level" radiological laboratory operated by Fluor Hanford, Inc. } \\
\text { Unacceptable results were for chloride, fluoride, and copper. } \\
\text { Unacceptable result was for conductivity. }\end{array}$} \\
\hline
\end{tabular}




\subsubsection{References}

ASME-NQA-1-1997 Edition. 1997. Q uality A ssurance Requirements for $\mathrm{N}$ uclear Facility A pplications. American Society of Mechanical Engineers, New York.

Comprehensive Environmental Response, Compensation, and Liability Act. 1980. Public Law 96-150, as amended, 94 Stat. 2767, 42 USC 9601 et seq.

DOE Order 5700.6C. "Quality Assurance."

DOE/RL-91-50, Rev. 2. 1997. Environmental M onitoring Plan, U nited States D epartment of E nergy Richland $O$ perations $O$ ffice. U.S. Department of Energy, Richland Operations Office, Richland, Washington.

DOE/RL-96-68. 1996. H anford A nalytical Services Q uality A ssurance Requirements Document. U.S. Department of Energy, Richland Operations Office, Richland, Washington.

EML-604. June, 1999. Semi-A nnual Report of the D epartment of Energy, O ffice of E nvironmental $M$ anagement, Q uality A ssessment Program. P. D. Greenlaw, Environmental Measurements Laboratory, U.S. Department of Energy, New York.

EML-605. December, 1999. Semi-A nnual Report of the Department of Energy, O ffice of Environmental $M$ anagement, Q uality A ssessment Program. P. D. Greenlaw, Environmental Measurements Laboratory, U.S. Department of Energy, New York.

EPA/005/80. 1980. Interim Guidelines and Specifications for Preparing Q uality A ssurance Project Plans. U.S. Environmental Protection Agency, Washington, D.C.
EPA QA/R-5. 1994. Requirements for Q uality A ssurance Project Plans for Environmental Data 0 perations. U.S. Environmental Protection Agency, Washington, D.C.

EPA 520/1-80-012. 1980. U pgrading Environmental Radiation Data: H ealth Physics Society Committee Report H PSR -1 (1980). U.S. Environmental Protection Agency, Washington, D.C.

ES-SSPM-001. 1998. Sampling Services Procedures M anual. Waste Management Federal Services, Inc., Northwest Operations, Richland, Washington.

MAPEP-99-56. 2000. Soil Sample M A PEP-99-56 Participating Laboratory Report. U.S. Department of Energy, Mixed Analyte Performance Evaluation Program, Radiological and Environmental Sciences Laboratory, Idaho Falls, Idaho.

NERL-Ci-0045. December 30, 1998. N ational Standards for W ater Proficiency T esting Studies, C riteria D ocument. U.S. Environmental Protection Agency, Washington, D.C.

PNL-MA-580, Rev. 2. 1996. Surface Environmental Surveillance Procedures M anual. R. W. Hanf and R. L. Dirkes (eds.), Pacific Northwest National Laboratory, Richland, Washington.

PNNL-13116. 2000. H anford Site G roundwater M onitoring for Fiscal Y ear 1999. M. J. Hartman, L. F. Morasch, and W. D. Webber (eds.), Pacific Northwest National Laboratory, Richland, Washington.

SW-846. 1986. T est M ethods for E valuating Solid W aste: Physical/C hemical $M$ ethods, Third Edition. U.S. Environmental Protection Agency, Office of Solid Waste and Emergency Response, Washington, D.C. 


\title{
Appendix A Additional Monitoring Results for 1999
}

\author{
G. W. Patton and T. M. Poston
}

This appendix contains additional information on 1999 monitoring results, supplementing the data summarized in the main body of the report. More detailed information is available in PNNL-13230, APP. 1. 


\begin{tabular}{|c|c|c|c|c|c|c|c|c|}
\hline & Table & A.1. Rad & ionuclide Concentratio & in Columbia River Wate & at Priest & oids Dam, 1999 Con & red to Previous 5 Years & \\
\hline \multirow[b]{3}{*}{ Radionuclide $^{\text {(a) }}$} & & \multicolumn{3}{|c|}{1999} & \multicolumn{3}{|c|}{$1994-1998$} & \multirow{3}{*}{$\begin{array}{l}\text { Ambient Surface } \\
\text { Water Quality } \\
\text { Standard, pCi/L }\end{array}$} \\
\hline & & \multirow{2}{*}{$\begin{array}{l}\text { No. of } \\
\text { Samples }\end{array}$} & \multirow{2}{*}{\multicolumn{2}{|c|}{\begin{tabular}{lc}
\multicolumn{2}{c}{ Concentration, $^{(\mathrm{b})}$ pCi/L } \\
Maximum Aver
\end{tabular}}} & \multirow{2}{*}{$\begin{array}{l}\text { No. of } \\
\text { Samples }\end{array}$} & \multicolumn{2}{|c|}{ Concentration, ${ }^{(b)}$ pCi/L } & \\
\hline & & & & & & Maximum & Average & \\
\hline \multicolumn{9}{|c|}{ Composite System } \\
\hline Tritium & & 12 & $58 \pm 7.7$ & $37 \pm 5.0$ & $58^{(c)}$ & $62 \pm 12$ & $36 \pm 6.2$ & $20,000^{(\mathrm{d})}$ \\
\hline Alpha (gross) & & 12 & $5.6 \pm 3.1$ & $0.90 \pm 0.86$ & 60 & $1.6 \pm 0.83$ & $0.42 \pm 0.094$ & $15^{(\mathrm{e}, \mathrm{f})}$ \\
\hline Beta (gross) & & 12 & $7.7 \pm 2.2$ & $0.92 \pm 1.9$ & 60 & $3.5 \pm 2.4$ & $1.1 \pm 0.26$ & $50^{(e, f)}$ \\
\hline Strontium-90 & & 12 & $0.097 \pm 0.034$ & $0.067 \pm 0.0098$ & 60 & $0.14 \pm 0.0049$ & $0.085 \pm 0.0052$ & $8^{(\mathrm{e}, \mathrm{f})}$ \\
\hline Technetium-99 & & 12 & $0.45 \pm 0.47$ & $-0.024 \pm 0.11$ & 60 & $1.6 \pm 0.69$ & $0.030 \pm 0.068$ & $900^{(\mathrm{d})}$ \\
\hline Iodine $-129^{(\mathrm{h})}$ & & 4 & $0.0000066 \pm 0.000011$ & $0.0000047 \pm 0.0000013$ & 20 & $0.00013 \pm 0.000013$ & $0.000017 \pm 0.000012$ & $1^{(\mathrm{d})}$ \\
\hline Uranium-234 & & 12 & $0.42 \pm 0.087$ & $0.25 \pm 0.044$ & 60 & $0.44 \pm 0.13$ & $0.24 \pm 0.015$ & .-(g) \\
\hline Uranium-235 & & 12 & $0.025 \pm 0.016$ & $0.0086 \pm 0.0050$ & 60 & $0.032 \pm 0.039$ & $0.0079 \pm 0.0019$ & .. \\
\hline Uranium-238 & & 12 & $0.38 \pm 0.080$ & $0.21 \pm 0.040$ & 60 & $0.35 \pm 0.11$ & $0.20 \pm 0.013$ & .. \\
\hline Uranium (total) & & 12 & $0.81 \pm 0.18$ & $0.47 \pm 0.084$ & 60 & $0.83 \pm 0.28$ & $0.44 \pm 0.028$ & -. \\
\hline \multicolumn{9}{|c|}{ Continuous System } \\
\hline \multirow[t]{2}{*}{ Beryllium-7 } & $\mathrm{P}$ & 12 & $0.096 \pm 0.021$ & $0.039 \pm 0.018$ & 72 & $0.22 \pm 0.092$ & $0.043 \pm 0.0085$ & $6,000^{(d)}$ \\
\hline & $\mathrm{D}$ & 12 & $0.11 \pm 0.061$ & $0.044 \pm 0.019$ & & & & \\
\hline \multirow[t]{2}{*}{ Potassium-40 } & $\mathrm{P}$ & 12 & $0.28 \pm 0.055$ & $0.13 \pm 0.048$ & 72 & $1.0 \pm 0.19$ & $0.31 \pm 0.059$ & .- \\
\hline & $\mathrm{D}$ & 12 & $0.72 \pm 0.17$ & $0.40 \pm 0.086$ & & & & \\
\hline \multirow[t]{2}{*}{ Cobalt-60 } & $\mathrm{P}$ & 12 & $0.0013 \pm 0.0016$ & $0.000045 \pm 0.00032$ & 72 & $0.0065 \pm 0.0057$ & $0.00050 \pm 0.00059$ & $100^{(d)}$ \\
\hline & $\mathrm{D}$ & 12 & $0.0031 \pm 0.0055$ & $0.00068 \pm 0.00086$ & & & & \\
\hline \multirow[t]{2}{*}{ Cesium-137 } & $\mathrm{P}$ & 12 & $0.0031 \pm 0.0016$ & $0.0012 \pm 0.00058$ & 72 & $0.24 \pm 5.0$ & $0.0040 \pm 0.0066$ & $200^{(d)}$ \\
\hline & $\mathrm{D}$ & 12 & $0.0023 \pm 0.0039$ & $0.00092 \pm 0.00070$ & & & & \\
\hline \multirow[t]{2}{*}{ Europium-155 } & $\mathrm{P}$ & 12 & $0.0032 \pm 0.0044$ & $0.00087 \pm 0.00098$ & 72 & $0.012 \pm 0.014$ & $0.0011 \pm 0.00090$ & $600^{(\mathrm{d})}$ \\
\hline & $\mathrm{D}$ & 12 & $0.0042 \pm 0.0064$ & $-0.00032 \pm 0.0017$ & & & & \\
\hline \multirow[t]{2}{*}{ Plutonium-239/240 } & $\mathrm{P}$ & 4 & $0.000028 \pm 0.000022$ & $0.000023 \pm 0.0000042$ & 40 & $0.00028 \pm 0.00010$ & $0.000031 \pm 0.000019$ & -. \\
\hline & $\mathrm{D}$ & 4 & $0.000044 \pm 0.000094$ & $0.000021 \pm 0.000020$ & & & & \\
\hline \multicolumn{9}{|c|}{$\begin{array}{l}\text { (a) Radionuclides measured using the continuous system show the particulate (P) and dissolved (D) fractions separately for 1999 values, 1994-1998 values are for combined particulate and } \\
\text { dissolved fractions. Other radionuclides are based on unfiltered samples collected by the composite system (see Section 4.2, "Surface Water and Sediment Surveillance"). }\end{array}$} \\
\hline \multicolumn{9}{|c|}{ (b) Maximum values are \pm total propagated analytical uncertainty ( 2 sigma). Averages are \pm 2 standard error of the calculated mean. } \\
\hline \multicolumn{9}{|c|}{ (c) Excludes one result of $200 \pm 22 \mathrm{pCi} / \mathrm{L}$. } \\
\hline \multicolumn{9}{|c|}{ (d) WAC 173-201A-050 and EPA-570/9-76-003. } \\
\hline \multicolumn{9}{|c|}{ (e) WAC 246-290. } \\
\hline \multicolumn{9}{|l|}{ (f) $\quad 40$ CFR 141.} \\
\hline (g) Dashes indica & te no c & oncentratior & ıides available. & & & & & \\
\hline
\end{tabular}


Table A.2. Radionuclide Concentrations in Columbia River Water at the Richland Pumphouse, 1999 Compared to Previous 5 Years

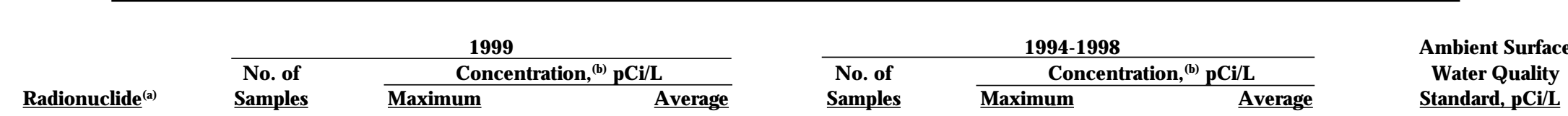

\section{Composite System}

Tritium

Alpha (gross)

Beta (gross)

Strontium-90

Technetium-99

lodine-129(g)

Uranium-234

Uranium-235

Uranium-238

Uranium (total)

\section{Continuous System}

Beryllium-7

Potassium-40

Cobalt- 60

Cesium-137

Europium-155

Plutonium-239/240

$\begin{aligned} 97 & \pm 11 \\ 1.8 & \pm 1.2 \\ 6.6 & \pm 2.5 \\ 0.092 & \pm 0.034 \\ 0.23 & \pm 0.46 \\ 0.00010 & \pm 0.0000044 \\ 0.31 & \pm 0.067 \\ 0.023 & \pm 0.016 \\ 0.25 & \pm 0.057 \\ 0.58 & \pm 0.14\end{aligned}$

$0.080 \pm 0.023$

$0.082 \pm 0.049$

$0.20 \pm 0.040$

$0.54 \pm 0.090$

$0.0016 \pm 0.0011$

$0.0024 \pm 0.0021$

$0.0037 \pm 0.0015$

$0.0026 \pm 0.0018$

$0.0016 \pm 0.0032$

$0.0077 \pm 0.013$

$0.000062 \pm 0.000037$

$0.00016 \pm 0.000091$

$\begin{aligned} 66 & \pm 11 \\ 0.73 & \pm 0.28 \\ 0.62 & \pm 1.6 \\ 0.071 & \pm 0.014 \\ -0.022 & \pm 0.070 \\ 0.000078 & \pm 0.000023 \\ 0.25 & \pm 0.019 \\ 0.11 & \pm 0.0034 \\ 0.21 & \pm 0.020 \\ 0.47 & \pm 0.038\end{aligned}$

$0.032 \pm 0.011$

$0.038 \pm 0.015$

$0.13 \pm 0.022$

$0.42 \pm 0.044$

$0.00011 \pm 0.00042$

$0.00034 \pm 0.00081$

$0.0014 \pm 0.00050$

$0.0010 \pm 0.00057$

$-0.00044 \pm 0.00092$

$0.0017 \pm 0.0023$

$0.000026 \pm 0.000024$

$0.000048 \pm 0.000078$

\section{Samples}

Maximum

Average

$\begin{array}{rr}58 & 150 \pm 11 \\ 60 & 2.2 \pm 1.1 \\ 60 & 3.4 \pm 1.7 \\ 60 & 0.30 \pm 0.081 \\ 60 & 0.53 \pm 0.52 \\ 17 & 0.00016 \pm 0.000013 \\ 60 & 0.50 \pm 0.13 \\ 60 & 0.048 \pm 0.022 \\ 60 & 0.53 \pm 0.14 \\ 60 & 1.0 \pm 0.30\end{array}$

54

$53^{(}$

54

54

54

34

\section{$28 \pm 12$}

$0.88 \pm 0.16$

$0.23 \pm 0.69$

$0.54 \pm 0.60$

$0.040 \pm 1.5$

$0.00017 \pm 0.000087$

$\begin{aligned} 75 & \pm 7.2 \\ 0.56 & \pm 0.11 \\ 1.1 & \pm 0.22 \\ 0.088 & \pm 0.0089 \\ 0.029 & \pm 0.045 \\ 0.00011 & \pm 0.000022 \\ 0.27 & \pm 0.020 \\ 0.0096 & \pm 0.0023 \\ 0.22 & \pm 0.017 \\ 0.50 & \pm 0.036\end{aligned}$

$0.56 \pm 1.0$

$0.28 \pm 0.063$

$0.0050 \pm 0.0084$

$-0.023 \pm 0.048$

$0.0010 \pm 0.0017$

$0.000044 \pm 0.000013$ $20,000^{(\mathrm{c})}$
$15^{(\mathrm{c}, \mathrm{d})}$
$50^{(\mathrm{c}, \mathrm{d})}$
$8^{(\mathrm{c}, \mathrm{d})}$
$900^{(\mathrm{e})}$
$1^{(\mathrm{e})}$
- (f) $^{(\mathrm{f})}$
$\cdots$
--
.-

$6,000^{(e)}$

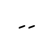

$100^{(e)}$

$200^{(e)}$

$600^{(e)}$

(a) Radionuclides measured using the continuous system show the particulate (P) and dissolved (D) fractions separately for 1999 values, 1994-1998 values are for combined particulate and dissolved fractions. Other radionuclides are based on unfiltered samples collected by the composite system (see Section 4.2, "Surface Water and Sediment Surveillance").

(b) Maximum values are \pm total propagated analytical uncertainty (2 sigma). Averages are \pm 2 standard error of the calculated mean.

(c) 40 CFR 141

(d) WAC 246-290

(e) WAC 173-201A-050 and EPA-570/9-76-003.

(f) Dashes indicate no concentration guides available.

(g) From 1994 through 1995, iodine-129 activities were obtained from the dissolved fraction of the continuous system.

(h) Excludes one value of $110 \pm 21 \mathrm{pCi} / \mathrm{L}$ on January 3, 1995. 


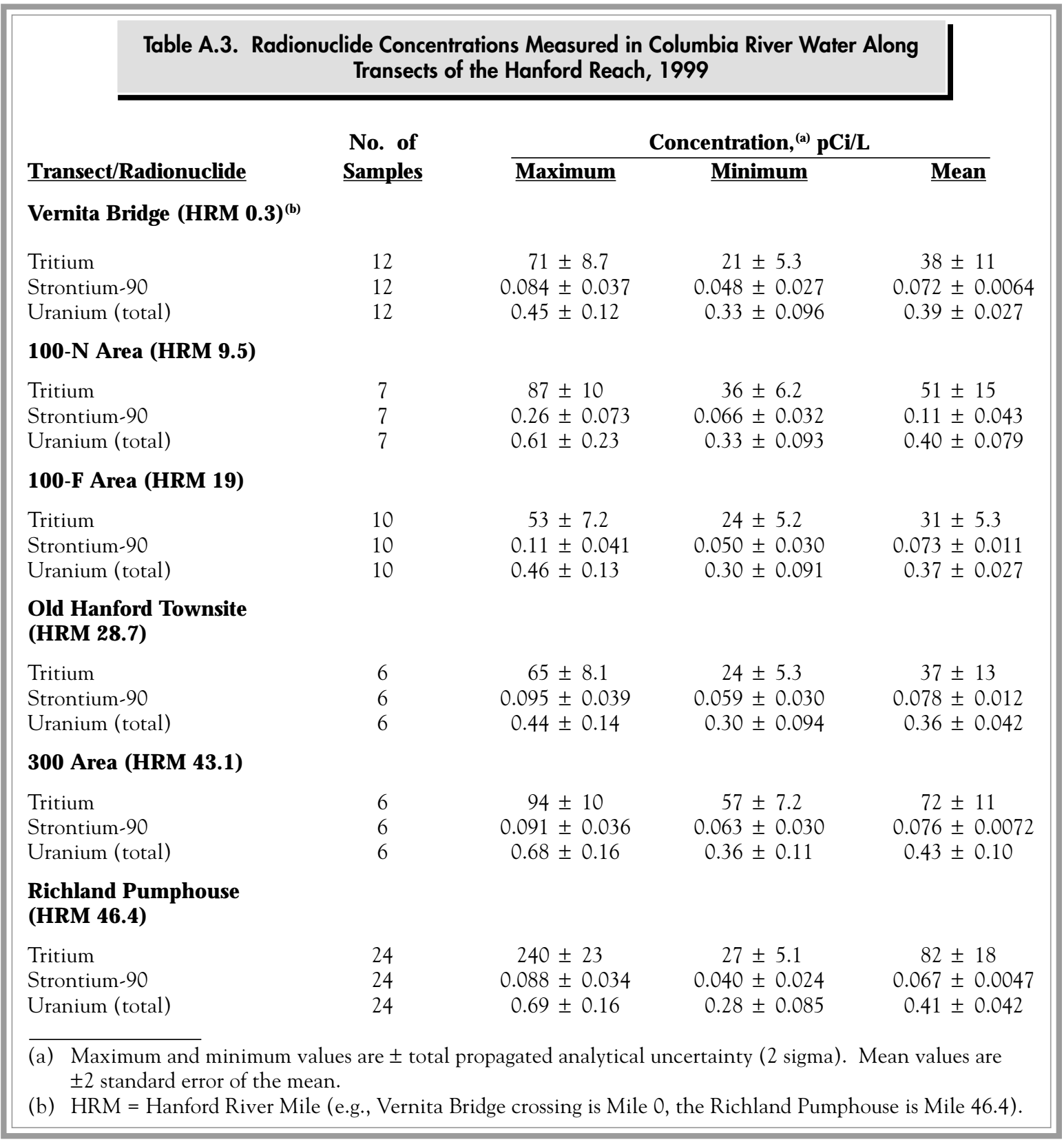




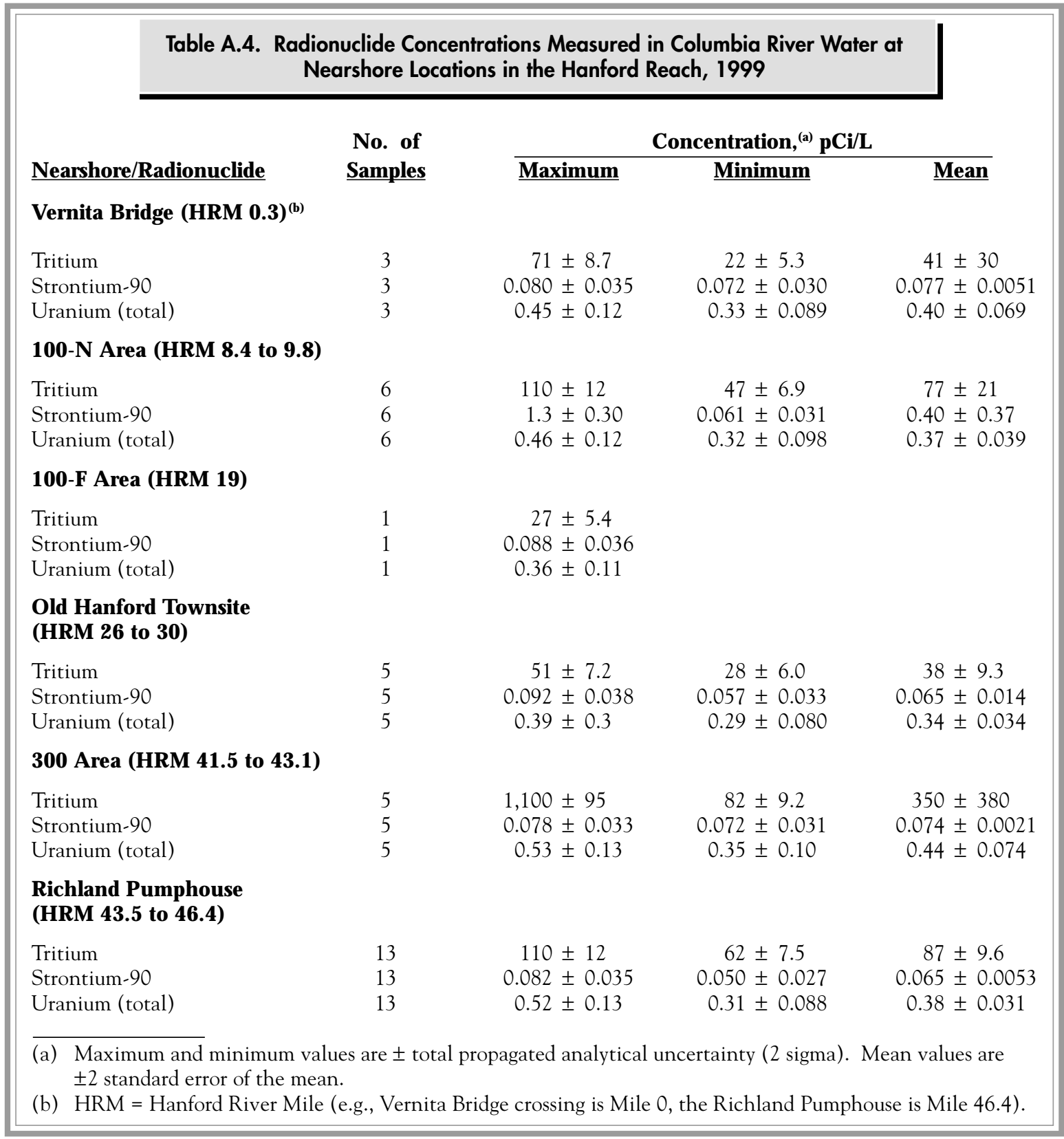




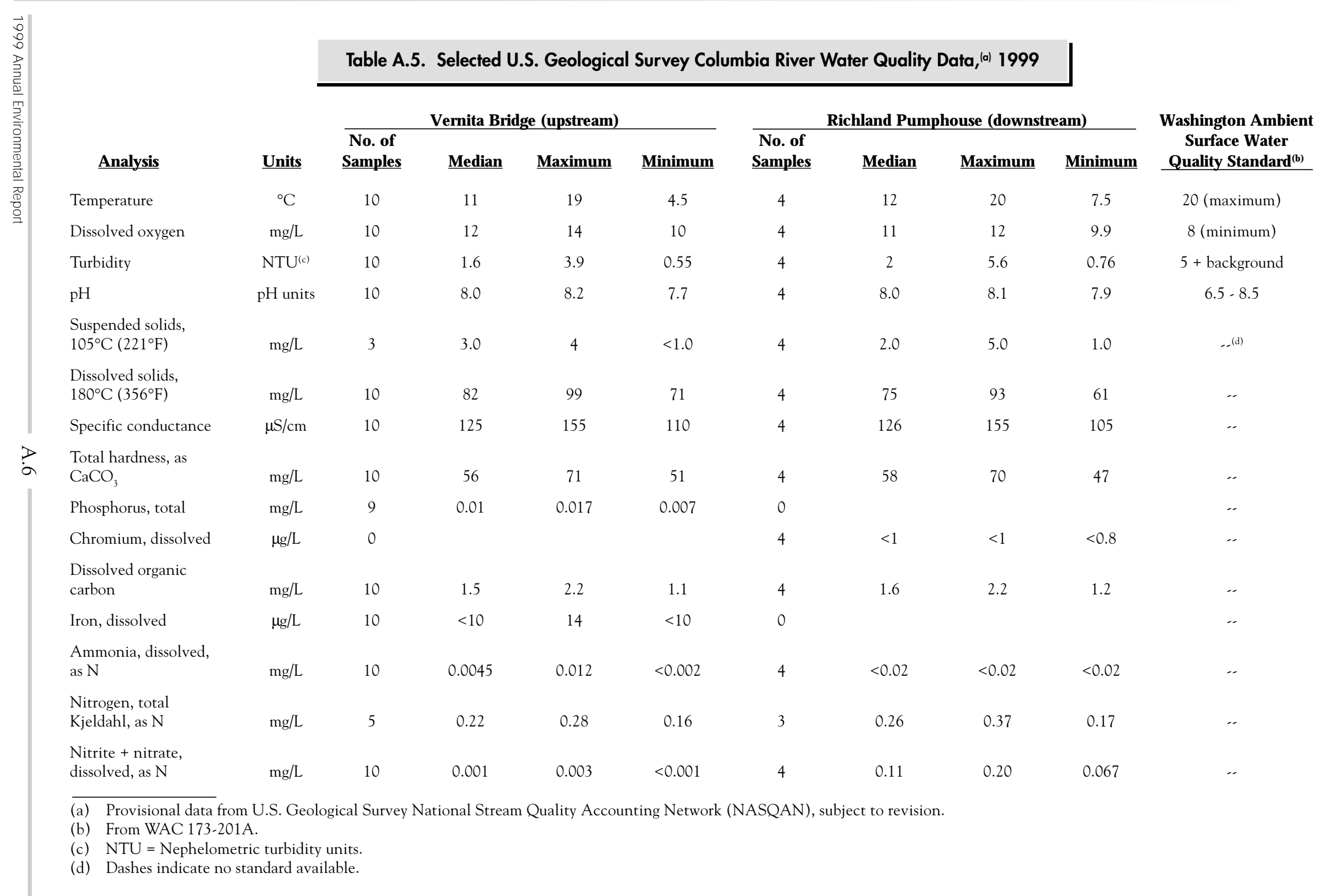


Table A.6. Radionuclide Concentrations in Sediments from the Columbia and Snake Rivers and from Columbia River Riverbank Springs, 1999 Compared to Previous 5 Years

Location

River Sediment

100-F Slough

Hanford Slough

\section{Cobalt -60}

Cesium-137

Europium-155

Plutonium-239/240

Strontium-90

Uranium-235

Uranium-238

McNary Dam

Cobalt -60

Cesium-137

Europium-155

Plutonium-239/240

Strontium-90

Uranium-235

Uranium-238

Priest Rapids Dam

\section{Cobalt- 60}

Cesium-137

Europium-155

Plutonium-239/240

Strontium-90

Uranium-235

Uranium-238
1999

\section{No. of}

Samples

Median $^{(a)}$

oncentration, pCi/g

Maximum $^{(\mathbf{b})}$

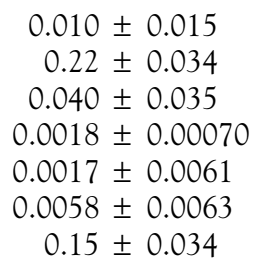

$0.15 \pm 0.034$

$0.0099 \pm 0.021$

$0.16 \pm 0.033$

$0.031 \pm 0.050$

$0.0030 \pm 0.00070$

$0.0043 \pm 0.0060$

$0.0087 \pm 0.0070$

$0.20 \pm 0.040$

$0.075 \pm 0.030$

$0.53 \pm 0.061$

$0.091 \pm 0.042$

$0.0094 \pm 0.0022$

$0.024 \pm 0.0090$

$0.026 \pm 0.013$

$0.60 \pm 0.11$

$0.042 \pm 0.041$

$0.60 \pm 0.11$

$0.082 \pm 0.088$

$0.015 \pm 0.0030$

$0.019 \pm 0.0080$

$0.037 \pm 0.014$

$0.73 \pm 0.12$
1994-1998

No. of Concentration, $\mathrm{pCi} / \mathrm{g}$

Samples

Median $^{(a)}$

Maximum $^{(\mathbf{b})}$

$0.033 \pm 0.011$

$0.49 \pm 0.054$

$0.061 \pm 0.033$

$0.0024 \pm 0.00082$

$0.013 \pm 0.0052$

$0.064 \pm 0.068$

$1.4 \pm 0.41$

$0.32 \pm 0.046$

$0.59 \pm 0.068$

$0.16 \pm 0.075$

$0.0076 \pm 0.0014$

$0.017 \pm 0.0052$

$0.24 \pm 0.16$

$2.4 \pm 0.88$

$0.22 \pm 0.040$

$1.0 \pm 0.11$

$0.13 \pm 0.069$

$0.014 \pm 0.0026$

$0.049 \pm 0.011$

$0.21 \pm 0.10$

$2.3 \pm 0.71$

1.4

$0.038 \pm 0.049$

$1.0 \pm 0.14$

$0.10 \pm 0.050$

$0.018 \pm 0.0032$

$0.025 \pm 0.0068$

$0.32 \pm 0.17$

$2.2 \pm 0.71$ 


\section{Location}

Ice Harbor Dam

(Snake River)

White Bluffs Slough

Cesium-137

Europium-155

Plutonium-239/240

Strontium-90

Uranium-235

Uranium-238

\begin{tabular}{r} 
\\
\\
\hline No. \\
\hline Samp \\
\hline 3 \\
3 \\
3 \\
3 \\
3 \\
3 \\
3 \\
1 \\
1 \\
1 \\
1 \\
1 \\
1 \\
1 \\
1 \\
1 \\
1 \\
1 \\
1 \\
1 \\
1 \\
\end{tabular}

Riverbank Spring Sediment

100-B Spring (38-3)

Cobalt -60

Cesium-137

Europium-155

Strontium-90

Uranium-235

Uranium-238

Table A.6. (contd)

1999

Concentration, $\mathrm{pCi} / \mathrm{g}$

Median $^{\text {(a) }}$
0.0030
0.27
0.063
0.0074
0.020
0.031
0.59

Maximum $^{(\mathbf{b})}$

$0.0053 \pm 0.013$

$0.28 \pm 0.039$

$0.066 \pm 0.035$

$0.0095 \pm 0.0020$

$0.024 \pm 0.0080$

$0.056 \pm 0.019$

$0.64 \pm 0.11$

$0.020 \pm 0.014$

$0.24 \pm 0.038$

$0.017 \pm 0.042$

$0.0021 \pm 0.00060$

$0.0063 \pm 0.0040$

$0.0049 \pm 0.0060$

$0.19 \pm 0.042$

$0.044 \pm 0.023$

$0.32 \pm 0.045$

$0.040+0.034$

$0.0024 \pm 0.00060$

$0.0023 \pm 0.0030$

$0.0065 \pm 0.0060$

$0.15 \pm 0.033$

\begin{tabular}{|c|c|c|}
\hline \multicolumn{3}{|c|}{ 1994-1998 } \\
\hline \multirow{2}{*}{$\begin{array}{l}\text { No. of } \\
\text { Samples }\end{array}$} & \multicolumn{2}{|c|}{ Concentration, pCi/g } \\
\hline & Median $^{(a)}$ & Maximum $^{(\mathbf{b})}$ \\
\hline 3 & -0.019 & $-0.0022 \pm 0.014$ \\
\hline 3 & 0.23 & $0.29 \pm 0.044$ \\
\hline 3 & 0.079 & $0.081 \pm 0.044$ \\
\hline 3 & 0.0085 & $0.0087 \pm 0.0019$ \\
\hline 3 & 0.018 & $0.019 \pm 0.0095$ \\
\hline 3 & 0.018 & $0.027 \pm 0.011$ \\
\hline 3 & 0.66 & $0.73 \pm 0.090$ \\
\hline 5 & 0.039 & $0.074 \pm 0.019$ \\
\hline 6 & 0.24 & $0.34 \pm 0.042$ \\
\hline 6 & 0.050 & $0.066 \pm 0.034$ \\
\hline 6 & 0.0020 & $0.0034 \pm 0.00073$ \\
\hline 6 & 0.0041 & $0.0050 \pm 0.0035$ \\
\hline 6 & 0.014 & $0.068 \pm 0.13$ \\
\hline 6 & 0.83 & $2.1 \pm 0.54$ \\
\hline 6 & 0.099 & $0.20 \pm 0.031$ \\
\hline 6 & 0.65 & $0.97 \pm 0.11$ \\
\hline 6 & 0.051 & $0.10 \pm 0.034$ \\
\hline 6 & 0.0045 & $0.0073 \pm 0.0017$ \\
\hline 6 & 0.0070 & $0.017 \pm 0.0055$ \\
\hline 6 & 0.0044 & $0.16 \pm 0.12$ \\
\hline 6 & 0.97 & $1.9 \pm 0.52$ \\
\hline
\end{tabular}

$0.0039 \pm 0.014$

$0.14 \pm 0.026$

$0.048 \pm 0.034$

$-0.0048 \pm 0.022$

$0.015 \pm 0.0090$

$0.40 \pm 0.073$
0.025

0.087

0.069

0.0034

0.065
$0.051 \pm 0.024$

$0.10 \pm 0.023$

$0.11 \pm 0.072$

$0.0041 \pm 0.0083$

$0.20 \pm 0.10$

$1.2 \pm 0.38$ 
Table A.6. (contd)

\section{Location}

100-F Spring (207-1)

300 Area Spring
Radionuclide

Cobalt-60

Cesium-137

Europium-155

Strontium-90

Uranium-235

Uranium-238

Cobalt-60

Cesium-137

Europium-155

Strontium-90

Uranium-235

Uranium-238

Cobalt-60

Cesium-137

Europium-155

Strontium-90

Uranium-235

Uranium-238

Cobalt -60

Cesium-137

Europium-155

Strontium-90

Uranium-235

Uranium-238

\begin{tabular}{c}
\hline No. of \\
Sample \\
\hline 1 \\
1 \\
1 \\
1 \\
1 \\
1
\end{tabular}

1999 Concentration, pCi/g

(c)

(c)

(c)

(c)

(c)

\section{2}

2

2

2

2

2

2
2

2

2

2
Median $^{(a)}$

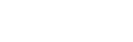
Maximum $^{(\mathbf{b})}$
$0.018 \pm 0.014$
$0.20 \pm 0.035$
$0.020 \pm 0.040$
$-0.0083 \pm 0.019$
$0.018 \pm 0.010$
$0.28 \pm 0.054$

0.016
0.13
0.062
0.0060
0.14
3.0
$0.020 \pm 0.010$
$0.21 \pm 0.029$
$0.086 \pm 0.035$
$0.011 \pm 0.023$
$0.18 \pm 0.037$
$3.7 \pm 0.57$

0.049
0.21
0.061
0.00086
0.021
0.52

$0.067 \pm 0.026$

$0.23 \pm 0.034$

$0.069 \pm 0.035$

$0.0071 \pm 0.022$

$0.024 \pm 0.011$

$0.60 \pm 0.10$
1994-1998

\begin{tabular}{ll} 
No. of & \multicolumn{2}{c}{ Concentration, $\mathbf{p C i} / \mathbf{g}$} \\
\cline { 2 - 2 } & Median $^{(\mathbf{a})}$ Maximum $^{(\mathbf{b})}$
\end{tabular}

0.028

0.17

0.033

0.0065

0.083

0.97

$0.044 \pm 0.024$

$0.32 \pm 0.040$

$0.055 \pm 0.031$

$0.0096 \pm 0.010$

$0.17 \pm 0.13$

$1.4 \pm 0.54$

0.011

0.17

0.084

0.0049

0.17

1.2

$0.015 \pm 0.021$

$0.19 \pm 0.046$

$0.13 \pm 0.066$

$0.0085 \pm 0.0048$

$0.20 \pm 0.14$

$1.5 \pm 0.54$

0.0088

0.073

0.045

0.0075

0.13

2.6

$0.016 \pm 0.0076$

$0.15 \pm 0.026$

$0.13 \pm 0.14$

$0.012 \pm 0.0060$

$0.41 \pm 0.16$

0.073

0.25

0.064

0.0074

0.024

1.5

$0.090 \pm 0.021$

$0.29 \pm 0.032$

$0.068 \pm 0.034$

$0.0086 \pm 0.011$

$0.23 \pm 0.14$

$1.9 \pm 0.54$

(a) Median values are not provided when only one sample analyzed.

(b) Values are \pm total propagated analytical uncertainty (2 sigma).

(c) Sediment was not available at the 1999 spring location. 


\begin{tabular}{|c|c|c|c|c|c|}
\hline \multirow[b]{2}{*}{ Metal } & \multicolumn{4}{|c|}{$\begin{array}{c}\text { Table A.7. Median Metal Concentrations (mg/ } / \mathrm{kg} \mathrm{dry} \mathrm{wt.)} \mathrm{in} \mathrm{Columbia} \mathrm{and} \\
\text { Snake River Sediments, } 1999\end{array}$} & \multirow[b]{2}{*}{$\begin{array}{c}(n=7) \\
\text { Riverbank } \\
\text { Springs }^{(b)} \\
\end{array}$} \\
\hline & $\begin{array}{l}(n=6) \\
\text { Priest Rapids } \\
\text { Dam } \\
\end{array}$ & $\begin{array}{c}(n=3) \\
\text { Hanford } \\
\text { Reach }^{(a)} \\
\end{array}$ & $\begin{array}{c}(n=6) \\
\text { McNary } \\
\text { Dam } \\
\end{array}$ & $\begin{array}{c}\quad(n=3) \\
\text { Ice H arbor Dam } \\
\text { (Snake River) } \\
\end{array}$ & \\
\hline Antimony & 0.86 & 0.75 & 0.86 & 0.78 & 0.59 \\
\hline Arsenic & 9.0 & 6.6 & 8.5 & 8.2 & 5.8 \\
\hline Beryllium & 1.6 & 1.8 & 1.8 & 2.0 & 1.2 \\
\hline Cadmium & 6.8 & 1.3 & 1.5 & 0.13 & 0.85 \\
\hline Chromium & 76 & 59 & 60 & 51 & 60 \\
\hline Copper & 32 & 23 & 31 & 29 & 14 \\
\hline Lead & 50 & 32 & 26 & 14 & 27 \\
\hline Mercury & 0.16 & 0.058 & 0.12 & 0.072 & 0.017 \\
\hline Nickel & 35 & 23 & 29 & 22 & 18 \\
\hline Selenium & 0.47 & 0.47 & 0.47 & 0.47 & 0.45 \\
\hline Silver & 0.17 & 0.58 & 0.15 & 0.073 & 0.066 \\
\hline Thalium & 1.3 & 0.76 & 0.80 & 0.41 & 0.63 \\
\hline Zinc & 530 & 280 & 230 & 94 & 150 \\
\hline \multicolumn{6}{|c|}{$\begin{array}{l}\text { (a) 100-F Slough, Hanford Slough, and White Bluffs Slough. } \\
\text { (b) 100-B Area, 100-F Area, Old Hanford Townsite, and } 300 \text { Area. }\end{array}$} \\
\hline
\end{tabular}


Table A.8. Radionuclide Concentrations Measured in Water from Riverbank Springs, 1999 Compared to Previous 5 Years

Location/Radionuclide

\section{0-B Spring}

Alpha (gross)

Beta (gross)

Strontium-90

Technetium-99

Tritium

\section{0-D Spring}

Alpha (gross)

Beta (gross)

Strontium-90

Tritium

\section{0-F Spring}

Alpha (gross)

Beta (gross)

Strontium-90

Tritium

Uranium (total)

\section{0-H Spring}

Alpha (gross)

Beta (gross)

Strontium-90

Technetium-99

Tritium

Uranium (total)

\section{0-K Spring}

Alpha (gross)

Beta (gross)

Strontium-90

Tritium
1999

No. of Concentation, ${ }^{(a)} \mathrm{pCi} / \mathrm{L}$

Maximum

$$
\begin{aligned}
& 2.0 \pm 1.4 \\
& 15 \pm 3.1 \\
& 4.5 \pm 1.0 \\
& \text { NS }
\end{aligned}
$$

$20,000 \pm 870$

$0.50 \pm 0.82$

$2.9 \pm 1.5$

$0.62 \pm 0.15$

$270 \pm 120$

$$
\begin{aligned}
6.3 & \pm 2.8 \\
16 & \pm 3.3 \\
0.0036 & \pm 0.027 \\
1,400 & \pm 180
\end{aligned}
$$

$4.8 \pm 0.80$

$$
\begin{aligned}
2.5 & \pm 1.6 \\
29 & \pm 4.8 \\
14 & \pm 3.1 \\
1.2 & \pm 0.47 \\
840 & \pm 150 \\
1.4 & \pm 0.27
\end{aligned}
$$

$4.1 \pm 2.1$

$6.3+2.1$

$0.023 \pm 0.032$

$6,700 \pm 390$
1994-1998

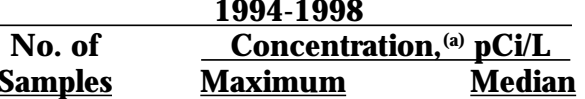

$2.4 \pm 1.2$

$38 \pm 4.6$

$0.031 \pm 0.045$

$25 \pm 3.2$

$24,000 \pm 1,800$

1.5

10
0.022

10

14,000

$2.9 \pm 1.9$

$21 \pm 3.3$

$9.4 \pm 1.8$

$12,000 \pm 1,000$

0.98

9.3

4,800

$41 \pm 18$

$65 \pm 11$

$0.099 \pm 0.091$

$1,800 \pm 240$

$9.2 \pm 1.2$

3.8

3.8
0.034

1,110

4.6

$10 \pm 3.7$

$72 \pm 8.6$

$25 \pm 4.5$

$140 \pm 15$

$2,300 \pm 270$

$9.3 \pm 1.0$

4.4

50

15
62

1,100
8.0

$3.2 \pm 1.8$

$5.0 \pm 2.4$

$0.59 \pm 0.13$

$20,000 \pm 1,500$

0.61

1.8

0.035

12,000
Washington State

Ambient Surface

Water Quality

Standard, (b) pCi/L

15
50
8
$900^{(c)}$
20,000

15
50

8

20,000

15

50

20,000

..(d)

15

50

900

20,000

15

50

20,000 
Table A.8. (contd)

\section{9

No. of
Samples \\ centration, ${ }^{\text {(a) }} \mathrm{pCi} / \mathrm{L}$ \\ Maximum \\ $0.84 \pm 0.97$ \\ $2.9 \pm 1.7$ \\ $0.026 \pm 0.034$ \\ $14,000 \pm 670$}

\section{Location/Radionuclide}

\section{0-N Spring (8-13)(c)}

Alpha (gross)

Beta (gross)

Strontium-90

Tritium

\section{Area Spring}

Alpha (gross)

Beta (gross)

Iodine-129

Technetium-99

Tritium

Uranium (total)

\section{No. of \\ Samples \\ 1994-1998 \\ Concentration, ${ }^{(a)} \mathrm{pCi} / \mathrm{L}$ \\ Maximum \\ Median}

\section{$8.1 \pm 3.3$}

$8.8 \pm 2.3$

$0.59 \pm 0.13$

$31,000 \pm 2,400$

0.72
3.5

3.5

0.079

19,000

$110 \pm 21$

$21 \pm 4.1$

$0.0055 \pm 0.00058$

$14 \pm 1.9$

$12,000 \pm 940$

$110 \pm 13$

$1,000 \pm 570$

$210 \pm 38$

\section{Old Hanford Townsite Spring}

Alpha (gross)

Beta (gross)

Iodine-129

Technetium-99

Tritium

Uranium (total)

$\begin{array}{rr}3 & 14 \pm 5.9 \\ 3 & 49 \pm 7.9 \\ 3 & 0.41 \pm 0.024 \\ 3 & 120 \pm 8.0 \\ 3 & 110,000 \pm 4,100 \\ 3 & 8.6 \pm 1.5\end{array}$

(a) Maximum values are \pm total propagated analytical uncertainty (2 sigma).

(b) WAC 246-290, 40 CFR 141, and Appendix C, Table C.2.

(c) Refer to Table 4.2.4 for additional details on 100-N Spring samples.

(d) $\mathrm{NS}=$ No sample.

(e) WAC 173-201A-050 and EPA-570/9-76-003.

(f) Dashes indicate no concentration guides available.

Washington State

Ambient Surface

Water Quality

Standard, (b) $\mathrm{pCi} / \mathrm{L}$

15
50
8
20,000

$$
\begin{gathered}
15 \\
50 \\
1 \\
900^{(e)} \\
20,000
\end{gathered}
$$

-(f)

15

50

1

20,000 


\section{References}

40 CFR 141. U.S. Environmental Protection Agency. "National Primary Drinking Water Regulations; Radionuclides; Proposed Rule." C ode of F ederal Regulations.

EPA-570/9-76-003. 1976. N ational Interim Primary D rinking W ater Regulations. Office of Water Supply, U.S. Environmental Protection Agency, Washington, D.C.
PNNL-13230, APP. 1. 2000. H anford Site Environmental Surveillance Data Report for $\mathrm{C}$ alendar Year 1999. L. E. Bisping, Pacific Northwest National Laboratory, Richland, Washington.

WAC 173-201A. "Water Quality Standards for Surface Waters of the State of Washington." Washington Administrative Code, Olympia, Washington.

WAC 246-290. "Group A Public Water Systems." Washington Administrative Code, Olympia, Washington. 


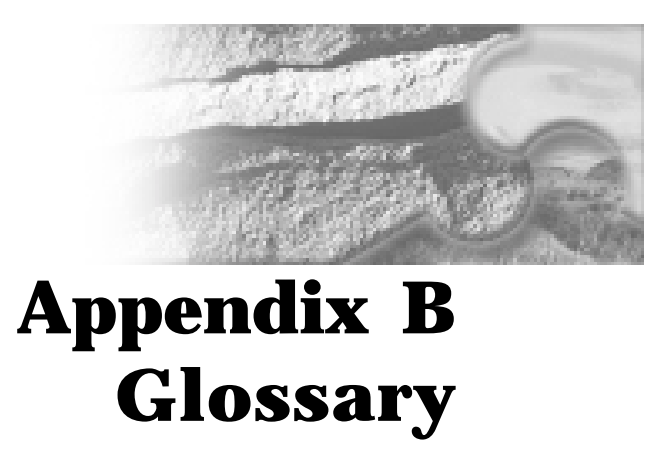

absorbed dose - Energy absorbed per unit mass from any kind of ionizing radiation in any kind of matter.

activation product - Material made radioactive by exposure to radiation from a source such as a nuclear reactor's neutrons.

adsorption - The accumulation of gases, liquids, or solutes on the surface of a solid or liquid.

anion - A negatively charged ion.

aquifer - Permeable geologic unit that can hold and/ or transmit significant quantities of water.

background radiation - Radiation in the natural environment, including cosmic rays from space and radiation from naturally occurring radioactive elements in the air, in the earth, and in our bodies. In the United States, the average person receives approximately 300 millirems of background radiation per year.

bank storage - Hydrologic term that describes river water that flows into and is retained in permeable stream banks during periods of high river stage. Flow is reversed during periods of low river stage.

becquerel (B q) - Unit of radioactivity equal to one nuclear transformation per second $(1 \mathrm{~Bq}=1 / \mathrm{s})$. Another unit of radioactivity, the curie, is related to the becquerel in which $1 \mathrm{Ci}=3.7 \times 10^{10} \mathrm{~Bq}$.

boundary dose rate - Dose rate measured or calculated at publicly accessible locations on or near the Hanford Site boundary.

clean closed - A facility is classified as "clean closed" under RCRA regulations when all dangerous waste has been removed and groundwater monitoring is no longer required. collective effective dose equivalent - Sum of the effective dose equivalents for individuals composing a defined population. The units for this are "personrem" or "person-sievert."

composite sample - Sample formed by mixing discrete samples taken at different times or from different locations.

confined aquifer - An aquifer bounded above and below by less-permeable layers. Groundwater in the confined aquifer is under a pressure greater than atmospheric pressure.

continuous sample - Sample formed by the continuous collection of the medium or contaminants within the medium during the entire sample period.

controlled area - An area to which access is controlled to protect individuals from exposure to radiation or radioactive and/or hazardous materials.

cosmic radiation - High-energy subatomic particles and electromagnetic radiation from outer space that bombard the earth. Cosmic radiation is part of natural background radiation.

curie (Ci) - A unit of radioactivity equal to 37 billion $\left(3.7 \times 10^{10}\right)$ nuclear transformations per second.

decay - The decrease in the amount of any radioactive material with the passage of time, as a result of the spontaneous emission from the atomic nuclei of nucleons or either alpha or beta particles, often accompanied by gamma radiation. When a radioactive material decays, the material may be converted to another radioactive species (decay product) or to a nonradioactive material.

derived concentration guide (DCG) - Concentrations of radionuclides in air and water that an individual could continuously consume, inhale, or 
be immersed in at average annual rates, and not receive an effective dose equivalent of greater than 100 millirems per year.

detection level - Minimum amount of a substance that can be measured with a $99 \%$ confidence that the analytical result is greater than zero.

dispersion - Process whereby effluents are spread or mixed as they are transported by groundwater or air.

dose equivalent - Product of the absorbed dose, the quality factor, and any other modifying factors. The dose equivalent is a quantity for comparing the biological effectiveness of different kinds of radiation on a common scale. The unit of dose equivalent is the rem. A millirem is one one-thousandth of a rem.

dosimeter - Portable device for measuring the total accumulated exposure or absorbed dose from ionizing radiation fields.

effective dose - See "effective dose equivalent."

effective dose equivalent - A value used for estimating the total risk of potential health effects from radiation exposure. This estimate is the sum of the committed effective dose equivalent (see above) from internal deposition of radionuclides in the body and the effective dose equivalent from external radiation received during a year.

effluent - Liquid or gaseous waste streams released from a facility.

effluent monitoring - Sampling or measuring specific liquid or gaseous effluent streams for the presence of pollutants.

exposure - The interaction of an organism with a physical agent (e.g., radiation) or a chemical agent (e.g., arsenic) of interest. Also used as a term for quantifying $\mathrm{x}$ and gamma radiation fields (see "roentgen").

external radiation - Radiation originating from a source outside the body. fallout - Radioactive materials that are released into the earth's atmosphere following a nuclear explosion or atmospheric release and that eventually fall to earth.

fission - The splitting or breaking apart of a nucleus into at least two other nuclei, accompanied with a release of a relatively large amount of energy. For example, when a heavy atom such as uranium is split, large amounts of energy, including radiation and neutrons, are released along with the new nuclei (which are fission products; see below).

fission products - Elements formed from fissioning. Many fission products are radioactive.

gamma radiation - Form of electromagnetic, highenergy radiation emitted from a nucleus. They require heavy shielding (e.g., concrete, steel) to be stopped and may cause biological damage when originating internally or externally to the body in sufficient amounts.

grab sample - A sample that is randomly collected or "grabbed" from the collection site.

grand mean - A "means of means" or an "overall mean" where there is some subdivision of the data where means were already provided for each subdivision.

groundwater - Subsurface water that is in the pore spaces of soil and geologic units.

gray (Gy) - Unit of absorbed dose in the International System of Units (SI) equal to 1 joule per kilogram. $1 \mathrm{~Gy}=100 \mathrm{rad}$.

half-life - Length of time in which a radioactive substance will lose one half of its radioactivity by decay. Half-lives range from a fraction of a second to billions of years, and each radionuclide has a unique half-life.

ion exchange - The reversible exchange of one species of ion for a different species of ion within a medium. 
irradiation - Exposure to radiation.

isotopes-Radionuclides (or nuclides) with the same number of protons (same atomic number) but a different number of neutrons (different mass). Isotopes of the same element (e.g., ${ }^{238} \mathrm{Pu},{ }^{239} \mathrm{Pu},{ }^{240} \mathrm{Pu}$, ${ }^{241} \mathrm{Pu}$ ) have almost identical chemical properties.

lysimeter - An instrument to measure the water percolating through soil and determine the materials dissolved by the water.

maximally exposed individual - A hypothetical member of the public residing near the Hanford Site who, by virtue of location and living habits, could receive the highest possible radiation dose from nuclides/radiation originating from Hanford.

mean - Average value of a series of measurements. The mean, $\mathrm{X}$, was computed as:

$$
X=\frac{1}{n} \sum_{i=1}^{n} X_{i}
$$

where $\mathrm{n}$ is the number of measurements and $\mathrm{X}_{\mathrm{i}}$ is the ith measurement.

median - Middle value in a set of results when the data are ranked in increasing or decreasing order.

millirem - A unit of radiation dose equivalent that is equal to one one-thousandth $(1 / 1000)$ of a rem. According to U.S. Department of Energy standards, an individual member of the public may receive no more than 100 millirems per year from a site's operation. This limit does not include radiation received for medical treatment or the $\sim 300$ millirems that people receive annually from natural background radiation.

minimum detectable concentration - Smallest amount or concentration of a radioactive or nonradioactive element that can be reliably detected in a sample.

mitigation - Prevention or reduction of expected risks to worksers, the public, or the environment. noble gas - Any of a group of chemically and biologically inert gases that includes argon, krypton, and xenon. These gases are not retained in the body following inhalation. The principal exposure pathways for radioactive noble gases are direct external dose from the surrounding air.

nuclide - A general term referring to all known isotopes, both stable and unstable, of the chemical elements (Shleien 1992).

offsite locations - Sampling and measurement locations outside the Hanford Site boundary.

onsite locations - Sampling and measurement locations within the Hanford Site boundary.

operable unit - A discrete area for which an incremental step can be taken toward comprehensively addressing site problems. The cleanup of a site can be divided into a number of operable units, depending on the complexity of the problems associated with the site.

outfall - End of a drain or pipe that carries wastewater or other effluents into a ditch, pond, or river.

plume - The cloud of a pollutant in air, surface water, or groundwater formed after the pollutant is released from a source.

plutonium - A heavy, radioactive, man-made metallic element consisting of several isotopes. One important isotope is ${ }^{239} \mathrm{Pu}$, which is produced by the irradiation of ${ }^{238} \mathrm{U}$. Routine analysis cannot distinguish between the ${ }^{239} \mathrm{Pu}$ and ${ }^{240} \mathrm{Pu}$ isotopes; hence, the term ${ }^{239 / 240} \mathrm{Pu}$ as used in this report is symbolic of the presence of one or both of these isotopes in the analytical results.

quality assurance - Actions that provide confidence that an item or process meets or exceeds that user's requirements and expectations.

quality control - Comprises all those actions necessary to control and verify the features and characteristics of a material, process, product, or service to specified requirements. Quality control is an element of quality assurance. 
rad - A special unit of absorbed dose equal to $100 \mathrm{ergs} / \mathrm{g}$ or $0.01 \mathrm{~J} / \mathrm{kg}$.

radiation - The energy emitted in the form of photons or particles such as those thrown off by transforming (decaying) atoms. For this report, radiation refers to ionizing types of radiation; not radiowaves, microwaves, radiant light, or other types of nonionizing radiation.

radioactivity - Property possessed by some isotopes of elements of emitting radiation (such as alpha, beta, or gamma photons) spontaneously in their decay process to stable element isotopes.

radioisotope - An unstable isotope of an element that decays or disintegrates spontaneously, emitting radiation (Shleien 1992).

radionuclide - A species of atoms having a particular number of protons $(Z)$, a particular number of neutrons $(\mathrm{A})$, and a particular atomic weight $(\mathrm{N}=\mathrm{Z}+\mathrm{A})$ that happens to emit radiation. Carbon- 14 is a radionuclide. Carbon-12 is not and is called just a "nuclide."

recruitment - Survival from one life form or stage to the next or from one age class to the next.

rem - A unit of dose equivalent and effective dose equivalent.

remediation - Reduction of known risks to the public and environment to an agreed upon level.

risk - The probability that a detrimental health effect will occur.

roentgen (R) - Unit of $x$ ray or gamma photon exposure measured in air, historically used to describe external radiation levels. An exposure of 1 roentgen typically causes an effective dose of $1 \mathrm{rem}$.

sievert (Sv) - Unit of dose equivalent and effective dose equivalent in the International System of Units (SI) equal to $100 \mathrm{rem}$. specific retention facilities - Historical structures consisting of cribs, ditches, trenches, or holes in the ground that received relatively small volumes of high concentration liquid radioactive waste. The small volume of liquid waste was designed to prevent flushing of the contaminants through the soil column to the groundwater.

spectrometer - A spectroscope with a calibrated scale for measuring the positions of spectral lines.

spectroscopy - The branch of physics concerned with the production, measurement, and interpretation of electromagnetic spectra arising from either emission or absorption of radiant energy by various substances.

spent fuel - Uranium metal or oxide and its metal container that have been used to power a nuclear reactor. It is highly radioactive and typically contains fission products, plutonium, and residual uranium.

standard error of the mean - A measure of the precision of a mean of observed values; that is, an estimate of how close a mean of observed values is expected to be to the true mean. The standard error (SE) of the mean is computed as

$$
S E=\sqrt{\frac{S^{2}}{n}}
$$

where $S^{2}$ is the variance of the measurements, $n$, computed as

$$
S_{M}^{2}=\frac{1}{n-1} \sum_{i=1}^{n}\left(X_{i}-X\right)^{2}
$$

This estimator, $\mathrm{S}^{2}$, includes the variance among the samples and the counting variance. The estimated $S^{2}$ may occasionally be less than the average counting variance.

thiourea - An organic chemical soluble in cold water used in photography, photocopying, and thyroid medication. 
transuranic - An element with an atomic number greater than 92 (92 is the atomic number of uranium).

thermoluminescent dosimeter - A device containing a material that, after being exposed to beta and/or gamma radiation, emits light when processed and heated. The amount of light emitted is proportional to the absorbed dose to the thermoluminescent dosimeter.

unconfined aquifer - An aquifer containing groundwater that is not confined above by relatively impermeable rocks. The pressure at the top of the unconfined aquifer is equal to that of the atmosphere. At Hanford, the unconfined aquifer is the uppermost aquifer and is most susceptible to contamination from site operations.

\section{Reference}

Shleien, B. (ed.). 1992. The Health Physics and Radiological $\mathrm{H}$ ealth $\mathrm{H}$ andbook, Revised E dition. Scinta, Inc., Silver Spring, Maryland. vadose zone - Underground area from the surface to the top of the water table or aquifer.

volatile organic compounds-Lightweight organic compounds that vaporize easily. Used in solvents and degreasing compounds as raw materials, volatile compounds are generally considered to be below the molecular weight of $\mathrm{C}_{10}$ hydrocarbons.

water table - Theoretical surface represented by the elevation of water surfaces in wells penetrating only a short distance into the unconfined aquifer.

wind rose - Star-shaped diagram that shows how often winds of various speeds blow from different directions, usually based on yearly averages. 


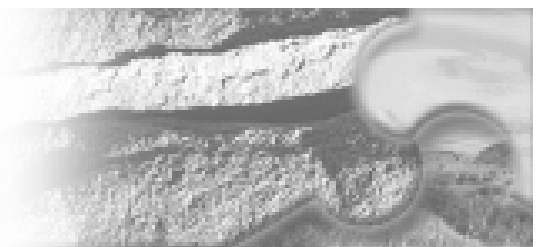 \\ Appendix C Standards and Permits}

Operations at the Hanford Site must conform to a variety of governmental standards and permits designed to ensure the biological and physical quality of the environment for public health, ecological, or aesthetic considerations. The primary environmental quality standards and permits applicable to Hanford Site operations in 1999 are listed in the following tables. The State of Washington has water quality standards for the Columbia River, defined in Washington Administrative Code (WAC 173201A). The Hanford Reach of the Columbia River has been designated as Class A (Excellent). This designation requires that the water be usable for substantially all needs, including drinking water, recreation, and wildlife. Class $\mathrm{A}$ water standards are summarized in Table C.1. Table C.2 summarizes drinking water standards from the U.S. Environmental Protection Agency (EPA) in the Code of Federal Regulations, (40 CFR 141) and WAC 246290. Select surface freshwater quality criteria for toxic pollutants are included in Table C.3.

Environmental radiation protection standards are published in U.S. Department of Energy (DOE) Order 5400.5. The order establishes limits for public radiation dose and gives guidance to keep radiation exposures to members of the public as low as reasonably achievable. These standards are based on guidelines recommended by authoritative organizations such as the International Commission on Radiological Protection and the National Council on Radiation Protection and Measurements. DOE initiated a policy to create and implement public radiation protection standards that are generally consistent with the standards used by the U.S. Nuclear Regulatory Commission to regulate and license non-DOE nuclear facilities, such as nuclear power plants. Table C. 4 shows the radiation standards from DOE Order 5400.5 and 40 CFR 61. These standards govern allowable public exposures to ionizing radiation from DOE operations.

In DOE Order 5400.5, the derived concentration guides are established that reflect the concentrations of radionuclides in water and air that an individual could continuously consume, inhale, or be immersed in at average annual levels without exceeding an effective dose equivalent of 100 millirems per year. Derived concentration guides are not exposure limits but are simply reference values that are provided to allow for comparisons of radionuclide concentrations in environmental media. Table C. 5 lists selected DOE derived concentration guides for radionuclides of particular interest at the Hanford Site. The guides are useful reference values but do not generally represent concentrations in the environment that ensure compliance with either the DOE, the $\mathrm{Clean} \mathrm{A}$ ir $\mathrm{A}$ ct, or drinking water dose standards.

Permits required for regulated releases to water and air have been issued by EPA under the National Pollutant Discharge Elimination System of the C lean W ater $A$ ct and the Prevention of Significant Deterioration requirements of the $C$ lean $A$ ir $A$ ct. Also, under authority granted by the $\mathrm{C}$ lean $\mathrm{A}$ ir $\mathrm{A}$ ct, the Washington State Department of Health issued a permit for Hanford Site radioactive air emissions. Permits to collect wildlife for environmental sampling are issued by the Washington State Department of Fish and Wildlife and the U.S. Fish and Wildlife Service. Current permits are discussed in Table C.6. 


\begin{tabular}{|c|c|}
\hline \multicolumn{2}{|c|}{$\begin{array}{c}\text { Table C.1. Washington State Water Quality Standards for the Hanford Reach of } \\
\text { the Columbia River }\end{array}$} \\
\hline Parameter & Permissible Levels \\
\hline Fecal coliform & $\begin{array}{l}\text { 1) Geometric mean value less than or equal to } 100 \text { colonies } / 100 \text { milliliters } \\
\text { 2) Less than or equal to } 10 \% \text { of samples may exceed } 200 \text { colonies/ } \\
100 \text { milliliters }\end{array}$ \\
\hline Dissolved oxygen & Greater than $8 \mathrm{mg} / \mathrm{L}$ \\
\hline Temperature & $\begin{array}{l}\text { 1) Less than or equal to } 20^{\circ} \text { Celsius }\left(68^{\circ} \text { Fahrenheit }\right) \text { as a result of human } \\
\text { activities } \\
\text { 2) When natural conditions exceed } 20^{\circ} \text { Celsius }\left(68^{\circ} \text { Fahrenheit }\right) \text {, no temper- } \\
\text { ature increases will be allowed that will raise the temperature of the } \\
\text { receiving water by more than } 0.3^{\circ} \text { Celsius }\left(32.5^{\circ} \text { Fahrenheit }\right) \\
\text { 3) Incremental temperature increases resulting from point sources shall not } \\
\text { at any time exceed } 34 /(\mathrm{T}+9) \text {, where } \mathrm{T}=\text { background temperature. } \\
\text { Incremental temperature increases resulting from nonpoint sources shall } \\
\text { not exceed } 2.8^{\circ} \text { Celsius }\left(37^{\circ} \text { Fahrenheit) }\right.\end{array}$ \\
\hline $\mathrm{pH}$ & $\begin{array}{l}\text { 1) } 6.5 \text { to } 8.5 \text { range } \\
\text { 2) Less than } 0.5 \text { unit induced variation }\end{array}$ \\
\hline Turbidity & Less than or equal to 5 nephelometric turbidity units over background turbidity \\
\hline $\begin{array}{l}\text { Toxic, radioactive, or } \\
\text { deleterious materials }\end{array}$ & $\begin{array}{l}\text { Concentrations shall be below those of public health significance, or which } \\
\text { cause acute or chronic toxic conditions to the most sensitive aquatic biota, or } \\
\text { which may adversely affect characteristic water uses }\end{array}$ \\
\hline Aesthetic value & $\begin{array}{l}\text { Shall not be impaired by the presence of materials or their effects, excluding } \\
\text { those of natural origin, which offend the senses of sight, smell, touch, or taste }\end{array}$ \\
\hline Radioactive substances & $\begin{array}{l}\text { Deleterious concentrations of radioactive materials for all classes shall be as } \\
\text { determined by the lowest practicable level attainable and in no case shall } \\
\text { exceed EPA drinking water regulations for radionuclides, as published in } \\
\text { EPA-570/9-76-003 or subsequent revisions thereto (see Table C.2) }\end{array}$ \\
\hline Toxic substances & $\begin{array}{l}\text { Shall not be introduced above natural background levels into waters of the } \\
\text { state that have the potential either singularly or cumulatively to adversely } \\
\text { affect characteristic water uses, cause acute or chronic toxicity to the most } \\
\text { sensitive biota dependent on those waters, or adversely affect public health, as } \\
\text { determined by the department (see Table C.3) }\end{array}$ \\
\hline
\end{tabular}




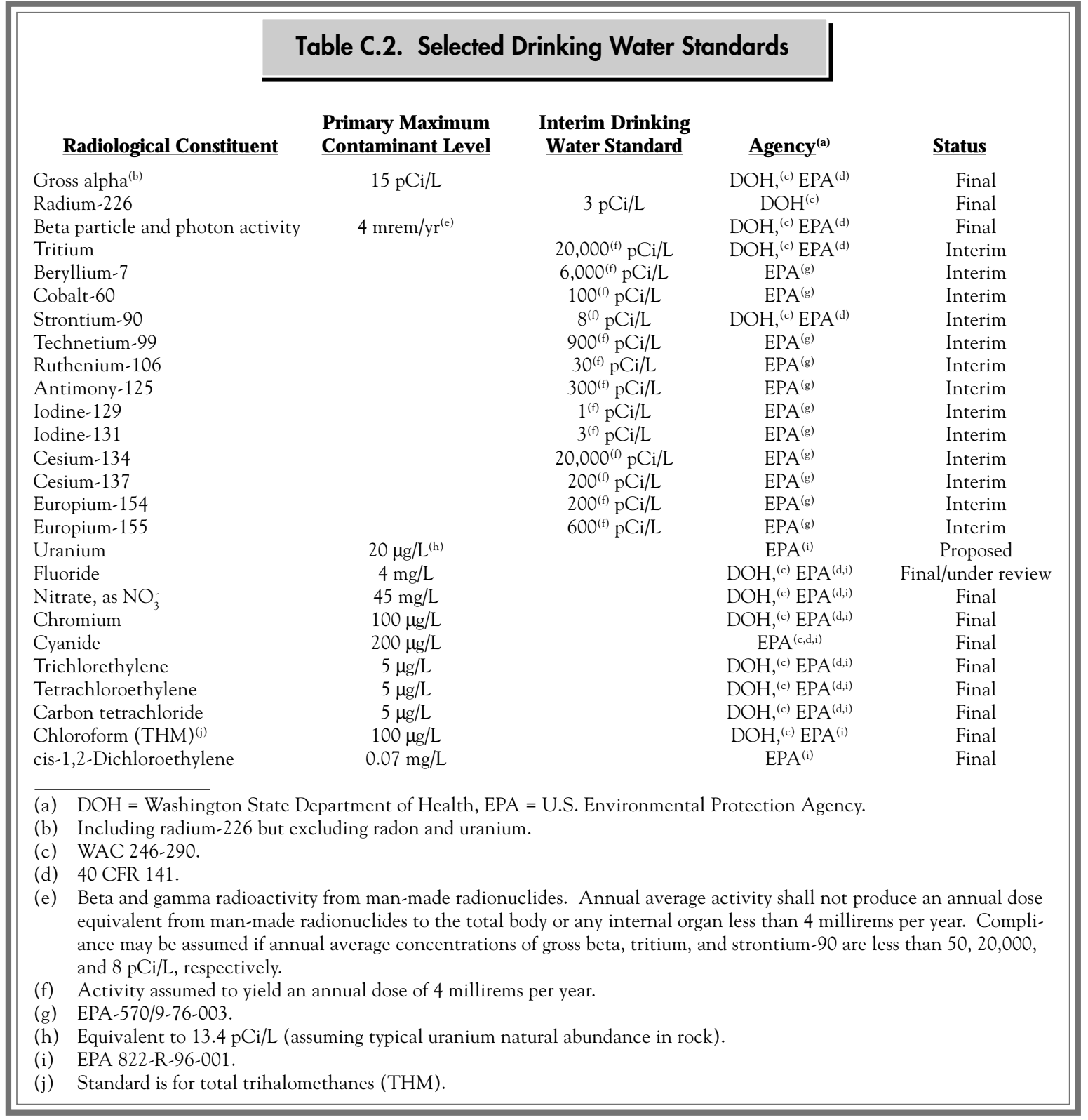




\section{Table C.3. Selected Surface Freshwater Quality Criteria for Toxic Pollutants}

\section{Compound}

Total Recoverable Metals

Antimony

Arsenic

Cadmium

Chromium(III) $)^{(\mathrm{e})}$

Chromium(VI)

Copper

Lead

Mercury

Nickel

Selenium

Silver

Thallium

Zinc

Anions

Cyanide $^{(q)}$

Chloride $^{(\mathrm{r})}$

\section{Organic Compounds}

Benzene

Carbon tetrachloride

Chloroform

1,2-Dichloroethane

Methylene chloride

Toluene

Tetrachloroethylene

1,1,2-Trichloroethane

Trichloroethylene

Vinyl chloride

1,4-Dichlorobenzene

\section{Level that \\ Yields A cute \\ Toxicity, $\mu \mathbf{g} / \mathbf{L}^{(a)}$}

Level that Yields Chronic Toxicity, $\mu g_{/ L^{(a)}}$
Level to Protect H uman Health for the Consumption of Water and Organisms, $\mu \mathrm{g} / \mathbf{L}^{(\mathrm{b})}$
(a) WAC $173-201 \mathrm{~A}-040$.
(b) 40 CFR 131.36.
(c) $\exp (1.128[\ln ($ hardness)]-3.828). Limiting value for 1992-1999 U.S. Geological Survey results is $47 \mathrm{mg} \mathrm{CaCO} / \mathrm{L}$. Hardness expressed as $\mathrm{mg} \mathrm{CaCO}_{3} / \mathrm{L}$.
(d) $\exp (0.7852[\ln ($ hardness $)]-3.490)$.
(e) Where methods to measure trivalent chromium are unavailable, these criteria are to be represented by total recoverable chromium.
(f) $\exp (0.8190[\ln ($ hardness $)]+3.688)$
(g) $\exp (0.8190[\ln ($ hardness $)]+1.561)$
(h) $\exp (0.9422[\ln ($ hardness $)]-1.464)$.
(i) $\exp (0.8545[\ln$ (hardness) $]-1.465)$.
(j) $\exp (1.273[\ln ($ hardness $)]-1.460)$.
(k) $\exp (1.273[\ln ($ hardness $)]-4.705)$
(l) $\exp (0.8460[\ln ($ hardness $)]+3.3612)$
(m) $\exp (0.8460[\ln ($ hardness $)]+1.1645)$.
(n) $\exp (1.72[\ln ($ hardness $)]-6.52)$
(o) $\exp (0.8473[\ln ($ hardness $)]+0.8604)$.
(p) $\exp (0.8473[\ln$ (hardness) $]+0.7614)$.
(q) Criteria based on weak and dissociable method.
(r) Dissolved in association with sodium.

$$
\begin{gathered}
190.0 \\
0.63^{(\mathrm{d})} \\
110^{(\mathrm{g})} \\
11.0 \\
6.2^{(\mathrm{i})} \\
1.2^{(\mathrm{k})} \\
0.012 \\
83^{(\mathrm{m})} \\
5.0 \\
-. \\
\overline{-} \\
56^{(\mathrm{p})}
\end{gathered}
$$$$
14
$$

-

-

-

-

1.2

0.25

6,800

0.8

0.60

2.7

400 


\section{Table C.4. Radiation Standards (dose limits ${ }^{[a]}$ ) for Protection of the Public from All Routine DOE Concentrations}

All Pathways (limits from DOE Order 5400.5)

The effective dose equivalent for any member of the public from all routine DOE operations ${ }^{(\mathrm{b})}$ shall not exceed the values given below.

\begin{tabular}{lcc} 
& \multicolumn{2}{c}{ Effective Dose Equivalent ${ }^{(\mathrm{c})}$} \\
& $\underline{\mathrm{mrem} / \mathrm{yr}}$ & $\underline{\mathrm{mSv} / \mathrm{yr}}$ \\
Routine public dose & 100 & 1 \\
Potential authorized temporary public dose & \\
& 500 & 5
\end{tabular}

Dose to N ative A quatic A nimal Organisms from Liquid Discharges (interim limits from DOE Order 5400.5)

Radioactive material in liquid waste discharged to natural waterways shall not cause an absorbed dose ${ }^{(e)}$ to native aquatic animal organisms that exceeds $1 \mathrm{rad} / \mathrm{d}(10 \mathrm{mGy} / \mathrm{d})$.

Drinking Water Pathway O nly (limits from 40 CFR 141 and DOE Order 5400.5)

Radionuclide concentrations in DOE-operated public drinking water supplies shall not cause persons consuming the water to receive an effective dose equivalent greater than 4 millirems per year $(0.04$ millisieverts per year). DOE operations shall not cause private or public drinking water systems downstream of the facility discharge to exceed the radiological drinking water limits in 40 CFR 141 (see Table C.2).

Air Pathways Only (limits from 40 CFR 61)

Public dose limit at location of maximum annual air concentration as a consequence of routine DOE operations $^{(\mathrm{b})}$

\section{Effective Dose Equivalent $^{(\mathrm{c})}$ $\underline{\mathrm{mrem} / \mathrm{yr}} \underline{\mathrm{mSv} / \mathrm{yr}}$}

10

(a) Radiation doses received from natural background, residual weapons testing and nuclear accident fallout, medical exposures, and consumer products are excluded from the implementation of these dose limits.

(b) "Routine DOE operations" implies normal, planned activities and does not include actual or potential accidental or unplanned releases.

(c) Effective dose equivalent is expressed in rem (or millirem) and sievert (or millisievert).

(d) Authorized temporary annual dose limits may be greater than 100 millirems per year (but cannot exceed 500 millirems per year) if unusual circumstances exist that make avoidance of doses greater than 100 millirems per year to the public impracticable. DOE Richland Operations Office is required to request and receive specific authorization from DOE Headquarters for an increase from the routine public dose limit to a temporary annual dose limit.

(e) Absorbed dose is expressed in rad (or millirad) with the corresponding value in gray (or milligray) in parentheses. 


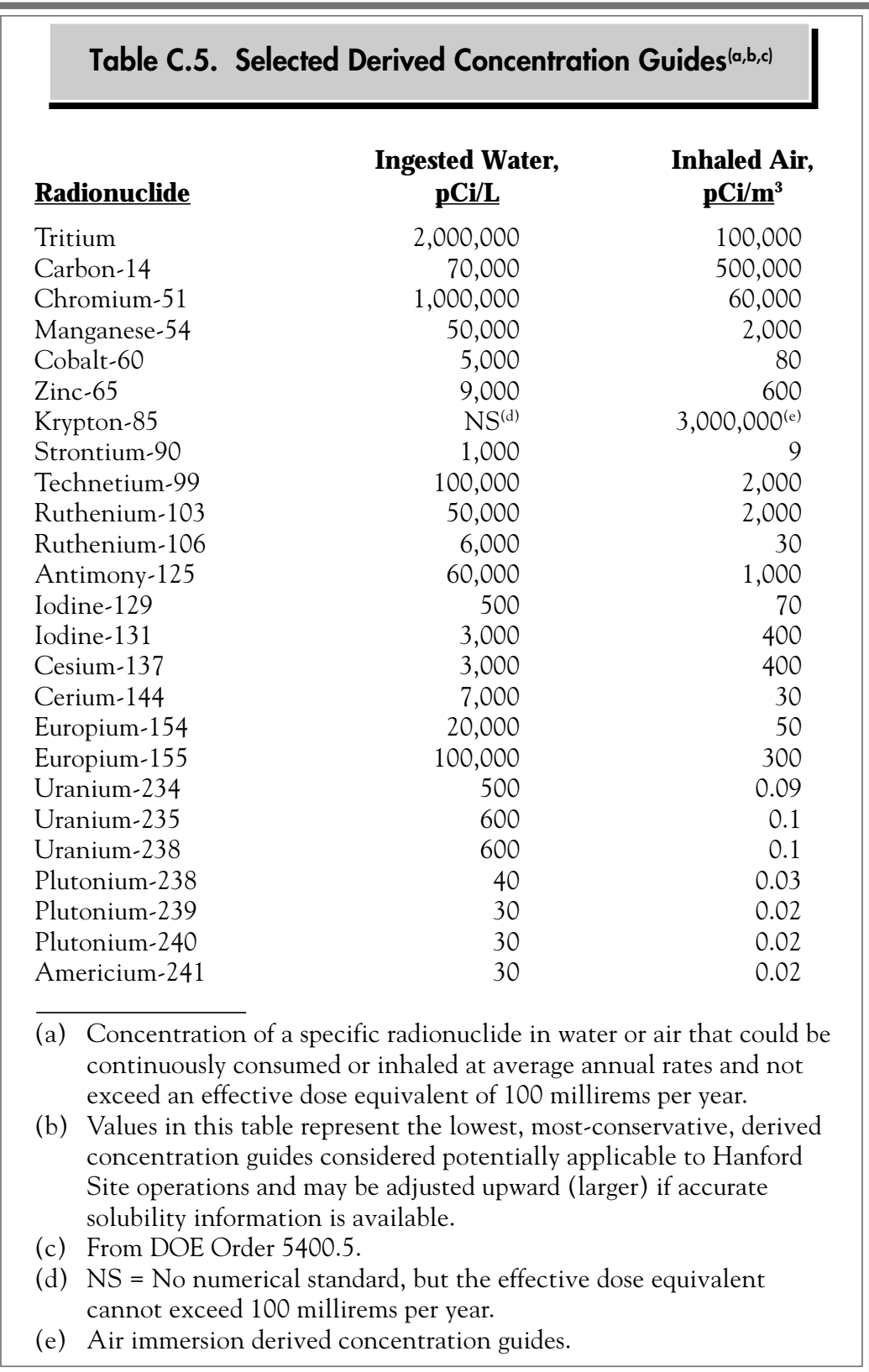




\section{Table C.6. Environmental Permits}

\section{Clean Water Act Permit}

Additional details are given in Section 2.2, "Compliance Status."

\section{Clean Air Act Permits}

Prevention of Significant Deterioration Permit No. PSD-X80-14, issued to DOE Richland Operations Office by EPA Region 10; covers emission of $\mathrm{NO}_{\mathrm{x}}$ to the atmosphere from the Plutonium-Uranium Extraction Plant and the Uranium-TriOxide Plant. No expiration date.

Radioactive Air Emission Permit No. FF-01, issued to DOE Richland Operations Office by the Washington State Department of Health under authority granted by the Clean Air Act; covers operations on the Hanford Site having a potential to emit radioactive airborne effluents. Initially issued August 15, 1991, the permit was updated August 1993.

\section{Wildlife Sampling Permits}

Scientific Collection Permit 99-165d, issued by Washington State Department of Fish and Wildife to Pacific Northwest National Laboratory for 1999; covered the collection of food fish, shellfish, and wildlife, including game fish, for environmental monitoring purposes. Renewed annually.

Federal Fish and Wildlife Permit No. 671877, issued by the U.S. Fish and Wildlife Service to Pacific Northwest National Laboratory; covers the collection of migratory wildlife. Expires December 31, 1999.

N ational Pollutant Discharge Elimination System Permits (governing effluent discharges to the Columbia River)

Permit \#WA-002591-7 includes the outfall for the 300 Area Treated Effluent Disposal Facility and two outfalls in the $100-\mathrm{K}$ Area.

A multisector general stormwater permit and stormwater permit WAR-10-000F.

Copies of the regulations concerning these permits may be obtained from the following organizations:

State of Washington Department of Ecology P.O. Box 47600

Olympia, WA 92504-7600
U.S. Environmental Protection Agency Region 10

1200 Sixth Avenue

Seattle, WA 98101
U.S. Department of Energy Richland Operations Office 825 Jadwin Ave.

Richland, WA 99352 


\section{References}

40 CFR 61. U.S. Environmental Protection Agency. "National Emission Standards for Hazardous Air Pollutants." C ode of Federal Regulations.

40 CFR 131.36. U.S. Environmental Protection Agency. "Toxics Criteria for Those States not Complying with the Clean Water Act Section 303(c)(2)(B)." C ode of Federal Regulations.

40 CFR 141. U.S. Environmental Protection Agency. "National Primary Drinking Water Regulations; Radionuclides; Proposed Rule." Code of Federal Regulations.

Clean Air Act. 1986. Public Law 88-206, as amended, 42 USC 7401 et seq.

Clean Water Act. 1977. Public Law 95-217, as amended, 91 Stat. 1566 and Public Law 96-148, as amended.
DOE Order 5400.5. "Radiation Protection of the Public and the Environment."

EPA-570/9-76-003. 1976. N ational Interim Primary D rinking W ater Regulations. Office of Water Supply, U.S. Environmental Protection Agency, Washington, D.C.

EPA 822-R-96-001. 1996. D rinking W ater Regulationsand $\mathrm{H}$ ealth A dvisories. Office of Water, U.S. Environmental Protection Agency, Washington, D.C.

WAC 173-201A. "Water Quality Standards for Surface Waters of the State of Washington." Washington Administrative Code, Olympia, Washington.

WAC 246-290. "Group A Public Water Systems." Washington Administrative Code, Olympia, Washington. 


\section{$\frac{20}{120}$ \\ Appendix D Dose Calculations}

\section{E. J. Antonio}

The radiological dose that the public could have received in 1999 from Hanford Site operations was calculated in terms of the "total effective dose equivalent." The total effective dose equivalent is the sum of the effective dose equivalent from external sources and the committed effective dose equivalent for internal exposure. Effective dose equivalent is a weighted sum of doses to organs and tissues that accounts for the sensitivity of the tissue and the nature of the radiation causing the dose. It is calculated in units of millirem (millisievert) ${ }^{(\mathrm{a})}$ for individuals and in units of person-rem for the collective dose received by the total population within an 80-kilometer (50-mile) radius of the site. This appendix describes how the doses in this report were calculated.

Releases of radionuclides from Hanford Site operations are usually too low to be measured in offsite air, drinking water, and food crops. Therefore, the air dose calculations were based on measurements made at the point of release (stacks and vents). The water pathway dose calculations were based on measurements of releases to the Columbia River (from the 100 Areas) or the difference in detectable radionuclide concentrations measured upstream and downstream of the site. Environmental radionuclide concentrations were estimated from the effluent measurements by environmental transport models.

The transport of radionuclides in the environment to the point of exposure is predicted by empirically derived models of exposure pathways. These models calculate radionuclide levels in air, water, and foods. Radionuclides taken into the body by inhalation or ingestion may be distributed among different organs and retained for various times. In addition, long-lived radionuclides deposited on the ground become possible sources for long-term external exposure and uptake by agricultural products. Dietary and exposure parameters were applied to calculate radionuclide intakes and radiological doses to the public. Standardized computer programs were used to perform the calculations. These programs contain internally consistent mathematical models that use site-specific dispersion and uptake parameters. These programs are incorporated in a master code, GENII (PNL-6584), which employs the dosimetry methodology described in International Commission on Radiological Protection reports (1979a, 1979b, 1980, 1981a, 1981b, 1982a, 1982b, 1988). The assumptions and data used in these calculations are described below.

CRITRII is used for assessment of radiological doses to aquatic organisms and their predators. Both internal and external doses to fish, crustacea, molluscs, and algae, as well as organisms that subsist on them such as muskrats, raccoons, and ducks, may be estimated using CRITRII (PNL-8150).

The computer program, CAP88-PC, was used to calculate dose to a maximally exposed individual as required by the Code of Federal Regulations (40 CFR 61, Subpart H) from airborne radionuclide effluents (other than radon) released at U.S. Department of Energy (DOE) facilities. Technical details of the CAP88-PC calculations are provided in detail in the 1999 air emissions report (DOE/RL-99-41).

(a) $1 \mathrm{rem}(0.01 \mathrm{~Sv})=1,000 \mathrm{mrem}(10 \mathrm{mSv})$. 


\section{Types of Dose Calculations Performed}

Calculations of radiological doses to the public from radionuclides released into the environment are performed to demonstrate compliance with applicable standards and regulations.

DOE requires:

- effective dose equivalent to be used in estimating public doses

- biokinetic models and metabolic parameters given by the International Commission on Radiological Protection to be used when estimating doses

- doses to the public to be calculated using facility effluent data when environmental concentrations are too low to measure accurately.

The calculation of the effective dose equivalent takes into account the long-term (50-years) internal exposure from radionuclides taken into the body during the current year. The effective dose equivalent is the sum of individual committed (50-years) organ doses multiplied by weighting factors that represent the proportion of the total health effect risk that each organ would receive from uniform irradiation of the whole body. Internal organs may also be irradiated from external sources of radiation. The external exposure received during the current year is added to the committed internal dose to obtain the total effective dose equivalent. In this report, the effective dose equivalent is expressed in rem (or millirem) with the corresponding value in sievert (or millisievert) in parentheses. The numerous transfer factors used for pathway and dose calculations have been documented in GENII (PNL-6584) and in PNL-3777, Rev. 2.

The following types of radiological doses were estimated.

B oundary DoseR ate ( $\mathrm{mrem} / \mathrm{h}$ and $\mathrm{mrem} / \mathrm{yr}$ ).

The external radiological dose rates during the year in areas accessible by the general public were determined from measurements obtained near operating facilities.

Maximally Exposed Individual Dose (mrem). The maximally exposed individual is a hypothetical member of the public who lives at a location and has a lifestyle that makes it unlikely that other members of the public would receive higher doses. All potentially significant exposure pathways to this hypothetical individual were considered, including the following:

- inhalation of airborne radionuclides

- submersion in airborne radionuclides

- ingestion of foodstuffs contaminated by radionuclides deposited on vegetation and the ground by both airborne deposition and irrigation water drawn from the Columbia River downstream of N Reactor

- exposure to ground contaminated by both airborne deposition and irrigation water

- ingestion of fish taken from the Columbia River

- recreation along the Columbia River, including boating, swimming, and shoreline activities.

80-kilometer (50-mile) Population Doses (person-rem). Regulatory limits have not been established for population doses. However, evaluation of the collective population doses to all residents within an 80-kilometer (50-mile) radius of Hanford Site operations is required by DOE Order 5400.5. The radiological dose to the collective population within 80 kilometer ( 50 mile) of the site was calculated to demonstrate compliance with environmental regulations, confirm adherence to DOE environmental protection policies, and provide information to the public. The 80 -kilometer (50-mile) population dose is the sum of the product of the individual doses and the number of individuals exposed for all pathways. 
Pathways similar to those used for the maximally exposed individual were used to calculate doses to the offsite population. In calculating the effective dose, an estimate was made of the fraction of the offsite population expected to be affected by each pathway. The exposure pathways for the population are as follows.

Drinking Water. The cities of Richland and Pasco obtain their municipal water directly and Kennewick indirectly from the Columbia River downstream from the Hanford Site. A total population of $\sim 70,000$ in the three cities drinks water derived from the Columbia River.

Irrigated Food. Columbia River water is withdrawn for irrigation of small vegetable gardens and farms in the Riverview district of Pasco in Franklin County. Enough food is grown in this district to feed an estimated 2,000 people. Commercial crops are

\section{Data}

The data that are needed to perform dose calculations are based on either measured upstream/ downstream differences or measured effluent releases and include information on initial transport through the atmosphere or river, transfer or accumulation in terrestrial and aquatic pathways, and public exposure. By comparison, radiological dose calculations based on measured activities of radionuclides in food require data describing only dietary and recreational activities and exposure times. These data are discussed below.

\section{Population Distribution and Atmospheric Dispersion}

Geographic distributions of the population residing within an 80-kilometer (50-mile) radius of the Hanford Site operating areas are shown in PNNL13230, APP. 1. These distributions are based on 1990 Bureau of the Census data (PNL-7803). These data influence the population dose by providing also irrigated by Columbia River water in the Horn Rapids area of Benton County. These crops are widely distributed.

River Recreation. These activities include swimming, boating, and shoreline recreation. Specific pathways include external exposure from radionuclides in the water or on the shoreline and ingestion of river water while swimming. An estimated 125,000 people who reside within 80 kilometers (50 miles) of the Hanford Site are assumed to be affected by these pathways.

Fish Consumption. Population doses from the consumption of fish obtained locally from the Columbia River were calculated from an estimated total annual catch of 15,000 kilograms per year (33,075 pounds per year) (without reference to a specified human group of consumers).

estimates of the number of people exposed to radioactive effluents and their proximity to the points of release.

Atmospheric dispersion data are also shown in PNNL-13230, APP. 1. These data describe the transport and dilution of airborne radioactive material, which influences the amounts of radionuclides being transported through the air to specific locations.

\section{Terrestrial and Aquatic Pathways}

Important parameters affecting the movement of radionuclides within exposure pathways such as irrigation rates, growing periods, and holdup periods are listed in Table D.1. Certain parameters are specific to the lifestyles of either "maximally exposed" or "average" individuals. 


\begin{tabular}{|c|c|c|c|c|c|}
\hline \multirow[b]{3}{*}{ Medium } & \multicolumn{4}{|c|}{ Table D.1. Food Pathway Parameters Used in Dose Calculations, 1999} & \multirow[b]{3}{*}{$\begin{array}{c}\text { Irrigation Rate, } \\
\mathrm{L} / \mathrm{m}^{2} / \mathrm{mo}^{2}\end{array}$} \\
\hline & \multicolumn{2}{|c|}{ Holdup, $d^{\text {(a) }}$} & \multirow[b]{2}{*}{ Growing Period, d } & \multirow[b]{2}{*}{$\begin{array}{l}\text { Yield, } \\
\underline{\mathrm{kg} / \mathrm{m}^{2}}\end{array}$} & \\
\hline & $\begin{array}{c}\text { Maximally Exposed } \\
\text { Individual } \\
\end{array}$ & $\begin{array}{c}\text { Average } \\
\text { Individual }\end{array}$ & & & \\
\hline Leafy vegetables & 1 & 14 & 90 & 1.5 & 150 \\
\hline Other vegetables & 5 & 14 & 90 & 4 & 170 \\
\hline Fruit & 5 & 14 & 90 & 2 & 150 \\
\hline Cereal & 180 & 180 & 90 & 0.8 & 0 \\
\hline Eggs & 1 & 18 & 90 & 0.8 & 0 \\
\hline Milk & 1 & 4 & .- & . & -. \\
\hline Hay & $(100)^{(\mathrm{b})}$ & $(100)$ & 45 & 2 & 200 \\
\hline Pasture & $(0)$ & $(0)$ & 30 & 1.5 & 200 \\
\hline Red meat & 15 & 34 & - & - & - \\
\hline Hay & $(100)$ & $(100)$ & 45 & 2 & 200 \\
\hline Grain & $(180)$ & $(180)$ & 90 & 0.8 & 0 \\
\hline Poultry & 1 & 34 & 90 & 0.8 & 0 \\
\hline Fish & 1 & 1 & - & - & .- \\
\hline Drinking water & 1 & 1 & -. & .- & .. \\
\hline
\end{tabular}

Table D.2. Dietary Parameters Used in Dose Calculations, 1999

Leafy vegetables

Other vegetables

Fruit

Grain

Eggs

Milk

Red meat

Poultry

Fish

Drinking water

\section{Maximally Exposed Individual \\ A verage \\ Individual}

$$
\begin{array}{r}
30 \mathrm{~kg} / \mathrm{yr} \\
220 \mathrm{~kg} / \mathrm{yr} \\
330 \mathrm{~kg} / \mathrm{yr} \\
80 \mathrm{~kg} / \mathrm{yr} \\
30 \mathrm{~kg} / \mathrm{yr} \\
270 \mathrm{~L} / \mathrm{yr} \\
80 \mathrm{~kg} / \mathrm{yr} \\
18 \mathrm{~kg} / \mathrm{yr} \\
40 \mathrm{~kg} / \mathrm{yr} \\
730 \mathrm{~L} / \mathrm{yr}
\end{array}
$$

$15 \mathrm{~kg} / \mathrm{yr}$

$140 \mathrm{~kg} / \mathrm{yr}$

$64 \mathrm{~kg} / \mathrm{yr}$

$72 \mathrm{~kg} / \mathrm{yr}$

$20 \mathrm{~kg} / \mathrm{yr}$

$230 \mathrm{~L} / \mathrm{yr}$

$70 \mathrm{~kg} / \mathrm{yr}$

$8.5 \mathrm{~kg} / \mathrm{yr}$

-.(a)

$440 \mathrm{~L} / \mathrm{yr}$

(a) Average individual consumption not identified; radiation doses were calculated based on estimated total annual catch of $15,000 \mathrm{~kg}$ $(33,075 \mathrm{lb})$. 
Table D.3. Residency Parameters Used in Dose Calculations, 1999

\begin{tabular}{lcc}
\hline & \multicolumn{2}{c}{ Exposure, $\mathbf{h} / \mathbf{y r}$} \\
\cline { 2 - 3 } \multicolumn{1}{c}{ Parameter } & $\begin{array}{c}\text { Maximally Exposed } \\
\text { Individual }\end{array}$ & $\begin{array}{c}\text { A verage } \\
\text { Individual }\end{array}$ \\
Ground contamination & 4,383 & 2,920 \\
Air submersion & 8,766 & 8,766 \\
Inhalation $^{(a)}$ & 8,766 & 8,766 \\
\hline (a) ${\text { Inhalation rates: adult } 270 \mathrm{~cm}^{3} / \mathrm{s} .}$ \\
\hline
\end{tabular}

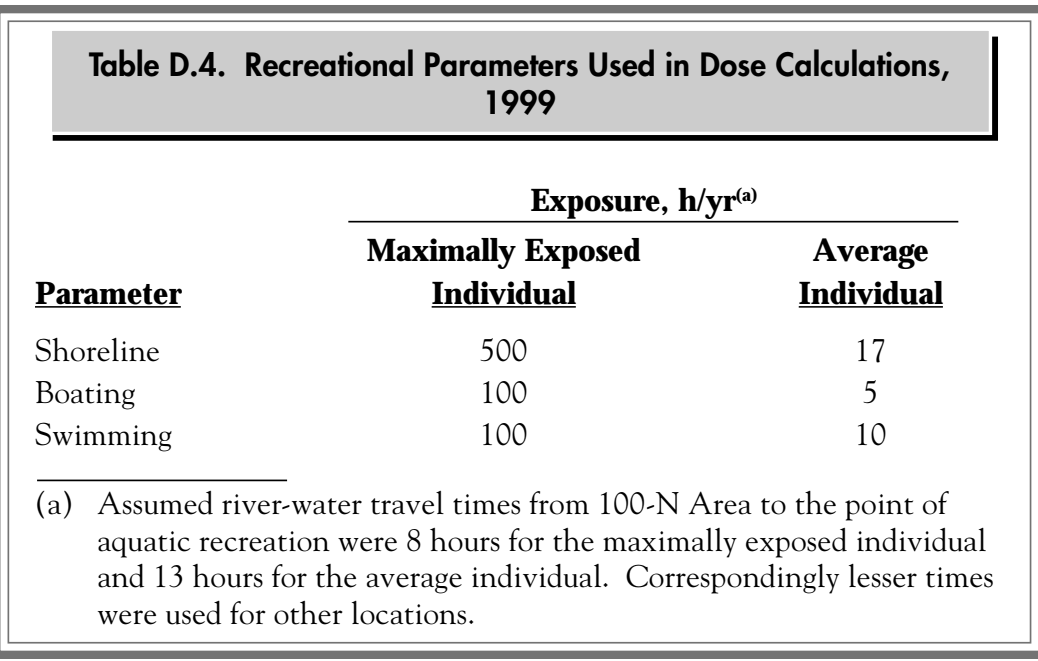

\section{Public Exposure}

The offsite radiological dose is related to the extent of external exposure to or intake of radionuclides released from Hanford Site operations. Tables D.2 through D.4 give the parameters describing the diet, residency, and river recreation assumed for "maximally exposed" and "average" individuals.

\section{D ose Calculation D ocumentation}

DOE established the Hanford Dose Overview Panel to promote consistency and defensibility of environmental dose calculations at Hanford. The panel is responsible for defining standard, documented computer codes and input parameters used for radiological dose calculations for the public in the vicinity of the Hanford Site. Only those procedures, models, and parameters previously defined by the panel were used to calculate the radiological doses (PNL-3777, Rev. 2). The calculations were then reviewed by the panel. Summaries of dose calculation technical details for this report are shown in Tables D.5 through D.9 and in PNNL-13230, APP. 1.

\section{Area D rinking Water}

Drinking water at the Fast Flux Test Facility contained slightly elevated levels of tritium. The potential doses to 400 Area workers consuming this water in 1999 are given in Table D.10. 
Table D.5. Technical Details of 100 Areas Airborne Release Dose Calculations, 1999

Facility name

Releases $(\mathrm{Ci})$

Meteorological conditions

$\overline{\mathrm{X}} / \mathrm{Q}^{\prime}$

Release height

Population distribution

Computer code

Doses calculated

Pathways considered

Files addressed
100-K Area

${ }^{60} \mathrm{Co}\left(3.9 \times 10^{-8}\right),{ }^{90} \mathrm{Sr}\left(1.9 \times 10^{-5}\right),{ }^{125} \mathrm{Sb}\left(5.0 \times 10^{-8}\right),{ }^{137} \mathrm{Cs}(4.5 \mathrm{x}$ $\left.10^{-5}\right),{ }^{154} \mathrm{Eu}\left(4.8 \times 10^{-8}\right),{ }^{238} \mathrm{Pu}\left(5.8 \times 10^{-7}\right),{ }^{239 / 240} \mathrm{Pu}\left(4.2 \times 10^{-6}\right)^{\text {(a) }}$, ${ }^{241} \mathrm{Pu}\left(5.1 \times 10^{-5}\right),{ }^{241} \mathrm{Am}\left(2.4 \times 10^{-6}\right)$

1999 annual average, calculated from data collected at the 100-K Area and the Hanford Meteorology Station from January through December 1999, using the computer code HANCHI

Maximally exposed individual, $3.2 \times 10^{-9} \mathrm{~s} / \mathrm{m}^{3}$ at $41 \mathrm{~km}(26 \mathrm{mi})$ $\mathrm{SE} ; 80-\mathrm{km}(50-\mathrm{mi})$ population, $7.8 \times 10^{-4} \mathrm{~s} / \mathrm{m}^{3}$ person-s $/ \mathrm{m}^{3}$

89-m (292-ft) effective stack height

375,000 (PNNL-11796, Table D-1)

GENII, Version 1.485, December 3, 1990 (e.g., PNL-6584)

Chronic, 1-yr exposure, 50-yr committed internal dose equivalent, and annual effective dose equivalent to individual and population

External exposure to plume and ground deposits Inhalation

Ingestion of locally produced foods

Radionuclide Library, Rev. 7-1-92

Food Transfer Library, Rev. 8-29-88

External Dose Factor Library, Rev. 5-9-88

Internal Dose Factor Library, Rev. 12-3-90

(a) This value includes gross alpha release data. Gross alpha and unspecified alpha results assumed to be 239/240Pu for dose calculations. 


\section{Table D.6. Technical Details of 100-N Area Liquid Release Dose Calculations, 1999}

Facility name

Releases $(\mathrm{Ci})$

Mean river flow

Shore-width factor

Population distribution

Computer code

Doses calculated

Pathways considered

Files addressed
100-N Area

${ }^{90} \mathrm{Sr}\left(7.3 \times 10^{-2}\right),{ }^{239} \mathrm{Pu}\left(1.5 \times 10^{-5}\right),{ }^{241} \mathrm{Am}\left(1.6 \times 10^{-6}\right)$

$4,110 \mathrm{~m}^{3} / \mathrm{s}\left(145,000 \mathrm{ft}^{3} / \mathrm{s}\right)$

0.2

70,000 for drinking water pathway

125,000 for aquatic recreation

2,000 for consumption of irrigated foodstuffs

$15,000 \mathrm{~kg} / \mathrm{yr}(33,075 \mathrm{lb} / \mathrm{yr})$ total harvest of Columbia River fish

GENII, Version 1.485, December 3, 1990 (e.g., PNL-6584)

Chronic, 1-yr exposure, 50-yr committed internal dose equivalent, and annual effective dose equivalent to individual and population

External exposure to irrigated soil, to river water, and to shoreline sediments

Ingestion of aquatic foods and irrigated farm products

Radionuclide Library, Rev. 7-1-92

Food Transfer Library, Rev. 8-29-88

External Dose Factor Library, Rev. 5-9-88

Internal Dose Factor Library, Rev. 12-3-90

Bioaccumulation Factor Library, Rev. 10-26-92 
Table D.7. Technical Details of 200 Areas Airborne Release Dose Calculations, 1999

Facility name

Releases (Ci)

Meteorological conditions

$\overline{\mathrm{X}} / \mathrm{Q}^{\prime}$

Release height

Population distribution

Computer code

Doses calculated

Pathways considered

Files addressed
200 Areas

200-East Area

${ }^{60} \mathrm{Co}\left(1.6 \times 10^{-9}\right),{ }^{90} \mathrm{Sr}\left(9.7 \times 10^{-5}\right)$ (a) $^{(129} \mathrm{I}\left(1.9 \times 10^{-4}\right),{ }^{137} \mathrm{Cs}(3.9 \times$ $\left.10^{-5}\right),{ }^{238} \mathrm{Pu}\left(1.9 \times 10^{-8}\right),{ }^{239 / 240} \mathrm{Pu}\left(6.9 \times 10^{-7}\right)^{(\mathrm{b})},{ }^{241} \mathrm{Pu}\left(1.2 \times 10^{-6}\right)$, ${ }^{241} \mathrm{Am}\left(5.6 \times 10^{-7}\right)$

200-West Area

${ }^{90} \mathrm{Sr}\left(3.1 \times 10^{-4}\right){ }^{\text {(a) }},{ }^{137} \mathrm{Cs}\left(2.5 \times 10^{-9}\right),{ }^{238} \mathrm{Pu}\left(4.9 \times 10^{-6}\right),{ }^{239 / 240} \mathrm{Pu}$ $\left(2.1 \times 10^{-4}\right)^{(\mathrm{b})},{ }^{241} \mathrm{Pu}\left(1.2 \times 10^{-4}\right),{ }^{241} \mathrm{Am}\left(4.5 \times 10^{-5}\right)$

1999 annual average, calculated from data collected at the Hanford Meteorology Station from January through December 1999, using the computer code HANCHI

Maximally exposed individual, $1.2 \times 10^{-8} \mathrm{~s} / \mathrm{m}^{3}$ at $34 \mathrm{~km}(21 \mathrm{mi}) \mathrm{SE}$; $80-\mathrm{km}(50-\mathrm{mi})$ population, $1.4 \times 10^{-3}$ person-s $/ \mathrm{m}^{3}$

89-m (292-ft) effective stack height

376,000 (PNNL-11796, Table D-2)

GENII, Version 1.485, December 3, 1990 (e.g., PNL-6584)

Chronic, 1-yr exposure, 50-yr committed internal dose equivalent, and annual effective dose equivalent to individual and population

External exposure to plume and ground deposits Inhalation

Ingestion of locally produced foods

Radionuclide Library, Rev. 7-1-92

Food Transfer Library, Rev. 8-29-88

External Dose Factor Library, Rev. 5-9-88

Internal Dose Factor Library, Rev. 12-3-90

(a) This value includes gross beta release data. Gross beta and unspecified beta results assumed to be ${ }^{90} \mathrm{Sr}$ for dose calculations.

(b) This value includes gross alpha release data. Gross alpha and unspecified alpha results assumed to be ${ }^{239 / 240} \mathrm{Pu}$ for dose calculations. 
Table D.8. Technical Details of 300 Area Airborne Release Dose Calculations, 1999

Facility name

Releases $(\mathrm{Ci})$

Meteorological conditions

$\overline{\mathrm{X}} / \mathrm{Q}^{\prime}$

Release height

Population distribution

Computer code

Doses calculated

Pathways considered

Files addressed
300 Area

${ }^{3} \mathrm{H}(\text { as HT) })^{\text {(a) }}\left(4.0 \times 10^{1}\right),{ }^{3} \mathrm{H}(\text { as HTO })^{(a)}\left(1.5 \times 10^{2}\right),{ }^{90} \mathrm{Sr}(1.0 \times$ $\left.10^{-5}\right)^{(\mathrm{b})},{ }^{125} \mathrm{Sb}\left(1.1 \times 10^{-7}\right),{ }^{137} \mathrm{Cs}\left(4.2 \times 10^{-7}\right),{ }^{239 / 240} \mathrm{Pu}\left(1.1 \times 10^{-6}\right)^{(\mathrm{c})}$, ${ }^{241} \mathrm{Am}\left(1.4 \times 10^{-7}\right),{ }^{241} \mathrm{Pu}\left(7.9 \times 10^{-8}\right)$

1999 annual average, calculated from data collected at the 300 Area and the Hanford Meteorology Station from January through December 1999, using the computer code HANCHI

Maximally exposed individual at residence, $7.5 \times 10^{-7} \mathrm{~s} / \mathrm{m}^{3}$ at $1.5 \mathrm{~km}$ (1 mi) E; $80-\mathrm{km}(50-\mathrm{mi})$ population, $6.4 \times 10^{-3}$ person-s $/ \mathrm{m}^{3}$

$10 \mathrm{~m}(33 \mathrm{ft})$

282,000 (PNNL-11796, Table D-3)

GENII, Version 1.485, December 3, 1990 (e.g., PNL-6584)

Chronic, 1-yr exposure, 50-yr committed internal dose equivalent, and annual effective dose equivalent to individual and population

External exposure to plume and ground deposits Inhalation

Ingestion of locally produced foods

Radionuclide Library, Rev 7-1-92

Food Transfer Library, Rev. 8-29-88

External Dose Factor Library, Rev. 5-9-88

Internal Dose Factor Library, Rev. 12-3-90

(a) $\mathrm{HT}=$ elemental tritium; $\mathrm{HTO}=$ tritiated water vapor.

(b) This value includes gross beta release data. Gross beta and unspecified beta results assumed to be ${ }^{90} \mathrm{Sr}$ for dose calculations.

(c) This value includes gross alpha release data. Gross alpha and unspecified alpha results assumed to be ${ }^{239 / 240} \mathrm{Pu}$ for dose calculations. 


\section{Table D.9. Technical Details of 400 Area Airborne Release Dose Calculations, 1999}

Facility name

Releases (Ci)

Meteorological conditions

$\overline{\mathrm{X}} / \mathrm{Q}^{\prime}$

Release height

Population distribution

Computer code

Doses calculated

Pathways considered

Files addressed
400 Area

${ }^{137} \mathrm{Cs}\left(1.9 \times 10^{-6}\right)^{(\mathrm{a})},{ }^{239 / 240} \mathrm{Pu}\left(3.0 \times 10^{-7}\right)^{(\mathrm{b})}$

1999 annual average, calculated from data collected at the 400 Area and the Hanford Meteorology Station from January through December 1999, using the computer code HANCHI

Maximally exposed individual at residence, $9.0 \times 10^{-8} \mathrm{~s} / \mathrm{m}^{3}$ at $11 \mathrm{~km}$ (7 mi) SE; $80-\mathrm{km}(50-\mathrm{mi})$ population, $4.4 \times 10^{-3}$ person-s $/ \mathrm{m}^{3}$

$10 \mathrm{~m}(33 \mathrm{ft})$

283,000 (PNNL-11796, Table D-4)

GENII, Version 1.485, December 3, 1990 (e.g., PNL-6584)

Chronic, 1-yr exposure, 50-yr committed internal dose equivalent, and annual effective dose equivalent to individual and population

External exposure to plume and ground deposits

Inhalation

Ingestion of locally produced foods

Radionuclide Library, Rev 7-1-92

Food Transfer Library, Rev. 8-29-88

External Dose Factor Library, Rev. 5-9-88

Internal Dose Factor Library, Rev. 12-3-90

(a) ${ }^{137} \mathrm{Cs}$ value for the 400 Area is derived fully from gross beta measurements.

(b) This value includes gross alpha release data. Gross alpha and unspecified alpha results assumed to be ${ }^{239 / 240} \mathrm{Pu}$ for dose calculations. 


\begin{tabular}{|c|c|c|c|c|c|}
\hline \multirow{2}{*}{\multicolumn{2}{|c|}{ Radionuclide }} & \multicolumn{4}{|c|}{$\begin{array}{l}\text { 0. Annual Dose to Workers in the } 400 \text { Area from Ingestion of Drinking Water } \\
\text { Obtained from Groundwater Wells, } 1999\end{array}$} \\
\hline & & $\begin{array}{l}\text { Drinking Water } \\
\text { Activity, } \mathrm{PCi} / \mathrm{L}^{\text {(a) }}\end{array}$ & $\underline{\text { Intake, }} \mathbf{p C i} / \mathbf{y r}^{(\mathbf{b})}$ & $\begin{array}{l}\text { Ingestion Dose } \\
\text { Factor, rem/pCi(c) }\end{array}$ & $\begin{array}{l}\text { Ingestion Dose, } \\
\text { rem/yr (Sv/yr) }\end{array}$ \\
\hline \multicolumn{2}{|c|}{ Gross alpha $^{(d)}$} & $0.62 \pm 0.90$ & 149 & $2.83 \times 10^{-7}$ & $\begin{array}{l}4.2 \times 10^{-5} \\
\left(4.2 \times 10^{-7}\right)\end{array}$ \\
\hline \multicolumn{2}{|c|}{ Gross beta $^{(e)}$} & $6.64 \pm 0.74$ & 1,594 & $5.00 \times 10^{-8}$ & $\begin{array}{l}8.0 \times 10^{-5} \\
\left(8.0 \times 10^{-7}\right)\end{array}$ \\
\hline \multicolumn{2}{|c|}{ Tritium } & $4,275 \pm 253$ & $1.03 \times 10^{6}$ & $6.40 \times 10^{-11}$ & $\begin{array}{l}6.6 \times 10^{-5} \\
\left(6.6 \times 10^{-7}\right)\end{array}$ \\
\hline \multicolumn{5}{|c|}{ Total } & $\begin{array}{l}1.9 \times 10^{-4} \\
\left(1.9 \times 10^{-6}\right)\end{array}$ \\
\hline \multicolumn{6}{|c|}{$\begin{array}{l}\text { (a) Drinking water activities are annual averages obtained from quarterly samples taken during } 1999 . \\
\text { (b) Intake is based on the assumption that a worker ingests } 1 \mathrm{~L} / \mathrm{d} \text { of groundwater during the entire working year } \\
\text { (taken to be } 240 \text { days for the analysis). } \\
\text { (c) Ingestion intake-to-dose conversion factors are taken from EPA/520/1-88-020 and converted from Interna- } \\
\text { tional System of Units (SI). Where the document lists dose factors for more than one chemical form of a } \\
\text { radionuclide, the most soluble chemical form was assumed. } \\
\text { (d) Gross alpha activities were assumed to be be }{ }^{234} \mathrm{U} \text { for the purposes of this analysis. } \\
\text { (e) Gross beta activities were assumed to be }{ }^{137} \mathrm{Cs} \text { for the purposes of this analysis. }\end{array}$} \\
\hline
\end{tabular}




\section{References}

40 CFR 61, Subpart H. U.S. Environmental Protection Agency. "National Emission Standards for Hazardous Air Pollutants." Code of Federal Regulations.

DOE Order 5400.5. "Radiation Protection of the Public and the Environment."

DOE/RL-99-41. 1999. Radionuclide Air Emissions Report for the Hanford Site, Calendar Year 1998. B. P. Gleckler and K. Rhoads, Waste Management Federal Services of Hanford, Inc. for U.S. Department of Energy, Richland Operations Office, Richland, Washington.

EPA/520/1-88-020. 1988. Limiting Values of Radionuclide Intake and Air Concentration and Dose Conversion Factors for Inhalation, Submersion, and Ingestion. Federal Guidance Report No. 11. K. F. Eckerman, A. B. Wolbarst, and A.C.B. Richardson, Office of Radiation Programs, U.S. Environmental Protection Agency, Washington, D.C.

International Commission on Radiological Protection. 1979a. "ICRP Publication 30, Part 1, Limits for Intakes of Radionuclides by Workers." Annals of the ICRP 2:3/4, Pergamon Press, Elmsford, New York.

International Commission on Radiological Protection. 1979b. "ICRP Publication 30, Supplement to Part 1, Limits for Intakes of Radionuclides by Workers." Annals of the ICRP 3:1-4, Pergamon Press, Elmsford, New York.

International Commission on Radiological Protection. 1980. "ICRP Publication 30, Part 2, Limits for Intakes of Radionuclides by Workers." Annals of the ICRP 4:3/4, Pergamon Press, Elmsford, New York.

International Commission on Radiological Protection. 1981a. "ICRP Publication 30, Supplement to Part 2, Limits for Intakes of Radionuclides by Workers." Annals of the ICRP 5:1-6, Pergamon Press, Elmsford, New York.
International Commission on Radiological Protection. 1981b. "ICRP Publication 30, Part 3 Including Addendum to Parts 1 and 2, Limits for Intakes of Radionuclides by Workers." Annals of the ICRP 6:2/3, Pergamon Press, Elmsford, New York.

International Commission on Radiological Protection. 1982a. "ICRP Publication 30, Supplement A to Part 3, Limits for Intakes of Radionuclides by Workers." Annals of the ICRP 7:1-3, Pergamon Press, Elmsford, New York.

International Commission on Radiological Protection. 1982b. "ICRP Publication 30, Supplement B to Part 3 Including Addendum to Supplements to Parts 1 and 2, Limits for Intakes of Radionuclides by Workers." Annals of the ICRP 8:1-3, Pergamon Press, Elmsford, New York.

International Commission on Radiological Protection. 1988. "ICRP Publication 30, Part 4, Limits for Intakes of Radionuclides by Workers: an Addendum." Annals of the ICRP 19:4, Pergamon Press, Elmsford, New York.

PNL-3777, Rev. 2. 1993. Recommended Environmental Dose Calculation Methods and Hanford-Specific Parameters. R. G. Schreckhise, K. Rhoads, J. S. Davis, B. A. Napier, and J. V. Ramsdell, Pacific Northwest Laboratory, Richland, Washington.

PNL-6584. 1988. GENII - The Hanford Environmental Radiation Dosimetry Software System, 3 vols. B. A. Napier, R. A. Peloquin, D. L. Strenge, and J. V. Ramsdell, Pacific Northwest Laboratory, Richland, Washington.

PNL-7803. 1991. Hanford Area 1990 Population and 50-Year Projections. D. M. Beck, B. A. Napier, M. J. Scott, A. G. Thurman, M. D. Davis, D. B. Pittenger, S. F. Shindle, and N. C. Batishko, Pacific Northwest Laboratory, Richland, Washington. 
PNL-8150. 1992. Methods for Estimating Doses to Organisms from Radioactive Materials Released into the Aquatic Environment. D. A. Baker and J. K. Soldat, Pacific Northwest Laboratory, Richland, Washington.

PNNL-11796. 1998. Hanford Site Environmental Data for Calendar Year 1997. L. E. Bisping, Pacific Northwest National Laboratory, Richland, Washington.
PNNL-13230, APP. 1. 2000. Hanford Site Environmental Surveillance Data for Calendar Year 1999. L. E. Bisping, Pacific Northwest National Laboratory, Richland, Washington. 


\section{Appendix E Radionuclides Detected by Gamma Spectroscopy (Gamma Scan)}

One of the several forms of radiation is gamma radiation. Gamma radiation is emitted by many radionuclides. Gamma spectroscopy, sometimes called a gamma scan, is used to detect the presence of the radionuclides shown in Table E.1. These radionuclides may be natural or result from Hanford Site operations. They include activation products formed by the absorption of a neutron by a stable element and fission products that occur following fission (splitting) of nuclear fuel radionuclides such as uranium-235 or plutonium-239. Some of these radionuclides may not be discussed in the main body of this report if they are below detection levels.

Table E.1. Radionuclides Analyzed by Gamma Spectroscopy

\section{Radionuclide}

Beryllium-7

Sodium-22

Sodium-24

Potassium-40

Manganese-54

Cobalt -58

Cobalt -60

Iron-59

Zinc-65

Zirconium/niobium-95

Molybdenum-99

Ruthenium-103

Ruthenium-106

Antimony-125

Iodine-131

Cesium-134

Cesium-137

Barium/lanthanum-140

Cerium-141

Cerium/praseodymium-144

Europium-152

Europium-154

Europium-155
Symbol

${ }^{7} \mathrm{Be}$

${ }^{22} \mathrm{Na}$

${ }^{24} \mathrm{Na}$

${ }^{40} \mathrm{~K}$

${ }^{54} \mathrm{Mn}$

${ }^{58} \mathrm{Co}$

${ }^{60} \mathrm{Co}$

${ }^{59} \mathrm{Fe}$

${ }^{65} \mathrm{Zn}$

${ }^{95} \mathrm{Zr} / \mathrm{Nb}$

${ }^{99} \mathrm{Mo}$

${ }^{103} \mathrm{Ru}$

${ }^{106} \mathrm{Ru}$

${ }^{125} \mathrm{Sb}$

${ }^{131} \mathrm{I}$

${ }^{134} \mathrm{Cs}$

${ }^{137} \mathrm{Cs}$

${ }^{140} \mathrm{Ba} / \mathrm{La}$

${ }^{141} \mathrm{Ce}$

${ }^{144} \mathrm{Ce} / \mathrm{Pr}$

${ }^{152} \mathrm{Eu}$

${ }^{154} \mathrm{Eu}$

${ }^{155} \mathrm{Eu}$

\section{Source}

Natural
Activation product
Activation product
Natural
Activation product
Activation product
Activation product
Activation product
Activation product
Activation product and fission product
Activation product and fission product
Activation product and fission product
Fission product
Activation product
Fission product
Activation product
Fission product
Fission product
Activation product and fission product
Fission product
Activation product
Activation product
Activation product




\title{
Threatened and Endangered Species
}

\author{
R. K. Zufelt
}

This appendix discusses the federal and state threatened and endangered species, candidate species, and plant species of concern potentially found on the Hanford Site. Threatened and endangered species are listed by the federal government in the
Code of Federal Regulations (50 CFR 17); Washington Natural Heritage Program (1999); and Washington State Department of Fish and Wildlife (2000). A more extensive discussion of listed species can be found in PNNL-6415, Rev. 1.

\section{Threatened or Endangered Species}

The purposes of the Endangered Species A ct, as amended, are to 1) provide a means to conserve critical ecosystems, 2) provide a program for the conservation of threatened and endangered species, and 3) ensure that appropriate steps are taken to achieve the purposes of the treaties and conventions established in the act. Threatened and endangered species of plants and animals on the Hanford Site are listed in Table F.1.

Identification of candidate species can assist environmental planning efforts by providing advance notice of potential listing as a threatened or endangered species, allowing resource managers to alleviate

\section{Hanford Status}

No plants or mammals on the federal list of endangered and threatened species (50 CFR 17) are known to occur on the Hanford Site. There are, however, one bird species and two species of fish on the federal list of threatened and endangered species (see Table F.1). In addition, eight species of plants and five species of birds have been listed as either threatened or endangered by Washington State. The National Marine Fisheries Service is responsible for the federal listing of anadromous fish (i.e., fish which require both saltwater and freshwater to complete a threats and thereby possibly remove the need to list species as endangered or threatened. Even if a candidate species is subsequently listed, the early notice could result in fewer restrictions on human activities in the environment by prompting candidate conservation measures to alleviate threats to the species. Washington State candidate animal species on the Hanford Site are listed in Table F.2. Plant species not listed as threatened or endangered but considered "candidates" for listing are identified by Washington State as "species of concern." Washington State plant species of concern found on the Hanford Site are listed in Table F.3.

life cycle). Upper-Columbia River steelhead and upper-Columbia River spring-run chinook salmon were listed as endangered evolutionary significant units by National Marine Fisheries Service in August 1997 and March 1999, respectively.

Several species of both plants and animals are under consideration for formal listing as candidate species by Washington State. There are 16 state-level candidate species of plants and animals (see Table F.2) and 46 plant species of concern (see Table F.3). 


\begin{tabular}{|c|c|c|c|}
\hline \multicolumn{3}{|c|}{$\begin{array}{l}\text { Table F.1. Federal- or Washington State-Listed Threatened (T) and Endangered (E) } \\
\text { Species on the Hanford Site }\end{array}$} & \multirow[b]{2}{*}{ State } \\
\hline Common Name & Scientific Name & Federal & \\
\hline \multicolumn{4}{|l|}{ Plants } \\
\hline $\begin{array}{l}\text { Columbia milkvetch } \\
\text { Dwarf evening primrose } \\
\text { Hoover's desert parsley } \\
\text { Loeflingia } \\
\text { Persistent sepal yellowcress } \\
\text { Umtanum desert buckwheat } \\
\text { White Bluffs bladderpod } \\
\text { White eatonella }\end{array}$ & $\begin{array}{l}\text { A stragalus columbianus } \\
\text { C amissonia ( } 0 \text { enothera) pygmaea } \\
\text { Lomatium tuberosum } \\
\text { L oeflingia squarrosa var. squarrosa } \\
\text { Rorippa columbiae } \\
\text { E riogonum codium } \\
\text { Lesquerella tuplashensis } \\
\text { E atonella nivea }\end{array}$ & $\begin{array}{l}\text { SC } \\
\text { SC } \\
\text { SC } \\
\text { C } \\
\text { C }\end{array}$ & $\begin{array}{l}\mathrm{T} \\
\mathrm{T} \\
\mathrm{T} \\
\mathrm{T} \\
\mathrm{T} \\
\mathrm{E} \\
\mathrm{E} \\
\mathrm{T}\end{array}$ \\
\hline \multicolumn{4}{|l|}{ Fish } \\
\hline $\begin{array}{l}\text { Spring-run chinook } \\
\text { Steelhead }\end{array}$ & $\begin{array}{l}\text { O ncorhynchus tshawytscha } \\
\text { O ncorhynchus mykiss }\end{array}$ & $\begin{array}{l}\mathrm{E} \\
\mathrm{E}\end{array}$ & $\begin{array}{l}\mathrm{C} \\
\mathrm{C}\end{array}$ \\
\hline \multicolumn{4}{|l|}{ B irds } \\
\hline $\begin{array}{l}\text { American white pelican } \\
\text { Bald eagle (a) } \\
\text { Ferruginous hawk } \\
\text { Sandhill crane } \\
\text { Western sage grouse }\end{array}$ & $\begin{array}{l}\text { Pelecanus erythrorhychos } \\
\text { H aliaeetus leucocephalus } \\
\text { B uteo regalis } \\
\text { G rus canadensis } \\
\text { C entrocercus urophasianus phaios }\end{array}$ & $\begin{array}{l}\mathrm{T} \\
\mathrm{SC} \\
\mathrm{SC}\end{array}$ & $\begin{array}{l}\mathrm{E} \\
\mathrm{T} \\
\mathrm{T} \\
\mathrm{E} \\
\mathrm{T}\end{array}$ \\
\hline $\begin{array}{l}\text { (a) Currently under review } \\
\mathrm{C}=\text { Candidate, } 50 \text { CFR } 1 \\
\mathrm{SC}=\text { Species of concern. }\end{array}$ & ange in status. & & \\
\hline
\end{tabular}




\section{Table F.2. Washington State Candidate Animal Species on the Hanford Site}

\section{Common Name}

\section{Molluscs}

Giant Columbia River spire snail ${ }^{(a)}$ Giant Columbia River limpet

Fish

Spring-run chinook ${ }^{(\mathrm{b})}$

Steelhead ${ }^{(b)}$

\section{Insects}

Columbia River tiger beetle ${ }^{(c)}$

\section{Birds}

Burrowing owl ${ }^{(a)}$

Common loon

Golden eagle

Loggerhead shrike ${ }^{(a)}$

Merlin

Northern goshawk ${ }^{(a, d)}$

Sage sparrow

Sage thrasher

\section{Reptiles}

Striped whipsnake

\section{Mammals}

Merriam's shrew

Washington ground squirrel ${ }^{(\mathrm{d}, e)}$

\section{Scientific Name}

Fluminicola ( = Lithoglyphus) columbiana

Fisherola (= Lanx) nuttalli

O ncorhynchus tshawytscha

O ncorhynchus mykiss

Cicindela columbica

A thene cunicularia
$G$ avia immer
A quila chrysaetos
L anius ludovicianus
Falco columbarius
A ccipter gentilis
A mphispiza belli
O reoscoptes montanus

$M$ asticophis taeniatus

Sorex merriami

Spermophilus washingtoni
(a) Federal species of concern.
(b) Federal endangered.
(c) Probable, but not observed, on the Hanford Site.
(d) Reported, but seldom observed, on the Hanford Site.
(e) Federal candidate. 
Table F.3. Washington State Plant Species of Concern on the Hanford Site

\section{Common Name}

Annual paintbrush

Awned halfchaff sedge

Basalt milk-vetch

Bristly combseed

Brittle prickly pear

Canadian St. John's wort

Chaffweed

Columbia River mugwort

Coyote tobacco

Crouching milkvetch

Desert dodder

Desert evening-primrose

False pimpernel

Fuzzytongue penstemon

Geyer's milkvetch

Grand redstem

Gray cryptantha

Great Basin gilia

Hedge hog cactus

Kittitas larkspur

Lowland toothcup

Miner's candle

Piper's daisy

Robinson's onion

Rosy balsamroot

Rosy pussypaws

Scilla onion

Shining flatsedge

Small-flowered evening-primrose

Small-flowered nama

Smooth cliffbrake

Snake River cryptantha

Southern mudwort

Stalked-pod milkvetch

Suksdorf's monkey flower

Winged combseed

\section{Scientific Name}

C astilleja exilis

Lipocarpha ( = H emicarpha) aristulata

A stragalus conjunctus var. rickardii

Pectocarya setosa

0 puntia fragilis

$\mathrm{H}$ ypericum majus

$C$ entunculus minimus

A rtemesia lindleyana

$\mathrm{N}$ icotiana attenuata

A stragalus succumbens

C uscuta denticulata

0 enothera caespitosa

Lindernia dubia anagallidea

Penstemon eriantherus whitedii

A stragalus geyeri

A mmannia robusta

C ryptantha leucophaea

G ilia leptomeria

Pediocactus simpsonii var. robustior

D elphinium multiplex

Rotala ramosior

C ryptantha scoparia

E rigeron piperianus

A llium robinsonii

Balsamorhiza rosea

C alyptridium roseum

A llium scilloides

C yperus bipartitus ( rivularis)

$C$ amissonia ( $=0$ enothera) minor

$\mathrm{N}$ ama densum var. parviflorum

Pellaea glabella simplex

$C$ ryptantha spiculifera ( $=C$. interrupta)

Limosella acaulis

A stragalus sclerocarpus

M imulus suksdorfii

Pectocarya linearis
State Listing ${ }^{(\mathrm{a})}$

R1

$\mathrm{R} 1$

R1

W

R1

S

R1

W

$S$

W

S

R2

R1

S

R1

$S$

R1

R1

W

R1

R1

S

W

W

S

W

S

R1

R1

W

S

W

W

R1

The following species have been reported on the Hanford Site, but the known collections are questionable in terms of location or identification, and have not been recently collected on the Hanford Site.

Beaked spike-rush

Dense sedge

Few-flowered collinsia

Giant helleborine

Medic milkvetch

Orange balsam

Palouse milkvetch

Palouse thistle

Porcupine sedge

Thompson's sandwort

E leocharis rostellata
C arex densa
C ollinsia sparsiflora var. bruciae
E pipactis gigantea
A stragalus speirocarpus
Impatiens aurella
A stragalus arrectus
C irsium brevifolium
C arex hystericina
A renaria franklinii thompsonii

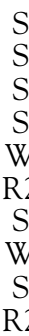

(a) $\mathrm{S}=$ Sensitive (i.e., taxa vulnerable or declining) and could become endangered or threatened without active management or removal of threats.

R1 = Taxa for which there are insufficient data to support listing as threatened, endangered, or sensitive (formerly monitor group 1 ).

$\mathrm{R} 2$ = Taxa with unresolved taxanomic questions (formerly monitor group 2).

$\mathrm{W}=$ Taxa that are more abundant and/or less threatened than previously assumed (formerly monitor group 3). 


\section{References}

50 CFR 17. U.S. Fish and Wildlife Service, Department of the Interior. "Endangered and Threatened Wildlife and Plants." C ode of F ederal Regulations.

Endangered Species Act. 1973. Public Laws 93-205 through 100-707.

National Marine Fisheries Service. 1999. ESA Status Pages. Available URL: http://www.nwr.noaa.gov/ 1salmon/salmesa/specprof.htm

PNNL-6415, Rev. 1. 2000. H anford Site $\mathrm{N}$ ational Environmental Policy A ct (NEPA) C haracterization. D. A. Neitzel (ed.), Pacific Northwest National Laboratory, Richland, Washington.
Washington Natural Heritage Program. 1999. Rare Plant Species C ounty L ist. Washington State Department of Natural Resources, Olympia, Washington. Available URL: http://www.wa.gov/dnr/htdocs/fr/ nhp/plantco.html

Washington State Department of Fish and Wildlife. 2000. Priority $\mathrm{H}$ abitats and Species List. Olympia, Washington. Available URL: http://www.wa.gov/ wdfw/hab/phspage.htm 